\section{Pacific Northwest} National Laboratory

Operated by Battelle for the U.S. Department of Energy

\title{
Hanford Site Environmental Report for Calendar Year 2001
}

\author{
Editors \\ T. M. Poston \\ R. W. Hanf \\ R. L. Dirkes \\ L. F. Morasch
}

September 2002

Prepared for the U.S. Department of Energy under Contract DE-AC06-76RL01830 


\title{
DISCLAIMER
}

This report was prepared as an account of work sponsored by an agency of the United States Government. Reference herein to any specific commercial product, process, or service by trade name, trademark, manufacturer, or otherwise does not necessarily constitute or imply its endorsement, recommendation, or favoring by the United States Government or any agency thereof, or Battelle Memorial Institute. This report is a summary of major or significant activities occurring at the Hanford Site only, and is not a full disclosure of all details associated with Hanford-related activities, nor a substitute for legally required information subject to reporting requirements regarding releases, violations, etc.

\author{
PACIFIC NORTHWEST NATIONAL LABORATORY \\ operated by \\ BATTELLE \\ for the \\ UNITED STATES DEPARTMENT OF ENERGY \\ under Contract DE-AC06-76RL01830
}

Printed in the United States of America
Available to DOE and DOE contractors from the
Office of Scientific and Technical Information,
P.O. Box 62, Oak Ridge, TN 37831-0062;
ph: (865) 576-8401
fax: $(865)$ 576-5728
email: reports@adonis.osti.gov

Available to the public from the National Technical Information Service, U.S. Department of Commerce, 5285 Port Royal Rd., Springfield, VA 22161

ph: (800) 553-6847

fax: (703) 605-6900

email: orders@ntis.fedworld.gov

online ordering: http://www.ntis.gov/ordering.htm

This document was printed on recycled paper. 


\section{U.S. Department of Energy Hanford Site \\ SEP $\quad 52002$}

02-CLO-0011

Addressees:

THE HANFORD SITE ENVIRONMENTAL REPORT FOR CALENDAR YEAR (CY) 2001 (PNNL-13910), RICHLAND, WASHINGTON, SEPTEMBER 2002

The Hanford Site Environmental Report is prepared and published annually by the U.S. Department of Energy (DOE) for distribution to local, state, and federal government agencies, Congress, the public, news media, and Hanford Site employees. The purpose of the report is to provide the reader with the most recent information available on Hanford Site environmental management activities and environmental compliance issues.

This report includes information for CY 2001 (including some early 2002 information) and contains sections summarizing the results of environmental monitoring efforts on and around the site, information on the Hanford Site's conformance to environmental permits, the status of the site's compliance with federal, state, and local regulations, and discusses important issues and actions.

The report was prepared for DOE by the Pacific Northwest National Laboratory (PNNL) with the support of other site contractors and describes programs conducted by PNNL, the research and development contractor; Fluor Hanford, Inc., the prime contractor for the nuclear legacy cleanup; Bechtel Hanford, Inc., the environmental restoration contractor; CH2M HILL Hanford Group, Inc., the contractor responsible for nuclear and chemical waste stored in Hanford's 177 underground storage tanks; Bechtel National, Inc., the contractor responsible for designing, building, and commissioning a waste treatment plant for vitrifying Hanford's tank waste; and MACTEC-ERS, a prime contractor to DOE's office in Grand Junction, Colorado, which is performing vadose zone work at Hanford; and numerous subcontractors at the Hanford Site.

If you have any questions or comments about this report, you may contact us, or Dana C. Ward, DOE Richland Operations Office, Closure Division, on (509) 372-1261 or by email at

Dana_C_Ward@rl.gov.

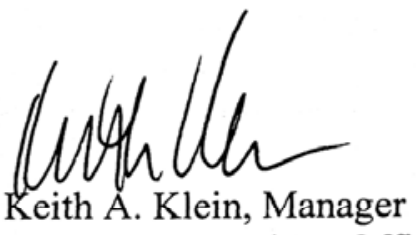

Richland Operations Office

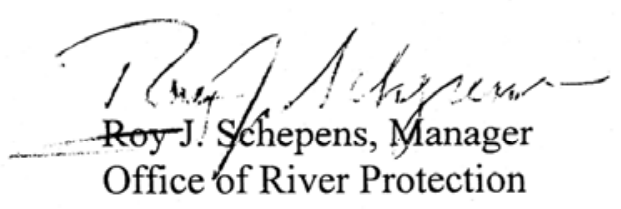

Attachment:

Hanford Site Environmental Report 


\section{Hanford Site Environmental Report for Calen dar Year 2001}

(Including some early 2002 information)

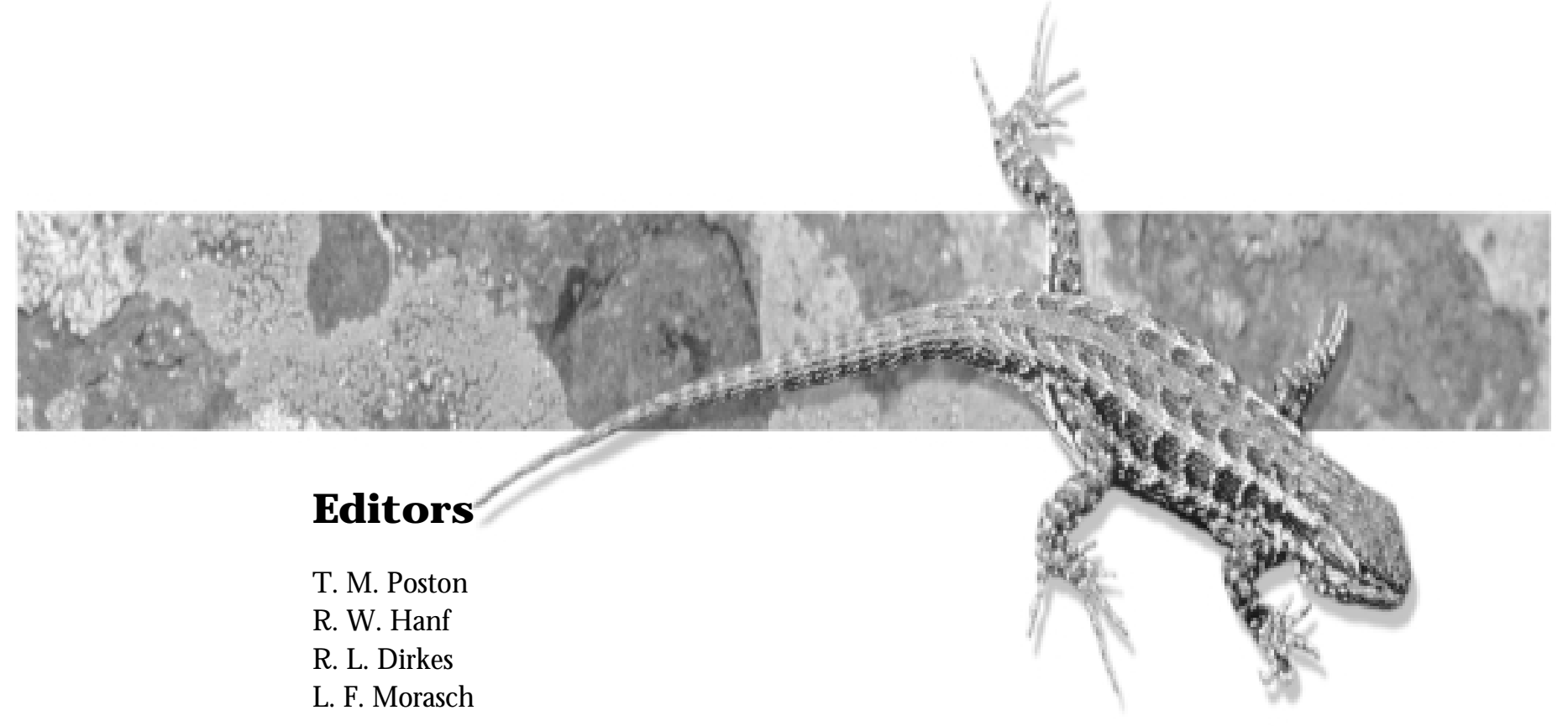

\section{Septem ber 2002}

Prepared for the U.S. Department of Energy by

Pacific $\mathrm{N}$ orthwest $\mathrm{N}$ ational Laboratory

under contract DE-A C 06-76R L01830, with

contributions from $\mathrm{CH} 2 \mathrm{M}$ HILL H anford G roup,

Inc.; M A CTEC-ERS; Fluor $\mathrm{H}$ anford, Inc. and

its subcontractors; Bechtel $\mathrm{N}$ ational, Inc.; and

Bechtel $\mathrm{H}$ anford, Inc. and its subcontractors

Pacific Northwest National Laboratory Richland,Washington 99352 


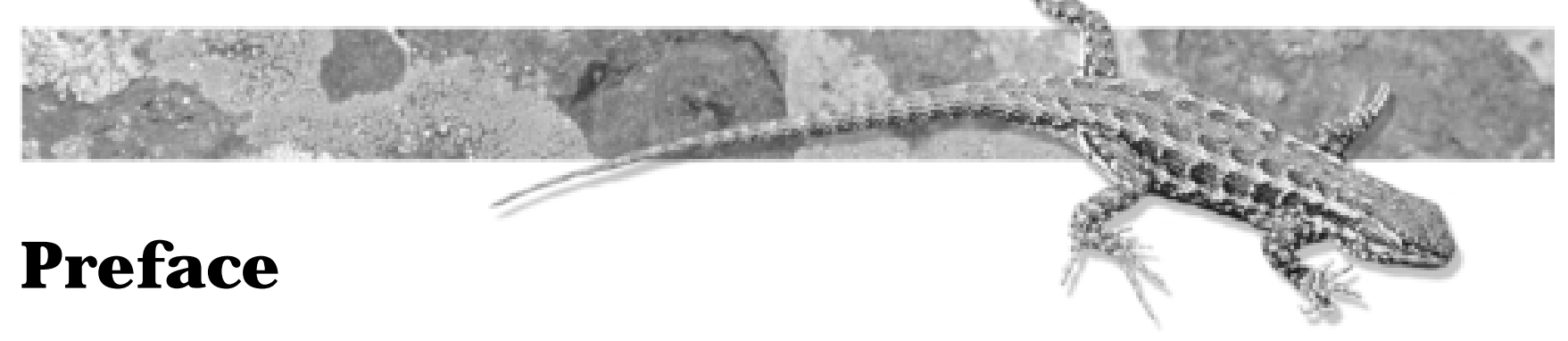

This Hanford Site environmental report is prepared annually pursuant to U.S. Department of Energy (DOE) Orders 5400.1, "General Environmental Protection Program" and 231.1, "Environment, Safety, and Health Reporting," and DOE M 231.1-1, Environment, Safety and Health Reporting Manual. The report is to provide an overview of activities at the site during 2001; to demonstrate the status of the site's compliance with applicable federal, state, and local environmental laws and regulations, executive orders, and DOE policies; and to summarize environmental data that characterize Hanford Site environmental management performance. The report also highlights significant environmental programs and efforts. Some historical and early 2002 information is included where appropriate. More detailed environmental compliance, monitoring, surveillance information may be of value; therefore, to the extent practical, additional pertinent reports have been referenced in the text.

Although this report was primarily written to meet DOE reporting requirements and guidelines, its purpose is to also provide useful summary information to members of the public, public officials, regulators, Hanford Site contractors, and elected representatives. Appendix A lists acronyms, abbreviations, unit conversion information, and nomenclature that may be useful for understanding the report.
The Pacific Northwest National Laboratory's Public Safety and Resource Protection Program produced this report for the DOE Richland Operations Office, Office of Site Services. Battelle operates the Pacific Northwest National Laboratory for DOE. Battelle is a not-for-profit, independent, contract research institute. Personnel from the Pacific Northwest National Laboratory and Fluor Hanford, Inc. and its subcontractors wrote major portions of the report. Bechtel National, Inc., CH2M HILL Hanford Group, Inc., MACTEC-ERS, and Bechtel Hanford, Inc. and its subcontractors also prepared or provided significant input to selected sections.

Copies of this report have been provided to many libraries in communities around the Hanford Site and to several university libraries in Washington and Oregon. Copies can also be found at the DOE's Reading Room located at the Consolidated Information Center in Richland, Washington. Copies of the report in electronic format (compact disk) can be obtained from Mr. R. W. (Bill) Hanf, Pacific Northwest National Laboratory, P.O. Box 999, Richland, Washington 99352 (bill.hanf@pnl.gov) while supplies last, or may be available for purchase from the National Technical Information Service, Springfield, Virginia 22161. Phone (703) 605-6000 or send an email request to http:// www.ntis.gov.

This report was issued in two hard-copy formats and two electronic formats. The hard-copy formats include this large technical report and a smaller, less detailed summary report consisting of approximately 50 pages (PN N L-13910-SUM). The electronic versions of both hard-copy formats a re available on the W orld W ide W eb at http:/ / hanford-site.pnl.gov/ envreport or http:/ / www.hanford.gov/ docs/ a nnualrp01/ ind ex.htm. The large report is also a vailable on a computer compact disk (CD) that conta ins copies of the Hanford Site Climatological Data Summary for 2001 with Historical Data (PN N L-13859), the Hanford Site Environmental Surveillance Data Report for Calendar Year 2001 (PN N L-13910, APP.1), the Hanford Site N ear-Facility Environmental M onitoring Data Report for Calendar Year 2001 (PN N L-13910, APP. 2), and the Hanford Site N ational Environmental Policy Act (N EPA) Characterization report (PN N L-6 415 ) as well.

0 ther environmental-related reports for the Hanford Site that may be of interest include Hanford Site Groundwater Monitoring for Fiscal Year 2001 (PN N L-13788), Calculating Potential-to-Emit Releases and Doses for FEM Ps and N OCS (HN F-3602), and Environmental Releases for Calendar Year 2001 (HN F-EP-0527-11).

Inquiries regarding this report or its companion documents should be directed to M r. D. C. (Dana) W ard, DO E Richland 0 perations 0 ffice, Closure Division, P.O . Box 550, M S A2-15, Richland, W ashington 99352 (Dana_C_W ard@rl.gov) or to Mr. T. M. (Ted) Poston, Pacific Northwest N ational Laboratory, P.O. Box 999, M S K6-75, Richland, W ashington 99352 (ted.poston@pnl.gov). 


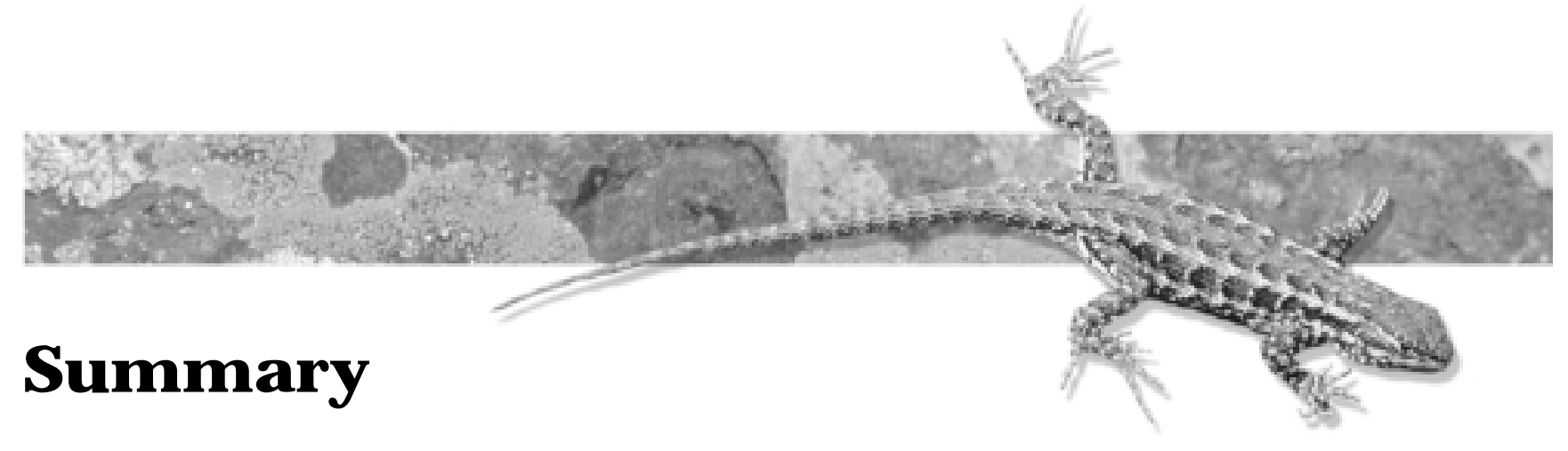

L. F. Morasch

Each year, the U.S. Department of Energy (DOE) publishes this integrated environmental report on the Hanford Site to summarize environmental data and information, describe environmental management performance, demonstrate the status of compliance with environmental regulations, and highlight major environmental programs and efforts. Individual sections of the report are designed to

- describe the Hanford Site and its mission

- summarize the status of compliance with environmental regulations

- describe the environmental programs at the Hanford Site
- discuss the estimated radiation exposure to the public from 2001 Hanford Site activities

- present effluent monitoring, environmental surveillance, and groundwater protection and monitoring information

- discuss activities to assure quality.

DOE's current primary mission at the Hanford Site includes cleaning up and shrinking the size of the site. It is the policy of DOE that all activities be carried out to comply with applicable federal, state, and local laws and regulations, DOE Orders, Secretary of Energy Notices, and directives, policies, and guidelines from DOE Headquarters and site operations.

\section{Compliance with Environmental Regulations in 2001}

A key element in Hanford's compliance program is the Tri-Party Agreement. The Tri-Party Agreement is an agreement among the Washington State Department of Ecology, U.S. Environmental Protection Agency (EPA), and DOE to achieve compliance with the remedial action provisions of the Comprehensive Environmental Response, Compensation, and Liability Act (CERCLA) and with treatment, storage, and disposal unit regulation and corrective action provisions of the Resource Conservation and Recovery Act (RCRA). In 2001, 39 of 41 specific TriParty Agreement cleanup milestones were completed on or before their required due dates. One milestone was delayed because of unanticipated costs and contracting issues, and one is expected to be completed under an agreement between DOE and the Washington State Department of Ecology.

Cleanup activities on the Hanford Site generate radioactive, mixed, and hazardous waste (Section 2.5). Mixed waste has both radioactive and hazardous non-radioactive substances. Hazardous waste contains either dangerous waste or extremely hazardous waste or both. This waste is handled and prepared for safe storage on the site or shipped to offsite facilities for treatment and disposal. In 2001, cleanup activities generated 328,500 kilograms (724,300 pounds) of solid mixed waste and 1.6 million kilograms (3.6 million pounds) of radioactive waste on the Hanford Site. There were 127,000 kilograms $(280,000$ pounds $)$ of mixed waste and 4.7 million kilograms ( 10.4 million pounds) of radioactive waste received at Hanford from offsite. During 2001 , a total of 59,000 kilograms $(130,000$ gallons) of hazardous waste was shipped off the Hanford Site. Liquid waste also was generated on the Hanford Site (Table 2.5.5). During 2001, there were 2.98 million liters (788,000 gallons) of waste added to the double-shell tanks; the total volume of liquid waste in the doubleshell tanks at the end of 2001 was 79.98 million liters (21.1 million gallons).

In addition to newly generated waste, significant quantities of legacy waste remain from years of nuclear material production and waste management activities. Most legacy waste from past operations at the Hanford Site resides in RCRA-compliant waste sites or is stored in several places awaiting cleanup and ultimate safe storage or disposal. Examples include high-level radioactive waste stored in single- and double-shell tanks and transuranic waste stored in vaults and on storage pads (see Section 2.5 for details). 
The site's compliance with federal acts in 2001 is summarized in Table S.1. For a detailed discussion of the site's compliance with environmental regulations during 2001, refer to Chapter 2 of this report.

Table S.1. Compliance with Federal Acts at the Hanford Site in 2001

\section{Regulation}

Comprehensive Environmental Response, Compensation, and Liability Act (CERC LA)

Emergency Planning and Community Right-to-Know Act

Resource Conservation and Recovery Act (RCRA)

Clean Air Act

Clean W ater Act

Safe Drinking Water Act

Toxic Substances Control Act

Federal Insecticide, Fungicide, and Rodenticide Act

Endangered Species Act

A merican Indian Religious Freedom Act, Antiquities Act, Archaeological and Historic Preservation Act, Archaeological Resources Protection Act, Historic Sites Buildings and Antiquities Act, $\mathrm{N}$ ational Historic Preservation $\mathrm{Act}$, and $\mathrm{N}$ ative American $\mathrm{G}$ raves Protection and Repatriation Act

$\mathrm{N}$ ational Environmental Policy Act Migratory Bird Treaty Act

\section{What it Covers}

Sites already conta minated by hazardous materials.

The public's right to information about hazardous chemicals in the community and establishes emergency planning procedures.

Hazardous waste being generated, transported, stored, treated, or disposed. The act primarily covers ongoing waste management at active facilities.

Air quality, including emissions from facilities and diffuse and unmonitored sources.

Discharges to U.S. waters.

Drinking water supplies operated by $D O E$.

Primarily chemicals called polychlorinated biphenyls.

Storage and use of pesticides.

Rare species of plants and animals.

Cultural resources.

Environmental impact statements for federal projects.

Migratory birds or their feathers, eggs, or nests.

\section{Status}

W ork on these sites followed CERC LA requirements and met the schedules established by the Tri-Party Agreement.

The Hanford Site met the reporting requirements contained in this act.

The W ashington State Department of Ecology identified two violations during 2001. Both violations were associated with chemical storage. DOE has implemented corrective action for one and has appealed the other. Resolution efforts are ongoing.

According to the W ashington State Department of Health, air emissions from Hanford Site facilities were well below state and federal standards. How ever, W ashington State Department of Health issued five notices of corrective action regarding stack emissions and corrective efforts are ongoing.

The Hanford Site had two N ational Pollutant Discharge Elimination System Permits and seven State W astewater Discharge Permits in 2001.

There were ten public water systems on the Hanford Site in 2001.

In 2001, DOE formed a team to resolve issues related to polychlorinated biphenyl issues on a sitewide basis at Hanford. The team created a users guide in 2001 to assure consistent interpretation and implementation of this act.

At the Hanford Site, pesticides are applied by licensed commercial pesticide operators.

Hanford activities followed the requirements of this act. The Hanford Site has eight plant species, two fish species, and five bird species on the federal or state list of threatened or endangered species.

0 ne hundred fifty cultural resources reviews were conducted on the Hanford Site.

Environmental impact statements and environmental assessments were prepared or conducted as needed.

Hanford activities used the ecological review process as needed to minimize any adverse effects to migratory birds. There are over 100 species of birds that occur on the Hanford Site that are protected by this act. 


\section{Environmental Occurrences}

Environmental releases of radioactive and regulated materials from the Hanford Site are reported to DOE and other federal and state agencies as required by law. The specific agencies notified depend on the type, amount, and location of the individual occurrence. The Hanford Site Occurrence Notification Center maintains both a computer database and a hardcopy file of event descriptions and corrective actions.

During 2001, there were no environmentally significant emergency occurrence reports filed. There was one environmentally significant unusual occurrence report filed in 2001. In May 2001, a subcontractor working at the 600-23 burial ground unearthed an unknown piece of equipment with a liquid reservoir. Approximately 38 liters (10 gallons) of an oily substance had leaked from this reservoir into the ground. Laboratory analysis revealed the presence of polychlorinated biphenyls in the spilled substance. The spill was entirely contained, and the equipment and contaminated soil were disposed of at the Environmental Restoration Disposal Facility.

Off-normal occurrences are discussed in Sections 2.2 and 2.4.

\section{Environmental Monitoring}

Environmental monitoring at the Hanford Site includes near-facility environmental monitoring, surface environmental surveillance, groundwater monitoring, and vadose zone monitoring. Near-facility monitoring includes the analysis of environmental samples collected near major nuclear-related installations, waste storage and disposal units, and remediation sites. Surface environmental surveillance consists of sampling and analyzing various media on and around the site (including the Columbia River) to detect potential contaminants and to assess their significance to environmental and human health. Groundwater sampling is conducted on the site to determine the distribution of radiological and chemical constituents in groundwater. The strategy for managing and protecting groundwater resources at the Hanford Site focuses on protection of the Columbia River, human health, the environment, treatment of groundwater contamination, and limitation of groundwater migration (Section 6.0). Vadose monitoring was conducted to better understand and alleviate the spread of subsurface contamination (Section 7.2).

The overall objectives of these monitoring and surveillance programs are to demonstrate compliance with applicable federal, state, and local regulations; confirm adherence to DOE environmental protection policies; and support environmental management decisions.

Environmental monitoring and surveillance results for 2001 are summarized in Table S.2. For detailed discussions of results, refer to the appropriate sections of this report.

\section{Facility Effluent Monitoring}

Liquid and airborne effluents that may contain radioactive or hazardous constituents are continually monitored when released to the environment at the Hanford Site. Facility operators perform the monitoring mainly through analyzing samples collected at points of release into the environment. Effluent monitoring data are evaluated to determine the degree of regulatory compliance for each facility and/or the entire site. The evaluations are also useful to assess the effectiveness of effluent treatment and pollution-management practices.

In 2001, only facilities in the 200 Areas discharged radioactive liquid effluents to the ground, which went to the State-Approved Land Disposal Site (Section 3.1.3). Radioactive air emissions usually come from a building stack or a vent. Radioactive emission discharge points are located in the 100, 200, 300, and 400 Areas. Table 3.1.1 of this document provides a summary of radionuclides discharged to the atmosphere at the Hanford Site in 2001. Non-radioactive air pollutants from such things as diesel-powered electrical generating plants were monitored. In 2001, the 200 Areas tank farms produced reportable ammonia emissions that are summarized in Table 3.1.2 of this document. 
Table S.2. Hanford Site Monitoring Results for 2001

\section{What was Monitored?}

Air

Columbia River W ater

Columbia River Shoreline Springs

Groundwater

Vadose Zone

Drinking W ater

Food and Farm Products

Fish and W ildlife

Effluent M onitoring

Soil and Vegetation
Air sampling equipment collected particles and gases, which were analyzed for radioactive materials. Air was sampled at 24 locations on Hanford, 11 perimeter locations, 8 nearby communities, and 2 distant communities.

Columbia River water was collected from 56 sampling points throughout the year. W ater samples were analyzed for radioactive and chemical materials. Water in the Columbia River continues to be designated Class A (Excellent) by the state of W ashington. This designation means that the water is usable for substantially all needs.

Groundwater discharges to the Columbia River via surface and subsurface locations. Discharges above the water level of the river are identified as riverbank springs. Samples of spring water were collected at 10 locations along the Columbia River shoreline.

$G$ roundwater samples were collected from 694 wells to analyze water quality. W ater levels were measured in several hundred wells on the site to map groundwater movement.

The vadose zone is the region between the ground surface and the top of the water table. Vadose zone characterization and monitoring are conducted to better understand and alleviate the spread of subsurface contamination.

The quality of the drinking water supplied by ten DOE-owned systems on the Hanford Site was analyzed.

Samples of alfalfa, grapes, leafy vegetables, milk, potatoes, tomatoes, and wine were collected from 20 locations around the Hanford Site.

G ame animals on the site and along the Hanford Reach and fish from the Columbia River were monitored at six locations. Carcass, bone, and muscle samples were analyzed to evaluate radionuclide levels.

Liquid effluents and airborne emissions that may contain radioactive or hazardous constituents are continually monitored on the Hanford Site.

Samples of soil and perennial vegetation were collected at onsite, perimeter, and distant locations. Thirty-eight soil samples and 13 vegetation samples were collected.

\section{The Bottom line}

All measurements of radioactive materials in air were below recommended guidelines.

As in past years, small amounts of radioactive materials were detected downriver from Hanford. However, the amounts were all far below federal and state limits. During 2001, there was no indication of any deterioration of Columbia River water quality resulting from site operations along the Hanford Reach.

Samples collected at the springs contained contaminants at levels above drinking water standards. However, concentrations in river water downstream of the shoreline springs remained far below federal and state limits.

Groundwater monitoring is focused on preventing the spread of contamination. Samples show that groundwater contaminant plumes are moving slowly from beneath former waste sites toward the Columbia River. Contaminant concentrations are declining in the largest plumes because of spreading and radioactive decay.

Vadose zone characterization was conducted at three sites in the 200 A reas, one site in the 100 Area, and one site in the 600 Area. Vadose zone monitoring occurred at four sites in 2001 . Technical demonstrations are designed to result in new, innovative methods for environmental monitoring and cleanup on the Hanford Site. In 2001 , six technical studies were conducted.

All DO E-owned drinking water systems on the Hanford Site met $W$ ashington State and EPA regulations. The annual average concentrations of radiological contaminants in all samples were below state and federal standards.

Radionuclide levels in samples of food and farm products were at normal environmental levels.

Samples of whitefish, rabbits, and Canada geese were collected and analyzed. Strontium-90 in the bones of rabbits onsite were above analytical detection limits. Radionuclide levels in edible tissues were all below analytical detection limits.

Some quantities of radionuclides were released to the environment at state and federally permitted release points. Tritium above natural background levels is released to the ground at the State-Approved Land Disposal facility in the 200 A reas under a state-approved discharge permit.

Some radionuclides were detected, but the concentrations were below dose-based reporting levels. 


\section{Waste Site Rem ediation}

Full-scale remediation of waste sites began in the 100 Areas in 1996 and continued in 2001 at several liquid waste disposal sites in the 100-B/C, 100-F, and 100-H Areas (Section 2.3.10.2). Remediation of the treatment, storage, and disposal units at the 100-N Area continued also. In 2001, the following activities were completed:

- 100-B/C Area - 110,000 metric tons (121,000 tons) of contaminated soil were removed and shipped to the Environmental Restoration Disposal Facility in 2001; a total of 732,000 metric tons ( 86,000 tons) has been removed since startup.

- 100-H Area - 136 metric tons (150 tons) of contaminated soil were removed and shipped to the Environmental Restoration Disposal Facility in 2001; a total of 413,000 metric tons (455,000 tons) has been removed since startup.

- 100-F Area - 321,000 metric tons (353,000 tons) of contaminated soil were removed and shipped to the Environmental Restoration Disposal Facility in 2001; a total of 470,000 metric tons $(517,000$ tons) has been removed since startup.

- $100-\mathrm{N}$ Area - a total of 112,200 metric tons $(123,500$ tons) of contaminated soil have been removed and shipped to the Environmental Restoration Disposal Facility since startup.

In 2001, remedial design for nine burial sites in the 100-B/C began. Decontamination and decommissioning activities continued in 2001 at the 100-D/DR, 100-H, and 100-F Areas. These activities are conducted to support the interim safe storage of the four reactor buildings for up to 75 years. The interim safe storage minimizes the potential risk to the environment, employees, and the public and reduces surveillance and maintenance costs. These activities are conducted as non-time-critical actions under CERCLA.

The environmental restoration contractor completed the final feasibility study for the Canyon Disposition Initiative in September 2001 and was in the final planning phase of the CERCLA remedial investigation/ feasibility study. The purpose of this initiative is to investigate the potential for using the five canyon buildings at the Hanford Site as disposal facilities for remediation waste, rather than demolishing the structures. This final feasibility study is a strategic document for decision-making affecting the future of the Hanford Site.

Remedial investigation/feasibility studies continued in 2001 at soil waste sites in the 200 Areas. The work at these operable units included feasibility studies, characterization, work plans, geophysical logging, and monitoring of ongoing remediation efforts.

Remediation work at the 300-FF-1 Operable Unit continued. With the exception of the 618-4 burial ground, excavation of all 300-FF-1 Operable Unit waste sites has been completed and more than 482,000 metric tons (531,000 tons) of contaminated material and debris have been taken to the Environmental Restoration Disposal Facility. Excavation is scheduled to be completed in 2002.

During 2001, activities continued across the Hanford Site to clean up waste from past practices. The activities are guided by the Tri-Party Agreement, an agreement to achieve compliance with CERCLA remedial action provisions and with RCRA treatment, storage and disposal unit regulations and corrective action provisions. Many programs are an integral part of Hanford cleanup.

Pollution Prevention Program. This program (Section 2.3.1) focuses on conservation of resources and energy, reduction of hazardous substance use, and prevention or minimization of pollutant releases. In 2001, the efforts of the program reduced the quantity of disposed waste by recycling 32,405 cubic meters (1.1 million cubic feet) of radioactive and mixed waste, 33,387 metric tons $(36,803$ tons) of RCRA hazardous waste, and 3,428 metric tons (3,779 tons) of sanitary waste. The cost savings for waste disposal in 2001 exceeded $\$ 23$ million for these activities. During 2001, the Hanford Site also recycled 673 metric tons ( 742 tons) of paper products and 708 metric tons ( 780 tons) of various metals.

Spent N uclear Fuel Project. This project (Section 2.3.2) provides safe, economic, and environmentally sound management of Hanford spent nuclear fuel and prepares the fuel for long-term storage. In 2001, the project installed two new underwater tables to increase productivity in the K-West Basin, fabricated 330 fuel baskets to hold spent nuclear fuel prior to loading the fuel into canister overpacks, removed 38 overpacks from the K Basins to the Canister Storage Building, and started construction at the $\mathrm{K}$ Basins to make the modifications necessary to transfer the spent nuclear fuel in K-East Basin to the K-West Basin.

River Corridor Project. This project (Section 2.3.3) provides for deactivation of contaminated facilities in all areas of the Hanford Site and for safe storage of nuclear fuel until it can be transferred to 
another facility, sold, or otherwise disposed. The River Corridor Project includes the Accelerated Deactivation Project, 324 and 327 Facilities Deactivation Project, 300 Area Liquid Effluent Facilities, Plutonium Finishing Plant, Waste Encapsulation and Storage and Facility Project, and the Equipment Disposition Project.

Advanced Reactors Transition Project. The mission of this project (Section 2.3.5) is to transition or convert the Plutonium Recycle Test Reactor facility, and facilities used for nuclear research, into structures that are in a safe and stable condition suitable for reuse or low cost surveillance and maintenance. The only facilities remaining to be cleaned up are in the southeastern part of the 300 Area, the high bay of the 337 Building, and the adjacent storage tank building, 3718M.

Office of River Protection. The Office of River Protection is responsible for managing DOE's River Protection Project, which is responsible for storage, retrieval, treatment, and disposal of high-level tank waste and closure of the tank farms on the Hanford Site (Section 2.3.6). The status of 177 waste tanks on the
Hanford Site was reported in Waste Tank Summary Report for Month Ending December 31, 2001.

Safety issues are of utmost concern, and Hanford tanks containing high-level waste were organized into categories in the 1990s to assure increased monitoring. Tanks that were assumed to be leaking were placed on a "Tank Watch List." There are 149 single-shell tanks and 28 double-shell tanks. The total estimated volume to date of radioactive waste leakage from single-shell tanks is $<2.84$ to 3.97 million liters $(<749,760$ to 1 million gallons). To date, 129 of the 149 single-shell tanks have been stabilized and the program is ahead of schedule. At the end of 2001, intrusion prevention work was completed on 108 single-shell tanks, and all the tanks were removed from the Tank Watch List.

The first 14 tanks that will deliver waste to the planned Waste Treatment Facility (i.e., vitrification plant) have been selected. Sampling has been performed in 12 of these tanks and characterization has been completed on 11 of them. This characterization information is being used to improve the design and future

Table S.3. Summary of G roundwater Pump-and-Treat Systems and a Soil-Vapor Extraction System

\begin{tabular}{|c|c|c|c|c|}
\hline Location & $\begin{array}{l}\text { Startup } \\
\text { Date }\end{array}$ & Contaminant & $\begin{array}{c}\text { Mass Removed } \\
\text { (Groundwater Processed) } \\
\text { in } 2001\end{array}$ & $\begin{array}{c}\text { Mass Removed } \\
\text { (Groundwater Processed) } \\
\text { Since Startup }\end{array}$ \\
\hline \multicolumn{5}{|c|}{ Groundwater Pump-and-Treat Systems } \\
\hline 100-D Area & 1997 & Hexavalent chromium & $\begin{array}{c}20.5 \text { kilograms } \\
\text { (96.7 million liters) }\end{array}$ & $\begin{array}{l}101.9 \text { kilograms } \\
\text { (550 million liters) }\end{array}$ \\
\hline 100-H Area & 1997 & Hexavalent chromium & $\begin{array}{c}5.8 \text { kilograms } \\
\text { (125.9 million liters) }\end{array}$ & $\begin{array}{c}27.5 \text { kilograms } \\
\text { (631.3 million liters) }\end{array}$ \\
\hline 100-K A rea & 1997 & Hexavalent chromium & $\begin{array}{c}36.2 \text { kilograms } \\
\text { (338.8 million liters) }\end{array}$ & $\begin{array}{l}148.3 \text { kilograms } \\
\text { (1.24 billion liters) }\end{array}$ \\
\hline $100-\mathrm{N}$ Area & 1995 & Strontium-90 & $\begin{array}{c}0.18 \text { curies } \\
\text { (114.7 million liters) }\end{array}$ & $\begin{array}{c}1.1 \text { curies } \\
\text { (666.5 million liters) }\end{array}$ \\
\hline $\begin{array}{l}200-\text { W est A rea } \\
(200-Z P-1) \\
\text { O perable Unit }\end{array}$ & 1994 & Carbon tetrachloride & $\begin{array}{l}\text { 1,177 kilograms } \\
\text { (326 million liters) }\end{array}$ & $\begin{array}{l}6,084 \text { kilograms } \\
\text { (1.67 billion liters) }\end{array}$ \\
\hline \multirow{4}{*}{$\begin{array}{l}200 \text {-W est A rea } \\
(200-U P-1) \\
\text { O perable Unit }\end{array}$} & 1994 & Carbon tetrachloride & $\begin{array}{l}2.41 \text { kilograms } \\
\text { (98.2 million liters) }\end{array}$ & $\begin{array}{c}20,615 \text { grams } \\
\text { (554.5 million liters) }\end{array}$ \\
\hline & 1994 & $\mathrm{~N}$ itrate & $\begin{array}{l}3,540 \text { kilograms } \\
\text { (98.2 million liters) }\end{array}$ & $\begin{array}{c}20,487 \text { kilograms } \\
\text { (554.5 million liters) }\end{array}$ \\
\hline & 1994 & Technetium-99 & $\begin{array}{c}8.3 \text { grams } \\
\text { (98.2 million liters) }\end{array}$ & $\begin{array}{c}78.56 \text { grams } \\
\text { (554.5 million liters) }\end{array}$ \\
\hline & 1994 & Uranium & $\begin{array}{l}15.5 \text { kilograms } \\
\text { (98.2 million liters) }\end{array}$ & $\begin{array}{c}136,740 \text { grams } \\
\text { (554.5 million liters) }\end{array}$ \\
\hline
\end{tabular}

Soil-Vapor Extraction

200-West Area $\quad 1992$ Carbon tetrachloride 710 kilograms $\quad 77,170$ kilograms




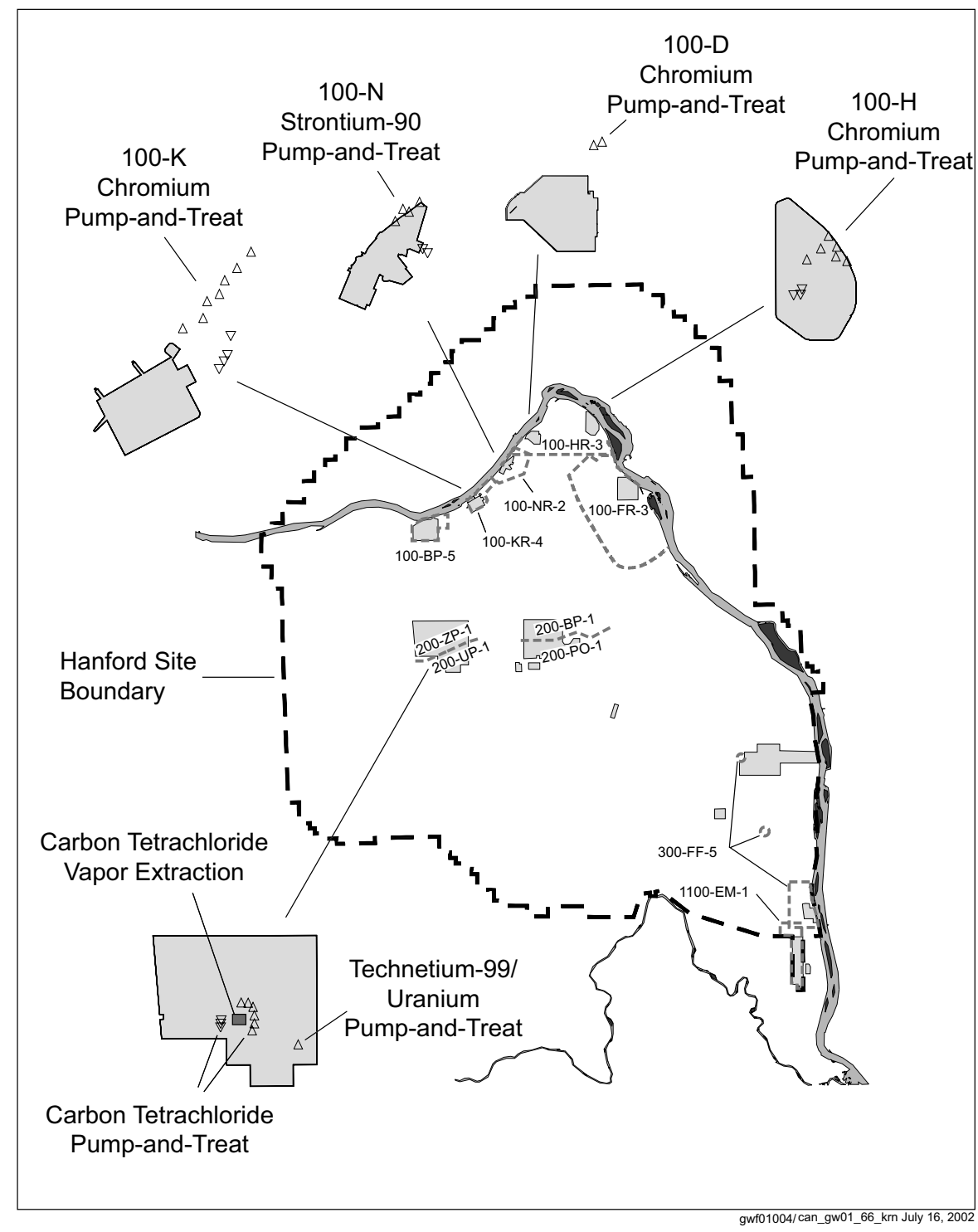

Figure S.1. DOE Pump-and-Treat Systems and Soil-Vapor Extraction System

operation of the Waste Treatment Facility. During 2001, an electrical substation, potable water services, effluent piping systems, and roads were completed for the Waste Treatment Plant. Construction of the plant as defined by the Tri-Party Agreement is scheduled to begin in 2002 .

Solid Waste Management. Solid waste management at the Hanford Site included the treatment, storage, and disposal of solid waste at many Hanford locations (Section 2.3.7). During 2001, 460 cubic meters (16,245 cubic feet) of low-level mixed waste were treated and/or directly disposed onsite. Eight packages containing defueled reactor compartments from the U.S. Navy were received and disposed of at the 200-East Area in 2001.

Liquid Effluent Treatment. Liquid effluents are managed in facilities that comply with RCRA and state regulations (Section 2.3.8). Approximately 32.7 million liters (8.6 million gallons) of liquid waste were stored at the Liquid Effluent Retention Facility and 95 million liters ( 25.1 million gallons) of liquid waste were treated at the 200 Area Effluent Treatment Facility in 2001. The 200 Area Treated Effluent Disposal Facility received $\sim 484$ million liters ( $\sim 128$ million gallons) of effluent in 2001.

Groundwater/N adoseZone Integration Project. The Groundwater/Vadose Zone Integration Project (Section 2.3.11) brings together all activities that affect Hanford's subsurface. Restoring the condition of the groundwater under the Hanford Site is a major focus of the Groundwater/Vadose Zone Integration Project. The goal of groundwater restoration is to prevent contaminants from entering the Columbia River, reduce the contamination in areas of high concentration, prevent 
the movement of contamination, and protect human health and the environment. Table S.3 lists a summary of the activities in 2001. Figure S.1 shows the location of groundwater remediation systems.

Revegetation and Mitigation Planning. During 2001, 50 hectares (123.5 acres) in the 100 Areas were planted with native grass and forb seed (Section 2.3.9). Following the seeding, 21,700 sagebrush seedlings were planted. In addition, the wetland habitat in the 100-B/C Area was planted to help restoration of the pit there. Two sites in the 600 Area were revegetated; 900 sagebrush seedlings were planted on the Wahluke North Slope; 50 bitterbrush seedlings were planted at the 618-4 burial ground; and the area around the electrical line towers in the 200-East Area was revegetated. Monitoring the sagebrush seedlings that were planted in December 2000 on the Fitzner/Eberhardt Arid Lands Ecology Reserve continued in 2001; this monitoring will continue through 2004.

\section{Potential Radiological Doses from 2001Hanford Operations}

During 2001, potential radiological doses to the public and biota from Hanford operations were evaluated to determine compliance with pertinent regulations and limits (Section 5.0). These doses were calculated using reported effluent releases and environmental surveillance data using version 1.485 GENII computer code and Hanford-specific parameters. The potential dose to the maximally exposed individual in 2001 from site operations was $0.009 \mathrm{mrem}\left(9 \times 10^{-5} \mathrm{mSv} / \mathrm{yr}\right)$. To put this value into perspective, the national average dose from background sources (Figure S.2), according to the National Council on Radiation Protection, is $\sim 300 \mathrm{mrem} / \mathrm{yr}(3 \mathrm{mSv} / \mathrm{yr})$, and the current DOE radiological dose limit for a member of the public is $100 \mathrm{mrem} / \mathrm{yr}$ $(1 \mathrm{mSv} / \mathrm{yr})$.

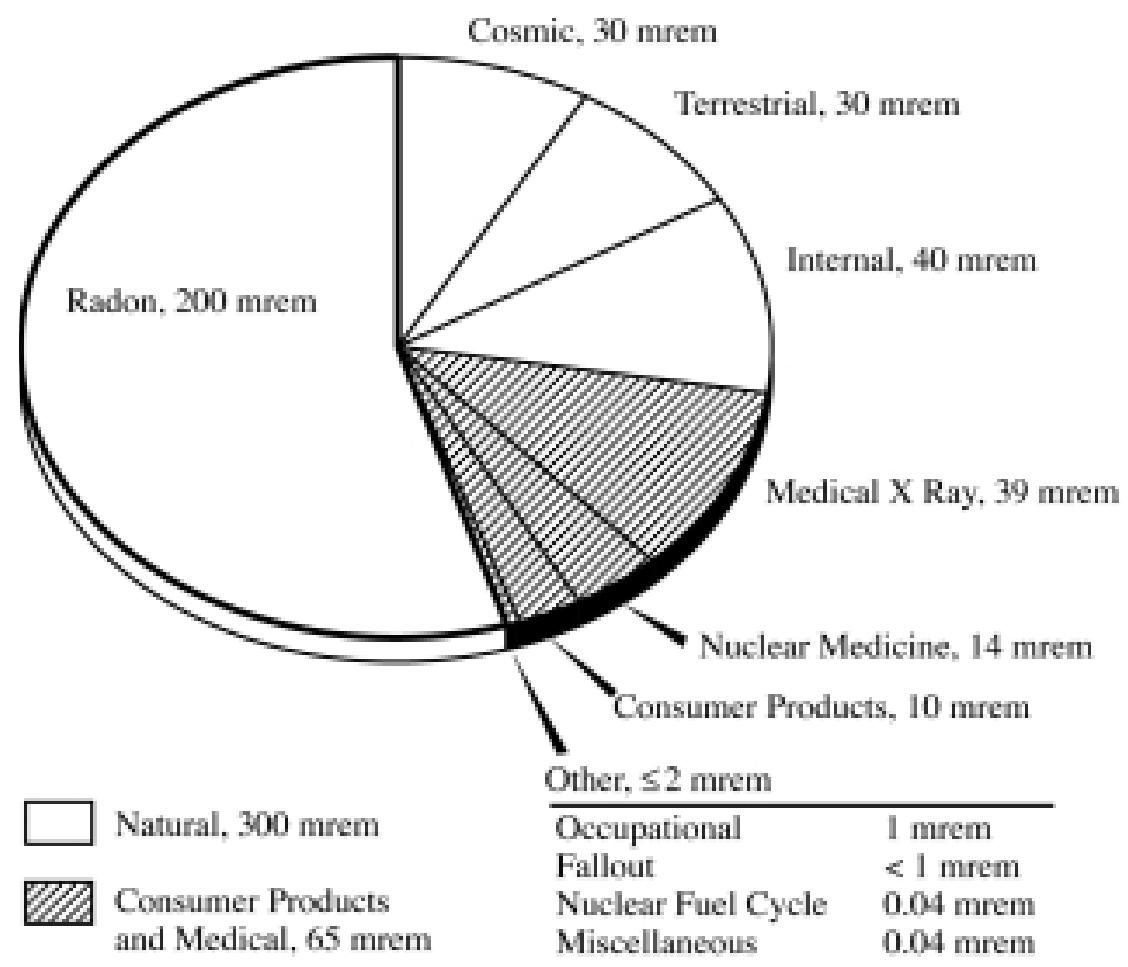

G01020114.97

Figure S.2. National Annual Average Radiological Doses from Various Sources (National Council on Radiation Protection and Measurements 1987) 


\section{Other Hanford Environ mental Programs}

\section{Clim ate and Meteorology}

Meteorological measurements are taken to support Hanford Site emergency preparedness, site operations, and atmospheric dispersion calculations. Weather forecasting and maintenance and distribution of climatological data are provided. The data are provided by the Hanford Meteorology Station, which is located on the Central Plateau. A complete report of climatological data for calendar year 2001 is contained in Hanford Site Climatological Data Summary 2001 with Historical Data.

\section{Cultural Resources}

Management of archaeological, historical, and traditional cultural resources at the Hanford Site complies with the requirements of various federal laws. During 2001, 150 cultural resource reviews were requested and conducted on the Hanford Site to comply with Section 106 of the National Historic Preservation Act.

Monitoring conducted during 2001 focused on four sites: Locke Island erosion, archaeological sites affected by visitors or nature, historic buildings, and places with Native American burials. A total of 86 archaeological sites, 3 buildings, and cemetery or burial locations were monitoring during 2001.

Public involvement is an important component of cultural resource management. To accomplish this goal, DOE developed mechanisms that allow the public access to cultural resources information and the ability to comment and make recommendations concerning the management of cultural resources on the Hanford Site. Native American involvement included the completion of several surveys, construction monitoring, and monthly meetings on cultural resource issues.

\section{Comm unity Operated Surveillance Program}

This program was initiated in 1990 to increase the public's involvement in and awareness of Hanford's surveillance program. During 2001, nine radiological air sampling stations were operated by local teachers at selected locations around the site perimeter.

\section{Quality Assurance}

Comprehensive quality assurance programs, which include various quality control practices and methods to verify data, are maintained to ensure data quality. The programs are implemented through quality assurance plans designed to meet requirements of the American National Standards Institute/American Society of Mechanical Engineers and DOE Orders. Quality assurance plans are maintained for all activities, and auditors verify conformance. Quality control methods include, but are not limited to, replicate sampling and analysis, analysis of field blanks and blind reference standards, participation in interlaboratory crosscheck studies, and splitting samples with other laboratories. Sample collection and laboratory analyses are conducted using documented and approved procedures. When sample results are received, they are screened for anomalous values by comparing them to recent results and historical data. Analytical laboratory performance on the submitted double blind samples, the EPA Laboratory Intercomparison Studies Program, and the national DOE Quality Assessment Program indicated that laboratory performance was adequate overall, was excellent in some areas, and needed improvement in others. 


\section{Acknow ledgments}

The production of this report was managed by the Pacific Northwest National Laboratory's Public Safety and Resource Protection Program under the direction of R. L. Dirkes.

Community-operated environmental surveillance stations were managed by local teachers who were responsible for collecting the samples and maintaining the stations. The managers and alternate managers for each station included the following:

Leslie Groves Park, Richland: C. A. Wagner, Manager, and D. R. Johns, Alternate Manager

Basin City Elementary School, Basin City: C. L. Stevenson, Manager, and K. McEachen, Alternate Manager

Edwin Markham Elementary School, North Franklin County: M. P. Madison, Manager, and K. A. Thomas, Alternate Manager

Kennewick: T. Droppo, Manager, and C. ZwienerThomas, Alternate Manager

Kiona-Benton High School, Benton City: A. J. Williamson, Manager, and K. Jones, Alternate Manager.

Mattawa: D. Weberling, Manager, and T. Lyall, Alternate Manager

Othello: J. Oord, Manager, and B. Taylor, Alternate Manager

Columbia Basin College, Pasco: L. DeWitt, Manager, and J. O’Neill, Alternate Manager
Heritage College, Toppenish: R. A. Landvoy, Manager, and D. F. Brown and Holli Ferguson, Alternate Managers.

The authors appreciate the comprehensive reviews of the draft report by A. L. Bunn, T. J Gilmore, and K. R. Price (Pacific Northwest National Laboratory).

A DOE review of the compliance sections was coordinated by P. J. Krupin, and conducted by T. L. Aldridge, G. D. Baston, G. M. Bell, R. M. Carosino, B. L. Charboneau, S. E. Clarke, K. V. Clarke, P.F.X. Dunigan, Jr., B. L. Foley, R. F. Guercia, J. B. Hall, D. R. Hildebrand, G. M. Neath, D. W. Lloyd, Y. T. Sherman, A. E. Teimouri, K. M. Thompson, and B. D. Williamson.

The report was prepared by Pacific Northwest National Laboratory staff: L. F. Morasch, text editor, and K. R. Neiderhiser, text processor. The index was prepared by K. L. Manke. Graphics were prepared by D. L. Liddell (Lockheed Martin Services, Inc.), M. A. Chamness, C. A. Newbill, D. C. Lanigan, J. T. Rieger, W. D. Webber, and R. K. Zufelt (Pacific Northwest National Laboratory), P. Call (U.S. Fish and Wildlife Service), and Hanford Site Central Mapping Services. J. Winslow (WinSome Design, Richland, Washington) designed the report cover and layout. Duplicating and printing arrangements were managed by S. J. Kophs, who was supported by G. A. Rowlette and M. I. Barrera. This report was produced using Adobe ${ }^{\circledR}$ PageMaker and formatted for the Internet by J. C. Melland and others in Pacific Northwest National Laboratory's Scientific and Technical Information Department. 


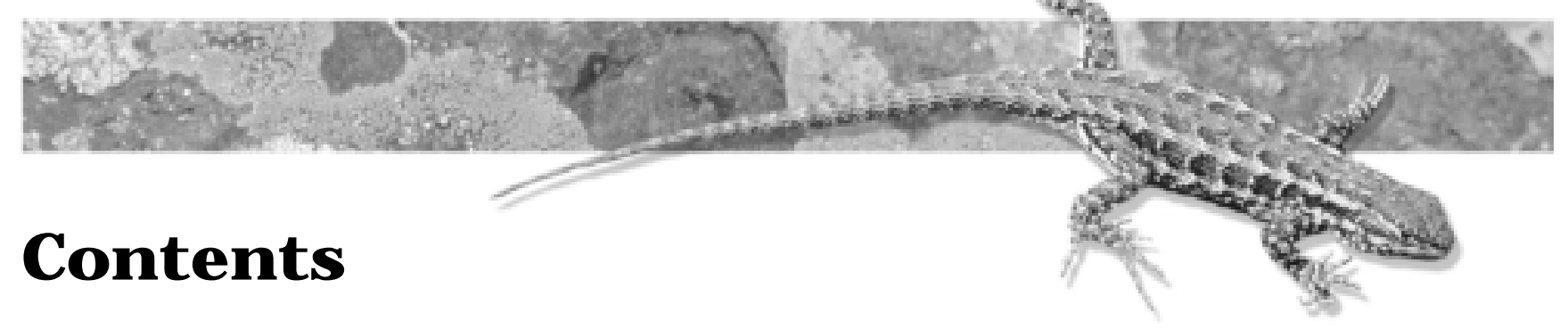

Preface iii

Summary .

Acknowledgments.

$\mathrm{xv}$

1.0 Introduction

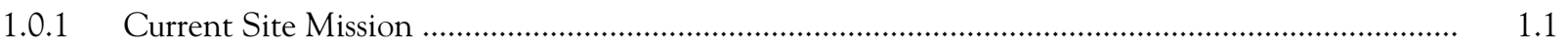

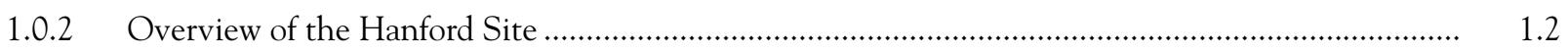

1.0.3 Site Management ..................................................................................................

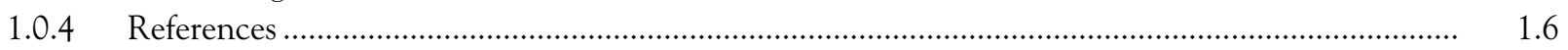

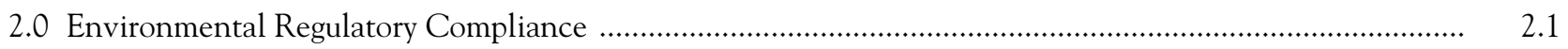

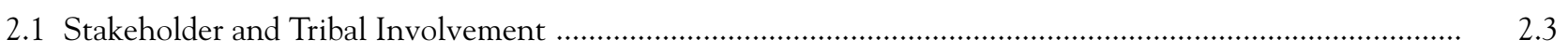

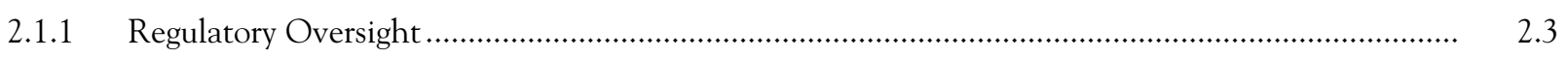

2.1.2 Hanford Federal Facility Agreement and Consent Order ........................................................... 2.3

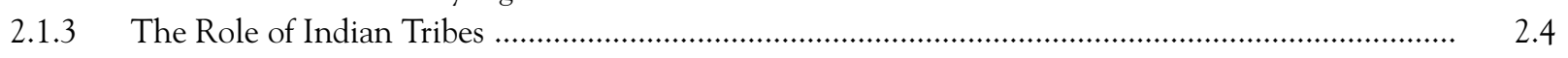

2.1.4 Hanford Natural Resource Trustee Council ............................................................................ 2.5

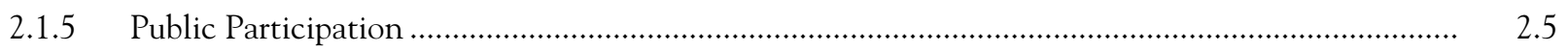

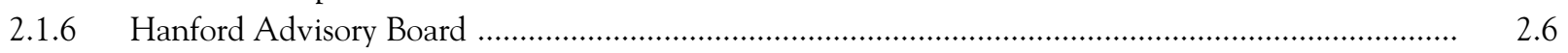

2.1.7 Hanford Site Technology Coordination Group ..................................................................... 2.6

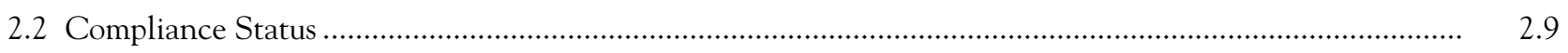

2.2.1 Hanford Federal Facility Agreement and Consent Order ......................................................... 2.9

2.2.1.1 Tri-Party Agreement Highlights ................................................................................... 2.9

2.2.1.2 Tri-Party Agreement Negotiated Change Requests ................................................... 2.11

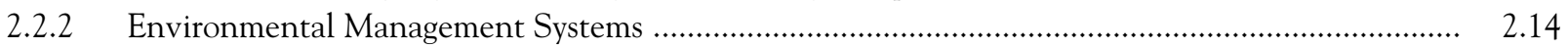

2.2.3 Chemical Management Systems ......................................................................................... 2.14

2.2.4 Comprehensive Environmental Response, Compensation, and Liability Act............................. 2.14

2.2.5 Emergency Planning and Community Right-To-Know Act .................................................... 2.15

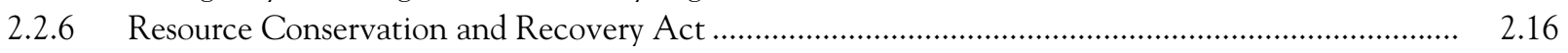

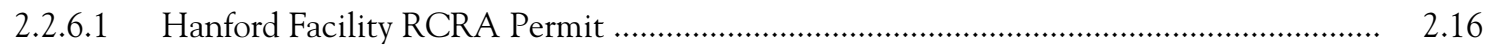

2.2.6.2 RCRA/Dangerous Waste Permit Applications and Closure Plans .................................. 2.16

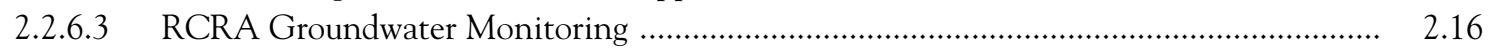

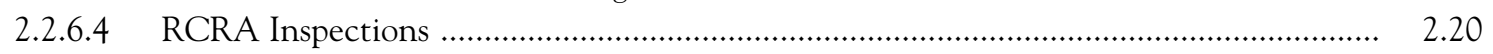

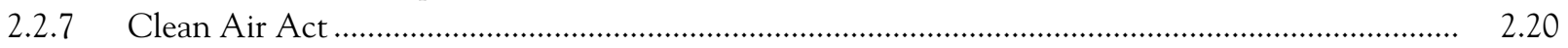

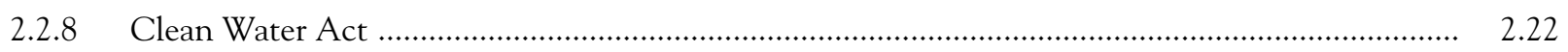

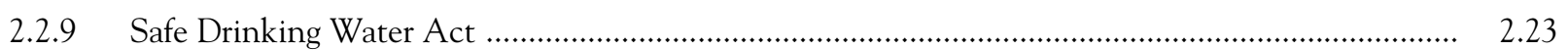

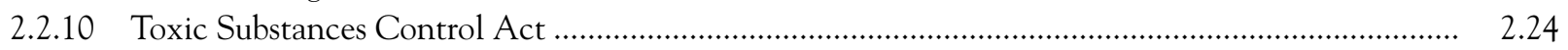

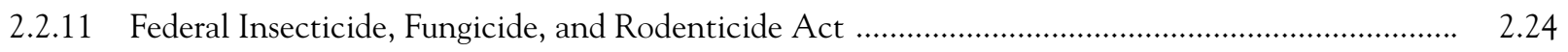

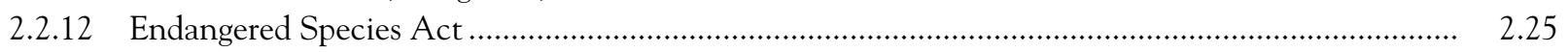

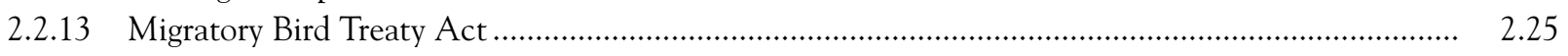

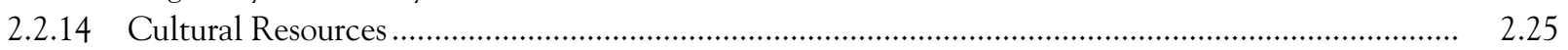




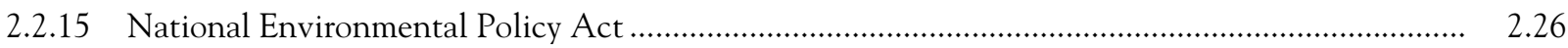

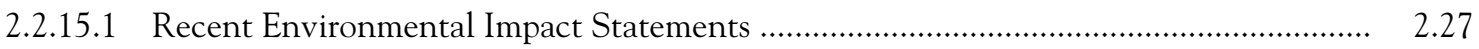

2.2.15.2 Programmatic and Offsite Environmental Impact Statements ..................................... 2.27

2.2.15.3 Site-Specific Environmental Impact Statements in Progress ....................................... 2.27

2.2.15.4 Recent Environmental Assessments ........................................................................... 2.28

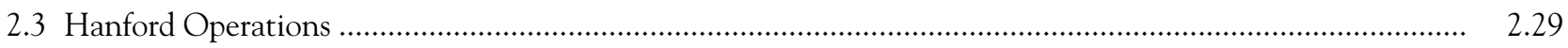

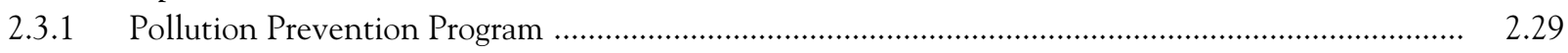

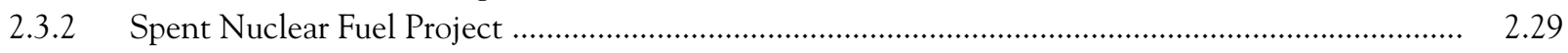

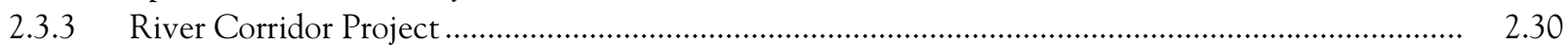

2.3.3.1 Accelerated Deactivation Project .............................................................................. 2.31

2.3.3.2 324 and 327 Facilities Deactivation Project ............................................................... 2.31

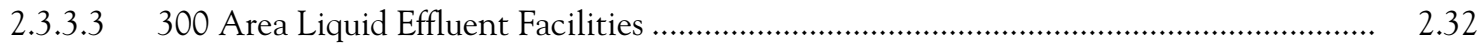

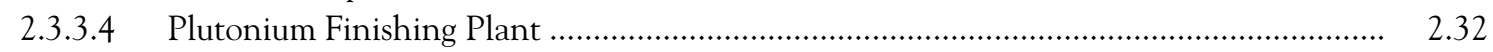

2.3.3.5 Waste Encapsulation and Storage Facility Project ....................................................... 2.33

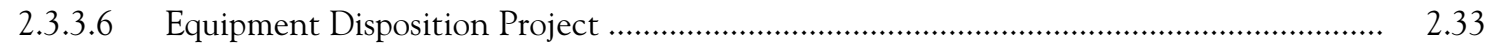

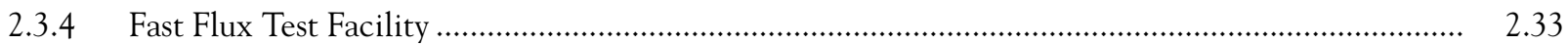

2.3.5 Advanced Reactors Transition Project ……............................................................... $\quad 2.34$

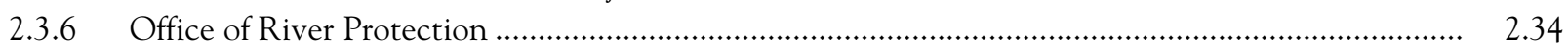

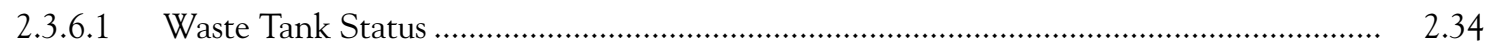

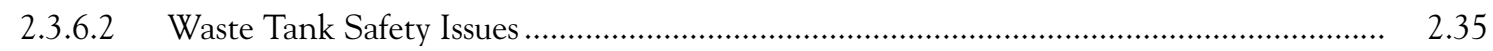

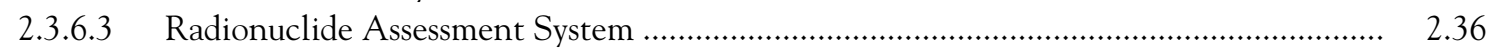

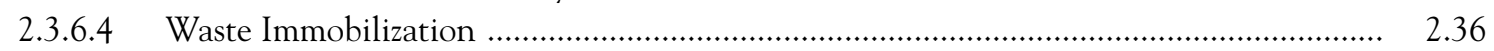

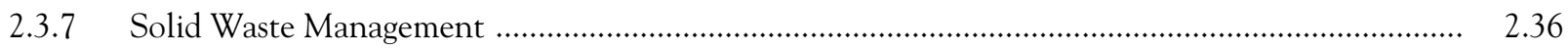

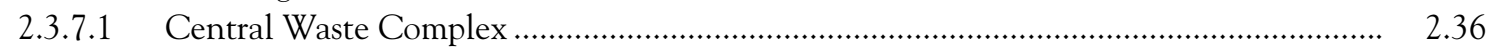

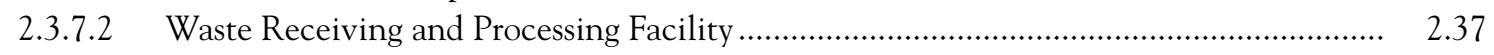

2.3.7.3 Radioactive Mixed Waste Disposal Facility .................................................................. 2.37

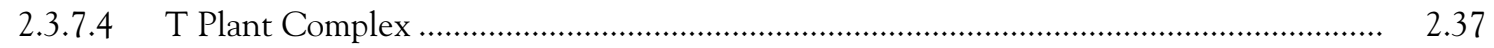

2.3.7.5 Radioactive Mixed Waste Treatment and Disposal .................................................... 2.38

2.3.7.6 Radioactive Mixed Waste Treatment Contracts ............................................................. 2.38

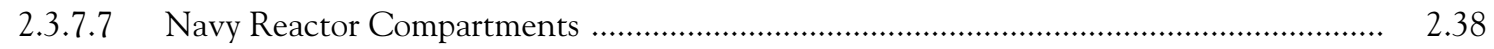

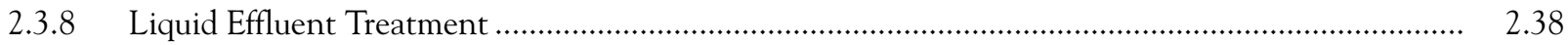

2.3.8.1 242-A Evaporator ………………………................................................................. 2.39

2.3.8.2 Liquid Effluent Retention Facility ………............................................................... $\quad 2.39$

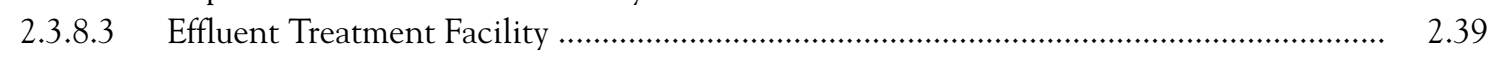

2.3.8.4 200 Area Treated Effluent Disposal Facility …........................................................... 2.40

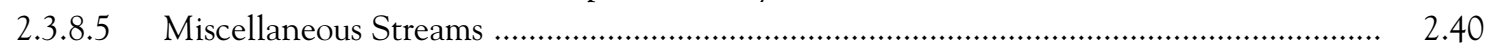

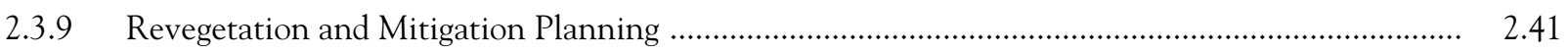

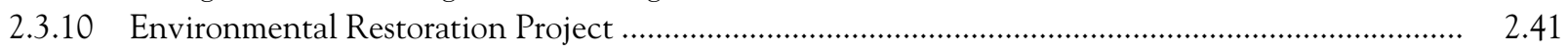

2.3.10.1 Environmental Restoration Disposal Facility …........................................................... 2.42

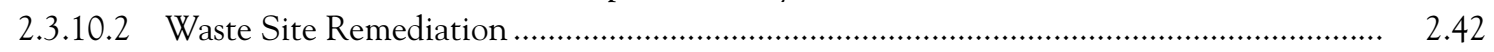

2.3.10.3 Facility Decommissioning Project .............................................................................. 2.43

2.3.10.4 233-S Plutonium Concentration Facility Decommissioning Project ............................. 2.43

2.3.10.5 Surveillance/Maintenance and Transition Project ..................................................... 2.43

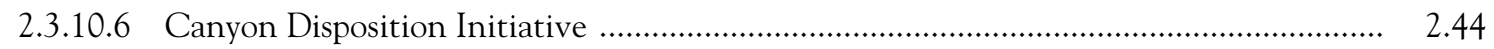

2.3.11 Groundwater/Vadose Zone Integration Project .................................................................... 2.44

2.3.11.1 Site-Wide Fieldwork Integration Focus Area ............................................................... 2.45

2.3.11.2 System Assessment Capability Focus Area ................................................................ 2.48

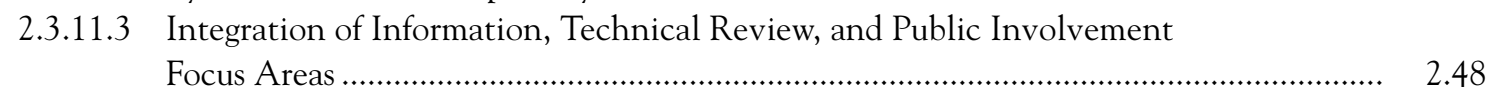

2.3.11.4 Vadose Zone Characterization in the Vicinity of 200 Areas Waste Sites ...................... 2..49

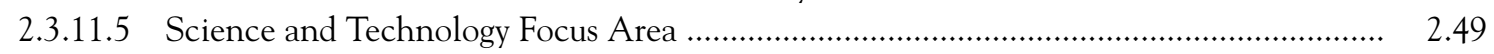


2.3.12 Research and Technology Development ….......................................................................... 2.50

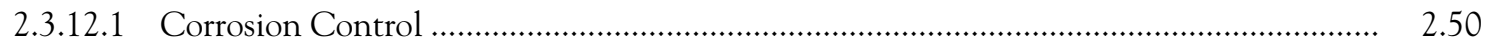

2.3.12.2 Remote Pit Operation Enhancements at Hanford ......................................................... 2.51

2.3.12.3 Double Salt Experiments ........................................................................................ 2.51

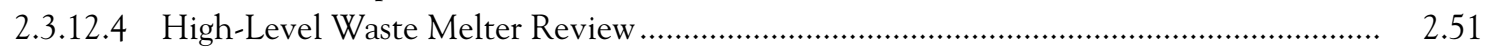

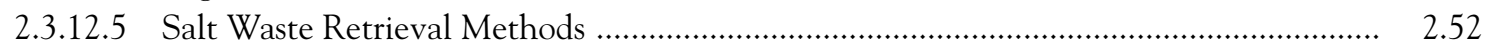

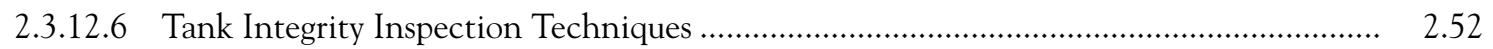

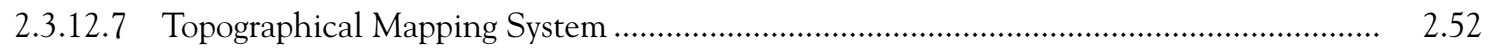

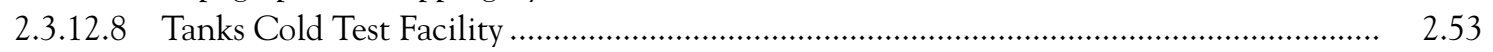

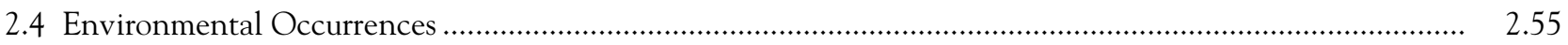

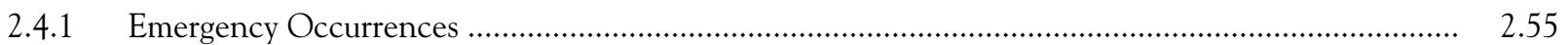

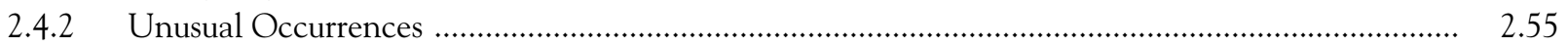

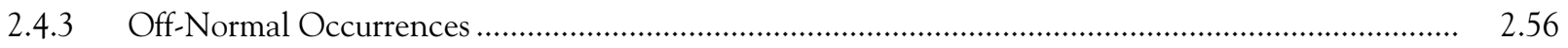

2.5 Waste Management and Chemical Inventories …….............................................................................. 2.57

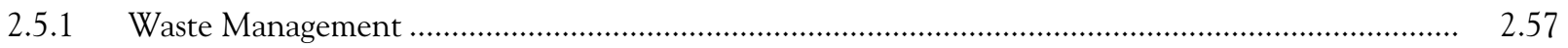

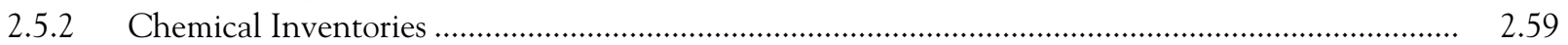

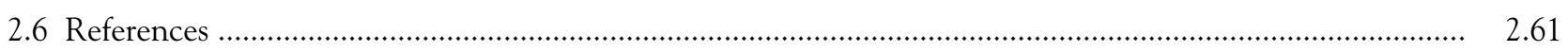

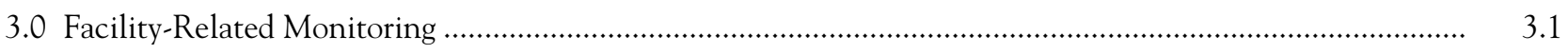

3.1 Facility Effluent Monitoring ...............................................................................................................

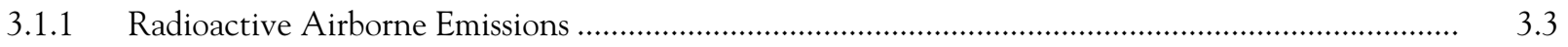

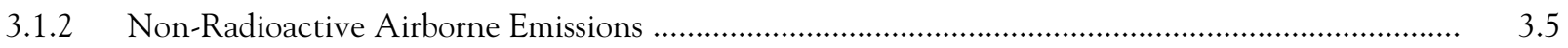

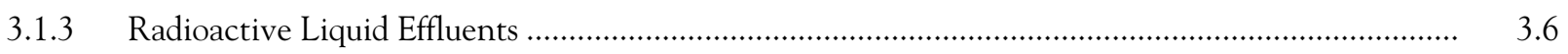

3.1.4 Non-Radioactive Hazardous Materials in Liquid Effluents ........................................................... 3.7

3.1.5 CERCLA and Washington Administrative Code Releases to the Environment ......................... 3.7

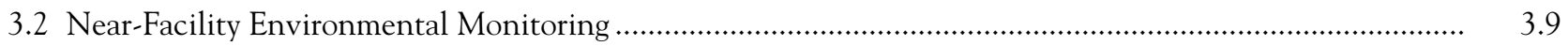

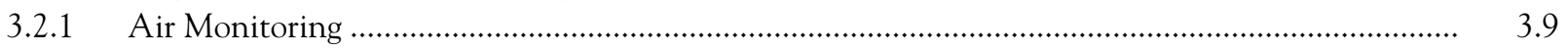

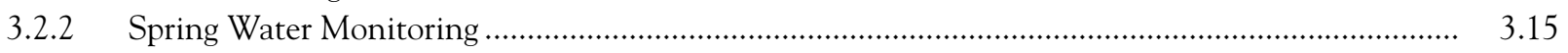

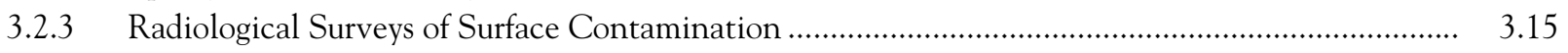

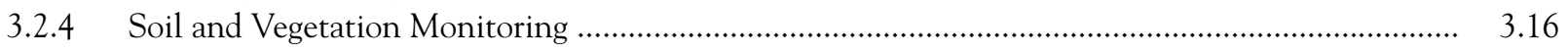

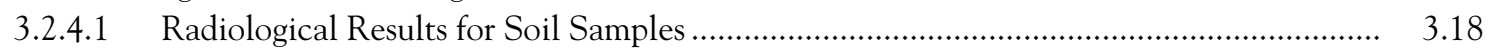

3.2.4.2 Radiological Results for Vegetation Samples ................................................................ 3.18

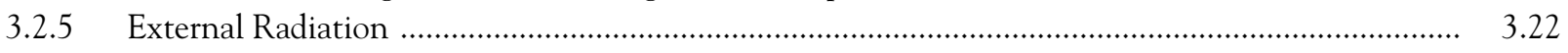

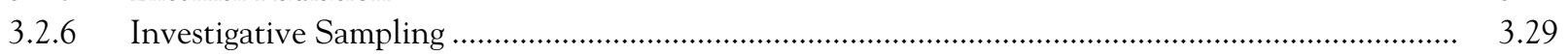

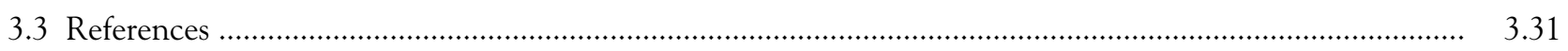

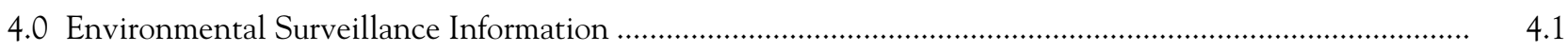

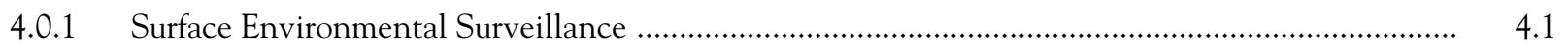

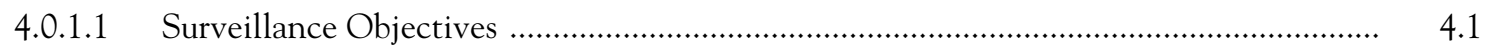

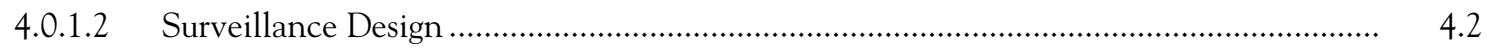

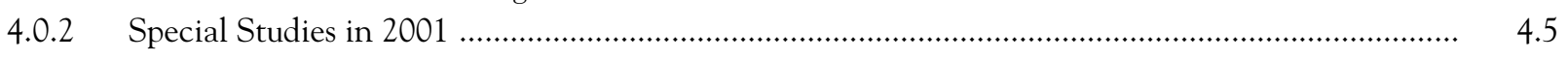

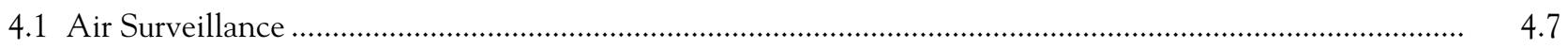

4.1.1 Collection of Air Samples and Analytes Tested ..................................................................

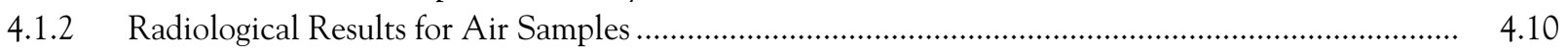

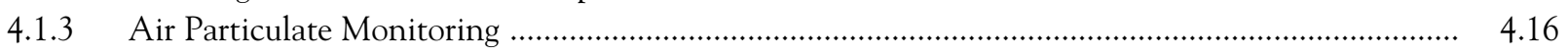


4.2 Surface Water and Sediment Surveillance ............................................................................................ 4.19

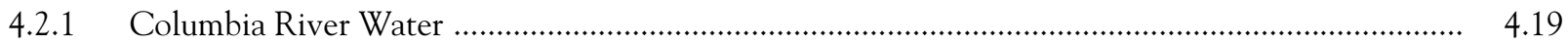

4.2.1.1 Collection of River-Water Samples and Analytes of Interest ....................................... 4.22

4.2.1.2 Radiological Results for River-Water Samples ............................................................. 4.23

4.2.1.3 Chemical and Physical Results for River-Water Samples ............................................. 4.28

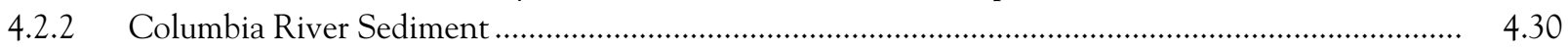

4.2.2.1 Collection of Sediment Samples and Analytes of Interest ......................................... 4.31

4.2.2.2 Radiological Results for Samples from River Sediment ............................................... 4.31

4.2.2.3 Radiological Results for Sediment Samples from Riverbank Springs ............................. 4.31

4.2.2.4 Chemical Results for Sediment Samples from the Columbia River and from

Riverbank Springs ............................................................................................... 4.32

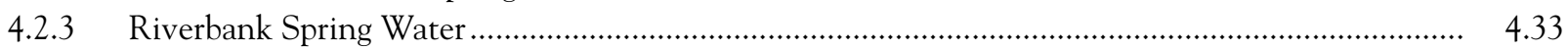

4.2.3.1 Collection of Water Samples from Riverbank Springs and Analytes of Interest ........... 4.34

4.2.3.2 Radiological Results for Water Samples from Riverbank Springs .................................. 4.34

4.2.3.3 Chemical Results for Water Samples from Riverbank Springs ...................................... 4.37

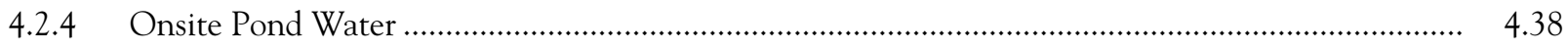

4.2.4.1 Collection of Pond Water Samples and Analytes of Interest ........................................ 4.38

4.2.4.2 Radiological Results for Pond Water Samples .................................................................. 4.38

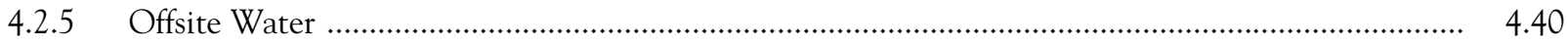

4.2.6 300 Area Near-Shore Contaminant Characterization ................................................................... 4.42

4.3 Radiological Surveillance of Hanford Site Drinking Water ...................................................................... 4.43

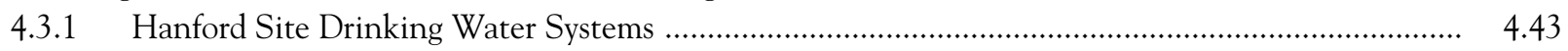

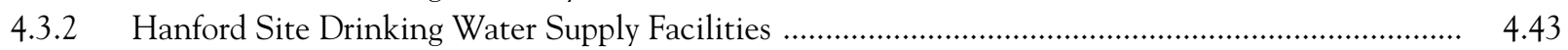

4.3.3 Collection of Drinking Water Samples and Analytes of Interest ............................................... 4.46

4.3.4 Radiological Results for Hanford Site Drinking Water ................................................................. 4.46

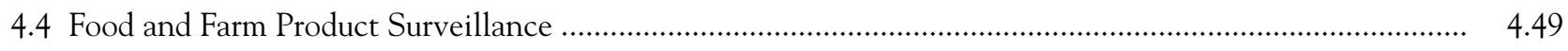

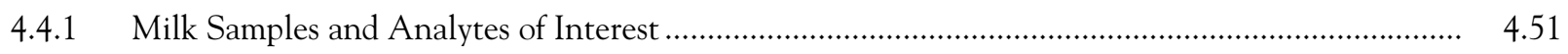

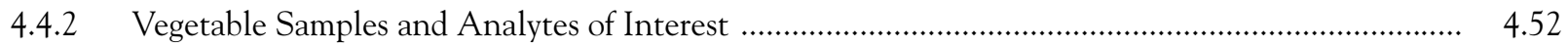

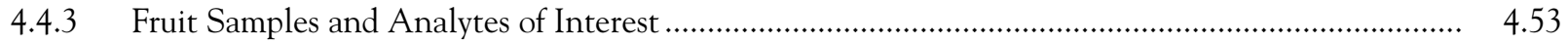

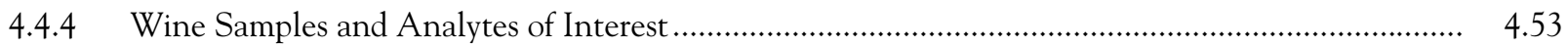

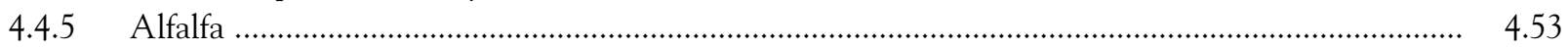

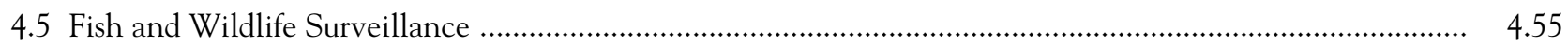

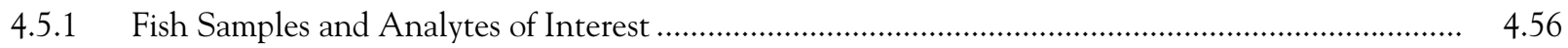

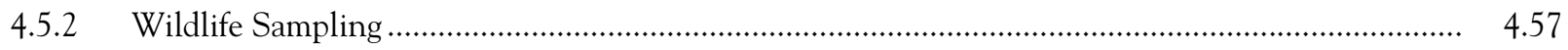

4.5.2.1 Goose Samples and Analytes of Interest .................................................................. 4.57

4.5.2.2 Rabbit Samples and Analytes of Interest ........................................................................ 4.58

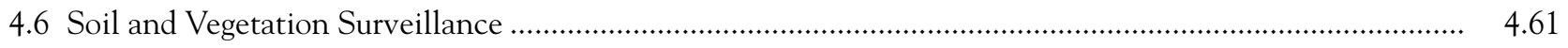

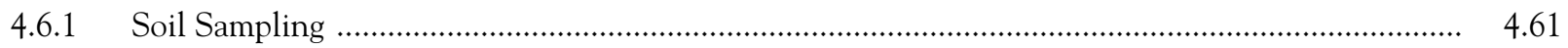

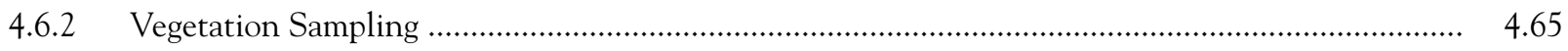

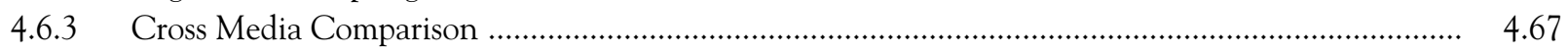

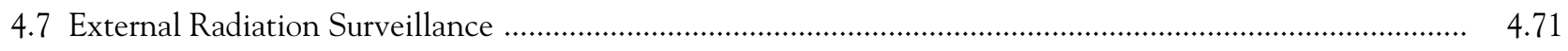

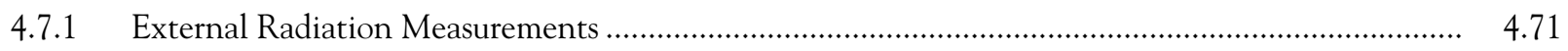

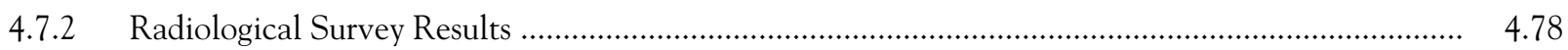

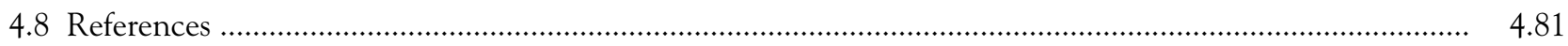


5.0 Potential Radiological Doses from 2001 Hanford Operations ...................................................................... 5.1

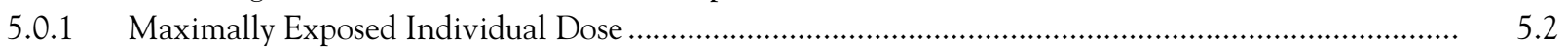

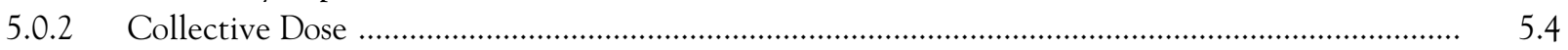

5.0.3 Compliance with Clean Air Act Standards ............................................................................. 5.7

5.0.4 Special Case Dose Estimates .......................................................................................... 5.8

5.0.4.1 Maximum "Boundary" Dose Rate ……...................................................................... 5.8

5.0.4.2 Sportsman Dose _.................................................................................................. 5.8

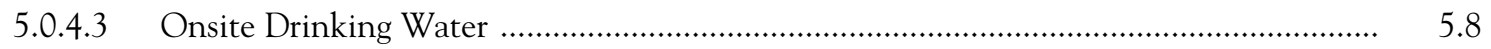

5.0.4.4 Inhalation Doses for Entire Year .................................................................................. 5.9

5.0.5 Doses from Non-DOE Sources .............................................................................................. 5.10

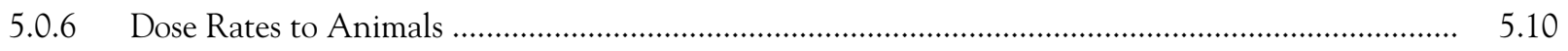

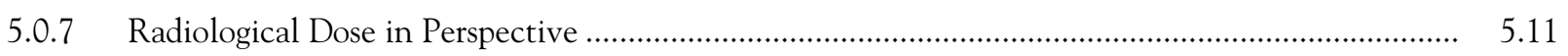

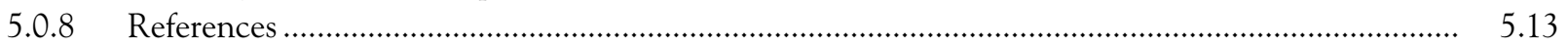

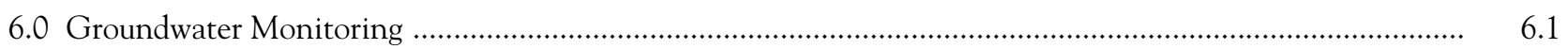

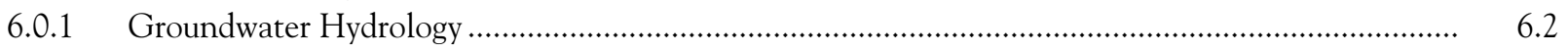

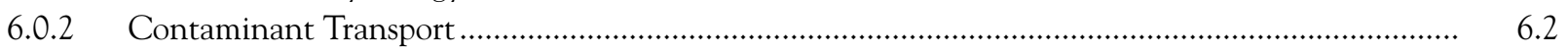

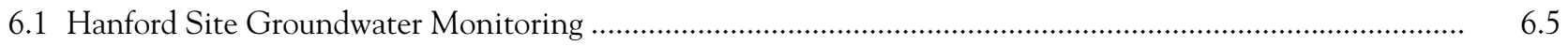

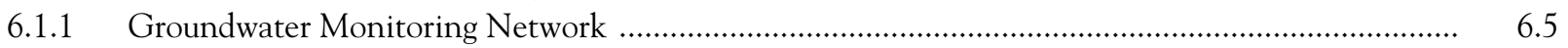

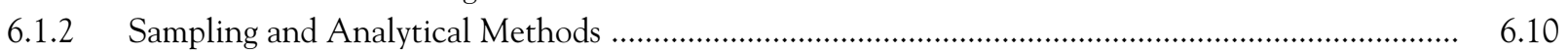

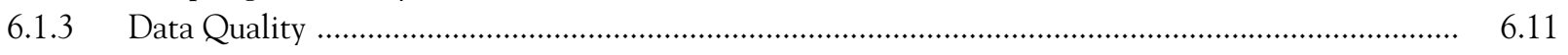

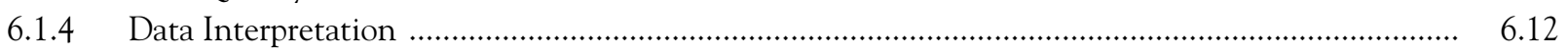

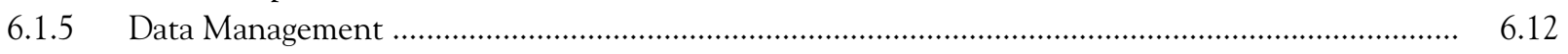

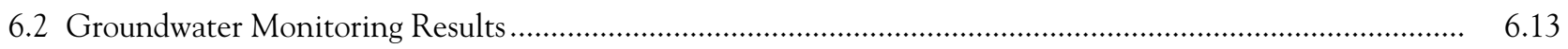

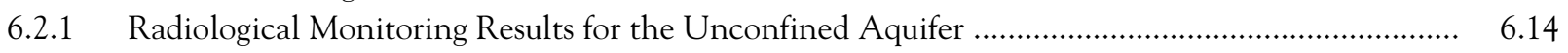

6.2.2 Chemical Monitoring Results for the Unconfined Aquifer ........................................................ 6.37

6.2.3 Radiological and Chemical Monitoring Results for the Upper Basalt-Confined Aquifer .............. 6.48

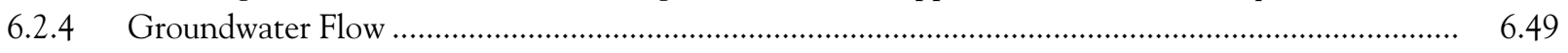

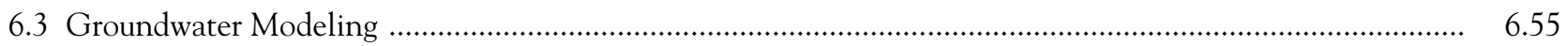

6.3.1 Consolidated Groundwater Model Progress in 2001 .............................................................. 6.55

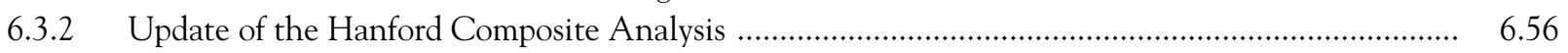

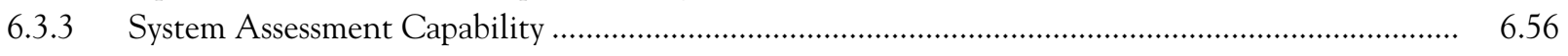

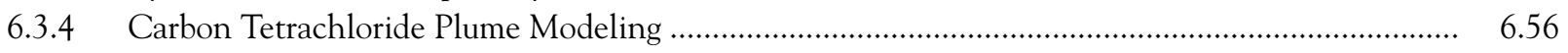

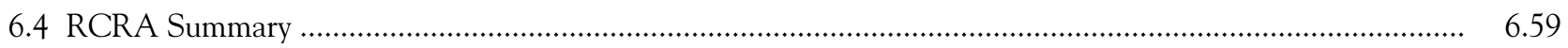

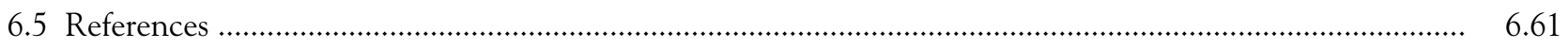

7.0 Vadose Zone Monitoring and Characterization …...................................................................................

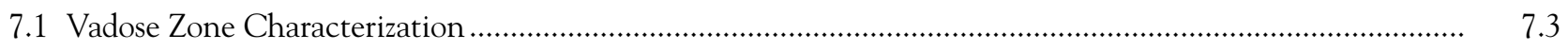

7.1.1 Drilling, Sampling, and Analysis of Soil at Waste Management Area B-BX-BY,

7.1.2 Characterization of Single-Shell Tank Waste Management Areas S-SX, 200-West Area .............. $\quad 7.5$

7.1.3 Geophysical Logging at Former Liquid Waste Disposal Facilities ................................................ 7.7

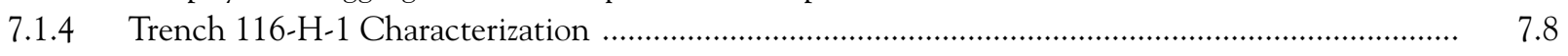

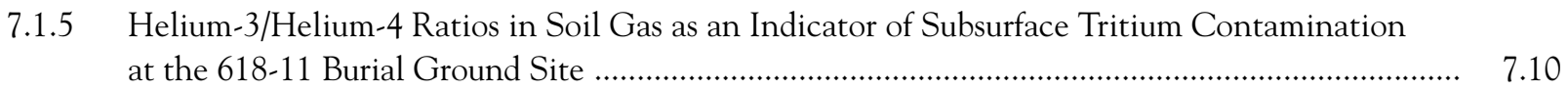

7.1.6 Geophysical and Statistical Investigation of the 618-4 Burial Ground ......................................... 7.12

7.1.7 Interim Measures at 200-West Area Tank Farms .......................................................................... 
7.2 Vadose Zone Monitoring

7.2.1 Leachate Monitoring at the Environmental Restoration Disposal Facility .................................... 7.15

7.2.2 Leachate and Soil Gas Monitoring at the Solid Waste Landfill ...................................................... 7.16

7.2.3 Carbon Tetrachloride Monitoring and Remediation ............................................................... 7.17

7.2.4 Hanford Tank Farms Vadose Zone Monitoring Project .............................................................. 7.20

7.2.5 An Instrumented Vadose Zone Monitoring Borehole at Waste Management Area B-BX-BY ....... 7.21

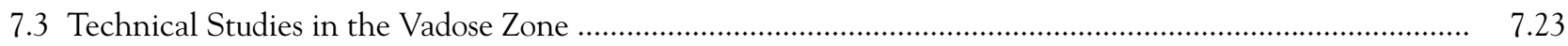

7.3.1 High-Resolution Seismic Methods for Subsurface Characterization ............................................ 7.23

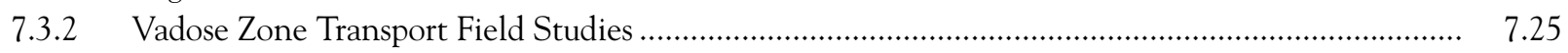

7.3.3 Hydrogeologic Influence of Clastic Dikes on Vadose Zone Transport ........................................... 7.26

7.3.4 Isotopic Fingerprinting of Radionuclide Sources at Single-Shell Tanks ........................................

7.3.5 Water Movement Through the Vadose Zone as Inferred from Isotopic and Chemical

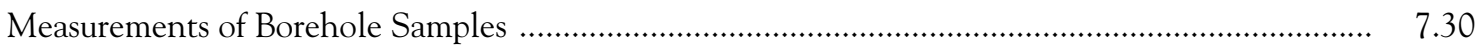

7.3.6 Predicting Deep Drainage Using Soil Hydraulic Properties and Soil Texture Data ....................... 7.31

7.4 Groundwater/Vadose Zone Integration Project Activities ....................................................................

7.4.1 Hanford Site Hydrogeologic Databases ...............................................................................

7.4.2 Initial Assessment Using the System Assessment Capability - Preliminary Vadose

Zone Results

7.5 References

8.0 Other Hanford Site Environmental Programs

8.1 Climate and Meteorology

8.1.1 Historical Information

8.1.2 Results of 2001 Monitoring

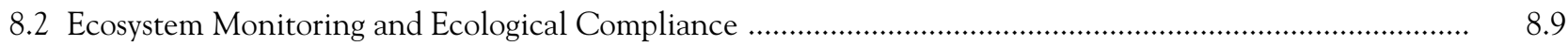

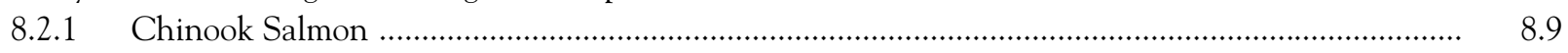

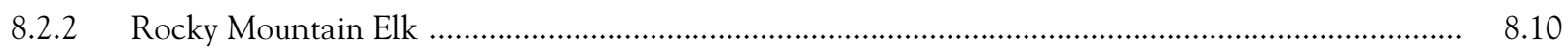

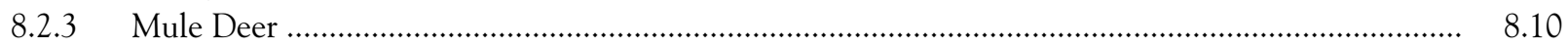

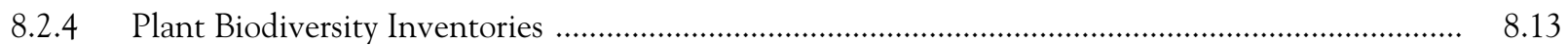

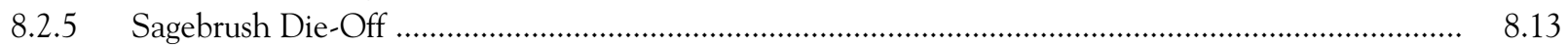

8.2.6 Ecological Compliance ........................................................................................................ 8.16

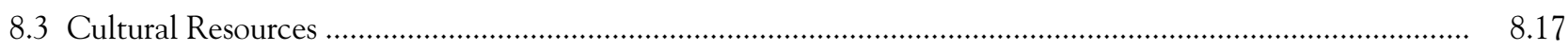

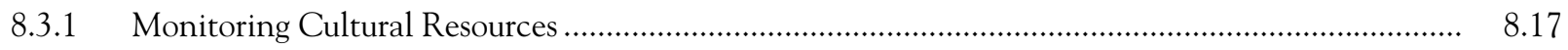

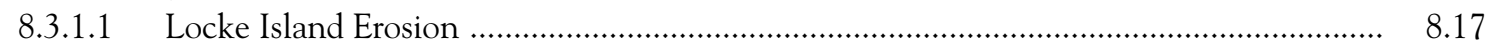

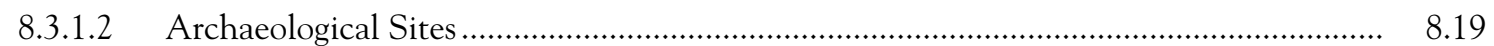

8.3.1.3 Historic Buildings ................................................................................................... 8.19

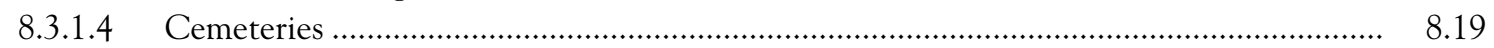

8.3.2 Native American Involvement ................................................................................. 8.19

8.3.3 Public Involvement ........................................................................................... 8.20

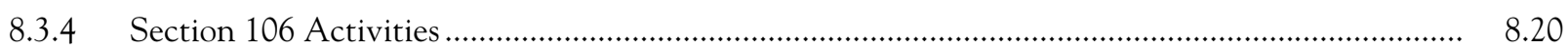

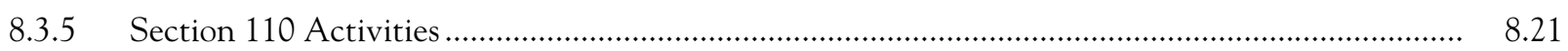

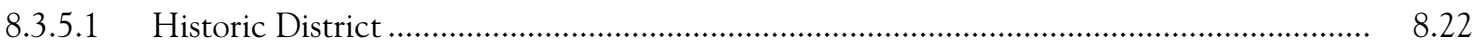

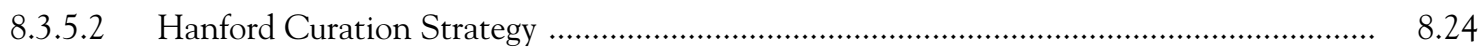

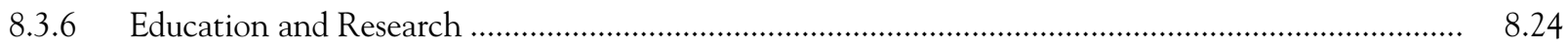

8.4 Community Involvement in Environmental Surveillance _............................................................... 
9.0 Quality Assurance

9.0.1 Environmental Surveillance and Groundwater Monitoring ........................................................... 9.1

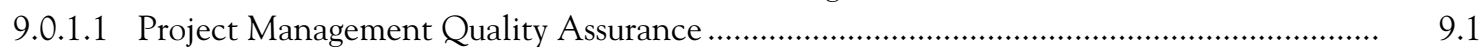

9.0.1.2 Sample Collection Quality Assurance/Quality Control ........................................................ 9.1

9.0.1.3 Analytical Results Quality Assurance/Quality Control …............................................... 9.2

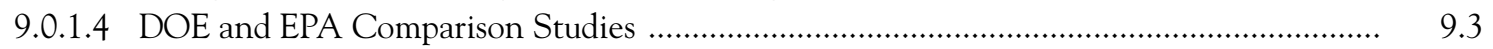

9.0.1.5 Pacific Northwest National Laboratory Evaluations ....................................................... 9.3

9.0.1.6 Quality Assurance Task Force Results ............................................................................... 9.3

9.0.1.7 Laboratory Internal Quality Assurance Programs ................................................................. 9.5

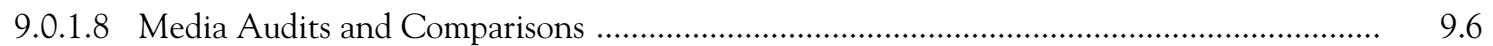

9.0.2 Effluent Monitoring and Near-Facility Environmental Monitoring .............................................. 9.6

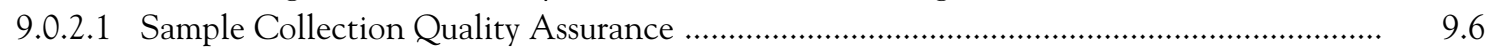

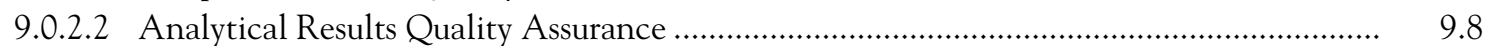

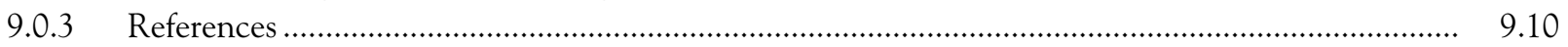

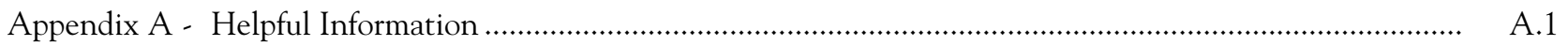

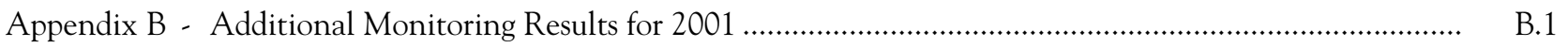

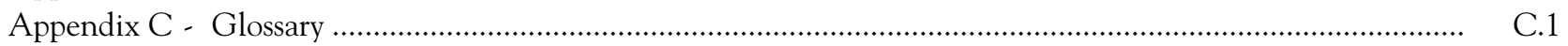

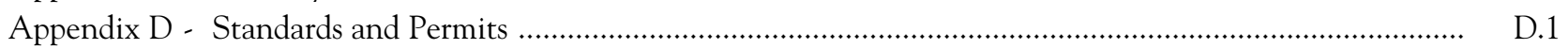

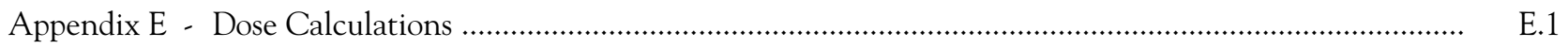

Appendix F - Radionuclides Detected by Gamma Spectroscopy …......................................................... F.1

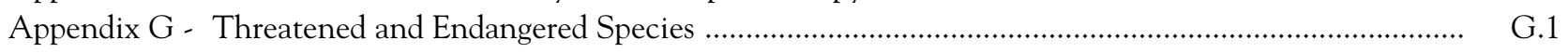

\section{Figures}

S.1 DOE Pump-and-Treat Systems and Soil-Vapor Extraction System .................................................... xi

S.2 National Annual Average Radiological Doses from Various Sources ................................................... xii

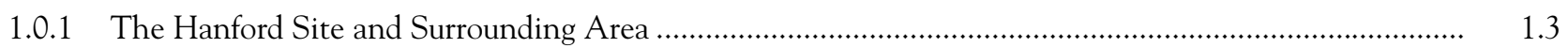

1.0.2 Management Units on the Hanford Reach National Monument ..........................................................

3.1.1 Liquid Releases of Selected Radionuclides from the Hanford Site, 1992 through 2001 ....................... 3.4

3.1.2 Airborne Releases of Selected Radionuclides from the Hanford Site, 1992 through 2001 .................... 3.4

3.2.1 Average Concentrations of Selected Radionuclides in Near-Facility Air Samples Compared to

Those in Distant Communities, 1996 through 2001

3.2.2 Average Concentrations of Selected Radionuclides in Near-Facility Soil Samples Compared to

Those in Distant Communities, 1996 through 2001

3.2.3 Average Concentrations of Selected Radionuclides in Near-Facility Vegetation Samples

Compared to Those in Distant Communities, 1996 through 2001

3.2.4 Annual Average Thermoluminescent Dosimeter Results in the 100-N Area, 1987 through 2001 ........ 3.27

3.2.5 Average Annual Dose Rates at N Springs, 1987 through 2001 ........................................................... 3.27 
3.2.7 Annual Average Thermoluminescent Dosimeter Results in the 300/400 Areas and at the 300 Area Treated Effluent Disposal Facility, 1991 through 2001

4.0.1 Primary Exposure Pathways

4.1.1 Air Sampling Locations, 2001

4.1.2 Gross Alpha Concentrations in Airborne Particulate Samples, 2001

4.1.3 Gross Beta Concentrations in Airborne Particulate Samples, 1996 through 2001

4.1.4 Annual Average Tritium Concentrations in Air and 300 Area Tritium Emissions, 1996 through 2001

4.1.5 Iodine-129 Concentrations in Air, 1996 through 2001

4.1.6 Annual Average Plutonium-239/240 Concentrations in Air, 1996 through 2001

4.1.7 Annual Average Uranium-238 Concentrations in Air, 1996 through 2001

4.1.8 Daily Average $\mathrm{PM}_{10}$ Concentrations at the Hanford Meteorological Station, February through December 2001

4.1.9 Daily Average $\mathrm{PM}_{10}$ and $\mathrm{PM}_{2.5}$ Concentrations from the Hanford Meteorological Station and 300 Area during November and December 2001

4.2.1 Sampling Locations for Water and Sediment, 2001

4.2.2 Mean, Maximum, and Minimum Monthly Columbia River Flow Rates at Priest Rapids Dam, 2001 .....

4.2.3 Annual Average Gross Alpha Concentrations in Columbia River Water, 1996 through 2001

4.2.4 Annual Average Gross Beta Concentrations in Columbia River Water, 1996 through 2001.

4.2.5 Annual Average Tritium Concentrations in Columbia River Water, 1996 through 2001

4.2.6 Annual Average Strontium-90 Concentrations in Columbia River Water, 1996 through 2001

4.2.7 Annual Average Total Uranium Concentrations in Columbia River Water, 1996 through 2001

4.2.8 Annual Average Iodine-129 Concentrations in Columbia River Water, 1996 through 2001

4.2.9 Tritium Concentrations in Water Samples from Columbia River Transects, September 2001

4.2.10 Tritium Concentrations in Columbia River Water Collected at the Hanford Shoreline, September 2001

4.2.11 U.S. Geological Survey Columbia River Water Quality Measurements, 1996 through 2001

4.2.12 Median, Maximum, and Minimum Concentrations of Selected Radionuclides Measured in Columbia and Snake River Sediment, 1996 through 2001

4.2.13 Median, Maximum, and Minimum Concentrations of Selected Metals Measured in Columbia and Snake River Sediment, 2001 
4.2.14 Concentrations of Constituents of Interest in Columbia River Riverbank Spring Water at the Hanford Town Site, 1996 through 2001

4.2.15 Concentrations of Constituents of Interest in Water from a Columbia River Riverbank Spring near the 300 Area, 1996 through 2001

4.2.16 Median, Maximum, and Minimum Gross Beta and Tritium Concentrations in Fast Flux Test Facility Pond Water Samples, 1996 through 2001

4.2.17 Median, Maximum, and Minimum Concentrations of Selected Radionuclides in West Lake Water Samples, 1996 through 2001

4.3.1 Hanford Site Primary Drinking Water Supply Facilities, 2001

4.3.2 Tritium Concentrations in Drinking Water from Three Wells in the 400 Area, 1984 through 2001 .....

4.4.1 Sampling Locations for Food and Farm Products, 2001

4.4.2 Median, Maximum, and Minimum Iodine-129 Concentrations in Milk Samples, 1996 through 2001

4.4.3 Median, Maximum, and Minimum Tritium Concentrations in Milk Samples Collected near the Hanford Site, 1998 through 2001

4.4.4 Median, Maximum, and Minimum Tritium Concentrations in Wine Samples Collected in 1996 through 2001

4.5.1 Fish and Wildlife Sampling Locations, 2001

4.5.2 Median and Maximum Strontium-90 Concentrations in Whitefish Carcasses, 2001 Compared to Four Previous Years

4.5.3 Median and Maximum Strontium-90 Concentrations in Canada Geese Bone, 2001 Compared to Three Previous Years

4.5.4 Median and Maximum Strontium-90 Concentrations in Rabbit Bone, 2001 Compared to Six Previous Years

4.6.1 Soil and Vegetation Sampling Locations, 2001

4.6.2 Median, Maximum, and Minimum Radionuclide Concentrations of Strontium-90, Cesium-137, Plutonium-238, and Plutonium-239/240 in Soil, 1993 through 2001

4.6.3 Mean, Maximum, and Minimum Concentrations of Plutonium-239/240 in Soil on the Fitzner/Eberhardt Arid Lands Ecology Reserve, 1984 through 2001

4.6.4 Annual Average Plutonium-239/240 Concentrations in Soil, Vegetation, and Air from 1984 through 2001

4.7.1 Thermoluminescent Dosimeter Locations and Station Numbers on the Hanford Site, 2001

4.7.2 Thermoluminescent Dosimeter Locations and Station Numbers for Community, Distant, and Perimeter Sites, 2001

4.7.3 Thermoluminescent Dosimeter Locations and Station Numbers along the Columbia River, 2001 
4.7.4 Median, Maximum, and Minimum Average Dose Rates at Selected Perimeter Locations,

1996 through 2001

4.7.5 Annual Average Dose Rates, 1996 through 2001

5.0.1 Locations Important to Dose Calculations

5.0.2 Calculated Dose to the Hypothetical, Maximally Exposed Individual, 1997 through 2001

5.0.3 Collective Dose to the Population within 80 Kilometers of the Hanford Site, 1997 through 2001

5.0.4 National Annual Average Radiological Doses from Various Sources

6.1.1 Unconfined Aquifer Monitoring Well Locations

6.1.2 Confined Aquifer Monitoring Well Locations

6.1.3 Locations of RCRA Groundwater Monitoring Waste Management Areas

6.2.1 Average Tritium Concentrations in the Unconfined Aquifer, 2001

6.2.2 Average Tritium and Carbon-14 Concentrations in the 100-K Area, 2001

6.2.3 Tritium Concentrations in Well 199-K-30, 1982 through 2001

6.2.4 Tritium Concentrations in Well 699-40-1, 1962 through 2001

6.2.5 Tritium Concentrations in Well 699-24-33, 1962 through 2001

6.2.6 Historical Tritium Concentrations on the Hanford Site

6.2.7 Average Tritium Concentrations and Groundwater Flow near the 300 Area, 2001

6.2.8 Location of the 618-11 Burial Ground

6.2.9 Average Tritium Concentrations in the Unconfined Aquifer at 618-11 Burial Ground, 2001

6.2.10 Average Iodine-129 and Tritium Concentrations in the Unconfined Aquifer, 2001

6.2.11 Average Technetium-99, Total Uranium, and Strontium-90 Concentrations in the Unconfined Aquifer near the 200-East Area, 2001

6.2.12 Technetium-99 Concentrations in Well 299-E33-38 near the B, BX, and BY Tank Farms, 1991 through 2001

6.2.13 Average Technetium-99 and Total Uranium Concentrations in the Unconfined Aquifer in the 200-West Area, 2001

6.2.14 Uranium Concentrations in Well 299-W19-36, a Former Pump-and-Treat Well Adjacent to U Plant, 1997 through 2001

6.2.15 Average Total Uranium Concentrations in the Unconfined Aquifer in the 300 Area, 2001

6.2.16 Average Strontium-90 Concentrations in the Unconfined Aquifer in the 100-N Area, 2001 
6.2.18 Average Filtered Chromium Concentrations in the 100-D and 100-H Areas, 2001

6.2.19 Filtered Chromium Concentrations in Well 199-D5-39 in the Southwestern 100-D Area, 1999 through 2001

6.2.20 Average Filtered Chromium Concentrations in the 100-K Area, 2001

6.2.21 Average Chlorinated Hydrocarbon Concentrations in the Unconfined Aquifer in the 200-West Area, 2001

6.2.22 Carbon Tetrachloride Concentrations in Well 299-W15-1 near the Northern Extraction Wells in the 200-West Area, 1994 through 2001

6.2.23 Results of Tritium and Other Constituents Sampled in Confined Aquifer Wells, 2001

6.2.24 Water-Table Elevations for the Unconfined Aquifer at the Hanford Site, March 2001

6.2.25 Transmissivity Distribution in the Unconfined Aquifer

6.2.26 Change in Water-Table Elevations between 2000 and 2001

6.3.1 Predicted Carbon Tetrachloride Plume using Conservative Natural Attenuation Parameters

6.3.2 Predicted Carbon Tetrachloride Plume using Realistic Natural Attenuation Parameters

7.1.1 Locations of New Boreholes 299-E33-45 and 299-E33-46 at Waste Management Area B-BX-BY

7.1.2 Concentrations versus Depth for Cesium-137 and Europium-152 in Borehole Samples at the 116-H-1 Trench

7.1.3 Locations of Monitoring Points and Results of Fiscal Year 2001 Helium Ratio Analyses at the 618-11 Burial Ground

7.2.1 The Rate of Leachate Generation at the Solid Waste Landfill Since Routine Monitoring Started in 1996

7.2.2 Key Organic Compounds Found in Leachate from the Solid Waste Landfill

7.2.3 Key Metals Found in Leachate from the Solid Waste Landfill

7.2.4 Time Series Concentrations of Carbon Tetrachloride in Soil Vapor Extracted from the 216-Z-9 Well Field and the 216-Z-1A/-12/-18 Well Field

7.3.1 Location Map of Sites Selected for High-Resolution Seismic Characterization.....

7.3.2 Photograph of the Clastic Dike Exposed in the Army Loop Road Excavation

7.3.3 Dye Infiltration Experiment at the Clastic Dike in the Army Loop Road Trench

7.3.4 Moisture Distribution within the Clastic Dike in the Army Loop Road Exposure

7.3.5 Oxygen Isotope Composition versus Depth for Samples of Porewater from Well 299-W22-48

7.3.6 Twenty-Year Record of Measured and Predicted Drainage from Buried Waste Test Facility Lysimeter

7.4.1 Cesium-137 History Matching Results for the 216-A-8 Crib..... 
7.4.2 System Assessment Capability Simulation of Total Hanford Annual Releases from the Vadose

Zone to Groundwater by Constituent

7.4.3 System Assessment Capability Simulation of Total Hanford Annual Releases of Tritium from the Vadose Zone to Groundwater by Waste Facility Types

8.1.1 Hanford Meteorological Monitoring Network Wind Roses, 2001

8.2.1 Number of Fall Chinook Salmon Spawning Redds in the Hanford Reach, 1948 through 2001

8.2.2 Number of Elk on the Hanford Site: Post-Calving and Post-Hunting Periods, 1975 through 2001 ........

8.2.3 Elk/Vehicle Collision Sites along State Highways 24 and 240, 1998 through 2001.

8.2.4 Percent of Mule Deer Bucks with Testicular Atrophy on the Hanford Site, 1994 through 2001

8.2.5 Roadside Survey Results for Trends in Fawn:Doe Ratios seen per Survey on the Hanford Site, 1994 through 2001

8.2.6 Rare Plant Locations on the Hanford Site based on Surveys from 1994 through 2001

8.3.1 Measured Loss at Locke Island's Erosion Transects during Calendar Year 2001

8.3.2 Total Measured Loss at Locke Island's Erosion Transects between November 1995 and September 2001

8.3.3 Cultural Resources Reviews Requested each Calendar Year

8.3.4 Former and Current Hanford Buildings and Structures Documented with a Washington State Historic Property Inventory Form

8.3.5 Historic Sites are Commonly Found during Surveys Conducted at the Hanford Site

8.3.6 KW Reactor, a Contributing Property Recommended for Mitigation within the Hanford Site Manhattan Project and Cold War Era Historic District

8.4.1 Community Members See Environmental Surveillance in Action at a Community-Operated Environmental Surveillance Station in Richland

A.1 A Graphical Representation of Maximum, Median, and Minimum Values

A.2 Data Plotted Using a Linear Scale

A.3 Data Plotted Using a Logarithmic Scale

A.4 Data with Error Bars Plotted Using a Linear Scale

\section{Tables}

S.1 Compliance with Federal Acts at the Hanford Site in 2001 
S.3 Summary of Groundwater Pump-and-Treat Systems and a Soil-Vapor Extraction System

2.2.1 Emergency Planning and Community Right-To-Know Act Compliance Reporting, 2001

2.2.2 RCRA Interim and Final Status Groundwater Monitoring Projects, September 2001

2.2.3 New RCRA Well Installations for Fiscal Year 2001

2.5.1 Quantities of Solid Waste Generated on the Hanford Site, kg ......

2.5.2 Quantities of Solid Waste Received from Offsite, $\mathrm{kg}$

2.5.3 Quantities of Hazardous Waste Shipped Offsite, kg....

2.5.4 Radioactive Solid Waste Stored or Disposed of on the Hanford Site, 2001

2.5.5 Quantities of Liquid Waste Generated and Stored within the Tank Farm System on the Hanford Site in Calendar Year 2001 and in each of the Previous 5 Calendar Years, L

2.5.6 Average Amount of Ten Hazardous Chemicals Stored in Greatest Quantity on the Hanford Site, 2001

3.1.1 Radionuclides Discharged to the Atmosphere at the Hanford Site, 2001

3.1.2 Non-Radioactive Constituents Discharged to the Atmosphere at the Hanford Site, 2001

3.1.3 Radionuclides in Liquid Effluents from the 200 Areas Discharged to the State-Approved Land Disposal Site, 2001

3.1.4 Radionuclides in Liquid Effluents from the 100 Areas Discharged to the Columbia River, 2001

3.1.5 Reportable Releases to the Environment at the Hanford Site, 2001

3.2.1 Near-Facility Routine Environmental Monitoring Samples and Locations, 2001

3.2.2 Near-Facility Air Sampling Locations and Analyses, 2001

3.2.3 Annual Average and Maximum Concentrations of Radionuclides in Near-Facility Air Samples, 2001

3.2.4 Radionuclide Concentrations in 100-N Area Riverbank Springs, 2001

3.2.5 Outdoor Contamination Status, 2001

3.2.6 Zone Status Change of Posted Contamination Areas, 2001

3.2.7 Average Radionuclide Concentrations Detected in Surface Soil Samples near the 1301-N Liquid Waste Disposal Facility, 1996 through 2001.

3.2.8 Average Radionuclide Concentrations Detected in all 100-N Area Surface Soil Samples, 1996 through 2001

3.2.9 Concentrations of Selected Radionuclides in all 100-N Area Surface Soil Samples, 2001

3.2.10 Concentrations of Selected Radionuclides in 200/600 Areas Surface Soil Samples, 2001

3.2.11 Concentrations of Selected Radionuclides in 300/400 Areas Surface Soil Samples, 2001 
3.2.12 Radionuclide Concentrations in Environmental Restoration Contractor Projects' Soil Samples, 2001

3.2.13 Average Radionuclide Concentrations Detected in Vegetation Samples Collected near the 1301-N Liquid Waste Disposal Facility, 1996 through 2001

3.2.14 Average Radionuclide Concentrations Detected in all 100-N Area Vegetation Samples, 1996 through 2001

3.2.15 Average Radionuclide Concentrations Detected in N Springs Vegetation Samples, 1996 through 2001

3.2.16 Concentrations of Selected Radionuclides in 100-N Area Vegetation Samples, 2001

3.2.17 Concentrations of Selected Radionuclides in 200/600 Areas Vegetation Samples, 2001

3.2.18 Concentrations of Selected Radionuclides in 300/400 Areas Vegetation Samples, 2001

3.2.19 Thermoluminescent Dosimeter Results for Waste Handling Facilities, 2000 and 2001, based on 24 hours/day

3.2.20 Investigative Sample Collections

4.0.1 Routine Environmental Surveillance Sample Types and Measurement Locations, 2001

4.0.2 Samples Collected for the Surface Environmental Surveillance Project and Analytical Results Obtained, 2001

4.1.1 Air Sampling Locations, Sample Composite Groups, and Analytes, 2001

4.1.2 Airborne Radionuclide Concentrations in the Hanford Environs, 2001 Compared to Previous Years

4.2.1 Surface Water Surveillance, 2001

4.2.2 Sediment Surveillance, 2001

4.2.3 Selected Radionuclide Concentrations in 100-N Area Riverbank Spring Water, 1996 through 2001

4.2.4 Concentration Ranges for Selected Chemicals in Water from Columbia River Springs, 1999 through 2001

4.3.1 DOE-Owned Drinking Water Systems on the Hanford Site, 2001

4.3.2 Selected Radiological Constituents in Hanford Site Drinking Water, 2001 Annual Average Concentrations, $\mathrm{pCi} / \mathrm{L}$

4.3.3 Tritium Concentrations in 400 Area Drinking Water Wells, 2001

4.4.1 Locations, Sampling Frequencies, and Analyses Performed for Routinely Sampled Food and Farm Products, 2001

4.5.1 Locations, Species, and Contaminants Sampled for Fish and Wildlife, 2001

4.6.1 Routine Soil and Vegetation Samples Collected and Analyzed, 2001 
4.6.2 Concentrations of Selected Radionuclides in Soil, 2001 Compared to Previous Years

4.6.3 Radionuclide Concentrations in Soil Collected from the Fitzner/Eberhardt Arid Lands Ecology

Reserve ......

4.6.4 Concentrations of Selected Radionuclides in Vegetation, 2001 Compared to Previous Years

4.7.1 Dose Rates Measured by Thermoluminescent Dosimeters at Perimeter and Offsite Locations, 2001 Compared to Previous 5 Years

4.7.2 Dose Rates Measured by Thermoluminescent Dosimeters on the Hanford Site, 2001 Compared to Previous 5 Years.

4.7.3 Dose Rates Measured by Thermoluminescent Dosimeters along the Hanford Reach of the Columbia River, 2001 Compared to Previous 5 Years....

4.7.4 Average Exposure Rates Measured by Pressurized Ionization Chambers at Four Offsite Locations, 2001

4.7.5 Quarterly Average Exposure Rates Measured by Thermoluminescent Dosimeters at Four Offsite Locations, 2001

5.0.1 Dose to the Hypothetical, Maximally Exposed Individual Residing at Sagemoor from 2001 Hanford Operations

5.0.2 Collective Dose to the Population from 2001 Hanford Operations

5.0.3 Comparison of Doses to the Public from Hanford Effluents to Federal Standards and Natural Background

5.0.4 Inhalation Doses based on 2001 Air Surveillance Data

5.0.5 Results of RAD-BCG Calculator Screenings

5.0.6 Estimated Risk from Various Activities and Exposures

5.0.7 Activities Comparable in Risk to the 0.009-mrem Dose Calculated for the 2001 Maximally Exposed Individual

6.0.1 Chemical and Radiological Groundwater Contaminants and Their Link to Site Operations......

6.1.1 Summary of Groundwater Monitoring Program by Geographic Area, Calendar Year 2001

6.1.2 Summary of Groundwater Monitoring Program by Monitoring Purpose, Calendar Year 2001

6.1.3 Hanford Site Well Naming System

6.1.4 Groundwater Analyzed for These Radionuclides and Other Parameters in 2001

6.2.1 Area of Contaminant Plumes at Levels above Drinking Water Standards

6.2.2 Summary of Maximum Concentrations by Geographic Area, Calendar Year 2001

6.2.3 Summary of Maximum Concentrations by Monitoring Purpose, Calendar Year 2001 
7.2.1 Carbon Tetrachloride Inventory in Primary Disposal Sites.....

7.2.2 Sensor Placement in Borehole 299-E33-46

7.3.1 Measured Drainage at the Hanford Solid Waste Landfill Compared to that Predicted by the Tank Farm Water Balance Model

7.3.2 Predicted Drainage Rates from the Tank Farm Water Balance Model Related to Percent Fines in Surface Sediment and Percentage of Annual Precipitation Based on a 20-Year Period

7.4.1 Types, Abundances, and Locations of Laboratory and Field Hydraulic Data on the Hanford Site

7.4.2 Distribution Coefficients Included in the Geochemical Compilation

7.4.3 Test Cases for Vadose Zone History Matching

7.4.4 Results of Vadose Zone History Matching

8.1.1 Requests for Meteorological Data from Facilities and Organizations on and off the Hanford Site, 2001

8.1.2 Monthly and Annual Climatological Data from the Hanford Meteorology Station, 2001

8.2.1 Numbers of Rorippa columbiae Stems Counted along the Hanford Reach of the Columbia River, 1994, 1998, 1999, 2000, and 2001

8.2.2 Decline of Sagebrush Conditions Measured along Six Transects within and along the Boundaries of the Sagebrush Die-Off Area on the Hanford Site

8.2.3 Ecological Reviews Performed, 1997 through 2001

9.0.1 Summary of Surface Environmental Surveillance Project Field Replicate Results, 2001

9.0.2 Summary of Laboratory Performance on DOE Quality Assessment Program Samples, 2001

9.0.3 Summary of Laboratory Performance on Environmental Resource Associates Proficiency Testing Program, 2001

9.0.4 Summary of Surface Environmental Surveillance Project Blind Spiked Determinations, 2001

9.0.5 Comparison of the Quality Assurance Task Force Intercomparison Well Water Results, 2001

9.0.6 Comparison of U.S. Food and Drug Administration Co-Sampling, 2001

9.0.7 Comparison of Thermoluminescent Dosimeter Results with Known Exposure, 2001

9.0.8 Hanford Site Laboratories used by Contractor and Sample Type, 2001

9.0.9 Waste Sampling and Characterization Facility Performance on DOE Quality Assessment Program Samples, 2001

9.0.10 222-S Analytical Laboratory Performance on DOE Quality Assessment Program Samples, 2001

9.0.11 222-S Analytical Laboratory Performance on EPA Laboratory Water Pollution Inorganic and Organic Studies, 2001 
A.2 Conversion Table

A.3 Names and Symbols for Units of Radioactivity

A.4 Conversions for Radiological Dose Units

A.5 Names and Symbols for Units of Radiation Dose or Exposure

A.6 Conversions for Radioactivity Units

A.7 Radionuclides and Their Half-Lives

A.8 Elemental and Chemical Constituent Nomenclature

B.1 Radionuclide Concentrations in Columbia River Water at Priest Rapids Dam, 2001 Compared to Previous 5 Years

B.2 Radionuclide Concentrations in Columbia River Water at the Richland Pumphouse, 2001 Compared to Previous 5 Years

B.3 Radionuclide Concentrations Measured in Columbia River Water along Transects of the Hanford Reach, 2001

B.4 Radionuclide Concentrations Measured in Columbia River Water at Near-Shore Locations in the Hanford Reach, 2001

B.5 Selected U.S. Geological Survey Columbia River Water Quality Data, 2001

B.6 Concentrations of Dissolved Metals in Columbia River Transect and Near-Shore Water Samples, 2001

B.7 Radionuclide Concentrations in Sediment from the Columbia River and from Columbia River Riverbank Springs, 2001 Compared to Previous 5 Years

B.8 Median Metal Concentrations in Columbia River Sediment, 2001

B.9 Radionuclide Concentrations Measured in Water from Riverbank Springs, 2001 Compared to Previous 5 Years

B.10 Annual Average Dose Rates Measured on and around the Hanford Site in Calendar Year 2001

D.1 Washington State Water Quality Standards for the Hanford Reach of the Columbia River

D.2 Selected Drinking Water Standards

D.3 Selected Surface Freshwater Quality Criteria for Toxic Pollutants

D.4 Radiation Standards for Protection of the Public from all Routine DOE Concentrations

D.5 Selected Derived Concentration Guides

D.6 Environmental Permits

E.1 Food Pathway Parameters used in Dose Calculations, 2001

E.2 Dietary Parameters used in Dose Calculations, 2001 
E.3 Residency Parameters used in Dose Calculations, 2001 ........................................................................ E.5

E.4 Recreational Parameters used in Dose Calculations, 2001 .................................................................... E.5

E.5 Technical Details of 100 Areas Airborne Release Dose Calculations, 2001 ......................................... E.6

E.6 Technical Details of 100-N Area Liquid Release Dose Calculations, 2001 ............................................ E.7

E.7 Technical Details of 200 Areas Airborne Release Dose Calculations, 2001 .......................................... E. E

E.8 Technical Details of 300 Area Airborne Release Dose Calculations, 2001 ........................................ E.9

E.9 Technical Details of 400 Area Airborne Release Dose Calculations, 2001 ......................................... E.10

E.10 Annual Dose to Workers in the 400 Area from Ingestion of Drinking Water Obtained from Groundwater Wells, 2001 .............................................................................................................. E.10

F.1 Radionuclides Analyzed by Gamma Spectroscopy …........................................................................ F.1

G.1 Federal or Washington State Threatened and Endangered Species on the Hanford Site ...................... G.2

G.2 Washington State Candidate Animal Species on the Hanford Site ................................................... G.3

G.3 Washington State Plant Species of Concern on the Hanford Site …….................................................. G.4 


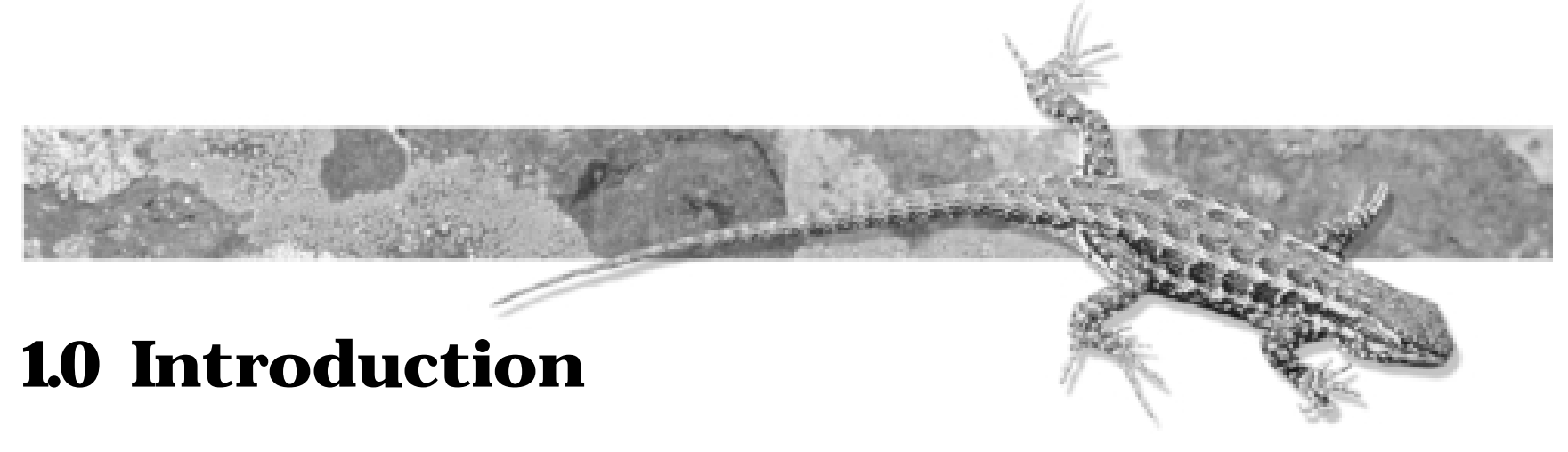

R. W. Hanf

This report, published annually since 1958, includes information and summary data that (1) provide an overview of activities at the Hanford Site during 2001, (2) characterize environmental management performance at the site; (3) demonstrate the status of the site's compliance with applicable federal, state, and local environmental laws and regulations; and (4) highlight significant environmental monitoring and surveillance programs and efforts.

Specifically, this report provides a short introduction to the Hanford Site, discusses the site mission, and briefly highlights the site's various environmentalrelated programs. Included are descriptions of the Environmental Restoration Project, the Effluent and Near-Facility Environmental Monitoring Program, the
Surface Environmental Surveillance Project, the Hanford Groundwater Monitoring Project, Vadose Zone Monitoring, the Hanford Cultural Resources Laboratory, Ecosystem Monitoring, Ecological Compliance, the Meteorological and Climatological Services Project, and information about other programs and projects. Also included are sections discussing environmental occurrences, current issues and actions, environmental cleanup and restoration activities, compliance issues, and descriptions of major operations and activities. Readers interested in more detail than that provided in this report should consult the technical documents cited in the text and listed in the reference sections. Descriptions of specific analytical and sampling methods used in the monitoring efforts are contained in the Hanford Site environmental monitoring plan (DOE/RL-91-50).

\subsection{Current Site Mission}

For more than 40 years, Hanford Site facilities were dedicated primarily to the production of plutonium for national defense and to the management of the resulting waste. Hanford was the first plutonium production site in the world. In recent years, efforts at the site have focused on developing new waste treatment and disposal technologies and characterizing and cleaning up contamination left from historical operations.

Currently, the Hanford Site's primary mission includes cleaning up and shrinking the size of the site from $\sim 1,517$ square kilometers ( 586 square miles) to $\sim 194$ square kilometers ( $\sim 75$ square miles) by the target date of 2012. Accelerating Cleanup and Shrinking the Site (DOE/RL-2000-62) states that the cleanup mission includes three strategies:

- restoring the Columbia River corridor by continuing to clean up Hanford Site sources of radiological and chemical contamination that threaten the air, groundwater, or Columbia River. It is expected that most river corridor projects will be completed by 2012 .

- transitioning the Central Plateau (200-East and 200-West Areas) from primarily inactive waste storage to active waste characterization, treatment, storage, and disposal operations which are expected to last for another 40 years.

- preparing for the future by getting ready for longterm stewardship, other U.S. Department of Energy (DOE) and non-DOE federal missions, and other public and private sector uses.

The goal of these strategies is to complete major portions of the site cleanup by 2012 and to do so in a manner that protects the environment and uses taxpayer's dollars wisely and efficiently. 


\subsection{Overview of the Hanford Site}

The Hanford Site lies within the semi-arid Pasco Basin of the Columbia Plateau in southeastern Washington State (Figure 1.0.1). The site occupies an area of $\sim 1,517$ square kilometers ( 586 square miles) located north of the city of Richland (DOE/EIS-0222). This large area has restricted public access and provides a buffer for the smaller areas on the site that historically were used for production of nuclear materials, waste storage, and waste disposal. The Columbia River flows eastward through the northern part of the Hanford Site and then turns south, forming part of the eastern site boundary.

The 78,900-hectare (195,000-acre) Hanford Reach National Monument (Figure 1.0.2) was established by a Presidential Proclamation in June 2000 (65 FR 114) to protect the nation's only non-impounded stretch of the Columbia River above Bonneville Dam and the largest remnant of the shrub-steppe ecosystem once blanketing the Columbia River Basin. In 2001, DOE and the U.S. Fish and Wildlife Service were joint stewards of the monument with the U.S. Fish and Wildlife Service administering three major management units of the monument totaling $\sim 66,775$ hectares $(\sim 165,000$ acres). These included (1) the Fitzner/Eberhardt Arid Lands Ecology Reserve Unit, a 312 square kilometer (120 square mile) tract of land in the southwestern portion of the Hanford Site; (2) the Saddle Mountain Unit, a 130 square kilometer (50 square mile) tract of land located northnorthwest of the Columbia River and generally south and east of State Highway 24; and (3) the Wahluke Unit, a 225 square kilometer (87 square mile) tract of land located north and east of both the Columbia River and the Saddle Mountain Unit (see Figure 1.0.1). The portion of the monument administered only by DOE included the McGee/Riverlands area (north and west of State Highway 24 and south of the Columbia River), the Columbia River islands in Benton County, the Columbia River corridor (one-quarter mile inland from the Hanford Reach shoreline) on the Hanford (Benton County) side of the river, and the sand dunes area located along the Hanford side of the Columbia River north of Energy Northwest. Approximately 162 hectares ( 400 acres) along the north side of the Columbia River, west of the Vernita Bridge, and south of State Highway 243 is managed by the Washington State Department of Fish and Wildlife. All of these lands have served as a safety and security buffer zone for Hanford Site operations since 1943, resulting in an ecosystem that has been relatively untouched for nearly 60 years.
The major DOE operational, administrative, and research areas on and around the Hanford Site (see Figure 1.0.1) include:

- The $\mathbf{1 0 0}$ A reas - located along the south shore of the Columbia River. These are the sites of nine retired plutonium production reactors. The 100 Areas occupy 11 square kilometers (4 square miles).

- The 200-West and 200-East A reas - centrally located on a plateau. These areas are $\sim 8$ and 11 kilometers ( $\sim 5$ and 7 miles), respectively, south and west of the Columbia River. These areas house facilities that received and dissolved irradiated fuel and then separated out the valuable plutonium. These facilities were called "separations plants." The 200 Areas cover $\sim 16$ square kilometers (6 square miles).

- The $\mathbf{3 0 0}$ A rea - located just north of the city of Richland. From the early 1940s until the advent of the cleanup mission, most research and development at the Hanford Site were carried out in the 300 Area. The 300 Area was also the location of nuclear fuel fabrication. This area covers $\sim 1.5$ square kilometers $(\sim 0.6$ square mile).

- The 400 A rea - location of the Fast Flux Test Facility, scheduled for deactivation. This special nuclear reactor was designed to test various types of nuclear fuel. The 400 Area is located $~ 8$ kilometers ( $\sim 5$ miles) northwest of the 300 Area and covers $\sim 0.61$ square kilometer ( $\sim .23$ square mile).

- The $\mathbf{6 0 0}$ Area - includes all of the Hanford Site not occupied by the 100, 200,300, and 400 Areas.

- The former 311-hectare (768-acre) 1100 A rea located generally between the 300 Area and the city of Richland. On October 1, 1998, this area was transferred to the Port of Benton as a part of DOE's Richland Operations Office economic diversification efforts and is no longer part of the Hanford Site. However, DOE contractors continue to lease facilities in this area.

- The Richland N orth A rea (off the site) - includes the Environmental Molecular Sciences Laboratory and other DOE and contractor facilities, mostly leased office buildings, generally located in the northern part of the city of Richland. 


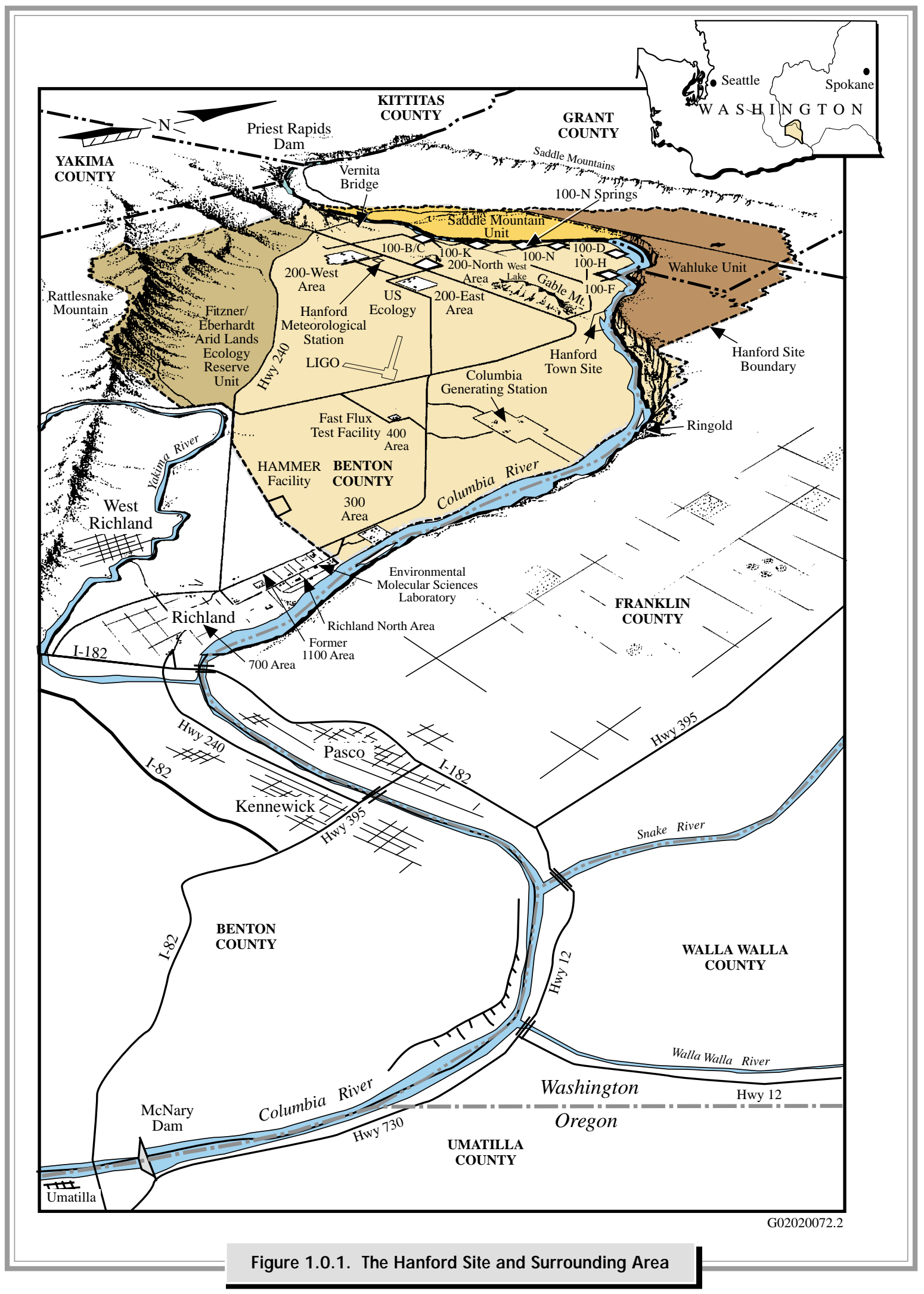




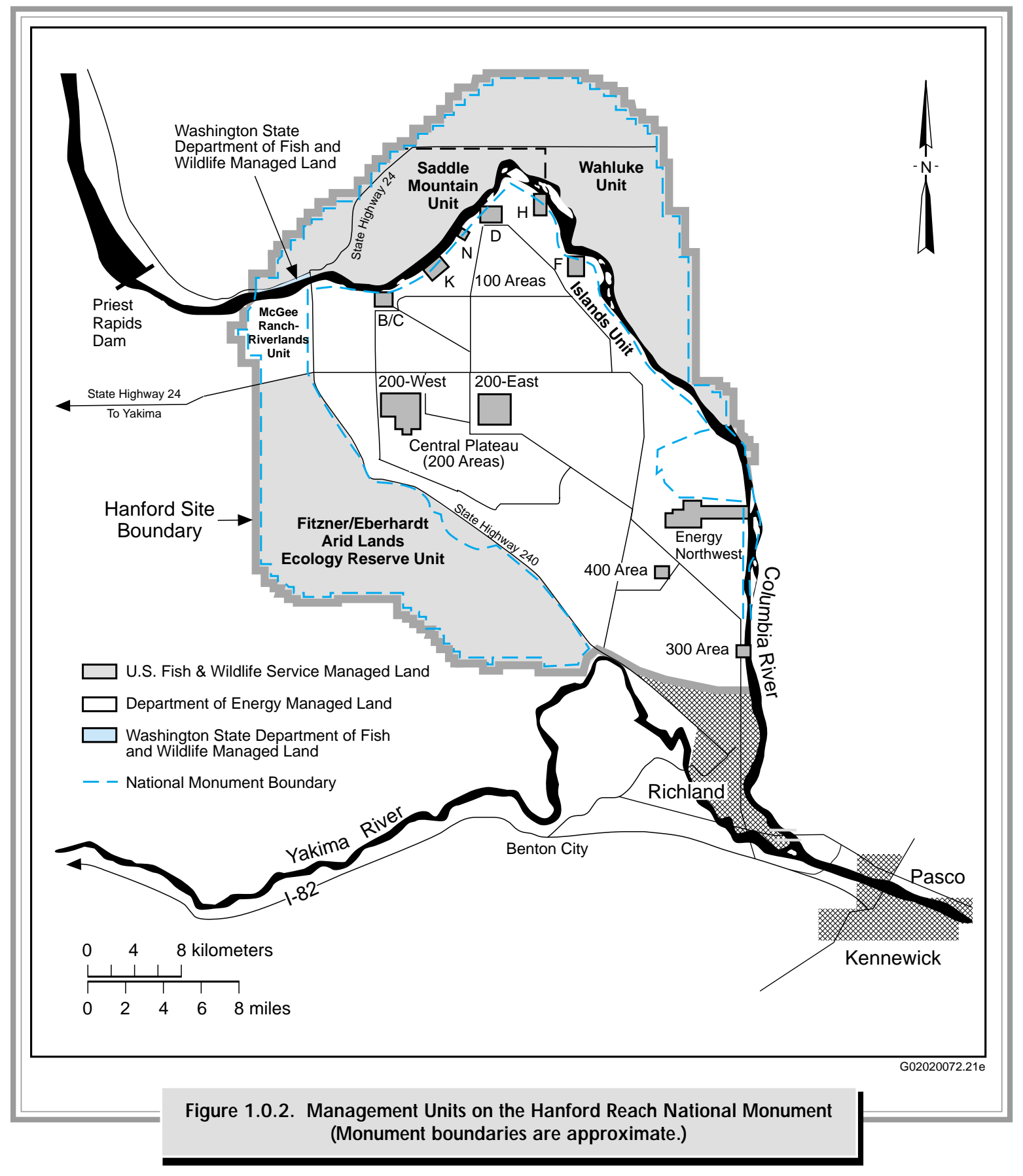

- The Volpentest $\mathrm{H}$ azardous Materials Management and Emergency Response Training and Education Center (also called HAMMER) - a worker safety training facility located on the site near the city of Richland. It consists of a 32-hectare $(80$-acre) main site and a 4,000-hectare $(10,000$-acre) law enforcement and security training site. The facility is owned by DOE, managed by Fluor Hanford, Inc., and used by site contractors, a variety of federal and state agencies, tribal governments, and private industry.
Other site related facilities (office buildings) are located within the Tri-City area.

Non-DOE operations and activities on Hanford Site leased land or in leased facilities include commercial power production by Energy Northwest (4.4 square kilometers [1.6 square miles]) and operation of a commercial low-level radioactive waste burial site by US Ecology, Inc. (0.4 square kilometer [0.2 square mile]). The National Science Foundation built the Laser Interferometer Gravitational-Wave Observatory for gravitational wave studies. The observatory, constructed 
between 1994 and 1999, is operated jointly by the California Institute of Technology and the Massachusetts Institute of Technology. R. H. Smith Distributing operates vehicle-fueling stations in the former 1100 Area and in the 200 Areas. Washington State University at Tri-Cities operated several laboratories in the 300 Area until March 2002. Livingston Rebuild Center, Inc. has leased the 1171 Building, in the former 1100 Area, to rebuild train locomotives. Johnson Controls, Inc. operates 42 diesel and natural gas package boilers to produce steam in the 200 and 300 Areas (replacing the old coalfired steam plants) and also has compressors supplying compressed air to the site. Kaiser Aluminum and Chemical Corporation leased the 313 Building in the 300 Area from 1994 until January 2002 to use an extrusion press that was formerly DOE owned.

Near the city of Richland, immediately adjacent to the southern boundary of the Hanford Site, Framatome ANP, Inc. operates a commercial nuclear fuel fabrication facility and Allied Technology Group Corporation operates a low-level radioactive waste decontamination, super compaction, and packaging facility.

\section{Site Managem ent}

The DOE's Richland Operations Office and the Office of River Protection manage the Hanford Site through several contractors and their subcontractors. Each contractor is responsible for safe, environmentally sound, maintenance and management of its activities or facilities; for waste management; and for monitoring any potential effluents to as sure environmental compliance. The U.S. Fish and Wildlife Service at the Hanford Site administered much of the site under the National Wildlife Refuge System and managed the land in accordance with the Presidential Proclamation (65 FR 114) establishing the Hanford Reach National Monument. The U.S. Fish and Wildlife Service was a joint steward of portions of the monument with DOE.

DOE Richland Operations Office. The DOE Richland Operations Office manages legacy cleanup, research, and other programs at the Hanford Site.

In 2001, the principal contractors for the DOE Richland Operations Office, and their respective responsibilities, included the following:

- Bechtel H anford, Inc. - the environmental restoration contractor. Bechtel Hanford, Inc. planned, managed, executed, and integrated a full range of activities for the cleanup of groundwater, contaminated soil, and inactive nuclear facilities. Bechtel Hanford, Inc.'s preselected subcontractors were CH2M HILL Hanford, Inc. and Eberline Services Hanford, Inc.

- Fluor Hanford, Inc. - the prime contractor for the nuclear legacy cleanup. Fluor Hanford, Inc.'s three principal subcontractors were Duke Engineering \& Services Hanford, Inc.; Duratek Federal Services of Hanford, Inc.; and Numatec Hanford Corporation. Other subcontractors to Fluor Hanford included Day \& Zimmerman Protection Technology Hanford.
- H anford Environmental Health Foundation Hanford Environmental Health Foundation's Health Risk Management Program worked to identify and analyze the hazards that Hanford personnel faced in the work environment. Hanford Environmental Health Foundation's occupational health services provided occupational medicine and nursing, medical surveillance, ergonomics assessment, exercise physiology, case management, psychology and counseling, fitness for duty evaluations, health education, infection control, immediate health care, industrial hygiene, and health, safety, and risk assessment.

- MACTEC-ERS - a prime contractor to the DOE Grand Junction Office. The Grand Junction Office has contracted with the DOE Richland Operations Office and the DOE Office of River Protection to conduct vadose zone, geophysical characterization, and monitoring work at former waste disposal facilities on the site.

- Pacific Northwest National Laboratory Battelle operated the Pacific Northwest National Laboratory for DOE's national security and energy missions. The core mission was to deliver environmental science and technology in the service of the nation and humanity. Pacific Northwest National Laboratory services included molecular science research, advanced processing technology, biotechnology, global environmental change research, and energy technology development.

DOE Office of River Protection. The DOE Office of River Protection was established by Congress in 1998 as a field office to manage DOE's largest, most complex environmental cleanup project-Hanford tank waste retrieval, treatment, and disposal. Sixty percent of the nation's high-level radioactive waste is stored at Hanford in aging tanks. 
The principal contractors for the DOE Office of River Protection in 2001 and their respective responsibilities included:

- B echtel N ational, Inc. - Bechtel National, Inc.'s contract mission is to design, build, and commission a Waste Treatment Plant to vitrify Hanford's tank waste. The project includes a pretreatment facility to separate the tank waste into high-level radioactive and low-activity radioactive streams. Separate vitrification facilities will immobilize the waste in a glass form encased in stainless steel canisters. Highlevel waste will be stored at the Hanford Site for eventual disposal at a federal repository. Lowactivity waste will be disposed of in concrete-lined trenches at the Hanford Site. The 10-year contract, worth $\$ 4$ billion, was awarded in December 2000.

- CH2M HILL Hanford Group, Inc. - the DOE Office of River Protection's prime contractor with responsibility for storing and retrieving for treatment 204 million liters (54 million gallons) of highly radioactive and hazardous waste stored in 177 underground tanks. The company's role includes characterizing the waste and delivering it to the future waste vitrification facility. In January 2001, the contract for CH2M HILL Hanford Group, Inc. was extended through 2006.

\subsection{References}

65 FR 114. June 13, 2000. Presidential Proclamation 7319, "Establishment of the Hanford Reach National Monument." Federal Register.

DOE/EIS-0222. 1999. Final Hanford Comprehensive Land-Use Plan Environmental Impact Statement. Online report. http://www.hanford.gov/eis/hraeis/hraeis.htm
DOE/RL-91-50, Rev. 3. 2000. Environmental Monitoring Plan, United States Department of Energy Richland Operations Office. U.S. Department of Energy, Richland Operations Office, Richland, Washington.

DOE/RL-2000-62, Rev. 2. 2001. Hanford 2012: Accelerating Cleanup and Shrinking the Site. Online report. http://www.hanford.gov/docs/rl-2000-62/index.html 


\title{
2.0 Environmental Regulatory Compliance
}

\author{
J. P. D uncan
}

This section describes how the Hanford Site achieves and maintains environmental and regulatory compliance. Subsections include (1) stakeholder and tribal involvement in the environmental restoration and waste management missions at the Hanford Site, (2) the current status of principal regulations and permits, (3) issues and actions arising from compliance efforts, (4) an annual summary of environmentally significant occurrences, and (5) waste management and chemical inventory information. It is the policy of the U.S. Department of Energy (DOE) that all activities be carried out in compliance with applicable federal, state, and local environmental laws and regulations, DOE Orders,
Secretary of Energy Notices, DOE Headquarters and site operations office directives, policies, and guidance. This includes those specific requirements, actions, plans, and schedules identified in the Hanford Federal Facility Agreement and Consent Order (also known as the TriParty Agreement; Ecology et al. 1998) and other compliance or consent agreements. Both the DOE Richland Operations Office and the DOE Office of River Protection recognize the importance of maintaining a proactive program of self-assessment and regulatory reporting to assure that environmental compliance is achieved and maintained at the Hanford Site. 


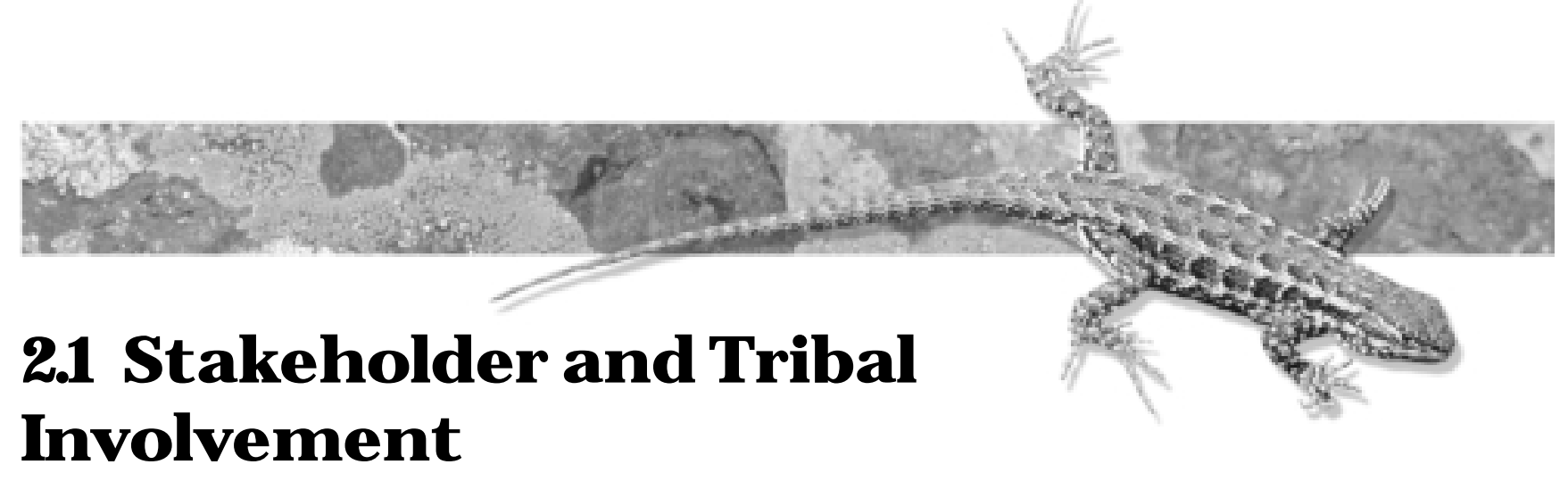

\section{J.P. Duncan}

Many entities have a role in DOE's mission of environmental restoration, waste management, and protection of the Columbia River at the Hanford Site. Stakeholders include federal, state, and local regulatory agencies; environmental groups; regional communities and governments; and the public. Indian Tribes and
Nations also have a special and unique involvement with the Hanford Site and maintain a government-togovernment relationship with DOE. The following sections describe the roles of the principal agencies, groups, organizations, and the public at the Hanford Site.

\subsection{Regulatory Oversight}

\section{K. A. Peterson}

Several federal, state, and local regulatory agencies are responsible for monitoring and enforcing compliance with applicable environmental regulations at the Hanford Site. The major agencies include the U.S. Environmental Protection Agency (EPA), Washington State Department of Ecology, Washington State Department of Health, and Benton Clean Air Authority.

EPA is the primary federal regulatory agency that develops, promulgates, and enforces environmental regulations and standards as directed in statutes passed by Congress. In some instances, EPA has delegated authority to the state or authorized the state program to operate in lieu of the federal program when the state's program meets or exceeds EPA's requirements. For instance, EPA has delegated certain enforcement authorities to the Washington State Department of Ecology for air pollution control and hazardous waste management. In other activities, the state program is assigned direct oversight of the DOE Richland
Operations Office as provided by federal law. For example, the Washington State Department of Health has direct authority under the Clean Air Act to enforce the standards and requirements under a statewide program to regulate radionuclide air emissions at applicable facilities (e.g., the Hanford Site). In accordance with 40 CFR 61, Subpart H, the Hanford Site is required to submit an annual report on the radionuclide emissions. Where federal regulatory authority is not delegated or only partially authorized to the state, EPA Region 10 is responsible for reviewing and enforcing compliance with EPA regulations as they pertain to the Hanford Site. In addition, EPA periodically reviews the adequacy of various state environmental programs and reserves the right to directly enforce federal environmental regulations.

Although Oregon does not have direct regulatory authority at the Hanford Site, DOE recognizes its interest in Hanford Site cleanup because of the state's location along the Columbia River. Oregon participates in the State and Tribal Government Working Group for the Hanford Site, which reviews the site's cleanup plans.

\subsection{Hanford Federal Facility Agreem ent and Consent Order}

\section{R. D. Morrison}

This order (also known as the Tri-Party Agreement; Ecology et al. 1998) is an agreement among the
Washington State Department of Ecology, EPA, and DOE to achieve environmental compliance at the Hanford Site with the Comprehensive Environmental Response, Compensation, and Liability Act (CERCLA), 
including the Superfund Amendments and Reauthorization Act of 1986 remedial action provisions, and with the Resource Conservation and Recovery Act (RCRA) treatment, storage, and disposal unit regulations and corrective action provisions. The Tri-Party Agreement (1) defines RCRA and CERCLA cleanup commitments, (2) establishes responsibilities, (3) provides a basis for budgeting, and (4) reflects a concerted goal to achieve regulatory compliance and remediation with enforceable milestones. A companion document to the Tri-Party Agreement is the Hanford Site Tri-Party Agreement Public Involvement Community Relations Plan (http:// www.hanford.gov/crp/toc.htm). This plan describes how public information and involvement activities are conducted for Tri-Party Agreement decisions.

The Tri-Party Agreement has continued to evolve as cleanup of the Hanford Site has progressed. Significant changes to the agreement have been negotiated to meet the changing conditions and needs of the cleanup. The most complex changes were made in 1993 with further modifications each year since. All significant changes to the agreement undergo a process of public involvement that assures communication and addresses the public's concerns prior to final approvals. Copies of the agreement are publicly available at DOE's Public Reading Room located in the Consolidated Information Center in Richland, Washington, and at information repositories in Seattle and Spokane, Washington, and Portland, Oregon. The Tri-Party Agreement can also be viewed on the Internet at http://www.hanford.gov/tpa/ tpahome.htm. To be placed on the mailing list for Tri-Party Agreement information, contact EPA or DOE directly, or call the Washington State Department of Ecology at 1-800-321-2008. Requests by mail can be sent to:
Hanford Mailing List: Informational Mailings
Public Involvement, M/S B3-30
P.O. Box 1000
Richland, WA 99352

\subsection{The Role of Indian Tribes}

\section{K. V. Clarke}

The Hanford Site is located on land ceded to the United States government by the Yakama Nation and the Confederated Tribes of the Umatilla Indian Reservation in the Treaties of 1855 . These tribes, as well as the $\mathrm{Nez}$ Perce Tribe, have treaty fishing rights on portions of the Columbia River. These tribes reserved the right to fish at all usual and accustomed places and the privilege to hunt, gather roots and berries, and pasture horses and cattle on open and unclaimed land. The Wanapum People are not a federally recognized tribe; however, they have historic ties to the Hanford Site as do the Confederated Tribes of the Colville Reservation, whose members are descendants of people who used the area known as the Hanford Site.

The Hanford Site environment supports a number of Native American foods and medicines and contains sacred places important to tribal cultures. The tribes hope to safely use these resources in the future and want to assure themselves that the Hanford environment is clean and healthy.

American Indian Tribal Governments have a special and unique legal and political relationship with the Government of the United States defined by history, treaties, statutes, court decisions, and the U.S. Constitution. In recognition of this relationship, DOE and each tribe interact and consult directly. Tribal government representatives from the Yakama Nation,
Confederated Tribes of the Umatilla Indian Reservation, and Nez Perce Tribe participate in DOE supported groups such as the State and Tribal Government Working Group, the Hanford Natural Resources Trustee Council, the Hanford Site Groundwater/Vadose Zone Integration Project, the Hanford Cultural Resources Program, and provide review and comments on draft documents. Both the Wanapum People and the Confederated Tribes of the Colville Reservation also are provided an opportunity to comment on documents and participate in cultural resource management activities.

The DOE American Indian and Alaska Native Tribal Government Policy (revised in November 2000) guides DOE's interaction with tribes for Hanford plans and activities. The policy states, among other things, "The Department will consult with any American Indian or Alaska Native tribal government with regard to any property to which that tribe attaches religious or cultural importance which might be affected by a DOE action." In addition to the DOE American Indian and Alaska Native Tribal Government Policy, laws such as the American Indian Religious Freedom Act, the Archaeological Resources Protection Act, the National Historic Preservation Act, and the Native American Graves Protection and Repatriation Act require consultation with tribal governments. The combination of the Treaties of 1855 , federal policy, executive orders, laws, regulations and the federal trust responsibility, provide the basis for tribal participation in Hanford Site plans and activities. DOE provides financial assistance through cooperative 
agreements with the Yakama Nation, Confederated Tribes of the Umatilla Indian Reservation, and $\mathrm{Nez}$
Perce Tribe to support their involvement in environmental management activities of the Hanford Site.

\subsection{Hanford Natural Resource Trustee Council}

\section{J. H. Zeisloft}

The President of the United States is required by CERCLA to appoint federal officials to act on behalf of the public as trustees for natural resources when natural resources may be injured, destroyed, lost, or threatened as a result of a release of hazardous substances. The President appointed the Secretary of Energy as the primary trustee for all natural resources located on, over, or under land administered by DOE. Other designated federal trustees for Hanford natural resources include the U.S. Department of the Interior represented by the U.S. Fish and Wildlife Service and the Bureau of Land Management, and the U.S. Department of Commerce represented by the National Oceanic and Atmospheric Administration.

CERCLA also authorizes state governors to designate a state trustee to coordinate all state trustee responsibilities. CERCLA further states that chairmen (or heads of governing bodies) of Indian tribes have essentially the same trusteeship over natural resources belonging to or held in trust for the tribe as state trustees. Indian tribes and state organizations have been designated as natural resource trustees for certain natural resources at or near the Hanford Site. Indian tribes include the Yakama Nation, Confederated Tribes of the Umatilla Indian Reservation, and Nez Perce Tribe. State organizations include Washington, represented by the Washington State Department of Ecology and Washington State Department of Fish and Wildlife, and Oregon, represented by the Oregon Department of Energy.

The responsibilities of trustees as established by CERCLA include cooperating with project managers to coordinate assessments, investigations and planning; carrying out damage assessments; and devising and implementing restoration plans. To formalize their responsibilities, the Hanford trustees signed a memorandum of agreement (1996) establishing the Hanford Natural Resource Trustee Council. The primary purpose of the council is to facilitate the coordination and cooperation of the trustees in their efforts to mitigate the impacts to natural resources that result from either hazardous substance releases within the Hanford Site or the remediation of those releases. The council also adopted bylaws to direct the process of arriving at consensus agreements.

The Hanford Natural Resource Council is performing an ongoing assessment of potential injury to Columbia River aquatic resources from exposure to hazardous substances released from the Hanford 100 Areas. The initial phase of this assessment involved preparation of an aquatic resources assessment plan (U.S. Fish and Wildlife Service 1999) by the U.S. Fish and Wildlife Service using the natural resource damage assessment regulations in 43 CFR 11 as guidance. The council approved the plan, which focused on several contaminants, including chromium that has migrated via groundwater flow to sections of the Columbia River used by fall chinook salmon for spawning. As recommended in the assessment plan, the council is studying these chromium releases to assess their potential to injure the salmon. The results of this study will aid the trustees, regulators, and DOE to develop, evaluate, and select remedial actions that minimize or eliminate any injury to the salmon.

The council also performed a pre-assessment screen for the former Hanford 1100 Area. In response to concerns raised by that screen, the trustees are coordinating with DOE on the collection and analysis of additional data pertaining to waste sites within the 1100 Area.

Additional information about the council, including its history and projects can be found on the Internet at http://www.hanford.gov/boards/nrtc.

\subsection{Public Participation}

\section{B. K. Wise}

Individuals may influence Hanford Site cleanup decisions through public participation activities. The public is provided opportunities to contribute their input and influence decisions through many forums, including Hanford Advisory Board meetings, Tri-Party Agreement activities, National Environmental Policy Act public meetings on various environmental impact statements, and other involvement activities. The Office of Intergovernmental, Public and Institutional Affairs (DOE Richland Operations Office) and the 
Office of Communication (DOE Office of River Protection) coordinate the planning and scheduling of public participation activities for the Hanford Site.

The Hanford Site Tri-Party Agreement Public Involvement Community Relations Plan (Tri-Party Agreement Agencies 2002) outlines how public information and involvement activities are conducted for Tri-Party Agreement decisions. Washington State Department of Ecology, DOE, and EPA developed and revised the plan with input from the public. The plan was approved in 1990. The plan is updated on an as-needed basis; the most recent revision occurred in January 2002. The plan can be found on the Internet at http://www.hanford.gov/crp/toc.htm.

A mailing list of about 3,300 individuals who have indicated an interest in participating in Hanford Site decisions is maintained. The mailing list also is used to send topic-specific information to those people who have requested it. Information is provided on upcoming decisions to elected officials, community leaders, special interest groups, and the media.
To inform the public of upcoming opportunities for public participation, the Hanford Update, a synopsis of all ongoing and upcoming Tri-Party Agreement public involvement activities, is published bimonthly. In addition, the Hanford Happenings calendar, which highlights Tri-Party Agreement meetings and comment periods, is distributed each month to the entire mailing list. To allow Hanford stakeholders and others to access up-todate information, documents from the Tri-Party Agreement's Administrative Record and Public Information Repository are available on the Internet at http:// www2.hanford.gov/arpir.

The public can obtain information about cleanup activities via a toll-free telephone line (800-321-2008). Members of the public can request information about any public participation activity and receive a response by contacting the Office of Intergovernmental, Public and Institutional Affairs (DOE Richland Operations Office) at (509) 376-7501. Also, a calendar of public involvement opportunities can be found on the Internet at http://www.hanford.gov/calendar/.

\subsection{Hanford Advisory Board}

\section{B. K. Wise}

The Hanford Advisory Board was chartered in January 1994 to advise DOE, EPA, and Washington State Department of Ecology on major Hanford Site cleanup policy issues. The Hanford Advisory Board was the first of many such advisory groups created by DOE at weapons production cleanup sites across the national DOE complex. The board consists of 31 members who represent a broad cross section of interests, including environmental, local governments, public health, business, tribal governments, and the public. Each board member has at least one alternate. Todd Martin, public at large, is the chairperson. The board has five standing committees: (1) Budgets and Contracts, (2) River/Plateau, (3) Health, Safety, and Environmental
Protection, (4) Tank Waste, and (5) Public Involvement and Communication.

The board held six 2-day meetings in fiscal year 2001. Members are engaged in discussions with representatives from the Tri-Party Agreement agencies on major cleanup issues, plans to treat tank waste, and budget priorities. The board produced 11 new pieces of consensus advice (making a total of 122), engaged in a series of meetings, participated in several workshops and engaged in informational exchanges with each other and representatives from the Tri-Party Agreement agencies. Information about the Hanford Advisory Board, including copies of its advice and responses can be found on the Internet at http://www.hanford.gov/ boards/hab/index.htm.

\subsection{Hanford Site Technology Coordination Group}

\section{L. Fassbender}

The Hanford Site Technology Coordination Group was established in 1994, and its structure was modified in early 2000. It consists of a Management Council and five subgroups aligned with the Environmental Management Focus Areas: (1) deactivation and decommissioning, (2) mixed waste, (3) subsurface contaminants,
(4) tanks, and (5) nuclear materials. The DOE Headquarters' Office of Environmental Management established the Focus Areas to develop and deliver solutions to technology needs identified at DOE sites across the nation. Subgroups of the Hanford Site Technology Coordination Group provide detailed documentation of the Hanford Site's technology needs to guide the focus areas' efforts in technology development. 
The Management Council continued to focus on Hanford Site policy issues related to technology development and deployment. Subgroups of the Hanford Site Technology Coordination Group identified and prioritized the site's science and technology needs, identified technology demonstration opportunities, interfaced with the Environmental Management Focus Areas, and helped assure that demonstrated technologies are deployed.

During 2001, the subgroups endorsed the science and technology needs developed by the site contractors for submittal to the Environmental Management Focus Areas and the Environmental Management Science Program. The Environmental Management Science Program sponsors basic research on fundamental issues that may be critical to ongoing technology development. This research may result in decreased public and worker risks, major cost reduction opportunities, schedule acceleration required to achieve DOE's cleanup mission, and answers to problems considered intractable without new knowledge. Hanford's science and technology needs can be found on the Internet at http://www.hanford.gov/ boards/stcg/. In addition, the subgroups heard and provided comments on numerous presentations on a variety of new technologies being demonstrated and/or deployed on the Hanford Site.
The DOE Richland Operations Office Associate Manager for Science and Technology chairs the Management Council, and the head of Fluor Hanford Technology Management Division is the co-chair. The Management Council includes four DOE Richland Operations Office Assistant Managers (River Corridor, Central Plateau, Planning and Integration, and Safety and Engineering), as well as representatives from the Office of Spent Nuclear Fuels, the Fast Flux Test Facility Project Office, and the Office of Training Services and Asset Transition. Representatives from the DOE Office of River Protection also participate. The Management Council includes two representatives from EPA, two from the Washington State Department of Ecology, one from the Oregon Department of Energy, three from the Hanford Advisory Board, and three from American Indian tribes (Yakama Nation, $\mathrm{Nez}$ Perce Tribe, and Confederated Tribes of the Umatilla Indian Reservation). The Hanford Site contractors also have designated representatives on the Management Council.

The elements of the Hanford Site Technology Coordination Group mission statement can be found on the Internet at http://www.hanford.gov/boards/stcg. 


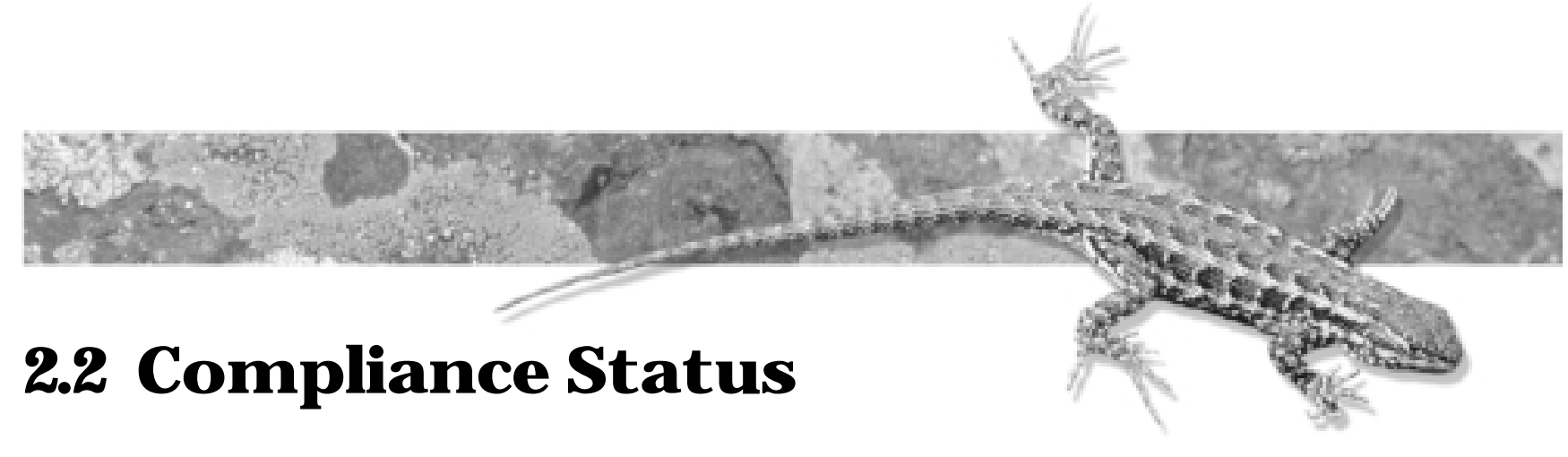

J. P. Duncan

This section summarizes the status of Hanford Site activities with regard to federal environmental protection statutes and associated state and local environmental regulations. Permits required under specific environmental protection regulations are discussed under their applicable statute.

\subsubsection{Hanford Federal Facility Agreement and Consent Order}

\section{R. D. Morrison}

The Hanford Federal Facility Agreement and Consent Order (Tri-Party Agreement; Ecology et al. 1998) commits DOE to achieve compliance with the remedial action provisions of CERCLA and with the treatment, storage, and disposal unit regulations and corrective action provisions of RCRA, including the state's implementing regulations. From 1989 through 2001, a total of 728 milestones and 268 target dates were completed on or ahead of schedule. In 2001, there were 41 specific cleanup milestones scheduled for completion: 39 were completed on or before their required due dates, 1 was delayed due to unanticipated cost escalation and contracting issues, and 1 is expected to be completed successfully under the terms of an agreement between the DOE and the Washington State Department of Ecology.

The Tri-Party Agreement contains a schedule, using enforceable major and interim milestones and unenforceable target dates, that reflects a goal of achieving full regulatory compliance and remediation in an aggressive manner.

\subsubsection{Tri-Party Agreement Highlights}

Highlights of milestone accomplishments during 2001 under the terms of the Tri-Party Agreement include (associated milestone numbers are shown in parenthesis):

- Excavation activities on the process effluent pipelines at the 100-BC Operable Unit were begun (M-16-26D).
- A report assessing the development of ultrasonic (or equivalent) testing equipment to determine tank-wall thickness and defects in the double-shell tanks was prepared and submitted to the Washington State Department of Ecology (M-48-02B).

- A site-specific Single-Shell Tank Waste Management Area Phase 1 RCRA Facility Investigation and/or Corrective Measures Study Work Plan Addenda for Waste Management Area T and TX-TY was developed and submitted to the Washington State Department of Ecology (M-45-54) (RPP-7578).

- Construction of upgrades to the ventilation and electrical systems in double-shell tanks began in a third tank farm (M-43-14).

- All Rocky Flats ash mixed waste currently stored in the Plutonium Finishing Plant was repackaged and shipped to Hanford's Central Waste Complex for storage (M-83-07).

- The installations of RCRA groundwater monitoring wells in accordance with major milestone $\mathrm{M}-24-00 \mathrm{M}$ were completed at the following locations:

- five wells in Single-Shell Tank Waste Management Area S-SX (M-24-49/55)

- four wells in Single-Shell Tank Waste Management Area TX-TY (M-24-50/53)

- three wells in Single-Shell Tank Waste Management Area B-BX-BY (M-24-51) 
- three wells in Single-Shell Tank Waste Management Area U (M-24-52)

- one well in Single-Shell Tank Waste Management Area T (M-24-54)

- The T Plant sludge storage conceptual design document was completed and submitted to the Washington State Department of Ecology (M-91-18).

- The disposal of contact-handled low-level mixed waste was begun (M-91-13).

- A draft and subsequently a final tank waste information requirements document was completed and submitted to the Washington State Department of Ecology (M-44-13E/14E) (RPP-8093).

- The annual Hanford Land Disposal Restrictions Report was completed and submitted to the Washington State Department of Ecology (M-26-01K) (DOE/RL-2001-20).

- The results of ultrasonic testing and static leak tests of miscellaneous waste tanks were prepared and submitted to the Washington State Department of Ecology (M-48-08).

- The DOE Office of River Protection's semiannual project compliance report was submitted to the Washington State Department of Ecology (M-62-01C) (01-ORP-104).

- Remedial action excavation on the J.A. Jones 1 and the 600-23 waste sites (north of the 300 Area and within the Pit 11 boundary just off of Route 2 South, respectively) was completed (M-16-41A).

- Remediation and backfill of 22 liquid waste sites and process effluent pipelines in the 100-DR-1 and the 100-DR-2 operable units were completed (M-16-07B).

- An evaluation of the development status of tritium treatment technology that would be pertinent to the cleanup and management of tritiated wastewater was prepared and submitted to the Washington State Department of Ecology (M-26-05H) (DOE/RL-2001-33).

- A written report documenting results of ultrasonic testing of the primary tank walls in four doubleshell tanks not previously examined was prepared and submitted to the Washington State Department of Ecology (M-48-09) (01-TOD-T022).
- A second report assessing the development of ultrasonic (or equivalent) testing equipment to determine tank-wall thickness and defects in the double-shell tanks was prepared and submitted to the Washington State Department of Ecology (M-48-02C) (01-TOD-T021).

- A double-shell tank waste volume projection report was developed and submitted to the Washington State Department of Ecology (M-46-00H) (RPP-8554).

- An annual update of the single-shell tank retrieval sequence document was developed and submitted to the Washington State Department of Ecology (M-45-02J) (RPP-8554).

- High-level waste tank characterization data and information were entered into an electronic database to make them available to the EPA and Washington State Department of Ecology thereby completing milestone M-44-16E. These data and information were from sampling and characterization work completed according to the appropriate waste information requirements document.

- Filter boxes were removed and verification sampling was completed at the $100-\mathrm{B}-12$ waste site in the 100-B Area (M-16-26G).

- Remediation and backfill of 10 liquid waste disposal sites and process effluent pipelines in the 100-HR-1 Operable Unit were completed (M-16-26C).

- Waste tank safety issues for high priority watch list tanks were mitigated and or resolved (M40-00).

- Start of construction for the K-East Basin and $\mathrm{K}$-West Basin facility modifications for the alternative fuel transfer strategy cask transportation system was approved (M-34-26-T01).

- Well drilling and sample collection in the 200-TW-1 Operable Unit was completed (M-15-41A).

- Well drilling and sample collection in the 200-TW-2 Operable Unit was completed (M-15-42A).

- A revised hazardous waste facility permit application identifying and describing all current and past structures and waste management areas associated with the single-shell tank system was prepared and submitted to the Washington State Department of Ecology (M-23-21).

- The S-112 tank saltcake waste retrieval technology demonstration functions and requirements 
document was prepared and submitted to the Washington State Department of Ecology (M-45-03-T03) (RPP-7825).

- Completed transfer of the remaining 235 metric tons ( 259 tons) of uranium billets (small bars) located in the 300 Area to the Portsmouth, Ohio site (M-92-06-T01).

- The single-shell tank C-104 sludge/hard heel, confined sluicing and robotic technologies, waste retrieval demonstration functions and requirements document was submitted to the Washington State Department of Ecology (M-45-03-T04) (RPP-7807).

- Phase II In Situ Redox Manipulation barrier emplacement, planning and well installation in the 100-HR-3 Operable Unit was completed (M-16-27B).

- The remedial investigation work plan for the plutonium/organic rich process waste group (operable unit 200-PW-1) was prepared and submitted to EPA (M-13-26) (DOE-RL-2001-01).

- Three 200 Areas National Priorities List Remedial Investigation/Feasibility Study or RCRA Facility Investigation/Corrective Measures Study work plans were prepared and submitted to the Washington State Department of Ecology (M-13-00L) and EPA (DOE-RL-2001-01; DOE/RL-2001-65; DOE/ RL-2001-66).

- The 300 Area Special Case Waste Project Management Plan (M-92-13) was reviewed by the Washington State Department of Ecology, and the Department's comments were incorporated into this document (HNF-5068).

- 300 Area Phase II Special Case Materials were packaged and shipped to the 200 Areas to fulfill the requirements of Tri-Party Agreement milestone M-92-15.

- 324 Building mixed waste and equipment were collected, containerized, removed, and shipped to the 200 Areas to fulfill the requirements of Tri-Party Agreement milestone M-89-02.

Since this annual report was issued last year, 26 negotiated change requests to the Tri-Party Agreement were approved. A summary of the significant changes is given in the following sections.

\subsubsection{Tri-Party Agreement Negotiated Change Requests}

Waste Management. There were two Tri-Party Agreement change requests related to waste management approved during 2001.

The annual land disposal restrictions report (DOE/RL-2001-20) is due by April 30 of each year. Technical discussions between DOE and the Washington State Department of Ecology resulted in significant changes to the report content. A 2-month extension to the due date for the 2000 report was approved to allow DOE and the Washington State Department of Ecology additional time to work together and produce a document that would be acceptable and satisfactory. Additionally, the time period covered by the report was adjusted from April 1 through March 31 of each year to January 1 through December 31 of each year.

Milestone M-91-12 states "...initiate thermal treatment of currently stored and newly generated contact-handled low level mixed waste. At least $600 \mathrm{~m}^{3}$ $\left(21,189 \mathrm{ft}^{3}\right)$ will be provided for treatment by December 2000." On January 12, 2001, the Washington State Department of Ecology notified DOE that the milestone had not been met. DOE believed that the milestone had been met and initiated the dispute resolution procedures of the Tri-Party Agreement to resolve the issue. The final settlement of this dispute was embodied in a change request that allowed DOE an additional 24 months to achieve sustained treatment capabilities.

Environmental Restoration. Eleven Tri-Party Agreement change requests related to environmental restoration were approved during 2001.

Three change requests added nine new milestones to the Tri-Party Agreement requiring the completion of remedial investigations and remedial actions in the 200-TW-1, 200-TW-2, and the 100-IU-6 Operable Units.

Interim milestone $\mathrm{M}-13-26$ required the submittal of the remedial investigation work plan for the 200-PW-1 Operable Unit by June 30, 2001. The focus of this work plan is the characterization of the vadose zone. Based upon the distribution of carbon tetrachloride in groundwater, it was believed there might be additional unidentified sources of carbon tetrachloride in the vadose zone. The EPA requested that the 200-PW-1 Operable Unit work plan incorporate all 
investigations needed to answer questions surrounding the operable unit's contaminants of concern, carbon tetrachloride being of particular concern. Inclusion of the investigation of the dispersed carbon tetrachloride vadose zone plume, as requested by the EPA, required the deferral of the milestone due date from June 30, 2001 to December 31, 2001.

Two approved change requests were related to the installation of RCRA monitoring wells on the Hanford Site. One change request established 5 new enforceable milestones requiring the installation of 11 new groundwater monitoring wells by December 31, 2001. The other change request changed the location of two wells to be installed under the terms of previously established milestones.

Interim milestone $\mathrm{M}-15-38 \mathrm{~A}$ required the submittal of a feasibility study/proposed plan for the Gable Mountain Pond/B Pond and Ditch Cooling Water Group and a closure plan for the 216-B-3 Pond System by November 30, 2001. Based on regulatory and stakeholder comments received on a related remedial investigation/ feasibility study work plan and a remedial investigation report, it was determined that interim milestone M-15-38A should be deferred to allow time for assessment of ecological impacts and to resolve human health and ecological risk assessment exposure scenarios prior to completion of the subject feasibility study/proposed plan. Therefore, a change request was approved which extended the due date of milestone M-15-38A to March 31, 2003.

Milestone M-16-26B originally required the completion of remediation of 51 waste sites as well as process effluent pipelines in the 100-BC-1, 100-BC-2, 100-DR-1, 100-DR-2, and 100-HR-1 operable units. The 100-BC-1 and 100-BC-2 pipeline remediation efforts encountered impacts when actual field conditions encountered during remediation differed from the design conditions. These events necessitated the approval of four new milestones (M-16-26D, M-16-26E, $\mathrm{M}-16-26 \mathrm{~F}$, and M-16-26G) covering the remediation of the $100-\mathrm{B} / \mathrm{C}$ Area pipelines and the extension of the due date for the original M-16-26B waste site remediation activities.

Milestone M-16-26C required the remediation of waste sites and process effluent pipelines in the 100-HR-1 Operable Unit by May 31, 2001. The discovery of two contaminants, arsenic and chromium, during the closeout sampling process for the waste sites required that additional research, sampling, and studies be performed. These additional activities prompted the approval of a change request providing a 4-month extension to the due date of this milestone.
The original M-16-03D milestone required the completion of remediation of the waste sites in the 300-FF-1 Operable Unit by May 31, 1999. Impacts occurred to this milestone resulting from the discovery of numerous drums during excavation, the emergence of questions regarding the protectiveness of the cleanup levels for uranium, and the time necessary to obtain valid results from soil leach tests. As a result, it became necessary to delete M-16-03D and associated follow on milestones M-16-03E and M-16-03F and create three new milestones. A change request was ultimately approved which created the three new milestones (M-16-03G, M-16-03H, and M-16-03I) thereby extending the due dates covering the remediation of the waste sites in the 300-FF-1 Operable Unit including the 618-4 burial ground.

DOE O ffice of River Protection. There were six Tri-Party Agreement change requests approved related to the DOE Office of River Protection during 2001.

The Washington State Department of Ecology completed an inspection of interim status compliance on the Hanford Site's single-shell tanks. The inspection consisted of a review of current and historic records, interviews of DOE and Hanford Site contractor personnel, and a facility walkdown. As a result of this inspection, the Washington State Department of Ecology identified alleged non-compliances with regulatory requirements and some related concerns. A change request was ultimately developed and approved which established 11 new enforceable milestones and one new target date, under the M-23-00 series of milestones, addressing the outcome of the inspection. A related change request also made modifications to the scope of target date M-45-06-T05 in support of the M-23-00 agreements. These modifications added the requirement for a description and depiction of all components of the single-shell tank system to the scope of target date M-45-06-T05.

The Washington State Department of Ecology and DOE concluded negotiations in August 2000 on nearterm Tri-Party Agreement milestones and target dates in the M-45-00 milestone series governing single-shell tank waste retrieval activities prior to September 30, 2006. This near-term strategy has shifted from focusing on maximizing the number of tanks entered for retrieval (regardless of waste volume or content) to a focus on scheduling the retrieval of waste from singleshell tanks with high volumes of contaminants of concern. The strategy also focuses on the performance of key retrieval technology demonstrations on a variety of waste forms in various tank farm locations and on the performance of risk assessments, incorporating vadose zone characterization data on a tank-by-tank basis, and 
on updating tank farm closure/postclosure work plans. The resulting change request established 14 new milestones and 8 new target dates.

In 1998, the Washington State Department of Ecology called on DOE to develop and submit a corrective action plan for the S, SX, B, BX, BY, T, TX, and TY single-shell tank farms, and that this plan at a minimum: (1) provide information equivalent to a RCRA Facility Investigation and include provisions to characterize the vadose zone and aquifer beneath the tank farms, (2) define the sources, nature, and extent of vadose zone contamination, and (3) identify actual or potential contaminant receptors. After extensive negotiations, agreement was reached on modifications to Tri-Party Agreement requirements within major milestone series M-45-00 (complete closure of all single-shell tank farms). These modifications included 11 new interim milestones and 9 new target dates.

One change request modified the completion dates for interim milestone $\mathrm{M}-45-54$ and target dates M-45-55-T01 and M-45-55-T02. These commitments required the development of plans and information for remedial investigations in the T, TX-TY, S-SX, and B-BX-BY Single-Shell Tank Waste Management Areas. These modifications became necessary as the result of an effort to better align the planning, characterization and final reporting requirements in response to data that have been collected and analyzed in the waste management areas.

Facilities Transition. Six Tri-Party Agreement change requests approved during 2001 were related to facility transition, i.e., the transition of a major facility from an expensive high maintenance shutdown/standby condition to a low maintenance, low cost, safe, stable condition to await final decommissioning.

Four change requests were approved establishing Tri-Party Agreement commitments related to the handling, storage, and disposition of various materials at the Plutonium Finishing Plant. Three of these change requests established three new interim milestones addressing the following materials: (1) the disposition of Hanford ash waste; (2) the disposition of sand, slag, and crucible waste; and (3) the solidification of plutonium bearing solutions that have been selected to be disposed of as transuranic-mixed waste. The fourth Plutonium Finishing Plant related change request established additional requirements and an extended start date of November 1, 2001 to conduct transition and disposition negotiations.
The due date of target date MX-92-11-T01 requiring the disposition of all Hanford Site non-radioactive sodium was extended from March 31, 2002 to September 30, 2004. This action was taken to establish a clearer understanding of the disposal/disposition of the remaining non-radioactive sodium and its alignment with other integrated site priorities.

Verification of three existing Tri-Party Agreement milestones was the subject of one milestone M-92-00 series related change request. Milestones M-92-14, M-92-15, and M-92-16 were re-confirmed in conjunction with the required project management plan. These milestones control the removal, transfer, and storage of 300 Area special case wastes.

Negotiations conducted by the Washington State Department of Ecology, EPA, and DOE Richland Operations Office resulted in the development of Change Number M-094-01-01, which defines proposed Tri-Party Agreement milestone M-94-00 (Establish Date for Final Disposition of all 300 Area Surplus Facilities under the M-094 series milestones). Proposed milestone M-94-00 provides the overall framework for disposition of the 300 Area surplus facilities, and aligns the M-94-00 milestones for 300 Area surplus facility disposition with the objective of completion by 2018 .

Spent Nuclear Fuel. There was one Tri-Party Agreement change request approved related to the Spent Nuclear Fuel Project during 2001. The approved change request adopted the "Alternate Fuel Transfer Strategy" into the existing spent nuclear fuel series of milestones. This strategy eliminates the need for certain construction activities in the K-East Basin that would otherwise be necessary to retrieve, clean, package, and remove spent nuclear fuel from the basin. The Alternate Fuel Transfer Strategy requires the K-East Basin fuel to be retrieved and packaged in shipping casks that are transported to the K-West Basin. The existing K-West Basin facilities will then be used to retrieve, clean, package, and remove the fuel. The strategy accelerates the removal of spent nuclear fuel and water from the K-East Basin.

A Tri-Party Agreement Change Request was approved in 2001 that changed some interim milestones without changing the 2004 date for having all the spent nuclear fuel removed from the K Basins. 


\subsubsection{Environmental Management Systems}

\section{H. T. Tilden II, G. D. Cummins, R. D. Lichfield, and L. M. Dittmer}

Major contractors at the Hanford Site have established Integrated Environment, Safety, and Health Management Systems. These systems, contractually mandated by DOE, are intended to protect the worker, public, and environment by integrating environment, safety, and health into the way work is planned, performed, and improved. The international voluntary consensus standard ISO 14001, Environmental Management Systems - Specifications with Guidance for Use, and DOE P 450.4, Safety Management System Policy, were used in the development of the systems. Basic elements of these systems include environmental policy, planning, implementation, checking and corrective action, and management review.

In 1998, DOE Headquarters approved the Integrated Environment, Safety, and Health Program
Description for the Pacific Northwest National Laboratory (https://sbms.pnl.gov/mgtsys/ms0ed010.htm). Also in 1998, Fluor Hanford, Inc. issued an Integrated Environmental, Safety, and Health Management System Plan (HNF-MP-003); and Bechtel Hanford, Inc. issued an Integrated Environmental, Safety, and Health Management System Description (BHI-01199). DOE has verified the following Hanford contractors as having adequately implemented Integrated Environmental, Safety and Heath Systems: Fluor Hanford, Inc. (August 2000), CH2M HILL Hanford Group, Inc. (May 2000), Bechtel Hanford, Inc. (May 2000), and Pacific Northwest National Laboratory (1998). Efforts continued in 2001 to implement and improve these environmental, safety, and health programs. Hanford Site contractors are moving to pursue ISO 14001 registration through either self-certification to the standard or certification by thirdparty registrars.

\subsubsection{Chemical Management Systems}

\section{T. Jansky}

The Hanford Site, with its numerous contractors, facilities, and processes, uses a variety of approaches for chemical management. Formal systems for the management of chemicals were developed and documented in 1997. These management systems are applicable to the acquisition, use, storage, transportation, and final disposition of chemicals including hazardous chemicals as defined in the Occupational Safety and Health Administration's Hazard Communication Standard (29 CFR 1910.1200, Appendices A and B). The chemical management systems have been reviewed periodically and improved as needed. Details on the chemical inventories stored at the Hanford Site may be found in Section 2.5.2.

\subsubsection{Com prehensive Environmental Response, Compensation, and Liability Act (CERCLA)}

\section{M. Dittmer}

In 1980, CERCLA was enacted to address response, compensation, and liability for past releases or potential releases of hazardous substances, pollutants, and contaminants to the environment. The EPA is the federal agency responsible for oversight of DOE's implementation of CERCLA. There is significant overlap between the state RCRA corrective action program (see Section 2.2.6) and CERCLA. Many waste management units are subject to remediation under both programs. The CERCLA program is implemented via 40 CFR 300, "National Oil and Hazardous Substances Pollution
Contingency Plan," which establishes procedures for characterization, evaluation, and remediation. The TriParty Agreement addresses CERCLA implementation at Hanford and is generally consistent with the national contingency plan process.

There are several remediation activities under way at Hanford that are accomplished using the CERCLA process (e.g., remedial investigation in the 200 and 300 Areas, cleanup in the 100, 200, and 300 Areas). Specific project activities and accomplishments are described in Sections 2.3.2 and 2.3.10. 


\subsubsection{Emergency Planning and Com m unity Right-To- Know Act}

\section{E. Zaloudek}

This act requires states to establish a state emergency response commission and local emergency planning committees and to develop a process to distribute information on hazardous chemicals present in facilities. These organizations gather information and develop emergency plans for local planning districts. Facilities that produce, use, or store extremely hazardous substances in quantities above threshold planning quantities must identify themselves to the state emergency response commission and the local emergency planning committee, and periodically provide information to support the emergency planning process. Facilities must also notify the state emergency response commission and the local emergency planning committee immediately after an accidental release of an extremely hazardous substance over the reportable quantity. Extremely hazardous substances are listed in 40 CFR 355 (Appendices A and B) along with the applicable threshold planning quantity.

The Hanford Site provides required hazardous chemical inventory information to the Washington State Department of Ecology's Community Right-ToKnow Unit; local emergency planning committees for Benton, Franklin, and Grant Counties; and to both the Richland and Hanford Site fire departments. The 2001
Hanford Site Tier Two Emergency and Hazardous Chemical Inventory (DOE/RL-2002-13) was issued as required by law.

Facilities must also report total annual releases of certain toxic chemicals. The Pollution Prevention Act requires additional information with the report, and Executive Order 13148 (65 FR 24595), Greening the Government Through Leadership in Environmental Management, extends the requirements to all federal facilities, regardless of the types of activities conducted. Based on evaluation of Hanford Site toxic chemical usage data during 2001, the Hanford Site was required to prepare a Toxic Chemical Release Inventory report for lead. The 2001 Toxic Chemical Release Inventory report (DOE/RL-2002-37) includes information about the quantities of lead released to the environment; transferred offsite for recycle, treatment, or disposal; recycled, treated or disposed onsite; source reduction activities involving lead; and other pollution prevention information.

For reporting year 2001, the Hanford Site issued the reports and notifications required by this act. Table 2.2.1 provides an overview of 2001 reporting under the Emergency Planning and Community RightTo-Know Act.

Table 2.2.1. Emergency Planning and Community Right-to-Know Act Compliance Reporting, 2001

\begin{tabular}{|c|c|c|c|}
\hline Sections of the Act & $\underline{\text { Yes }}^{(a)}$ & $\underline{\mathbf{N o}}^{(\text {a) }}$ & Not Required $^{(a)}$ \\
\hline Planning notification & $X^{(b)}$ & & \\
\hline
\end{tabular}

302-303: Planning notification

304: Extremely hazardous substances release notification $\mathrm{X}$

311-312: Material safety data sheet/chemical inventory

$\mathrm{X}$

313: Toxic chemical release inventory reporting

$\mathrm{X}$

(a) "Yes" indicates that notifications were provided and/or reports were issued under the applicable provisions. "No" indicates that notifications or reports should have been provided but were not. "Not Required" indicates that no actions were required under the applicable provisions, either because triggering thresholds were not exceeded or no releases occurred.

(b) These notifications apply to the Hanford Site but were completed prior to 2001. 


\subsubsection{Resource Conservation and Recovery Act (RCRA)}

\section{J. Hartman}

RCRA was enacted in 1976 with the objective of protecting human health and the environment. In 1984, the Hazardous and Solid Waste Amendments re-authorized RCRA and imposed new requirements on the management of hazardous waste. The most important aspect of RCRA is its establishment of "cradle-to-grave" management to track hazardous waste from generator to treatment, storage, and disposal. The Washington State Department of Ecology has the authority for enforcing RCRA in the state. At Hanford, RCRA regulates $\sim 70$ hazardous waste treatment, storage, or disposal units that have received waste since implementation of the act.

\subsubsection{Hanford Facility RCRA Permit}

\section{J. C. Sonnichsen}

TheHanfordFacility RCRA Permit(WA7890008967), Dangerous Waste Portion that was issued by the Washington State Department of Ecology has been in effect since late September 1994 (DOE/RL-91-28). The permit provides the foundation for all future RCRA permitting on the Hanford Site in accordance with provisions of the Tri-Party Agreement (Ecology et al. 1998). Modification E, Revision 7, of the Hanford Facility RCRA Permit was appealed. Settlement of the appeal has been completed and Revision 8 of the Hanford Facility RCRA Permit is scheduled to be issued in fall 2002.

\subsubsection{RCRA/Dangerous Waste Permit Applications and Closure Plans}

\section{J. C. Sonnichsen}

For purposes of RCRA and Washington State dangerous waste regulations (WAC 173-303), the Hanford Site is considered a single facility that encompasses $\sim 70$ treatment, storage, and disposal units. The Tri-Party Agreement recognized that all of the units could not be issued permits simultaneously, and a schedule was established to submit unit-specific Part B dangerous waste permit applications and closure plans to the Washington State Department of Ecology.

During February 2001, Revision 7 (Modification E) of the Hanford Facility RCRA Permit Dangerous Waste Portion was issued. In March 2001, this permit was appealed by the permittees (DOE Richland Operations Office, Bechtel Hanford, Inc., Fluor Hanford, Inc., Pacific Northwest National Laboratory, and CH2M HILL Hanford Group, Inc.) to the Washington State Department of Ecology to resolve some issues about permit conditions. During 2001, eight Part A, Form 3, revisions were certified and submitted to the Washington State Department of Ecology. Since appeal of the permit, one Part B permit application for final status has been submitted to the Washington State Department of Ecology (DOE/RL-2001-64).

\subsubsection{RCRA Groundwater Monitoring}

\section{B. A. Williams}

RCRA groundwater monitoring is part of the Hanford Site Groundwater Monitoring Project (see Section 6.2). Table 2.2.2 lists the 24 facilities and units (or waste management areas) that require groundwater monitoring and notes their monitoring status, and Figure 6.1.3 shows the locations of these units. Samples were collected from 233 RCRA wells sitewide in 2001, the same number as during 2000. A summary of groundwater monitoring activities and results for these sites during 2001 is provided in Section 6.4.

Groundwater samples were analyzed for a variety of dangerous waste constituents and site-specific constituents, including selected radionuclides. The constituent lists meet the minimum RCRA regulatory requirements and are integrated to supplement other groundwater monitoring project requirements (e.g., Atomic Energy Act, CERCLA) at the Hanford Site.

During 2001, 16 new RCRA wells were installed (Table 2.2.3) to fulfill the requirements of Tri-Party Agreement milestone M-24-00M. The installation of these 16 wells was successfully completed in November 2001, ahead of the completion deadline of December 31, 2001. Of these 16 wells, 3 were installed at Waste Management Area B-BX-BY located in the 200-East Area, 1 at Waste Management Area T, 4 at Waste Management Area TX-TY, 3 at Waste Management Area U, and 5 at Waste Management Area S-SX all located in the 200-West Area. All the wells were completed as shallow (top of the aquifer) monitoring wells. The wells have well screens $\sim 10.7$ meters ( $\sim 35$-feet) long intended to monitor the uppermost portion of the unconfined aquifer. Well data package summaries will be published in 2002 that contain characterization and construction 
Table 2.2.2. RCRA Interim and Final Status Groundwater Monitoring Projects, September 2001

\section{TSD Units,}

date initiated

1301-N LWDF,

December 1987

1324-N/NA LWDF,

December 1987

1325-N LWDF

December 1987

183-H solar evaporation

basins, June 1985

216-A-29 ditch,

November 1988

216-B-3 pond,

November 1988

216-B-63 trench,

August 1991

216-S-10 pond and

ditch, August 1991

216-U-12 crib,

September 1991

316-5 process trenches,

June 1985

LERF, July 1991

LLWMA 1

September 1988
Final Status TSD Unit

Groundwater Monitoring

SD Unit

Groundwater Monitoring

$\begin{array}{cc}\text { Indicator } & \begin{array}{c}\text { Groundwater } \\ \text { Quality }\end{array} \\ \text { Parameter } & \text { Assessment, date } \\ \text { Evaluation }^{(a)} & \text { initiated }\end{array}$

Evaluation $^{(a)}$

initiated

\begin{tabular}{ccc} 
Groundwater Monitoring \\
\hline $\begin{array}{c}\text { Detection } \\
\text { Evaluation }\end{array}$ & $\begin{array}{c}\text { Compliance } \\
\text { Evaluation }\end{array}$ & $\begin{array}{c}\text { Action, date } \\
\text { initiated }\end{array}$
\end{tabular}

$X^{(b)}$

$\mathrm{X}^{(\mathrm{b})}$

$X^{(b)}$

X, 1993

\section{initiated}

\section{Groundwater \\ Monitoring}

Regulations

40 CFR 265.93(b)

WAC 173-303-400

40 CFR 265.93(b)

WAC 173-303-400

40 CFR 265.93(b)

WAC 173-303-400

X, 1998

40 CFR 264

WAC 173-303-645(10)

40 CFR 265.93(b)

WAC 173-303-400

40 CFR 265.93(b)

WAC 173-303-400

40 CFR 265.93(b)

WAC 173-303-400

40 CFR 265.93(b)

WAC $173-303-400$

40 CFR 265.93(d)

WAC 173-303-400

40 CFR 264

WAC 173-303-645(10)

40 CFR 265.93(b)

WAC 173-303-400

40 CFR 265.93(b)

WAC 173-303-400
Year

Scheduled

for Part B

or Closure

$1999^{(c)}$

1999(c)

1999(c)

$1994^{(c)}$

$2006^{(c)}$

$2003^{\text {(c) }}$

$2006^{(c)}$

$2006^{(c)}$

$2006^{\text {(c) }}$

$1996^{(c, d)}$

$1998^{(e, f)}$

$2002^{(f, g)}$ 
TSD Units,

date initiated

LLWMA 2,

September 1988

LLWMA 3,

October 1988

LLWMA 4,

October 1988

NRDWL, October 1986

PUREX cribs $^{(\mathrm{h})}$

1988

WMA A-AX,

February 1990

WMA B-BX-BY,

February 1990

WMA C,

February 1990

WMA S-SX,

October 1991

WMA T,

February 1990

WMA TX-TY,

September - October 1991

Table 2.2.2. (contd)

Interim Status TSD Unit

Ground

$\begin{array}{cc}\text { Indicator } & \begin{array}{c}\text { Groundwater } \\ \text { Quality }\end{array} \\ \text { Parameter } & \text { Assessment, date }\end{array}$

Evaluation ${ }^{(a)}$

X

X

X, 1997

initiated

Evaluation

Evaluation

\section{Corrective \\ Action, date \\ initiated}

Groundwater
Monitoring

Regulations

40 CFR 265.93(b) WAC $173-303-400$

40 CFR 265.93(b) WAC $173-303-400$

40 CFR 265.93(b) WAC 173-303-400

40 CFR 265.93(b) WAC 173-303-400

40 CFR 265.93(d) WAC 173-303-400

40 CFR 265.93(b) WAC 173-303-400

40 CFR 265.93(d) WAC 173-303-400

40 CFR 265.93(b) WAC 173-303-400

40 CFR 265.93(d) WAC 173-303-400

40 CFR 265.93(d) WAC 173-303-400

40 CFR 265.93(d) WAC $173-303-400$
Year

Scheduled

for Part B

or Closure

$2002^{(f, g)}$

$2002^{(f, g)}$

$2002^{(f, g)}$

$2006^{\text {(c) }}$

$\mathrm{TBD}^{(\mathrm{c}, \mathrm{i})}$

$\mathrm{TBD}^{(c, i)}$

$\mathrm{TBD}^{(\mathrm{c}, \mathrm{i})}$

$\mathrm{TBD}^{(\mathrm{c}, \mathrm{i})}$

$\mathrm{TBD}^{(\mathrm{c}, \mathrm{i})}$

$\mathrm{TBD}^{(\mathrm{c}, \mathrm{i})}$

$\mathrm{TBD}^{(\mathrm{c}, \mathrm{i})}$ 
Table 2.2.2. (contd)

Interim Status TSD Unit

Groundwater Monitoring

Groundwater

TSD Units,

date initiated

Indicator

Parameter
Evaluation $^{(a)}$
Groundwater
Quality

Assessment, date

initiated

X, 2000

WMA U,

October 1990

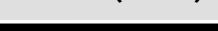

(a) Contamination indicator parameters ( $\mathrm{pH}$, specific conductance, total organic carbon, and total organic halides) used to determine if a facility is affecting groundwater quality. Exceeding the established limits means that additional evaluation and sampling are required (i.e., groundwater quality assessment). An X in the assessment column indicates whether an evaluation was needed or an assessment was required.

(b) Monitored according to interim status plan as specified in closure plans.

(c) Closure/postclosure plan; TSD unit will close under WAC 173-303-610.

(d) Closure plan pending Washington State Department of Ecology approval.

(e) Statistical evaluations suspended in January 2001 because only one downgradient well is not dry.

(f) Part B permit; TSD unit scheduled to operate under final status regulations beginning in year indicated.

(g) Facility Part B permit and final status groundwater monitoring plan contingent on completion of solid waste environmental impact statement.

(h) 216-A-10, 216-A-36B, and 216-A-37-1 combined into one RCRA monitoring unit. RCRA monitoring will be performed according to interim status groundwater quality assessment requirements.

(i) Unscheduled.

LERF $\quad=$ Liquid effluent retention facility.

LLWMA = Low-level waste management area.

LWDF = Liquid waste disposal facility.

NRDWL $\quad=$ Nonradioactive Dangerous Waste Landfill.

PUREX = Plutonium-uranium extraction (plant).

RCRA $=$ Resource Conservation and Recovery Act of 1976

TBD $=$ To be determined.

TSD $=$ Treatment, storage, or disposal (unit).

WMA $\quad$ = Waste management area. 


\begin{tabular}{|lll|}
\hline \multicolumn{3}{|c|}{ Table 2.2.3. } \\
& New RCRA Well Installations for \\
Fiscal Year 2001 \\
Well Number & Well ID & Program Project \\
\hline 299-E33-337 & C3390 & B tank farm \\
299-E33-338 & C3391 & B tank farm \\
299-E33-339 & C3392 & B tank farm \\
299-W10-27 & C3125 & TX-TY tank farms \\
299-W10-28 & C3400 & T tank farm \\
299-W14-18 & C3396 & TX-TY tank farms \\
299-W15-763 & C3339 & TX-TY tank farms \\
299-W15-765 & C3397 & TX-TY tank farms \\
299-W18-40 & C3395 & U tank farm \\
299-W19-44 & C3393 & U tank farm \\
299-W19-45 & C3394 & U tank farm \\
299-W22-81 & C3123 & SX tank farm \\
299-W22-82 & C3124 & SX tank farm \\
299-W22-83 & C3126 & SX tank farm \\
299-W22-84 & C3398 & S tank farm \\
299-W22-85 & C3399 & SX tank farm \\
\hline
\end{tabular}

details including detailed geologic and geophysical descriptions and a complete set of sample analytical data.

The dropping water table beneath the Central Plateau, resulting from the near cessation of wastewater discharges to ground-disposal facilities on the plateau, has caused some wells in the RCRA groundwater monitoring networks to go dry. Pump-and-treat operations have changed the direction of groundwater flow under some RCRA treatment, storage, and disposal units, requiring some well network design changes. Washington State Department of Ecology and DOE have agreed to focus near-term monitoring well construction on upgrades at single-shell tank farm waste management areas and to defer new wells at other waste management areas.

No major changes occurred during 2001 in RCRA facility groundwater monitoring at the waste management units. At the end of 2001, 11 RCRA waste management areas were monitored under interim status indicator parameter evaluation, 7 were monitored under interim status assessment, 4 were monitored under final status detection evaluation, and 2 were monitored under final status corrective action. All the facilities being monitored under RCRA are scheduled for closure under the Site Part B RCRA Permit except the Liquid Effluent Retention Facility and low-level burial grounds (LowLevel Waste Management Areas 1 to 4), which are operating facilities. The Liquid Effluent Retention Facility is currently monitored under final status detection evaluation program and Low-Level Waste Management Areas 1 to 4 will be added as soon as the Part B permit is approved.

\subsubsection{RCRA Inspections}

\section{R. C. Bowman}

Hanford Site contractors and DOE are working to resolve outstanding notices of violation and warning letters of non-compliance that were received from the Washington State Department of Ecology during 2001. These documents identify conditions that are alleged to be non-compliant with RCRA requirements. The following list of RCRA non-compliance issues are being addressed:

- The Washington State Department of Ecology issued a Notice of Correction on March 1, 2001, following a compliance inspection associated with the storage of a potentially shock-sensitive chemical (trade name Collodion) in the form of waste and/or product in the 222-S Laboratory Complex, Waste Sampling and Characterization Facility, and Plutonium Finishing Plant. The Notice of Correction identified three alleged violations, three corrective measures, and three concerns. DOE has implemented the identified corrective measures.

- On March 26, 2001, the Washington State Department of Ecology issued a Notice of Penalty in response to the identification of alleged waste management violations associated with the storage of a potentially shock-sensitive chemical (trade name Collodion) in the form of waste and/or product in the 222-S Laboratory Complex, Waste Sampling and Characterization Facility, and Plutonium Finishing Plant laboratories. The Notice of Penalty levied a penalty of $\$ 57,800$ against DOE and Fluor Hanford, Inc. This issue was appealed to the Pollution Control Hearing Board (an independent Washington State appeals board). Resolution efforts are ongoing.

\subsubsection{Clean Air Act}

\section{K. A. Peterson}

Federal, state, and local agencies enforce the standards and requirements of the Clean Air Act to regulate air emissions at facilities such as the Hanford Site. A summary of the major agency interfaces and applicable regulations for the Hanford Site is provided in the 
following paragraphs. Section 3.1 discusses air emissions from Hanford facilities. Sections 3.2 and 4.1 discuss monitoring efforts at the site to determine compliance with this act and other applicable laws and regulations. Appendix D, Table D.6 provides a summary of permits covering air emissions on the Hanford Site.

DOE and EPA signed the Federal Facility Compliance Agreement for Radionuclides NESHAP (EPA 1994). The agreement provides a compliance plan and schedule that are being followed to bring the Hanford Site into compliance with Clean Air Act requirements under 40 CFR 61, Subpart H, for continuous measurement of emissions from applicable airborne emission sources. All scheduled milestones of the Federal Facility Compliance Agreement (EPA 1994) were met in 2001, and Hanford Site air emissions remained well below the levels that approach the state and EPA offsite emission standard of 10 millirems per year. The requirements for flow and emissions measurements, quality assurance, and sampling documentation have been implemented at all Hanford Site emission sources and/or are tracked for milestone progress in accordance with a schedule approved by EPA and monitored by the Washington State Department of Health.

The Washington State Department of Health's Division of Radiation Protection regulates radioactive air emissions statewide through delegated authority from EPA and Washington State legislative authority. The Washington State Department of Health implements the federal/state requirements under state regulation WAC 246-247. Prior to beginning any work that would result in creating a new or modified source of radioactive airborne emissions, a notice of construction application must be submitted to the Washington State Department of Health and EPA for review and approval. Assuring adequate emission controls, emissions monitoring/sampling, and/or annual reporting of air emissions are typical requirements for radioactive air emission sources. The Hanford Site operates under state license FF-01 for such emissions. Conditions specified in the FF-01 license were incorporated into the Hanford Site air operating permit issued in July 2001. The Hanford Site air operating permit was issued in accordance with Title V of the Clean Air Act Amendments of 1990, and will be implemented through federal and state programs under 40 CFR 70 and WAC 173-401. The permit is intended to provide a compilation of applicable Clean Air Act requirements both for radioactive and non-radioactive emissions at the Hanford Site. The permit requires the DOE Richland Operations Office to submit periodic reports and an annual compliance certification to the Washington State Department of Ecology.
The Washington State Department of Ecology's Nuclear Waste Program regulates air toxic and criteria pollutant emissions from the Hanford Site. The Department enforces state regulatory controls for air contaminants as allowed under the Washington Clean Air Act (RCW 70.94). The Washington State Department of Ecology's implementing requirements (e.g., WAC 173-400; WAC 173-460) specify a review of new source emissions, permitting, applicable controls, reporting, notifications, and provisions of compliance with the general standards for applicable sources of Hanford Site emissions.

EPA regulates other potential air emission sources at the Hanford Site. Under 40 CFR 61, Subpart M, EPA regulations specifically address asbestos management requirements under the Clean Air Act. These regulations apply at the Hanford Site with regard to building demolition and/or asbestos renovation and waste disposal operations. Asbestos at Hanford is handled in accordance with federal/local regulations and approved contractor procedures. In addition, 40 CFR 82 requires regulation of the service, maintenance, repair, and disposal of certain systems containing Class I and Class II ozone-depleting substances (refrigerants) within facility systems at the Hanford Site. Implementation of the ozone-depleting substance management requirements on the Hanford Site is administered at the facility/project level, as applicable.

At the local level, the Benton Clean Air Authority was designated authority by EPA to establish a local oversight and compliance program for asbestos renovation and/or demolitions, as regulated by EPA under the National Emission Standards for Hazardous Air Pollutants (40 CFR 61, Subpart M). In addition, the Benton Clean Air Authority regulates open burning, as an extension of the Washington State Department of Ecology's open burning requirements (WAC 173-425). The Benton Clean Air Authority administers federal/ state regulations by reference, as well as imposes additional requirements on sources within the local agency's jurisdiction.

\section{Clean Air Act Enforcem ent Inspections}

\section{R. C. Bowman}

Hanford Site contractors and DOE are working to resolve outstanding notices of violation and warning letters of non-compliance that were received from the Washington State Department of Health and 
Washington State Department of Ecology during 2001. These documents identify conditions that are alleged to be non-compliant with Clean Air Act requirements. The following list of non-compliance issues are being addressed:

- On January 16, 2001, the Washington State Department of Health issued a Notice of Correction against all sampling systems (including the sampling system on stack 291-Z-1 that provides ventilation for the Plutonium Finishing Plant) used to measure emissions from facilities on the Hanford Site. The Washington State Department of Health wrote the Notice of Correction based on findings associated with inspection of the 291-Z-1 sample probe and their review of sample filters used to measure emissions from various facilities located on the Hanford Site. They alleged that there were two reported instances of monitored releases attributed to particles deposited in the sample line. The Notice of Correction required that DOE develop criteria and a schedule for the full review of all emission sampling systems (major and minor) on the Hanford Site. DOE provided a response to this Notice of Correction. Corrective action efforts are ongoing.

- A Notice of Violation and Compliance Order was received on March 23, 2001. The Washington State Department of Health alleged that DOE failed to properly notify them following a continuous air monitor alarm in stack 291-Z-1 at the Plutonium Finishing Plant on February 23, 2001, which indicated a release of radioactive material to the air. The Notice of Violation and Compliance Order required DOE to propose to the Washington State Department of Health a corrective action to assure this does not recur. The Washington State Department of Health also posed a number of questions regarding the extent and nature of the release, as well as decisions that were made during and after the event. DOE provided a response to this Notice of Violation and Compliance Order. Corrective action efforts are ongoing.

- On May 11, 2001, the Washington State Department of Health issued a Notice of Correction against emission unit 296-P-23. This unit is a stack at the $\mathrm{S}$ tank farm. The Notice of Correction was issued based on findings associated with inspection of the S tank farm. The Washington State Department of Health alleged that emission unit 296-P-23 was not maintained in a condition consistent with as-low-as-reasonably-achievable control technology. The Notice of Correction required that DOE provide a procedure that assures emission unit indication devices (continuous air monitor data, high-efficiency particulate air differential pressure readings, etc.) are monitored and evaluated for changing conditions that may indicate abatement controls are not operating as designed. This procedure applies to all DOE emission units on the Hanford Site. DOE provided a response to this Notice of Correction. Corrective action efforts are ongoing.

- On July 10, 2001, the Washington State Department of Health issued a Notice of Correction against the 296-S-16 emission unit. The 296-S-16 emission unit is a stack at the 222-S laboratory. The Washington State Department of Health wrote the Notice of Correction based on their concern that a temporary repair of the high-efficiency particulate air filter clamping mechanism did not meet the as-low-asreasonably-achievable control technology standard requirements. The Notice of Correction required that DOE provide a plan and schedule to replace the existing high-efficiency particulate air filter housing. The Notice of Correction also required additional sampling and testing of the current high-efficiency particulate air filter installation until the high-efficiency particulate air filter housing is replaced. DOE provided a response to this Notice of Correction. Corrective action efforts are ongoing.

- A Notice of Violation and Compliance Order was received from the Washington State Department of Health on October 15, 2001. The Washington State Department of Health alleged that DOE's prime contractor, Fluor Hanford, Inc., is in violation of WAC 246-247-040(4), which states that all existing emission units shall use as-low-as-reasonablyachievable control technology. This Notice of Violation and Compliance order is associated with the Notice of Correction issued by the Washington State Department of Health on May 11, 2001. All corrective actions associated with this Notice of Violation and Compliance Order were completed.

\subsubsection{Clean Water Act}

\section{J. A Winterhalder}

The Clean Water Act applies to point source discharges to waters of the United States. At the Hanford
Site, the regulations are applied through National Pollutant Discharge Elimination System (40 CFR 122) permits that govern effluent discharges to the Columbia 
River. There is one National Pollutant Discharge Elimination System permit, WA-002591-7, for the Hanford Site. The permit covers three active outfalls: outfall 001 for the 300 Area Treated Effluent Disposal Facility and outfalls 003 and 004 in the 100-K Area. Fluor Hanford, Inc. is the holder of this permit.

The Hanford Site was covered by one stormwater permit in 2001. EPA's National Pollutant Discharge Elimination System Storm Water Multi-Sector General Permit WAR05A57F establishes the terms and conditions under which stormwater discharges associated with industrial activity are authorized. This permit was issued on May 30, 2001, and supersedes all other National Pollutant Discharge Elimination System stormwater permits previously in effect at the site.

Wastewater from the William R. Wiley Environmental Molecular Sciences Laboratory located in the Richland North Area, is discharged to the city of Richland's wastewater treatment facility under pretreatment permit CR-IU005. This permit, formerly issued by the city to the DOE Richland Operations Office, was re-issued to Battelle on October 1, 2001.

There are numerous sanitary waste discharges to the ground throughout the site. Sanitary waste from the
400 Area is discharged to the Energy Northwest treatment facility (see Figure 1.0.1 for Energy Northwest location). Sanitary waste from the 300 Area, the former 1100 Area, and other facilities north of, and in, Richland discharge to the city of Richland treatment facility.

\section{State Wastew ater Discharge Permit Program}

\author{
W. E. Toebe
}

The Washington State Department of Ecology, State Wastewater Discharge Permit Program regulates the discharge or disposal of wastewater to surface or ground waters. The program's goal is to maintain the highest purity of public waters by limiting pollutant discharges to the greatest extent possible. In calendar year 2001, the Hanford Site had seven state waste discharge permits issued by the Washington State Department of Ecology. A brief summary of each permit is provided in Appendix D, Table D.6.

\subsection{Safe Drinking Water Act}

\section{M. Kelly}

There were nine public water systems on the Hanford Site in 2001. All public water systems are required to meet the Safe Drinking Water Act, the Safe Drinking Water Act Amendments of 1986, and the Safe Drinking Water Act Amendments of 1996. Specific performance requirements are defined within the federal regulations (40 CFR 141, EPA-570/9-76-003, EPA 822-R-96-001) and WAC 246-290. The drinking water program has been updated to comply with the changing regulatory requirements. A complete revision of WAC 246-290 was issued on April 9, 1999, and all site water programs have had the necessary changes incorporated.

The compliance monitoring program elements are updated annually with monitoring cycles beginning in January. Drinking water is monitored for radionuclides, inorganics, synthetic and volatile organics, lead, copper, asbestos, disinfectant byproducts, and coliform bacteria. All sampling results for 2001 met the requirements of the Washington State Department of Health. Sample results for radiological monitoring of drinking water are discussed in Section 4.3.

The 200-East Area water treatment plant remains on standby if needed. The 283-W water treatment plant in the 200-West Area, provides potable water to customers in both 200 Areas as the primary water supply. The 300 Area treatment plant remains on standby if needed. The well that supplied water to the Hanford Patrol Training Academy was taken out of service for potable use in May 1999. The well remains in service for irrigation purposes only. The training academy is now supplied by the city of Richland, which maintains the system and samples the quality of the drinking water. Drinking water at the Fast Flux Test Facility (400 Area) was drawn from a local groundwater well (499-S1-8J). 


\subsubsection{Toxic Substances Control Act}

\section{A. L. Prignano}

Requirements in the Toxic Substances Control Act that apply to the Hanford Site primarily involve regulation of polychlorinated biphenyls. Federal regulations for use, storage, and disposal of polychlorinated biphenyls are found in 40 CFR 761. The state of Washington also regulates certain classes of polychlorinated biphenyls through the Dangerous Waste Regulations in WAC 173-303.

Non-radioactive and certain categories of radioactive polychlorinated biphenyl waste are stored and disposed of in accordance with 40 CFR 761. Other radioactive polychlorinated biphenyl waste remains in storage onsite pending the development of adequate treatment and disposal technologies and capacities. Electrical equipment that might contain polychlorinated biphenyls or polychlorinated biphenyl items is maintained and serviced in accordance with 40 CFR 761 .

The "Framework Agreement for Management of Polychlorinated Biphenyls in Hanford Tank Waste" signed on August 31, 2000 (http://yosemite.epa.gov/ R10/OWCM.NSF/permits/hanfordframework), has resulted in EPA, Washington State Department of Ecology, and DOE and its Hanford Site contractors working together to resolve the regulatory issues associated with managing polychlorinated biphenyl waste at the Waste Vitrification Plant (now under construction), in tank farms, and at affected units upstream and downstream of the tank farms. The flexibility of the 1998 polychlorinated biphenyl disposal amendments in 40 CFR 761 is used at the Hanford Site to allow necessary storage and to expedite disposal of Toxic Substances Control Act regulated polychlorinated biphenyl waste.
An operational run was performed at the 242-A evaporator (200-East Area) on polychlorinated biphenyl waste under the authority of a risk-based disposal approval in March 2001 (Section 2.3.8.1). EPA approved the run in February 2001. This activity reduced tank waste volume by $\sim 2,441,591$ liters $(\sim 645,000$ gallons). In 2001, work continued on a RCRA risk assessment for treatment of tank waste at the future Waste Vitrification Plant. Results of this assessment will be used to evaluate polychlorinated biphenyls regulated by the Toxic Substances Control Act as well. Additional disposal approvals for polychlorinated biphenyl waste originating from cleanup activities, double-shell tanks, the Liquid Effluent Retention Facility, and the Effluent Treatment Facility were prepared during 2001 for submittal to EPA in 2002.

A polychlorinated biphenyl strategy team and a polychlorinated biphenyl technical team consisting of DOE Richland Operations Office, DOE Office of River Protection, and DOE Hanford Site contractor representatives were formed to expedite resolution of polychlorinated biphenyl issues on a Hanford sitewide basis. A Toxic Substances Control Act Polychlorinated Biphenyl Hanford Site Users Guide was drafted in 2001 (DOE/ RL-2001-50) to assure consistent interpretation and implementation of Toxic Substances Control Act polychlorinated biphenyl regulations throughout the Hanford Site. In addition, discussions were held with representatives throughout the DOE complex to identify and address various Toxic Substances Control Act/ polychlorinated biphenyl compliance topics.

\subsubsection{Federal Insecticide, Fungicide, and Rodenticide Act}

\section{J. M. Rodriguez}

The Federal Insecticide, Fungicide, and Rodenticide Act is administered by EPA. The standards administered by the Washington State Department of Agriculture to regulate the implementation of the act in Washington State include: Washington Pesticide Control
Act (RCW 15.58), Washington Pesticide Application Act (RCW 17.21), and rules relating to general pesticide use codified in WAC 16-228. At the Hanford Site, pesticides are applied by commercial pesticide operators who are listed on one of two commercial pesticide applicator licenses and by a private commercial applicator. 


\subsection{Endangered Species Act}

\section{R. K. Zufelt}

Many rare species of native plants and animals are known to exist on the Hanford Site. Three species that may occur onsite (bald eagle, steelhead trout, and spring chinook salmon) are listed by the U.S. Fish and Wildlife Service as either threatened or endangered (50 CFR 17.11). Others are listed by the Washington Department of Fish and Wildlife as endangered, threatened, or sensitive species (see Appendix G). The bald eagle is currently under review for a change in listing status. The site wildlife monitoring program is discussed in Section 8.2.

Bald eagles are seasonal visitors to the Hanford Site. Several nesting attempts along the Hanford Reach were documented by Pacific Northwest National Laboratory in the 1990s. The Hanford Site bald eagle management plan (DOE/RL-94-150) was finalized in 1994. That plan established seasonal 800-meter (2,600-foot) zones of restricted access around all active nest sites and five major communal roosting sites. If nesting activities at the historical nesting sites are observed in January and early February, all Hanford-related activities within the restricted access zone are constrained or limited until the pair abandons nesting or successfully rears young. In 1997 and 1998, nests were built by two pairs of eagles, but the nesting attempts were abandoned by May. One pair attempted to nest again in 1999. The pair occupied and tended the nest through August, but no eggs were laid and no young were reared. The nest was again occupied for a short time in 2000 , but no nesting activity was observed. In 2001, the pair attempted to nest again but abandoned the nest by mid-March.

Steelhead and salmon are regulated as evolutionary significant units by the National Marine Fisheries Service based on their historical geographic spawning areas. The evolutionary significant units for the upper Columbia River steelhead and the upper Columbia River spring-run chinook salmon were listed as endangered in August 1997 and March 1999, respectively. A Hanford Site steelhead management plan (DOE/RL2000-27) was prepared and will serve as the formal plan for the National Marine Fisheries Service as required under the Endangered Species Act. Like the bald eagle management plan, the steelhead management plan discusses mitigation strategies and lists activities that can be conducted without impacting steelhead trout or their habitats.

\subsubsection{Migratory Bird Treaty Act}

\section{R. Sackschewsky}

The Migratory Bird Treaty Act prohibits taking or disturbing specified migratory birds or their feathers, eggs, or nests. There are over 100 species of birds that regularly occur on the Hanford Site that are protected by the Migratory Bird Treaty Act.

All Hanford Site projects with a potential to effect federally-or state-listed species of concern complied with the requirements of this act by using the ecological review process as described in the Hanford Site Biological Resources Management Plan (DOE/RL-96-32). When applicable, the ecological reviews produced recommendations to minimize the adverse impact to migratory birds, such as performing work outside of the nesting season and minimizing the loss of habitat.

\subsubsection{Cultural Resources}

\section{W. Harvey}

Cultural resources on the Hanford Site are mainly subject to the provisions of the following seven acts, one executive order, and one Presidential Proclamation: American Indian Religious Freedom Act; Antiquities Act; Archaeological and Historic Preservation Act; Archaeological Resources Protection Act; Executive Order 11593, Protection and Enhancement of the Cultural Environment (36 FR 8921); Historic Sites, Buildings, and Antiquities Act;
National Historic Preservation Act; Native American Graves Protection and Repatriation Act, and Proclamation 7319 of June 9, 2000 (65 FR 37253). Compliance with these regulations is accomplished through an active management and monitoring program. Included is the review of all proposed projects to assess their potential impact on cultural resources and the periodic inspection of known archaeological sites and historic buildings to determine their condition and eligibility for listing in the National Register of Historic Places. The effects of land 
management policies on archaeological sites and buildings, and management of a repository for federally owned archaeological collections and Manhattan Project and Cold War era artifacts are also evaluated. Federal agencies, as a matter of policy, are directed by Executive Order 11593 and Section 110 of the National Historical Preservation Act to administer the cultural and historic properties under their control in a spirit of stewardship and trusteeship for future generations.

In 2001, 150 cultural resource reviews were conducted on the Hanford Site to comply with Section 106 of the National Historic Preservation Act. The American Indian Religious Freedom Act requires federal agencies to help protect and preserve the rights of Native Americans to practice their traditional religions. DOE cooperates with Native Americans by providing site access for organized religious activities. The regulations of the Native American Graves Protection and Repatriation Act provides a process to determine the rights of Indian Tribes "to certain Native American human remains, funerary objects, sacred objects, or objects of cultural patrimony with which they are affiliated" (43 CFR 10). Proclamation 7319 of June 9, 2000 established the Hanford Reach National Monument that incorporated selected areas of the Hanford Site. Administered by DOE Richland Operations Office and the U.S. Fish and Wildlife Service, "the monument is one of the few remaining archaeological rich areas in the western Columbia Plateau, containing well-preserved remnants of human history spanning more than 10,000 years" (65 FR 37253). President Clinton issued a memorandum to the Secretary of Energy the same day the proclamation was signed directing DOE to manage and protect "...objects of scientific and historic interest... where practical" in the site's central area as if they were in monument lands.

See Section 8.3 for more details regarding the cultural resources program on the Hanford Site.

\subsubsection{National Environmental Policy Act}

\section{T. Jansky}

The National Environmental Policy Act requires consideration of the effects of federal actions before those actions are taken. The preparation of an environmental impact statement is required for federal actions determined to be major federal actions with the potential to impact the quality of the human environment. Other National Environmental Policy Act documents include an environmental assessment prepared when it is uncertain if a proposed action has the potential to significantly impact the environment and, therefore, would require the preparation of an environmental impact statement. A summary and status of environmental assessments that apply to specific activities and facilities on the Hanford Site may be found in the National Environmental Policy Act Source Guide for the Hanford Site (HNF-SP0903). The report is updated annually. A supplemental analysis is prepared to consider new information developed since issuance of a National Environmental Policy Act environmental impact statement and record of decision. The purpose is to consider if the federal action is still bounded by the original environmental impact statement and record of decision or if a supplemental environmental impact statement is required.

Additionally, certain types of actions may fall into typical classes that have already been analyzed by DOE and have been determined not to result in a significant environmental impact. These actions are called categorical exclusions, and, if eligibility criteria are met, they are exempt from National Environmental Policy Act environmental assessment or environmental impact statement requirements. Typically, the DOE Richland Operations Office documents more than 20 specific categorical exclusions annually, involving a variety of actions by multiple contractors. In addition, sitewide categorical exclusions are applied to routine, typical actions conducted daily on the Hanford Site. In 2001, there were 20 sitewide categorical exclusions.

The Council on Environmental Quality, which reports directly to the President, was established to oversee the National Environmental Policy Act process. National Environmental Policy Act documents are prepared and approved in accordance with Council on Environmental Quality National Environmental Policy Act regulations (40 CFR 1500-1508), DOE National Environmental Policy Act implementation procedures (10 CFR 1021), and DOE Order 451.1B Change 1. In accordance with the Order, DOE documents prepared for CERCLA projects incorporate National Environmental Policy Act values such as analysis of cumulative, offsite, ecological, and socioeconomic impacts to the extent practicable in lieu of preparing separate National Environmental Policy Act documentation.

Each year, Pacific Northwest National Laboratory updates a document (PNL-6415) that describes the environment on the Hanford Site. This document is intended to provide a consistent description of the Hanford Site environment and specific information on the affected environment and statutory and regulatory requirements for the many National Environmental Policy 
Act documents prepared by DOE contractors. This report contains the relevant data for use in preparing documents for Hanford National Environmental Policy Act, Washington State Environmental Policy Act (RCW 43.21C), and CERCLA documents.

\subsubsection{Recent Environmental Impact Statements}

\section{T. Jansky}

The potential environmental impact associated with ongoing, major operations at the site has been analyzed in environmental impact statements issued in the past several years and the ensuing records of decision. Additional National Environmental Policy Act reviews and supplemental analyses as appropriate are being conducted during the course of the actions, moving forward as described in the records of decision.

A final environmental impact statement for the stabilization of plutonium-bearing materials at the Plutonium Finishing Plant was issued in May 1996 (DOE/EIS-0244F). The proposed action is to stabilize selected plutonium-bearing materials for interim storage and immobilize some materials for transport to a Hanford Site solid waste management facility. The record of decision was issued in July 1996 (61 FR 36352). Five supplemental analyses approved through 2000 (DOE/ EIS-0244-FS/SA1 through DOE/EIS-0244-FS/SA5) resulted in determinations that no additional National Environmental Policy Act analyses were required.

A supplemental analysis (DOE/EIS-0244-FS/SA6) was issued on May 4, 2001, and provided the basis to determine if a supplemental environmental impact statement was required prior to packaging plutonium alloys for shipment to the Waste Isolation Pilot Plant (with potential interim storage at the Hanford Site before shipment). The analysis determined that a supplemental environmental impact statement was not required.

A supplemental analysis (DOE/EIS-0244-FS/SA7) was issued on August 6, 2001, and provided the basis to determine if a supplemental environmental impact statement was required before disposition of all Plutonium Finishing Plant plutonium-bearing solutions either as (1) stored plutonium oxide using a magnesium hydroxide and/or oxalate precipitation process, or (2) waste. This document reported that additional National Environmental Policy Act analysis was not required.

The DOE Office of River Protection is planning to perform a supplemental environmental impact statement to the Tank Waste Remediation System Environmental Impact Statement (DOE/EIS-0189) because of a potential change in the management of immobilized low-activity waste. A Notice of Intent to prepare an environmental impact statement is being prepared.

\subsubsection{Programmatic and Offsite Environmental Im pact Statements}

\author{
M. T. Jansky
}

The draft environmental impact statement, Idaho High-Level Waste $\mathcal{E}$ Facilities Disposition Final Environmental Impact Statement (DOE/EIS-0287D), was issued by the Idaho National Engineering and Environmental Laboratory in December 1999 for the disposition of Idaho high-level waste and facilities in which Hanford was listed as an alternative disposal site. Public comments were received through April 2000. The final environmental impact statement was expected to be issued in 2001 but is now expected to be released in 2002.

The Final Programmatic Environmental Impact Statement for Accomplishing Expanded Civilian Nuclear Energy Research and Development and Isotope Production Missions in the United States, Including the Role of the Fast Flux Test Facility (DOE/EIS-0310) was issued in December 2000. The final statement evaluated the expanded civilian nuclear energy research and development and isotope production missions in the United States including the role of the Fast Flux Test Facility at the Hanford Site (see Section 2.3.4). A Record of Decision was issued on January 19, 2001 (66 FR 7877) indicating the Fast Flux Test Facility would be permanently deactivated. On April 25, 2001, the new Secretary of Energy, Spencer Abraham, suspended the National Environmental Policy Act Record of Decision ordering a thorough and comprehensive review of the Fast Flux Test Facility, which included an initial review of all information that might be relevant to a decision on the future of the facility, as well as a review of expressions of interest to commercially operate the facility. After these extensive review efforts, DOE announced on December 19, 2001, that deactivation of the facility would proceed.

\subsubsection{Site-Specific Environm ental Im pact Statements in Progress}

\author{
M. T. Jansky
}

A draft environmental impact statement, Hanford Site Solid (Radioactive and Hazardous) Waste Program Environmental Impact Statement (DOE/EIS-0286) is 


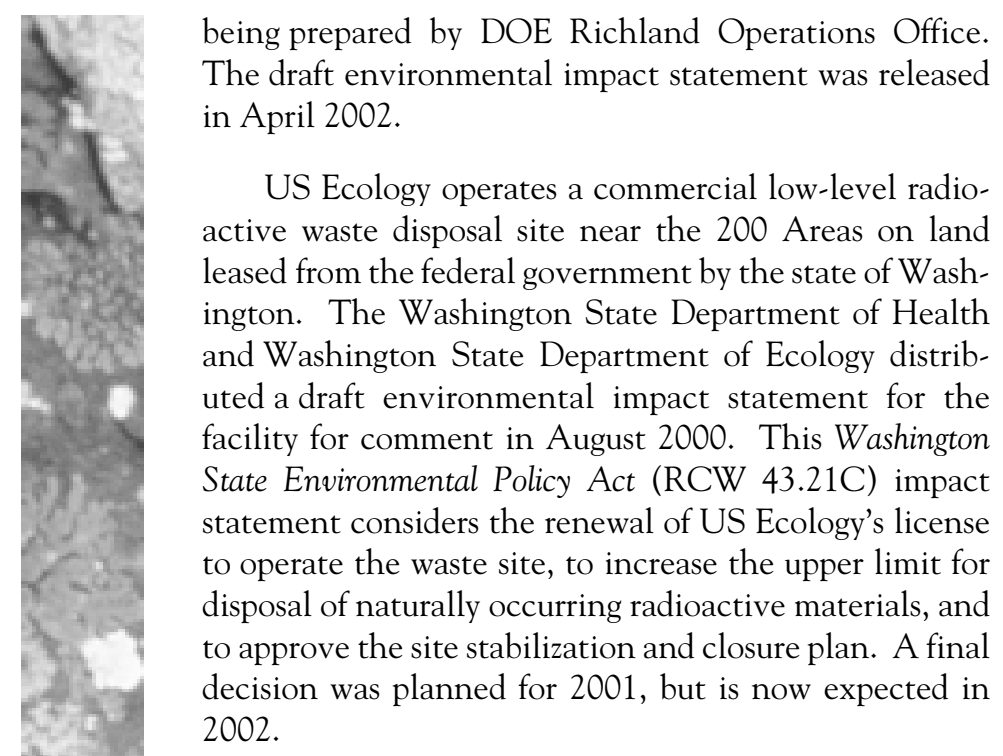

\subsubsection{Recent Environmental Assessments}

M. T. Jansky

An environmental assessment was prepared to determine whether an environmental impact statement would be required for storage of $\mathrm{K}$ Basins' sludge at the 221-T Building (T Plant, 200-West Area) at the Hanford Site (DOE/EA-1369). The environmental assessment analyzed the impact of modifications to the $\mathrm{T}$ Plant Complex, and the offloading and storage of up to 70 cubic meters (2,480 cubic feet) of K Basins' sludge. A finding of no significant impact was issued on June 20, 2001, determining that no further review was required under the National Environmental Policy Act.

An environmental assessment was prepared to determine whether an environmental impact statement would be required for continued operation of onsite locations for a supply of raw aggregate materials (e.g., sand and gravel) for new facility construction, maintenance of existing facilities and transportation corridors, and fill and capping material for remediation and other sites (DOE/EA-1403). The environmental assessment analyzed the potential impact of removing $~ 7.6$ million cubic meters ( 10 million cubic yards) of aggregate material over the next 10 years. A finding of no significant impact was issued on October 10, 2001, determining that no further review was required under the National Environmental Policy Act. 


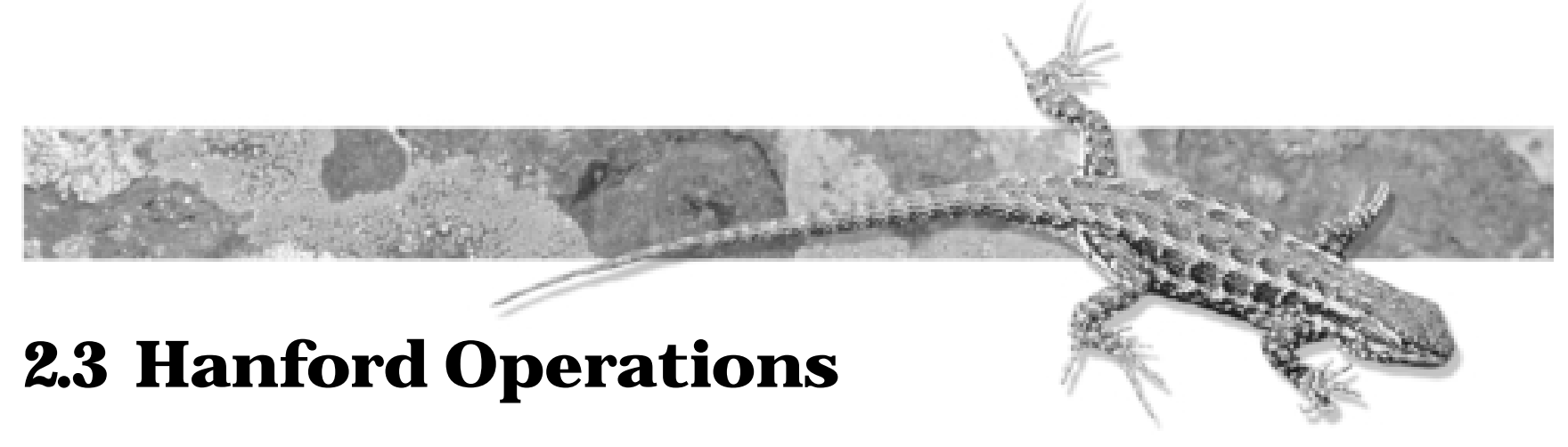

\section{J. P. Duncan}

This section describes continuing Hanford Site environmental and regulatory activities. Included are self-assessments, inspections by regulatory agencies, stakeholder communications identifying environmental compliance issues, and project compliance activities. Activities, accomplishments, and relevant issues are presented and discussed openly with the regulators and with the public to assure resolution.

\subsection{Pollution Prevention Program}

\section{J. M. Stitt}

Pollution prevention is DOE's preferred approach to environmental management. The Hanford Site Pollution Prevention Program is an organized and continuing effort to reduce the quantity and toxicity of hazardous, radioactive, mixed, and sanitary waste. The program fosters the conservation of resources and energy, the reduction of hazardous substance use, and the prevention or minimization of pollutant releases to all environmental media from all operations and site cleanup activities.

The program is designed to satisfy DOE requirements, executive orders, and federal and state regulations and requirements. In accordance with sound environmental management, preventing pollution through source reduction is the first priority in this program; the second priority is environmentally safe recycling. Waste treatment to reduce quantity, toxicity, or mobility (or a combination of these) is considered only when source reduction and recycling are not possible or practical. Approved disposal to the environment at permitted sites is the last option.

Overall responsibility for the Hanford Site Pollution Prevention Program resides with the DOE Richland Operations Office. The office defines overall program requirements that each Hanford Site prime contractor is responsible for meeting.

Hanford Site pollution prevention efforts in 2001 helped to reduce disposal quantities through source reduction and recycling by an estimated 32,405 cubic meters $(1,144,371$ cubic feet) of radioactive and mixed waste, 33,387 metric tons (36,803 tons) of RCRA hazardous/dangerous waste, and 3,428 metric tons $(3,779$ tons $)$ of sanitary waste. Waste disposal cost savings in 2001 exceeded $\$ 23$ million for these activities. During 2001, the Hanford Site recycled 673 metric tons (742 tons) of paper products and 708 metric tons (780 tons) of various metals.

\subsection{Spent Nuclear Fuel Project}

\section{J. Watson}

The Spent Nuclear Fuel Project was established in February 1994 to provide safe, economically, and environmentally sound management of Hanford Site spent (irradiated) nuclear fuel, and to prepare the fuel for longterm storage or final disposal. During 2001, the project continued to make progress on an accelerated strategy to move spent fuel stored in the K-West and K-East Basins in the 100-K Area, away from the Columbia River into the Canister Storage Building in the 200-East Area. The 40-year-old K Basins temporarily store 2,100 metric tons (2,300 tons) of N Reactor spent fuel and a small quantity of slightly irradiated single-pass reactor fuel. The spent fuel is removed from underwater storage in the $\mathrm{K}$ Basins and placed in dry interim storage in the 200-East Area. Prior to interim storage, the fuel is cleaned and packaged into containers called multi-canister overpacks. The overpacks are vacuum processed to remove any water and then mechanically sealed at the Cold Vacuum Drying Facility located in the $100-\mathrm{K}$ Area. The dried overpacks are then transported to the Canister Storage 
Building, a welded cap is attached over the mechanical seal, and the overpack is put in dry storage. The multicanister overpacks will be maintained in dry storage, pending a decision by the Secretary of Energy on final disposition. If necessary, the repackaged spent fuel could remain in dry storage for up to 40 years. This strategy supports completion of fuel removal from the $\mathrm{K}$ Basins by the Tri-Party Agreement date of July 2004.

The corrosion of fuel, as well as fuel handling operations have led to the accumulation of sludge and debris in old fuel storage canisters and on the floors of the $\mathrm{K}$ Basins. The majority of the sludge is in the K-East Basin. The sludge, debris, and empty storage canisters will be removed during the same time period the spent nuclear fuel is removed. Water remaining in the basins will also be removed, treated at the Effluent Treatment Facility and disposed of onsite. Debris and old fuel canisters will be transported to the Environmental Restoration Disposal Facility for disposal to the extent possible. Debris that does not meet acceptance criteria for the Environmental Restoration Disposal Facility will be transferred to the appropriate onsite waste management facility. The $\mathrm{K}$ Basins will then be prepared for interim stabilization pending final remediation.

The Spent Nuclear Fuel Project also includes in its mission, the gathering of other spent nuclear fuel stored elsewhere on the Hanford Site and the relocation of that spent nuclear fuel to the 200-East Area Interim Storage Area or to the Canister Storage Building. Other spent nuclear fuels and their storage locations include:

- fuel from the Fast Flux Test Facility in the 400 Area

- fuel from the Training, Research, and Isotope Production General Atomics in the 400 Area
- reactor fuel from Shippingport, Pennsylvania, at T Plant in the 200-West Area

- miscellaneous special case and research reactor fuels in the 324, 325, and 327 buildings in the 300 Area.

Major accomplishments of the Spent Nuclear Fuel Project in 2001 included the following items:

- Installed two new underwater tables to increase productivity in the K-West Basin used to sort, inspect, and repackage the spent nuclear fuel.

- Fabricated nearly 330 fuel baskets to hold spent nuclear fuel prior to loading the fuel in a multicanister overpack.

- Removed 38 multi-canister overpacks containing $\sim 178.6$ metric tons ( 196.9 tons) of spent nuclear fuel to the Canister Storage Building. This brings the cumulative number of multi-canister overpacks removed to date to 39 , representing 183.4 metric tons (202.2 tons) of spent nuclear fuel.

- Started construction at the K-East and K-West Basins to make the modifications necessary to transfer the K-East Basin spent nuclear fuel inventory to the K-West Basin.

\subsubsection{River Corridor Project}

\section{G. J. LeBaron}

The mission of the River Corridor Project includes the following activities:

- for assigned contaminated facilities in the 200 and 300 Areas

- deactivate in preparation for decontamination and decommissioning

- perform surveillance and maintenance

- characterize as necessary to identify and mitigate hazards
- collect and treat 300 Area process wastewater

- provide for safe and secure storage of special nuclear material, nuclear material, and nuclear fuel until these materials can be transferred to another facility, sold, or otherwise dispositioned.

To accomplish these tasks, the River Corridor Project oversees the efforts discussed in the following sections. 


\subsubsection{Accelerated Deactivation Project}

\section{J. M. Barnett}

The mission of the Accelerated Deactivation Project is to complete facility deactivation and closure activities while maintaining the facilities in a safe and compliant status until they are turned over to the Environmental Restoration Program.

300 Area Accelerated Deactivation. Accelerated deactivation in the 300 Area focuses on several 300 Area buildings and structures that date back to 1943. It includes fuel supply facilities that were used to support the manufacturing of nuclear fuel for the Hanford Site reactors. Significant accomplishments during 2001 included the following activities:

- demolished the 303-K Building structure

- completed the transfer of 235 metric tons (259 tons) of uranium billets (short, thick bars) to Portsmouth, Ohio

- completed the transfer of 135 metric tons (149 tons) of contaminated uranium fuel to the 200 Areas low-level burial grounds.

200 Area Accelerated Deactivation. Accelerated deactivation in the 200 Area includes the surveillance, maintenance, and deactivation of facilities in the 200-East Area, 200-West Area, and Fitzner/Eberhardt Arid Lands Ecology Reserve.

Facilities where work was conducted under this program in 2001 included the 224-T facility in the 200-West Area. The cells at the 224-T facility were deactivated and closed during the 1960s. However, no documentation could be found concerning the flushing and final state of the cells and few entries had been made since its closure. During 2001, remote entries were made into each cell and a non-destructive analysis was performed to determine the amount of plutonium remaining in each vessel. Plans are being made to more fully characterize the vessels and cells. Plans were also prepared to start characterizing the duct work at $231-\mathrm{Z}$ and to determine what would need to be done to transfer the Fitzner/ Eberhardt Arid Lands Ecology Reserve to the U.S. Fish and Wildlife Service.

\subsubsection{324 and 327 Facilities Deactivation Project}

\author{
D.E. Rasmussen
}

Construction of the 324 and 327 Buildings was completed and operations began in 1966 and 1953, respectively. These buildings contain hot cells that were used for radiological research and development work. Both facilities were transferred to Fluor Hanford, Inc. in 1996 for deactivation and closure. (Refer to Section 2.2.1 for more information about Tri-Party Agreement milestones.)

Significant accomplishments achieved at the 324 Building in 2001 included the following:

- Equipment and debris from B-Cell were removed and shipped to the 200 Areas in support of successful fulfillment of Tri-Party Agreement milestone M-89-02.

- The dispersible materials from the B-Cell floor were collected, put in containers, and shipped to the 200 Areas in support of successful fulfillment of Tri-Party Agreement milestone M-89-02.

- Twenty-one grout containers and five mixed waste containers were packaged and shipped to the 200-West Area Burial Ground and Central Waste Complex in support of completion of Tri-Party Agreement milestone M-89-02.

- Phase II Special Case Waste materials were packaged and removed from the facility on schedule, meeting Tri-Party Agreement milestone M-92-15.

Significant accomplishments achieved at the 327 Building in 2001 included the following:

- Waste packaging and shipping activities were completed for 3.8 cubic meters ( 134.2 cubic feet) of mixed low-level waste, 0.52 cubic meter ( 18.4 cubic feet) of transuranic waste, and 0.74 cubic meter (26.1 cubic feet) of non-radioactive dangerous waste.

- A Washington State Department of Ecologywitnessed inspection of the Burst Test Heat Exchanger Pit was performed, with no regulatory issues identified. Analysis and disposition of slightly radioactive residual water in the pit were completed. 
- Eleven legacy waste buckets from F Cell and four legacy waste buckets from the Supplemental Enriched Recovery Facility Cell were transferred to A Cell, in support of special case waste disposition activities relating to the Tri-Party Agreement milestone M-92-16, which is ahead of schedule. Transfer of retrievable material cans from dry storage to A Cell was completed in support of dry storage cleanout activities. Washington State Department of Ecology personnel visited the 327 Facility to observe the status of special case waste disposition activities, with no issues identified.

- Interim cleanout of I Cell was completed, with removal of unneeded material/equipment.

\subsubsection{Area Liquid Effluent Facilities}

\section{J. R. Hilliard}

340 Waste Handling Facility. In the past, the 340 Waste Handling Facility provided for the receipt, storage, and shipment of low-level, mixed, liquid waste from the 300 Area to the double-shell tanks. The accumulated waste was pumped into railcars, transported to the 200-East Area for neutralization, then transferred to double-shell tanks for storage. The facility ceased receiving waste in September 1998 and is currently in a standby mode awaiting deactivation.

310 Treated Effluent Disposal Facility. Currently, industrial wastewater generated throughout the Hanford Site is accepted and treated in the 300 Area Treated Effluent Disposal Facility. Laboratories, research facilities, office buildings, and former fuel fabrication facilities in the 300 Area are the primary sources of wastewater. The wastewater consists of once-through cooling water, steam condensate, and other industrial wastewater. The facility began operation in December 1994.

This facility is designed for continuous receipt of wastewater, with a storage capacity of up to 5 days at the design flow rate of 1,100 liters per minute ( 300 gallons per minute). The treatment process includes iron co-precipitation to remove heavy metals, ion exchange to remove mercury, and ultraviolet light/hydrogen peroxide oxidation to destroy organics and cyanide. Sludge from the iron co-precipitation process is dewatered and used for backfill in the low-level waste burial grounds. The treated liquid effluent is monitored and discharged through an outfall to the Columbia River under a National Pollutant Discharge Elimination System permit No. WA 002591-7 (see Section 2.2.8). Capability exists to divert the treated effluent to holding tanks before discharge, if needed, until a determination can be made for final disposal based on sampling. In 2001, 241 million liters (64 million gallons) of wastewater were treated. On December 7, 2001, the facility also processed its 2 billionth liter ( 529 millionth gallon) since beginning operations.

\subsubsection{Plutonium Finishing Plant}

\section{W. J. McKenna}

In 1949, the Plutonium Finishing Plant began to process plutonium nitrate solutions into metallic form for shipment to nuclear weapons production facilities. Operation of this plant continued into the late 1980s. In 1996, DOE issued a shutdown order for the plant, authorizing deactivation and transition of the plutonium processing portions of the facility in preparation for decommissioning.

The mission is to stabilize, immobilize, repackage and/or properly dispose of plutonium-bearing materials in the plant; to deactivate and dismantle the processing facilities; and to provide for the safe and secure storage of nuclear materials until final disposition. Several processes have been designed and brought on line to accelerate this work.

Significant accomplishments achieved at the Plutonium Finishing Plant during 2001 included the following:

- In March 2001, seismically qualified storage racks were installed at the $2736-Z$ vaults.

- Startup of the outer-can welder occurred in April 2001.

- In June 2001, packaging of the plutonium/aluminum Group 1 alloy residues was completed.

- In July 2001, the Plutonium Finishing Plant reached 2 million man-hours without a lost workday injury.

- In August 2001, the solutions stabilization oxalate precipitation process began.

- Stabilization and repackaging of plutonium metals and corrosion products from disintegrated metals was completed in September 2001, attaining a key goal set by the Defense Nuclear Facilities Safety Board.

- A second stabilization and packaging system was brought on line in December 2001, doubling plant capacity. 
- The plutonium stabilization rate was quadrupled in fiscal year 2000 and again in fiscal year 2001.

- More than $30 \%$ of the total plutonium inventory was stabilized in 2001, and the project is on track to complete the stabilization and packaging phase by May 2004.

\subsubsection{Waste Encapsulation and Storage Facility Project}

\section{F. M. Simmons}

The mission of the Waste Encapsulation and Storage Facility Project is to provide safe interim storage of encapsulated radioactive cesium and strontium. The facility was initially constructed as a portion of the B Plant complex and began service in 1974. There are currently 601 strontium fluoride capsules and 1,335 cesium chloride capsules stored at the facility. The capsules will be stored at the Waste Encapsulation and Storage Facility until 2018. The capsules then will be shipped to the vitrification plant for high-level waste vitrification. The final capsule shipment is scheduled for 2022.

\subsubsection{Equipment Disposition Project}

\section{L. Klages}

When the Hanford Site was dedicated to the defense production mission, rail and other heavy equipment was used to handle and transport radioactive or hazardous materials and/or enter facilities where radioactive and hazardous materials were present. Through use, the equipment became radiologically and/or chemically contaminated to the point where the equipment was either removed from service and buried on site, or managed for future use or disposition.

In fiscal year 1995, the need to manage radiologically contaminated rail equipment became apparent and the Equipment Disposition Project was established. The technical objective of the project is the disposition of 37 contaminated railcars, 5 pieces of heavy equipment, 1 condenser, 1 skid-mounted concrete burial box filled with K-Basin materials, and 2 skid-mounted concrete burial boxes filled with ion exchange columns left over from past Hanford programs. During 2001, four pieces of the heavy equipment totaling 113 cubic meters $(3,054$ cubic feet) were radiologically surveyed, determined to be uncontaminated, and released for unrestricted use offsite. In addition, 20,455 kilograms (45,000 pounds) of steel and 38,636 kilograms (85,000 pounds) of lead were obtained when one contaminated fuel cask car was recycled by GTS Duratek in Tennessee.

\subsection{Fast Flux Test Facility}

\section{A. Gantt}

The Fast Flux Test Facility is a 400-megawatt thermal, liquid metal cooled reactor located in the 400 Area. It was built in the late 1970s to test plant equipment and fuel for the Liquid Metal Fast Breeder Reactor Program. The Fast Flux Test Facility operated from April 1982 to April 1992, during which time it successfully tested advanced nuclear fuels, materials, and safety designs and also produced a variety of isotopes for medical research. The reactor has been in a standby mode since December 1993. Fuel has been removed from the reactor vessel and stored in two sodium-filled vessels and in aboveground, dry-storage casks. Twenty-three of the facility's 100 plant systems were deactivated during the previous deactivation period from 1993-1997.

On December 22, 1998, Secretary of Energy Bill Richardson announced the decision to remove the Fast
Flux Test Facility from consideration as a tritium supply source. However, the Secretary asked that a program plan be developed that clearly defined other potential uses of the facility and the roles and responsibilities of potential users. A program plan was prepared and reviewed by the Nuclear Energy Research Advisory Committee. The committee recommended that a comprehensive research and development plan be prepared for DOE that would include the Fast Flux Test Facility. See Section 2.2.15.2 for more information about the plan (DOE/EIS-0310).

On April 25, 2001, Secretary of Energy, Spencer Abraham, ordered a thorough and comprehensive review of the Fast Flux Test Facility, which included an initial review of all information that might be relevant to a decision on the future of the Fast Flux Test Facility, as well as a review of expressions of interest to commercially operate the facility. After these extensive review 
efforts, DOE announced on December 19, 2001, that the department would proceed with deactivation of the facility.

While the decision process continued, the Fast Flux Test Facility staff made progress on repairs to fuel handling machines that will be needed for deactivation. New control systems were installed on the closed loop ex-vessel machine and on the interim examination and maintenance cell sodium removal system, which is used to wash sodium from the fuel assemblies before they are placed in storage. The design was completed for the necessary repairs to the solid waste cask and procurement and fabrication of parts was initiated. Testing and repair activities are scheduled to continue through the first quarter of 2003.

A detailed summary of the status of the Fast Flux Test Facility can be found on the Internet at http:// www.fftf.org/currstat/.

\subsubsection{Advanced Reactors Transition Project}

\section{A. Gantt}

The mission of this project is to transition or convert the Plutonium Recycle Test Reactor facility and the nuclear energy legacy facilities into structures that are in a safe and stable condition suitable for reuse or low cost surveillance and maintenance. Legacy facilities are those used for nuclear research projects conducted in the past at the Hanford Site. Although these legacy facilities existed in many areas of the Hanford Site, the only facilities remaining to be cleaned up are in the southeastern part of the 300 Area, the 337 Building high bay area and the adjacent storage tank building, 3718M. Deactivation of legacy facilities includes the disposition of non-radioactive sodium and sodium-potassium alloy originally used in the development and testing of components for use in liquid metal-cooled reactors.

In 2001, at the Plutonium Recycle Test Reactor/ 309 Building, located in the 300 Area, the fuel transfer pit was drained and residual contamination was stabilized. The exhaust fans, which provided forced exhaust flow through the stack, have been taken out of service. Except for some pending repairs to the roof, this facility is in a condition for low cost surveillance and maintenance until deactivation, decontamination, and decommissioning are performed in accordance with the 300 Area Accelerated Closure Project Plan (HNF-6465).

In 2001, a small cold trap in the high-bay of the 337 Building, containing about 91 kilograms (200 pounds) of sodium metal, was welded shut and shipped to an offsite disposal facility. (A cold trap is a device used in sodium systems to remove and trap chemical impurities.) The asbestos abatement and insulation removal was completed on the sodium test loop piping; this was the last step in preparation to remove the sodium wetted piping for disposal. The pipe loop has been severed from the $3718 \mathrm{M}$ storage tank $(\sim 189,000$ liters [ $\sim 50,000$ gallons] volume), the composite reactor component test activity vessel, and the sodium cold trap $(\sim 2,650$ liters [ 700 gallons] volume), which were prepared for future cleaning. Removal of the sodium-wetted piping is in progress.

\subsubsection{Office of River Protection}

Congress established the Office of River Protection in 1998 as a DOE field office reporting directly to the DOE Assistant Secretary for Environmental Management. The Office of River Protection is responsible for managing DOE's River Protection Project to store, retrieve, treat, and dispose of high-level tank waste and close the tank farm facilities at the Hanford Site.

\subsubsection{Waste Tank Status}

\section{P. A. Powell}

The status of the 177 waste tanks as of December 2001 was reported in HNF-EP-0182, Waste Tank Summary Report for Month Ending December 31, 2001. This report is published monthly; the December report provided the following information:

- number of high-level waste tanks

- 149 single-shell tanks

- 28 double-shell tanks

- number of high-level waste tanks assumed to have leaked

- 67 single-shell tanks

- 0 double-shell tanks 
- chronology of single-shell tank leaks

- 1956: first high-level waste tank reported as suspected of leaking (tank 241-U-104)

- 1973: largest estimated leak reported (tank 241-T-106; 435,000 liters [115,000 gallons])

- 1988: tanks 241-AX-102, 241-C-201, 241-C-202, 241-C-204, and 241-SX-104 confirmed as having leaked

- 1992: latest tank (241-T-101) added to list of tanks assumed to have leaked, bringing total to 67 single-shell tanks

- 1994: tank 241-T-111 was declared to have leaked again.

The total estimated volume to date of radioactive waste leakage from single-shell tanks is $<2.84$ to 3.97 million liters ( $<750,000$ to 1 million gallons).

To date, 129 of the 149 (87\%) single-shell tanks have been stabilized and the program is ahead of schedule. At the end of 2001, intrusion prevention work was completed on 108 single-shell tanks. This involved capping off connecting pipes, risers, and pit covers to prevent any liquids from entering the tanks. Partial interim isolation was completed on 40 single-shell tanks. This involved capping off in the same manner as intrusion prevention except risers and piping were required to stabilize the tanks.

During 2001, four tanks (241-S-106, 241-S-109, 241-U-105, and 241-U-106) were declared stabilized. Waste was pumped from 13 single-shell tanks into the double-shell tank system. Portions of the waste in tanks 241-S-109, 241-S-111, 241-SX-101, 241-SX-102, 241-SX-103, 241-SX-105, 241-U-102, 241-U-107, 241-U-108, 241-U-109, 241-BY-105, 241-BY-106, and 241-AX-101 were removed. This pumping removed 1.9 million liters $(500,000$ gallons $)$ of waste from the single-shell tanks. The addition of this waste and dilution water to the double-shell tank system required the transfer of 1.4 million liters (400,000 gallons) of waste from the double-shell tank system in the 200-West Area to the double-shell tank system in the 200-East Area, through the new 10.5-kilometer (6.5-mile) long crosssite transfer pipeline. The ability to transfer waste safely from the 200-West Area to the 200-East Area has allowed a significant amount of single-shell tank waste to be transferred to the safer and environmentally compliant double-shell tank system. For the safe and timely removal of waste from the single-shell tank system, temporary transfer piping (above ground and shielded) has been installed.
To assure safe storage and retrieval, 136 of 177 (76\%) tanks have been characterized. Characterization data and resulting safety controls have allowed the safe storage of tank waste and the removal of all tanks from the Watch List. Currently, the first 14 tanks that will deliver waste to the Waste Treatment Facility (i.e., vitrification plant) have been selected. Sampling has been performed in 12 of these tanks, with characterization analysis performed on 11 of them. This characterization information is being used to improve the design and operation of the Waste Treatment Facility.

\subsubsection{Waste Tank Safety Issues}

\section{P. A. Powell}

The Waste Tank Safety Program was established in accordance with the Public Law 101-510, Defense Authorization Act, Section 3137, "Safety Measures for Waste Tanks at Hanford Nuclear Reservation" (1990). The focal point of the program is the identification and resolution of safety issues involving high-priority waste tanks. The tasks to resolve safety issues are planned and implemented in the following order: (1) evaluate and define the associated safety issue, (2) identify and close any associated unreviewed safety questions, (3) mitigate any hazardous conditions to assure safe storage of the waste, (4) monitor waste storage conditions, and (5) resolve the respective safety issues. Each of these steps has supporting tasks of some combination of monitoring, mathematical analyses, laboratory studies, and in-tank sampling or testing. The path followed depends on whether the waste requires treatment or can be stored safely by implementing strict controls.

Within the Waste Tank Safety Program, the Safety Issue Resolution Project focused on resolving safety issues involving flammable gas, organic complexants, organic solvents, high-heat, and criticality. The tanks of concern were placed on a Watch List and categorized by safety issue. By 1996, all 24 ferrocyanide tanks had been removed from the Watch List, and the issue was deemed resolved by DOE and the Defense Nuclear Facilities Safety Board. In 1998, 18 tanks containing organic complexants were removed from the Watch List, and in August 2000, the 2 remaining tanks containing organic solvents were taken off the Watch List. The high-heat tank (241-C-106) was removed from the Watch List in 1999. At the end of 2000, 25 flammable gas tanks remained on the Watch List, but in January 2001 tank 241-SY-101 was removed after DOE, the Defense Nuclear Facilities Safety Board, and other stakeholders agreed the safety issue for that tank had been resolved. In August 2001, the 24 remaining flammable gas tanks 
were removed from the Watch List. The tank safety issues have been declared closed and there is no longer an active Watch List.

\subsubsection{Radionuclide Assessment System}

\section{R. G. McCain and P. D. Henwood}

In the past, MACTEC-ERS, under the direction of the DOE Grand Junction Office, completed baseline vadose zone characterization in the vicinity of the single-shell tank farms. Their baseline data were reported in GJ-HAN-120; DOE/ID/12584-268, GJPO-HAN-4; and GJO-99-113-TAR, GJO-HAN-28. The baseline characterization effort identified subsurface contaminant plumes in the vicinity of the single-shell tank farms, with cobalt-60, cesium-137, europium-154/152, and uranium-235/238 as the predominant contaminants. Minor amounts of antimony-125 and tin-126 also were detected.

In fiscal year 2001, a program was established to monitor changes in contaminant levels in existing wells in the vicinity of the single-shell tanks. The Radionuclide Assessment System was developed and deployed to support vadose zone monitoring in the tank farms. The system uses a simpler spectral gamma logging system that is mounted in a much smaller and lighter vehicle. Since specific contaminants have been identified and quantified by the baseline characterization, the primary focus of the monitoring program is to identify changes in contaminant levels. Therefore, the Radionuclide Assessment System records counts in eight contiguous energy "windows." Energy ranges have been chosen for optimum sensitivity to natural and commonly encountered manmade radionuclides. Detection of changes in contaminant profiles that may be indicative of continuing migration are based on comparison of successive log runs.

Radionuclide Assessment System monitoring activities began in June 2001. By September 30, 2001, a total of 1,950 meters (6,400 feet) of logging had been performed in 113 boreholes in single-shell tank farms A, U, $\mathrm{T}, \mathrm{BX}$, and SX. Specific borehole monitoring intervals are selected on the basis of intersection with known contaminant plumes, proximity to tanks known to have leaked or to subsurface contaminant plumes, or proximity to tanks containing relatively large volumes of drainable liquid. Borehole intervals also may be logged in support of tank farms operations. The logging frequency is determined by the overall priority. Most boreholes of interest will be logged on a yearly basis. A few boreholes will be logged on a quarterly basis. The goal of the monitoring program is to collect data from all boreholes at least once in a five-year period.

\subsubsection{Waste Im mobilization}

\section{P. A. Powell}

Approximately 204 million liters (54 million gallons) of radioactive and hazardous waste, accumulated from more than 40 years of plutonium production operations, are stored in 149 underground single-shell tanks and 28 underground double-shell tanks. The Waste Treatment Plant will be built on 26 hectares (65 acres) located on the Central Plateau outside of the Hanford 200-East Area. Currently, three major facilities will be constructed: a pretreatment facility, a high-level waste vitrification facility, and a low-activity waste vitrification facility. Supporting facilities will be constructed also. The River Protection Project is currently upgrading tank farm facilities to deliver waste to the planned Waste Treatment Plant.

During 2001, infrastructure construction for the Waste Treatment Plant was completed. This included the installation of an electrical substation, potable water services, effluent piping systems, and roads. Additionally, excavation for the Waste Treatment Plant footprint was begun. Construction as defined by the Tri-Party Agreement is scheduled to begin in 2002.

\subsubsection{Solid Waste Managem ent}

Solid waste management includes the treatment, storage, and/or disposal of solid waste produced as a result of Hanford Site operations or from offsite sources that are authorized by DOE to ship waste to the site. The following sections contain information regarding specific site locations.

\subsubsection{Central Waste Com plex}

\section{G. Saueressig}

Waste is received at the Central Waste Complex in the 200-West Area from sources at the Hanford Site and any offsite sources that are authorized by DOE to 
ship waste to the Hanford Site for treatment, storage, and disposal. Ongoing cleanup, research, and development activities on the Hanford Site, as well as remediation activities, generate most of the waste received at the Central Waste Complex. Offsite waste has been primarily from other DOE sites and U.S. Department of Defense facilities. The characteristics of the waste received vary greatly, including low-level, transuranic, or mixed waste, and radioactively contaminated polychlorinated biphenyls.

The Central Waste Complex can store as much as 22,710 cubic meters (801,996 cubic feet) of low-level mixed waste and transuranic waste. This capacity is adequate to store the projected volumes of low-level, transuranic, mixed waste, and radioactively contaminated polychlorinated biphenyls to be generated from the sites identified above, assuming on-schedule treatment of the stored waste. Treatment will reduce the amount of waste in storage and make room for newly generated mixed waste. The dangerous waste designation of each container of waste is established at the point of origin based on process knowledge or sample analysis.

\subsubsection{Waste Receiving and Processing Facility}

\section{H. C. Boynton}

The Waste Receiving and Processing Facility began operations in 1997 and analyzes, characterizes, and prepares drums and boxes of waste for disposal. The facility can process 4,800 square meters $(52,000$ square feet) of waste and is located near the Central Waste Complex in the 200-West Area.

Waste destined for the Waste Receiving and Processing Facility includes legacy waste as well as newly generated waste from current site cleanup activities. The waste consists primarily of contaminated cloth, paper, rubber, metal, and plastic. Processed waste that qualifies as low-level waste and meets disposal requirements is buried directly onsite. Low-level waste not meeting direct burial requirements is processed in the facility for onsite burial or prepared for future treatment at other onsite or offsite treatment, storage, and disposal facilities. Waste designated at the facility to be transuranic is certified and packaged for shipment to the Waste Isolation Pilot Plant in Carlsbad, New Mexico, for permanent disposal. Other materials requiring further processing to meet disposal criteria are retained, pending treatment.

\subsection{Radioactive Mixed Waste Disposal Facility}

\author{
D. E. Nester
}

The Radioactive Mixed Waste Disposal Facility is located in the 218-W-5 low-level waste burial ground in the 200-West Area and is designated as trenches 31 and 34. Trench 34 began to be used for disposal during September 1999. Currently, there are $\sim 1,075$ cubic meters $(37,963$ cubic feet) of waste contained in about 715 waste packages in trench 34 . No waste is currently stored in trench 31 . However, trench 31 will be used for storage, when needed, to accommodate large items awaiting disposal into trench 34 . The trenches are rectangular landfills, with approximate base dimensions of 76 by 30 meters ( 250 by 100 feet). The bottoms of the excavations slope slightly, giving a variable depth of 9 to 12 meters ( 30 to 40 feet). These trenches comply with RCRA requirements because they have double liners and systems to collect and remove leachate. The bottom and sides of the facilities are covered with a layer of soil 1 meter (3.28 feet) deep to protect the liner system during fill operations. There is a recessed section at the end of each excavation that houses a sump for leachate collection. Access to the bottom of each trench is provided by ramps along the perimeter walls.

\subsubsection{T Plant Complex}

\section{B. M. Barnes}

The T Plant complex in the 200-West Area provides waste treatment and storage and decontamination services for the Hanford Site. The T Plant complex currently operates under RCRA interim status. In 2001, the following activities occurred at the T Plant complex:

- performed content verification of waste being shipped to solid waste facilities for storage or disposal

- re-packaged and/or sampled waste to meet solid waste acceptance criteria or to determine acceptability of waste for treatment

- treated dangerous and mixed waste to meet RCRA requirements for land disposal

- decontaminated equipment to allow for reuse or disposal as waste

- stored 72 elements of spent reactor fuel (from Shippingport, Pennsylvania) in a water basin. 


\subsubsection{Radioactive Mixed Waste Treatment and Disposal}

\section{E. Nester}

During 2001, 460 cubic meters (16,245 cubic feet) of DOE mixed low-level waste were treated and/or direct disposed. The waste materials were obtained from a number of projects including the following:

- 445 cubic meters $(15,715$ cubic feet $)$, or about 1,125 packages of various sizes, of mixed low-level waste debris previously stored at the Central Waste Complex were shipped to the Allied Technology Group Mixed Waste Treatment Facility located in Richland, Washington. Allied Technology Group used their RCRA-permitted treatment process of macroencapsulation to make the debris compliant with the requirements of EPA and the state of Washington land disposal restrictions. The treated waste was then returned to Hanford for final disposal at the Radioactive Mixed Waste Disposal Facility.

- $\sim 11.4$ cubic meters ( 14.9 cubic yards), or about 55 drums of mixed low-level waste solids (e.g., soil and granulated activated charcoal) that were contaminated with organic waste constituents and were previously stored at the Central Waste Complex were shipped to the Allied Technology Group Mixed Waste Treatment Facility located in Richland, Washington. Allied Technology Group used their RCRA-permitted thermal treatment unit $\left(\right.$ GASVIT $\left.^{\circledR}\right)$ to treat the waste according to EPA and Washington State Department of Ecology land disposal treatment standards. The treated waste residues were then returned to Hanford for final disposal at the Radioactive Mixed Waste Disposal Facility.

- 3.7 cubic meters ( 130.7 cubic feet), or $\sim 10$ packages of mixed low-level waste were disposed directly into the Radioactive Mixed Waste Disposal Facility during the reporting period. This waste came from various Hanford Site operations and either met RCRA land disposal restrictions in the as-generated state, or was treated according to Treatment-byGenerator provisions in WAC 173-303-170(3)(b) to treat the waste to meet the RCRA and state land disposal restrictions.

\subsubsection{Radioactive Mixed Waste Treatment Contracts}

\author{
D. E. Nester
}

In November 1995, Westinghouse Hanford awarded a contract to Allied Technology Group, Richland, Washington, for thermal treatment of Hanford's mixed waste in accordance with RCRA and the Toxic Substances Control Act. Transfer of the thermal treatment contract occurred in 1996 when Fluor Hanford, Inc. became the Hanford Site prime contractor. On November 19, 2001, Allied Technology Group announced a shutdown of all their facilities due to financial issues; on December 4, 2001, they filed for Chapter 11 bankruptcy. At the time of shutdown, Hanford had $\sim 310$ cubic meters ( 10,948 cubic feet) of mixed low-level waste still residing at Allied Technology Groups' Richland facility. DOE Richland Operations Office and site contractors worked with Allied Technology Group during December, and will continue to work with them in calendar year 2002 to resolve the situation.

During 1997, a competitive procurement was conducted to process mixed waste requiring non-thermal treatment in accordance with RCRA. The contract was also awarded to Allied Technology Group. During 2001, Allied Technology Group processed 445 cubic meters (15,715 cubic feet) of Hanford's mixed low-level waste debris and process solids via this contract. The treated waste was returned to Hanford for disposal at the Radioactive Mixed Waste Disposal Facility.

\subsubsection{Navy Reactor Compartments}

\section{S. G. Arnold}

Eight disposal packages containing defueled United States Navy reactor compartments were received and placed in trench 94 in the 200-East Area during 2001. Four were submarine reactor compartments, and four were cruiser reactor compartments. This brings the total number of reactor compartments received to 102. All Navy reactor compartments shipped to the Hanford Site for disposal have originated from decommissioned nuclear-powered submarines or cruisers.

\subsubsection{Liquid Eff luent Treatment}

Liquid effluents are managed in treatment, storage, and disposal facilities to comply with RCRA and state regulations. 


\subsubsection{242-A Evaporator}

\section{S. S. Lowe}

The 242-A evaporator in the 200-East Area concentrates dilute liquid tank waste by evaporation. This reduces the volume of tank waste and eliminates the need to construct additional double-shell tanks. The concentrated tank waste is returned to the double-shell tanks for storage. One operational run was conducted at the evaporator in 2001. The process treated 3.2 million liters $(840,000$ gallons) of tank waste and produced 3.1 million liters $(820,000$ gallons) of process condensate. One operational run is planned at the 242-A evaporator for 2002.

Effluent treatment and disposal capabilities are available to support the continued operation of the 242-A evaporator. The Effluent Treatment Facility in the 200-East Area (see Section 2.3.8.3) was constructed to treat the process condensate from the evaporator and other radioactive liquid waste. The process condensate is sent to the Liquid Effluent Retention Facility for interim storage while awaiting treatment in the Effluent Treatment Facility. Cooling water and non-radioactive steam condensate from the evaporator are discharged to the 200 Area Treated Effluent Disposal Facility.

\subsubsection{Liquid Effluent Retention Facility}

\section{S. S. Lowe}

The Liquid Effluent Retention Facility in the 200-East Area consists of three RCRA-compliant surface basins to temporarily store process condensate from the 242-A evaporator and other aqueous waste. The Liquid Effluent Retention Facility provides equalization of the flow and $\mathrm{pH}$ of the feed to the Effluent Treatment Facility. Each basin has a maximum capacity of 29.5 million liters (7.8 million gallons). Generally, spare capacity is maintained in the event a leak should develop in an operational basin. Each basin is constructed of two, flexible, high-density polyethylene membrane liners. A system is provided to detect, collect, and remove leachate from between the primary and secondary liners. Beneath the secondary liner is a soil/bentonite clay barrier should the primary and secondary liners fail. Each basin has a floating membrane cover constructed of very low-density polyethylene to keep out unwanted material and to minimize evaporation of the basin contents. The facility began operating in April 1994 and receives liquid waste from both RCRA- and CERCLAregulated cleanup activities. Approximately 32.7 million liters (8.6 million gallons) of aqueous waste were stored in the basins at the end of 2001. Groundwater is receding from beneath the facility, which is affecting facilityrelated groundwater monitoring activities. Alternative monitoring methods are being investigated.

\subsubsection{Effluent Treatment Facility}

\section{S. S. Lowe}

Liquid effluents are treated in the Effluent Treatment Facility (200-East Area) to remove toxic metals, radionuclides, and ammonia and destroy organic compounds. The treated effluent is stored in verification tanks, sampled and analyzed, and discharged to the State-Approved Land Disposal Site (also known as the 616-A crib). The treatment process constitutes best available technology and includes $\mathrm{pH}$ adjustment, filtration, ultraviolet light/peroxide destruction of organic compounds, reverse osmosis to remove dissolved solids, and ion exchange to remove the last traces of contaminants. The facility began operating in December 1995. Treatment capacity of the facility is a maximum of 570 liters per minute (150 gallons per minute). Approximately 95.0 million liters (25.1 million gallons) of aqueous waste were treated in 2001.

The treated effluent is sampled to verify that the radioactive and hazardous waste constituents have been reduced to regulatory levels, then discharged via a dedicated pipeline to the State-Approved Land Disposal Site. The disposal site is located north of the 200-West Area and consists of an underground drain field. Tritium in the liquid effluent cannot be removed practically, and the location of the disposal site maximizes the time for migration of contaminated groundwater to the Columbia River, and allows time for radioactive decay of the tritium (12-year half-life). The disposal site is permitted under the WAC 173-216 State Waste Discharge Permit Program. The discharge permit requires monitoring of the groundwater and the treated effluent to assure that levels for certain constituents are not exceeded. Permit limits were not exceeded in 2001. The discharge permit for the Effluent Treatment Facility is due to be renewed in 2005 .

Secondary waste from treating aqueous waste is concentrated, dried, and packaged in 208-liter (55-gallon) drums. The solid secondary waste from treating RCRAregulated aqueous waste (e.g., 242-A evaporator process condensate) is transferred to the Central Waste Complex for subsequent treatment, if needed, to meet land disposal restriction treatment standards and disposed in 
the Mixed Waste Disposal Unit in the 200-West Area. The solid secondary waste from treating CERCLAregulated aqueous waste (e.g., 200-UP-1 groundwater) is disposed of in the Environmental Restoration Disposal Facility near the 200-West Area.

\subsubsection{Area Treated Effluent Disposal Facility}

\section{S. S. Lowe}

The 200 Area Treated Effluent Disposal Facility is a collection and disposal system for non-RCRA permitted waste streams. The individual waste streams must be treated or otherwise comply with best available technology/all known available and reasonable treatment in accordance with WAC 173-240, which is the responsibility of the generating facilities. The 200 Area Treated Effluent Disposal Facility consists of $~ 18$ kilometers ( 11 miles) of buried pipeline connecting three pumping stations, one disposal sample station (6653 Building) and two 2-hectare (5-acre) disposal ponds located east of the 200-East Area. The facility began operating in April 1995 and has a capacity of 12,900 liters per minute (3,400 gallons per minute). There are currently 13 waste streams being sent to the 200 Area Treated Effluent Disposal Facility. Approximately 484 million liters ( 128 million gallons) of effluent were discharged in 2001.

The discharge from the 200 Area Treated Effluent Disposal Facility must comply with limits in the WAC 173-216 State Waste Discharge Permit. The discharge permit requires monitoring of the effluent and the groundwater to assure that concentrations for certain constituents are not exceeded. End-of-pipe sampling and continuous online monitoring (for flow, $\mathrm{pH}$, and conductivity) of the combined waste stream are performed at the 6653 Building. The individual generating facilities also are required to perform online monitoring and sampling; the requirements depend on the individual waste streams. There were no violations of permit limits or conditions in 2001. The discharge permit for the 200 Area Treated Effluent Disposal Facility is due to be renewed in 2005 .

\subsubsection{Miscellaneous Streams}

\section{J. C. Sonnichsen}

In February 1995, the Washington State Department of Ecology approved a Plan and Schedule for Disposition and Regulatory Compliance for Miscellaneous Streams
(DOE/RL-93-94). This plan and schedule required that all miscellaneous streams be permitted under WAC 173-216. Categorical permits were used to permit miscellaneous streams with similar characteristics. Categorical permits have been issued for the following:

- hydrotesting, maintenance, and construction discharges (Permit ST 4508, May 1997)

- cooling water discharges and uncontaminated streams condensate (Permit ST 4509, May 1998)

- industrial stormwater discharge (Permit ST 4510, April 1999).

The permitting process was completed in 1999 with the issuance of the last Categorical Permit ST 4510. All milestones identified in the plan and schedule (DOE/ RL-93-94) have been fulfilled, and the annual submittal of the Hanford Site Miscellaneous Streams Inventory report is no longer required.

In January 2000, DOE issued the Pollution Prevention and Best Management Practices Plan for State Waste Discharge Permits ST 4508, ST 4509, and ST 4510 (DOE/RL-97-67). This plan summarized the compliance requirements stated in all the categorical permits and set conditions for the individual streams. The pollution prevention and best management practices plan details implementation of remediation activities to prevent further contamination of groundwater.

Permit ST 4508 is scheduled to expire on May 30, 2002. Its renewal application is required to be submitted 180 days prior to permit expiration. Recognizing that Permits ST 4509 and ST 4510 are scheduled to expire over the next two calendar years, it was decided that it was cost-effective to submit a permit application for all three categorical permits. The single permit application for all three permits, Documentation for Renewal of State Waste Discharge Permits ST 4508, ST4509, and ST 4510 (DOE/RL-2001-60), was completed and submitted to the Washington State Department of Ecology during November 2001.

In compliance with WAC 173-218, which requires registration of Class $\mathrm{V}$ underground injection control wells, a significant and ongoing effort to verify the location and status of all Class $\mathrm{V}$ underground injection control wells on the Hanford Site began in February 2000. On the Hanford Site, Class V injection wells include the injection of stormwater and other small quantities of uncontaminated wastewater (i.e., condenser condensate). A large number of underground injection control wells were determined to be inactive and were removed from the list of active wells. In most 
cases, these injection wells amount to locations where small quantities of non-contaminated wastewater percolate into the soil (i.e., small percolation drains).
Registration of Hanford Site Class V Underground Injection Wells (DOE/RL-88-11) was submitted to the Washington State Department of Ecology in March 2001.

\section{Revegetation and Mitigation Planning}

\section{A. R. Johnson and M. R. Sackschewsky}

Bechtel Hanford, Inc. completed revegetation on 50 hectares (124 acres) of remediated lands in the 100 Areas. Planting occurred in November and December 2001 and included 22 hectares ( 55 acres) in the $100-\mathrm{H}$ Area and 28 hectares (69 acres) in the 100-D/DR Area. Both areas were seeded with Hanford-derived native grass and forb seed. Following the seeding, the area was mulched, and 21,700 sagebrush (Artemisia tridentata) seedlings were planted. Representative plots within each of the areas will be monitored to document plant survival and community establishment.

The wetland habitat by the $100-\mathrm{B} / \mathrm{C}$ Area created in early 2000 near the Columbia River was enhanced with the planting of an additional 1.6 hectares ( 4 acres) along the slopes of the pit. The area included 0.8 hectares ( 2 acres) that were seeded with grass and forbs and 2 separate acres that were planted with sagebrush tubelings. This planting effort will provide the borrow area with a much needed seed source to promote continual restoration of the pit.

Two sites in the 600 Area, the J.A. Jones and 600-23 sites were revegetated following remediation. The J.A. Jones site, north of the 300 Area, and the 600-23 site (which lies within the boundary of gravel pit 11 just off of Route 2 South $\sim 1.6$ kilometers [ 1 mile] north of the Wye Barricade) were seeded with native grasses and forbs, and then planted with sagebrush and bitterbrush (Purshia tridentata) seedlings. These sites will be incorporated into the monitoring program to document plant survival and succession.

The 600-104 bioremediated site on the Wahluke North Slope was originally broadcast seeded with native species in the fall of 1997. To further promote the establishment of shrubs in this community, 900 sagebrush seedlings were planted across the 0.8-hectare (2-acre) site in the spring of 2001.

In January 2001, 50 bitterbrush seedlings were planted as additional mitigation for shrubs lost during the initial stages of the 618-4 Burial Ground remediation. The plants were protected with biodegradable plastic mesh tubes and staked to prevent browsing by deer. In June and August, each bitterbrush plant was irrigated with 19 liters (5 gallons) of water. A 19-liter (5-gallon) bucket with a 0.04-centimeter (1/64-inch) hole drilled in the bottom to slowly release the water was placed at the base of each plant. These shrubs will be monitored for survival in future years.

A new electrical transmission line with tower pads was installed to provide electrical power to the planned vitrification plant near the 200-East Area. The areas surrounding the tower pads that were disturbed during pad installations were revegetated during February 2001. This revegetation was considered a rectification planting and was part of the overall vitrification plant mitigation effort. The effort included broadcast seeding of Sandberg's bluegrass and sagebrush at each tower pad. Total area was $\sim 8$ hectares ( $\sim 20$ acres $)$.

Monitoring of survival and growth continued for $\sim 90,000$ sagebrush seedlings that were planted on about 90 hectares (222 acres) at 9 locations on the Fitzner/ Eberhardt Arid Lands Ecology Reserve Unit during December 2000. This effort was the last phase of sagebrush transplanting as compensatory mitigation for the disturbance of sagebrush habitat resulting from the development of the site and infrastructure for the planned waste vitrification facility. Monitoring of these plants will continue through fiscal year 2004.

\subsection{Environmental Restoration Project}

DOE selected an environmental restoration contractor in 1994 to perform environmental restoration projects at the Hanford Site. The Environmental Restoration Project includes characterization and remediation of contaminated soil and groundwater, sitewide vadose zone/groundwater project integration, decontamination and decommissioning of facilities, surveillance and maintenance of inactive waste sites, and the transition of facilities into the surveillance and maintenance program. 


\subsubsection{Environmental Restoration Disposal Facility}

\author{
M. A. Casbon
}

The Environmental Restoration Disposal Facility is located near the 200-West Area. The facility began operations in July 1996 and serves as the central disposal site for contaminated waste removed during cleanup operations conducted under CERCLA on the Hanford Site. To provide a barrier to contaminant migration from the facility, the Environmental Restoration Disposal Facility was constructed to RCRA Subtitle C Minimum Technology Requirements including a double liner and leachate collection system. Remediation waste disposed in the facility include soil, rubble, or other solid waste materials contaminated with hazardous, low-level radioactive or mixed (combined hazardous, chemical, and radioactive) waste.

In 2000, waste was first placed into the first of two new cells (cells 3 and 4) that were constructed in 1999. Later in 2000, an interim cover was placed over portions of cells 1 and 2 that had been filled to their final configuration. Waste continued to be placed in cells 3 and 4 during 2001; as of early 2002, the facility had received over 3.1 million metric tons ( 3.43 million tons) of contaminated soil and other waste.

\subsubsection{Waste Site Rem ediation}

J. G. April, F. V. Roeck, G. R. Frank, R. D. Belden, J. A. Lerch, and D. F. Obenauer

Full-scale remediation of waste sites began in the 100 Areas in 1996. Remediation and backfill activities continued through 2001 at several liquid waste disposal sites in the 100-B/C, 100-H, and 100-F Areas. Remediation of the treatment, storage, and disposal units at 100-N Area continued through 2001. Figure 1.0.1 shows the former reactor areas along the Columbia River.

In 2001, 110,000 metric tons (121,000 tons) of contaminated soil in the 100-B/C Area were removed and shipped to the Environmental Restoration Disposal Facility. The cumulative amount of contaminated soil removed and shipped to the facility through December 2001 were 732,000 metric tons (806,000 tons).

In the $100-\mathrm{H}$ Area, 136 metric tons (150 tons) of soil were removed from the waste sites during 2001. Since the beginning of remediation, 413,000 metric tons (455,000 tons) of contaminated soil were removed and shipped to the Environmental Restoration Disposal Facility.
Remediation in the 100-F Area continued with the removal of 321,000 metric tons (353,000 tons) of contaminated soil in 2001. A total of 470,000 metric tons (517,000 tons) of contaminated soil has been removed from the 100-F Area and disposed of at the Environmental Restoration Disposal Facility.

Remediation continued at the 116-N-3 Treatment, Storage, and Disposal Facility and began at the 116-N-1 Treatment, Storage, and Disposal Facility, which are both located within the 100-NR-1 Operable Unit. Remediation of these treatment, storage, and disposal facilities is being completed as required by the Hanford Sitewide RCRA Permit. In 2001, 109,000 metric tons (120,000 tons) of contaminated soil were removed from $116-\mathrm{N}-3$ and 3,200 metric tons (3,500 tons) of contaminated soil were removed from $116-\mathrm{N}-1$. The total contaminated soil removed through 2001 from the 100-NR-1 Operable Unit is 137,520 metric tons (151,121 tons), all of which was disposed of at the Environmental Restoration Disposal Facility.

The interim record of decision for the 100 Areas Burial Grounds, issued September 16, 2000, specified a cleanup remedy to remove/treat/dispose contaminated soil, structures, and debris from the 100 Areas burial ground sites. Remedial design for 9 burial ground sites in the 100-B/C Area began in 2001.

Remediation work at the 300-FF-1 Operable Unit began in the 300 Area in 1997 (see Figure 1.0.1). Historically, both chemical and radiological materials were disposed of at the 300-FF-1 waste sites. With the exception of the 618-4 burial ground, excavation of all 300-FF-1 Operable Unit waste sites has been completed and more than 482,000 metric tons ( 531,000 tons) of contaminated material and debris have been transported to Environmental Restoration Disposal Facility through 2001. Excavation of the 618-4 burial ground is scheduled to be complete in 2002.

An interim action record of decision for the 300-FF-2 Operable Unit (EPA 2001) was issued in 2001. The record of decision includes 56 waste sites that require remedial action based on an anticipated industrial land use scenario. The selected remedy prescribed by the record of decision consists of removal of contaminated soil and debris, treatment (as necessary) and disposal at the Environmental Restoration Disposal Facility or other approved facility, site re-contouring/backfill and infiltration control measures, and institutional controls. Cleanup of the 300-FF-2 Operable Unit waste sites is scheduled to begin in 2002.

A record of decision (EPA 1999) was issued for the 100 Areas remaining sites in 1999. The record of 
decision includes 207 waste sites that were not previously addressed in the 1995100 Areas record of decision, or the 1997 amendment to the 100 Areas record of decision (100 Areas solid waste burial sites and waste sites at $100-\mathrm{N}$ Area were not included). It specified a remove/treat/dispose remedy for contaminated soil, structures, and debris at 46 of the remaining sites. The cleanup remedy is the same method applied to 100 Areas record of decision sites and is consistent with other cleanup actions that are currently being conducted within the 100 Areas. The remaining 161 sites are classified as candidate sites for confirmatory sampling to determine if there is residual contamination above cleanup levels. Based on the confirmatory sampling efforts, sites shown to be contaminated will move directly into remove/treat/dispose while uncontaminated sites will be closed out. In 2001, DOE completed design of remedial actions for the remaining sites.

\subsubsection{Facility Decom missioning Project}

\section{R. R. Nielson}

Decontamination and decommissioning activities continued in 2001 in the 100-D/DR, 100-H, and 100-F Areas. These activities are conducted to support the interim safe storage of the four reactor buildings (D, DR, F, and $H$ ) for up to 75 years. Interim safe storage minimizes potential risks to the environment, employees, and the public and reduces surveillance and maintenance costs. These activities are conducted as non-time-critical removal actions under CERCLA. During the year, all planned pourback work at DR and F Reactors was completed. (Pourbacks are the process of enclosing openings in the safe storage enclosure wall with structural concrete to prevent inadvertent pest or weather intrusion.) The subcontract for the safe storage enclosure roofs for DR and F Reactors was awarded. The roof design for the DR Reactor was completed by the subcontractor and approved by the environmental restoration contractor; the subcontractor began work onsite at the end of 2001. The roof design for F Reactor was completed by the subcontractor as well. Biological cleanup, legacy waste removal, asbestos abatement, liquid pipe checks, and other pre-demolition activities were ongoing in 2001 in various demolition areas of the $\mathrm{D}$ and $\mathrm{H}$ Reactors. Demolition of D Reactor also was initiated in 2001 and progressed through three areas (the lunchroom, the valve pit and shops, and the fan room and ventilation system tunnels).

Demolition work at F Reactor Fuel Storage Basin continues. A de-watering system was installed to remove remaining water from the basin. Wastewater was shipped to the Effluent Treatment Facility for treatment and disposal. EPA approval was obtained to reuse the upper 5.2 meters ( 17 feet) of fill as backfill. A remotecontrolled excavator was deployed in the fuel storage basin to assist in sample collection and removal of high contamination areas within the remaining 1 meter (3.28 feet) of fill. A small number of spent nuclear fuel elements were removed and shipped to the $\mathrm{K}$ Area fuel storage basins.

A de-watering system also was installed at the $100-\mathrm{H}$ Area fuel storage basin. Wastewater is being removed and shipped to the Effluent Treatment Facility for treatment and disposal.

\subsubsection{233-S Plutonium Concentration Facility Decom m issioning Project}

\section{R. R. Nielson}

Decontamination and decommissioning activities continued in 2001 at the 233-S Plutonium Concentration Facility located in the 200-West Area adjacent to the Reduction-Oxidation Plant. This work is being performed as a non-time-critical removal action under CERCLA. The 233-S facility and associated process equipment were used to concentrate plutonium produced at the Reduction-Oxidation Plant from 1955 to 1967. Dismantling of the process hood area continued, including the removal of 11 process vessels and over 500 meters (1,600 feet) of process hood piping. The ventilation system was modified to increase flow in the process hood area to better protect workers. The nondestructive assay of several hundred waste packages was completed. The facility poses special challenges to workers, engineering methods, safety documentation, and work methods because of the estimated large quantities of fissile material in the facility and high levels of contamination.

\subsubsection{Surveillance/ Maintenance and Transition Project}

\section{J. W. Golden}

This project performs surveillance and maintenance of inactive facilities and waste sites until final disposition can begin. The project also provides for the transfer, or transition, of facilities and waste sites into the Environmental Restoration Program after deactivation has been completed. Facilities transferred in 1998 and 1999 included the Plutonium-Uranium 
Extraction Plant, B Plant, and 224-B Building. Also, the project performs surveillance and maintenance of the Reduction-Oxidation Plant, U Plant, the 224-U Building, N Reactor, B Reactor, C Reactor, and the KE and $\mathrm{KW}$ Reactors (excluding the fuel storage basins). The project maintains 14 interim status RCRA treatment, storage, and disposal units awaiting closure. Also, the project maintains three major air emission stacks and three minor emission stacks as defined by 40 CFR 61 .

Outdoor tasks within the project include the Radiation Area Remedial Action Program, which is responsible for the surveillance, maintenance, and decontamination or stabilization of 955 inactive waste sites that include former cribs, ponds, ditches, trenches, unplanned release sites, and burial grounds. These sites are maintained by performing periodic surveillances, radiation surveys, and herbicide applications and by initiating timely responses to identified problems. The overall objective of this project is to maintain these sites in a safe and stable configuration until final remediation strategies are identified and implemented. The objective is to prevent the contaminants in these sites from spreading in the environment.

Plutonium-Uranium Extraction Plant and B Plant. The Plutonium-Uranium Extraction Plant (also referred to as the PUREX Plant) was transferred to the environmental restoration contractor after deactivation in 1999 and is being maintained in a surveillance and maintenance mode before decommissioning. The plant has a single effluent stack emission point that is a major emission unit as defined in 40 CFR 61. Also, there are 45 RCRA treatment, storage, and disposal vessels within the facility and containment structure. An annual roof inspection is performed from within the facility and from the outside to assess the condition of a facility that no longer has heat or utility services.

The B Plant, excluding the 296-B-1 stack, was transferred to the environmental restoration contractor in 1999. The facility effluent emission point through the 296-B-1 stack was transferred on August 10, 2000. The facility is being maintained in a surveillance and maintenance mode before decommissioning. The plant maintains two stack emission points that are major emission units by definition of 40 CFR 61 . The plant contains 54 RCRA treatment, storage, and disposal vessels within the facility and containment structure. An annual roof inspection is performed from within the facility and from the outside to assess the condition of a facility that no longer has heat or utility services.

\subsubsection{Canyon Disposition Initiative}

\section{J. W. Golden and C. W. Hedel}

The environmental restoration contractor completed the final feasibility study report (under CERCLA) for the Canyon Disposition Initiative in September 2001. The purpose of the Canyon Disposition Initiative is to investigate the potential for using the five canyon buildings at the Hanford Site as disposal facilities for Hanford Site remediation waste, rather than demolishing the structures for onsite disposal. While Canyon Disposition Initiative strategy, planning, and sampling activities actually began in the mid-1990s, the final feasibility study (DOE/RL-2001-11) was completed in 2001 and was the final phase in the CERCLA remedial investigation/ feasibility study planning for disposition of the 221-U Facility. The 221-U Chemical Processing Facility (U Plant) was used as a pilot project for the Canyon Disposition Initiative. The Tri-Parties consider the process for the evaluation of $U$ Plant to also apply to the remaining four canyon buildings. There were five alternatives selected for final evaluation and screening: (1) Alternative 0 - No Action, (2) Alternative 1 - Full Removal and Disposal, (3) Alternative 3 - Entombment with Internal Waste Disposal, (4) Alternative 4 Entombment with Internal/External Waste Disposal, and (5) Alternative 6 - Close in Place - Collapsed Structure. The final feasibility study (DOE/RL-2001-11) determined that Alternatives 3, 4, and 6 met the requirements to protect human health and the environment, as well as being consistent with the 2012 cleanup plan for the Central Plateau. The final remedy will be selected during the record of decision process. Determining the final state of the five canyon buildings figures prominently in DOE's plan for the Central Plateau as an area for long-term waste treatment, storage, and disposal operations in support of Hanford cleanup operations. The final feasibility study report (DOE/ RL-2001-11) was, therefore, a strategic document for decision-making affecting the future of the Hanford Site.

\subsubsection{Groundwater/Nadose Zone Integration Project}

\author{
G. B. Mitchem, M. N. Jarayssi, and L. R. Curry \\ DOE established the Groundwater/Vadose Zone \\ Integration Project (Integration Project) in 1997 as its
}

centerpiece for water resources protection for the Hanford Site. Specifically, the Integration Project coordinates all projects at Hanford involved in characterizing, 
monitoring, and remediating the groundwater, the vadose zone (the soil above the groundwater), and the Columbia River.

The project team includes staff from Bechtel Hanford, Inc. and its environmental restoration contractor team, CH2M HILL Hanford Group, Inc.; Fluor Hanford, Inc.; and Pacific Northwest National Laboratory, as well as support from other national laboratories and universities. The Hanford Groundwater Monitoring Project is under the umbrella of the Integration Project.

During 2001, the Integration Project team compiled an array of accomplishments that span its key focus areas - Site-Wide Fieldwork Integration Focus Area, the System Assessment Capability Focus Area, Science and Technology Focus Area, Integration of Information Focus Area, Technical Review Focus Area, and Public Involvement Focus Area. The efforts within these task areas directly support the DOE's plan for the Hanford Site.

\subsubsection{Site-Wide Fieldw ork Integration Focus Area}

\section{Groundwater Restoration}

\section{C. Swanson}

The overall objectives of groundwater restoration at sites adjacent to the Hanford Reach are to:

- protect aquatic receptors in the river bottom substrate from contaminants in the groundwater entering the Columbia River

- reduce levels of contamination in the areas of highest concentration

- prevent further movement of contamination

- protect human health and the environment.

Summary descriptions of the groundwater restoration activities are discussed below.

Chromium. Groundwater contaminated with chromium underlies portions of the 100-D, 100-H, and 100-K Areas (the 100-HR-3 and 100-KR-4 Operable Units) and is of concern because of a potential to affect the Columbia River ecosystem. Low levels of chromium are toxic to aquatic organisms, particularly those that use the riverbed sediment as habitat (DOE/RL-94-102; DOE/RL-94-113). The relevant standard for protection of freshwater aquatic life is $10 \mu \mathrm{g} / \mathrm{L}$ of chromium (WAC 173-201A). Chromium concentrations exceeding $600 \mu \mathrm{g} / \mathrm{L}$ have been measured in the porewater of riverbed sediment adjacent to the 100-D Area (BHI-00778).

In 1994, a groundwater extraction system was installed in the 100-D Area to test chromium removal from groundwater using ion exchange technology. Following the record of decision in 1996 (EPA 1996), fullscale pump-and-treat systems were constructed in the 100-D, $100-\mathrm{H}$, and 100-K Areas. The objective of these systems is to remove hexavalent chromium contamination from the groundwater and, thus, prevent or reduce the movement of chromium to the river.

In 2001, the total amount of groundwater treated by pump-and-treat systems in the 100-D and 100-H Areas was 222.6 million liters ( 58.8 million gallons), with the removal of 26.3 kilograms (58 pounds) of hexavalent chromium. Since 1997, more than 1.18 billion liters (311.8 million gallons) of groundwater have been treated, with 129.4 kilograms (285.4 pounds) of chromium removed (DOE/RL-2002-05). Treated groundwater is re-injected into the aquifer upgradient from the 100-H Area extraction wells. Groundwater from both the $100-\mathrm{D}$ and $100-\mathrm{H}$ sites is treated in the $100-\mathrm{H}$ Area using separate treatment systems.

In 2001, the 100-KR pump-and-treat system treated 338.8 million liters (89.5 million gallons) of groundwater. During the process, 36.2 kilograms (79.8 pounds) of chromium were removed. Total chromium removed since operations began in 1997 is 148.3 kilograms (328.1 pounds) through treatment of 1.24 billion liters (327.4 million gallons) of water (DOE/RL-2002-05). Treated groundwater is re-injected into the aquifer upgradient from the 100-KR-4 extraction wells.

To further evaluate chromium and other groundwater contamination that might enter the Columbia River between monitoring wells, 178 aquifer sample tubes were installed in 1997 along and parallel to the Columbia River shoreline. The distance between the sample tubes was $\sim 610$ meters $(\sim 2,000$ feet $)$, except in known chromium plumes, where distance was reduced to $\sim 305$ meters $(\sim 1,000$ feet $)$. Sample tubes are constructed of 0.6 -centimeter $(0.25$-inch) inner-diameter polyethylene tubing with a screen at the bottom that is placed anywhere from 0.9 to 9 meters ( 3 to 30 feet) below ground surface. Sample tube installations begin upstream from the 100-B/C Area and continue downstream $\sim 40$ kilometers ( $\sim 25$ miles) to near the Hanford town site. Sample tube locations are shown in Figure 7.1.8.

In the fall of 2001, 28 tube samples were collected and analyzed for carbon-14, chromium, gross beta, 
nitrate, strontium-90, sulfate, total uranium, and tritium. The results are being used to characterize groundwater near the Columbia River in support of remediation operations, monitoring objectives, and other environmental programs. Sample tube data provide site-specific information on the distribution of chromium that enters the river at locations near sensitive ecological receptors (e.g., salmon spawning areas). Additional discussion of chromium in groundwater in the 100 Areas is presented in Section 7.1.6.2.

In addition to pump-and-treat remediation, in situ redox manipulation technology continues to be demonstrated in the southwestern 100-D Area to address hexavalent chromium contamination in groundwater. This technology immobilizes hexavalent chromium by reducing the soluble, more toxic, chromate ion to highly-insoluble, less toxic, chromium hydroxide or iron chromium hydroxide. This is accomplished by injecting a chemical-reducing agent into closely spaced wells to form a permeable reactive barrier. Following reduction, the reagent and reaction products are pumped out of the wells. Chromium is immobilized as groundwater naturally flows past the barrier. This groundwater cleanup technique was tested in 1997 through 1999 in five injection wells and then expanded to include additional injection wells in 2000 and 2001. In 2001, the treatment zone was expanded by injecting the chemical-reducing agent into 28 new wells. Chromium concentrations are low $(<100 \mu \mathrm{g} / \mathrm{L})$ along the line of the reactive barrier and to the northwest (downgradient) of the center of the barrier $\sim 100$ meters ( 330 feet) toward the Columbia River.

Barrier construction continued in 2001 and is expected be completed in late 2002 or early 2003. By the end of calendar year 2001, 28 additional wells had been constructed and treated, increasing the barrier length to 433 meters (1,420 feet) (DOE/RL-2002-01). The barrier is 15 meters ( 48 feet) wide along its entire length. The final barrier should be over 680 meters (2,230 feet) long. The barrier will intercept and neutralize chromiumcontaminated groundwater moving from the aquifer to the Columbia River. The current pump-and-treat systems will also continue to operate.

Strontium-90. The 100-NR-2 (N Springs) pumpand-treat system began operating in 1995 north of $\mathrm{N}$ Reactor and was designed to reduce the flux of strontium-90 to the Columbia River. The pump-andtreat system operates extraction wells to maintain hydraulic capture. Groundwater is pumped into a treatment system to remove the strontium- 90 contamination, with treated water re-injected upgradient into the aquifer. The system was upgraded in 1996 and has continued to operate through 2001. About 114.7 million liters
(30.3 million gallons) were processed in fiscal year 2001. During that period, 0.18 curies of strontium were removed from the groundwater. Over 665.4 million liters (175.7 million gallons) of groundwater have been processed since the system began operation, removing 1.1 curies of strontium (DOE/RL-2002-05).

Carbon Tetrachloride. The carbon tetrachloride plume in the 200-West Area (originating in the 200-ZP-1 Operable Unit) covers over 11 square kilometers (4.2 square miles). The 200-ZP-1 pump-and-treat system has operated as a pilot-scale treatability test from 1994 to 1996, with full operation beginning in 1996. In 2001, 326 million liters (86.1 million gallons) of groundwater were treated, removing over 1,177 kilograms (2,595 pounds) of carbon tetrachloride. A total of 1.67 billion liters ( 441 million gallons) have been processed since startup, removing 6,084 kilograms $(13,413$ pounds) of carbon tetrachloride.

Uranium, Technetium-99, Carbon Tetrachloride, and Nitrates. Treatment of the groundwater plume underlying the 200-UP-1 Operable Unit in the 200-West Area continued throughout 2001. The contaminant plume contains uranium, technetium-99, carbon tetrachloride, and nitrate. A pump-and-treat system has operated since 1994 to contain the high concentration area of the uranium and technetium-99 plume. During early operations, groundwater was treated using ion-exchange resin to remove the uranium and technetium-99, and granular activated carbon to remove carbon tetrachloride. Since 1997, contaminated groundwater has been transferred by pipeline to basin 43 at the 200 Area Effluent Treatment Facility. Sophisticated treatment technology removes all four contaminants. Treated groundwater is then discharged north of the 200-West Area at the State-Approved Land Disposal Site.

The pump-and-treat system operated continually during 2001, with the single extraction well pumping 98.2 million liters ( 25.9 million gallons) of groundwater, which were treated to remove 8.3 grams $(0.0183$ pound) of technetium-99, 15.5 kilograms (34.2 pounds) of uranium, 2.41 kilograms (5.3 pounds) of carbon tetrachloride, and 3,540 kilograms (7,804 pounds) of nitrate. The pump-and-treat operation made significant progress toward reducing technetium-99 concentrations to below required cleanup concentration levels, but less progress was made with uranium (DOE/RL-2001-53).

Tritium. An investigation to determine the source and extent of tritium in groundwater near an old radioactive burial site was completed. DOE will use the findings from this work to determine if any action is needed at the burial site to protect public health and environmental safety. 


\section{Soil-Vapor Extraction}

\section{J. Rohay}

Soil-vapor extraction systems designed to remove carbon tetrachloride vapor from the vadose zone beneath the 200-West Area began operating in 1992 and continued through 2001. Soil-vapor extraction has been conducted in the vicinity of three historical carbon tetrachloride disposal sites: the 216-Z-1A tile field, the 216-Z-9 trench, and the 216-Z-18 crib. Extracted soil vapor is pumped through granular activated carbon, which absorbs carbon tetrachloride. The granular activated carbon is then shipped offsite for treatment.

Three soil-vapor extraction systems have operated at three different flow rates: 14.2 cubic meters $(500$ cubic feet) per minute, 28.3 cubic meters ( 1,000 cubic feet) per minute, and 42.5 cubic meters (1,500 cubic feet) per minute. However, only the 14.2 cubic meters ( 500 cubic feet) per minute system operated during 2001; the other two systems were maintained in standby mode. Passive soil-vapor extraction systems, which use atmospheric pressure fluctuations to pump carbon tetrachloride vapor from the vadose zone, were installed at wells near the 216-Z-1A tile field and 216-Z-18 crib in 1999. These passive systems operated throughout 2001. Since operations began, soil-vapor extraction has removed 77,170 kilograms $(170,130$ pounds) of carbon tetrachloride from the vadose zone.

\section{Rem edial Investigation/Feasibility Studies in the 200 Areas}

\section{B. H. Ford and M. E. Todd}

Remedial investigation/feasibility studies continued in 2001 at soil waste sites in the 200 Areas. Work was performed within the characterization and regulatory framework defined in the 200 Areas Remedial Investigation/Feasibility Study Implementation Plan (DOE/ RL-98-28). Work was performed at several operable units, which were at various stages of the CERCLA process for remedial investigation/feasibility study. Summary descriptions of activities performed in 2001 are provided below.

200-CW-1 Operable Unit. The 200-CW-1 Operable Unit consists of former ponds and ditches located within the 200-East Area and north and east of the 200-East Area. These sites received mostly cooling water from facilities such as the Plutonium-Uranium Extraction Plant and B Plant. A remedial investigation report was prepared and conditionally approved by the regulators pending some additional ecological work for the 200 Areas (DOE/RL-2000-35). This remedial investigation report evaluated the results of the fieldwork (i.e., the remedial investigation) performed the previous year. The report analyzed soil contaminant data collected from 27 test pits, 2 boreholes, and 191 soil samples from 4 waste sites (216-A-25 pond, 216-B-2-2 ditch, 216-B-3-3 ditch, and 216-B-3 pond) as reported in BHI-01367. The feasibility study for the operable unit began in 2001. Regulatory comments on the remedial investigation report required a delay in the feasibility study pending preparation of a 200 Area ecological evaluation report and a data quality assessment process to determine the need for additional data to support the ecological assessment of the operable unit. In addition, work on the Central Plateau risk assessment framework resulted in a delay to the feasibility study while exposure scenarios were negotiated and evaluated for the plateau. The feasibility study will re-start in 2002 and will incorporate information from both the ecological evaluation and the risk framework project.

200-CS-1 Operable Unit. The 200-CS-1 Operable Unit consists of waste sites that received chemical sewer wastewater from major plant facilities in both the 200-West and 200-East Areas. A remedial investigation/ feasibility study work plan was approved in 2000 that defines planned remedial investigation activities at four representative waste sites: $216-\mathrm{S}-10$ pond, 216-S-10 ditch, 216-B-63 trench, and 216-A-29 ditch (DOE/ RL-99-44). The work conducted in 2001 included test pit characterization at the 216-A-29 ditch. The installation of vadose zone boreholes, geophysical logging, and completion of the remaining test pits will be conducted in 2003.

200-LW-1 Operable Unit. The waste sites in this operable unit received two types of waste: liquid waste from 300 Area process laboratories that supported radiochemistry metallurgical experiments and liquid waste resulting mainly from 200 Area laboratories that supported the major chemical processing facilities and equipment decontamination from $\mathrm{T}$ Plant. The draft work plan (DOE/RL-2001-66) was prepared and submitted for regulatory review. The work plan proposed remedial investigation at four representative waste sites (216-T-28 crib, 216-B-58 trench, 216-S-20 crib, and 216-Z-7 crib) and included borehole drilling, soil sampling, and geophysical logging.

200-MW-1 Operable Unit. The waste sites in this operable unit consist mainly of crib, French drain, and trench waste sites that received moderate-to-low volume equipment, decontamination, and ventilation system waste, plus small-volume waste streams commonly disposed to French drains. The draft work plan (DOE/RL-2001-65) was prepared and submitted for regulator review. The work plan proposes remedial investigation at five representative waste sites (216-A-4 crib, 216-T-33 crib, 216-T-13 trench, 216-U-3 French 
drain, and 200-E-4 French drain). The work includes installing vadose zone boreholes and test pits to collect soil samples and conducting geophysical logging at the boreholes.

200-PW-2 Operable Unit. Waste sites in this operable unit received uranium-rich condensate/process waste, primarily from waste streams generated at U Plant, Reduction-Oxidation Plant, and PlutoniumUranium Extraction Plant, as well as B Plant and semiworks facilities. The draft work plan (DOE/RL-2000-60) was prepared and submitted for regulator review. The work plan proposes remedial investigation activities at four representative waste sites (216-A-19 trench, 216-B-12 crib, 216-A-10 crib, and 216-A-36B crib). The work includes installing vadose zone boreholes to collect soil samples, and conducting geophysical logging.

200-TW-1 and 200-TW-2 Operable Units. The 200-TW-1 Operable Unit consists of waste sites, mostly cribs and trenches, that received waste associated with uranium recovery activities at U Plant. The 200-TW-2 Operable Unit consists of waste sites, mostly cribs and trenches, that received waste from the decontamination processes at B Plant and T Plant. The work plan (DOE/ RL-2000-38) was prepared and approved by the regulators. The work plan proposes remedial investigation activities at three representative waste sites (216-T-26 crib in the 200-TW-1 Operable Unit, and the 216-B-7A crib and 216-B-38 trench in the 200-TW-2 Operable Unit). The field efforts for these two operable units were completed in 2001 and consisted of installation, soil sampling, and geophysical logging of three vadose zone boreholes (one each at the 216-T-26 crib, the 216-B-38 trench, and the 216-B-7A crib). In addition, five drive casings were installed and geophysically logged at the 216-B-38 trench. The drive casing data were used to determine the optimum location for the borehole at that waste site. Borehole summary reports were initiated for each operable unit and will be completed in 2002. Data from the laboratory analysis will be compiled into a remedial investigation report in 2002.

200-PW-1 Operable Unit. The 200-PW-1 Operable Unit contains waste sites that received significant quantities of both carbon tetrachloride and plutonium, as well as other contaminants associated with process waste, from the Plutonium Finishing Plant and Plutonium Reclamation Facility. A remedial investigation/ feasibility study work plan for this operable unit was submitted for regulatory review in 2001 (DOE/RL-2001-01). The work plan includes a strategy to reduce carbon tetrachloride levels. Remedial investigation is expected to focus on two representative waste sites including the 216-Z-1A tile field and the 216-Z-9 trench and on potential carbon tetrachloride waste sites and associated pipelines.
200-BP-1 Prototype Hanford Barrier Performance Monitoring. Performance monitoring of the Prototype Hanford Barrier continued in 2001. Activities included water balance monitoring, stability surveys, and biotic surveys. An annual letter report will be prepared in 2002 to document the monitoring results.

\subsubsection{System Assessment Capability Focus Area}

\section{B. W. Bryce}

The first assessment using the System Assessment Capability was completed. The System Assessment Capability is a suite of computer models and analysis techniques that is used to predict the movement and fate of contaminants that will remain on the Hanford Site after closure. It also is used to estimate the effects of those contaminants to human health, the environment, the Columbia River, and the local economy and cultures. The System Assessment Capability is envisioned as a tool to assess the merits of remediation, isolation, and containment alternatives for specific areas of the Hanford Site. Refer to Sections 6.3.3 and 7.4.2 for more information on the System Assessment Capability.

\subsubsection{Integration of Information, Technical Review, and Public Involvement Focus Areas}

\author{
M. N. Jarayssi and E. A. Jenkins
}

As part of the Integration Project's mission to integrate and provide information Hanford staff can use in their work, a Virtual Library was issued as a user-friendly means for reviewing and using site environmental data. Additional data sources will be incorporated into the Virtual Library during the coming year.

Another integration effort the project began in 2001 was the Central Plateau Risk Framework Guidance. This effort is aimed at establishing a set of short- and long-term risk parameters, such as site future uses and geographic buffer zones, that will be used consistently to make cleanup and closure decisions by all programs operating on Hanford's Central Plateau.

Technical review and public involvement remained key to the Integration Project's success in the past year. The expert panel, which provides oversight and review of the project, continued to give the effort high marks for its work. Staff met regularly with interested individuals, organizations, and Tribal Nations to obtain feedback about the project. These activities range from monthly 
public meetings to opportunities to learn about the project via the environmental restoration contractor Internet site (http://www.erc.rl.gov).

\subsubsection{Vadose Zone Characterization in the Vicinity of 200 Areas Waste Sites}

\section{R. G. McCain and P. D. Henwood}

In fiscal year 2001, the methods developed for vadose zone baseline characterization around the singleshell tanks was extended to liquid waste disposal sites and burial grounds in the 200 Areas. The DOE Grand Junction Office developed two logging systems to detect and identify manmade gamma-emitting radionuclides in the vadose zone. The Spectral Gamma Logging System uses a high-purity germanium semiconductor detector with a relative efficiency of $\sim 35 \%$. This detector is capable of quantifying gamma-emitting radionuclides from background levels to several thousand picocuries per gram. A second system, the high-rate logging system, was specifically developed for use in zones of high gamma flux. With supplemental shielding, this system is capable of measuring radionuclide levels up to several hundred million picocuries per gram (cesium-137). In June 2001, these logging systems were deployed in existing boreholes within and adjacent to waste disposal sites in the 200 Areas. In addition, new groundwater monitoring wells and new boreholes associated with ongoing waste site investigations were logged.

Approximately 860 boreholes have been identified in the vicinity of waste sites. It is intended that all available boreholes will be logged as part of the baseline vadose zone characterization project. Prioritization of individual boreholes is based on data needs of Hanford remedial investigation or remediation projects as well as published estimates of waste discharges.

Existing boreholes in the 200 Areas have been evaluated in terms of proximity to waste sites, waste site disposal history, waste site location, and relevance to near-term characterization efforts in the ongoing remedial investigation/feasibility study process. This forms the basis for initial project scheduling. This schedule will be periodically updated to fulfill the needs of ongoing site characterization activities as necessary and to support the installation of new groundwater monitoring wells.

The log data will provide a comprehensive baseline of existing subsurface contamination conditions to support waste site characterization activities. The logs also provide input to subsurface transport and risk assessment models implemented under the System Assessment Capability. Finally, a comprehensive and consistent baseline data set constitutes a benchmark against which future measurements can be compared to track gammaemitting radionuclides in the vadose zone. Section 7.1 of this report provides additional information on vadose zone characterization.

\subsubsection{Science and Technology Focus Area}

\section{D. Freshley}

The Integration Project's Science and Technology efforts focus on providing new knowledge, data, and tools to enable the cleanup and stewardship mission at the Hanford Site. In addition to promoting new technologies and methods to solve Hanford's soil and groundwater cleanup problems, Science and Technology seeks to improve the scientific basis for decisions on actions taken by DOE to protect the Columbia River and its ecological systems, while preparing the Hanford Site for the future. The activities of the Science and Technology Focus Area are funded by the Integration Project, by the DOE Environmental Management Science Program, and by the DOE Office of Science and Technology.

During 2001, the Integration Project Science and Technology Focus Area completed the following:

Soil Inventory. The soil inventory team delivered estimates of contaminant inventories at individual waste disposal locations to the System Assessment Capability for use in their Rev. 0 assessment. A report was published on development and application of the Soil Inventory Model and its application to soil waste sites on the Central Plateau (BHI-01496). The Soil Inventory Model was applied to generate inventory estimates for 46 radionuclides and 27 chemicals at 88 liquid-waste disposal sites.

S-SX Tank Farm Investigation. Laboratory and modeling studies were completed for the S-SX field investigation. These studies, performed by the Integration Project Science and Technology Focus Area and Environmental Management Science Program, addressed a number of scientific issues associated with the composition of tank wastes that leaked to the vadose zone, the chemical species present in the vadose zone associated with the tank wastes, movement of water and contaminants through the vadose zone, and the geochemical behavior of cesium-137, chromium, and technetium-99. The results of these investigations were 
summarized in an appendix of the S-SX Field Investigation Report prepared by the River Protection Project for the DOE Office of River Protection (RPP-7884).

Vadose Zone Transport Field Study. This study involved completion of a field experiment that called for the injection of a high-salt solution (sodium thiosulfate) into the vadose zone to emulate the behavior of tank waste. Field data on the movement of this solution were collected using various geophysical methods and neutron probes, and by collecting core samples and evaluating tracer movements. The solution spread laterally, and moved downward more deeply into the vadose zone that did a dilute solution injected during earlier field experiments in 2000. The new field data provide refined estimates for transport parameters determined from actual field observations. These results were compared with results obtained from laboratory-scale experiments, to better understand how to apply the results of laboratory experiments to real-life scenarios in the field. The results are summarized in PNNL-13679. Section 7.3.2 of this report also provides a discussion of this study.

Groundwater/River Interface. Conceptual models were completed for the groundwater/river interface at the 100-D, 100-K, and 100-H Areas. The conceptual models included descriptions of the groundwater flow and contaminant distributions in the near-river groundwater. A numerical model demonstrating water and contaminant particle movement was developed for the 100-H Area and the model was used to evaluate dilution factors for future revisions of the System Assessment Capability. The results are summarized in a report (PNNL-13674).
Biological Fate and Transport. Laboratory experiments for the uptake of technetium-99 by rainbow trout through the water pathway were completed. The results will be used to develop risk assessment parameters needed for sitewide and site-specific risk assessments at the Hanford Site.

National Academy of Sciences Review. The National Academy of Sciences/National Research Council Committee on Environmental Remediation Science and Technology at the Hanford Site completed its 18-month review of the Integration Project Science and Technology Focus Area. The results of their review were presented on August 1, 2001, to DOE Environmental Management, who commissioned the review. The committee concluded there is a long-term and continuing need for the Science and Technology Focus Area to support cleanup and stewardship of the Hanford Site. The committee also noted that given the technical and organizational complexity of the task, the Integration Project has made a good start in creating a science and technology roadmap, defining and initiating a science and technology program, and fulfilling the promise of its mission (National Research Council 2001). They recommended increased documentation of science and technology projects, prioritization of research activities, and effective use of peer review. Additionally, they made recommendations for reprioritization of work as well as several specific technical recommendations.

\subsubsection{Research and Technology Development}

\section{T. M. Brouns}

The Tanks Focus Area was created in 1994 by DOE's Office of Environmental Management to integrate radioactive tank waste remediation efforts across the DOE complex. In support of the DOE Office of River Protection, the Tanks Focus Area addressed a number of high priority issues in 2001 that are discussed in the following sections.

\subsubsection{Corrosion Control}

Because of the time and cost involved with baseline corrosion control methods, the Tanks Focus Area and contractors at the Hanford Site established a program to develop electrochemical noise-based corrosion monitoring systems for the Hanford double-shell tanks. The corrosion monitoring system, like most electrochemical noise-based systems, measures fluctuations in current and voltage on carbon-steel electrodes immersed in the tank waste. Different forms of corrosion create different patterns in current and voltage; by monitoring the fluctuations in current and voltage on each channel, the active form of corrosion can be established. Four systems, designed and fabricated by Hiline Engineering in Richland, Washington, have been installed under this program since 1997. The most recent installation occurred on January 3, 2001, with deployment of a probe in double-shell tank AN-104. In addition to eight channels of corrosion monitoring electrodes on the probe, the AN-104 system is also fitted with an array of 22 thermocouples, a movable verification thermocouple, a tank waste high-surface level detector, ports for pressure/gas sampling, a set of strain gauges, and an integrated water 
lance (a high-pressure water nozzle used to cut a path through the waste) to facilitate rapid installation. These features add a great deal of functionality to the probe, could provide for a better understanding of the relationship between corrosion and other tank operating parameters, and optimize the use of the riser that houses the probe in the tank.

\subsubsection{Remote Pit Operation Enhancements at Hanford}

To reduce worker exposure and enable more thorough removal of discarded materials in valve pits throughout Hanford's tank farms, the Tanks Focus Area worked with site users to develop functions and requirements for the "Pit Viper," a remote pit-operations system. In 2001, Pacific Northwest National Laboratory issued awards for the various Pit Viper components. The backhoe, which serves as the deployment platform and provides gross positioning capability, was purchased from FERMEC. The manipulator arm, which performs the more dexterous movements within the pit area, was purchased from Cybernetix of Marseilles, France. A previously developed remote control console was modified for use with the Pit Viper components.

During the summer of 2001, assembly and cold testing of the system components took place at the Hazardous Materials Management and Emergency Response Facility (also known as the HAMMER Training and Education Center). Following a safety review and numerous demonstrations for site users and other interested parties, the system was moved to the $\mathrm{C}$ tank farm and deployed in the heel pit of tank C-104 in December 2001. The system successfully performed various pit cleanup, repair and maintenance tasks during the 3-day deployment.

\subsubsection{Double Salt Experiments}

Double salts are chemical compounds made up of multiple anions or cations. Historically, Hanford tank characterization data provided scant evidence of double salts, and commercial chemistry models used to predict solid formation scenarios during waste transfer did not adequately predict their formation. The high ionic strength of Hanford Site tank waste solutions can lead to uncertainties in equilibrium calculations for transporting dissolved saltcake. As new discoveries of double salts in Hanford tank waste are uncovered, the model database to predict waste transfer behaviors requires updating. A series of calculations was performed on concentrated sodium nitrate to compare experimental results with predictions made by the Environmental Simulation Program for actual Hanford saltcake dissolution in an effort to improve the Environmental Simulation Program database. Approximately 180 double-salt samples were prepared in 2000 to conduct aging experiments. In 2001, experiments to determine the effectiveness of the saltcake dissolution process with double salts and at higher operating temperatures were conducted. Data from this effort will be used to expand the Environmental Simulation Program model to include information on critical double salts found in Hanford waste.

\subsubsection{High-Level Waste Melter Review}

At the request of DOE Headquarters, in 2001 the Tanks Focus Area coordinated a technical review of alternatives for solidification of Hanford Site high-level waste that could achieve major cost reductions within reasonable long-term risks. The review method consisted of an in-depth data collection and analysis effort conducted by a study team. The study included information on Hanford Site waste; identification of improvements in waste loading, waste processing, and waste forms; waste forms produced through a melting process; waste canister packaging modifications that relate to increasing the waste form volume in repository waste form packages; and an assessment of melter technologies. The results of the study team analyses were documented in a detailed report (PNNL-13582), which was then reviewed by a panel of independent technical experts. Based on their review, the technical experts recommended a research and development program for future melter advancements.

Their principal conclusions and recommendations included the following: (1) no waste forms were found to be better than the current borosilicate glass form; (2) modest research should be conducted on other silicates and iron-phosphate glasses; (3) no melters were found better than the current Joule-heated ceramic melter technology; (4) substantial improvements are needed in the current melter technology to achieve higher waste loading, a higher and more predictable processing rate, and lower disposal costs; (5) a short but intense research effort should be conducted on the advanced cold crucible melter to determine the potential for replacing the current technology; and (6) the biggest challenge in containing cost is the development of a total system plan. The review team cautioned that in developing the system plan, concentrating on one segment of the system could unbalance the overall system and eliminate the potential for cost savings. 
Although the review team's findings included recommendations for improvements in vitrification operations and melter technology, it also reinforced the baseline highlevel waste treatment path using Joule-heated melters.

\subsubsection{Salt Waste Retrieval Methods}

In compliance with the Tri-Party Agreement (Ecology et al. 1998), saltcake waste must be removed from Hanford single-shell tank S-102 by fiscal year 2006. In an effort to determine a method that does not increase liquid waste volume during retrieval, in 2001 the Tanks Focus Area supported investigations into two potential low-water retrieval technologies. One is the Dual Nozzle Pulsating Mixer Pump, a collaboration with the DOE Office of Defense Nuclear Nonproliferation and experts from the Mining Chemical Combine Facility in Zheleznogorsk, Russia. Adapted from the original single-nozzle design, the Dual Nozzle Pulsating Mixer Pump contains a second nozzle located at a higher elevation for spraying a jet of water (with a projected cleaning radius of between 6 to 13 meters [19.5 to 42.5 feet]) at tank residuals near the tank's edge in order to wash the solids toward the retrieval pump. After cold testing, the system will undergo testing in radioactive plutonium-uranium extraction waste in two sizes of tanks.

The other retrieval method is a fluidic-based pulsejet system developed by AEA Technology of the United Kingdom. In August 2001, full-scale-system testing was completed at the vendor's U.S. facility in Charlotte, North Carolina. The testing provided the basis to determine how much - or how little - water is needed for retrieval operations using the fluidic system. Hanford Site users will evaluate each technology's development and testing efforts in determining a preferred retrieval method for tank S-102.

\subsubsection{Tank Integrity Inspection Techniques}

To maintain safe storage of radioactive waste in Hanford's 28 double-shell tanks, the knuckle area (i.e., the curved "corners" near the bottom of the tank where the wall meets the floor) of each primary tank must be inspected for integrity - not an easy task considering this area is inaccessible using conventional measurement techniques. In 2001, the Tanks Focus Area helped make adaptations to a crawler-based, ultrasonic Synthetic Aperture Focusing Technique to assess tank integrity using remotely operated nondestructive examination equipment. In September 2001, a report (PNNL-13682) was issued describing the functions, requirements, development, and procurement strategy of the double-shell tank knuckle region ultrasonic scanning system. The system also includes an adapted off-the-shelf crawler, which serves as a delivery vehicle for the system. As part of the development effort, the Center for Nondestructive Evaluation at Iowa State University joined the Synthetic Aperture Focusing Technique Team to help them understand sound propagation of the knuckle region of these tanks. The Center for Nondestructive Evaluation provided the team with a computational algorithm to perform experimental flaw manipulation without having to fabricate a large number of flawed samples. Following a peer review of the development effort and subsequent successful cold testing, the system is ready for deployment. It will provide the ability to provide long-term measurements of the entire knuckle region - where areas of mechanical stress are concentrated - and a portion of the tank floor to accurately size in length and depth any cracks found.

\subsubsection{Topographical Mapping System}

In a collaborative effort that began a decade ago, the Tanks Focus Area sponsored development of a Topographical Mapping System, a tool capable of gathering and analyzing topographical data on obstacles and tank waste topography, and generating a three-dimensional computer map of the data. The system will help waste retrieval planning and assessment and will provide a measure of retrieval performance. It also will furnish data on residual tank-waste volumes, which will be helpful when planning tank closures. In 2001, testing and demonstration work on Topographical Mapping System started anew to update the system in support of deployment in tank U-107 to measure the waste surface profile and estimate the volume before and after a "sprinkler/salt well" retrieval test. The system uses a structured light technique that projects a laser plane onto the surface to be mapped. A camera is then used to image the resulting laser plane's contour line and, using a triangulation-based analytical method, generates a surface profile from the data gathered. In 2001, the system underwent computer upgrades and measurement accuracy testing, followed by acceptance testing. In September 2001, the Topographical Mapping System was installed in single-shell tank U-107. Site users will evaluate the performance of the Topographical Mapping System and, if acceptable, will recommend the system for deployment in Hanford Site tank S-112 before, during, and after retrieval of the tank waste. 


\subsubsection{Tanks Cold Test Facility}

To adequately prepare for deployment of various retrieval technologies in Hanford's single-shell tanks, and eventual testing of waste mixing and mobilization technologies for Hanford's double-shell tanks, cold testing of the retrieval equipment is needed, as well as a facility in which to develop and cold test the equipment. In 2001, the Tanks Focus Area assisted the River Protection Project with the development of facility requirements by calling on retrieval equipment cold testing experts from across the DOE complex. The 4-hectare (10-acre) Cold Test Facility, to be located near Hanford's Hazardous Materials Management Emergency Response training facility (also known as the HAMMER facility), will be used for testing, equipment acceptance, and training to support a broad range of River Protection Project retrieval activities in a non-radioactive, simulated environment. The facility will include (1) a mock waste tank made of steel that is 23 meters (75 feet) in diameter with an open top capable of staging up to 2.3 million liters $(600,000$ gallons) of simulated waste that will include sand, clay, soluble salts, and liquids containing sodium nitrate (materials similar to sludge, saltcake, and supernatant liquid, the three basic types of Hanford tank waste); and (2) a superstructure spanning this tank, with platforms at $\sim 11$ and 17 meters ( 35 and 55 feet) above the tank bottom to simulate the heights of Hanford's older single-shell tanks and newer doubleshell tanks. Initial activities at the facility will focus on equipment testing, operator training, and retrieval demonstrations of Tanks Focus Area-sponsored retrieval technologies planned for use in tanks C-104, S-102, and S-112. Construction of the facility began in fall 2001, with equipment development and testing scheduled for summer 2002.

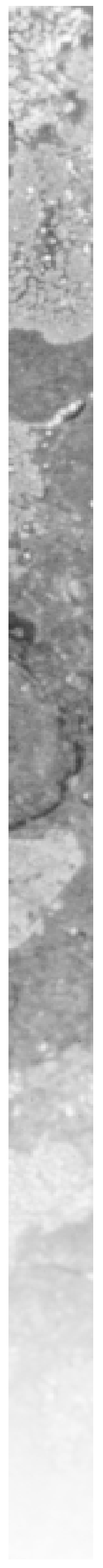




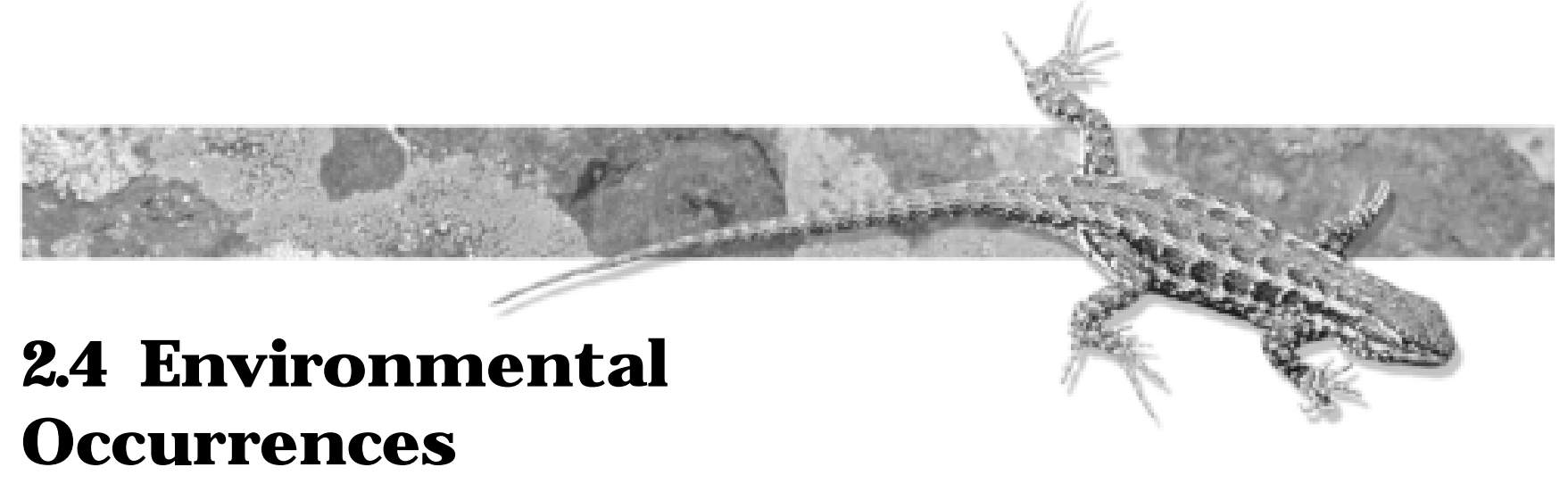

B. G . F ritz

Onsite and offsite environmental releases of radioactive and regulated materials are reported to DOE and other federal and state agencies as required by law. The specific agencies notified depend on the type, amount, and location of the individual occurrence. In some cases, an occurrence may be under continuing observation and evaluation. All emergency, unusual, and off-normal occurrences at the Hanford Site are reported to the Hanford Site Occurrence Notification Center. This center is responsible for maintaining both a computer database and a hardcopy file of event descriptions and corrective actions. Copies of occurrence reports are made available for public review in DOE's Public Reading Room located in Richland, Washington. The following sections summarize some of the unusual and off-normal environmental occurrences not discussed in Sections 2.1 through 2.3 or that were not discussed in detail. For each occurrence, the title and report number from the Hanford Site Occurrence Notification Center is given in the heading.

\subsection{Em ergency Occurrences}

Emergency occurrences are defined in DOE Order $232.1 \mathrm{~A}$ as "the most serious occurrences and require an increased alert status for onsite personnel and, in specific cases, for offsite authorities." There were no environmentally significant emergency occurrence reports filed during 2001.

\subsubsection{Unusual Occurrences}

Unusual occurrences are defined as "a non-emergency occurrence that exceeds the off-normal occurrence threshold criteria, is related to safety, environment, health, security or operations" by DOE Order 232.1A. There was one environmentally significant unusual occurrence report filed in 2001.

- PCB release at the 600-23 Remediation Site (RL-BHI-REMACT-2001-0007)

On May 10, 2001, a subcontractor was involved in excavation activities at the 600-23 burial site. The 600-23 burial site is located north of the Wye Barricade on Route 2 South, near mile marker six, on the east side of the road. The site was used to dispose of non-radioactive construction debris and drums. At 1500 hours on May 10, 2001, the subcontractor unearthed an unknown piece of equipment. The equipment had an engine with a liquid reservoir. Approximately 38 liters (10 gallons) of an oily substance leaked from this reservoir to the ground. The equipment was placed on a plastic tarp within a bermed area. The contaminated soil was excavated and placed into containers. Laboratory analysis of the contaminated soil revealed the presence of polychlorinated biphenyls in the spilled substance. It was estimated that $\sim 1.2$ kilograms ( 2.6 pounds) of polychlorinated biphenyls were released to the soil. This exceeded the CERCLA reportable quantity. The spill was entirely contained and the equipment and contaminated soil were disposed of at the Environmental Restoration Disposal Facility. 


\subsubsection{Off-Normal Occurrences}

The DOE order describes off-normal occurrences as "abnormal or unplanned events or conditions that adversely affect, potentially affect, or are indicative of depredation in the safety, safeguards and security, environmental or health protection, performance or operation of a facility." Four off-normal occurrences with environmental impacts not discussed in other sections are outlined here.

\section{- Brush Fire (RL-PHMC-FSS-2001-0009)}

On Thursday, August 16, 2001, a spark ignited grass and sagebrush at a remote jobsite in the 600 Area. The spark was generated by a metal-cutting chop saw at $\sim 1300$ hours. Employees at the scene expended two portable fire extinguishers in an attempt to control the fire. This proved ineffective, and the Hanford Fire Department was called to the scene. At $\sim 1512$ hours, the fire was contained. The resulting damage was between 0.8 to $1.6 \mathrm{hec}$ tares ( 2 to 4 acres) of burned grass and sagebrush.

- Oil in Well 699-43-2 (RL-BHI-GROUNDWTR2001-0001)

Well 699-43-2 is located just south of the Hanford town site. On February 8, 2001, a field inspection team was collecting data on the water level and depth of the well using an electronic water-sensing tape (e-tape). After removing the e-tape from the well, members of the inspection team noticed an oily aroma, and an oily substance on their hands, gloves, and the e-tape. Rags used to clean the e-tape were placed in plastic bags for later disposal. Laboratory analysis of the oily substance identified it as a light diesel hydrocarbon determined to be ignitable. The waste generated by sampling of the well was determined to be unregulated and was disposed of accordingly. The well was locked and secured, and it was identified in the Waste Information Data System.

- Employees suffer respiratory irritation as a result of severe winds and resulting dust (RP-CHGTANKFARM-2001-0020)

On March 22, 2001, five employees from a 200-West Area tank farm reported to the Hanford Environmental Health Foundation with various respiratory complaints. All five employees were diagnosed with upper airway irritation and complications. Hanford Environmental Health Foundation doctors determined the cause to be exposure to dusty conditions on March 19, 2001. All five employees had preexisting conditions of asthma and/or allergies.

- 200-West Area unscheduled shutdown due to wind speed and blowing dust (RP-CHG-TANKFARM2001-0027)

At 1415 hours on April 30, 2001, all non-essential activities in the 200-West Area were suspended by the shift manager. Sustained winds of $11 \mathrm{~m} / \mathrm{s}$ (25 mph) and wind blown dust triggered the suspension of operations. At 1515 hours, all nonessential employees were instructed to go home. 


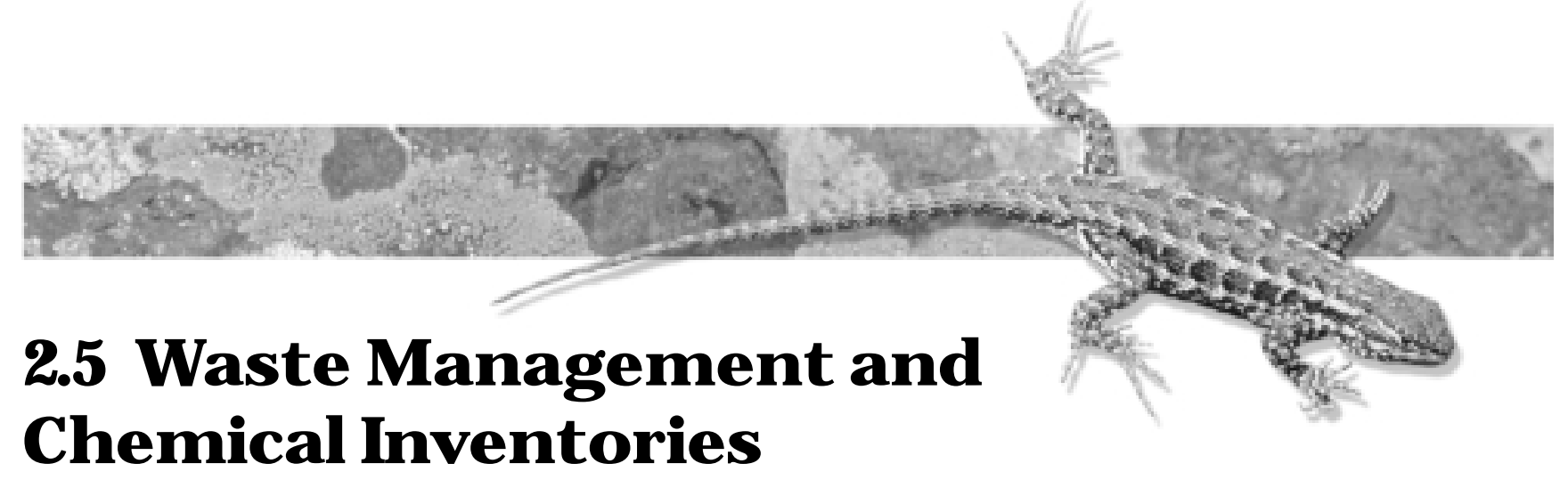

\author{
L. P. Diediker and D. L. Dyekman
}

\subsubsection{Waste Management}

Waste produced from Hanford Site cleanup operations is classified as either radioactive, non-radioactive, mixed, or hazardous. Radioactive waste is categorized as transuranic, high-level, and low-level. Mixed waste has both radioactive and hazardous non-radioactive substances. Hazardous waste contains either dangerous waste or extremely hazardous waste or both, as defined in WAC 173-303. Hanford's hazardous waste is managed in accordance with WAC 173-303.

Radioactive and mixed waste is currently handled in several ways. High-level waste is stored in underground single- and double-shell tanks. The method used to manage low-level waste depends on the source, composition, and concentration of the waste. Low-level waste is stored in either the tank system, on storage pads, or is buried. Transuranic waste is stored in vaults or on underground and aboveground storage pads from which it can be retrieved.

An annual report lists the dangerous waste generated, treated, stored, and disposed of onsite and offsite (DOE/RL-2002-06). Dangerous waste is treated, stored, and prepared for disposal at several Hanford Site facilities. Dangerous waste generated at the site also is shipped offsite for disposal, destruction, or recycling.

Non-dangerous waste generated at the Hanford Site historically has been buried near the 200 Areas Solid Waste Landfill. Beginning in 1999, non-dangerous waste has been disposed at the Roosevelt Regional landfill near Goldendale, Washington, through a contract with Basin Disposal, Inc. Since 1996, medical waste has been shipped to Waste Management of Kennewick. Asbestos has been shipped to Basin Disposal, Inc. in Pasco and the onsite Environmental Restoration
Disposal Facility. Since 1996, non-regulated drummed waste has been shipped to Waste Management of Kennewick.

Non-dangerous waste originates at a number of areas across the site. Examples include construction debris, office trash, cafeteria waste, and packaging materials. Other materials and items classified as non-dangerous waste are solidified filter backwash and sludge from the treatment of river water, failed and broken equipment and tools, air filters, uncontaminated used gloves and other clothing, and certain chemical precipitates such as oxalates. Non-hazardous demolition waste from 100 Areas decommissioning projects is buried in situ or in designated sites in the 100 Areas.

Annual reports document the quantities and types of solid waste generated onsite, received, shipped offsite, and disposed of at the Hanford Site (HNF-EP-0125-14). The solid waste program is regulated by the Resource Conservation and Recovery Act and Toxic Substances Control Act discussed in Section 2.2. Solid waste generated onsite or received from offsite and disposed of at the Hanford Site from 1996 through 2001 is listed in Tables 2.5.1 and 2.5.2. Quantities of hazardous waste shipped offsite from 1996 through 2001 are shown in Table 2.5.3. Table 2.5.4 provides a detailed summary of the radioactive solid waste stored or disposed of in 2001.

The liquid waste generated in 2001 and stored in underground storage tanks is included in the annual dangerous waste report (DOE/RL-2002-06). Table 2.5.5 is a summary of the liquid waste generated from 1996 through 2001, which is stored in underground storage tanks. 


\begin{tabular}{|c|c|c|c|c|c|c|}
\hline \multirow[b]{2}{*}{ Waste Categor } & \multicolumn{5}{|c|}{ Table 2.5.1. Q uantities of Solid Waste ${ }^{(\mathrm{a})}$ Generated on the Hanford Site, kg (lb) } & \multirow[b]{2}{*}{$\underline{2001}$} \\
\hline & $\underline{1996}$ & $\underline{1997}$ & $\underline{1998}$ & $\underline{1999}$ & $\underline{2000}$ & \\
\hline Mixed & $\begin{array}{c}199,000 \\
(439,000)\end{array}$ & $\begin{array}{c}442,000 \\
(975,000)\end{array}$ & $\begin{array}{c}509,000 \\
(1,120,000)\end{array}$ & $\begin{array}{c}421,000 \\
(928,000)\end{array}$ & $\begin{array}{c}441,000 \\
(973,000)\end{array}$ & $\begin{array}{c}328,500 \\
(724,300)\end{array}$ \\
\hline Radioactive & $\begin{array}{c}3,870,000 \\
(8,530,000)\end{array}$ & $\begin{array}{c}6,590,000 \\
(14,500,000)\end{array}$ & $\begin{array}{c}1,470,000 \\
(3,240,000)\end{array}$ & $\begin{array}{c}957,000 \\
(2,110,000)\end{array}$ & $\begin{array}{c}700,000 \\
(1,544,000)\end{array}$ & $\begin{array}{c}1,675,200 \\
(3,693,800)\end{array}$ \\
\hline
\end{tabular}

\begin{tabular}{|c|c|c|c|c|c|c|}
\hline & Table 2.5.2. & antities of So & d Waste ${ }^{(a)}$ Rec & ed from 0 ffsi & kg (lb) & \\
\hline Waste Category & 1996 & 1997 & 1998 & 1999 & 2000 & 2001 \\
\hline Mixed & $\begin{array}{c}2,070 \\
(4,560)\end{array}$ & $\begin{array}{c}3,560 \\
(7,850)\end{array}$ & $\begin{array}{c}267 \\
(589)\end{array}$ & $\begin{array}{c}1,306 \\
(2,880)\end{array}$ & $\begin{array}{c}1,381 \\
(3,045)\end{array}$ & $\begin{array}{c}127,000 \\
(280,000)\end{array}$ \\
\hline Radioactive & $\begin{array}{c}1,670,000 \\
(3,680,000)\end{array}$ & $\begin{array}{c}1,430,000 \\
(3,150,000)\end{array}$ & $\begin{array}{c}2,870,000 \\
(6,330,000)\end{array}$ & $\begin{array}{c}2,325,700 \\
(5,128,000)\end{array}$ & $\begin{array}{c}6,958,000 \\
(15,343,000)\end{array}$ & $\begin{array}{r}4,736,500 \\
(10,444,000)\end{array}$ \\
\hline $\begin{array}{l}\text { (a) Solid waste i } \\
\text { compartmen }\end{array}$ & des containeri & liquid waste. & Solid waste qua & ies do not inc & le United State & Navy reactor \\
\hline
\end{tabular}

\begin{tabular}{|c|c|c|c|c|c|c|}
\hline \multirow[b]{2}{*}{ Waste Category } & \multicolumn{5}{|c|}{ Table 2.5.3. Q uantities of Hazardous Waste ${ }^{(a)}$ Shipped 0 ffsite, $k g$ (lb) } & \multirow[b]{2}{*}{$\underline{2001}$} \\
\hline & $\underline{1996}$ & $\underline{1997}$ & $\underline{1998}$ & $\underline{1999}$ & $\underline{2000}$ & \\
\hline \multirow[t]{2}{*}{ Containerized } & $\begin{array}{c}590,000 \\
(1,300,000)\end{array}$ & $\begin{array}{c}110,000 \\
(243,000)\end{array}$ & $\begin{array}{c}65,700 \\
(145,000)\end{array}$ & $\begin{array}{c}1,732,700^{(\mathrm{b})} \\
(3,820,600)\end{array}$ & $\begin{array}{l}33,200^{(\mathrm{b})} \\
(73,220)\end{array}$ & $\begin{array}{c}56,000^{(\mathrm{b})} \\
(124,000)\end{array}$ \\
\hline & & & & $\begin{array}{c}70,000^{(c)} \\
(154,000)\end{array}$ & $\begin{array}{c}315,500^{(c)} \\
(695,700)\end{array}$ & $\begin{array}{c}2,600^{(\mathrm{c})} \\
(5,800)\end{array}$ \\
\hline Bulk Solids & 0 & $\begin{array}{c}335,000 \\
(739,000)\end{array}$ & $\begin{array}{c}47,500 \\
(105,000)\end{array}$ & $\begin{array}{c}402,300^{(\mathrm{d})} \\
(887,000)\end{array}$ & 0 & 0 \\
\hline Bulk Liquids & $\begin{array}{c}98,800 \\
(218,000)\end{array}$ & $\begin{array}{c}5,025,000 \\
(11,100,000)\end{array}$ & $\begin{array}{c}41,800 \\
(92,200)\end{array}$ & 0 & 0 & 0 \\
\hline Total & $\begin{array}{c}689,000 \\
(1,520,000)\end{array}$ & $\begin{array}{c}5,470,000 \\
(12,100,000)\end{array}$ & $\begin{array}{c}155,000 \\
(342,000)\end{array}$ & $\begin{array}{c}2,205,000 \\
(4,862,000)\end{array}$ & $\begin{array}{c}348,700 \\
(768,883)\end{array}$ & $\begin{array}{c}59,000 \\
(130,000)\end{array}$ \\
\hline \multicolumn{7}{|c|}{$\begin{array}{l}\text { (b) Hazardous waste only. } \\
\text { (c) Mixed waste (radioactive and hazardous). } \\
\text { (d) Includes } 399,875 \mathrm{~kg}(882,000 \mathrm{lb}) \text { of material associat }\end{array}$} \\
\hline
\end{tabular}




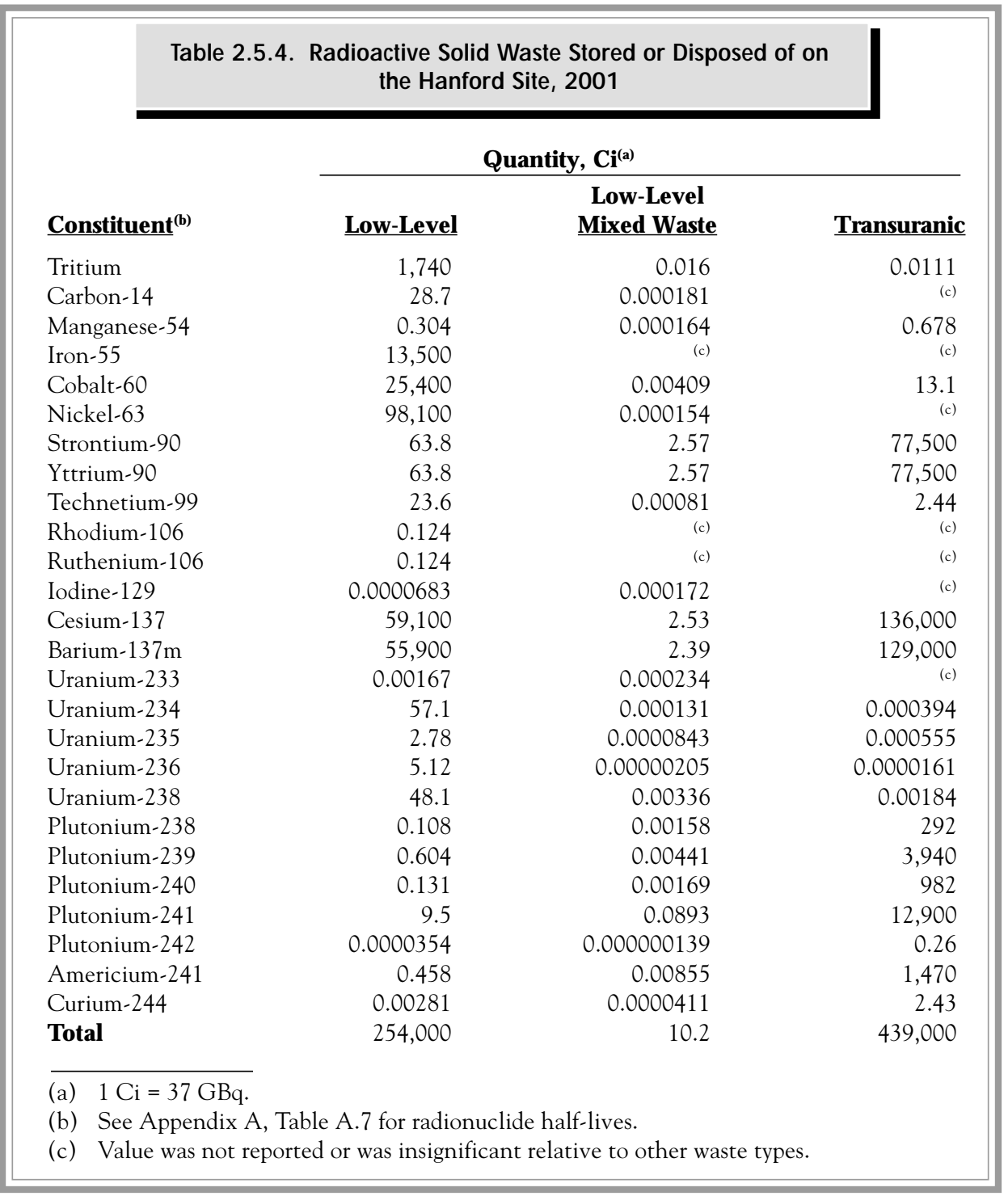

\subsubsection{Chemical Inventories}

Types, quantities, and locations of hazardous chemicals are tracked through prime contractor-specific chemical management system requirements (see Section 2.2.3), which include compliance activities associated with the Emergency Planning and Community Right-To-Know Act (see Section 2.2.5). The 2001
Hanford Site Tier Two Emergency and Hazardous Chemical Inventory (DOE/RL-2002-13) was issued in February 2002 in compliance with Section 312 of the act. Table 2.5.6 summarizes the information reported, listing the 10 hazardous chemicals stored in greatest quantity on the Hanford Site in 2001. 
Table 2.5.5. Q uantities of Liquid Waste(a) $G$ enerated and Stored within the Tank Farm System on the Hanford Site in Calendar Year 2001 and in each of the Previous 5 Calendar Years, L (gal)

$\begin{array}{lcccccc}\text { Type of Waste } & \underline{\mathbf{1 9 9 6}}^{(\mathbf{b})} & \underline{\mathbf{1 9 9 7}}^{(\mathbf{b}, \mathbf{c})} & \underline{\mathbf{1 9 9 8}}^{(\mathbf{b}, \mathbf{c})} & \underline{\mathbf{1 9 9 9}}^{(\mathbf{b}, \mathbf{c})} & \underline{\mathbf{2 0 0 0}}^{(\mathbf{b})} & \underline{\mathbf{2 0 0 1}}^{(\mathbf{b})} \\ \text { Volume of waste added } & 2,420,000 & 796,000 & 1,715,000 & 5,420,000 & 8,920,000 & 2,980,000 \\ \text { to double-shell tanks } & (639,000) & (210,000) & (453,000) & (1,432,000) & (2,357,000) & (788,000) \\ & 72,256,000 & 69,245,000 & 70,969,000 & 73,290,000 & 79,630,000 & 79,980,000 \\ \text { Total volume in double- } & (19,090,000) & (18,295,000) & (18,750,000) & (19,363,000) & (21,038,000) & (21,131,000) \\ \text { shell tanks (year end) } & 4,341,000 & 3,800,000 & 0 & 3,097,000 & 2,580,000 & 2,580,000 \\ \text { Volume evaporated at } & (1,147,000) & (1,004,000) & & (818,000) & (682,000) & (682,000) \\ \text { 242-A } & 630,000 & 244,000 & 859,000 & 2,930,000 & 2,250,000 & 590,000 \\ \text { Volume pumped from } & (166,000) & (64,000) & (227,000) & (774,100) & (595,000) & (155,000) \\ \text { single-shell tanks } & & & & & & \end{array}$

(a) Quantity of liquid waste is defined as liquid waste sent to double-shell underground storage tanks during these years. This does not include containerized waste (e.g., barreled) included in the solid waste category.

(b) Quantity of liquid waste is defined as shown by different categories on left-hand side of table during these years. This does not include containerized waste (e.g., barreled) included in the solid waste category.

(c) Quantity of liquid waste shown is corrected figure for these years.

(d) Volume does not include dilution or flush water.

\begin{tabular}{|c|c|}
\hline \multicolumn{2}{|c|}{$\begin{array}{l}\text { Table 2.5.6. Average Amount of Ten Hazardous } \\
\text { Chemicals Stored in G reatest } Q \text { uantity } \\
\text { on the Hanford Site, } 2001\end{array}$} \\
\hline H azardous Chemical & $\begin{array}{c}\text { A verage } \\
\text { Q uantity, kg (lb) }\end{array}$ \\
\hline Mineral oil & $1,800,000(3,900,000)$ \\
\hline Sodium & $1,000,000(2,300,000)$ \\
\hline Diesel fuel (Grades 1 and 2) & $2,800,000(6,200,000)$ \\
\hline Ethylene glycol & $250,000(540,000)$ \\
\hline Nitrogen & $73,000(160,000)$ \\
\hline Argon & $67,000(150,000)$ \\
\hline $\begin{array}{l}\text { Crystalline silica (quartz, } \\
\text { cristobalite, tridymite) }\end{array}$ & $65,000(140,000)$ \\
\hline Propane & $39,000(85,000)$ \\
\hline Sulfuric acid & $37,000(82,000)$ \\
\hline Carbon & $35,000(77,000)$ \\
\hline
\end{tabular}




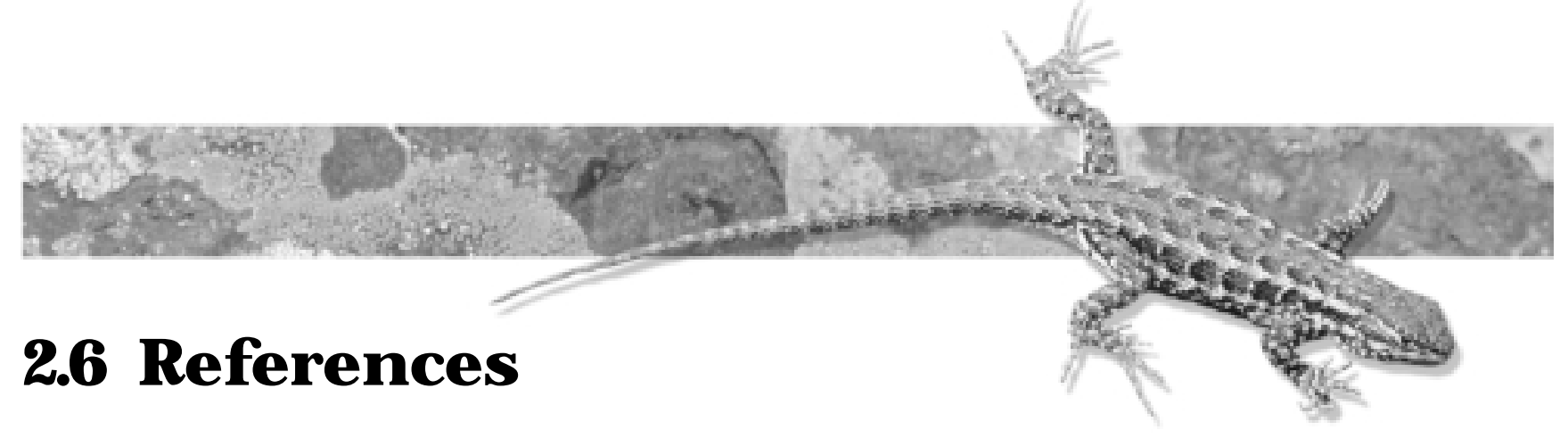

01-ORP-104. 2001. Office of River Protection (ORP) Semi-Annual Project Compliance Report for the Waste Treatment Plant February 1, 2001-July 31, 2001. U.S. Department of Energy, Office of River Protection, Richland, Washington.

01-TOD-T021. 2001. Status Report for Lower Knuckle Ultrasonic Testing Technology Development September 2001. U.S. Department of Energy, Office of River Protection, Richland, Washington.

01-TOD-T022. 2001. Results of Ultrasonic Testing of the Primary Tank Walls in 4 DSTS, Tanks 241-AW-101, AW-105, AY-101, and AN-102. U.S. Department of Energy, Office of River Protection, Richland, Washington.

10 CFR 1021. U.S. Department of Energy. "Compliance with the National Environmental Policy Act." Code of Federal Regulations.

29 CFR 1910.1200. U.S. Department of Labor. "Hazard Communication." Code of Federal Regulations.

40 CFR 61, Subpart H. U.S. Environmental Protection Agency. "National Emissions Standards for Emissions of Radionuclides Other Than Radon From Department of Energy Facilities." Code of Federal Regulations.

40 CFR 61, Subpart M. U.S. Environmental Protection Agency. "National Emission Standard for Asbestos." Code of Federal Regulations.

40 CFR 70. U.S. Environmental Protection Agency. "State Operating Permit Programs." Code of Federal Regulations.

40 CFR 82. U.S. Environmental Protection Agency. "Protection of Stratospheric Ozone." Code of Federal Regulations.

40 CFR 122. U.S. Environmental Protection Agency. "EPA Administered Permit Programs: The National Pollutant Discharge Elimination System." Code of Federal Regulations.

40 CFR 141. U.S. Environmental Protection Agency. "National Primary Drinking Water Regulations; Radionuclides; Proposed Rule." Code of Federal Regulations.
40 CFR 264. U.S. Environmental Protection Agency. "Standards for Owners and Operators of Hazardous Waste Treatment, Storage, and Disposal Facilities." Code of Federal Regulations.

40 CFR 265. U.S. Environmental Protection Agency. "Interim Status Standards for Owners and Operators of Hazardous Waste Treatment, Storage, and Disposal Facilities." Code of Federal Regulations.

40 CFR 300. U.S. Environmental Protection Agency. "National Oil and Hazardous Substances Pollution Contingency Plan." Code of Federal Regulations.

40 CFR 355. U.S. Environmental Protection Agency. "Emergency Planning and Notification." Code of Federal Regulations.

40 CFR 761. U.S. Environmental Protection Agency. "Polychlorinated Biphenyls (PCBs) Manufacturing, Processing, Distribution in Commerce, and Use Prohibitions." Code of Federal Regulations.

40 CFR 1500-1508. Council on Environmental Quality. "Regulations for Implementing the Procedural Provisions of the National Environmental Policy Act." Code of Federal Regulations.

43 CFR 10. U.S. Department of Interior. "Native American Graves Protection and Repatriation Act." Code of Federal Regulations.

43 CFR 11. U.S. Department of the Interior. "Natural Resource Damage Assessments." Code of Federal Regulations.

50 CFR 17.11. U.S. Department of the Interior. "Endangered and Threatened Wildlife." Code of Federal Regulations.

36 FR 8921. May 13, 1971. Executive Order 11593, "Protection and Enhancement of the Cultural Environment." Federal Register.

61 FR 36352. U.S. Department of Energy. "Record of Decision for Plutonium Finishing Plant Stabilization Final Environmental Impact Statement, Hanford Site, Richland, Washington." Federal Register. 
65 FR 24595. Executive Order 13148. “Greening the Government Through Leadership in Environmental Management." Federal Register.

65 FR 37253. 2000. "Establishment of the Hanford Reach National Monument." Proclamation 7319 of June 9, 2000, by the President of the United States of America. Federal Register.

66 FR 7877. U.S. Department of Energy. "Programmatic Environmental Impact Statement for Accomplishing Expanded Civilian Nuclear Energy Research and Development and Isotope Production Missions in the United States, Including the Role of the Fast Flux Test Facility." Federal Register.

Antiquities Act of 1906. 1906. 34 Stat. 225, 16 USC 431-433.

American Indian Religious Freedom Act. 1978. Public Law 95-341, as amended, 42 USC 1996, 1996 note.

Archaeological and Historic Preservation Act. 1974. Public Law 93-291, as amended, 16 USC 469-469c-1.

Archaeological Resources Protection Act of 1979. 1979. Public Law 96-95, as amended, 16 USC 470-470ii.

Atomic Energy Act. 1954. Chapter 1073, 68 Stat. 919, 42 USC 2011 et seq.

BHI-00778. 1996. Chromium in River Substrate Pore Water and Adjacent Groundwater: 100-D/DR Area, Hanford Site, Washington. Bechtel Hanford Inc., Richland, Washington.

BHI-01199. 1999. Integrated Environmental, Safety, and Health Management System Description. Bechtel Hanford, Inc., Richland, Washington.

BHI-01367, Rev. 0. 2000. 200-CW-1 Operable Unit Borehole/Test Pit Summary Report. Prepared by CH2M HILL Hanford, Inc. for Bechtel Hanford, Inc. for the U.S. Department of Energy, Richland, Washington.

BHI-01496. 2001. Hanford Soil Inventory Model. B. C. Simpson, R. A. Corbin, and S. F. Agnew, Bechtel Hanford, Inc., Richland, Washington.

Clean Air Act. 1986. Public Law 88-206, as amended, 42 USC 7401 et seq.

Clean Air Act Amendments. 1990. Public Law 101-549, as amended.

Clean Water Act. 1977. Public Law 95-217, as amended, 91 Stat. 1566 and Public Law 96-148 as amended.
Comprehensive Environmental Response, Compensation, and Liability Act. 1980. Public Law 96-150, as amended, 94 Stat. 2767, 42 USC 9601 et seq.

Defense Authorization Act. 1990. Public Law 101-510, as amended.

DOE/EA-1369. 2001. Environmental Assessment for K Basins Sludge Storage at 221-T Building, Hanford Site, Richland, Washington. U.S. Department of Energy, Richland Operations Office, Richland, Washington.

DOE/EA-1403. 2001. Environmental Assessment for Use of Existing Borrow Areas, Hanford Site, Richland, Washington. U.S. Department of Ecology, Richland Operations Office, Richland, Washington.

DOE/EIS-0189. 1996. Final Environmental Impact Statement for the Tank Waste Remediation System. U.S. Department of Energy and Washington State Department of Ecology, Richland, Washington.

DOE/EIS-0244F. 1996. Final Environmental Impact Statement - Plutonium Finishing Plant Stabilization, May 1996. U.S. Department of Energy, Richland, Washington.

DOE/EIS-0244-FS/SA1. 1997. Supplement Analysis for the Immobilization of Plutonium-Bearing Materials at the Plutonium Finishing Plant, Hanford Site, Richland, Washington. U.S. Department of Energy, Richland Operations Office, Richland, Washington.

DOE/EIS-0244-FS/SA2. 1999. Increasing Batch Size for Thermal Stabilization of Plutonium Finishing Plant Metals, Oxides, and Process Residues, 200 West Area, Hanford Site, Richland, Washington. U.S. Department of Energy, Richland Operations Office, Richland, Washington.

DOE/EIS-0244-FS/SA3. 2000. Supplement Analysis for Project W-460, Plutonium Finishing Plant Plutonium Stabilization and Packaging System, 200 West Area, Hanford Site, Richland, Washington. U.S. Department of Energy, Richland Operations Office, Richland, Washington.

DOE/EIS-0244-FS/SA4. 2000. Supplement Analysis for Changes to the Immobilization Alternative, Plutonium Finishing Plant, 200 West Area, Hanford Site, Richland, Washington. U.S. Department of Energy, Richland Operations Office, Richland, Washington.

DOE/EIS-0244-FS/SA5. 2000. Supplement Analysis for Magnesium Hydroxide Precipitation Process at the Plutonium Finishing Plant, 200 West Area, Hanford Site, Richland, Washington. U.S. Department of Energy, Richland Operations Office, Richland, Washington. 
DOE/EIS-0244-FS/SA6. 2001. Supplement Analysis for the Disposition of Plutonium-Bearing Alloys at the Plutonium Finishing Plant, 200 West Area, Hanford Site, Richland, Washington. U.S. Department of Energy, Richland Operations Office, Richland, Washington.

DOE/EIS-0244-FS/SA7. 2001. Supplement Analysis for the Disposition of Plutonium-Bearing Solutions at the Plutonium Finishing Plant, 200 West Area, Hanford Site, Richland, Washington. U.S. Department of Energy, Richland Operations Office, Richland, Washington.

DOE/EIS-0286, DRAFT. 2002. Hanford Site Solid (Radioactive and Hazardous) Waste Program Environmental Impact Statement. U.S. Department of Energy, Richland Operations Office, Richland, Washington.

DOE/EIS-0287D. 1999. Idaho High-Level Waste $\mathscr{E}$ Facilities Disposition Draft Environmental Impact Statement. U.S. Department of Energy, Idaho National Engineering and Environmental Laboratory, Idaho Falls, Idaho.

DOE/EIS-0310. 2000. Final Programmatic Environmental Impact Statement for Accomplishing Expanded Civilian Nuclear Energy Research and Development and Isotope Production Missions in the United States, Including the Role of the Fast Flux Test Facility. U.S. Department of Energy, Office of Nuclear Energy, Science and Technology, Washington, D.C.

DOE/ID/12584-268, GJPO-HAN-4. 1996. Vadose Zone Characterization Project at the Hanford Tank Farms, SX Tank Farm Report. U.S. Department of Energy, Albuquerque Operations Office and Grand Junction Office for Richland Operations Office, Richland, Washington.

DOE Order 232.1A. "Occurrence Reporting and Processing of Operations Information."

DOEOrder 451.1B. "National Environmental Policy Act Compliance Program."

DOE P 450.4. 1996. Safety Management System Policy. U.S. Department of Energy, The Office of Environment, Safety and Health, Washington D.C.

DOE/RL-88-11, Rev. 2. 2001. Registration of Hanford Site Class V Underground Injection Wells. U.S. Department of Energy, Richland Operations Office, Richland, Washington.

DOE/RL-91-28, Rev. 4. 1998. Hanford Facility Waste Permit Application, General Information Portion. U.S. Department of Energy, Richland Operations Office, Richland, Washington.
DOE/RL-93-94, Rev. 1. 1994. Plan and Schedule for Disposition and Regulatory Compliance for Miscellaneous Streams. U.S. Department of Energy, Richland Operations Office, Richland, Washington.

DOE/RL-94-102. 1995. Proposed Plan for Interim Remedial Measure at the 100-HR-3 Operable Unit. Prepared by CH2M HILL Hanford, Inc. for Bechtel Hanford, Inc. for U.S. Department of Energy, Richland Operations Office, Richland, Washington.

DOE/RL-94-113. 1995. Proposed Plan for Interim Remedial Measure at the 100-KR-4 Operable Unit. Prepared by CH2M HILL Hanford, Inc. for Bechtel Hanford, Inc. for U.S. Department of Energy, Richland Operations Office, Richland, Washington.

DOE/RL-94-150. 1994. Bald Eagle Site Management Plan for the Hanford Site, South-Central Washington. R. E. Fitzner and S. G. Weiss, Pacific Northwest Laboratory and CH2M HILL Hanford, Inc. for U.S. Department of Energy, Richland Operations Office, Richland, Washington.

DOE/RL-96-32, Rev. 0. 2000. Hanford Site Biological Resources Management Plan. U.S. Department of Energy, Richland Operations Office, Richland, Washington.

DOE/RL-97-67, Rev. 3. 2000. Pollution Prevention and Best Management Practices Plan for State Waste Discharge Permits ST 4508, ST 4509, and ST 4510. U.S. Department of Energy, Richland Operations Office, Richland, Washington.

DOE/RL-98-28. 1999. 200 Areas Remedial Investigation/ Feasibility Study Implementation Plan - Environmental Restoration Program. U.S. Department of Energy, Richland Operations Office, Richland, Washington.

DOE/RL-99-44, Rev. 0. 2000. 200-CS-1 Operable Unit RI/FS Work Plan and RCRA TSD Unit Sampling Plan. U.S. Department of Energy, Richland Operations Office, Richland, Washington.

DOE/RL-2000-27, Rev. 0. 2000. Threatened and Endangered Species Management Plan: Salmon and Steelhead. U.S. Department of Energy, Richland Operations Office, Richland, Washington.

DOE/RL-2000-35, Rev. 0. 2001. 200-CW-1 Operable Unit Remedial Investigation Report. U.S. Department of Energy, Richland Operations Office, Richland, Washington. 
DOE/RL-2000-38, Rev. 0. 2001. 200-TW-1 Scavenged Waste Group Operable Unit and 200-TW-2 Tank Waste Group Operable Unit RI/FS Work Plan. U.S. Department of Energy, Richland Operations Office, Richland, Washington.

DOE/RL-2000-60, Draft A. 2000. 200-PW-2 UraniumRich Process Waste Group Operable Unit RI/FS Work Plan and RCRA TSD Unit Sampling Plan. U.S. Department of Energy, Richland Operations Office, Richland, Washington.

DOE/RL-2001-01, Draft A. 2001. 200-PW-1 Plutonium/ Organic-Rich Process Condensate/Process Waste Group Operable Unit RI/FS Work Plan. U.S. Department of Energy, Richland Operations Office, Richland, Washington.

DOE/RL-2001-11, Rev. 0. 2001. Final Feasibility Study for the Canyon Disposition Initiative (221-U Facility). U.S. Department of Energy, Richland Operations Office, Richland, Washington.

DOE/RL-2001-20. 2001. Calendar Year 2000 Hanford Site Mixed Waste Land Disposal Restrictions Report. U.S. Department of Energy, Richland Operations Office, Richland, Washington.

DOE/RL-2001-33. 2001. 2001 Evaluation of Tritium Removal and Mitigation Technologies for Wastewater Treatment. U.S. Department of Energy, Richland Operations Office, Richland, Washington.

DOE/RL-2001-50. 2002. Toxic Substances Control Act Polychlorinated Biphenyls Hanford Site Users Guide. U.S. Department of Energy, Richland Operations Office, Richland, Washington.

DOE/RL-2001-53, Rev. 0. 2001. Fiscal Year 2001 Annual Summary Report for the 200-UP-1 and 200-ZP-1 Operable Unit Pump-and-Treat Operations. U.S. Department of Energy, Richland Operations Office, Richland, Washington.

DOE/RL-2001-60, Rev. 1. 2001. Documentation for Renewal of State Waste Discharge Permits ST 4508, ST4509, and ST4510. U.S. Department of Energy, Richland Operations Office, Richland, Washington.

DOE/RL-2001-64. WTP Dangerous Waste Permit Application. U.S. Department of Energy, Richland Operations Office, Richland, Washington.

DOE/RL-2001-65, Draft A. 2001. 200-MW-1 Miscellaneous Waste Group Operable Unit RI/FS Work Plan. U.S. Department of Energy, Richland Operations Office, Richland, Washington.
DOE/RL-2001-66, Draft A. 2001. 200-LW-1 300 Area Chemical Laboratory Waste Group Operable Unit RI/FS Work Plan. U.S. Department of Energy, Richland Operations Office, Richland, Washington.

DOE/RL-2002-01, Rev. 0. 2002. Fiscal Year 2001 Annual Summary Report for the In Situ REDOX Manipulation Operations. U.S. Department of Energy, Richland Operations Office, Richland, Washington.

DOE/RL-2002-05, Decisional Draft. 2002. CY01 Annual Summary Report for the 100-HR-3, 100-KR-4, and 100-NR-2 Operable Unit Pump-and-Treat Operations. U.S. Department of Energy, Richland Operations Office, Richland, Washington.

DOE/RL-2002-06. 2002. Hanford Facility Annual Dangerous Waste Report, CY 2001. U.S. Department of Energy, Richland Operations Office, Richland, Washington.

DOE/RL-2002-13. 2002. 2001 Hanford Site Tier Two Emergency and Hazardous Chemical Inventory: Emergency Planning and Community Right-to-Know Act Section 312. U.S. Department of Energy, Richland Operations Office, Richland, Washington.

DOE/RL-2002-37, Rev. 0. 2002. 2001 Toxic Chemical Release Inventory. U.S. Department of Energy, Richland Operations Office, Richland, Washington.

Ecology - see Washington State Department of Ecology.

Emergency Planning and Community Right-To-Know Act. 1986. Public Law 99-499, as amended, 100 Stat. 1728, 42 USC 11001 et seq.

Endangered Species Act of 1973. 1973. Public Laws 93-205 through 100-707, as amended, 87 Stat. 884, 16 USC 1531 et seq.

EPA-570/9-76-003. 1976. National Interim Primary Drinking Water Regulations. U.S. Environmental Protection Agency, Office of Water Supply, Washington, D.C.

EPA 822-R-96-001. 1996. Drinking Water Regulations and Health Advisories. U.S. Environmental Protection Agency, Office of Water, Washington, D.C.

EPA - U.S. Environmental Protection Agency. 1994. Federal Facility Compliance Agreement for Radionuclides NESHAP, for the U.S. Department of Energy, Richland Operations Office, Richland, Washington. U.S. Environmental Protection Agency, Region 10, Seattle, Washington. 
EPA - U.S. Environmental Protection Agency. 1996. Records of Decision for the 100-HR-3 and 100-KR-4 Operable Units. U.S. Environmental Protection Agency, Washington, D.C.

EPA - U.S. Environmental Protection Agency. 1999. Interim Remedial Action Record of Decision for the 100-BC-1, 100-BC-2, 100-DR-1, 100-DR-2, 100-FR-1, 100-FR-2, 100-HR-1, 100-HR-2, 100-KR-1, 100-KR-2, 100-IU-2, 100-IU-6, and 200-CW-3 Operable Units, Hanford Site, Benton County, Washington. U.S. Environmental Protection Agency, Region 10, Seattle, Washington.

EPA - U.S. Environmental Protection Agency. 2001. Record of Decision for the 300-FF-2 Operable Unit, Hanford Site, Richland, Washington. U.S. Environmental Protection Agency, Washington, D.C.

Federal Insecticide, Fungicide, and Rodenticide Act. 1975. Public Laws 94-51 through 94-140, as amended, 7 USC 136 et seq.

GJ-HAN-120. 1999. Hanford Tank Farms Vadose Zone, Tank Summary Data Report for Tank T-106. Prepared by MACTEC-ERS for the U.S. Department of Energy, Grand Junction Office, Grand Junction, Colorado.

GJO-99-113-TAR, GJO-HAN-28. 1999. Hanford Tank Farms Vadose Zone, B Tank Farm Report. Prepared by MACTEC-ERS for the U.S. Department of Energy, Grand Junction Office, Grand Junction, Colorado.

Historic Sites, Buildings and Antiquities Act. 1935. Chapter 593, as amended, 16 USC 461-467.

HNF-5068, Rev. 1. 2000. Project Management Plan for the 300 Area Special-Case Waste. W. L. Johnson and J. R. Robertson, Fluor Hanford, Inc., Richland, Washington.

HNF-6465. 2000. Project Summary for the Hanford Site 300 Area Accelerated Closure Project Plan. Fluor Hanford, Inc., Richland, Washington.

HNF-EP-0125-14. 2002. Summary of Radioactive Solid Waste Received in the 200 Areas During Calendar Year 2001. D. L. Hagel, Waste Management Federal Services of Hanford, Inc., Richland, Washington.

HNF-EP-0182, Rev. 165. 2002. Waste Tank Summary Report for Month Ending December 31, 2001. CH2M HILL Hanford Group, Inc., Richland, Washington.

HNF-MP-003. 1997. Integrated Environment, Safety and Health Management System Plan. Fluor Daniel Hanford, Inc., Richland, Washington.
HNF-SP-0903, Rev. 8. 2001. National Environmental Policy Act Source Guide for the Hanford Site. Fluor Daniel Hanford, Inc., Richland, Washington.

ISO 14001. 1996. Environmental Management Systems-Specifications with Guidance for Use. American Society for Testing and Materials, West Conshohocken, Pennsylvania.

Memorandum of Agreement. 1996. Memorandum of Agreement Among the United States Department of Energy, United States Department of the Interior, Nez Perce Tribe, State of Oregon, Confederated Tribes of the Umatilla Indian Reservation, State of Washington (including the Departments of Ecology and Fish and Wildlife), and the Confederated Tribes and Bands of the Yakama Indian Nation. U.S. Department of Energy, Richland Operations Office, Richland, Washington.

Migratory Bird Treaty Act. 1918. Chapter 128, as amended, 40 Stat. 755, 16 USC 703-712.

National Environmental Policy Act. 1969. Public Law 91-190, as amended, 42 USC 4321 et seq.

National Historic Preservation Act. 1966. Public Law 89-665, as amended, 16 USC 470 et seq.

National Research Council. 2001. Science and Technology for Environmental Cleanup at Hanford. National Academy Press, Washington, D.C.

Native American Graves Protection and Repatriation Act. 1990. Public Law 101-601, as amended, 25 USC 3001 et seq.

PNNL-6415, Rev. 12. 2000. Hanford Site National Environmental Policy Act (NEPA) Characterization. D. A. Neitzel (ed.), and E. J. Antonio, C. J. Fosmire, R. A. Fowler, C. S. Glantz, S. M. Goodwin, D. W. Harvey, P. L. Hendrickson, D. G. Horton, T. M. Poston, A. C. Rohay, P. D. Thorne, and M. K. Wright, Pacific Northwest National Laboratory, Richland, Washington.

PNNL-13582. 2001. High-Level Waste Melter Study Report. J. M. Perez, Jr., D. K. Peeler, D. F. Bickford, D. M. Strachan, D. E. Day, M. B. Triplett, D. S. Kim, J. D. Vienna, S. L. Lambert, R. S. Wittman, and S. L. Marra, Pacific Northwest National Laboratory, Richland, Washington.

PNNL-13674. 2001. Zone of Interaction Between Hanford Site Groundwater and Adjacent Columbia River. R. E. Peterson and M. P. Connelly, Pacific Northwest National Laboratory, Richland, Washington. 
PNNL-13679. 2001. Vadose Zone Transport Field Study: Status Report. G. W. Gee and A. L. Ward, Pacific Northwest National Laboratory, Richland, Washington.

PNNL-13682. 2001. Development of a Remotely Operated NDE System for Inspection of Hanford's Double Shell Waste Tank Knuckle Regions. Annual Report. A. F. Pardini, J. M. Alzheimer, S. L. Crawford, A. A. Diaz, K. L. Gervais, R. V. Harris, D. M. Riechers, T. J. Samuel, G. J. Schuster, J. C. Tucker, and R. A. Roberts, Pacific Northwest National Laboratory, Richland, Washington.

Pollution Prevention Act. 1990. Public Law 101-508, as amended, 104 Stat. 1388-321, 41 USC 13101 et seq.

Resource Conservation and Recovery Act. 1976. Public Law 94-580, as amended, 90 Stat. 2795, 42 USC 6901 et seq.

Revised Code of Washington (RCW) 15.58. Washington Pesticide Control Act.

Revised Code of Washington (RCW) 17.21. Washington Pesticide Application Act.

Revised Code of Washington (RCW) 43.21C. Washington State Environmental Policy Act.

Revised Code of Washington (RCW) 70.94. Washington Clean Air Act.

RPP-7578, Rev. 1A. 2001. Site-Specific SST Phase 1 RFI/ CMS Work Plan Addendum for WMAS T and TX-TY. J. D. Crumpler, CH2M HILL Hanford Group, Inc., Richland, Washington.

RPP-7807, Rev. 0. 2001. Single-Shell Tank 241-C-104 Full Scale Sludge/Hard Heel, Confined Sluicing and Robotic Technologies, Waste Retrieval Demonstration Functions and Requirements. CH2M HILL Hanford Group, Inc., Richland, Washington.

RPP-7825, Rev. 0. 2001. Single-Shell Tank S-112 Full Scale Saltcake Waste and Retrieval Technology Demonstration Functions and Requirements. CH2M HILL Hanford Group, Inc., Richland, Washington.

RPP-7884, Rev. 0. 2002. Field Investigation Report for Waste Management Area S-SX. Prepared for the Office of River Protection by CH2M HILL Hanford Group, Richland, Washington.

RPP-8093. 2001. Draft Fiscal Year 2002 Tank Characterization Technical Sampling Basis and Waste Information Requirements Document. M. R. Adams, J. G. Douglas, and J. W. Hunt, CH2M HILL Hanford Group, Inc., Richland, Washington.
RPP-8554. 2001. Single-Shell Tank Retrieval Sequence and Double-Shell Tank Space Evaluation. CH2M HILL Hanford Group, Inc., Richland, Washington.

Safe Drinking Water Act. 1974. Public Law 93-523, as amended, 88 Stat. 1660, 42 USC 300 fet seq.

Safe Drinking Water Act Amendments of 1986. 1986. Public Law 99-339, as amended, Stat. 666, 42 USC 300 f et seq.

Safe Drinking Water Act Amendments of 1996. 1996. Public Law 104-182, as amended, Stat. 1613, 42 USC $300 \mathrm{f}$ et seq.

Superfund Amendments and Reauthorization Act. 1986. Public Law 99-499, as amended, 100 Stat. 1613, 42 USC 11001 et seq.

Toxic Substances Control Act. 1976. Public Law 94-469, as amended, 90 Stat. 2003, 15 USC 2601 et seq.

Tri-Party Agreement Agencies. 2002. Hanford Site TriParty Agreement Public Involvement Community Relations Plan. U.S. Department of Energy, Richland Operations Office, Richland, Washington.

U.S. Fish and Wildlife Service. 1999. Hanford Site 100 Area Assessment Plan Volume I: Columbia River Aquatic Resources. Prepared for the Hanford Natural Resource Trustee Council by U.S. Fish and Wildlife Service Upper Columbia River Basin Field Office, Spokane, Washington.

WAC 16-228. "Pesticide Regulations." Washington Administrative Code, Olympia, Washington.

WAC 173-201A. "Water Quality Standards for Surface Waters of the State of Washington." Washington Administrative Code, Olympia, Washington.

WAC173-216. "State Waste Discharge Program." Washington Administrative Code, Olympia, Washington.

WAC 173-218. "Underground Injection Control Program." Washington Administrative Code, Olympia, Washington.

WAC 173-240. "Submission of Plans and Reports for Construction of Wastewater Facilities." Washington Administrative Code, Olympia, Washington.

WAC 173-303. "Dangerous Waste Regulations." Washington Administrative Code, Olympia, Washington.

WAC 173-303-170. "Agricultural Water Supply Facilities." Washington Administrative Code, Olympia, Washington. 
WAC 173-303-400. "Interim Status Facility Standards." Washington Administrative Code, Olympia, Washington.

WAC 173-303-610. "Closure and Postclosure." Washington Administrative Code, Olympia, Washington.

WAC 173-303-645. "Releases from Regulated Units." Washington Administrative Code, Olympia, Washington.

WAC 173-400. "General Regulations for Air Pollution Sources." Washington Administrative Code, Olympia, Washington.

WAC 173-401. "Operating Permit Regulation." Washington Administrative Code, Olympia, Washington.

WAC 173-425. "Open Burning." Washington Administrative Code, Olympia, Washington.
WAC 173-460. "Controls for New Sources of Toxic Air Pollutants." Washington Administrative Code, Olympia, Washington.

WAC 246-247. "Radiation Protection-Air Emissions." Washington Administrative Code, Olympia, Washington.

WAC 246-290. "Group A Public Water Supplies." Washington Administrative Code, Olympia, Washington.

Washington State Department of Ecology, U.S. Environmental Protection Agency, and U.S. Department of Energy. 1998. Hanford Federal Facility Agreement and Consent Order. Document No. 89-10, Rev. 5 (The TriParty Agreement), Olympia, Washington. 


\title{
3.0 Facility-Related Monitoring
}

\author{
C. J. Perkins
}

The following sections provide information about facility-related environmental monitoring programs at the Hanford Site, including effluent monitoring (Section 3.1) and near-facility environmental monitoring (Section 3.2).

The monitoring of effluents and contaminants at Hanford Site facilities is necessary to determine the effects these materials may have on the public, workers at the site, and the environment. Effluent monitoring is conducted by the various site contractors at their facilities pursuant to requirements in DOE Order 5400.1. At the Hanford Site, effluent monitoring includes (1) collecting samples for analyses, (2) measuring liquid and airborne effluents to characterize and quantify contaminants released to the environment, (3) providing information to assess the potential impact to the public,
(4) providing a means to control effluents at or near the point of discharge, and (5) determining compliance with applicable standards and permit requirements.

Near-facility environmental monitoring consists of routine monitoring of environmental media near facilities that have the potential to discharge or have discharged, stored, or disposed of radioactive or hazardous contaminants. Monitoring locations are generally associated with major, nuclear-related installations, waste storage and disposal units, and remediation efforts.

Additional program sampling and effluent information is contained in Hanford Site Near-Facility Environmental Monitoring Data Report for Calendar Year 2001 (PNNL-13910, APP. 2) and in Environmental Releases for Calendar Year 2001 (HNF-EP-0527-11). 


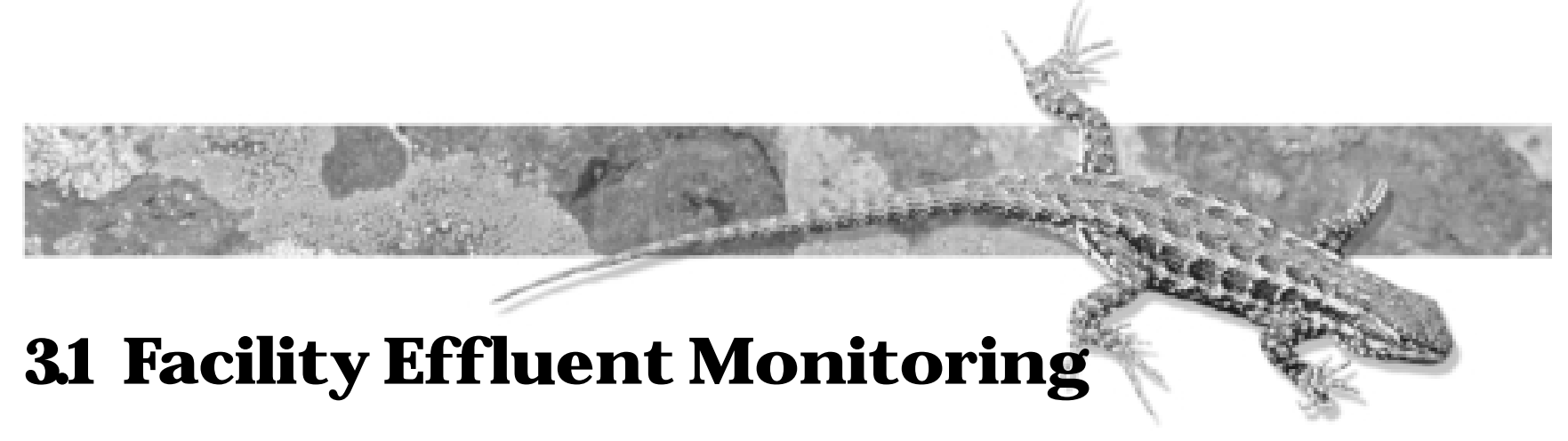

L. P. D iediker and D. J. Rokkan

Liquid and airborne effluents that may contain radioactive or hazardous constituents are continually monitored when released to the environment at the Hanford Site. Facility operators perform the monitoring mainly through analyzing samples collected at points of release into the environment. Effluent monitoring data are evaluated to determine the degree of regulatory compliance for each facility and/or the entire site. The evaluations are also useful to assess the effectiveness of effluent treatment and control systems and pollutionmanagement practices. Major facilities have their own individual effluent monitoring plans, which are part of the comprehensive Hanford Site environmental monitoring plan (DOE/RL-91-50).

Measuring devices quantify most facility effluent flows, but some flows are calculated using process information. For most radioactive air emission units, which are primarily ventilated stacks, effluent sampling methods include continuous sampling or periodic measurements. For most liquid effluent streams, proportional sampling or grab sampling is used. Liquid and airborne effluents with a potential to contain radioactive materials at prescribed threshold levels are measured for total alpha and total beta concentrations and, as warranted, specific radionuclides. Non-radioactive constituents and parameters are either measured directly or sampled and analyzed.

Tritium, cobalt-60, strontium-90, iodine-129, cesium-137, plutonium-238, plutonium-239/240, plutonium-241, and americium-241 were released to the environment through state and federally permitted release points. Most of the radionuclides in effluents at the site are nearing levels indistinguishable from the low concentrations of radionuclides in the environment that occur naturally or originated from atmospheric nuclear-weapons testing. The site mission of environmental cleanup is largely responsible for the downward trend in radioactive emissions, which results in smaller radiation doses to the maximally exposed member of the public. Figures 3.1.1 and 3.1.2 depict quantities of several longer-lived radionuclides released from the site over the past 10 years. In 2001, releases of radioactive and non-radioactive constituents in effluents were less than applicable dose and release standards, respectively.

Effluent release data are documented in several reports besides this one, and all are available to the public. For instance, the U.S. Department of Energy (DOE) annually submits to the U.S. Environmental Protection Agency (EPA) and Washington State Department of Health a report of radioactive airborne emissions from the site (DOE/RL-2002-20), in compliance with Title 40, Code of Federal Regulations, Part 61 (40 CFR 61) and Washington Administrative Code (WAC) 246-247. Data quantifying the radioactive liquid and airborne effluents are reported to DOE annually in an environmental releases report (HNF-EP0527-11). Summaries of monitoring results are reported annually (HNF-EP-0527-11) for liquid effluents discharged to the Columbia River (regulated by the National Pollutant Discharge Elimination System Permit), liquid effluents discharged to the soil (regulated by WAC 173-216), and for non-radioactive air emissions.

\subsection{Radioactive Airborne Em issions}

Radioactive airborne emissions from Hanford Site activities contain particulate and volatile forms of radionuclides. Emissions with the potential to exceed $1 \%$ of the $10-\mathrm{mrem} / \mathrm{yr}$ standard for offsite doses are monitored continuously.
The continuous monitoring of radioactive emissions involves analyzing samples collected at points of discharge to the environment, usually from a stack or a vent. Samples are analyzed for total alpha and total beta concentration, as well as selected radionuclides. The selection of the specific radionuclides sampled, analyzed, 


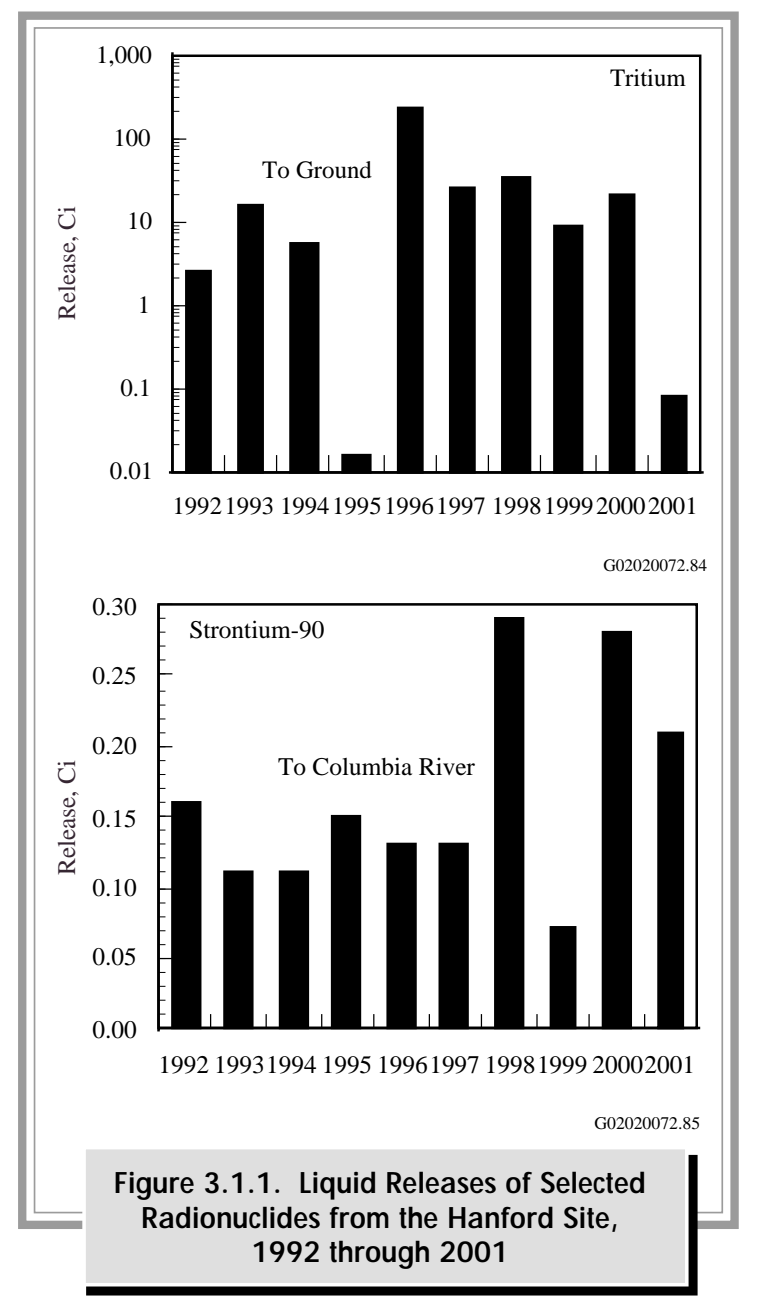

and reported is based on (1) an evaluation of maximum potential of unmitigated emissions expected from known radionuclide inventories in a facility or activity area, (2) the sampling criteria given in contractor environmental compliance manuals, and (3) the potential each radionuclide has to contribute to the public dose. Continuous air monitoring systems with alarms also are used at selected emission points when a potential exists for radioactive emissions to exceed normal operating ranges at levels requiring immediate personnel alert.

Radioactive emission discharge points, which generally are actively ventilated stacks, are located in the 100 , 200, 300, 400, and 600 Areas. The principal sources for these emissions are summarized below.

- In the 100 Areas, emissions originated via normal evaporation from two water-filled storage basins (100-K East and 100-K West Fuel Storage Basins, which contain irradiated nuclear fuel), the Cold Vacuum Drying Facility, the 105-KW Integrated Water Treatment filter backwash system, and a lowlevel radiological laboratory. In 2001, five radioactive emission points were active in the 100 Areas.

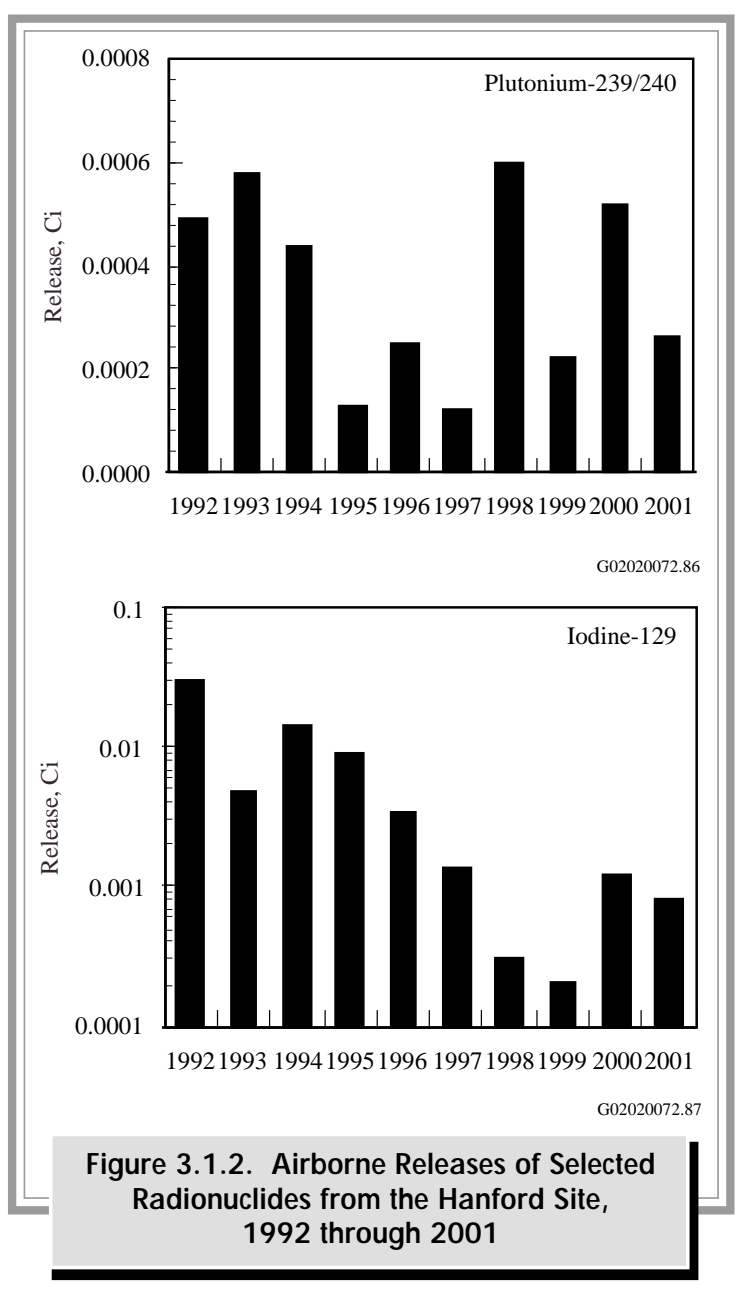

- In the 200 Areas, the primary sources of radionuclide emissions were the Plutonium Finishing Plant, T Plant, 222-S laboratory, underground tanks that were storing high-level radioactive waste, waste evaporators, and the inactive Plutonium-Uranium Extraction Plant. In 2001, 49 radioactive emission points were active in the 200 Areas.

- The 300 Area primarily has laboratories and research facilities. Primary sources of airborne radionuclide emissions were the 324 Waste Technology Engineering Laboratory, 325 Applied Chemistry Laboratory, 327 Post-Irradiation Laboratory, and 340 Vault and Tanks. In 2001, 22 radioactive emission discharge points were active in the 300 Area.

- The 400 Area has the shutdown Fast Flux Test Facility, the Maintenance and Storage Facility, and the Fuels and Materials Examination Facility. Operations and support activities at the Fast Flux Test Facility and Maintenance and Storage Facility released small quantities of radioactive material to the environment. In 2001, five radioactive emission points were active in the 400 Area. 
- The 600 Area has the Waste Sampling and Characterization Facility, at which low-level radiological and chemical analyses of various types of samples (e.g., particulate air filters, liquid, soil, and vegetation) are performed. This facility had two radioactive emission points in 2001, which are considered as being in the 200-West Area for release and dose-modeling purposes.

A summary of the Hanford Site radioactive airborne emissions in 2001 is provided in Table 3.1.1.

\subsubsection{Non-Radioactive Airborne Em issions}

Non-radioactive air pollutants emitted from powergenerating and chemical processing facilities are monitored when activities at a facility are known to generate potential pollutants of concern.

In past years, gaseous ammonia has been emitted from the Plutonium-Uranium Extraction Plant, 242-A evaporator, AP tank farm, and AW tank farm, all located in the 200-East Area. Ammonia emissions are tracked only when activities at these facilities are capable of generating them. In 2001, the 200 Areas tank farms produced reportable ammonia emissions, summarized in Table 3.1.2.

Onsite diesel-powered electrical generating plants emitted particulate matter, sulfur oxides, nitrogen oxides, volatile organic compounds, carbon monoxide, and lead. The total annual releases of these constituents are reported in accordance with the air quality standards established in WAC 173-400. Power plant emissions are calculated from the quantities of fossil fuel consumed, using EPA-approved formulas (AP-42).

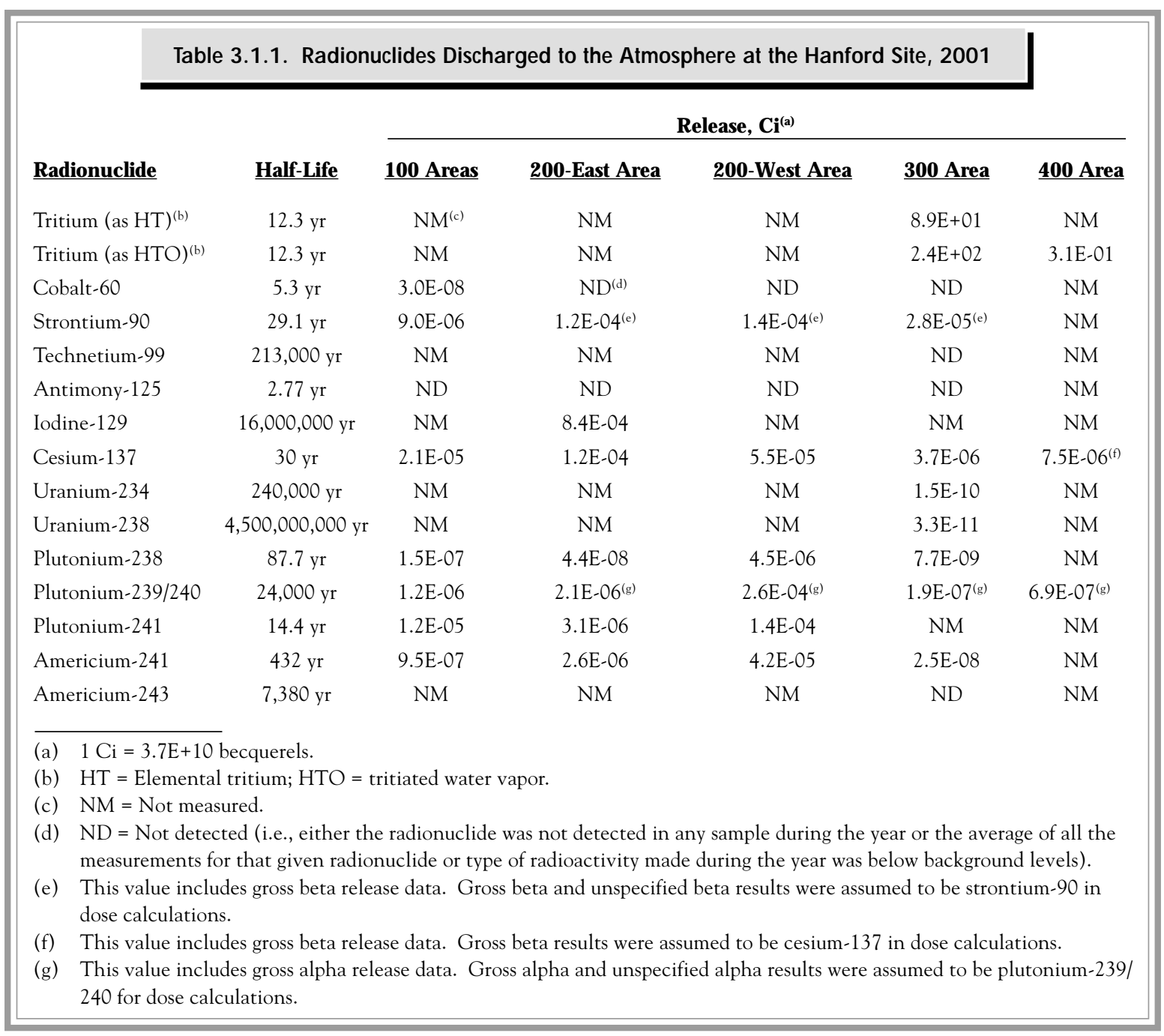


Table 3.1.2. Non-Radioactive Constituents Discharged to the Atmosphere at the Hanford Site, 2001

\section{Constituent}

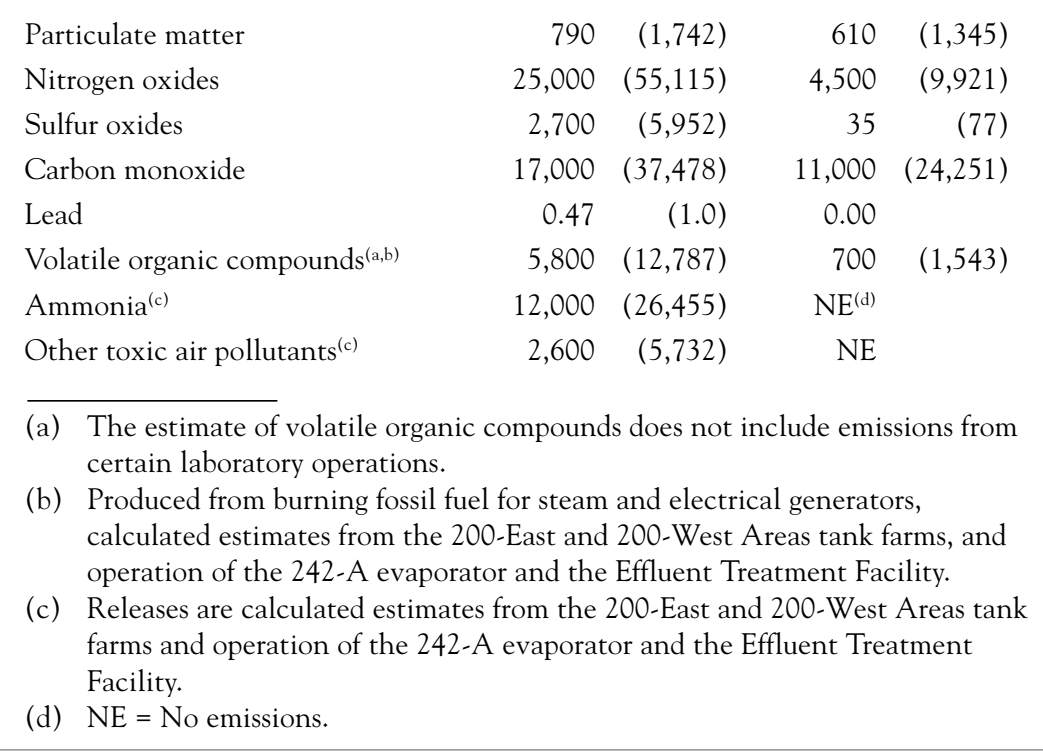

Should activities result in chemical emissions in excess of quantities reportable under the Comprehensive Environmental Response, Compensation, and Liability Act of 1980 (CERCLA), the release totals are immediately reported to EPA. If the emissions remain stable at predicted levels, they may be reported annually with EPA's permission. Table 3.1.2 summarizes the emissions of nonradioactive constituents in 2001 (Note: the 100, 400, and 600 Areas have no non-radioactive emission sources of regulatory concern). Table 3.1.2 also includes emission estimates from the carbon tetrachloride vapor extraction work in the 200-West Area. These emissions are accounted for in the table category of "other toxic air pollutants" and do not require reporting because they are below the respective reportable quantity.

\subsection{Radioactive Liquid Effluents}

Liquid effluents are discharged from facilities in all areas of the Hanford Site. Effluents that normally or potentially contain radionuclides include cooling water, steam condensate, process condensate, and wastewater from laboratories and chemical sewers. These wastewater streams are sampled and analyzed for total alpha and total beta, as well as selected radionuclides.

In 2001, only facilities in the 200 Areas discharged radioactive liquid effluents to the ground, which went to a single location, the 616-A crib, also known as the

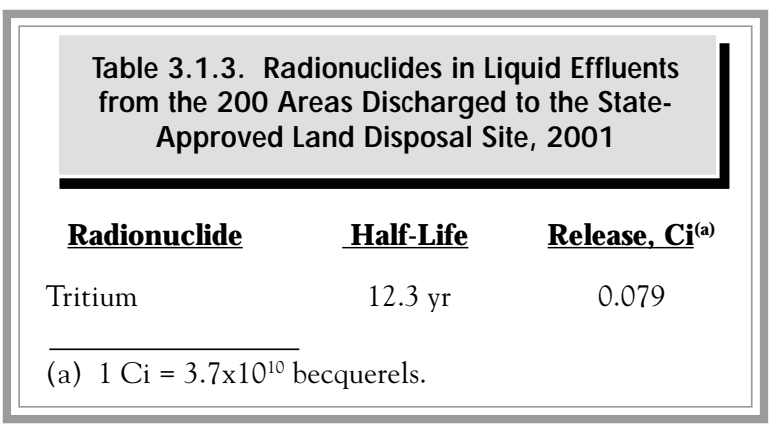

State-Approved Land Disposal Site. A summary of radioactive liquid effluents is provided in Table 3.1.3. Table 3.1.4 summarizes data on radionuclides in liquid effluents released from the 100 Areas to the Columbia River, the sources of which include secondary cooling water used at the 100-K Fuel Storage Basins and shoreline seepage of groundwater that has passed near the retired $1301-\mathrm{N}$ and $1325-\mathrm{N}$ cribs in the $100-\mathrm{N}$ Area. These measured values are used to determine potential radiation doses to the public via the liquid pathway.

\begin{tabular}{|c|c|c|}
\hline \multicolumn{3}{|c|}{$\begin{array}{l}\text { Table 3.1.4. Radionuclides in Liquid Effluents } \\
\text { from the } 100 \text { Areas Discharged to the } \\
\text { Columbia River, } 2001\end{array}$} \\
\hline Radionuclide & H alf-Life & Release, $\mathbf{C i}^{(\mathrm{a})}$ \\
\hline Tritium & $12.3 \mathrm{yr}$ & 0.11 \\
\hline Strontium-90 & $29.1 \mathrm{yr}$ & 0.21 \\
\hline Plutonium-239/240 & $24,000 \mathrm{yr}$ & 0.000039 \\
\hline Americium-241 & $432 \mathrm{yr}$ & 0.00001 \\
\hline
\end{tabular}




\subsection{Non-Radioactive Hazardous Materials in Liquid Effluents}

Non-radioactive hazardous materials in liquid effluents are monitored in the 100, 200, 300, and 400 Areas. These effluents are discharged to the State-Approved Land Disposal Site and to the Columbia River. Effluents entering the environment at designated discharge points are sampled and analyzed to determine compliance with the National Pollutant Discharge Elimination System permits and the state waste discharge permits for the site (40 CFR 122 and WAC 173-216). Should chemicals in liquid effluents exceed quantities reportable under
CERCLA, the release totals are immediately reported to the EPA. With EPA's permission, if emissions remain stable at predicted levels, they may be reported annually. A synopsis of the permitted National Pollutant Discharge Elimination System and state waste discharge activities in 2001 is given in Section 2.2.8.

Liquid waste containing both radioactive and hazardous constituents is stored at the 200 Areas in underground waste storage tanks or interim storage facilities.

\subsection{CERCLA and Washington Administrative Code Releases to the Environment}

Releases that are reportable to the state and/or EPA include spills or discharges of hazardous substances or dangerous wastes to the environment, other than releases permitted under state or federal law. Accidents and equipment failures cause the majority of these releases. Releases of hazardous substances that are continuous and stable in quantity and rate, but that exceed specified limits, must be reported as required by Section 103(f)(2) of CERCLA.

Spills or non-permitted discharges of dangerous wastes or hazardous substances to the environment are required to be reported (WAC 173-303-145). This requirement applies to spills or discharges onto the ground, into the groundwater, into the surface water (i.e., Columbia River), or into the air such that human health or the environment is threatened, regardless of the quantity of dangerous waste or hazardous substance.

In accordance with both CERCLA and Washington Administrative Code reporting requirements (WAC 173-303-145), three releases were reported in 2001. Table 3.1.5 contains a synopsis of those releases. 


\begin{tabular}{|c|c|c|}
\hline Material & Quantity & Description \\
\hline Radioactive air & $\begin{array}{l}\text { Small amount (potential only; no } \\
\text { actual release to environment) }\end{array}$ & $\begin{array}{l}\text { While a velocity probe was being withdrawn from the } \\
291-Z-1 \text { stack, the stack sampling system was inadvertently } \\
\text { bumped, which dislodged material within the sampling line } \\
\text { that caused the constant air monitor to annunciate. It was } \\
\text { later determined that no uncontrolled elevated emission } \\
\text { from the stack occurred, but nonetheless an initial notifi- } \\
\text { cation was made to the Washington State Department of } \\
\text { Health. }\end{array}$ \\
\hline Carbon disulfide & $1.2 \mathrm{~kg}(2.6 \mathrm{lb})$ & $\begin{array}{l}\text { Liquid carbon disulfide was released to the inside of a card- } \\
\text { board storage box being delivered to the } 1163 \text { Building (the } \\
\text { Central Storage Building in the former } 1100 \text { Area). The } \\
\text { liquid leaked through the container to the concrete floor } \\
\text { underneath. Several employees inhaled the vapors from the } \\
\text { leaked chemical. They were sent to the Hanford Environ- } \\
\text { mental Health Foundation for precautionary evaluation. } \\
\text { The Washington State Department of Ecology was notified } \\
\text { of the incident because of the "threat to human health." } \\
\text { This is a highly volatile material that may be fatal if } \\
\text { inhaled, swallowed, or absorbed through the skin. }\end{array}$ \\
\hline $\begin{array}{l}\text { Low-level } \\
\text { radioactive liquid }\end{array}$ & $\begin{array}{l}7.68 \mathrm{~L}(2 \mathrm{gal}) ; 160 \mathrm{pCi} / \mathrm{L}(5.9 \mathrm{~Bq} / \mathrm{L}) \\
\text { alpha and } 290 \mathrm{pCi} / \mathrm{L}(10.7 \mathrm{~Bq} / \mathrm{L}) \text { beta }\end{array}$ & $\begin{array}{l}\text { Leachate from the Effluent Retention Disposal Facility } \\
\text { leaked to the immediate soil column after a relief valve } \\
\text { failed in a pipeline. This type of relief valve is located in } \\
\text { manholes with soil bottoms. The leachate was released } \\
\text { into three separate manholes. }\end{array}$ \\
\hline $\begin{array}{l}\text { Polychlorinated } \\
\text { biphenyls } \\
\text { (Aroclors } 1248 \text { and } \\
\text { 1254) }\end{array}$ & $\begin{array}{l}\sim 37.9 \mathrm{~L}(10 \mathrm{gal}) \text { of oil matrix; at } \\
\text { least } 1.18 \mathrm{~kg}(2.6 \mathrm{lb}) \text { of oil }\end{array}$ & $\begin{array}{l}\text { On May 10, 2001, during excavation work at the 600-23 } \\
\text { burial ground (Operable Unit 100-1U-6), a tank was } \\
\text { unearthed that began leaking polychlorinated biphenyl- } \\
\text { contaminated oil to the underlying soil in an amount that } \\
\text { exceeded the CERCLA reportable quantity amount of } \\
454 \mathrm{~g}(1 \mathrm{lb}) \text {. The affected soil was cleaned up and disposed } \\
\text { of properly. }\end{array}$ \\
\hline \multicolumn{3}{|c|}{$\begin{array}{l}\text { (a) As required by WAC } 173-303-145 \text {. } \\
\text { CERCLA }=\text { C omprehensive Environmental Response, Compensation, and Liability A ct of } 1980 .\end{array}$} \\
\hline
\end{tabular}




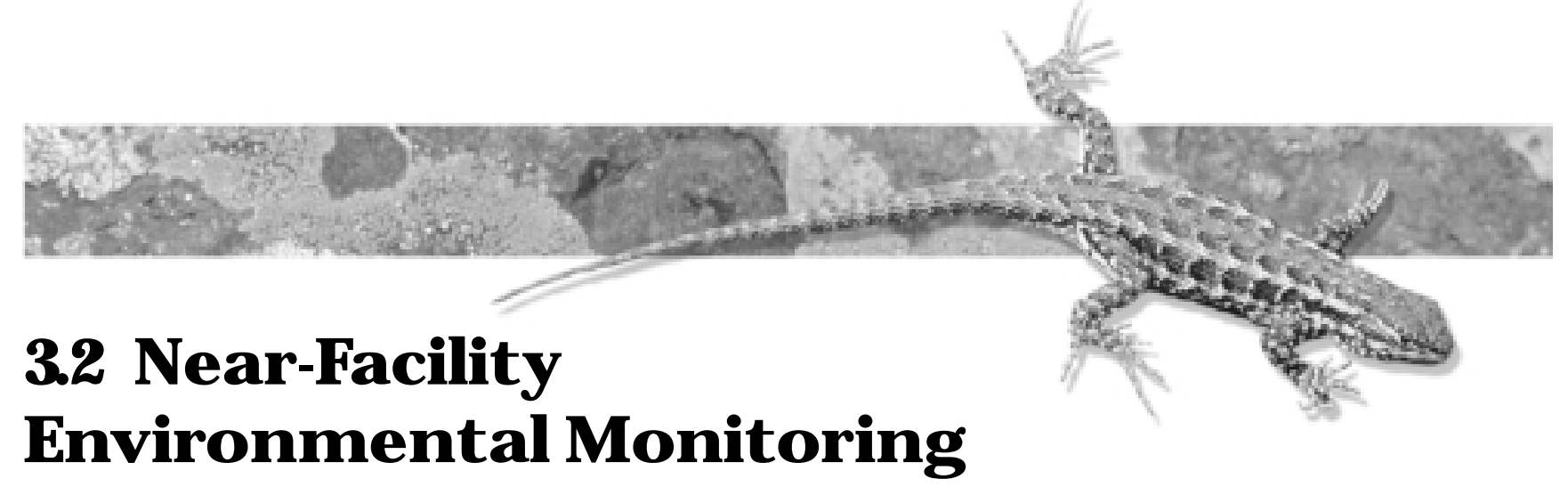

\author{
C. J. Perkins, B. M. Markes, S. M. McKinney, and R. M. Mitchell
}

Near-facility environmental monitoring is defined as routine monitoring near facilities that have the potential to discharge, or have discharged, stored, or disposed of radioactive or hazardous contaminants. Monitoring locations are associated with nuclear facilities such as the Plutonium Finishing Plant, Canister Storage Building, and the 100-K Fuel Storage Basins; inactive nuclear facilities such as $\mathrm{N}$ Reactor and the Plutonium-Uranium Extraction Plant; and active and inactive waste storage or disposal facilities such as burial grounds, cribs, ditches, ponds, underground waste storage tanks, and trenches.

Much of the monitoring program consists of collecting and analyzing environmental samples and conducting radiological surveys in areas near facilities. The program also is designed to evaluate and report analytical data, determine the effectiveness of facility effluent monitoring and controls, measure the adequacy of containment at waste disposal sites, and detect and monitor unusual conditions. The program implements applicable portions of DOE Orders 435.1, 5400.1, 5400.5, and 5484.1; 10 CFR 835 and 40 CFR 61; and WAC 246-247.

Near Hanford Site facilities, several types of environmental media are sampled, and various radiological and non-radiological measurements are taken. These sample types and measurements include air, spring water, surface contamination, soil, vegetation, and external radiation. Samples are collected from known or expected effluent pathways. These pathways are generally downwind of potential or actual airborne releases and downgradient of liquid discharges.

Active and inactive waste disposal sites and the terrain surrounding them are surveyed to detect and characterize radioactive surface contamination. Routine radiological survey locations include former waste disposal cribs and trenches, retention basin perimeters, ditch banks, solid waste disposal sites (e.g., burial grounds), unplanned release sites, tank farm perimeters, stabilized waste disposal sites, roads, and firebreaks in and around the site operational areas.

Sampling and analysis information and analytical results for 2001 are summarized in the following sections. Additional data may be found in Hanford Site NearFacility Environmental Monitoring Data Report for Calendar Year 2001 (PNNL-13910, APP. 2). Nearfacility monitoring in 2001 is summarized in Table 3.2.1, which indicates the type, quantity, and general location of samples collected.

\title{
3.2.1 Air Monitoring
}

In 2001, routine monitoring for radioactivity in air near Hanford Site facilities used a network of continuously operating samplers at 76 locations (Table 3.2.2) (sampling locations illustrated in PNNL-13910, APP. 2). Air samplers were located primarily at or within $\sim 500$ meters ( 1,500 feet) of sites and/or facilities having the potential for, or history of, environmental releases and were predominantly located in the prevailing downwind direction. To avoid duplication of sampling, air data for the 300 and 400 Areas, some onsite remediation projects, and some offsite distant locations were obtained from Pacific Northwest National Laboratory.
Samples were collected according to a schedule established before the 2001 monitoring year. Airborne particles were sampled at each sampling location by drawing air through a glass-fiber filter. The filters were collected biweekly, field surveyed for gross radioactivity, held for at least 7 days, and then analyzed for gross alpha and beta activity. The 7-day holding period was necessary to allow for the decay of naturally occurring, short-lived radionuclides that would otherwise obscure detection of longer-lived radionuclides associated with emissions from nuclear facilities. The gross radioactivity measurements were used to indicate changes in trends in the near-facility environment. 
Table 3.2.1. Near-Facility Routine Environmental Monitoring Samples and Locations, 2001

\begin{tabular}{|c|c|c|c|c|c|c|c|c|c|c|}
\hline \multirow[b]{2}{*}{ Sample Type } & \multirow{2}{*}{$\begin{array}{l}\text { N umber } \\
\text { of Sample } \\
\text { Locations }\end{array}$} & \multicolumn{9}{|c|}{ O perational A rea } \\
\hline & & $\underline{100-B / C}$ & $\underline{100-D / D R}$ & $\underline{100-K}$ & $\underline{100-F}$ & $\underline{100-\mathrm{H}}$ & $\underline{100-N}$ & $\underline{E R D F}^{(a)}$ & $\begin{array}{l}200 / \\
600 \\
\end{array}$ & $\begin{array}{l}300 / \\
400 \\
\end{array}$ \\
\hline Air & 76 & 3 & 3 & 8 & 6 & 6 & 5 & 3 & $41^{(\mathrm{b})}$ & 1 \\
\hline Water & 10 & 0 & 0 & 0 & 0 & 0 & 10 & 0 & 0 & 0 \\
\hline Soil & 92 & 1 & 0 & 0 & 2 & 2 & 11 & 1 & 57 & 18 \\
\hline Vegetation & 75 & 0 & 0 & 0 & 0 & 0 & 9 & 0 & 49 & 17 \\
\hline External radiation & 133 & 5 & 0 & $15^{\text {(c) }}$ & 5 & 3 & 14 & 3 & $67^{(\mathrm{d})}$ & 21 \\
\hline \multicolumn{11}{|c|}{ Environmental Restoration Disposal Facility in the 200-West Area. } \\
\hline \multirow{2}{*}{\multicolumn{11}{|c|}{$\begin{array}{l}\text { Includes } 1 \text { station at the Wye Barricade, } 19 \text { in the } 200 \text {-East Area, and } 21 \text { in the } 200 \text {-West Area. } \\
\text { Includes } 11 \text { locations in the } 100-\mathrm{KE} / \mathrm{KW} \text { Areas and } 4 \text { at the Cold Vacuum Drying Facility. }\end{array}$}} \\
\hline & & & & & & & & & & \\
\hline \multicolumn{11}{|c|}{ Includes 66 locations in the 200 Areas and 1 location at the $212-\mathrm{R}$ facility in the 200 -North Area. } \\
\hline
\end{tabular}

For most specific radionuclide analyses, the amount of radioactive material collected on a single filter during a 2-week period was too small to be measured accurately. To increase the accuracy of the analysis, the samples were combined into either quarterly or semiannual composite samples for each location.

Figure 3.2.1 shows the average concentrations of selected radionuclides in the 100 and 200/600 Areas compared to DOE derived concentration guides and air concentrations measured in distant communities. The DOE derived concentration guides (DOE Order 5400.5) are reference values that are used as indexes of performance. The data indicate a large degree of variability. Air samples collected from areas located at or directly adjacent to Hanford Site facilities had higher concentrations than did those samples collected farther away. In general, analytical results for most radionuclides were at or near Hanford Site background levels, which is much less than DOE derived concentration guides but greater than those measured off the site. The data also show that concentrations of certain radionuclides were higher within different operational areas. Table 3.2.3 shows the annual average and maximum concentrations of radionuclides in near-facility air samples during 2001. A complete listing of the 2001 near-facility ambient air monitoring results can be found in PNNL-13910, APP. 2. Results for selected Pacific Northwest National Laboratory air samples are also reported in PNNL-13910, APP.2, as well as in Section 4.1.

The 2001 analytical results for the remedial action projects at the $100-\mathrm{B} / \mathrm{C}, 100-\mathrm{H}$, and 100-F Areas generally indicated that for most radionuclides, concentrations were greater than levels measured off the site, though well within historical ranges.

At the 100-B/C Area, ambient air monitoring was re-established in February 2001 at three locations. These locations were the same ones used in 1999 when cleanup activities were temporarily halted. The radionuclides uranium-234 and -238 were consistently detected. Strontium-90 and uranium-235 were detected occasionally in 2001.

Remedial action activities for fiscal year 2001 were completed at the $100-\mathrm{H}$ site, and air monitoring ended in March 2001. Uranium-234 and plutonium-239/240 were detected in two of the four composite samples analyzed in 2001.

At the 100-F remedial action site, ambient air monitoring continued at four locations in 2001. Uranium-234 and -238 were detected consistently; strontium-90, uranium-235, and plutonium-239/240 were detected occasionally.

In 2001, two samplers operated at each of the 105-DR and 105-F interim safe storage projects. The quarterly analytical results from these air samples were generally similar to the results seen over the past 3 years.

Air monitoring at the $105-\mathrm{H}$ and 105-D interim safe storage projects began in November 2000 and, at the request of project management, the air sampler at 105-D was operated only while actual decontamination and decommissioning work was being done (i.e., one work shift on weekdays). For this location, sample volumes were significantly lower than for all other nearfacility air samplers. The overall effect of reduced sample volumes was radionuclide concentrations that appeared to be higher than those measured at the other site samplers. Air sample concentrations are mathematically calculated by dividing the concentration (picocuries) measured in the laboratory by the sample volume (cubic meters of air that passed through the filter). Environmental air sample concentrations are typically very low (at or near background levels) and when divided by a 


\begin{tabular}{|c|c|c|c|c|c|}
\hline \multicolumn{5}{|c|}{ Table 3.2.2. Near-Facility Air Sampling Locations and Analyses, 2001} & \\
\hline \multirow{2}{*}{\multicolumn{3}{|c|}{$\begin{array}{l}\text { Number of } \\
\text { Samplers }\end{array}$}} & \multirow[b]{2}{*}{$\underline{E D P ~ C o d e}^{(\mathrm{a})}$} & Analyses & \\
\hline & & & & Biweekly & Composite \\
\hline \multicolumn{2}{|c|}{$\begin{array}{l}100-\mathrm{B} / \mathrm{C} \text { remedial action } \\
\text { project }\end{array}$} & 3 & $\mathrm{~N} 464, \mathrm{~N} 465, \mathrm{~N} 466$ & $\begin{array}{l}\text { Gross alpha, } \\
\text { gross beta }\end{array}$ & $\begin{array}{l}\mathrm{GEA},{ }^{(\mathrm{b})} \mathrm{Sr}-90, \mathrm{Pu} \text {-iso, }{ }^{(\mathrm{c})} \\
\mathrm{U}^{-i \mathrm{so}^{(\mathrm{d})}}\end{array}$ \\
\hline \multicolumn{2}{|c|}{$\begin{array}{l}105-\mathrm{D} \text { interim safe storage } \\
\text { project }\end{array}$} & 1 & N523 & $\begin{array}{l}\text { Gross alpha, } \\
\text { gross beta }\end{array}$ & $\begin{array}{l}\text { GEA, Sr-90, Pu-iso, } \\
\text { U-iso }\end{array}$ \\
\hline \multicolumn{2}{|c|}{$\begin{array}{l}105-\mathrm{DR} \text { interim safe storage } \\
\text { project }\end{array}$} & 2 & N492, N493 & $\begin{array}{l}\text { Gross alpha, } \\
\text { gross beta }\end{array}$ & $\begin{array}{l}\text { GEA, Sr-90, Pu-iso, } \\
\text { U-iso }\end{array}$ \\
\hline \multicolumn{2}{|c|}{$\begin{array}{l}105-\mathrm{F} \text { interim safe storage } \\
\text { project }\end{array}$} & 2 & N494, N495 & $\begin{array}{l}\text { Gross alpha, } \\
\text { gross beta }\end{array}$ & $\begin{array}{l}\text { GEA, Sr-90, Pu-iso, } \\
\text { U-iso }\end{array}$ \\
\hline \multicolumn{2}{|c|}{$\begin{array}{l}\text { 105-F remedial action } \\
\text { project }\end{array}$} & 4 & N519, N520, N521, N522 & $\begin{array}{l}\text { Gross alpha, } \\
\text { gross beta }\end{array}$ & $\begin{array}{l}\text { GEA, Sr-90, Pu-iso, } \\
\text { U-iso }\end{array}$ \\
\hline \multicolumn{2}{|c|}{$\begin{array}{l}105-\mathrm{H} \text { interim safe storage } \\
\text { project }\end{array}$} & 2 & N524, N525 & $\begin{array}{l}\text { Gross alpha, } \\
\text { gross beta }\end{array}$ & $\begin{array}{l}\text { GEA, Sr-90, Pu-iso, } \\
\text { U-iso }\end{array}$ \\
\hline \multicolumn{2}{|c|}{$\begin{array}{l}100-\mathrm{H} \text { remedial action } \\
\text { project }\end{array}$} & 4 & N507, N508, N509, N510 & $\begin{array}{l}\text { Gross alpha, } \\
\text { gross beta }\end{array}$ & $\begin{array}{l}\text { GEA, Sr-90, Pu-iso, } \\
\text { U-iso }\end{array}$ \\
\hline \multicolumn{2}{|c|}{$100-\mathrm{K}$ spent nuclear fuels } & 8 & $\begin{array}{l}\text { N401, N402, N403, N404, } \\
\text { N476, N477, N478, N479 }\end{array}$ & $\begin{array}{l}\text { Gross alpha, } \\
\text { gross beta }\end{array}$ & $\begin{array}{l}\text { GEA, Sr-90, Pu-iso, } \\
\text { U-iso, Pu-241, Am-241 }\end{array}$ \\
\hline \multicolumn{2}{|c|}{$\begin{array}{l}\text { 100-NR-1 remedial action } \\
\text { and } 100-\mathrm{N} \text { surveillance, } \\
\text { maintenance/transition } \\
\text { projects }\end{array}$} & 5 & $\begin{array}{l}\text { N102, N103, N105, N106, } \\
\text { N526 }\end{array}$ & $\begin{array}{l}\text { Gross alpha, } \\
\text { gross beta }\end{array}$ & $\begin{array}{l}\text { GEA, Sr-90, Pu-iso, } \\
\text { U-iso }\end{array}$ \\
\hline \multicolumn{2}{|c|}{ 200-East Area } & 17 & $\begin{array}{l}\text { N019, N158, N498, N499, } \\
\text { N957, N967, N968, N969, } \\
\text { N970, N972, N973, N976, } \\
\text { N977, N978, N984, N985, } \\
\text { N999 }\end{array}$ & $\begin{array}{l}\text { Gross alpha, } \\
\text { gross beta }\end{array}$ & $\begin{array}{l}\text { GEA, Sr-90, Pu-iso, } \\
\text { U-iso }\end{array}$ \\
\hline \multicolumn{2}{|c|}{$\begin{array}{l}\text { Canister Storage Building, } \\
\text { 200-East Area }\end{array}$} & 2 & $\mathrm{~N} 480, \mathrm{~N} 481$ & $\begin{array}{l}\text { Gross alpha, } \\
\text { gross beta }\end{array}$ & $\begin{array}{l}\text { GEA, Sr-90, Pu-iso, } \\
\text { U-iso, } \mathrm{Pu}-241, \mathrm{Am}-241\end{array}$ \\
\hline \multicolumn{2}{|c|}{ 200-West Area } & 21 & $\begin{array}{l}\text { N155, N161, N165, N168, } \\
\text { N200, N304, N433, N441, } \\
\text { N442, N449, N456, N457, } \\
\text { N956, N963, N964, N965, } \\
\text { N966, N974, N975, N987, } \\
\text { N994 }\end{array}$ & $\begin{array}{l}\text { Gross alpha, } \\
\text { gross beta }\end{array}$ & $\begin{array}{l}\text { GEA, Sr-90, Pu-iso, } \\
\text { U-iso }\end{array}$ \\
\hline \multicolumn{2}{|c|}{300 Area } & 1 & N130 & $\begin{array}{l}\text { Gross alpha, } \\
\text { gross beta }\end{array}$ & $\begin{array}{l}\text { GEA, Sr-90, Pu-iso, } \\
\text { U-iso }\end{array}$ \\
\hline \multirow{2}{*}{\multicolumn{2}{|c|}{$\begin{array}{l}\text { Environmental Restoration } \\
\text { Disposal Facility } \\
600 \text { Area }\end{array}$}} & 3 & N482, N517, N518 & $\begin{array}{l}\text { Gross alpha, } \\
\text { gross beta }\end{array}$ & $\begin{array}{l}\text { GEA, Sr-90, Pu-iso, } \\
\text { U-iso }\end{array}$ \\
\hline & & 1 & N981 & $\begin{array}{l}\text { Gross alpha, } \\
\text { gross beta }\end{array}$ & $\begin{array}{l}\text { GEA, Sr-90, Pu-iso, } \\
\text { U-iso }\end{array}$ \\
\hline \multicolumn{6}{|c|}{$\begin{array}{l}\text { (a) EDP Code = Sampler location code. See PNNL-13910, APP. } 2 . \\
\text { (b) GEA = Gamma energy analysis. } \\
\text { (c) Isotopic plutonium-238 and }-239 / 240 . \\
\text { (d) Isotopic uranium-234, }-235 \text {, and }-238 .\end{array}$} \\
\hline
\end{tabular}




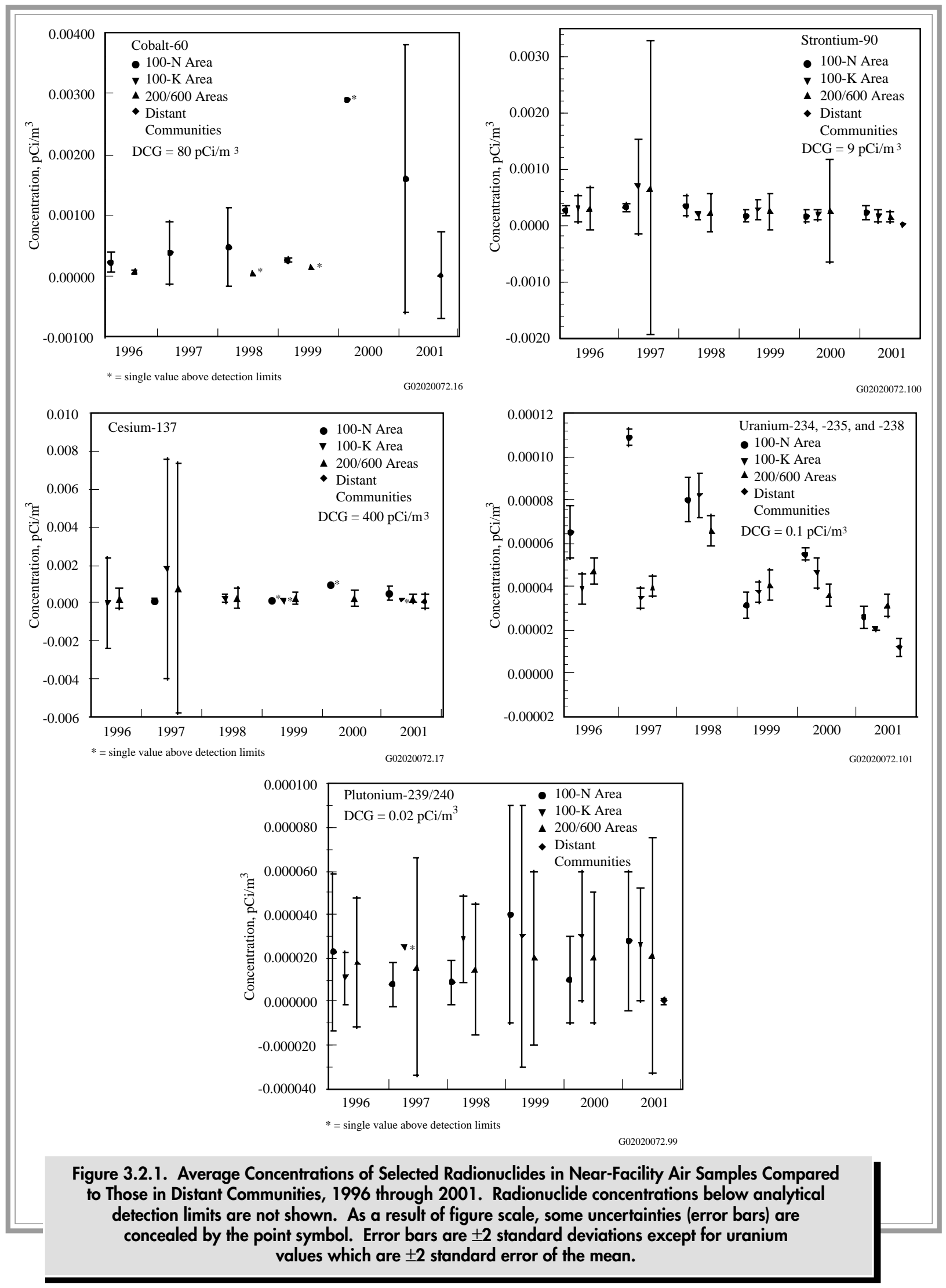


Table 3.2.3. Annual Average and Maximum Concentrations $\left(\mathrm{aCi} / \mathrm{m}^{3}\right)^{(\mathrm{a})}$ of Radionuclides in Near-Facility Air Samples, 2001

\begin{tabular}{|c|c|c|c|c|c|c|c|}
\hline \multicolumn{8}{|c|}{$\begin{array}{l}\text { Table 3.2.3. Annual Average and Maximum Concentrations }\left(\mathrm{aCi} / \mathrm{m}^{3}\right)^{(\mathrm{a})} \text { of Radionuclides } \\
\text { in Near-Facility Air Samples, } 2001\end{array}$} \\
\hline \multicolumn{4}{|c|}{ Cobalt-60 } & \multicolumn{4}{|c|}{$\underline{\text { Uranium-234 }}$} \\
\hline Site & Average $^{(\mathbf{b})}$ & Maximum $^{(\mathrm{c})}$ & EDP Code ${ }^{(d)}$ & Site & A verage $^{(\mathbf{b})}$ & Maximum $^{(\mathrm{c})}$ & EDP Code ${ }^{(\mathrm{d})}$ \\
\hline$\overline{100}-\mathrm{B} / \mathrm{C} \mathrm{RA}^{(\mathrm{e})}$ & $-17 \pm 150$ & $52 \pm 76$ & $\mathrm{~N} 466$ & $100-\mathrm{B} / \mathrm{C} \mathrm{RA}^{(\mathrm{e})}$ & $12 \pm 4.6$ & $15 \pm 8.9$ & $\mathrm{~N} 465$ \\
\hline 100-F RA & $-3.8 \pm 69$ & $31 \pm 92$ & N519 & 100-F RA & $16 \pm 11$ & $26 \pm 13$ & N522 \\
\hline 100-H RA & $45 \pm 150$ & $180 \pm 190$ & N508 & 100-H RA & $8.7 \pm 12$ & $14 \pm 11$ & N508 \\
\hline $105-\mathrm{DR} / \mathrm{F} / \mathrm{D} / \mathrm{H}$ & & & & $105-\mathrm{DR} / \mathrm{F} / \mathrm{D} / \mathrm{H}$ & & & \\
\hline $\mathrm{ISS}^{(f)}$ & $30 \pm 180$ & $210 \pm 120$ & N524 & $\mathrm{ISS}^{(\mathrm{f})}$ & $20 \pm 12$ & $35 \pm 20$ & N493 \\
\hline $100-K$ & $4.5 \pm 73$ & $65 \pm 74$ & N479 & $100-\mathrm{K}$ & $10 \pm 9.8$ & $26 \pm 12$ & $\mathrm{~N} 403$ \\
\hline $100-\mathrm{N}^{(\mathrm{g})}$ & $1,600 \pm 2,200$ & $2,900 \pm 830$ & N105 & $100-\mathrm{N}^{(\mathrm{g})}$ & $13 \pm 6.2$ & $19 \pm 9.9$ & N106 \\
\hline 200-East & $9.3 \pm 71$ & $100 \pm 88$ & N985 & 200-East & $13 \pm 11$ & $27 \pm 12$ & N969 \\
\hline 200-West & $1.1 \pm 80$ & $120 \pm 99$ & N165 & 200-West & $15 \pm 10$ & $25 \pm 13$ & N956 \\
\hline 300 Area & $6.2 \pm 45$ & $22 \pm 65$ & N130 & 300 Area & $12 \pm 1.9$ & $13 \pm 7.6$ & N130 \\
\hline $\mathrm{ERDF}^{(\mathrm{h})}$ & $290 \pm 10$ & $300 \pm 140$ & N482 & $\mathrm{ERDF}^{(\mathrm{h})}$ & $18 \pm 5.2$ & $23 \pm 11$ & N517 \\
\hline $\begin{array}{l}\text { Distant } \\
\text { community }^{(i)} \\
\text { DCG }^{(j)}\end{array}$ & $20 \pm 700$ & $\begin{array}{l}450 \pm 120 \\
80,000,000\end{array}$ & & $\begin{array}{l}\text { Distant } \\
\text { community }^{(i)} \\
\text { DCG }^{(j)}\end{array}$ & $13 \pm 13$ & $\begin{array}{l}27 \pm 11 \\
90,000\end{array}$ & \\
\hline \multicolumn{4}{|c|}{ Strontium-90 } & \multicolumn{4}{|c|}{$\underline{\text { Uranium-235 }}$} \\
\hline Site & Average $^{(b)}$ & $\underline{\text { Maximum }}^{(\mathrm{c})}$ & $\underline{E D P ~ C o d e}^{(\mathrm{d})}$ & Site & Average $^{(b)}$ & $\underline{\text { Maximum }}^{(c)}$ & EDP Code \\
\hline$\overline{100}-\mathrm{B} / \mathrm{C} \mathrm{RA}^{(\mathrm{e})}$ & $\overline{140 \pm 100}$ & $\overline{140 \pm 100}$ & $\mathrm{~N} 466$ & $100-\mathrm{B} / \mathrm{C} \mathrm{RA}^{(\mathrm{e})}$ & $7.4 \pm 2.2$ & $8.5 \pm 6.5$ & N465 \\
\hline 100-F RA & $190 \pm 88$ & $250 \pm 130$ & N519 & 100-F RA & $4.6 \pm 0.19$ & $4.7 \pm 4.2$ & N520 \\
\hline $\begin{array}{l}\text { 100-H RA } \\
105-\mathrm{DR} / \mathrm{F} / \mathrm{D} / \mathrm{H}\end{array}$ & $25 \pm 80$ & $280 \pm 230$ & N507 & $\begin{array}{l}\text { 100-H RA } \\
105-\mathrm{DR} / \mathrm{F} / \mathrm{D} / \mathrm{H}\end{array}$ & $6.6 \pm 13$ & $12 \pm 13$ & N509 \\
\hline $\mathrm{ISS}^{(f)}$ & $460 \pm 880$ & $1,900 \pm 950$ & N523 & ISS $^{(f)}$ & $9.1 \pm 4.0$ & $13 \pm 9.6$ & $\mathrm{~N} 492$ \\
\hline $100-K$ & $170 \pm 110$ & $270 \pm 130$ & N479 & $100-\mathrm{K}$ & $1.9 \pm 2.7$ & $4.3 \pm 5.3$ & N478 \\
\hline $100-\mathrm{N}^{(\mathrm{g})}$ & $230 \pm 120$ & $290 \pm 140$ & N102 & $100-\mathrm{N}^{(\mathrm{g})}$ & $5.2 \pm 2.4$ & $6.4 \pm 5.3$ & N102 \\
\hline 200-East & $160 \pm 98$ & $300 \pm 130$ & N480 & 200-East & $5.8 \pm 2.4$ & $7.8 \pm 5.3$ & N984 \\
\hline 200-West & $160 \pm 110$ & $270 \pm 120$ & N161 & 200-West & $4.8 \pm 2.6$ & $9.0 \pm 7.3$ & N168 \\
\hline 300 Area & $32 \pm 150$ & $85 \pm 84$ & N130 & 300 Area & $2.6 \pm 2.7$ & $3.5 \pm 4.3$ & N130 \\
\hline $\mathrm{ERDF}^{(\mathrm{h})}$ & $220 \pm 110$ & $280 \pm 120$ & N517 & $\mathrm{ERDF}^{(\mathrm{h})}$ & $3.1 \pm 4.9$ & $6.3 \pm 5.6$ & $\mathrm{~N} 482$ \\
\hline $\begin{array}{l}\text { Distant } \\
\text { community }^{(i)} \\
\text { DCG }^{(j)}\end{array}$ & $-29 \pm 63$ & $\begin{array}{c}14 \pm 56 \\
9,000,000\end{array}$ & & $\begin{array}{l}\text { Distant } \\
\text { community } \\
\text { DCG }^{(\mathrm{i})}\end{array}$ & $0.30 \pm 0.40$ & $\begin{array}{c}0.67 \pm 2.9 \\
100,000\end{array}$ & \\
\hline \multicolumn{4}{|c|}{ Cesium-137 } & \multicolumn{4}{|c|}{$\underline{\text { Uranium-238 }}$} \\
\hline Site & Average $^{(b)}$ & $\underline{\text { Maximum }}^{(c)}$ & $\underline{\text { EDP Code }}^{(\mathrm{d})}$ & Site & A verage $^{(\mathbf{b})}$ & $\underline{\text { Maximum }}^{(c)}$ & EDP Code \\
\hline$\overline{100}-\mathrm{B} / \mathrm{C} \mathrm{RA}^{(\mathrm{e})}$ & $18 \pm 120$ & $57 \pm 110$ & N464 & $\overline{100}-\mathrm{B} / \mathrm{C} \mathrm{RA}^{(\mathrm{e})}$ & $12 \pm 4.4$ & $14 \pm 8.5$ & $\mathrm{~N} 466$ \\
\hline 100-F RA & $5.3 \pm 45$ & $46 \pm 76$ & N519 & 100-F RA & $12 \pm 13$ & $26 \pm 12$ & N522 \\
\hline 100-H RA & $-41 \pm 300$ & $87 \pm 190$ & N509 & 100-H RA & $1.9 \pm 3.8$ & $9.6 \pm 9.3$ & N508 \\
\hline $105-\mathrm{DR} / \mathrm{F} / \mathrm{D} / \mathrm{H}$ & & & & $105-\mathrm{DR} / \mathrm{F} / \mathrm{D} / \mathrm{H}$ & & & \\
\hline $\mathrm{ISS}^{(f)}$ & $37 \pm 190$ & $350 \pm 780$ & N523 & $\mathrm{ISS}^{(f)}$ & $18 \pm 17$ & $43 \pm 21$ & $\mathrm{~N} 493$ \\
\hline $100-\mathrm{K}$ & $48 \pm 100$ & $160 \pm 150$ & N476 & $100-\mathrm{K}$ & $10 \pm 10$ & $26 \pm 12$ & $\mathrm{~N} 403$ \\
\hline $100-\mathrm{N}^{(\mathrm{g})}$ & $520 \pm 360$ & $740 \pm 270$ & N105 & $100-\mathrm{N}^{(\mathrm{g})}$ & $7.9 \pm 3.2$ & $11 \pm 6.8$ & N103 \\
\hline 200-East & $230 \pm 110$ & $340 \pm 190$ & N984 & 200-East & $12 \pm 8.2$ & $21 \pm 11$ & N984 \\
\hline 200-West & $260 \pm 280$ & $570 \pm 240$ & N155 & 200-West & $13 \pm 9.6$ & $25 \pm 12$ & N457 \\
\hline 300 Area & $-5.5 \pm 78$ & $22 \pm 61$ & N130 & 300 Area & $11 \pm 9.0$ & $16 \pm 8.6$ & N130 \\
\hline $\mathrm{ERDF}^{(\mathrm{h})}$ & $150 \pm 36$ & $160 \pm 130$ & $\mathrm{~N} 482$ & $\mathrm{ERDF}^{(\mathrm{h})}$ & $13 \pm 9.6$ & $20 \pm 10$ & N517 \\
\hline $\begin{array}{l}\text { Distant } \\
\text { community }^{(i)} \\
\text { DCG }^{(i)}\end{array}$ & $100 \pm 420$ & $\begin{array}{c}400 \pm 510 \\
400,000,000\end{array}$ & & $\begin{array}{l}\text { Distant } \\
\text { community }^{(i)} \\
\text { DCG }^{(j)}\end{array}$ & $14 \pm 11$ & $\begin{array}{l}24 \pm 10 \\
100,000\end{array}$ & \\
\hline
\end{tabular}


Table 3.2.3. (contd)

\begin{tabular}{|c|c|c|c|c|c|c|c|}
\hline \multicolumn{8}{|c|}{ Table 3.2.3. (contd) } \\
\hline \multicolumn{8}{|c|}{ Plutonium-238 } \\
\hline Site & Average $^{(\mathbf{b})}$ & Maximum $^{(c)}$ & EDP Code ${ }^{(d)}$ & \multicolumn{4}{|c|}{ Plutonium-241 } \\
\hline \multirow{2}{*}{$\begin{array}{l}100-\mathrm{B} / \mathrm{CRA}^{(\mathrm{e})} \\
100-\mathrm{RA}\end{array}$} & $80 . \pm 10$ & $13 \pm 11$ & N464 & Site & Average $^{(b)}$ & Maximum $^{(c)}$ & EDP Code ${ }^{(\mathrm{d})}$ \\
\hline & $3.3 \pm 12$ & $16 \pm 14$ & N520 & $\frac{310}{100-K}$ & $-30 \pm 690$ & $530 \pm 190$ & $\mathrm{~N} 478$ \\
\hline $\begin{array}{l}\text { 100-H RA } \\
105-\mathrm{DR} / \mathrm{F} / \mathrm{D} / \mathrm{H}\end{array}$ & $-0.59 \pm 12$ & $30 \pm 27$ & N507 & 200-East & $-340 \pm 650$ & $-49 \pm 50$ & $\mathrm{~N} 480$ \\
\hline $\begin{array}{l}\text { ISS }{ }^{(f)} \\
\text { If }^{\prime} / \mathrm{D} / \mathrm{H} \\
\end{array}$ & $17 \pm 22$ & $28 \pm 21$ & $\mathrm{~N} 493$ & $\begin{array}{l}\text { Distant } \\
\text { community }\end{array}$ & & Not reported & \\
\hline $100-\mathrm{K}$ & $-0.094 \pm 19$ & $14 \pm 21$ & N401 & $\begin{array}{l}\text { community }^{(1)} \\
\text { DCG }^{(j)}\end{array}$ & & $\begin{array}{l}\text { Not reported } \\
1,000,000\end{array}$ & \\
\hline $100-\mathrm{N}^{(\mathrm{g})}$ & $2.7 \pm 15$ & $18 \pm 16$ & N105 & & & & \\
\hline 200-East & $2.4 \pm 11$ & $19 \pm 23$ & N480 & \multirow{2}{*}{\multicolumn{4}{|c|}{ Americium-241 }} \\
\hline 200-West & $2.7 \pm 11$ & $16 \pm 11$ & N457 & & & & \\
\hline 300 Area & $2.6 \pm 1.6$ & $3.1 \pm 8.7$ & N130 & Site & Average $^{(b)}$ & Maximum $^{(c)}$ & EDP Code $^{(\mathrm{d})}$ \\
\hline $\mathrm{ERDF}^{(\mathrm{h})}$ & $2.7 \pm 11$ & $9.3 \pm 11$ & N518 & $100-\mathrm{K}$ & $5.5 \pm 11$ & $15 \pm 10$ & N476 \\
\hline $\begin{array}{l}\text { Distant } \\
\text { community }^{(i)} \\
\text { DCG }^{(j)}\end{array}$ & $-0.53 \pm 0.69$ & $\begin{array}{c}0.15 \pm 1.8 \\
30,000\end{array}$ & & $\begin{array}{l}\text { 200-East } \\
\text { Distant } \\
\text { community }^{(i)} \\
\text { DCG }^{(j)}\end{array}$ & $3.2 \pm 2.9$ & $\begin{array}{c}4.7 \pm 9.0 \\
\text { Not reported } \\
20,000\end{array}$ & $\mathrm{~N} 480$ \\
\hline & Plutoni & $1-239 / 240$ & & & & & \\
\hline Site & Average $^{(b)}$ & Maximum $^{(\mathrm{c})}$ & EDP Code $^{(d)}$ & & & & \\
\hline $100-\mathrm{B} / \mathrm{C} \mathrm{RA}^{(\mathrm{e})}$ & $1.8 \pm 2.0$ & $3.0 \pm 4.5$ & $\mathrm{~N} 464$ & & & & \\
\hline 100-F RA & $9.9 \pm 2.8$ & $11 \pm 6.8$ & N521 & & & & \\
\hline 100-H RA & $18 \pm 160$ & $42 \pm 23$ & N507 & & & & \\
\hline & & & & & & & \\
\hline \multirow{2}{*}{$\begin{array}{l}\text { ISS }^{(f)} \\
100-K\end{array}$} & $35 \pm 76$ & $130 \pm 62$ & N523 & & & & \\
\hline & $26 \pm 26$ & $48 \pm 24$ & $\mathrm{~N} 403$ & & & & \\
\hline $100-\mathrm{N}^{(\mathrm{g})}$ & $28 \pm 32$ & $50 \pm 18$ & N105 & & & & \\
\hline 200-East & $8.5 \pm 9.0$ & $19 \pm 9.4$ & N968 & & & & \\
\hline 200-West & $27 \pm 82$ & $180 \pm 61$ & N449 & & & & \\
\hline 300 Area & $0.055 \pm 2.1$ & $0.79 \pm 0.82$ & N130 & & & & \\
\hline $\mathrm{ERDF}^{(\mathrm{h})}$ & $81 \pm 320$ & $430 \pm 130$ & N482 & & & & \\
\hline $\begin{array}{l}\text { Distant } \\
\text { community }^{(i)} \\
\text { DCG }^{(j)}\end{array}$ & $0.19 \pm 1.6$ & $\begin{array}{c}1.6 \pm 2.1 \\
20,000\end{array}$ & & & & & \\
\hline (a) To convert & t to internation & netric system un & ts, multiply aCi & 000037 to obtai & $3 \mathrm{q} / \mathrm{m}^{3}$. & & \\
\hline (b) \pm 2 standar & d deviations. & & & & & & \\
\hline (c) \pm total ana & alytical uncertai & & & & & & \\
\hline (d) See PNNL & -13910, APP. 2 & & & & & & \\
\hline (e) $\mathrm{RA}=\mathrm{Rem}$ & nedial Action pr & & & & & & \\
\hline (f) ISS = Inte & rim Safe Storag & roject. & & & & & \\
\hline (g) Includes 1 & 00-NR-1 remed & action project at & d $100-\mathrm{N}$ surveil & naintenance/tran & ion project. & & \\
\hline (h) $\quad \mathrm{ERDF}=\mathrm{Er}$ & nvironmental R & oration Disposal & Facility. & & & & \\
\hline (i) See Sectio & n 4.1 & & & & & & \\
\hline (j) DOE Deri & ved Concentrat & Guide. & & & & & \\
\hline
\end{tabular}

small sample volume, the resulting concentration will appear to be higher than the calculated concentration obtained from an air sample with a higher (normal) sample volume.

The airborne contaminant levels in the 100-K Area were similar to those measured over the previous years. Facility emissions in the 100-K Area decreased substantially in 1996 and subsequent radionuclide concentrations in the ambient air samples have been near detection limits. Strontium-90 and uranium-234 and -238 were detected consistently. Occasionally, plutonium-239/240 and americium-241 were detected also.
Analytical results for ambient air samples from the 100-NR-1 remedial action and 100-N surveillance and maintenance/transition projects in 2001 were similar to those measured in previous years. A fifth air sampling location was added in August 2001 at the 100-NR-1 project to monitor ambient air near remedial action activities at the $116-\mathrm{N}-3$ treatment, storage, and disposal unit. Strontium-90, uranium-234 and -238 , and plutonium-239/240 were detected consistently. Occasionally detected were cobalt-60, cesium-137, uranium-238, and plutonium-238. Cobalt-60 was detected at only one of the five 100-N Area air sampling locations in 2001. The concentrations of cobalt-60 at 
this location were considerably higher than at any other near-facility air sampling location at Hanford in 2001. The sampling location was near the retired $1325-\mathrm{N}$ Liquid Waste Disposal Facility (116-N-3 treatment, storage, and disposal facility), which was being excavated to remove contaminated soil throughout 2001.

In 2001, radionuclide levels measured in the 200-East Area were generally similar to those measured over the previous years. Strontium-90, uranium-234 and -238 , and plutonium-239/240 were detected consistently. Occasionally, cesium-137 and uranium-235 were detected.

Radionuclide levels measured in the 200-West Area were similar to results for previous years. Uranium-234 and -238 and plutonium-239/240 were detected consistently. Strontium-90, cesium-137, and uranium-235 were occasionally detected.
The air sampling network at the Environmental Restoration Disposal Facility (200-West Area) used two existing Hanford Site samplers for upwind monitoring (one near-facility sampler, "N-963;" one Pacific Northwest National Laboratory sampler, station \#13 "200 W SE" [see Section 4.1]) and three air samplers at the facility that provided downwind coverage. The 2001 analytical results indicated that strontium-90, uranium-234, -235 , and -238 , and plutonium-239/240 levels were slightly higher than 2000 levels. Consistently detected were uranium-234 and -238 and plutonium239/240. Cobalt-60, cesium-137, and strontium-90 were occasionally detected.

The remedial action, interim safe storage, and surveillance and maintenance/transition projects discussed above are described in more detail in Section 2.3.10.

\subsubsection{Spring Water Monitoring}

In the past, radioactive effluent streams were sent to the $1301-\mathrm{N}$ and $1325-\mathrm{N}$ Liquid Waste Disposal Facilities in the 100-N Area. After moving through the soil column to the water table, this waste migrated with the groundwater and contributed to the release of radionuclides to the Columbia River. Radionuclides from these facilities enter the Columbia River along the riverbank region sometimes called N Springs. Groundwater springs and/or shoreline seepage wells at the $\mathrm{N}$ Springs are sampled annually to verify that the reported radionuclide releases to the Columbia River are conservative (i.e., not underreported). The amount of radionuclides entering the Columbia River at these springs (i.e., release) is calculated based on analyses of monthly samples collected from monitoring well 199-N-46 located near the shoreline. Analytical results and discussion of these releases may be found in Section 3.1 and in HNF-EP-0527-11. A groundwater pump-and-treat system designed to reduce the discharge of strontium-90 to the Columbia River in the $100-\mathrm{N}$ Area was put into operation in 1995 and continued to operate in 2001.
Additional discussion about this system and its effects may be found in Section 6.2.

In October 2001, samples were collected from ten 100-N Area shoreline wells. The samples were collected using a bailer carefully lowered into the water column of each well to avoid sediment suspension, and a 4-liter (1-gallon) sample was obtained. Analyses of these samples detected tritium, strontium-90, and gammaemitting radionuclides.

In 2001, the levels of strontium-90 detected in samples from riverbank springs were highest in N Springs wells Y302 and Y303, which are nearest well 199-N-46. None of the concentrations exceeded the DOE derived concentration guide value. Tritium and gammaemitting radionuclide concentrations were below analytical detection limits in 2001. Tritium and strontium-90 data from 2001 riverbank springs sampling are summarized in Table 3.2.4.

\subsection{Radiological Surveys of Surface Contam ination}

Radiological surveys are used to monitor and detect contamination on the Hanford Site. The main types of contaminated areas are underground radioactive materials areas, contamination areas, soil contamination areas, and high contamination areas.

Underground radioactive materials areas are areas that have contamination contained below the soil surface. These areas are typically stabilized cribs, burial grounds, covered ponds, trenches, and ditches. Barriers over the contamination sources are used to inhibit radionuclide transport to the surface environs. These areas are surveyed at least annually to document the current radiological status.

Contamination/soil contamination areas may or may not be associated with an underground structure containing radioactive material. A breach in the surface 


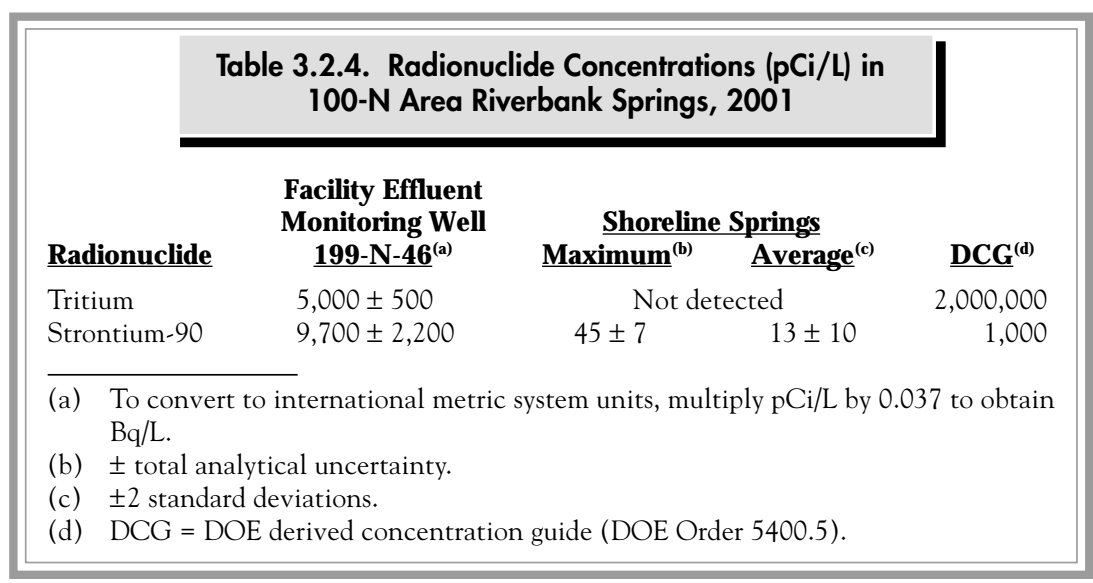

barrier of a contaminated underground area may result in the growth of contaminated vegetation. Insects or animals may burrow into the soil and bring contamination to the surface. Vent pipes or risers from an underground structure may be a source of speck contamination (particles with a diameter less than 0.6 centimeter [0.25 inch]). Areas of contamination not related to subsurface structures can include sites contaminated with fallout from effluent stacks and sites that are the result of unplanned releases (e.g., contaminated tumbleweeds, animal feces). All contaminated areas may be susceptible to contamination migration and are surveyed at least annually to document the current radiological status (locations of contaminated areas are illustrated in PNNL-13910, APP. 2).

At the end of 2001, the Hanford Site had 3,638 hectares $(\sim 8,990$ acres $)$ of posted outdoor contamination areas (all types) and 668 hectares (1,650 acres) of posted underground radioactive materials areas not including active facilities. It was estimated that the external dose rate at $80 \%$ of the outdoor contaminated areas was less than $1 \mathrm{mrem} / \mathrm{h}(0.01 \mathrm{mSv} / \mathrm{h})$, though direct dose rate readings from isolated radioactive specks could have been higher. Table 3.2.5 lists the contaminated areas and underground radioactive materials areas. Vehicles equipped with radiation detection devices and a global positioning system were again used in 2001 to more accurately measure the extent of the contamination. Area measurements are entered into the Hanford Geographical Information System, a computer database maintained by Bechtel Hanford, Inc.

The number and size of contaminated areas vary from year to year for several reasons: stabilization of areas of known contamination, discovery of new areas of contamination, and/or ongoing improvement of the geographical measurements of contaminated areas. Table 3.2.6 summarizes the effects of these efforts during 2001.

Stabilization activities in 2001 resulted in the re-classification of $\sim 14$ hectares ( 34 acres) from contamination/soil contamination areas to underground radioactive materials areas in the 100 and 200 Areas.

Though small areas of contamination were newly identified in 2001, no individual large areas were found. During 2001, $\sim 18$ hectares ( 44 acres) across the site were either newly discovered contamination/soil contamination areas or had their boundaries re-defined.

\subsubsection{Soil and Vegetation Monitoring}

Soil and vegetation samples were collected on, or adjacent to, waste disposal sites and from locations downwind and near or within the boundaries of operating facilities and remedial action sites. Samples were collected to evaluate long-term trends in environmental accumulation of radioactivity and to detect potential migration and deposition of facility effluents. Special samples also were collected where potential physical or biological pathway problems were identified. Contaminant movement can occur as the result of resuspension from radioactively contaminated surface areas, absorption of radionuclides by the roots of vegetation growing on or near underground and surface-water disposal units, or animal activities at the waste site. The sampling methods and locations used are discussed in detail in DFSNW-OEM-001. Radiological analyses of soil and vegetation samples included strontium-90, isotopic uranium, isotopic plutonium, and gamma-emitting radionuclides.

The number and location of soil and vegetation samples collected in 2001 are summarized in Table 3.2.1. A comprehensive presentation of the analytical data can be found in PNNL-13910, APP. 2. Only those radionuclide concentrations above analytical detection limits are discussed in this section.

Each 1-kilogram (2.2-pound) soil sample represented a composite of five plugs of soil, each 2.5 centimeters ( 1 inch) deep and 10 centimeters ( 4 inches) in diameter collected from each site. Each vegetation sample ( $\sim 500$ grams [ 16.1 ounces]) consists of new-growth 
leaf cuttings taken from the available species of interest at a sample location. Often, the vegetation sample consisted of a composite of several like members of the sampling site plant community to avoid decimation of any individual plant through overharvesting.

In the spring through early summer of each year, soil and vegetation samples are collected on the Hanford Site and submitted for radioanalyses. The analyses include those for radionuclides expected to be found in the areas sampled (i.e., gamma-emitting radionuclides, strontium isotopes, uranium isotopes, and/or plutonium isotopes). The results are then compared to levels found at various offsite sampling locations in Yakima, Benton, and Franklin Counties (see Section 4.6). Comparison of the levels can be used to determine the difference between contributions from site operations and remedial action sites and contributions from natural sources and worldwide fallout.

Soil sampling results also are compared to the "accessible soil" concentrations (WHC-SD-EN-TI-070) developed specifically for use at the Hanford Site (see PNNL-13910, APP. 2 for complete listing). These radioactive concentration values were established to assure that effective dose equivalents to the public do not exceed the established limits for any reasonable scenario, such as direct exposure, inadvertent ingestion, inhalation, and ingestion of food crops, including animal products. The accessible soil concentration values are based on a radiation dose estimate scenario where an individual would have to spend 100 hours per year in direct contact with the contaminated soil. The conservatism inherent in pathway modeling assures that the required degrees of protection are in place (WHC-SD-EN-TI070). These concentrations apply specifically to the Hanford Site with respect to onsite disposal operations, stabilization, cleanup, and decontamination and decommissioning operations.

Some degree of variability is always associated with the collection and analysis of environmental samples. Therefore, minor variations in concentrations from year to year are expected. In general, radionuclide concentrations in soil and vegetation samples collected from, or adjacent to, waste disposal facilities were higher than the concentrations in samples collected farther away and were significantly higher than concentrations measured offsite. The data also show, as expected, that concentrations of certain radionuclides were higher within different operational areas when compared to concentrations measured in distant communities. Generally, the predominant radionuclides were activation and fission products in the $100-\mathrm{N}$ Area, fission products in the 200 Areas, and uranium in the 300/400 Areas.
Table 3.2.5. Outdoor Contamination Status, 2001

\begin{tabular}{|c|c|c|c|c|}
\hline Area & \multicolumn{2}{|c|}{$\begin{array}{c}\text { Contamination } \\
\text { A reas, }^{\left({ }^{(a)}\right.} \text { ha (acres) }\end{array}$} & \multicolumn{2}{|c|}{$\begin{array}{c}\text { Underground } \\
\text { Radioactive Material } \\
\text { A reas, }{ }^{(b)} \text { ha (acres }\end{array}$} \\
\hline $100-B / C$ & 0 & $(0)$ & 39 & (96) \\
\hline $100-\mathrm{D} / \mathrm{DR}$ & 0 & (0) & 39 & (96) \\
\hline $100-\mathrm{F}$ & 0 & (0) & 34 & (84) \\
\hline $100-\mathrm{H}$ & 0 & $(0)$ & 14 & (35) \\
\hline $100-K$ & 9 & (22) & 62 & (153) \\
\hline $100-\mathrm{N}$ & 29 & $(72)$ & 12 & $(30)$ \\
\hline 200-East ${ }^{(c)}$ & 67 & (166) & 143 & (353) \\
\hline 200-West ${ }^{(\mathrm{c})}$ & 36 & (89) & 225 & $(556)$ \\
\hline 300 & 19 & $(47)$ & 45 & (111) \\
\hline 400 & 0 & (0) & 0 & (0) \\
\hline $600^{(d)}$ & 3,478 & $(8,594)$ & 55 & (136) \\
\hline Totals & 3,638 & $(8,990)$ & 668 & $(1,650)$ \\
\hline \multicolumn{5}{|r|}{$\begin{array}{l}\text { nination } \\
\text { oth } \\
\text { n/soil }\end{array}$} \\
\hline tion as & $\begin{array}{l}\text { eas with o } \\
\text { e areas tha } \\
\text { l as under } \\
\text { ink farms. }\end{array}$ & $\begin{array}{l}\text { ly undergrc } \\
\text { had contar } \\
\text { ound radio }\end{array}$ & $\begin{array}{l}\text { nd conta } \\
\text { nation/so } \\
\text { tive mat }\end{array}$ & $\begin{array}{l}\text { ation. Does } \\
\text { ontamina- } \\
\text {. }\end{array}$ \\
\hline $\begin{array}{l}\text { (d) Includ } \\
\text { outside } \\
\text { from } 2 \\
\text { waste } \\
\text { ary tha } \\
\text { 216-S- } \\
\text { Restor }\end{array}$ & $\begin{array}{l}\text { C controll } \\
200 \text {-East } \\
\text { East Area } \\
\text { ssal facilit } \\
\text { ceived was } \\
\text { 216-U-11 } \\
\text { n Disposal }\end{array}$ & $\begin{array}{l}\mathrm{d} \text { area and } \\
\text { Area bound } \\
\text { cilities (e.g } \\
\text { s outside th } \\
\text { e from } 200 \\
\text { The first } \\
\text { acility was }\end{array}$ & $\begin{array}{l}\text { aste dispo } \\
\text { y that rec } \\
216-A-25 \\
200-\text { Wes } \\
\text { lest Area } \\
1 \text { of the } \mathrm{E} \\
\text { dded duri }\end{array}$ & $\begin{array}{l}\text { facilities } \\
\text { ed waste } \\
\text { 16-B-3) and } \\
\text { rea bound- } \\
\text { ilities (e.g., } \\
\text { ronmental } \\
1997 \text {. }\end{array}$ \\
\hline
\end{tabular}

\begin{tabular}{|c|c|c|c|c|}
\hline \multicolumn{5}{|c|}{$\begin{array}{l}\text { Table 3.2.6. Zone Status Change of Posted } \\
\text { Contamination Areas, } 2001^{(a)}\end{array}$} \\
\hline \multicolumn{2}{|c|}{ Areas } & Zone Changes $^{(b)}$ & \multicolumn{2}{|c|}{ A rea, ha (acres) } \\
\hline 100 & & CA to URM & 8 & $(19.8)$ \\
\hline 100 & & None to CA & 3 & $(7.4)$ \\
\hline $200-\mathrm{H}$ & East & CA to URM & 4.5 & $(11.1)$ \\
\hline $200-1$ & West & CA to URM & 1.4 & $(3.5)$ \\
\hline $200-1$ & -West & None to CA & 6 & $(14.8)$ \\
\hline 300 & & None to CA & 8 & (19.7) \\
\hline 400 & & None to report & 0 & (0) \\
\hline 600 & & None to CA & 1 & $(2.5)$ \\
\hline (a) & \multicolumn{4}{|c|}{$\begin{array}{l}\text { Changes from stabilization activities, newly discovered } \\
\text { sites, or re-surveyed using a global positioning system. } \\
\text { CA = Contamination/soil contamination area. } \\
\text { URM = Underground radioactive materials area. }\end{array}$} \\
\hline
\end{tabular}




\subsubsection{Radiological Results for Soil Sam ples}

In Hanford soil samples, cobalt-60, strontium-90, cesium-137, plutonium-239/240, and uranium were detected consistently. The concentrations of these radionuclides were elevated near and within facility boundaries when compared to historical concentrations measured off the site. Figure 3.2.2 shows average soil values for 2001 and the preceding 5 years. The levels demonstrate a high degree of variability.

Generally, the surface soil samples collected near the 1301-N Liquid Waste Disposal Facility exhibited somewhat higher radionuclide concentrations than those collected at the other soil sampling locations in the $100-\mathrm{N}$ Area. Average radionuclide concentrations detected in the surface soil samples near the facility from 1996 through 2001 are presented in Table 3.2.7. Results were at or near historical levels measured on the Hanford Site, and the concentrations for most radionuclides were lower than the 2000 levels.

Average radionuclide concentrations detected in all of the surface soil samples collected in the 100-N Area from 1996 through 2001 are presented in Table 3.2.8. The average values for $100-\mathrm{N}$ Area soil were also down in 2001 for most radionuclides. The 2001 maximum, average, offsite average concentrations, and accessible soil concentrations are compared in Table 3.2.9.

Soil samples were collected from 57 of 111 sampling locations in the 200/600 Areas in 2001. Analytical results from soil samples taken from the 200/600 Areas showed generally level trends for the average values for all of the radionuclides measured in 2001. Sampling location D146, located at the southern end of the Environmental Restoration Disposal Facility in the 200-West Area, is now sampled on an annual basis. The 2001 maximum, average, offsite average, and accessible soil concentrations are compared in Table 3.2.10. Complete listings of radionuclide concentrations and sampling location maps are provided in PNNL-13910, APP. 2.

Soil samples were collected from 18 sampling locations in the 300/400 Areas in 2001: 17 from the 300 Area and 1 from the 400 Area. The 2001 maximum, average, offsite average concentrations, and accessible soil concentrations are compared in Table 3.2.11. Complete listings of radionuclide concentrations and sampling location maps are provided in PNNL-13910, APP. 2. For the samples collected in 2001, average values remained elevated for uranium isotopes but were much lower than the concentrations reported in 2000. Uranium concentrations were expected to be higher in the 300 Area samples than at other site locations because uranium was used during past fuel fabrication operations in the 300 Area.

In 2001, one soil sample was collected at the remedial action project in the 100-B/C Area, and two each at the remedial action projects in the $100-\mathrm{F}$ and $100-\mathrm{H}$ Areas. Four samples were collected from the 100-NR-1 remedial action project site. A single sample was collected from the Environmental Restoration Disposal Facility (200-West Area) to determine the effectiveness of contamination controls. Sample results from each of these locations were comparable to those seen at other locations at Hanford. The samples collected from these locations provide baseline data to be compared with future samples. Table 3.2.12 provides a summary of the analytical data for selected radionuclides. All of the 2001 data are provided in PNNL-13910, APP. 2.

\subsubsection{Radiological Results for Vegetation Samples}

In Hanford vegetation samples, cobalt-60, strontium-90, cesium-137, plutonium-239/240, and uranium were detected consistently. Concentrations of these radionuclides in vegetation were elevated near and within facility boundaries compared to concentrations measured off the site. Figure 3.2.3 shows average vegetation values for 2001 and the preceding 5 years. The results demonstrate a high degree of variability.

Average radionuclide concentrations detected in the vegetation samples near the retired 1301-N Liquid Waste Disposal Facility (also known as the 116-N-3 treatment, storage, and disposal unit) from 1996 through 2001 are presented in Table 3.2.13. In 2001, concentrations in these samples were well within the range of historical levels.

Average radionuclide concentrations detected in all of the vegetation samples collected in the 100-N Area from 1996 through 2001 are presented in Table 3.2.14. These concentrations were also within the range of historical values. The levels of cesium-137 and strontium-90 at the 100-N Area were higher than levels found in the 200 and 300/400 Areas.

Vegetation samples collected along the 100-N Area shoreline (N Springs) contain radionuclides that were not completely retained in the soil columns beneath the retired 1301-N and 1325-N Liquid Waste Disposal Facilities. Radionuclides concentrations were similar in 2000 and 2001, with the exception of a single positive result for cobalt-60 in 2001. Table 3.2.15 shows the average radionuclide concentrations detected in the vegetation samples collected along N Springs from 1996 to 2001. 


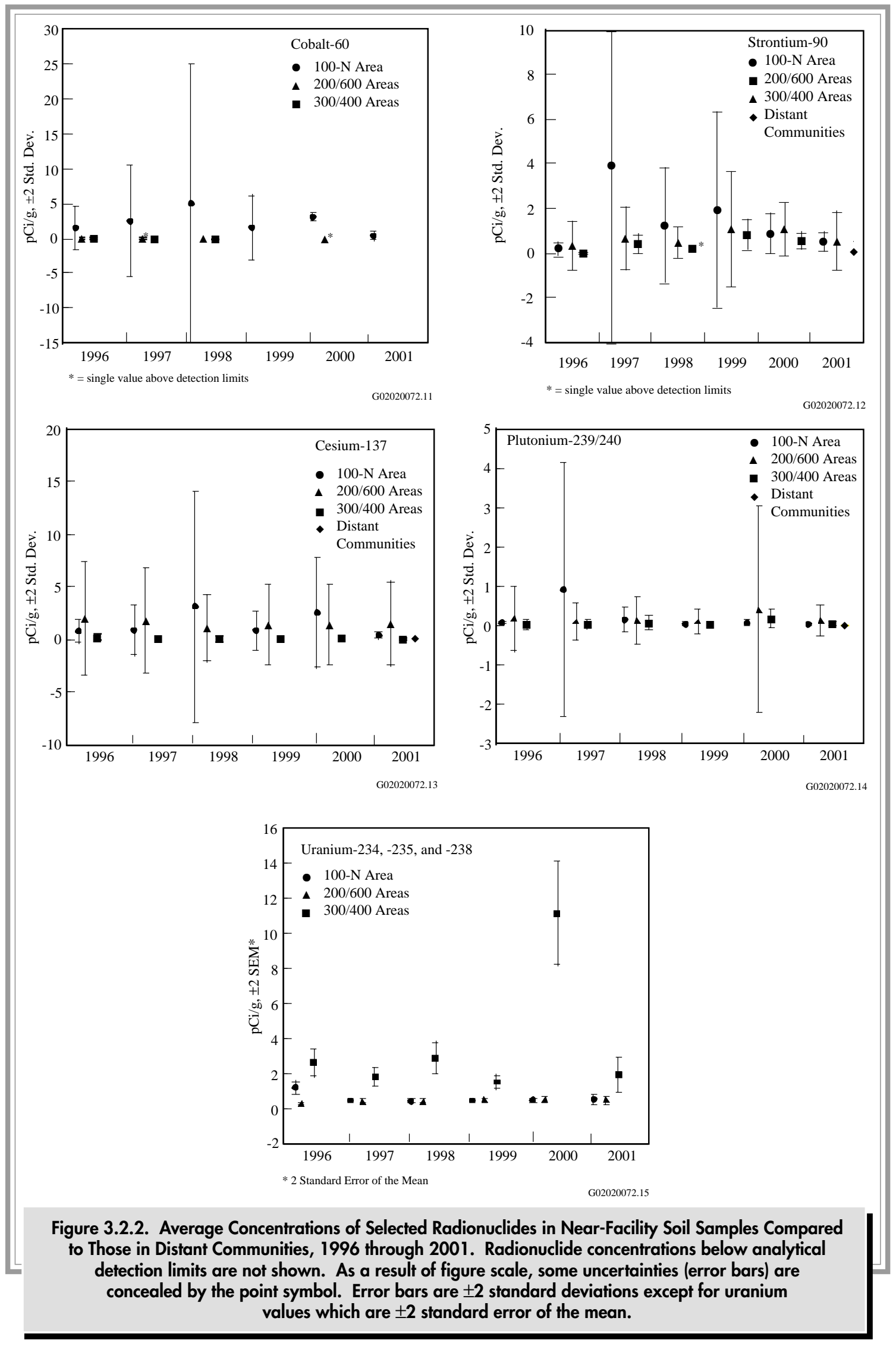


Table 3.2.7. Average Radionuclide Concentrations $\left(\mathrm{pCi} / \mathrm{g}^{[\mathrm{la}]} \mathrm{dry}\right.$ wt. (b) $^{(b)}$ Detected in Surface Soil Samples near the 1301-N Liquid Waste Disposal Facility, 1996 through 2001

\begin{tabular}{|c|c|c|c|c|c|c|c|}
\hline Year & ${ }^{60} \mathrm{Co}$ & ${ }^{90} \mathrm{Sr}$ & ${ }^{137} \mathrm{Cs}$ & ${ }^{234} \mathbf{U}$ & ${ }^{235} \mathrm{U}$ & ${ }^{238} \mathrm{U}$ & ${ }^{239 / 240} \mathrm{Pu}$ \\
\hline 1996 & $2.5 \pm 7.8$ & $0.23 \pm 0.11$ & $0.98 \pm 1.0$ & $0.57 \pm 0.24$ & $0.059 \pm 0.049$ & $0.56 \pm 0.38$ & $0.066 \pm 0.019$ \\
\hline 1997 & $4.3 \pm 9.0$ & $5.8 \pm 19.0$ & $1.5 \pm 2.6$ & $0.22 \pm 0.11$ & $0.020 \pm 0.007$ & $0.22 \pm 0.01$ & $1.2 \pm 3.4$ \\
\hline 1998 & $8.5 \pm 24$ & $1.6 \pm 2.8$ & $5.2 \pm 13$ & $0.22 \pm 0.19$ & $0.039 \pm 0.013$ & $0.16 \pm 0.07$ & $0.19 \pm 0.34$ \\
\hline 1999 & $2.6 \pm 5.0$ & $2.9 \pm 4.8$ & $1.3 \pm 1.9$ & $0.21 \pm 0.086$ & $0.014 \pm 0.006$ & $0.19 \pm 0.07$ & $0.094 \pm 0.048$ \\
\hline 2000 & $1.6 \pm 0.68$ & $1.0 \pm 0.82$ & $2.7 \pm 5.6$ & $0.20 \pm 0.066$ & $0.016 \pm 0.000004$ & $0.22 \pm 0.09$ & $0.07 \pm 0.07$ \\
\hline 2001 & $0.46 \pm 0.76$ & $0.48 \pm 0.42$ & $0.39 \pm 0.4$ & $0.25 \pm 0.08$ & $0.024 \pm 0.01$ & $0.26 \pm 0.05$ & $0.04 \pm 0.04$ \\
\hline
\end{tabular}

(a) To convert to international metric system units, multiply pCi/g by 0.037 to obtain $\mathrm{Bq} / \mathrm{g}$.

(b) \pm 2 standard deviations.

\begin{tabular}{|c|c|c|c|c|c|c|c|}
\hline \multirow[b]{2}{*}{ Year } & \multicolumn{6}{|c|}{$\begin{array}{l}\text { Table 3.2.8. Average Radionuclide Concentrations }\left(\mathrm{pCi} / \mathrm{g}^{[\mathrm{ac}]} \mathrm{dry} \text { wt.) }\right)^{(\mathrm{b})} \text { Detected } \\
\text { in all } 100-\mathrm{N} \text { Area Surface Soil Samples, } 1996 \text { through } 2001\end{array}$} & \multirow[b]{2}{*}{${ }^{239 / 240} \mathrm{Pu}$} \\
\hline & ${ }^{60} \mathrm{Co}$ & ${ }^{90} \mathrm{Sr}$ & ${ }^{137} \mathrm{Cs}$ & ${ }^{234} \mathrm{U}$ & ${ }^{235} \mathrm{U}$ & ${ }^{238} \mathrm{U}$ & \\
\hline 1996 & $1.5 \pm 3.0$ & $0.20 \pm 0.22$ & $0.077 \pm 1.1$ & $0.567 \pm 0.082$ & $0.038 \pm 0.021$ & $0.566 \pm 0.125$ & $0.07 \pm 0.016$ \\
\hline 1997 & $2.5 \pm 8.0$ & $3.9 \pm 16$ & $0.89 \pm 2.4$ & $0.21 \pm 0.04$ & $0.020 \pm 0.002$ & $0.207 \pm 0.036$ & $0.91 \pm 3.2$ \\
\hline 1998 & $4.9 \pm 20$ & $1.2 \pm 2.6$ & $3.1 \pm 11$ & $0.214 \pm 0.063$ & $0.033 \pm 0.008$ & $0.166 \pm 0.026$ & $0.15 \pm 0.3$ \\
\hline 1999 & $1.6 \pm 4.6$ & $2.0 \pm 4.4$ & $0.84 \pm 1.8$ & $0.22 \pm 0.04$ & $0.016 \pm 0.004$ & $0.20 \pm 0.03$ & $0.029 \pm 0.05$ \\
\hline 2000 & $3.1 \pm 0.6$ & $0.84 \pm 0.9$ & $2.5 \pm 5.2$ & $0.22 \pm 0.09$ & $0.018 \pm 0.007$ & $0.22 \pm 0.03$ & $0.058 \pm 0.074$ \\
\hline 2001 & $0.4 \pm 0.68$ & $0.48 \pm 0.42$ & $0.39 \pm 0.36$ & $0.24 \pm 0.09$ & $0.024 \pm 0.01$ & $0.25 \pm 0.07$ & $0.031 \pm 0.04$ \\
\hline \multicolumn{8}{|c|}{$\begin{array}{l}\text { To convert to international metric system units, multiply } \mathrm{pCi} / \mathrm{g} \text { by } 0.037 \text { to obtain } \mathrm{Bq} / \mathrm{g} \text {. } \\
\pm 2 \text { standard deviations. }\end{array}$} \\
\hline
\end{tabular}

\begin{tabular}{|c|c|c|c|c|c|c|c|}
\hline \multicolumn{7}{|c|}{$\begin{array}{c}\text { Table 3.2.9. Concentrations of Selected Radionuclides (pCi/g[a] dry wt.) in all 100-N Area } \\
\text { Surface Soil Samples, } 2001\end{array}$} & \multirow[b]{2}{*}{${ }^{239 / 240} \mathrm{Pu}$} \\
\hline & ${ }^{60} \mathrm{Co}$ & ${ }^{90} \mathrm{Sr}$ & ${ }^{137} \mathrm{Cs}$ & ${ }^{234} \mathrm{U}$ & ${ }^{235} \mathrm{U}$ & ${ }^{238} \mathrm{U}$ & \\
\hline Maximum $^{(\mathrm{b})}$ & $1.0 \pm 0.08$ & $0.7 \pm 0.3$ & $0.6 \pm 0.08$ & $0.32 \pm 0.08$ & $0.03 \pm 0.02$ & $0.3 \pm 0.08$ & $0.06 \pm 0.03$ \\
\hline Average $e^{(c)}$ & $0.4 \pm 0.76$ & $0.48 \pm 0.42$ & $0.39 \pm 0.36$ & $0.240 \pm 0.09$ & $0.024 \pm 0.01$ & $0.25 \pm 0.07$ & $0.031 \pm 0.04$ \\
\hline Distant community ${ }^{(c, d)}$ & $\mathrm{NR}^{(\mathrm{e})}$ & $0.052 \pm 0.11$ & $0.15 \pm 0.32$ & NR & NR & $0.13 \pm 0.11$ & $0.0055 \pm 0.012$ \\
\hline $\begin{array}{l}\text { Accessible soil } \\
\text { concentration } \\
(\text { WHC-SD-EN-TI-070)(f) }\end{array}$ & 7.1 & 2,800 & 30 & 630 & 170 & 370 & 190 \\
\hline $\begin{array}{l}\text { (a) To convert to intern } \\
\text { (b) } \pm \text { total analytical un } \\
\text { (c) } \pm 2 \text { standard deviatio } \\
\text { (d) See Section 4.6. } \\
\text { (e) NR = Not reported. } \\
\text { (f) Hanford soils that ar }\end{array}$ & $\begin{array}{l}\text { tional metric } \\
\text { ertainty. } \\
\text { not behind }\end{array}$ & security fences. & ultiply pCi/g & by 0.037 to obt: & $\mathrm{n} \mathrm{Bq} / \mathrm{g}$. & & \\
\hline
\end{tabular}




\begin{tabular}{|c|c|c|c|c|c|c|c|}
\hline \multicolumn{8}{|c|}{$\begin{array}{c}\text { Table 3.2.10. Concentrations of Selected Radionuclides (pCi/g }{ }^{[a]} \text { dry wt.) in } 200 / 600 \text { Areas } \\
\text { Surface Soil Samples, } 2001\end{array}$} \\
\hline & ${ }^{60} \mathrm{Co}$ & ${ }^{90} \mathrm{Sr}$ & ${ }^{137} \mathrm{Cs}$ & ${ }^{234} \mathrm{U}$ & ${ }^{235} \mathrm{U}$ & ${ }^{238} \mathrm{U}$ & ${ }^{239 / 240} \mathrm{Pu}$ \\
\hline Maximum $^{(\mathrm{b})}$ & $\mathrm{ND}^{(\mathrm{c})}$ & $3.8 \pm 0.8$ & $11.0 \pm 1.6$ & $0.47 \pm 0.1$ & $0.048 \pm 0.022$ & $0.43 \pm 0.01$ & $0.98 \pm 0.21$ \\
\hline Average $\mathrm{d}^{(\mathrm{d})}$ & ND & $0.55 \pm 1.3$ & $1.5 \pm 4.0$ & $0.22 \pm 0.11$ & $0.02 \pm 0.02$ & $0.22 \pm 0.11$ & $0.13 \pm 0.4$ \\
\hline Distant community ${ }^{(\mathrm{d}, \mathrm{e})}$ & $\mathrm{NR}^{(f)}$ & $0.052 \pm 0.11$ & $0.15 \pm 0.32$ & NR & NR & $0.13 \pm 0.11$ & $0.0055 \pm 0.012$ \\
\hline \multicolumn{8}{|l|}{$\begin{array}{l}\text { Accessible soil concen- } \\
\text { tration limits } \\
(\text { WHC-SD-EN-TI-070) })^{(\mathrm{g})}\end{array}$} \\
\hline $\begin{array}{l}\text { (a) To convert to internati } \\
\text { (b) } \pm \text { total analytical unce } \\
\text { (c) ND = Not detected. } \\
\text { (d) } \pm 2 \text { standard deviations } \\
\text { (e) See Section 4.6. } \\
\text { (f) NR = Not reported. } \\
\text { (g) Hanford soils that are } 1\end{array}$ & $\begin{array}{l}\text { onal met } \\
\text { tainty. } \\
\text { tot behin }\end{array}$ & $\begin{array}{l}\text { system units, } \mathrm{m} \\
\text { ecurity fences. }\end{array}$ & ultiply pCi/g & y 0.037 to obta & $\mathrm{Bq} / \mathrm{g}$. & & \\
\hline
\end{tabular}

\begin{tabular}{|c|c|c|c|c|c|c|c|}
\hline \multicolumn{8}{|c|}{$\begin{array}{c}\text { Table 3.2.11. Concentrations of Selected Radionuclides (pCi/g }{ }^{[\mathrm{ad}]} \text { dry wt.) in 300/400 Areas } \\
\text { Surface Soil Samples, } 2001\end{array}$} \\
\hline & ${ }^{60} \mathrm{Co}$ & ${ }^{90} \mathrm{Sr}$ & ${ }^{137} \mathrm{Cs}$ & ${ }^{234} \mathbf{U}$ & ${ }^{235} \mathrm{U}$ & ${ }^{238} \mathrm{U}$ & ${ }^{239 / 240} \mathrm{Pu}$ \\
\hline Maximum $^{(\mathrm{b})}$ & $\mathrm{ND}^{(c)}$ & ND & $0.15 \pm 0.03$ & $5.7 \pm 1.1$ & $0.31 \pm 0.084$ & $5.9 \pm 1.1$ & $0.08 \pm 0.03$ \\
\hline Average $^{(\mathrm{d})}$ & ND & ND & $0.05 \pm 0.08$ & $0.94 \pm 3.0$ & $0.06 \pm 0.17$ & $0.95 \pm 3.2$ & $0.041 \pm 0.06$ \\
\hline Distant community ${ }^{(\mathrm{d}, \mathrm{e})}$ & $N R^{(f)}$ & $0.052 \pm 0.11$ & $0.15 \pm 0.32$ & NR & $\mathrm{NR}$ & $0.13 \pm 0.11$ & $0.0055 \pm 0.012$ \\
\hline \multicolumn{8}{|l|}{$\begin{array}{l}\text { Accessible soil concen- } \\
\text { tration limits } \\
(\text { WHC-SD-EN-TI-070)(g) }\end{array}$} \\
\hline $\begin{array}{l}\text { (a) To convert to internati } \\
\text { (b) } \pm \text { total analytical uncer } \\
\text { (c) ND = Not detected. } \\
\text { (d) } \pm 2 \text { standard deviations. } \\
\text { (e) See Section 4.6. } \\
\text { (f) NR = Not reported. } \\
\text { (g) Hanford soils that are } \mathrm{n}\end{array}$ & $\begin{array}{l}\text { onal met } \\
\text { tainty. } \\
\text { ot behin }\end{array}$ & $\begin{array}{l}\text { system units, m } \\
\text { security fences. }\end{array}$ & nultiply $\mathrm{pCi} / \mathrm{g} \mathrm{b}$ & 0.037 to ob & $\mathrm{Bq} / \mathrm{g}$. & & \\
\hline
\end{tabular}

The 2001 analytical results for vegetation samples collected at the 100-N Area are compared to offsite averages in Table 3.2.16. A complete list of radionuclide concentrations and sampling location maps are provided in PNNL-13910, APP. 2. In 2001, analytical results from vegetation samples collected from the 100-N Area were slightly elevated compared to those observed in 2000. The radionuclide levels measured in 100-N Area vegetation were greater than those measured off the Hanford Site.

Vegetation samples from 49 of 115 sampling locations were collected in the 200/600 Areas in 2001. The 2001 maximum and average concentrations for selected radionuclides are compared to the offsite average in Table 3.2.17. A complete list of radionuclide concentrations and sampling location maps is provided in PNNL-13910, APP. 2. Analytical results from vegetation samples taken in 2001 from the 200/600 Areas were comparable to those observed in previous years. Radionuclide levels for strontium-90, cesium-137, and plutonium-239/240 were greater than those measured off the Hanford Site.

Seventeen vegetation samples were collected from the 300/400 Areas in 2001. The 2001 maximum, average, offsite average, and accessible soil limits for 300/400 Areas samples are listed in Table 3.2.18. Complete listings of radionuclide concentrations and sampling location maps are provided in PNNL-13910, APP. 2. 
Table 3.2.12. Radionuclide Concentrations (pCi/g $\mathrm{g}^{[\mathrm{la}]} \mathrm{dry}$ wt. \pm total analytical uncertainty) in Environmental Restoration Contractor Projects' Soil Samples, 2001

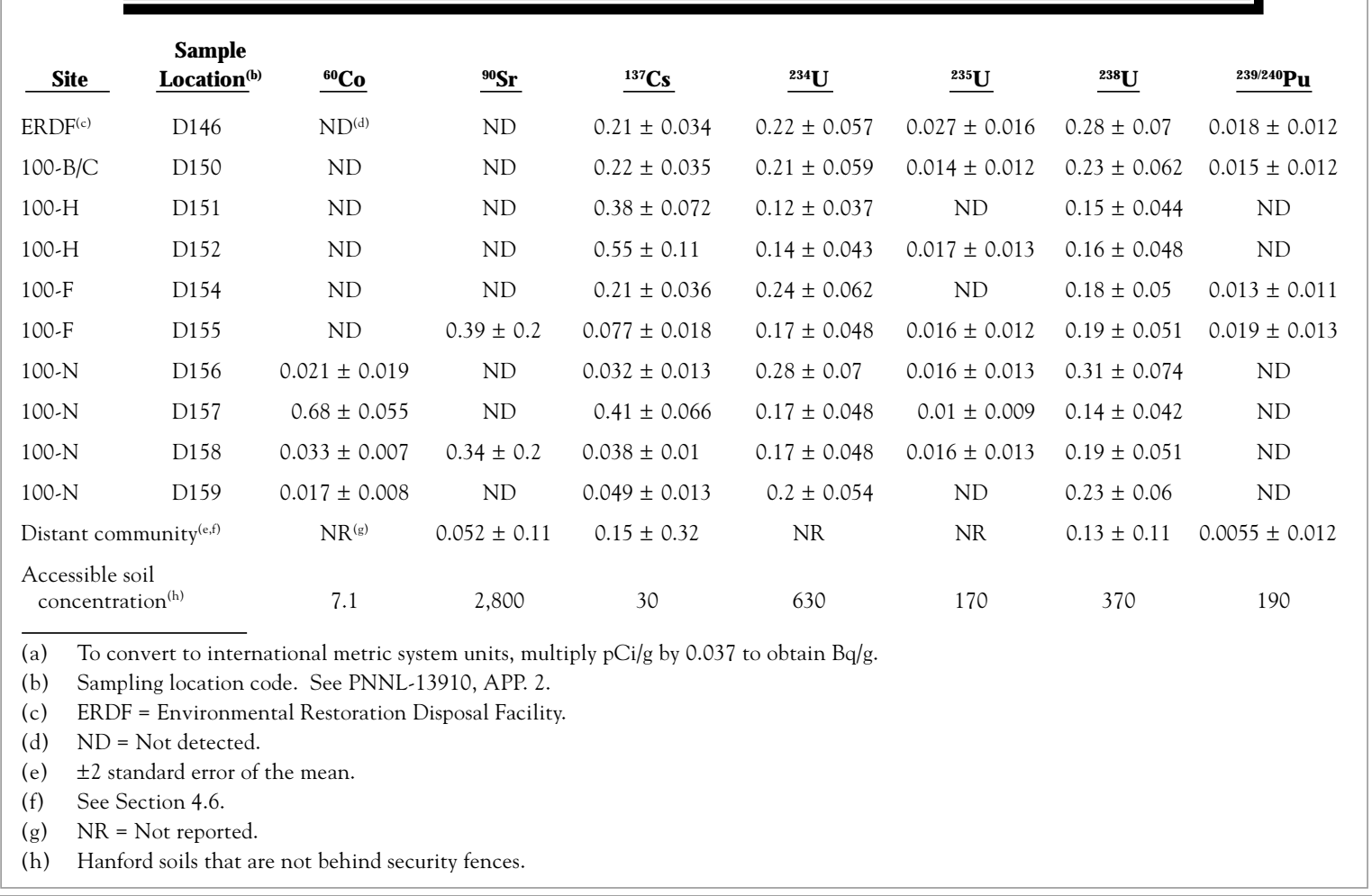

The levels of most radionuclides measured in the 300 Area were greater than those measured off the Hanford Site, and uranium levels were higher than levels measured in either the 100 and 200 Areas. The higher uranium levels were expected because uranium was released during past fuel fabrication operations in the 300 Area. In the 400 Area, the levels recorded for most radionuclides were higher than those measured off the site in previous years.

\subsubsection{External Radiation}

External radiation fields were monitored near facilities and waste handling, storage, and disposal sites to measure and assess the impact of operations. Thermoluminescent dosimeters were used at numerous fixed locations to gather dose rate information over longer periods of time. Thermoluminescent dosimeter results were used individually or averaged to determine dose rates in a given area for a particular sampling period. A summary of the 2000 and 2001 thermoluminescent dosimeter results can be found in Table 3.2.19. Individual thermoluminescent dosimeter results and locations are provided in PNNL-13910, APP. 2. Specific information regarding external radiation sampling methods and locations can be found in DFSNW-OEM-001. Dose rate information for Hanford perimeter locations can be found in Section 4.6.
Environmental thermoluminescent dosimeters measure dose rates from all types of external radiation sources. These sources include cosmic radiation, naturally occurring radioactivity in air and soil, and fallout from past nuclear weapons testing, as well as any contribution from Hanford Site activities. These outside radiation sources may cause an estimated $20 \%$ deviation in thermoluminescent dosimeter results.

Near-facility monitoring uses the Harshaw thermoluminescent dosimeter system, which includes the Harshaw 8807 dosimeter and the Harshaw 8800 reader. The packaging, which uses an O-ring seal, protects the dosimeter from light, heat, moisture, and dirt. The thermoluminescent dosimeters were placed 1 meter (3.28 feet) above the ground near facilities, active and 


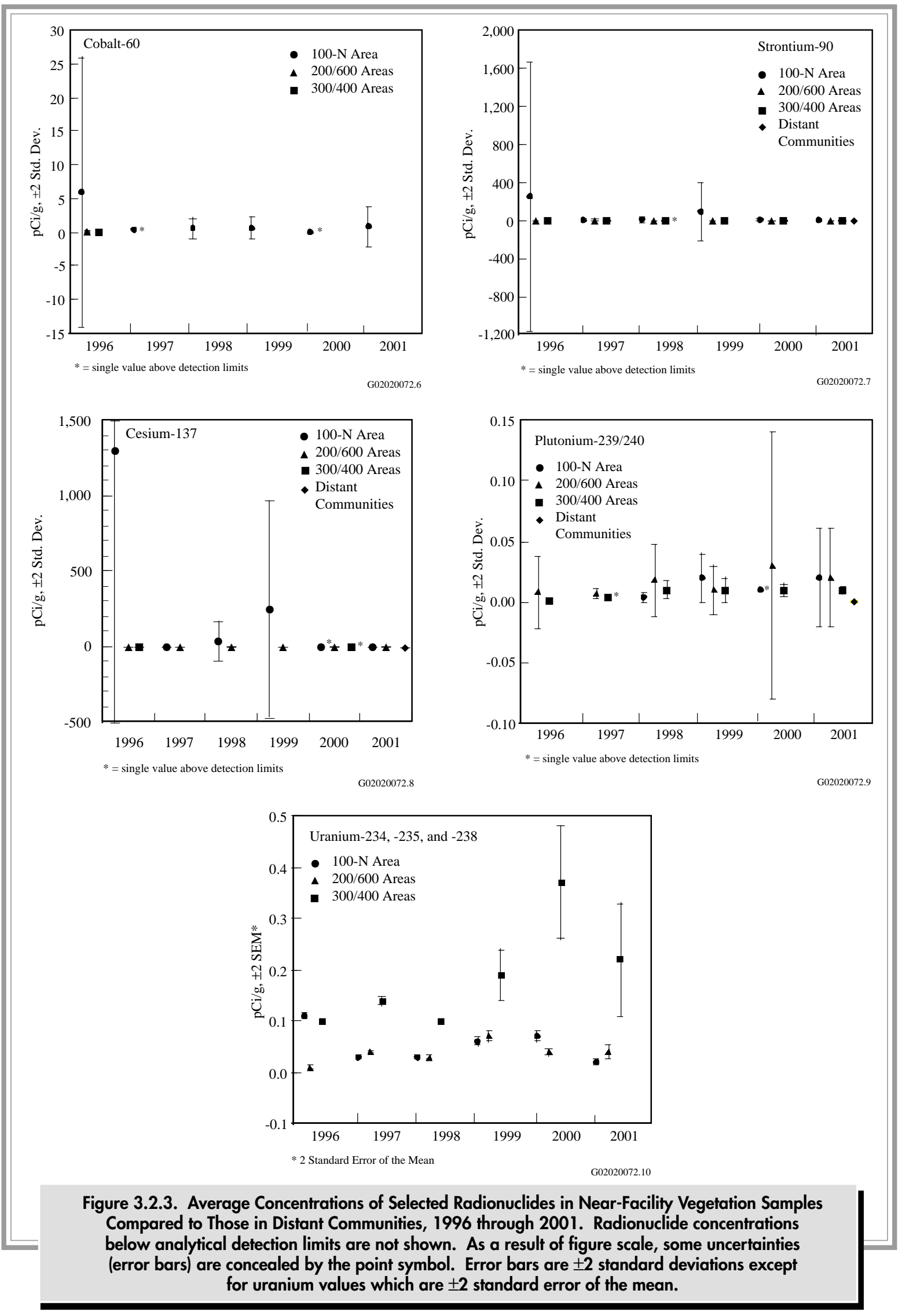




\begin{tabular}{|c|c|c|c|c|}
\hline \multirow[b]{2}{*}{ Year } & \multicolumn{4}{|c|}{$\begin{array}{l}\text { Table 3.2.13. Average Radionuclide Concentrations }\left(\mathrm{pCi} / \mathrm{g}^{[\mathrm{a}]} \mathrm{dry} \text { wt. }\right)^{(b)} \\
\text { Detected in Vegetation Samples Collected near the } 1301-\mathrm{N} \text { Liquid } \\
\text { Waste Disposal Facility, } 1996 \text { through } 2001\end{array}$} \\
\hline & ${ }^{60} \mathrm{Co}$ & ${ }^{90} \mathrm{Sr}$ & ${ }^{137} \mathrm{Cs}$ & ${ }^{239 / 240} \mathrm{Pu}$ \\
\hline 1996 & $7.9 \pm 22$ & $750 \pm 2,200$ & $2,750 \pm 9,200$ & $-0.013 \pm 0.38^{(c)}$ \\
\hline 1997 & $0.42^{(\mathrm{d})}$ & $0.49^{(\mathrm{d})}$ & $0.14 \pm 0.08$ & $\mathrm{ND}^{(\mathrm{e})}$ \\
\hline 1998 & $0.54 \pm 0.93$ & $13.6 \pm 38.0$ & $50.1 \pm 140$ & $0.0071^{(\mathrm{d})}$ \\
\hline 1999 & $0.99 \pm 1.7$ & $205 \pm 340$ & $505 \pm 720$ & $0.017 \pm 0.009$ \\
\hline 2000 & ND & $0.09 \pm 0.019$ & $0.2^{\text {(d) }}$ & ND \\
\hline 2001 & $0.17 \pm 0.17$ & $3.4 \pm 9.2$ & $0.26 \pm 0.24$ & ND \\
\hline $\begin{array}{l}\text { (a) } \\
\text { (b) } \\
\text { (c) } \\
\text { (d) } \\
\text { (e) }\end{array}$ & \multicolumn{4}{|c|}{$\begin{array}{l}\text { To convert to international metric system units, multiply } \mathrm{pCi} / \mathrm{g} \text { by } 0.037 \text { to obtain } \mathrm{Bq} / \mathrm{g} \text {. } \\
\pm 2 \text { standard deviations. } \\
\text { Negative value indicates results at or below background levels of radioactivity. } \\
\text { Single value above detection limit. } \\
\text { ND = Not detected. }\end{array}$} \\
\hline
\end{tabular}

\begin{tabular}{|c|c|c|c|c|}
\hline \multirow[b]{2}{*}{ Year } & \multicolumn{4}{|c|}{$\begin{array}{l}\text { Table 3.2.14. Average Radionuclide Concentrations (pCi/g } \text { g }^{[a]} \text { dry wt.) }{ }^{(b)} \\
\text { Detected in all } 100-\mathrm{N} \text { Area Vegetation Samples, } 1996 \text { through } 2001\end{array}$} \\
\hline & ${ }^{60} \mathrm{Co}$ & ${ }^{90} \mathrm{Sr}$ & ${ }^{137} \mathrm{Cs}$ & ${ }^{239 / 240} \mathrm{Pu}$ \\
\hline 1996 & $6.0 \pm 20$ & $250 \pm 1,400$ & $1,300 \pm 7,000$ & $-0.0051 \pm 0.013^{(\mathrm{c})}$ \\
\hline 1997 & $0.42 \pm 0.05$ & $3.6 \pm 14$ & $0.16 \pm 0.19$ & $\mathrm{ND}^{(\mathrm{d})}$ \\
\hline 1998 & $0.62 \pm 1.5$ & $12 \pm 32$ & $38 \pm 130$ & $0.0042 \pm 0.004$ \\
\hline 1999 & $0.61 \pm 1.6$ & $91 \pm 300$ & $250 \pm 720$ & $0.022 \pm 0.02$ \\
\hline 2000 & $0.05 \pm 0.03$ & $5.7 \pm 19$ & $0.2^{(\mathrm{e})}$ & $0.009^{(\mathrm{e})}$ \\
\hline 2001 & $0.89 \pm 3.0$ & $3.5 \pm 9.0$ & $0.38 \pm 0.44$ & $0.024 \pm 0.04$ \\
\hline $\begin{array}{ll}\text { (a) } & 1 \\
\text { (b) } & \pm \\
\text { (c) } & 1 \\
\text { (d) } & 1 \\
\text { (e) } & 5\end{array}$ & \multicolumn{4}{|c|}{$\begin{array}{l}\text { To convert to international metric system units, multiply } \mathrm{pCi} / \mathrm{g} \text { by } 0.037 \text { to obtain } \mathrm{Bq} / \mathrm{g} \text {. } \\
\pm 2 \text { standard error of the mean. } \\
\text { Negative value indicates results at or below background levels of radioactivity. } \\
\mathrm{ND}=\text { Not detected. } \\
\text { Single value above detection limit. }\end{array}$} \\
\hline
\end{tabular}

inactive surface-water disposal sites, and remedial action projects. The dosimeters were exchanged and analyzed each calendar quarter. The Radiological Calibrations Facility in the 318 Building ( 300 Area) calibrates the response of the chips; results are reported in terms of external dose.

In 2001, there were 133 thermoluminescent dosimeter locations collecting external radiation information. At six locations, the dosimeter results showed a decrease in external radiation from 2000 levels. At one location (212-R in the 200-North Area), there was a 20\% increase in the amount of radiation detected. At the remaining locations, there were no changes in the amount of external radiation detected.
At the former 116-B-11 and 116-C-1 Liquid Waste Disposal Facilities (located in the 100-B/C Area), five thermoluminescent dosimeter sites monitored dose rates in 2001. In the 100-F Area, five thermoluminescent dosimeter monitoring sites were used. In the 100-H Area, three thermoluminescent dosimeter monitoring sites were used. Remedial action activities by the environmental restoration contractor were completed in 2001, and the dosimeters were removed in September 2001. Dose rates measured in 2001 at each location were comparable to those measured in 2000 .

Cleanup activities at the 100-K Fuel Storage Basins and adjacent retired reactor buildings in the $100-\mathrm{K}$ Area continue to be monitored. Dose rates in this area in 2001 


\begin{tabular}{|c|c|c|c|c|}
\hline \multirow[b]{2}{*}{ Year } & \multicolumn{4}{|c|}{$\begin{array}{l}\text { Table 3.2.15. Average Radionuclide Concentrations }\left(\mathrm{pCi} / \mathrm{g}^{[\mathrm{a}]} \mathrm{dry} \text { wt. }\right)^{(\mathrm{b})} \\
\text { Detected in N Springs Vegetation Samples, } 1996 \text { through } 2001\end{array}$} \\
\hline & ${ }^{60} \mathrm{Co}$ & ${ }^{90} \mathrm{Sr}$ & ${ }^{137} \mathrm{Cs}$ & ${ }^{239 / 240} \mathrm{Pu}$ \\
\hline 1996 & $0.01 \pm 0.01$ & $2.4 \pm 6.0$ & $0.15^{(\mathrm{c})}$ & $-0.0015 \pm 0.002^{(\mathrm{d})}$ \\
\hline 1997 & $N D^{(e)}$ & $6.2 \pm 17.0$ & $0.18 \pm 0.24$ & ND \\
\hline 1998 & $0.068^{(c)}$ & $21.0 \pm 26.0$ & ND & $0.0028^{(\mathrm{c})}$ \\
\hline 1999 & ND & $0.98 \pm 1.1$ & $0.42 \pm 0.70$ & ND \\
\hline 2000 & ND & $9.4 \pm 22.0$ & ND & $0.009^{(\mathrm{c})}$ \\
\hline 2001 & $0.57^{(\mathrm{c})}$ & $4.7 \pm 9.2$ & ND & $0.008^{(c)}$ \\
\hline $\begin{array}{ll}\text { (a) } & \\
\text { (b) } & \pm \\
\text { (c) } & 5 \\
\text { (d) } & 1 \\
\text { (e) } & 1\end{array}$ & \multicolumn{4}{|c|}{$\begin{array}{l}\text { To convert to international metric system units, multiply pCi/g by } 0.037 \text { to obtain Bq/g. } \\
\pm 2 \text { standard deviations. } \\
\text { Single value above detection limit. } \\
\text { Negative value indicates results at or below background levels of radioactivity. } \\
\text { ND = Not detected. }\end{array}$} \\
\hline
\end{tabular}

\begin{tabular}{|c|c|c|c|c|c|c|c|c|}
\hline \multicolumn{9}{|c|}{$\begin{array}{l}\text { Table 3.2.16. Concentrations of Selected Radionuclides (pCi/g } \mathrm{g}^{[\mathrm{a}]} \text { dry wt.) in } 100-\mathrm{N} \text { Area } \\
\text { Vegetation Samples, } 2001\end{array}$} \\
\hline & & ${ }^{60} \mathrm{Co}$ & ${ }^{90} \mathrm{Sr}$ & ${ }^{137} \mathrm{Cs}$ & ${ }^{234} U$ & ${ }^{235} \mathrm{U}$ & ${ }^{238} \mathrm{U}$ & ${ }^{239 / 240} \mathrm{Pu}$ \\
\hline \multicolumn{2}{|c|}{ Maximum $^{(b)}$} & $3.8 \pm 0.3$ & $11.0 \pm 1.6$ & $0.71 \pm 0.16$ & $0.016 \pm 0.09$ & $0.006^{(c)}$ & $0.013 \pm 0.007$ & $0.055 \pm 0.018$ \\
\hline \multicolumn{2}{|c|}{ Average $^{(\mathrm{d})}$} & $0.89 \pm 3.0$ & $3.5 \pm 9.0$ & $0.38 \pm 0.44$ & $0.01 \pm 0.01$ & & $0.01 \pm 0.01$ & $0.024 \pm 0.04$ \\
\hline \multicolumn{2}{|c|}{ Distant community ${ }^{(\mathrm{d}, \mathrm{e})}$} & $\mathrm{NR}^{(f)}$ & $0.066 \pm 0.059$ & $0.0022 \pm 0.034$ & $\mathrm{NR}$ & NR & $\mathrm{ND}^{(\mathrm{g})}$ & $0.00078 \pm 0.0016$ \\
\hline $\begin{array}{l}\text { (a) } \\
\text { (b) } \\
\text { (c) } \\
\text { (d) } \\
\text { (e) } \\
\text { (f) } \\
\text { (g) }\end{array}$ & $\begin{array}{l}\text { To convert to int } \\
\pm \text { total analytical } \\
\text { Single value abo } \\
\pm 2 \text { standard devi } \\
\text { See Section } 4.6 \text {. } \\
\text { NR = Not report } \\
\text { ND = Not detect }\end{array}$ & $\begin{array}{l}\text { ternational } \mathrm{m} \\
1 \text { uncertainty } \\
\text { ve detection } \\
\text { ations. } \\
\text { ed. } \\
\text { ted. }\end{array}$ & ic system units, mı & ultiply pCi/g by 0 . & 037 to obtain $\mathrm{Bq}$ & & & \\
\hline
\end{tabular}

\begin{tabular}{|c|c|c|c|c|c|c|c|c|}
\hline \multicolumn{9}{|c|}{$\begin{array}{l}\text { Table 3.2.17. Concentrations of Selected Radionuclides (pCi/g }{ }^{[a]} \text { dry wt.) in } 200 / 600 \text { Areas } \\
\text { Vegetation Samples, } 2001\end{array}$} \\
\hline & ${ }^{60} \mathrm{Co}$ & ${ }^{90} \mathrm{Sr}$ & ${ }^{137} \mathrm{Cs}$ & ${ }^{234} \mathrm{U}$ & ${ }^{235} \mathrm{U}$ & ${ }^{238} \mathrm{U}$ & ${ }^{239 / 240} \mathrm{Pu}$ \\
\hline \multicolumn{2}{|c|}{ Maximum $^{(b)}$} & $\mathrm{ND}^{(\mathrm{c})}$ & $4.8 \pm 0.7$ & $0.8 \pm 0.3$ & $0.05 \pm 0.02$ & $0.01 \pm 0.006$ & $0.05 \pm 0.02$ & $0.1 \pm 0.03$ \\
\hline \multicolumn{2}{|c|}{ Average ${ }^{(d)}$} & ND & $1.0 \pm 3.0$ & $0.17 \pm 0.30$ & $0.019 \pm 0.02$ & $0.006 \pm 0.003$ & $0.018 \pm 0.02$ & $0.021 \pm 0.04$ \\
\hline \multicolumn{2}{|c|}{ Distant community ${ }^{(\mathrm{d}, \mathrm{e})}$} & $\mathrm{NR}^{(f)}$ & $0.066 \pm 0.059$ & $0.0022 \pm 0.034$ & NR & NR & ND & $0.00078 \pm 0.0016$ \\
\hline \multicolumn{9}{|c|}{$\begin{array}{l}\text { (a) To convert to international me } \\
\text { (b) } \pm \text { total analytical uncertainty. } \\
\text { (c) ND = Not detected. } \\
\text { (d) } \pm 2 \text { standard deviations. } \\
\text { (e) See Section 4.6. } \\
\text { (f) NR = Not reported. }\end{array}$} \\
\hline
\end{tabular}




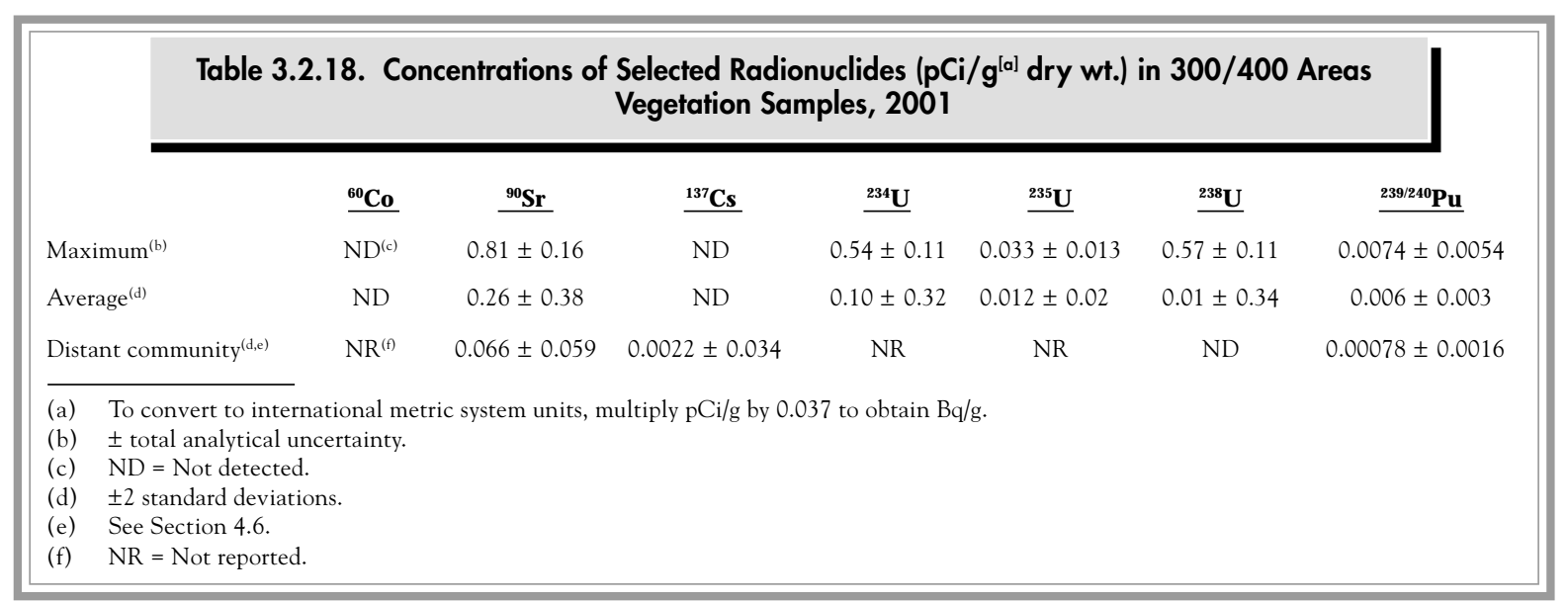

\begin{tabular}{|c|c|c|c|c|c|c|}
\hline \multirow[b]{3}{*}{ A rea } & \multicolumn{5}{|c|}{$\begin{array}{l}\text { Table 3.2.19. Thermoluminescent Dosimeter Results }(\mathrm{mrem} / \mathrm{yr})^{(a)} \text { for Waste Handling } \\
\text { Facilities, } 2000 \text { and } 2001 \text {, based on } 24 \text { hours/day }\end{array}$} & \multirow[b]{3}{*}{$\%$ Change $^{(b)}$} \\
\hline & \multirow{2}{*}{$\begin{array}{c}\text { No. of } \\
\text { Locations, } 2001\end{array}$} & \multicolumn{2}{|c|}{2000} & \multicolumn{2}{|c|}{2001} & \\
\hline & & Maximum & Mean & Maximum & Mean & \\
\hline $100-B / C$ & 5 & 87 & 84 & 94 & 88 & 5 \\
\hline $100-\mathrm{F}$ & 5 & 88 & 85 & 87 & 83 & -2 \\
\hline $100-\mathrm{H}$ & 3 & 90 & 88 & 95 & 71 & -19 \\
\hline $100-\mathrm{K}$ & 11 & 390 & 120 & 419 & 125 & 4 \\
\hline $100-\mathrm{N}$ & 14 & 4,700 & 1,100 & 991 & 319 & -71 \\
\hline $200 / 600$ & 66 & 300 & 106 & 317 & 114 & 7 \\
\hline $212-\mathrm{R}$ & 1 & 2,500 & 2,000 & 2,800 & 1,809 & -10 \\
\hline $300 \mathrm{TEDF}^{(\mathrm{c})}$ & 6 & 85 & 83 & 90 & 85 & 2 \\
\hline 300 & 8 & 180 & 100 & 172 & 106 & 6 \\
\hline 400 & 7 & 81 & 80 & 84 & 82 & 3 \\
\hline $\mathrm{CVDF}^{(\mathrm{d})}$ & 4 & 81 & 75 & 81 & 78 & 4 \\
\hline $\mathrm{ERDF}^{(\mathrm{e})}$ & 3 & 93 & 89 & 111 & 93 & 4 \\
\hline \multicolumn{7}{|c|}{$\begin{array}{l}\text { (a) To convert to international metric system units, multiply mrem/yr } \\
\text { (b) Numbers indicate a decrease }(-) \text { or increase from the } 2000 \text { mean. } \\
\text { (c) TEDF }=300 \text { Area Treated Effluent Disposal Facility. } \\
\text { (d) CVDF }=\text { Cold Vacuum Drying Facility. } \\
\text { (e) } \text { ERDF = Environmental Restoration Disposal Facility. }\end{array}$} \\
\hline
\end{tabular}

slightly increased by $4 \%$ relative to 2000 values, due primarily to natural fluctuation. For the same reason, the four thermoluminescent dosimeter monitoring sites around the Cold Vacuum Drying Facility also showed an annual dose rate increase of $4 \%$ in 2001.

The 2001 results for the $100-\mathrm{N}$ Area indicate that direct radiation levels are highest near facilities that contained or received liquid effluent from $\mathrm{N}$ Reactor. These facilities primarily include the retired 1301-N and 1325-N Liquid Waste Disposal Facilities. The results for these two facilities were noticeably higher than those for other 100-N Area thermoluminescent dosimeter locations, but were significantly lower than dose levels measured at these locations in 2000. This reduction was directly attributable to the removal of source material from the facilities by the environmental restoration contractor. Overall, the average dose rate measured in the $100-\mathrm{N}$ Area in 2001 was $~ 71 \%$ lower than that measured in 2000. Annual average thermoluminescent dosimeter results for the entire 100-N Area from 1987 through 2001 are presented in Figure 3.2.4.

Dose rates were measured at the $\mathrm{N}$ Springs shoreline to determine potential external radiation doses to the public as well as to onsite workers. Because of the cleanup at the liquid waste disposal facilities, the "skyshine" effect (i.e., radiation reflected by the atmosphere back to the earth's surface) at the N Springs shoreline continued to slowly decrease in 2001 (see Figure 3.2.5 for annual average since 1987).

The highest dose rates in the 200 Areas were measured near waste handling facilities. The location within 

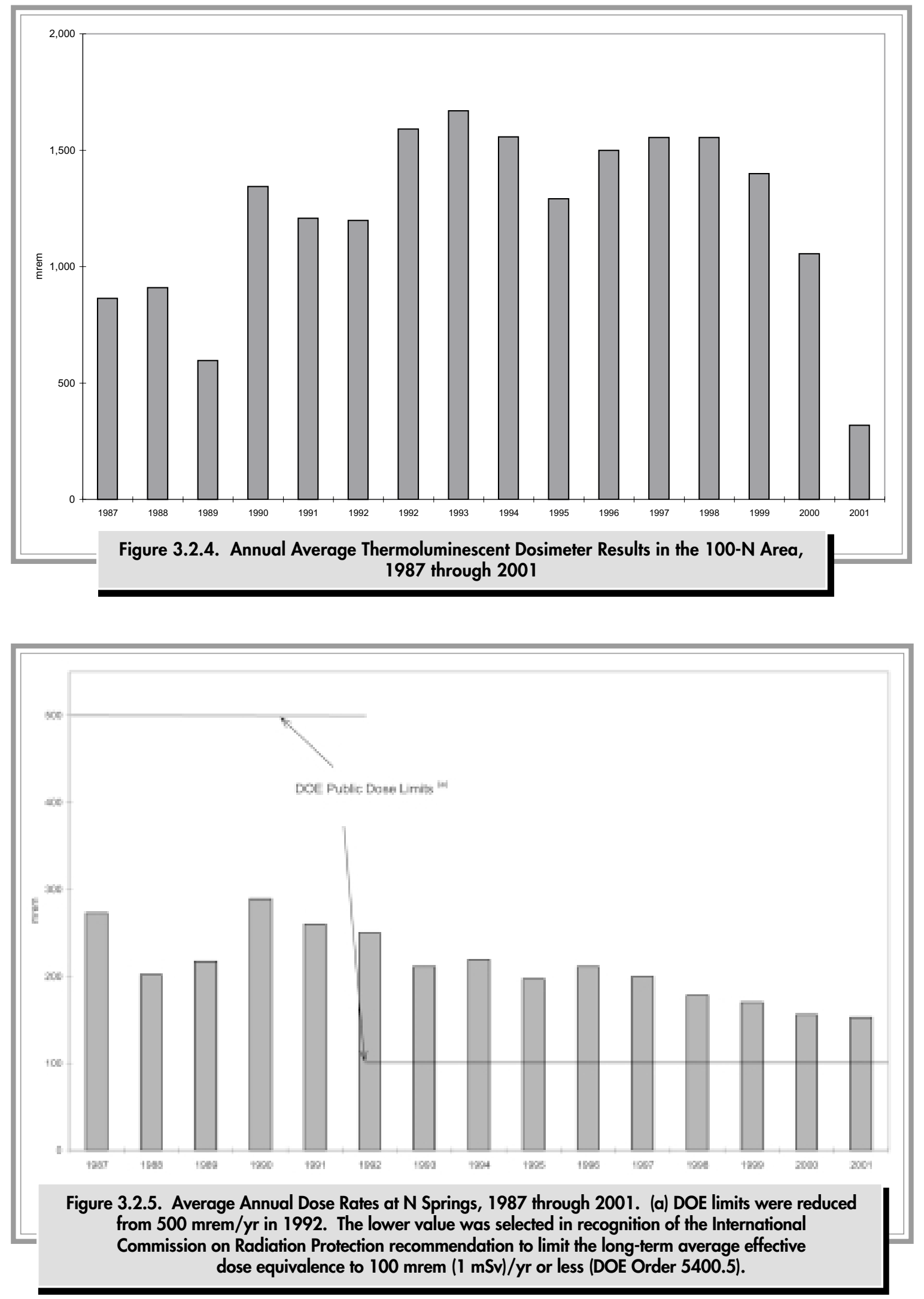
the 200 Areas exhibiting the highest dose rate was at the AZ tank farm in the 200-East Area. The average annual dose rate measured in 2001 in the 200 Areas was slightly higher than the average 2000 measurement. The annual average thermoluminescent dosimeter results from 1987 through 2001 are presented in Figure 3.2.6.

This is the sixth year that thermoluminescent dosimeters have been placed at the Environmental Restoration Disposal Facility to evaluate dose rates during ongoing activities. Dose rates measured in 2001 were comparable to the 2000 results.

The highest dose rates in the 300 Area in 2001 were measured near the retired $316-3$ process trench. The average dose rates measured in 2001 in the 300 Area, at the 300 Area Treated Effluent Disposal Facility, and in the 400 Area were similar to those measured in 2000 . The annual average thermoluminescent dosimeter results for the 300 and 400 Areas from 1991 through 2001 are presented in Figure 3.2.7.
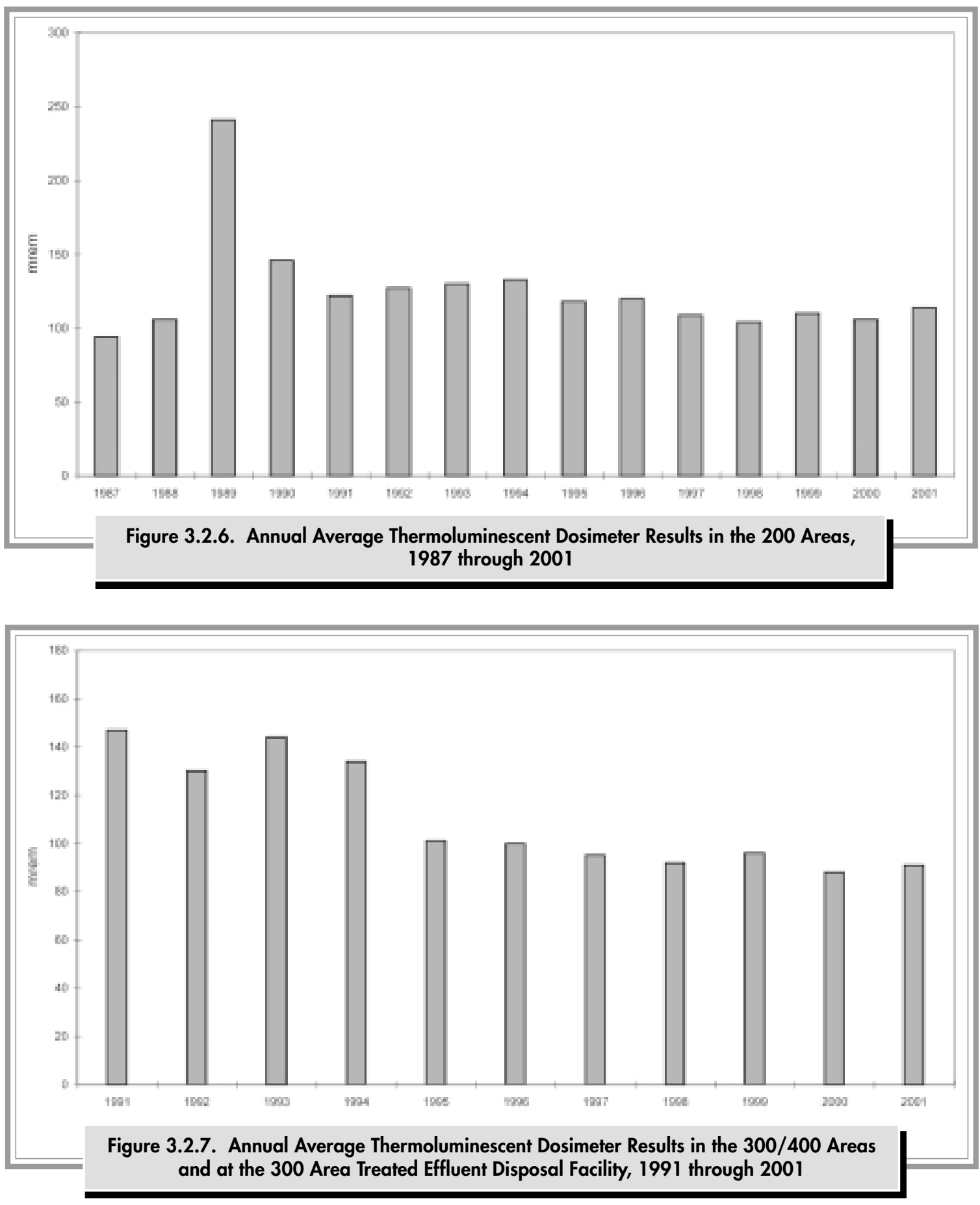
One thermoluminescent dosimeter monitoring site is located in the 200 North Area at the (contaminated) 212-R Railroad Car Disposition Area. This location was established in 2000 to monitor expected high radiation levels in the immediate vicinity. The annual average dose rate at $212-\mathrm{R}$ in 2001 showed an increase of $20 \%$ compared to 2000. Dose rates measured at this location exceed the DOE annual external dose limit to the members of the public; however, no member of the public, or Hanford worker, would conceivably spend an entire year at this location.

\subsubsection{Investigative Sampling}

Investigative sampling was conducted in the operations areas to monitor the presence or movement of radioactive and/or hazardous materials around areas of known or suspected contamination or to verify radiological conditions at specific project sites. Investigative sampling took place near facilities such as storage and disposal sites for at least one of the following reasons:

- to follow up radiological surface surveys that had indicated radioactive contamination was present

- to conduct preoperational surveys to characterize the radiological/chemical conditions at a site before facility construction, operation, or ultimate remediation

- to determine if biotic intrusion (e.g., animal burrows or deep-rooted vegetation) had created a potential for contaminants to spread

- to determine the integrity of waste containment systems.

Generally, the predominant radionuclides discovered during these efforts were cesium-137, strontium-90, and plutonium-239/240 in the 100 and 200 Areas and uranium-234, -235 , and -238 in the 300 Area. Hazardous chemicals generally have not been identified above background levels in preoperational environmental monitoring samples.

Investigative samples collected in 2001 included mammals (mice, bats, rabbit), animal feces (mouse, coyote, bird), soils, and vegetation (tumbleweeds, rabbitbrush, grass). Methods for collecting investigative samples are described in DFSNW-OEM-001. Field monitoring was conducted to detect beta/gamma and alpha radioactivity in samples before they were submitted for analysis. Field monitoring results are expressed as disintegrations per minute per 100 square centimeters. Beta/gamma radiation field surveys were conducted with a GeigerMüeller detector, while alpha radiation field surveys were performed with a portable alpha meter. Laboratory analyses results and field readings are provided in Section 7.0, PNNL-13910, APP. 2.
In 2001, five investigative samples were analyzed for radionuclides at the 222-S laboratory in the 200-West Area. Of the samples analyzed, all showed measurable levels of activity. Another 63 contaminated investigative environmental samples were reported and disposed of without isotopic analyses (though field instrument survey readings were recorded) during cleanup operations. See Table 3.2.20 for a summary of historical investigative sample collections.

In 2001, there were 20 instances of radiological contamination in investigative soil samples. Of the 20, 11 were identified as speck or soil speck contamination. None of the investigative soil samples were submitted for radioisotopic analysis. Eighteen of the 20 locations were cleaned up, and the contaminated soil was disposed of in low-level burial grounds. At the remaining sites, the contamination levels did not exceed limitations of the posting and the soil was left in place.

The number of investigative soil contamination incidents, range of radiation dose levels, and radionuclide concentrations in 2001 were generally within historical values (WHC-MR-0418). Areas of special soil sampling that were found outside radiological control areas and that had dose rate levels greater than radiological control limits were cleaned up or posted as surface contamination areas.

Table 3.2.20. Investigative Sample Collections ${ }^{(0)}$

\begin{tabular}{lccc}
\hline \multicolumn{5}{c}{ Sample Type } \\
\cline { 3 - 4 } Year & Soil & Vegetation & Wildlife $^{(\mathbf{b})}$ \\
1994 & 94 & 39 & 27 \\
1995 & 73 & 39 & 25 \\
1996 & 37 & 21 & 41 \\
1997 & 51 & 46 & 30 \\
1998 & 41 & 51 & 55 \\
1999 & 42 & 85 & 16 \\
2000 & 25 & 66 & 12 \\
2001 & 20 & 31 & 10 \\
& \multicolumn{3}{l}{} \\
(a) & Annual number of samples collected. \\
(b) & May include wildlife-related materials (e.g., feces, \\
& nests, etc.)
\end{tabular}


In 2001, there were 31 instances of radiological contamination in investigative vegetation samples. Of the 31 instances, 27 were identified as tumbleweeds or tumbleweed fragments, one as grass, and three as rabbitbrush. None of these samples were analyzed for radionuclide activities. There were eight tumbleweed samples with elevated field readings. Of these, five were from the 218-E-12B burial ground in the 200-East Area, two were found on the SX-SY tank farm in the 200-East Area, and one was suspected to have originated from an inactive transfer line between the B tank farm and the 244-B evaporator in the 200-East Area. Investigative vegetation samples not sent to the laboratory for analysis were disposed of in low-level burial grounds.

Tumbleweed and rabbitbrush are deep-rooted species and become radiologically contaminated by the uptake of below ground contaminants through their root systems. Herbicide application is intended to halt vegetation growth before this uptake occurs. During 2001, application techniques were improved, and administrative procedures were implemented to improve vegetation management. The reduced number of incidents (31) in 2001 appears to reflect these improvements. Nevertheless, contaminated vegetation continued to be identified by radiological surveys. However, as "old" contaminated vegetation from past years is identified and cleaned up, subsequent years should show the results of program improvements.

Investigative wildlife samples were collected directly from or near facilities to monitor and track the effectiveness of measures designed to deter animal intrusion. Samples were collected either as part of an integrated pest management program designed to limit the access of animals to radioactive materials, or as a result of finding radiologically contaminated wildlife-related material (e.g., feces, nests) during radiation surveys.

Radiological surveys were performed after the collection of wildlife to determine whether an animal was radioactively contaminated. If a live animal was found to be free of contamination, it was taken to an area of suitable habitat, still in a controlled area, and released. If an animal was contaminated, a decision was made based on the level of contamination, location, and frequency of occurrence either to collect the animal as a sample or to dispose of the animal in a low-level burial ground.

In 2001, ten wildlife and wildlife-related samples were collected, five of which were submitted for laboratory analysis. The number of samples submitted for analysis depended on opportunity (i.e., resulting from the pest control activities), the technical merits of having isotopic analyses results, and the analytical budget, rather than prescheduled sampling at established sampling points.

The maximum radionuclide concentrations in investigative wildlife samples in 2001 were in mouse feces collected near the 241-TX-155 diversion box in the 200-West Area. Contaminants included strontium89/90, cesium-137, europium-154, europium-155, plutonium-238, and plutonium-239/240. The numbers of animals found to be radioactively contaminated in 2001 were the lowest since 1994, and the range of radionuclide activities were within historical levels (WHC-MR-0418).

In May 2001, contaminated feces were found around the 241-AY/AZ construction trailers in the 200-East Area. Examination of the fecal pellets did not provide a conclusive determination of whether they were weathered mouse feces or fragments of bird feces. The area has a history of contaminated mouse feces. However, a bird feeder at the site also attracted large numbers of birds. The feeder was immediately removed.

The feces were collected and submitted for analysis. Contaminants included cobalt-60, strontium-89/90, cesium-137, europium-154, europium-155, plutonium238, and plutonium-239/240. A sampling effort for avian feces was established in the area, the sampling stations were monitored for 3 months, and no further contamination was noted.

There were five cases of contaminated wildlife or related samples found during cleanup operations that were not submitted to a laboratory for analysis. These samples included ant mounds and mouse feces.

Special characterization projects conducted or completed in 2001 to ascertain the radiological, and in some cases, potential hazardous chemical status of site-specific operations included the project listed below:

- A preoperational monitoring plan (RPP-6877) was developed in support of the Waste Vitrification initiative. As part of this plan, a survey is being conducted on the proposed location for the Remote-Handled Immobilized Low-Activity Waste Disposal Facility in the 200-East Area. Tasks completed in 2001 included radiological and ground penetrating radar surveys and surface and subsurface soil sampling at three locations near the ash disposal pile. Following the completion of all the tasks outlined in the monitoring plan, the obtained data will be published in a final report. The report is scheduled for publication in 2004. 


\subsection{References}

10 CFR 835. U.S. Department of Energy. "Occupational Radiation Protection." Code of Federal Regulations.

40 CFR 61. U.S. Environmental Protection Agency. "National Emission Standards for Hazardous Air Pollutants." Code of Federal Regulations.

40 CFR 122. U.S. Environmental Protection Agency. "EPA Administered Permit Programs: The National Pollutant Discharge Elimination System." Code of Federal Regulations.

AP-42. 1995. Compilation of Air Pollutant Emission Factors, Volume I: Stationary Point and Area Sources, Fifth Edition. Office of Air Quality Planning and Standards, Office of Air and Radiation, U.S. Environmental Protection Agency, Research Triangle Park, North Carolina.

Comprehensive Environmental Response, Compensation, and Liability Act. 1980. Public Law 96-150, as amended, 94 Stat. 2767, 42 USC 9601 et seq.

DFSNW-OEM-001. 2002. Operational Environmental Monitoring. S. M. McKinney, Duratek Federal Services, Northwest Operations, Richland, Washington.

DOE Order 435.1. "Radioactive Waste Management."

DOE Order 5400.1. "General Environmental Protection Program."

DOE Order 5400.5. "Radiation Protection of the Public and the Environment."

DOE Order 5484.1. "Environmental Protection, Safety, and Health Protection Information Reporting Requirements."

DOE/RL-91-50, Rev. 3. 2000. Environmental Monitoring Plan, United States Department of Energy Richland Operations Office. U.S. Department of Energy, Richland Operations Office, Richland, Washington.

DOE/RL-2002-20. 2002. Radionuclide Air Emissions Report for the Hanford Site, Calendar Year 2001. D. J. Rokkan, K. Rhoads, and L. H. Staven, U.S. Department of Energy, Richland Operations Office, Richland, Washington.
HNF-EP-0527-11. 2002. Environmental Releases for Calendar Year 2001. D. L. Dyekman, Fluor Hanford, Inc., Richland, Washington.

PNNL-13910, APP. 2. 2002. Hanford Site Near-Facility Environmental Monitoring Data Report for Calendar Year 2001. C. J. Perkins, R. M. Mitchell, B. M. Markes, S. M. McKinney, and R. C. Roos, Waste Management Technical Services for Pacific Northwest National Laboratory, Richland, Washington.

RPP-6877. 2000. Remote-Handled Immobilized Low-Activity Waste Disposal Facility Preoperational Monitoring Plan. D. G. Horton, S. P. Reidel, and Yi-Ju Chien, Pacific Northwest National Laboratory, R. M. Mitchell, Waste Management Federal Services, Inc., Northwest Operations for CH2M HILL Hanford Group, Inc., Richland, Washington.

WAC 173-216. "State Waste Discharge Program." Washington Administrative Code, Olympia, Washington.

WAC 173-303-145. "Spills and Discharges Into the Environment." Washington Administrative Code, Olympia, Washington.

WAC 173-400. "General Regulations for Air Pollution Sources." Washington Administrative Code, Olympia, Washington.

WAC 246-247. "Radiation Protection-Air Emissions." Washington Administrative Code, Olympia, Washington.

WHC-MR-0418. 1994. Historical Records of Radioactive Contamination in Biota at the 200 Areas of the Hanford Site. A. R. Johnson, B. M. Markes, J. W. Schmidt, A. N. Shah, S. G. Weiss, and K. J. Wilson, Westinghouse Hanford Company, Richland, Washington.

WHC-SD-EN-TI-070. 1992. Soil Concentration Limits for Accessible and Inaccessible Areas. P. D. Rittman, Westinghouse Hanford Company, Richland, Washington. 


\title{
4.0 Environmental Surveillance Information
}

\author{
R. W. Hanf and L. E. Bisping
}

The following sections describe results of the Hanford Site surface environmental surveillance and drinking water surveillance projects for 2001 and include, where applicable, information on both radiological and non-radiological constituents. The objectives, criteria, design, and description of these projects are summarized below and provided in detail in the Hanford Site environmental monitoring plan (DOE/RL91-50). Radiological doses associated with the surveillance results are discussed in Section 5.0. The quality assurance and quality control programs developed to assure the value of surveillance data are described in Section 9.0.

Many samples are collected and analyzed for the Hanford Site environmental surveillance project, and the resulting data are compiled in a large database. It is not practical nor desirable to list individual results in this report; therefore, only summary information is included, emphasizing those radionuclides or chemicals of Hanford Site origin that are important to the environment or human health and safety. Supplemental data for some sections can be found in Appendix B. More detailed results for specific surface environmental surveillance sampling locations are contained in Hanford Site Environmental Surveillance Data Report for Calendar Year 2001 (PNNL-13910, APP. 1). The intent of these sections (Sections 4.1 through 4.7) is to provide current surveillance data, to compare 2001 data to past data and existing and accepted standards, and to present a general overview of Hanford Site surveillance activities.

In addition to Hanford Site environmental surveillance, environmental monitoring is conducted at or near facilities on the site. These near-facility monitoring efforts are discussed in Section 3.2.

\subsubsection{Surface Environmental Surveillance}

The Pacific Northwest National Laboratory's Surface Environmental Surveillance Project is a multimedia environmental monitoring effort to measure the concentration of radionuclides and chemicals in environmental media and assess the potential effects of these materials on the environment and the public. Samples of air, surface water, sediment, soil and natural vegetation, agricultural products, fish, and wildlife are collected routinely or periodically. Analyses include the measurement of radionuclides at very low environmental levels and non-radiological chemicals, including metals and anions. In addition, ambient external radiation is measured.

The project focuses on routine releases from U.S. Department of Energy (DOE) facilities on the Hanford Site; however, the project also responds to unplanned releases and releases from non-DOE operations on and near the site. Surveillance results are provided annually through this report series. In addition, unusual results or trends are reported to the DOE
Richland Operations Office and the appropriate facility managers when they occur. Whereas effluent and nearfacility environmental monitoring are conducted by the facility operating contractor or designated subcontractor, environmental surveillance is conducted under an independent program that reports directly to the DOE Richland Operations Office, Office of Site Services.

\subsubsection{Surveillance Objectives}

The general requirements and objectives for environmental surveillance are contained in DOE Orders 5400.1, "General Environmental Protection Program," and 5400.5, "Radiation Protection of the Public and the Environment." The broad objectives (DOE Order 5400.1) are to demonstrate compliance with legal and regulatory requirements, to confirm adherence to DOE environmental protection policies, and to support environmental management decisions. 
These requirements are embodied in the surveillance objectives stated in the DOE Orders and DOE/ EH-0173T, Environmental Regulatory Guide for Radiological Effluent Monitoring and Environmental Surveillance, and include the following:

- determine compliance with applicable environmental quality standards, public exposure limits, and applicable laws and regulations; the requirements of DOE Orders; and the environmental commitments made in environmental impact statements, environmental assessments, safety analysis reports, or other official DOE documents. Additional objectives include conducting preoperational assessments, assessing radiological doses to the public and environment, assessing doses from other local sources, reporting alarm levels and potential doses exceeding reporting limits (DOE Order 5400.5, Chapter II, Section 7), and maintaining an environmental monitoring plan

- determine background levels and site contributions of contaminants in the environment

- determine long-term accumulation of site-related contaminants in the environment and predict trends

- characterize and define trends in the physical, chemical, and biological conditions of environmental media

- determine effectiveness of treatment and controls in reducing effluents and emissions

- determine validity and effectiveness of models to predict the concentrations of pollutants in the environment

- detect and quantify unplanned releases

- identify and quantify new environmental quality problems.

DOE/EH-0173T stipulates that subsidiary objectives for surveillance should be considered. Subsidiary objectives applicable to the site include the following:

- obtain data and maintain the capability to assess the consequence of accidents

- provide public assurance; address issues of concern to the public, stakeholders, regulators, and business community

- enhance public understanding of site environmental issues, primarily through public involvement and by providing public information
- provide environmental data and assessments to assist the DOE in environmental management of the site.

\subsubsection{Surveillance Design}

The DOE Orders require that the content of surveillance programs be determined on a site-specific basis by the DOE site offices. The surveillance programs must reflect facility characteristics; applicable regulations; hazard potential; quantities and concentrations of materials released; extent and use of affected air, land, and water; and specific local public interests and concerns. Environmental surveillance at the Hanford Site is designed to meet the listed objectives while considering the environmental characteristics of the site and potential and actual releases from site operations. Surveillance activities focus on the effect to the environment and compliance with public health and environmental standards or protection guides rather than on providing detailed radiological and chemical characterization. Experience gained from environmental surveillance and studies conducted at the Hanford Site for more than 50 years provide valuable technical background for planning the surveillance design and managing the site.

The Hanford Site environmental surveillance project historically focused on radionuclides in various media and non-radiological water quality parameters. In recent years, surveillance for non-radiological constituents, including hazardous chemicals, has been expanded. A detailed chemical pathway and exposure analysis for the Hanford Site was completed in 1995 (PNL-10714). The analysis helped guide the selection of chemical surveillance media, sampling locations, and chemical constituents.

Each year, a radiological pathway analysis and exposure assessment is performed. The 2001 pathway analysis was based on 2001 source-term data and on the comprehensive pathway and dose assessment methods included in the Generation II (GENII) computer code (PNL-6584) used to estimate radiation doses to the public from Hanford Site operations. The Biota Dose Calculator, a spreadsheet program, was used to calculate doses to animals. The results of the pathway analysis and exposure assessment serve as a basis for future years' surveillance program design.

Exposure is defined as the interaction of an organism with a physical or chemical agent of interest. Thus, exposure can be quantified as the amount of chemical or physical agent available for absorption at the organism's exchange boundaries (i.e., skin contact, lungs, gut). An exposure pathway is identified based on (1) examination 
of the types, location, and sources (contaminated soil, raw effluent) of contaminants; (2) principal release mechanisms; (3) probable environmental fate and transport (including persistence, partitioning, and intermediate transfer) of contaminants of interest; and, most important, (4) location and activities of the potentially exposed populations. Mechanisms that influence the fate and transport of a chemical through the environment and influence the amount of exposure a person might receive at various receptor locations are listed below.

Once a radionuclide or chemical is released into the environment, it may be

- transported (e.g., migrate downstream in solution or on suspended sediment, travel through the atmosphere, or be carried off the site by contaminated wildlife)
- physically or chemically transformed (e.g., deposition, precipitation, volatilization, photolysis, oxidation, reduction, hydrolysis or radionuclide decay)

- biologically transformed (e.g., biodegradation)

- accumulated in the receiving media (e.g., sorbed strongly in the soil column, stored in organism tissues).

The primary pathways for movement of radioactive materials and chemicals from the site to the public are the atmosphere and surface water. Figure 4.0.1 illustrates these potential routes and exposure pathways to humans.

The significance of each pathway was determined from measurements and calculations that estimated the

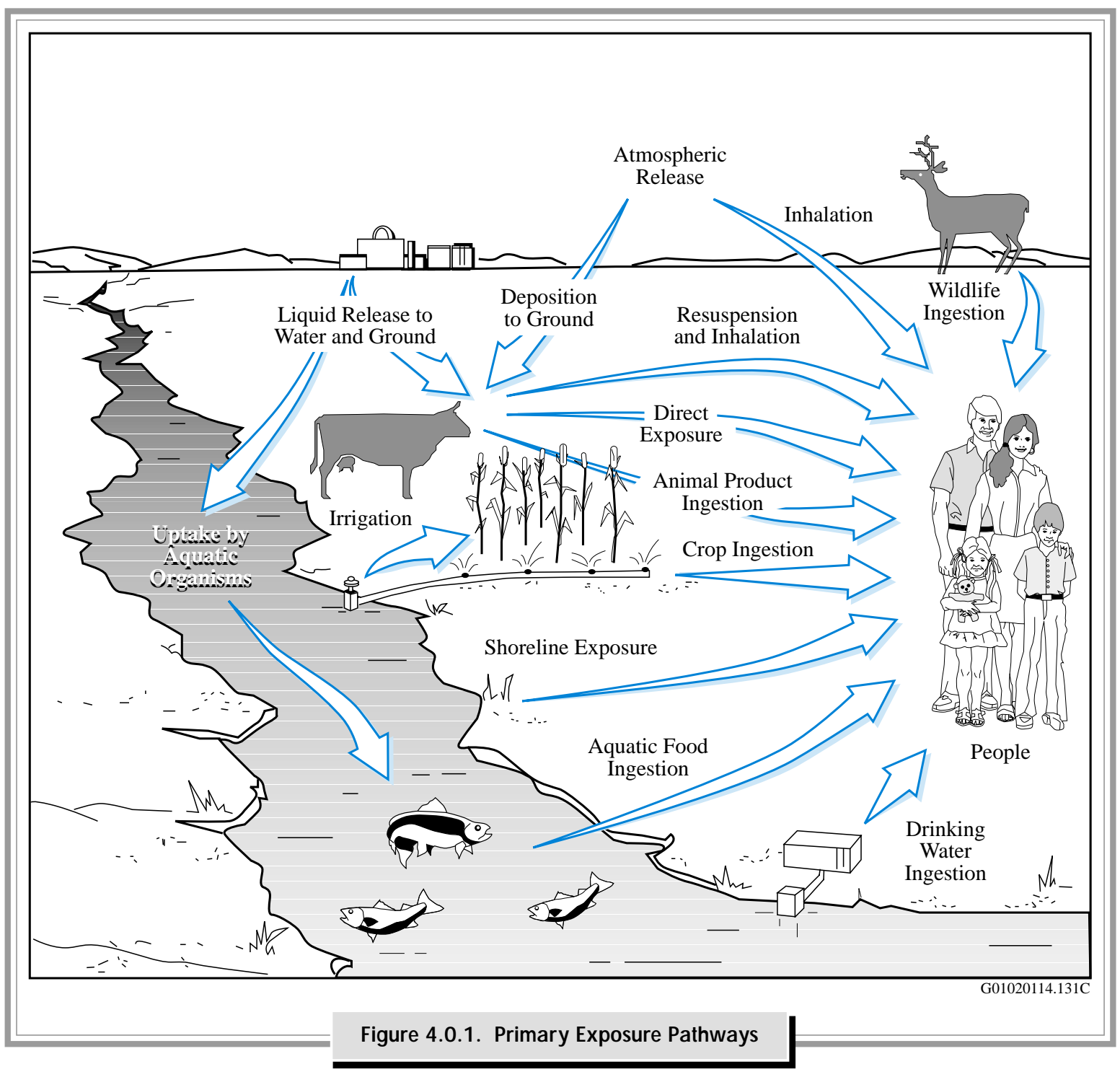


amount of radioactive material or chemical transported along each pathway and by comparing the concentrations or potential doses to environmental and public health protection standards or guides. Pathways were also evaluated based on prior studies and observations of radionuclide and chemical movement through the environment and food chains. Calculations based on effluent data showed the expected concentrations off the Hanford Site, for all Hanford-produced radionuclides and chemicals, to be frequently below the levels that could be detected by monitoring technology. To assure that radiological and chemical analyses of samples were sufficiently sensitive, minimum detectable concentrations of key radionuclides and chemicals were established at levels well below applicable health standards.

Environmental and food chain pathways were monitored near facilities releasing effluents and at potential offsite receptor locations. The surveillance design at Hanford used a stratified sampling approach to monitor these pathways. Samples were collected, and radionuclide and chemical concentrations were measured in three general surveillance zones that extended from onsite operational areas to the offsite environs.

The first surveillance zone extended from near the operational areas to the site perimeter. The environmental concentrations of releases from facilities and fugitive sources (those released from other than monitored sources such as contaminated soils) generally would be the highest and, therefore, most easily detected in this zone. The second surveillance zone consisted of a series of perimeter sampling stations positioned near or just inside the site boundary, along State Highway 240, which runs through the site from Richland to the Yakima Barricade, and along the Columbia River (see Figure 1.0.1). The third surveillance zone consisted of locations in communities within an 80-kilometer (50-mile) radius of the site. Surveillance was conducted in communities to obtain measurements at locations where a large number of people potentially could be exposed to Hanford Site releases and to document that contaminant levels were well below standards established to protect public health. Table 4.0.1 summarizes the sample types and measurement locations in all three zones for 2001. A summary of the number and types of samples collected during 2001, and the number of analytical results obtained from those samples is provided in Table 4.0.2. Except for special studies, soil and vegetation samples are only collected every 3 to 5 years. Soil and vegetation samples were collected in 2001.

Background concentrations were measured at distant locations and compared with concentrations measured on the site and at perimeter and community locations. Background locations were essentially unaffected by Hanford Site operations (i.e., these locations could be used to

\begin{tabular}{|c|c|c|c|c|c|c|c|c|}
\hline \multirow[b]{4}{*}{ Type } & \multicolumn{7}{|c|}{$\begin{array}{c}\text { Table 4.0.1. Routine Environmental Surveillance Sample Types and } \\
\text { Measurement Locations, } 2001\end{array}$} & \\
\hline & \multirow[b]{3}{*}{$\begin{array}{c}\text { Total } \\
\text { Number }\end{array}$} & \multicolumn{7}{|c|}{ Sample Locations } \\
\hline & & \multirow[b]{2}{*}{$\underline{\text { Onsite }}^{(a)}$} & \multirow[b]{2}{*}{$\begin{array}{c}\text { Site } \\
\text { Perimeter }^{(\mathbf{b})}\end{array}$} & \multirow[b]{2}{*}{$\underline{\text { Nearby }}^{(c)}$} & \multirow[b]{2}{*}{$\underline{\text { Distant }}^{(c)}$} & \multicolumn{3}{|c|}{ Columbia River } \\
\hline & & & & & & $\underline{\text { Upstream }}^{(\mathrm{c})}$ & $\begin{array}{l}\text { Hanford } \\
\text { Reach }^{(b)}\end{array}$ & Downstream $^{(\mathrm{c})}$ \\
\hline Air & 45 & 24 & 11 & $8^{(\mathrm{d})}$ & $2^{(\mathrm{d})}$ & & & \\
\hline Spring water & 8 & & & & & & 8 & \\
\hline Spring sediment & 5 & & & & & & 5 & \\
\hline Columbia River & 7 & & & & & 2 & 4 & 1 \\
\hline Irrigation water & 2 & & 2 & & & & & \\
\hline Drinking water & 4 & 4 & & & & & & \\
\hline River sediment & 6 & & & & & 1 & 3 & 2 \\
\hline Ponds & 2 & 2 & & & & & & \\
\hline Foodstuffs & 7 & & & 5 & 2 & & & \\
\hline Wildlife & 6 & 3 & & & 1 & & 1 & 1 \\
\hline External dose & 76 & 29 & 38 & 7 & 2 & & & \\
\hline $\begin{array}{l}\text { External shoreline } \\
\text { radiation }\end{array}$ & 14 & & 14 & & & & & \\
\hline Exposure rate & 4 & & & 3 & 1 & & & \\
\hline Soil & 39 & 24 & 8 & 2 & 5 & & & \\
\hline Vegetation & 14 & 8 & 4 & & 2 & & & \\
\hline $\begin{array}{l}\text { (a) Surveillance } \\
\text { (b) Surveillance } \\
\text { (c) Surveillance } \\
\text { (d) } \\
\text { Includes com }\end{array}$ & $\begin{array}{l}\text { Zone } 1 . \\
\text { Zone } 2 . \\
\text { Zone } 3 \text {. } \\
\text { amunity-ope }\end{array}$ & ted environ & mental surveill & ance stations & & & & \\
\hline
\end{tabular}




\begin{tabular}{|c|c|c|}
\hline \multicolumn{3}{|c|}{$\begin{array}{c}\text { Table 4.0.2. Samples Collected for the } \\
\text { Surface Environmental Surveillance } \\
\text { Project and Analytical Results } \\
\text { O btained, } 2001\end{array}$} \\
\hline Media & $\begin{array}{c}\text { N umber of } \\
\text { Samples } \\
\text { Collected }\end{array}$ & $\begin{array}{c}\text { N umber of } \\
\text { A nalytical } \\
\text { R esults } \\
\text { O btained }\end{array}$ \\
\hline Air & 1,605 & 4,161 \\
\hline Biota & 428 & 3,932 \\
\hline Soil and sediment & 109 & 1,281 \\
\hline Surface water & 635 & 6,345 \\
\hline Drinking water & 16 & 64 \\
\hline External radiation & 290 & 290 \\
\hline Totals & 3,083 & 16,073 \\
\hline
\end{tabular}

measure ambient environmental levels of chemicals and radionuclides). Comparing concentrations at these background locations to concentrations measured on or near the site indicated the impact, if any, of Hanford Site operations.

To the extent possible, radiological dose assessments should be based on direct measurements of dose rates and radionuclide activities in environmental media. However, the amounts of most radioactive materials released from Hanford Site operations in recent years generally have been too small to be measured directly once dispersed in the offsite environment. For the measurable radionuclides, often it was not possible to distinguish levels resulting from worldwide fallout and natural sources from those associated with Hanford Site releases. Therefore, offsite doses in 2001 were estimated using the following methods:

- Doses from monitored air emissions and liquid effluents released to the Columbia River were estimated by applying environmental transport and dose calculation models to measured effluent monitoring data and selected environmental measurements.

- Doses from fugitive air emissions (e.g., from unmonitored, resuspended, contaminated soils) were estimated from measured airborne concentrations at site perimeter locations.

- Doses from fugitive liquid releases (e.g., unmonitored groundwater seeping into the Columbia River) were estimated by evaluating differences in measured concentrations in Columbia River water upstream and downstream from the Hanford Site.

The surveillance design is reviewed annually based on the above considerations as well as an awareness of planned waste management and environmental restoration activities. The final sampling design and schedule are documented annually in the environmental surveillance master sampling schedule (e.g., PNNL-13418 for 2001).

\subsubsection{Special Studies in 2001}

In August and September 2001, the Surface Environmental Surveillance Project and the Washington State Department of Health conducted a contaminant characterization and biological and human dose/risk assessment study of the Columbia River shoreline of the 300 Area. This work was also supported by Washington State Department of Ecology and U.S. Environmental Protection Agency (EPA) staff. Numerous samples of river water, shoreline springs water, river bottom porewater (within the gravels on the river bottom), riparian and aquatic plants, terrestrial biota, and aquatic organisms were collected and analyzed for radiological and chemical contaminants. Samples were collected near three known shoreline springs in the 300 Area and from two reference sites - one upstream near the Vernita Bridge and the other downstream of the study area. The study results and assessment are summarized in a technical report issued in 2002 (PNNL-13692). 


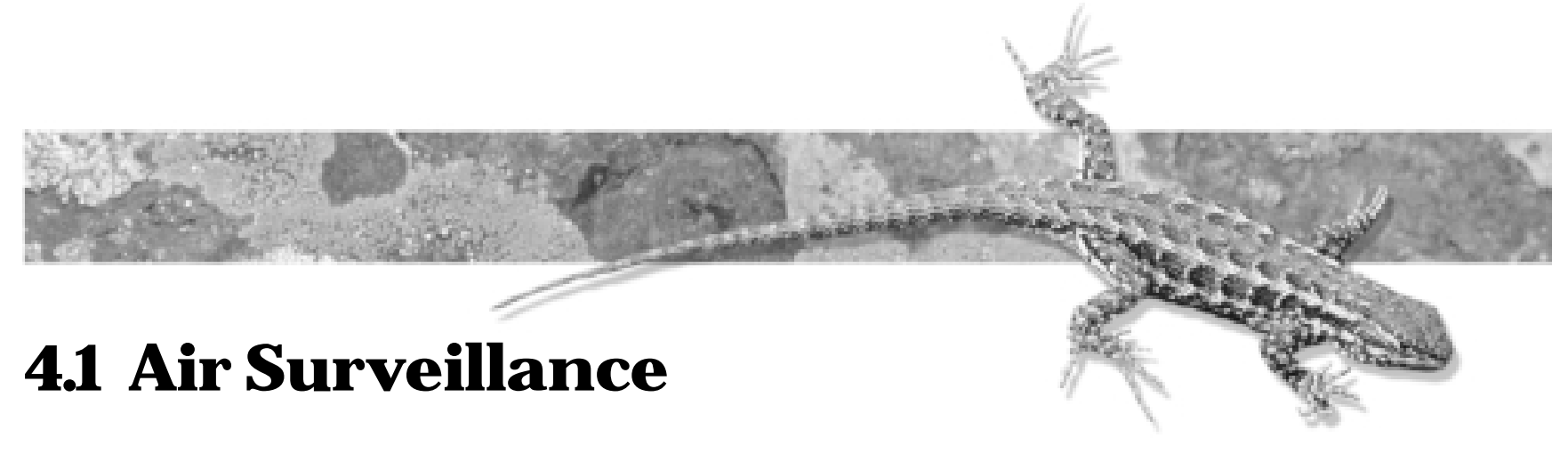

B. G. F ritz

Atmospheric releases of radioactive material from the Hanford Site to the surrounding region are a potential source of human exposure. Radioactive constituents in air are monitored at a network of air sampling locations on and around the Hanford Site. Detailed descriptions of all routine radiological sampling and analytical techniques are provided in the environmental monitoring plan (DOE/RL-91-50). Comparing measured radionuclide concentrations from locations on and around the Hanford Site to upwind sites assumed to be uninfluenced by Hanford Site operations provides an evaluation of the impact of radionuclide air emissions from the Hanford Site. A complete listing of all radiological analytical results summarized in this section is reported separately (PNNL-13910, APP. 1). Nonradiological, particulate monitoring data is also summarized in Section 4.1.3.

\subsection{Collection of Air Samples and Analytes Tested}

Airborne radionuclide samples were collected at 45 continuously operating samplers: 24 on the Hanford Site, 11 near the site perimeter, 8 in nearby communities, and 2 in distant communities (Figure 4.1.1 and Table 4.1.1). Nine of the stations were communityoperated environmental surveillance stations (discussed in Section 8.4) that were managed and operated by local school teachers (under contract with Pacific Northwest National Laboratory) as part of an ongoing DOEsponsored program to promote public awareness of Hanford Site environmental monitoring programs. Air samplers on the Hanford Site were located primarily around major operational areas to maximize the ability to detect radiological contaminants resulting from site operations. Perimeter samplers were located around the site, with emphasis on the prevailing downwind directions to the south and east of the site (discussed in Section 8.1). Samplers located in Basin City, Benton City, Kennewick, Mattawa, Othello, Pasco, and Richland provided data for the nearest population centers. Samplers in the distant communities of Toppenish and Yakima provided background data for communities essentially unaffected by Hanford Site operations.

Samples were collected according to a schedule established before the monitoring year (PNNL-13418). The air sampling locations and the analytes tested for at each location are given in Table 4.1.1. Airborne particles were sampled at each of these locations by continuously drawing air through a high efficiency glassfiber filter. The samples were transported to an analytical laboratory and stored for at least 72 hours. The storage period was necessary to allow for the decay of shortlived, naturally occurring radionuclides (e.g., radon gas decay products) that would otherwise obscure detection of longer-lived radionuclides potentially present from Hanford Site emissions. The filters were then analyzed for gross beta radioactivity, and most filters were also analyzed for gross alpha radioactivity.

Historically, for most radionuclides, the amount of radioactive material collected on the filter during a 2 -week period has been too small for accurate analysis. In order to increase the sensitivity and accuracy of the analysis, biweekly samples were combined into quarterly composite samples. The quarterly composite samples were analyzed for specific gamma-emitting radionuclides (see Appendix F), strontium-90, and plutonium isotopes. Selected composite samples also were analyzed for uranium isotopes.

Samples were collected for iodine-129 analysis at four locations by drawing air through a chemically treated, low-background petroleum-based charcoal adsorbent cartridge. Samples were collected monthly and combined to form quarterly composite samples for each location.

Atmospheric water vapor was collected for tritium analysis at 21 locations by continuously drawing air through cartridges containing silica gel, which were exchanged every 4 weeks. The collection efficiency of 


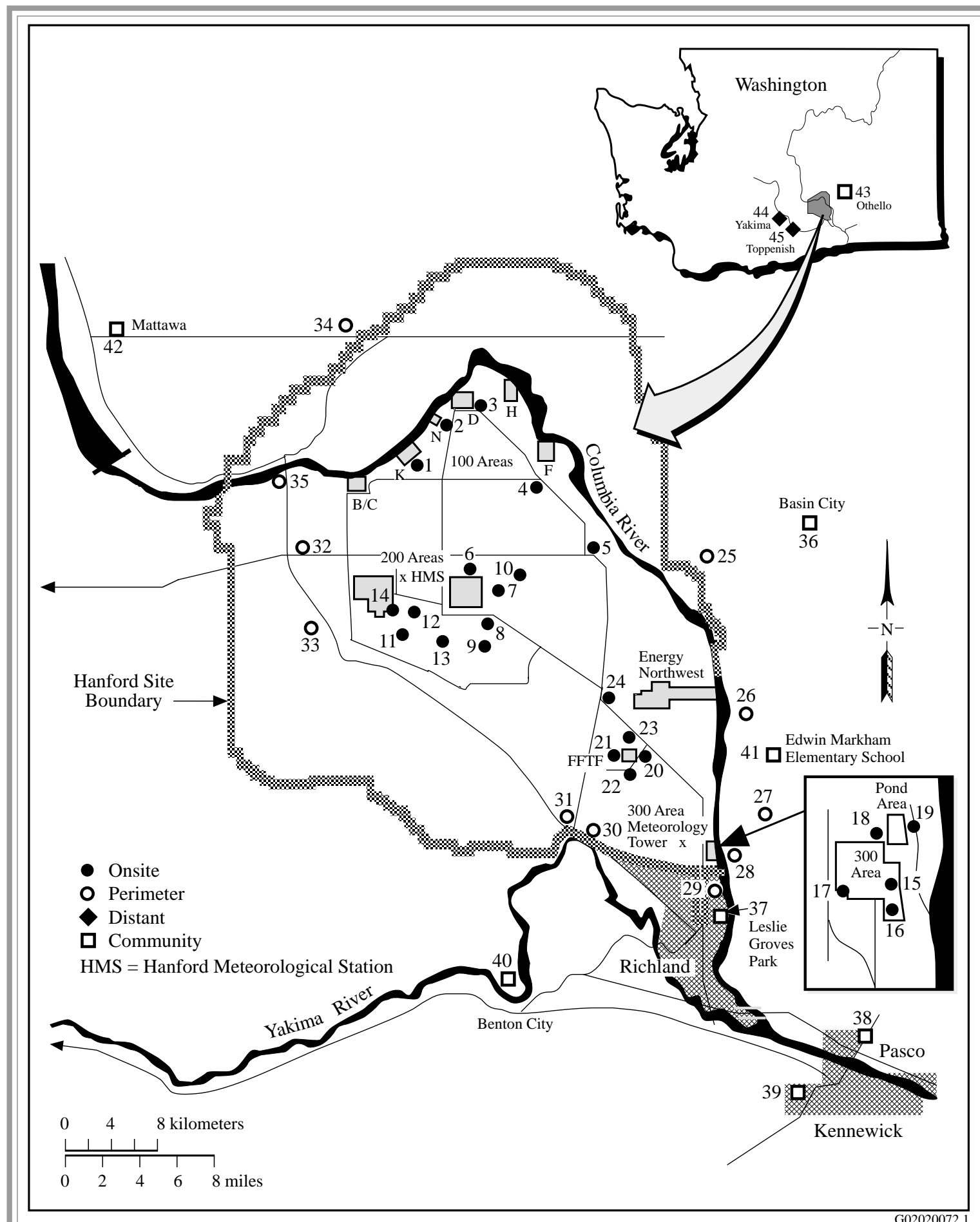

Figure 4.1.1. Air Sampling Locations, 2001 (see Table 4.1.1 for location names) 
Table 4.1.1. Air Sampling Locations, Sample Composite Groups, and Analytes, 2001

ocation

Location

Onsite

2

3

4

5

6

7

8

9

10

11

12

13

14

15

16

17

18

19

20

21

22

23

24

Perimeter

25

26

27

28

29

30

31

32

33

34

35
Sampling Location

Analytes $^{(b)}$

Composite Group

100 Areas

Alpha, Beta, ${ }^{3} \mathrm{H}$

Alpha, Beta, ${ }^{3} \mathrm{H}$

Alpha, Beta

Alpha, Beta

Alpha, Beta

Beta

Alpha, Beta

Alpha, Beta, ${ }^{3} \mathrm{H},{ }^{129} \mathrm{I}$

Alpha, Beta

Alpha, Beta

Alpha, Beta

Alpha, Beta, ${ }^{3} \mathrm{H}$

Alpha, Beta

Alpha, Beta

Alpha, Beta, ${ }^{3} \mathrm{H}$

Alpha, Beta, ${ }^{3} \mathrm{H}$

Alpha, Beta, ${ }^{3} \mathrm{H}$

Alpha, Beta, ${ }^{3} \mathrm{H}$

Alpha, Beta, ${ }^{3} \mathrm{H}$

Alpha, Beta, ${ }^{3} \mathrm{H}$

Alpha, Beta

Alpha, Beta

Alpha, Beta

Alpha, Beta

Alpha, Beta, ${ }^{3} \mathrm{H},{ }^{129} \mathrm{I}$

Alpha, Beta

Alpha, Beta, ${ }^{3} \mathrm{H}$

Alpha, Beta, ${ }^{3} \mathrm{H},{ }^{129} \mathrm{I}$

Beta

Alpha, Beta

${ }^{3} \mathrm{H}$

Prosser Barricade

Yakima Barricade

Rattlesnake Springs

Wahluke Slope

$S$ End Vernita Bridge
Alpha, Beta

Alpha, Beta

Alpha, Beta, ${ }^{3} \mathrm{H}$

Alpha, Beta
Hanford Townsite

$\mathrm{N}$ of $200 \mathrm{E}$

200 E Area

Gamma, Sr, Pu, U

B Pond

Gamma, Sr, Pu, U

200 W South East

Gamma, Sr, Pu, U

Gamma, Sr, Pu, U

Gamma, Sr, Pu, U

300 Area

$300 \mathrm{NE}$

Gamma, Sr, Pu, U

400 Area

Gamma, Sr, Pu

Wye Barricade

Gamma, Sr, Pu, U

Ringold Met Tower

Gamma, Sr, Pu

W End of Fir Road

Gamma, Sr, Pu, U

Dogwood Met Tower

Gamma, Sr, Pu, U

Byers Landing

Battelle Complex

Prosser Barricade

Gamma, Sr, Pu, U

Gamma

Gamma, Sr, Pu, U

Yakima Barricade

Gamma, Sr, Pu

Wahluke Slope

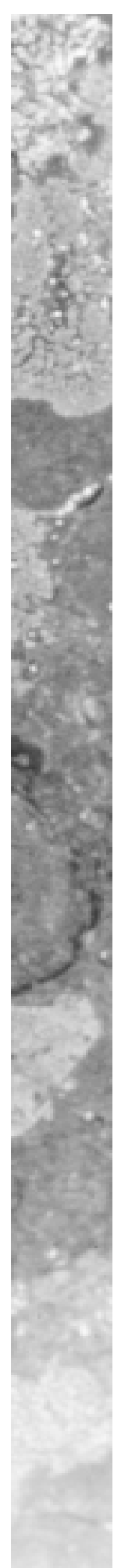




\begin{tabular}{|c|c|c|c|c|c|}
\hline & \multirow[b]{2}{*}{ Sampling Location } & \multicolumn{2}{|c|}{ Table 4.1.1. (contd) } & \multirow[b]{2}{*}{ Analytes $^{(c)}$} \\
\hline & $\begin{array}{l}\text { Map(a) } \\
\text { ocation }\end{array}$ & & $\underline{A n a l y t e s}^{(b)}$ & Composite Group & \\
\hline \multicolumn{6}{|c|}{ Nearby Communities } \\
\hline & 36 & Basin City School ${ }^{(\mathrm{d})}$ & Alpha, Beta, ${ }^{3} \mathrm{H}$ & Basin City School & Gamma, Sr, Pu, U \\
\hline & 37 & Leslie Groves-Rchlnd $d^{(\mathrm{d})}$ & Alpha, Beta, ${ }^{3} \mathrm{H}$ & Leslie Groves-Rchlnd & Gamma, Sr, Pu, U \\
\hline & 38 & $\mathrm{Pasco}^{(\mathrm{d})}$ & Beta & Tri-Cities & Gamma, Sr, Pu \\
\hline & 39 & Kennewick $^{(\mathrm{d})}$ & Alpha, Beta & & \\
\hline & 40 & Benton City (d) & Beta & Benton City & Gamma \\
\hline & 41 & $\begin{array}{l}\text { Edwin Markham } \\
\text { School }^{(\mathrm{d})}\end{array}$ & Alpha, Beta, ${ }^{3} \mathrm{H}$ & $\begin{array}{l}\text { Edwin Markham } \\
\text { School }\end{array}$ & Gamma, Sr, Pu, U \\
\hline & 42 & Mattawa $^{(\mathrm{d})}$ & Beta & Mattawa & Gamma \\
\hline & 43 & Othello ${ }^{(\mathrm{d})}$ & Beta & Othello & Gamma \\
\hline \multicolumn{6}{|c|}{ Distant Communities } \\
\hline & 44 & Yakima & Alpha, Beta, ${ }^{3} \mathrm{H},{ }^{129} \mathrm{I}$ & Yakima & Gamma, Sr, Pu, U \\
\hline & 45 & Toppenish $^{(\mathrm{d})}$ & Alpha, Beta, ${ }^{3} \mathrm{H}$ & Toppenish & Gamma, Sr, Pu, U \\
\hline \multicolumn{6}{|c|}{ 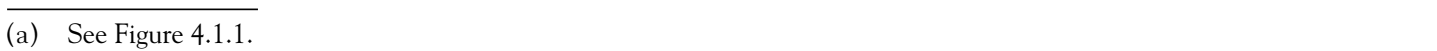 } \\
\hline \multicolumn{6}{|c|}{$\begin{array}{l}\text { (b) Alpha (gross) and beta (gross) samples are collected and analyzed every } 2 \text { weeks, }{ }^{3} \mathrm{H} \text { samples are collected and analyzed } \\
\text { every } 4 \text { weeks, and }{ }^{129} \mathrm{I} \text { samples are collected every } 4 \text { weeks, combined into a quarterly composite sample and analyzed for } \\
\text { each location. } \\
\text { (c) Gamma spectroscopy, strontium-90, isotopic plutonium }\left({ }^{238} \mathrm{Pu},{ }^{239 / 240} \mathrm{Pu}\right) \text {, and isotopic uranium }\left({ }^{234} \mathrm{U},{ }^{235} \mathrm{U},{ }^{238} \mathrm{U}\right) \text { analyses } \\
\text { are performed on quarterly composite samples. } \\
\text { (d) A community-operated environmental surveillance station. }\end{array}$} \\
\hline
\end{tabular}

the silica gel adsorbent is discussed in Patton et al. (1997). The collected water was distilled from the silica gel and analyzed for its tritium content.
The samples collected at the community-operated environmental surveillance stations were submitted to the analytical laboratory and treated the same as all other submitted samples.

\subsection{Radiological Results for Air Samples}

Radiological air sampling results for onsite, site perimeter, nearby communities, and distant communities for gross alpha, gross beta, and specific radionuclides are summarized in Table 4.1.2.

A detectable value is defined in this section as a value reported above the minimum detectable level and above the total propagated analytical uncertainty. A nominal detection limit is defined as the average total propagated analytical uncertainty of the population of reported values.

For 2001, the average gross alpha concentrations in air on the Hanford Site were comparable to levels measured at distant stations (see Table 4.1.2), indicating that the onsite levels were predominantly a result of natural sources and worldwide radioactive fallout. The average gross alpha concentrations for perimeter locations and nearby communities were higher than the onsite and distant averages. The differences between perimeter, distant, and onsite concentrations were not statistically significant. The average of the community samples collected in 2001 was significantly higher (two-sample means t-test, 95\% confidence level) than onsite alpha concentrations in 2001, and community samples from 1996 through 2000. Gross alpha concentrations measured onsite and at distant locations were lower in 2001 than in recent years (see Table 4.1.2). Figure 4.1.2 compares all 2001 data for the community and distant locations. The reason the average gross alpha concentration for the community locations was higher than the average for the distant locations was a spike in early July. This spike is suspected to be the result of laboratory error or contamination. All of the elevated samples 


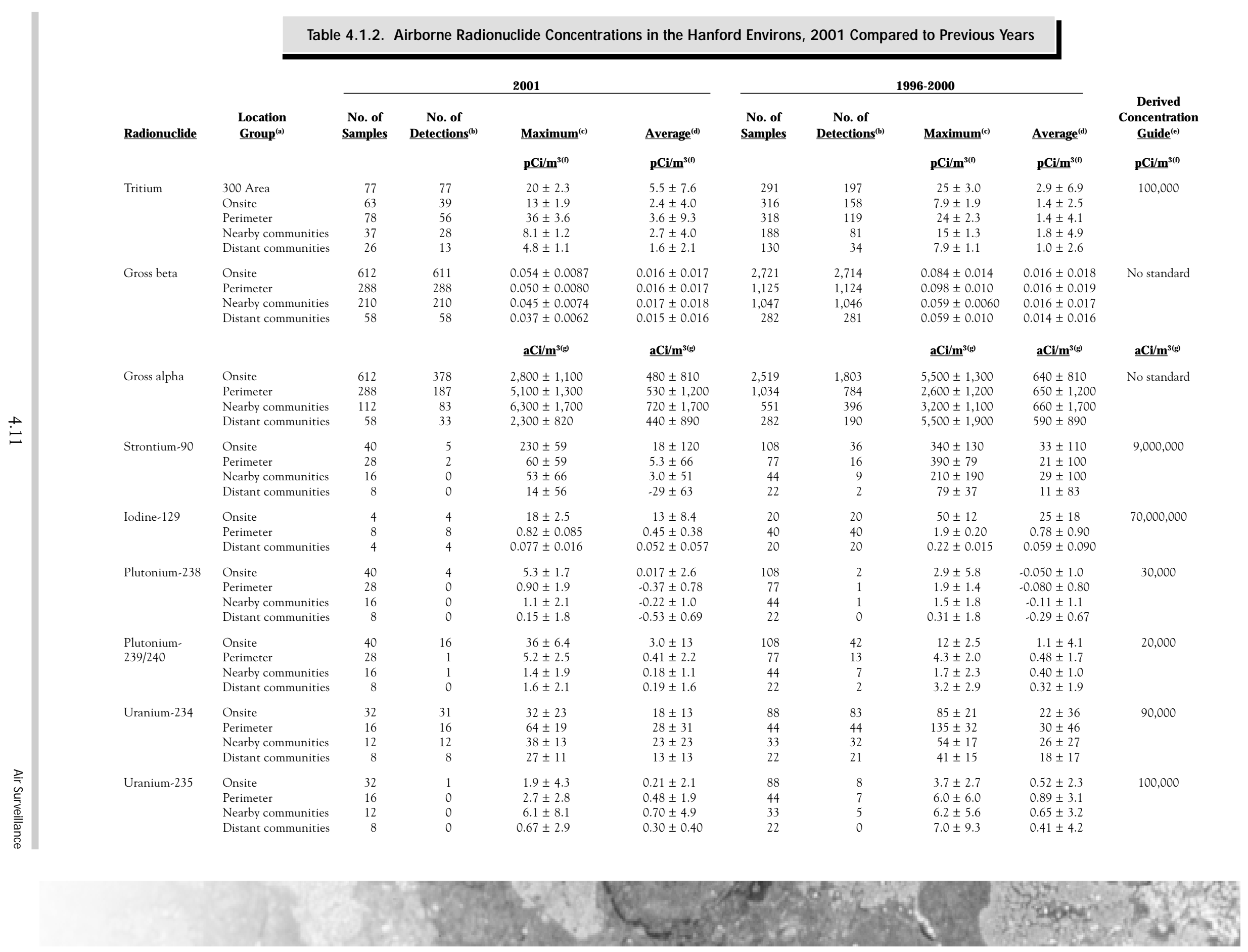


Table 4.1.2. (contd)

2001

$\begin{array}{cc}\text { No. of } & \text { No. of } \\ \text { Samples } & \text { Detections }\end{array}$

\section{Radionuclide}

Location
Group $^{(\text {(a) }}$

32
16
12
8
49
33
29
9
49
33
29
9

Distant communitie

\section{Maximum $^{(c)}$}

\section{$\underline{a C i} / m^{3(9)}$}

$42 \pm 17$

$50 \pm 16$

$52 \pm 16$

$24 \pm 10$

$3,300 \pm 750$

$910 \pm 740$

$680 \pm 650$

$450 \pm 120$

$480 \pm 300$

$650 \pm 600$

$450 \pm 490$

$400 \pm 510$

(contel)

(a) Location groups are identified in Table 4.1.1

(b) Detection is defined as a value reported above the minimum detectable activity and above the total propagated analytical uncertainty.

(c) Maximum single sample result \pm total analytical uncertainty. Negative concentration values are explained in Appendix A.

(d) Average of all samples \pm 2 times the standard deviation.

(e) DOE derived concentration guide (see Appendix D, Table D.5)

(f) $1 \mathrm{pCi}=0.037 \mathrm{~Bq}$

(g) There are 1 million attocuries $(\mathrm{aCi})$ in 1 picocurie $(\mathrm{pCi})$.

$1996-2000$

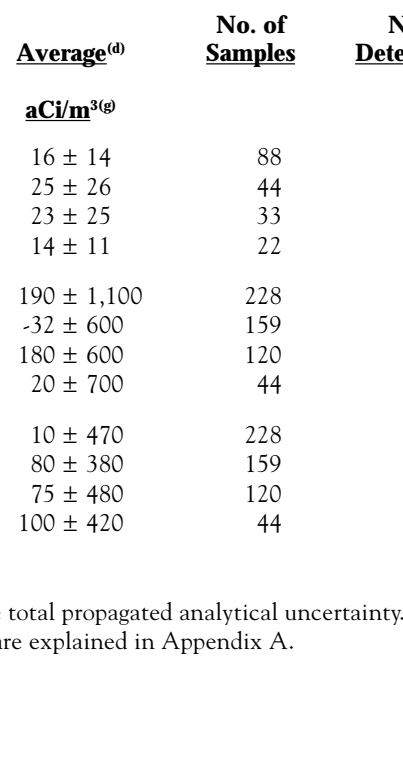

\begin{tabular}{|c|c|}
\hline Maximum $^{(\mathrm{c})}$ & Average $^{(d)}$ \\
\hline$\underline{a C i / m^{3(g)}}$ & $\underline{a C i} / m^{3(g)}$ \\
\hline $\begin{array}{r}92 \pm 27 \\
136 \pm 32 \\
56 \pm 18 \\
33 \pm 15\end{array}$ & $\begin{array}{l}20 \pm 35 \\
28 \pm 45 \\
23 \pm 25 \\
17 \pm 16\end{array}$ \\
\hline $\begin{array}{c}3,800 \pm 2,500 \\
1,000 \pm 530 \\
1,800 \pm 3,600 \\
680 \pm 440\end{array}$ & $\begin{array}{r}74 \pm 780 \\
8.0 \pm 840 \\
-5.3 \pm 930 \\
125 \pm 530\end{array}$ \\
\hline $\begin{array}{c}710 \pm 530 \\
1,200 \pm 2,000 \\
2,100 \pm 3,100 \\
390 \pm 290\end{array}$ & $\begin{array}{r}-3.2 \pm 600 \\
6.8 \pm 640 \\
47 \pm 710 \\
9.1 \pm 520\end{array}$ \\
\hline
\end{tabular}

Derived

Concentration

Guide $^{\text {(e) }}$

$\underline{\mathrm{aC} i / \mathrm{m}^{3(9)}}$

100,000

$80,000,000$

$400,000,000$ 


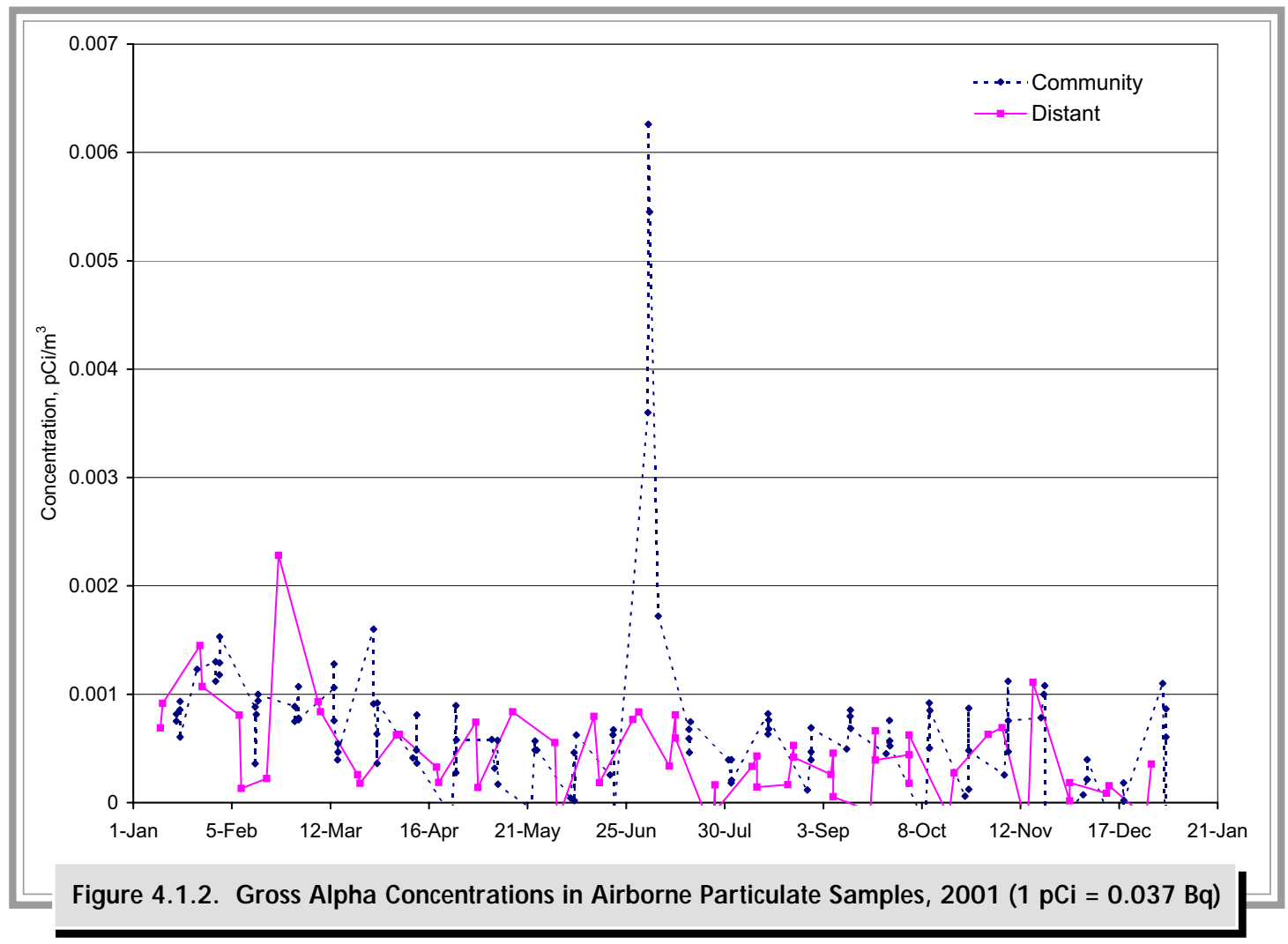

were analyzed in the same batch, and the locations of the elevated samples make it highly unlikely that the increased values are a result of actual environmental concentrations.

Gross beta concentrations in air for 2001 (Figure 4.1.3) peaked during the winter, repeating a pattern of natural annual radioactivity fluctuations (Eisenbud 1987). The average gross beta concentration was slightly higher at the site perimeter than the annual average concentration at the distant location; however, the difference was not statistically significant (two-tailed t-test, 5\% significance level). The 2001 average values were similar to the average values reported for 1996 through 2000 (see Table 4.1.2).

Average tritium concentrations measured in 2001 were slightly higher than values reported for 1996 through 2000 (see Table 4.1.2 and Figure 4.1.4). For non-300 Area samples in 2001, 67\% were considered detected (the analytical method is capable of detecting concentrations below $3 \mathrm{pCi} / \mathrm{m}^{3}\left[0.11 \mathrm{~Bq} / \mathrm{m}^{3}\right]$ ). All 300 Area sample results were above the minimum detectable concentration. Tritium releases in the 300 Area (associated with research and development activities; see Table 3.1.1) resulted in 300 Area concentrations that were elevated relative to other sampling locations. Figure 4.1.4 shows the 2001 average tritium concentrations for all distance classes between 1996 and
2001, and the tritiated water released from the 300 Area for each year. More tritium was released from the 300 Area in 2001 than in 2000, accounting for the increase in averages from 2000 to 2001. Despite the slight increase in tritium emissions in 2001, the highest measured concentration $\left(36 \mathrm{pCi} / \mathrm{m}^{3}\left[1.3 \mathrm{~Bq} / \mathrm{m}^{3}\right]\right)$ detected at location 29 on Figure 4.1.1 on October 2, 2001 was only $0.036 \%$ of the DOE derived concentration guide (see Appendix D, Table D.5)

The annual average tritium concentration measured at the site perimeter $\left(3.6 \pm 9.3 \mathrm{pCi} / \mathrm{m}^{3}[0.13 \pm\right.$ $0.34 \mathrm{~Bq} / \mathrm{m}^{3} \mathrm{]}$ ) was significantly higher (two-tailed t-test, $5 \%$ significance level) than the annual average value at the distant locations $\left(1.6 \pm 2.1 \mathrm{pCi} / \mathrm{m}^{3}[0.059 \pm\right.$ $\left.0.078 \mathrm{~Bq} / \mathrm{m}^{3} \mathrm{l}\right)$. This difference is largely influenced by the proximity of locations 28 and 29 (see Figure 4.1.1) to the 300 Area $(<3.2$ kilometers [2 miles]). However, even with these two locations removed, the difference between perimeter and distant sampling locations is statistically significant. The significant difference between distant and perimeter locations indicate a detectable Hanford source of tritium. However, the annual average tritium concentration measured at the site perimeter in 2001 was less than $0.004 \%$ of the DOE derived concentration guide $\left(100,000 \mathrm{pCi} / \mathrm{m}^{3}\left[3,704 \mathrm{~Bq} / \mathrm{m}^{3}\right] ; \mathrm{DOE}\right.$ Order 5400.5). For further evaluation of the trends in tritium concentration on and around the Hanford Site, see PNNL-13909. 

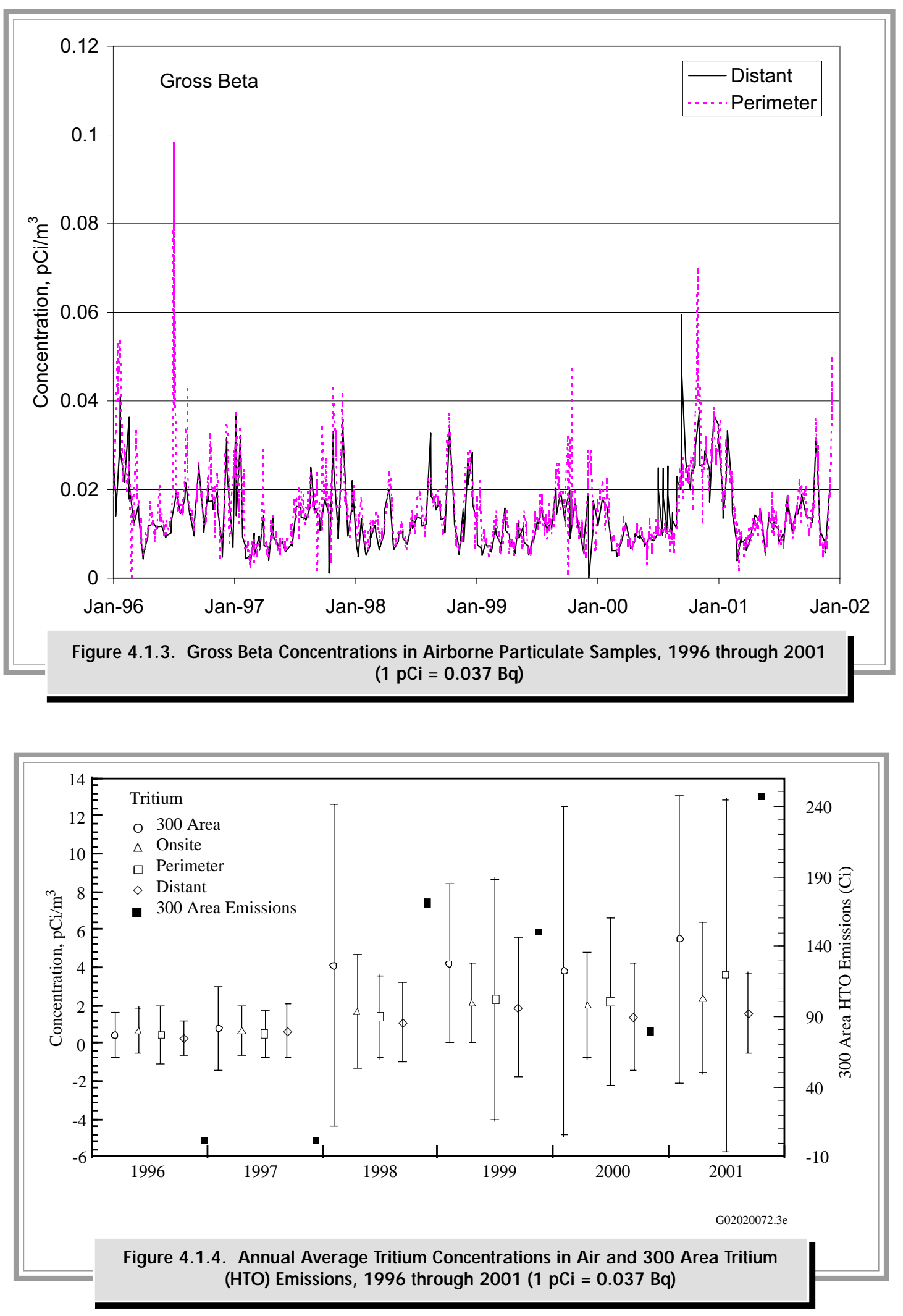
A total of 94 samples were analyzed for strontium-90 in 2001 (see Table 4.1.2). Only 7.6\% (7 of 92) samples analyzed were above the detection limit. Comparison of the average reported concentration at different distance classes was impossible due to the low number of samples above the minimum detectable concentration. The highest measured strontium-90 concentration $\left(230 \pm 59 \mathrm{aCi} / \mathrm{m}^{3}\left[8.5 \pm 2.2\left(\mathrm{~Bq} / \mathrm{m}^{3}\right]\right)\right.$ was in the 100 Areas composite sample in the third quarter of 2001. This maximum value was $0.0026 \%$ of the DOE derived concentration guide ( 9 million aCi $\left./ \mathrm{m}^{3}\left[0.33 \mathrm{~Bq} / \mathrm{m}^{3}\right]\right)$.

Iodine-129 analyses were performed on samples collected onsite at a location downwind of the PlutoniumUranium Extraction Plant, at two downwind perimeter locations, and at a distant location (Yakima) in 2001 (see Table 4.1.1). Onsite concentrations in 2001 were elevated compared to those measured at the site perimeter, and perimeter levels were higher than those measured at the distant location, Yakima (Figure 4.1.5 and Table 4.1.2). Concentration differences between these locations were statistically significant (log transformed, two-tailed $\mathrm{t}$-test, $5 \%$ significance level) and indicated a Hanford source. Onsite and perimeter air concentrations have remained at their respective levels from 1996 through 2001 (see Figure 4.1.5). Onsite air concentrations of iodine-129 were influenced by minor emissions (0.00084 curie [31 MBq]; see Table 3.1.1) from the Plutonium-Uranium Extraction Plant and possible releases from waste storage tanks and cribs. The annual average iodine -129 concentration $\left(0.45 \pm 0.38 \mathrm{aCi} / \mathrm{m}^{3}\right.$ $\left.\left[0.017 \pm 0.014 \mu \mathrm{Bq} / \mathrm{m}^{3}\right]\right)$ at the downwind perimeter in 2001 was less than $0.000001 \%$ of the DOE derived concentration guide (70 million $\left.\mathrm{aCi} / \mathrm{m}^{3}\left[2.6 \mathrm{~Bq} / \mathrm{m}^{3}\right]\right)$.

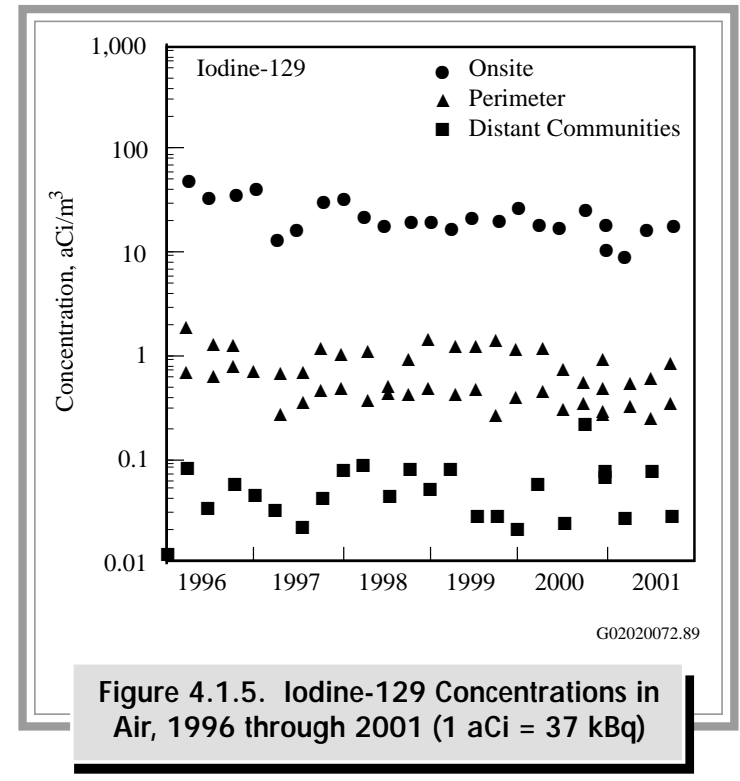

Plutonium-238 was detected in four of the onsite composite samples in 2001 (nominal detection limit of $\left.1.8 \mathrm{aCi} / \mathrm{m}^{3}\left[0.067 \mu \mathrm{Bq} / \mathrm{m}^{3}\right]\right)$. The four samples were all from the 100 Areas composite group. The maximum reported plutonium-238 concentration in 2001 was $5.3 \pm$ $1.7 \mathrm{aCi} / \mathrm{m}^{3}\left(0.1 \pm 0.063 \mu \mathrm{Bq} / \mathrm{m}^{3}\right)$, or five thousand times below the DOE derived concentration guide for plutonium-238 $\left(30,000 \mathrm{aCi} / \mathrm{m}^{3}\left[1.1 \mathrm{mBq} / \mathrm{m}^{3}\right]\right)$.

The average plutonium-239/240 concentrations detected in onsite and offsite air samples are given in Table 4.1.2 and Figure 4.1.6. The annual average air concentration of plutonium-239/240 at the site perimeter was $0.41 \pm 2.2 \mathrm{aCi} / \mathrm{m}^{3}\left(0.015 \pm 0.081 \mu \mathrm{Bq} / \mathrm{m}^{3}\right)$, which was $0.002 \%$ of the DOE derived concentration guide $\left(20,000 \mathrm{aCi} / \mathrm{m}^{3}\left[741\left(\mathrm{~Bq} / \mathrm{m}^{3}\right]\right)\right.$. The annual average air concentrations appeared to be higher for the site perimeter locations than the distant locations; however, the difference was not statistically significant (log transformed, two-tailed t-test, $5 \%$ significance level). The maximum Hanford Site plutonium-239/240 air concentration $\left(36 \pm 6.4 \mathrm{aCi} / \mathrm{m}^{3}\left[1.3 \pm 0.2 \mu \mathrm{Bq} / \mathrm{m}^{3}\right]\right)$ was observed for the 100 Areas composite sample (locations 1, 2, and 3 on Figure 4.1.1). This represented less than $0.18 \%$ of the DOE derived concentration guide $\left(20,000 \mathrm{aCi} / \mathrm{m}^{3}\left[741\left(\mathrm{~Bq} / \mathrm{m}^{3}\right]\right)\right.$ for plutontium-239/240.

Average isotopic uranium concentrations (uranium-234, -235, and -238) in airborne particulate matter in 2001 were similar to average concentrations between 1996 and 2000 for all distance classes (see Table 4.1.2 and Figure 4.1.7). The 2001 annual average uranium-238 concentration for the site perimeter was

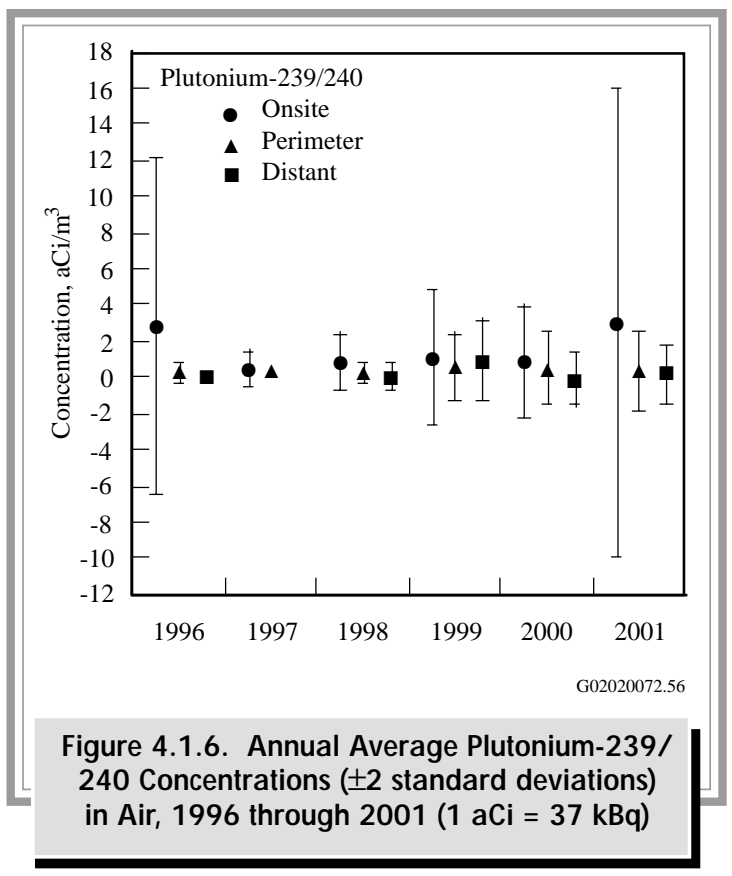




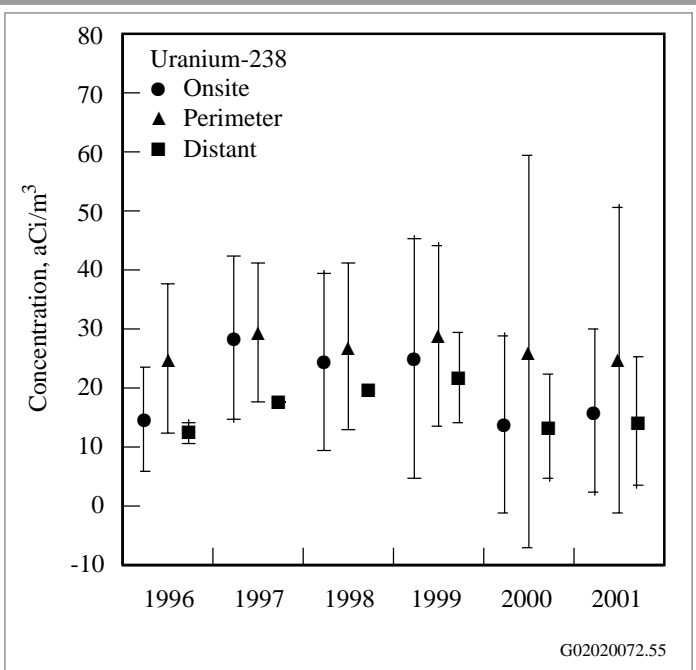

Figure 4.1.7. Annual Average Uranium-238 Concentrations ( \pm 2 standard deviations) in Air, 1996 through 2001 (1 aCi = 37 kBq)

$25 \pm 26 \mathrm{aCi} / \mathrm{m}^{3}\left(0.93 \pm 0.96 \mu \mathrm{Bq} / \mathrm{m}^{3}\right)$, which is less than $0.03 \%$ of the DOE derived concentration guide $\left(100,000 \mathrm{aCi} / \mathrm{m}^{3}\left[3.7 \mathrm{mBq} / \mathrm{m}^{3}\right]\right)$.
Quarterly composite samples were analyzed by gamma spectroscopy. Naturally occurring beryllium-7 and potassium-40 were routinely identified. The potential Hanford-origin gamma-emitting radionuclides of cobalt- 60 and cesium-137 were of particular interest. Cobalt-60 and cesium-137 results for 2001 samples are included in Table 4.1.2. Of the 120 samples analyzed by gamma spectroscopy, only one had cobalt 60 or cesium- 137 concentrations measured above the minimum detectable activity. This sample was collected from the 100 Areas composite group during the second quarter of 2001. The detected sample had a cobalt -60 concentration of $3,300 \pm 750 \mathrm{aCi} / \mathrm{m}^{3}\left(120 \pm 28 \mu \mathrm{Bq} / \mathrm{m}^{3}\right)$, and a cesium-137 concentration of $480 \pm 300 \mathrm{aCi} / \mathrm{m}^{3}$ $\left(18 \pm 11 \mu \mathrm{Bq} / \mathrm{m}^{3}\right)$. The cobalt -60 concentration was $0.004 \%$ of the DOE derived concentration guide for cobalt-60. For cesium-137, the sample with the highest measured concentration was collected at location 28 during the third quarter $\left(650 \pm 600 \mathrm{aCi} / \mathrm{m}^{3}[24 \pm\right.$ $\left.\left.22 \mu \mathrm{Bq} / \mathrm{m}^{3}\right]\right)$. This maximum was $0.00016 \%$ of the DOE derived concentration guide $\left(400\right.$ million aCi $/ \mathrm{m}^{3}$ $\left.\left[14.8 \mathrm{~Bq} / \mathrm{m}^{3}\right]\right)$ for cesium-137.

\subsection{Air Particulate Monitoring}

Airborne particulate matter (dust) is one of the U.S. Environmental Protection Agency's (EPA's) criteria pollutants. The EPA classifies particulate matter by particle size. $\mathrm{PM}_{10}$ is defined as a particle having an aerodynamic diameter less than 10 micrometers. Similarly, $\mathrm{PM}_{2.5}$ is defined as a particle having an aerodynamic diameter $<2.5$ micrometers (a sample of $\mathrm{PM}_{10}$ includes $\mathrm{PM}_{2.5}$ ). The EPA's National Ambient Air Quality Standard for $\mathrm{PM}_{10}$ requires less than a $150 \mu \mathrm{g} / \mathrm{m}^{3}$ for a 24-hour average concentration, and less than a $50 \mu \mathrm{g} / \mathrm{m}^{3}$ annual average. There is currently no EPA standard for $\mathrm{PM}_{2.5}$. Health risk studies have shown a positive correlation between increases in concentrations of airborne particulate matter and increased hospital admissions for pulmonary and heart conditions (Schwartz 1994; Morgan et al. 1998; Ostro et al. 1999). Various studies have indicated that a $100 \mu \mathrm{g} / \mathrm{m}^{3}$ increase in $\mathrm{PM}_{10}$ concentrations (difference between EPA 24-hour and annual averages) has a relative risk ${ }^{(a)}$ of $\sim 1.17$ for hospital admissions for pneumonia and chronic obstructive pulmonary disorder (Schwartz 1994). Similar relationships were found between $\mathrm{PM}_{10}$ concentrations and daily human mortality in areas where windblown dust was the main contributor to high $\mathrm{PM}_{10}$ concentrations (similar to the Hanford Site) (Ostro et al. 1999).

In February of 2001, continuous monitoring of particulate matter mass concentrations in air on the Hanford Site began. The motivation for this was the decrease in vegetative cover on a large portion of the site after the 24 Command Fire in 2000 (PNNL-13487) as well as information requests from the public. It was theorized that the decrease in vegetative cover would result in increased wind erosion, and subsequently, increased particulate matter concentrations in air. Particulate monitoring was done with a tapered element oscillating microbalance located at the base of the Hanford Meteorological Station's meteorological tower located between the 200-East and 200-West Areas (see Figure 4.1.1). The tapered element oscillating microbalance collected sample continuously, and $\mathrm{PM}_{10}$ data were gathered throughout most of 2001.

Figure 4.1.8 shows the daily average $\mathrm{PM}_{10}$ concentrations recorded at the Hanford Meteorological Station

(a) Relative risk here refers to the increase in hospital admissions after $\mathrm{PM}_{10}$ levels rise. When $\mathrm{PM}_{10}$ increased by $100 \mu \mathrm{g} / \mathrm{m}^{3}$, a $17 \%$ increase in hospital admissions for pneumonia and chronic obstructive pulmonary disorder occurred. 


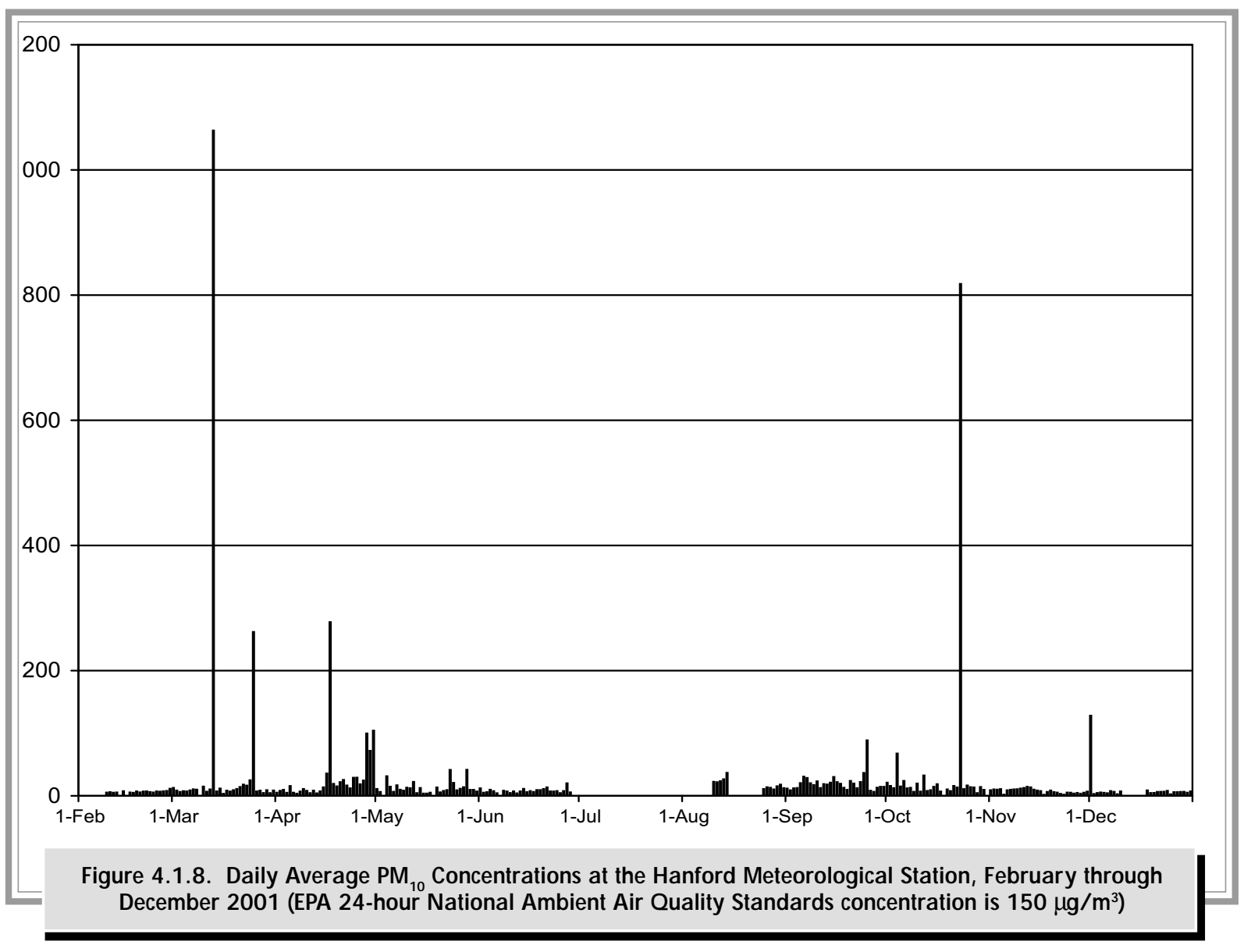

during 2001. The EPA 24-hour standard for $\mathrm{PM}_{10}$ $\left(150 \mu \mathrm{g} / \mathrm{m}^{3}\right)$ was exceeded four times during 2001 (March 13, March 25, April 17, October 23). However, the Hanford Site is not required to meet the EPA standard. The Benton Clean Air Authority maintains an air monitoring network that is responsible for determining Benton County's compliance with the EPA standards for ambient air quality pollutant concentrations, which includes $\mathrm{PM}_{10}$. The 4 days that exceeded the EPA standard at the Hanford Meteorological Station were days characterized by dry, windy conditions.

By the end of October 2001, three additional tapered element oscillating microbalances were purchased and installed. One of these instruments was installed at the Hanford Meteorological Station and configured to monitor $\mathrm{PM}_{2.5}$. The other two instruments were installed at the 300 Area meteorological tower (see Figure 4.1.1) and configured to measure $\mathrm{PM}^{10}$ and $\mathrm{PM}^{2.5}$. Figure 4.1.9 illustrates data collected after all four tapered element oscillating microbalances were installed. Although Figure 4.1 .9 represents less than $20 \%$ of the calendar year, the trend it reveals is expected to continue into 2002. The particulate concentrations are generally low, consisting mainly of $\mathrm{PM}_{2.5}\left(\mathrm{PM}_{2.5} \approx \mathrm{PM}_{10}\right)$, and show little spatial variability. This indicates that most of the measured particulate matter on these low concentration days is not generated locally, but transported into the region, since larger $\mathrm{PM}_{10}$ particles do not remain suspended in air as long as smaller $\mathrm{PM}_{2.5}$ particles. On the other hand, on the day with high particulate matter concentration (December 1), the $\mathrm{PM}_{10}$ concentration was much larger than the $\mathrm{PM}_{2.5}$ concentration. Also, the higher $\mathrm{PM}_{10}$ levels at the Hanford Meteorological Station on December 1 compared to the 300 Area might reflect the 200 Areas' proximity to the area burned by the 2000 range fire. Similar to other days in 2001 with high $\mathrm{PM}_{10}$ concentrations, December 1 had high winds (gusts $>80 \mathrm{~km} / \mathrm{h}[>50 \mathrm{mph}]$ ). 


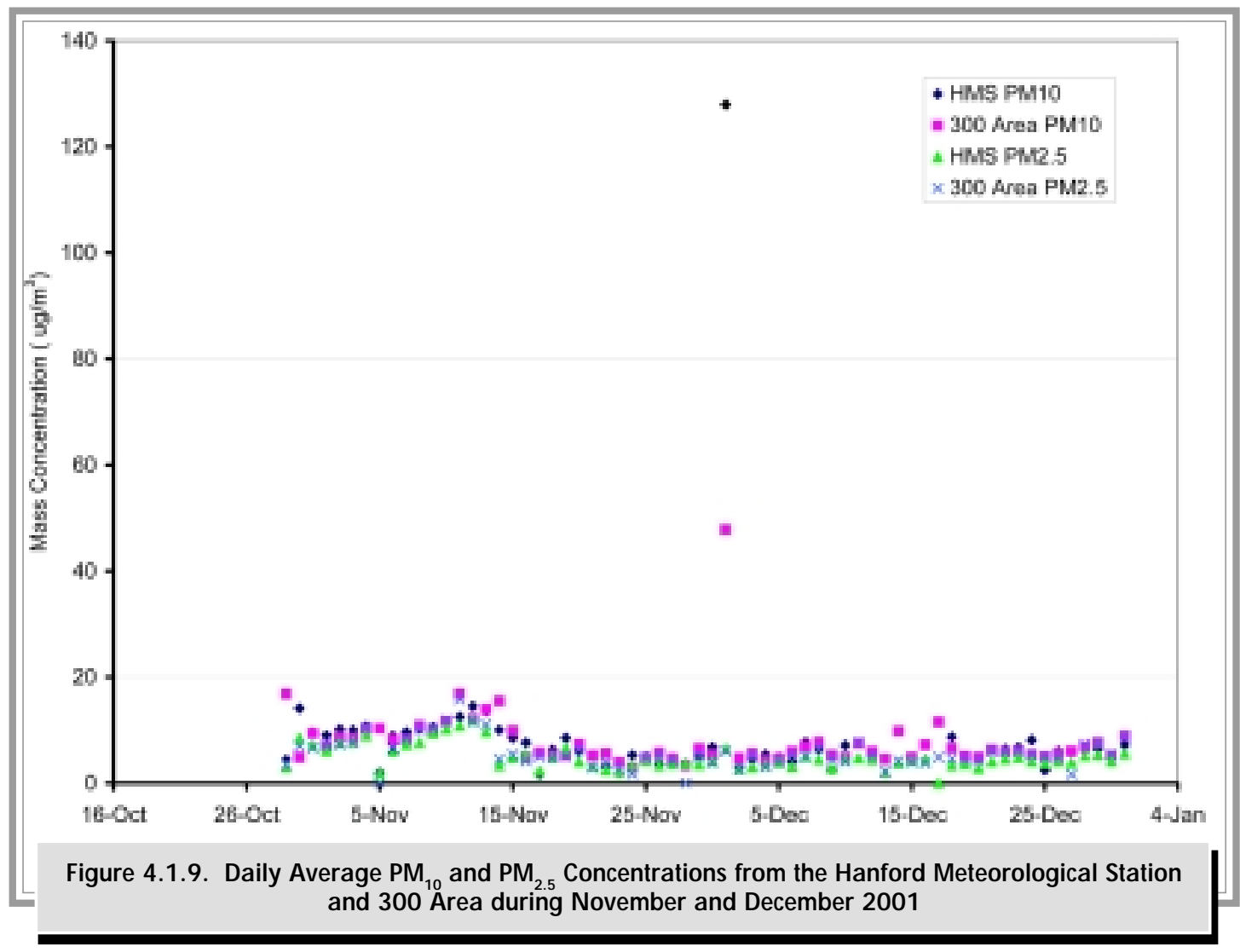




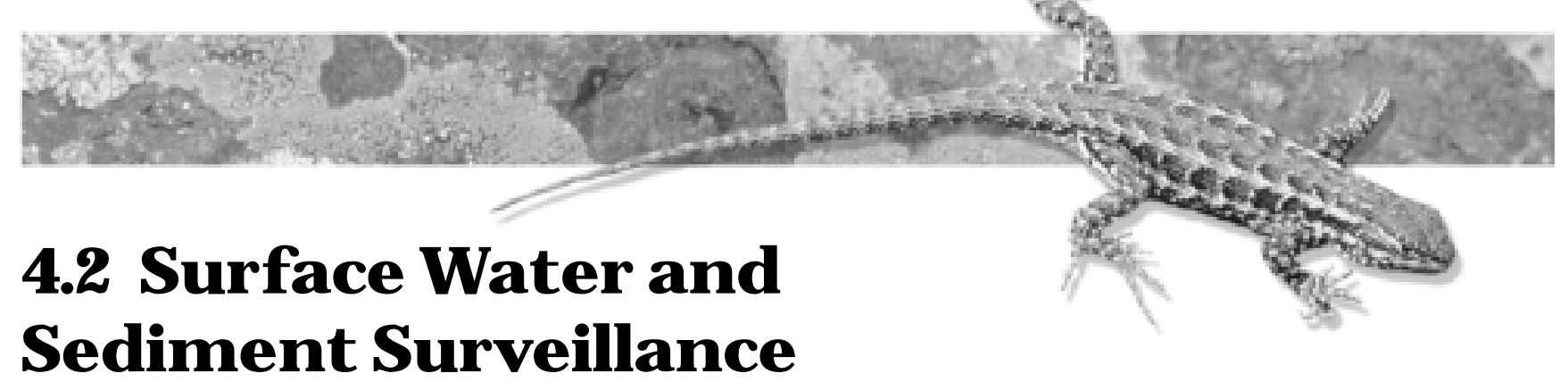

\section{G. W. Patton}

Samples of surface water and sediment on and near the Hanford Site were collected and analyzed to determine the potential impact to the public and to the aquatic environment from Hanford-originated radiological and chemical contaminants. Surface-water bodies included in routine surveillance were the Columbia River and associated riverbank springs, onsite ponds, and irrigation sources (Figure 4.2.1). Sediment surveillance was conducted for the Columbia River and riverbank springs. Tables 4.2.1 and 4.2.2 summarize the sampling locations, types, frequencies, and analyses included in surface water and sediment surveillance during 2001. This section describes the surveillance efforts and summarizes the results for these aquatic environments. Detailed analytical results are reported in PNNL-13910, APP. 1.

\subsubsection{Colum bia River Water}

The Columbia River is the second largest river in the continental United States in terms of total flow and is the dominant surface-water body on the Hanford Site. The original selection of the Hanford Site for plutonium production and processing was based, in part, on the abundant water supply offered by the river. The river flows through the northern edge of the site and forms part of the site's eastern boundary. The river is used as a source of drinking water for onsite facilities and communities located downstream from the Hanford Site. Water from the river downstream of the site also is used for crop irrigation. In addition, the Hanford Reach of the Columbia River is used for a variety of recreational activities, including hunting, fishing, boating, water-skiing, and swimming.

Originating in the mountains of eastern British Columbia, the Columbia River and its tributaries drain an area of $\sim 670,000$ square kilometers $(260,000$ square miles) en route to the Pacific Ocean. The flow of the river is regulated by three dams in Canada and eleven dams in the United States, seven upstream and four downstream of the Hanford Site. Priest Rapids Dam is the nearest upstream dam and McNary Dam is the nearest downstream dam from the site. The Hanford Reach of the Columbia River extends from Priest Rapids Dam to the head of Lake Wallula (created by McNary Dam) near Richland, Washington. The Hanford Reach is the last stretch of the Columbia River in the United States above Bonneville Dam that remains unimpounded.
River flow through the Hanford Reach fluctuates significantly and is controlled primarily by operations at Priest Rapids Dam. Annual average flows of the Columbia River below Priest Rapids Dam are usually around 3,400 cubic meters $(120,000$ cubic feet $)$ per second (WA-94-1). In 2001, however, the Columbia River had below normal flows; the average daily flow rate below Priest Rapids Dam was 2,140 cubic meters $(75,700$ cubic feet $)$ per second. The peak monthly average flow rate occurred during January $(3,820$ cubic meters [135,000 cubic feet] per second) (Figure 4.2.2). The lowest monthly average flow rate occurred during July (1,600 cubic meters [56,600 cubic feet] per second). Daily flow rates varied from 1,040 to 3,820 cubic meters (36,800 to 135,000 cubic feet) per second during 2001. As a result of fluctuations in discharges, the depth of the river varies significantly over time. River stage (surface level) may change along the Hanford Reach by up to 3 meters (10 feet) within a few hours (Section 3.3.7 in PNL-10698). Seasonal changes of approximately the same magnitude are also observed. River-stage fluctuations measured at the 300 Area are approximately half the magnitude of those measured near the 100 Areas because of the effect of the pool behind McNary Dam (PNL-8580) and the relative distance of each area from Priest Rapids Dam. The width of the river varies from $\sim 300$ to 1,000 meters ( 980 to 3,300 feet) through the Hanford Site.

Hanford pollutants, both radiological and chemical, enter the Columbia River along the Hanford Reach. In 


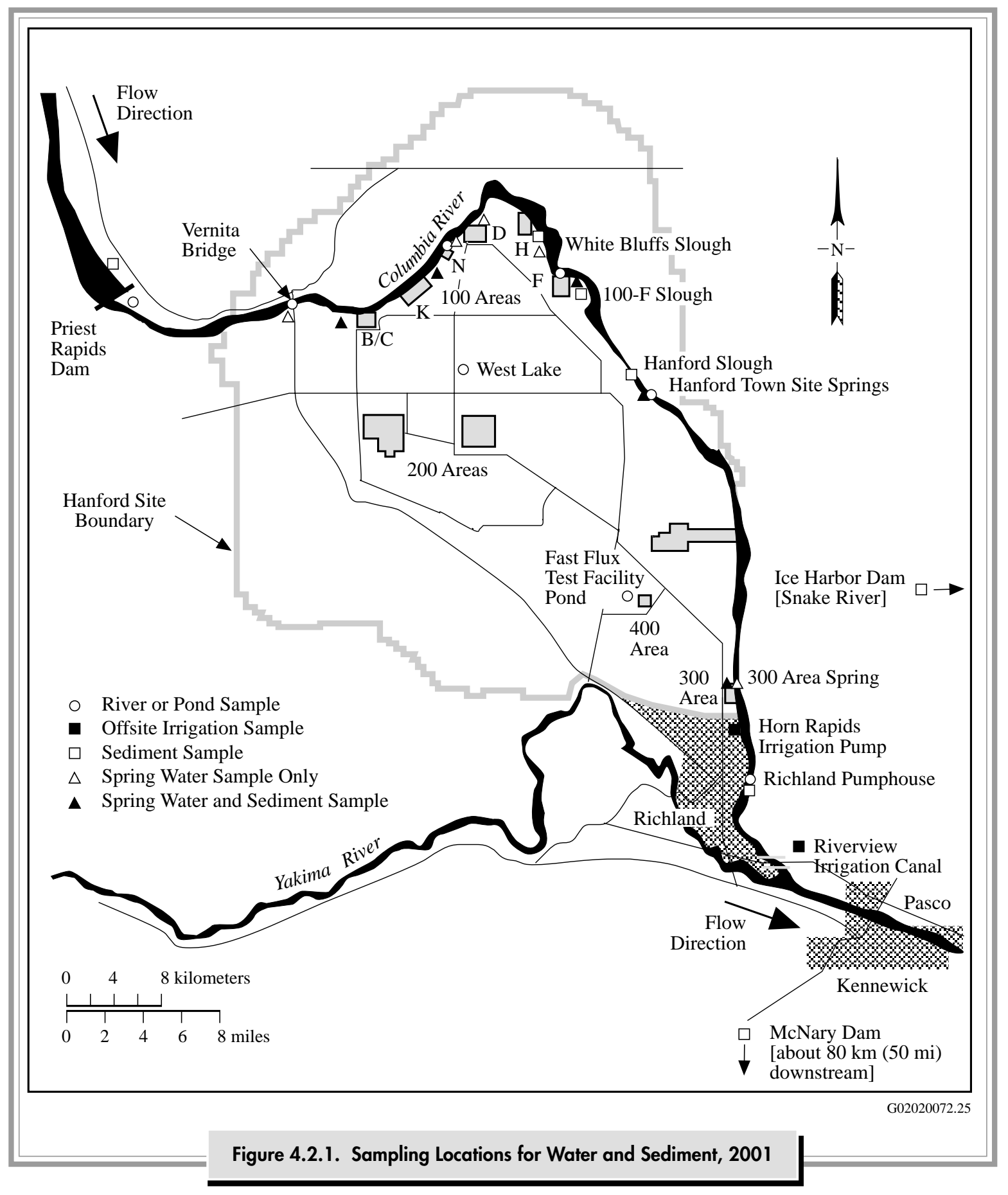

addition to permitted direct discharges of liquid effluents from Hanford facilities, contaminants in groundwater from past operational discharges to the ground seep into the river (DOE/RL-92-12; PNL-5289; PNL-7500; WHC-SD-EN-TI-006). Effluents from each direct discharge point are monitored routinely and reported by the responsible operating contractor (see Section 3.1). Direct discharges are identified and regulated for nonradiological constituents under the National Pollutant Discharge Elimination System in compliance with the
Clean W ater Act. The discharges permitted at the Hanford Site by National Pollutant Discharge Elimination System are summarized in Section 2.2.8.

Washington State has classified the stretch of the Columbia River from Grand Coulee Dam to the Washington-Oregon border, which includes the Hanford Reach, as Class A, Excellent (WAC 173-201A). Water quality criteria and water use guidelines have been established in conjunction with this designation and are provided in Appendix D (Table D.1). 
Table 4.2.1. Surface Water Surveillance, 2001

Location

\section{Columbia River - Radiological}

Priest Rapids Dam and Richland Pumphouse

Vernita Bridge and Richland

Pumphouse

100-F, 100-N, 300, and Hanford

town site

\section{Columbia River - N on-Radiological}

Vernita Bridge and Richland

Pumphouse ${ }^{(i)}$

100-F, 100-N, 300, and Hanford town site

\section{Onsite Ponds}

West Lake

Fast Flux Test Facility pond

\section{O ffsite Irrigation Water}

Riverview irrigation canal

Horn Rapids

\section{Riverbank Springs}

100-H Area

100-F Area

100-B Area

100-D, 100-K, and 100-N Areas

Hanford town site

300 Area

\section{Sample Type}

Cumulative

Particulate (filter)

Soluble (resin)

Grab (transects)

Grab (transects)

Grab

Grab (transects)

Grab (transects)

Grab (transects)

Grab

Grab

Grab

Grab

Grab

A

Grab

A

Grab

A

Grab

A

Grab

Grab
Frequency $^{(\mathrm{a})}$

Analyses

$\mathrm{Comp}^{(\mathrm{b})}$

Q Comp ${ }^{(e)}$

M Cont ${ }^{(f)}$

Q Cont ${ }^{(\mathrm{g})}$

M Cont

Q Cont

Alpha, beta, lo ${ }^{3} \mathrm{H},{ }^{(c)}{ }^{90} \mathrm{Sr},{ }^{99} \mathrm{Tc}, \mathrm{U}^{(\mathrm{d})}$

${ }^{129} \mathrm{I}$

Gamma energy analysis

$\mathrm{Pu}^{(\mathrm{h})}$

Gamma energy analysis

$\mathrm{Pu}$

1o ${ }^{3} \mathrm{H},{ }^{90} \mathrm{Sr}, \mathrm{U}$

lo ${ }^{3} \mathrm{H},{ }^{90} \mathrm{Sr}, \mathrm{U}$

NASQAN, temperature, dissolved oxygen, turbidity, $\mathrm{pH}$, alkalinity, anions, suspended solids, dissolved solids, specific conductance, hardness (as $\mathrm{CaCO}_{3}$ ), $\mathrm{Ca}, \mathrm{P}, \mathrm{Cr}, \mathrm{Mg}$, $\mathrm{N}$-Kjeldahl, $\mathrm{Fe}, \mathrm{NH}_{3}, \mathrm{NO}_{3}+\mathrm{NO}_{2}$ $\mathrm{ICP}^{(\mathrm{j})}$ metals, anions $\mathrm{VOA}^{(\mathrm{k})}$

ICP metals, anions

Alpha, beta, ${ }^{3} \mathrm{H},{ }^{90} \mathrm{Sr},{ }^{99} \mathrm{Tc}, \mathrm{U}$, gamma energy analysis

Alpha, beta, ${ }^{3} \mathrm{H}$, gamma energy analysis

Alpha, beta, ${ }^{3} \mathrm{H},{ }^{90} \mathrm{Sr}$, U, gamma energy analysis

Alpha, beta, ${ }^{3} \mathrm{H},{ }^{90} \mathrm{Sr}, \mathrm{U}$, gamma energy analysis

Alpha, beta, ${ }^{3} \mathrm{H},{ }^{90} \mathrm{Sr},{ }^{99} \mathrm{Tc}, \mathrm{U}$, gamma energy analysis, ICP metals, anions Alpha, beta, ${ }^{3} \mathrm{H},{ }^{90} \mathrm{Sr}, \mathrm{U}$, gamma energy analysis, ICP metals, anions, VOA Alpha, beta, ${ }^{3} \mathrm{H},{ }^{90} \mathrm{Sr},{ }^{99} \mathrm{Tc}$, gamma energy analysis, ICP metals, anions, VOA Alpha, beta, ${ }^{3} \mathrm{H},{ }^{90} \mathrm{Sr}$, gamma energy analysis, ICP metals, anions, VOA (100-K Area only)

Alpha, beta, ${ }^{3} \mathrm{H},{ }^{129} \mathrm{I},{ }^{90} \mathrm{Sr},{ }^{99} \mathrm{Tc}, \mathrm{U}$, gamma energy analysis, ICP metals, anions Alpha, beta, ${ }^{3} \mathrm{H},{ }^{129} \mathrm{I},{ }^{90} \mathrm{Sr}$, gamma energy analysis, ICP metals, anions, VOA

(a) $\mathrm{A}=$ Annually; $\mathrm{M}=$ Monthly; $\mathrm{Q}=$ Quarterly; Comp = Composite

(b) M Comp indicates river water was collected hourly and composited monthly for analysis.

(c) $10{ }^{3} \mathrm{H}=$ Low-level tritium analysis $(10-\mathrm{pCi} / \mathrm{L}$ detection limit), which includes an electrolytic preconcentration.

(d) $\mathrm{U}=$ Isotopic uranium-234, -235 , and -238 .

(e) Collected weekly and composited for quarterly analysis.

(f) $\quad$ M Cont $=$ River water was sampled for $2 \mathrm{wk}$ by continuous flow through a filter and resin column and multiple samples were composited monthly for analysis.

(g) Q Cont $=$ River water was sampled for $2 \mathrm{wk}$ by continuous flow through a filter and resin column and multiple samples were composited quarterly for analysis.

(h) $\mathrm{Pu}=$ Isotopic plutonium-238 and $-239 / 240$

(i) Numerous water quality analyses are performed by the U.S. Geological Survey in conjunction with the National Stream Quality Accounting Network (NASQAN) Program.

(j) ICP = Inductively coupled plasma analysis method.

(k) $\mathrm{VOA}=$ Volatile organic compounds. 
Table 4.2.2. Sediment Surveillance, 2001

Location $^{(\mathrm{a})}$

River

Priest Rapids Dam:

2 locations near the dam

White Bluffs Slough

100-F Slough

Hanford Slough

Richland

McNary Dam:

2 locations near the dam

Ice Harbor Dam:

3 locations near Levy Landing

Springs ${ }^{(f)}$

100-B Area

100-K Area

100-N Area

100-F Area

Hanford town site springs

300 Area
Frequency

$\mathrm{A}^{(\mathrm{e})}$

A

A

A

A

A

A

A

A

A

A

A

A

\section{Analyses}

All river sediment analyses included gamma energy analysis, ${ }^{90} \mathrm{Sr}, \mathrm{U}^{(\mathrm{b})}, \mathrm{Pu}^{(\mathrm{c})}, \mathrm{ICP}^{(\mathrm{d})}$ metals

(a) See Figure 4.2.1.

(b) $\mathrm{U}=$ Uranium-235 and -238 analyzed by low-energy photon analysis.

(c) $\mathrm{Pu}=$ Isotopic plutonium-238 and $-239 / 240$.

(d) ICP = Inductively coupled plasma analysis method.

(e) $\mathrm{A}=$ Annually.

(f) Sediment is collected when available.

\subsubsection{Collection of River-} Water Sam ples and Analytes of Interest

Samples of Columbia River water were collected throughout 2001 at the locations shown in Figure 4.2.1. Samples were collected from fixed-location monitoring stations at Priest Rapids Dam and the Richland Pumphouse and from Columbia River transects and nearshore locations near the Vernita Bridge, 100-F Area, 100-N Area, Hanford town site, 300 Area, and Richland Pumphouse. Samples were collected upstream from Hanford Site facilities at Priest Rapids Dam and Vernita Bridge to provide background data from locations unaffected by site operations. Samples were collected from all other locations to identify any increase in contaminant concentrations attributable to Hanford operations. The Richland Pumphouse is the first downstream point of
Columbia River water withdrawal for a municipal drinking water supply.

The fixed-location monitoring stations at Priest Rapids Dam and the Richland Pumphouse consisted of both an automated sampler and a continuous flow system. Using the automated sampler, unfiltered samples of Columbia River water (cumulative samples) were obtained hourly and collected weekly. Weekly samples were combined into monthly composite samples for radiological analyses (see Table 4.2.1). Using the continuous flow system, particulate and soluble constituents in Columbia River water were collected by passing water through a filter and then through a resin column. Filter and resin samples were exchanged approximately every 14 days and were combined into quarterly composite samples for radiological analyses. The river sampling locations and the methods used for sample collection are discussed in detail in DOE/RL-91-50. 


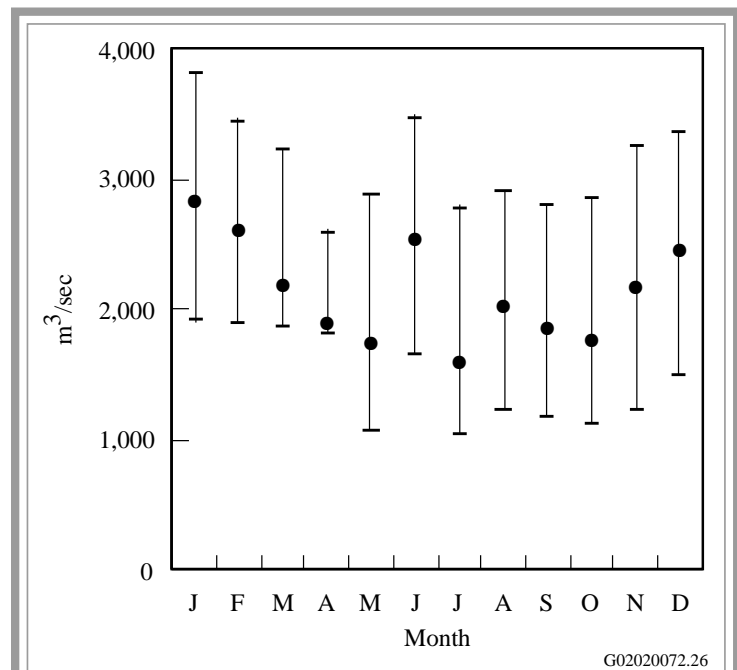

Figure 4.2.2. Mean, Maximum, and Minimum Monthly Columbia River Flow Rates at Priest Rapids Dam, 2001

Radionuclides of interest were selected for analysis based on

- their presence in effluents discharged from site facilities or in near-river groundwater underlying the Hanford Site

- their importance in determining water quality, verifying effluent control and monitoring systems, and determining compliance with applicable standards.

Analytes of interest in water samples collected from Priest Rapids Dam and the Richland Pumphouse included gross alpha, gross beta, selected gamma emitters, tritium, strontium-90, technetium-99, iodine-129, uranium-234, -235, -238, plutonium-238, and plutonium-239/240. Gross alpha and beta measurements are indicators of the general radiological quality of the river and provide a timely indication of change. Gamma energy analysis provides the ability to detect numerous specific radionuclides (see Appendix F). Sensitive radiochemical analyses were used to determine the concentrations of tritium, strontium-90, technetium-99, iodine-129, uranium-234, $-235,-238$, plutonium-238, and plutonium-239/240 in river water during the year. Analytical detection levels for all radionuclides were less than $12 \%$ of their respective water quality criteria levels (see Appendix D, Tables D.1 and D.2).

Transect sampling (multiple samples collected along a line across the Columbia River) was initiated as a result of findings of a special study conducted during 1987 and 1988 (PNL-8531). That study concluded that, under certain flow conditions, contaminants entering the river from the Hanford Site are not completely mixed when sampled at routine monitoring stations located downriver. Incomplete mixing results in a slightly conservative (high) bias in the data generated using the routine, single-point, sampling system at the Richland Pumphouse. In 1999, the transect sampling strategy was modified, with some of the mid-river sampling points shifted to near-shore locations in the vicinity of the transect. For example, at the 100-N Area instead of collecting ten evenly-spaced cross-river transect samples, only six cross-river samples were collected, and the other four samples were obtained at near-shore locations. This sampling pattern allows the cross-river concentration profile to be determined and provides information over a larger portion of the Hanford shoreline where the highest contaminant concentrations would be expected. The Vernita Bridge and the Richland Pumphouse transects and near-shore locations were sampled quarterly during 2001. Annual transect and near-shore sampling was conducted at the 100-F Area, 100-N Area, Hanford town site, and 300 Area locations in late summer when river flows were low.

Columbia River transect water samples collected in 2001 were analyzed for both radiological and chemical contaminants (see Table 4.2.1). Metals and anions were selected for analysis following reviews of existing surface-water and groundwater data, various remedial investigation/feasibility study work plans, and preliminary Hanford Site risk assessments (DOE/RL-92-67; PNL-8073; PNL-8654; PNL-10400; PNL-10535). All radiological and chemical analyses of transect samples were performed on grab samples of unfiltered water, except for metals analyses, which were performed on both filtered and unfiltered samples.

In addition to radiological monitoring conducted, non-radiological water quality monitoring was performed by the U.S. Geological Survey. Samples were collected along Columbia River transects quarterly at the Vernita Bridge and the Richland Pumphouse (see Appendix B, Table B.5). Sample analyses were performed at the U.S. Geological Survey laboratory in Denver, Colorado for numerous physical parameters and chemical constituents.

\subsubsection{Radiological Results for River-Water Sam ples}

Fixed Location Sampling. Results of the radiological analyses of Columbia River water samples collected at Priest Rapids Dam and the Richland Pumphouse during 2001 are reported in PNNL-13910, APP. 1 and summarized in Appendix B (Tables B.1 and B.2). These tables also list the maximum and 
mean concentrations of selected radionuclides detected in Columbia River water in 2001 and during the previous 5 years. All radiological contaminant concentrations measured in Columbia River water in 2001 were less than DOE derived concentration guides (DOE Order 5400.5) and Washington State ambient surfacewater quality criteria (WAC 173-201A and 40 CFR 141; see Appendix D, Tables D.5, D.3, and D.2). Significant results are discussed in the following paragraphs, and comparisons to previous years are provided.

Radionuclide concentrations monitored in Columbia River water were low throughout the year. During 2001, the radionuclides consistently detected in river water greater than two times their associated total propagated analytical uncertainty included tritium, strontium-90, iodine-129, uranium-234, -238, plutonium-239/240, and naturally occurring beryllium-7 and potassium -40 . The concentrations of all other radionuclides were typically below detection limits. Tritium, strontium-90, iodine-129, and plutonium-239/240 exist in worldwide fallout, as well as in effluents from Hanford facilities. Tritium and uranium occur naturally in the environment, in addition to being present in Hanford Site effluents.

Figures 4.2.3 and 4.2.4 illustrate the average annual gross alpha and gross beta concentrations, respectively, at Priest Rapids Dam and the Richland Pumphouse during the past 6 years. The 2001 average gross alpha and gross beta concentrations were similar

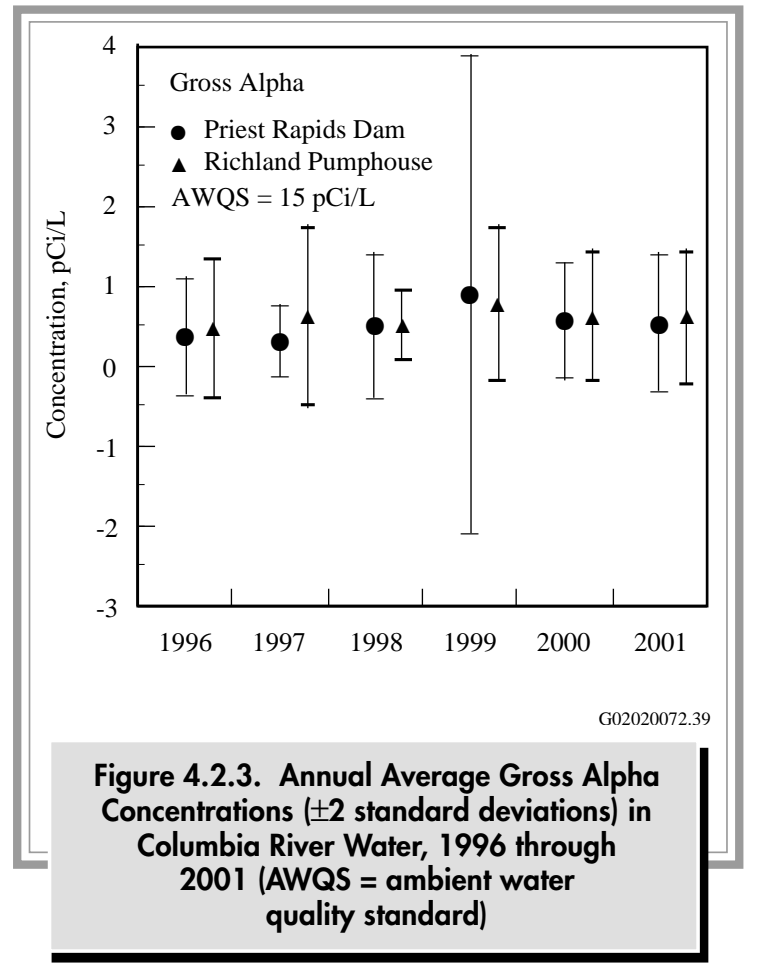

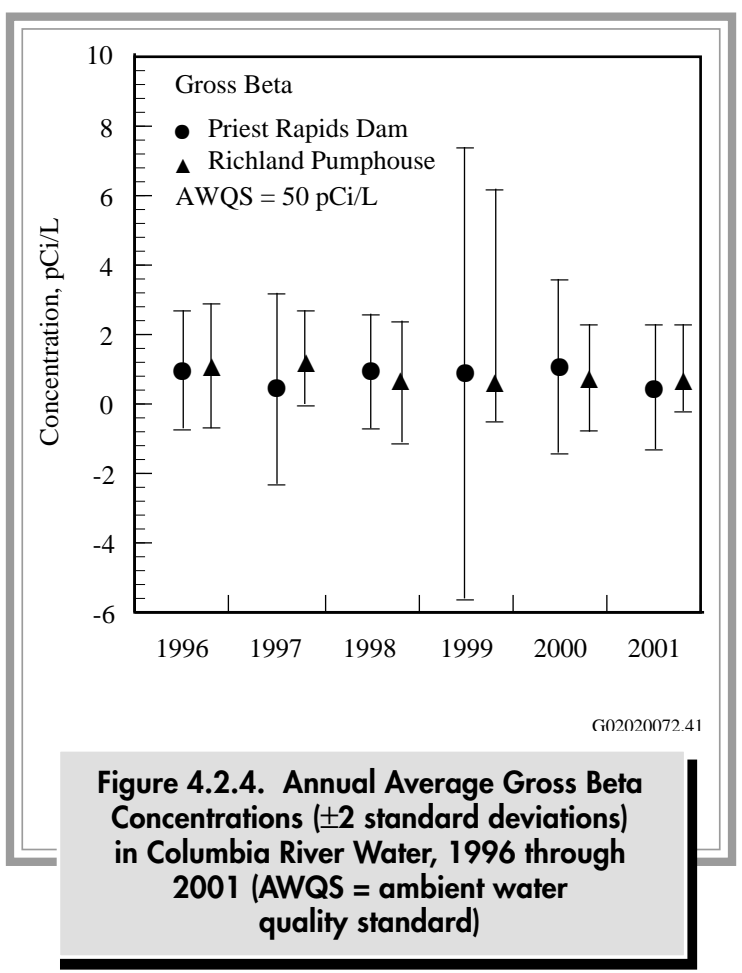

to those observed during recent years. Monthly measurements at the Richland Pumphouse in 2001 were not statistically higher than those measured at Priest Rapids Dam. Unless otherwise noted in this section, the statistical tests for differences are paired sample comparisons and two-tailed t-tests, $5 \%$ significance level. The average alpha concentration in Columbia River water at the Richland Pumphouse in 2001 was less than the state ambient surface-water quality criteria level of $15 \mathrm{pCi} / \mathrm{L}$ $(0.56 \mathrm{~Bq} / \mathrm{L})$.

Figure 4.2.5 compares the annual average tritium concentrations at Priest Rapids Dam and Richland Pumphouse from 1996 through 2001. Statistical analysis indicated that monthly tritium concentrations in river water samples at the Richland Pumphouse were higher than concentrations in samples from Priest Rapids Dam. However, 2001 average tritium concentrations in Columbia River water collected at the Richland Pumphouse were only $0.4 \%$ of the state ambient surface-water quality criteria level of $20,000 \mathrm{pCi} / \mathrm{L}$ $(740 \mathrm{~Bq} / \mathrm{L})$. Onsite sources of tritium entering the river include groundwater seepage and direct discharge from permitted outfalls located in the 100 Areas (see Sections 3.1 and 7.1). Tritium concentrations measured at the Richland Pumphouse, while representative of river water used by the city of Richland for drinking water, tend to overestimate the average tritium concentrations across the river at this location (PNL-8531). This bias is attributable to the contaminated 200 Areas' groundwater plume entering the river along the portion of shoreline 


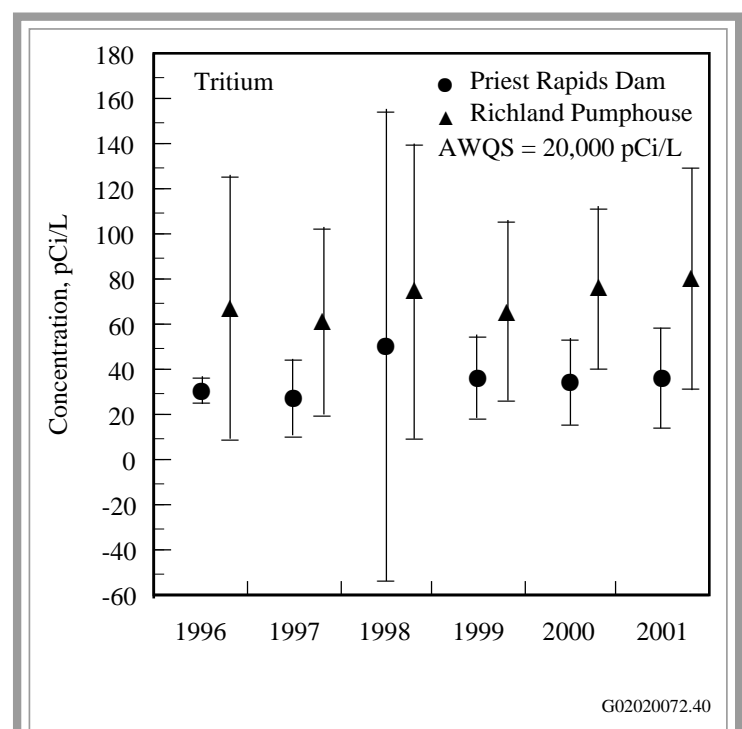

Figure 4.2.5. Annual Average Tritium Concentrations ( \pm 2 standard deviations) in Columbia River Water, 1996 through 2001 (AWQS = ambient water quality standard)

extending from the Hanford town site to below the 300 Area, which is relatively close to the Richland Pumphouse sample intake. This plume is not completely mixed within the river at the Richland Pumphouse. Sampling along cross-river transects at the pumphouse during 2001 confirmed the existence of a concentration gradient in the river under certain flow conditions and is discussed subsequently in this section. The extent to which samples taken from the Richland Pumphouse overestimate the average tritium concentrations in the Columbia River at this location is variable and appears to be related to the flow rate of the river just before and during sample collection.

The annual average strontium- 90 concentrations in Columbia River water collected from Priest Rapids Dam and the Richland Pumphouse from 1996 through 2001 are presented in Figure 4.2.6. Levels observed in 2001 were similar to those reported previously. Groundwater plumes containing strontium-90 enter the Columbia River throughout the 100 Areas (see Section 6.1.6.1). Some of the highest strontium-90 levels that have been found in onsite groundwater are the result of past discharges to the 100-N Area liquid waste disposal facilities. Despite the Hanford Site source, there was no statistical difference between monthly strontium-90 concentrations at Priest Rapids Dam and the Richland Pumphouse in 2001. Average strontium-90 concentrations in Columbia River water at the Richland Pumphouse were less than $0.8 \%$ of the $8-\mathrm{pCi} / \mathrm{L}(0.30-\mathrm{Bq} / \mathrm{L})$ state ambient surfacewater quality criteria level.

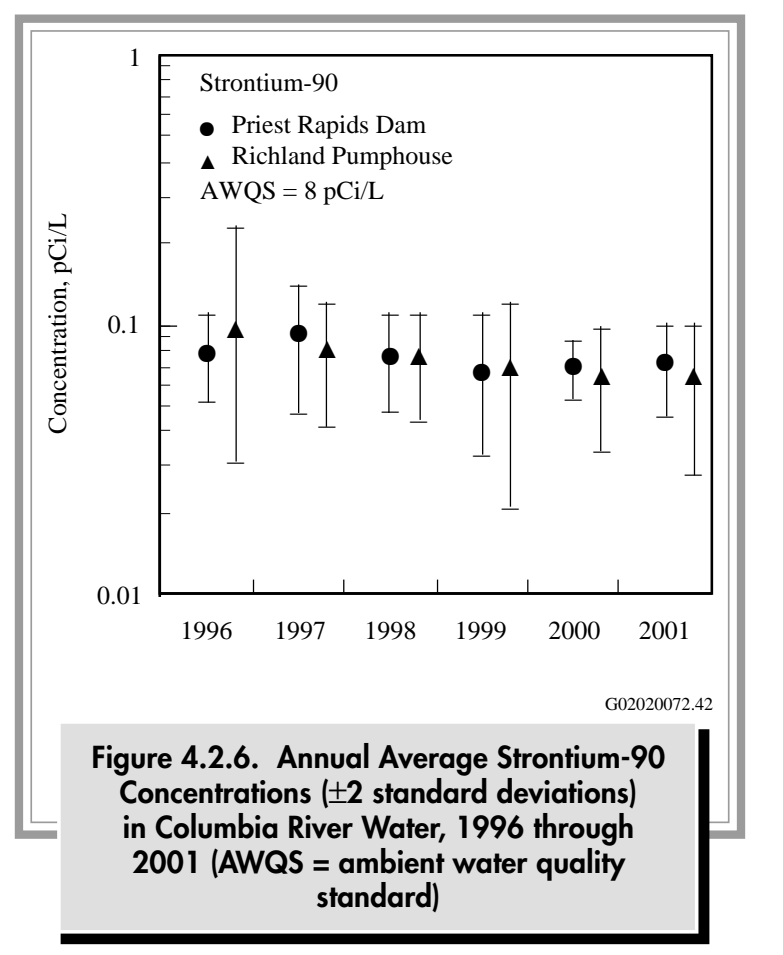

Annual average total uranium concentrations (i.e., the sum of uranium-234, -235, -238) at Priest Rapids Dam and the Richland Pumphouse for 1996 through 2001 are shown in Figure 4.2.7. Total uranium concentrations observed in 2001 were similar to those observed during recent years. Monthly total uranium concentrations measured at the Richland Pumphouse in 2001 were statistically higher than those measured at

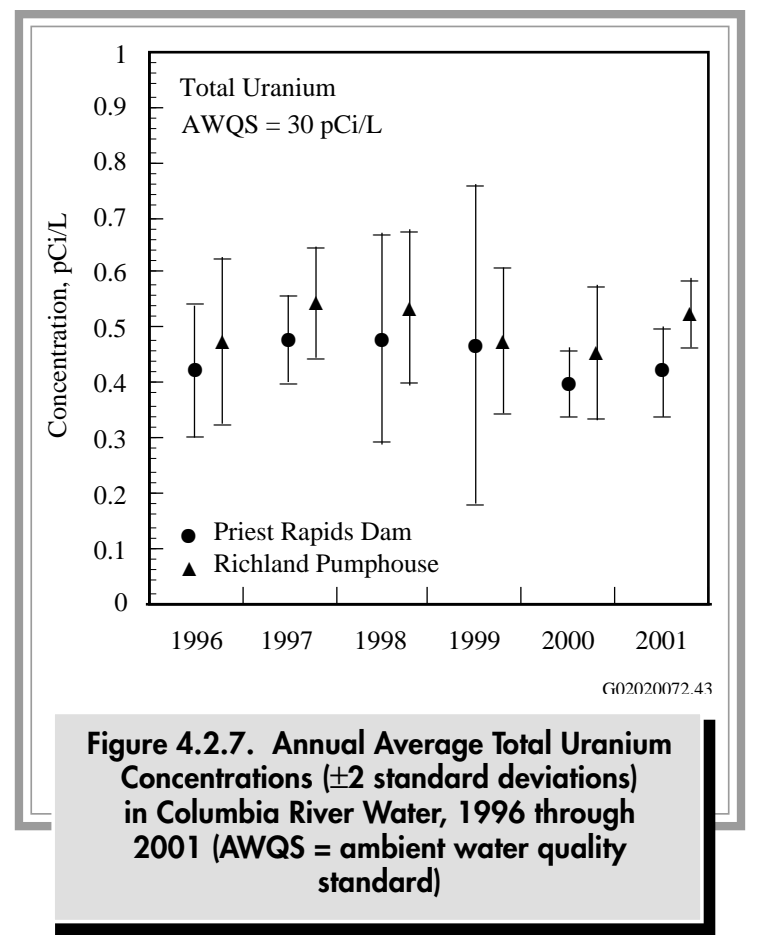


Priest Rapids Dam. Although there is no direct process discharge of uranium to the river, uranium is present in the groundwater beneath the 300 Area as a result of past Hanford operations (see Section 6.1). Hanford groundwater discharges to the Columbia River and groundwater contaminants have been detected at elevated levels in riverbank springs at the 300 Area (see Section 4.2.3). Naturally occurring uranium is also known to enter the river across from the Hanford Site via irrigation return water and groundwater seepage associated with extensive irrigation north and east of the Columbia River (PNL-7500). There are no ambient surface-water quality criteria levels directly applicable to uranium. However, total uranium levels in the river during 2001 were well below the EPA drinking water standard of $30 \mu \mathrm{g} / \mathrm{L}$ ( 27 pCi/L [1.0 Bq/L], Appendix D, Table D.2).

The annual average iodine-129 concentrations at Priest Rapids Dam and the Richland Pumphouse for 1996 through 2001 are presented in Figure 4.2.8. The average iodine-129 concentration in Columbia River water at the Richland Pumphouse was extremely low during 2001 ( $0.012 \%$ of the state ambient surface-water quality criteria level of $1 \mathrm{pCi} / \mathrm{L}[1$ million $\mathrm{aCi} / \mathrm{L}$ $\{0.037 \mathrm{~Bq} / \mathrm{L}\}])$ and similar to levels observed during recent years. The onsite source of iodine-129 to the Columbia River is the discharge of contaminated groundwater along the portion of shoreline downstream of the Hanford town site (see Section 6.1). The iodine-129 plume originated in the 200 Areas from past waste disposal practices. Quarterly iodine-129 concentrations in Columbia River water at the Richland Pumphouse were statistically higher than those at Priest Rapids Dam.

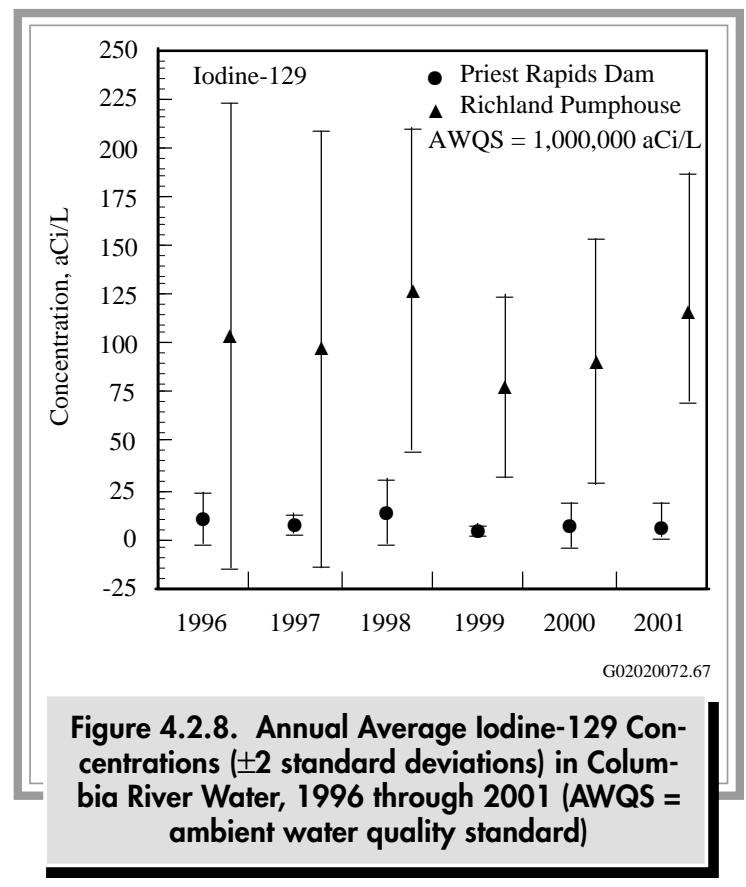

Plutonium-239/240 concentrations were at or near the detection limits for some filter (particulate) and most resin (dissolved) components. Average plutonium239/240 concentrations on filter samples at Priest Rapids Dam and the Richland Pumphouse were $0.00099 \pm 0.0030 \mathrm{pCi} / \mathrm{L}(0.000037 \pm 0.00011 \mathrm{~Bq} / \mathrm{L})$ and $0.000033 \pm 0.000058 \mathrm{pCi} / \mathrm{L}(0.0000012 \pm$ $0.000002 \mathrm{~Bq} / \mathrm{L}$ ), respectively. With the exception of one sample each at Priest Rapids Dam and the Richland Pumphouse, plutonium was only detected for the particulate fraction of the continuous water sample (i.e., detected on the filters but not detected on the resin column). No state ambient surface-water quality criteria level exists for plutonium-239/240. However, if the DOE derived concentration guides (see Appendix D, Table D.5), which are based on a 100-mrem dose standard, are converted to the 4-mrem dose equivalent used to develop the drinking water standard and ambient surface-water quality criteria level, $1.2 \mathrm{pCi} / \mathrm{L}$ $(0.044 \mathrm{~Bq} / \mathrm{L})$ would be the relevant guideline for plutonium-239/240. There were no statistical differences in plutonium-239/240 concentrations for filter samples collected at Priest Rapids Dam and the Richland Pumphouse. Statistical comparisons for dissolved plutonium concentrations at Priest Rapids Dam and the Richland Pumphouse were not performed because the majority of the concentrations were below the detection limit.

\section{River Transect and Near-Shore Sampling.}

Radiological results from samples collected along Columbia River transects and at near-shore locations near the Vernita Bridge, 100-F Area, 100-N Area, Hanford town site, 300 Area, and Richland Pumphouse during 2001 are presented in Appendix B (Tables B.3 and B.4) and PNNL-13910, APP. 1. Sampling locations were documented using a global positioning system. Constituents consistently detected at concentrations greater than two times their associated total propagated analytical uncertainty included tritium, strontium-90, uranium-234, and uranium-238. All measured concentrations of these radionuclides were less than applicable state ambient surface-water quality criteria levels.

Tritium concentrations measured along Columbia River transects during September 2001 are depicted in Figure 4.2.9. The results are displayed such that the observer's view is upstream from the Richland Pumphouse. Vernita Bridge is the most upstream transect. Stations 1 and 10 are located along the Benton County and Franklin/Grant Counties shorelines, respectively. The 100-N Area, Hanford town site, 300 Area, and Richland Pumphouse transects have higher tritium concentrations at the Hanford shore compared to the opposite shore. The presence of a tritium concentration gradient in the Columbia River at the Richland 


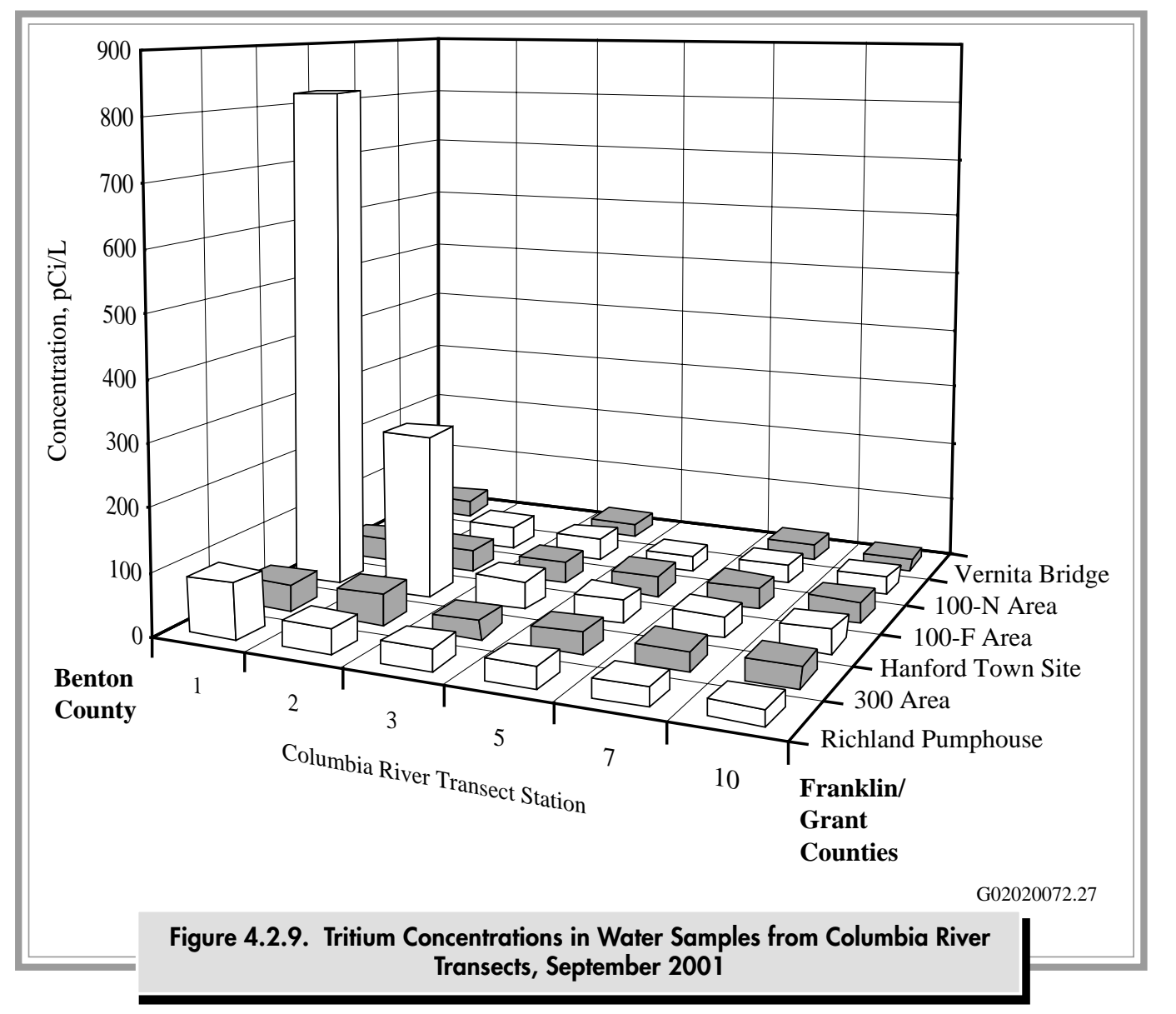

Pumphouse supports previous conclusions made in HW-73672 and PNL-8531 that contaminants in the 200 Areas' groundwater plume entering the river at, and upstream of, the 300 Area are not completely mixed at the Richland Pumphouse. The gradient is most pronounced during periods of relatively low river flow. Since transect sampling began in 1987, the mean tritium concentration measured along the Richland Pumphouse transect was less than that measured in monthly composited samples from the pumphouse, illustrating the conservative bias (i.e., overestimate) of the fixedlocation monitoring station. The highest tritium concentration detected in 2001 samples of cross river transect water was $820 \pm 73 \mathrm{pCi} / \mathrm{L}(30 \pm 2.7 \mathrm{~Bq} / \mathrm{L})$ (see Appendix B, Table B.3), which was detected along the shoreline of the Hanford town site. This is a location where groundwater containing tritium levels over $20,000 \mathrm{pCi} / \mathrm{L}(740 \mathrm{~Bq} / \mathrm{L})$ is known to discharge to the river (see Section 6.1.6.1).

Tritium concentrations for near-shore water samples collected at the Hanford (Benton County) shoreline during September 2001 are shown in Figure 4.2.10. The near-shore sampling locations are identified according to Hanford river markers, which are a series of signpost markers ( 1.6 kilometers [ 1 mile] apart) that originate at Vernita Bridge (Hanford river marker $\# 0$ ) and end just upriver from the Richland Pumphouse (Hanford river marker \#46). The concentrations of tritium in near-shore water samples collected at the 100-N Area, Hanford town site, and 300 Area were elevated compared to concentrations in samples collected near the Vernita Bridge. There was a wide range of tritium concentrations measured for the shoreline samples with the concentrations increasing near discharge points for the groundwater tritium plume (see Section 6.0, Figures 6.1.11, 6.1.12, and 6.1.19). The tritium concentrations in near-shore samples collected from the Richland shore were only slightly higher that those measured at Vernita Bridge. In 2001, the highest tritium concentration observed in near-shore water samples was $5,100 \pm 440 \mathrm{pCi} / \mathrm{L}(189 \pm 16 \mathrm{~Bq} / \mathrm{L})$ (see Appendix B, Table B.4), which was detected along the shoreline of the Hanford town site.

In 2001, strontium-90 concentrations in Hanford Reach river water for both transect and near-shore samples were similar to background concentrations for all locations, except for the 100-N Area. The 100-N Area had elevated strontium-90 concentrations in some samples obtained at near-shore locations. The mean strontium-90 concentration found during transect 


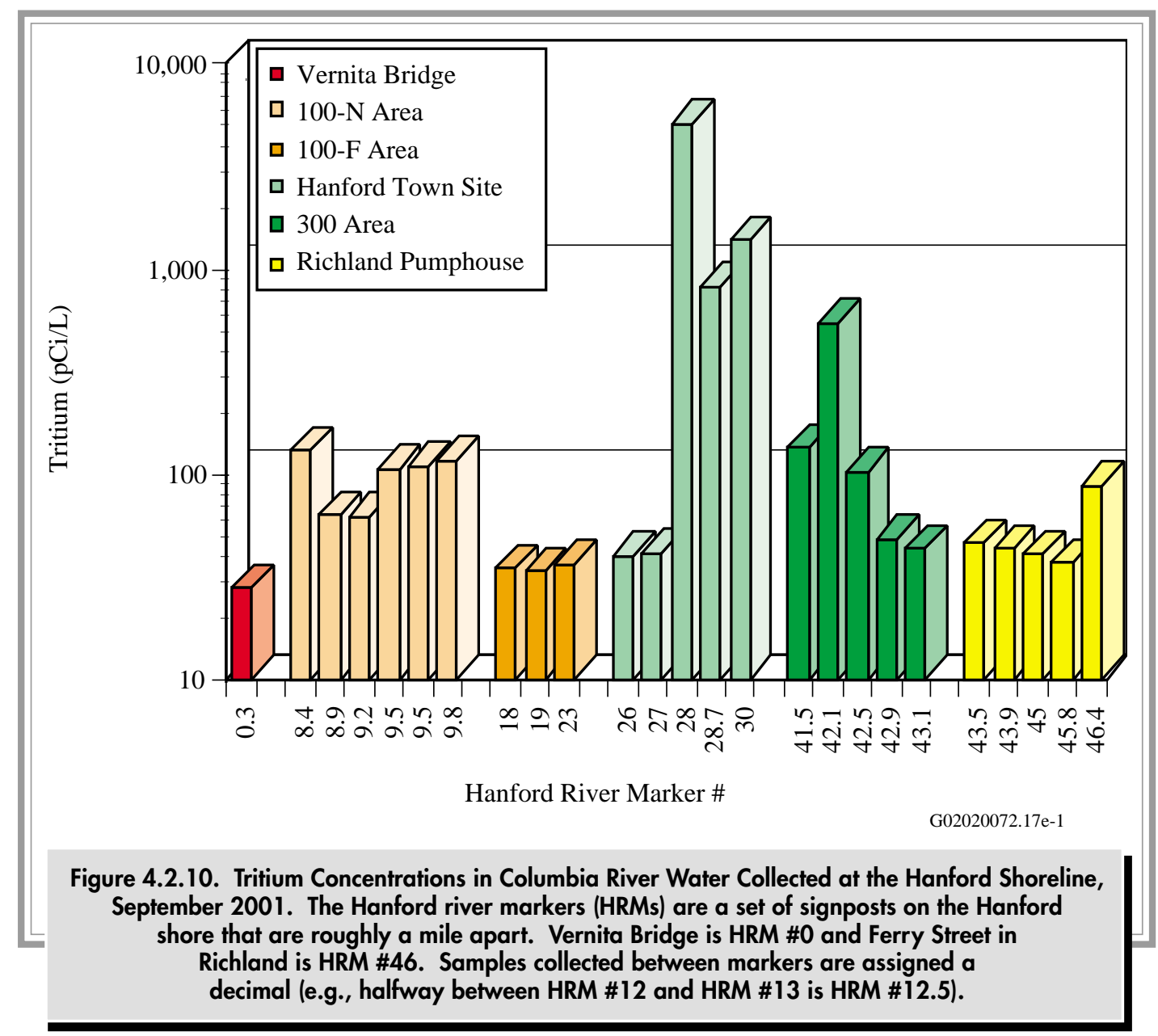

sampling at the Richland Pumphouse was similar to that measured in monthly composite samples from the pumphouse, indicating that strontium-90 levels in water collected from the fixed-location monitoring station are representative of the average strontium-90 concentrations in the river at this location.

Total uranium concentrations in Hanford Reach water in 2001 were elevated along the Franklin County shoreline in both the 300 Area and Richland Pumphouse transects. The highest total uranium concentration was measured near the Franklin County shoreline of the Richland Pumphouse transect and likely resulted from groundwater seepage and water from irrigation return canals on the Franklin County side of the river that contained naturally occurring uranium (PNL-7500). The mean concentration of total uranium across the Richland Pumphouse transect was similar to that measured in monthly composite samples from the pumphouse.

\subsubsection{Chemical and Physical Results for River-Water Samples}

The U.S. Geological Survey and Pacific Northwest National Laboratory compiled chemical and physical water quality data for the Columbia River during 2001. A number of the parameters measured have no regulatory limits; however, they are useful as indicators of water quality and contaminants of Hanford origin. Potential sources of pollutants not associated with Hanford include irrigation return water and groundwater seepage associated with extensive irrigation north and east of the Columbia River (PNL-7500).

U.S. Geological Survey. Figure 4.2.11 shows U.S. Geological Survey results for the Vernita Bridge and Richland Pumphouse for 1996 through 2001 (2001 results are preliminary) for several water quality parameters with respect to their applicable standards. The complete list of preliminary results obtained through the 


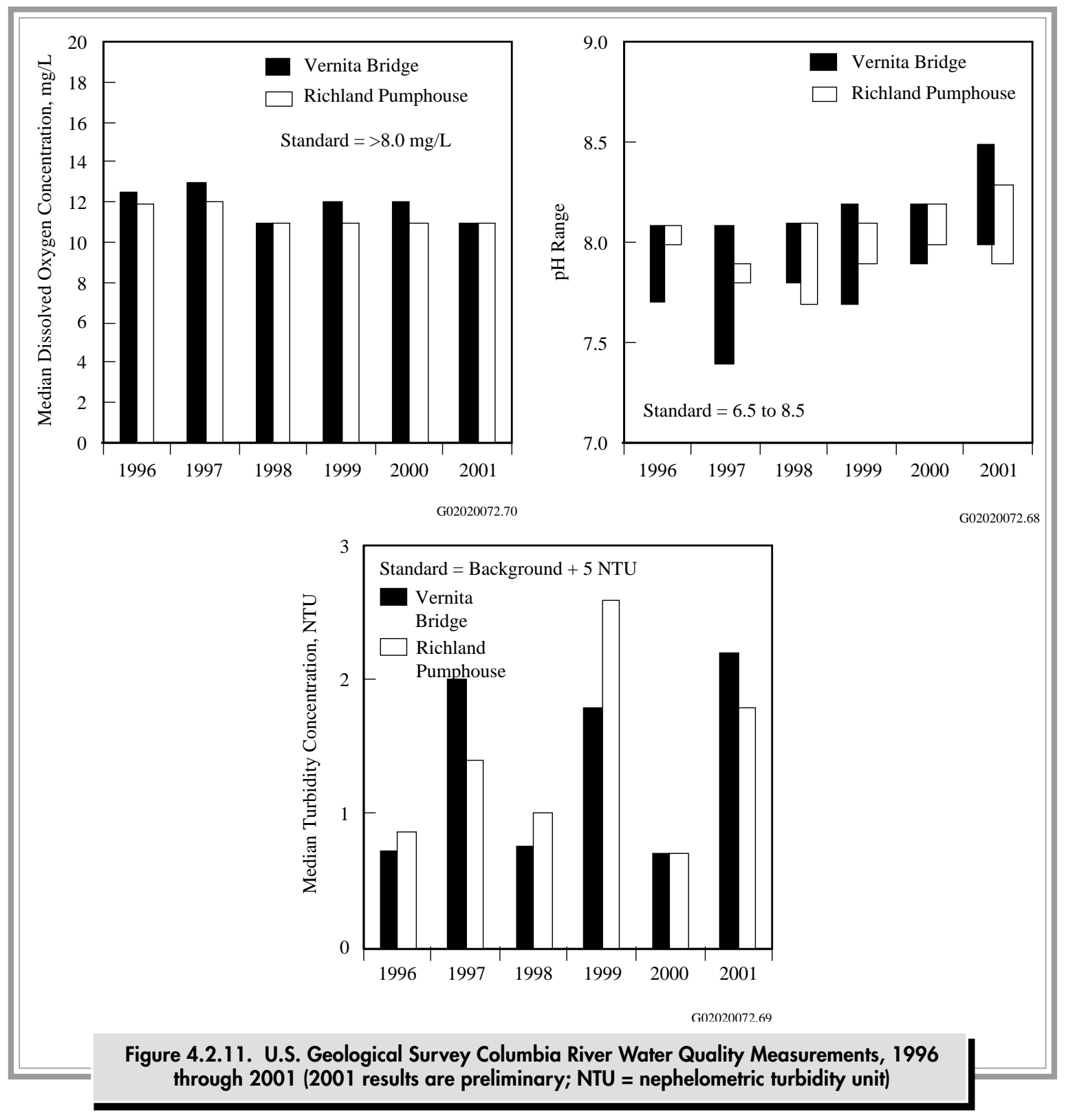

U.S. Geological Survey National Stream Quality Accounting Network program is documented in PNNL-13910, APP. 1 and is summarized in Appendix B (Table B.5). Final results are published annually by the U.S. Geological Survey (e.g., WA-99-1). The 2001 U.S. Geological Survey results were comparable to those reported during the previous 5 years. Applicable standards for a Class A-designated surface-water body were met. During 2001, there was no indication of any deterioration of water quality resulting from site operations along the Hanford Reach of the Columbia River (see Appendix D, Table D.1).

River T ransect and N ear-Shore Samples. Results of chemical sampling conducted by Pacific Northwest National Laboratory along transect and near-shore locations of the Columbia River in 2001 at the Vernita Bridge, 100-F Area, 100-N Area, Hanford town site, 300 Area, and Richland Pumphouse are provided in PNNL-13910, APP. 1. The concentrations of metals and anions observed in river water in 2001 were similar to those observed in the past and remain below regulatory limits. Several metals and anions were detected in Columbia River transect samples both upstream and downstream of the Hanford Site. Arsenic, antimony, cadmium, chromium, lead, nickel, thallium, and zinc were detected in the majority of samples, with similar levels at most locations. Beryllium, selenium, and silver were detected occasionally. Nitrate concentrations for water samples from the Benton County shoreline near the Richland Pumphouse were similar to mid-river 
samples. Nitrate, sulfate, and chloride concentrations were slightly elevated, compared to mid-river samples, along the Franklin County shoreline at the Richland Pumphouse transects and likely resulted from groundwater seepage associated with extensive irrigation north and east of the Columbia River. Nitrate contamination of some Franklin County groundwater has been documented by the U.S. Geological Survey (1995) and is associated with high fertilizer and water usage in agricultural areas. Numerous wells in western Franklin County exceed the EPA maximum contaminant level for nitrate (40 CFR 141; USGS Circular 1144). Average nitrate and chloride results were slightly higher for quarterly concentrations at the Richland Pumphouse transect compared to the Vernita Bridge transect. Nitrate, chloride, and sulfate concentrations were slightly elevated, compared to mid-river, for the Franklin County shoreline at the 300 Area. There were no apparent concentration gradients near the Hanford shoreline for anions measured in transect samples collected at the Vernita Bridge, 100-N Area, 100-F Area, and Hanford town site.

Washington State ambient surface-water quality criteria for cadmium, copper, lead, nickel, silver, and zinc are total-hardness dependent (WAC 173-201A; see Appendix D, Table D.3). Criteria for Columbia River water were calculated using a total hardness of $47 \mathrm{mg} / \mathrm{L}$ as calcium carbonate, the limiting value based on U.S. Geological Survey monitoring of Columbia River water near Vernita Bridge and the Richland Pumphouse over the past years. The total hardness reported by the U.S. Geological Survey at those locations from 1992 through 2001 ranged from 47 to $77 \mathrm{mg} / \mathrm{L}$ as calcium carbonate. All metal and anion concentrations in river water were less than the state ambient surfacewater quality criteria levels for the protection of aquatic life from both acute and chronic toxicity levels (see Appendix B, Table B.6 and Appendix D, Table D.3). Arsenic concentrations exceeded the EPA standard for the protection of human health for the consumption of water and organisms; however, this EPA value is $>10,500$ times lower than the state chronic toxicity value and similar concentrations were found at the Vernita Bridge and the Richland Pumphouse (see Appendix D, Table D.3). The concentrations of volatile organic compounds in Columbia River water samples (e.g., chlorinated solvents, benzene) were below detection limits in most samples, with no indication of a Hanford source.

\subsubsection{Colum bia River Sediment}

Upon release to the Columbia River, radioactive and non-radioactive materials were dispersed rapidly, sorbed onto detritus and inorganic particles, incorporated into aquatic biota, deposited on the riverbed as sediment, or flushed out to sea. The concentrations of the radioactive material decreased as it underwent radioactive decay. Fluctuations in the river flow rate, as a result of the operation of hydroelectric dams, annual spring freshets, and occasional floods, have resulted in the resuspension, relocation, and subsequent redeposition of the sediment (DOE/RL-91-50). Sediment in the Columbia River contains low concentrations of radionuclides and metals of Hanford Site origin as well as radionuclides from nuclear weapons testing fallout (Beasley et al. 1981; BNWL-2305; PNL-8148; PNL-10535). Potential public exposures are well below the level at which routine surveillance of Columbia River sediment is required (PNL-3127; Wells 1994). However, periodic sampling is necessary to confirm the low levels and to assure that no significant changes have occurred for this pathway. The accumulation of radioactive materials in sediment can lead to human exposure by ingestion of aquatic organisms, sediment resuspension into drinking water supplies, or as an external radiation source irradiating people who are fishing, wading, sunbathing, or participating in other recreational activities associated with the river or shoreline (DOE/EH-0173T).

Since the shutdown of the last single-pass reactor at Hanford in 1971, the contaminant concentrations in the surface sediment have been decreasing as a result of radioactive decay and the subsequent deposition of uncontaminated material (Cushing et al. 1981). However, discharges of some pollutants from the Hanford Site to the Columbia River still occur via permitregulated liquid effluent discharges (see Section 3.1) and via contaminated groundwater seepage (see Section 4.2.3).

Several studies have been conducted on the Columbia River to investigate the difference in sediment grainsize composition and total organic carbon content at routine monitoring sites (Beasley et al. 1981; PNL-10535; PNNL-13417). Physical and chemical sediment characteristics were found to be highly variable among monitoring sites along the Columbia River. Samples containing the highest percentage of silts, clays, and total organic carbon were generally collected from the pools near all the dams and from White Bluffs Slough. 


\subsubsection{Collection of Sediment Sam ples and Analytes of Interest}

During 2001, samples of Columbia River surface sediment were collected at depths of 0 to 15 centimeters ( 0 to 6 inches) from six river locations that were permanently submerged and six riverbank springs that were periodically inundated (see Figure 4.2.1 and Table 4.2.2). Sediment sampling locations were documented using a global positioning system. In addition, sediment samples were collected behind Ice Harbor Dam on the Snake River.

Samples were collected upstream of Hanford Site facilities from the Priest Rapids Dam pool (the nearest upstream impoundment) to provide background data from an area unaffected by site operations. Samples were collected downstream of the Hanford Site above McNary Dam (the nearest downstream impoundment) to identify any increase in contaminant concentrations. Any increases in contaminant concentrations found in sediment above McNary Dam compared to that found above Priest Rapids Dam do not necessarily reflect a Hanford Site source. The confluences of the Columbia River with the Yakima, Snake, and Walla Walla Rivers lie between the Hanford Site and McNary Dam. Several towns, irrigation water returns, and factories in these drainages also may contribute to the contaminant load found in McNary Dam sediment; thus, sediment samples are periodically taken at Ice Harbor Dam to assess Snake River inputs. Sediment samples also were collected along the Hanford Reach of the Columbia River from areas close to contaminant discharges (e.g., riverbank springs), from slackwater areas where fine-grained material is known to deposit (e.g., the White Bluffs, 100-F Area, and Hanford Sloughs), and from the publicly accessible Richland shoreline.

Monitoring sites at McNary and Priest Rapids Dams consisted of two stations spaced equidistant (approximately) on a transect line crossing the Columbia River; the samples were collected near the boat exclusion buoys at each dam. On the Snake River, sediment samples were collected at three locations at Levy Landing, which is a public park located upriver from Ice Harbor Dam. All other monitoring sites consisted of a single sampling location. Samples of permanently inundated river sediment were collected using a clam-shell style sediment dredge. Samples of periodically inundated river sediment, (riverbank springs sediment) were collected using a large plastic spoon, immediately following the collection of riverbank springs water samples. Sampling methods are discussed in detail in DOE/RL-91-50. All sediment samples were analyzed for gamma emitting radionuclides (see Appendix F), strontium-90, uranium-234, uranium-235, uranium-238, and metals (DOE/RL-91-50). Selected river sediment samples were also analyzed for plutonium-238, and plutonium239/240. The specific analytes selected for sediment samples were based on findings of previous Columbia and Snake River sediment investigations, reviews of past and present effluents discharged from site facilities, and reviews of contaminant concentrations observed in groundwater monitoring wells near the river.

\subsubsection{Radiological Results for Sam ples from River Sediment}

Results of the radiological analyses on river sediment samples collected during 2001 are reported in PNNL-13910, APP. 1 and summarized in Appendix B (Table B.7). Radionuclides consistently detected in river sediment adjacent and downstream of the Hanford Site during 2001 included potassium-40, cesium-137, uranium-238, plutonium-238, and plutonium-239/240. The concentrations of all other radionuclides were below detection limits for most samples. Cesium-137 and plutonium isotopes exist in worldwide fallout, as well as in effluents from Hanford Site facilities. Uranium occurs naturally in the environment in addition to being present in Hanford Site effluents. Comparisons of contaminant levels between sediment sampling locations are made below. Because of variations in the bioavailability of contaminants in various sediment, no federal or state freshwater sediment criteria are available to assess the sediment quality of the Columbia River (EPA 822-R-96-001).

Radionuclide concentrations reported in river sediment in 2001 were similar to those reported for previous years (see Appendix B, Table B.7). Median, maximum, and minimum concentrations of selected radionuclides measured in Columbia (1995 through 2000) and Snake River sediment from 1996 through 2001 are presented in Figure 4.2.12. Sampling areas include stations at Priest Rapids, McNary, and Ice Harbor Dams as well as the Hanford Reach stations (White Bluffs, 100-F Area and Hanford Sloughs, and the Richland Pumphouse).

\subsubsection{Radiological Results for Sediment Samples from Riverbank Springs}

Sampling of sediment from riverbank springs began in 1993 at the Hanford town site and the 300 Area. Sampling of the riverbank springs in the 100-B, 100-F, 


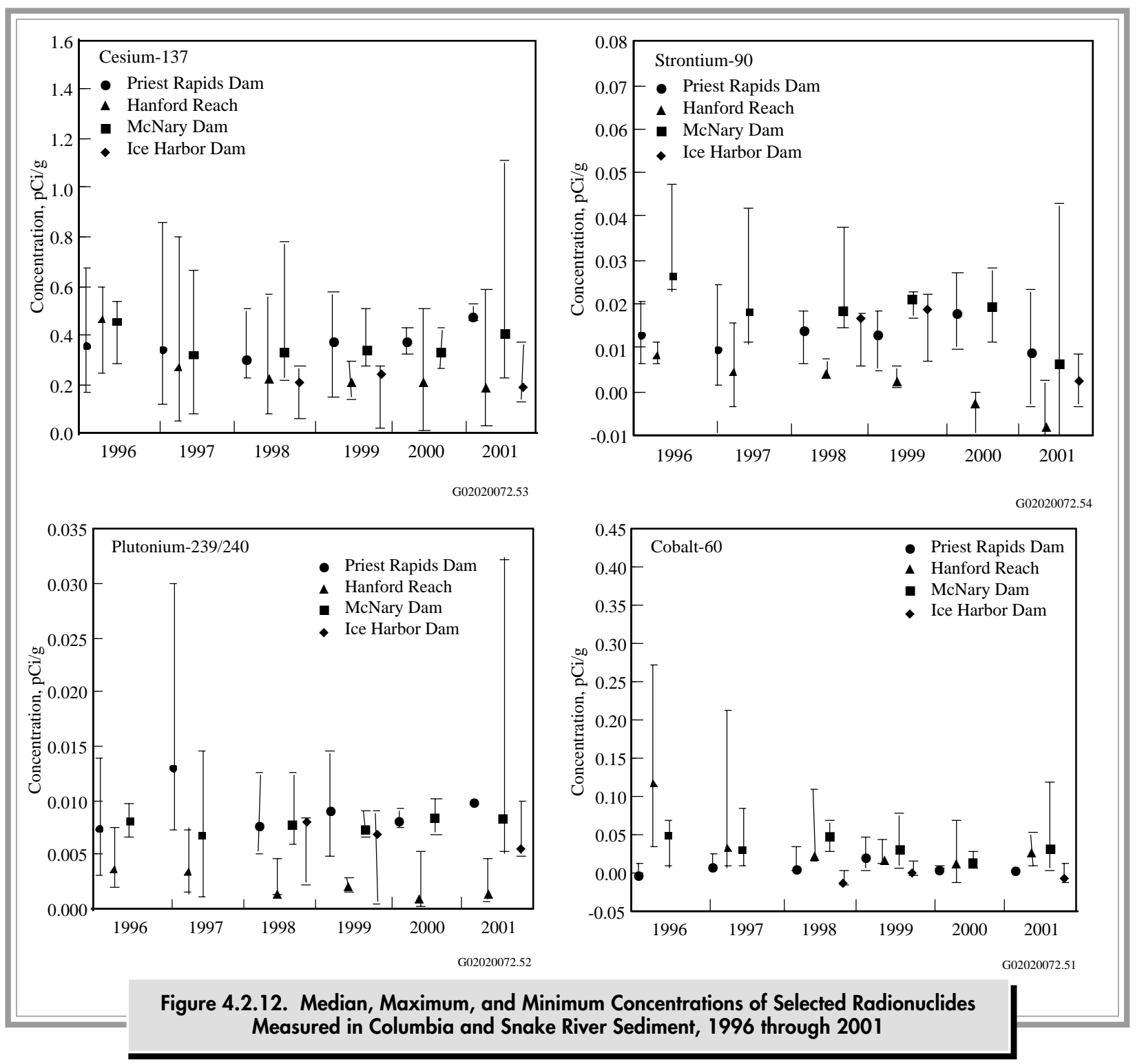

and 100-K Areas began in 1995. Substrates at all other riverbank springs sampling locations consist of predominantly large cobble and are unsuitable for sample collection.

Radiological results for sediment collected from riverbank springs in 2001 are presented in PNNL-13910, APP. 1 and are summarized in Appendix B (Table B.7). Results were similar to those observed for previous years. In 2001, sediment samples were collected at riverbank springs in the 100-B, 100-F, and 300 Areas. There was no sediment available for sampling at the $100-\mathrm{K}$ and 100-N Area locations. In 2001, radionuclide concentrations in riverbank spring sediment were similar to those observed in river sediment.

\subsubsection{Chemical Results for Sediment Samples from the Colum bia River and from Riverbank Springs}

Metal concentrations (total metals, reported on a dry weight basis) observed in Columbia River sediment in 2001 are reported in PNNL-13910, APP. 1 and are summarized in Appendix B (Table B.8). Detectable amounts of most metals were found in all river sediment samples (Figure 4.2.13). Maximum and median concentrations of most metals were higher for sediment collected at Priest Rapids Dam compared to either 


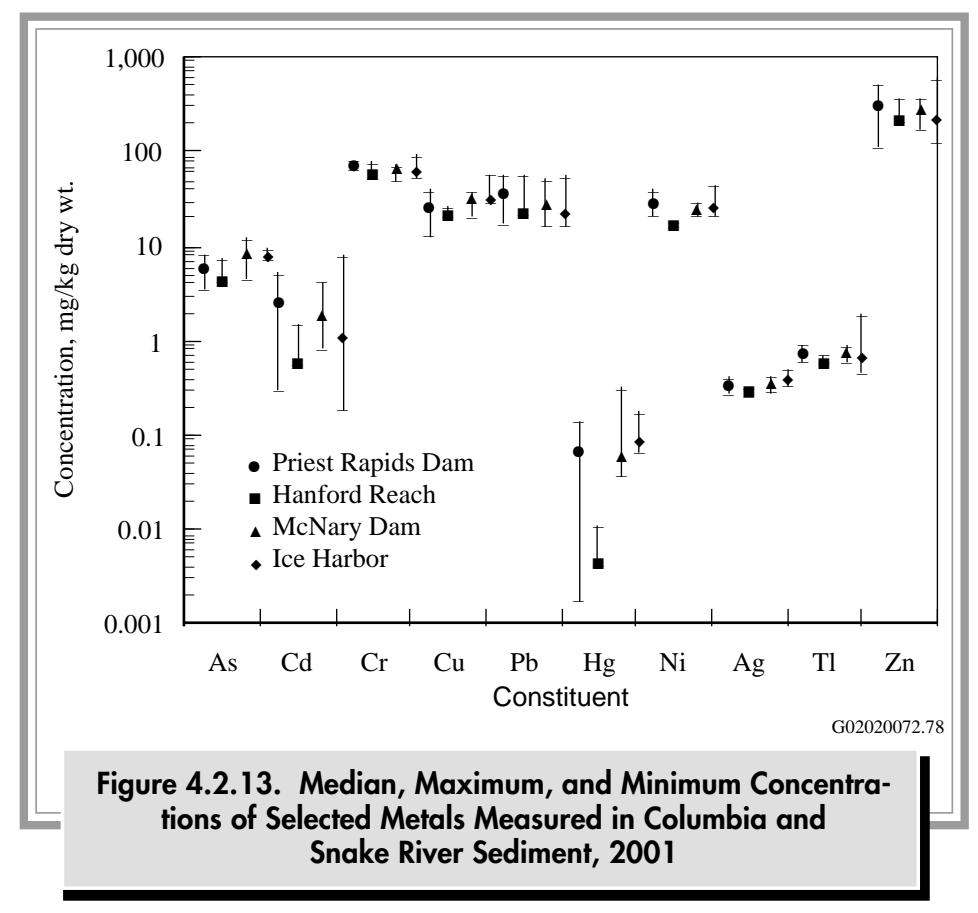

Hanford Reach or McNary Dam sediment. The concentrations of cadmium, chromium, lead, nickel, thallium, and zinc had the largest differences between locations. Metal concentrations in riverbank spring sediment samples in 2001 were similar to concentrations in Hanford Reach sediment samples. Currently, there are no Washington State freshwater sediment quality criteria for comparison to the measured values.

\subsubsection{Riverbank Spring Water}

The Columbia River is the primary discharge area for the unconfined aquifer underlying the Hanford Site (see Section 6.1.2). Groundwater provides a means for transporting Hanford-associated contaminants, which have leached into groundwater from past waste disposal practices, to the Columbia River (DOE/RL-92-12; PNL-5289; PNL-7500; WHC-SD-EN-TI-006). Contaminated groundwater enters the Columbia River via surface and subsurface discharge. Discharge zones located above the water level of the river are identified in this report as riverbank springs. Routine monitoring of riverbank springs offers the opportunity to characterize the quality of groundwater being discharged to the river and to assess the potential human and ecological risk associated with the spring water.

The seepage of groundwater into the Columbia River has occurred for many years. Riverbank springs were documented along the Hanford Reach long before Hanford Site operations began during World War II (Jenkins 1922). In the early 1980s, researchers walked the 66-kilometer (41-mile) stretch of Benton County shoreline of the Hanford Reach and identified 115 springs (PNL-5289). They reported that the predominant areas of groundwater discharge at that time were in the vicinity of the 100-N Area, Hanford town site, and 300 Area. The predominance of the 100-N Area may no longer be valid because of declining water-table elevations in response to the cessation of liquid waste discharges to the ground from Hanford Site operations and pump-and-treat operations at the 100-N Area. In recent years, it has become increasingly difficult to locate riverbank springs in the 100-N Area.

The presence of riverbank springs also varies with river stage. Groundwater levels in the 100 and 300 Areas are heavily influenced by river stage fluctuations (see Section 6.1). Water levels in the Columbia River fluctuate greatly on annual and even daily cycles and are controlled by the operation of Priest Rapids Dam upstream of the site. Water flows into the aquifer (as bank storage) as the river stage rises and then flows in the opposite direction as the river stage falls. Following an extended period of low river flow, groundwater discharge zones located above the water level of the river may cease to exist once the level of the groundwater comes into equilibrium with the level of the river. Thus, springs are most readily identified immediately following a decline in river stage. Bank storage of river water also affects the contaminant concentration of the springs. 
Spring water discharge immediately following a river stage decline generally consists of river water or a river/ groundwater mix. The percentage of groundwater in the spring water discharge is believed to increase over time following a drop in river stage. Measuring the specific conductivity of the spring water discharge provides an indicator of the extent of bank storage because the Hanford Site groundwater has higher specific conductivity than the Columbia River.

Because of the effect of bank storage on groundwater discharge and contaminant concentration, it is difficult to estimate the volume of contaminated groundwater discharged to the Columbia River within the Hanford Reach. The estimated total groundwater discharge from the upstream end of the 100 Areas to south of the 300 Area is $\sim 66,500$ cubic meters (2.35 million cubic feet) per day. ${ }^{(a)}$ This represents only $0.02 \%$ of the long-term average daily flow rate of the Columbia River, which illustrates the tremendous dilution potential afforded by the river. Studies of riverbank springs conducted in 1983 (PNL-5289), in 1988 (PNL-7500), and a near-shore study (PNNL-11933) also noted that discharges from the springs had a localized effect on river contaminant concentrations. These studies reported that the volume of groundwater entering the river at these locations was very small compared to the flow of the river and that the impact of groundwater discharges to the river was minimal.

\subsubsection{Collection of Water Sam ples from Riverbank Springs and Analytes of Interest}

Routine monitoring of selected riverbank springs was initiated in 1988. Currently, riverbank spring water samples are collected for environmental surveillance and to support groundwater operable unit investigations. The locations of all riverbank springs sampled in 2001 are identified in Figure 4.2.1. Sample collection methods are described in DOE/RL-91-50. Analytes of interest for samples from riverbank springs were selected based on findings of previous investigations, reviews of contaminant concentrations observed in nearby groundwater monitoring wells, and results of preliminary risk assessments. Sampling is conducted annually when river flows are low, typically in late summer or early fall.

The below normal flows on the Columbia River in 2001 allowed samples of water from riverbank springs to be collected in the spring and fall of 2001. All samples collected during 2001 were analyzed for gamma-emitting radionuclides, gross alpha, gross beta, and tritium. Samples from selected springs were analyzed for strontium-90, technetium-99, iodine-129, and uranium-234, -235, and -238. All samples were analyzed for metals and anions, with volatile organic compounds analyzed at selected locations. All analyses were conducted on unfiltered samples, except for metals analyses, which were conducted for both filtered and unfiltered samples.

Hanford-origin contaminants continued to be detected in water from riverbank springs entering the Columbia River along the Hanford Site during 2001. The locations and extent of contaminated discharges were consistent with recent groundwater surveys. Tritium, strontium-90, technetium-99, iodine-129, uranium-234, -235, and -238, metals, and anions (chloride, fluoride, nitrate, and sulfate) were detected in spring water. Volatile organic compounds were near or below the detection limits for most samples. The contaminant concentrations in water from riverbank springs are typically lower than those found in nearshore groundwater wells because of bank storage effects.

Results of radiological and chemical analyses conducted on samples from riverbank springs in 2001 are documented in PNNL-13910, APP. 1. Radiological results obtained in 2001 are summarized in Appendix B (Table B.9) and compared to those reported in 1996 through 2000. In the following discussion, radiological and chemical results are addressed separately. Contaminant concentration trends are illustrated for selected locations.

\subsubsection{Radiological Results for Water Samples from Riverbank Springs}

All radiological contaminant concentrations measured in riverbank springs in 2001 were less than the DOE derived concentration guides (DOE Order 5400.5; see Appendix D, Table D.5). However, the spring near well $199-\mathrm{N}-8 \mathrm{~T}$ at the $100-\mathrm{N}$ Area that has historically exceeded the DOE derived concentration guide for strontium-90 only had observed flow during one (1997) sampling attempt in the last 6 years; thus, an alternative spring was sampled in the $100-\mathrm{N}$ Area. Tritium concentrations in water samples collected in 2001 from riverbank springs at the Hanford town site exceeded the state ambient surface-water quality criteria level

(a) Personal communication from S. P. Luttrell to G. W. Patton, Pacific Northwest National Laboratory, Richland, Washington, January 1995. 
of $20,000 \mathrm{pCi} / \mathrm{L} \quad(740 \mathrm{~Bq} / \mathrm{L}) \quad(W A C ~ 173-201 \mathrm{~A}$; 40 CFR 141). The maximum tritium concentration in riverbank spring water collected in 2001 at the $100-\mathrm{N}$ Area was $17,000 \mathrm{pCi} / \mathrm{L}(630 \mathrm{~Bq} / \mathrm{L})$, which was $86 \%$ of the state ambient surface water criteria level (WAC 173-201A; 40 CFR 141). At the 300 Area, the maximum tritium levels was $12,000 \mathrm{pCi} / \mathrm{L}(440 \mathrm{~Bq} / \mathrm{L})$, which was $60 \%$ of the criteria. The strontium-90 concentration in riverbank spring water was greater than the criteria level at the $100-\mathrm{H}$ Area location. Total uranium concentrations exceeded the EPA drinking water standard (EPA 822-R-96-001) in the 300 Area (see Appendix D, Table D.2). The gross alpha concentration exceeded the ambient surface-water quality criteria level (15 pCi/L [0.56 Bq], Appendix D, Table D.2) in riverbank spring water at the 300 Area, which is consistent with the elevated uranium levels. All other radionuclide concentrations in 300 Area springs water were less than the state ambient surfacewater quality criteria levels. Gross beta concentrations in riverbank spring water at the 100-B Area, 100-H Area, Hanford town site, and 300 Area were elevated compared to other riverbank spring water locations. Concentrations of selected radionuclides in riverbank spring water near the Hanford town site (spring 28-2) from 1996 through 2001 are provided in Figure 4.2.14. Several of the radionuclides show what appear to be increasing trends since 1995; however, radionuclide concentrations measured in the early 1990s were similar to the 2001 concentrations (see Figure 4.2.13 in PNNL11472). Annual fluctuations in these values may reflect the influence of bank storage during the sampling period.

Figure 4.2.15 depicts concentrations of selected radionuclides in the 300 Area riverbank spring water (spring 42-2) from 1996 through 2001. Results in 2001 were slightly higher than those observed previously and were probably influenced by the below average Columbia River flows in 2001. The elevated tritium levels measured in the 300 Area riverbank springs are indicators of the contaminated groundwater plume from the 200 Areas (Section 5.9 in PNL-10698). Elevated uranium concentrations exist in the unconfined aquifer beneath the 300 Area in the vicinity of the former uranium fuel fabrication facilities and inactive waste sites. The gross alpha and gross beta concentrations in 300 Area riverbank springs water from 1996 through 2001 parallel uranium and are likely associated with its presence.

Tritium concentrations varied widely with location. The highest tritium concentration detected in riverbank springs was at the Hanford town site $(110,000 \pm$ $4,100 \mathrm{pCi} / \mathrm{L}[4,070 \pm 152 \mathrm{~Bq} / \mathrm{L}])$, followed by the $100-\mathrm{N}$ Area $(17,000 \pm 800 \mathrm{pCi} / \mathrm{L}[629 \pm 30 \mathrm{~Bq} / \mathrm{L}])$, and
300 Area $(12,000 \pm 580 \mathrm{pCi} / \mathrm{L}[444 \pm 21 \mathrm{~Bq} / \mathrm{L}])$. The state ambient surface-water quality criteria level for tritium is $20,000 \mathrm{pCi} / \mathrm{L}(740 \mathrm{~Bq} / \mathrm{L})$. Tritium concentrations in all riverbank spring samples were elevated compared to the 2001 average Columbia River concentration at Priest Rapids Dam $(37 \pm 22 \mathrm{pCi} / \mathrm{L}[1.4 \pm 0.81 \mathrm{~Bq} / \mathrm{L}])$.

Samples from riverbank springs in the 100-B, 100-H, $100-\mathrm{K}$, and 300 Areas and the Hanford town site were analyzed for technetium-99. All results were below the EPA drinking water standard (see Appendix D, Table D.2). The highest technetium-99 concentration was found in riverbank spring water from the Hanford town site $(110 \pm 75 \mathrm{pCi} / \mathrm{L}[4.1 \pm 2.8 \mathrm{~Bq} / \mathrm{L}])$, which was higher than the observed gross beta concentrations $(36 \pm 5.8 \mathrm{pCi} / \mathrm{L}[1.3 \pm 0.21 \mathrm{~Bq} / \mathrm{L}])$.

Samples from riverbank springs at the Hanford town site and 300 Area were analyzed for iodine-129. The highest concentration was measured in a water sample from the Hanford town site spring $(0.25 \pm 0.022 \mathrm{pCi} / \mathrm{L}$ $[0.0093 \pm 0.00081 \mathrm{~Bq} / \mathrm{L}])$. This value was elevated compared to the 2001 average measured at Priest Rapids $\operatorname{Dam}(0.0000025 \pm 0.000017 \mathrm{pCi} / \mathrm{L}[0.000000092 \pm$ $0.00000063 \mathrm{~Bq} / \mathrm{L}]$ ) but was below the $1-\mathrm{pCi} / \mathrm{L}$ (0.037-Bq/L) surface-water quality criteria level (see Appendix D, Table D.2).

Uranium was sampled in riverbank spring water in the 100-H Area, 100-F Area, Hanford town site, and 300 Area in 2001. The highest level was found in 300 Area spring water $(100 \pm 19 \mathrm{pCi} / \mathrm{L}[3.7 \pm 0.70 \mathrm{~Bq} / \mathrm{L}])$, which was collected from a spring located downgradient from the retired 300 Area process trenches. The 300 Area spring had elevated gross alpha concentration $(87 \pm$ $8.7 \mathrm{pCi} / \mathrm{L}[3.2 \pm 0.32 \mathrm{~Bq} / \mathrm{L}]$, which paralleled that of uranium.

Samples from riverbank springs were analyzed for strontium-90 in the 100-B, 100-D, 100-F, 100-H, 100-K, and $100-\mathrm{N}$ Areas. The highest strontium-90 concentration detected in riverbank spring water was at the $100-\mathrm{H}$ Area $(14 \pm 3.2 \mathrm{pCi} / \mathrm{L}[0.52 \pm 0.12 \mathrm{~Bq} / \mathrm{L}])$. This value was above the ambient surface water quality criteria of $8 \mathrm{pCi} / \mathrm{L}(0.30 \mathrm{~Bq} / \mathrm{L})$.

Historically, riverbank seepage in the 100-N Area has been monitored for contaminants by sampling from well 199-N-8T, which is located close to the river; well 199-N-46 (caisson), which is slightly inland from well 199-N-8T (PNNL-11795, Figure 3.2.4); or riverbank springs. Since 1993, 100-N Area seepage samples for the Surface Environmental Surveillance Project have been collected only from riverbank springs. The Near-Facility Environmental Monitoring Program (see 

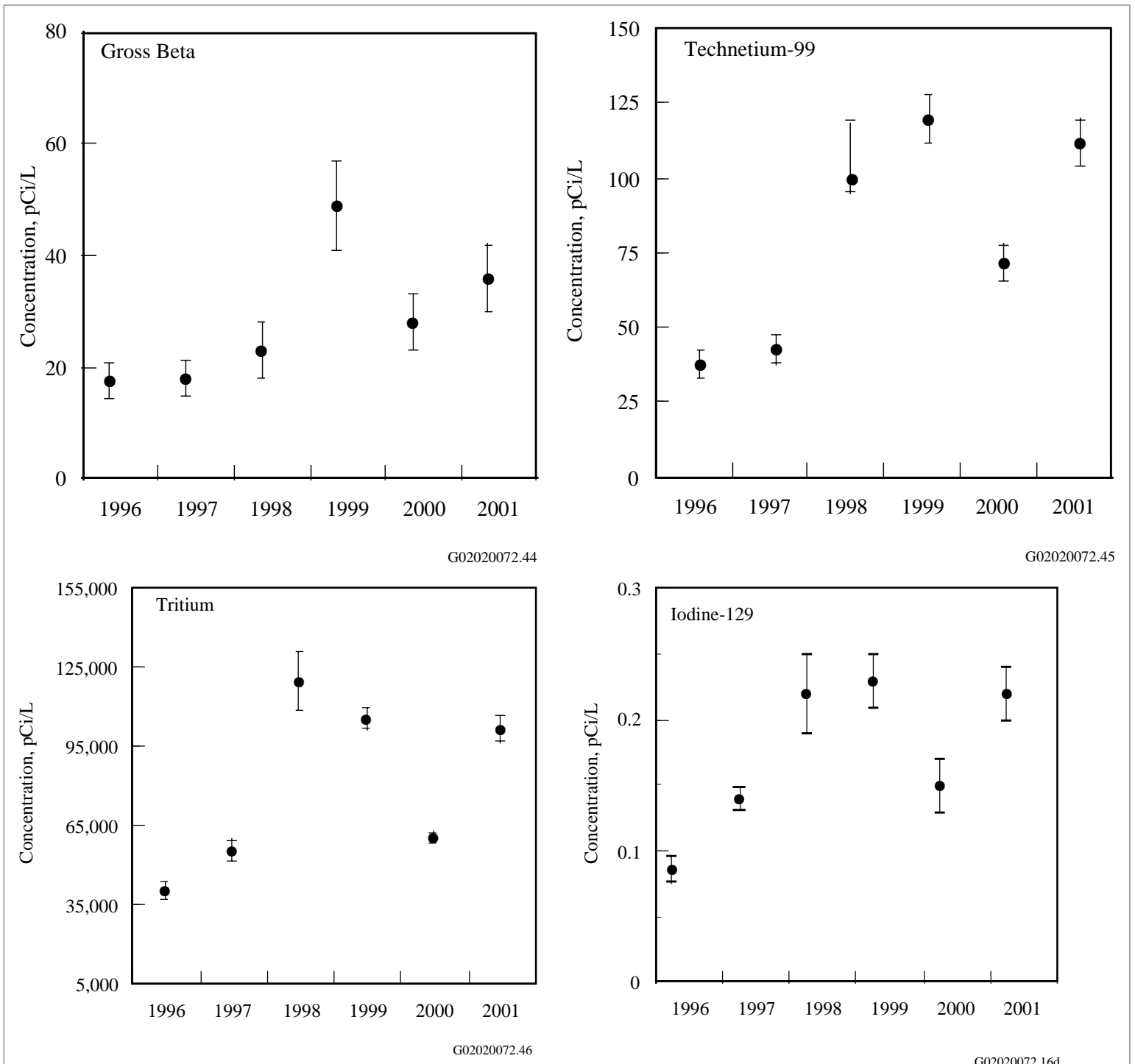

Figure 4.2.14. Concentrations (results \pm 2 total propagated analytical uncertainty) of Constituents of Interest in Columbia River Riverbank Spring Water at the Hanford Town Site (Spring 28-2), 1996 through 2001. As a result of figure scale, some uncertainties (error bars) are concealed by the point symbol.

Section 3.2.2) also collects water samples along the 100-N shoreline at monitoring well $199-\mathrm{N}-46$ and at shoreline seepage wells. The Near-Facility Environmental Monitoring Program reported all strontium-90 concentrations in calendar year 2001 samples were below the $1,000 \mathrm{pCi} / \mathrm{L}(37 \mathrm{~Bq} / \mathrm{L}) \mathrm{DOE}$ derived concentration guide for shoreline seepage wells near monitoring well 199-N-46 (see Table 3.2.4). For 1993 to 2001, there were no visible riverbank springs directly adjacent to wells $199-\mathrm{N}-8$ T or 199-N-46 during the Surface Environmental Surveillance Project sampling periods; with the exception of one sample collected in 1997. The samples from 100-N Area riverbank springs were, therefore, collected from a downstream riverbank spring. Contaminant concentrations measured in the water from the two riverbank springs locations sampled in previous years were distinctly different from each other (Table 4.2.3). Historically, the concentrations of strontium-90 and gross beta were considerably higher in the riverbank spring directly adjacent to well 199-N-8T than for the downstream spring. Tritium levels in water from riverbank springs are typically elevated at both locations, and the 2001 tritium result for the $100-\mathrm{N}$ riverbank spring was similar to those found in previous years (see Table 4.2.3). Tritium was the only specific radionuclide detected at the $100-\mathrm{N}$ Area riverbank spring in 2001. 

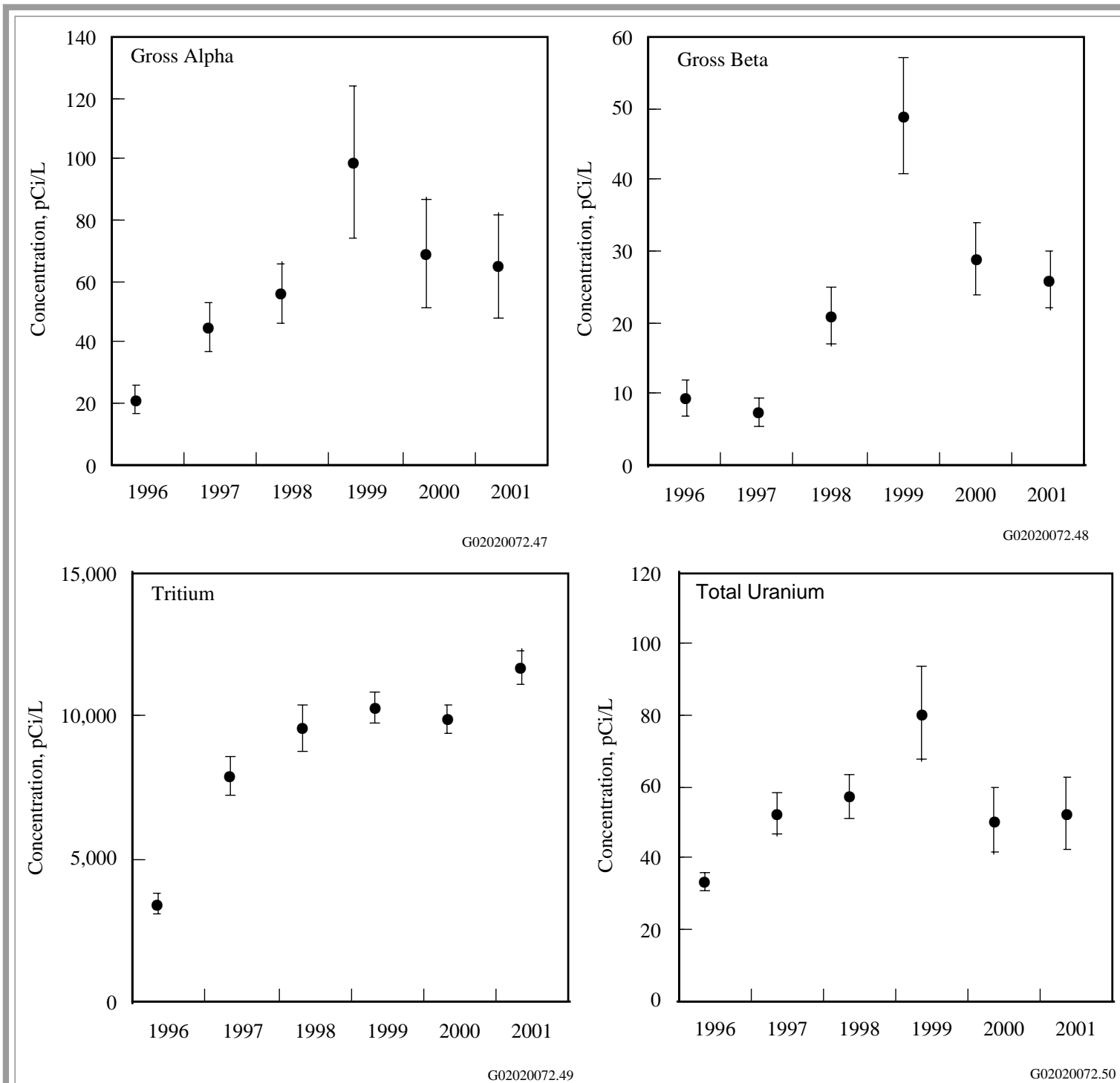

Figure 4.2.15. Concentrations (results \pm 2 total propagated analytical uncertainty) of Constituents of Interest in Water from a Columbia River Riverbank Spring near the 300 Area (Spring 42-2), 1996 through 2001. 2001 results are for the May 10, 2001 sampling event.

\subsubsection{Chemical Results for Water Samples from Riverbank Springs}

Concentration ranges of selected chemicals measured in riverbank springs water in 1999 through 2001 are presented in Table 4.2.4. For most locations, the 2001 chemical sample results were similar to those reported previously (PNNL-12088). Nitrate concentrations were highest in the 300 Area. Chromium concentrations were generally highest in the $100-\mathrm{D}, 100-\mathrm{H}$, and $100-\mathrm{K}$ Areas' riverbank springs. Hanford groundwater monitoring results for 2001 indicated similar contaminant concentrations in shoreline areas (see Section 6.1).

The ambient surface-water quality criteria for cadmium, copper, lead, nickel, silver, and zinc are totalhardness dependent (WAC 173-201A; see Appendix D, Table D.3). For comparison purposes, spring water criteria were calculated using the same 47-mg calcium carbonate per liter hardness given in Appendix D, Table D.3. Most metal concentrations measured in water from riverbank springs collected from the Hanford Site shoreline in 1999 through 2001 were below ambient surface-water acute toxicity levels (WAC 173-201A). 
Table 4.2.3. Selected Radionuclide Concentrations in 100-N Area Riverbank Spring Water, 1996 through 2001

\begin{tabular}{|c|c|c|c|}
\hline \multirow[b]{2}{*}{$\underline{\text { Year }}$} & \multicolumn{3}{|c|}{ Concentration, $\mathrm{pCi} / \mathrm{L}^{(\mathrm{a})}$} \\
\hline & $\underline{\text { Tritium }}$ & Gross Beta & Strontium-90 \\
\hline $1996^{(\mathrm{b})}$ & $17,000 \pm 1,300$ & $4.5 \pm 1.8$ & $0.053 \pm 0.048$ \\
\hline $1997^{\text {(b) }}$ & $19,000 \pm 1,500$ & $3.5 \pm 1.6$ & $0.59 \pm 0.13$ \\
\hline $1997^{\text {(c) }}$ & $14,000 \pm 1,100$ & $16,000 \pm 1,400$ & $9,900 \pm 1,800$ \\
\hline $1998^{(\mathrm{b})}$ & $24,000 \pm 1,900$ & $2.3 \pm 2.1$ & (d) \\
\hline $1999^{(\mathrm{b})}$ & $14,000 \pm 670$ & $2.9 \pm 1.7$ & $0.026 \pm 0.034$ \\
\hline $2000^{(\mathrm{b})}$ & $18,000 \pm 800$ & $5.9 \pm 2.1$ & $-0.0026 \pm 0.037$ \\
\hline $2001^{(\mathrm{b})}$ & $17,000 \pm 800$ & $3.7 \pm 1.8$ & $0.013 \pm 0.043$ \\
\hline $2001^{(\mathrm{b})}$ & $6,500 \pm 430$ & $5.5 \pm 2.0$ & $0.039 \pm 0.044$ \\
\hline (a) & \multicolumn{3}{|c|}{$\begin{array}{l}\text { Concentrations are } \pm 2 \text { total propagated analytical uncer- } \\
\text { tainty. To convert to international metric system, multiply }\end{array}$} \\
\hline b) $\stackrel{r}{S}$ & $\begin{array}{l}\text { le collected from } \\
199-\mathrm{N}-8 \mathrm{~T} \text {. }\end{array}$ & iverbank spring & ownstream of \\
\hline (c) & $\begin{array}{l}\text { ples collected fro } \\
\text {-N Area spring } 8\end{array}$ & $\begin{array}{l}\text { spring below wel } \\
3 \text {, see PNNL-117 }\end{array}$ & $\begin{array}{l}199-\mathrm{N}-8 \mathrm{~T} \\
95 \text {, Figure 3.2.4). }\end{array}$ \\
\hline (d) & $\begin{array}{l}\text { ple was lost durin } \\
\text { ratory. }\end{array}$ & processing at the & analytical \\
\hline
\end{tabular}

However, concentrations of chromium in 100-B, 100-K, $100-\mathrm{N}, 100-\mathrm{D}, 100-\mathrm{H}$, and 100-F, and 300 Areas spring water were above state ambient surface water acute toxicity levels (see Appendix D, Table D.3). Arsenic concentrations in riverbank spring water were well below state ambient surface water chronic toxicity levels, but all samples (including upriver Columbia River water samples) exceeded the federal limit for the protection of human health for the consumption of water and organisms; however, this EPA value is $>10,500$ times lower than the state chronic toxicity standard (40 CFR 141; see Appendix D, Table D.3). Nitrate concentrations at all spring water locations were below the drinking water standard (see Appendix D, Table D.2).

\subsection{Onsite Pond Water}

Two onsite ponds (see Figure 4.2.1), located near operational areas, were sampled periodically during 2001. The ponds are inaccessible to the public and, therefore, did not constitute a direct offsite environmental impact during 2001. However, they were accessible to migratory waterfowl, creating a potential biological pathway for the dispersion of contaminants (PNL-10174). The Fast Flux Test Facility pond is a disposal site for process water (primarily cooling water drawn from groundwater wells). West Lake, the only naturally occurring pond on the site, is located north of the 200-East Area (ARH-CD-775). West Lake has not received direct effluent discharges from Hanford Site facilities but is influenced by changing water-table elevation as a result of previous discharge of water to the ground in the 200 Areas.

\subsubsection{Collection of Pond Water Sam ples and Analytes of Interest}

In 2001, grab samples were collected quarterly from the Fast Flux Test Facility pond and from West Lake. Unfiltered aliquots of all samples were analyzed for gross alpha and gross beta concentrations, gamma-emitting radionuclides, and tritium. West Lake samples also were analyzed for technetium-99 and uranium-234, -235, and -238. Constituents were chosen for analysis based on their known presence in local groundwater or in effluents discharged to the pond and their potential to contribute to the overall radiation dose to the public.

\subsubsection{Radiological Results for Pond Water Sam ples}

Analytical results from pond water samples collected during 2001 are reported in PNNL-13910, APP. 1. With the exceptions of uranium-234 and uranium-238 concentrations in samples from West Lake, radionuclide concentrations in onsite pond water were less than the DOE derived concentration guides (DOE Order 5400.5; see Appendix D, Table D.5). The median gross alpha, and total uranium concentrations exceeded their ambient surface-water quality criteria in West Lake. The median concentrations of all other radionuclides were below state ambient surface-water quality criteria levels (WAC 173-201A; 40 CFR 141; see Appendix D, Tables D.1 and D.2).

Figure 4.2.16 shows the annual gross beta and tritium concentrations in Fast Flux Test Facility pond water 
Table 4.2.4. Concentration Ranges for Selected Chemicals in Water from Columbia River Springs, 1999 through 2001

\begin{tabular}{|c|c|}
\hline & $\begin{array}{c}\text { Ambient } \\
\text { Water Qualit } \\
\text { Criteria Leve }\end{array}$ \\
\hline \\
\hline Antimony & NA \\
\hline Arsenic & 190 \\
\hline Cadmium & 0.59 \\
\hline Chromium (b) $^{(b)}$ & 10 \\
\hline Copper & 6 \\
\hline Lead & 1.1 \\
\hline Nickel & 83 \\
\hline Silver ${ }^{(c)}$ & 0.94 \\
\hline Thallium & NA \\
\hline Zinc & 55 \\
\hline
\end{tabular}

\section{No. of Samples \\ Total Recoverable Metals $(\mu \mathrm{g} / \mathrm{L})$ \\ Chromium ${ }^{(\mathrm{d})}$ \\ Mercury}

96

0.012

Selenium

\begin{tabular}{cccc} 
& & & \\
\hline 100-B Area & 100-K Area & 100-N Area & 100-D Area \\
\hline 5 & 6 & 4 & 5 \\
& & & \\
$0.081-0.28$ & $0.14-0.24$ & $0.19-0.24$ & $0.18-0.22$ \\
$0.93-1.6$ & $0.32-2.1$ & $1.4-3.4$ & $0.66-1.3$ \\
$0.010-0.021$ & $0.0044-0.051$ & $0.011-0.031$ & $0.017-0.091$ \\
$8.9-20$ & $2.1-82$ & $5.6-12$ & $24-150$ \\
$0.20-2.1$ & $0.38-0.85$ & $0.25-0.40$ & $0.38-1.4$ \\
$0.014-0.16$ & $0.0078-0.016$ & $0.0050-0.016$ & $0.0073-0.017$ \\
$0.037-1.6$ & $0.12-1.7$ & $0.027-1.0$ & $0.22-1.8$ \\
$0.0012-0.021$ & $0.0012-0.021$ & $0.0012-0.021$ & $0.0043-0.021$ \\
$0.0035-0.020$ & $0.0035-0.021$ & $0.010-0.016$ & $0.026-0.098$ \\
$1.1-5.0$ & $0.76-3.0$ & $1.5-3.7$ & $1.7-5.0$
\end{tabular}

100

100-F Area

\section{Hanford}

11

100-F Ar

Town Site

300 Area

No. of Samples

Anions (mg/L)

Nitrate

$45^{(1)}$

6

4

5

\section{$0.23-0.42$}

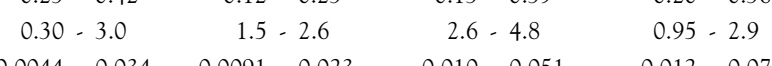

4

4

$\begin{array}{llll}0.30 & 0.0091-0.023 & 0.010-0.051 & 0.012-0.078\end{array}$

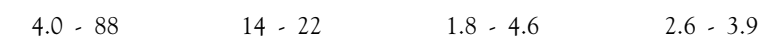

$\begin{array}{llll}0.29-5.6 & 0.32-0.45 & 0.20-0.56 & 0.38-0.46\end{array}$

$\begin{array}{llll}0.0050-0.57 & 0.0078-0.033 & 0.0049-0.058 & 0.0050-0.034\end{array}$

$\begin{array}{llll}0.070-1.2 & 0.070-2.2 & 0.68-1.7 & 0.055-2.1\end{array}$

$\begin{array}{llll}0.0052-0.021 & 0.0012-0.042 & 0.0043-0.053 & 0.0049-0.021\end{array}$

$\begin{array}{llll}0.0059-0.026 & 0.0035-0.011 & 0.013-0.020 & 0.013-0.028\end{array}$

$$
\begin{array}{lllllllll}
8.1-20 & 2.2-93 & 7.6-14 & 24-170 & 4.0-99 & 17-33 & 1.8-5.4 & 2.9-24
\end{array}
$$

$0.00098-0.0013^{(\mathrm{e})} 0.00098-0.0013^{(\mathrm{f})} 0.00044-0.0006^{(\mathrm{g})} \quad 0.00086-0.004^{(\mathrm{e})} \quad 0.00056-0.002^{(\mathrm{h})} \quad 0.0017-0.0038^{(\mathrm{g})} 0.00089-0.0026^{(\mathrm{i})} 0.00088-0.0047^{(\mathrm{e})}$

$\begin{array}{llllllllll}1.2 & -2.2 & 0.11-2.2 & 0.41-0.96 & 0.67-2.7 & 0.39-2.9 & 0.94-2.3 & 1.2-2.3 & 2.3-4.1\end{array}$

$\begin{array}{llllllll}5 & 3 & 7^{(j, k)} & 6^{(k)} & 4^{(k)} & 6^{(k)} & 6\end{array}$

(a) Ambient Water Quality Criteria Values (WAC 173-201A-040) for chronic toxicity unless otherwise noted.

(b) Value for hexavalent chromium.

(c) Value for acute toxicity; chronic value not available.

(d) Value for trivalent chromium.

(e) No 2001 result, $n=4$.

(f) No 2001 result, $n=3$.

(g) No 2001 result, $n=2$.

(h) Two 2001 results, $\mathrm{n}=6$

(i) No 2001 restt, n=6.

(j) One nitrate result of $295 \mathrm{mg} / \mathrm{L}$ for riverbank spring (SD-110-2) on October 17, 2000 was not included in the range because it was considered an anomalously high value.

(k) No 2001 result.

(1) Drinking water standard (WAC 246-290) 

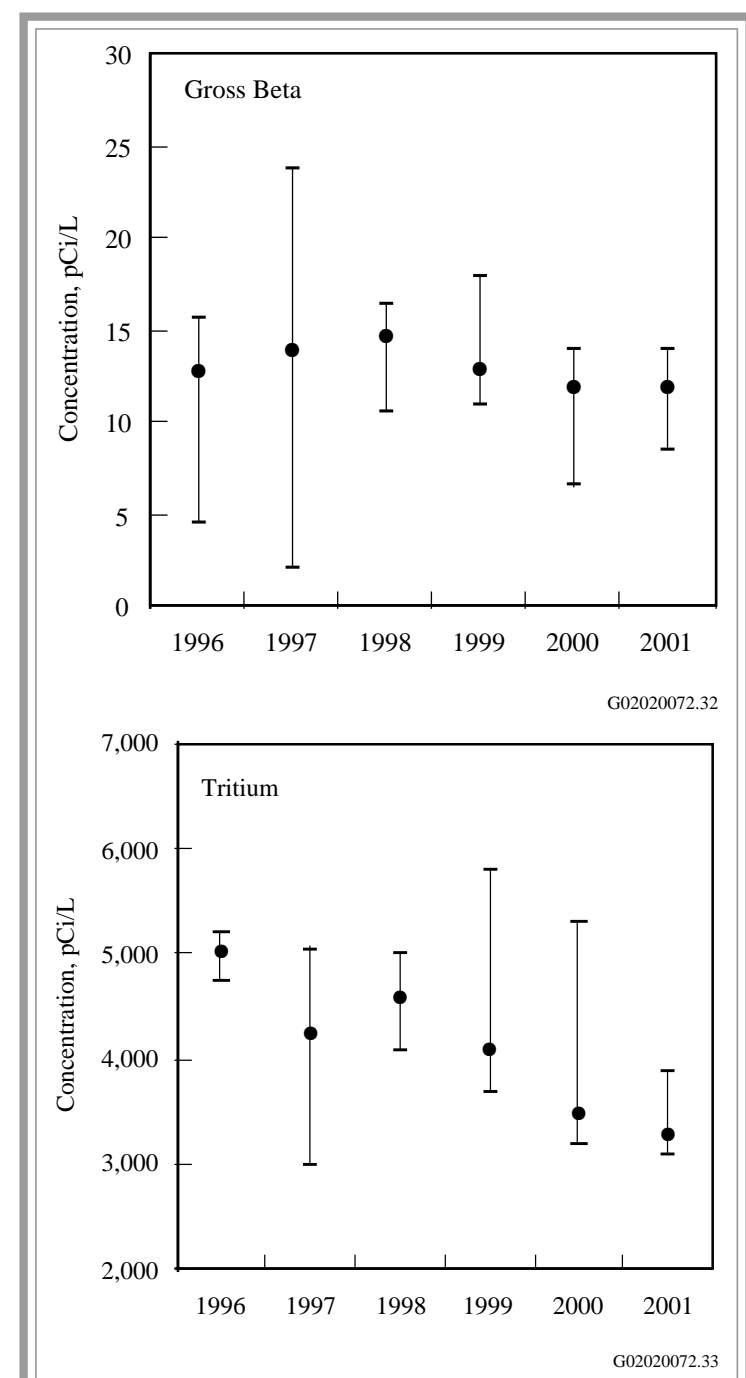

Figure 4.2.16. Median, Maximum, and Minimum Gross Beta and Tritium Concentrations in Fast Flux Test Facility Pond Water Samples, 1996 through 2001 from 1996 through 2001. Median levels of both constituents have remained stable in recent years. The median tritium concentration in Fast Flux Test Facility pond water during 2001 was $16 \%$ of the state ambient surface-water quality criteria.

The annual concentrations of selected radionuclides from 1996 through 2001 in West Lake water are shown in Figure 4.2.17. Median radionuclide concentrations in West Lake during 2001 were similar to those observed in the past. The gross alpha and gross beta levels in West Lake water are believed to result from high levels of naturally occurring uranium in the surrounding soil (BNWL-1979; PNL-7662). Annual median total uranium concentrations have remained stable over the last 6 years, but the range is large. The highest concentrations measured in 2001 were in the summer, when the water level in the pond was low. It is thought that the relatively large concentration of suspended sediment in the samples was causing the elevated results. Similar total uranium levels were reported in PNNL-7662 for West Lake samples that contained high concentrations of suspended sediment. Because of the high suspended sediment concentrations, strontium-90 analyses for West Lake water samples were not conducted in 2001. Declines in groundwater levels beneath the 200 Areas have been recorded since the decommissioning of the processing ponds and the shutdown of production facilities (see Section 6.1). As a result, the water level in West Lake has dropped. Median concentrations of tritium and technetium-99 in West Lake in 2001 were $0.57 \%$ and $39 \%$, respectively, of the state ambient surface-water quality criteria levels and reflected local groundwater concentrations. The concentrations of all other measured radionuclides were below their detection limits, except for naturally occurring potassium-40.

\subsubsection{Offsite Water}

During 2001, water samples were collected from an irrigation canal located across the Columbia River and downstream from the Hanford Site at Riverview and from an irrigation water supply on the Benton County shoreline near the southern boundary of the Hanford Site (Horn Rapids irrigation pumping station). As a result of public concerns about the potential for Hanford-associated contaminants in offsite water, sampling was conducted to document the levels of radionuclides in water used by the public. Consumption of vegetation irrigated with Columbia River water downstream of the site has been identified as one of the primary pathways contributing to the potential dose to the hypothetical maximally exposed individual and any other member of the public (see Section 5.0).

\section{Collection, Analysis, and Results for Irrigation Water}

Water in the Riverview irrigation canal was sampled three times in 2001 during the irrigation season. Unfiltered samples of the canal water were analyzed for gross alpha, gross beta, gamma emitters, tritium, strontium-90, and uranium-234, -235 , and -238 . Results are presented in PNNL-13910, APP. 1. In 2001, 


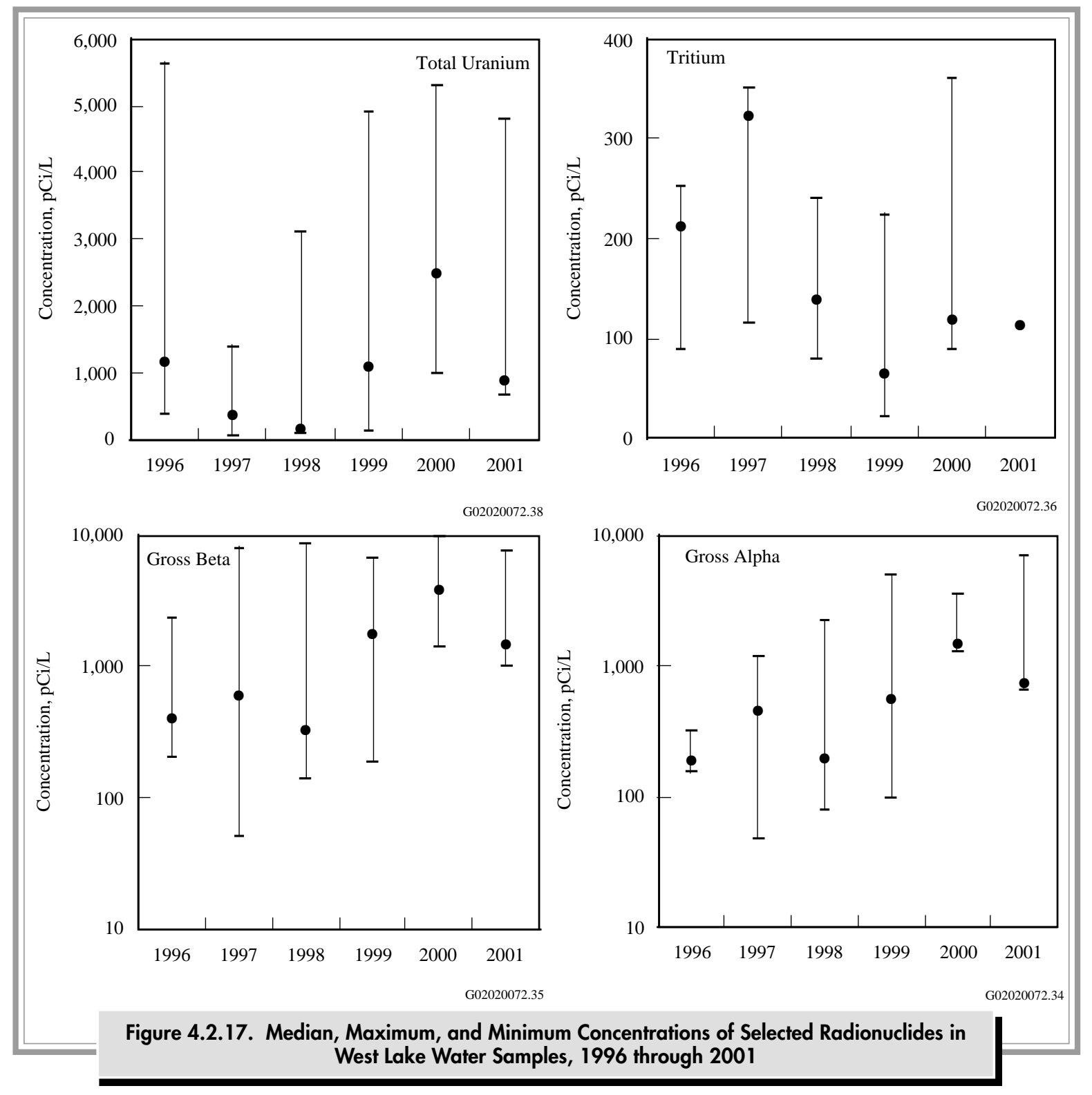

radionuclide concentrations measured in this canal's water were at the same levels detected in the Columbia River. All radionuclide concentrations were below the DOE derived concentration guides and state ambient surface-water quality criteria levels (DOE Order 5400.5; WAC 173-201A; 40 CFR 141). The strontium-90 levels in the irrigation water during 2001 ranged from $0.056 \pm 0.028$ to $0.082 \pm 0.040 \mathrm{pCi} / \mathrm{L}(0.0021 \pm 0.0010$ to $0.0031 \pm 0.0015 \mathrm{~Bq} / \mathrm{L}$ ) and were similar to those reported for the Columbia River at Priest Rapids Dam and the Richland Pumphouse (see Section 4.2.1).
The water sample from the Horn Rapids irrigation pumping station was analyzed for the same analytes as the Riverview irrigation canal water, except for tritium. All radionuclide concentrations were below both DOE derived concentration guides and state ambient surfacewater quality criteria levels (DOE Order 5400.5; WAC 173-201A; 40 CFR 141) and were similar to Columbia River concentrations (see Section 4.2.1). 


\subsubsection{Area Near-Shore Contam inant Characterization}

Pacific Northwest National Laboratory and the Washington State Department of Health conducted a contaminant characterization and biological and human dose/risk assessment for the near-shore of the Columbia River at the 300 Area. The objective of this study was to characterize the radiological and chemical conditions existing in the near-shore environment of the Columbia River by collecting water, biota, and sediment samples and measuring external radiation levels during a time period when the effects of riverbank spring discharges and groundwater upwelling into the river was likely to be maximized. Additionally, this study assessed the potential impact on resident ecological receptors and people that may visit this location. The study was conducted during August to October 2001 to coincide with expected low river stage. A number of contaminants are present in groundwater at the 300 Area and the nearshore environment can be exposed through riverbank springs and groundwater upwelling. Therefore, the sampling locations selected for this study were centered near historic riverbank spring discharges and the contaminants of concerns were primarily known groundwater contaminants (i.e., radionuclides, metals, anions, and volatile organics). This report is currently in production (PNNL-13692). 


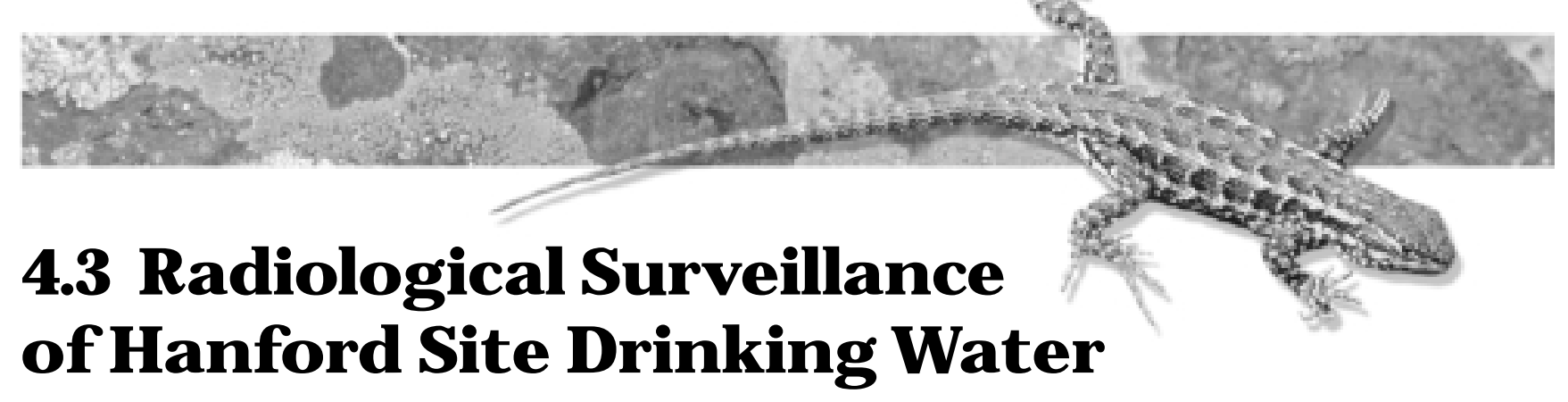

\author{
R. W . H anf and L. M . K elly
}

The quality of drinking water at the Hanford Site is monitored by routinely collecting and analyzing drinking water samples and comparing the resulting analytical data with established drinking water standards and guidelines (WAC 246-290; 40 CFR 141; EPA-570/ 9-76-003; EPA 822-R-96-001; DOE Order 5400.5; see Appendix D, Tables D.2 and D.5). In 2001, Pacific Northwest National Laboratory conducted radiological surveillance of drinking water supplied to Hanford Site facilities by DOE-owned pumps and water treatment facilities. Fluor Hanford, Inc. conducted routine chemical and microbiological monitoring of these drinking water systems.

The national primary drinking water regulations of the Safe D rinking W ater A ct apply to the drinking water supplies at the Hanford Site. In Washington State, these regulations are enforced by the Washington State
Department of Health. Washington Administrative Code (WAC 246-290) requires that all drinking water analytical results be reported routinely to the Washington State Department of Health. In recent years, radiological results for the Hanford Site have been reported to the state through this annual environmental report and through an annual supplemental data compilation (PNNL-13910, APP. 1). Non-radiological data have been reported to the state by Fluor Hanford, Inc. or its predecessors but have not been published.

All DOE-owned drinking water systems on the Hanford Site were in compliance with Washington State and EPA annual average radiological drinking water standards in 2001, and results were similar to those observed in recent years (see Section 4.3 in PNNL-13230 and PNNL-13487).

\title{
4.3.1 Hanford Site Drinking Water Systems
}

In 2001, drinking water was supplied to DOE facilities on the site by ten DOE-owned, contractor-operated, water treatment and distribution systems (Table 4.3.1), and one system owned and operated by the city of Richland. Nine of these systems (including Richland's system) used water pumped from the Columbia River. One system used groundwater from beneath the site.
Fluor Hanford, Inc. operated most of the systems. Bechtel Hanford, Inc. operated one system in the 100-N Area that was supplied with water from a pumping station operated by Fluor Hanford, Inc. The city of Richland provided drinking water to the 300 Area, Richland North Area, and HAMMER facility.

\subsubsection{Hanford Site Drinking Water Supply Facilities}

In 2001, radionuclide concentrations in onsite drinking water were monitored at the four DOE-owned water supply facilities shown in Figure 4.3.1. The 100-B Area pumphouse continued to serve as the primary Columbia River pumping station for many areas on the site (100-B and 100-N Areas, 200-West Area, 251 Building, and 100 Areas Fire Station). The 181-KE-pumphouse supplied water (Columbia River) for the 100-K
Area. Water for the 200-East Area, which formerly came from the 283-E water treatment plant located in the 200-East Area, was supplied by the 283-W water treatment plant (located in the 200-West Area). Water for this treatment plant was obtained from the Columbia River via the $100-\mathrm{B}$ or $100-\mathrm{D}$ raw water export lines. The 283-E treatment plant was designated as an emergency supply facility in 1999 and was maintained in a 


\begin{tabular}{|c|c|c|}
\hline Location & Source of Supply & Notes \\
\hline $100-\mathrm{D}$ & $\begin{array}{l}\text { Columbia River via } 181-\mathrm{B} \text { or } \\
\text { D raw water export }\end{array}$ & $\begin{array}{l}\text { The } 100-\mathrm{D} \text { water treatment facility was perma- } \\
\text { nently removed from service on July } 12,2000 \text {, but } \\
\text { the pumping facility remains operational. }\end{array}$ \\
\hline $100-B$ & $\begin{array}{l}\text { Columbia River via } 181-\mathrm{B} \text { pump- } \\
\text { house and } 100-\mathrm{B} \text { raw water export } \\
\text { line or via the } 181-\mathrm{D} \text { pumphouse } \\
\text { and } 100-\mathrm{D} \text { raw water export line }\end{array}$ & $\begin{array}{l}\text { Filtered and chlorinated at } 182-\text { B Reservoir } \\
\text { pumphouse. }\end{array}$ \\
\hline $100-K$ & $\begin{array}{l}\text { Columbia River via } \\
181-\text { KE pumphouse }\end{array}$ & $\begin{array}{l}\text { Filtered and chlorinated at } 185-\text { KE Water Treat- } \\
\text { ment Plant. }\end{array}$ \\
\hline $100-\mathrm{N}$ & $\begin{array}{l}\text { Columbia River via } 181-\text { B pump- } \\
\text { house and } 100-\mathrm{B} \text { raw water export } \\
\text { line or via the } 181-\mathrm{D} \text { pumphouse } \\
\text { and } 100-\mathrm{D} \text { raw water export line }\end{array}$ & $\begin{array}{l}\text { Filtered and chlorinated at } 186-\mathrm{N} \text { Water Treat- } \\
\text { ment Plant. This is a small skid-mounted pack- } \\
\text { age plant that contains three banks of various } \\
\text { sized filters and a sodium hypochlorite system for } \\
\text { disinfection. }\end{array}$ \\
\hline 200-E & $\begin{array}{l}\text { Normally from the Columbia } \\
\text { River via the } 283-\text { W Water } \\
\text { Treatment Plant. In emergencies, } \\
\text { supplied via } 181-\mathrm{B} \text { or D raw } \\
\text { water export and } 283-\mathrm{E} \text { Water } \\
\text { Treatment Plant. }\end{array}$ & $\begin{array}{l}\text { Filtered and chlorinated at 283-W Water Treat- } \\
\text { ment Plant. The clearwells at } 283-\text {-E serve as } \\
\text { reservoirs that supply the 200-East Area distri- } \\
\text { bution system. Under normal conditions, the } \\
\text { clearwells are supplied from the } 283-\text { W Water } \\
\text { Treatment Plant. The } 283 \text {-E Water Treatment } \\
\text { Plant is maintained in standby mode for emer- } \\
\text { gencies. }\end{array}$ \\
\hline 200-W & $\begin{array}{l}\text { Columbia River via } 181-\text { B pump- } \\
\text { house and } 100-\mathrm{B} \text { raw water export } \\
\text { line or via the } 181-\mathrm{D} \text { pumphouse } \\
\text { and } 100-\mathrm{D} \text { raw water export line }\end{array}$ & $\begin{array}{l}\text { Filtered and chlorinated at } 283-\mathrm{W} \text { Water Treat- } \\
\text { ment Plant. }\end{array}$ \\
\hline $\begin{array}{l}251 \text { Building } \\
\text { (electrical switching) }\end{array}$ & $\begin{array}{l}\text { Columbia River via } 181-\text { B pump- } \\
\text { house and } 100-B \text { raw water export } \\
\text { line or via the } 181-\mathrm{D} \text { pumphouse } \\
\text { and } 100-\mathrm{D} \text { raw water export line }\end{array}$ & Filtered and chlorinated at 251 Building. \\
\hline $\begin{array}{l}609 \text { Building } \\
\text { (100 Areas Fire Station) }\end{array}$ & $\begin{array}{l}\text { Columbia River via } 181-\text { B pump- } \\
\text { house and } 100-B \text { raw water export } \\
\text { line or via the } 181-\mathrm{D} \text { pumphouse } \\
\text { and } 100-\mathrm{D} \text { raw water export line }\end{array}$ & Filtered and chlorinated at 609 Building. \\
\hline 400 Area & $\begin{array}{l}\text { Wells 499-S1-8J, 499-S0-8, } \\
\text { and 499-S0-7 }\end{array}$ & $\begin{array}{l}\text { Supplied from well 499-S1-8J (P-16); } \\
\text { wells } 499-\mathrm{S} 0-8(\mathrm{P}-14) \text { and } 499-\mathrm{S} 0-7(\mathrm{P}-15) \text { are } \\
\text { the dire emergency supplies. Whichever well has } \\
\text { the lowest tritium levels, as demonstrated by } \\
\text { sampling and analysis, is considered the primary } \\
\text { backup well. Wells P-14 and P-15 were not used } \\
\text { in 2001. Chlorination only. }\end{array}$ \\
\hline 300 Area & $\begin{array}{l}\text { Treated Columbia River water } \\
\text { via city of Richland }\end{array}$ & 300 Area distribution system. \\
\hline \multicolumn{3}{|c|}{$\begin{array}{l}\text { (a) The system in the 100-N Area was operated by Bechtel Hanford, Inc. All other systems were operated by Fluor } \\
\text { Hanford, Inc. }\end{array}$} \\
\hline
\end{tabular}






standby mode in 2001. The 181-D pumphouse in the $100-\mathrm{D}$ Area continues to operate and supply water to the 100-D raw water export line. This line was used as a backup to the 100-B raw water export line in 2001.

The 400 Area continued to use well 499-S1-8J (P-16) as the primary drinking water supply well, with wells 499-S0-8 (P-14) and 499-S0-7 (P-15) serving as backup supplies. Well 499-S1-8J is 122 meters (401 feet) deep and was installed in April 1985. Well
499-S0-8 is 90 meters (294 feet) deep and was installed in March 1972. Well 499-S0-7 (P-15), 122 meters (399 feet) deep, was installed in March 1972. The backup well with the lowest tritium level, as demonstrated by sampling and analysis, is considered the primary backup water supply. Neither well 499-S0-8 nor 499-S0-7 was used as a drinking water source in 2001. In addition to supplying drinking water, these three wells were also important for maintaining fire suppression capabilities within the 400 Area, where they are located. 


\subsection{Collection of Drinking Water Samples and Analytes of Interest}

Drinking water samples for radiological analyses were collected according to a schedule established at the beginning of the calendar year (PNNL-13418). Samples at all of the locations were collected and analyzed quarterly. Samples from three locations were grab samples of untreated water. The 400 Area samples were grab samples of treated water. The Hanford Groundwater Monitoring Project collected samples of raw well water from the 400 Area drinking water wells. These samples were analyzed monthly. Drinking water samples obtained from the 400 Area in May were co-sampled with the Washington State Department of Health. The analytical results from the state's samples help to verify the quality of the drinking water data reported herein and in PNNL-13910, APP. 1.

In the 300 Area, water from the city of Richland's system was not monitored for radiological contaminants through the site drinking water surveillance project; however, personnel from Pacific Northwest National Laboratory's Surface Environmental Surveillance Project routinely collected water samples from the Columbia
River at the Richland Pumphouse, which is the city of Richland's drinking water intake. The analytical results (radiological) for these raw river water samples can be found in Appendix B (Table B.2).

The city of Richland also monitors its water for radiological and chemical contaminants, and for general water quality and reports the data in its annual newsletter to consumers (City of Richland 2002), and on its web page (http://www.ci.richland.wa.us/UPS/ waterquality.html). Sampling of 300 Area drinking water for non-radiological analyses was conducted routinely by Fluor Hanford, Inc. to monitor the DOE-owned, contractor-operated water distribution system within the area. However, as stated earlier, non-radiological data are reported directly to the state and are not discussed in this report.

All 2001 drinking water samples collected for radiological analysis were analyzed for gross alpha, gross beta, tritium, and strontium-90.

\subsubsection{Radiological Results for Hanford Site Drinking Water}

Results for radiological monitoring of Hanford Site drinking water during 2001 are summarized in Table 4.3.2. Individual analytical results are reported in PNNL-13910, APP. 1. The maximum amount of betagamma radiation from manmade radionuclides allowed in drinking water by Washington State and EPA is an annual average concentration that will not produce an annual dose equivalent to the whole body or any internal organ greater than $4 \mathrm{mrem} / \mathrm{yr}(0.04 \mathrm{mSv} / \mathrm{yr})$. If both tritium and strontium-90 are present, the sum of their annual effective dose equivalent to bone marrow must not exceed 4 mrem $(0.04 \mathrm{mSv})$. Compliance with this standard may be assumed if the annual average concentrations for gross alpha, gross beta, tritium, and strontium-90, by themselves, are less than 50, 15, 20,000 , and $8 \mathrm{pCi} / \mathrm{L},(1.85,0.555,740$, and $0.296 \mathrm{~Bq} / \mathrm{L})$, respectively (40 CFR 141 and WAC 246-290). If two or more radionuclides are present, the total annual dose equivalent to the body or a specific organ cannot exceed $4 \mathrm{mrem} / \mathrm{yr}$.
The Hanford Groundwater Monitoring Project collected and analyzed raw water samples monthly from all three 400 Area drinking water wells. Results from these samples show that tritium levels continued to be lowest in well 499-S1-8J, which was the only well used for drinking water in 2001, and consistently highest in well 499-S0-7 (Table 4.3.3; Figure 4.3.2). A tritium plume that originates in the 200-East Area extends under the 400 Area and has historically affected tritium concentrations in wells 499-S0-7 and 499-SO-8 (see Figure 4.3.2). During 2001, annual average tritium concentrations in both of these wells were below the $20,000 \mathrm{pCi} / \mathrm{L}(740 \mathrm{~Bq} / \mathrm{L})$ state and federal annual average drinking water standard. However, the tritium concentration in well 499-S0-7 in February was slightly above the drinking water standard. An unusually low reading in well 499-S1-8J in August $(246 \pm 200 \mathrm{pCi} / \mathrm{L}$ $[9.1 \pm 7.4 \mathrm{~Bq} / \mathrm{L}])$ was marked in the Hanford Environmental Information System database as a suspect value even though a re-analysis of the sample confirmed the low result. 
Table 4.3.2. Selected Radiological Constituents in Hanford Site Drinking Water, 2001 Annual Average Concentrations, $\mathrm{pCi} / \mathrm{L}^{(\mathrm{a}, \mathrm{b})}$

\begin{tabular}{|c|c|c|c|c|c|}
\hline System & $\begin{array}{c}\text { No. of } \\
\text { Samples }^{(c)}\end{array}$ & Gross Alpha & Gross Beta & Tritium & Strontium-90 \\
\hline 100-B Area ${ }^{(\mathrm{d})}$ & 4 & $0.16 \pm 0.46^{(\mathrm{e})}$ & $1.56 \pm 1.24^{(\mathrm{e})}$ & $182 \pm 79^{(f, g)}$ & $0.073 \pm 0.026^{(f)}$ \\
\hline 100-D Area ${ }^{(d)}$ & 4 & $0.95 \pm 1.50^{(\mathrm{h})}$ & $0.62 \pm 1.69^{(\mathrm{e})}$ & $11.1 \pm 163^{(\mathrm{e})}$ & $0.09 \pm 0.04$ \\
\hline 100-K Area ${ }^{(d)}$ & 4 & $0.37 \pm 0.74^{(\mathrm{e})}$ & $1.71 \pm 0.79^{(\mathrm{d})}$ & $44.3 \pm 186^{(f)}$ & $0.08 \pm 0.01$ \\
\hline 400 Area $(\text { FFTF })^{(i)}$ & 4 & $0.90 \pm 3.08^{(\mathrm{e})}$ & $8.81 \pm 7.29$ & $3,457 \pm 662$ & $-0.009 \pm 0.01^{(\mathrm{e})}$ \\
\hline Standards & & $15^{(\mathrm{j}, \mathrm{k})}$ & $50^{(k, 1)}$ & $20,000^{(k, m)}$ & $8^{(\mathrm{j}, \mathrm{k})}$ \\
\hline
\end{tabular}

(a) Multiply pCi/L by 0.037 to convert to $\mathrm{Bq} / \mathrm{L}$.

(b) Average value \pm 2 standard deviations.

(c) Grab samples collected and analyzed quarterly.

(d) Untreated raw water.

(e) For all results, total analytical error $>$ result.

(f) For 1 result, total analytical error $>$ result.

(g) No value reported for the second quarter of the calendar year.

(h) For 3 results, total analytical error $>$ result.

(i) FFTF = Fast Flux Test Facility; samples collected at the tap.

(j) WAC 246-290.

(k) 40 CFR 141.

(l) Equivalent to $4 \mathrm{mrem} / \mathrm{yr}(0.04 \mathrm{mSv} / \mathrm{yr})$ standard.

(m) Concentration assumed to yield an annual dose of $4 \mathrm{mrem} / \mathrm{yr}(0.04 \mathrm{mSv} / \mathrm{yr})$.

\begin{tabular}{|c|c|c|c|}
\hline Sampling Date & $\begin{array}{l}\text { Primary Drinking Water } \\
\text { Well 499-S1-8] (P-16) }\end{array}$ & $\begin{array}{l}\text { Backup Drinking Water } \\
\text { Well 499-S0-8 (P-14) }\end{array}$ & $\begin{array}{l}\text { Backup Drinking Water } \\
\text { Well 499-S0-7 (P-15) }\end{array}$ \\
\hline February 6, 2001 & $3,790 \pm 440$ & $4,170 \pm 460$ & $20,700 \pm 1,200$ \\
\hline February 28, 2001 & $3,430 \pm 420$ & $3,540 \pm 430$ & $14,000 \pm 940$ \\
\hline March 27, 2001 & $4,050 \pm 460$ & $3,920 \pm 460$ & $16,300 \pm 1,000$ \\
\hline April 17, 2001 & $3,560 \pm 440$ & $3,890 \pm 470$ & $16,300 \pm 1,100$ \\
\hline May 16, 2001 & $3,470 \pm 430$ & $3,990 \pm 460$ & $16,100 \pm 1,000$ \\
\hline June 19, 2001 & $3,200 \pm 410$ & $4,220 \pm 470$ & $15,000 \pm 990$ \\
\hline July 23, 2001 & $3,400 \pm 420$ & $3,560 \pm 430$ & $12,300 \pm 860$ \\
\hline August 21, 2001 & $246 \pm 200^{(c)}$ & $3,440 \pm 410$ & $14,600 \pm 950$ \\
\hline September 21, 2001 & $3,900 \pm 470$ & $4,040 \pm 480$ & $14,900 \pm 1,000$ \\
\hline October 25, 2001 & $3,180 \pm 410$ & $3,560 \pm 430$ & $15,000 \pm 980$ \\
\hline November 16, 2001 & $3,270 \pm 410$ & $3,430 \pm 420$ & $12,400 \pm 860$ \\
\hline December 13, 2001 & $3,490 \pm 470$ & $3,610 \pm 480$ & $12,400 \pm 920$ \\
\hline \multicolumn{4}{|c|}{$\begin{array}{l}\text { (b) Reported concentration } \pm 2 \text { total propagated analytical error. } \\
\text { (c) Marked as a suspect value in the Hanford Environmental Information System database. }\end{array}$} \\
\hline
\end{tabular}




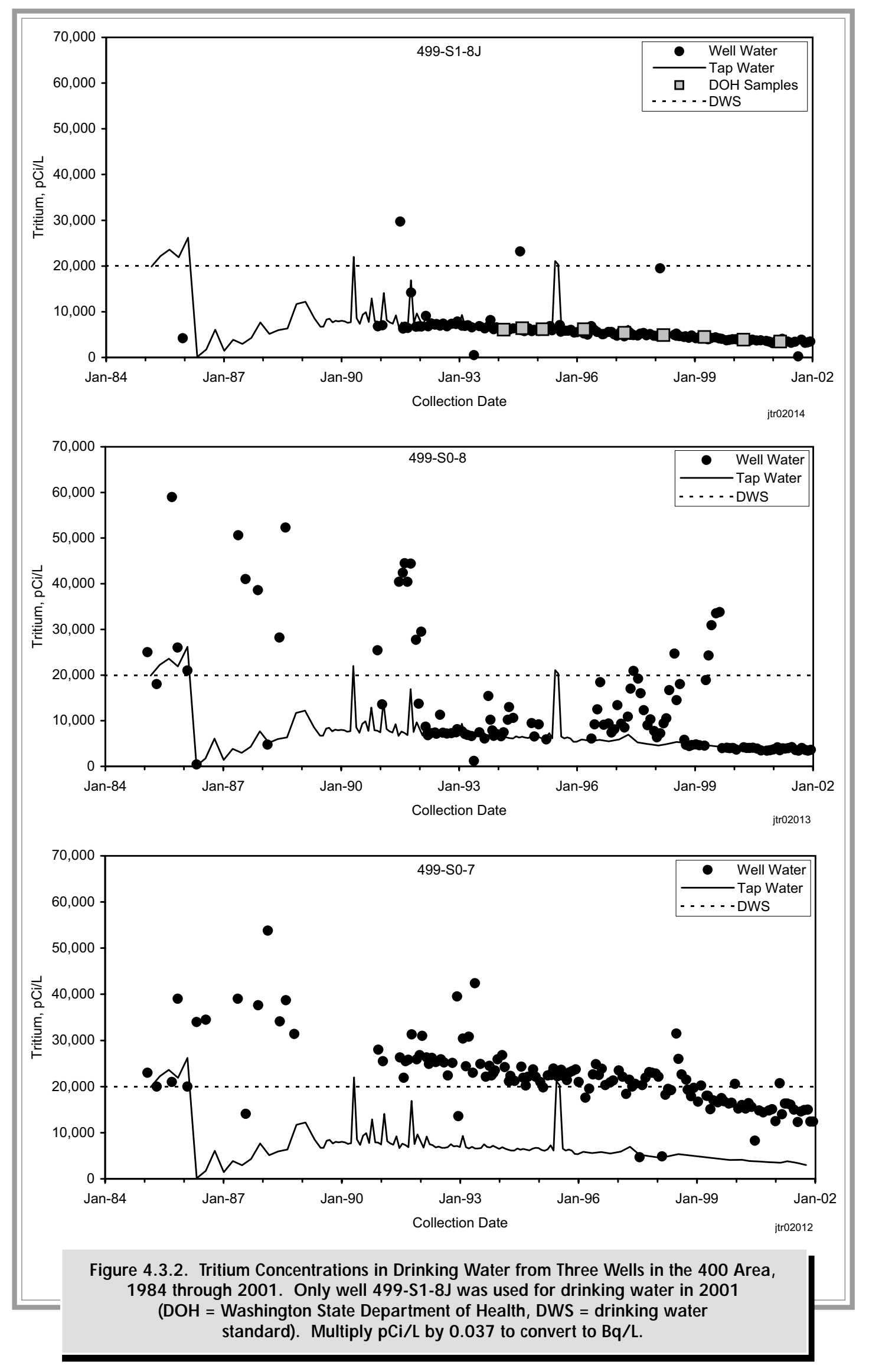




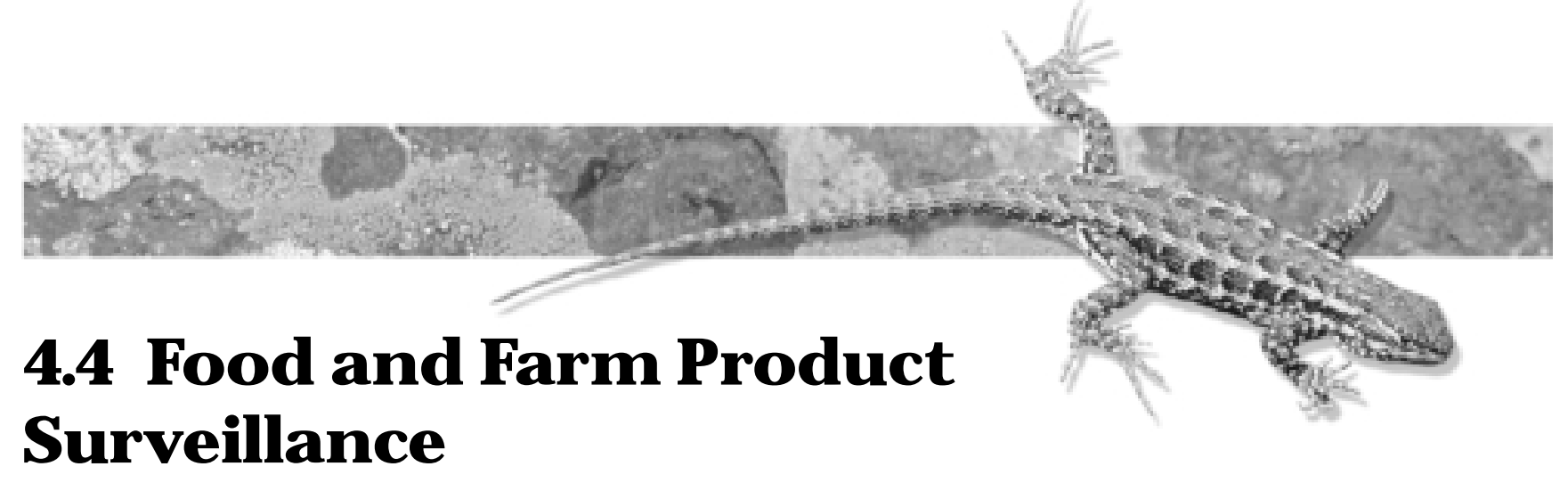

B. L. Tiller

Food products, including milk, vegetables, fruits, and wine, were collected routinely in 2001 at several locations surrounding the Hanford Site (Figure 4.4.1). Samples of alfalfa also were collected at selected locations. Routine samples were collected primarily from locations in the prevailing downwind directions (south and east of the site) where airborne effluents or fugitive dust from the Hanford Site could be deposited. Samples were collected also in generally upwind directions and at locations somewhat distant from the site to provide information on reference radiation levels in foodstuff.

Routine food and farm product sampling determines the potential influence of Hanford Site releases in two ways:

- through the comparison of results from downwind locations to those from generally upwind or distant locations

- through the comparison of results from locations irrigated with Columbia River water withdrawn downstream from the Hanford Site to results from locations irrigated with water from other sources.

The food and farm product sampling schedule was modified in 1996 by establishing a 2- or 3-year rotation to sample certain farm products. Specific details of the 2001 food and farm product sampling, including sampling locations and radionuclides analyzed, are reported in DOE/RL-91-50 and PNNL-13418, and are summarized in Table 4.4.1. Analyses for some radionuclides that historically have not been detected in food or farm products have been discontinued.

Gamma scans (cobalt-60, cesium-137, and other radionuclides; see Appendix F) and strontium-90 analyses were performed for nearly all products. Milk was analyzed for iodine-129 and tritium; wine also was analyzed for tritium. Results for fruits and vegetables are reported in picocuries per gram wet weight. Radionuclide levels in alfalfa are reported in picocuries per gram dry weight. Results for tritium are reported in picocuries per liter of liquid distilled from milk and wine. Most tritium is found as water, and very little tritium is organically bound to other constituents present in food products.

Tritium and iodine-129 from site facilities are released to the atmosphere and to the Columbia River via riverbank springs. Strontium-90 from Hanford is released to the Columbia River through riverbank springs. Cesium-137 is present in atmospheric fallout from weapons testing and is found in Hanford Site radiological waste.

For many radionuclides, concentrations are below levels that can be detected by the analytical laboratory. When this occurs for an entire group of samples, a nominal detection limit is estimated by using two times the total propagated analytical uncertainty (2 sigma). This value from a group of samples is used as an estimate of the lower level of detection for that analyte and particular food product. The total propagated analytical uncertainty includes all sources of analytical error associated with the analysis (e.g., counting errors and errors associated with weight and volumetric measurements). Theoretically, re-analysis of the sample should yield a result that falls within the range of the uncertainty $95 \%$ of the time. Results and uncertainties not given in this report may be found in PNNL-13910, APP. 1. Radiological dose considerations were calculated and reported in Section 5.0. 


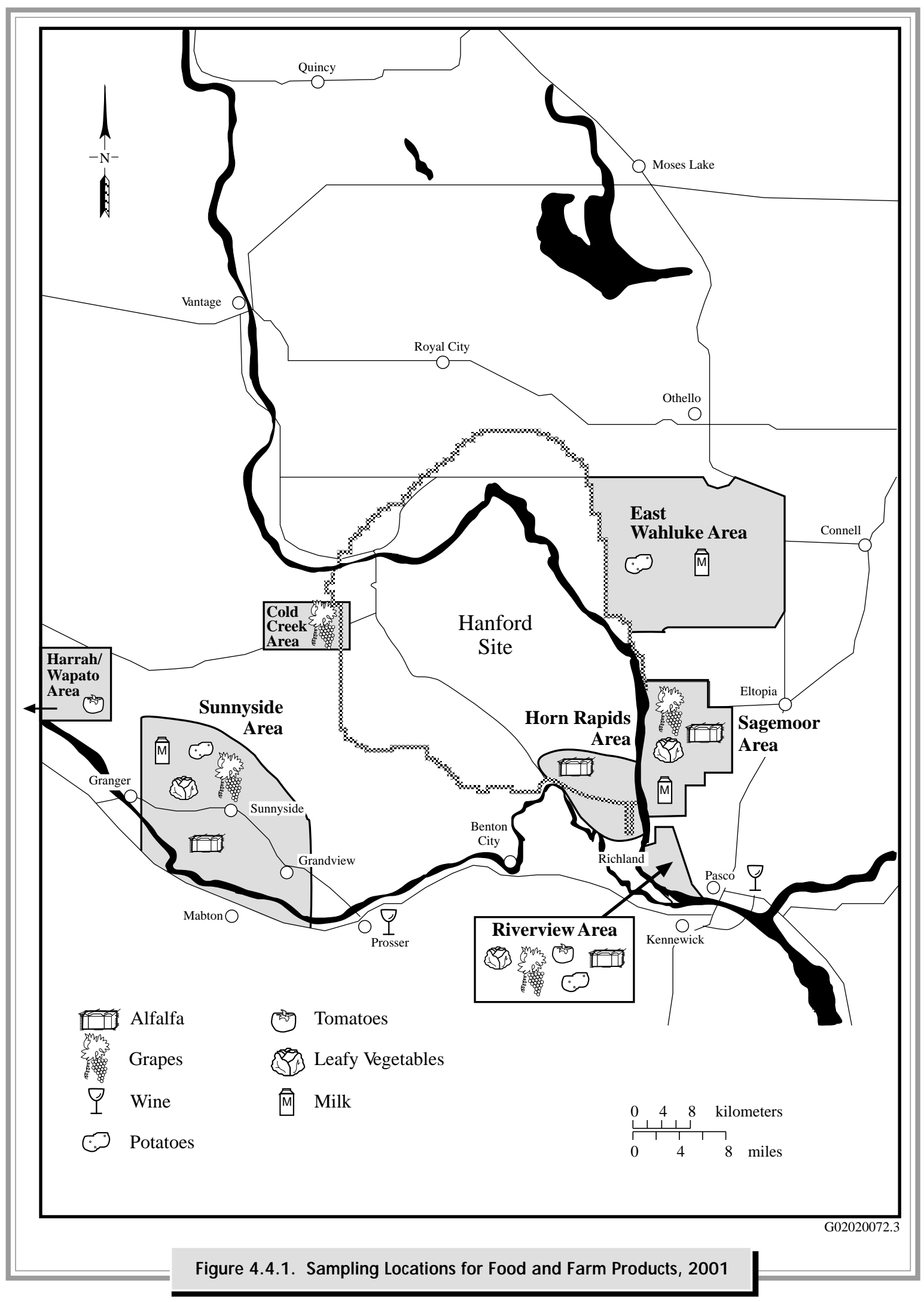


Table 4.4.1. Locations, Sampling Frequencies, and Analyses Performed for Routinely Sampled Food and Farm Products, $2001^{\text {(a) }}$

\begin{tabular}{|c|c|c|c|c|c|c|c|}
\hline \multirow[b]{2}{*}{ Product } & \multicolumn{2}{|c|}{$\underline{\text { N umber of Locations }}$} & \multirow[b]{2}{*}{ Sampling Frequency $^{(\mathbf{b})}$} & \multicolumn{4}{|c|}{ N umber of Samples A nalyzed } \\
\hline & Upwind & Downwind & & ${ }^{3} \underline{\mathbf{H}}$ & Gamma & ${ }^{90} \underline{\mathrm{Sr}}$ & 129] \\
\hline Milk & 1 & 2 & Q or SA & 12 & 12 & 12 & 6 \\
\hline Vegetables & 2 & 2 & A & 2 & 6 & 6 & 0 \\
\hline Fruit & 3 & 2 & A & 0 & 4 & 4 & 0 \\
\hline Wine & 2 & 2 & A & 4 & 4 & 0 & 0 \\
\hline Alfalfa & 1 & 3 & $\mathrm{BE}$ & 0 & 4 & 4 & 0 \\
\hline $\begin{array}{l}\text { (a) Produc } \\
\text { (b) } \mathrm{Q}=\mathrm{qu}\end{array}$ & $\begin{array}{l}\text { hay include } \\
\text { rly, SA }=\mathrm{s}\end{array}$ & $\begin{array}{l}\text { tiple varieties } \\
\text { innually, } \mathrm{A}=\end{array}$ & $\begin{array}{l}\text { ch category. } \\
\text { dly, } \mathrm{BE}=\text { Biennial. }\end{array}$ & & & & \\
\hline
\end{tabular}

\subsubsection{Milk Samples and Analytes of Interest}

Composite samples of raw, whole milk were collected in 2001 from three dairy farms in the East Wahluke Area and from three dairy farms in the Sagemoor Area. These sampling areas are located near the site perimeter in the prevailing downwind direction (see Figure 4.4.1). Milk samples also were collected from a Sunnyside Area dairy to indicate background radionuclide concentrations at a generally upwind location.

Samples of milk were analyzed for tritium, strontium-90, iodine-129, and gamma emitters such as cesium-137, because these radionuclides have the potential to move through the air-pasture-cow milk or waterpasture-cow milk food chains to humans.

Worldwide fallout radionuclides in feed and/or drinking water may be a significant source of radionuclides in milk products; however, measured levels of radionuclides in milk from private dairies near the Hanford Site are usually near levels considered to be background. In 2001, gamma scans and strontium-90 analyses of milk samples were conducted quarterly, and iodine-129 analyses were conducted on two semiannual composite samples. Since 1995, tritium concentrations have been below the detection level of standard liquid scintillation counting methods. In 1998, an electrolytic enrichment technique (DOE/RL-91-50) to measure low levels of tritium in milk samples was instituted. The electrolytic enrichment technique has a detection limit of $\sim 10 \mathrm{pCi} / \mathrm{L}(\sim 0.37 \mathrm{~Bq} / \mathrm{L})$ of water distilled from milk as compared to $\sim 180 \mathrm{pCi} / \mathrm{L}(\sim 6.66 \mathrm{~Bq} / \mathrm{L})$ for the analytical technique used prior to 1996 .

Strontium-90 was detected in 2 of 12 (17\%) milk samples analyzed in 2001. These two positive results (0.46 and $0.41 \mathrm{pCi} / \mathrm{L}[0.017$ and $0.015 \mathrm{~Bq} / \mathrm{L}]$ ) were reported in one of four Sunnyside Area samples and in one of four Wahluke Area samples. These concentrations are close to the analytical detection limit $(0.35 \mathrm{pCi} / \mathrm{L}[0.013 \mathrm{~Bq} / \mathrm{L}])$ and are consistent with 4 of 24 results found above the analytical detection limit in 1999 and 2000 combined. While there is no strontium-90 standard for milk, the drinking water standard (based on a 2-liter per day consumption) is $8 \mathrm{pCi} / \mathrm{L}$ $(0.3 \mathrm{~Bq} / \mathrm{L})$ (40 CFR 141). The maximum milk consumption rate for estimating dose is $\sim 0.75$ liter per day (see Appendix E, Table E.2).

Iodine-129 concentrations were determined by high-resolution mass spectrometry in six milk samples. In recent years, the levels of iodine-129 in milk collected from generally downwind dairies in the Sagemoor and East Wahluke Areas have persisted at concentrations greater than levels measured upwind in Sunnyside (Figure 4.4.2). Iodine-129 concentrations have declined with the end of nuclear production at the Hanford Site. While there is no iodine-129 standard for milk, the drinking water standard is $1.0 \mathrm{pCi} / \mathrm{L}(0.037 \mathrm{~Bq} / \mathrm{L})$, one thousand times greater than results reported for milk samples from these three areas over the past decade (EPA-570/9-76-003).

No manmade gamma emitters (including cesium-137) were detectable in 2001 milk samples (PNNL-13910, APP. 1).

Tritium was analyzed by an electrolytic enrichment method in quarterly composite milk samples from the East Wahluke, Sagemoor, and Sunnyside Areas (see Figure 4.4.1) in 2001. The results indicate Sagemoor Area milk had higher (approximately two times) median tritium concentrations when compared to milk 


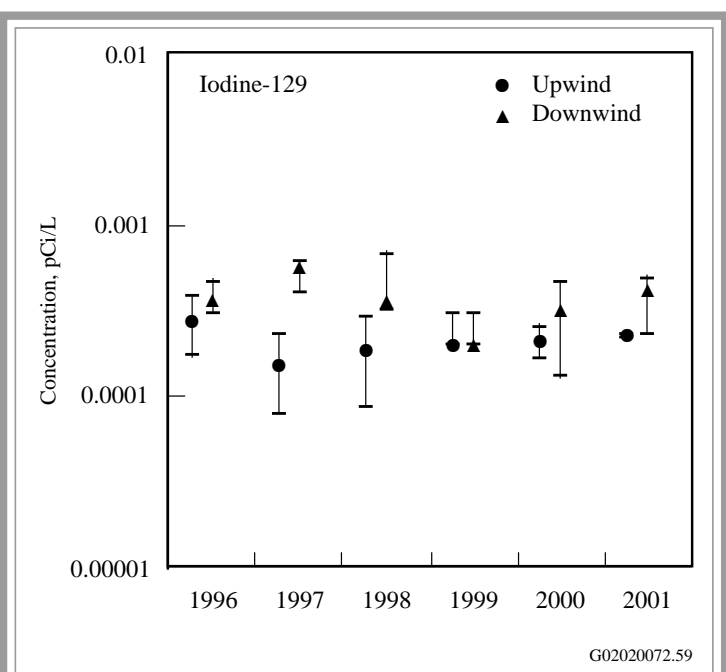

Figure 4.4.2. Median, Maximum, and Minimum lodine-129 Concentrations in Milk Samples, 1996 through 2001

from both the Sunnyside and the East Wahluke Areas (Figure 4.4.3). Elevated tritium concentrations in milk from the Sagemoor Area are consistent with results in previous years (see results in Figure 4.4.3).

In the 1999 Hanford Site environmental report (PNNL-13230, Section 4.4), tritium concentrations in dairy water were reported in conjunction with the milk samples and illustrated the ability to predict tritium concentrations in dairy milk from tritium concentrations in the well water used by the dairies. The dairies in all three of the areas sampled in 2001 use well water. The Franklin County aquifers used by the dairies in the Sagemoor and East Wahluke Areas have historically been recharged by Columbia River water brought into the areas by the Columbia Basin Irrigation Project. Water for the Columbia Basin Irrigation Project is obtained from the Columbia River upstream of the Grand Coulee Dam. Background tritium levels in Columbia River water in the 1960s ranged from 800 to $5,540 \mathrm{pCi} / \mathrm{L}(30$ to $205 \mathrm{~Bq} / \mathrm{L}$ ). These concentrations were influenced by fallout from worldwide aboveground

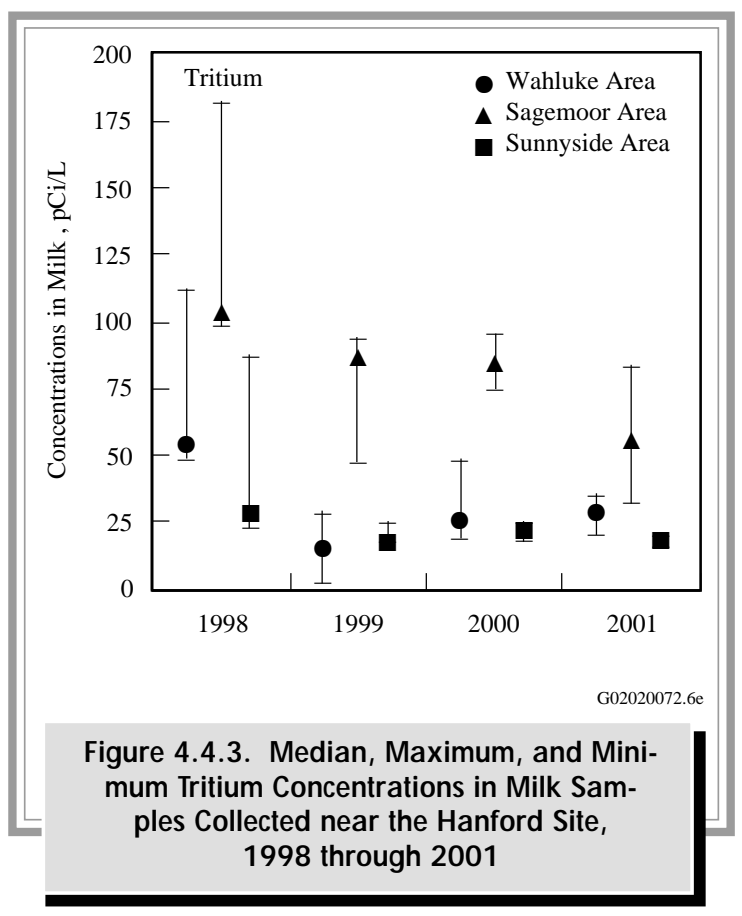

nuclear weapons testing (Wyerman et al. 1970). Irrigation water from the Columbia River containing these comparatively high tritium levels entered the groundwater aquifers in Franklin County as a result of overapplication and leaking canals. Over the past 30 years, tritium levels in the aquifer have slowly decreased as a result of radiological decay and possible dilution caused by subsequent recharge with less-contaminated irrigation water. Based on a 12.3-year half-life, if we assume an aquifer having a concentration of $1,000 \mathrm{pCi} / \mathrm{L}$ $(37 \mathrm{~Bq} / \mathrm{L}$ ) in 1963 (assumes some dilution with natural groundwater), the estimated level after three half-lives in 1999 would be $115 \mathrm{pCi} / \mathrm{L}(4.26 \mathrm{~Bq} / \mathrm{L})$. While the relationships between tritium in milk and groundwater used by the dairies are interesting, the actual levels of tritium in milk are a minor contributor to the dose received by those who consume milk (see Section 5.0). While there is no tritium standard for milk, the standard for drinking water is $20,000 \mathrm{pCi} / \mathrm{L}(740 \mathrm{~Bq} / \mathrm{L})$.

\subsubsection{Vegetable Sam ples and Analytes of Interest}

Leafy vegetables are routinely sampled to monitor for airborne contaminants. Samples of leafy vegetables (i.e., cabbage and beets) and vegetables (i.e., tomatoes and potatoes) were obtained during the summer from gardens and farms located within selected sampling areas (see Figure 4.4.1). The Riverview Area also was sampled because of its exposure to potentially contaminated irrigation water withdrawn from the Columbia River downstream of the Hanford Site. All vegetable samples from all sampling areas were analyzed for gamma-emitting radionuclides and strontium-90.

Measurements of gamma emitters in vegetable and leafy vegetable samples were all less than their respective detection limit $(0.02 \mathrm{pCi} / \mathrm{g}[0.00054 \mathrm{~Bq} / \mathrm{g}])$ and were consistent with results seen in recent years (PNNL-13910, APP. 1). Strontium-90 was not detected in any vegetable (potato and tomato) samples but was 
detected in one of three leafy vegetable samples collected in 2001. The single result reported above the analytical detection limit in 2001 was similar to previous years and between the upwind concentration (from Sunnyside) and other downwind concentrations (from
East Wahluke) seen in recent years (PNNL-13487). Results from another downwind location, the Riverview Area, fell below the analytical detection limit (0.002 to $0.006 \mathrm{pCi} / \mathrm{g}[0.000074$ to $0.00022 \mathrm{~Bq} / \mathrm{g}]$ ).

\subsubsection{Fruit Samples and Analytes of Interest}

Concord grapes were collected during the fall harvest from the areas shown in Figure 4.4.1. All grape samples were analyzed for gamma-emitting radionuclides and strontium-90. Measurable levels of cesium-137 were reported slightly above the detection limit $(0.007 \pm 0.004 \mathrm{pCi} / \mathrm{g}[0.00026 \pm 0.00015 \mathrm{~Bq} / \mathrm{g}])$ from the Riverview Area. Strontium-90 and other manmade gamma-emitting radionuclides were not detected in grapes in 2001. These results are consistent with measurements in grapes, cherries, and melons over recent years (PNL-10575; PNNL-11140; PNNL11473; PNNL-11796; PNNL-12088; PNNL-13230). The nominal level of detection for cesium-137 was $0.01 \mathrm{pCi} / \mathrm{g}(0.00037 \mathrm{~Bq} / \mathrm{g})$ wet weight and strontium-90 was 0.002 to $0.05 \mathrm{pCi} / \mathrm{g}(0.000074$ to $0.0019 \mathrm{~Bq} / \mathrm{g})$ dry weight.

\subsubsection{Wine Sam ples and Analytes of Interest}

Locally produced red and white wines (2001 vintage grapes) were analyzed for gamma-emitting radionuclides and tritium. The wines were made from grapes grown at individual vineyards downwind of the site and at an upwind location in the lower Yakima Valley. Two samples each of red and white wine were obtained from each location and analyzed. An electrolytic enrichment method was used for tritium analysis in water distilled from the wine.

Tritium levels in 2001 wine samples were consistent with past results. While there is no tritium standard for wine, the drinking water standard is $20,000 \mathrm{pCi} / \mathrm{L}$ $(740 \mathrm{~Bq} / \mathrm{L}), \sim 430$ times greater than maximum concentrations reported in wines from these two areas in 2001 (EPA-570/9-76-003). Tritium concentrations were higher in Columbia Basin wines when compared to Yakima Valley wines (Figure 4.4.4). Red wine from the Columbia Basin contained similar levels of tritium as those found in white wine sampled from the same region. Gamma spectroscopy did not indicate the presence of cesium-137 or any other gamma-emitting manmade radionuclide in any of the 2001 wine samples. The observed differences between wines and/or regions are consistent with past results and are likely related to irrigation/well water sources as discussed with tritium in milk (see Section 4.4.1).

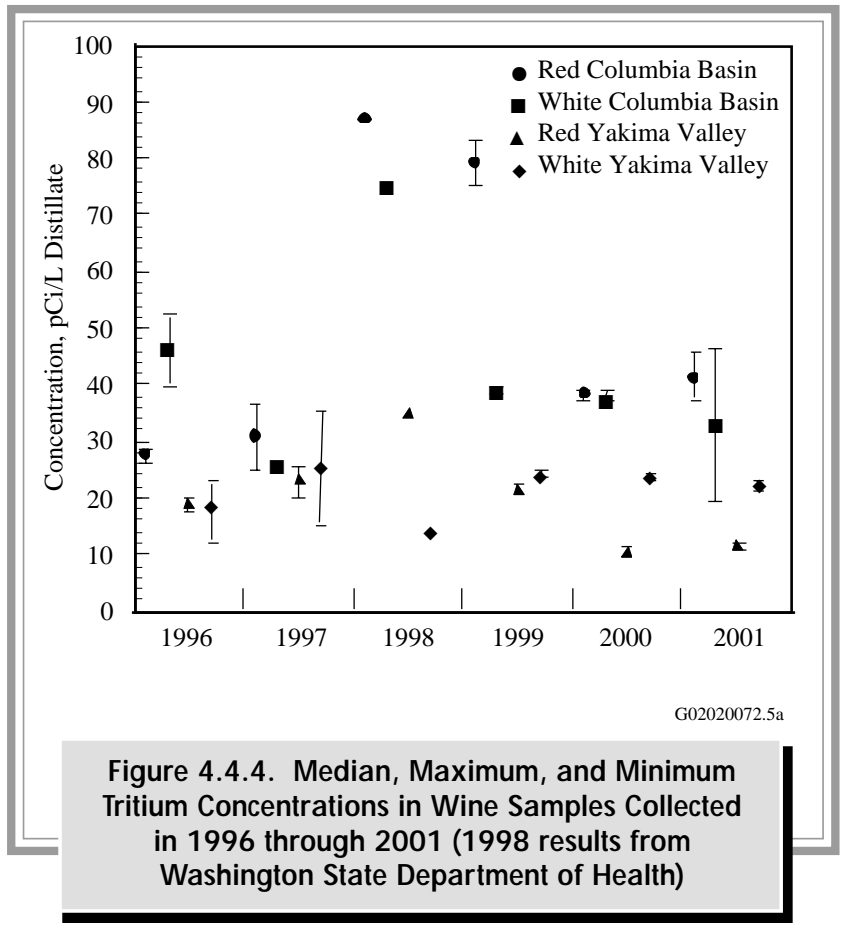

strontium-90. Measurable levels of cesium-137 and other manmade gamma-emitting radionuclides were not detected in alfalfa in 2001. The nominal level of 
detection for cesium-137 in alfalfa was $0.02 \mathrm{pCi} / \mathrm{g}$ $(0.00074 \mathrm{~Bq} / \mathrm{g})$ dry weight. Strontium-90 was found above the analytical detection limit $(0.02$ to $0.05 \mathrm{pCi} / \mathrm{g}$ [0.00074 to $0.00185 \mathrm{~Bq} / \mathrm{g}$ ] dry weight) in two of the four samples submitted for analysis in 2001. The highest concentration $(0.15 \pm 0.08 \mathrm{pCi} / \mathrm{g}[0.0056 \pm 0.003 \mathrm{~Bq} / \mathrm{g}]$ dry weight) was detected in a sample from the Horn Rapids Area. These results were consistent with measurements in alfalfa in past years (PNL-10575; PNNL11140; PNNL-11473; PNNL-11796; PNNL-12088; PNNL-13230). 


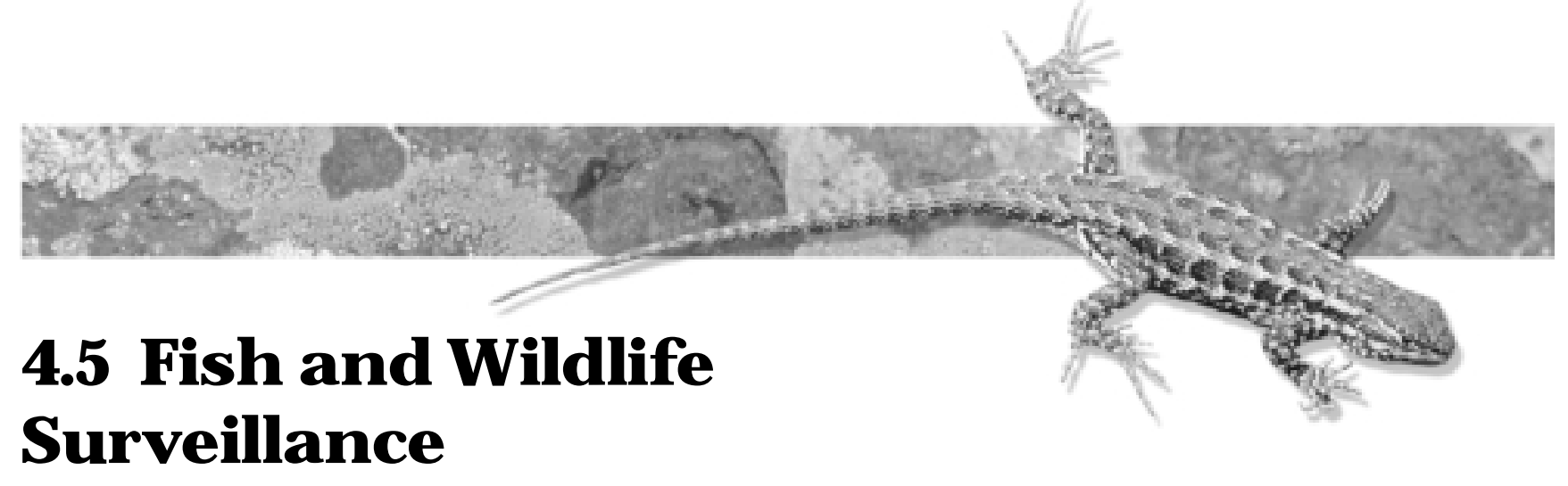

B. L. Tiller

Contaminants in fish and wildlife that inhabit the Columbia River and Hanford Site are monitored for several reasons. Wildlife have access to areas of the site containing radioactive or chemical contamination, and aquatic organisms (fish, bivalves, etc.) can be exposed to contamination entering the river along the shoreline. Fish and some wildlife species exposed to Hanford contaminants might be harvested for food and may potentially contribute to offsite public exposure. In addition, detection of contaminants in wildlife may indicate that wildlife are entering contaminated areas (e.g., burrowing in waste burial grounds) or that materials are moving out of contaminated areas (e.g., through blowing dust or food-chain transport). Consequently, fish and wildlife samples are collected at selected locations annually (Figure 4.5.1). More detailed rationale for the selection of specific species sampled in 2001 can be found in DOE/RL-91-50.

Routine background sampling is conducted approximately every 5 years at locations believed to be unaffected by Hanford releases. Additional background data also may be collected during special studies.

As a result of changing operations on the Hanford Site, the frequency of fish and wildlife sampling was modified significantly in 1995 . Species that had been collected annually were placed on a rotating schedule so that surveillance of all key species would be accomplished over a 3-year period. Factors supporting these changes included the elimination of many onsite radiological sources and a decrease in environmental concentrations of radionuclides of interest. Additionally, several radionuclides that were monitored in the past had not been detected in recent wildlife samples because they were no longer present in the environment in sufficient amounts to accumulate in wildlife or they did not accumulate in fish or wildlife tissues of interest.

For each species of fish or wildlife, radionuclides are selected for analysis based on the potential for the contaminant to be found at the sampling site and to accumulate in the organism (Table 4.5.1). At the Hanford Site, strontium-90 and cesium-137 have been historically the most frequently measured radionuclides in fish and wildlife.

Strontium-90 is chemically similar to calcium; consequently, it accumulates in hard tissues rich in calcium such as bone, antlers, and eggshells. Strontium-90 has a biological half-life in hard tissue of 14 to 600 days (PNL-9394). Hard-tissue concentrations may profile an organism's lifetime exposure to strontium-90. However, strontium-90 generally does not contribute much to human dose because it does not accumulate in edible portions of fish and wildlife. Spring water in the 100-N and 100-H Areas are the primary sources of strontium-90 from Hanford to the Columbia River; however, the current contribution relative to historical fallout from atmospheric weapons testing is small (less than 2\%) (PNL-8817).

Cesium-137 is particularly important because it is chemically similar to potassium and is found in the muscle tissues of fish and wildlife. Having a relatively short biological half-life (less than 200 days in muscle; less than 20 days in the gastrointestinal tract [PNL-9394]), cesium-137 is an indicator of more recent exposure to radioactive materials and is also a major constituent of historical worldwide fallout.

Fish and wildlife samples were analyzed by gamma spectrometry to detect a number of gamma emitters (see Appendix F). However, gamma spectrometry results for most radionuclides are not discussed here because levels were too low to measure or measured concentrations were considered artifacts of low-background counts. Low-background counts occur at random intervals during sample counting and can produce occasional spurious false-positive results.

For many radionuclides, concentrations are below levels that can be detected by the analytical laboratory. When this occurs for an entire group of samples, two 


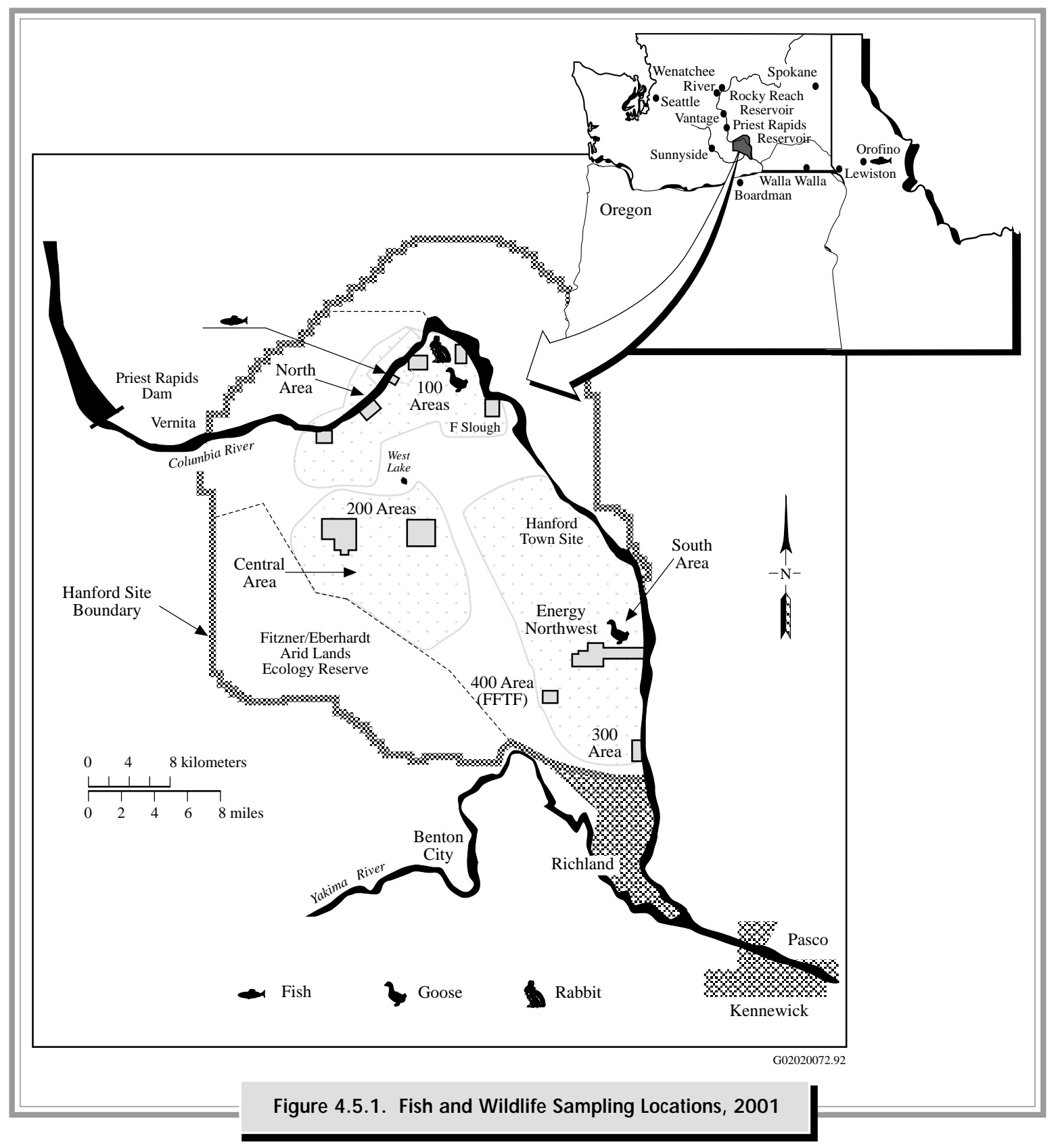

times the total propagated analytical uncertainty is used as an estimate of the nominal detection level for that analyte and particular medium. Results and propagated uncertainties for all results may be found in PNNL-13910, APP. 1.
Wet-weight analytical detection levels for cesium-137 in muscle and strontium- 90 in bone/carcass tissues were $\sim 0.04 \mathrm{pCi} / \mathrm{g}(\sim 0.0015 \mathrm{~Bq} / \mathrm{g})$ and $0.01 \mathrm{pCi} / \mathrm{g}$ $(0.0037 \mathrm{~Bq} / \mathrm{g})$, respectively.

\subsubsection{Fish Samples and Analytes of Interest}

The amounts of radiological contamination measured in fish samples are well below levels that are known to cause adverse biological effects and contribute only a small proportion of the radiation dose to the maximally exposed individual (see Section 5.0). However, monitoring fish and other organisms for uptake and exposure to radionuclides at both nearby and distant locations continues to be important to track the extent and long-term 
trends of contamination in the Columbia River environment. In 2001, five whitefish were collected from the Columbia River near the 100-N Area, and two whitefish were obtained from a reference site near Orofino, Idaho (see Figure 4.5.1). Whitefish analyzed in 2001 from the reference site were collected by sportsmen fishing the Clearwater River in the fall of 1999 and donated to Pacific Northwest National Laboratory. Fillets and the eviscerated remains (carcass) of fish were analyzed for a variety radiological contaminants and results from the nearby and distant locations were compared and are discussed below. All analytical data for 2001 samples are given in PNNL-13910, APP. 1.

In 2001, fillet (muscle) samples were analyzed with gamma spectrometry for cesium-137 and other gamma-emitting radionuclides (PNNL-13910, APP. 1). Cesium-137 results were below the analytical detection limit $(0.04 \mathrm{pCi} / \mathrm{g}[0.0015 \mathrm{~Bq} / \mathrm{g}]$ wet weight $)$ in all seven whitefish fillet samples collected in 2001. These results are consistent with results from whitefish fillet samples $(n=12)$ analyzed and reported from 1995 through 2000 (PNNL-13487) and support results reported throughout the 1990s that indicate a gradual decline in cesium-137 levels in whitefish.
Strontium-90 was only found in the two whitefish carcass samples analyzed in 2001 and both were from the reference site (collected in 1999) (Figure 4.5.2). Levels of strontium-90 in carcass tissues collected from the $100-\mathrm{N}$ to $100-\mathrm{D}$ Areas in 2001 were consistent with levels observed in samples collected over the preceding 5 years. Strontium-90 concentrations in carcass tissue would need to exceed $600 \mathrm{pCi} / \mathrm{g}(22.2 \mathrm{~Bq} / \mathrm{g})$ wet weight to be near the current DOE dose limit of $1.0 \mathrm{rad} /$ day (0.01 Gy/day) for aquatic organisms (see Section 5.0). The hypothetical dose associated with the consumption of Hanford Reach fish is discussed in Section 5.0.

\subsubsection{Wildlife Sampling}

Monitoring various biota for uptake and exposure to radionuclides both near and distant from Hanford Site operations continues so that long-term trends of contamination in the ecosystem can be tracked. Wildlife sampled and analyzed in 2001 for radioactive constituents included cottontail rabbits and Canada geese. Wildlife samples were analyzed for gamma emitters and strontium-90.

\subsubsection{Goose Sam ples and Analytes of Interest}

Ten goose samples were collected from the Hanford Reach and one was collected from the reference location near Vantage, Washington, in the early fall of 2001 (see Figure 4.5.1). Radionuclide levels found in these samples were compared to levels in samples collected onsite in 1995, 1997, and 1999.
Cesium-137 was not detected $(<0.02 \mathrm{pCi} / \mathrm{g})$ in any goose muscle samples collected from the Hanford Site. The concentration in the sample obtained from the reference site in 2001 was reported to be $0.15 \pm$ $0.02 \mathrm{pCi} / \mathrm{g}(0.056 \pm 0.00074 \mathrm{~Bq} / \mathrm{g})$ wet weight. The number of results reported at or below the analytical detection limit in 2001 was similar to the number reported for 28 goose samples collected from the Hanford Reach between 1995 and 2000. The 2001 levels were consistent with levels reported for other waterfowl collected on the Hanford Site (PNL-10174) and suggest that resident geese do not accumulate measurable amounts of cesium along the Hanford Reach of the Columbia River.

Strontium-90 concentrations found in goose bones were similar between the two areas sampled on the Hanford Site in 2001 (see Figure 4.5.1) and the reference 


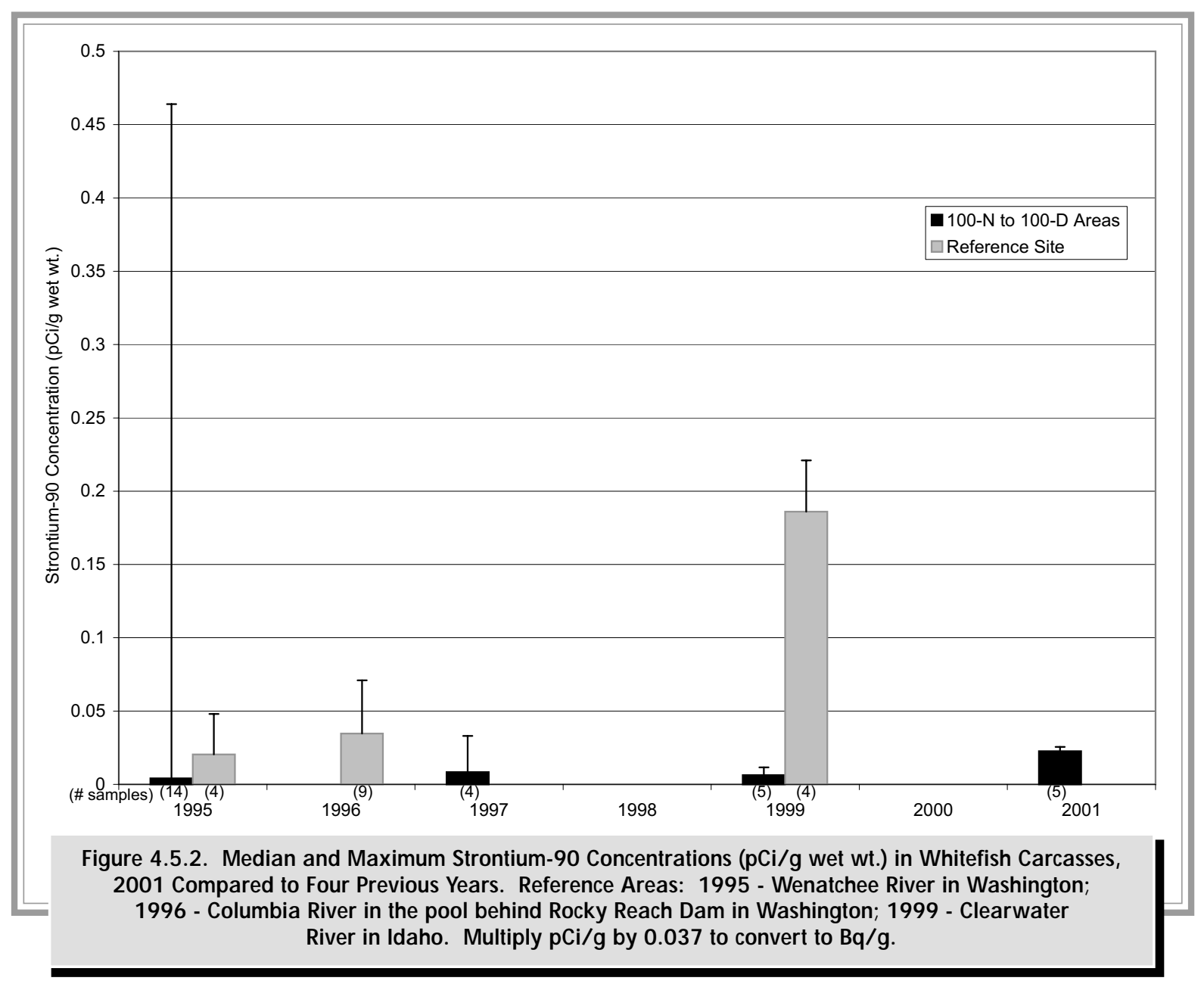

site (Figure 4.5.3). Median and maximum results reported from Hanford goose samples in 2001 were higher than any reported from 1995 through $2000(n=28)$, but were similar to results from reference (background) samples obtained in $1995(\mathrm{n}=10), 1999(\mathrm{n}=3)$, and 2001 $(\mathrm{n}=1)$. While the apparent increase in strontium-90 concentrations in Hanford Site goose samples obtained in 2001 is noteworthy, the strontium-90 concentration in bone would need to exceed $60 \mathrm{pCi} / \mathrm{g}(2.2 \mathrm{~Bq} / \mathrm{g})$ wet weight to be near the current DOE dose limit of $0.1 \mathrm{rad} /$ day $(0.0008 \mathrm{~Gy} /$ day $)$ for terrestrial organisms (see Section 5.0).

\subsubsection{Rabbit Samples and Analytes of Interest}

Rabbits are good indicators of regional radioactive contamination because they have relatively small home ranges, occupy burrows, and can enter fenced-restricted areas. However, due to the cyclic-patterns of the populations over time, sampling rabbits can be very difficult when numbers are low. In 2000, jackrabbits were listed as a sensitive species of concern in Washington State. As a result, rabbit sampling in the Central Plateau was not conducted.

In 2001, muscle and bone samples of cottontail rabbits were collected from near the 100-N Area. Reference samples of rabbits were collected near Boardman, Oregon (see Section 5.4.1), in $1990(\mathrm{n}=10)$.

Muscle. Cesium-137 concentrations in muscle samples from four rabbits collected on the Hanford Site in 2001 were all below the analytical detection limit (0.02 pCi/g [0.00074 Bq/g] wet weight). These results are similar to those seen from a reference location sampled in 1990 and do not indicate elevated exposures from Hanford-derived sources.

Bone. Strontium-90 concentrations in the bones of four rabbits on the site were all above the analytical detection limit in 2001 (Figure 4.5.4). Three of the four sample results were reported near the analytical detection limit of $0.04 \mathrm{pCi} / \mathrm{g}(0.0015 \mathrm{~Bq} / \mathrm{g})$; one sample was reported to be $9.0 \mathrm{pCi} / \mathrm{g}(0.33 \mathrm{~Bq} / \mathrm{g})$. Results from animals collected on the Hanford Site suggest onsite 

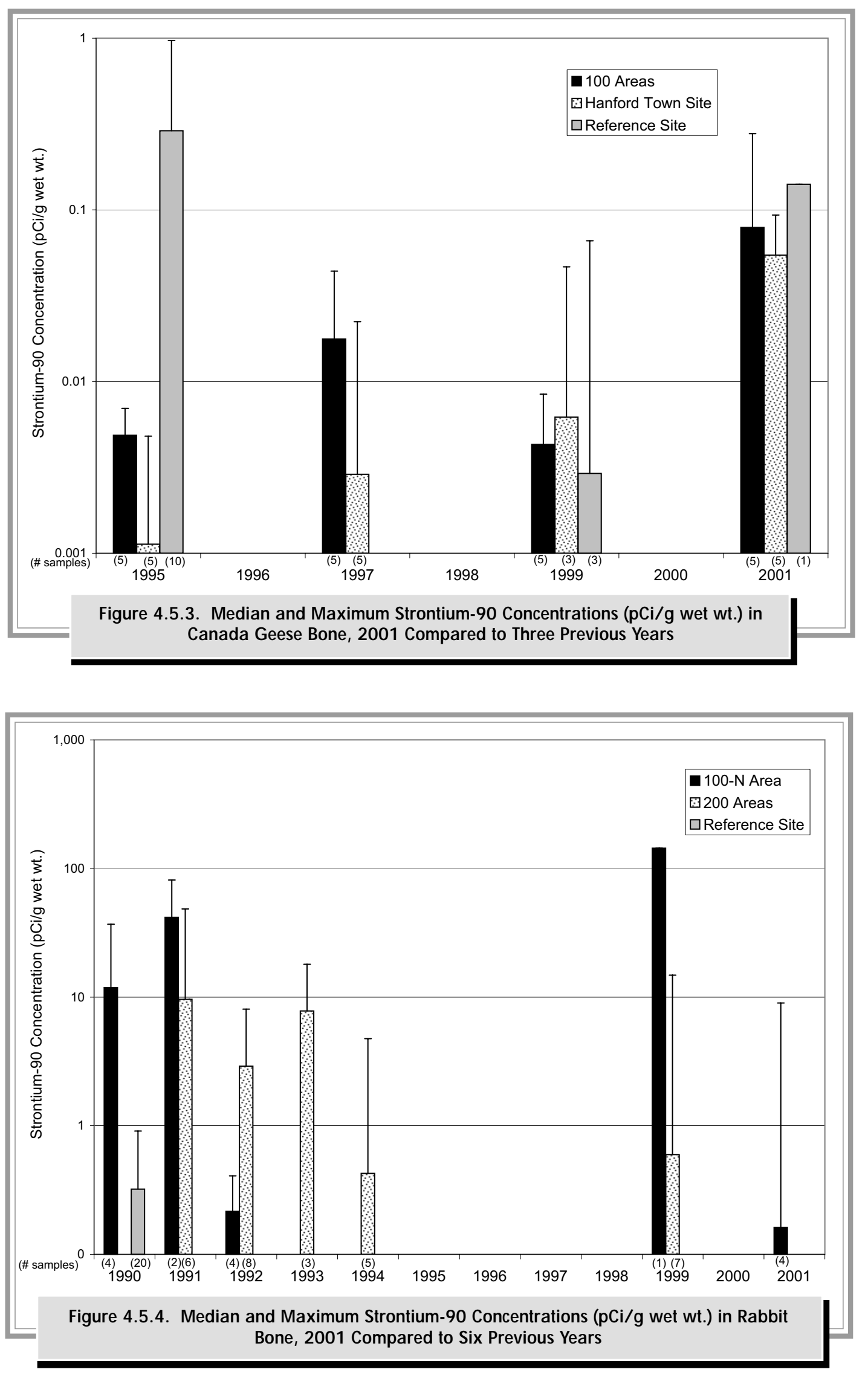
exposure to low levels of strontium- 90 around the $100-\mathrm{N}$ and 200 Areas. Although low sample sizes are available to interpret the long-term trends, major changes in strontium-90 within rabbit bone tissues are not apparent over the past decade. Strontium-90 concentrations in bone tissues would need to exceed $60 \mathrm{pCi} / \mathrm{g}(2.2 \mathrm{~Bq} / \mathrm{g})$ wet wt. to be near the current DOE dose limit of $0.1 \mathrm{rad} /$ day $(0.0008 \mathrm{~Gy} /$ day) for terrestrial organisms (see Section 5.0). 


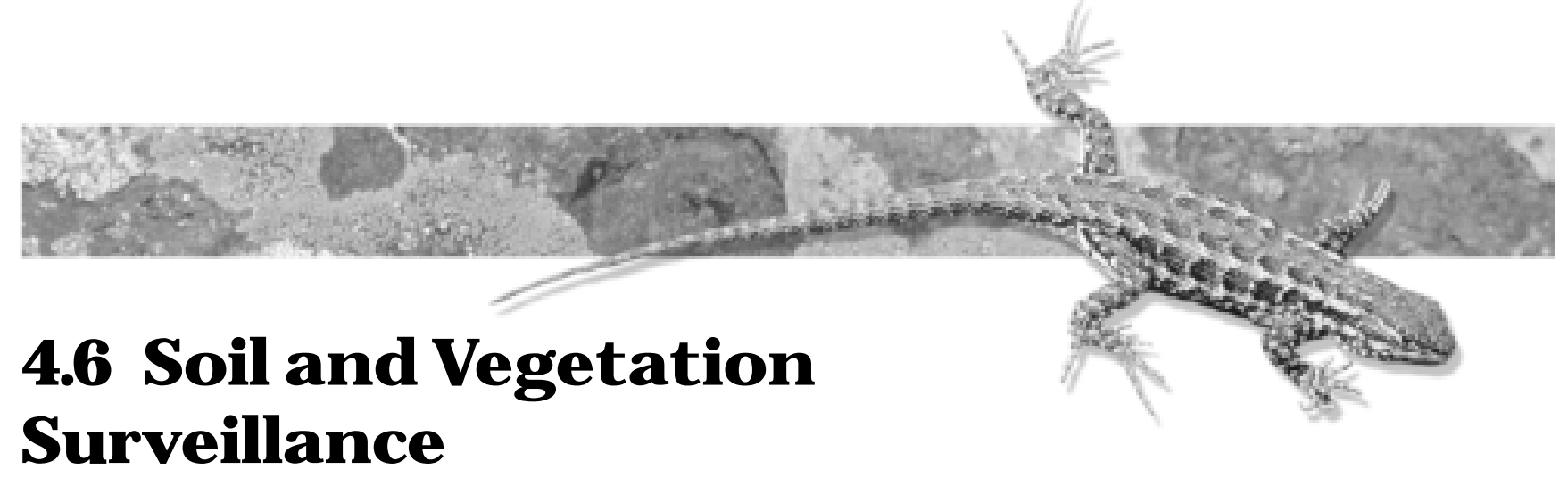

B. L. Tiller and B. G. Fritz

Soil surveillance provides information on long-term contamination trends and baseline environmental radionuclide concentrations at undisturbed locations (DOE/RL-91-50). Surveillance of perennial vegetation provides information on atmospheric deposition of radioactive materials in uncultivated areas and at onsite locations adjacent to potential sources of manmade radioactivity. Accordingly, radionuclide concentrations in soil and perennial vegetation provide a baseline against which unplanned releases can be compared.
Soil and perennial vegetation samples have been collected on and around the Hanford Site for more than 50 years. Consequently, a large database exists that thoroughly documents onsite and offsite levels of manmade radionuclides in soil and perennial vegetation at specific locations. Routine radiological surveillance of soil and vegetation on and around Hanford was last conducted in 1998 (Section 4.6 in PNNL-12088). In 2001, thirteen vegetation samples and 38 soil samples were collected (Figure 4.6.1).

\subsubsection{Soil Sampling}

In 2001, soil samples were collected at the locations shown in Figure 4.6.1. Samples were organized into four distinct groups: (1) onsite, (2) the Fitzner/Eberhardt Arid Lands Ecology Reserve, (3) perimeter, and (4) distant. Onsite sampling locations were collected at undisturbed locations around industrial development on the site. Two samples were collected on the Fitzner/Eberhardt Arid Lands Ecology Reserve on the northeastern side of Rattlesnake Mountain. Perimeter samples were collected at the edge of the Hanford Site and at downwind locations in Franklin County. Distant samples were collected at McNary Dam, Sunnyside, Toppenish, Walla Walla, and Washtucna.

Soil samples consisted of five plugs, each 2.54 centimeters ( 1 inch) deep and 10.2 centimeters ( 4 inches) in diameter that were collected within 10 meters (33 feet) of one another and combined into one bulk sample. Soil samples were dried to remove residual moisture and sieved at the laboratory prior to analysis to remove rocks and plant debris.

All samples were analyzed for gamma-emitting radionuclides, strontium-90, uranium-234, -235, -238, and plutonium-238, -239/240. Selected samples were analyzed for americium-241 (Table 4.6.1). The 2001 analytical results were compared to results from 1993, 1994, and 1998 (Table 4.6.2). In 1996, results of an assessment of Hanford background radionuclide concentrations in soils were published (DOE/RL-96-12). These assessment results provided comparison values (median and 95th percentile ${ }^{[a]}$ concentrations) for radionuclides that are routinely monitored on the Hanford Site.

In 2001, observed mean radionuclide concentrations in onsite soil samples analyzed for plutonium isotopes, strontium-90, cesium-137, uranium-238, and americium-241 were at or below their respective averages from 1993, 1994, and 1998 (see Table 4.6.2). This indicated that there has been no appreciable increase in radionuclide concentrations in onsite soil in the last several years. There were also no increases in soil concentrations of any measured radionuclide at distant or perimeter locations. The onsite average soil concentrations in 2001 were higher than at site perimeter or distant locations for the radionuclides measured (see Table 4.6.2). This was consistent with historical data and reflected the higher onsite soil concentrations associated with years of nuclear materials production. The

(a) The percentile is a statistical grouping of values, $95 \%$ of all values fall below the 95 th percentile; hence, the 95 th percentile is used as an estimate of the upper bound. 


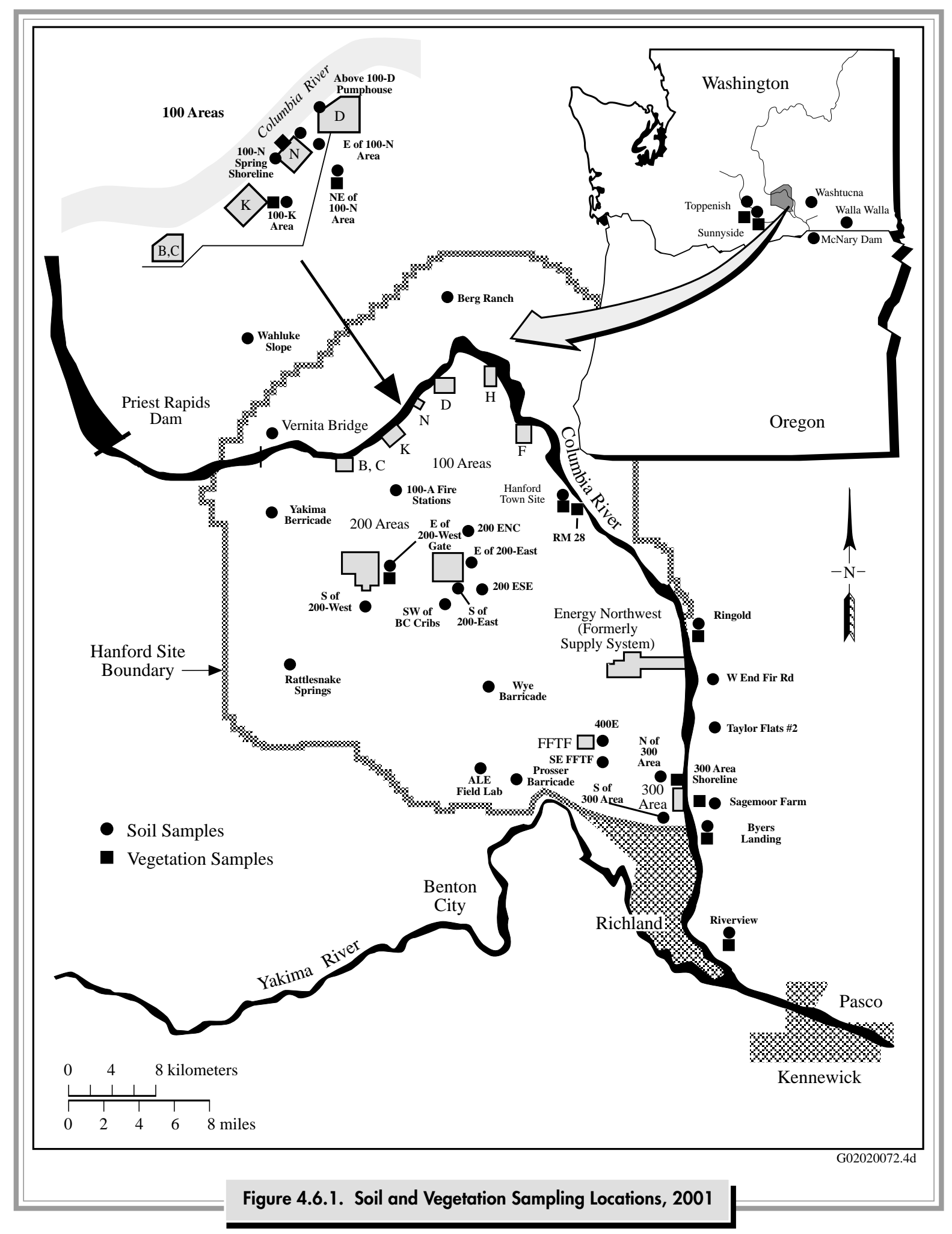


Table 4.6.1. Routine Soil and Vegetation Samples Collected and Analyzed, 2001

$\begin{array}{lcc}\text { Location } & \begin{array}{c}\text { No. of } \\ \text { Samples }\end{array} & \text { Frequency } \\ \text { Onsite } & & \\ \text { ALE } & 20 & \text { Annual to once every } 5 \mathrm{yr} \\ \text { Perimeter } & 2 & \text { Annual to once every } 5 \mathrm{yr} \\ \text { Distant } & 11 & \text { Annual to once every } 5 \mathrm{yr} \\ & 5 & \text { Annual to once every } 5 \mathrm{yr}\end{array}$

\section{Vegetation}

$\begin{array}{lll}\text { Onsite } & 4 & \text { Annual to once every } 5 \mathrm{yr} \\ \text { Perimeter } & 4 & \text { Annual to once every } 5 \mathrm{yr} \\ \text { Shoreline } & 3 & \text { Annual to once every } 5 \mathrm{yr} \\ \text { Distant } & 2 & \text { Annual to once every } 5 \mathrm{yr}\end{array}$

\author{
Analytes $^{(a)}$ \\ Gamma, ${ }^{90} \mathrm{Sr}, \mathrm{U}_{\text {iso }}, \mathrm{Pu},{ }^{\text {(c) }} 241 \mathrm{Am}$ \\ Gamma, ${ }^{90} \mathrm{Sr}, \mathrm{U}_{\text {iso }}, \mathrm{Pu},{ }^{241} \mathrm{Am}$ \\ Gamma, ${ }^{90} \mathrm{Sr}, \mathrm{U}_{\text {iso }}, \mathrm{Pu},{ }^{241} \mathrm{Am}$ \\ Gamma, ${ }^{90} \mathrm{Sr}, \mathrm{U}_{\text {iso }}, \mathrm{Pu},{ }^{241} \mathrm{Am}$
}

(a) Not all analytes are analyzed for at each location.

(b) Onsite denotes sample locations designated as "onsite." Some perimeter samples are collected inside the Hanford Site boundary.

(c) Plutonium-238 and plutonium-239/240.

(d) Fitzner-Eberhardt Arid Lands Ecology Reserve.

sampling location east of the 200-West gate (see Figure 4.6.1) had the highest observed concentrations of any sampling location. This was consistent with historical results.

Maximum soil concentrations of several radionuclides at various distance classes were higher in 2001 than in previous years. Maximum concentrations of strontium-90 and uranium-238 on the site were higher in 2001 than maximums observed since 1993 (Figure 4.6.2 and Table 4.6.2). At the site perimeter, the plutonium239/240 maximum concentration was slightly higher than in recent years. Uranium-238 maximum concentrations at perimeter and distant locations were also higher in 2001 than in the last 8 years, but the differences were not statistically significant.

In the past, soil samples from the Fitzner/Eberhardt Arid Lands Ecology Reserve were included in the perimeter grouping. After the transfer of management of this reserve to the U.S. Fish and Wildlife Service in 1997, results from the Rattlesnake Springs and Arid Lands Ecology Field Laboratory stations were reported separately. Results for some radionuclides measured at these locations in 2001 were elevated compared to results from 1993 and 1998 (Table 4.6.3).

Concentrations of plutonium-239/240 in soil samples from the Fitzner/Eberhardt Arid Lands Ecology Reserve in 2001 had statistically significant increases $(\alpha=0.05)$ in concentrations from samples analyzed from recent years. In 1993 and 1998, plutonium-239/ 240 samples from the reserve had an average concentration of $0.0054 \pm 0.0062 \mathrm{pCi} / \mathrm{g}(0.20 \pm 0.23 \mathrm{mBq} / \mathrm{g})$ (see Table 4.6.3). In 2001, the two samples collected on the reserve had an average plutonium-239/240 concentration of $0.012 \mathrm{pCi} / \mathrm{g}(0.44 \mathrm{mBq} / \mathrm{g})$. The maximum plutonium-239/240 value reported on the reserve in 2001 exceeded the maximum plutonium-239/240 concentration from 1993 and 1998 by a factor of two. However, concentrations of plutonium-239/240 in 2001 were not elevated relative to results from the last 18 years (Figure 4.6.3). While the changes in radionuclide concentrations in soil onsite and near the perimeter are noted, effective doses received by members of the public from these levels are small (see Section 5.0).

The median background concentration and the 95 th percentile background concentration of uranium-238 near and on the Hanford Site have been reported as 0.76 and $1.18 \mathrm{pCi} / \mathrm{g}(0.028$ and $0.044 \mathrm{~Bq} / \mathrm{g})$, respectively (DOE/RL-95-55). These background concentrations were based primarily on low-energy photon spectrometry. Low-energy photon spectrometry results for uranium-238 are generally higher than alpha spectrometry results; however, the degree of difference varies, depending on the soil type and particle-size distribution. Maximum uranium-238 concentrations measured in soil on and around the Hanford Site in 2001 by alpha spectrometry were below the reported median background level. 


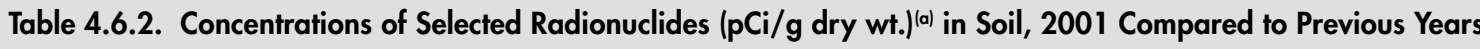

\section{Location \\ Radionuclide}

\section{No. of}

Samples

No.

Onsit

$$
\begin{aligned}
& { }^{241} \mathrm{Am} \\
& { }^{239 / 240} \mathrm{Pu} \\
& { }^{238} \mathrm{Pu} \\
& { }^{137} \mathrm{Cs} \\
& { }^{90} \mathrm{Sr} \\
& { }^{238} \mathrm{U}_{\text {leps }}(\mathrm{e})
\end{aligned}
$$

$\mathrm{ALE}^{(9)}$

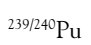

${ }^{239} / 240 \mathrm{Pu}$

${ }^{238} \mathrm{Pu}$

${ }^{90} \mathrm{Sr}$

${ }^{90} \mathrm{Sr}$

Perimeter

3
20
20
20
20
20

3
20
18

${ }^{241} \mathrm{Am}$
${ }^{239 / 240} \mathrm{Pu}$
${ }^{238} \mathrm{Pu}$
${ }^{137} \mathrm{Cs}$
${ }^{90} \mathrm{Sr}$
${ }^{238} \mathrm{U}_{\text {leps }}^{(\text {s })}$
${ }^{238} \mathrm{U}_{\text {iso }}^{(f)}$

\section{Mean $^{(\mathrm{c})}$}

$0.0060 \pm 0.013$ $0.028 \pm 0.068$

$0.00079 \pm 0.0029$ $1.0 \pm 5.1$

$$
0.25 \pm 1.3
$$

$$
0.15 \pm 0.21
$$

$0.012 \pm 0.0066$ $0.00038 \pm 0.00020$ $0.26 \pm 0.034$

$0.077 \pm 0.018$

$0.13 \pm 0.021$

$0.0085 \pm 0.016$ $0.00026 \pm 0.00036$ $0.22 \pm 0.31$

$0.049 \pm 0.071$

$0.16 \pm 0.19$

$0.0055 \pm 0.012$

$0.00021 \pm 0.0029$ $0.15 \pm 0.32$ $0.052 \pm 0.11$

$0.15 \pm 0.11$

1993, 1994, and 1998

\begin{tabular}{c} 
No. of \\
Sample \\
\hline \multicolumn{1}{c}{10} \\
48 \\
48 \\
48 \\
48 \\
35 \\
13 \\
\\
2 \\
2 \\
2 \\
2 \\
2 \\
2 \\
3 \\
19 \\
19 \\
19 \\
19 \\
15 \\
4 \\
2 \\
4 \\
4 \\
4 \\
4 \\
3 \\
1 \\
\end{tabular}

\section{No.}

Maximum $^{(\mathbf{d})}$

$0.013 \pm 0.0029$

$0.13 \pm 0.019$

$0.0068 \pm 0.0012$

$12 \pm 1.4$

$0.57 \pm 0.11$

$0.014 \pm 0.0026$

$0.00045 \pm 0.00033$

$0.27 \pm 0.039$

$0.084 \pm 0.035$

$0.13 \pm 0.033$ $0.00014 \pm 0.00019$ $0.030 \pm 0.0044$ $0.48+0.064$ $0.11 \pm 0.041$

$0.38 \pm 0.078$

$0.0043 \pm 0.00090$ $0.014 \pm 0.0022$ $0.00047 \pm 0.00019$ $0.14 \pm 0.046$

$0.24 \pm 0.051$

Detected (b) $^{(\text {) }}$

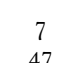

47

33
46

48

35

13

2
2
2
2
2
2
2
19
14
18
19
13
4

2
4
3
4
4
2
1

\section{Mean}

$0.038 \pm 0.15$ $0.034 \pm 0.20$ $0.00060 \pm 0.0026$ $0.90 \pm 4.6$ $0.15 \pm 0.30$ $0.67 \pm 0.47$ $0.15 \pm 0.085$

$0.0054 \pm 0.0062$ $0.00018 \pm 0.00033$ $0.18 \pm 0.23$ $0.068 \pm 0.079$ $0.76 \pm 0.71$ $0.16 \pm 0.14$ $0.0021 \pm 0.0031$ $0.0070 \pm 0.0079$ $0.00029 \pm 0.00067$

$0.28 \pm 0.34$

$0.069 \pm 0.068$

$0.68 \pm 0.54$

$0.19 \pm 0.15$

$0.0055 \pm 0.0033$ $0.0090 \pm 0.013$ $0.00037+0.00039$ $0.47 \pm 0.46$ $0.13 \pm 0.15$ $0.74 \pm 0.15$
Maximum $^{\text {(d) }}$

$2.4 \pm 0.14$ $0.53 \pm 0.058$ $12 \pm 1.3$ $0.70 \pm 0.13$ $1.5 \pm 0.29$ $0.25 \pm 0.042$

$0.0076 \pm 0.0012$ $0.00036 \pm 0.00020$ $0.29 \pm 0.039$ $0.11 \pm 0.022$ $1.0 \pm 0.50$ $0.21 \pm 0.029$ $0.0030 \pm 0.0015$ $0.013 \pm 0.0021$ $0.00083 \pm 0.00050$ $0.62 \pm 0.073$ $0.15 \pm 0.029$ $0.30 \pm 0.045$

$0.0066 \pm 0.0024$ $0.017 \pm 0.0021$ $0.00059 \pm 0.00025$ $0.74 \pm 0.083$ $0.24 \pm 0.055$ $0.81 \pm 1.1$ $0.10 \pm 0.022$

(a) $1 \mathrm{pCi}=0.037 \mathrm{~Bq}$.

(b) Detection is defined as a value reported above the minimum detectable activity or above the total analytical uncertainty. A detection for gamma-emitting radionuclides is defined as a value above the minimum detectable activity.

(c) Reported mean values \pm 2 standard deviations.

(d) Reported maximum values \pm the total analytical uncertainty.

(e) Samples analyzed by low-energy photon system.

(f) Isotopic uranium.

(g) Fitzner/Eberhardt Arid Lands Ecology Reserve Unit. 


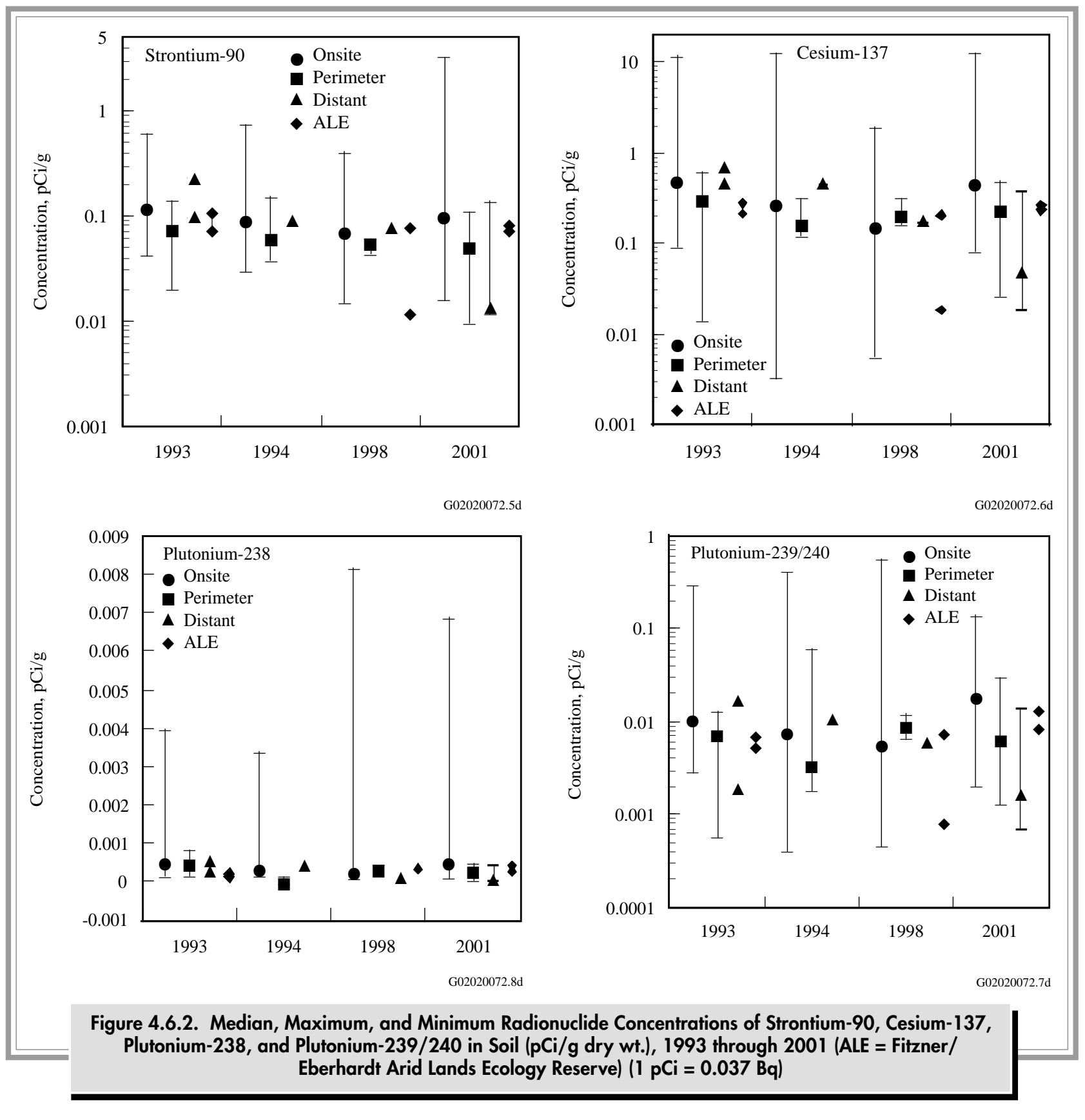

\subsubsection{Vegetation Sampling}

Vegetation samples were collected at 13 locations on and around the Hanford Site in 2001 (see Figure 4.6.1). Samples were organized into four distinct groups: (1) onsite, (2) perimeter, (3) Columbia River shoreline, and (4) distant upwind (see Table 4.6.1). Onsite sampling locations were generally selected in areas around industrial development on the site. The downwind perimeter locations were Ringold, Byers Landing, Sagemoor, and Riverview (see Figure 4.6.1). These four locations lie generally east and southeast of the site.
They are expected to be in areas of highest offsite accumulation of contaminants from site stack emissions.

Perennial vegetation samples consisted of the current year's growth of leaves, stems, and new branches collected from sagebrush and rabbitbrush. Sample vegetation was dried before analyses, and analytical results were reported on a dry weight basis. Shoreline vegetation samples were usually taken from a predominant species at the sampling location. A contaminant was detected if 


\begin{tabular}{|c|c|c|c|c|}
\hline \multirow[b]{2}{*}{ Location $^{(b)}$} & \multicolumn{3}{|c|}{$\begin{array}{l}\text { Table 4.6.3. Radionuclide Concentrations (pCi/g dry wt.) }{ }^{(a)} \text { in Soil Collected } \\
\text { from the Fitzner/Eberhardt Arid Lands Ecology Reserve }\end{array}$} & \multirow[b]{2}{*}{2001} \\
\hline & Radionuclide & $1993^{(c)}$ & $\underline{1998}^{(\mathrm{d})}$ & \\
\hline Rattlesnake Springs & $\begin{array}{l}\text { Strontium-90 } \\
\text { Cesium-137 } \\
\text { Uranium-238(d) } \\
\text { Plutonium-238 } \\
\text { Plutonium-239/240 }\end{array}$ & $\begin{aligned} 0.07 & \pm 0.02 \\
0.29 & \pm 0.04 \\
0.51 & \pm 0.39 \\
0.0002 & \pm 0.0001 \\
0.007 & \pm 0.001\end{aligned}$ & $\begin{aligned} 0.08 & \pm 0.02 \\
0.21 & \pm 0.03 \\
0.11 & \pm 0.02 \\
0.0004 & \pm 0.0002 \\
0.008 & \pm 0.001\end{aligned}$ & $\begin{aligned} 0.084 & \pm 0.035 \\
0.24 & \pm 0.035 \\
0.13 & \pm 0.033 \\
0.00031 & \pm 0.00024 \\
0.014 & \pm 0.0015\end{aligned}$ \\
\hline Reserve Field Laboratory & $\begin{array}{l}\text { Strontium-90 } \\
\text { Cesium-137 } \\
\text { Uranium-238(d) } \\
\text { Plutonium-238 } \\
\text { Plutonium-239/240 }\end{array}$ & $\begin{array}{c}0.11 \pm 0.02 \\
0.22 \pm 0.04 \\
1.01 \pm 0.50 \\
0.0002 \pm 0.0002 \\
0.006 \pm 0.001\end{array}$ & $\begin{array}{c}0.012 \pm 0.004 \\
0.02 \pm 0.01 \\
0.21 \pm 0.04 \\
\mathrm{ND}^{(e)} \\
0.0009 \pm 0.0005\end{array}$ & $\begin{aligned} 0.078 & \pm 0.033 \\
0.27 & \pm 0.039 \\
0.19 & \pm 0.028 \\
0.00045 & \pm 0.00033 \\
0.0093 & \pm 0.0020\end{aligned}$ \\
\hline $\begin{array}{l}\text { (a) } 1 \mathrm{pCi}=0.037 \mathrm{~Bq} . \\
\text { (b) See Figure 4.6.1. } \\
\text { (c) } \pm \text { total analytical un } \\
\text { (d) } 1993 \text { uranium-238 w } \\
\text { (e) ND = Not detected. }\end{array}$ & $\begin{array}{l}\text { ainty. } \\
\text { etermined by low-ener }\end{array}$ & on analysis; 1998 & 1 determined by al & ctrometry. \\
\hline
\end{tabular}

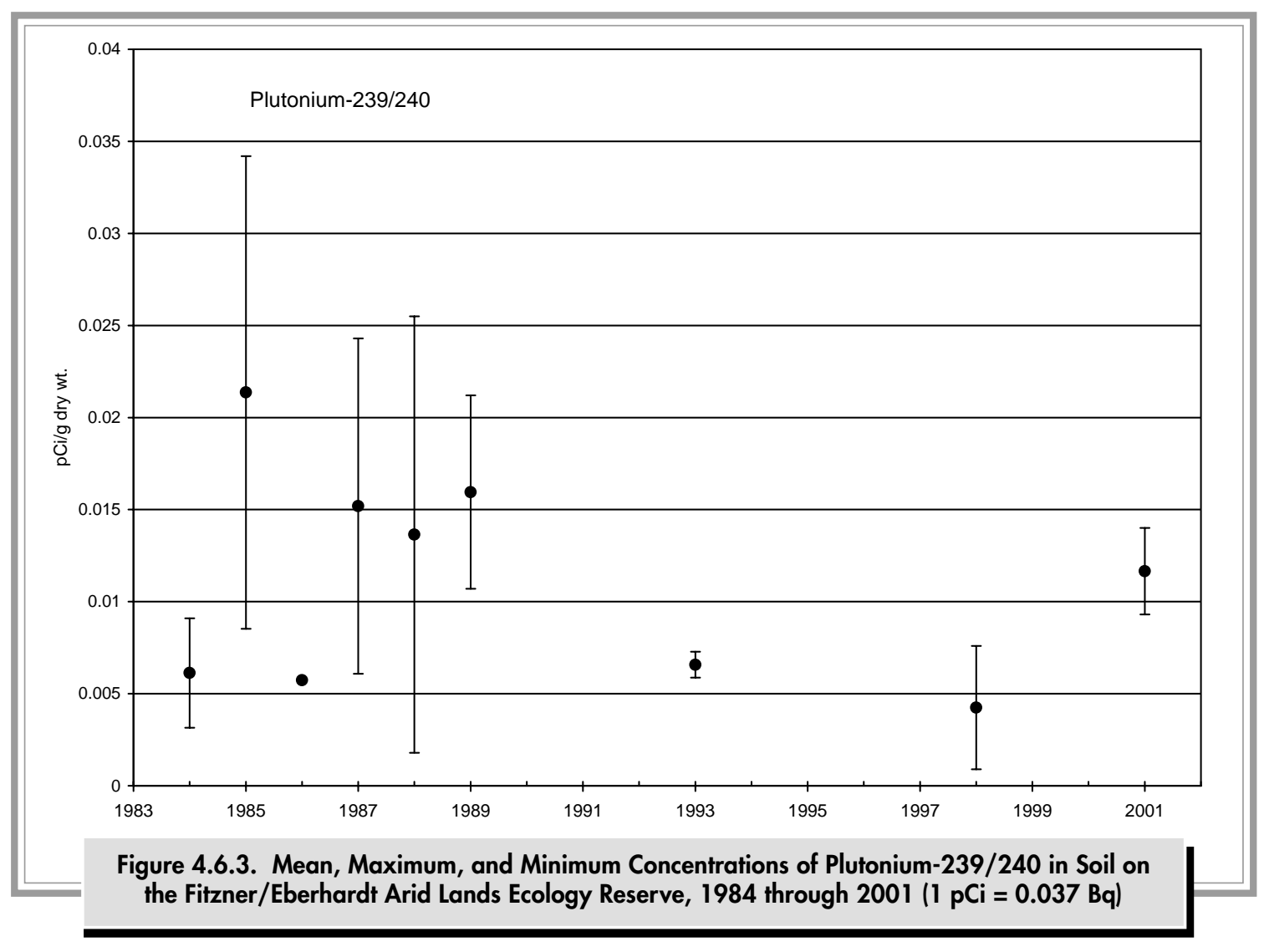


the analytical result was greater than the minimum detectable concentration, and was larger than the total analytical uncertainty.

Vegetation sampling results in 2001 generally confirmed observations from past sampling efforts. Strontium-90, cesium-137, plutonium-238, and uranium-238 concentrations were all below nominal detection limits at distant and shoreline locations (Table 4.6.4), as were cesium-137 and strontium-90 concentrations at perimeter locations. Nominal detection limits for strontium-90, cesium-137, plutonium-238, and uranium-238 were $0.14,0.03,0.0002$, and $0.005 \mathrm{pCi} / \mathrm{g}(5.2,1.1,0.0074$, and $0.19 \mathrm{mBq} / \mathrm{g})$, respectively. Uranium-238 was detected in three of four perimeter samples collected. These three samples were from Franklin County, across the eastern boundary of the Hanford Site. The maximum uranium-238 concentration measured in vegetation during 2001 was collected at Byers Landing $(0.016 \pm 0.0094 \mathrm{pCi} / \mathrm{g}[0.60 \pm$ $0.35 \mathrm{mBq} / \mathrm{g}]$ ). This result was higher than the maximum onsite uranium-238 concentration measured in 2001. The average uranium-238 concentration at perimeter locations was similar to the average of samples collected in 1993, 1994, and 1998.

Concentrations of plutonium-238 and uranium-238 in onsite samples were all less than the detection limit. Cesium-137 and strontium-90 were each measured in one sample, and results were similar to those from past years (see Table 4.6.4).

The percentage of samples collected in 2001 with measurable plutonium-239/240 concentrations increased relative to those samples collected in 1993, 1994, and 1998. Between 1993 and 1998, >40\% of the vegetation samples analyzed had detectable concentrations of plutonium-239/240. In 2001, plutonium-239/240 was detected in all vegetation samples collected and analyzed. The 2001 average concentrations for all distance classes increased relative to the average concentration measured during the past 8 years (see Table 4.6.4).

\subsubsection{Cross Media Com parison}

In 2001, slightly increased plutonium-239/240 concentrations were detected in soil, vegetation, and air samples on and near the Hanford Site. In general, the increases were only apparent on a relatively short time scale. Figure 4.6.4 illustrates annual average plutonium-239/240 concentrations over an 18-year period at onsite and perimeter locations for vegetation and air, and onsite and Fitzner/Eberhardt Arid Lands Ecology Reserve locations for soil. For some distance class/media combinations, 2001 indicated an increase in plutonium-239/240 concentration relative to the past several sampling periods. This included onsite and perimeter vegetation, Fitzner/Eberhardt Arid Lands Ecology Reserve soil, and onsite atmospheric particulates. With the exception of perimeter vegetation, all of the 2001 averages were below levels measured in the previous
17 years. It is possible that the increase in plutonium-239/240 observed in 2001 was related to the 24 Command Hanford fire of 2000. It is likely that the increases were not a result of additional contamination, but rather the movement of contaminants already present in soil no longer held in place by vegetative cover. This conclusion is based on the following facts. The increase of plutonium-239/240 detected in the Fitzner/ Eberhardt Arid Lands Ecology Reserve soil was small and could be the result of random variation. There was significant wind erosion of soil in the burned area after the fire (PNNL-13487) and significant particulate transport in 2001 (see Section 4.1.3). Plutonium is tightly bound to soil and uptake by plants is generally minimal (Eisenbud 1987), so increases in plutonium-239/240 in new vegetative growth is likely due to atmospheric particles deposited onto plant foliage. 
Table 4.6.4. Concentrations of Selected Radionuclides (pCi/g dry wt.)(a) in Vegetation, 2001 Compared to Previous Years

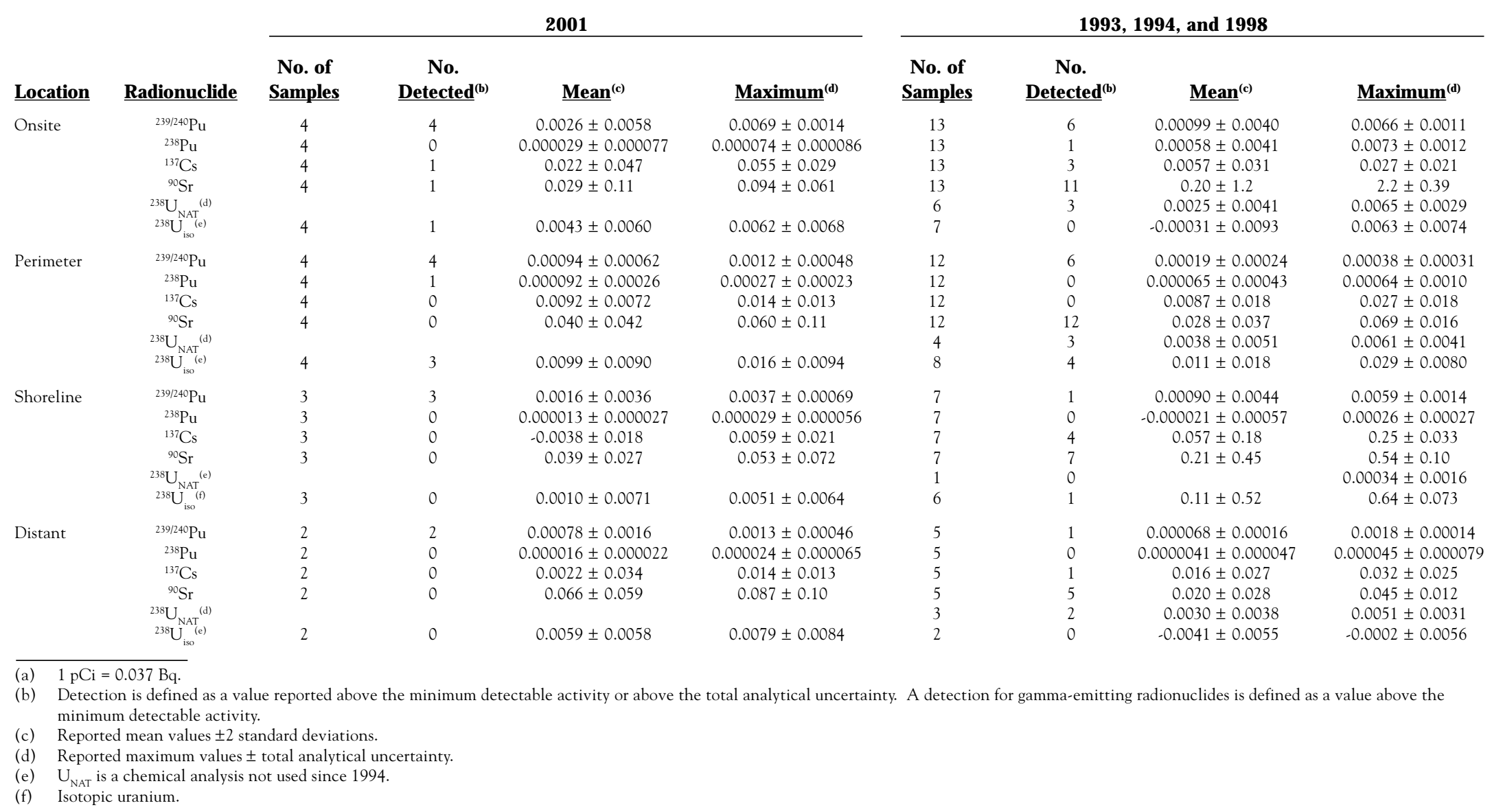




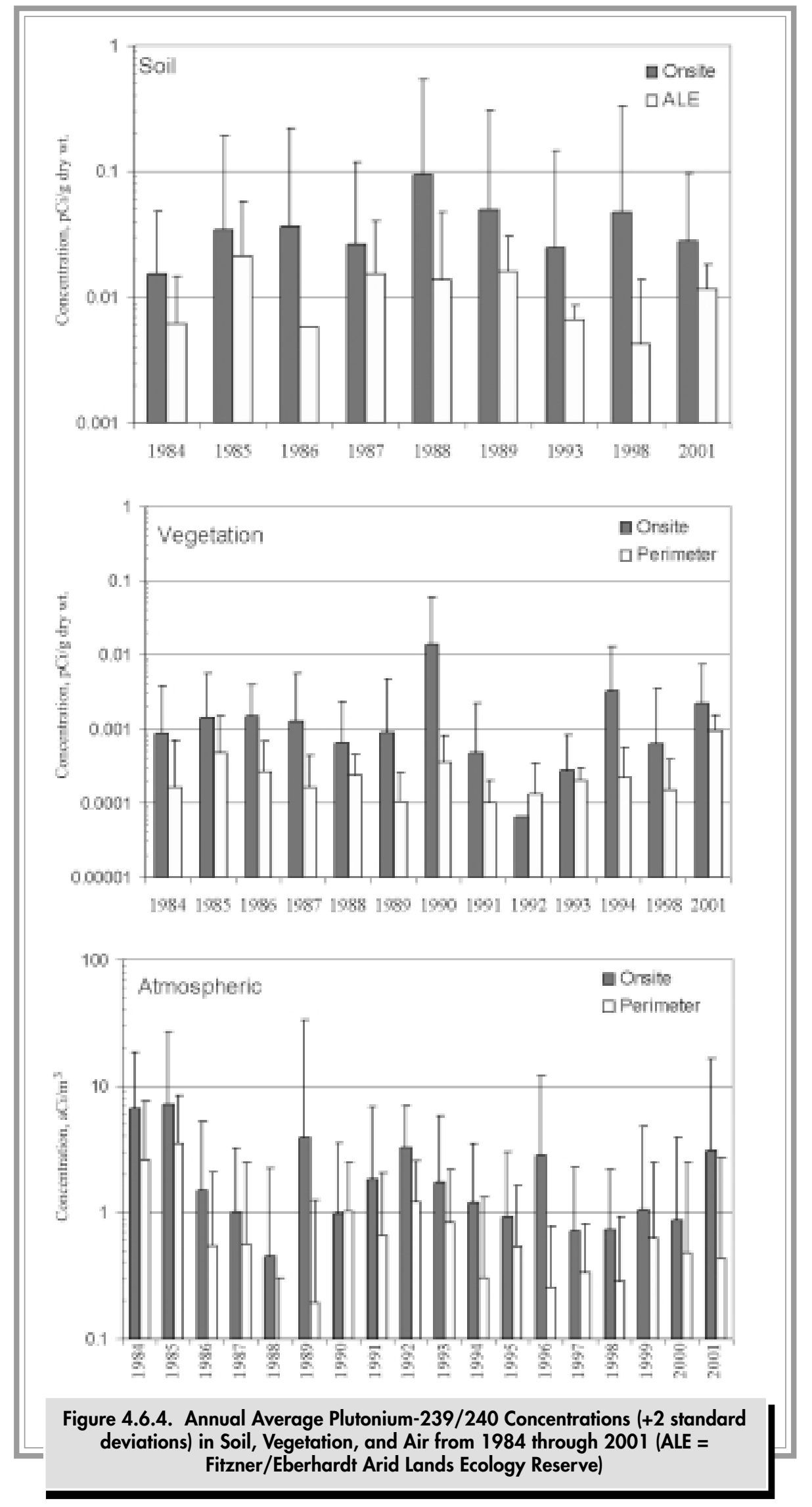




\title{
4.7 External Radiation Surveillance
}

\author{
E. J. A ntonio
}

External radiation is defined as radiation originating from a source external to the body. External radiation fields consist of a natural component and an anthropogenic, or manmade, component. The natural component can be divided into (1) cosmic radiation; (2) primordial radionuclides, primarily potassium-40, thorium-232, and uranium-238; and (3) an airborne component, primarily radon and its progeny. The manmade component consists of radionuclides generated for or from nuclear medicine, power, research, waste management, and consumer products containing nuclear materials. Environmental radiation fields may be influenced by the presence of radionuclides deposited as worldwide fallout from atmospheric testing of nuclear weapons or those produced and released to the environment during the production or use of nuclear fuel. During any year, external radiation levels can vary from $15 \%$ to $25 \%$ at any location because of changes in soil moisture and snow cover (National Council on Radiation Protection and Measurements 1987).

The interaction of radiation with matter results in energy being deposited in that matter. This is why your hand feels warm when exposed to a light source (e.g., sunlight, flame). Ionizing radiation energy deposited in a mass of material is called radiation absorbed dose. A special unit of measurement, called the rad, was introduced for this concept in the early 1950s. The International System of Units introduced the Gray and is defined as follows: 1 Gray is equivalent to $100 \mathrm{rad}$ (American Society for Testing and Materials 1993).

One device for measuring radiation absorbed dose is the thermoluminescent dosimeter that absorbs and stores energy of ionizing radiation within the dosimeter's crystal lattice. By heating the dosimeter material under controlled laboratory conditions, the stored energy is released in the form of light, which is measured and related to the amount of ionizing radiation energy stored in the material. Thermoluminescence, or light output exhibited by dosimeters, is proportional to the energy absorbed, which by convention is related to the amount of radiation exposure $(\mathrm{X})$, which is measured in units of roentgen (R). The exposure is multiplied by a factor of 0.98 to convert to a dose (D) in rad to soft tissue (Shleien 1992). This conversion factor relating $R$ to rad is, however, assumed to be unity (1) throughout this report for consistency with past reports. This dose is further modified by a quality factor, $Q=1$, for beta and gamma radiation and the product of all other modifying factors (N). N is assumed to be unity to obtain dose equivalence $(\mathrm{H})$ measured in rem. The international unit, the sievert $(\mathrm{Sv})$ is equivalent to $100 \mathrm{rem}$.

$$
\begin{aligned}
& \mathrm{D}(\mathrm{rad})=\mathrm{X}(\mathrm{R}) * 1.0 \\
& \mathrm{H}(\mathrm{rem})=\mathrm{D} * \mathrm{~N} * \mathrm{Q}
\end{aligned}
$$

For a point of reference, a radiological dose of $100 \mathrm{rem}$ (1 Sv) beta/gamma to an 8-ounce (227-gram) cup of water will deposit enough energy in the water to increase the temperature of the water by about $1^{\circ} \mathrm{F}$ $\left(0.55^{\circ} \mathrm{C}\right)$.

In 2001, environmental external radiation exposure rates were measured at locations on and off the Hanford Site using thermoluminescent dosimeters and pressurized ionization chambers. External radiation and surface contamination surveys at specified locations were performed with portable radiation survey instruments.

\subsubsection{External Radiation Measurements}

The Harshaw 8800-series environmental dosimeter consists of two TLD-700 chips and two TLD-200 chips and provides both shallow and deep dose measurement capabilities. The two TLD-700 chips were used to determine the average total environmental dose at each location. The average dose rate was computed by dividing 
the average total environmental dose by the number of days the dosimeter was in the field. Quarterly dose equivalent rates (millirem per day) at each location were converted to annual dose equivalent rates (millirem per year) by averaging the quarterly dose rates and multiplying by 365 days per year. The two TLD-200 chips were included only to determine doses in the event of a radiological emergency and were not needed in 2001.

Thermoluminescent dosimeters were positioned 1 meter (3.28 feet) above the ground at 29 onsite locations (Figure 4.7.1). Figure 4.7.2 shows the locations around the site perimeter, in nearby communities, and distant locations. Figure 4.7.3 gives the locations along the Columbia River shoreline. One onsite thermoluminescent dosimeter surveillance location was added in 2001 and one was moved from a community station to a shoreline location due to vandalism. All thermoluminescent dosimeters were collected and read quarterly.

To determine the maximum dose rate for each distance classification, the annual average dose rates, as calculated above for each location, were compared and the highest value was reported. The uncertainties associated with the maximum dose rates were calculated as two standard deviations of the quarterly dose rates then corrected to annual rates.

All community and most of the onsite and perimeter thermoluminescent dosimeter locations were collocated with air monitoring stations. The onsite and perimeter locations were selected based on determinations of the highest potentials for public exposures (i.e., access areas, downwind population centers) from past and current Hanford Site operations. The two background stations in Yakima and Toppenish were chosen because they are generally upwind and distant from the site.

The shoreline of the Columbia River in the Hanford Reach was monitored by a series of 26 thermoluminescent dosimeters located in the area from upstream of the B Reactor to downstream of Bateman Island at the mouth of the Yakima River. Ground contamination surveys also were conducted quarterly at 13 shoreline locations. These measurements are made to estimate radiation exposure levels attributed to sources on the Hanford Site, to estimate background levels along the shoreline, and to help assess exposures to onsite personnel and offsite populations. Ground contamination surveys were conducted using Geiger-Müeller meters (Geiger counters) and Bicron ${ }^{\circledR}$ Microrem meters. Results are reported in counts per minute and microrem per hour, respectively. Geiger counter measurements were made within 2.54 centimeters ( 1 inch) of the ground and covered a 1 -square meter (10-square feet) area. The Bicron ${ }^{\circledR}$ measurements were taken 1 meter (3.28 feet) above the ground surface and at least 10 meters ( 33 feet) away from devices or structures which may have contributed to the ambient radiation levels.

Pressurized ionization chambers were situated at four community-operated monitoring stations (see Section 8.4). These instruments provided a way to measure ambient exposure rates near and downwind of the site and at locations distant and upwind of the site. Realtime exposure-rate data are displayed at each station to provide information to the public and to serve as an educational tool for the teachers who manage the stations.

\section{External Radiation Results}

Thermoluminescent dosimeter readings were converted to annual dose equivalent rates by the process described above. Table 4.7.1 shows the maximum and mean dose rates for perimeter and offsite locations measured in 2001 and the previous 5 years. External dose rates reported in Tables 4.7.1 through 4.7.3 include the maximum annual dose rate ( \pm 2 standard deviations) for all locations within a given surveillance zone and the mean dose rate ( \pm 2 standard error of the mean) for each distance class. Locations were classified (or grouped) based on their location on or near the Hanford Site.

Table 4.7.2 summarizes the results of 2001 onsite measurements, which are grouped by operational area. The average dose rates in all operational areas were higher than average dose rates measured at distant locations. The highest annual average dose rate on the site (96 $\pm 8 \mathrm{mrem} / \mathrm{yr}[0.96 \pm 0.08 \mathrm{mSv} / \mathrm{yr}]$ ) was detected around the 200 Areas and was due to former waste disposal activities at B Pond. The 5-year maximum onsite dose rate $(138 \pm 31 \mathrm{mrem} / \mathrm{yr}[1.38 \pm 0.31 \mathrm{mSv} / \mathrm{yr}])$ was measured in 1996 near the US Ecology low-level waste disposal facility.

The annual dose rates measured offsite in 2001 are given in Table 4.7.1 and Appendix B, Table B.10. The mean perimeter dose rate was $91 \pm 4 \mathrm{mrem} / \mathrm{yr}(0.91 \pm$ $0.04 \mathrm{mSv} / \mathrm{yr})$ in 2001, the maximum was $99 \pm$ $16 \mathrm{mrem} / \mathrm{yr}(0.99 \pm 0.16 \mathrm{mSv} / \mathrm{yr})$, and the 5 -year perimeter mean dose rate was $89 \pm 2 \mathrm{mrem} / \mathrm{yr}(0.89 \pm$ $0.02 \mathrm{mSv} / \mathrm{yr}$ ). The location of the maximum perimeter dosimeter result was across the Columbia River from the 300 Area at Byers Landing (location 4 on Figure 4.7.2). For the past few years, Byer's Landing has had the highest and most variable thermoluminescent dosimeter readings (Figure 4.7.4). 


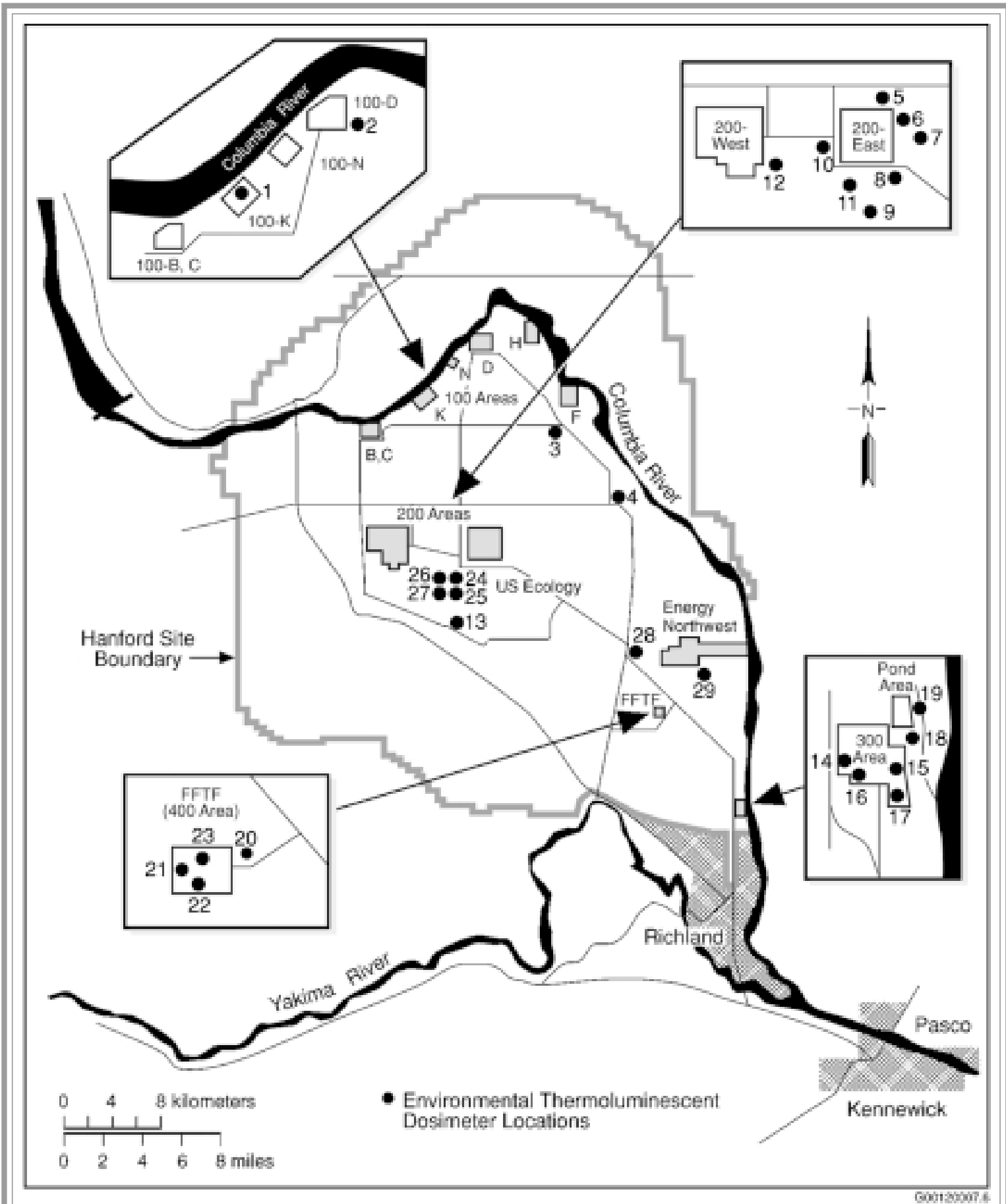

Figure 4.7.1. Thermoluminescent Dosimeter Locations and Station N umbers on the Hanford Site, 2001 (see Appendix B, Table B.10 for station names) 


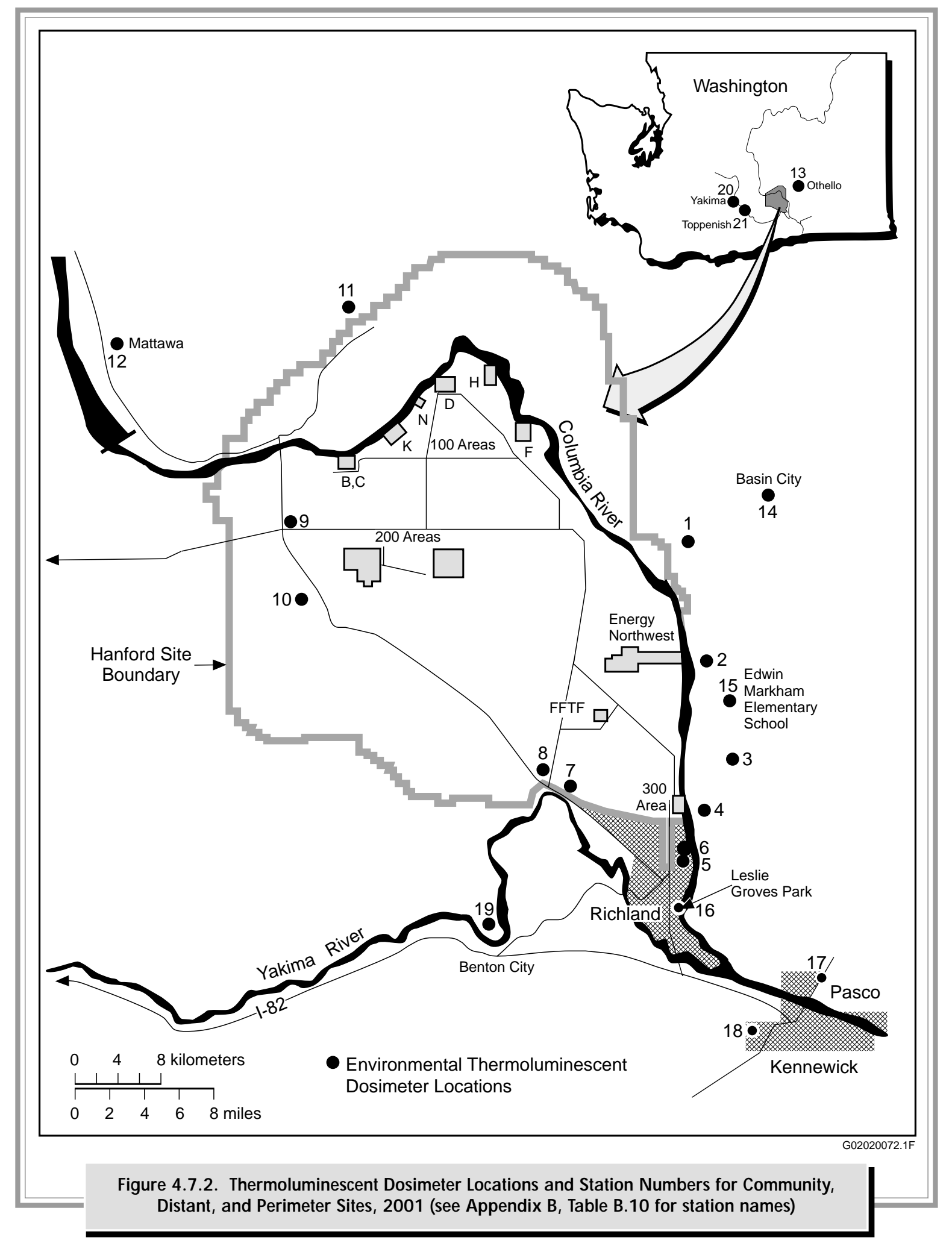




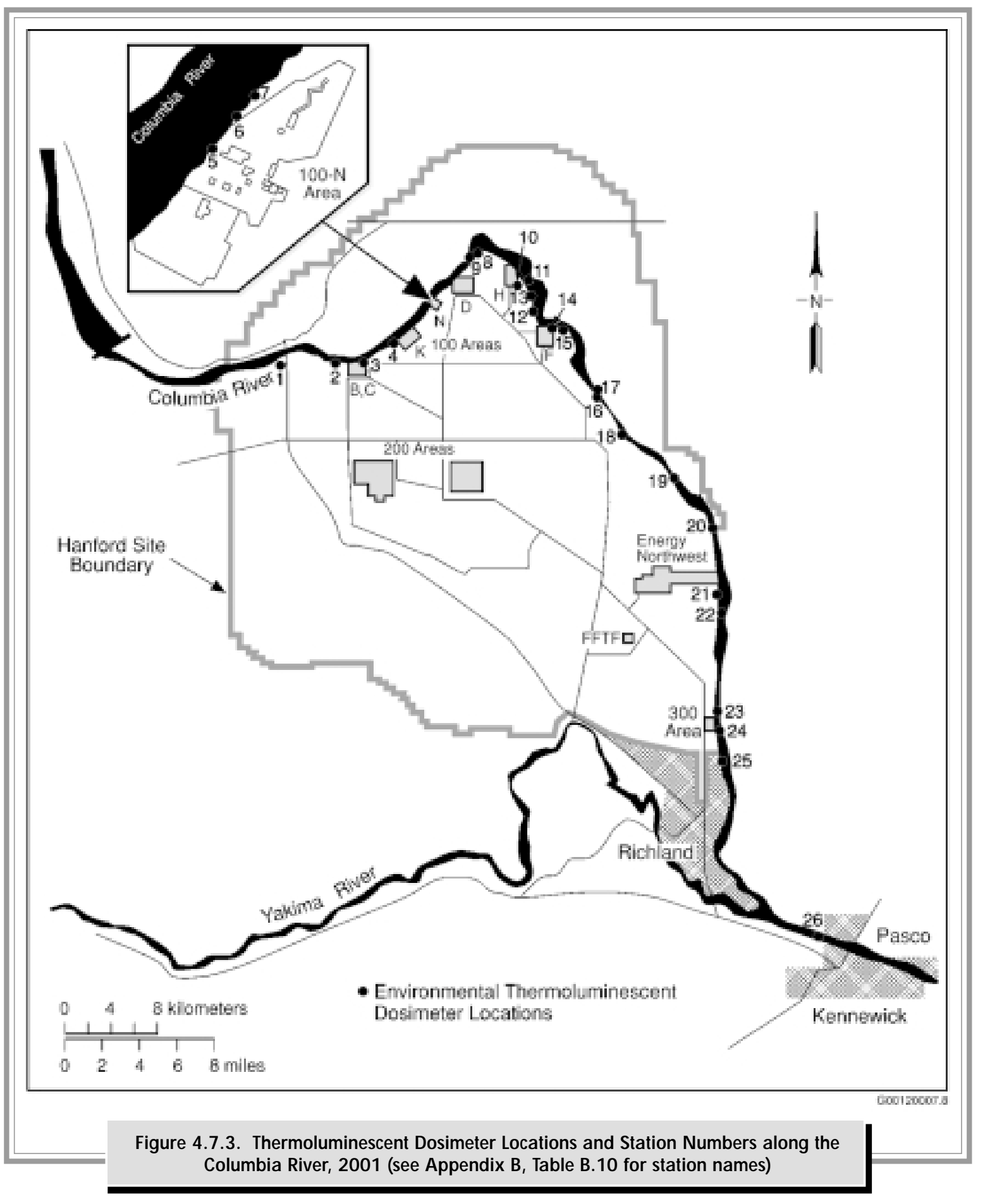




\begin{tabular}{|c|c|c|c|c|c|c|}
\hline \multirow[b]{3}{*}{ Location } & \multicolumn{6}{|c|}{$\begin{array}{l}\text { Table 4.7.1. Dose Rates (mrem/ yr[a]) Measured by Thermoluminescent Dosimeters at } \\
\text { Perimeter and Offsite Locations, } 2001 \text { Compared to Previous } 5 \text { Years }\end{array}$} \\
\hline & \multirow[b]{2}{*}{$\begin{array}{l}\text { Map } \\
\text { Location }^{(b)}\end{array}$} & \multicolumn{2}{|c|}{2001} & \multicolumn{3}{|c|}{$1996-2000$} \\
\hline & & $\underline{M a x i m u m}^{(c)}$ & $\underline{\text { Mean }}^{(\mathrm{d})}$ & $\begin{array}{r}\text { No. of } \\
\text { Samples }\end{array}$ & $\underline{\text { Maximum }}^{(\mathrm{c})}$ & $\underline{M e a n}^{(d)}$ \\
\hline Perimeter & $1-12$ & $99 \pm 16$ & $91 \pm 4$ & 75 & $106 \pm 8$ & $89 \pm 2$ \\
\hline Community & $13-19$ & $86 \pm 5$ & $80 \pm 3$ & 61 & $90 \pm 9$ & $79 \pm 2$ \\
\hline Distant & $20-21$ & $73 \pm 8$ & $72 \pm 2$ & 16 & $75 \pm 9$ & $71 \pm 1$ \\
\hline \multicolumn{7}{|c|}{$\begin{array}{l}\text { (a) Multiply by } 10 \text { to convert to } \mu \mathrm{Sv} / \mathrm{yr} \text {. } \\
\text { (b) All station locations are shown on Figure } 4.7 .2 \text { and are described in Appendix B, Table B.10. } \\
\text { (c) Maximum annual average dose rate for all locations within a given distance classification }( \pm 2 \text { standard } \\
\text { deviations). } \\
\text { (d) Means computed by averaging annual means for each location within distance class }( \pm 2 \text { standard error of the } \\
\text { mean). }\end{array}$} \\
\hline
\end{tabular}

\begin{tabular}{|c|c|c|c|c|c|c|}
\hline \multirow[b]{3}{*}{ Location } & \multicolumn{5}{|c|}{$\begin{array}{l}\text { Table 4.7.2. Dose Rates (mrem/ } y^{[a]} \text { ) Measured by Thermoluminescent Dosimeters } \\
\text { on the Hanford Site, } 2001 \text { Compared to Previous } 5 \text { Years }\end{array}$} & \\
\hline & \multirow[b]{2}{*}{$\begin{array}{c}\text { Map } \\
\text { Location }^{(b)}\end{array}$} & \multicolumn{2}{|c|}{2001} & \multicolumn{3}{|c|}{$1996-2000$} \\
\hline & & $\underline{\text { Maximum }}^{(\mathrm{c})}$ & $\underline{\text { Mean }}^{(\mathrm{d})}$ & $\begin{array}{l}\text { No. of } \\
\text { Samples }\end{array}$ & $\underline{\text { Maximum }}^{(\mathrm{c})}$ & Mean ${ }^{(d)}$ \\
\hline 100 Areas & $1-3$ & $87 \pm 10$ & $84 \pm 5$ & 12 & $88 \pm 4$ & $80 \pm 4$ \\
\hline 200 Areas & $4-12$ & $96 \pm 8$ & $88 \pm 2$ & 39 & $98 \pm 9$ & $88 \pm 2$ \\
\hline 300 Area & $13-18$ & $87 \pm 8$ & $83 \pm 2$ & 30 & $89 \pm 7$ & $82 \pm 1$ \\
\hline 400 Area & $19-22$ & $86 \pm 9$ & $83 \pm 2$ & 20 & $89 \pm 7$ & $83 \pm 1$ \\
\hline 600 Area & $23-29$ & $94 \pm 7$ & $88 \pm 2$ & 30 & $138 \pm 31$ & $92 \pm 6$ \\
\hline Combined onsite & $1-29$ & $96 \pm 8$ & $86 \pm 2$ & 131 & $138 \pm 31$ & $86 \pm 2$ \\
\hline \multicolumn{7}{|c|}{$\begin{array}{l}\text { (a) Multiply by } 10 \text { to convert to } \mu \mathrm{Sv} / \mathrm{yr} \text {. } \\
\text { (b) All station locations are shown on Figure } 4.7 .2 \text { and are described in Appendix B, Table B. } 10 \text {. } \\
\text { (c) Maximum annual average dose rate for all locations within a given distance classification ( } \pm 2 \text { standard } \\
\text { deviations). } \\
\text { (d) Means computed by averaging annual means for each location within distance class }( \pm 2 \text { standard error of the } \\
\text { mean). }\end{array}$} \\
\hline
\end{tabular}

The mean background dose rate (measured at distant communities) in 2001 was $72 \pm 2 \mathrm{mrem} / \mathrm{yr}(0.71 \pm$ $0.02 \mathrm{mSv} / \mathrm{yr})$ compared to the previous year's mean of $69 \pm 1 \mathrm{mrem} / \mathrm{yr}(0.69 \pm 0.01 \mathrm{mSv} / \mathrm{yr})(\mathrm{PNNL}-13487)$ and the 5 -year average of $71 \pm 1 \mathrm{mrem} / \mathrm{yr}(0.71 \pm$ $0.01 \mathrm{mSv} / \mathrm{yr}$ ). The variation in dose rates may be partially attributed to changes in natural background radiation that can occur as a result of changes in annual cosmic radiation (up to 10\%) and terrestrial radiation (15\% to 25\%) (National Council on Radiation Protection and Measurements 1987). Other factors possibly affecting the annual dose rates reported here have been described in PNL-7124. Figure 4.7.5 displays a comparison of dose rates between onsite, perimeter, and distant thermoluminescent dosimeter locations from 1996 through 2001.

Dose rates were highest along the shoreline near the $100-\mathrm{N}$ Area and were $\sim 1.3$ times the typical shoreline dose rates (see Table 4.7.3). The higher dose rates measured along the 100-N Area shoreline have been attributed to past waste management practices in that area (PNL-3127). The 2001 maximum annual shoreline dose rate was $129 \pm 6 \mathrm{mrem} / \mathrm{yr}(1.29 \pm 0.06 \mathrm{mSv} / \mathrm{yr})$, which is not significantly different from the maximum 
Table 4.7.3. Dose Rates ( $\mathrm{mrem} / \mathrm{yr}^{[\mathrm{a}]}$ ) Measured by Thermoluminescent Dosimeters along the Hanford Reach of the Columbia River, 2001 Compared to Previous 5 Years

\begin{tabular}{|c|c|c|c|c|c|c|}
\hline \multirow[b]{2}{*}{ Location } & \multirow[b]{2}{*}{$\begin{array}{c}\text { Map } \\
\text { Location }^{(b)}\end{array}$} & \multicolumn{2}{|c|}{2001} & \multicolumn{3}{|c|}{ 1996-2000 } \\
\hline & & $\underline{\text { Maximum }}^{(\mathrm{c})}$ & $\underline{\text { Mean }}^{(\mathrm{d})}$ & $\begin{array}{c}\text { No. of } \\
\text { Samples }\end{array}$ & $\underline{\text { Maximum }}^{(c)}$ & $\underline{\text { Mean }}^{(\mathrm{d})}$ \\
\hline Typical shoreline & $1-22$ & $101 \pm 22$ & $88 \pm 3$ & 110 & $102 \pm 15$ & $85 \pm 1$ \\
\hline 100-N shoreline & $23-26$ & $129 \pm 6$ & $111 \pm 21$ & 17 & $173 \pm 11$ & $122 \pm 11$ \\
\hline All shoreline & $1-26$ & $129 \pm 6$ & $91 \pm 4$ & 127 & $173 \pm 11$ & $90 \pm 3$ \\
\hline
\end{tabular}

(a) Multiply by 10 to convert to $\mu \mathrm{Sv} / \mathrm{yr}$.

(b) All station locations are shown on Figure 4.7.2 and are described in Appendix B, Table B.10.

(c) Maximum annual average dose rate for all locations within a given distance classification $( \pm 2$ standard deviations).

(d) Means computed by averaging annual means for each location within distance class ( \pm 2 standard error of the mean).

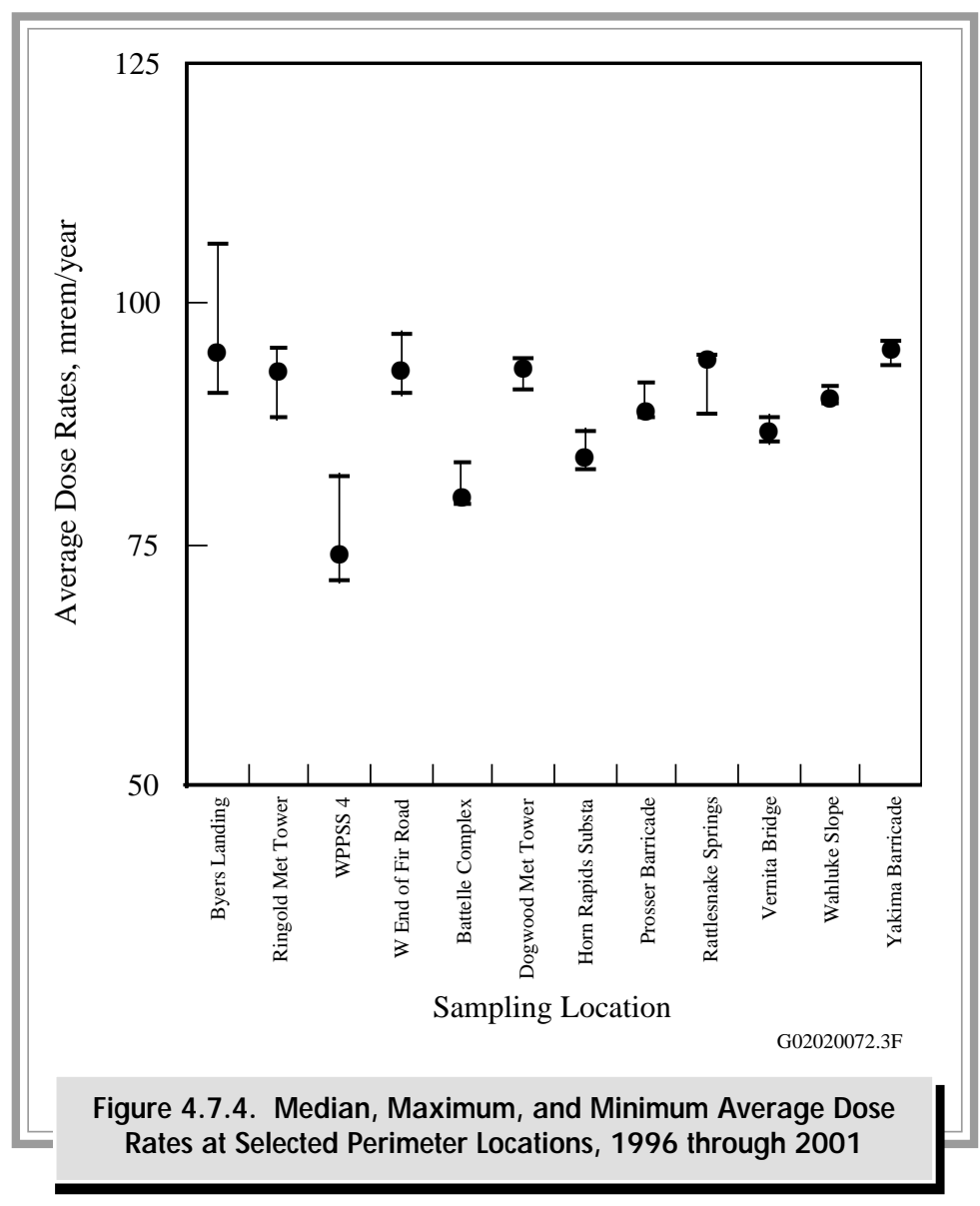




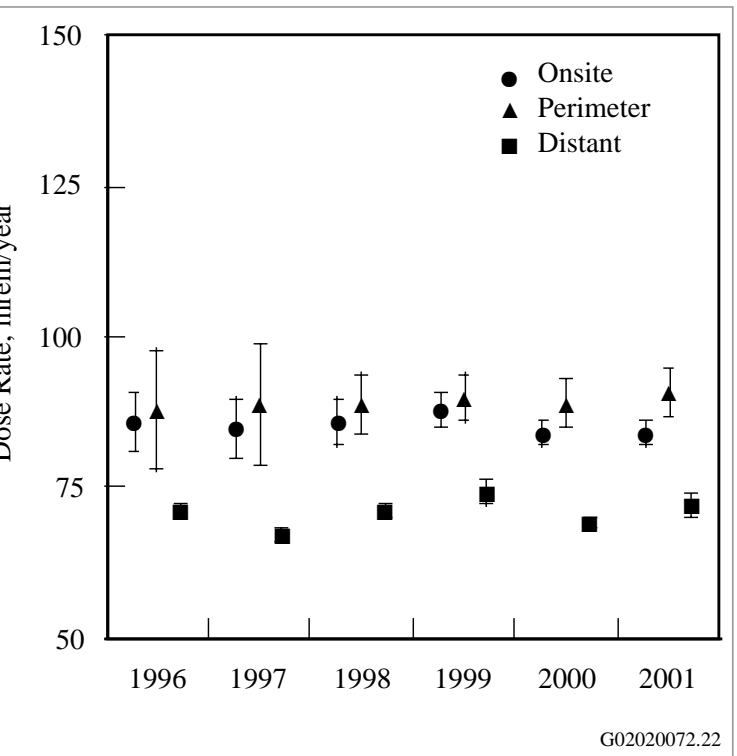

Figure 4.7.5. Annual Average Dose Rates ( \pm 2 standard error of the mean), 1996 through 2001 of $131 \pm 7 \mathrm{mrem} / \mathrm{yr}(1.31 \pm 0.07 \mathrm{mSv} / \mathrm{yr})$ measured in 2000 (PNNL-13487), but is significantly different than the 5 -year maximum of $173 \pm 11 \mathrm{mrem} / \mathrm{yr}(1.73 \pm$ $0.11 \mathrm{mSv} / \mathrm{yr}$ ) measured in 1996 . The 5 -year maximum also was measured along the $100-\mathrm{N}$ shoreline. The general public does not have legal access to the 100-N Area shoreline above the high-water line but does have access to the adjacent Columbia River and to the shoreline below the high-water line. The dose implications associated with this access are discussed in Section 5.0.

\subsubsection{Radiological Survey Results}

In 2001, Geiger counters and Bicron ${ }^{\circledR}$ Microrem meters were used to perform radiological surveys at selected Columbia River shoreline locations. These surveys provide a coarse screening for elevated radiation fields. The surveys showed that radiation levels at the selected locations were comparable to levels observed at the same locations in previous years. The highest dose rate measured with the Bicron ${ }^{\circledR}$ Microrem meter $(20 \mu \mathrm{rem} / \mathrm{h}[0.2(\mathrm{~Sv} / \mathrm{h}])$ was measured in winter along the 100-N Area shoreline; the lowest dose rate measured was $4 \mu \mathrm{rem} / \mathrm{h}(0.04 \mu \mathrm{Sv} / \mathrm{h})$ and was recorded at several other locations in the spring and autumn. The highest reported count rate measured with the Geiger counter in ground level surveys was 100 counts per minute. The lowest ground level count rate ( $>50$ counts per minute) was recorded at the same location and on the same day that the lowest Bicron ${ }^{\circledR}$ reading was recorded.

Survey data are not included in the 2001 surveillance data report (PNNL-13910, APP. 1) but are maintained in project files at Pacific Northwest National Laboratory and can be obtained on written request from the Surface Environmental Surveillance Project manager.

Gamma radiation levels in air were monitored in 2001 at four community-operated air monitoring stations (see Section 8.4). These stations were located in Leslie Groves Park in Richland, at Edwin Markham
Elementary School in north Franklin County, at Basin City Elementary School in Basin City, and at Heritage College in Toppenish (see Figure 4.1.1). Measurements were collected to determine ambient gamma radiation levels near and downwind of the site and upwind and distant from the site, to display real-time exposure rate information to the public living near the station, and for educational aids for the teachers who manage the stations.

Readings at the Leslie Groves Park and Heritage College stations were collected every 10 seconds with a Reuter-Stokes Model RSS-121 pressurized ionization chamber, and an average reading was recorded every hour by a flat panel computer system located at the station. Data were obtained monthly from the computer via modem. Similar data collection systems were installed at Basin City and at Edwin Markham School during 2001. At these locations, data were collected every second and averaged every minute. The 1 -minute averages were used to generate either a 30 - or 60 -minute average, depending on location. Data were not collected at Basin City and Edwin Markham Schools every month because of the transition to the new systems. The data collected at all four stations each month in 2001 are summarized in Table 4.7.4.

Average monthly exposure rates ranged from a maximum of $11.9 \mu \mathrm{R} / \mathrm{h}(24.9 \mu \mathrm{pW} / \mathrm{kg} / \mathrm{s})$ in Richland 
Table 4.7.4. Average Exposure Rates Measured by Pressurized lonization Chambers at Four Offsite Locations ${ }^{(\mathrm{a})}, 2001$

Exposure Rate, $\mu R / h^{(b)}$ (number of readings) ${ }^{(c)}$

Month

January

February

Mean

Maximum

Minimum

Mean

Maximum

Minimum

March

Mean

Maximum

Minimum

April

Mean

Maximum

Minimum

May

June

Mean

Maximum

Minimum

Mean

Maximum

Minimum

July

August

Maximum

Minimum

Mean

Maximum

Minimum

September

Mean

Maximum

Minimum

October

Mean

Maximum

Minimum

November

Mean

Maximum

Minimum

December

Mean

Maximum

Minimum

\section{Leslie Groves Park ${ }^{(d)}$}

(744)

10.0

6.4

8.7

9.7

5.6

8.5

9.6

4.7

8.4

(720)

(276)

(648)

4.9

8.5

9.1

6.9

8.5

9.4

8.3

8.5

9.4

7.4

8.4

9.0

5.6

8.6

9.3

7.4

8.5

8.5
9.3

4.6

8.1

9.6

4.4

8.8

11.9

5.2

(744)

(744)

(681)

(720)

Basin City ${ }^{(e)}$

Edwin Markham $^{(\mathrm{f})}$

Toppenish ${ }^{(\mathrm{d})}$

$\mathrm{ND}^{(\mathrm{g})}$

ND

ND

ND

ND

ND

ND

ND

ND

ND

ND

ND

ND

ND

ND

ND

ND

ND

ND

ND

ND

ND

ND

ND

ND

ND

ND

ND

ND

ND

7.9

(568)

7.4

7.4

7.8

11.0

(720)

7.3
ND

ND

ND

ND

ND

ND

ND

ND

ND

ND

ND

ND

ND

ND

ND

ND

ND

ND

ND

ND

ND

7.4

8.4

6.8

7.5

8.4

4.7

7.4
8.3

8.3
6.0

7.6

10.1

4.5

7.5

10.9

4.4
(872)

(a) Sampling locations are illustrated in Figure 4.1.1.

(b) To convert to international metric system units (picowatts per kilogram), multiply exposure rates by 2.109 .

(c) Number of 30- or 60-minute averages used to compute monthly average.

(d) Readings are stored every 60 minutes. Each 60-minute reading is an average of 360 individual measurements.

(e) Readings were collected every second and averaged each minute. Minute averages were used to compute 60 minute maximum, minimum, and average values.

(f) Readings were collected every second and averaged each minute. Minute averages were used to compute 30 minute maximum, minimum, and average values.

(g) $\mathrm{ND}=$ No data collected; instrument problems. 
(Leslie Groves Park) in December to a minimum of $4.4 \mu \mathrm{R} / \mathrm{h}(9.3 \mathrm{pW} / \mathrm{kg} / \mathrm{s})$ at Richland in November and at Edwin Markham School in December (see Table 4.7.4). Mean readings at the stations near Hanford were consistently between 7.4 and $8.9 \mu \mathrm{R} / \mathrm{h}$, (15.6 and $18.8 \mathrm{pW} / \mathrm{kg} / \mathrm{s})$ and readings at the distant station (Heritage College) ranged between 7.9 and $8.7 \mu \mathrm{R} / \mathrm{h}(16.7$ and $18.3 \mathrm{pW} / \mathrm{kg} / \mathrm{s})$. These average exposure rates were similar to exposure rates measured by thermoluminescent dosimeters at these locations (Table 4.7.5).

Table 4.7.5. $Q$ uarterly Average Exposure Rates $\left(\mu R / h^{[a, b]}\right)$ Measured by Thermoluminescent Dosimeters at Four Offsite Locations, ${ }^{(c)} 2001$

\begin{tabular}{|c|c|c|c|c|}
\hline & Leslie Groves Park & Basin City & Edwin Markham & Toppenish \\
\hline \multicolumn{5}{|c|}{ Q uarter Ending } \\
\hline March & NS & $8.9 \pm 0.08$ & $8.5 \pm 0.04$ & $7.8 \pm 0.21$ \\
\hline June & NS & $8.4 \pm 0.25$ & $8.5 \pm 0.13$ & $8.0 \pm 0.54$ \\
\hline September & NS & NS & $8.8 \pm 0.33$ & 7.7 \\
\hline December & 10.4 & $9.5 \pm 0.42$ & $9.1 \pm 0.46$ & $9.0 \pm 0.54$ \\
\hline
\end{tabular}

(a) \pm 2 standard deviations.

(b) To convert to international metric system units (picowatts per kilogram), multiply exposure rates by 2.109.

(c) Sampling locations shown on Figure 4.1.1.

NS $=$ No sample. 


\subsection{References}

40 CFR 141. U.S. Environmental Protection Agency. "National Primary Drinking Water Regulations; Radionuclides; Proposed Rule." Code of Federal Regulations.

American Society for Testing and Materials. 1993. "E 380-93 Standard Practice for Use of the International System of Units (SI) (the Modernized Metric System)." In Annual Book of ASTM Standards. Philadelphia, Pennsylvania.

ARH-CD-775. 1976. Geohydrologic Study of the West Lake Basin. R. E. Gephart, P. A. Eddy, R. C. Arnett, and G. A. Robinson, Atlantic Richfield Hanford Company, Richland, Washington.

Beasley, T. M., L. A. Ball, and J. E. Andrews III. 1981. "Hanford-Derived Plutonium in Columbia River Sediments." Science 214(20):913-915.

BNWL-1979. 1976. Environmental Surveillance at Hanford for CY-1975. D. R. Speer, J. J. Fix, and P. J. Blumer, Pacific Northwest Laboratory, Richland, Washington.

BNWL-2305. 1977. Association of Hanford Origin Radionuclides with Columbia River Sediment. D. E. Robertson and J. J. Fix, Pacific Northwest Laboratory, Richland, Washington.

City of Richland. 2002. City of Richland Water Quality Report 2001. City of Richland, Richland, Washington.

Clean Water Act. 1977. Public Law 95-217, as amended, 91 Stat. 1566 and Public Law 96-148 as amended.

Cushing, C. E., D. G. Watson, A. J. Scott, and J. M. Gurtisen. 1981. "Decrease of Radionuclides in Columbia River Biota Following Closure of the Hanford Reactors." Health Physics 41:59-67.

DOE/EH-0173T. 1991. Environmental Regulatory Guide for Radiological Effluent Monitoring and Environmental Surveillance. U.S. Department of Energy, Washington, D.C.

DOE Order 5400.1. "General Environmental Protection Program."

DOE Order 5400.5. "Radiation Protection of the Public and the Environment."
DOE/RL-91-50, Rev. 3. 2000. Environmental Monitoring Plan, United States Department of Energy Richland Operations Office. U.S. Department of Energy, Richland Operations Office, Richland, Washington. Available at http://www.hanford.gov/docs/rl-91-50/ index.htm

DOE/RL-92-12. 1992. Sampling and Analysis of 100 Area Springs. U.S. Department of Energy, Richland Operations Office, Richland, Washington.

DOE/RL-92-67. 1992. Final Remedial Investigation/ Feasibility Study - Environmental Assessment Report for the 1100-EM-1 Operable Unit, Hanford. U.S. Department of Energy, Richland Operations Office, Richland, Washington.

DOE/RL-95-55. 1995. Hanford Site Background: Evaluation of Existing Soil Radionuclide Data. U.S. Department of Energy, Richland Operations Office, Richland, Washington.

DOE/RL-96-12. 1996. Hanford Site Background: Part 2, Soil Background for Radionuclides. U.S. Department of Energy, Richland Operations Office, Richland, Washington.

Eisenbud, M. 1987. Environmental Radioactivity from Natural, Industrial, and Military Sources. Third Edition, Chapter 5, Academic Press, Inc., New York.

EPA-570/9-76-003. 1976. National Interim Primary Drinking Water Regulations. U.S. Environmental Protection Agency, Office of Water Supply, Washington, D.C.

EPA 822-R-96-001. 1996. Drinking Water Regulations and Health Advisories. U.S. Environmental Protection Agency, Office of Water, Washington, D.C.

HW-73672. 1962. Dispersion of 300 Area Liquid Effluent in the Columbia River. G. E. Backman, Hanford Atomic Products Operation, General Electric Company, Richland, Washington.

Jenkins, O. P. 1922. Underground Water Supply of the Region About White Bluffs and Hanford. State of Washington Department of Conservation and Development, Olympia, Washington. 
Morgan, G., S. Corbett, and J. Wlodarczyk. 1998. "Air Pollution and Hospital Admissions in Sydney, Australia, 1990 to 1994.” Am. J Public Health 88:1761-1766.

National Council on Radiation Protection and Measurements. 1987. Ionizing Radiation Exposure of the Population of the United States. NCRP Report No. 93, Bethesda, Maryland.

Ostro, B. D., S. Hurley, and M. J. Lipsett. 1999. "Air Pollution and Daily Mortality in the Coachella Valley, California: A Study of PM10 Dominated by Coarse Particles." Environmental Research 81:231-238.

Patton, G. W., A. T. Cooper, and M. R. Tinker. 1997. "Ambient Air Sampling for Tritium - Determination of Breakthrough Volumes and Collection Efficiencies for Silica Gel Absorbent." Health Physics 72:397-407.

PNL-3127. 1980. Radiological Survey of Exposed Shorelines and Islands of the Columbia River Between Vernita and the Snake River Confluence. M. J. Sula, Pacific Northwest Laboratory, Richland, Washington.

PNL-5289. 1984. Investigation of Ground-Water Seepage from the Hanford Shoreline of the Columbia River. W. D. McCormack and J.M.V. Carlile, Pacific Northwest Laboratory, Richland, Washington.

PNL-6584 (3 vols). 1988. GENII - The Hanford Environmental Radiation Dosimetry Software System. B. A. Napier, R. A. Peloquin, D. L. Strenge, and J. V. Ramsdell, Pacific Northwest Laboratory, Richland, Washington.

PNL-7124. 1989. The Determination of the Penetrating Radiation Dose at Hanford. L. A. Rathbun, Pacific Northwest Laboratory, Richland, Washington.

PNL-7500. 1990. 1988 Hanford Riverbank Springs Characterization Report. R. L. Dirkes, Pacific Northwest Laboratory, Richland, Washington.

PNL-7662. 1991. An Evaluation of the Chemical, Radiological, and Ecological Conditions of West Lake on the Hanford Site. T. M. Poston, K. R. Price, and D. R. Newcomer, Pacific Northwest Laboratory, Richland, Washington.

PNL-8073. 1992. Hanford Site Ground-Water Monitoring for 1990. J. C. Evans, R. W. Bryce, and D. J. Bates, Pacific Northwest Laboratory, Richland, Washington.

PNL-8148. 1992. Hanford Site Environmental Report for Calendar Year 1991. R. K. Woodruff, R. W. Hanf, and R. E. Lundgren (eds.), Pacific Northwest Laboratory, Richland, Washington.

PNL-8531. 1993. Columbia River Monitoring: Distribution of Tritium in Columbia River Water at the
Richland Pumphouse. R. L. Dirkes, Pacific Northwest Laboratory, Richland, Washington.

PNL-8580. 1993. Water Level Measurements for Modeling Hydraulic Properties in the 300-FF-5 and 100 Aggregate Area Operable Units. M. D. Campbell, W. J. McMahon, and K. R. Simpson, Pacific Northwest Laboratory, Richland, Washington.

PNL-8654. 1993. Columbia River Monitoring: Summary of Chemical Monitoring Along Cross Sections at Vernita Bridge and Richland. R. L. Dirkes, G. W. Patton, and B. L. Tiller, Pacific Northwest Laboratory, Richland, Washington.

PNL-8817. 1993. Contribution of Hanford Liquid Effluents to Strontium-90 Levels in Offsite Soils. R. E. Jaquish, Pacific Northwest Laboratory, Richland, Washington.

PNL-9394. 1994. Ecotoxicity Literature Review of Selected Hanford Site Contaminants. C. J. Driver, Pacific Northwest Laboratory, Richland, Washington.

PNL-10174. 1994. A Qualitative Evaluation of Radionuclide Concentrations in Hanford Site Wildlife, 1983 through 1992. T. M. Poston and A. T. Cooper, Pacific Northwest Laboratory, Richland, Washington.

PNL-10400. 1995. Identification of Contaminants of Concern, Columbia River Comprehensive Impact Assessment-Draft. B. A. Napier, N. C. Batishko, D. A. HeiseCraff, M. F. Jarvis, and S. F. Snyder, Pacific Northwest Laboratory, Richland, Washington.

PNL-10535. 1995. Environmental Monitoring of Columbia River Sediments: Grain-Size Distribution and Containment Association. M. L. Blanton, W. W. Gardiner, and R. L. Dirkes, Pacific Northwest Laboratory, Richland, Washington.

PNL-10575. 1995. Hanford Site Environmental Data for Calendar Year 1994 - Surface and Columbia River. L. E. Bisping, Pacific Northwest Laboratory, Richland, Washington.

PNL-10698. 1995. Hanford Site Ground-Water Monitoring for 1994. P. E. Dresel, P. D. Thorne, S. P. Luttrell, B. M. Gillespie, W. D. Webber, J. K. Merz, J. T. Rieger, M. A. Chamness, S. K. Wurstner, and B. E. Optiz, Pacific Northwest Laboratory, Richland, Washington.

PNL-10714. 1995. Nonradiological Chemical Pathway Analysis and Identification of Chemicals of Concern for Environmental Monitoring at the Hanford Site. M. L. Blanton, A. T. Cooper, and K. J. Castleton, Pacific Northwest Laboratory, Richland, Washington. 
PNNL-11140. 1995. 1995 Surface Environmental Surveillance Data. L. E. Bisping, Pacific Northwest National Laboratory, Richland, Washington.

PNNL-11472. 1997. Hanford Site Environmental Report for Calendar Year 1996. R. L. Dirkes and R. W. Hanf (eds.), Pacific Northwest National Laboratory, Richland, Washington.

PNNL-11473. 1997. Hanford Site Environmental Data for Calendar Year 1996. L. E. Bisping, Pacific Northwest National Laboratory, Richland, Washington.

PNNL-11795. 1998. Hanford Site Environmental Report for Calendar Year 1997. R. L. Dirkes and R. W. Hanf (eds.), Pacific Northwest National Laboratory, Richland, Washington.

PNNL-11796. 1998. Hanford Site Environmental Data for Calendar Year 1997. L. E. Bisping, Pacific Northwest National Laboratory, Richland, Washington.

PNNL-11933. 1998. Survey of Radiological Contaminants in the Near Shore Environment at the Hanford Site 100-N Reactor Area. S. P. Van Verst, C. L. Albin, G. W. Patton, M. L. Blanton, T. M. Poston, A. T. Cooper, and E. J. Antonio, Pacific Northwest National Laboratory, Richland, Washington.

PNNL-12088. 1999. Hanford Site Environmental Report for Calendar Year 1998. R. L. Dirkes, R. W. Hanf, and T. M. Poston (eds.), Pacific Northwest National Laboratory, Richland, Washington.

PNNL-13230. 2000. Hanford Site Environmental Report for Calendar Year 1999. T. M. Poston, R. W. Hanf, and R. L. Dirkes (eds.), Pacific Northwest National Laboratory, Richland, Washington.

PNNL-13417. 2001. Simultaneously-Extracted Metals/ Acid-Volatile-Sulfide and Total Metals in Surface Sediment from the Hanford Reach of the Columbia River and the Lower Snake River. G. W. Patton and E. A. Crecelius, Pacific Northwest National Laboratory, Richland, Washington.

PNNL-13418. 2001. Hanford Site Environmental Surveillance Master Sampling Schedule. L. E. Bisping, Pacific Northwest National Laboratory, Richland, Washington.

PNNL-13487. 2001. Hanford Site Environmental Report for Calendar Year 2000. T. M. Poston, R. W. Hanf, R. L. Dirkes, and L. F. Morasch (eds.), Pacific Northwest National Laboratory, Richland, Washington.

PNNL-13692. 2002. Survey of Radiological and Chemical Contaminants in the Near-Shore Environment at the Hanford Site 300 Area. G. W. Patton, S. P. Van Verst,
B. L. Tiller, E. J. Antonio, and T. M. Poston, Pacific Northwest National Laboratory, Richland, Washington.

PNNL-13909. 2002. Radionuclide Concentrations in Air on the Hanford Site: A Ten-Year Trend Report. B. G. Fritz and G. W. Patton, Pacific Northwest National Laboratory, Richland, Washington.

PNNL-13910, APP. 1. 2002. Hanford Site Environmental Surveillance Data Report for Calendar Year 2001. L. E. Bisping, Pacific Northwest National Laboratory, Richland, Washington.

Safe Drinking Water Act. 1974. Public Law 93-523, as amended, 88 Stat. 1660, 42 USC 300 f et seq.

Schwartz, J. 1994. " $\mathrm{PM}_{10}$, Ozone, and Hospital Admissions for the Elderly in Minneapolis-St. Paul, Minnesota." Archives of Environmental Health 49(5):366-373.

Shleien, B. 1992. The Health Physics and Radiological Health Handbook, Revised Edition. Scinta, Inc., Silver Spring, Maryland.

U.S. Geological Survey. 1995. Nitrate Concentrations in Ground Water of the Central Columbia Plateau. Open File Report 95-445, U.S. Geological Survey, Tacoma, Washington.

U.S. Geological Survey Circular 1144. "Water Quality in the Central Columbia Plateau, Washington and Idaho, 1992-95.” A. K. Williamson, M. D. Munn, S. J. Ryker, R. J. Wagner, J. C. Ebbert, and A. M. Vanderpool, U.S. Geological Survey, Tacoma, Washington.

WA-94-1. 1995. Water Resources Data, Washington Water Year 1994. W. D. Wiggins, G. P. Ruppert, R. R. Smith, L. L. Reed, L. E. Hubard, and M. L. Courts, U.S. Geological Survey, Tacoma, Washington.

WA-99-1. 2000. Water Resources Data Washington Water Year 1999. T. J. Zembrzuski, Jr., W. D. Wiggins, R. R. Smith, S. M. Knowles, and V. F. Renslow, U.S. Department of Interior, Washington, D.C.

WAC 173-201A. "Water Quality Standards for Surface Waters of the State of Washington." Washington Administrative Code, Olympia, Washington.

WAC 173-201A-40. "Toxic Substances." Washington Administrative Code, Olympia, Washington.

WAC 246-290. "Group A Public Water Supplies." Washington Administrative Code, Olympia, Washington.

Wells, D. 1994. Radioactivity in Columbia River Sediments and Their Health Effects. Washington State Department of Health, Olympia, Washington. 
WHC-SD-EN-TI-006. 1992. Hydrologic and Geologic Data Available for the Region North of Gable Mountain, Hanford Site, Washington. R. E. Peterson, Westinghouse Hanford Company, Richland, Washington.
Wyerman, T. A., R. K. Farnswirth, and G.L.Stewart. 1970. "Tritium in Streams in the United States, 1961-1968." Radiological Health Data and Reports, pp. 421-429. 


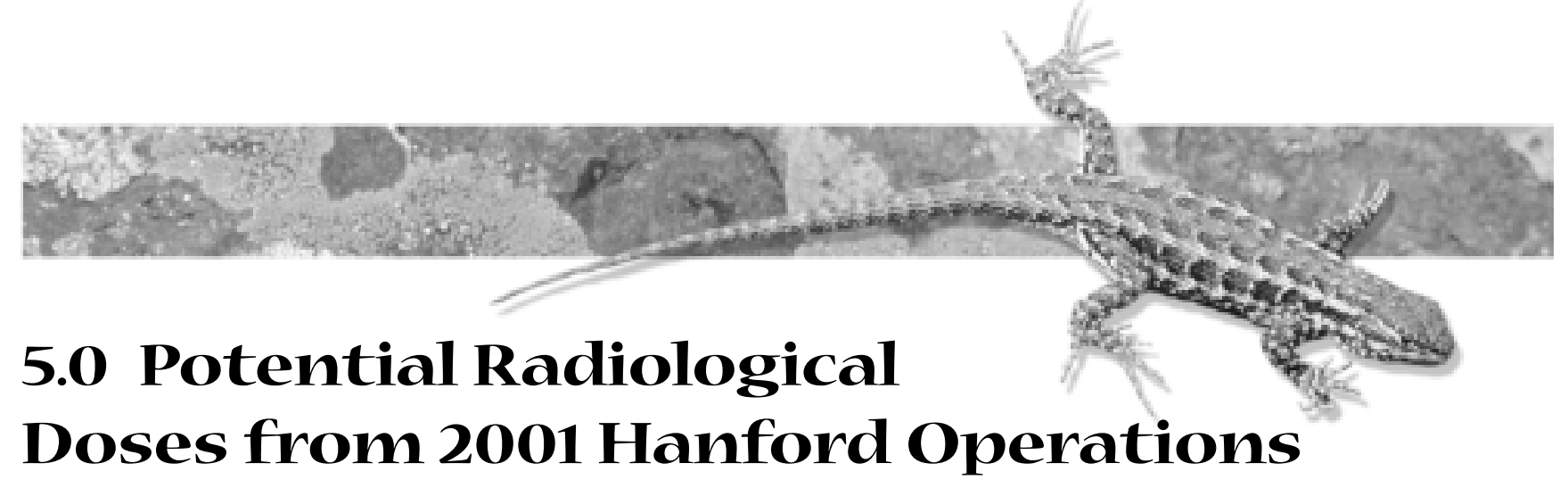

\author{
E. J. Antonio and K. Rhoads
}

During 2001, potential radiological doses to the public and biota from Hanford Site operations were evaluated in detail to determine compliance with pertinent regulations and limits. The potential sources of radionuclide contamination included gaseous emissions from stacks and ventilation exhausts, liquid effluents from operating wastewater treatment facilities, and contaminated groundwater seeping into the Columbia River. Other potential sources included fugitive emissions from contaminated soil areas and facilities. The methods used to calculate the potential doses are detailed in Appendix E.

The radiological impact of 2001 Hanford Site operations was assessed in terms of the:

- dose to a hypothetical, maximally exposed individual at an offsite location using a multimedia pathway assessment (U.S. Department of Energy [DOE] Order 5400.5; see Section 5.0.1)

- collective dose to the population residing within 80 kilometers (50 miles) of Hanford Site operating areas (see Section 5.0.2)

- dose for air pathways, using U.S. Environmental Protection Agency (EPA) methods, for comparison to the Clean Air Act standards in 40 CFR 61, Subpart H (see Section 5.0.3)

- maximum dose rate from external radiation at a publicly accessible location at or just within the site boundary (see Section 5.0.4.1)

- dose to an avid sportsman who consumes wildlife that may have been contaminated with radionuclides originating on the site (see Section 5.0.4.2)

- inhalation dose associated with measured radionuclide concentrations in air (see Section 5.0.4.4)
- absorbed dose received by animals exposed to radionuclide releases to the Columbia River and to radionuclides in onsite surface water bodies (see Section 5.0.6).

It is generally accepted that radiological dose assessments should be based on direct measurements of radiation dose rates and radionuclide concentrations. However, the amounts of most radioactive materials released during 2001 from Hanford Site sources were generally too small to be measured directly once they were dispersed in the offsite environment. For many of the radionuclides present in measurable amounts, it was difficult to separate the contributions from Hanford sources from the contributions from worldwide fallout and from naturally occurring uranium and its decay products. Therefore, in nearly all instances, offsite doses were estimated using GENII - The Hanford Environmental Radiation Dosimetry Software System, Version 1.485 (PNL-6584) and the Hanford Site-specific parameters listed in Appendix E and in PNNL-13910, APP. 1. As a comparison, air surveillance data were used to assess the maximum inhalation doses at onsite and offsite monitoring stations.

As in the past, radiological doses from the water pathway were calculated based on the differences in radionuclide concentrations between upstream and downstream sampling points on the Columbia River. During 2001, tritium, technetium-99, iodine-129, and uranium isotopes were found in the Columbia River downstream of Hanford at greater levels than predicted based on direct discharges from the 100 Areas (see Section 4.2 and Appendix B). All other radionuclide concentrations were lower than those predicted from known releases. Riverbank spring water, containing radionuclides, is known to enter the river along the portion of shoreline extending from the 100-B/C Area downstream to the 300 Area (see Sections 4.2 and 7.1). No direct discharge of radioactive materials from the 300 Area to the Columbia River was reported in 2001. 


\subsubsection{Maximally Exposed Individual Dose (Offsite Resident)}

The maximally exposed individual is a hypothetical person who lives at a location and has a lifestyle that makes it unlikely that any other member of the public would receive a higher radiological dose. This individual's exposure pathways were chosen to maximize the combined doses from all reasonable environmental routes of exposure to radionuclides in Hanford Site effluents and emissions using a multimedia pathway assessment (DOE Order 5400.5). In reality, such a combination of maximized parameters is highly unlikely to apply to any single individual.

The location of the hypothetical maximally exposed individual can vary from year to year, depending on the relative contributions of the several sources of radioactive effluents released to the air and to the Columbia River from Hanford facilities (Figure 5.0.1). In 2001, the dose assessment determined that the DOE maximally exposed individual was located across the Columbia River from the 300 Area, at Sagemoor (see Figure 5.0.1). For the calculation, it was assumed that this individual:

- inhaled and was submersed in airborne radionuclides

- received external exposure to radionuclides deposited on the ground
- ingested locally grown food products that had been irrigated with water from the Columbia River

- used the Columbia River for recreational purposes, resulting in direct exposure from water and radionuclides deposited on the shoreline

- ingested locally caught fish.

Doses were calculated using effluent data in Tables 3.1.1 and 3.1.4 and the calculated quantities of radionuclides assumed to be present in the Columbia River from riverbank springs. The estimated releases to the river from these sources were derived from the difference between the upstream and downstream concentrations. These radionuclides were assumed to enter the river through groundwater seeps between the 100-B/C Area and the 300 Area.

The calculated doses for the DOE maximally exposed individual in 2001 are summarized in Table 5.0.1. Site-specific parameters for food pathways, diet, and recreational activity used for the dose calculations are contained in Appendix E (Tables E.1, E.2, and E.4, respectively).

Historically at Hanford, there has been one primary expression of radiological risk to an offsite individual: this is the maximally exposed individual dose. However, the maximally exposed individual dose is currently calculated by two different methods in response to two different requirements:

- One maximally exposed individual dose computation is required by DOE Order 5400.5 and is calculated using the GENII computer code. This calculation considers all reasonable environmental pathways (e.g., air, water, food) that maximize a hypothetical individual offsite exposures to Hanford's radiological effluents and emissions.

- A second estimate of maximally exposed individual dose is required by the Clean Air Act and is calculated using an EPA dose modeling computer code (CAP-88) or other methods accepted by EPA for estimating offsite exposure. This offsite dose is based solely on an airborne radionuclide emissions pathway and considers Hanford's stack emissions and emissions from diffuse and unmonitored sources (e.g., windblown dust).

Because the DOE and EPA computer codes use different input parameters, the location and predicted dose of each agency's maximally exposed individual may be different. However, the estimated doses from both methods have historically been significantly lower than health-based exposure criteria.

Recently, DOE has allowed private businesses to locate their activities and personnel on the Hanford Site. This has created the need to calculate a maximum onsite occupational dose for an individual who is employed by a non-DOE business and works within the boundary of the Hanford Site. This dose is based on a mix of air emission modeling data, the individual's exposure at an onsite work location, and the individual's potential offsite exposure.

Another way to estimate risk is to calculate the collective dose. This dose is based on exposure to Hanford radiological contaminants through the food, water, and air pathways and is calculated for the population residing within 80 kilometers (50 miles) of the Hanford Site operating areas. The collective dose is reported in units of person-rem (personsievert), which is the average estimated individual dose multiplied by the total number of people in the population. 


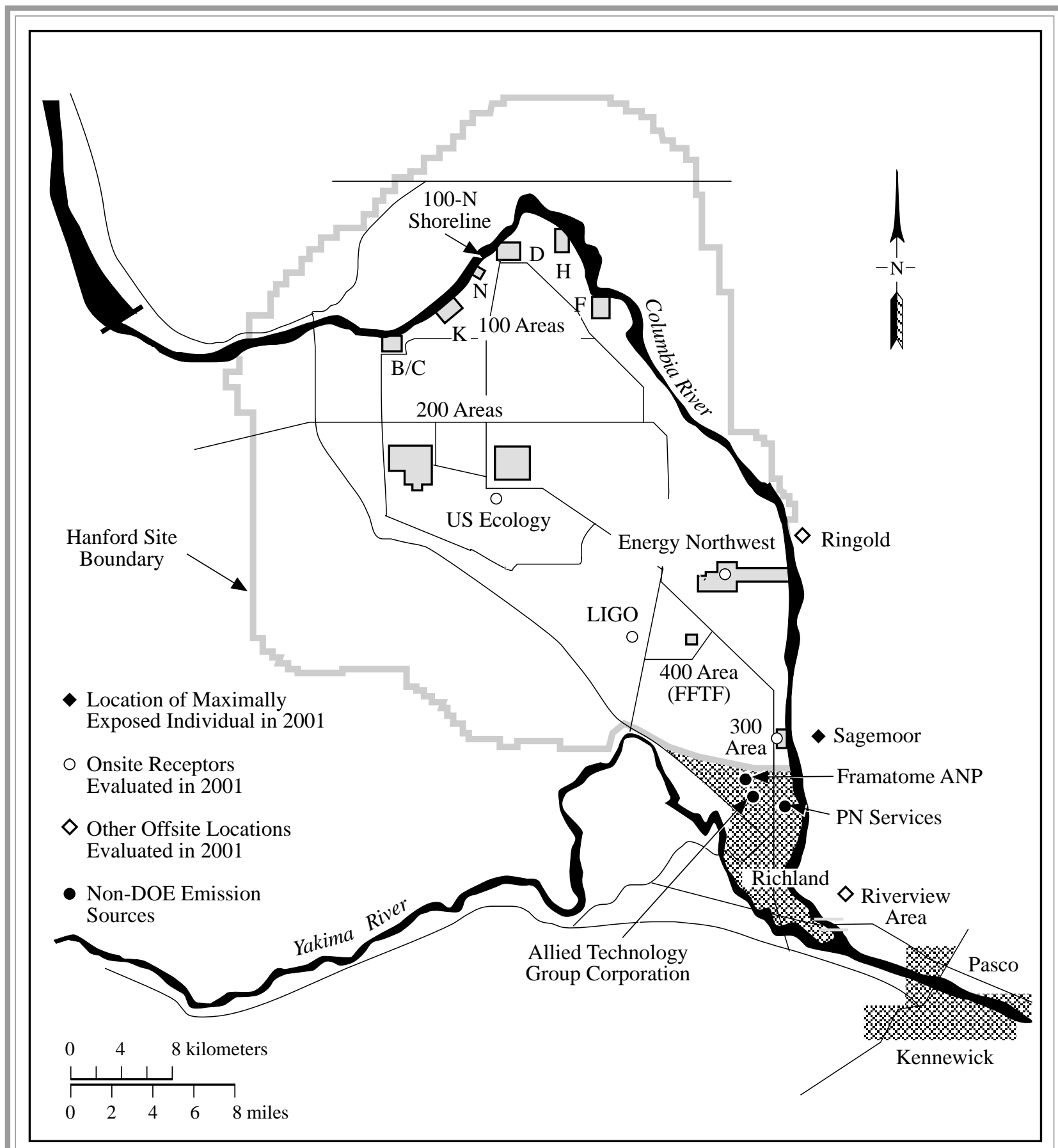

G02020072.96

Figure 5.0.1. Locations Important to Dose Calculations 


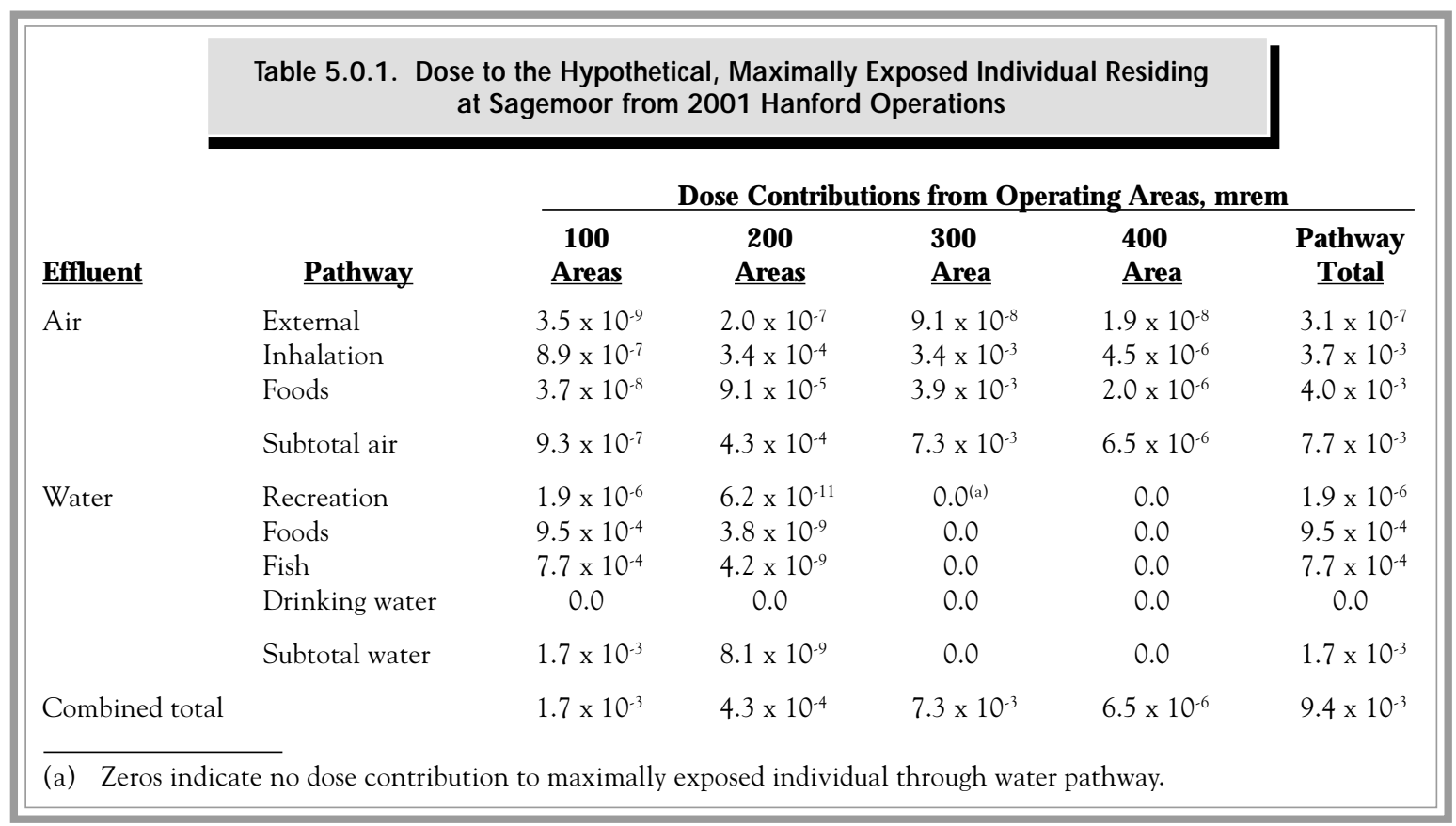

In 2001, the total dose to the DOE maximally exposed individual at Sagemoor was calculated to be $0.009 \mathrm{mrem} / \mathrm{yr}\left(9 \times 10^{-5} \mathrm{mSv} / \mathrm{yr}\right)$. The primary pathways contributing to this dose (and the percentage of all pathways) were:

- the consumption of food products grown downwind of Hanford (42\%) and inhalation of air downwind of Hanford (39\%), exposed principally to airborne releases of tritium from the 300 Area

- the consumption of fish from the Columbia River $(10 \%)$ or foods irrigated with water withdrawn downstream of Hanford (8\%), containing principally strontium-90.

The dose calculated for the maximally exposed individual for 2001 was $0.009 \%$ of the DOE limit of $100 \mathrm{mrem} / \mathrm{yr}(1 \mathrm{mSv} / \mathrm{yr})$ specified in DOE Order 5400.5. For comparison purposes, the doses from Hanford operations for the maximally exposed individuals for 1997 through 2001 are illustrated in Figure 5.0.2.

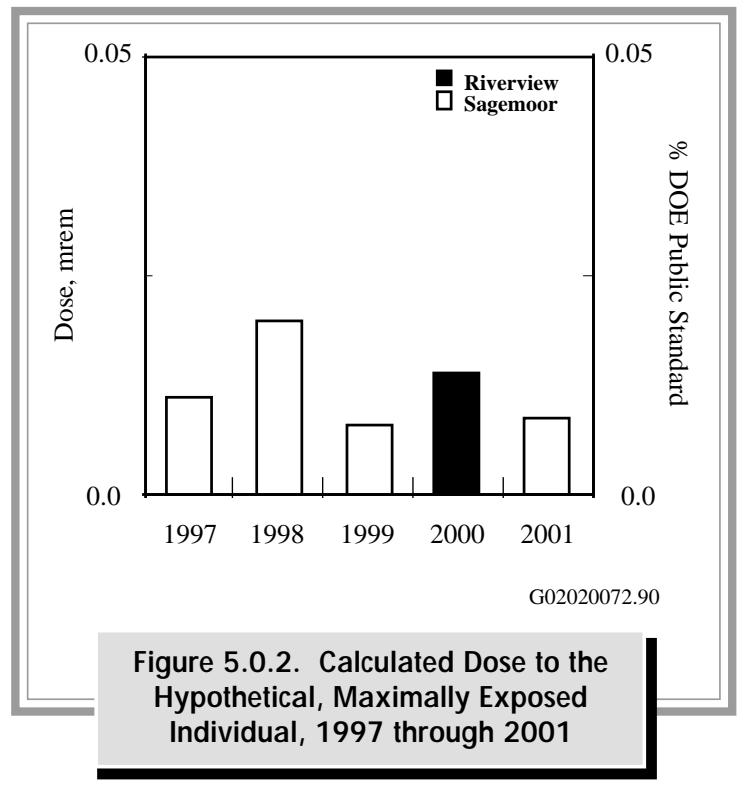

\subsubsection{Collective Dose}

The regional collective dose from 2001 Hanford Site operations was estimated by calculating the radiological dose to the population residing within an 80-kilometer (50-mile) radius of the onsite operating areas. Collective dose is defined as the sum of doses to all individual members of the public within 80 kilometers (50 miles) of the operating areas at Hanford. In
2001, the collective dose calculated for the population was 0.4 person-rem/yr (0.004 person-Sv/yr), a slight increase from the 2000 collective dose $(0.3$ person-rem/yr [0.003 person-Sv/yr]) (Table 5.0.2). Summaries of technical details for the calculations of dose from airborne releases are given in Appendix E, Tables E.5 to E.9. 
Table 5.0.2. Collective Dose to the Population from 2001 Hanford O perations

\begin{tabular}{|c|c|c|c|c|c|c|}
\hline Effluent & Pathway & $\begin{array}{c}100 \\
\text { A reas }\end{array}$ & $\begin{array}{c}200 \\
\text { A reas }\end{array}$ & $\begin{array}{c}300 \\
\text { Area }\end{array}$ & $\begin{array}{c}400 \\
\text { Area }\end{array}$ & $\begin{array}{c}\text { Pathway } \\
\text { Total }\end{array}$ \\
\hline \multirow[t]{4}{*}{ Air } & External & $7.1 \times 10^{-7}$ & $2.2 \times 10^{-5}$ & $9.2 \times 10^{-7}$ & $9.6 \times 10^{-7}$ & $2.5 \times 10^{-5}$ \\
\hline & Inhalation & $2.7 \times 10^{-4}$ & $5.4 \times 10^{-2}$ & $5.1 \times 10^{-2}$ & $3.4 \times 10^{-4}$ & $1.1 \times 10^{-1}$ \\
\hline & Foods & $1.1 \times 10^{-5}$ & $1.3 \times 10^{-2}$ & $2.8 \times 10^{-1}$ & $2.3 \times 10^{-4}$ & $2.9 \times 10^{-1}$ \\
\hline & Subtotal air & $2.8 \times 10^{-4}$ & $6.7 \times 10^{-2}$ & $3.3 \times 10^{-1}$ & $5.7 \times 10^{-4}$ & $4.0 \times 10^{-1}$ \\
\hline \multirow[t]{5}{*}{ Water } & Recreation & $1.4 \times 10^{-5}$ & $3.0 \times 10^{-10}$ & $0.0^{(a)}$ & 0.0 & $1.4 \times 10^{-5}$ \\
\hline & Foods & $9.9 \times 10^{-4}$ & $3.9 \times 10^{-9}$ & 0.0 & 0.0 & $9.9 \times 10^{-4}$ \\
\hline & Fish & $2.9 \times 10^{-4}$ & $1.6 \times 10^{-9}$ & 0.0 & 0.0 & $2.9 \times 10^{-4}$ \\
\hline & Drinking water & $2.4 \times 10^{-3}$ & $4.6 \times 10^{-8}$ & 0.0 & 0.0 & $2.4 \times 10^{-3}$ \\
\hline & Subtotal water & $3.7 \times 10^{-3}$ & $5.2 \times 10^{-8}$ & 0.0 & 0.0 & $3.7 \times 10^{-3}$ \\
\hline \multicolumn{2}{|c|}{ Combined total } & $4.0 \times 10^{-3}$ & $6.7 \times 10^{-2}$ & $3.3 \times 10^{-1}$ & $5.7 \times 10^{-4}$ & $4.0 \times 10^{-1}$ \\
\hline
\end{tabular}

(a) Zeros indicate no dose contribution to the population through the water pathway.

Primary pathways contributing to the 2001 collective dose included:

- inhalation of radionuclides (28\%) that were released to the air, principally tritium from 300 Area stacks and plutonium isotopes emitted from 200 Areas stacks

- consumption of foodstuffs (72\%) contaminated with radionuclides, principally tritium from 300 Area stacks and plutonium isotopes emitted from 200 Areas stacks.

The 80-kilometer (50-mile) collective doses attributed to Hanford operations from 1997 through 2001 are compared in Figure 5.0.3. Collective doses reported for 2001 are based on population data from the 2000 census, whereas doses for 1997 to 2000 were based on the 1990 census. Between 1990 and 2000, the population within 80 kilometers (50 miles) of the major operating areas on the Hanford Site increased by $24 \%$ to $29 \%$. This change accounts for part of the increase in collective dose from 2000 to 2001 shown in Figure 5.0.3.

The average individual dose from 2001 Hanford Site operations based on a population of 486,000 within 80 kilometers $(50$ miles) was $0.0008 \mathrm{mrem} / \mathrm{yr}$ $(0.008 \mu \mathrm{Sv} / \mathrm{yr})$. To place this estimated dose into perspective, it may be compared with doses received from other routinely encountered sources of radiation such as natural terrestrial and cosmic background radiation, medical treatment and $\mathrm{x}$-rays, natural radionuclides in the body, and inhalation of naturally occurring radon. The national annual average radiological dose from these other sources is illustrated in Figure 5.0.4. The

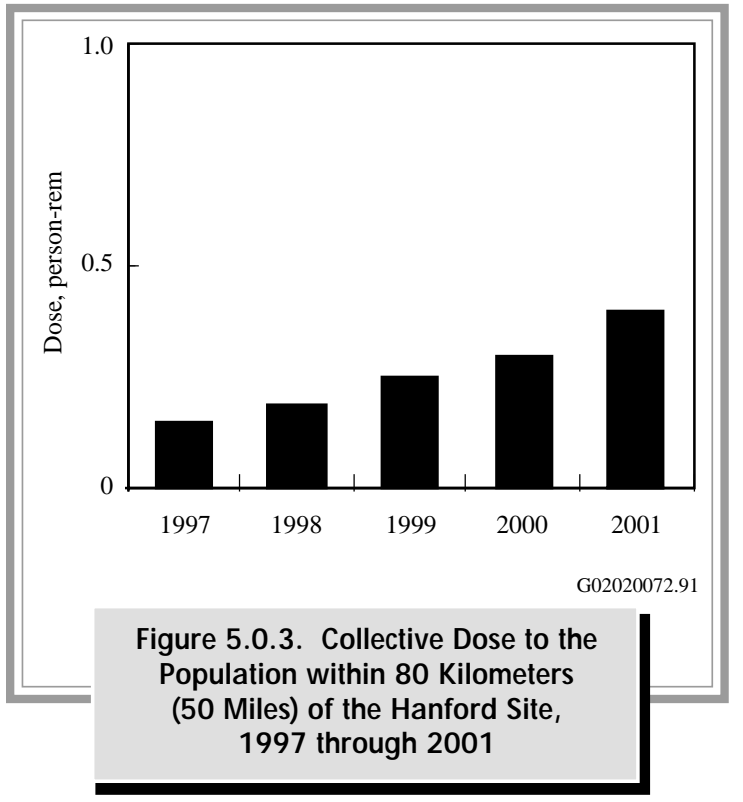

estimated annual average individual dose to members of the public from Hanford Site sources in 2001 was $\sim 0.0003 \%$ of the estimated annual individual dose (300 mrem) received from natural background sources.

The doses from Hanford effluents to the DOE maximally exposed individual and to the population within 80 kilometers ( 50 miles) are compared to appropriate standards and natural background radiation in Table 5.0.3. This table shows that the calculated radiological doses from Hanford Site operations in 2001 were a small percentage of the standards and of doses from natural background sources. 


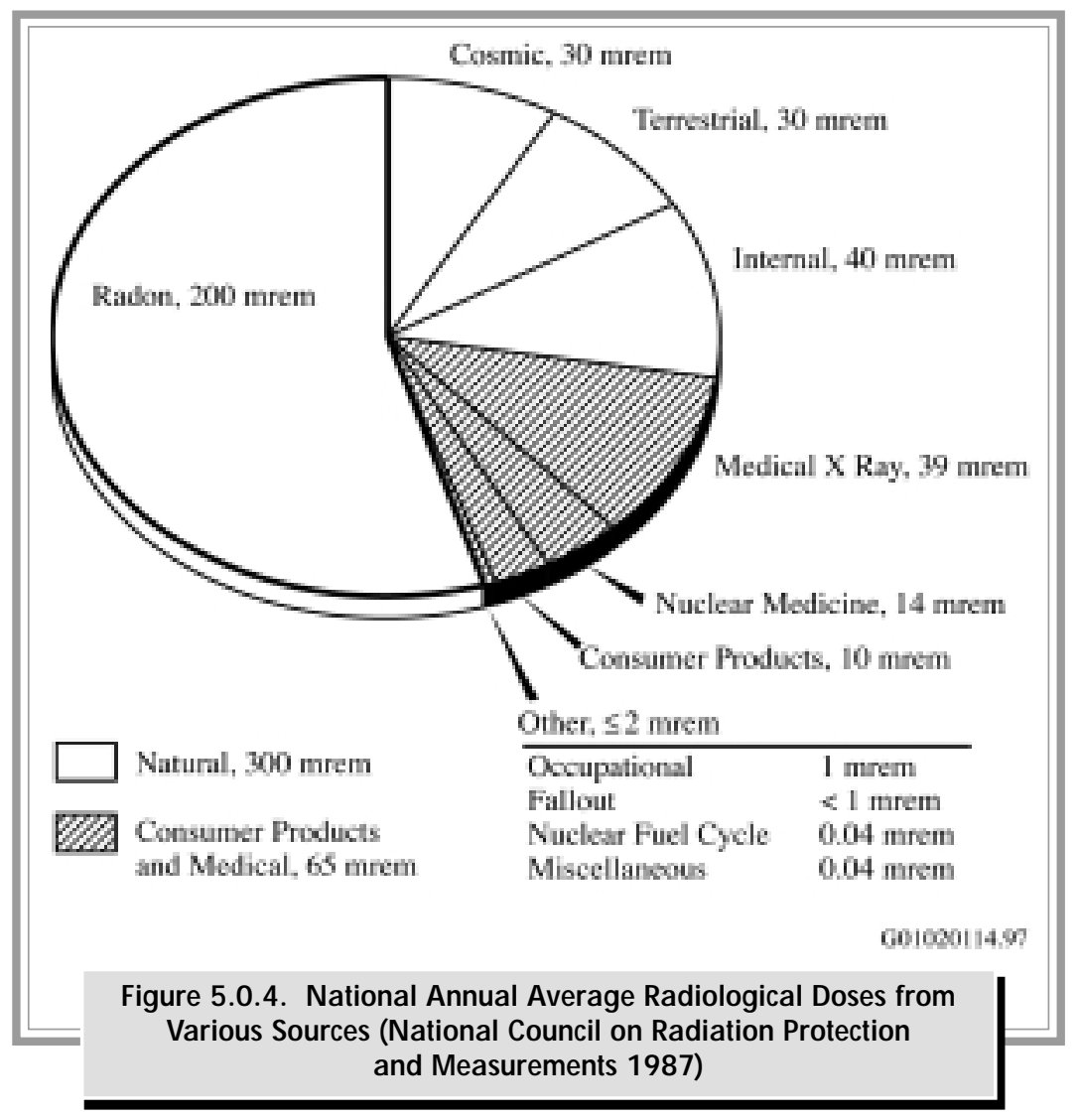

Table 5.0.3. Comparison of Doses to the Public from Hanford Effluents to Federal Standards and Natural Background

\section{Standard}

DOE - $100 \mathrm{mrem} / \mathrm{yr}$ all pathways $\mathrm{MEI}^{(\mathrm{b}, \mathrm{c})}$

EPA - $10 \mathrm{mrem} / \mathrm{yr}$ air pathway $\mathrm{MEI}^{(\mathrm{d})}$

\section{Background Dose}

$300 \mathrm{mrem} / \mathrm{yr}$ average

U.S. individual ${ }^{(\mathrm{e})}$

$$
0.009 \mathrm{mrem} / \mathrm{yr}
$$

110,000 person-rem/yr

to population within

$80 \mathrm{~km}(50 \mathrm{mi})$

0.4 person-rem/yr

0.0004

(a) To convert the dose values to $\mathrm{mSv}$ or person-Sv, divide by 100 .

(b) DOE Order 5400.5.

(c) MEI = Maximally exposed individual.

(d) 40 CFR 61.

(e) National Council on Radiation Protection and Measurements (1987). 


\subsubsection{Compliance with Clean Air Act Standards}

In addition to complying with the all-pathways dose limits established by DOE Order 5400.5, DOE facilities are required to demonstrate that they comply with standards established by the EPA for airborne radionuclide emissions under the Clean Air Act in 40 CFR 61, Subpart H. This regulation specifies that no member of the public shall receive a dose greater than $10 \mathrm{mrem} / \mathrm{yr}$ $(0.1 \mathrm{mSv} / \mathrm{yr})$ from exposure to airborne radionuclide emissions, other than radon, released at DOE facilities. Whereas DOE uses the GENII computer code at Hanford to determine dose to the all-pathways maximally exposed individual, EPA requires the use of CAP-88 (EPA 402-R-00-004) or other EPA-approved models to demonstrate compliance with the requirements in 40 CFR 61, Subpart H. The assumptions embodied in the CAP-88 code differ slightly from standard assumptions used with the GENII code. Therefore, air pathway doses calculated by the two codes may differ somewhat. In addition, the maximally exposed individual for air pathways may be evaluated at a different location from the all-pathways maximally exposed individual discussed in Section 5.0.1 because of the relative contributions from each exposure pathway.

The EPA regulation also requires that each $\mathrm{DOE}$ facility submit an annual report to EPA that supplies information about atmospheric emissions for the preceding year and their potential offsite dose. For more detailed information about 2001 air emissions on the Hanford Site, refer to DOE's report to EPA (DOE/ RL-2002-20).

Maximum Dose to Non-DOE Workers on the Site. The DOE Richland Operations Office received guidance from EPA Region 10 and the Washington State Department of Health that, in demonstrating compliance with the 40 CFR 61 standards, it should evaluate potential doses to non-DOE employees who work on the Hanford Site, but who are not under direct DOE control. Accordingly, the doses to members of the public employed at non-DOE facilities that were outside accesscontrolled areas on the Hanford Site were evaluated for the 2001 EPA air emissions report (DOE/RL-2002-20). These locations included the Columbia Generating Station operated by Energy Northwest, the Laser Interferometer Gravitational Wave Observatory (LIGO) operated by the University of California, a commercial metal extrusion facility in the 313 Building at the north end of the 300 Area (leased until January 2002), and a research laboratory on the west side of the 300 Area leased to Washington State University (see Figure 5.0.1). Because 300 Area emissions accounted for the majority of the air pathway dose during 2001, a person working in the commercial metal extrusion facility in the 300 Area received the highest dose for non-DOE employees who worked on the Hanford Site. The dose was calculated to be $0.12 \mathrm{mrem} / \mathrm{yr}(0.0012 \mathrm{mSv} / \mathrm{yr})$, assuming full-time occupancy at that location for the year.

EPA guidance does not currently permit adjustment of doses calculated using the CAP-88 code to account for less than full-time occupancy at locations within the site boundary. However, if a realistic occupancy period of 2,000 hours per year were assumed for workers at onsite non-DOE facilities, the doses to individuals at any of the locations evaluated would be lower than the dose to the maximally exposed offsite individual that has historically been evaluated for compliance with the EPA standard. Methods to estimate doses to individuals within the site boundary are currently under discussion by DOE and EPA.

Maximum Dose to an Offsite Maximally Exposed Individual. In 2001, the maximally exposed offsite individual for air pathways using EPA specified methods was determined to be at a location in the Sagemoor area of Franklin County, $\sim 1.5$ kilometers ( $\sim 1$ mile) directly across the Columbia River from the 300 Area (see Figure 5.0.1). The potential air pathway dose from stack emissions to a maximally exposed individual at that location was calculated to be $0.048 \mathrm{mrem} / \mathrm{yr}(0.00048 \mathrm{mSv} / \mathrm{yr})$, which represented $<0.5 \%$ of the EPA standard. This corresponds to the dose for offsite individuals calculated for previous annual air emission reports to EPA.

Dose from Diffuse and Fugitive Sources of A irborne Radionuclides. The December 15, 1989, revisions to the Clean Air Act (40 CFR 61, Subpart H) required DOE facilities to estimate the dose to a member of the public for radionuclides released from all potential sources of airborne radionuclides. DOE and EPA interpreted the regulation to include diffuse and fugitive sources as well as monitored point sources (i.e., stacks). EPA has not specified or approved methods to estimate air emissions from diffuse sources, and standardization has been difficult because of the wide variety of such sources at DOE sites. The method developed at Hanford to estimate potential diffuse source emissions is based on environmental surveillance measurements of airborne radionuclides at the site perimeter, as described in DOE/RL-2002-20. During 2001, the estimated dose to a maximally exposed individual at a location in the Sagemoor area from diffuse sources was $0.38 \mathrm{mrem} / \mathrm{yr}$ $(0.0038 \mathrm{mSv} / \mathrm{yr})$. The dose to a non-DOE worker in the 300 Area from diffuse and fugitive sources would be 
similar to, or lower than, the dose at the site perimeter. Therefore, the potential combined dose from stack emissions and diffuse sources during 2001 was well below the EPA $10 \mathrm{mrem} / \mathrm{yr}(0.1 \mathrm{mSv} / \mathrm{yr})$ standard for either onsite or offsite members of the public.

\subsubsection{Special Case Dose Estimates}

The parameters used to calculate the dose to the DOE maximally exposed individual were selected to provide a scenario yielding a reasonable upper (or bounding) estimate of the dose. However, such a scenario may not have necessarily resulted in the highest conceivable radiological dose. Other low-probability exposure scenarios existed that could have resulted in somewhat higher doses. Four scenarios that could have potentially lead to larger doses included (1) an individual who spent time at the site boundary location with the maximum external radiological dose rate, (2) a sportsman who consumed contaminated wildlife that migrated from the site, (3) a person who drank water at the Fast Flux Test Facility in the 400 Area, and (4) an individual who breathed the measured radionuclide concentrations in air for an entire year. The potential doses resulting from these scenarios are examined in the following sections.

\subsubsection{Maximum "Boundary" Dose Rate}

The boundary radiological dose rate is the external radiological dose rate measured at publicly accessible locations at or near the Hanford Site boundary. The maximum boundary dose rate was determined from radiation exposure measurements using thermoluminescent dosimeters at locations where elevated dose rates might be expected on the site and at representative locations off the site. These boundary dose rates were not used to calculate annual doses to the general public because no one could actually reside at any of these boundary locations. However, these rates were used to determine the dose to a specific individual who might have spent some time at that location.

External radiological dose rates measured in 2001 are described in Section 4.6. Radiation measurements made along the 100-N Area shoreline (see Figure 5.0.1) were consistently above background levels and represented the highest measured boundary dose rates. The Columbia River provided public access to within $\sim 100$ meters ( 330 feet) of the N Reactor and supporting facilities at this location.

The highest dose rate along the 100-N Area shoreline during 2001 was $0.015 \mathrm{mrem} / \mathrm{h}(0.00015 \mathrm{mSv} / \mathrm{h})$, or $\sim 1.5$ times the average dose rate of $0.01 \mathrm{mrem} / \mathrm{h}$ $(0.0001 \mathrm{mSv} / \mathrm{h})$ normally observed at other shoreline locations. Therefore, for every hour someone spent near the 100-N Area shoreline during 2001, the external radiological dose received from Hanford operations was $\sim 0.005 \mathrm{mrem}(\sim 0.00005 \mathrm{mSv})$ above the average shoreline dose rate. If an individual had spent 2 hours at that location, he or she would have received a dose comparable to the annual dose calculated for the hypothetical maximally exposed individual at Sagemoor. Members of the public could reach the $100-\mathrm{N}$ shoreline by boat and could have legally occupied the shoreline area below the high water line. However, the topography of the shoreline below the high water line near the $100-\mathrm{N}$ Area is very rocky and visitors are not likely to remain on shore for extended periods.

\subsubsection{Sportsman Dose}

Wildlife have access to areas of the Hanford Site that are contaminated with radioactive materials. Sometimes wildlife acquire radioactive contamination and migrate off the site. Wildlife sampling was conducted on the site to estimate the maximum contamination levels that might have existed in animals from Hanford that were hunted off the site. Because this scenario had a relatively low probability of occurrence, this pathway was not considered in the maximally exposed individual calculation.

Radionuclide concentrations in most consumable portions of wildlife obtained within the Hanford Site boundary were below contractual detection limits for gamma-emitting radionuclides, except for naturally occurring potassium-40 and for cesium-137 in one goose sample collected at a background location (see Section 4.5). The radiological dose to a person consuming 1 kilogram (2.2 pounds) of that goose was calculated to be $\sim 7 \mu \mathrm{rem}(\sim 0.07 \mu \mathrm{Sv})$. Strontium-90 was the only radionuclide, possibly of Hanford origin, detected in wildlife samples in 2001 and was only found in bone samples. Because bone is not consumed by humans, a dose to a sportsman from this pathway was viewed as relatively implausible and was not included in this report.

\subsubsection{Onsite Drinking Water}

During 2001, groundwater was used as drinking water by workers at the Fast Flux Test Facility in the 400 Area, and Columbia River water was used as a 
drinking water source in the $100-\mathrm{B}, 100-\mathrm{D}, 100-\mathrm{K}$, and 200 Areas. Therefore, these water supplies were sampled and analyzed throughout the year in accordance with applicable drinking water regulations (40 CFR 141). All annual average radionuclide concentrations measured during 2001 were below applicable drinking water standards. However, tritium in the Fast Flux Test Facility groundwater wells was detected at levels greater than typical background values (see Section 4.3 and Appendix E).

Based on the measured concentrations, the potential annual dose to Fast Flux Test Facility workers (an estimate derived by assuming a consumption of 1 liter [0.26 gallon] per day for 240 working days) would be $\sim 0.02 \mathrm{mrem}(\sim 0.2 \mu \mathrm{Sv})$. This dose is well below the drinking water dose limit of $4 \mathrm{mrem} / \mathrm{yr}(40 \mu \mathrm{Sv} / \mathrm{yr})$ for public drinking water supplies.

\subsubsection{Inhalation Doses for Entire Year}

Air surveillance data presented in Section 4.1 (Tables 4.1.2 and 4.1.3) were used to determine radiological doses from inhaling radionuclides in air. A nominal inhalation rate of 23 cubic meters ( 812 cubic feet) per day of air and an exposure period of 8,766 hours (365 days) were assumed for all offsite calculations. For onsite locations, the exposure period was reduced to 2,000 hours (250 8-hour workdays) to simulate a typical work year, and the breathing rate was increased to 28.8 cubic meters ( 1,017 cubic feet) per day to account for light duty work.

Table 5.0.4 presents radiological inhalation doses, in millirem per year, to hypothetical offsite individuals

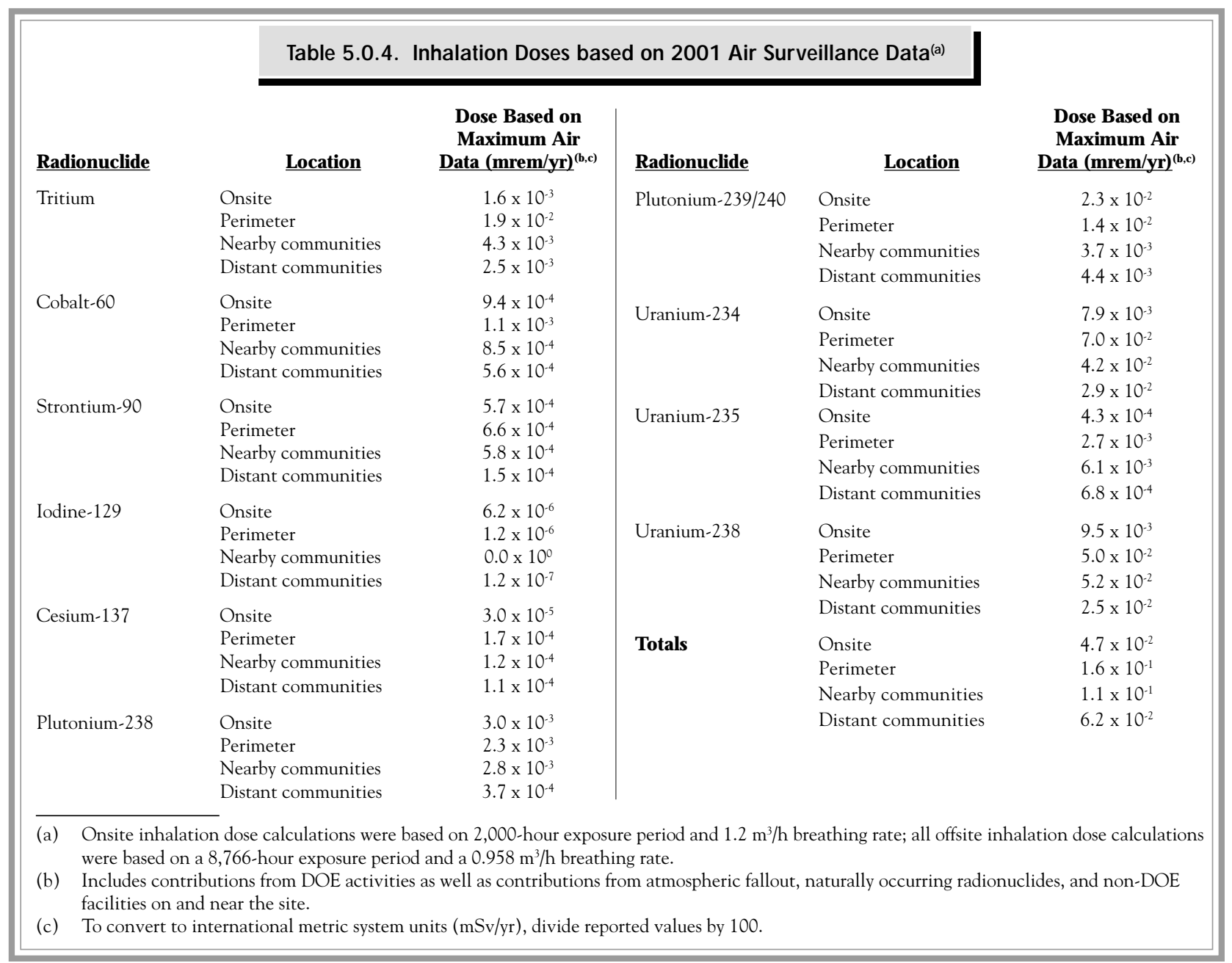


modeled to be in the same location for the entire year and to onsite individuals located near air surveillance stations during their workday. The maximum air concentrations utilized in the calculations were assumed to be constant for the year-long evaluation period.
Inhalation doses calculated using this method ranged from $0.047 \mathrm{mrem}(0.00047 \mathrm{mSv})$ at onsite locations to $0.16 \mathrm{mrem}(0.0016 \mathrm{mSv})$ at the site perimeter. These were comparable to doses reported for air pathways in Section 5.0.3.

\subsubsection{Doses from Non-DOE Sources}

DOE Order 5400.5, Section II, paragraph 7, has a reporting requirement for combined DOE and other manmade doses exceeding $100 \mathrm{mrem} / \mathrm{yr}(1 \mathrm{mSv} / \mathrm{yr})$. In 2001, various non-DOE industrial sources of public radiation exposure existed on or near the Hanford Site. These included a commercial low-level radioactive waste burial ground at Hanford operated by US Ecology; a nuclear power-generating station at Hanford operated by Energy Northwest; a nuclear-fuel production plant operated near the site by Framatome ANP Richland, Inc.; a commercial, low-level, radioactive waste treatment facility operated near the site by Allied Technology Group; and a commercial decontamination facility operated near the site by PN Services (see Figure 5.0.1).
DOE maintains an awareness of these other sources of radiation, which, if combined with the DOE sources, might have the potential to cause a dose exceeding $10 \mathrm{mrem} / \mathrm{yr}(0.1 \mathrm{mSv} / \mathrm{yr})$ to any member of the public. With information gathered from these companies (via personal communication and annual reporting), it was conservatively estimated that the total 2001 individual dose from their combined activities was on the order of $0.05 \mathrm{mrem} / \mathrm{yr}\left(5 \times 10^{-4} \mathrm{mSv} / \mathrm{yr}\right)$. Therefore, the combined dose from Hanford area non-DOE and DOE sources to a member of the public for 2001 was well below any regulatory dose limit.

\subsubsection{Dose Rates to Animals}

Conservative (upper) estimates have been made of the radiological dose to native aquatic organisms in accordance with the DOE Order 5400.5 interim requirement for management and control of liquid discharges. The current limit for dose to aquatic biota is $1 \mathrm{rad}$ $(10 \mathrm{mGy})$ per day. The proposed limit for terrestrial biota is $0.1 \mathrm{rad}(1 \mathrm{mGy})$ per day. Surveillance data from Columbia River shoreline springs, the Fast Flux Test Facility pond, and West Lake were evaluated using the RAD-BCG Calculator (a screening method to estimate radiological doses to aquatic and terrestrial biota). The RAD-BCG Calculator (a) (DOE 2000) is an Excel spreadsheet that initially compares radionuclide concentrations measured by routine surveillance programs to a set of conservative biota concentration guides (e.g., $1 \mathrm{rad}$ [10 mGy] per day for aquatic biota). For samples containing multiple radionuclides, a sum of fractions is calculated to account for the contribution to dose from each radionuclide relative to the dose guideline. If the sum of fractions exceeds 1.0, then the dose guideline has been exceeded.

The biota concentration guides are very different from the derived concentration guides that are used to assess radiological doses to humans. If the estimated dose exceeds the guideline (sum of fractions $>1.0$ ), additional calculations are performed to more accurately evaluate exposure of the biota to the radionuclides. The process may culminate in a site-specific assessment requiring additional sampling and study of exposure.

Maximum concentrations of radionuclides in Columbia River and onsite pond sediment, and riverbank springs and pond water were evaluated using the RAD-BCG Calculator. The results indicated that all spring data resulted in doses below the guidelines (sum of fractions <1.0) (Table 5.0.5). Subsequent evaluations using the RAD-BCG Calculator, site-specific concentration factors derived from special surveillance data, and field survey data gathered to document pond use by shorebirds and other wildlife provided a more accurate sum of fractions (0.02). Radiological doses to plants and animals were also evaluated and were determined to be below guidelines based on the available data. The RAD-BCG Calculator was a useful tool for initially screening sites for biota doses and then for focusing on the sites where the likelihood of exceeding proposed guidelines was greatest.

(a) Memorandum from Dr. David Michaels (Assistant Secretary for Environmental, Safety, and Health) to Distribution, Availability of DOE Technical Standard, "A Graded Approach for Evaluating Radiation Doses to Aquatic and Terrestrial Biota (Project ENVR0011)," for use in DOE Compliance and Risk Assessment Activities, dated July 19, 2000. 


\begin{tabular}{|c|c|c|}
\hline \multicolumn{3}{|c|}{$\begin{array}{l}\text { Table 5.0.5. Results of RAD-BCG Calculator }{ }^{(a)} \\
\text { Screenings }\end{array}$} \\
\hline Location & $\begin{array}{l}\text { Initial Screen } \\
\text { (Sum of } \\
\text { Fractions Value) }\end{array}$ & Pass or Fail \\
\hline 100-F Slough & $3.2 \times 10^{-2}$ & Pass \\
\hline Hanford Slough & $2.5 \times 10^{-2}$ & Pass \\
\hline McNary Dam & $2.1 \times 10^{-1}$ & Pass \\
\hline Priest Rapids Dam & $1.5 \times 10^{-1}$ & Pass \\
\hline Richland & $3.6 \times 10^{-2}$ & Pass \\
\hline 100-B Spring & $8.9 \times 10^{-2}$ & Pass \\
\hline 100-D Spring ${ }^{(\mathrm{b})}$ & $2.0 \times 10^{-3}$ & Pass \\
\hline 100-F Spring & $1.1 \times 10^{-1}$ & Pass \\
\hline 100-H Spring ${ }^{(\mathrm{b})}$ & $6.2 \times 10^{-2}$ & Pass \\
\hline 100-K Spring ${ }^{(\mathrm{b})}$ & $2.2 \times 10^{-5}$ & Pass \\
\hline 100-N Spring & $2.1 \times 10^{-4}$ & Pass \\
\hline \multirow{2}{*}{$\begin{array}{l}300 \text { Area Spring } \\
\text { Hanford Town Site Springs } \\
\end{array}$} & $7.3 \times 10^{-1}$ & Pass \\
\hline & $1.8 \times 10^{-2}$ & Pass \\
\hline Vernita Bridge Spring ${ }^{(\mathrm{b})}$ & $2.0 \times 10^{-3}$ & Pass \\
\hline \multicolumn{3}{|c|}{$\begin{array}{l}\text { A screening method to estimate radiological doses to aquatic } \\
\text { and terrestrial biota. } \\
\text { (b) No sediment data used; only water data for screening. }\end{array}$} \\
\hline
\end{tabular}

\subsubsection{Radiological Dose in Perspective}

This section provides information to put the potential health risks associated with the release of radioactive materials from the Hanford Site into perspective. Several scientific studies (National Research Council 1980, 1990; United Nations Science Committee on the Effects of Atomic Radiation 1988) were performed to estimate the possible risk of detrimental health effects from exposure to low levels of radiation. These studies provided vital information to government and scientific organizations that recommend radiological dose limits and standards for public and occupational safety.

Although no increase in the incidence of health effects from low doses of radiation has actually been confirmed by the scientific community, regulatory agencies conservatively (cautiously) assume that the probability of these types of health effects at low doses (down to zero dose) is the same per unit dose as the health effects observed at much higher doses (e.g., in atomic bomb survivors, individuals receiving medical exposures, or radium dial painters). This concept is known as the linear no threshold hypothesis. Under these assumptions, even natural background radiation, which is hundreds of times greater than radiation from current Hanford Site releases, increases each person's probability or chance of developing a detrimental health effect.
Not all scientists agree on how to translate the available data on health effects into the numerical probability (risk) of detrimental effects from low-level radiological doses. Some scientific studies have indicated that low radiological doses may cause beneficial effects (e.g., Sagan 1987). Because cancer and hereditary diseases in the general population are caused by many sources (e.g., genetic defects, sunlight, chemicals, background radiation), some scientists doubt that the risk from low-level radiation exposure can ever be conclusively proven. In developing Clean Air Act regulations, EPA uses a probability value of $\sim 4$ per 10 million (0.0004) for the risk of developing a fatal cancer after receiving a dose of $1 \mathrm{mrem}$ (0.01 mSv) (EPA 520/1-89-005). Additional data (National Research Council 1990) support the reduction of even this small risk value, possibly to zero, for certain types of radiation when the dose is spread over an extended time.

Government agencies are trying to determine what level of risk is safe for members of the public exposed to pollutants from industrial operations (e.g., DOE facilities, nuclear power plants, chemical plants, hazardous waste sites). All of these industries are considered beneficial to people in some way such as providing electricity, national defense, waste disposal, and consumer products. 
Government agencies have a complex task to establish environmental regulations that control levels of risk to the public without unnecessarily reducing needed benefits from industry.

One perspective on risks from industry is to compare them to risks involved in other typical activities. For instance, two risks that an individual experiences when flying on an airplane are added radiological dose (from a stronger cosmic radiation field that exists at higher altitudes) and the possibility of being in an aircraft accident. Table 5.0.6 compares the estimated risks from various radiological doses to the risks of some activities encountered in everyday life. Table 5.0.7 lists some activities considered approximately equal in risk to that from the dose received by the maximally exposed individual from monitored Hanford effluents in 2001.

Table 5.0.6. Estimated Risk from Various Activities and Exposures ${ }^{(a)}$

\section{Activity or Exposure Per Year}

Smoking 1 pack of cigarettes per day (lung/heart/other diseases)

Home accidents

Taking contraceptive pills (side effects)

Drinking 1 can of beer or $0.12 \mathrm{~L}$ ( $4 \mathrm{oz}$ ) of wine per day (liver cancer/cirrhosis)

Firearms, sporting (accidents)

Flying as an airline passenger (cross-country roundtrip - accidents)

Eating approximately $54 \mathrm{~g}$ (4 tbsp) of peanut butter per day (liver cancer)

Pleasure boating (accidents)

Drinking chlorinated tap water (trace chloroform - cancer)

Riding or driving in a passenger vehicle (483 km [300 mi])

Eating $41 \mathrm{~kg}(90 \mathrm{lb})$ of charcoal-broiled steaks (gastrointestinal tract cancer)

Natural background radiological dose ( 300 mrem [3 mSv])

Flying as an airline passenger (cross-country roundtrip - radiation)

Dose of $1 \mathrm{mrem}(0.01 \mathrm{mSv})$ for $70 \mathrm{yr}$

Dose to the maximally exposed individual living near Hanford

\section{Risk of Fatality}

$3,600 \times 10^{-6}$

$100 \times 10^{-6(\mathrm{~b})}$

$20 \times 10^{-6}$

$10 \times 10^{-6}$

$10 \times 10^{-6(\mathrm{~b})}$

$8 \times 10^{-6(b)}$

$8 \times 10^{-6}$

$6 \times 10^{-6(b)}$

$3 \times 10^{-6}$

$2 \times 10^{-6(b)}$

$1 \times 10^{-6}$

0 to $120 \times 10^{-6}$

0 to $5 \times 10^{-6}$

0 to $0.4 \times 10^{-6}$

0 to $0.004 \times 10^{-6}$

(a) These values are generally accepted approximations with varying levels of uncertainty; there can be significant variation as a result of differences in individual lifestyle and biological factors (Atallah 1980; Dinman 1980; Ames et al. 1987; Wilson and Crouch 1987; Travis and Hester 1990).

(b) Real actuarial values. Other values are predicted from statistical models. For radiological dose, the values are reported in a possible range from the least conservative $(0)$ to the currently accepted most conservative value.

Table 5.0.7. Activities Comparable in Risk to the $0.009-\mathrm{mrem}(0.0009-\mathrm{mSv})$ Dose Calculated for the 2001 Maximally Exposed Individual

Driving or riding in a car $1 \mathrm{~km}(0.6 \mathrm{mi})$

Smoking less than $1 / 100$ of a cigarette

Flying approximately $2.2 \mathrm{~km}(1.4 \mathrm{mi})$ on a commercial airliner

Eating approximately 2 tsp of peanut butter

Eating one $0.15-\mathrm{kg}(5.2-\mathrm{oz})$ charcoal-broiled steak

Drinking $0.88 \mathrm{~L}$ (approximately $29 \mathrm{oz}$ ) of chlorinated tap water

Being exposed to natural background radiation for $16 \mathrm{~min}$ in a typical terrestrial location

Drinking approximately $0.03 \mathrm{~L}(0.5 \mathrm{oz})$ of wine or $0.09 \mathrm{~L}(1.6 \mathrm{oz})$ of beer 


\subsubsection{References}

40 CFR 61, Subpart H. U.S. Environmental Protection Agency. "National Emissions Standards for Emissions of Radionuclides Other Than Radon From Department of Energy Facilities." Code of Federal Regulations.

40 CFR 141. U.S. Environmental Protection Agency. "National Primary Drinking Water Regulations; Radionuclides." Code of Federal Regulations.

Ames, B. N., R. Magaw, and L. S. Gold. 1987. "Ranking Possible Carcinogenic Hazards.” Science 236:271-280.

Atallah, S. 1980. "Assessing and Managing Industrial Risk." Chemical Engineering 9/8/80:94-103.

Clean Air Act. 1986. Public Law 88-206, as amended, 42 USC 7401 et seq.

Dinman, B. D. 1980. "The Reality and Acceptance of Risk." Journal of the American Medical Association (JAMA) (11):1226-1228.

DOE. 2000. A Graded Approach for Evaluating Radiation Doses to Aquatic and Terrestrial Biota. Interim Technical Standard. ENVR-0011. Prepared by U.S. Department of Energy, Office of Environmental Policy and Guidance; Air, Water, and Radiation Division (EH-412), Washington, D.C.

DOE Order 5400.5. "Radiation Protection of the Public and the Environment."

DOE/RL-2002-20. 2002. Radionuclide Air Emissions Report for the Hanford Site, Calendar Year 2001. D. J. Rokkan, N. A. Homan, K. Rhoads, and L. H. Staven, U.S. Department of Energy, Richland Operations Office, Richland, Washington.

EPA 402-R-00-004. 2000. Updated User's Guide for CAP88-PC, Version 2.0. Office of Radiation and Indoor Air, U.S. Environmental Protection Agency, Washington, D.C.

EPA 520/1-89-005. 1989. Risk Assessment Methodology: Draft Environmental Impact Statement for Proposed NESHAPS for Radionuclides, Vol. 1, Background Information Document. U.S. Environmental Protection Agency, Washington, D.C.
National Council on Radiation Protection and Measurements. 1987. Ionizing Radiation Exposure of the Population of the United States. NCRP Report No. 93, Bethesda, Maryland.

National Research Council. 1980. The Effects on Populations of Exposure to Low Levels of Ionizing Radiation: 1980. Committee on the Biological Effects of Ionizing Radiations, National Academy Press, Washington, D.C.

National Research Council. 1990. Health Effects of Exposure to Low Levels of Ionizing Radiation. Committee on the Biological Effects of Ionizing Radiations, National Academy Press, Washington, D.C.

PNL-6584 (3 vols). 1988. GENII - The Hanford Environmental Radiation Dosimetry Software System. B. A. Napier, R. A. Peloquin, D. L. Strenge, and J. V. Ramsdell, Pacific Northwest Laboratory, Richland, Washington.

PNNL-13910, APP. 1. 2002. Hanford Site Environmental Surveillance Data Report for Calendar Year 2001. L. E. Bisping, Pacific Northwest National Laboratory, Richland, Washington.

Sagan, L. A. 1987. Health Physics Society Official Journal: Special Issue on Radiation Hormesis 52(5).

Travis, C. C. and S. T. Hester. 1990. "Background Exposure to Chemicals: What Is the Risk?" Risk Analysis 10(4).

United Nations Science Committee on the Effects of Atomic Radiation. 1988. Sources, Effects and Risks of Ionizing Radiation. Report E.88.1X.7, United Nations, New York.

Wilson, R. and E.S.C. Crouch. 1987. "Risk Assessment and Comparisons: An Introduction." Science 236(4799):267-270. 


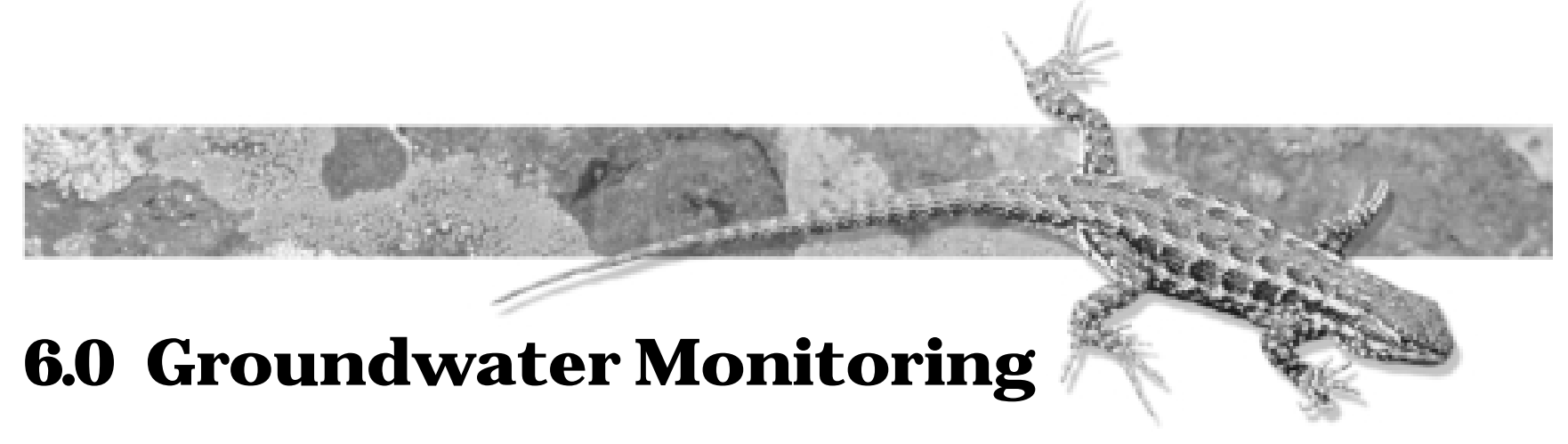

D. R. Newcomer

The strategy for managing and protecting groundwater resources at the Hanford Site focuses on protecting the Columbia River, human health, and the environment; treating groundwater contamination; and limiting the migration of contaminants from the 200 Areas (see DOE/RL-98-48 and DOE/RL-98-56). To support this strategy, the Hanford Groundwater Monitoring Project continues to monitor the quality of groundwater. The project, which is conducted by staff of the Pacific Northwest National Laboratory, is designed to detect and characterize new groundwater contamination and to document the distribution and movement of existing contaminant plumes. Monitoring provides the historical baseline to evaluate current and future risk from exposure to groundwater contamination and to decide on remedial options.

The Hanford Groundwater Monitoring Project includes sitewide groundwater monitoring mandated by U.S. Department of Energy (DOE) Orders and near-field groundwater monitoring conducted to assure that operations in and around specific waste disposal facilities comply with applicable regulations.

Collection and analysis of groundwater samples to determine the distribution of radiological and chemical constituents were major parts of the groundwater monitoring effort. In addition, hydrogeologic characterization and modeling of the groundwater flow system were used to assess the monitoring network and to evaluate potential effects of Hanford Site groundwater contamination. Other work included data management, interpretation, and reporting. The purpose of this section is to provide an overall summary of groundwater monitoring during 2001. Additional details concerning the Hanford Groundwater Monitoring Project are available in PNNL-13788, Hanford Site Groundwater Monitoring for Fiscal Year 2001.

Groundwater monitoring was conducted to accomplish the following tasks:

- assess the impact of radiological and hazardous chemicals on groundwater as a result of Hanford Site operations
- evaluate potential offsite effects from the groundwater pathway

- verify compliance with applicable environmental laws and regulations

- evaluate effectiveness of groundwater remediation

- identify and characterize new or existing groundwater quality problems

- evaluate the potential human exposure to contaminants in groundwater.

Background conditions, or the quality of groundwater on the site unaffected by operations, must be known to assess the effect of Hanford Site operations on groundwater quality. Data on the concentration of contaminants of concern in groundwater that existed before site operations began are not available. Therefore, concentrations of naturally occurring chemical and radiological constituents in groundwater sampled from wells located in areas unaffected by site operations, including upgradient locations, provide the best estimate of pre-Hanford groundwater quality. Summaries of background conditions are tabulated in several reports (PNL-6886; PNL-7120; DOE/RL-96-61; and Appendix A of WHC-EP-0595).

In 2001, groundwater samples were collected from both the unconfined and upper confined aquifers beneath the Hanford Site. The unconfined aquifer was monitored extensively because it contains contaminants from Hanford Site operations (PNNL-13788) and provides a potential pathway for contaminants to reach points of human exposure (e.g., water supply wells, Columbia River). The upper confined aquifer was monitored, though less extensively and less frequently than the unconfined aquifer, because it also provides a potential pathway for contaminants to migrate off the site. Some sampling also was conducted at the request of the Washington State Department of Health.

Sitewide groundwater monitoring is designed to meet the project objectives stated in DOE Order 5400.1 
and the tasks described in the preceding paragraphs. The effects of Hanford Site operations on groundwater have been monitored for more than 50 years under this project and its predecessors. Near-field monitoring of groundwater around specific waste facilities was performed to meet the requirements of the Resource Conservation and Recovery Act (RCRA) (40 CFR 265) and Washington Administrative Codes (WAC 173-216; WAC 173-303; WAC 173-304) as well as applicable DOE Orders (e.g., 435.1, 5400.1, 5400.5). Groundwater monitoring was also performed in conjunction with cleanup investigations under the Comprehensive Environmental Response, Compensation, and Liability Act (CERCLA) (40 CFR 300).

To evaluate the effect of remediation efforts on groundwater, groundwater within the contaminant plumes must be monitored to characterize and define flow patterns and trends in the concentrations of radiological or chemical constituents. Monitoring is required to quantify the existing groundwater quality problem and to provide a baseline of environmental conditions against which future changes can be assessed.

Areas that potentially could be a source of contamination also were monitored to characterize and define trends in the condition of the groundwater. These areas were monitored to identify and quantify emerging or potential problems in groundwater quality. Potential source areas included active waste disposal facilities or facilities that had generated or received waste in the past. Most of these facilities are located within the 100, 200, and 300 Areas. However, some sources such as the 618-11 burial ground are located outside these operational areas.

Water supplies on and near the Hanford Site potentially provide the most direct route for human exposure to contaminants in groundwater. In 2001, one of the site's ten DOE-owned, contractor-operated drinking water systems provided groundwater for human consumption on the site. This system supplied water at the Fast Flux Test Facility (see Section 4.3). Water supply wells used by the city of Richland are located near the site's southern boundary. Monitoring wells near these water systems were sampled routinely to assure that any potential water quality problems would be identified long before regulatory limits were reached.

Summary results for groundwater monitoring in 2001 are discussed in Section 6.1.

\subsubsection{Groundwater Hydrology}

Both confined and unconfined aquifers are present beneath the Hanford Site. An aquifer is a watersaturated geologic interval or unit that has a high permeability, meaning it can transmit significant quantities of water. A confined aquifer is bounded above and below by low-permeability materials that restrict the vertical movement of water. The confining layers may be dense rock, such as the central parts of basalt flows, silt, clay, or well-cemented sediment (i.e., caliche). Extensive, confined aquifers at the site are found primarily within interflows and interbeds of the Columbia River basalts.

An unconfined aquifer, or water-table aquifer, is overlain by unsaturated sediment. The upper surface of the saturated zone in an unconfined aquifer, which is called the water table, rises and falls in response to changes in the volume of water stored in the aquifer. The unconfined aquifer is bounded below either by the basalt surface or, in places, by relatively impervious clays and silts. Laterally, the unconfined aquifer is bounded by basalt ridges and by the Yakima and Columbia Rivers. The basalt ridges have a low permeability and act as a barrier to the lateral flow of groundwater where they rise above the water table (RHO-BWI-ST-5, p. II-116).

The unconfined aquifer, which forms the uppermost groundwater zone, has been directly affected by wastewater disposal at the Hanford Site. The unconfined aquifer discharges primarily into the Columbia River and is the most thoroughly monitored aquifer beneath the site. Confined aquifers are generally isolated from the unconfined aquifer by dense rock that forms the interior of the basalt flows. However, interflow between the unconfined aquifer and the confined aquifer system is known to occur at faults that bring a water-bearing interbed in contact with other sediments or where the overlying basalt has been eroded to reveal an interbed (Newcomb et al. 1972; RHO-RE-ST-12 P; WHC-MR-0391).

\subsubsection{Contaminant Transport}

The history of contaminant releases and the physical and chemical principles of mass transport control the distribution of radionuclides and chemicals in groundwater. Processes that control the movement of these contaminants at the Hanford Site are discussed in the following paragraphs. 


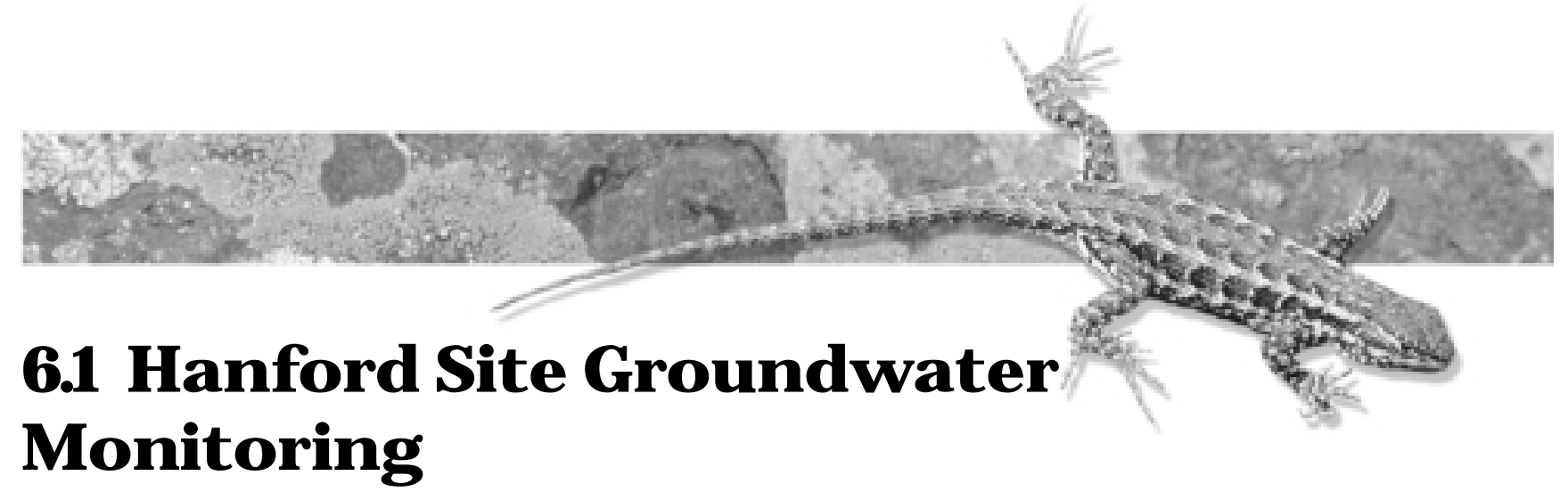

D. R. N ewcomer and M . J. H artman

Groundwater monitoring at the Hanford Site is an integral part of the $\mathrm{H}$ anford Site $\mathrm{G}$ round-W ater Protection $M$ anagement Plan (DOE/RL-89-12). That plan assures that monitoring at active waste disposal facilities complies with requirements of RCRA and Washington State regulations, as well as requirements for operational monitoring around reactor and chemical processing facilities and environmental surveillance monitoring. Pacific Northwest National Laboratory staff manage these monitoring efforts to assess the distribution and movement of existing groundwater contamination, to identify and characterize potential and emerging groundwater contamination problems, and to integrate the various groundwater projects to minimize redundancy.

The Integrated Monitoring Plan for the $\mathrm{H}$ anford Groundwater M onitoring Project (PNNL-11989) describes how DOE will implement the groundwater monitoring requirements outlined in DOE/RL-89-12 and DOE/RL-91-50. The purpose of the integrated monitoring plan is to (1) describe the monitoring well networks, constituents, sampling frequencies, and criteria used to design the monitoring program; (2) identify federal and state groundwater monitoring requirements and regulations; and (3) provide a list of wells, constituents, and sampling frequencies for groundwater monitoring conducted on the Hanford Site. Federal and state regulations include RCRA, CERCLA, and Washington Administrative Codes (see Section 2.2).

Information on contaminant distribution and transport are integrated into a sitewide evaluation of groundwater quality, which is documented in an annual groundwater monitoring report (e.g., PNNL-13788). Groundwater monitoring is also carried out during CERCLA cleanup investigations. These investigations, managed by Bechtel Hanford, Inc., are documented in annual summary reports (e.g., DOE/RL-2002-01).

\subsection{Groundwater Monitoring Network}

Groundwater samples were collected from 735 wells for all monitoring programs during 2001. A summary that accounts for the number of all groundwater wells monitored during 2001 according to geographic area and monitoring purpose is provided in Tables 6.1.1 and 6.1.2, respectively. The number of wells in Table 6.1.1 is subdivided by geography into the $100,200,300,400$, and 600 Areas (see Figure 1.0.1). In Table 6.1.2, the purposes for which monitoring was conducted are divided into restoration, waste management, and environmental surveillance. Restoration refers to wells associated with groundwater remediation activities, including pump-and-treat systems and innovative technology demonstrations. Waste management refers to wells sampled to determine impacts, if any, of a waste management unit (e.g., RCRA facility) on groundwater. Environmental surveillance refers to wells sampled to detect impacts, if any, of site operations on groundwater over the entire Hanford Site and adjacent offsite areas. The number of wells installed and abandoned in 2001 is also shown for each of the tables.

The locations of sampled wells are shown in Figures 6.1.1 and 6.1.2; well names are indicated only for those wells specifically discussed in the text. Because of the density of unconfined aquifer wells in the operational areas, well names in these areas are also shown on detailed maps in the following sections. Figure 6.1.3 shows the locations of facilities where groundwater monitoring was conducted to comply with RCRA (also see Appendix A in PNNL-13788). Wells at the Hanford Site generally follow a naming system that indicates the approximate location of the well. The prefix of the well name indicates the area of the site, as shown in Table 6.1.3. The names for 600 Area wells follow a local coordinate system in which the numbers indicate the distance relative to an arbitrary datum location in the south-central part of the site. 


\begin{tabular}{|c|c|c|c|c|c|c|c|}
\hline \multicolumn{7}{|c|}{$\begin{array}{l}\text { Table 6.1.1. Summary of Groundwater Monitoring Program by Geographic Area } \\
\text { Calendar Year } 2001\end{array}$} & \multirow[b]{2}{*}{600 A rea ${ }^{(a)}$} \\
\hline & & Hanford Site & 100 A reas & 200 A reas & 300 A rea & 400 A rea & \\
\hline \multicolumn{2}{|c|}{$\begin{array}{l}\text { Number of wells } \\
\text { monitored }\end{array}$} & 735 & 218 & 271 & 41 & 4 & 201 \\
\hline \multicolumn{2}{|c|}{ Number of sampling } & 2,095 & 836 & 810 & 87 & 37 & 325 \\
\hline \multicolumn{2}{|c|}{$\begin{array}{l}\text { Number of analyses } \\
\text { performed }\end{array}$} & 18,051 & 5,532 & 8,046 & 669 & 267 & 3,537 \\
\hline \multicolumn{2}{|c|}{ Number of results } & 66,153 & 17,548 & 30,948 & 2,427 & 373 & 14,857 \\
\hline \multicolumn{2}{|c|}{$\begin{array}{l}\text { Percent of non- } \\
\text { detectable results }\end{array}$} & 41 & 26 & 42 & 68 & 21 & 51 \\
\hline \multicolumn{2}{|c|}{$\begin{array}{l}\text { Number of installed } \\
\text { wells } s^{(b)}\end{array}$} & 58 & 31 & 23 & 0 & 0 & 4 \\
\hline \multicolumn{2}{|c|}{$\begin{array}{l}\text { Number of } \\
\text { abandoned wells }\end{array}$} & 99 & 3 & 4 & 2 & 0 & 90 \\
\hline $\begin{array}{l}\text { (a) } \\
\text { (b) }\end{array}$ & $\begin{array}{l}\text { Includes the fo } \\
\text { Does not inclu }\end{array}$ & $\begin{array}{l}\text { r } 1100 \text { and } 3000 \\
\text { wo wells deepen }\end{array}$ & $\begin{array}{l}\text { reas. } \\
\text { in the } 200 \mathrm{Ar}\end{array}$ & & & & \\
\hline
\end{tabular}

\begin{tabular}{|c|c|c|c|c|}
\hline \multicolumn{5}{|c|}{$\begin{array}{l}\text { Table 6.1.2. Summary of G roundwater Monitoring Program by } \\
\text { Monitoring Purpose, (a) Calendar Year } 2001\end{array}$} \\
\hline & & Restoration & Waste Management & Environmental Surveillance \\
\hline \multicolumn{2}{|c|}{$\begin{array}{l}\text { Number of wells } \\
\text { monitored }\end{array}$} & 220 & 241 & 450 \\
\hline \multicolumn{2}{|c|}{$\begin{array}{l}\text { Number of sampling } \\
\text { events }\end{array}$} & 561 & 636 & 640 \\
\hline \multicolumn{2}{|c|}{$\begin{array}{l}\text { Number of analyses } \\
\text { performed }\end{array}$} & 5,272 & 8,562 & 10,389 \\
\hline \multicolumn{2}{|c|}{ Number of results } & 18,114 & 35,918 & 37,040 \\
\hline \multicolumn{2}{|c|}{$\begin{array}{l}\text { Percent of non- } \\
\text { detectable results }\end{array}$} & 38 & 44 & 44 \\
\hline \multicolumn{2}{|c|}{$\begin{array}{l}\text { Number of installed } \\
\text { wells }\end{array}$} & 31 & 27 & 0 \\
\hline \multicolumn{2}{|c|}{$\begin{array}{l}\text { Number of } \\
\text { abandoned wells }\end{array}$} & 0 & 0 & 99 \\
\hline (a) & $\begin{array}{l}\text { Because of co-s } \\
\text { events, analyse }\end{array}$ & $\begin{array}{l}\mathrm{g} \text { between grou } \\
\mathrm{ts} \text {, and non-det }\end{array}$ & $\begin{array}{l}\text { water monitoring progra } \\
\text { able results overlap betw }\end{array}$ & $\begin{array}{l}\text { s, the wells monitored, sampling } \\
\text { en monitoring purposes. }\end{array}$ \\
\hline
\end{tabular}




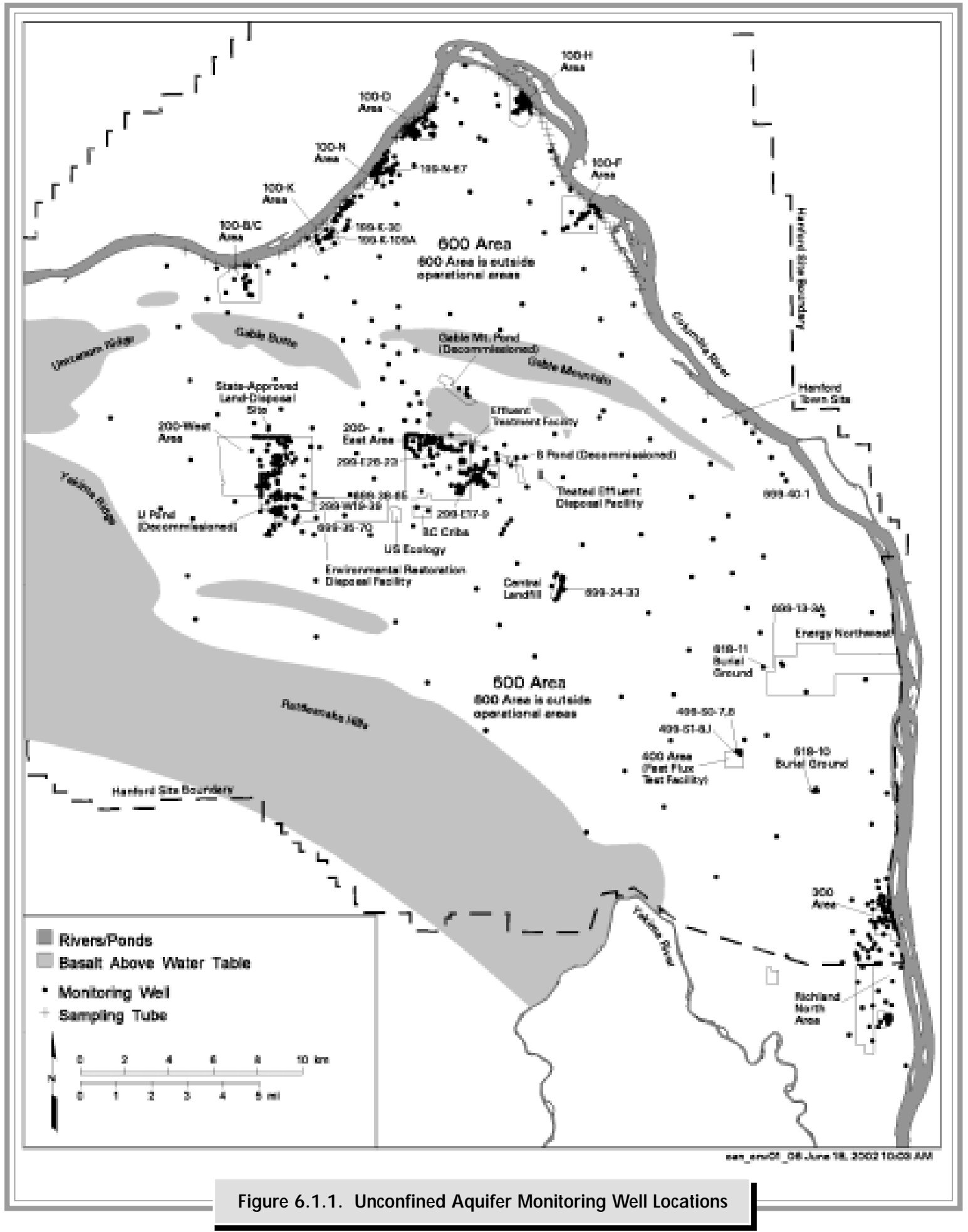




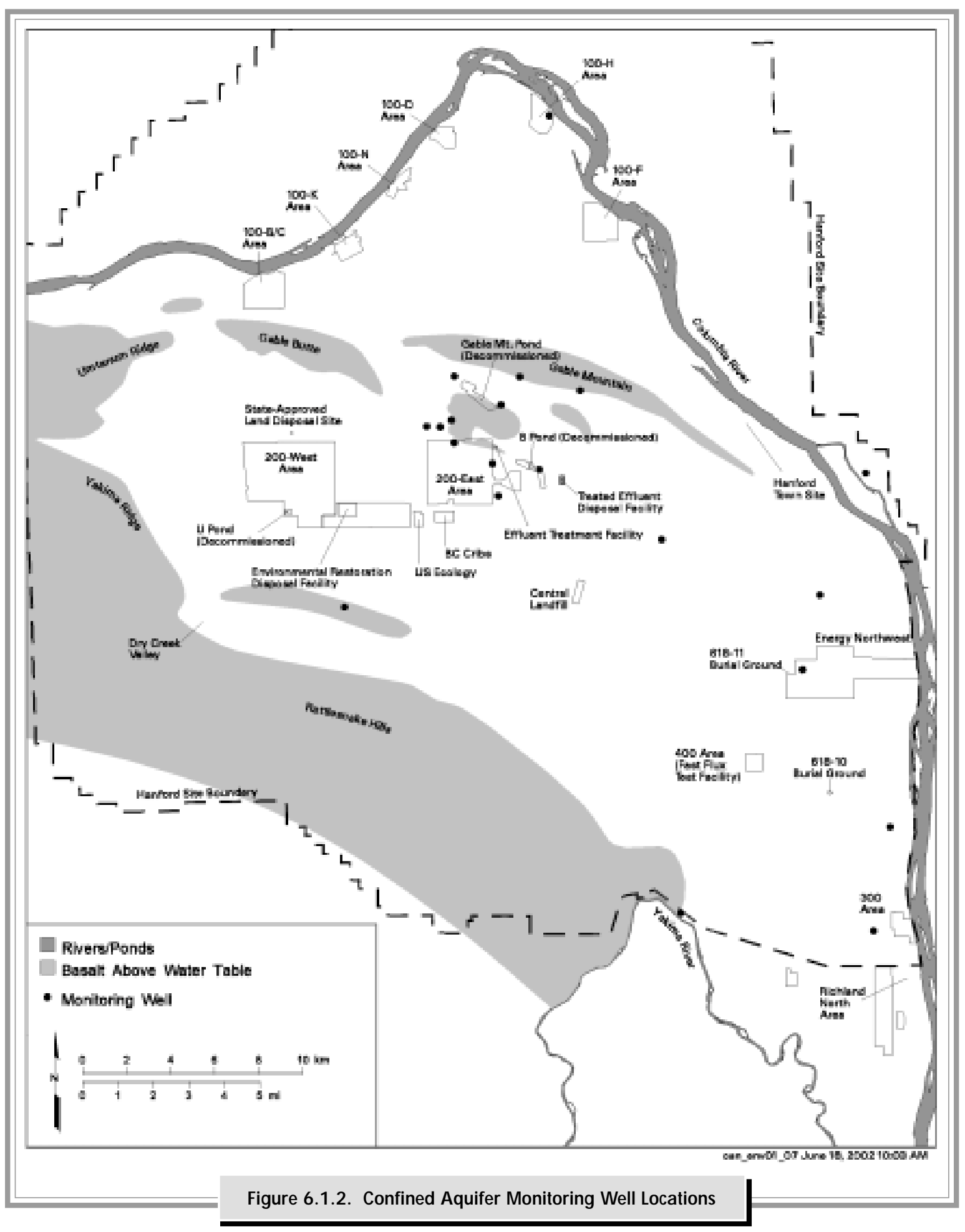




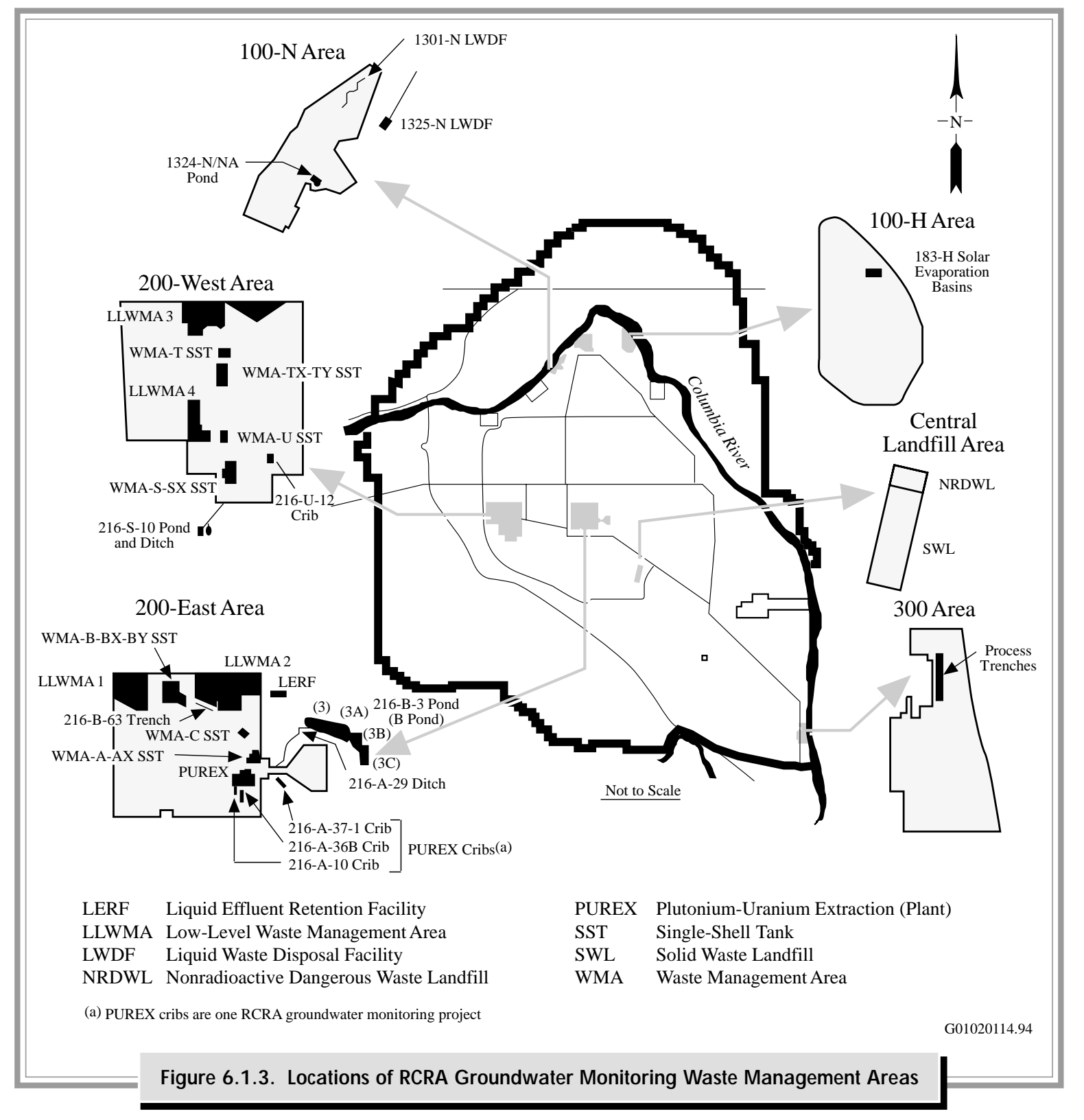

The monitoring frequency for the wells was selected based on regulatory requirements, variability of historical data, proximity to waste sources (PNL-6456), and characteristics of the groundwater flow system at the sampling location. Of the 735 wells sampled, 316 were sampled once, 147 twice, 58 three times, 128 four times, and 86 wells were sampled more than four times during the year. The sampling frequency is every 3 years for several wells that have consistently shown concentrations with steady historical trends. Wells showing larger variability are sampled more frequently (annually or more often). Wells that monitor source areas are sampled more frequently than wells that do not monitor source areas. Contaminants with greater mobility (e.g., tritium) in groundwater may be sampled more frequently than contaminants that are not very mobile (e.g., strontium-90).

Most groundwater monitoring wells on the site are 10 to 20 centimeters ( 4 to 8 inches) in diameter. Monitoring wells for the unconfined aquifer are constructed with well screens or perforated casing generally in the upper 3 to 6 meters ( 10 to 20 feet) of the unconfined aquifer, with the open interval extending across the water table. This construction allows sample collection at the top of the aquifer, where maximum concentrations of radionuclides and maximum concentrations of chemicals tend to be found. Wells monitoring the shallowest of the basalt-confined aquifers have screens, 
Table 6.1.3. Hanford Site Well Naming System

\begin{tabular}{|c|c|c|c|}
\hline \multirow[b]{2}{*}{$\begin{array}{l}\text { Example } \\
\text { Well Name }\end{array}$} & \multicolumn{2}{|c|}{ Table 6.1.3. Hanford Site Well Naming System } & \multirow[b]{2}{*}{ Area } \\
\hline & Area & $\begin{array}{l}\text { Example } \\
\text { Well Name }\end{array}$ & \\
\hline 199- & 100 A reas & 399- & 300 A rea \\
\hline $199-B 3-47$ & 100-B/C Area & $399-1-17 \mathrm{~A}$ & 300 Area \\
\hline $\begin{array}{l}199-\mathrm{D} 5-12 \\
199-\mathrm{F} 8-3\end{array}$ & $\begin{array}{l}\text { 100-D Area } \\
\text { 100-F Area }\end{array}$ & 499- & 400 A rea \\
\hline 199-H4-3 & 100-H Area & 499-S1-8J & 400 Area \\
\hline $\begin{array}{l}199-\mathrm{K}-30 \\
199-\mathrm{N}-67\end{array}$ & $\begin{array}{l}\text { 100-K Area } \\
100-\mathrm{N} \text { Area }\end{array}$ & 699- & 600 A rea \\
\hline 299- & 200 A reas & $\begin{array}{l}699-50-53 \mathrm{~A} \\
699-42-\mathrm{E} 9 \mathrm{~A}\end{array}$ & $\begin{array}{l}600 \text { Area north and west of datum } \\
600 \text { Area north and east of datum }\end{array}$ \\
\hline 299-W19-3 & 200-West Area & 699-S19-11 & 600 Area south and west of datum \\
\hline 299-E28-4 & 200-East Area & 699-S19-E13 & 600 Area south and east of datum \\
\hline
\end{tabular}

perforated casing, or an open hole within the monitored aquifer. Wells drilled before 1985 were generally constructed with carbon steel casing. Since 1985, RCRA monitoring wells and CERCLA characterization wells have been constructed with stainless steel casing and screens. Most monitoring wells on the site are sampled using either submersible or Hydrostar ${ }^{\mathrm{TM}}$ pumps (a registered trademark of Instrumentation Northwest, Inc., Redmond, Washington), though some wells are sampled with bailers or airlift systems.

\subsection{Sampling and Analytical Methods}

Samples were collected for all programs following documented sampling procedures that conform to U.S. Environmental Protection Agency (EPA) guidelines (EPA 1986), or other EPA methods, and ASTM standards (American Society for Testing and Materials 1986). The methods used for radiochemical analyses were developed by the analytical laboratory and are recognized as acceptable within the technical radiochemistry industry. Analytical techniques used are listed in PNNL-13080 and CERCLA work plans. The samples were analyzed for $\sim 40$ different radiological constituents and 290 different chemical and biological parameters during 2001 (Table 6.1.4).

The number of sampling events, analyses performed, and results in 2001 is summarized in Table 6.1.1 by geographic area and in Table 6.1 .2 by monitoring purpose. A sampling event refers to a groundwater sample collected from a single well at a distinct point in time for the purpose of one or more field or laboratory analyses. An analysis refers to a field or laboratory method used for determining the concentration of one or more constituents in a sample. A result refers to a concentration value associated with a constituent whether it is detected or not. Tables 6.1.1 and 6.1.2 also show the percentage of results where the concentration values were less than the minimum levels of detection. Concentration values less than the minimum levels of detection indicate that no constituents were found.

The percentage of non-detectable results can vary, depending on the analytical method used or constituents analyzed. Some constituents can be analyzed by different methods that yield different minimum levels of detection. A constituent detected using a method capable of low minimum levels of detection may not be detected using a method with a higher minimum level of detection. Different analytical methods have a wide range in the number of constituents analyzed. A method capable of analyzing for a large number of constituents, such as volatile organic analyses, can often yield a high number of non-detectable results. This is because most of the constituents associated with the method are not targeted for analysis. The percent of non-detectable results in Tables 6.1.1 and 6.1.2 is largely attributed to analysis of volatile organic compounds, metals, and gamma-emitting radionuclides. Some constituents, such as chloride, are rarely non-detectable because ambient concentrations are typically greater than the minimum level of detection. 
Co-sampling efforts occur between different groundwater monitoring programs to increase monitoring efficiency at the Hanford Site. Co-sampling is incorporated into Table 6.1.2 to account for all wells monitored, sampling events, analyses performed, results, and non-detectable results by each monitoring purpose. A co-sample is defined as a single sample collected from a well, but is used by more than one monitoring program, regardless of the types or number of analyses performed by each monitoring program. Thus, as shown in Table 6.1.2, many of the wells monitored, sampling events, analyses performed, results, and nondetectable results are associated with more than one monitoring purpose.

Most groundwater samples collected on the site in 2001 were analyzed for tritium. Selected samples were analyzed for other radionuclides. Analytical results for radionuclides are generally presented in picocuries (Becquerels) per liter; however, the results for total uranium, which is usually measured by laser fluorescence, are given in micrograms per liter.

Nitrate analyses were performed on many samples collected during 2001 because of the extensive areas with elevated nitrate concentrations that originate from onsite and offsite sources (see Section 6.2.2). However, nitrate concentrations were less than the EPA 45-mg/L drinking water standard (40 CFR 141) for most of the affected areas. Selected monitoring wells were used for additional chemical surveillance.

Table 6.1.4. Groundwater Analyzed for These Radionuclides and 0 ther Parameters in 2001

\section{Radionuclides}

Americium-241

Antimony-125

Beryllium-7

Carbon-14

Cerium/Praseodymium-144

Cesium-134

Cesium-137

Cobalt -58

Cobalt -60

Curium isotopes

Europium isotopes

Gross alpha

Gross beta

Iodine-129

Iron-59

Neptunium-237

Nickel-63

Niobium-94

Plutonium isotopes

Potassium-40

Radium isotopes

Ruthenium-103

Ruthenium-106

Strontium-90

Technetium-99

Thorium isotopes

Tin-113

Tritium

Uranium isotopes

Uranium (total)

Zinc-65

\section{General Parameters}

Alkalinity

Biochemical oxygen demand

Chemical oxygen demand

Conductance (field and laboratory)

Dissolved oxygen (field)

Hardness

Oxidation reduction potential

$\mathrm{pH}$ (field)

Temperature

Total dissolved solids

Total organic carbon

Total organic halogens

Total suspended solids

Turbidity

\section{Metals}

\author{
Al, As, Be, Co, K, Mg, Na, Se, Si \\ $\mathrm{Ca}, \mathrm{Cr}, \mathrm{Fe}, \mathrm{Hg}, \mathrm{Li}, \mathrm{Mn}, \mathrm{Ni}, \mathrm{Pb}, \mathrm{V}$ \\ $\mathrm{Ag}, \mathrm{Ba}, \mathrm{Cd}, \mathrm{Cu}, \mathrm{Mo}, \mathrm{S}, \mathrm{Sb}, \mathrm{Sn}, \mathrm{Sr}$, silica, Tl, Zn \\ Hexavalent chromium
}

\section{Anions \\ $\mathrm{Br}, \mathrm{Cl}, \mathrm{F}^{-}, \mathrm{NO}_{2}^{-}, \mathrm{NO}_{3}^{-}, \mathrm{PO}_{4}^{-3}, \mathrm{SO}_{4}^{-2}$ $\mathrm{CN}, \mathrm{NH}_{3}$}

\section{Other Parameters}

$\mathrm{NH}_{4}^{+}$

Pesticides

Polychlorinated biphenyls

Semivolatile organic compounds

Volatile organic compounds

Herbicides

Coliform bacteria

Diesel oil

Gasoline

Oil and grease

Phenols

Total petroleum hydrocarbons

Total petroleum hydrocarbons - diesel range

Total petroleum hydrocarbons - gasoline range

\subsection{Data Quality}

Data quality is assessed primarily by evaluating accuracy, precision, and detection of field and laboratory analytical measurements. Representativeness, completeness, and comparability are also parameters used to evaluate overall data quality. Laboratory quality control checks, replicate sampling and analysis, analysis of blind standards and blanks, and interlaboratory comparisons are used to evaluate these parameters. Data quality is described in Section 9.0 and in much detail in Appendix B, PNNL-13788. 


\subsection{Data Interpretation}

The chemical composition of groundwater may fluctuate from differences in the contaminant source, recharge, or groundwater flow field. The range of this concentration fluctuation can be estimated by taking many samples, but there are limits to the number that can be practicably taken. Comparison of results through time helps interpret this variability.

Overall sample uncertainty may be factored into data evaluation by considering the concentration trend in a given well over time. This often helps identify gross errors, and overall, long-term trends can be distinguished from short-term variability. The interpretation of concentration trends depends on an understanding of chemical properties as well as site hydrogeology. The trend analysis, in turn, aids in refining the conceptual model of the chemical transport.
Plume maps presented in Section 6.2 illustrate site groundwater chemistry. Although analytical data are available only at specific points where wells were sampled, contours are drawn to join the approximate locations of equal chemical concentration or radionuclide activity levels. The contour maps are simplified representations of plume geometry because of map scale, the lack of detailed information, and the fact that plume depth and thickness cannot be fully represented on a two-dimensional map. Plume maps are powerful tools because knowledge of concentrations in surrounding wells, groundwater flow, site geology, and other available information are factored into their preparation.

\subsection{Data Management}

Each monitoring program has access to groundwater data collected by other programs through a common database, the Hanford Environmental Information System. This database contains 1,763,494 groundwater monitoring result records as of the end of 2001. The majority of data are loaded into the database from electronic files provided by the analytical laboratories. After the data are verified and/or validated, they are made available to federal and state regulators for retrieval. 


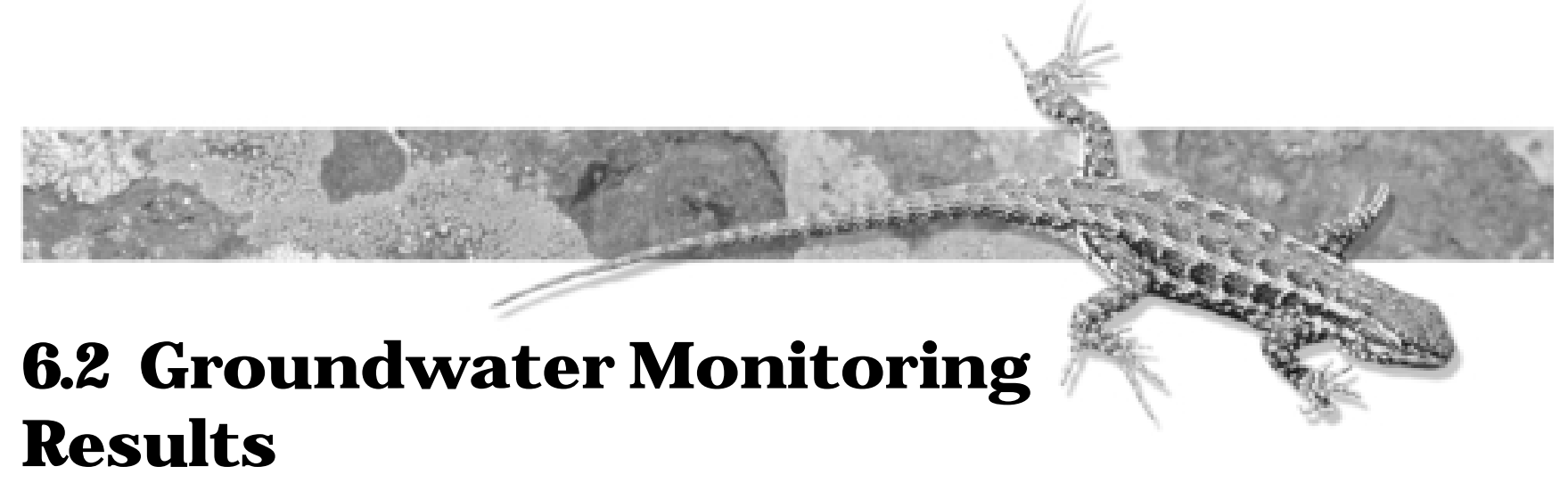

D. R. N ewcomer

The following sections summarize the distribution of radioactive and chemical contaminants detected in Hanford Site groundwater during 2001. These discussions are followed by a summary of groundwater monitoring results for RCRA sites (Section 6.4). Detailed information on groundwater monitoring, including listings of analysis results for each monitoring well in electronic format, is available in PNNL-13788. However, because PNNL-13788 (the annual groundwater report) covers the fiscal year (October 2000 through September 2001), it does not include results from the last 3 months of 2001. This report includes a summary of results for January through December 2001.

One way to assess the potential impact of radionuclides and chemicals in groundwater is to compare their concentrations to EPA's drinking water standards and DOE's derived concentration guides (40 CFR 141 and DOE Order 5400.5; see Appendix D, Tables D.2 and D.5). The drinking water standards were established to protect public drinking water supplies. The DOE derived concentration guides were established to protect the public from radionuclides resulting from DOE operations. Specific drinking water standards have been defined for only a few radiological constituents. Drinking water standards have been calculated for other radionuclides, using an annual dose of $4 \mathrm{mrem} / \mathrm{yr}$ (0.04 millisievert $/ \mathrm{yr}$ ). Calculations of these standards consider their half-life, the energy and nature of the radioactive decay, and the physiological factors such as its buildup in particular organs. Drinking water standards are more restrictive than derived concentration guides because the standards are based on an annual dose of $4 \mathrm{mrem} / \mathrm{yr}$ ( 0.04 millisievert/yr) to the affected organ. The guides are based on an effective dose equivalent of $100 \mathrm{mrem} / \mathrm{yr}$ (1 millisievert/yr) (see Appendix D, Tables D.2 and D.5).
In addition, the standards use older factors to calculate the concentrations that would produce a $4-\mathrm{mrem} / \mathrm{yr}$ (0.04 millisievert/yr) dose than are used to calculate the guides. Thus, the standards used in this section do not always agree with the guides, which are available only for radionuclides. Primary and secondary drinking water standards are given for some chemical constituents; secondary standards are based on aesthetic (e.g., odor, taste) rather than health considerations.

The total area of contaminant plumes with concentrations exceeding drinking water standards was estimated to be $\sim 208$ square kilometers ( 80 square miles) in 2001. This area, which is a decrease of $\sim 1 \%$ compared to 2000 , (a) occupies $\sim 14 \%$ of the total area of the Hanford Site. The most widespread contaminants within these plumes were tritium, iodine-129, nitrate, carbon tetrachloride, trichloroethene, chromium, strontium-90, technetium-99, and uranium. The area of contaminant plumes for these constituents at levels above drinking water standards are summarized in Table 6.2.1. Most of the contaminant plume area, represented by tritium, lies southeast of the 200-East Area extending to the Columbia River (Figure 6.2.1). The total volume of contaminant plumes at levels above drinking water standards during 2001 was estimated to be 1.03 trillion liters ( 272 billion gallons). Contaminant plumes with concentrations exceeding DOE derived concentration guides occur in isolated areas. The only contaminants at levels above DOE derived concentration guides in 2001 were tritium, uranium, and strontium-90.

Summaries of maximum concentrations for the most widespread contaminants are presented by geographic area in Table 6.2.2 and by monitoring purpose in Table 6.2.3. As expected, most of the maximum

(a) The total area of contaminated plumes in 2000 was changed from $\sim 231$ to $\sim 210$ square kilometers ( $~ 89$ to $~ 81$ square miles) because of a re-interpretation of the data and changes to the monitoring network. 
Table 6.2.1. Area of Contaminant Plumes at Levels above Drinking Water Standards (adapted from PN N L-13788)

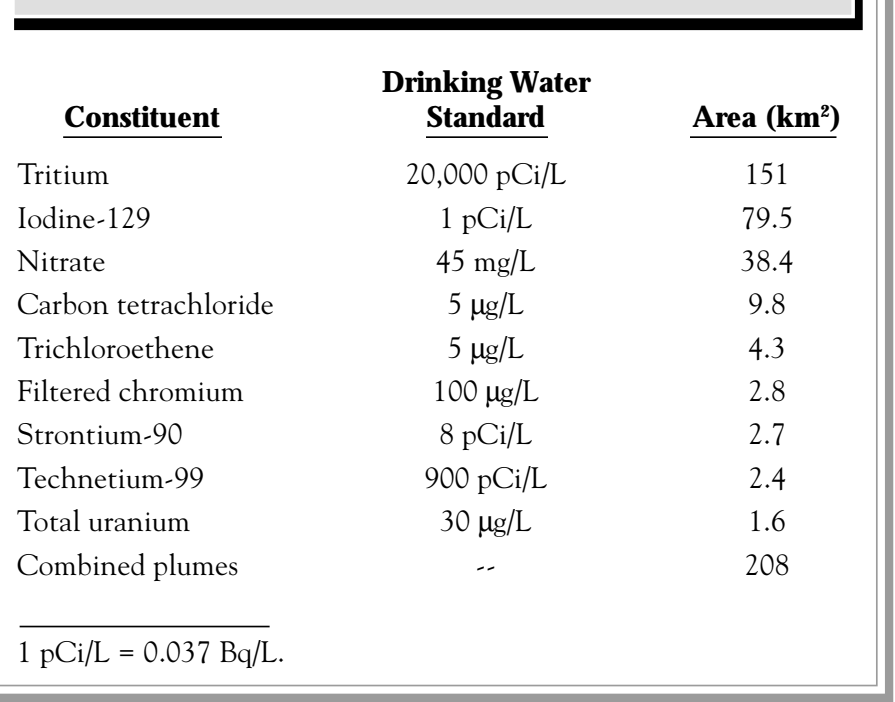

concentrations were detected in the 100 and 200 Areas because these areas contain the largest number of waste sites that have affected groundwater quality (see Table 6.2.2). Some contaminants were not detected or not analyzed for in some of the areas. Strontium-90 is not a contaminant of concern in the 400 Area; therefore, samples from this area were not analyzed for strontium-90 during 2001. For each monitoring purpose, the maximum concentrations detected were greater than the drinking water standards for all of the most widespread contaminants listed in Table 6.2.3. A list of drinking water standards for these contaminants is provided in Table D.2 in Appendix D.

\subsubsection{Radiological Monitoring Results for the Unconfined Aquifer}

Hanford Site groundwater was analyzed for the radionuclides listed in Table 6.1.4. The distribution of tritium, iodine-129, technetium-99, uranium, strontium-90, carbon-14, cesium-137, cobalt-60, and plutonium are discussed in the following sections. Tritium and iodine-129 are the most widespread radiological contaminants associated with past site operations. Technetium-99 and uranium plumes are extensive in the 200 Areas and adjacent 600 Area. Strontium-90 plumes exhibit high concentrations in the 100 Areas but are of relatively smaller extent. Strontium-90 also occurs in the 200 Areas and near the former Gable Mountain Pond in the 600 Area. Carbon-14 is present in two small plumes in the 100-K Area. Cesium-137, cobalt-60, and plutonium contamination occurs in isolated areas in the 200 Areas. Gross alpha and gross beta results are used as indicators of radionuclide distribution and are not discussed in detail because the specific radionuclides contributing to these measurements are discussed individually. Several other radionuclides, including ruthenium-106, antimony-125, and americium-241, are associated with waste from Hanford Site operations. Because of their low concentrations in groundwater, they are not discussed in this section. Halflives of the radionuclides are presented in Appendix A, Table A.7.

Tritium. Tritium, which is present in irradiated nuclear fuel, was released in process condensates associated with decladding and dissolution of the fuel. Tritium also was manufactured as part of the Hanford mission by irradiating targets containing lithium in several reactors from 1949 to 1952 (DOE/EIS-0119F; WHC-SD-EN-RPT-004). In the late 1960s, tritium production took place in N Reactor (WHC-MR-0388).

Tritium was present in many historical waste streams at the Hanford Site and is highly mobile, essentially moving at the same velocity as the groundwater. Consequently, the extent of groundwater contamination from site operations is generally reflected by tritium distribution. For this reason, tritium is the most frequently monitored radionuclide at the Hanford Site. Figure 6.2.1 shows the 2001 distribution of tritium in the unconfined aquifer. Tritium is one of the most widespread contaminants in groundwater across the Hanford Site and exceeded the 20,000-pCi/L (740-Bq/L) drinking water standard in portions of the 100, 200, 400, and 600 Areas. Of these areas, tritium levels exceeded the 2 million-pCi/L (74,000-Bq/L) DOE derived concentration guide in portions of the 200 and 600 Areas. The highest tritium concentration measured at the Hanford Site in 2001 was 5.29 million pCi/L $(196,000 \mathrm{~Bq} / \mathrm{L})$ near the 618-11 burial ground. Tritium levels are expected to decrease because of dispersion and radioactive decay (half-life is 12.35 years).

In 2001, the only liquid effluent containing tritium was discharged to the soil column at the State-Approved Land Disposal Site, which began operating in 1995 and 


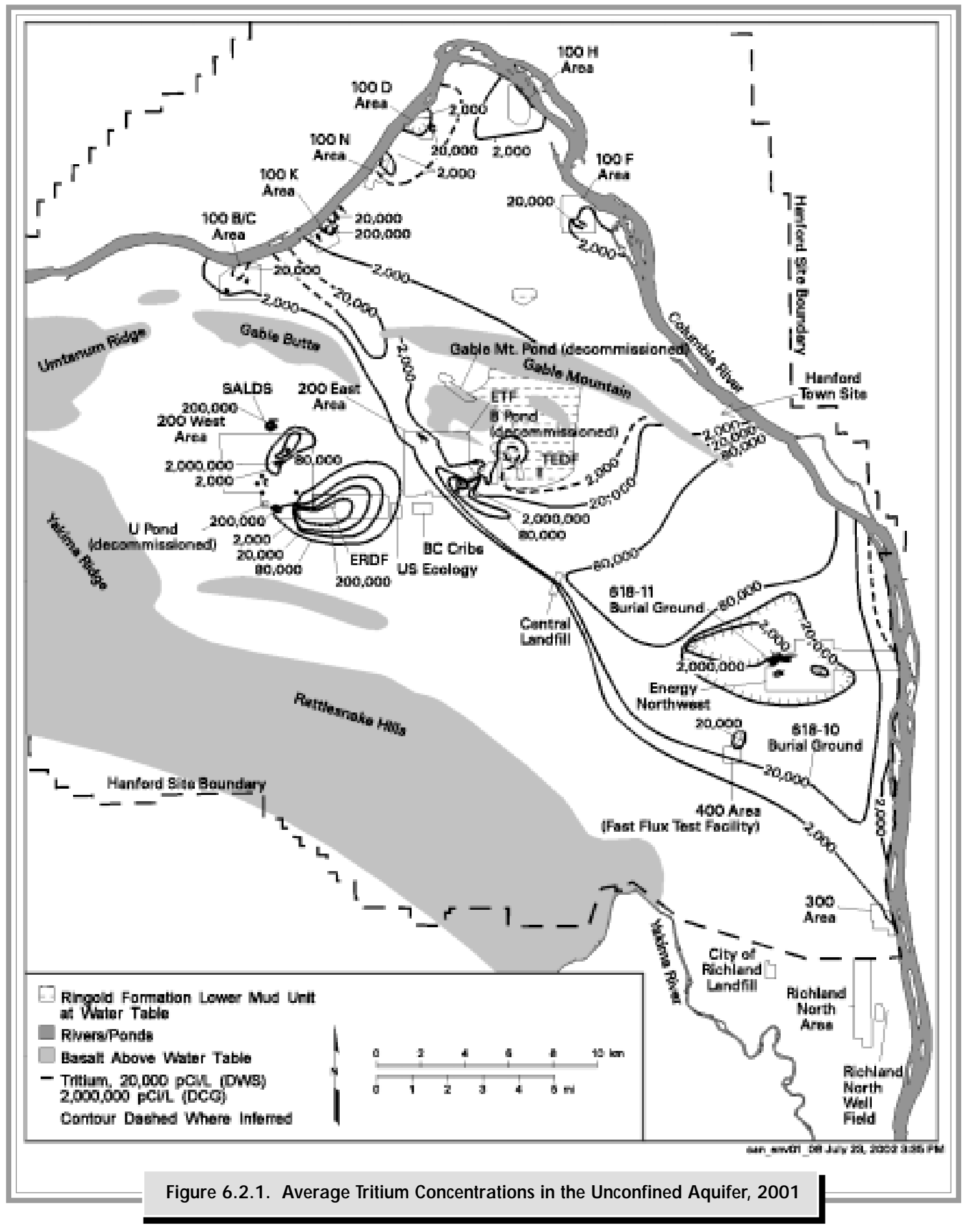




\begin{tabular}{|c|c|c|c|c|c|c|}
\hline Constituent & H anford Site & 100 A reas & 200 A reas & 300 A rea & 400 A rea & 600 A rea $^{(a)}$ \\
\hline Tritium (pCi/L) & $5,290,000$ & $1,140,000$ & $4,300,000$ & 8,870 & 27,700 & $5,290,000$ \\
\hline Iodine-129 (pCi/L) & 26 & Not detected & 22.4 & Not detected & Not detected & 26 \\
\hline Nitrate (mg/L) & 1,300 & 125 & 1,300 & 89 & 29.2 & 162 \\
\hline Carbon tetrachloride $(\mu \mathrm{g} / \mathrm{L})$ & 7,400 & Not detected & 7,400 & 0.41 & Not detected & 7.1 \\
\hline Trichloroethene $(\mu \mathrm{g} / \mathrm{L})$ & 21 & 19 & 21 & 3.3 & Not detected & 15 \\
\hline Filtered chromium $(\mu \mathrm{g} / \mathrm{L})$ & 5,660 & 5,660 & 1,640 & 4.4 & Not detected & 106 \\
\hline Strontium-90 (pCi/L) & 12,000 & 9,690 & 12,000 & 3.64 & Not analyzed & 3.9 \\
\hline Technetium-99 (pCi/L) & 81,500 & 243 & 81,500 & Not detected & Not detected & 168 \\
\hline Total uranium $(\mu \mathrm{g} / \mathrm{L})$ & 3,110 & 43.7 & 3,110 & 198 & 0.2 & 22.7 \\
\hline
\end{tabular}

\begin{tabular}{|c|c|c|c|}
\hline \multicolumn{4}{|c|}{$\begin{array}{l}\text { Table 6.2.3. Summary of Maximum Concentrations by Monitoring Purpose, } \\
\text { Calendar Year } 2001\end{array}$} \\
\hline Constituent & Restoration & Waste Management & Surveillance \\
\hline Tritium $(\mathrm{pCi} / \mathrm{L})$ & $5,290,000$ & $4,300,000$ & $5,290,000$ \\
\hline Iodine-129 (pCi/L) & 16.7 & 22.4 & 26 \\
\hline Nitrate $(\mathrm{mg} / \mathrm{L})$ & 553 & 1,300 & 1,300 \\
\hline Carbon tetrachloride $(\mu \mathrm{g} / \mathrm{L})$ & 7,400 & 4,600 & 6,200 \\
\hline Trichloroethene $(\mu \mathrm{g} / \mathrm{L})$ & 21 & 14 & 19 \\
\hline Filtered chromium $(\mu \mathrm{g} / \mathrm{L})$ & 5,660 & 1,640 & 2,370 \\
\hline Strontium-90 (pCi/L) & 9,690 & 1,500 & 12,000 \\
\hline Technetium-99 (pCi/L) & 22,900 & 81,500 & 12,600 \\
\hline Total uranium $(\mu \mathrm{g} / \mathrm{L})$ & 3,110 & 678 & 1,040 \\
\hline \multicolumn{4}{|c|}{$\begin{array}{l}\text { (a) Maximum concentrations may be the same between monitoring purposes because of } \\
\text { co-sampling between groundwater monitoring programs. } \\
1 \mathrm{pCi} / \mathrm{L}=0.037 \mathrm{~Bq} / \mathrm{L} \text {. }\end{array}$} \\
\hline
\end{tabular}

is located just north of the 200-West Area. The total radionuclides received by this facility in 2001 was 0.08 curies ( 2.96 billion becquerels) of tritium.

Tritium in the $\mathbf{1 0 0}$ A reas. In 2001, there was no waste containing tritium discharged in the 100 Areas. All the tritium detected here comes from past activities at Hanford. Tritium concentrations greater than the drinking water standard were detected in groundwater beneath portions of the 100-B/C, 100-F, 100-K, and 100-N Areas. The largest tritium plume in the 100 Areas, with concentrations above the drinking water standard, occurs along the Columbia River in the northeast part of the $100-\mathrm{N}$ Area.

Tritium concentrations in groundwater beneath most the 100-B/C Area declined during 2001. However, tritium concentrations continued to exceed the drinking water standard in several wells in the northern and southwestern parts of the 100-B/C Area. Most of the tritium contamination is associated with past liquid disposal practices at $100-\mathrm{B} / \mathrm{C}$ retention basins and trenches near the Columbia River. In 2001, the maximum tritium concentration was $40,700 \mathrm{pCi} / \mathrm{L}(1,510 \mathrm{~Bq} / \mathrm{L})$ in the southwestern part of the 100-B/C Area.

One well in the 100-F Area contained tritium at concentrations greater than the drinking water standard. A maximum of $38,600 \mathrm{pCi} / \mathrm{L}(1,430 \mathrm{~Bq} / \mathrm{L})$ occurred near the 118-F-1 burial ground in 2001. Tritium levels in this well have remained relatively stable the last few years. The burial ground received only solid waste, and the source of the tritium contamination is not known. 
A tritium plume near the KE Reactor in the $100-\mathrm{K}$ Area continued to contain the highest tritium concentrations within the 100 Areas. The maximum concentration was 1.14 million pCi/L $(42,200 \mathrm{~Bq} / \mathrm{L})$ immediately downgradient of the 116-KE-1 crib (Figure 6.2.2). The tritium concentrations at this location (well 199-K-30) are most likely the result of downward migration of tritium in moisture from the vadose zone. This tritium is associated with the 116-KE-1 crib. Carbon-14 is a co-contaminant with tritium in the groundwater. The tritium trend for well 199-K-30 is shown in Figure 6.2.3. A second source of this plume is past leakage of the KE Fuel Storage Basin, with the latest leakage occurring in 1993. Tritium concentrations in the plume farther downgradient of the 116-KE-1 crib continued to rise in 2001 and most likely indicate the arrival of the plume originating from leakage of the KE Fuel Storage Basin in 1993. In the northwestern corner of the $100-\mathrm{K}$ burial ground, tritium concentrations increased rapidly to levels above the drinking water standard from late 2000 through 2001. The maximum concentration was $98,100 \mathrm{pCi} / \mathrm{L}$ $(3,630 \mathrm{~Bq} / \mathrm{L})$ in 2001 . The elevated tritium in this area is from a previously unidentified plume to the east or southeast and circumstantial evidence suggests the burial ground is the source. Near the KW Reactor Building, tritium concentrations exceeded the drinking water standard in one well in 2001. Tritium levels greater than the drinking water standard, but much less than the DOE derived concentration guide, continued to occur during 2001 in a small area near a pump-and-treat extraction well between the 116-K-1 Liquid Waste Disposal Trench and the Columbia River.

A tritium plume at levels exceeding the drinking water standard occurs in the northern part of the 100-N Area. This plume, which generally occurs in the same area as the strontium- 90 plume, is associated with past liquid disposal to the 1301-N and 1325-N Liquid Waste Disposal Facilities. The size of the tritium plume at levels above the drinking water standard continued to decrease in 2001 because of dispersion and radioactive decay. The maximum tritium level reported in the 100-N Area in 2001 was $36,900 \mathrm{pCi} / \mathrm{L}(1,370 \mathrm{~Bq} / \mathrm{L})$ near the Columbia River.

Tritium in the 200-East and 600 A reas. The highest tritium concentrations in the 200-East Area continued to be measured in wells near cribs that received effluent from the Plutonium-Uranium Extraction Plant. Tritium levels are decreasing slowly in most wells in this area because of dispersion and radioactive decay. However, levels greater than the DOE derived concentration guide were detected in one well (299-E17-9) near the 216-A-36B crib in the southeastern part of the 200-East Area. The maximum tritium level detected in this well was 4.3 million $\mathrm{pCi} / \mathrm{L}(159,000 \mathrm{~Bq} / \mathrm{L})$ in 2001 , which is greater than the maximum detected in this well in 2000. Tritium concentrations continued to exceed the drinking water standard in many wells monitoring the cribs near the Plutonium-Uranium Extraction Plant.

In the plume that extends from the southeastern portion of the 200-East Area, tritium concentrations above $200,000 \mathrm{pCi} / \mathrm{L}(7,400 \mathrm{~Bq} / \mathrm{L})$ occurred in a small area downgradient of the Plutonium-Uranium Extraction Plant and did not extend beyond the 200-East Area boundary. The plume area at levels above $200,000 \mathrm{pCi} / \mathrm{L}$ $(7,400 \mathrm{~Bq} / \mathrm{L})$ has extended at least as far southeast as the Central Landfill in the past (PNL-8073).

A widespread tritium plume extends from the southeastern portion of the 200-East Area to the Columbia River (see Figure 6.2.1). In the western part of this tritium plume, a control in the movement of the plume to the southeast is the presence of the low permeability Ringold Formation lower mud unit at the water table east of the 200-East Area (PNNL-12261). Flow to the southeast also appears to be controlled by a zone of highly permeable sediment, stretching from the 200-East Area toward the 400 Area (PNL-7144). Near Energy Northwest, an area of lower tritium concentration is a result of a higher degree of cemented Ringold Formation sediment in the unconfined aquifer. The shape of the tritium plume indicates that tritium discharges to the Columbia River between the Hanford town site and the 300 Area. The highest tritium concentrations discharging to the river occurred near the Hanford town site, where concentrations in groundwater wells ranged from $\sim 90,000$ to $106,000 \mathrm{pCi} / \mathrm{L}(\sim 3,300$ to 3,900 Bq/L) during 2001.

Separate tritium pulses associated with the two episodes of Plutonium-Uranium Extraction Plant operations can be distinguished in the plume. A trend plot (Figure 6.2.4) of the tritium concentrations in well 699-40-1 east of the 200-East Area near the shore of the Columbia River clearly shows the arrival of a pulse in the mid-1970s. High tritium concentrations near the Columbia River result from discharges to the ground during the operation of the Plutonium-Uranium Extraction Plant from 1956 to 1972. Following an 11-year shutdown, plant operation began in 1983 and ceased in December 1988. This resulted in elevated tritium levels measured in several wells downgradient from the 200-East Area. Movement of the leading edge of this later pulse shows arrival near the Central Landfill in early 1987 (Figure 6.2.5). Tritium concentrations from the earlier pulse shown in Figure 6.2.4 were at least three times the maximum concentrations in the later pulse. The effects of the 1983 to 1988 operational period have not been detected near the Columbia River. 


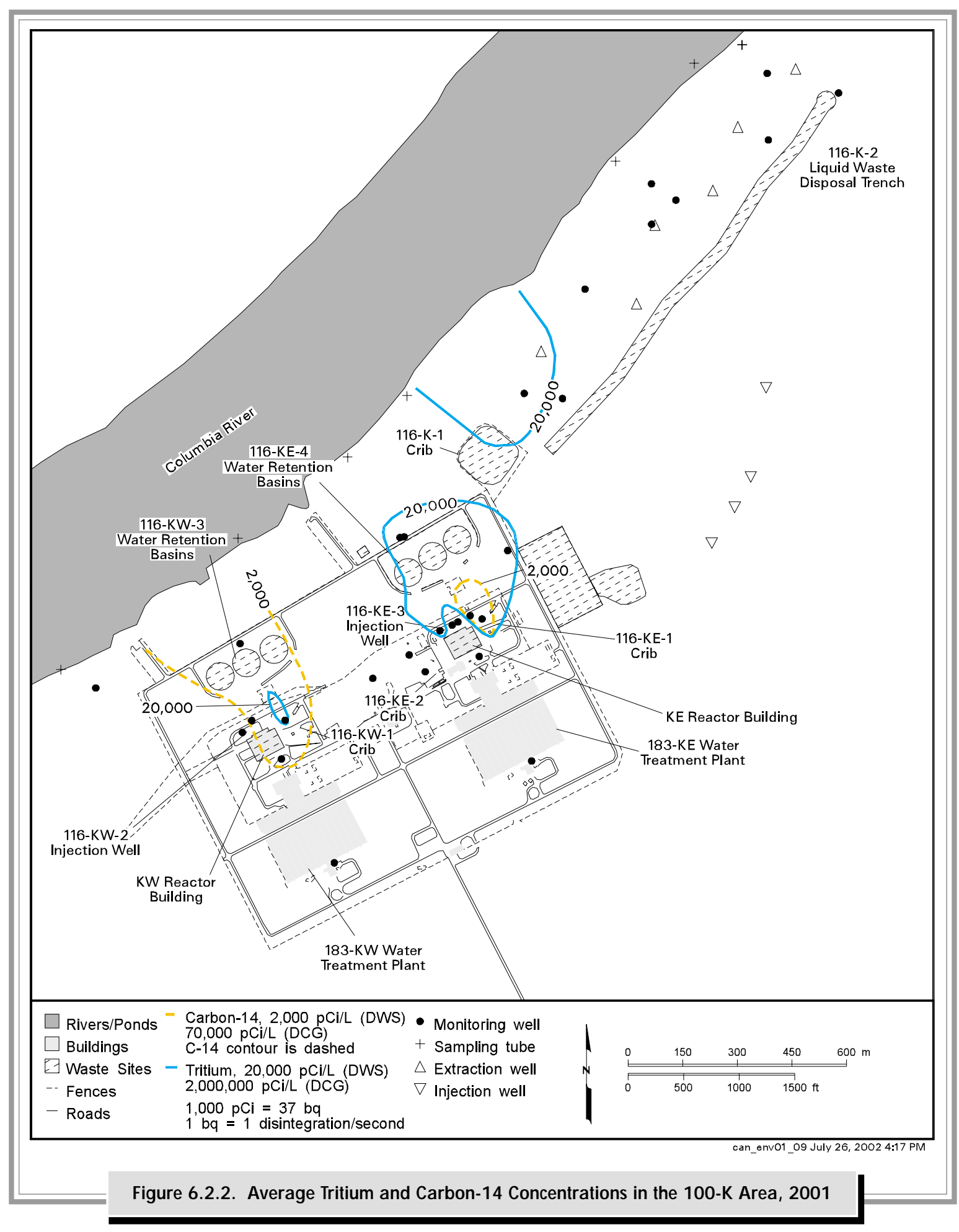



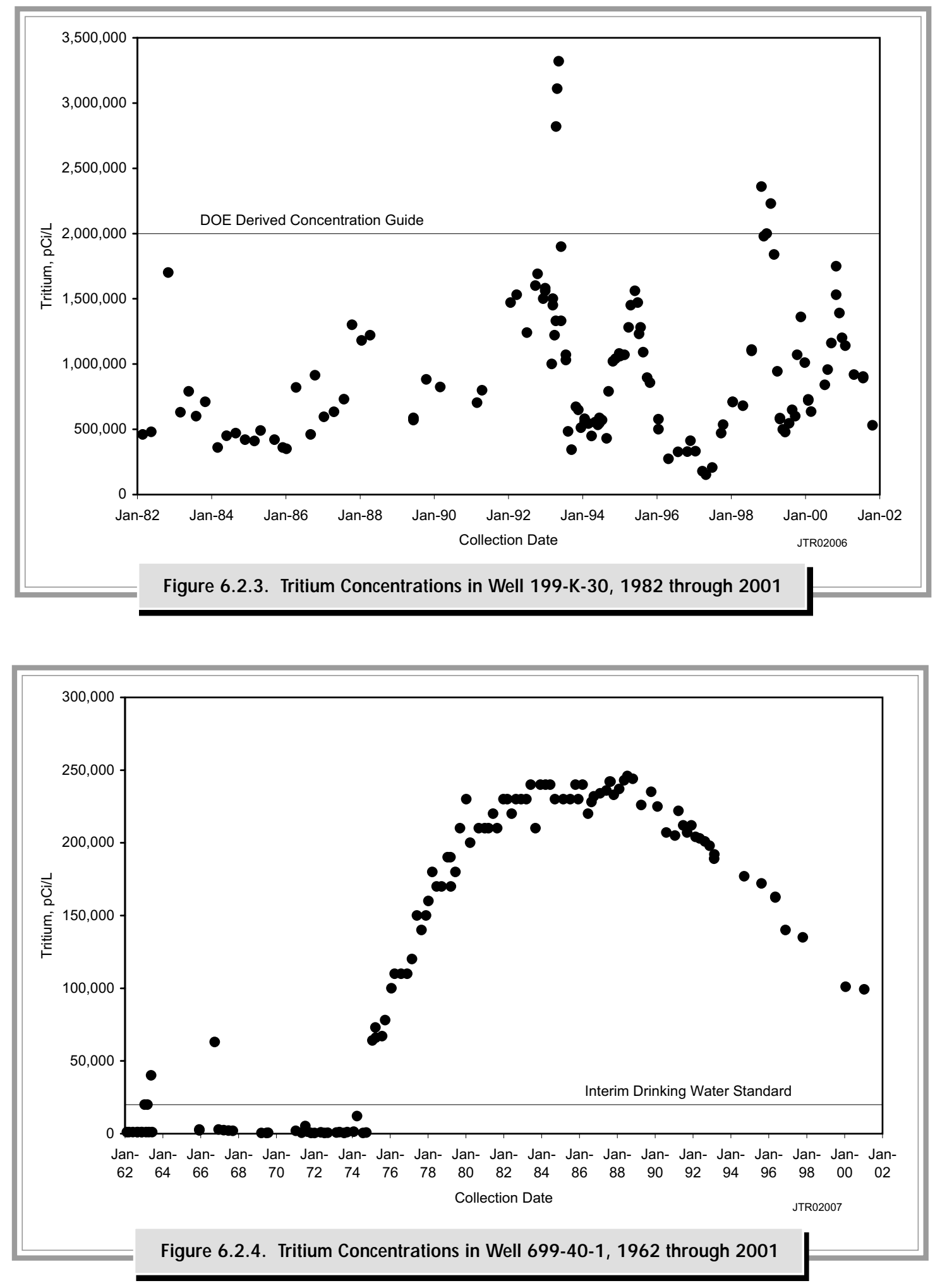


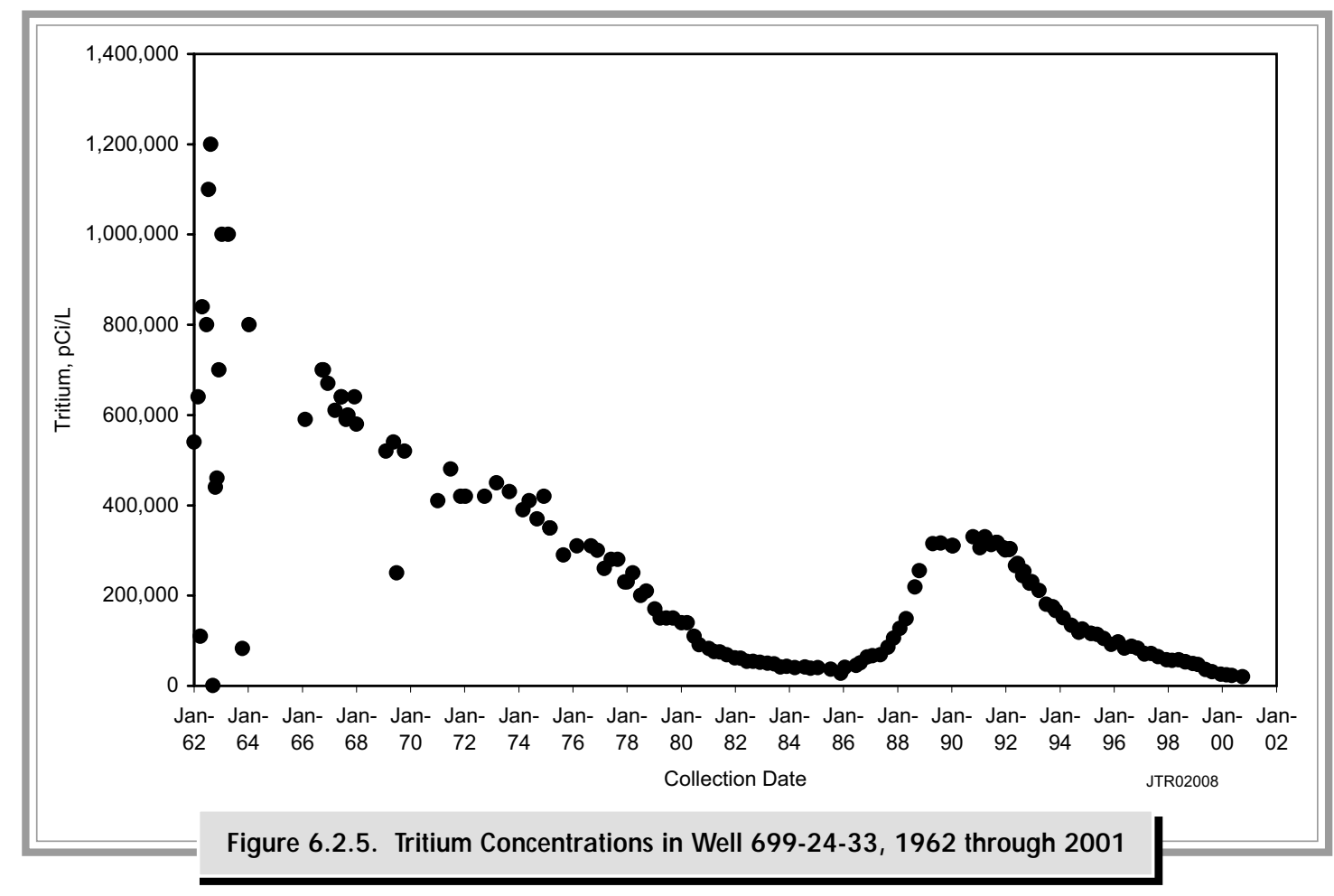

The tritium plume, which has been monitored since the 1960s, provides information on the extent of groundwater contamination over time. Figure 6.2.6 shows the distribution of tritium in selected years from 1964 through 2001. This figure was created from maps in BNWL-90, BNWL-1970, PNL-5041, PNL-6825 (Section 5.0), PNNL-11141, and PNNL-13404. The contours in the original references were recalculated and interpreted to provide uniform contour intervals. Figure 6.2.6 shows that tritium at levels greater than the drinking water standard reached the Columbia River near the Hanford town site in approximately the mid-1970s. By the late 1980s, tritium at these levels was discharging to the Columbia River several kilometers south of the Hanford town site. The tritium plume continued to expand in the southeastern part of the Hanford Site. By 1995, tritium at concentrations exceeding $20,000 \mathrm{pCi} / \mathrm{L}$ $(740 \mathrm{~Bq} / \mathrm{L})$ was entering or very near the Columbia River along greater portions of the shoreline extending between the Hanford town site and the 300 Area. Tritium levels did not change significantly between 1995 and 2001.

Tritium also is found at levels above the drinking water standard in the northwestern part of the 200-East Area (see Figure 6.2.1). This plume appears to extend to the northwest through the gap between Gable Mountain and Gable Butte where a pulse of tritium also occurs at levels above the drinking water standard. In one well near the Columbia River between the $100-\mathrm{B} / \mathrm{C}$ and 100-K Areas, tritium levels exceeded the drinking water standard for the first time in 2001. This indicates that the leading edge of the tritium pulse extending to the northwest through the gap reached the Columbia River during 2001. Sources of tritium in these areas include waste sites in the vicinity of B Plant. The tritium distribution to the northwest and southeast of the 200-East Area indicates a divide in groundwater flow direction across the 200-East Area.

Tritium in the 200-West A rea. Tritium from sources near the Reduction-Oxidation Plant forms the most extensive plume associated with the 200-West Area. The Reduction-Oxidation Plant is located in the southeastern part of the 200-West Area and operated from 1951 through 1967. This plume extends into the 600 Area east of the 200-West Area to US Ecology's facility and the eastern part of the plume curves to the north (see Figure 6.2.1). This plume has generally stopped spreading and has begun to decrease in size in some areas of the plume because of radioactive decay. The movement of plumes in the 200-West Area is expected to be slow because the Ringold Formation sediment that underlies the area has low permeability and restricts flow. Movement of the plumes in the 200-West Area also is slowing further because of declining hydraulic gradients. The highest tritium concentrations in the plume are declining, and the maximum concentration detected in this plume east of the Reduction-Oxidation Plant in 2001 was $859,000 \mathrm{pCi} / \mathrm{L}(31,800 \mathrm{~Bq} / \mathrm{L})$. Tritium concentrations exceeded the drinking water standard in much of the plume, including a small area near the former 


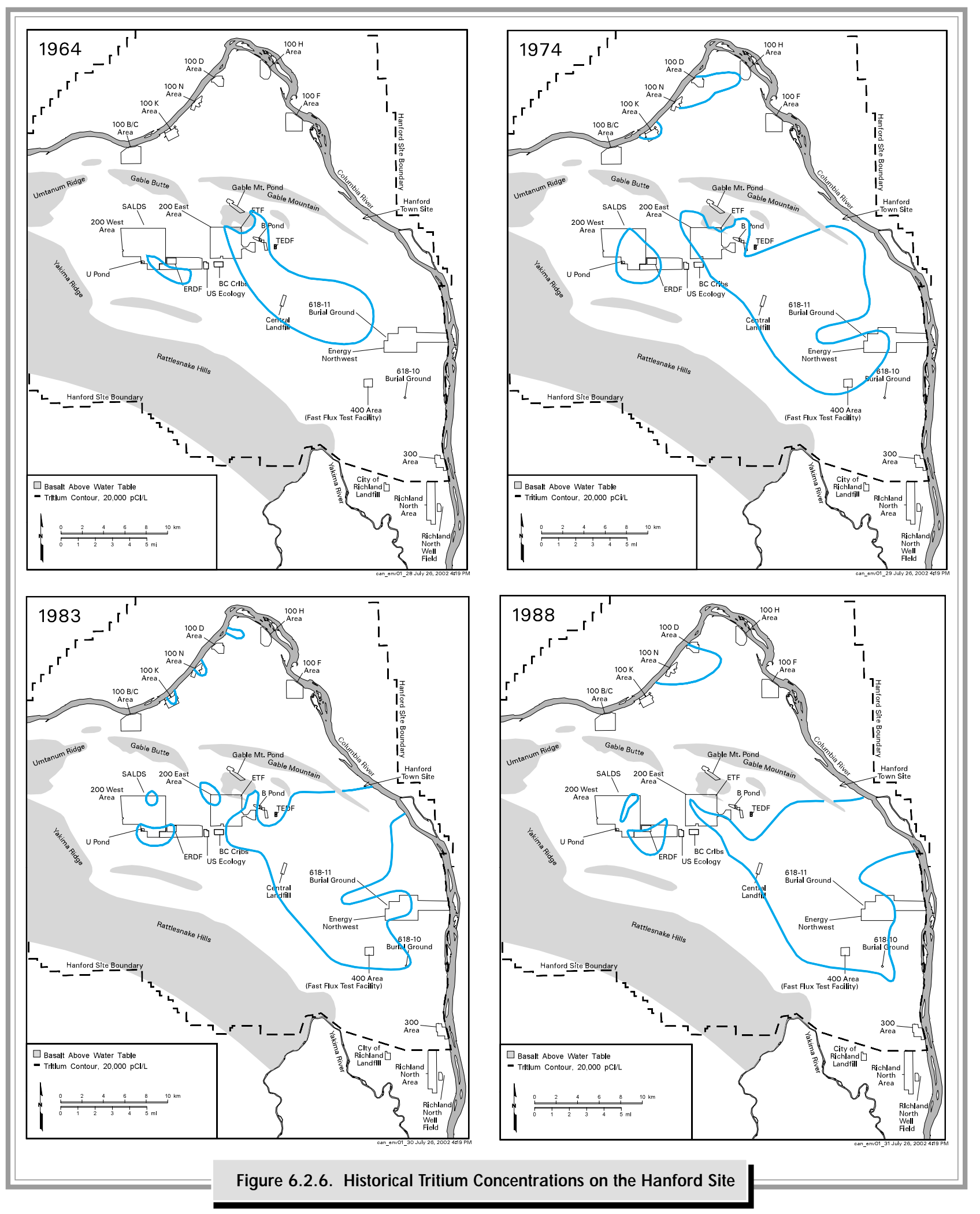




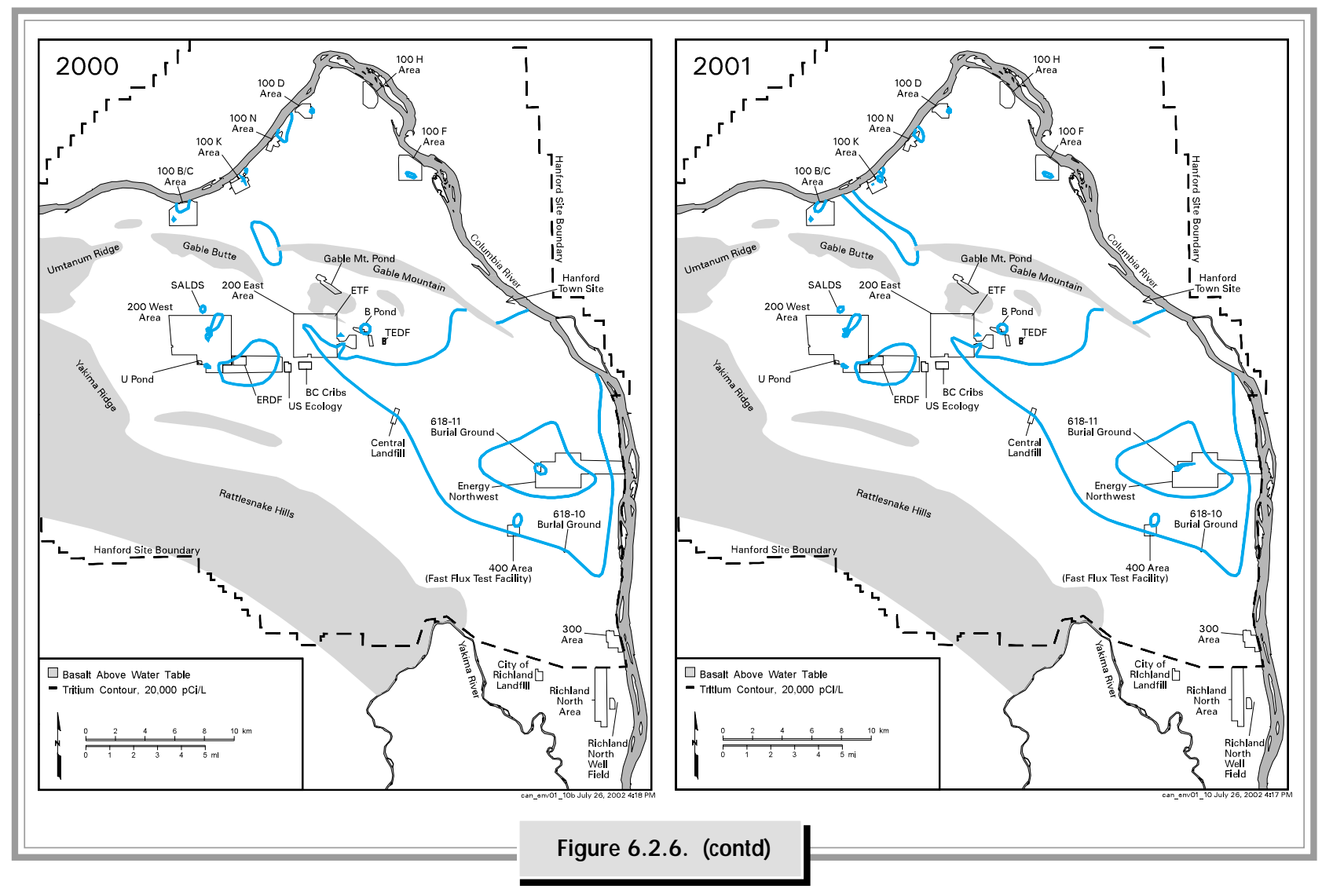

216-S-25 crib and S-SX tank farm upgradient of the Reduction-Oxidation Plant. The maximum tritium concentration in these areas in 2001 was $155,000 \mathrm{pCi} / \mathrm{L}$ $(5,740 \mathrm{~Bq} / \mathrm{L})$ adjacent to the former $216-\mathrm{S}-25 \mathrm{crib}$. Tritium concentrations near this facility decreased during 2000 and 2001 after several years of increasing concentrations.

A smaller tritium plume covers much of the northern part of the 200-West Area and extends to the northeast (see Figure 6.2.1). This plume is associated with former T Plant waste sites, including TY tank farm, the 242-T evaporator, $\mathrm{T}$ Pond, and inactive disposal cribs and trenches. The highest tritium concentration detected in the 200-West Area was 1.69 million pCi/L $(63,000 \mathrm{~Bq} / \mathrm{L})$ just east of the TX and TY tank farms near the 216-T-26 crib. Tritium concentrations at this location, which exceeded the DOE derived concentration guide in 2001, increased sharply in 1999, decreased in 2000 and early 2001, and then began to increase again in mid-2001. The area where the drinking water standard was exceeded extends northeast past the northern boundary of the 200-West Area.

Tritium concentrations in the top of the unconfined aquifer generally declined in 2001 at wells monitoring the State-Approved Land Disposal Site just north of the 200-West Area. At one of the wells monitoring this facility, tritium concentrations increased sharply to a maximum of $670,000 \mathrm{pCi} / \mathrm{L}(24,800 \mathrm{~Bq} / \mathrm{L})$ in early 2001 and then decreased sharply to levels less than the 20,000-pCi/L (740-Bq/L) drinking water standard during the latter part of 2001. The reason for this spike is that increased levels of tritium were discharged to the State-Approved Land Disposal Site during late 2000. In the deeper portion of the unconfined aquifer, tritium concentrations rose to a maximum of $980,000 \mathrm{pCi} / \mathrm{L}$ $(36,300 \mathrm{~Bq} / \mathrm{L})$ by early 2001 and then decreased to $750,000 \mathrm{pCi} / \mathrm{L}(27,800 \mathrm{~Bq} / \mathrm{L})$ by late 2001 . This rise and fall in the tritium concentrations is from the effluent from an earlier discharge containing tritium (prior to April 1999). Approximately 0.08 curies (2.96 billion becquerels) of tritium were discharged to this facility during 2001. By the end of December 2001, 325 curies $(\sim 12.025$ trillion becquerels) of tritium and over 424 million liters (112 million gallons) of treated effluent containing tritium had been discharged to this facility since operations began in 1995.

Tritium in the 300 Area and 618-11 Burial Ground. The eastern portion of the tritium plume that emanates from the 200-East Area continues to move to the east-southeast and discharge into the Columbia River (see Figure 6.2.1). The southern edge of the tritium plume extends into the 300 Area, as shown in Figure 6.2.7. 


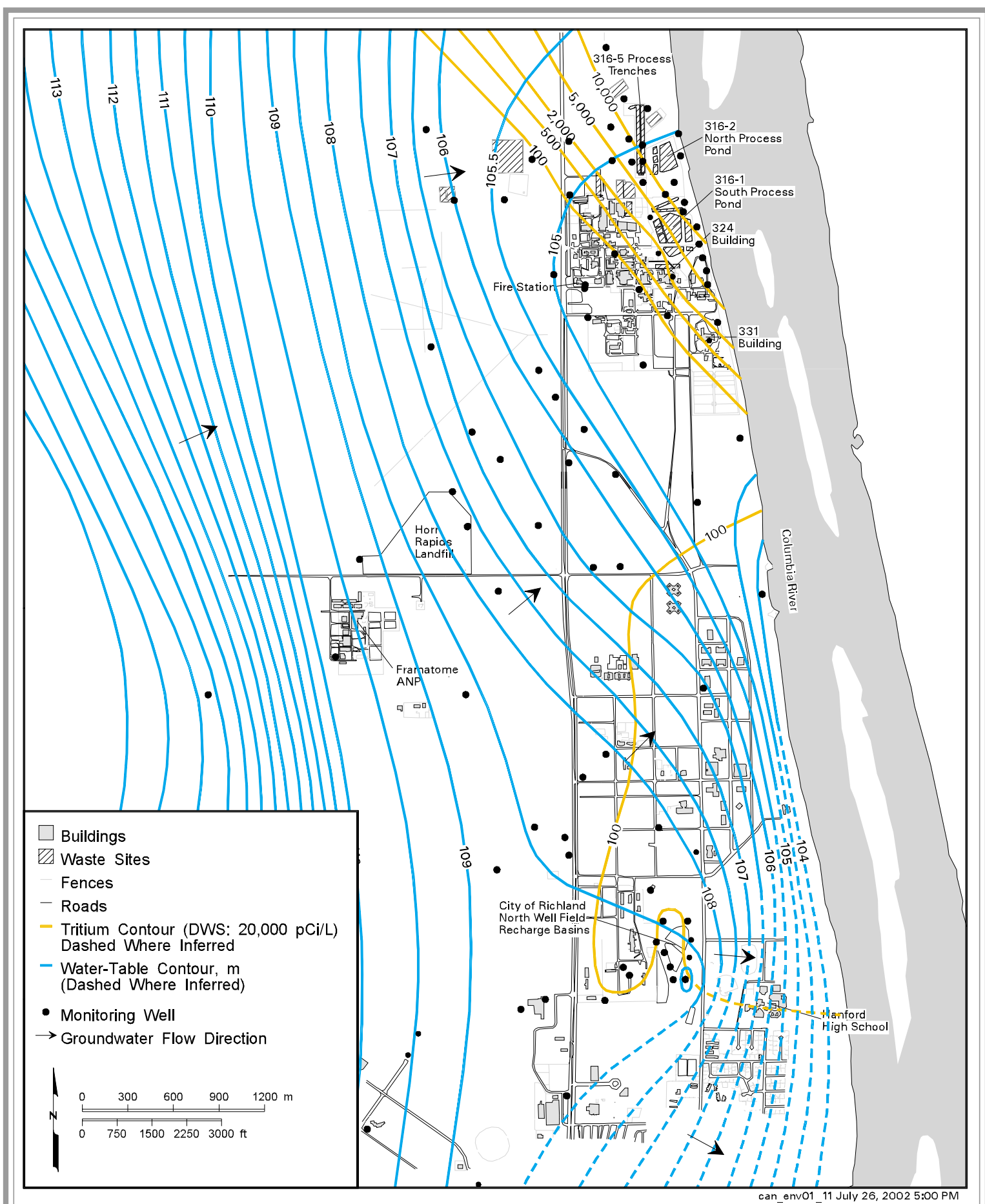

Figure 6.2.7. Average Tritium Concentrations and Groundwater Flow near the 300 Area, 2001 
Figure 6.2.7 shows that tritium concentrations decrease from $>10,000 \mathrm{pCi} / \mathrm{L}(>370 \mathrm{~Bq} / \mathrm{L})$ in the northeastern part of the 300 Area to $<100 \mathrm{pCi} / \mathrm{L}(<3.7 \mathrm{~Bq} / \mathrm{L})$ in the southwestern part of the 300 Area. The tritium contours shifted slightly to the northeast, indicating that the tritium plume in the 300 Area decreased in size between 2000 and 2001. Although tritium in the 300 Area is at levels (a maximum of $8,870 \mathrm{pCi} / \mathrm{L}[329 \mathrm{~Bq} / \mathrm{L}]$ ) less than the drinking water standard, a concern has been the potential migration of tritium to a municipal water supply to the south. The municipal water supply consists of the city of Richland's well field and recharge ponds (see Figure 6.2.7). The highest tritium level detected south of the 300 Area was $551 \mathrm{pCi} / \mathrm{L}(20 \mathrm{~Bq} / \mathrm{L})$ near the well field. Monitoring data indicate that the Hanford Site tritium plume has not reached the municipal water supply.

The tritium plume is not expected to affect the well field because of the influence of groundwater flow from the Yakima River, recharge from agricultural irrigation, and recharge from infiltration ponds at the well field (see Figure 6.2.7). The Yakima River is at a higher elevation than the water table and recharges the groundwater in this area. Groundwater flows from west to east (see Figure 6.2.7), minimizing the southward movement of the regional tritium plume from the Hanford Site. Recharge from agricultural irrigation occurs south of the
Hanford Site boundary and contributes to eastward flow. The recharge ponds are supplied with Columbia River water, which infiltrates to the groundwater. The amount of recharge water exceeded the amount pumped at the well field by a factor of at least 2:1 in 2001, resulting in groundwater flow away from the well field. Recharge creates a mound that further assures that tritiumcontaminated groundwater will not reach the well field.

The highest tritium concentrations measured in Hanford Site groundwater in 2001 were in one well (699-13-3A) immediately downgradient of the 618-11 burial ground. The maximum tritium concentration at this well was 5.29 million pCi/L $(196,000 \mathrm{~Bq} / \mathrm{L})$ in 2001 . The 618-11 burial ground is located west of the Energy Northwest reactor complex in the eastern 600 Area (Figure 6.2.8). The burial ground was active from 1962 to 1967 before the Energy Northwest reactor complex was constructed and received a variety of low- and high-level waste from the 300 Area. A special investigation in 2000 determined that the burial ground was the source of the tritium contamination (PNNL-13228). However, potential tritium source materials and locations within the burial ground have not been identified.

The investigation continued in 2001 to define the lateral and vertical extent of contamination. The 2001 study defined a tritium plume that is narrow and extends

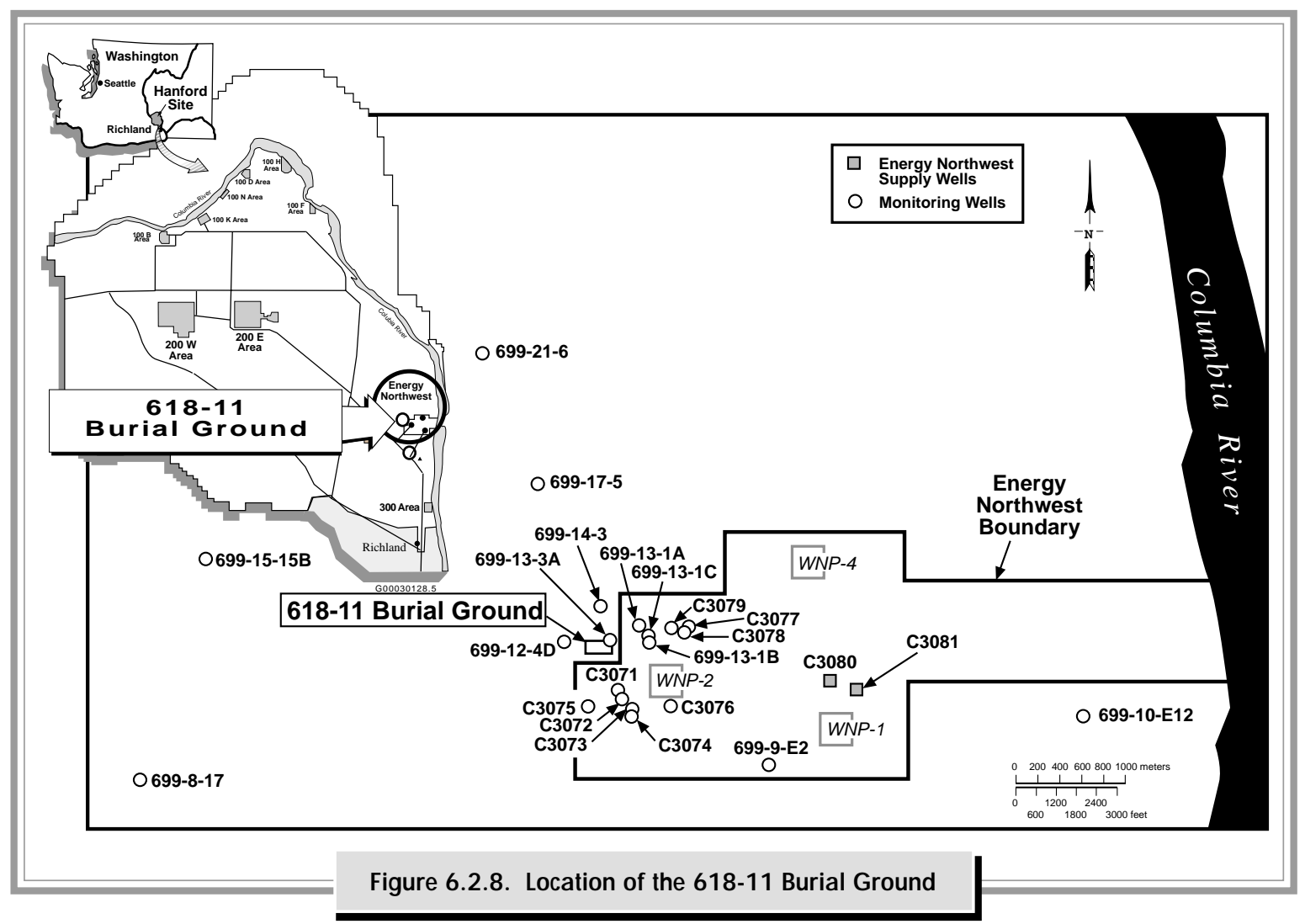


$\sim 900$ meters ( 984 yards) east-northeast of the burial ground (Figure 6.2.9). The vertical extent of the plume was throughout the unconfined aquifer above a silt layer that is 13 meters ( 43 feet) below the water table. Based on this extent, the plume is estimated to contain between 190 and 235 curies (7.03 and 8.70 trillion becquerels) of tritium. The estimated travel time for the tritium plume to reach the Columbia River is between 43 and 166 years. Therefore, tritium in this plume will most likely decay to levels less than the drinking water standard before it reaches the river.

Tritium in the $\mathbf{4 0 0}$ A rea. The tritium plume that originated in the 200-East Area extends under the 400 Area. The maximum concentration detected in this area during 2001 was $27,700 \mathrm{pCi} / \mathrm{L}(1,030 \mathrm{~Bq} / \mathrm{L})$ in the northern part of the 400 Area. The water supply wells also are located in the northern part of the 400 Area. Tritium levels in the primary (499-S1-8J) and backup (499-S0-7 and 499-S0-8) water supply wells did not exceed the annual average drinking water standard of $20,000 \mathrm{pCi} / \mathrm{L}(740 \mathrm{~Bq} / \mathrm{L})$ in 2001 . However, tritium levels in one of these wells (499-S0-7) did exceed the drinking water standard in one monthly sample $(20,700 \mathrm{pCi} / \mathrm{L}[767 \mathrm{~Bq} / \mathrm{L}])$ in early 2001 . Tritium levels in the 400 Area are slowly declining because of dispersion and radioactive decay. Additional information on the 400 Area water supplies is provided in Section 4.3.

Iodine-129. Iodine-129 has a relatively low drinking water standard $(1 \mathrm{pCi} / \mathrm{L}[0.037 \mathrm{~Bq} / \mathrm{L}])$, has the potential to accumulate in the environment as a result of long-term releases from nuclear fuel reprocessing facilities (Soldat 1976), and has a long half-life (16 million years). The iodine-129 plume at levels exceeding the drinking water standard is extensive in the 200 and 600 Areas. No groundwater samples showed iodine-129 concentrations above the $500-\mathrm{pCi} / \mathrm{L}(18.5-\mathrm{Bq} / \mathrm{L}) \mathrm{DOE}$ derived concentration guide in 2001. Iodine-129 may be released as a vapor during fuel dissolution and during other elevated temperature processes and, thus, may be associated with process condensate waste. At the Hanford Site, the main contributor of iodine-129 to groundwater is past-practice liquid discharges to cribs in the 200 Areas. Iodine-129 has essentially the same high mobility in groundwater as tritium. The highest level of iodine-129 detected in 2001 on the Hanford Site was $26 \mathrm{pCi} / \mathrm{L}(0.96 \mathrm{~Bq} / \mathrm{L})$ in the 600 Area east of the Reduction-Oxidation Plant in the 200-West Area.

lodine-129 in the 200-East A rea. The highest iodine-129 concentrations in the 200-East Area are in the southeast near the Plutonium-Uranium Extraction Plant and in the northwest in the vicinity of B Plant (Figure 6.2.10). The maximum level of iodine-129 detected in 2001 in the 200-East Area was $9.8 \mathrm{pCi} / \mathrm{L}$
$(0.36 \mathrm{~Bq} / \mathrm{L})$ south of the Plutonium-Uranium Extraction Plant near the 216-A-36B crib. Iodine-129 concentrations near this area are declining slowly or are stable. The iodine-129 plume extends from the PlutoniumUranium Extraction Plant area southeast into the 600 Area and appears coincident with the tritium plumes (see Figure 6.2.10). The iodine-129 plume likely had the same sources as the tritium plume. The iodine-129 plume appears smaller than the tritium plume because of the lower initial concentration of iodine-129. The iodine-129 contamination can be detected as far to the east as the Columbia River but at levels less than the drinking water standard. Data indicate that the portion of the iodine-129 plume at levels above the drinking water standard moved 2.5 kilometers (1.6 miles) toward the Columbia River between 1990 and 2001. The leading edge of the iodine-129 plume at levels equal to the $1 \mathrm{pCi} / \mathrm{L}(0.037 \mathrm{~Bq} / \mathrm{L})$ drinking water standard was 3 to 4 kilometers (1.9 to 2.5 miles) from the river in 2001. Iodine-129 also is present in groundwater at levels above the drinking water standard in the northwestern portion of the 200-East Area and extends northwest into the gap between Gable Mountain and Gable Butte.

lodine-129 in the 200-West A rea. The distribution of iodine-129 in Hanford Site groundwater is shown in Figure 6.2.10. The highest level detected in the $200-$ West Area in 2001 was $22.4 \mathrm{pCi} / \mathrm{L}(0.83 \mathrm{~Bq} / \mathrm{L})$ near the TX and TY tank farms. This level occurs in a plume that extends northeast toward T Plant. The iodine-129 plume, which is generally coincident with the technetium-99 and tritium plumes in this area, most likely originates from the 242-T evaporator located between the TX and TY tank farms. A much larger iodine-129 plume occurs in the southeastern part of the 200-West Area, which originates near the ReductionOxidation Plant, and extends east into the 600 Area. This plume is essentially coincident with the tritium plume, though there appears to be a contribution from cribs to the north near U Plant. In 2001, the maximum concentration detected in this plume was $26 \mathrm{pCi} / \mathrm{L}$ $(0.96 \mathrm{~Bq} / \mathrm{L})$ in the 600 Area east of the ReductionOxidation Plant. Iodine-129 levels in this plume have not changed significantly in the last several years.

Technetium-99. Technetium-99, which has a half-life of 210,000 years, was produced as a high-yield fission byproduct and was present in waste streams associated with fuel reprocessing. Past reactor operations also may have resulted in the release of some technetium-99 associated with fuel element breaches. Technetium-99 is typically associated with uranium through the fuel processing cycle, but uranium is less mobile in groundwater. Under the chemical conditions that exist in Hanford Site groundwater, technetium-99 is normally present in 


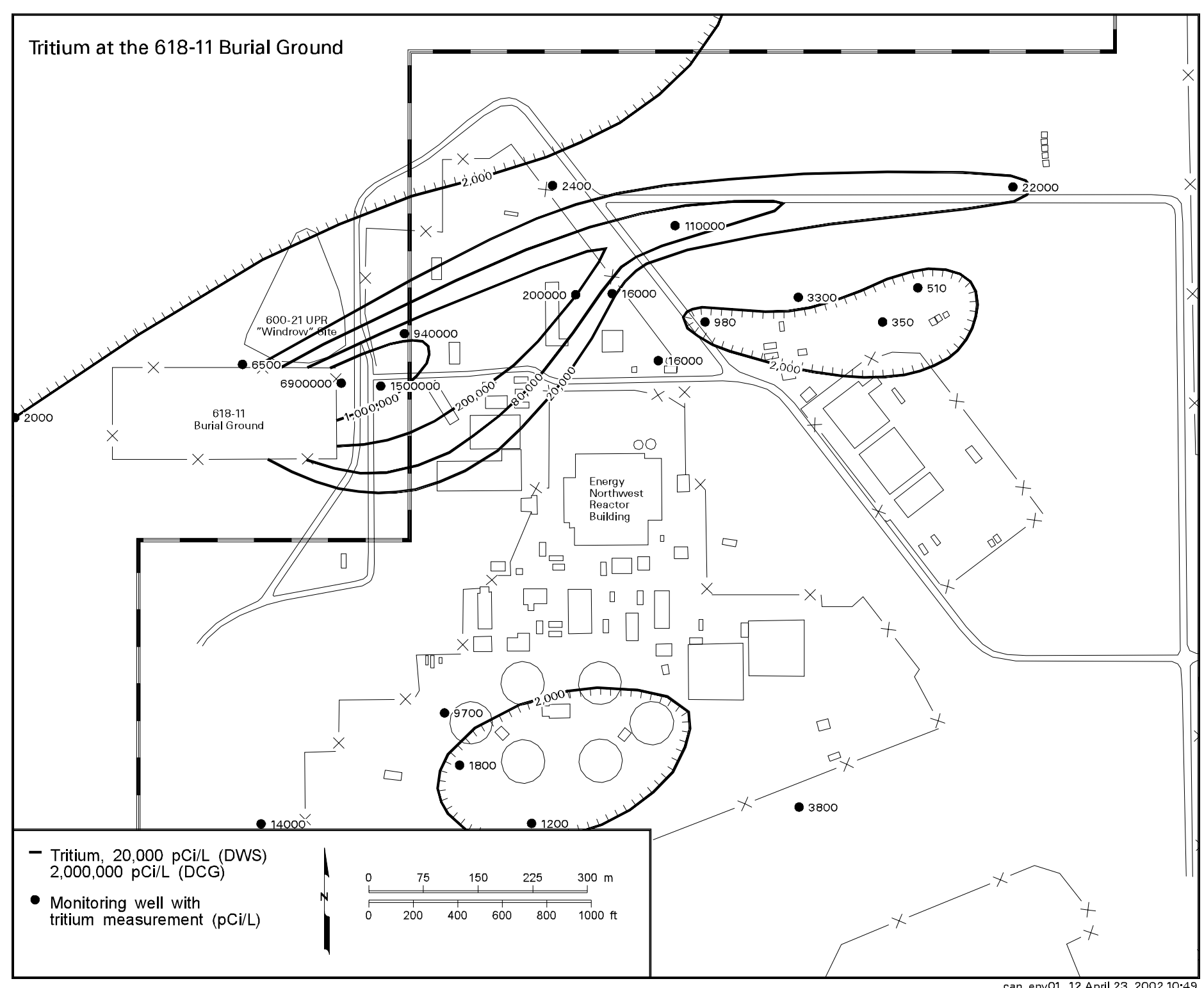

can env01 12 Aorl 23. 2002 10:49

Figure 6.2.9. Average Tritium Concentrations in the Unconfined Aquifer at 618-11 Burial Ground, 2001 


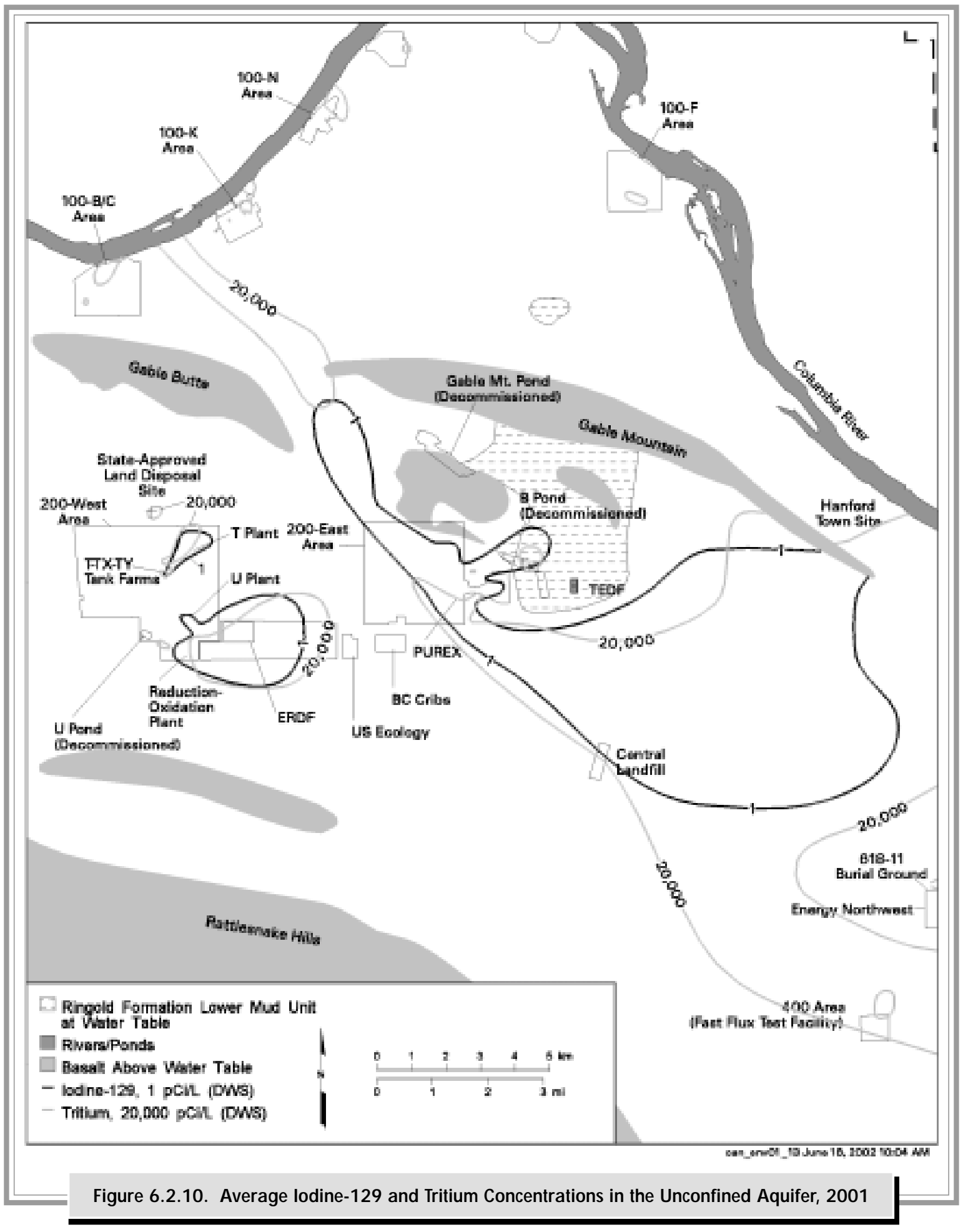


solution as anions that sorb poorly to sediments. Therefore, technetium-99 is very mobile in site groundwater.

The DOE derived concentration guide is $100,000 \mathrm{pCi} / \mathrm{L}(3,700 \mathrm{~Bq} / \mathrm{L})$ and the interim drinking water standard is $900 \mathrm{pCi} / \mathrm{L}(33 \mathrm{~Bq} / \mathrm{L}$ ) for technetium-99. Technetium-99 was found at concentrations greater than the $900-\mathrm{pCi} / \mathrm{L}$ interim drinking water standard in the 200-East and 200-West Areas. The highest level measured on the Hanford Site in 2001 was $81,500 \mathrm{pCi} / \mathrm{L}$ $(3,020 \mathrm{~Bq} / \mathrm{L})$ near the SX tank farm in the 200 -West Area.

Technetium-99 in the 200-East A rea. Groundwater in the northwestern part of the 200-East Area and a part of the 600 Area north of the 200-East Area contains technetium-99 at concentrations above the interim drinking water standard (Figure 6.2.11). The source of the technetium contamination was apparently the BY cribs (Section 2.9.1 in PNNL-13116). However, some of this contamination is believed to originate from tank farms B, BX, and BY (PNNL-11826). Technetium-99 concentrations began to decrease in several wells monitoring tank farms B, BX, and BY in 2001 after reaching a maximum concentration in late 2000 to early 2001 (Figure 6.2.12). The maximum concentration in the 200-East Area in 2001 occurred at the BY cribs at a level of $12,600 \mathrm{pCi} / \mathrm{L}(467 \mathrm{~Bq} / \mathrm{L})$. Technetium-99 concentrations in the plume north of the 200-East Area have exceeded the drinking water standard (maximum of $3,200 \mathrm{pCi} / \mathrm{L}[118 \mathrm{~Bq} / \mathrm{L}]$ in 2000 ). The sampling frequency for wells in this area was changed from annual to triennial; thus, the wells were not sampled in 2001. The wells in this area will be sampled in 2002 and 2003. This larger portion of the plume to the north appears to be moving north through the gap between Gable Mountain and Gable Butte. Increasing technetium-99 concentrations southeast of the BX and BY tank farms in recent years indicate that part of the technetium-99 plume is moving to the southeast.

Technetium-99 in the 200-West A rea. The largest technetium-99 plume in the 200-West Area originates from cribs that received effluent from U Plant and extends into the 600 Area to the east (Figure 6.2.13). The technetium plume is approximately in the same location as the uranium plume because technetium-99 and uranium, which are typically associated with the same fuel reprocessing cycle, were disposed to the same 216-U-1, 216-U-2, and 216-U-17 cribs. A pump-andtreat system reduced technetium-99 concentrations in the central part of the plume in 2001 (see Section 2.3.11). Technetium-99 concentrations have generally declined in the central part of the plume since pump-and-treat operations began in 1997. The maximum level in this plume was detected at a concentration of $22,900 \mathrm{pCi} / \mathrm{L}$ $(848 \mathrm{~Bq} / \mathrm{L})$.

Several wells that monitor tank farms T, TX, and TY consistently showed technetium-99 concentrations above the interim drinking water standard in recent years (see Figure 6.2.13). In 2001, the highest was $5,670 \mathrm{pCi} / \mathrm{L}(210 \mathrm{~Bq} / \mathrm{L})$ east of the TX and TY tank farms. The 200-ZP-1 pump-and-treat operation immediately to the south is having a significant influence on the distribution of contaminants beneath the TX and TY tank farms. A large cone of depression in the water table is resulting in the movement of contaminants beneath the tank farms toward the pump-and-treat system.

In the northeastern corner of $\mathrm{T}$ tank farm, technetium-99 levels were above the interim drinking water standard. The maximum in this area was $5,010 \mathrm{pCi} / \mathrm{L}(186 \mathrm{~Bq} / \mathrm{L})$ in 2001 . Technetium-99 concentrations have generally declined in the northeastern corner of $\mathrm{T}$ tank farm after reaching maximum concentrations in the late 1990s. The sources of the technetium-99 contamination include tank farms $\mathrm{T}$, TX, and TY (PNNL-11809).

Technetium-99 contamination in small areas in the southern part of the 200-West Area originates near tank farms $S$ and SX and the 216-S-13 crib. Multiple sources of technetium-99 contribute to groundwater contamination in this area (PNNL-11810; PNNL-13441). The maximum level detected was $81,500 \mathrm{pCi} / \mathrm{L}(3,020 \mathrm{~Bq} / \mathrm{L})$ in the southwestern corner of tank farm SX. This was the highest technetium-99 concentration detected on the Hanford Site in 2001.

Total U ranium. There were numerous possible sources of uranium released to the groundwater at the Hanford Site in the past, including fuel fabrication, fuel reprocessing, and uranium recovery operations. Uranium may exist in several states, including elemental uranium or uranium oxide as well as tetravalent and hexavalent cations. Only the hexavalent form has significant mobility in groundwater, largely by forming dissolved carbonate species. Uranium mobility is, thus, dependent on oxidation state, $\mathrm{pH}$, and the presence of carbonate. Uranium is observed to migrate in site groundwater but is retarded relative to more mobile species such as technetium-99 and tritium. The EPA's drinking water standard for uranium ${ }^{(b)}$ is $30 \mu \mathrm{g} / \mathrm{L}$, which is protective of both chemical toxicity and cancer risk.

(b) The final rule for the uranium drinking water standard was promulgated on December 7, 2000, and becomes effective on December 8, 2003 (40 CFR Parts 9, 141, and 142). 


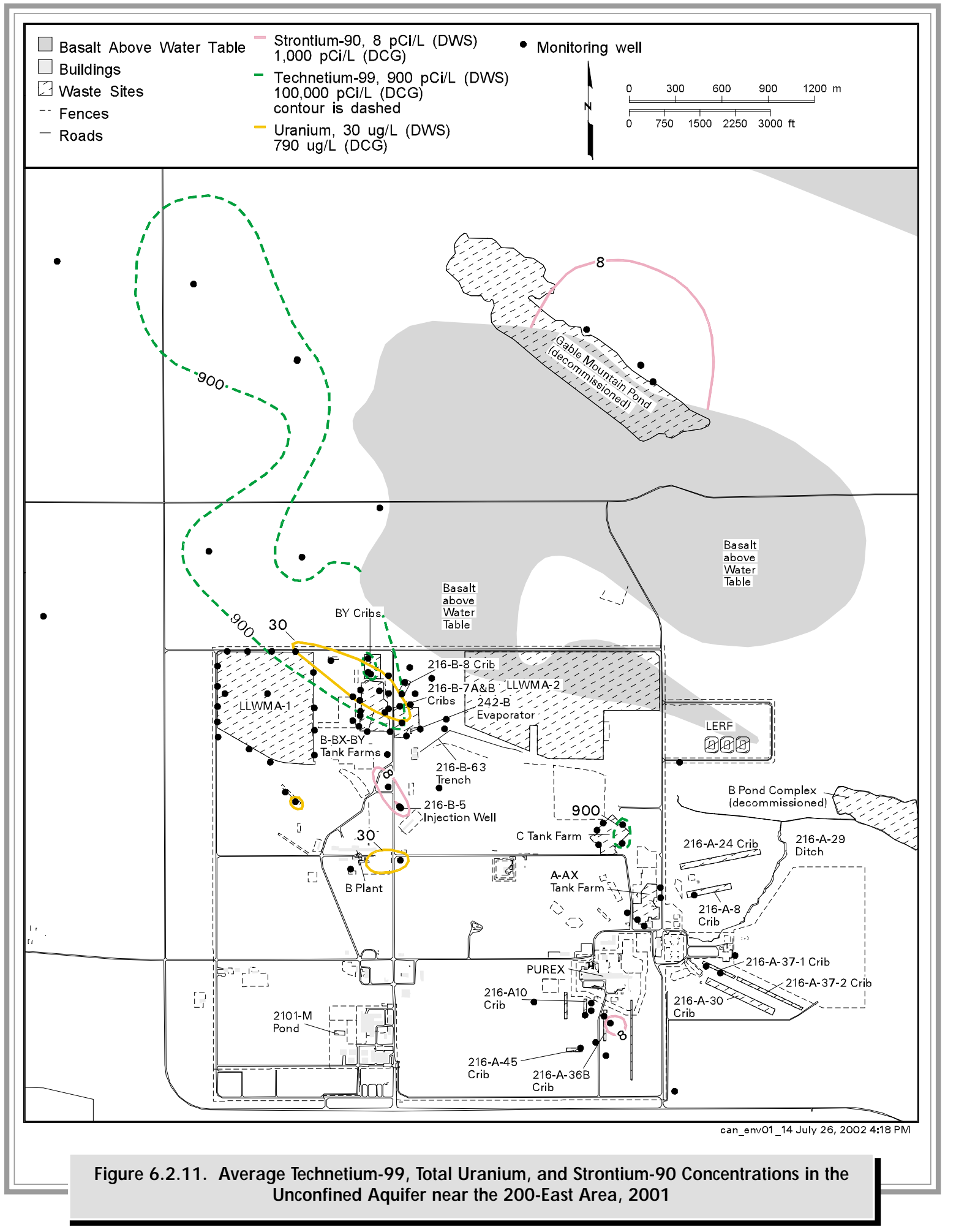




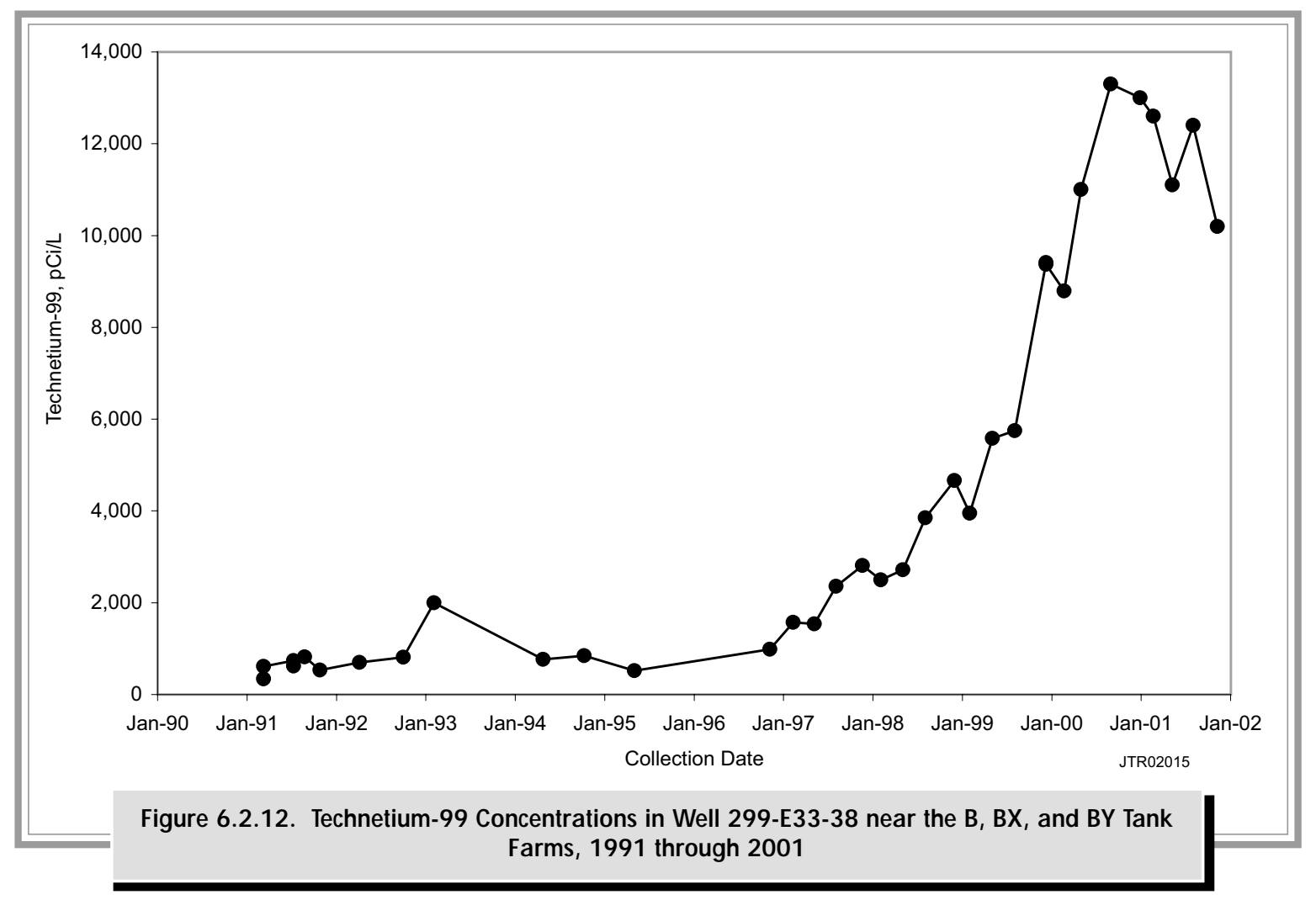

The DOE derived concentration guide that represents an annual effective dose equivalent of $100 \mathrm{mrem} / \mathrm{yr}$ ( 1 millisievert/yr) is $790 \mu \mathrm{g} / \mathrm{L}$ for uranium.

Total uranium has been detected at concentrations greater than the drinking water standard in portions of the 100, 200, and 300 Areas. The highest levels detected at the Hanford Site in 2001 were in the 200-West Area near U Plant, where uranium levels were $3,110 \mu \mathrm{g} / \mathrm{L}$ and exceeded the DOE derived concentration guide.

Total U ranium in the 100 A reas. Uranium was detected at levels exceeding the $30-\mu \mathrm{g} / \mathrm{L}$ drinking water standard in a small area in the $100-\mathrm{H}$ Area. The maximum level detected in 2001 was $43.7 \mu \mathrm{g} / \mathrm{L}$ between the 183-H solar evaporation basins and the Columbia River. Concentrations of uranium (and associated technetium-99) in the 100-H Area have generally fluctuated in response to changes in groundwater levels in the past several years. Near the river, low groundwater levels are usually associated with higher concentrations. Past leakage from the $183-\mathrm{H}$ solar evaporation basins is the source of the 100-H Area uranium contamination.

Total U ranium in the 200-East A rea. In the 200-East Area, uranium contamination at levels greater than the drinking water standard is limited to isolated areas associated with B Plant (see Figure 6.2.11). The uranium distribution in 2001 indicates the highest concentrations were in the vicinity of the $\mathrm{B}, \mathrm{BX}$, and BY tank farms; BY cribs; and 216-B-5 injection well that has been inactive since 1947. The highest concentration detected was $678 \mu \mathrm{g} / \mathrm{L}$ at the BY tank farm (south of the BY cribs). The uranium plume, which is associated with technetium-99 at the BY tank farm area, has a narrow northwest-southeast shape. Though unclear, a likely source of the uranium contamination is from the tank farm area.

Total U ranium in the 200-West A rea. The highest uranium concentrations in Hanford Site groundwater occurred near U Plant (see Figure 6.2.13). The 216-U -1 and $216-U-2$ cribs are the major sources of the uranium. The maximum detected in this area and on the Hanford Site in 2001 was $3,110 \mu \mathrm{g} / \mathrm{L}$ in a former pump-and-treat well adjacent to U Plant (Figure 6.2.14). The uranium plume, which extends into the 600 Area to the east, is approximately in the same location as the technetium-99 plume discussed above. Uranium and technetium-99 were typically associated with the same fuel reprocessing cycle and were disposed to the same cribs. However, uranium is less mobile than technetium-99 because of its stronger sorption to the sediment. A greater proportion of the uranium contamination remains at or near the source area. The general configuration of the uranium plume is similar to past years. The high concentrations exceeded the DOE 


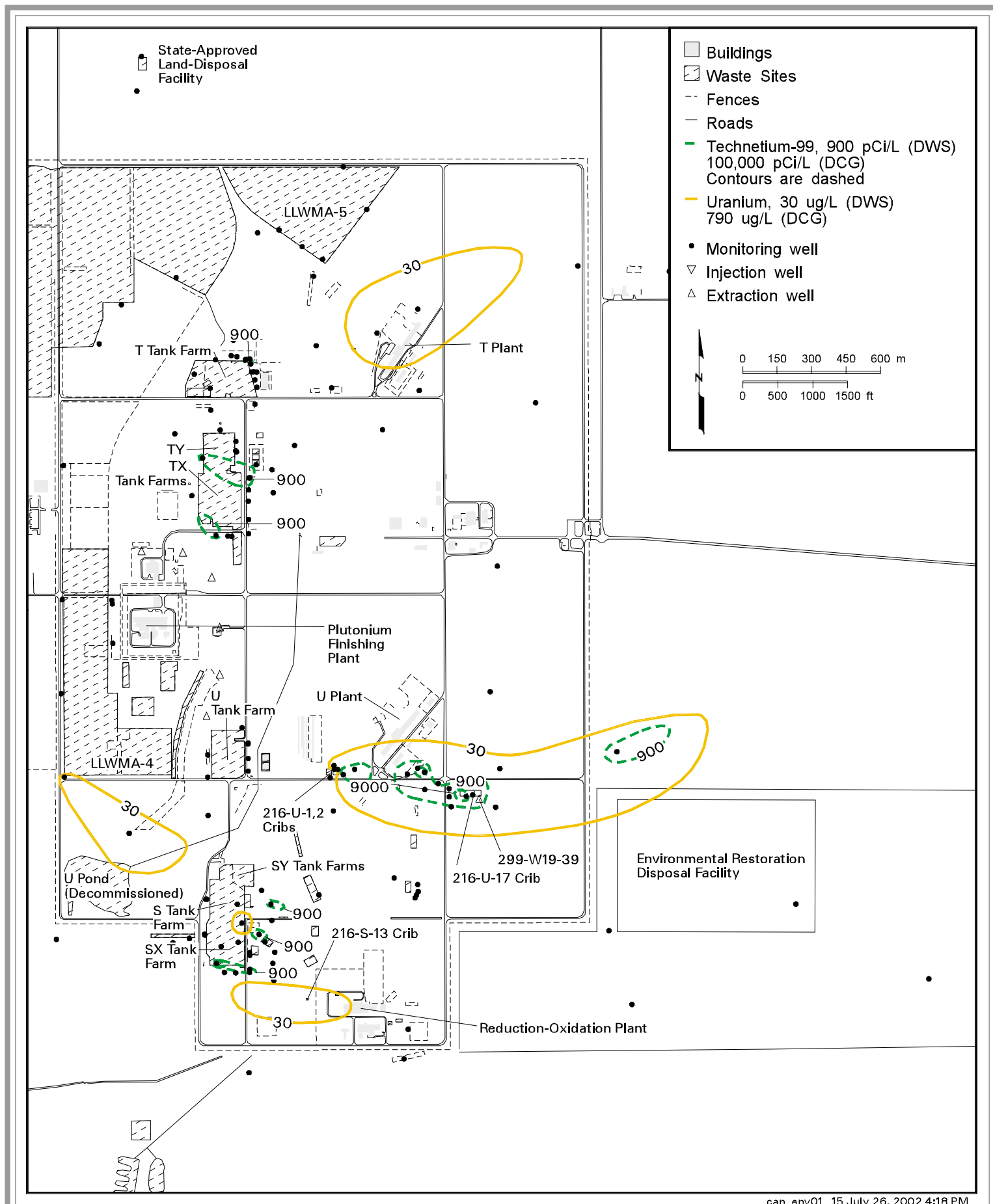

Figure 6.2.13. Average Technetium-99 and Total Uranium Concentrations in the Unconfined Aquifer in the 200-West Area, 2001 


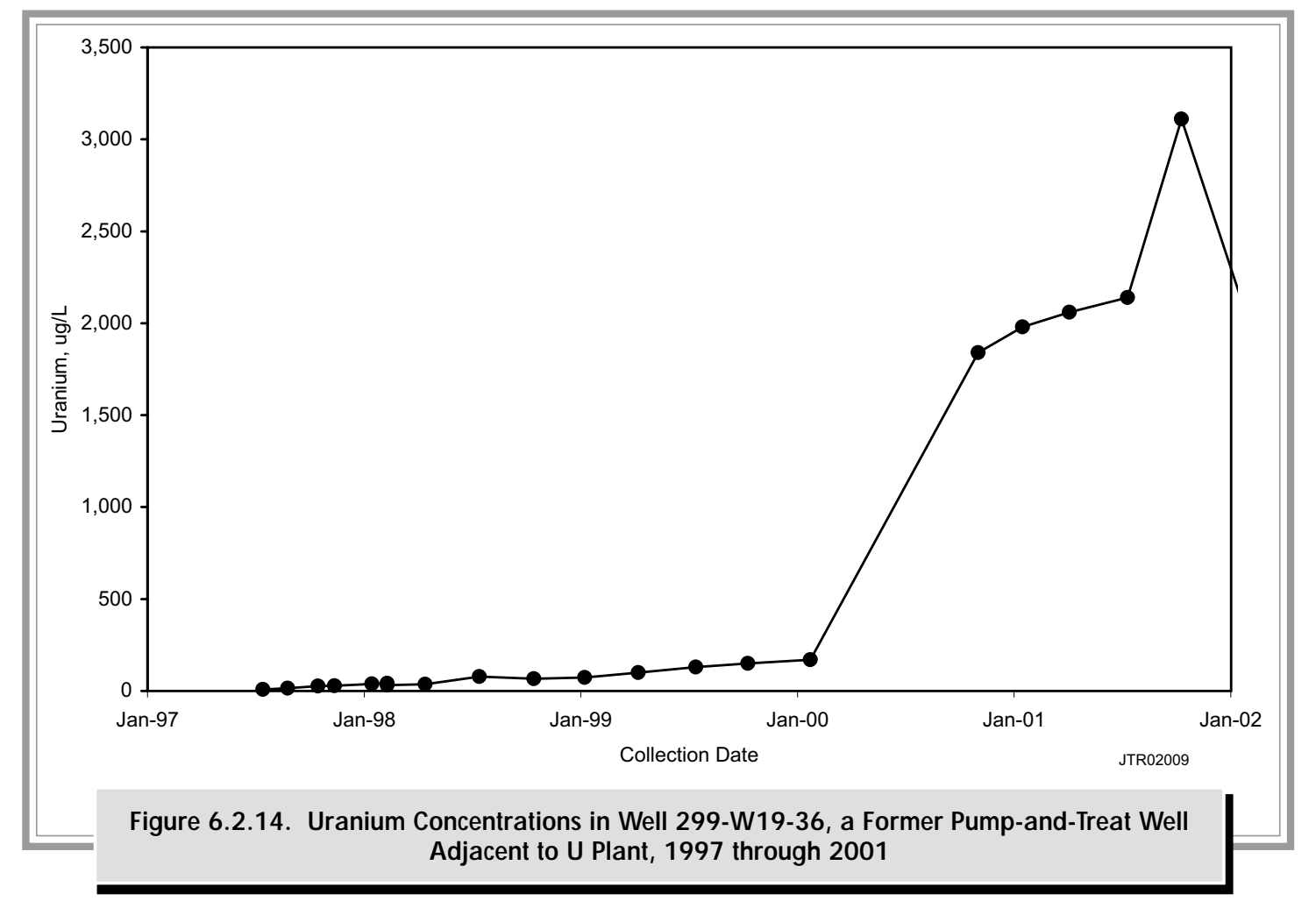

derived concentration guide for uranium. A pumpand-treat system continued to operate in 2001 to remove uranium from groundwater (see Section 2.3.11).

In the northern part of the 200-West Area, a localized area of uranium contamination occurs near T Plant, where concentrations were above the drinking water standard at a maximum level of $433 \mu \mathrm{g} / \mathrm{L}$.

Total U ranium in the 300 A rea. A plume of uranium contamination exists near former uranium fuel fabrication facilities and inactive waste sites known to have received uranium waste. The plume extends downgradient from inactive liquid waste disposal facilities to the Columbia River (Figure 6.2.15). The major source of the contamination is the inactive $316-5$ process trenches, as indicated by the distribution of the uranium concentrations downgradient from these trenches. The maximum concentration detected at this area in 2001 was $198 \mu \mathrm{g} / \mathrm{L}$ southeast of the South Process Pond near the Columbia River. Because wastewater is no longer discharged to the $316-5$ process trenches, elevated concentrations at the south end of the process trenches indicate that the soil column contributes uranium contamination to the groundwater. Uranium levels in the 300 Area fluctuate annually but show an overall decline. The annual fluctuation in uranium levels is caused by river stage changes, which results in mobilization of more uranium during high river stages in spring and less uranium during low river stages in fall and early winter.

A localized area of elevated levels of uranium between the 324 Building and the Columbia River moved downgradient with groundwater flow to a position adjacent to the Columbia River in recent years. The source of this localized uranium is suspected to be the former 307 trenches. In 2001, the elevated uranium concentrations adjacent to the river declined to a maximum level $(110 \mu \mathrm{g} / \mathrm{L})$ that is no longer distinguishable from concentrations in the process trenches uranium plume.

Strontium-90. Strontium-90 was produced as a high-yield fission product and was present in waste streams associated with past fuel reprocessing. Reactor operations also resulted in the release of some strontium-90 associated with fuel element breaches. Strontium-90 mobility in Hanford Site groundwater is reduced by adsorption onto sediment particles. However, strontium-90 is moderately mobile in groundwater because its adsorption is much weaker than for other radionuclides such as cesium- 137 and plutonium. Because of sorption, a large proportion of the strontium-90 in the subsurface is not present in solution. The half-life of strontium-90 is 29.1 years.

In 2001, strontium-90 concentrations greater than the $8-\mathrm{pCi} / \mathrm{L}(0.3-\mathrm{Bq} / \mathrm{L})$ drinking water standard were 


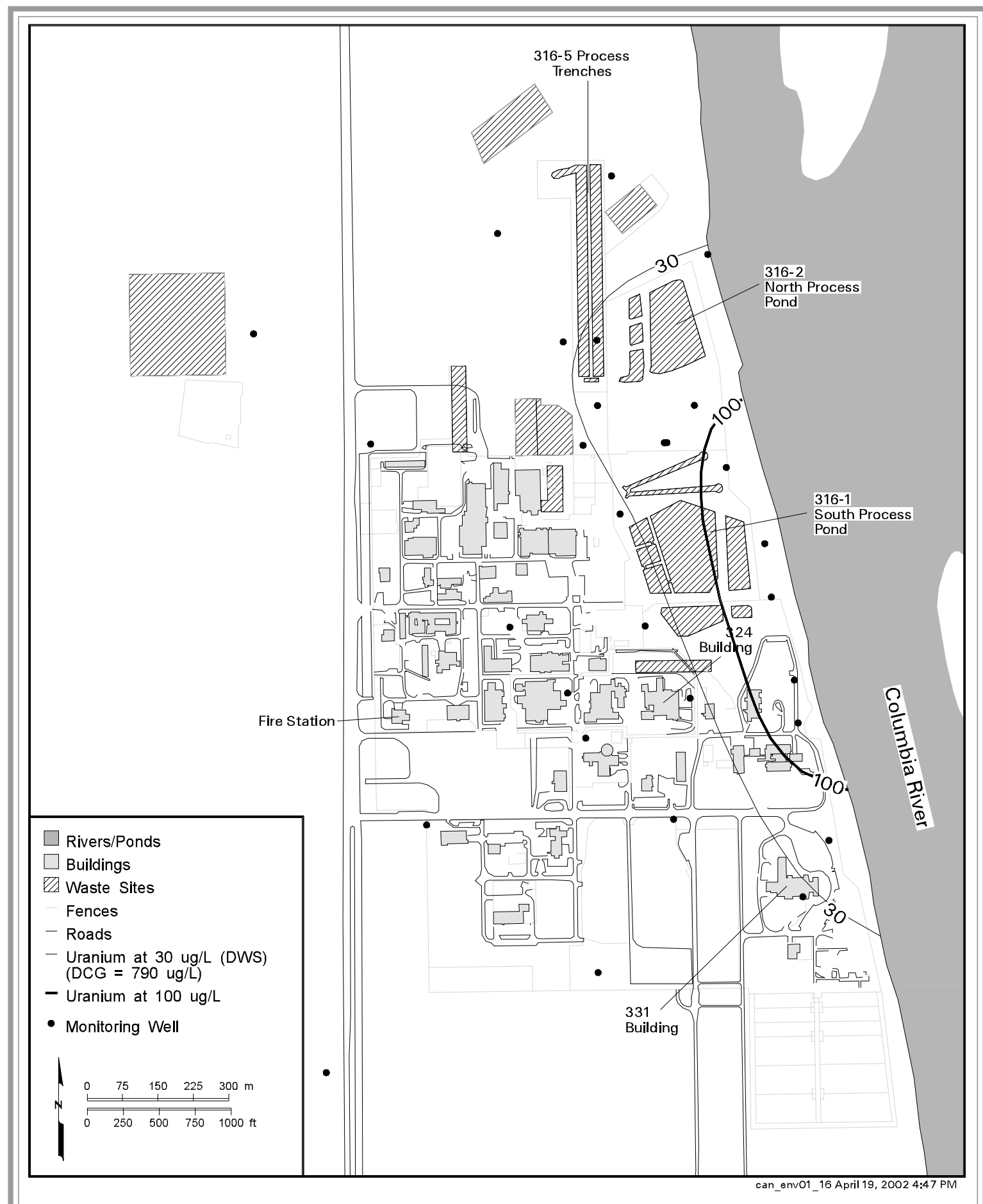

Figure 6.2.15. Average Total Uranium Concentrations in the Unconfined Aquifer in the 300 Area, 2001 
found in one or more wells in each of the 100 and 200 Areas. Levels of strontium-90 were greater than the $1,000-\mathrm{pCi} / \mathrm{L}(37-\mathrm{Bq} / \mathrm{L}) \mathrm{DOE}$ derived concentration guide in the 100-K, 100-N, and 200-East Areas. The 100-N Area had the widest distribution detected at the Hanford Site during 2001. The maximum concentration detected at the Hanford Site was $12,000 \mathrm{pCi} / \mathrm{L}$ $(444 \mathrm{~Bq} / \mathrm{L})$ in the 200-East Area.

Strontium-90 in the 100 A reas. Strontium-90 concentrations greater than the drinking water standard extend from the B Reactor to the Columbia River in the northeastern part of the $100-\mathrm{B} / \mathrm{C}$ Area. The highest concentration was found near the inactive 116-C-1 trench. The maximum concentration increased to $135 \mathrm{pCi} / \mathrm{L}(5.0 \mathrm{~Bq} / \mathrm{L})$ during 2001. The sources for the strontium-90 appear to be inactive liquid waste disposal sites near B Reactor and inactive liquid overflow trenches near the Columbia River (DOE/EIS-0119F).

Strontium-90 is not widely distributed in the 100-D Area. Strontium-90 levels were consistently greater than the drinking water standard in one well near the inactive D Reactor fuel storage basin in the past. However, this well was decommissioned in late 1999, and strontium-90 levels in nearby wells were less than the drinking water standard in 2001. Strontium-90 was detected at levels just above the drinking water standard near the former 116-D-7 retention basin in the northern part of the 100-D Area. The maximum concentration in this area was $13.1 \mathrm{pCi} / \mathrm{L}(0.49 \mathrm{~Bq} / \mathrm{L})$ in 2001. Strontium-90 levels near the former 116-D-7 retention basin have not changed significantly in recent years.

Strontium-90 exceeded the drinking water standard near the 116-F-14 retention basins and 116-F-2 and 116-F-9 trenches in the eastern part of the 100-F Area. The maximum concentration detected in 2001 was $37.6 \mathrm{pCi} / \mathrm{L}(1.4 \mathrm{~Bq} / \mathrm{L})$. Strontium-90 levels fluctuate with changing river levels in the 100-F Area.

In the 100-H Area, strontium-90 contamination levels greater than the drinking water standard were present in an area adjacent to the Columbia River near the $107-\mathrm{H}$ retention basin. The maximum detected in the $100-\mathrm{H}$ Area in 2001 was $38.1 \mathrm{pCi} / \mathrm{L}(1.4 \mathrm{~Bq} / \mathrm{L})$ between the retention basin and the Columbia River. The source of the contamination is past disposal of reactor coolant containing strontium-90 to the $107-\mathrm{H}$ retention basin, the $107-\mathrm{H}$ liquid waste disposal trench, and the $107-\mathrm{H}$ sludge burial trench in the $100-\mathrm{H}$ Area. Contaminated soil was excavated from the upper portion of the vadose zone at these facilities and disposed of to the Environmental Restoration Disposal Facility during 1999 and 2000. Strontium-90 levels are generally stable in the $100-\mathrm{H}$ Area.
Strontium-90 at levels greater than the drinking water standard continues to occur in isolated areas in the 100-K Area. These areas include fuel storage basin drain fields/injection wells associated with the $\mathrm{KE}$ and KW Reactors and the area between the inactive $116-\mathrm{K}-2$ liquid waste disposal trench and the Columbia River. The maximum concentration detected in 2001 was $5,210 \mathrm{pCi} / \mathrm{L}(193 \mathrm{~Bq} / \mathrm{L})$ at well $199-\mathrm{K}-109 \mathrm{~A}$, the only well in the $100-\mathrm{K}$ Area where levels were above the DOE derived concentration guide. The original source of the strontium-90 in this well was identified as pastpractice disposal to the 116-KE-3 drain field/injection well near KE Reactor (PNNL-12023). Strontium-90 is a co-contaminant with chromium in the groundwater, which is undergoing treatment by a pump-and-treat system. However, strontium-90 is not removed by the treatment system that removes chromium from the extracted groundwater. Therefore, strontium-90 is returned to the aquifer via the pump-and-treat injection wells. Strontium-90 concentrations measured in the returned groundwater are less than the drinking water standard. The maximum strontium-90 concentration near the disposal trench in 2001 was 38.9 pCi/L $(1.4 \mathrm{~Bq} / \mathrm{L})$, the same as in 2000 . Near the KW Reactor, strontium-90 is elevated above the drinking water standard. The maximum strontium-90 concentration near the KW Reactor was 41.9 pCi/L $(1.6 \mathrm{~Bq} / \mathrm{L})$ in 2001.

The distribution of strontium-90 in the 100-N Area is shown in Figure 6.2.16. Strontium-90 was detected at concentrations greater than the DOE derived concentration guide in several wells located between the 1301-N Liquid Waste Disposal Facility, a source of the strontium-90, and the Columbia River. The 1325-N Liquid Waste Disposal Facility is also a source of strontium-90 in groundwater. The maximum level detected in the 100-N Area has been near the head end of the 1301-N facility (well 199-N-67), where concentrations have ranged between 18,000 and $24,000 \mathrm{pCi} / \mathrm{L}$ $(670$ and $890 \mathrm{~Bq} / \mathrm{L})$ in recent years. However, this well could not be sampled in 2001 because of a low water table. The distribution of strontium-90 near this facility has not changed significantly in the past 20 years.

In the 100-N Area, strontium-90 discharges to the Columbia River through springs along the shoreline. Sections 3.2 and 4.2 give the results of spring water sampling. Because of high concentrations in wells near the river, it was expected that strontium-90 exceeded the drinking water standard at the interface between the groundwater and the river (DOE/RL-96-102). The highest strontium-90 concentration in a near-river well in 2001 was $9,690 \mathrm{pCi} / \mathrm{L}(359 \mathrm{~Bq} / \mathrm{L})$. This was the highest strontium-90 concentration detected in 100-N Area groundwater during 2001. Strong, positive correlations between high groundwater-level elevations and high 


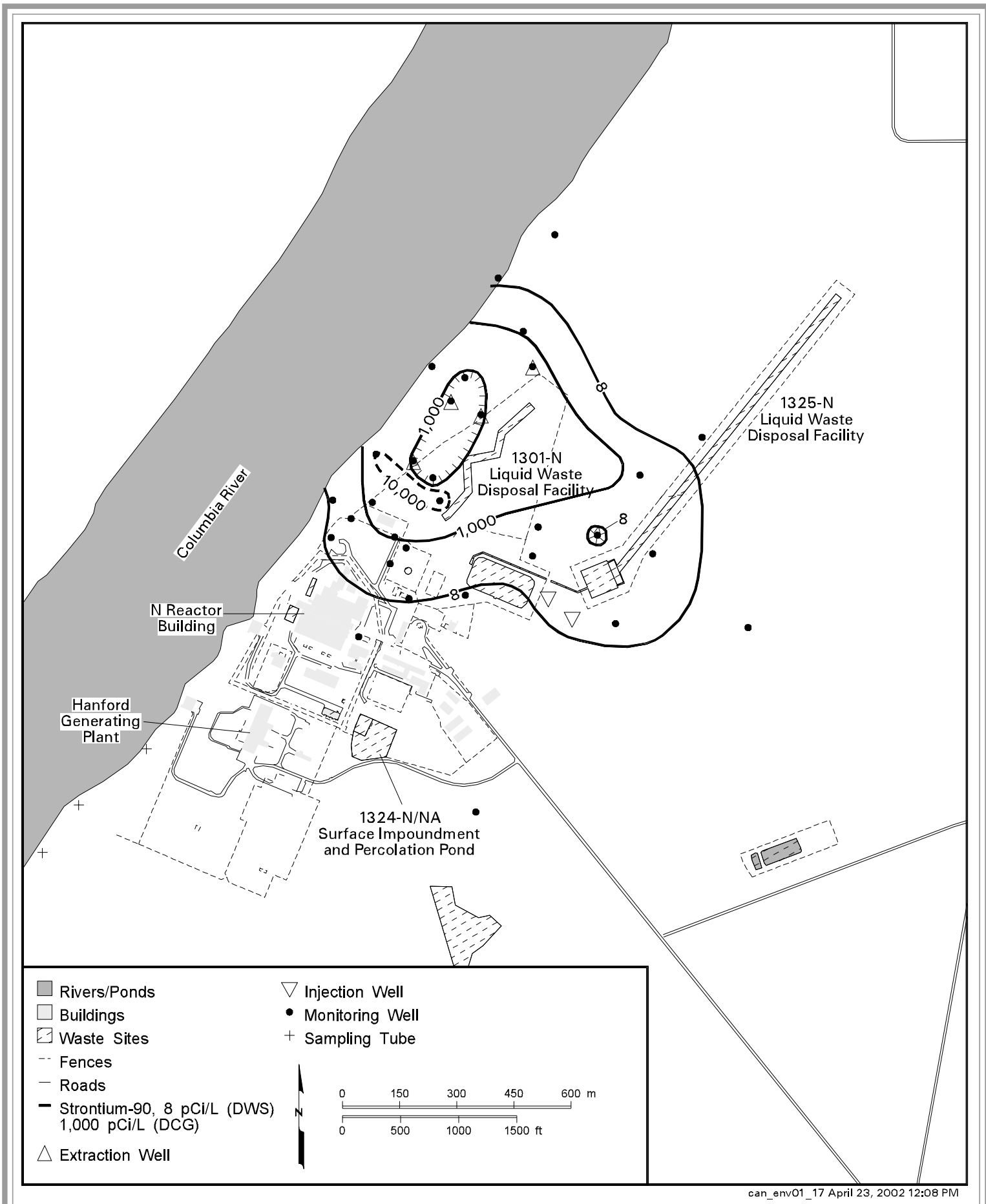

Figure 6.2.16. Average Strontium-90 Concentrations in the Unconfined Aquifer in the 100-N Area, 2001 
strontium-90 concentrations in wells indicate that strontium-90 is remobilized during periods of high water levels. A pump-and-treat system continued to operate in 2001 to reduce the discharge of strontium-90 to the Columbia River (see Section 2.3.11).

\section{Strontium-90 in the 200 and 600 Areas.}

Strontium-90 distribution in the 200-East Area is shown in Figure 6.2.11. Strontium-90 concentrations in the 200-East Area were above the DOE derived concentration guide in two wells near the inactive 216-B-5 injection well. The maximum strontium-90 concentration detected near the injection well in 2001 was $12,000 \mathrm{pCi} / \mathrm{L}(444 \mathrm{~Bq} / \mathrm{L})$, which was the highest strontium-90 concentration detected on the Hanford Site in 2001. The former injection well received an estimated 27.9 curies (1.03 trillion becquerels) of strontium-90 during 1945 and 1946 (PNL-6456). Elsewhere in the 200-East Area, strontium-90 was detected above the drinking water standard in one well near the Plutonium-Uranium Extraction Plant cribs. Strontium-90 levels increased in this well to $21 \mathrm{pCi} / \mathrm{L}$ $(0.78 \mathrm{~Bq} / \mathrm{L})$ in 2001.

In the 200-West Area, strontium-90 was detected at a level exceeding the $8-\mathrm{pCi} / \mathrm{L}(0.3-\mathrm{Bq} / \mathrm{L})$ drinking water standard in one well near the Reduction-Oxidation Plant cribs. The maximum concentration near the cribs was $76.2 \mathrm{pCi} / \mathrm{L}(2.8 \mathrm{~Bq} / \mathrm{L})$ in 2001 . Strontium-90 levels have been increasing in this well in recent years.

In the 600 Area, the highest strontium-90 concentrations have been measured in the past near the former Gable Mountain Pond area (see Figure 6.2.11). The level of strontium-90 rose above the DOE derived concentration guide in 2000. Strontium-90 contamination in this area resulted from the discharge of radioactive liquid waste to the former Gable Mountain Pond during its early use. Wells near this former pond were not sampled during 2001 because of waste management issues associated with sample disposal. Many wells completed above the basalt in this area are becoming difficult to sample because of declining groundwater levels.

Carbon-14. Carbon-14 concentrations occur in the $100-\mathrm{K}$ Area and exceed the 2,000-pCi/L $(74-\mathrm{Bq} / \mathrm{L})$ interim drinking water standard in two small plumes near the KE and KW Reactors (see Figure 6.2.2). The sources of the carbon-14 were the $116-\mathrm{KE}-1$ and 116-KW-1 condensate cribs, respectively. However, waste disposal to these cribs ended in 1971. Carbon-14 was included with tritium in the condensate wastewater disposed to the cribs. However, the distribution of carbon-14 in groundwater is not the same as for tritium because carbon-14 sorbs onto sediment and is less mobile than tritium (PNNL-12023). The maximum concentration in 2001 was 12,900 pCi/L (478 Bq/L) near the $116-\mathrm{KW}-1$ crib. Carbon-14 levels have remained stable in most of the $100-\mathrm{K}$ Area wells. The DOE derived concentration guide for carbon-14 is $70,000 \mathrm{pCi} / \mathrm{L}(2,590 \mathrm{~Bq} / \mathrm{L})$. Carbon-14 has a long halflife of 5,730 years, which suggests that some of the carbon-14 will reach the Columbia River before it decays. A portion of the carbon-14 will likely remain fixed on soil particles.

Cesium-137. Cesium-137, which has a half-life of 30 years, was produced as a high-yield fission product and was present in historical waste streams associated with fuel processing. Former reactor operations also may have resulted in the release of some cesium-137 associated with fuel element breaches. Normally, cesium-137 is strongly sorbed on soil and, thus, is not very mobile in Hanford Site groundwater. The interim drinking water standard for cesium-137 is $200 \mathrm{pCi} / \mathrm{L}$ $(7.4 \mathrm{~Bq} / \mathrm{L})$; the $\mathrm{DOE}$ derived concentration guide is $3,000 \mathrm{pCi} / \mathrm{L}(110 \mathrm{~Bq} / \mathrm{L})$.

Cesium-137 was detected in three wells located near the inactive 216-B-5 injection well in the 200-East Area. The injection well received waste containing cesium-137 from 1945 to 1947 . The maximum cesium-137 concentration in 2001 was $1,910 \mathrm{pCi} / \mathrm{L}$ $(70.7 \mathrm{~Bq} / \mathrm{L})$, which is greater than the interim drinking water standard. Cesium-137 appears to be restricted to the immediate vicinity of the former injection well.

Cobalt-60. Cobalt-60 in groundwater is typically associated with waste generated by reactor effluent disposed to the ground in the past. Cobalt-60 is normally present as a divalent transition metal cation and, as such, tends to be immobile in groundwater. However, complexing agents may mobilize it. All cobalt-60 levels in groundwater samples analyzed in 2001 were less than the $100-\mathrm{pCi} / \mathrm{L}(3.7-\mathrm{Bq} / \mathrm{L})$ interim drinking water standard. The DOE derived concentration guide for cobalt-60 is $5,000 \mathrm{pCi} / \mathrm{L}(185 \mathrm{~Bq} / \mathrm{L})$.

Cobalt-60 was detected in the northwestern part of the 200-East Area. This is the same area where the technetium-99 contamination associated with the BY cribs is found. Apparently, cobalt in this plume is mobilized by reaction with cyanide or ferrocyanide in the waste stream, forming a dissolved cobalt species. The maximum concentration measured in 2001 was $71 \mathrm{pCi} / \mathrm{L}(2.6 \mathrm{~Bq} / \mathrm{L})$ at the BY cribs. Cobalt-60 levels near the BY cribs generally decreased in 2001 along with associated cyanide and technetium-99 after reaching maximum concentrations in 2000. Because of its relatively short half-life (5.3 years), much of the cobalt-60 in groundwater in this area has decayed to low concentrations. 
Plutonium. Plutonium was released to the soil column in the past at several locations in both the 200-West and 200-East Areas. Plutonium is generally considered to sorb strongly to sediment, which limits its mobility in the aquifer. The DOE derived concentration guide for both plutonium-239 and plutonium-240 is $30 \mathrm{pCi} / \mathrm{L}(1.1 \mathrm{~Bq} / \mathrm{L})$. Radiological analysis is incapable of distinguishing between plutonium-239 and plutonium-240; therefore, the results are expressed as a concentration of plutonium-239/240. There is no explicit drinking water standard for plutonium-239/240; however, the gross alpha drinking water standard of $15 \mathrm{pCi} / \mathrm{L}(0.56 \mathrm{~Bq} / \mathrm{L})$ would be applicable at a minimum. However, if the DOE derived concentration guide based on a 100-millirem (1-millisievert) dose standard is converted to the 4-millirem (40-microsieverts) dose equivalent used for the drinking water standard, $1.2 \mathrm{pCi} / \mathrm{L}$ $(0.04 \mathrm{~Bq} / \mathrm{L})$ would be the relevant guideline. The halflives of plutonium-239 and plutonium-240 are 24,000 and 6,500 years, respectively.
The only location where plutonium isotopes were detected in groundwater on the Hanford Site was near the inactive 216-B-5 injection well in the 200-East Area. The maximum plutonium-239/240 concentration near this injection well during 2001 was $63 \mathrm{pCi} / \mathrm{L}$ $(2.3 \mathrm{~Bq} / \mathrm{L})$, which exceeds the $30-\mathrm{pCi} / \mathrm{L}(1.1-\mathrm{Bq} / \mathrm{L}) \mathrm{DOE}$ derived concentration guide. Plutonium levels near the injection well have changed significantly since monitoring for plutonium began in the 1980s. Because plutonium is strongly adsorbed to sediments and may have been injected into the aquifer as suspended particles, it is likely that the values measured result in part from solid rather than dissolved material. The injection well received an estimated 244 curies ( 9.03 trillion becquerels) of plutonium-239/240 during its operation from 1945 to 1947 (PNL-6456).

\subsubsection{Chemical Monitoring Results for the Unconfined Aquifer}

Chemical analyses performed by various monitoring programs at the Hanford Site have identified several hazardous chemicals in groundwater at concentrations greater than their respective drinking water standards. Nitrate, chromium, and carbon tetrachloride are the most widely distributed of these hazardous chemicals and have the highest concentrations in groundwater at the Hanford Site. Hazardous chemicals that are less widely distributed and have lower concentrations in groundwater include chloroform, trichloroethene, tetrachloroethene, cis-1,2-dichloroethene, cyanide, and fluoride.

A number of parameters such as $\mathrm{pH}$, specific conductance, total carbon, total organic carbon, and total organic halides are used as indicators of contamination. These are mainly discussed in Section 6.4. Other chemical parameters listed in Table 6.1.4 are indicators of the natural chemical composition of groundwater and are usually not considered contaminants from operations at the Hanford Site. These include alkalinity, aluminum, calcium, iron, magnesium, manganese, potassium, silica, and sodium. Chloride and sulfate occur naturally in groundwater. However, these constituents also have been introduced as contaminants from site operations. There are no primary drinking water standards for chloride or sulfate. The secondary standard for each is $250 \mathrm{mg} / \mathrm{L}$ and is based on aesthetic rather than health considerations; therefore, they will not be discussed in detail. The analytical technique used to determine the concentration of metals in groundwater provides results for a number of constituents. These trace metal constituents, rarely observed at greater than background concentrations, include antimony, arsenic, barium, beryllium, boron, cadmium, copper, nickel, silver, vanadium, and zinc.

The following presents a summary of the chemical constituents in groundwater at concentrations greater than existing or proposed drinking water standards (40 CFR 141 and EPA 822-R-96-001; see Appendix D).

Nitrate. Many groundwater samples collected in 2001 were analyzed for nitrate. The distribution of nitrate on the Hanford Site is shown in Figure 6.2.17; this distribution is similar to previous evaluations. Nitrate is the most widespread chemical contaminant in Hanford Site groundwater because of its mobility in groundwater and the large volumes of liquid waste containing nitrate discharged to the ground. However, the areas affected by levels greater than the drinking water standard are small. Nitrate was measured at concentrations greater than the drinking water standard $(45 \mathrm{mg} / \mathrm{L}$ as nitrate ion) in portions of the $100,200,300,600$, and former 1100 Areas. The maximum nitrate concentration measured on the Hanford Site was $1,300 \mathrm{mg} / \mathrm{L}$ in the 200-West Area. Nitrate contamination in the unconfined aquifer reflects the extensive use of nitric acid in decontamination and chemical reprocessing operations. Nitrate is associated primarily with process condensate 


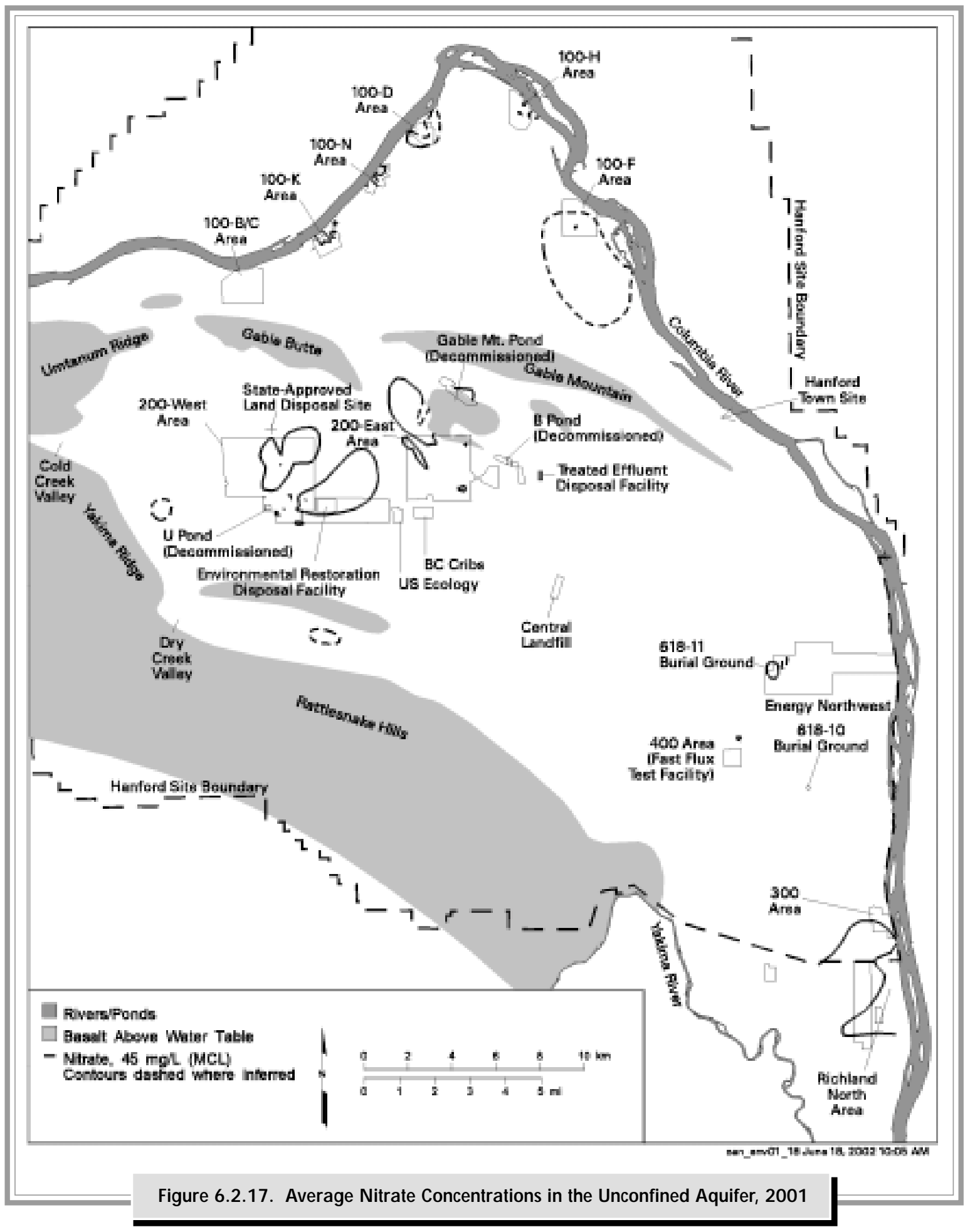


liquid waste, though other liquids discharged to the ground also contained nitrate. However, additional sources of nitrate, primarily associated with agriculture, occur off the site to the south, west, and southwest.

Nitrate in the 100 A reas. Nitrate was measured at concentrations exceeding the drinking water standard in all 100 Areas except the 100-B/C Area. Nitrate concentrations have generally been rising in many 100 Area wells.

Nitrate is found at levels greater than the drinking water standard in much of the 100-D Area. The highest nitrate level found in the 100-D Area in 2001 was $89.7 \mathrm{mg} / \mathrm{L}$ near the 120-D-1 ponds. Nitrate concentrations near the 120-D-1 ponds continued to show an increasing trend in 2001.

Nitrate continues to be widely distributed in the 100-F Area and the adjacent 600 Area to the south. The central and southern portions of the 100-F Area and the adjacent 600 Area contain nitrate at levels greater than the drinking water standard. Trends showed increasing or stable nitrate levels in many of the 100-F Area wells in 2001. The nitrate plume extends to the south and southeast into the 600 Area from upgradient sources near F Reactor. In the southern part of the 100-F Area, groundwater flow was to the southeast. The maximum nitrate detected in the 100-F Area in 2001 was $116 \mathrm{mg} / \mathrm{L}$ near F Reactor.

A nitrate plume with concentrations above the drinking water standard lies in the eastern portion of the 100-H Area adjacent to the Columbia River. The highest concentrations are restricted to a small area downgradient of the former $183-\mathrm{H}$ solar evaporation basins. The maximum nitrate detected in 2001 was $94.3 \mathrm{mg} / \mathrm{L}$ between the basins and the river.

Nitrate is widely distributed in the $100-\mathrm{K}$ Area and has multiple sources, including septic system drain fields and past-practice disposal to the soil column. The drinking water standard for nitrate was exceeded in a number of $100-\mathrm{K}$ Area wells during 2001 . In the $100-\mathrm{K}$ Area, nitrate levels decreased in a number of wells between 1999 and 2000. The maximum concentration detected in the $100-\mathrm{K}$ Area in 2001 was $119 \mathrm{mg} / \mathrm{L}$ in a well adjacent to the KE Reactor.

Although detected over most of the 100-N Area, nitrate contamination above the drinking water standard occurs at isolated locations in the 100-N Area. The maximum in the $100-\mathrm{N}$ Area was $125 \mathrm{mg} / \mathrm{L}$ in a well located between the 1301-N Liquid Waste Disposal Facility and the Columbia River.
Nitrate in the 200-East A rea. The nitrate plume in the 200-East Area covers a nearly identical area to that of the tritium plume. However, the area with nitrate exceeding the drinking water standard is smaller than the area with tritium exceeding its drinking water standard. Nitrate exceeds the drinking water standard in the northern part of the 200-East Area and adjacent 600 Area to the northwest and near the PlutoniumUranium Extraction Plant in the southeastern part of the 200-East Area. In the northern part of the 200-East Area, the plume has two parts, a western plume that extends from B Plant to the northwest and an eastern portion that extends from the BY and surrounding cribs to the north and northwest. The two portions of the plume join northwest of the 200-East Area and extend through the gap between Gable Butte and Gable Mountain. A 2001 nitrate plume map of the northern part of the 200-East Area and the adjacent 600 Area is presented in Figure 2.9-9 of PNNL-13788.

Past disposal practices related to the BY cribs is a major contributor to the high nitrate concentrations in the northern part of the 200-East Area and adjacent 600 Area. Some nitrate may be associated with past releases from the B-BX-BY tank farms. In 2001, the highest 200-East Area concentrations were reported in several wells near the BY and 216-B-8 cribs, where nitrate concentrations continued to increase. The maximum concentration was $748 \mathrm{mg} / \mathrm{L}$ in a well west of the BY cribs. Nitrate originating from the BY cribs is a co-contaminant with cobalt-60, cyanide, and technetium-99.

High nitrate concentrations continued to be found near liquid waste disposal facilities that received effluent from Plutonium-Uranium Extraction Plant operations. Nitrate concentrations in wells near the inactive 216-A-10 and 216-A-36B cribs have tended to decrease in the past few years but remained greater than the drinking water standard, though these cribs were removed from service in 1987. An exception to these decreases is an increase to a maximum of $233 \mathrm{mg} / \mathrm{L}$ in one well adjacent to the 216-A-36B crib.

Nitrate has been known to be elevated above the drinking water standard in a few wells near the former Gable Mountain Pond north of the 200-East Area. However, these wells were not sampled in 2001 because they are sampled on a triennial schedule.

Nitrate in the 200-West A rea. Nitrate concentrations greater than the drinking water standard were widespread in groundwater beneath the 200-West Area and adjacent parts of the 600 Area. The major nitrate plumes were found in wells east of U Plant and wells in 
the north-central part of the 200-West Area. The widespread distribution of nitrate reflects the multiple sources in the 200-West Area. Nitrate plume maps of the 200-West and adjacent 600 Areas are presented in Figure 2.8-10 of PNNL-13788.

Near U Plant, widespread nitrate contamination is associated with the tritium and iodine- 129 plumes. The nitrate contamination in this area is attributed to multiple sources, including the $216-\mathrm{U}-1$ and $216-\mathrm{U}-2$ cribs southwest of U Plant and the 216-U-17 crib southeast of U Plant. The 216-U-1 and 216-U-2 cribs received more than 1 million kilograms ( 2.2 million pounds) of chemicals containing nitrate during their operation from 1951 to 1967 (PNL-6456). The highest nitrate concentration measured in the plume in 2001 was $553 \mathrm{mg} / \mathrm{L}$ near the inactive 216-U-17 crib. Nitrate concentrations decreased near this crib in 2001. A pumpand-treat system continued to operate in this area (see Section 2.3.11). However, nitrate is not the primary target of the pump-and-treat system. The primary target of the pump-and-treat system is uranium and technetium-99.

Nitrate concentrations continued to be elevated above the drinking water standard near other inactive cribs to the south that are associated with the U Plant and Reduction-Oxidation Plant. These elevated levels represent nitrate plumes that merge with the plume from the U Plant area. The maximum nitrate concentration reported in these areas in 2001 was $54 \mathrm{mg} / \mathrm{L}$ at a crib near the Reduction-Oxidation Plant.

A small, isolated plume of elevated nitrate occurs west of the Reduction-Oxidation Plant near the inactive 216-S-25 crib and S and SX tank farms, where the maximum concentration was $646 \mathrm{mg} / \mathrm{L}$. Nitrate concentrations in this small plume appear to be associated with technetium-99.

A large area, encompassing much of the northern half of the 200-West Area, contains nitrate in groundwater at concentrations much greater than the drinking water standard. Wells showing the highest concentrations are located near several inactive liquid waste disposal facilities that received waste from early T Plant operations. A large amount of nitrate was disposed to these cribs (e.g., 2.3 million kilograms [ 5.1 million pounds] of nitrate to the 216-T-7 crib). Maximum concentrations in these wells in 2001 ranged up to $1,300 \mathrm{mg} / \mathrm{L}$ just south of the $\mathrm{T}$ tank farm. These are the highest nitrate concentrations measured on the Hanford Site during 2001. Nitrate concentrations have increased in many of the wells near $\mathrm{T}$ tank farm in the past several years.

A smaller area of elevated nitrate concentrations above the drinking water standard is located in vicinity of the Plutonium Finishing Plant, which is in the central part of the 200-West Area. One source of the elevated nitrate is the 216-Z-9 trench, which received $\sim 1.3$ million kilograms ( $\sim 2.9$ million pounds) of chemicals containing nitrate from 1955 to 1962 . The highest reported concentration in 2001 at the Plutonium Finishing Plant was $299 \mathrm{mg} / \mathrm{L}$ in a pump-and-treat extraction well adjacent to the trench, which is located east of the Plutonium Finishing Plant.

N itrate in the 300, 600, and Former 1100 A reas.

Nitrate contamination occurs near the city of Richland in the former 1100 Area, Richland North Area, and adjacent parts of the 600 Area along the southern boundary of the Hanford Site. This contamination is apparently affected by nitrate sources off the Hanford Site. These sources may include agriculture, food processing, and nuclear fuel manufacturing at offsite commercial facilities. The part of this plume with nitrate concentrations greater than the drinking water standard extends from off the site, south of the Hanford Site, to the 300 Area to the northeast. Nitrate concentrations generally continued to increase in the southern part of the Hanford Site and the adjacent area south of the Hanford Site in 2001. The maximum nitrate concentration in 2001 was $282 \mathrm{mg} / \mathrm{L}$ off the Hanford Site just south of the Hanford Site boundary (EMF-1865, Addendum 27). This nitrate is likely the result of agriculture to the west and southwest. A 2001 plume map showing detail of the nitrate distribution is presented in Figure 2.12-9 in PNNL-13788.

Although most nitrate detected on the site is the result of Hanford Site operations, elevated nitrate concentrations in the western part of the site appear to be the result of increasing agricultural activity in offsite areas (e.g., Cold Creek Valley). There is no known source of nitrate in these areas associated with site operations, and groundwater flow is from the west toward the Hanford Site facilities to the east. Nitrate levels have fluctuated considerably in wells upgradient of the 200 Areas over the past 30 years. In Cold Creek Valley, nitrate levels have been near or greater than the drinking water standard in one well since 1985. A maximum nitrate concentration of $59.3 \mathrm{mg} / \mathrm{L}$ was found in a well located just north of the Rattlesnake Hills.

Nitrate was detected at levels exceeding the drinking water standard in a well downgradient of the 400 Area process ponds. These levels, which have remained steady, were attributed to a former sanitary sewage lagoon west and upgradient of the process ponds. The maximum concentration observed was $82.8 \mathrm{mg} / \mathrm{L}$ in 2001 . 
Chromium. Use of chromium on the Hanford Site has been extensive. In the 100 Areas, sodium dichromate was added to cooling water as a corrosion inhibitor, and some residual chromium in soil and groundwater remains from that use. Chromium was used for decontamination in the 100,200, and 300 Areas and for oxidation state control in the Reduction-Oxidation Plant process. In the hexavalent form, chromium is present in a soluble anionic state. Thus, hexavalent chromium is freely mobile in the groundwater. The drinking water standard for chromium is $100 \mu \mathrm{g} / \mathrm{L}$.

Both filtered and unfiltered samples were collected from several of the wells onsite for analyses of chromium and other metals. Unfiltered samples may contain metals present as particulate matter, whereas filtered samples are representative of the more mobile, dissolved metals. Filtered samples also may contain some colloidal particles that are fine enough to pass through the filter. In general, filtered samples provide the best indication of groundwater contamination levels for chromium because unfiltered samples are subject to greater variability introduced by the sampling process. Chromium concentrations in filtered samples, which are considered representative of dissolved hexavalent chromium, will be used to describe the level of contamination in the discussion below.

Chromium in the 100 Areas. Chromium was detected above the drinking water standard in 2001 in the 100-D, $100-\mathrm{H}, 100-\mathrm{K}$, and $100-\mathrm{N}$ Areas. The maximum detected concentration was $5,660 \mu \mathrm{g} / \mathrm{L}$ in the 100-D Area. Groundwater pump-and-treat systems continued to operate in 2001 to reduce the amount of hexavalent chromium entering the Columbia River at the 100-D, 100-H, and 100-K Areas (see Section 2.3.11). The purpose of the pump-and-treat systems is to prevent discharge of hexavalent chromium into the Columbia River at concentrations exceeding $11 \mu \mathrm{g} / \mathrm{L}$, which is the EPA's standard for protection of freshwater aquatic life (EPA 822-Z-99-001).

The chromium distribution in the 100-D Area is shown in Figure 6.2.18. Chromium contamination at levels greater than the drinking water standard is defined by two plumes that appear to be merging. The chromium plume in the southwestern part of the 100-D Area has expanded in size to the north, where chromium concentrations have been increasing in recent years. The source of the chromium plume in the southwestern part of the 100-D Area has not been identified with certainty, but is suspected to be past use of sodium dichromate at the $183-\mathrm{DR}$ water treatment facility or at a transfer station. In 2001, the maximum chromium concentration from filtered samples was $5,660 \mu \mathrm{g} / \mathrm{L}$ in the southwestern plume near the Columbia River, where concentrations increased significantly in 2001 (Figure 6.2.19). The southwestern plume contains the highest concentrations of hexavalent chromium on the Hanford Site. The source of the chromium plume in the northern part of the 100-D Area is sodium dichromate released to the ground at former facilities near D Reactor. Leakage from inactive retention basins and liquid waste disposal trenches north of D Reactor may also have contributed to this chromium plume. The maximum chromium concentration in the northern plume was $830 \mu \mathrm{g} / \mathrm{L}$ in 2001. The area of low chromium concentrations between the plumes is suspected to be a result of past leakage of clean water from the 182-D reservoir.

A small chromium plume in the northeastern part of the $100-\mathrm{H}$ Area contains chromium levels greater than the drinking water standard (see Figure 6.2.18). In 2001, the maximum chromium concentration from filtered samples collected from the shallow parts of the unconfined aquifer was $101 \mu \mathrm{g} / \mathrm{L}$ between the former $183-\mathrm{H}$ solar evaporation basins and the Columbia River. Chromium levels have fluctuated in response to changing water-table conditions. Potential sources include past disposal of sodium dichromate near H Reactor, disposal to the inactive $107-\mathrm{H}$ liquid waste disposal trench, and chromium in acid waste stored in the former $183-\mathrm{H}$ basins (Peterson and Connelly 1992). Upgradient sources include waste sites in the 100-D Area. Chromium was also found at levels above the drinking water standard in one well monitoring the deeper part of the unconfined aquifer. Filtered samples from this well, located near the former $183-\mathrm{H}$ basins, contained $140 \mu \mathrm{g} / \mathrm{L}$ of chromium in 2001. Chromium levels in this well have been decreasing in recent years. Chromium concentrations exceeded the drinking water standard in two 600-Area wells west of the 100-H Area. The maximum chromium concentration in these wells in 2001 was $106 \mu \mathrm{g} / \mathrm{L}$.

Chromium in the 100-K Area occurs in groundwater at levels greater than the drinking water standard in three areas (Figure 6.2.20). Two localized areas of chromium contamination occur near the KW Reactor and the water treatment basins southeast of the KE Reactor. The maximum concentration near the KW Reactor in 2001 was $564 \mu \mathrm{g} / \mathrm{L}$. Chromium concentrations in the plume near the KW Reactor increased in 2001. One potential source of the chromium plume near the KW Reactor is the railcar transfer station and storage tanks southeast of the $183-\mathrm{KW}$ water treatment plant.

The other small chromium plume occurs near the $183-\mathrm{KE}$ water treatment basins. The most likely sources of this chromium are sodium dichromate storage tanks or the railcar transfer station near the area. The maximum chromium concentration in this plume in 2001 was 


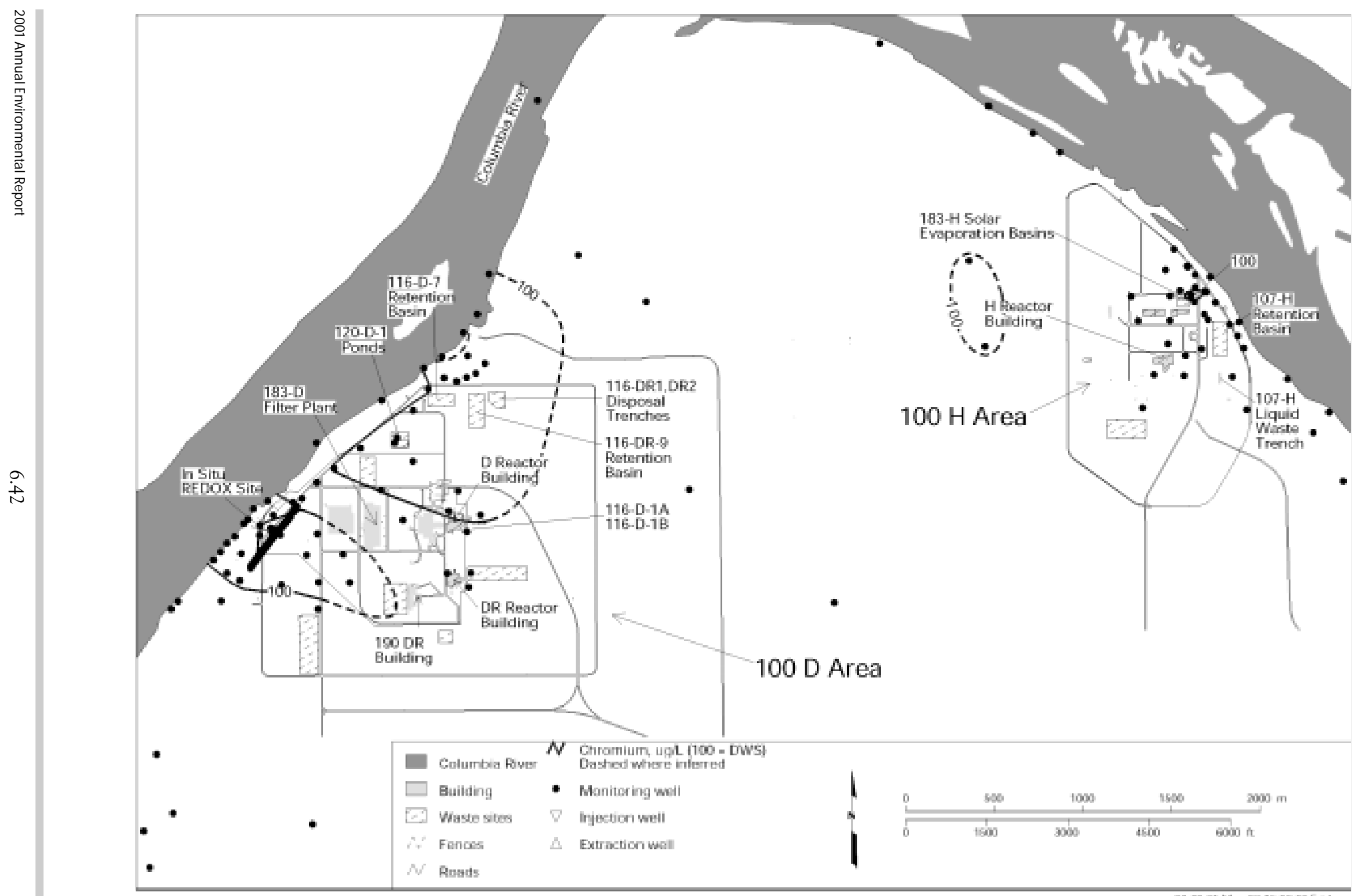

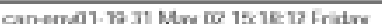

Figure 6.2.18. Average Filtered Chromium Concentrations in the 100-D and 100-H Areas, 2001 


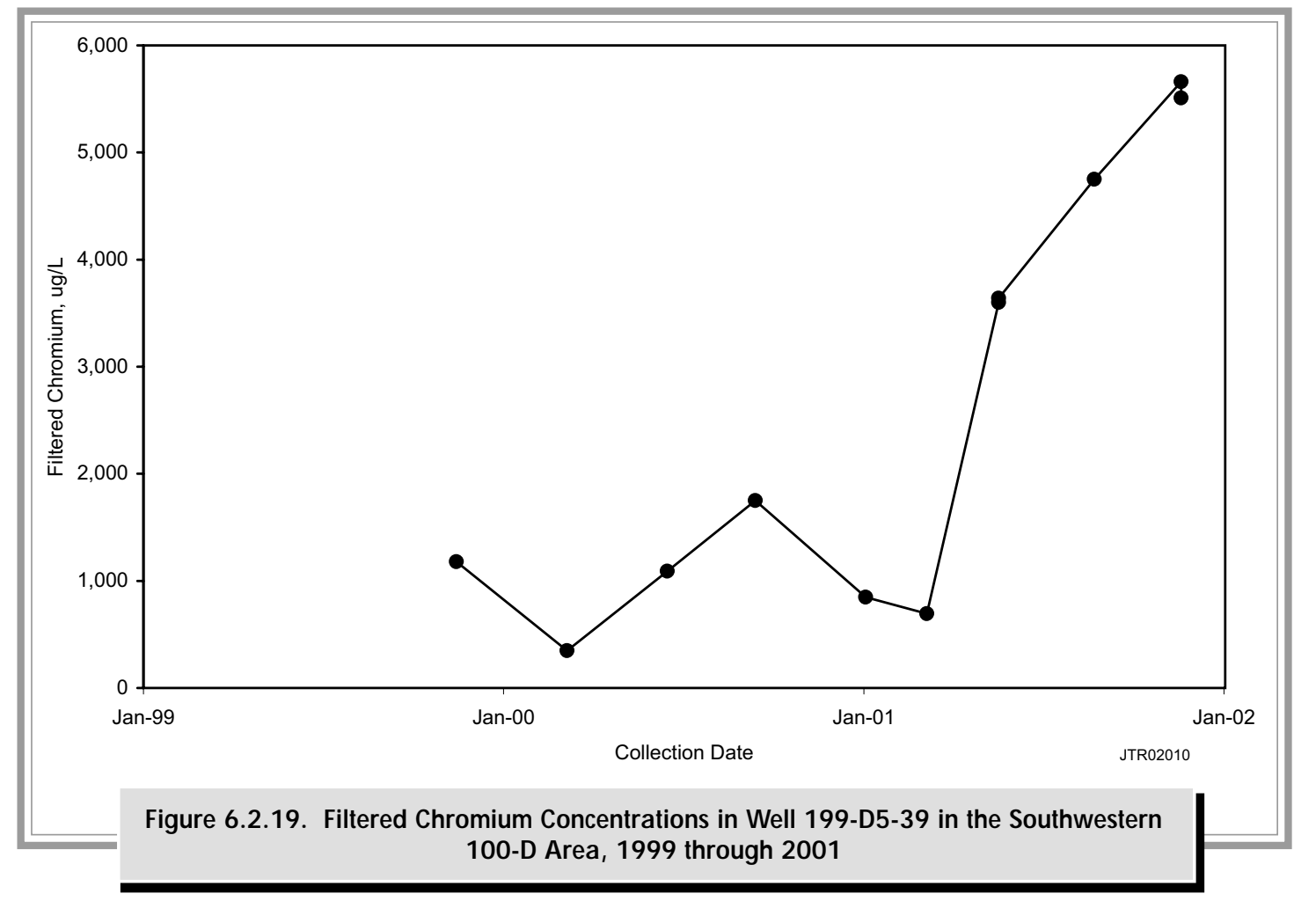

$1,332 \mu \mathrm{g} / \mathrm{L}$ adjacent to the treatment basins. Chromium concentrations in this plume have generally been rising.

A much wider area of chromium contamination is found in vicinity of the former $116-\mathrm{K}-2$ liquid waste disposal trench to the northeast. The maximum concentration in this area was $155 \mu \mathrm{g} / \mathrm{L}$ in 2001.

In the 100-N Area, chromium contamination is not widespread in groundwater. However, filtered samples in one well that monitors a locally confined unit within the Ringold Formation have consistently shown concentrations at steady levels greater than the drinking water standard. This well is northwest of the 1301-N Liquid Waste Disposal Facility. The maximum chromium concentration in 2001 was $173 \mu \mathrm{g} / \mathrm{L}$. Chromium was disposed to the 1301-N Liquid Waste Disposal Facility until the early 1970s (DOE/RL-96-39).

Chromium in the 200 A reas. Chromium at concentrations greater than the drinking water standard in the 200-East Area was found in one well on the southern boundary of $\mathrm{A}$ and $\mathrm{AX}$ tank farms. The maximum concentration detected in samples collected from this well in 2001 was 1,640 $\mu \mathrm{g} / \mathrm{L}$. Elevated metal (chromium, nickel, and manganese) concentrations historically found at this well are related to corrosion of the well screen (PNNL-13404).

Chromium contamination has been found in small areas in the 200-West Area. Areas where concentrations exceeded the drinking water standard in 2001 include the T, TX, TY, and S-SX tank farms and near the Reduction Oxidation Plant. Filtered samples from a well east of TX and TY tank farms showed a maximum concentration of $287 \mu \mathrm{g} / \mathrm{L}$, the highest filtered chromium concentration in the 200-West Area. Chromium concentrations have generally been increasing near the TX and TY tank farms. A small chromium plume in the vicinity of $\mathrm{T}$ tank farm showed a maximum chromium concentration of $225 \mu \mathrm{g} / \mathrm{L}$ in 2001 . The $216-\mathrm{T}-36 \mathrm{crib}$ and pipes leading to the crib are suspected of being a source of the chromium contamination at $\mathrm{T}$ tank farm. Filtered chromium concentrations were detected at levels above the drinking water standard for the first time at the southern end of the S-SX tank farm in December 2000. The maximum chromium concentration was $138 \mu \mathrm{g} / \mathrm{L}$ in January 2001. However, chromium concentrations at S-SX tank farm fell to levels less than the drinking water standard by late 2001. Near the Reduction Oxidation Plant, chromium concentrations have shown an increasing trend since 1997 and increased to a level $(161 \mu \mathrm{g} / \mathrm{L})$ above the drinking water standard in 2001.

Chromium in Other A reas. Filtered chromium concentrations have consistently exceeded the drinking water standard south of the 200-East Area. This area was not sampled for filtered chromium in 2001 because the sampling frequency was changed from annual to every 3 years. The maximum concentration detected in 


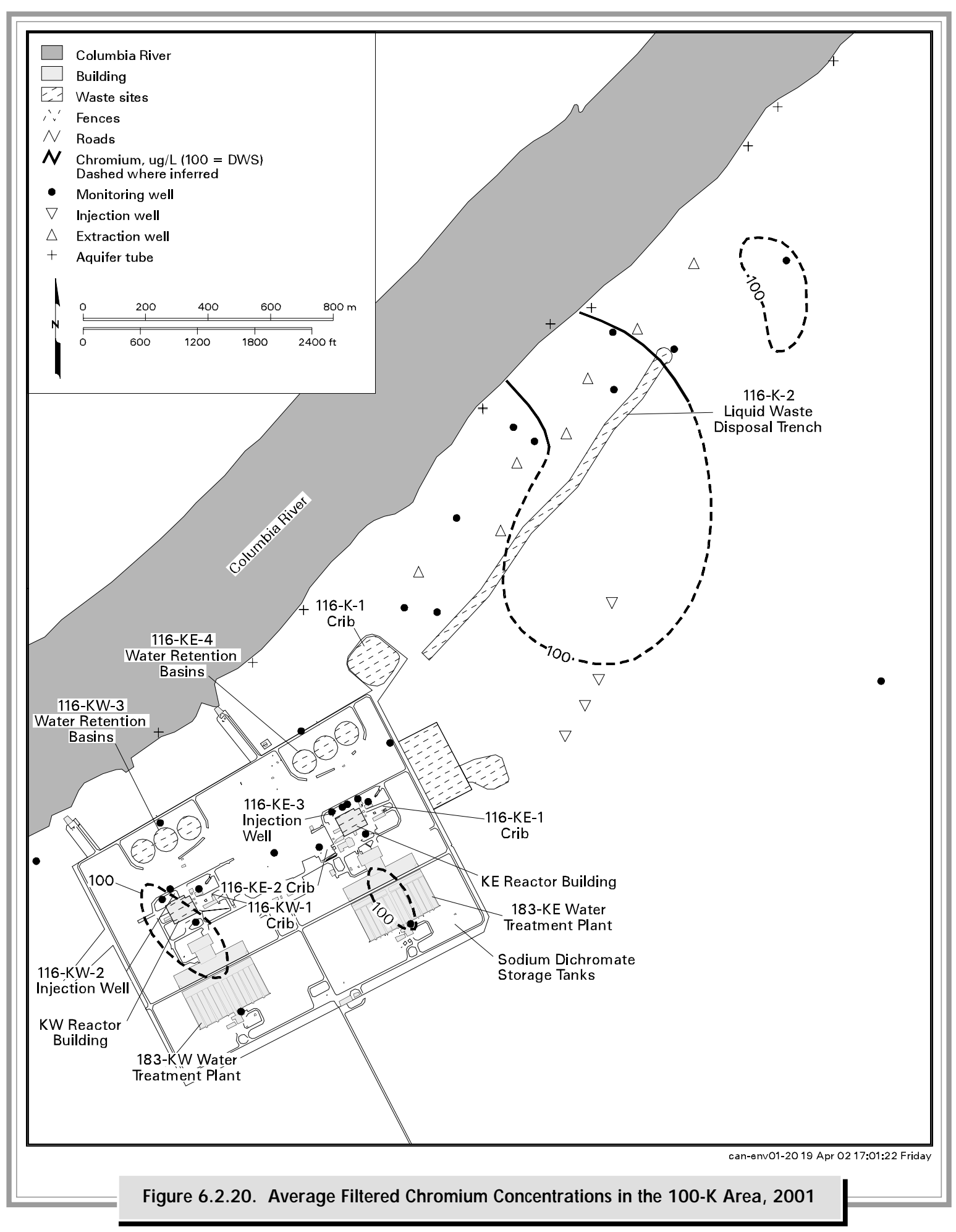


filtered samples in this area in 2000 was $201 \mu \mathrm{g} / \mathrm{L}$. Filtered chromium will be sampled in this area in 2003. The extent of chromium contamination in this area is poorly defined, and the source has not been determined.

Carbon Tetrachloride. Carbon tetrachloride occurs at levels exceeding the $5-\mu \mathrm{g} / \mathrm{L}$ drinking water standard in much of the 200-West Area and represents one of the most significant contaminant plumes at the Hanford Site (Figure 6.2.21). The plume, which covers an area that is more than 11 square kilometers (4 square miles), extends past the 200-West Area boundary into the 600 Area. The maximum detected concentration in 2001 was $7,400 \mu \mathrm{g} / \mathrm{L}$ north of the Plutonium Finishing Plant in the 200-West Area.

The bulk of the contamination is believed to be from pre-1973 waste disposal operations associated with the Plutonium Finishing Plant in the west-central part of the 200-West Area. Major sources identified in this area include the 216-Z-9 trench, the 216-Z-1A drain/tile field, and the 216-Z-18 crib. Carbon tetrachloride was used as the carrier solvent for tributyl phosphate in the final purification of plutonium. Carbon tetrachloride was also used in the same facility as a non-flammable thinning agent while machining plutonium. A minor source of carbon tetrachloride is a former waste disposal crib near T Plant. Carbon tetrachloride is immiscible in water but exhibits a relatively high solubility $(805,000 \mu \mathrm{g} / \mathrm{L}$ at $\left.20^{\circ} \mathrm{C}\left[68^{\circ} \mathrm{F}\right]\right)$. Carbon tetrachloride has been found to have a relatively high degree of mobility in groundwater. Mobilization above the water table can also occur through vapor transport. Sources of carbon tetrachloride in the vadose zone are discussed in Section 7.2.

Wells in vicinity of the Plutonium Finishing Plant showed the highest concentrations in the plume, with levels exceeding the drinking water standard by more than two orders of magnitude. The maximum concentration was $7,400 \mu \mathrm{g} / \mathrm{L}$ near the northern pump-and-treat extraction wells just north of the plant. Pump-and-treat operations, which began in 1994, have influenced the distribution of carbon tetrachloride. The purpose of the pump-and-treat system is to contain the portion of the carbon tetrachloride plume where concentrations are $>2,000 \mu \mathrm{g} / \mathrm{L}$, which extends to the north reaching the TX-TY tank farms (see Section 2.3.11). In recent years, the center of the plume area within the $4,000-\mu \mathrm{g} / \mathrm{L}$ contour increased in size because of the effects of pumping from the extraction wells downgradient of this area. The plume center moved to the north and east toward the extraction wells in recent years, as evidenced by increased concentrations in several extraction and monitoring wells (BHI-01311). The extraction wells are located north and east of the Plutonium Finishing Plant. However, in 2001 carbon tetrachloride concentrations generally decreased in the center of the plume, as illustrated in Figure 6.2.22. This indicates that the center of the plume at high concentrations is beginning to decrease in size. Carbon tetrachloride concentrations were below the minimum detection limit in the vicinity of the injection wells southwest of the plant during 2001. Concentrations have declined because of injection of the treated water.

The carbon tetrachloride plume is divided into two major lobes, one in the northern half and one in the southern half of the 200-West Area. In the northern lobe, an area of increasing carbon tetrachloride concentrations has moved slowly beyond the northeastern 200-West Area boundary since 1997. This area is the greatest concern for transport of carbon tetrachloride from the 200-West Area. The highest concentration detected in this northern lobe in 2001 was $1,200 \mu \mathrm{g} / \mathrm{L}$ near the eastern boundary of the 200-West Area. In the southern lobe, carbon tetrachloride concentrations continue to increase near the S-SX tank farm to a maximum level of $190 \mu \mathrm{g} / \mathrm{L}$ during 2001.

Geostatistical models of the carbon tetrachloride concentrations for 2000 and 2001 were used to compare overall changes in the distribution of the plume. The model was developed in 2000 to increase the efficiency in the monitoring program by optimizing the number of samples. Comparison of the 2000 and 2001 models shows a decrease of $\sim 500$ to $1,500 \mu \mathrm{g} / \mathrm{L}$ in the center of the plume near the Plutonium Finishing Plant. The model comparison shows an increase of a few hundred to $\sim 1,500 \mu \mathrm{g} / \mathrm{L}$ north of the Plutonium Finishing Plant. A large area of small increases (ranging up to $\sim 500 \mu \mathrm{g} / \mathrm{L}$ ) occurred in the eastern part of the 200-West Area and adjacent 600 Area and in the northwestern and southwestern part of the plume. These large areas of small increases indicate that the carbon tetrachloride plume continued to expand laterally between 2000 and 2001. An area of small decreases (ranging up to $\sim 500 \mu \mathrm{g} / \mathrm{L}$ ) in carbon tetrachloride concentrations is north of the 200-West Area near the State-Approved Land Disposal Site, where treated effluent that does not contain carbon tetrachloride is discharged to the ground and recharges the unconfined aquifer.

The extent of carbon tetrachloride contamination in deeper parts of the aquifer is uncertain because of the limited concentration data from depths below the water table. The limited amount of data indicates that the concentrations are highest at the top of the aquifer and decline with depth at most locations within the plume. Carbon tetrachloride contamination has been detected to depths greater than 60 meters (197 feet) below the water table. In recent years, carbon tetrachloride was detected at levels of $1,600 \mu \mathrm{g} / \mathrm{L} \mathrm{(1998)}$ at 33 meters 


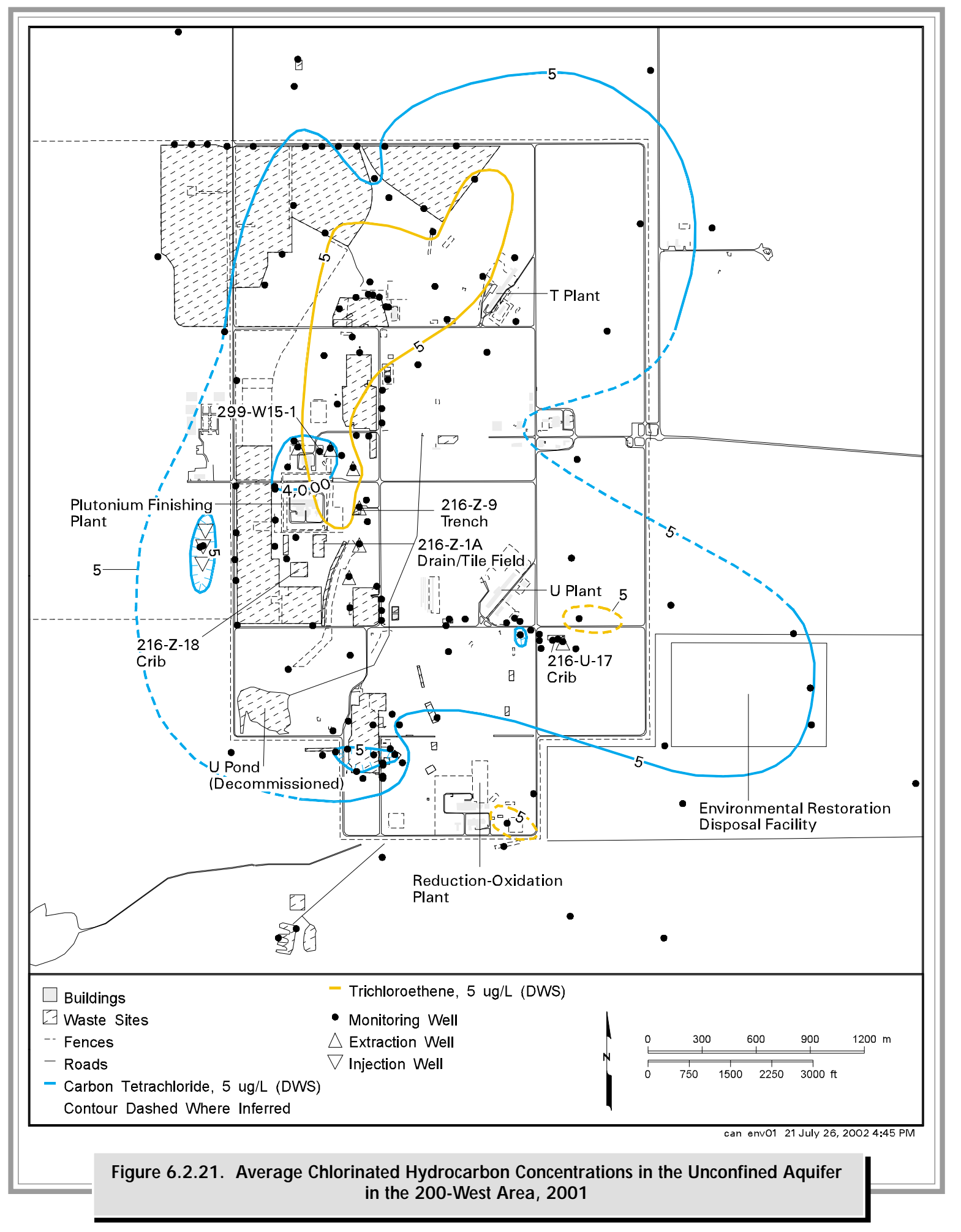




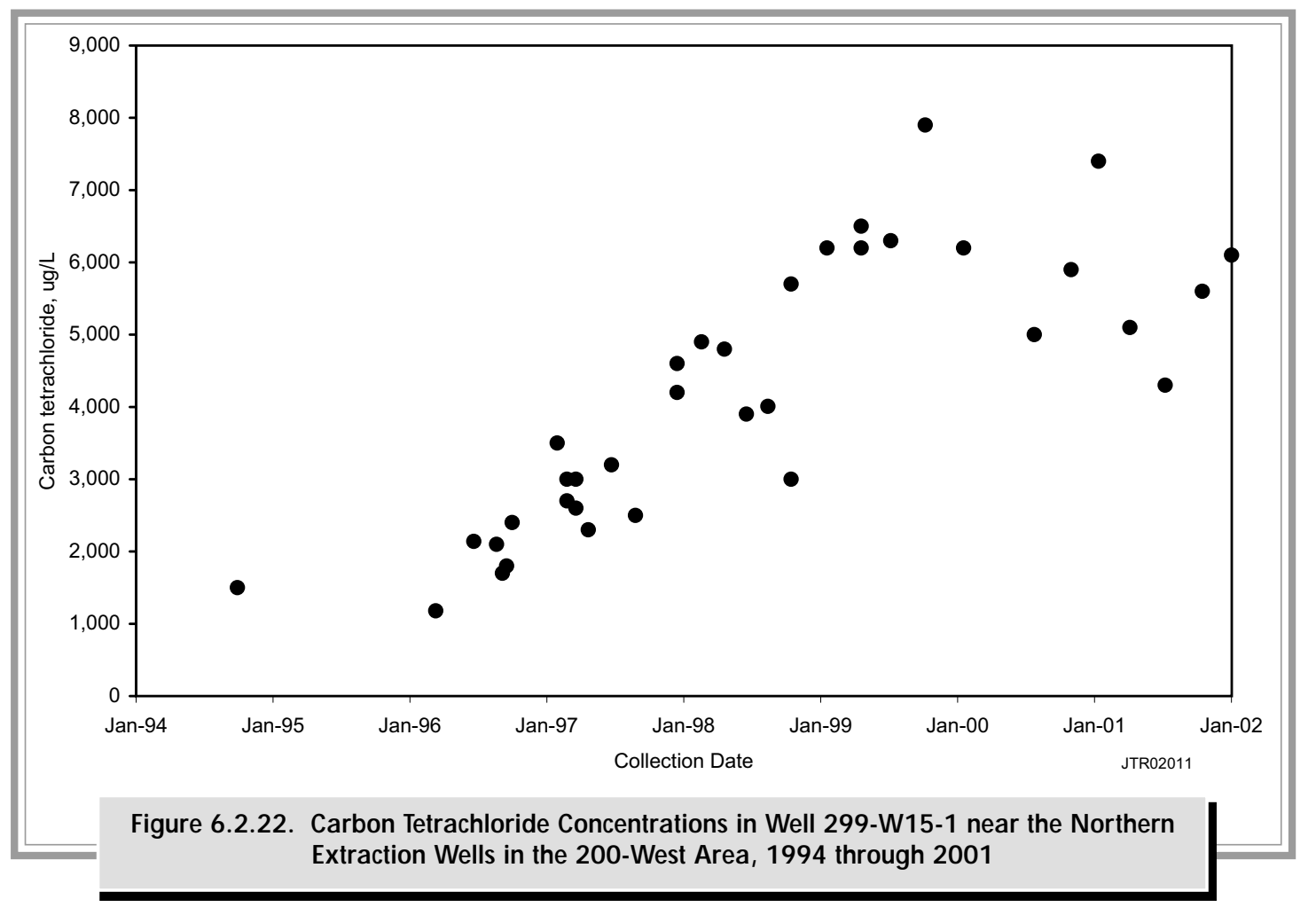

(108 feet) below the water table near $\mathrm{T}$ tank farm, $590 \mu \mathrm{g} / \mathrm{L}(1998)$ at 68 meters (223 feet) below the water table near TX-TY tank farm, and $5.6 \mu \mathrm{g} / \mathrm{L}$ (1999) at 53 meters (174 feet) below the water table near S-SX tank farm.

Changes in groundwater flow since decommissioning $\mathrm{U}$ Pond may have influenced the plume configuration and the concentrations at particular locations. Another potential influence is the continued spreading of carbon tetrachloride above the water table, in either the liquid or the vapor phase. Free-phase, liquid, carbon tetrachloride above and possibly below the water table may provide a continuing source of contamination, in which case, lateral expansion of the carbon tetrachloride plume would continue.

Chloroform. A chloroform plume appears to be associated with, but not exactly coincident with, the carbon tetrachloride plume in the 200-West Area. The highest chloroform concentrations were measured in the vicinity of the Plutonium Finishing Plant, where the maximum level was $160 \mu \mathrm{g} / \mathrm{L}$ in early 2001. However, chloroform concentrations at this location dropped to levels less than the drinking water standard by late 2001 . The drinking water standard for chloroform is $100 \mu \mathrm{g} / \mathrm{L}$ (total trihalomethanes), which is 20 times higher than that for carbon tetrachloride. The origin of chloroform is suspected to be a biodegradation product of carbon tetrachloride or an anaerobic degradation product associated with septic drain fields.
Trichloroethene. A commonly used organic solvent, trichloroethene has a drinking water standard of $5 \mu \mathrm{g} / \mathrm{L}$. In 2001, trichloroethene was detected at levels greater than the drinking water standard in several wells in the 100, 200, and 600 Areas. The most widespread area of contamination occurred in the 200-West Area.

Trichloroethene in the 100 and 600 Areas. Trichloroethene was detected at levels greater than the drinking water standard in the southwestern corner of the 100-F Area and in the adjacent 600 Area. Trichloroethene concentrations in this area showed increases in the 100-F Area and a slowly declining trend in the adjacent 600 Area. The maximum concentration detected in the 100-F Area was $18 \mu \mathrm{g} / \mathrm{L}$. No specific sources of this contamination have been identified.

In the 100-K Area, a localized area of trichloroethene contamination occurs near the KW Reactor complex. This area of contamination resulted from the past disposal/spillage of organic solvents. One well downgradient of the KW Reactor showed a maximum trichloroethene concentration above the drinking water standard at a level of $19 \mu \mathrm{g} / \mathrm{L}$. Trichloroethene concentrations appear to be constant with time.

In 2001, trichloroethene concentrations decreased to levels less than the $5-\mu \mathrm{g} / \mathrm{L}$ drinking water standard near the DOE's inactive Horn Rapids Landfill in the southern part of the Hanford Site. This contamination degrades naturally and has an origin off the Hanford Site. 
Trichloroethene in the 200 A reas. Trichloroethene was detected at levels greater than the drinking water standard in several parts of the 200-West Area (see Figure 6.2.21). The most significant area extends from the Plutonium Finishing Plant northeast to an area west of T Plant. The source of the contamination is presumably past disposal in these plant areas. The highest concentration was $21 \mu \mathrm{g} / \mathrm{L}$ northeast of the Plutonium Finishing Plant near the northern extraction wells for the carbon tetrachloride 200-ZP-1 pump-and-treat system. A smaller, isolated area of contamination occurs downgradient of the U Plant cribs, where the maximum concentration was $11 \mu \mathrm{g} / \mathrm{L}$. Another localized area of trichloroethene contamination occurs east of the Reduction-Oxidation Plant in the southern part of the 200-West Area. The maximum concentration in this area in 2001 was $9.4 \mu \mathrm{g} / \mathrm{L}$.

cis-1,2-Dichloroethene. Concentrations of cis1,2-dichloroethene remain elevated in one well near the former process trenches and ponds in the 300 Area. This well is completed in the bottom of the unconfined aquifer and is the only well on the site where this constituent is found at levels above the 70- $\mathrm{gg} / \mathrm{L}$ drinking water standard. In 2001, a maximum concentration of $190 \mu \mathrm{g} / \mathrm{L}$ was measured in this well. The source of the cis-1,2dichloroethene is the inactive $316-5$ process trenches.

Cyanide. Waste fractionation activities performed in the late 1950s used large quantities of sodium and nickel ferrocyanide to recover cesium-137. Large volumes of aqueous supernatant waste containing excess ferrocyanide were disposed to the ground in both the northern and southern portions of the 200-East Area. Smaller quantities were also disposed to former cribs in the 200-West Area. Procedures used to analyze for cyanide do not distinguish between ferrocyanide and free cyanide. Cyanide results reported here are, thus, normally assumed to be residual ferrocyanide associated with the discharges from the waste fractionation activities performed more than 30 years ago. A chemical speciation study performed in 1988 indicated that approximately one-third of the cyanide in groundwater is present as free cyanide and the rest may be present as ferrocyanide (Section 4.1 in PNL-6886 and Section 3.2.2 in PNL-7120). The drinking water standard for cyanide is $200 \mu \mathrm{g} / \mathrm{L}$.

The highest cyanide levels were detected in samples collected from wells in the northwestern part of the 200-East Area. Samples collected from two wells near the inactive BY cribs showed concentrations above the drinking water standard in 2001. The maximum concentration near the cribs was $423 \mu \mathrm{g} / \mathrm{L}$. Cyanide levels near the cribs generally decreased in 2001 along with associated technetium-99 and cobalt-60 after reaching maximum concentrations in 2000. Although cobalt-60 is normally immobile in the subsurface, it appears to be chemically complexed by cyanide or ferrocyanide. The complexed chemical species is more soluble and more mobile in groundwater.

Fluoride. At this time, fluoride has a primary drinking water standard of $4 \mathrm{mg} / \mathrm{L}$ and a secondary standard of $2 \mathrm{mg} / \mathrm{L}$. Secondary standards are based primarily on aesthetic rather than health considerations. Fluoride was detected above the primary drinking water standard in two wells monitoring T tank farm in the 200-West Area in 2001. The maximum fluoride concentration was $4.9 \mathrm{mg} / \mathrm{L}$ on the east side of T tank farm. A few other wells near $\mathrm{T}$ tank farm showed concentrations above the secondary standard. Aluminum fluoride nitrate used in past 200-West Area processes is the probable source of the fluoride contamination.

\subsection{Radiological and Chem ical Monitoring Results for the Upper Basalt-Confined Aquifer}

Monitoring the upper basalt-confined aquifer is important because of the potential for downward migration of contaminants from the overlying unconfined aquifer. Contaminants that reach the upper basaltconfined aquifer have the potential to migrate off the Hanford Site. The upper basalt-confined aquifer is also monitored to assess the potential migration of contaminants onto the Hanford Site from offsite sources.

The upper basalt-confined aquifer is monitored by $\sim 20$ wells that are sampled annually to triennially. Most of these wells are located near the 200 Areas in the central part of the Hanford Site (see Figure 6.1.2). During 2001, eleven upper basalt-confined aquifer wells were sampled for chemical and radiological constituents. During 2001, most of the wells that represent the upper basalt-confined aquifer were sampled for tritium, iodine-129, and nitrate. These constituents are the most widespread in the overlying unconfined aquifer, are most mobile in groundwater, and provide an early warning of potential contamination in the upper basaltconfined aquifer. Groundwater samples from the upper basalt-confined aquifer were also analyzed for other anions besides nitrate, cations, gross alpha, gross beta, 
gamma-emitters, strontium-90, and technetium-99. The distribution of sample results for selected constituents is shown in Figure 6.2.23.

The only constituent that showed levels exceeding the drinking water standard was technetium-99 in one well in the northern part of the 200-East Area. Technetium-99 was at a level of $1,120 \mathrm{pCi} / \mathrm{L}(41 \mathrm{~Bq} / \mathrm{L})$ during 2001. Technetium-99 levels in this well have decreased very slowly. Contamination in this well is attributed to migration of high-salt waste down the borehole during construction when it was open to both the unconfined and confined aquifers (RHO-RE-ST-12 P). Tritium and nitrate were at levels less than their respective drinking water standards in 2001 and iodine-129 was not detected in samples from the upper basaltconfined aquifer. The distribution of contaminants in the upper basalt-confined aquifer is discussed more thoroughly in the fiscal year 2001 annual groundwater report (PNNL-13788).

Aquifers confined below the uppermost basalt layers are affected much less from Hanford Site contamination than the unconfined aquifer system within the overlying sediment. The contamination found in the basaltconfined aquifers may be attributed to several factors. These factors include areas where the confining layers of basalt have been eroded away, areas where past disposal of large amounts of water resulted in downward gradients, and areas where wells penetrating to the confined aquifers provided pathways for contaminant migration. These factors produced intercommunication between the aquifers, meaning they permitted the flow of groundwater from the unconfined aquifer to the underlying confined aquifer, thereby increasing the potential to spread contamination.

Intercommunication between the unconfined and basalt-confined aquifers in vicinity of the northern part of the 200-East Area has been identified previously in RHO-BWI-ST-5 and RHO-RE-ST-12 P. Several confined aquifer wells north and east of the 200-East Area that show evidence of intercommunication with the overlying unconfined aquifer were identified in PNL-10817. Intercommunication between the unconfined and confined aquifers in this area has been attributed to erosion of the upper Saddle Mountains Basalt and a downward vertical gradient that resulted from groundwater mounding associated with past waste disposal. Since the groundwater mound diminished, the downward vertical gradient has decreased in recent years and was negligible in 2001.

Groundwater data indicate that a downward hydraulic gradient from the unconfined to the confined aquifers also occurs in the western portion of the Hanford Site and in regions north and east of the Columbia River. However, groundwater chemical and radiological data from most confined aquifer wells in these other areas do not exhibit evidence of contamination.

\subsubsection{Groundwater Flow}

The water-table elevation contours shown in Figure 6.2.24 indicate the direction of groundwater flow and the magnitude of the hydraulic gradient in the unconfined aquifer. Groundwater flow is generally perpendicular to the water-table contours from areas of higher elevation to areas of lower elevation. Areas where the contours are closer together are high-gradient areas, where the driving force for groundwater flow is greater. However, because sediment with low permeability inhibits groundwater flow, producing steeper gradients, a high gradient does not necessarily mean high groundwater velocity. Lower transmissivity and steeper gradients are often associated with areas where the water table is below the bottom of the Hanford formation and the aquifer is entirely within the less permeable Ringold sediment. Figure 6.2.25 shows the generalized distribution of transmissivity as determined from aquifer pumping tests and groundwater flow model calibration. Additional information on aquifer hydraulic properties at Hanford is presented in DOE/RW-0164 (Vol. 2) and PNL-8337.
Recharge of water within the unconfined aquifer (RHO-ST-42) comes from several sources. Natural recharge occurs from infiltration of precipitation along the mountain fronts, run-off from intermittent streams such as Cold and Dry Creeks on the western margin of the site, and limited infiltration of precipitation on the site. The Yakima River, where it flows along the southern boundary of the site, also recharges the unconfined aquifer. The Columbia River is the primary discharge area for the unconfined aquifer. However, the Columbia River also recharges the unconfined aquifer for short periods during high-river stage, when river water is transferred into the aquifer along the riverbank. Recharge from infiltration of precipitation is highly variable on the Hanford Site both spatially and temporally. The rate of natural recharge depends primarily on soil texture, vegetation, and climate (Gee et al. 1992; PNL-10285). Natural recharge rates range from near zero, where fine-grained soil and deep-rooted vegetation are present, to greater than 10 centimeters per year (4 inches per year) in areas where soil is coarse textured and bare of vegetation. 


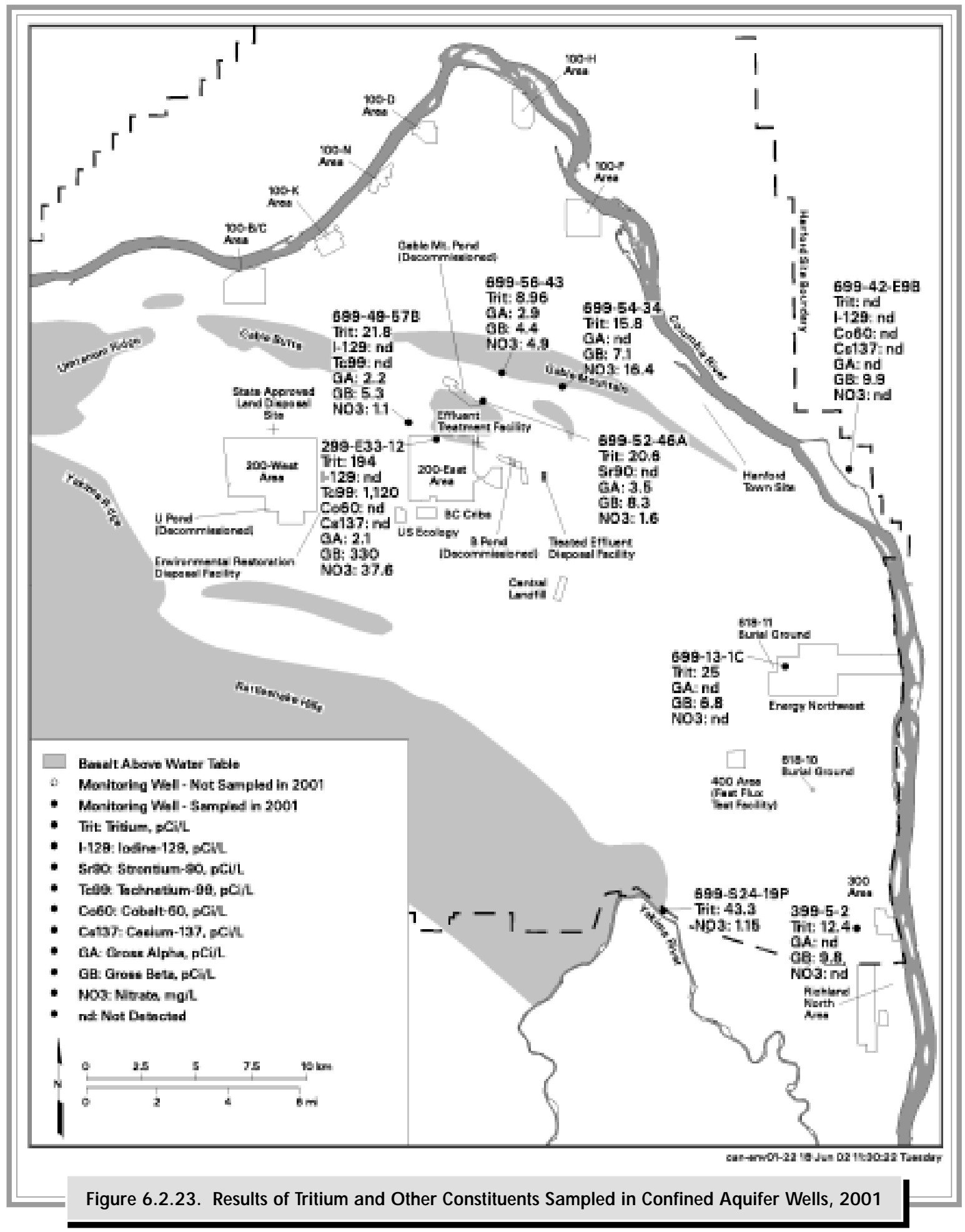




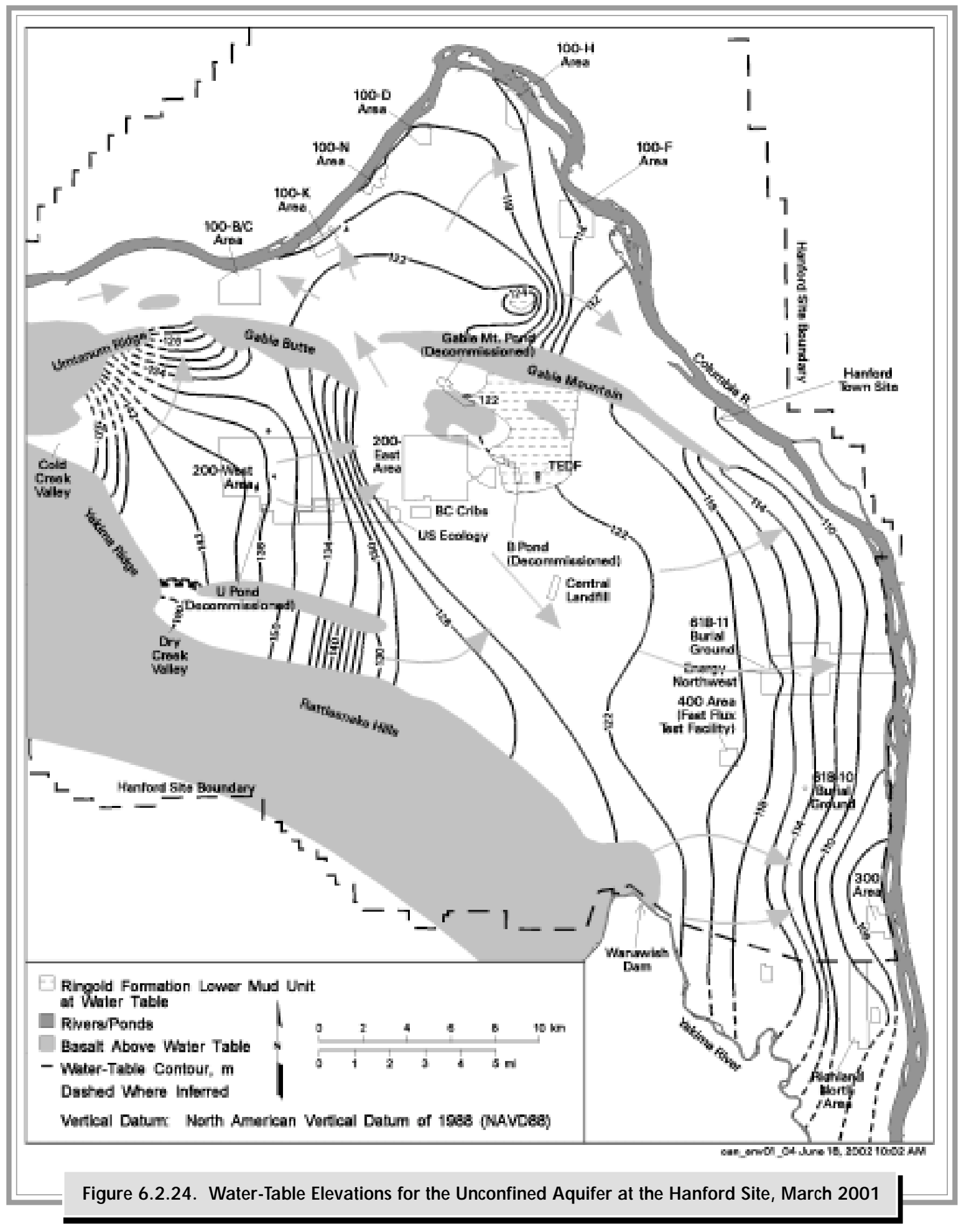




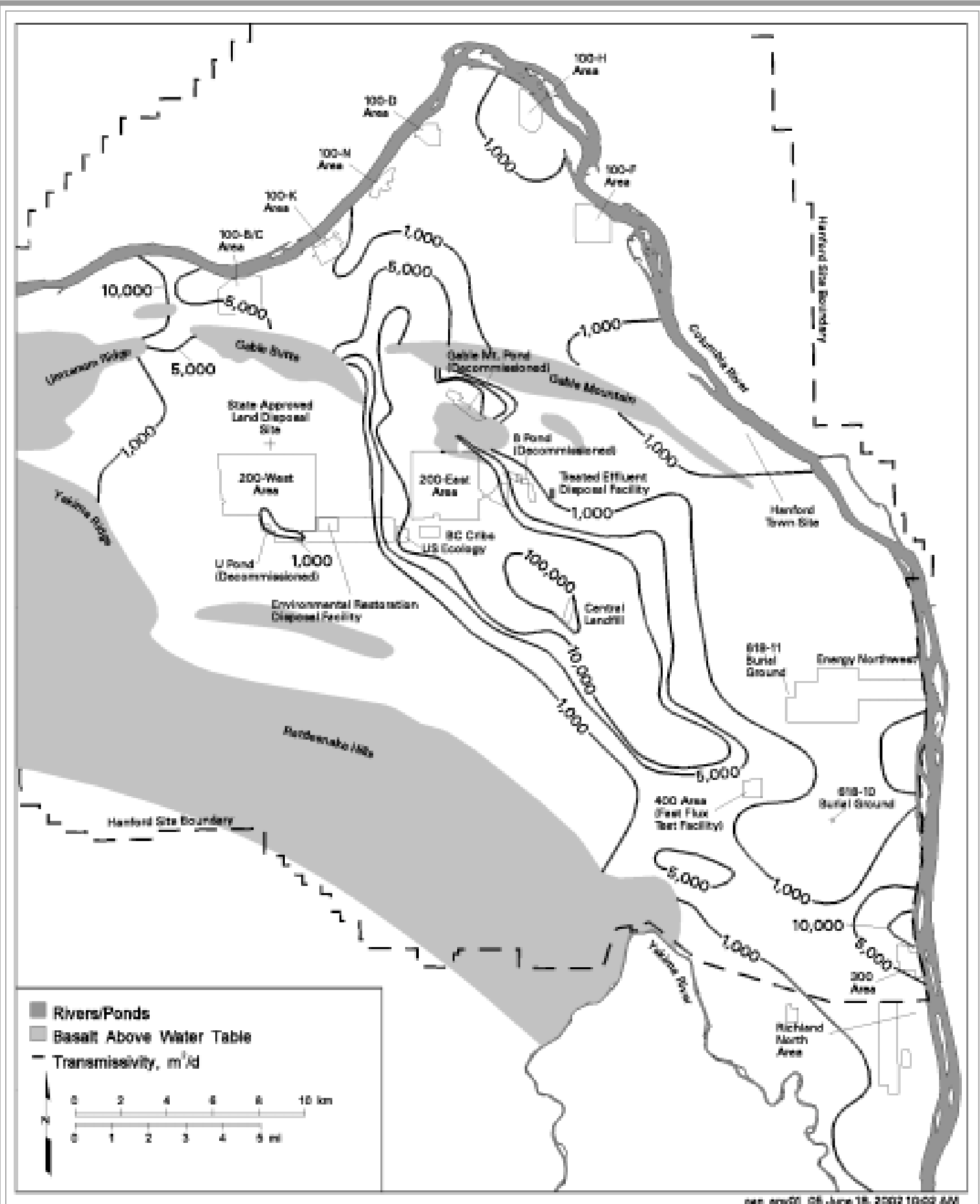

Figure 6.2.25. Transmissivity Distribution in the Unconfined Aquifer 
Large-scale, artificial recharge to the unconfined aquifer occurred because of past liquid waste disposal in the operating areas and offsite agricultural irrigation to the west and south. Discharge of wastewater caused the water table to rise over most of the Hanford Site. Since the peak discharge in 1984, discharge of wastewater to the ground has been significantly reduced and, in response, the water table subsequently declined over most of the site. The water table continues to decline, as illustrated by Figure 6.2.26. The water table declined up to 0.25 meter ( 0.8 foot) over most of the site between 2000 and 2001. The largest decline in the water table was 1 meter (3.28 feet) near a pump-and-treat system in the $100-\mathrm{K}$ Area. A result of the declining water table is that 32 wells have gone dry in the 200 Areas since 1997.

The decline in the water table has altered the flow pattern of the unconfined aquifer, which is generally from the recharge areas in the west to the discharge areas (primarily the Columbia River) in the east and north. Water levels in the unconfined aquifer have continually changed as a result of variations in the volume and location of wastewater discharge. Consequently, the movement of groundwater and its associated constituents has also changed with time (see Sections 6.2.1 and 6.2.2).

In the past, two major groundwater mounds formed near the 200-East and 200-West Areas in response to wastewater discharges. The first of these mounds was created by disposal at the 216-U-10 pond (U Pond) in the 200-West Area. After U Pond was decommissioned in 1984, the mound slowly dissipated. The water table continues to decline in this area (see Figure 6.2.26). The second major mound was created by discharge to the decommissioned, or former, 216-B-3 pond (B Pond), east of the 200-East Area. The water-table elevation near B Pond increased to a maximum before 1990 and decreased because of reduced discharge. After discharge to B Pond ceased in August 1997, the decline in the water-table elevation accelerated. Groundwater mounding related to wastewater discharges also occurred in the 100 and 300 Areas in the past. However, groundwater mounding in these areas was not as great as in the 200 Areas primarily because of lower discharge volumes. 


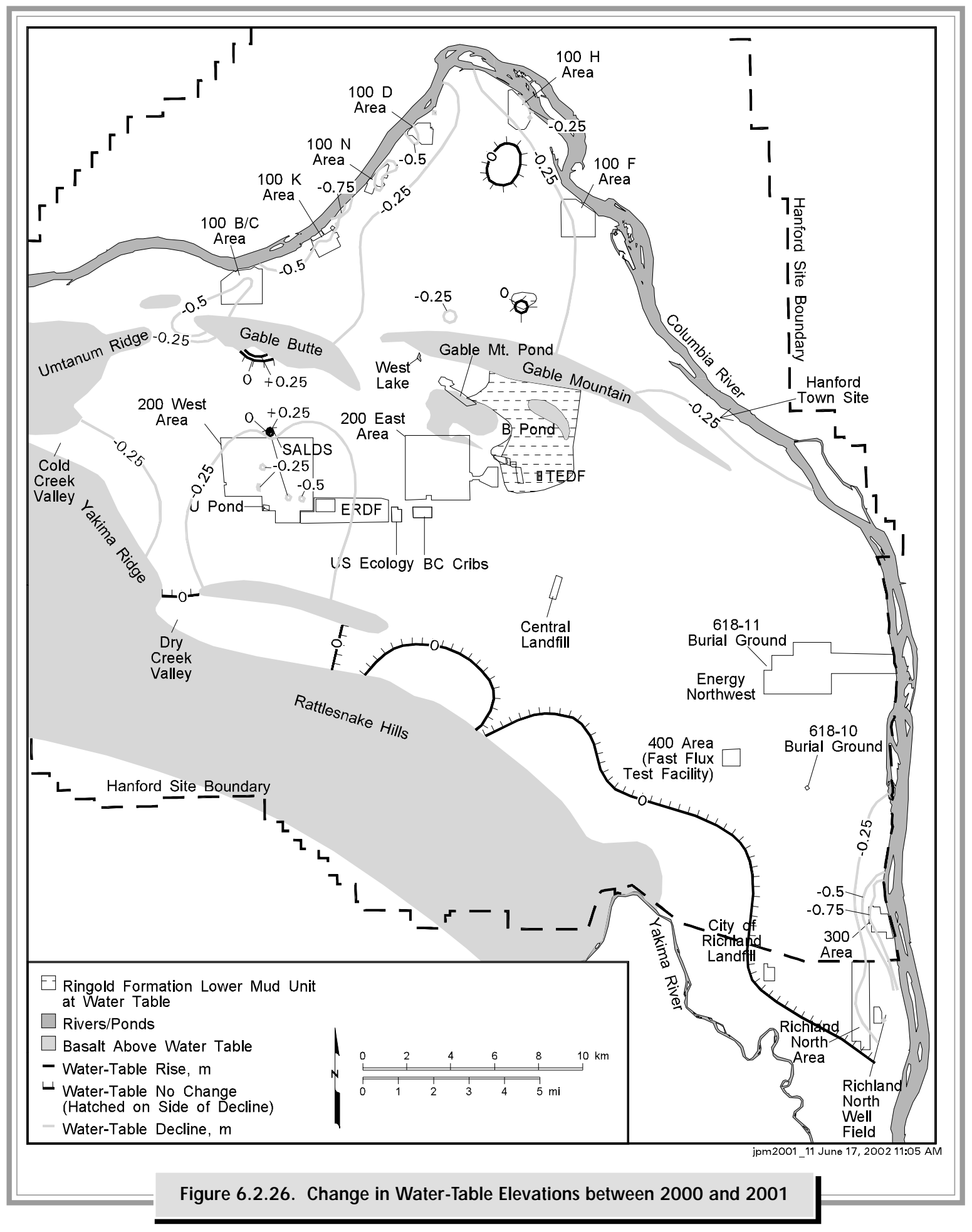




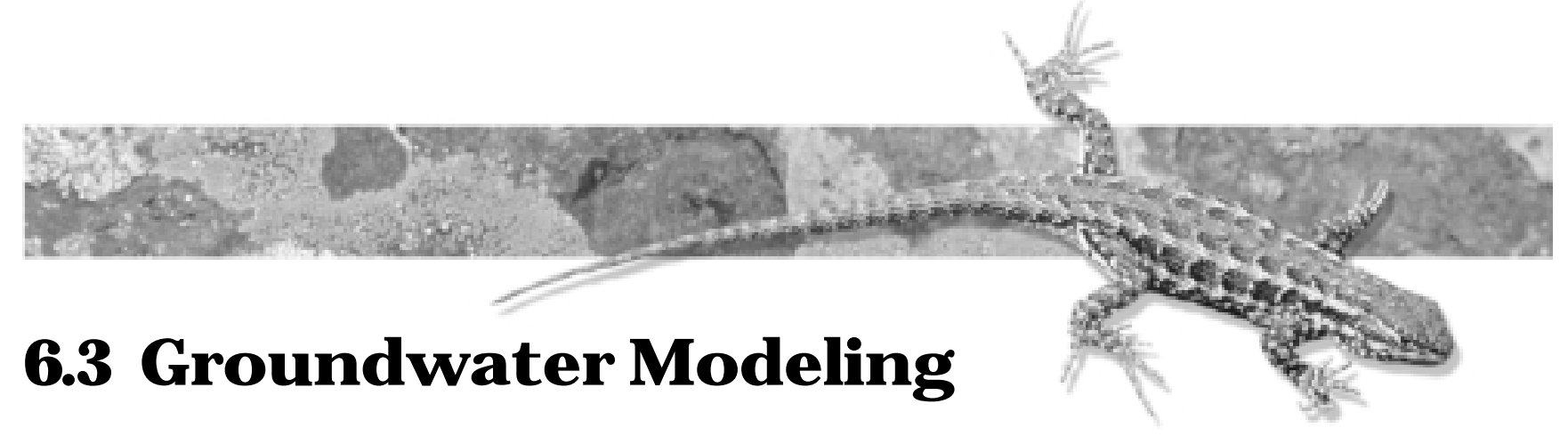

D. R. N ewcomer

Researchers use numerical modeling of groundwater flow and contaminant transport to simulate future groundwater flow conditions and predict the migration of contaminants through the groundwater pathway. DOE consolidated multiple versions of sitewide groundwater flow and contaminant transport models into one model to eliminate redundancies and promote consistency in addressing sitewide groundwater problems (DOE/RL-2000-11). The code used to implement the consolidated groundwater model is the Coupled Fluid, Energy, and Solute Transport (CFEST-96) code, which was developed by CFEST Co., Irvine, California (Gupta
1997). During 2001, progress on development of the consolidated groundwater model focused on sources of uncertainty and how to address uncertainty in groundwater modeling (PNNL-13641). During 2001, the consolidated model was used for the following applications:

- updating the Hanford Site Composite Analysis

- producing an initial assessment using the System Assessment Capability

- modeling the 200-West Area carbon tetrachloride plume.

\subsubsection{Consolidated Groundwater Model Progress in 2001}

A major objective in the development of the consolidated groundwater model is to improve contaminant transport predictions by addressing uncertainty in the model (PNNL-13641). Major uncertainties can be estimated by developing alternate conceptual models (sensitivity analysis) and by establishing probability distributions for key parameters (uncertainty analysis). Each conceptual model is then calibrated based on historical observations of hydraulic head measurements and contaminant concentrations. Results of the calibrated alternative models will span the range of likely future contaminant movement through groundwater. During 2001, calibration of the existing groundwater flow model and one alternative conceptual model was completed.

A three-dimensional transient version of the baseline groundwater flow model was re-calibrated in 2001 (PNNL-13447). The calibration period was extended over a longer period (1943 to 1996). The calibration incorporated new estimates of artificial discharges and river stages before 1979 and a complete set of hydraulic head measurements from 1943 to 1996. The transient inverse calibration procedure significantly improved the model's ability to simulate changes in the water table over the entire Hanford Site. However, the calibration indicated that other conceptual model components are needed to improve the historical aquifer system behavior. One of these components is recharge to the unconfined aquifer system from the underlying basalt-confined aquifer system. Thus, the first major alternative conceptual model included the effects of groundwater movement between these two aquifer systems.

The investigation on the effects of groundwater leakage between the upper basalt-confined aquifer and the overlying unconfined aquifer system is described in PNNL-13623. The objective of this study was to determine whether inclusion of groundwater leakage between these two aquifers could improve model calibration. The results of the investigation indicated that, over the entire prediction period of 1948 to 1996, the overall model fit of the water-level measurements was a slight improvement over the baseline model fit. The calibrated model with basalt leakage is a more realistic conceptual model and incorporates parameter estimates that are closer to expected ranges. However, best-fit estimates of some parameters such as specific yield continued to be unrealistic, indicating that additional improvements in the conceptual model are needed. 


\subsubsection{Update of the Hanford Com posite Analysis}

The consolidated groundwater model was used to simulate groundwater contaminant transport from selected waste sites to support an addendum to the Composite Analysis (PNNL-11800, Addendum 1). The addendum analysis was required for continued authorization of low-level waste disposal at the Hanford Site. The analysis addressed the impact of these selected waste sites on groundwater. These waste sites, which were not included in the first Composite Analysis (PNNL-11800) conducted in 1998, included the Plutonium Uranium Extraction Plant tunnels, the chemical separations plants, and some CERCLA sites in the 200-East and 200-West Areas. Technetium-99 and iodine-129 were used as representative mobile constituents.
Results of the addendum analysis indicated that the effects of the additional sites pose no significant increases in radiological doses during the next 1,000 years, and that conclusions of the 1998 composite analysis remain valid. Predicted radionuclide concentration estimates and resulting doses in groundwater from the composite analysis demonstrate the need for continued control of land use and monitoring programs at the Hanford Site. These are necessary to meet the long-term objective in protecting human health and the environment. This analysis supports the concept of retiring the Hanford Site boundary to the proposed buffer zone boundary at the time of Hanford Site closure in 2050.

\subsubsection{System Assessment Capability}

The System Assessment Capability (Section 2.3.11.2) is a tool being developed to predict the cumulative sitewide effects from all significant contaminants at the Hanford Site. This tool uses several linked models to simulate the movement of contaminants from waste sites through the vadose zone, groundwater, and Columbia River to receptors. It then assesses the risk to humans, other living organisms, the local economy, and cultures. The consolidated sitewide groundwater model was used as the groundwater component of the System Assessment Capability to simulate contaminant transport through the groundwater. During 2001, an initial assessment was performed using the System Assessment Capability.
The major objective of the initial assessment was to demonstrate the linkage of models. For the initial assessment, a two-dimensional groundwater model with variable aquifer thickness was determined to be suitable for calculating transport of contaminant constituents. The model simulated the transport of 10 different radionuclide and chemical constituents released from 890 waste sites for the period 1944 through 3050.

\subsubsection{Carbon Tetrach loride Plume Modeling}

The consolidated groundwater model was used to simulate the migration of carbon tetrachloride from the $\mathrm{Z}$ crib in the 200-West Area to an assumed compliance boundary $\sim 5,000$ meters $(\sim 16,400$ feet) from the source (PNNL-13560). The purpose of the study was to provide upper and lower estimates of the amount of carbon tetrachloride at the source area that will most likely result in carbon tetrachloride concentrations exceeding $5 \mu \mathrm{g} / \mathrm{L}$ at the boundary. The modeling study concluded that for amounts between 7,500 and 75,000 kilograms $(16,500$ and 165,000 pounds) of carbon tetrachloride, the concentration of $5 \mu \mathrm{g} / \mathrm{L}$ may be exceeded depending on source removal efforts. If 75,000 kilograms ( 165,000 pounds) or more of carbon tetrachloride reaches groundwater, then concentrations of $5 \mu \mathrm{g} / \mathrm{L}$ would be exceeded at the compliance boundary. Carbon tetrachloride concentrations would not likely exceed $5 \mu \mathrm{g} / \mathrm{L}$ at the boundary if 7,500 kilograms (16,500 pounds) or less carbon tetrachloride reached groundwater at the source area.

In 2001, additional modeling of the 200-West carbon tetrachloride plume was conducted to predict the carbon tetrachloride concentration distribution using both realistic and conservative natural attenuation parameters. Natural attenuation parameters are important in predicting the movement of the carbon tetrachloride plume from the 200-West Area. The sitewide model grid was refined in the area between the source area and the Columbia River. Three modeling cases were evaluated:

- a continuing source of carbon tetrachloride in contact with the groundwater 
- the effect of complete removal of the carbon tetrachloride source

- the effects of assuming that no continuing source ever existed.

For the first case with a continuing source in contact with the groundwater, the effect of using conservative and realistic natural attenuation parameters is illustrated in Figures 6.3.1 and 6.3.2. Figure 6.3.1 shows that carbon tetrachloride concentrations exceed $5 \mu \mathrm{g} / \mathrm{L}$ outside the Central Plateau waste management area if conservative parameters are assumed (natural attenuation values set to zero). Under these conservative conditions, the size of the plume will continue to grow until the mass rate of carbon tetrachloride entering the Columbia River reaches the source release rate. If realistic natural attenuation parameters are used, then carbon tetrachloride concentrations will not exceed $5 \mu \mathrm{g} / \mathrm{L}$ outside the Central Plateau waste management area (see Figure 6.3.2). Under these realistic conditions, natural attenuation limits the growth of the plume.

For the second case with complete source removal and the third case with no continuing source using conservative natural attenuation parameters, carbon tetrachloride concentrations will not exceed $5 \mu \mathrm{g} / \mathrm{L}$ outside the Central Plateau waste management area.

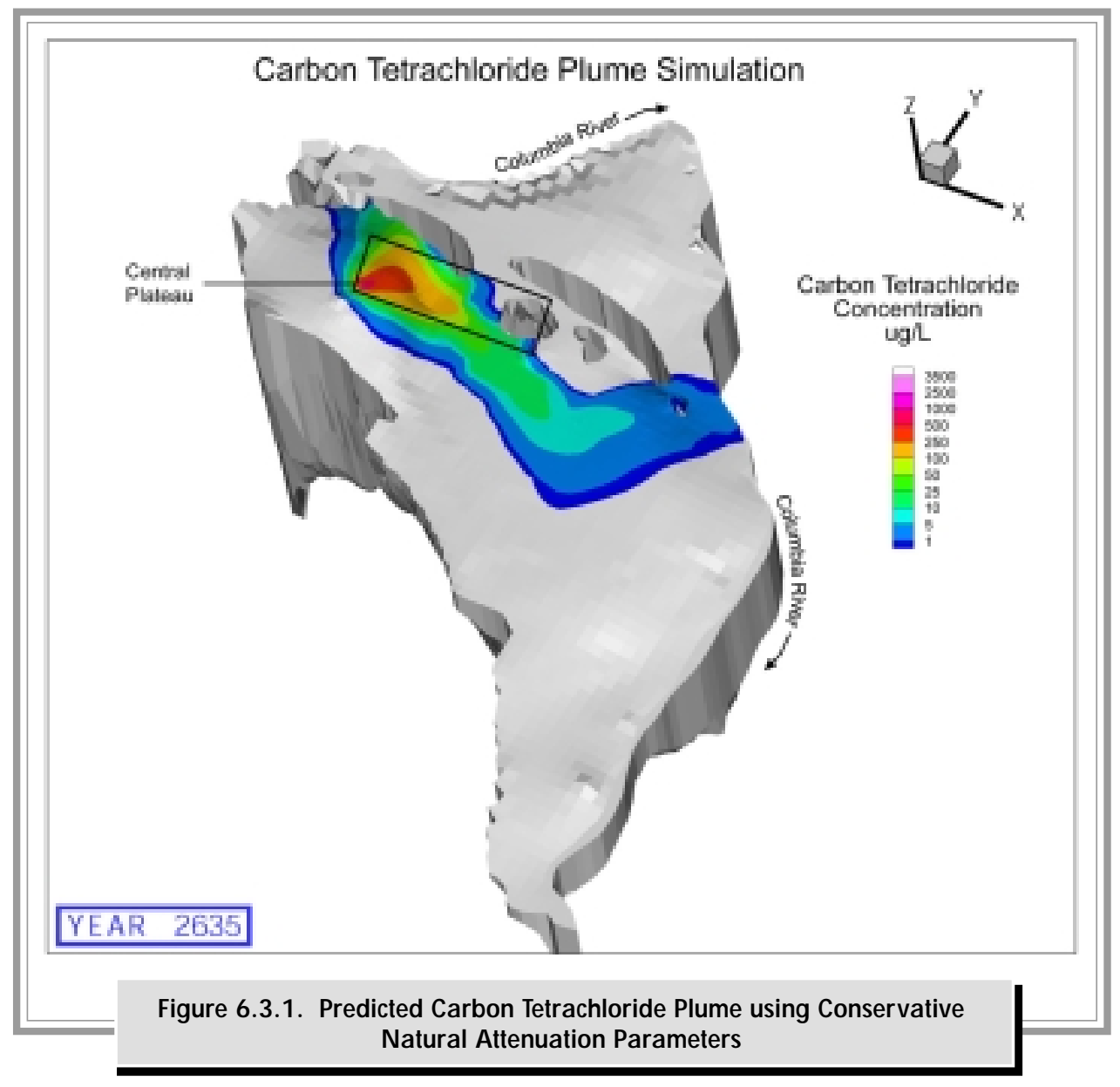




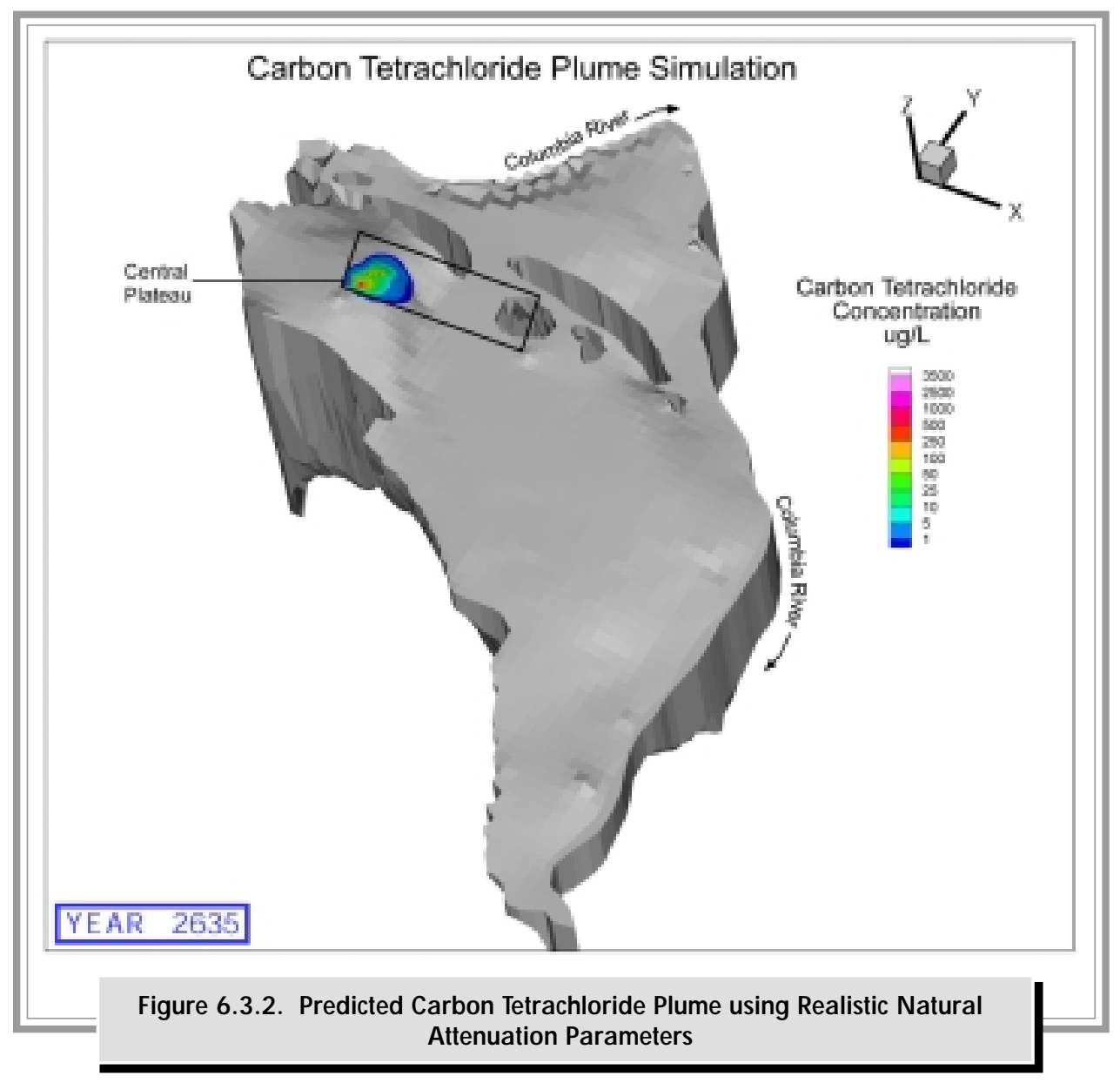




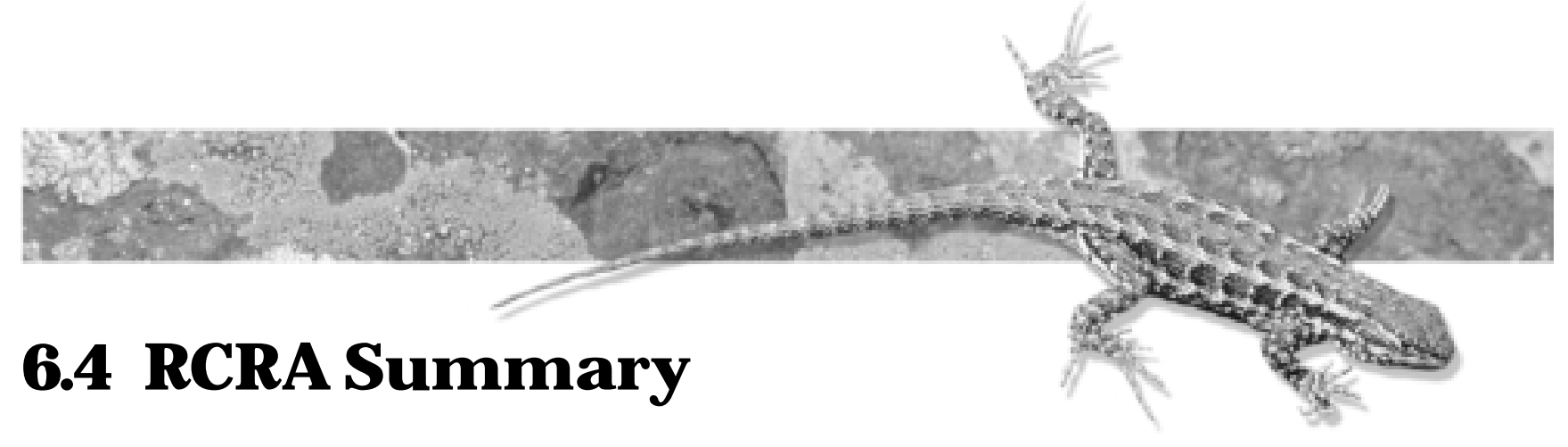

\section{J. H artman}

More than 60 treatment, storage, and disposal units are recognized under the RCRA permit for the Hanford Site. The units that required groundwater monitoring are grouped into 24 waste management areas. Locations of these sites were given in Figure 6.1.3. Table 6.4.1 provides a summary of groundwater monitoring activities and results for these sites during calendar year 2001. Additional information, including complete listings of constituents measured in monitoring wells from October 2000 through September 2001, is available in PNNL13788. Although radionuclide results are discussed in Table 6.4.1, it is noted that they are not regulated under RCRA. These results are presented for completeness, identifying impacts of constituents regulated by RCRA as well as the A tomic E nergy A ct.

\begin{tabular}{|c|c|c|}
\hline \multicolumn{3}{|c|}{ Table 6.4.1. Summary of RCRA Monitoring Results in 2001} \\
\hline RCRA Unit & Monitoring Status & H ighlights in 2001 \\
\hline 1301-N facility & Indicator evaluation & No contamination indicator parameter exceedance. \\
\hline 1325-N facility & Indicator evaluation & No contamination indicator parameter exceedance. \\
\hline 1324-N/NA facilities & Indicator evaluation & No contamination indicator parameter exceedance. \\
\hline 183-H basins & Corrective action & $\begin{array}{l}\text { Corrective-action monitoring continued during operation of the } 100-\mathrm{HR}-3 \\
\text { chromium pump-and-treat system. Leakage from basins in past contaminated } \\
\text { groundwater with chromium, nitrate, technetium-99, and uranium. CERCLA } \\
\text { program directs corrective action. }\end{array}$ \\
\hline 216-A-29 ditch & Indicator evaluation & No contamination indicator parameter exceedance. \\
\hline 216-B-3 pond & Indicator evaluation & $\begin{array}{l}\text { Washington State Department of Ecology issued guidance letter regarding alter- } \\
\text { native statistical methods. DOE submitted proposal for new approach in } \\
\text { November } 2001 \text {. }\end{array}$ \\
\hline $216-\mathrm{B}-63$ trench & Indicator evaluation & No contamination indicator parameter exceedance. \\
\hline $\begin{array}{l}\text { 216-S-10 pond and } \\
\text { ditch }\end{array}$ & Indicator evaluation & $\begin{array}{l}\text { No contamination indicator parameter exceedance. Another downgradient well } \\
\text { went dry in 2001, leaving just one useable, shallow, downgradient well. }\end{array}$ \\
\hline $216-\mathrm{U}-12 \mathrm{crib}$ & Assessment & $\begin{array}{l}\text { Nitrate and technetium-99 plumes mingled from various sources, including crib. } \\
\text { Monitoring network contains just two useable downgradient wells and no } \\
\text { upgradient wells. }\end{array}$ \\
\hline $316-5$ process trenches & Corrective action & $\begin{array}{l}\text { Trenches and other sources contaminated groundwater with cis-1,2- } \\
\text { dichloroethene, trichloroethene, and uranium. Corrective action deferred to } \\
\text { CERCLA; involves monitored natural attenuation of contaminants. Trichloro- } \\
\text { ethene declined below } 5 \mu \mathrm{g} / \mathrm{L} \text { maximum contaminant level. New monitoring } \\
\text { plan written, implementing alternative statistical methods. }\end{array}$ \\
\hline LERF & Indicator evaluation & $\begin{array}{l}\text { Another downgradient well went dry in 2001, leaving just one useable down- } \\
\text { gradient well. Washington State Department of Ecology directed DOE to cease } \\
\text { statistical evaluations. }\end{array}$ \\
\hline LLWMA 1 & Indicator evaluation & No contamination indicator parameter exceedance. \\
\hline LLWMA 2 & Indicator evaluation & No contamination indicator parameter exceedance. \\
\hline LLWMA 3 & Indicator evaluation & $\begin{array}{l}\text { No contamination indicator parameter exceedance. Wells going dry. Poor down- } \\
\text { gradient coverage. }\end{array}$ \\
\hline LLWMA 4 & Indicator evaluation & $\begin{array}{l}\text { No contamination indicator parameter exceedance. Wells going dry. Only two } \\
\text { downgradient wells. }\end{array}$ \\
\hline
\end{tabular}




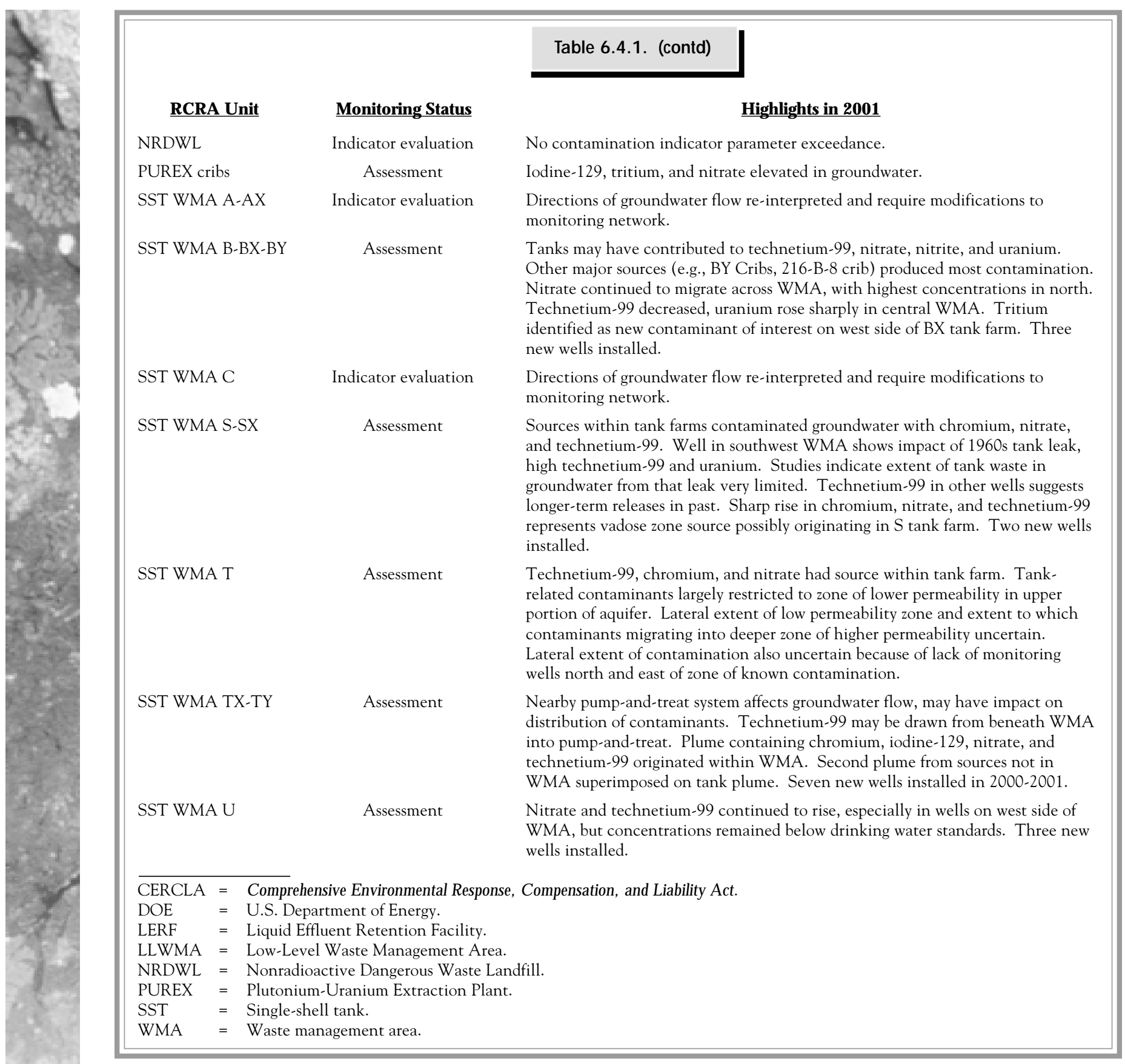




\subsection{References}

40 CFR 9. U.S. Environmental Protection Agency. "OMB Approval Under the Paperwork Reduction Act." Code of Federal Regulations.

40 CFR 141. U.S. Environmental Protection Agency. "National Primary Drinking Water Regulations; Radionuclides; Proposed Rule." Code of Federal Regulations.

40 CFR 142. U.S. Environmental Protection Agency. "National Primary Drinking Water Regulations Implementation." Code of Federal Regulations.

40 CFR 265. U.S. Environmental Protection Agency. "Interim Status Standards for Owners and Operators of Hazardous Waste Treatment, Storage, and Disposal Facilities." Code of Federal Regulations.

40 CFR 300. U.S. Environmental Protection Agency. "National Oil and Hazardous Substances Pollution Contingency Plan." Code of Federal Regulations.

American Society for Testing and Materials (ASTM). 1986. Annual Book of ASTM Standards. Philadelphia, Pennsylvania.

Atomic Energy Act. 1954. Chapter 1073, 68 Stat. 919, 42 USC 2011 et seq.

BHI-01311, Rev. 0. 1999. Hydrogeologic Conceptual Model for the Carbon Tetrachloride and Uranium/ Technetium Plumes in the 200 West Area: 1994 Through 1999 Update. L. C. Swanson, V. J. Rohay, and J. M. Faurote, Bechtel Hanford, Inc., Richland, Washington.

BNWL-90. 1965. Evaluation of Radiological Conditions in the Vicinity of Hanford for 1964. R. H. Wilson (ed.), Pacific Northwest Laboratory, Richland, Washington.

BNWL-1970. 1976. Environmental Monitoring Report on Radiological Status of the Ground Water Beneath the Hanford Site, January-December 1974. J. R. Raymond, D. A. Myers, J. J. Fix, V. L. McGhan, and P. M. Schrotke, Pacific Northwest Laboratory, Richland, Washington.

Comprehensive Environmental Response, Compensation, and Liability Act. 1980. Public Law 96-150, as amended, 94 Stat. 2767, 42 USC 9601 et seq.
DOE/EIS-0119F. 1992. Decommissioning of Eight Surplus Production Reactors at the Hanford Site, Richland, Washington, Final Environmental Impact Statement. U.S. Department of Energy, Washington, D.C.

DOE Order 435.1. "Radioactive Waste Management."

DOE Order 5400.1. "General Environmental Protection Program."

DOE Order 5400.5. "Radiation Protection of the Public and the Environment."

DOE/RL-89-12, Rev. 2. 1995. Hanford Site GroundWater Protection Management Plan. D. B. Barnett, J. S. Schmid, S. S. Lowe, W. L. Allen, N. A. Ballantyne, C. H. Dohrer, M. J. Hartman, F. N. Hodges, D. G. Horton, V. G. Johnson, K. J. Lueck, D. J. Ortiz, A. J. Knepp, B. H. Ford, S. P. Hope, D. K. Tyler, R. D. Hildebrand, D. E. Olson, R. E. Peterson, G. L. Kasza, D. A. Myers, S. P. Luttrell, P. D. Thorne, and K. R. Moser. U.S. Department of Energy, Richland Operations Office, Richland, Washington.

DOE/RL-91-50, Rev. 3. 2000. Environmental Monitoring Plan United States Department of Energy Richland Operations Office. U.S. Department of Energy, Richland Operations Office, Richland, Washington.

DOE/RL-96-39. 1998. 100-NR-1 Treatment, Storage, and Disposal Units Corrective Measure Study/Closure Plan. U.S. Department of Energy, Richland Operations Office, Richland, Washington.

DOE/RL-96-61, Rev. 0. 1997. Hanford Site Background: Part 3, Groundwater Background. U.S. Department of Energy, Richland Operations Office, Richland, Washington.

DOE/RL-96-102. 1998. Proposed Plan for Interim Remedial Actions at the 100-NR-1 Source Sites Operable Unit and the 100-NR-2 Groundwater Operable Unit. U.S. Department of Energy, Richland Operations Office, Richland, Washington.

DOE/RL-98-48, Draft C. 1998. Groundwater/Vadose Zone Integration Project Specification. Prepared by Bechtel Hanford, Inc. for the U.S. Department of Energy, Richland Operations Office, Richland, Washington. 
DOE/RL-98-56. 1999. Groundwater/Vadose Zone Integration Project, Project Management Plan. U.S. Department of Energy, Richland Operations Office, Richland, Washington.

DOE/RL-2000-11, Rev. 1. 2000. Recommendations for Selection of a Site-Wide Groundwater Flow and Transport Model. U.S. Department of Energy, Richland Operations Office, Richland, Washington.

DOE/RL-2002-01. 2002. Calendar Year 2001 Annual Summary Report for the 100-HR-3, 100-KR-4, and 100-NR-2 Operable Units and Pump-and-Treat Operations. U.S. Department of Energy, Richland Operations Office, Richland, Washington.

DOE/RW-0164 (2 vols). 1988. Consultation Draft, Site Characterization Plan, Reference Repository Location, Hanford Site, Washington. U.S. Department of Energy, Richland Operations Office, Richland, Washington.

EMF-1865, Addendum 27. 2002. Quarterly Groundwater Monitoring Summary - Fourth Quarter 2001. Framatome ANP, Inc., Richland, Washington.

EPA. 1986. Test Methods for Evaluating Solid Waste: Physical/Chemical Methods, SW-846, Third Edition. Office of Solid Waste and Emergency Response, U.S. Environmental Protection Agency, Washington, D.C.

EPA 822-R-96-001. 1996. Drinking Water Regulations and Health Advisories. U.S. Environmental Protection Agency, Office of Water, Washington, D.C.

EPA 822-Z-99-001. 1999. National Recommended Water Quality Criteria-Correction. U.S. Environmental Protection Agency, Office of Water, Washington, D.C. Available URL: http://www.epa.gov/ost/pc/revcom.pdf

Gee, G. W., M. J. Fayer, M. L. Rockhold, and M. D. Campbell. 1992. "Variations in Recharge at the Hanford Site." Northwest Science 66(4):237.

Gupta, S. K. 1997. Draft User's Manual, CFEST-96 Flow and Solute Transport, Constant/Variable Density, Computationally Efficient, and Low Disk PC/Unix Version. Environmental System Technologies, Irvine, California.

Newcomb, R. C., J. R. Strand, and F. J. Frank. 1972. Geology and Ground-Water Characteristics of the Hanford Reservation of the U.S. Atomic Energy Commission, Washington. Geological Survey Professional Paper 717, U.S. Geological Survey, Washington, D.C.

Peterson, R. E., and M. P. Connelly. 1992. "Characterization of a Chromium Plume in Groundwater Along the Columbia River Shoreline, Hanford Site, Washington." Presented at 1992 Fall Meeting, American
Geophysical Union, San Francisco, California, December 7-11, 1992. EOS Transactions, American Geophysical Union 73:43; also WHC-SA-1674-VA, Westinghouse Hanford Company, Richland, Washington.

PNL-5041. 1984. Ground-Water Surveillance at the Hanford Site for CY 1993. L. S. Prater, J. T. Rieger, C. S. Cline, E. J. Jensen, T. L. Liikala, K. R. Oster, and P. A. Eddy, Pacific Northwest Laboratory, Richland, Washington.

PNL-6456. 1988. Hazard Ranking System Evaluation of CERCLA Inactive Waste Sites at Hanford. R. D. Stenner, K. H. Cramer, K. A. Higley, S. J. Jette, D. A. Lamar, T. J. McLaughlin, D. R. Sherwood, and N. C. Van Houten, Pacific Northwest Laboratory, Richland, Washington.

PNL-6825. 1989. Hanford Site Environmental Report for Calendar Year 1988. R. E. Jaquish and R. W. Bryce, Pacific Northwest Laboratory, Richland, Washington.

PNL-6886. 1989. Hanford Site Ground-Water Monitoring for January Through June 1988. J. C. Evans, R. W. Bryce, and D. R. Sherwood, Pacific Northwest Laboratory, Richland, Washington.

PNL-7120. 1989. Hanford Site Ground-Water Monitoring for July Through December 1988. J. C. Evans, R. W. Bryce, D. R. Sherwood, M. L. Kemner, and D. R. Newcomer, Pacific Northwest Laboratory, Richland, Washington.

PNL-7144. 1990. An Initial Inverse Calibration of the Ground-Water Flow Model for the Hanford Unconfined Aquifer. E. A. Jacobson and M. D. Freshley, Pacific Northwest Laboratory, Richland, Washington.

PNL-8073. 1992. Hanford Site Ground-Water Monitoring for 1990. J. C. Evans, R. W. Bryce, and D. J. Bates, Pacific Northwest Laboratory, Richland, Washington.

PNL-8337. 1992. Summary and Evaluation of Available Hydraulic Property Data for the Hanford Site Unconfined Aquifer System. P. D. Thorne and D. R. Newcomer, Pacific Northwest Laboratory, Richland, Washington.

PNL-10285. 1995. Estimated Recharge Rates at the Hanford Site. M. J. Fayer and T. B. Walters, Pacific Northwest Laboratory, Richland, Washington.

PNL-10817. 1995. Hydrochemistry and Hydrogeologic Conditions Within the Hanford Site Upper Basalt Confined Aquifer System. F. A. Spane, Jr. and W. D. Webber, Pacific Northwest Laboratory, Richland, Washington.

PNNL-11141. 1996. Hanford Site Ground-Water Monitoring for 1995. P. E. Dresel, J. T. Rieger, W. D. Webber, 
P. D. Thorne, B. M. Gillespie, S. P. Luttrell, S. K. Wurstner, and T. L. Liikala, Pacific Northwest National Laboratory, Richland, Washington.

PNNL-11800. 1998. Composite Analysis for Low-Level Waste Disposal in the 200 Area Plateau of the Hanford Site. C. T. Kincaid, M. P. Bergeron, C. R. Cole, M. D. Freshley, N. Hassig, V. G. Johnson, D. I. Kaplan, R. J. Serne, G. P. Steile, D. L. Strenge, P. D. Thorne, L. W. Vail, G. A. Whyatt, and S. K. Wurstner, Pacific Northwest National Laboratory, Richland, Washington.

PNNL-11800, Addendum 1. 2001. Addendum to Composite Analysis for Low-Level Waste Disposal in the 200 Area Plateau of the Hanford Site. M. P. Bergeron, E. J. Freeman, and S. K. Wurstner, Pacific Northwest National Laboratory, Richland, Washington.

PNNL-11809. 1998. Results of Phase I Groundwater Quality Assessment for Single-Shell Tank Waste Management Areas T and TX-TY at the Hanford Site. F. N. Hodges, Pacific Northwest National Laboratory, Richland, Washington.

PNNL-11810. 1998. Results of Phase I Groundwater Quality Assessment for Single-Shell Tank Waste Management Areas S-SX at the Hanford Site. V. G. Johnson and C. J. Chou, Pacific Northwest National Laboratory, Richland, Washington.

PNNL-11826. 1998. Results of Phase I Groundwater Quality Assessment for Single-Shell Tank Waste Management Areas B-BX-BY at the Hanford Site. S. M. Narbutovskih, Pacific Northwest National Laboratory, Richland, Washington.

PNNL-11989, Rev. 2. 2000. Integrated Monitoring Plan for the Hanford Groundwater Monitoring Project. M. J. Hartman, P. E. Dresel, J. W. Lindberg, D. R. Newcomer, and E. C. Thornton, Pacific Northwest National Laboratory, Richland, Washington.

PNNL-12023. 1998. Groundwater Monitoring for the 100-K Area Fuel-Storage Basins: July 1996 through April 1998. V. G. Johnson, C. J. Chou, M. J. Hartman, and W. D. Webber, Pacific Northwest National Laboratory, Richland, Washington.

PNNL-12261. 2000. Revised Hydrogeology for the Suprabasalt Upper Aquifer System, 200 East Area, Hanford Site, Washington. B. A. Williams, B. N. Bjornstad, R. Schalla, and W. D. Webber, Pacific Northwest National Laboratory, Richland, Washington.

PNNL-13080. 2000. Hanford Site Groundwater: Settings, Sources, and Methods. M. J. Hartman (ed.), Pacific Northwest National Laboratory, Richland, Washington.
PNNL-13116. 2000. Hanford Site Groundwater Monitoring for Fiscal Year 1999. M. J. Hartman, L. F. Morasch, and W. D. Webber (eds.), Pacific Northwest National Laboratory, Richland, Washington.

PNNL-13228. 2000. Evaluation of Elevated Tritium Levels in Groundwater Downgradient from the 618-11 Burial Ground Phase I Investigations. P. E. Dresel, B. A. Williams, J. C. Evans, R. M. Smith, C. J. Thompson, and L. C. Hulstrom, Pacific Northwest National Laboratory, Richland, Washington.

PNNL-13404. 2001. Hanford Site Groundwater Monitoring for Fiscal Year 2000. M. J. Hartman, L. F. Morasch, and W. D. Webber (eds.), Pacific Northwest National Laboratory, Richland, Washington.

PNNL-13441. 2000. RCRA Groundwater Quality Assessment Report for Waste Management Area S-SX (November 1997 through April 2000). V. G. Johnson and C. J. Chou, Pacific Northwest National Laboratory, Richland, Washington.

PNNL-13447. 2001. Hanford Site-Wide Model Calibration Using Inverse Methodology. C. R. Cole, M. P. Bergeron, S. K. Wurstner, P. D. Thorne, S. Orr, and M. I. McKinley, Pacific Northwest National Laboratory, Richland, Washington.

PNNL-13560. 2001. Assessment of Carbon Tetrachloride Groundwater Transport in Support of the Hanford Carbon Tetrachloride Innovative Technology Demonstration Program. M. J. Truex, C. J. Murray, C. R. Cole, R. J. Cameron, M. D. Johnson, R. S. Skeen, and C. D. Johnson, Pacific Northwest National Laboratory, Richland, Washington.

PNNL-13623. 2001. Transient Inverse Calibration of Site-Wide Groundwater Model to Hanford Operational Impacts from 1943 to 1996 - Alternative Conceptual Model Considering Interaction with Uppermost Basalt Confined Aquifer. V. R. Vermeul, C. R. Cole, M. P. Bergeron, P. D. Thorne, and S. K. Wurstner, Pacific Northwest National Laboratory, Richland, Washington.

PNNL-13641. 2001. Uncertainty Analysis FrameworkHanford Site-Wide Groundwater Flow and Transport Model. C. R. Cole, M. P. Bergeron, C. J. Murphy, P. D. Thorne, S. K. Wurstner, and P. Rogers, Pacific Northwest National Laboratory, Richland, Washington.

PNNL-13788. 2002. Hanford Site Groundwater Monitoring for Fiscal Year 2001. M. J. Hartman, L. F. Morasch, and W. D. Webber (eds.), Pacific Northwest National Laboratory, Richland, Washington. 
Resource Conservation and Recovery Act. 1976. Public Law 94-580, as amended, 90 Stat. 2795, 42 USC 6901 et seq.

RHO-BWI-ST-5. 1979. Hydrologic Studies Within the Columbia Plateau, Washington: An Integration of Current Knowledge. R. E. Gephart, R. C. Arnett, R. G. Baca, L. S. Leonhart, F. A. Spane, Jr., D. A. Palumbo, and S. R. Strait, Rockwell Hanford Operations, Richland, Washington.

RHO-RE-ST-12 P. 1984. An Assessment of Aquifer Intercommunication in the B Pond - Gable Mountain Pond Area of the Hanford Site. M. J. Graham, G. V. Last, and K. R. Fecht, Rockwell Hanford Operations, Richland, Washington.

RHO-ST-42. 1981. Hydrology of the Separations Area. M. J. Graham, M. D. Hall, S. R. Strait, and W. R. Brown, Rockwell Hanford Operations, Richland, Washington.

Soldat, J. K. 1976. "Radiation Doses from Iodine-129 in the Environment." Health Physics 30:61-70.

WAC173-216. "State Waste Discharge Program." Washington Administrative Code, Olympia, Washington.
WAC 173-303. "Dangerous Waste Regulations." Washington Administrative Code, Olympia, Washington.

WAC 173-304. "Minimal Functional Standards for Solid Waste Handling." Washington Administrative Code, Olympia, Washington.

WHC-EP-0595. 1993. Westinghouse Hanford Company Operational Groundwater Status Report, 1990-1992. V. G. Johnson, Westinghouse Hanford Company, Richland, Washington.

WHC-MR-0388. 1992. Past Practices Technical Characterization Study - 300 Area - Hanford Site. M. S. Gerber, Westinghouse Hanford Company, Richland, Washington.

WHC-MR-0391. 1992. Field Trip Guide to the Hanford Site. S. P. Reidel, K. A. Lindsey, and K. R. Fecht, Westinghouse Hanford Company, Richland, Washington.

WHC-SD-EN-RPT-004. 1993. Summary of 100-B/C Reactor Operations and Resultant Wastes, Hanford Site. M. S. Gerber, Westinghouse Hanford Company, Richland, Washington. 
Most of the groundwater contamination at the Hanford Site resulted from discharge of wastewater from reactor operations, reactor fuel fabrication, and processing of spent reactor fuel. Table 6.0.1 lists the principal contaminants found in each operational area and the type of operation that generated them. In the 100 Areas, discharges included reactor cooling water, fuel storage basin water, filter backwash, and smaller amounts of waste from a variety of other processes. In the 200 Areas, large quantities of wastewater from fuel reprocessing were discharged to the ground. Other contamination sources in the 200 Areas included plutonium purification waste and decontamination waste. The plutonium purification process resulted in the discharge of large amounts of liquid organic chemicals in addition to aqueous solutions. This has produced widespread contaminant plumes. Non-aqueous liquid may also be present, and this would result in a continuing source of contamination that is very difficult to clean up. Groundwater contamination in the 300 Area resulted mainly from discharge of waste from fuel fabrication and laboratory operations.

Liquid effluents discharged to the ground at Hanford Site facilities percolated down through the unsaturated zone toward the water table. Radionuclide and chemical constituents move through the soil column and, in some cases, enter the groundwater. In some locations, sufficient water was discharged to saturate the soil column to the surface. Not all contaminants move at the same rate as the water in the subsurface. Chemical processes such as adsorption onto soil particles, chemical precipitation, and ion exchange slow the movement of some constituents such as strontium-90, cesium-137, and plutonium239/240. However, these processes may be affected by the chemical characteristics of the waste such as high ionic strength, acidity, or presence of chemical complexants. Other radionuclides, such as technetium-99, iodine-129, and tritium, and chemicals, such as nitrate, are not as readily retained by the soil and move vertically through the soil column at a rate nearly equal to the infiltrating water. When the contaminants reach the water table, their concentrations are reduced by dilution with groundwater. As these dissolved constituents move with the groundwater, many radionuclides and chemicals adhere to sediment particle surfaces (adsorption) or diffuse into the particles (absorption). Radionuclide concentrations are also reduced by radioactive decay.

Outside the source areas (i.e., liquid disposal sites), there is typically little or no downward gradient (driving force or head), so contamination tends to remain in the upper part of the aquifer. In the source areas, where large volumes of wastewater were discharged, a large vertical hydraulic gradient developed that moved contaminants downward in the aquifer. Layers of low-permeability silt and clay within the unconfined aquifer also limit the vertical movement of contaminants. Flow in the unconfined aquifer is generally toward the Columbia River, which acts as a drainage area for the groundwater flow system at Hanford (see Section 6.2.4). Contamination that reaches the river is further diluted by river water.

\begin{tabular}{|lll|}
\hline Table 6.0.1. Chemical and Radiological Groundwater Contaminants and Their Link to Site O perations \\
\hline$\underline{\text { Areas }}$ & \multicolumn{1}{|c|}{ Facilities Type } & \multicolumn{1}{c|}{ Contaminants Generated } \\
100 & Reactor operations & Tritium, ${ }^{60} \mathrm{Co},{ }^{90} \mathrm{Sr}$, hexavalent chromium, sulfate \\
200 & Irradiated fuel processing & $\begin{array}{l}\text { Tritium, }{ }^{90} \mathrm{Sr},{ }^{99} \mathrm{Tc},{ }^{129} \mathrm{I},{ }^{137} \mathrm{Cs}, \text { Pu, U, cyanide, hexavalent } \\
\text { chromium, fluoride, nitrate }\end{array}$ \\
200 & Plutonium purification & $\mathrm{Pu}$, carbon tetrachloride, chloroform, nitrate \\
300 & Fuel fabrication & ${ }^{99} \mathrm{Tc}, \mathrm{U}$, hexavalent chromium, trichloroethene \\
\hline
\end{tabular}




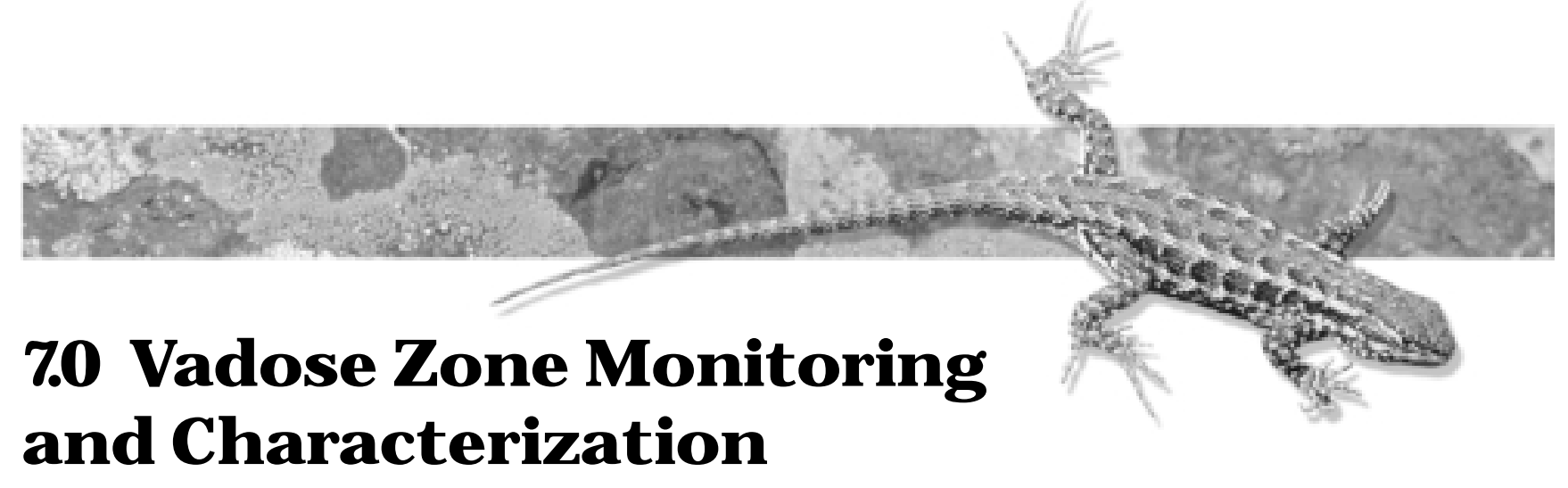

D. G. H orton

The vadose zone is defined as the area between the ground surface and the water table. This subsurface zone also is referred to as the unsaturated zone or the zone of aeration. The vadose zone functions as a transport pathway or storage area for water and other materials located between the soil surface and the groundwater aquifers. Historically, the vadose zone at industrialized and waste disposal areas at the Hanford Site has been contaminated with large amounts of radioactive and non-radioactive materials through the intentional and unintentional discharge of liquid waste to the soil column, the burial of contaminated solid waste, and the airborne contaminants deposited on the ground. Depending on such factors as the makeup of the soil, the geology of the area, the nature of the waste, and the amount of water or other fluids available to mobilize the contaminant, contaminants can move downward and laterally through the soil column, can be chemically bound to soil particles (and immobilized), or can be contained by geologic formations.

Radioactive and hazardous waste in the soil column from past intentional liquid waste disposal, unplanned leaks, solid waste burial grounds, and underground tanks at the Hanford Site are potential sources of continuing and future vadose zone and groundwater contamination. Subsurface source characterization, vadose zone moni- toring, soil-vapor monitoring, and vadose zone remediation were conducted in fiscal year 2001 to better understand the distribution and mechanisms that control the movement of subsurface contamination. This chapter summarizes major findings from those efforts, focused primarily on vadose zone soil contamination associated with reactor operations, past single-shell tank leaks, and liquid disposal to ground as a result of spent fuel processing. This chapter also summarizes several technical studies whose results could lead to new understanding of contaminant interactions with the soil column and new and improved methods to characterize and monitor the vadose zone.

An overview of the major soil column sources of groundwater contamination is provided in PNNL-13080. This chapter discusses vadose zone contamination that could affect groundwater in the future. An overall evaluation depends, to a large degree, on integration of vadose zone and groundwater monitoring and characterization data to present a comprehensive picture of contaminant fate and transport. Significant fiscal year 2001 vadose zone results are summarized here. However, the bulk of the data interpretation on the effect to groundwater is presented and discussed in Section 6.1. 


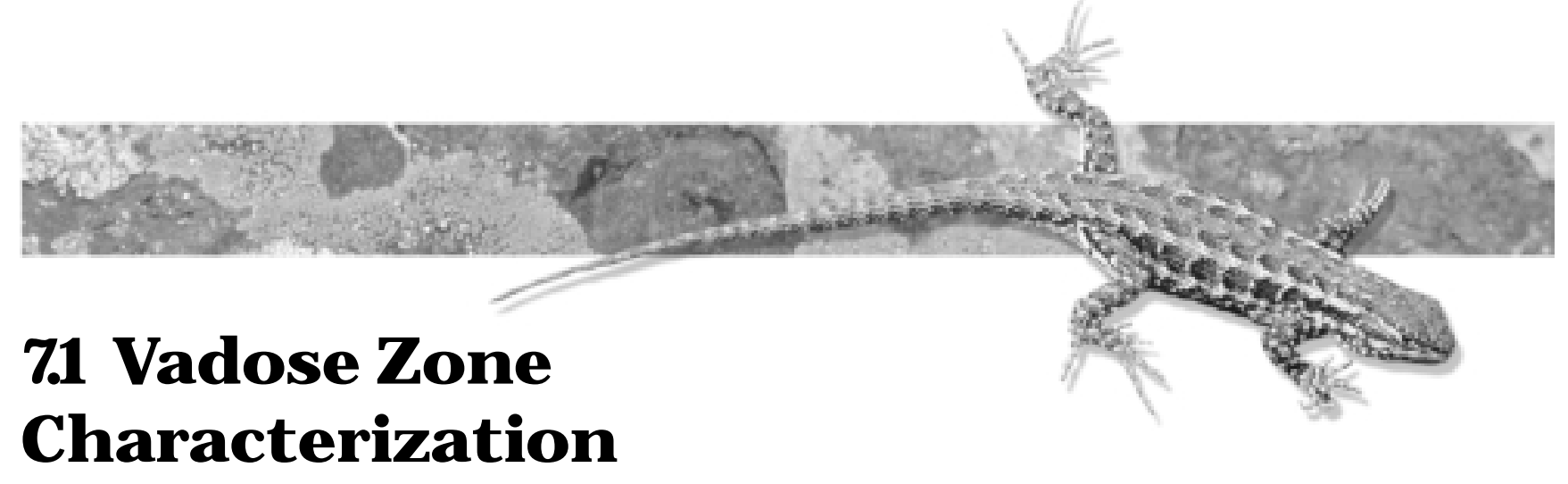

D. G. Horton

This section describes significant vadose zone characterization activities that occurred during fiscal year 2001. These characterization activities were done to further the understanding of physical and chemical properties of the vadose zone and vadose zone contamination. Vadose zone characterization activities at single-shell tank farms in fiscal year 2001 were concentrated at the B, BX, and BY tank farms in the 200-East Area and the S and SX, tank farms in the 200-West Area. Two new boreholes were drilled at Waste Management Area B-BX-BY through subsurface contaminant plumes. A third borehole was drilled immediately outside the tank farms to obtain uncontaminated core for comparison with the contaminated material obtained in the tank farms. Interim measures (Section 7.1.7) were completed at single-shell tank farms in fiscal year 2001 to minimize the subsurface movement of contaminants by preventing surface water from encroaching onto the tank farms. Although these efforts are not strictly characterization efforts, they are important and related because they help minimize the spread of contamination beyond existing contaminated regions.

During fiscal year 2001, baseline spectral gamma logging of selected wells at past-practice, liquid waste disposal facilities began. The results will be a baseline against which future monitoring results can be compared.

Vadose zone characterization activities were completed at one site in the 100-H Area to support remediation in the reactor areas.

Finally, characterization activities were completed at two burial grounds in the 600 Area, north of the city of Richland. The results of these activities provide a clearer picture of the distribution of subsurface contaminants in this area.

\subsection{Drilling, Sam pling, and Analysis of Soil at Waste Managem ent Area B-BX-BY, 200East Area}

\section{A. Myers}

Two boreholes were drilled in single-shell tank farms at Waste Management Area B-BX-BY to obtain drill cores from contaminated sediment. Analysis of the samples will further our knowledge about contaminant distribution in this area and about migration of subsurface contaminants.

BX Tank Farm. Borehole 299-E33-45 was drilled in the BX tank farm east of single-shell tank BX-102 (RPP-7921). The location of the borehole is shown in Figure 7.1.1. The site for this borehole was selected based on information from spectral gamma logging of many drywells in the vicinity. The drywell logs indicated numerous radionuclides dispersed through the vadose zone to the full depth of the wells. The borehole was planned and constructed to characterize those radionuclides and collect samples for chemical and radiochemical analysis to determine the extent of non-gamma emitting radioisotopes in the soil around the wells.

A perched water zone, i.e., a local zone of saturation in the vadose zone caused by an impermeable sediment layer stopping the downward movement of water, was encountered $\sim 69.2$ meters ( 227 feet) below ground surface. Water samples from the perched zone were collected for chemical and radiological analysis. Groundwater was encountered at a depth of 77.4 meters (254 feet) below ground surface, and the borehole was advanced to a total depth of 79.6 meters (261 feet). Groundwater was sampled to ascertain the technetium-99 concentration and to determine whether or not the borehole should be completed as a Resource Conservation and Recovery Act of 1976 (RCRA)-compliant monitoring well. The technetium-99 concentration ( 1,500 pCi/L $[\sim 55.5 \mathrm{~Bq} / \mathrm{L}])$ 


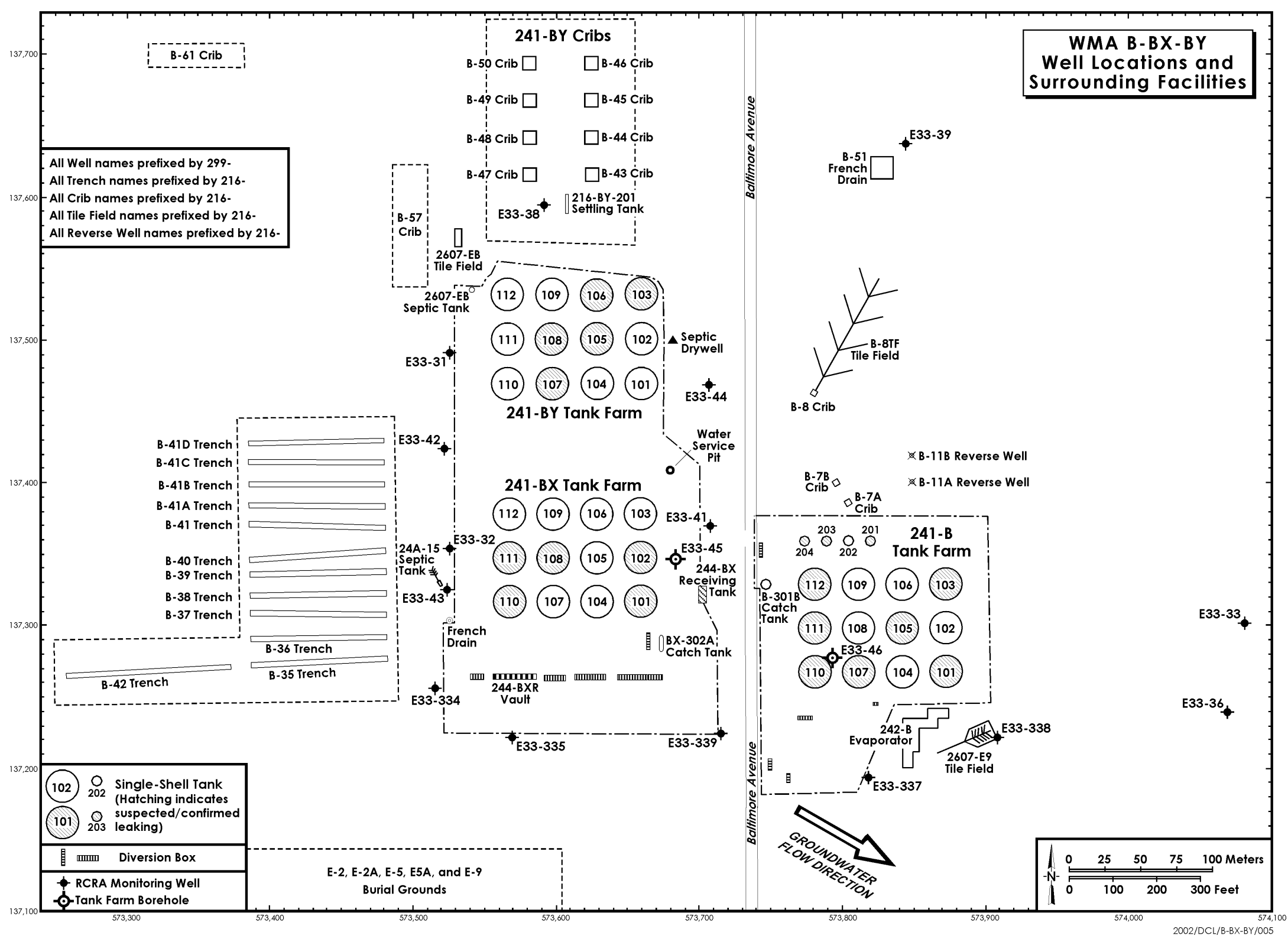

Figure 7.1.1. Locations of New Boreholes 299-E33-45 and 299-E33-46 at Waste Management Area B-BX-BY 
was below the agreed-upon criterion of $4,000 \mathrm{pCi} / \mathrm{L}$ $(148 \mathrm{~Bq} / \mathrm{L})$ for completion as a monitoring well. Sediment samples also were collected at depth intervals within the borehole. The borehole was geophysically logged using gross and spectral gamma tools and a neutron tool to measure soil moisture.

Some difficulty was experienced in decommissioning the borehole as portions of the hole collapsed as the casing was removed. An agreement with the Washington State Department of Ecology was reached to assure that abandonment of the borehole was consistent with the guidelines and intent of WAC 173-160. The borehole was decommissioned in accordance with the agreedupon plan.

Analytical data are being collected from the samples obtained in the borehole. The results of those tests will be available in fiscal year 2002 and will be reported in a field investigation report for Waste Management Area B-BX-BY.

B T ank Farm. Borehole 299-E33-46 was drilled in the B tank farm adjacent to the B-110 single-shell tank. The location of the borehole is shown in Figure 7.1.1. The site for this borehole was selected based on data that indicated the possible presence of strontium-90. Initial identification of strontium-90 was based on spectral gamma logging that pointed to a potential source between 21 and 25 meters (69 and 82 feet) below ground surface in nearby drywells. Whereas strontium-90 has a relatively short half-life (29.1 years) and is not very mobile in soil, other longer-lived and more mobile radionuclides were likely to be present.

The borehole was advanced using the cable-tool technique. Thirty-three split-spoon samples were collected. In addition, 102 composite samples were collected every 0.6 meter (2 feet), through intervals from which split-spoon samples were not collected, starting from immediately below the first split-spoon sample at $\sim 3.7$ meters $(\sim 12$ feet $)$ and continuing to 80 meters (262 feet) below ground surface.

Groundwater was encountered at a depth of 78 meters (256 feet) below ground surface, and the borehole was drilled to a total depth of 80.5 meters (264 feet). A temporary screen was installed and groundwater was sampled to ascertain the technetium-99 concentration and to determine whether or not the borehole should be completed as a RCRA-compliant monitoring well. The technetium-99 concentration was below the agreed-upon criterion of $4,000 \mathrm{pCi} / \mathrm{L}$ $(148 \mathrm{~Bq} / \mathrm{L})$ for completion as a groundwater monitoring well. The borehole was geophysically logged using gross and spectral gamma tools and a neutron tool to measure soil moisture.

Borehole 299-E33-46 was completed as a vadose zone monitoring structure (see Section 7.2.5).

\subsection{Characterization of Single-Shell Tank Waste Managem ent Area S-SX, 200-West Area}

\section{Compiled by D. G. Horton}

Characterization activities continued at the S-SX tank farms in the 200-West Area in fiscal year 2001.

A series of four reports were issued in fiscal year 2001 describing the sampling and analysis associated with five boreholes drilled in or adjacent to the S-SX tank farms. The boreholes are: 299-W22-48 and 299-W22-50 (PNNL-13757-1), 299-W23-234 also known as 41-09-39 (PNNL-13757-3), 299-W23-19 (PNNL-13757-2), and C3082 (PNNL-13757-4). The work described in these reports occurred in 1998, 1999, and 2000; preliminary results were reported in previous Hanford Site environmental reports (PNNL-12088; PNNL-13230; PNNL13487). This section summarizes and compares the final results from analyses of samples from the five boreholes. Complete discussions of the sampling, analytical techniques, and results are found in the reports cited above.
Boreholes 299-W22-48 and 299-W22-50 were drilled and completed as RCRA groundwater monitoring wells in fiscal year 2000 east of the SX tank farm (see Figure 6.1.24). They were drilled in uncontaminated sediment and serve as baseline wells to compare with those drilled in contaminated areas of the tank farm. Continuous core samples were collected from both boreholes during drilling.

Borehole 41-09-39 was originally drilled in December 1996 adjacent to the southeastern edge of tank SX-109 to a depth of 40 meters (131 feet). The purpose of the borehole was to determine the presence of cesium-137 at depths of 20 to 40 meters (65 to 131 feet). The borehole was deepened in 1997 to 68.6 meters (225 feet), and sediment samples were collected wherever possible. The borehole was decommissioned in 1999 at which time samples were obtained from portions of the borehole that were previously unsampled. 
In 1999, borehole 299-W23-19 was drilled 3 meters (10 feet) from the southwestern edge of tank SX-115. The purpose of the borehole was to characterize the vadose zone sediment in the area of a 189,000-liter (49,900-gallon) leak that occurred in the mid-1960s. Near-continuous sediment samples were collected down to a depth of $\sim 62.5$ meters ( 205 feet $)$. The borehole was completed as a groundwater monitoring well in 2000.

Borehole C3082 was installed adjacent to tank SX-108 in 2000. Tank SX-108 had leaked between 9,084 and 132,475 liters (2,400 and 35,000 gallons) in 1962 (HNF-EP-0182). Borehole C3082 was drilled at an angle and aligned to pass beneath the tank, through a zone of high contamination, and terminate at a depth of 45 meters (147 feet). Sediment samples were obtained from 16 zones in the borehole.

Borehole 299-W23-19 encountered essentially the same stratigraphy and lithologies as the aforementioned boreholes except that the upper Ringold Formation is missing in borehole 299-W23-19. Borehole C3082 penetrated backfill and the Hanford formation and terminated in the upper Plio-Pleistocene unit.

Borehole samples were analyzed for anions, electrical conductivity, metals, $\mathrm{pH}$, radionuclides, and water content. Differences in the analytical results between tank farm boreholes and the baseline boreholes were considered to be indicators of contamination from tank waste.

A nions and Metals (Nitrate and Sodium). Nitrate is the most concentrated anion in tank liquors. Its high concentration and mobility in the vadose zone make nitrate one of the most sensitive indicators of tank waste migrating through the vadose zone. Also, sodium is the dominant cation in tank fluids and is mobile in the vadose zone environment. Both nitrate and sodium profiles closely resemble the electrical conductivity profiles.

In borehole 41-09-39, elevated nitrate was encountered to a depth of 38.7 meters ( 127 feet) and sodium was elevated to a depth of 38.7 meters (127 feet), though moderate sodium values existed to $\sim 47$ meters ( 154 feet). These deeper sodium concentrations may have been due to contaminants carried down on the drilling equipment during the drilling process (PNNL13757-3). Nitrate in samples from C3082 was elevated throughout the total depth of the borehole, and sodium concentrations were high to a depth of $\sim 39.6$ meters $(\sim 130$ feet $)$.

Nitrate in borehole 299-W23-19 was elevated from 19.8 to $\sim 47.6$ meters ( 65 to $\sim 156$ feet). Nitrate concentrations were generally within natural range in samples deeper than 47.6 meters (156 feet) except for the two deepest samples. The two deepest samples were collected below the highest water-table level recorded during the time that tank SX-115 was suspected to have leaked. Thus, the deepest nitrate concentrations may have resulted from nitrate in a water table that was higher than the current water table. In general, the distribution of nitrate with depth in borehole 299-W23-19 suggests that the leading edge of the nitrate plume is 47.6 meters ( 156 feet) deep.

Elevated sodium concentrations began abruptly at 22.3 meters (73 feet) below ground surface in borehole 299-W23-19 and extended to $\sim 48.3$ meters ( 158 feet) below ground surface. The bottom of the sodium profile was not sharp, but gradually decreases until natural concentrations were attained at $\sim 39.6$ meters $(\sim 130$ feet $)$ below ground surface.

In boreholes 41-09-39 and C3082, sodium was slightly elevated throughout the upper part of the boreholes but did not greatly increase until 23.1 to 25.3 meters ( 76 to 83 feet) below ground surface. In borehole 41-09-39, sodium concentration decreased to natural levels at 40.6 meters (133 feet) below ground surface; sodium remained above natural levels in borehole C3082 to total depth.

Evidence for ion exchange reactions in the vadose zone was seen in the boreholes impacted by tank waste. This was especially evident for sodium, calcium, and magnesium. The sediment samples showed that the sodium in the leaked tank fluids had replaced the other major cations on exchange sites in the native sediment. The displaced cations were effectively pushed ahead of the sodium bearing fluids as they migrated downward.

Electrical Conductivity. The natural, dilution corrected, electrical conductivity in boreholes 200-W22-48 and 299-W22-50 was between $\sim 200$ and $6,000 \mu \mathrm{S} / \mathrm{cm}$. Because the 1:1 water extract values are diluted with respect to the natural porewater, the diluted value is multiplied by the dilution factor, i.e., the amount of water added, to obtain the natural value for the sediment (PNNL-13757-1). One sample in borehole 299-W22-50 showed $\mathrm{pH}$ and electrical conductivity values greater than the other samples from the two uncontaminated boreholes. The electrical conductivity of that sample was considered natural and resulted from dissolved minerals in the sample (PNNL-13757-1).

The electrical conductivity versus depth profiles for boreholes 41-09-39 and C3082 were similar, although the electrical conductivity of the sediment beneath tank SX-108 (C3082) was an order of magnitude greater than the conductivity of the sediment adjacent to tank SX-109 (41-09-39). The data from these two boreholes 
suggested that contamination had reached 40.3 meters (132 feet) in borehole 41-09-39 and was below 44 meters (144 feet) in borehole C3082. For both boreholes, however, the bulk of the contamination was higher, between 24.4 and 39.6 meters ( 80 and 130 feet) in borehole 41-09-39 and between 22.9 and 32 meters ( 75 and 105 feet) in borehole C3082.

The electrical conductivity profile from borehole 299-W23-19 was somewhat different than the profile of the other two boreholes. The profile showed that the contaminant plume had reached the bottom of a silt-rich sediment at 47.6 meters (156 feet) and the bulk of contamination was within the silt unit between $~ 36.6$ and 47.6 meters ( 120 and 156 feet). This was deeper than the bulk of contamination shown by electrical conductivity from boreholes 41-09-39 and C3082 where the bulk of the contamination was in the geologic unit above the silt unit.

pH. The $\mathrm{pH}$ from 1:1 sediment:water extracts versus depth for all five boreholes indicated that natural $\mathrm{pH}$ values of uncontaminated sediment were between $\sim 7.0$ and 8.5 with a few samples extending to near 9.0.

In none of the contaminated boreholes was the $\mathrm{pH}$ as high as might be expected where tank fluids completely saturate sediment $(\mathrm{pH}>13$; PNNL-11495). This may have resulted from neutralizing reactions with the sediment and/or carbon dioxide in the vadose zone. Because of these possible neutralizing reactions, $\mathrm{pH}$ is not considered a good indicator of the extent of contamination, although it is essential to understand contaminant behavior in the vadose zone.

Radionuclides. Concentrations of technetium-99, a contaminant from leaked waste tank fluids, were found to be elevated in sediment from the three contaminated boreholes at the SX tank farm. Technetium-99 is thought to be extremely mobile in the vadose zone (PNL-10379). The distribution of elevated technetium-99 generally mimics that of electrical conductivity and nitrate. Using the distribution of technetium-99, the leading edge of the contaminant plume was at depths of 41.2 and 42 meters (135 and 138 feet) in boreholes 41-09-39 and C3082. In borehole 299-W23-19, the bulk of technetium-99 contamination was above 47.6 meters (156 feet) below ground surface, but elevated technetium-99 concentrations (between 6 and $68 \mathrm{pCi} / \mathrm{mL}$ ) extended to the deepest sample. The deepest sediment sample contained $176 \mathrm{pCi} / \mathrm{mL}$ of technetium-99, which may be a result of past interactions with groundwater containing technetium-99.

In summary, the $\mathrm{pH}$ of sediment samples did not identify the leading edge of contaminant plumes in the SX tank farm. However, the more mobile indicators, such as electrical conductivity, nitrate, sodium, and technetium, suggested that the leading edge of the contaminant plume was at a depth of 38.7 to 41.2 meters (127 to 135 feet) in borehole 41-09-39 and 42 meters to $>44.2$ meters (138 to $>145$ feet) (i.e., deeper than the bottom of the borehole) in borehole C3082. In these two boreholes, the bulk of contamination appeared to be significantly shallower than the leading edge of the plume. In borehole 299-W23-19, the bulk of contamination was between a depth of 37.2 and 47.6 meters (122 and 156 feet), but some contamination extended to groundwater.

Water Content. Although there was some correlation between moisture content and the presence of contamination, the relationship was not straightforward because the moisture content also reflects changes in the physical characteristics of the sediment. Fine-grained sediment tended to have a higher moisture content than coarse-grained sediment, and those differences were mixed with moisture differences due to leaked fluids. Therefore, moisture by itself was not considered a good indicator of contamination, though moisture content tended to be higher in contaminated zones.

\subsection{Geophysical Logging at Former Liquid Waste Disposal Facilities}

S. M. Sobczyk, P. D. Henwood, R. G. McCain, and S. E. Kos

Geophysical logging was conducted in fiscal year 2001 to support

- the 200 Areas Vadose Zone Characterization

- the 200-TW-1 Scavenged Waste Group Operable Unit
- the 200-TW-2 Tank Waste Group Operable Unit Remedial Investigation/Feasibility Study

- installation of new RCRA groundwater monitoring wells.

Spectral gamma logging in existing boreholes near the liquid waste disposal sites and solid waste burial grounds in the Hanford Site 200 Areas began during fiscal year 2001. The purpose of this work was to detect 
and quantify naturally occurring and manmade gammaemitting radionuclides in the vadose zone. This was an extension of the baseline characterization work completed in the Hanford Site single-shell tank farms in previous years (e.g., PNNL-13230; PNNL-13487). The newly acquired spectral gamma logs will establish a baseline for comparison of future logs identifying gammaemitting contaminants and tracking the rate of contaminant movement in the vadose zone.

The spectral gamma logs provided information regarding the nature and extent of vadose zone radiological contamination associated with former liquid waste disposal facilities. Data from each borehole were analyzed to determine concentrations of naturally occurring radionuclides such as potassium-40, uranium-238, thorium-232, and associated decay progeny, as well as manmade gamma-emitting radionuclides such as cesium-137, cobalt-60, and europium-152 and -154. Variations in concentrations of naturally occurring radionuclides are used to correlate geologic layers. The presence of manmade gamma emitters helps define the extent of the contaminated areas under the disposal facilities.

The logging system, the logging methods, and the data collection and analysis procedures are described in documents available on the worldwide web at http:// www.gjo.doe.gov/programs/hanf/HTFVZ.html.

During fiscal year 2001, data from spectral gamma logging were collected in 30 boreholes in or near waste sites in the 200 Areas. Fifteen existing boreholes were logged for the 200 Areas Vadose Zone Characterization Project. Eight new characterization boreholes were logged for the 200-TW-1 Scavenged Waste Group Operable Unit and the 200-TW-2 Tank Waste Group Operable Unit Remedial Investigation/Feasibility Study. In addition, seven new RCRA groundwater monitoring wells, which were installed during fiscal year 2001, were logged. Results of the 200 Areas Vadose Zone Characterization Project are posted on the worldwide web at: http://www.gjo.doe.gov/programs/hanf/HTFVZ.html.

In 2001, the 200 Areas Vadose Zone Characterization Project was in full operation. Gamma spectra were collected in boreholes and monitoring wells located within and near waste disposal sites (e.g., ponds, ditches, cribs, and burial grounds) in the 200-East and 200-West Areas. Priority for logging existing boreholes was determined by the data needs of ongoing investigation efforts of the Groundwater/Vadose Zone Integration Project.

The logging done for the 200 Areas Vadose Zone Characterization Project identified deep contamination in borehole 299-E33-20 near the 216-B-11B injection well (see Figure 7.1.1 for location of well 216-B-11B). In this borehole, cesium-137 and cobalt- 60 were detected at depths below 73.2 meters (240 feet). These depths coincided with historical water levels; the depth to water was reported at 74.1 meters (243 feet) in July 1956, 71.4 meters (234 feet) in November 1989, and 76.5 meters (251 feet) in April 2000. The increased water levels in the late 1980s were probably due to the 216-B-3 pond system (B Pond), but the cesium-137 and cobalt -60 concentrations may have come from the 216-B-11A and 216-B-11B injection wells located $\sim 4.6$ meters $(\sim 15$ feet $)$ northeast of the logged borehole. The discharges to the B Pond system caused a groundwater mound in this area that has since receded, leaving contaminated soil in the vicinity.

Logging for the 200-TW-1 Scavenged Waste Group Operable Unit and 200-TW-2 Tank Waste Group Operable Unit was done at the 216-B-38 specific retention trench (see Figure 7.1.1 for location of the trench). The maximum concentration of cesium-137 measured to date in any borehole logged outside of tank farms is $300,000 \mathrm{pCi} / \mathrm{g}(11,100 \mathrm{~Bq} / \mathrm{g})$ of cesium-137 between $\sim 6$ and 10 meters ( 20 and 35 feet $)$ depth in a characterization borehole (C3104) located near the 216-B-38 trench. This cesium-137 concentration level is about three orders of magnitude less than the maximum cesium-137 concentration detected in the single-shell tank farms.

Seven RCRA groundwater monitoring wells installed during fiscal year 2001 were logged. Four of those wells (299-E33-339, 299-W19-45, 299-W18-40, and 299-W15-765) showed indications of naturally occurring radon in groundwater. Radon in a borehole may increase the observed gamma counts so that, if the gross gamma log is being used for geologic correlations, the presence of radon must be considered.

\subsection{Trench 116+H-1Characterization}

\section{J. J. Kious}

Bechtel Hanford, Inc. remediated the 116-H-1 trench in spring 2000. Characterization for site closeout was subsequently completed and documented in fiscal year 2001. Characterization consisted of determining the vertical distribution of contaminants of concern in the vadose zone between the base of the 116- $\mathrm{H}-1$ trench and the water table. This section summarizes the characterization activities and results. A complete description of the characterization work can be found in BHI-01541. 
The 116- $\mathrm{H}-1$ trench, located in the 100-H Area, received $\sim 90$ million liters ( $\sim 2.4$ million gallons) of reactor cooling water and an unknown volume of water and sludge from the operation and deactivation of the $107-\mathrm{H}$ retention basin. The waste contained 90 kilograms (198 pounds) of sodium dichromate.

Borehole C3048 was drilled at the northern end of the trench $\sim 5$ meters ( $\sim 16$ feet) from the inlet pipe. The borehole was drilled to a total depth of 9.76 meters (32 feet) below the bottom of the trench. The bottom of the trench is 4.9 meters ( 16 feet) below grade. The sediment encountered during drilling was pebblecobble gravel with thin interbeds of sand and silt. The water table was encountered at a depth of 8.01 meters (26.3 feet).

Eight sediment samples were collected at 1 -meter (3.28-feet) intervals between 0.76 and 7.8 meters (2.5 and 25.6 feet) drilled depth. Samples were sent to the laboratory to measure concentrations of constituents of concern (arsenic, carbon-14, cesium-137, cobalt-60, europium-152, -154 , and -155 , hexavalent chromium, mercury, plutonium-239/240, total strontium, and uranium-238).

Analytical results showed that the concentrations of most constituents decreased with increasing depth. For several constituents, there was a sharp decrease in concentration at a depth of 2 meters ( 6.5 feet) below the trench bottom. This was most dramatic for cesium-137 and europium-152 (Figure 7.1.2). Cobalt-60 and mercury were detected only above a borehole depth of 2 meters (6.5 feet) with maximums of $1.4 \mathrm{pCi} / \mathrm{g}$ $(0.052 \mathrm{~Bq} / \mathrm{g})$ and $0.12 \mathrm{mg} / \mathrm{kg}$ at 1 meter (3.28 feet), respectively. Arsenic, europium-154, plutonium-239/ 240, strontium-90, and uranium-238 showed slight decreases in concentrations with depth. All results for carbon-14 and europium-155 were below minimum detectable levels. Unlike the other constituents, hexavalent chromium showed a maximum concentration below a depth of 2 meters (6.5 feet) below the trench bottom. The maximum hexavalent chromium concentration was 0.47 to $0.59 \mathrm{mg} / \mathrm{kg}$ at 4.1 to 5.2 meters ( 13.5 to 17.1 feet), which is 2.8 to 3.9 meters ( 9 to 13 feet) above the water table. The deepest sample, from a depth of 6.1 meters (20 feet), contained no detectable hexavalent chromium.

Finally, the moisture content of all samples was below $\sim 10 \%$, which is within the normal range of Hanford Site sediment. This indicates that water used for dust control during remediation activities has not driven contaminants deeper into the soil column.

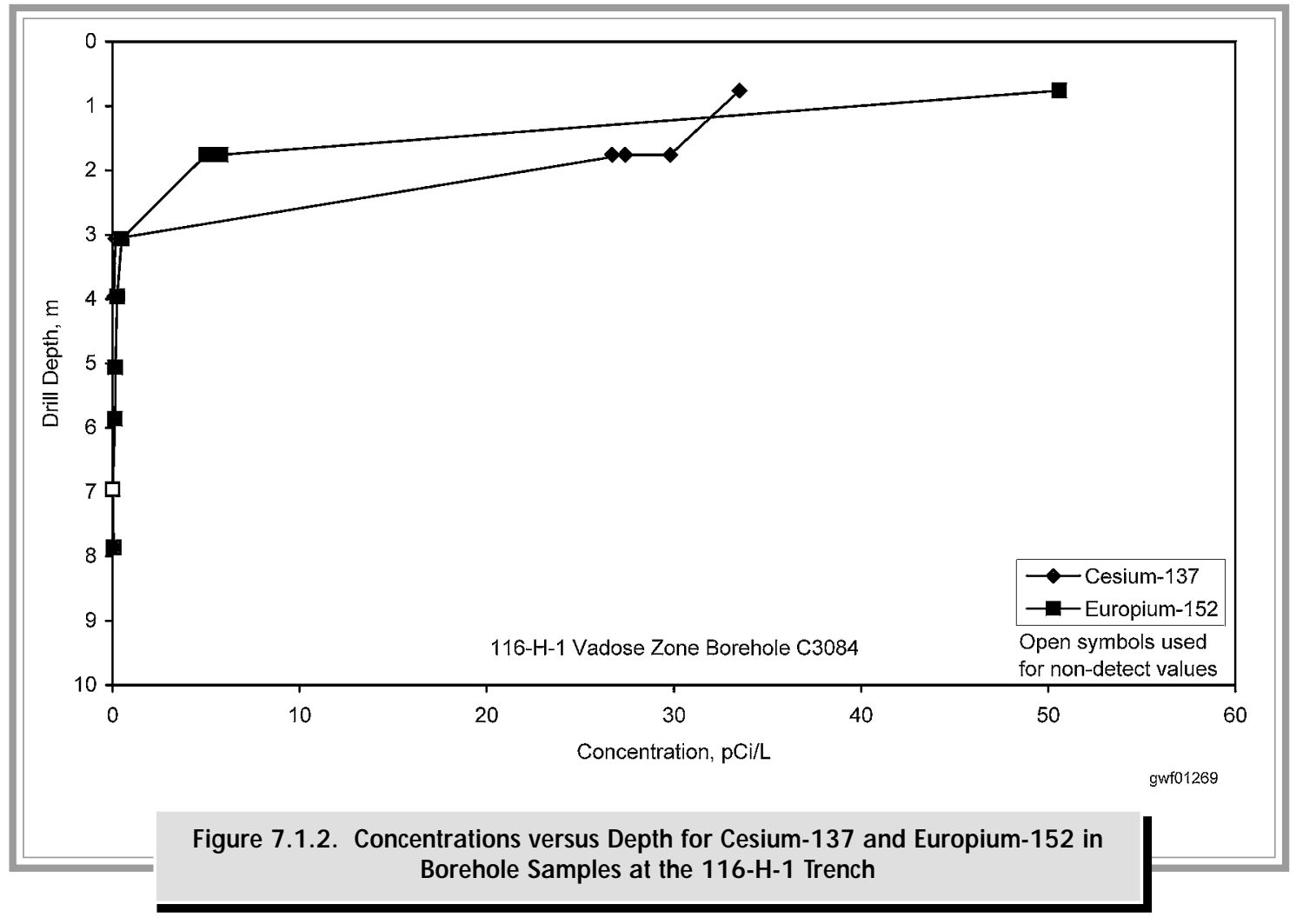




\subsection{Helium-3/Helium-4 Ratios in Soil Gas as an Indicator of Subsurface Tritium Contamination at the 618-11Burial Ground Site}

\author{
P. E. Dresel and K. B. Olsen
}

A groundwater sample collected in January 2000 from well 699-13-3A, located along the eastern fence line of the 618-11 burial ground (Figure 7.1.3), contained 8.1 million $\mathrm{pCi} / \mathrm{L}(299,700 \mathrm{~Bq} / \mathrm{L})$ of tritium. This was the highest concentration of tritium detected at the Hanford Site in recent years. To determine the extent of the groundwater contamination, investigators used helium-3 in the vadose zone as a surrogate tracer for tritium in groundwater. The investigation began in fiscal year 2000 and continued through fiscal year 2001. The fiscal year 2000 investigation established the burial ground as the source of tritium in groundwater and showed that the contamination extended east (downgradient) of the burial ground. A soil gas survey was performed in summer 2001 to determine the direction and extent of tritium groundwater contamination downgradient of the burial ground. The results of the soil gas survey were used to define locations for groundwater sampling and monitoring well installation. Section 6.1 discusses the results of the groundwater investigation at the 618-11 burial ground and contains a plume map for tritium in the area. This section summarizes the soil gas investigation results.

Samples of soil gas collected at the 618-11 burial ground were analyzed for helium isotopes (helium-3 and helium-4) to determine helium-3/helium-4 ratios. The technique is based on the decay of tritium, with a half-life of 12.32 years. Tritium decays to the stable, inert isotope helium-3. As tritium decays, its daughter isotope, helium-3, begins to build up in the vadose zone and groundwater at the rate of tritium decay. The helium-3 then diffuses away from the source and toward the surface. Soil gas monitoring at the 618-11 burial ground was based on the measurement of helium-3 in the soil gas to identify vadose and/or groundwater sources of tritium in the subsurface environment. The results are expressed as the ratio of helium-3 to helium-4, normalized to the ratio in the atmosphere. Thus, the background value for soil gas that has not been affected by tritium contamination is expected to be close to 1.00 .
Fifty-four soil gas sampling points were installed north and east of the 618-11 burial ground in fiscal year 2000. Twenty-seven new soil gas sampling points were installed in fiscal year 2001 east (downgradient) of the 618-11 burial ground (see Figure 7.1.3). All sampling points were completed at 6 meters ( 20 feet) below ground surface. Each sampling location was allowed to equilibrate for at least 24 hours before soil gas samples were collected. Several of the fiscal year 2000 sample points were re-sampled in fiscal year 2001 to complete the spatial coverage and to look at temporal changes.

The results of analyses of the soil gas samples from the fiscal year 2001 sampling are shown in Figure 7.1.3. Helium-3/helium-4 ratios from samples from the northern and southern ends of the area approached background levels (1.0). The helium-3/helium-4 ratios reached a maximum of 1.65 in transect 1 , closest to the burial ground. The plume is narrower and helium-3/ helium-4 ratios were smaller in transect 3, to the east. Only one soil gas sampling point in transect 4 showed a signal greater than background. The value at that point was higher than the maximum seen in transect 3 , though transect 4 was farther from the source. The higher ratio seen in transect 4 was believed to be because transect 4 is topographically low compared to the other transects; so the soil gas points in transect 4 are closer to the water table and the source of helium-3. The soil gas helium results indicate the centerline of the tritium plume and bound the lateral extent.

Six locations for groundwater samples were chosen, based on the results of the soil gas monitoring. Four of the boreholes drilled for the groundwater sampling were completed as monitoring wells for ongoing sampling of the tritium plume. The results of the groundwater sampling were in agreement with the extent of contamination defined by the soil gas study (see Figure 7.1.3). 


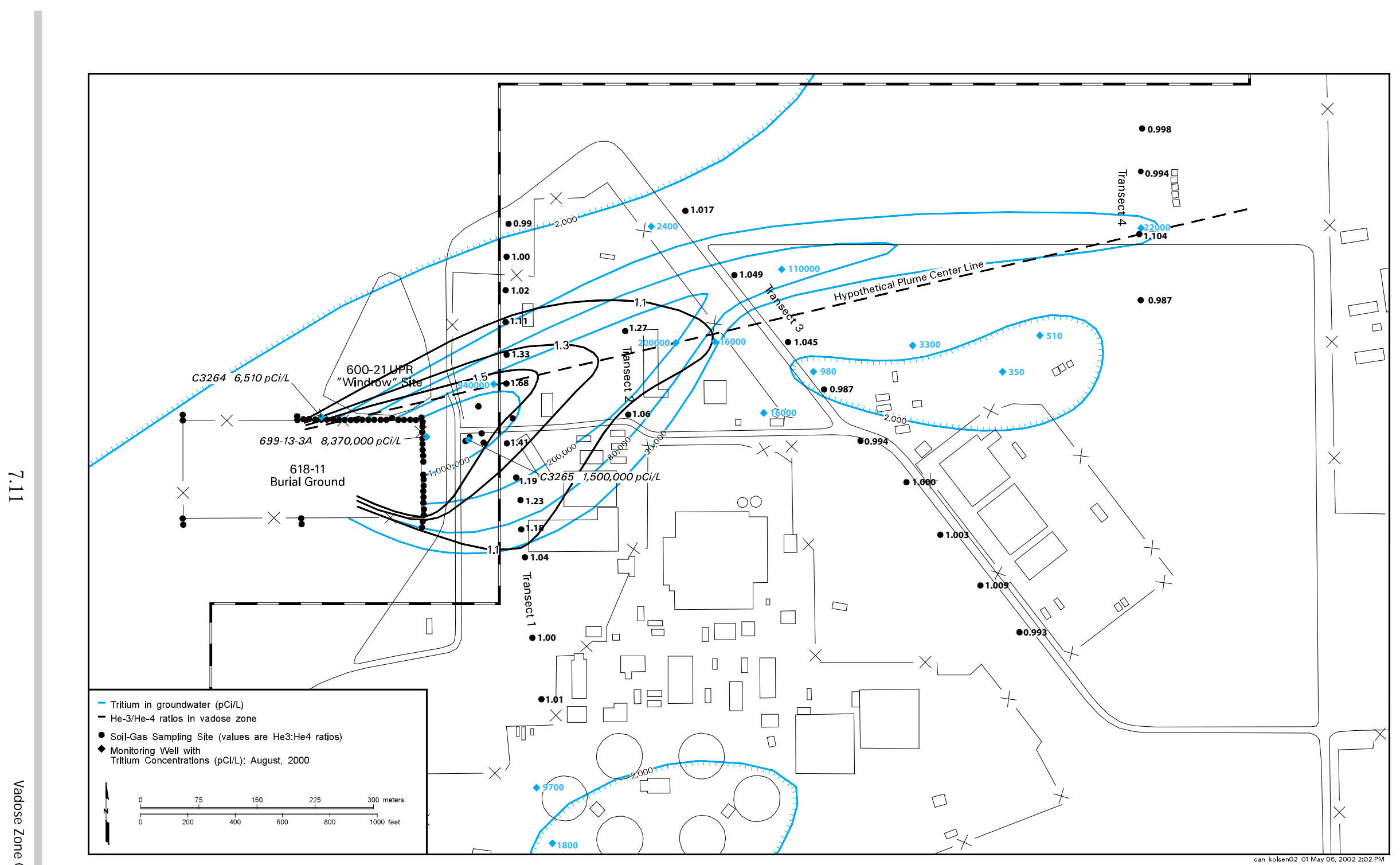

Figure 7.1.3. Locations of Monitoring Points and Results of Fiscal Year 2001 Helium Ratio Analyses at the 618-11 Burial Ground 


\subsection{Geophysical and Statistical Investigation of the 618-4 Burial Ground}

\section{J. Murray, G. V. Last, and Y. Chien}

A geophysical and statistical investigation of the 618-4 burial ground was completed in fiscal year 2001. The objective was to use the Enhanced Site Characterization System to analyze previously collected geophysical data and new geophysical data to map the distribution of buried waste. The Enhanced Site Characterization System is a set of geostatistical techniques to simultaneously analyze multiple data sets. This section provides a brief summary of the characterization work at the 618-4 burial ground. A full description of the work is given in PNNL-13656.

The 618-4 burial ground is located north of the 300 Area, 1.6 kilometers ( 1 mile) north of the city of Richland and 340 meters (1,120 feet) west of the Columbia River. The burial ground consists of a single pit that is 160 meters ( 525 feet) long, 32 meters ( 105 feet) wide, and 6 meters (20 feet) deep (DOE/RL-88-31). The burial ground received trash and debris contaminated with uranium from nuclear fuel manufacturing processes in the 300 Area between 1955 and 1961.

Geophysical surveys using ground penetrating radar, magnetometer, and metal detectors were conducted over the burial ground in 1991 (WHC-SD-EN-TI-061) revealing metallic waste in the main part of the pit. The burial ground was partly excavated during 1997 and 1998 as part of the environmental restoration at the 300-FF-1 Operable Unit. In April 1998, excavation was stopped after 338 drums containing depleted uranium metal shavings and uranium-oxide powder were exposed.

A re-interpretation of the 1991 ground penetrating radar data in 1999 showed the presence of two anomalies; one coincided with the location of known, buried drums adjacent to the 338 exposed drums, and the second was located $\sim 20$ to 30 meters ( $\sim 65$ to 98 feet) southwest of the buried drums. A detailed geophysical investigation was conducted over the central, unexcavated portion of the burial ground in 2001 to better define the boundaries of the two anomalies identified in 1999.

Five variables were incorporated into the Enhanced Site Characterization System analysis: time domain electromagnetic data, magnetic field strength, the thickness of the fill overlying the buried waste (from ground penetrating radar data), the slope of the top of the buried waste (from ground penetrating radar data and surface elevation measurements), and the amplitude of the ground penetrating radar reflection.

The newly acquired geophysical data allowed estimates of the number of drums remaining in the unexcavated parts of the 618-4 burial ground. The number of remaining drums was estimated to be between $\sim 770$ and 850 depending on their stacking arrangement and size.

A combination of box plots and discriminant function analysis showed that the area of known drums and the southwest anomaly are similar to one another and different from the rest of the study area. The major differences between the two anomalies and the rest of the study area are that the two anomalies have a higher magnetic field strength, indicating the presence of ferric metals, and a greater thickness of overlying fill material

The results of the study showed that analyses using the Enhanced Site Characterization System could successfully integrate multiple geophysical variables and group observations into clusters that are relevant for planning the excavation of buried waste. The deployment of the Enhanced Site Characterization System and use of multivariate geostatistical methods allowed construction of a conceptual model of the distribution of buried waste at the 618-4 burial ground. The conceptual model provided information that can increase the efficiency of remediating the burial ground.

\subsection{Interim Measures at 200-West Area Tank Farms}

\section{A. Myers}

The River Protection Project's Vadose Zone Project is finding ways to reduce the movement of tank farm contaminants in the vadose zone. Infiltration of water through the vadose zone has been identified as the primary means by which contaminants are displaced beneath the farms. Two interim measures were taken during fiscal year 2001: placing surface water controls adjacent to tank farms in the 200-West Area, and testing and capping water lines associated with S, SX, and U tank farms in the 200-West Area.

Surface Water Controls. The tank farms in the 200-West Area were originally located in areas that would allow gravity flow of intertank transfer liquids to 
the farms and minimize the need for supplemental pumping to transfer waste from the point of origin to the storage tanks. Because of this, the tank farms are situated in areas of relatively low elevation. Placement of the farms at a lower elevation was helpful in filling the tanks, but it resulted in the tank farms being potential accumulation points for surface water run-on from major meteorological events or from breaks in waterlines supplying facilities in the 200 Areas. One notable instance of a natural meteorological event occurred in 1978 when a Chinook wind melted a substantial snow pack and water flooded Waste Management Area T tank farm. An example of a failed waterline occurred in 1993 when a 35-centimeter (13.8-inch) water main failed during construction activities and released an estimated 2.2 liters $(580,051$ gallons) that ultimately reached the $\mathrm{S}$ and SY tank farms.

During fiscal year 2001, berms and other diversion structures were placed in the 200-West Area to redirect run-on away from the tank farms. Whereas precipitation falling directly on the tank farm surfaces remains as a source of recharge, surface water run-on from land adjacent to these farms has been effectively redirected and eliminated from the tank farm. Plans are presently being implemented to construct similar controls in the 200-East Area during fiscal year 2002.

Testing and Capping of Waterlines. Aging water-supply pipelines in the 200-West Area have been used for up to 2.5 times their design life. These lines that service the tank farms are a major potential source of water that could mobilize contaminants present in the vadose zone. The ongoing water requirements of the single-shell tank farms were assessed to ascertain which lines were essential for operations. Those lines that were determined to be unnecessary are being isolated, cut, and capped near the large diameter trunk lines that supply water throughout the 200 Areas. Those lines that were found to be necessary for continued operations are being leak tested; lines found to be leaking will be removed from service and replacement lines constructed.

During fiscal year 2001, two lines leading to the S, SX, and SY tank farms were abandoned by capping. Lines servicing the U tank farm and the 242-S evaporator were tested for leakage. The three lines tested showed no measurable losses when tested for 24 hours. 


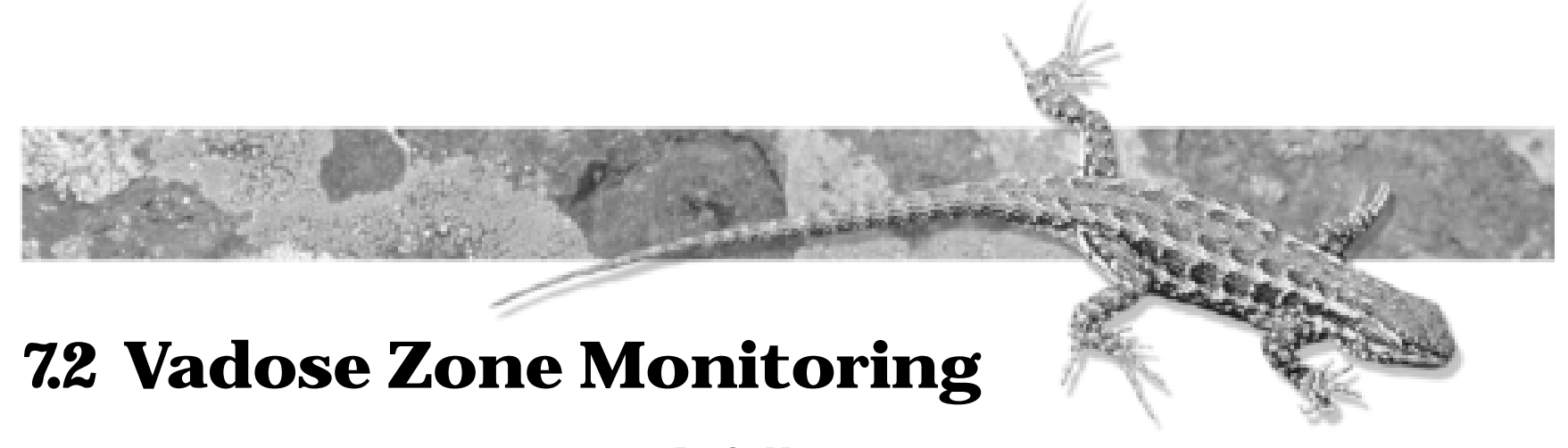

D. G. H orton

Vadose zone monitoring occurred at four major areas on the Hanford Site in fiscal year 2001. Leachate and soil gas monitoring continued at the Environmental Restoration Disposal Facility and the Solid Waste Landfill. Also, soil gas monitoring at the carbon tetrachloride expedited-response-action site continued during fiscal year 2001. During the year, borehole geophysical monitoring of dry wells in single-shell tank farms to detect leaks and the migration of subsurface contaminants continued.
In addition to these monitoring activities, several vadose zone monitoring instruments were installed at one borehole at Waste Management Area B-BX-BY tank farms. These instruments will provide continuous soil column monitoring in that tank farm.

\subsubsection{Leachate Monitoring at the Environmental Restoration Disposal Facility}

\section{J. M. Faurote}

The Environmental Restoration Disposal Facility is used to dispose of radioactive, hazardous, dangerous, and mixed waste generated during waste management and remediation activities at the Hanford Site. In fiscal year 2001, the results of groundwater monitoring and sampling at the Environmental Restoration Disposal Facility for the year 2000 were published (BHI-01489). Part of the published results contains laboratory analyses of leachate collected from beneath the facility. This section discusses those results.

The Environmental Restoration Disposal Facility began operation in July 1996. Located between the 200-East and 200-West Areas (see Figure 6.1.1), the facility is currently operating one trench that is receiving waste. That trench became active during June 2000. Two other trenches received waste until September 2000. Interim covers were placed over the used parts of those cells. A fourth trench was constructed but has not been used to date. The four existing trenches have an area of $\sim 20$ hectares ( $\sim 50$ acres).

Each trench is lined to collect leachate resulting from water added to the trench as a dust suppressant and natural precipitation. The liner in the trench slopes to a sump and the leachate is pumped from the sump to the holding tanks. After $\sim 760,000$ liters ( 200,770 gallons) of leachate are collected, samples are taken and analyzed for 64 semivolatile organics, 41 volatile organics, 23 metals, 9 radionuclides, and gross alpha and gross beta. The number of samples collected during the year depends on the amount of leachate collected.

The leachate monitoring data provide a contents inventory of the Effluent Treatment Facility, where the leachate is disposed, and provide quarterly information for delisting analyses. The purpose of the delisting analyses is to determine if the leachates can be handled as nonhazardous waste. The results also are used to determine whether there are additional analytes in the leachate that should be monitored in the groundwater beneath the facility.

Analyses of leachate collected from the Environmental Restoration Disposal Facility indicate that the liquid collected to date meets established limits (ROD 1999; BHI-01489). The data also show that the leachate contains several common inorganic ions and metals that are usually associated with leachates from landfills receiving primarily soil (BHI-01489). In addition, phthalate esters, plasticizers commonly encountered in landfill leachates that have contacted synthetic liner materials, also were present. Based on the analytical results of leachate samples, no additional analytes are required for monitoring the groundwater beneath the facility. 


\subsubsection{Leachate and Soil Gas Monitoring at the Solid Waste Landfill}

\section{R. A. Del Mar}

The Solid Waste Landfill is a land disposal facility located at the Central Landfill in the center of the Hanford Site (see Figure 6.1.1). The Solid Waste Landfill covers an area of $\sim 26.7$ hectares $(\sim 66$ acres) and began operations in 1973 to receive non-hazardous, non-radioactive sanitary waste generated from Hanford Site operations. The Solid Waste Landfill stopped receiving waste in 1996 and an interim cover consisting of 0.6 to 1.2 meters ( 2 to 4 feet) of soil was placed over all trenches. Current monitoring at the Solid Waste Landfill consists of quarterly sampling of groundwater, soil gas, and leachate. Recent groundwater monitoring results are discussed in Section 6.1. This section summarizes leachate and soil gas monitoring results.

In all, the Solid Waste Landfill consisted of $\sim 70$ single-wide trenches, and 14 double-wide trenches. Based on trench geometry and the thickness of the waste layer, the capacity of a trench per linear meter was $\sim 30.6$ cubic meters ( 40 cubic yards) for the double trenches, and 8.4 cubic meters ( 11 cubic yards) for the single trenches. Based on this estimation, total design capacity of the Solid Waste Landfill was $\sim 596,400$ cubic meters ( 780,060 cubic yards).
Leachate Monitoring. One of the double-wide trenches is lined with a plastic material to collect leachate generated by precipitation filtering through the overlying refuse. This liner covers an area of $\sim 88$ square meters ( $~ 950$ square feet). A discharge pipe continuously drains leachate by gravity flow from the trench to a nearby collection pump. However, because the liner only collects leachate from 1 of 84 trenches, and it is installed under one of the newer trenches built after implementation of regulations restricting land disposal practices, leachate collected from this trench may not be representative of leachate drainage throughout the entire landfill area. Still, it provides some indication of the rate of infiltration and some of the contaminants that may be reaching the groundwater.

Leachate is collected from the trench every 10 to 14 days. Figure 7.2.1 shows the rate of leachate generation since routine monitoring was started in 1996. For the past 2 to 3 years, the generation rate has been between 3.8 to 7.6 liters per day ( 1 to 2 gallons per day), which is consistent with what is expected based on precipitation, soil type, and the vegetative cover.

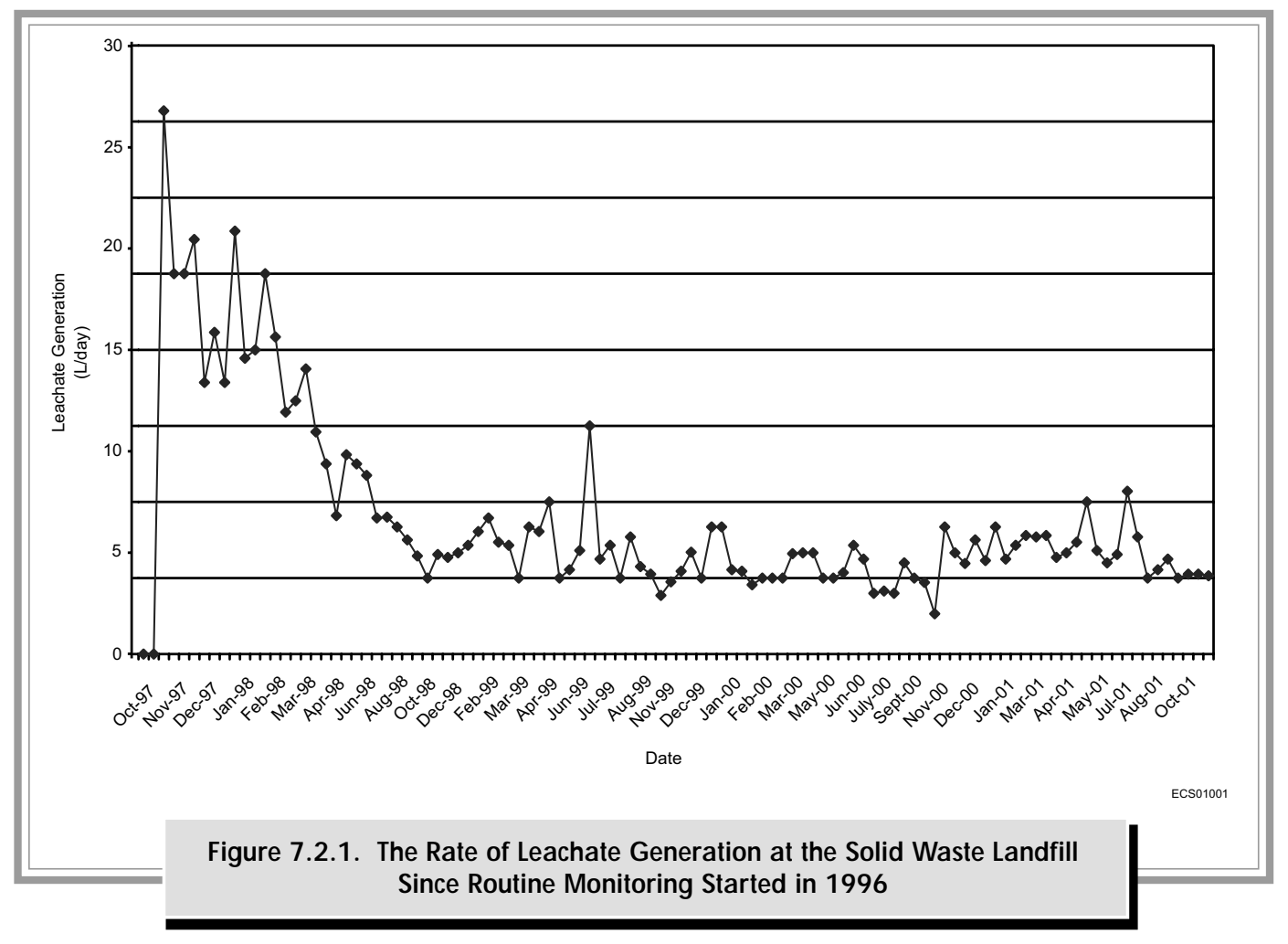


Figures 7.2.2 and 7.2.3 provide historical data on some of the key metal and organic contaminants found in the leachate. Some of these contaminants (most notably 1,4-dioxane, arsenic, manganese, and nickel) continue to be found in concentrations exceeding groundwater quality criteria (WAC 173-200) and/or maximum contaminant levels (WAC 246-290).

The most notable change during the 2000/2001 sampling period was a brief spike in several non-chlorinated organic constituents, including 2-butanone, 2-hexanone, and 2-pentanone, which were found in the 20 to $30 \mu \mathrm{g} / \mathrm{L}$ range. All of these organics were again below detectable limits during the latest sampling period, i.e., third quarter of fiscal year 2001.
Soil Gas Monitoring. Soil gas monitoring at the Solid Waste Landfill uses eight shallow monitoring stations located around the perimeter of the landfill. Each station consists of two soil gas probes at depths of $\sim 2.75$ and 4.6 meters ( $~ 9$ and 15 feet). Soil gas is monitored quarterly to determine concentrations of carbon dioxide, methane, oxygen, and several key volatile organic compounds. No contaminants of concern were discovered above reporting limits during the 2000/2001 sampling period.

\subsection{Carbon Tetrachloride Monitoring and Remediation}

\section{J. Rohay}

Soil-vapor extraction is being used to remove carbon tetrachloride from the vadose zone in the 200-West Area. The U.S. Environmental Protection Agency (EPA) and the Washington State Department of Ecology authorized the U.S. Department of Energy (DOE) to initiate this remediation in 1992 as a Comprehensive Environmental Response, Compensation, and Liability A ct of 1980 (CERCLA) expedited response action. The primary focus in the following discussion is on fiscal year 2001 activities associated with the carbon tetrachloride removal. For descriptions of past work, see BHI-00720 and Section 3.2 in PNNL-13404.

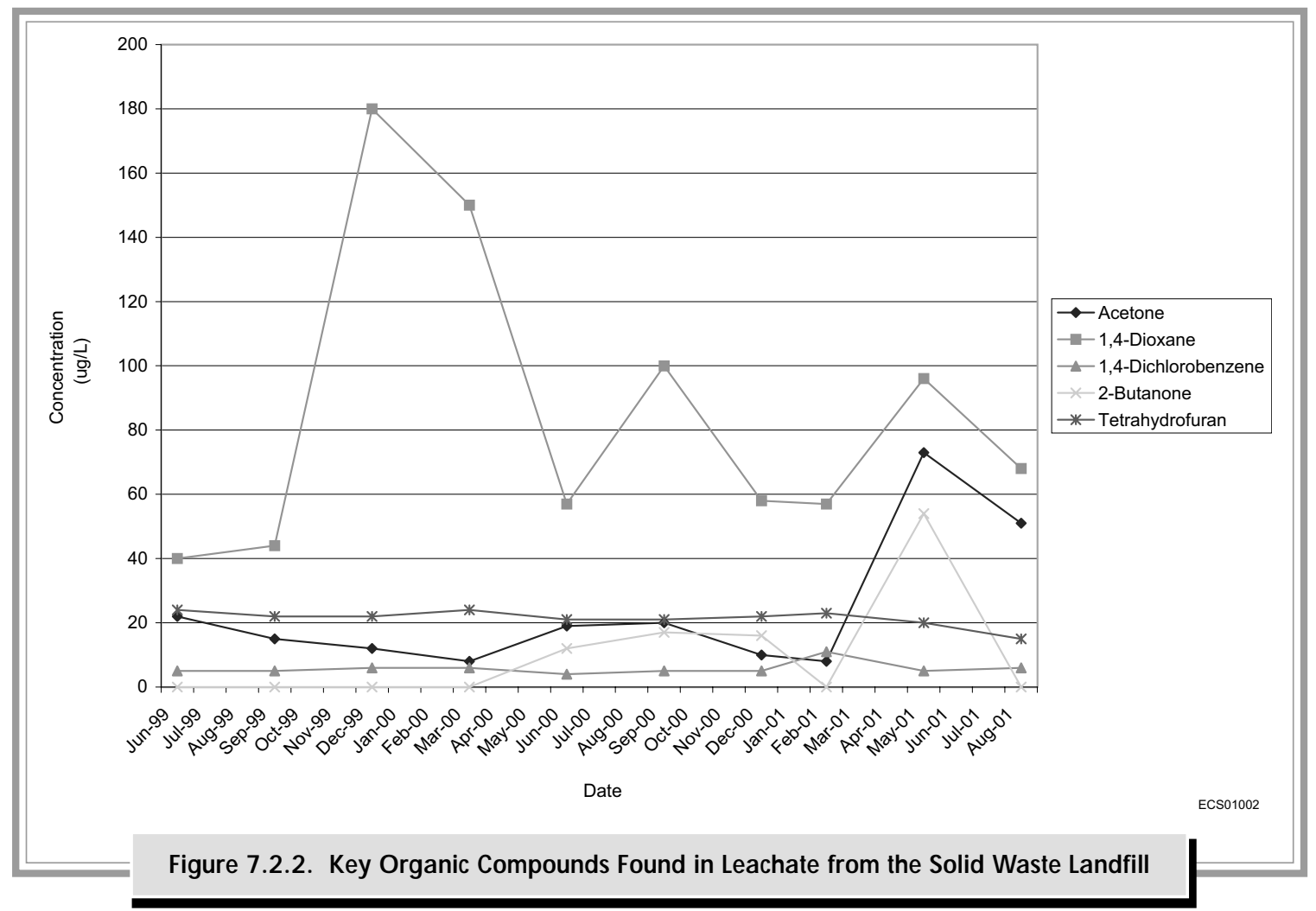




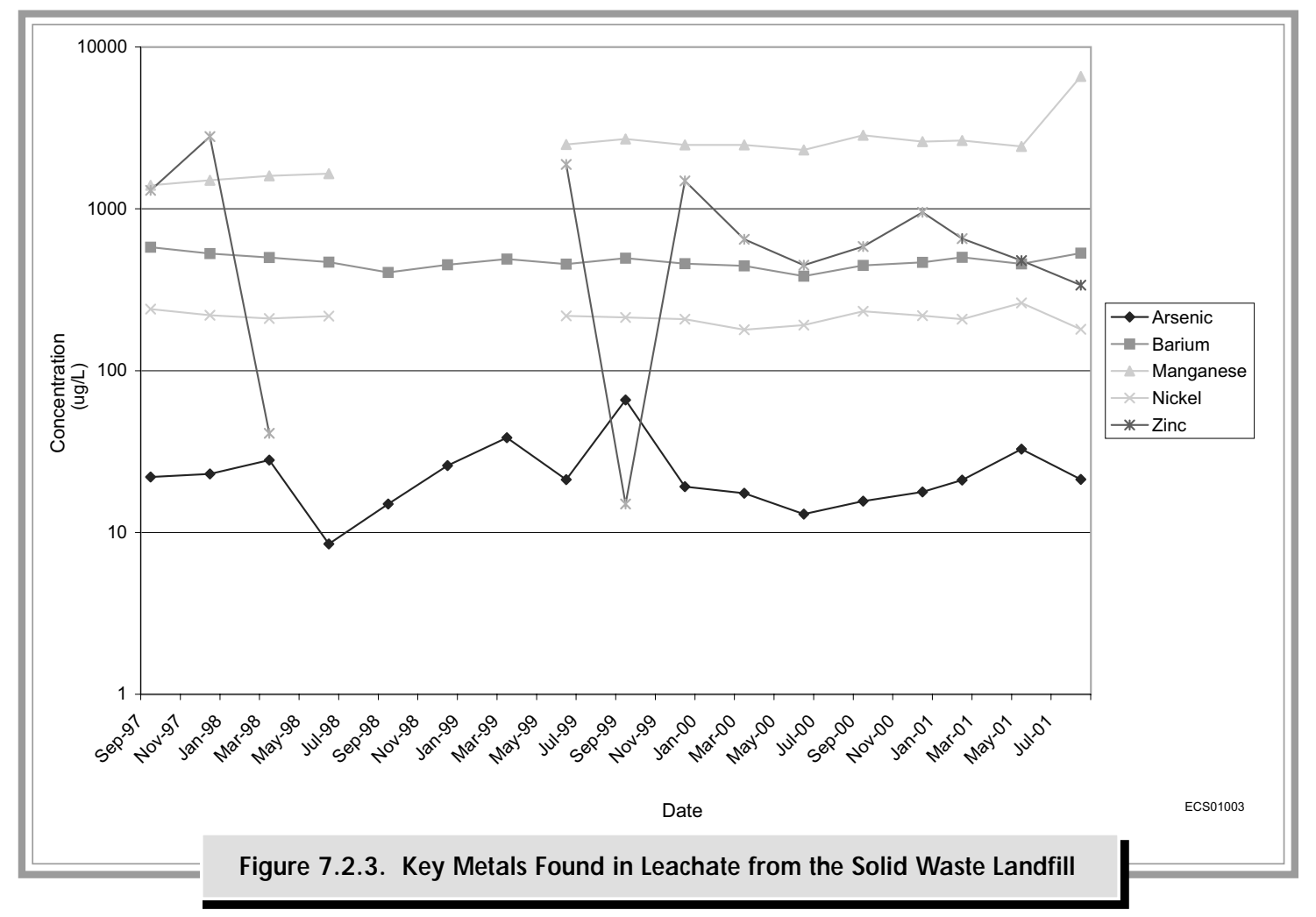

There are three soil-vapor extraction systems in use: $14.2,28.3$, and 42.5 cubic meter $(18.5,37$, and 56 cubic yard) systems. The 14.2 cubic meters per minute (18.5 cubic yards per minute) soil-vapor extraction system operated from April 4 through July 18, 2001, at the combined $216-Z-1 \mathrm{~A} /-12 /-18$ well field and from July 20 through September 30, 2001, at the 216-Z-9 well field (see PNNL-13080 for location maps of the well fields). The system was maintained in standby mode throughout fiscal year 2000 and during the winter in fiscal year 2001 (October 1, 1999, through April 3, 2001). The 28.3 and 42.5 cubic meters per minute ( 37 and 56 cubic yards per minute) soil-vapor extraction systems were maintained in standby mode during fiscal years 2000 and 2001.

To track the effectiveness of the extraction effort, soil-vapor concentrations of carbon tetrachloride were monitored at the inlet to the soil-vapor extraction system and at individual online extraction wells during the 6-month operating period. To assess the impact of nonoperation of the soil-vapor extraction system, soil-vapor concentrations of carbon tetrachloride were monitored at offline wells and probes during the entire fiscal year.

Soil-V apor Extraction. Soil-vapor extraction to remove carbon tetrachloride from the vadose zone resumed April 4, 2001, at the 216-Z-1A/-12/-18 well field. Initial online wells were selected within the perimeter of the 216-Z-1A tile field. As extraction continued, wells farther away from the tile field and wells within the 216-Z-12 and 216-Z-18 cribs were brought online. Extraction wells open near the less-permeable PlioPleistocene Unit, where the highest carbon tetrachloride concentrations have consistently been detected, were selected to optimize mass removal of contaminant. (The Plio-Pleistocene Unit is a geologic stratum that may be a confining layer to carbon tetrachloride vapors.) Initial carbon tetrachloride concentrations measured at the soil-vapor extraction system inlet were $\sim 40 \mathrm{ppmv}$ (Figure 7.2.4). After 15 weeks of extraction, concentrations had decreased to $\sim 25 \mathrm{ppmv}$. The daily mass-removal rate increased significantly at least once during this period as a result of adjustments in the mix of online wells and the flow rate.

Soil-vapor extraction resumed July 20, 2001, at the 216-Z-9 well field. Initial online wells were selected close to the 216-Z-9 trench. As extraction continued, wells farther away from the trench were brought online. Each selection of online wells included wells open near the groundwater and wells open near the Plio-Pleistocene Unit. Initial carbon tetrachloride concentrations measured at the soil-vapor extraction system inlet were $\sim 215$ ppmv (see Figure 7.2.4). After 10 weeks of extraction, concentrations had decreased to $\sim 40 \mathrm{ppmv}$. The daily mass removal rate increased significantly at least once during this period as a result of adjustments in the mix of online wells and the flow rate. 


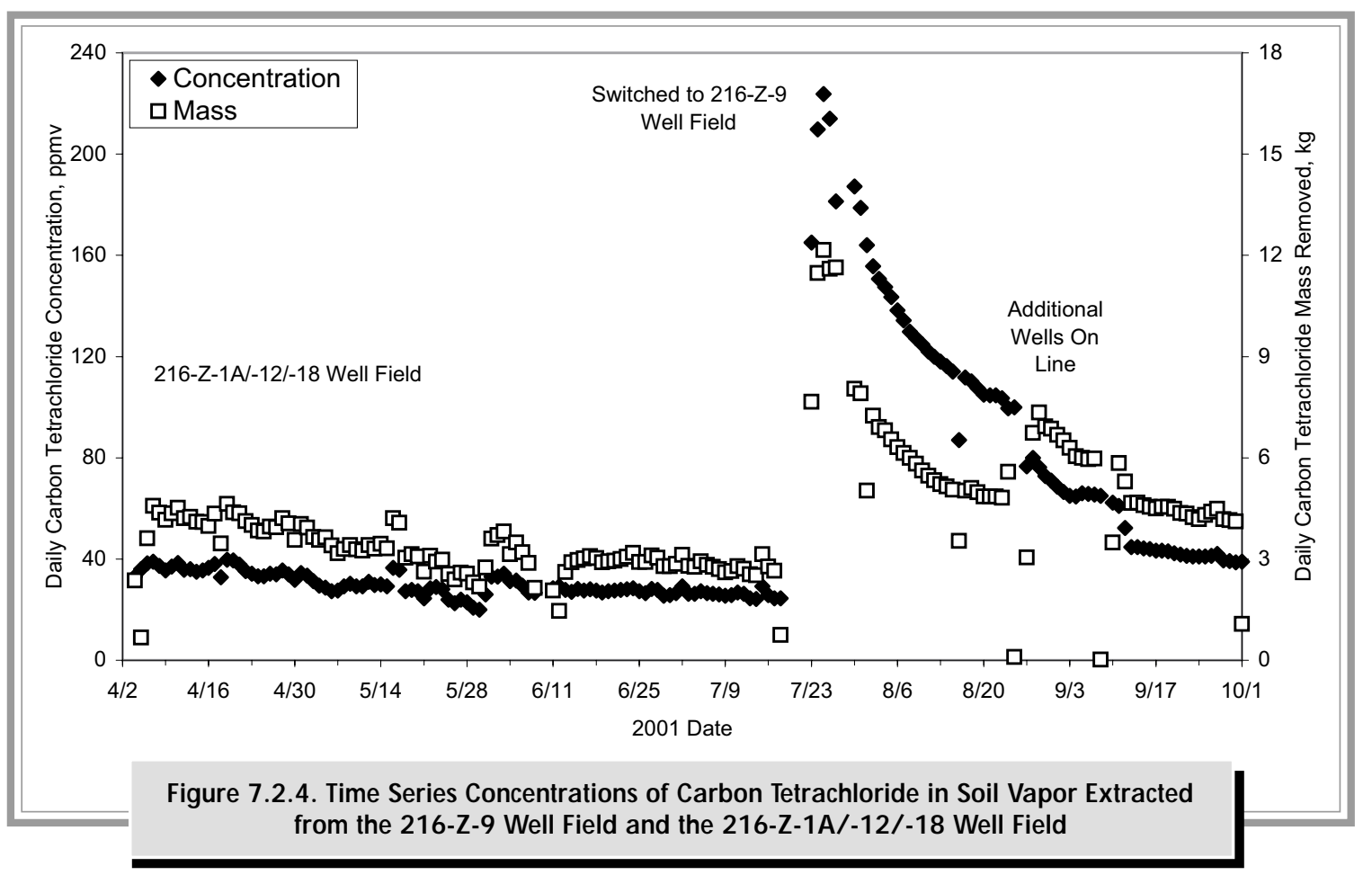

During 6 months of soil-vapor extraction in fiscal year 2001, 709 kilograms (1,563 pounds) of carbon tetrachloride were removed from the vadose zone. Of this total, 335 kilograms (738 pounds) were removed from the 216-Z-1A/-12/-18 well field during 106 days of operation and 374 kilograms (824 pounds) were removed from the 216-Z-9 well field during 74 days of operation.

As of September 2001, 77,169 kilograms $(170,128$ pounds) of carbon tetrachloride had been removed from the vadose zone since extraction operations started in 1991 (Table 7.2.1). Since initiation, the extraction systems are estimated to have removed $7 \%$ of the residual mass at well field $216-Z-1 \mathrm{~A} /-12 /-18$ and $22 \%$ of the mass at well field 216-Z-9. This estimate assumes that all of the mass that has not been lost to the atmosphere $(21 \%$ of the original inventory), dissolved in groundwater (2\% of the original inventory), or biodegraded ( $1 \%$ of the original inventory) is still available in the vadose zone as residual mass (BHI-00720; WHC-SD-EN-TI-101).

\begin{tabular}{|c|c|c|c|}
\hline Well Field & $\begin{array}{c}\text { Estimated } \\
\text { Mass Discharged } \\
1955 \text { to } 1973^{(\text {a) }}(\mathbf{k g})^{(\mathbf{b})} \\
\end{array}$ & $\begin{array}{c}\text { Estimated Mass } \\
\text { Lost to A tmosphere } \\
1955 \text { to } 1990^{\text {(c) }}(\mathrm{kg}) \\
\end{array}$ & $\begin{array}{c}\text { Mass Removed U sing } \\
\text { Soil-V apor Extraction } \\
1991 \text { to } 2001^{\text {(d) }}(\mathrm{kg}) \\
\end{array}$ \\
\hline $216-Z-1 A$ & 270,000 & 56,700 & $23,846^{(\mathrm{e})}$ \\
\hline $216-Z-9$ & 130,000 to 480,000 & 27,300 to 100,800 & 53,323 \\
\hline $216-Z-18$ & 170,000 & 35,700 & \\
\hline Total & 570,000 to 920,000 & 119,700 to 196,800 & 77,169 \\
\hline $\begin{array}{l}\text { (a) Based } \\
\text { (b) To cor } \\
\text { (c) Based } \\
\text { (d) Based } \\
\text { (e) Includ } \\
\text { overla }\end{array}$ & $\begin{array}{l}\text { E/RL-91-32. } \\
\text { g to lbs, multiply by } 2.205 \\
\text { HC-SD-EN-TI-101. } \\
\text { II-00720. } \\
\text { s removed from } 216-Z-18\end{array}$ & 1 & de because the well fields \\
\hline
\end{tabular}


Monitoring at 0 ffline Wells and Probes. During fiscal year 2001, soil-vapor concentrations of carbon tetrachloride were monitored near the ground surface, near the Plio-Pleistocene Unit ( $\sim 0$ meters [ 131 feet] below ground surface), and near groundwater ( 66 meters [ 217 feet] below ground surface). Soil-vapor concentrations were monitored near the ground surface and groundwater to assess whether non-operation of the soilvapor extraction system is allowing carbon tetrachloride to migrate out of the vadose zone. The maximum concentration detected near the ground surface (between 2 and 10 meters [ 6 and 30 feet] below ground surface) was 17 ppmv. Near the groundwater, at a depth of 58 meters (190 feet) below ground surface, the maximum concentration was 9 ppmv.

Soil-vapor concentrations also were monitored above and within the Plio-Pleistocene Unit to provide an indication of concentrations that could be expected during restart of the soil-vapor extraction system. The maximum concentration detected near the PlioPleistocene Unit (between 25 and 41 meters [82 and 134 feet] below ground surface) in 2001 was $360 \mathrm{ppmv}$ at 35 meters (115 feet) below ground surface at the 216-Z-9 site. During monitoring in fiscal years 1997, 1998, 1999, and 2000, the highest carbon tetrachloride concentrations also were detected in the same well.

At the $216-\mathrm{Z}-1 \mathrm{~A} /-12 /-18$ well field, the maximum carbon tetrachloride concentration detected near the Plio-Pleistocene Unit in 2001 was 306 ppmv at 41 meters (134 feet) below ground surface adjacent to the 216-Z-1A tile field. During monitoring in fiscal years 1997, 1998, 1999, and 2000, the highest concentrations were detected at wells within the 216-Z-1A tile field.

The temporary suspension of soil-vapor extraction in fiscal year 2001 appears to have caused minimal transport of carbon tetrachloride through the soil surface to the atmosphere. This view is supported by the fact that carbon tetrachloride concentrations did not increase significantly at the near-surface probes monitored in fiscal year 2001. In addition, suspending operations of the soil-vapor extraction system appears to have had no negative impact on groundwater quality, because carbon tetrachloride concentrations have not increased significantly near the water table since that time.

Passive Soil-V apor Extraction. Passive soil-vapor extraction is a remediation technology that uses naturally-induced pressure gradients between the subsurface and the surface to drive soil vapor to the surface. In general, falling atmospheric pressure causes subsurface vapor to move to the atmosphere through wells, while rising atmospheric pressure causes atmospheric air to move into the subsurface. Passive soil-vapor extraction systems are designed to use this phenomenon to remove carbon tetrachloride from the vadose zone.

Passive soil-vapor extraction systems were installed at the end of fiscal year 1999 at eight boreholes that are open near the vadose/groundwater interface at the 216-Z-1A/-12/-18 well field. The passive systems are outfitted with check valves that only allow soil vapor to flow out of the borehole (i.e., one way movement), and a canister holding granular activated carbon that adsorbs carbon tetrachloride before the soil vapor is vented to the atmosphere. The check valve prohibits flow of atmospheric air into the borehole during a reverse barometric pressure gradient, which would dilute and spread carbon tetrachloride vapors in the subsurface.

Three of eight boreholes have instruments to measure hourly air pressure differentials between the ground surface and the bottom of the borehole, carbon tetrachloride concentrations, temperature, and flow rates. These data can be used to calculate an hourly estimate of the amount of mass removed from the well. Analysis of the granular activated carbon in the cartridge provides a timeintegrated estimate of the mass removed while the granular activated carbon was inline.

At the two boreholes with instruments near the 216-Z-1A tile field, the peak carbon tetrachloride concentrations were 40 and 46 ppmv. One well located at the southeastern corner of the 216-Z-18 crib had a peak concentration of 14 ppmv. Flow rates measured at the wells ranged from 0 to as high as 0.4 cubic meters per minute $(0.5$ cubic yards per minute). Approximately 200 grams of carbon tetrachloride were removed by the passive extraction system in 2001.

\subsubsection{Hanford Tank Farm s Vadose Zone Monitoring Project}

S. M. Sobczyk, P. D. Henwood, A. W. Pearson, R. G. M CC ain, and S. E. KoS

A comprehensive monitoring project was established in fiscal year 2001 for selected borehole intervals in the single-shell tank farms. The logging system used for monitoring was the Radionuclide Assessment System. The logging results were compared to an established baseline of existing contamination in the vadose zone 
beneath the single-shell tank farms. The objective was to detect changes occurring since the baseline data were collected.

The general approach of the monitoring project is to prioritize boreholes according to the potential for detectable changes in vadose zone gamma activity and to provide data that will assist in identifying or verifying future tank leaks. Accordingly, boreholes are ranked according to (1) boreholes with measurements that indicate contaminant movement in the past, (2) boreholes located near a tank containing a significant volume of drainable liquid, or (3) boreholes located near a tank that has leaked a significant volume of liquid. The methods used to prioritize boreholes are described in MACHGLP 1.8.1. Geophysical monitoring also supports waste retrieval operations and other tank farm activities. When routine monitoring with the Radionuclide Assessment System identifies anomalies, the Spectral Gamma Logging System, the High Resolution Logging System, and the neutron moisture tool may be used for special investigations.

Radionuclide Assessment System spectral gamma logging began in June 2001 and has continued since that time. The Radionuclide Assessment System was used in 113 drywells monitoring the vadose zone at the single-shell tank farm during fiscal year 2001. Routine monitoring reports for the Hanford Tank Farms Vadose Zone Monitoring Project were issued quarterly to summarize the logging results, to provide the status of any ongoing special investigations, and to provide an updated listing of borehole intervals where logging is planned in the coming months. Logging results can be found on the worldwide web at http://www.gjo.doe.gov/ programs/hanf/HTFVZ.html.
Radionuclide Assessment System logging was started in tank farms A, BX, SX, T, and U in June 2001. No contaminant movement was detected in tank farms A, $\mathrm{BX}$, and SX. Possible contaminant movement was identified in four boreholes in the $\mathrm{U}$ tank farm and in five boreholes in the $\mathrm{T}$ tank farm. A special report is being prepared to document contaminant migration at $U$ tank farm to support waste retrieval operations.

Identification of contaminant movement in the $\mathrm{U}$ tank farm was based on comparison of current spectral gamma logs with baseline data. The comparison indicated downward migration of uranium-238 and - 235 from 1995 through 2001. Comparison of data collected in 1995 and 2001 showed zones with contamination in 2001 that did not have contamination in 1995. This was interpreted as downward movement of uranium. The four boreholes showing subsurface movement of contamination are between tanks U-107 and U-104 in the U tank farm. Radionuclide Assessment System monitoring of these boreholes will be implemented on a quarterly basis beginning in 2002 .

Identification of possible contaminant migration in the $T$ tank farm was based on comparison of Radionuclide Assessment System data with baseline data collected with the Spectral Gamma Logging System. Because this involves comparing the responses from two different detectors, each with different response characteristics, the degree of confidence in the identification is somewhat less, relative to the $\mathrm{U}$ tank farm. The boreholes in $\mathrm{T}$ tank farm do not define as discrete an area as at $\mathrm{U}$ tank farm. These boreholes also have been placed on a quarterly monitoring schedule and future comparisons between successive Radionuclide Assessment System logs are expected to provide more definitive information.

\subsubsection{An Instrumented Vadose Zone Monitoring Borehole at Waste Managem ent Area B-BX-BY}

G. W. G ee, A. L. W ard, J. C. Ritter, J. B. Sisson, J. M. H ubbell, H. A. Sydnor, and D. A. M yers

The Office of River Protection's Vadose Zone Project drilled borehole 299-E33-46 to 80.5 meters (264 feet) below ground surface in the B tank farm in fiscal year 2001 (see Section 7.1.1). Upon reaching final depth, groundwater samples were collected and analyzed for technetium-99. The analyses showed that technetium-99 was $<2,000 \mathrm{pCi} / \mathrm{L}(74 \mathrm{~Bq} / \mathrm{L})$, well below the predetermined criterion of $4,000 \mathrm{pCi} / \mathrm{L}(148 \mathrm{~Bq} / \mathrm{L})$ for completing the borehole as a groundwater monitoring well. However, researchers at Pacific Northwest National Laboratory and Idaho National Engineering and Environmental Laboratory presented a proposal to complete the borehole as the first-ever instrumented vadose zone monitoring structure to be constructed in a Hanford Site tank farm. A complete description of the monitoring structure can be found in PNNL-13712. A summary description is given below.

The conventional technology for subsurface characterization is drilling a series of boreholes and collecting sediment samples during drilling, then analyzing the samples in a laboratory. The resulting network of drywells installed around each tank is then used for continuous monitoring for leak detection. The maximum detection depth is limited by the drywell depth. 
During July and August 2001, instruments and sensors for vadose zone monitoring were installed in the B tank farm in a borehole located adjacent to tank B-110. Duratek Federal Services, Northwest Operations drilled the 0.2-meter- (6-inch-) diameter borehole under the direction of CH2M HILL Hanford Group, Inc. The borehole, 299-E22-46, had a steel case with bentonite and sand at the bottom. A vadose zone monitoring system was lowered to the bottom of the hole. The system included an advanced tensiometer and heat-dissipation probes to measure soil water pressure and monitor for perched water or water-table elevations. Temperature and water-content sensors were installed to measure soil temperature and moisture content. The water-content sensor was set against the borehole wall using its attached lever arm. Table 7.2.2 indicates the types of sensors and their depths in the borehole.

Once the vadose zone monitoring system was placed satisfactorily, it was grouted in place with a silica flour slurry. The grout was allowed to settle a few minutes, and a sand plug was added on top of the grout. The addition of grout and sand was repeated up to a depth of 6.2 meters
(20 feet) below ground surface, where the backfill materials were switched to sand and native materials. A water fluxmeter was installed at 6 meters ( 20 feet) below ground surface and extends to within 20 centimeters (8 inches) of the ground surface. A water fluxmeter measures infiltration or drainage. A data logger was installed on the surface to collect and store the field data.

The B tank farm installation is the first installation of a vadose zone monitoring system in the sand and gravel at the Hanford Site. Information gained from this installation will provide guidance to modify the system's electrode geometry to better track changes in vadose zone water content. A preliminary examination of the data collected at borehole 299-E33-46 indicates abnormally high water-content readings at depths of 66.4 and 68.9 meters (218 and 226 feet). A similar high watercontent reading was observed in the laboratory when saline solutions $>200 \mathrm{mS} / \mathrm{m}(2 \mathrm{mmho} / \mathrm{cm})$ were used to calibrate the sensors. Thus, adding a salinity sensor to the vadose zone monitoring system sensor is recommended for future arrays of vadose zone monitoring sensors.

\begin{tabular}{|c|c|c|c|c|}
\hline \multirow{2}{*}{\multicolumn{3}{|c|}{ Sensor A rray N umber }} & \multicolumn{2}{|c|}{ ensor Placement in Borehole 299-E33-46 } \\
\hline & & & Depth, m (ft) & Type of Sensor \\
\hline & 1 & & 0.6 and 0.91 ( 2 and 3$)$ & AT, HDS, WCS, WFM \\
\hline & 2 & & $1.8(6)$ & AT, HDS, WCS \\
\hline & 3 & & $2.7(9)$ & AT, HDS, WCS \\
\hline & 4 & & $4.6(15)$ & AT, HDS, WCS \\
\hline & 5 & & $16.1(53)$ & AT, HDS, WCS \\
\hline & 6 & & $25(82)$ & AT, HDS, WCS \\
\hline & 7 & & $66.4(218)$ & AT, SS, HDS, WCS \\
\hline & 8 & & $69(226)$ & AT, SS, HDS, WCS \\
\hline $\begin{array}{l}\text { AT } \\
\text { HDS } \\
\text { SS } \\
\text { WCS } \\
\text { WFM }\end{array}$ & \multicolumn{4}{|c|}{$\begin{array}{l}=\text { Advanced tensiometer. } \\
=\text { Heat dissipation sensor. } \\
=\text { Solution sampler. } \\
=\text { Water content sensor. } \\
=\text { Water flux meter. }\end{array}$} \\
\hline
\end{tabular}




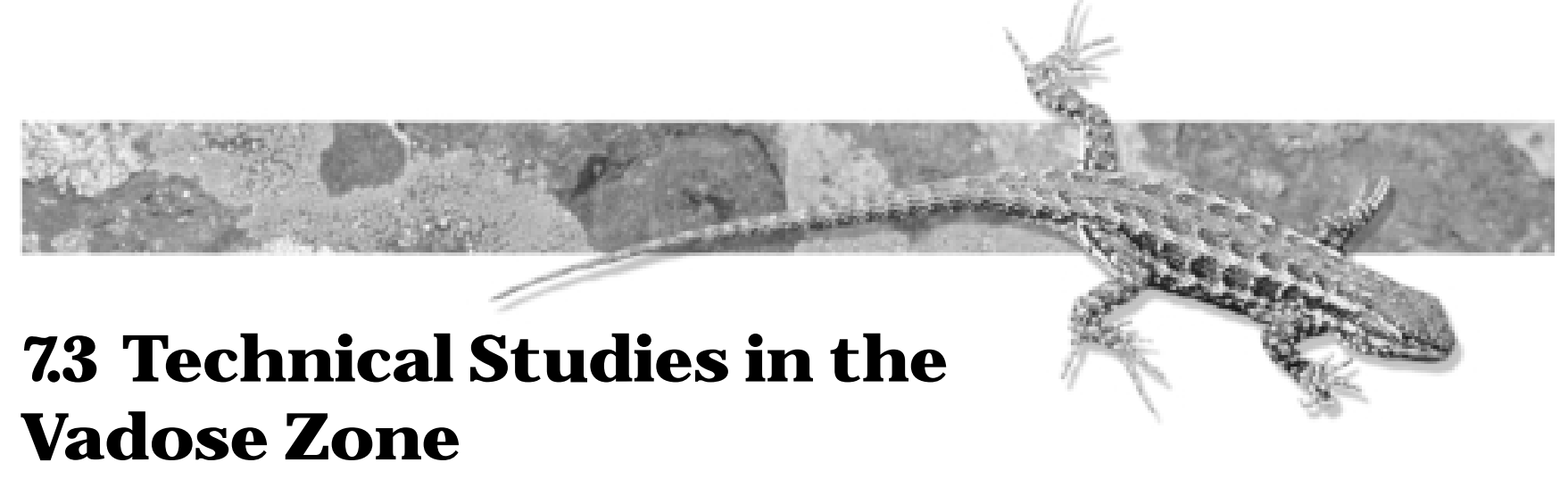

D. G. Horton

This section summarizes the activities and results of technical studies done at the Hanford Site in fiscal year 2001 to better understand the vadose zone and vadose zone contamination. These studies were designed to help develop new, innovative methods for cleanup and monitoring at the Hanford Site. These studies include the demonstration and testing of several geophysical methods to monitor and characterize the soil column (Sections 7.3.1 and 7.3.2), the use of chemical parameters to distinguish various sources of subsurface waste and subsurface moisture to understand transport processes in the vadose zone (Sections 7.3.4 and 7.3.5), infiltration experiments at a clastic dike site to determine the hydrologic properties of clastic dikes (Section 7.3.3), and development of a model to predict the migration of subsurface contaminants based on measured infiltration rates (Section 7.3.6).

\subsection{High-Resolution Seism ic Methods for Subsurface Characterization}

\section{E. J. Freeman}

High-resolution seismic characterization experiments were conducted at the Hanford Site in May 2001. The objective was to create an image of the sedimentary units at selected sites with sufficient resolution to identify distinct sediment layers from the ground surface to the water table. It was hoped that the continuous images of the sediment layers in the vadose zone could be used to identify field scale sediment-layer differences with some degree of confidence. Field-scale sediment-layer differences are important in modeling fluid flow and contaminant transport in the vadose zone. This section presents a brief summary of the experiments and their results. Freeman and Bachrach (2001) ${ }^{(\mathrm{a})}$ give a full discussion of the experimental methods and the results.

Four sites were selected to test the high-resolution seismic method: the Sisson-Lu experimental site in the 200-East Area, the proposed disposal site for immobilized low-activity waste in the 200-East Area, an excavated area south of Waste Management Area S-SX in the
200-West Area, and a clastic dike location south of the 200-East Area on Army Loop Road (Figure 7.3.1).

The Sisson-Lu experimental site, located southwest of the Plutonium-Uranium Extraction Plant, was chosen because there is a large quantity of neutron probe moisture data available from several wells completed to 18.6 meters (60 feet) depth at the site. The high-resolution seismic survey completed at this site showed changes in the sediment layering to a depth of $\sim 50$ meters $(\sim 165$ feet $)$. Comparing the existing neutron probe data with the new seismic data showed that the best reflectors are the tops of the low moisture zones, which correspond to coarsegrained units. In addition, the data suggest that not all sedimentary layers are continuous along the 14-meter(45-foot-) long survey line. Finally, the data also show the orientation of what are interpreted to be elongate deposits (possibly a buried channel).

The immobilized low-activity waste site is located west of the Sisson-Lu site. This site was chosen because it is the location of the proposed repository for future

(a) Letter report from E. Freeman and R. Bachrach (Pacific Northwest National Laboratory, Richland, Washington) to F. M. Mann (CH2M HILL Hanford Group, Inc., Richland, Washington), Application of High Resolution Shallow Seismic Methods for Subsurface Characterization at the Hanford Site, dated September 25, 2001. 


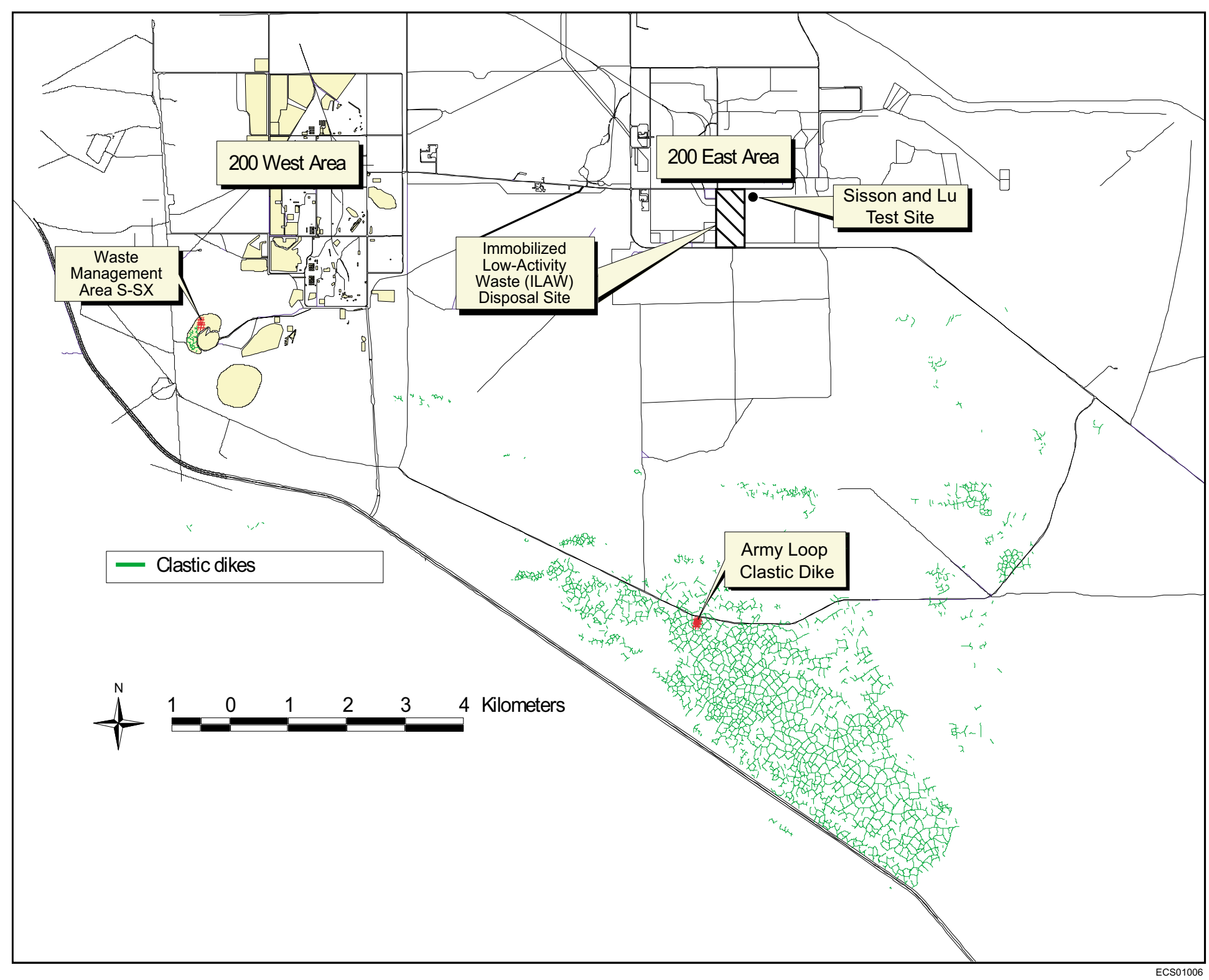

Figure 7.3.1. Location Map of Sites Selected for High-Resolution Seismic Characterization 
vitrified waste. The objective of the seismic method was to survey to a depth of $\sim 100$ meters $(\sim 330$ feet $)$. The results of the survey clearly showed the water table at a depth of 90 to 95 meters (295 to 312 feet). This is a significant improvement compared to the depth achieved previously with ground penetrating radar surveys. Additionally, comparison of the seismic profile with the geologist's log from a groundwater well located $\sim 10$ meters ( 33 feet) north of one of the survey lines showed good agreement between the geologist's observations and the seismic survey results.

In addition to the large-scale features such as lithologic contacts and the water table, small-scale features were identified in the survey profiles. Potential channels or depressions and fault or slump structures were interpreted from discontinuous and offset seismic reflections.

The excavated area south of the S-SX tank farms was selected because the upper 5 meters ( 16 feet) of sediment had been removed, permitting the potential for deeper signal penetration. There was an attempt to specifically identify a gravel layer previously thought to exist at a depth of $\sim 20$ meters ( $\sim 65$ feet) beneath the site. That gravel layer was not positively identified, but a gravel unit at a depth of 45 meters (148 feet) was recognized. In addition, the gravel layer appeared to be laterally continuous along the entire 30-meter (98-foot) profile. Other lithologic contacts could be identified on the seismic profile that corresponded to lithology changes in the geologist's log.
The clastic dike site was located $\sim 100$ meters (328 feet) south of Army Loop Road and 1.6 kilometers (1 mile) east of Goose Egg Hill. (Clastic dikes are vertical, sedimentary features that crosscut horizontal bedding. See Section 7.3.3 for more on clastic dikes.) The site was selected because of the prominent profile of the dikes in ground penetrating radar surveys previously conducted. The objective was to determine whether the dike would be detected by the seismic survey. The clastic dikes consisted of laminated sand and silt, with the laminations oriented subparallel to the dike. The sediment surrounding the dike was dominantly sand. The dike was detected by the seismic survey but the image was not as pronounced as the image previously obtained from ground penetrating radar.

The seismic profiles obtained in 2001 showed the capability of the method to image distinct lithologies throughout the entire vadose zone. The seismic technique did well in identifying individual sedimentary layers and structural features, interpreted to be faults and ancient stream channels. Such features may influence variability of fluid and contaminant flow in the vadose zone. The seismic profiles correlated well to geologist's logs and neutron probe logs at sites where they were available. The seismic method was much cheaper than drilling boreholes and provided good quality, continuous three-dimensional pictures of the subsurface.

\subsection{Vadose Zone Transport Field Studies}

\section{G. W. Gee and A. L. Ward}

Studies began at the Hanford Site to evaluate the processes controlling the transport of fluids in the vadose zone and to develop a reliable database for testing vadose zone transport models. These models are needed to evaluate contaminant migration through the vadose zone to underlying groundwater at the Hanford Site. Details of the work accomplished in fiscal year 2001 can be found in PNNL-13679. This section summarizes the work completed to date.

A study site, known as the Sisson-Lu site in the 200-East Area (see Figure 7.3.1), was selected because it had previously been characterized extensively using several geophysical monitoring techniques. Building on the characterization efforts of the past 20 years, instruments were installed at the site to use eight characterization methods: advanced tensiometers, neutron probe, electrical resistance tomography, high-resolution resistivity, cross-borehole radar, and cross-borehole seismic surveys. Sediment coring was used to obtain samples for analyzing chemical and isotopic tracers.

Laboratory-scale experiments suggest that fluid properties may influence transport behavior through the Hanford Site vadose zone. Yet, the importance of these influences to field-scale transport is largely unknown, thereby limiting the accuracy of contaminant-transport predictions. To assess the importance of these interactions in field-scale solute transport, tank leaks were simulated by performing a series of injections with dilute fluids in late spring and early summer of 2000 and with hypersaline fluids (excessively saline solutions such as those found in single-shell tanks) during the spring of 2001. In both tests, a suite of isotopic and ionic tracers was included in the injected fluids. A summary of the 2000 test results can be found in PNNL-13487.

The tests in fiscal year 2001, which were designed partly to evaluate the effects of fluid properties and transport processes, involved the injection of 
19,000 liters (5,020 gallons) of hypersaline fluid over the course of 5 weeks. This was followed by 11,400 liters (3,010 gallons) of solute-free water applied in a 2-week period. The eight characterization methods were used to monitor the infiltration and re-distribution of the liquid over the course of 3 months.

Results show that the subsurface distributions of both the dilute and hypersaline fluids are controlled by interactions between small-scale horizontal stratification and fluid properties. The centers of mass for the two plumes were similar in the lateral and transverse directions, but were significantly different in depth. The hypersaline plume had traveled 2.6 times deeper than the dilute plume.

Concentration profiles of tracers in the liquid were generally asymmetric with a large mass occurring at a depth of 5 to 7 meters (16 to 23 feet), and a smaller mass at a depth of 10 to 12 meters ( 33 to 39 feet). Also, there was a preferred flow path to the southeast. The locations of the mass peaks were coincident with the general depths of finer-textured layers which occur at $\sim 6$ meters ( $\sim 20$ feet $)$ and at $\sim 12$ meters ( $~ 39$ feet $)$ depths. The fine sand sediment in these layers controlled the migration of the water and caused a substantial increase in horizontal spreading. The moisture plume was confined to a depth of 13 meters (43 feet) in the fiscal year 2000 test but was detected at depths of 16 meters ( 52 feet) in the southwestern part of the monitoring site in 2001. Thus, the plume had penetrated below the lower, 12 -meter (39-foot) finegrained, confining layer.
These observations emphasize the need to consider local-scale textural discontinuities in conceptual models of field-scale transport at the Hanford Site because they appear to cause lateral spreading of vadose-zone plumes. Lateral spreading of contaminant plumes has been noted in the vadose zone at Hanford Site tank farms and other waste sites. Work in 2001 has led to the development of a scaling method that can be coupled with inverse-flow modeling to estimate parameters for heterogeneous soil at the field scale. Application of this technique to estimate the hydraulic parameters from the Vadose Zone Transport Study field experiments has begun with a twodimensional simulation. Pacific Northwest National Laboratory's computer code called Subsurface Transport Over Multiple Phases (PNNL-12030; PNNL-12034) was combined with the universal inverse modeling code, UCODE (Poeter and Hill 1998), to estimate unsaturated hydraulic parameters. The prediction of water-content distributions using laboratory-measured parameter values resulted in poor model fits. However, using field-scale values from the new scaling technique resulted in significantly better model fits for both water content and pressure head.

The techniques being developed in the Vadose Zone Field Transport Study are critical to the development of long-term, field-scale transport predictions describing the subsurface distribution of fluids and contaminants.

\subsubsection{Hydrogeologic Inf luence of Clastic Dikes on Vadose Zone Transport}

\section{J. Murray, D. G. Horton, A. L. Ward, and G. W. Gee}

A 3-year study of clastic dikes and their influence on vertical movement of moisture and contaminants in the vadose zone began in fiscal year 2000 and continued in 2001. The study is funded by DOE's Environmental Management Science Program. The goal is to describe the geometric and hydrologic properties of clastic dikes and extrapolate those properties to the vadose zone beneath waste storage and disposal facilities. Results of the work accomplished in 2000 were summarized in PNNL-13487. This section summarizes the work accomplished in 2001.

Clastic dikes are common sedimentary structures in the vadose zone at the Hanford Site (BHI-01103). The dikes are vertical to subvertical structures that are often contorted and irregular. They crosscut the normal subhorizontal sand and silt beds of the Hanford formation. Previous investigators have proposed that the dikes may provide a preferential path for contaminated water leaking from waste tanks to move through the thick unsaturated zone to the unconfined aquifer. However, there is insufficient evidence to determine if that speculation is accurate. One of the goals of this study is to provide information that can be used to evaluate that speculation.

The main focus of the project in 2001 was to study a site near Army Loop Road (see Figure 7.3.1 for the location of the clastic dike site at Army Loop Road). Ground-penetrating radar surveys, air photos, and field mapping were used to select a site to trench across a clastic dike. In June 2001, a clastic dike at the Army Loop Road site was trenched with a backhoe to a depth 
of $\sim 3.5$ meters $(\sim 11$ feet) (Figure 7.3.2). The exposed clastic dike was in a sand-dominated portion of the Hanford formation. The dike excavated at the Army Loop Road site was 2 meters ( 6.5 feet) thick.

Instruments to measure airpermeability were used to measure the permeability of the dike and the host sediment. The results indicated the median air permeability of the dike was about one order of magnitude lower than the permeability in the matrix. The overall variability of permeability in the dike-matrix system was approximately four orders of magnitude. This was an important observation, because some methods used to scale permeability data from the point-source scale to the field scale assume that variability in the system is low. This means it would be questionable to apply those scaling methods to a clastic dike system.

The continuity of the vertical bands within the dike was measured. A line was laid out across the dike on the floor of the excavation. Each vertical band that crossed the line was then traced up and down the excavation to see if it was continuous. In most cases, the bands could be traced for $\sim 1.6$ meters $(\sim 5.25$ feet $)$ before they pinched out or were obstructed by a cross-cutting band. The range of continuity observed was from 0.2 to 7.7 meters ( 0.6 to 25 feet), with all but one band having an apparent continuity of $<\sim 2.5$ meters ( $<\sim 8.2$ feet). This degree of continuity will affect transport through the clastic dike and will be used to construct models of the properties within the dike.

A large-scale infiltration experiment was conducted at the Army Loop Road site. A drip irrigation system was used to apply specific amounts of fluid. Three applications of water were applied to the clastic dike and surrounding matrix, and the progress of the infiltrating water was monitored for each application rate. Water content, matric potential (i.e., a measure of the amount of water in unsaturated material), and electrical conductivity were measured throughout the tests.

Once steady state was achieved with the third (and lowest) application rate, the irrigation supply tank was switched to a solution of potassium bromide and the tracer dye known as Brilliant Blue FCF. The presence of the potassium bromide made it easier to detect the

wetting front in the subsurface. Solution application was continued until the potassium bromide moved below $\sim 0.5$ meter. Further movement of the water was monitored with a neutron probe and cross-borehole radar instruments in boreholes that extended to a depth of $\sim 7$ meters ( 23 feet $)$.

The excavation began after the application of the tracer in the infiltration area. After construction of the main excavation area was complete, an additional face was excavated at the edge of the infiltration area so that the distribution of the dye could be examined. The upper portion of Figure 7.3.3 shows a composite color photographic image of the dye in the sediment, and the lower portion of the figure is a map of the moisture distribution in the face of the excavation. The photographic image shows the heterogeneous distribution of the blue dye. The dike is in the center-right area of the image, from 3 to 5 meters (10 to 16 feet), and tended to transmit less dye. However, some of the deepest penetrations of the dye occurred in restricted bands within the dike.

The map of the moisture distribution (bottom part of Figure 7.3.3) was made using time domain reflectometry probe measurements. Although the moisture map captures the main features seen in the photographic image, the important heterogeneity in the distribution of dye and moisture is not captured in the map. Figure 7.3.4 shows the moisture distribution and indicates that much greater levels of moisture are stored in the clastic dike. 


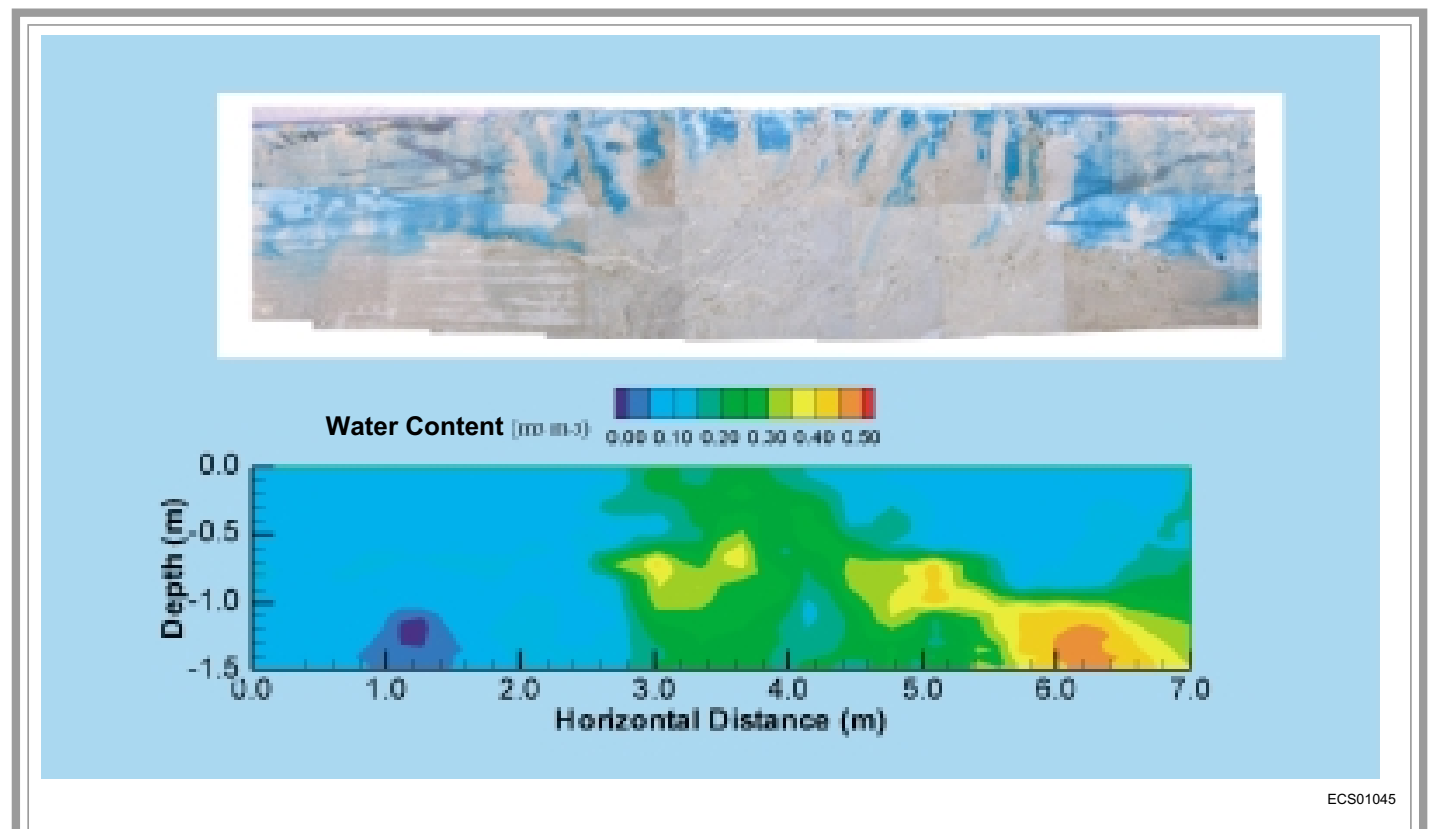

Figure 7.3.3. Dye Infiltration Experiment at the Clastic Dike in the Army Loop Road Trench. The upper image is a photo of the exposure showing the distribution of the blue dye. The lower image is a computer generated map of moisture distribution in the dike and adjacent sediment. The dike is between about 3 and 5 meters (10 and 16 feet).

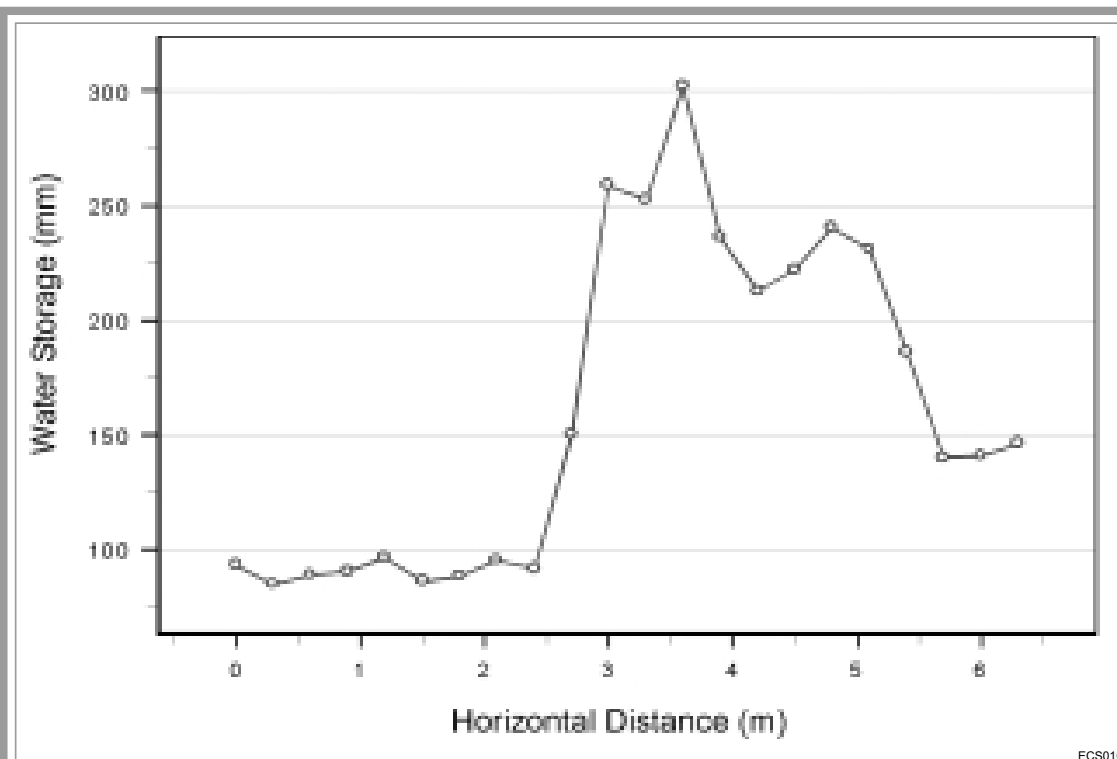

Figure 7.3.4. Moisture Distribution within the Clastic Dike in the Army Loop Road Exposure. The dike is between 3 and 5 meters (10 and 16 feet). 
One important feature noted in the excavation and infiltration experiment was a clastic sill that extends from one side of the dike. (A sill is similar to a dike except that a sill is parallel to the enclosing geologic beds instead of cross-cutting the geologic beds.) This sill was detected prior to the excavation, when the access boreholes for the infiltration tests were being installed. Moisture data recorded prior to any infiltration activities at the site indicated the presence of a high-moisture zone at a depth of $\sim 1.5$ meters ( $~ 5$ feet) that was present only on the western side of the dike, but not on the eastern side.

Based on previous experience, it was suspected that the feature was a clastic sill. The sill exerted a major influence on the movement of moisture during the experiment. On the side of the dike with no sill, the moisture appears to have migrated uniformly through the sediment. On the side of the dike with the sill, however, moisture penetrated below the sill relatively late during the experiments. Exposing the sill during the excavation showed that moisture had migrated several meters laterally within the sill, carrying moisture well outside of the infiltration zone. This suggested that sills are important controls on vadose zone transport. The results also indicated that even though the air permeability and saturated hydraulic conductivity within the dike and sill were very low, clastic dikes may still be fast transport paths under unsaturated conditions in the vadose zone.

The results of this study indicated that conceptual and numeric models of fluid and contaminant transport through the vadose zone should consider clastic dikes and clastic sills in the subsurface capable of influencing flow.

\subsubsection{Isotopic Fingerprinting of Radionuclide Sources at Single-Shell Tanks}

\section{J. C. Evans, P. E. Dresel, and O. T. Farmer}

Researchers from Lawrence Berkeley National Laboratory and Pacific Northwest National Laboratory analyzed stable and long-lived isotopes in drill core samples from the S-SX tank farm, 200-West Area, in 2001. The purpose of the work was to show whether isotopic and chemical ratios could differentiate among leak events. This section summarizes the results of that effort. The full text of the experimental methods and results can be found in Evans et al. 2001.(b)

Sediment core samples were obtained from borehole 3082, the slant borehole at tank SX-108 (see Section 7.1.2 for more information about the borehole at SX-108). Concentrations of trace metals, common anions, and selected radionuclides were measured from samples of the core in an attempt to differentiate among several possible contaminant sources. The chosen constituents were the isotopic systems of cesium, iodine, and molybdenum and the relatively mobile constituents chloride, nitrate, sulfate, and technetium-99.

The analytical results for cesium-137 and technetium-99 concentrations versus depth showed two concentration peaks for each radionuclide with the more mobile technetium-99 the deeper of the two. The cesium data, however, were inconclusive with respect to separating different leak events for the two peaks because the sample preparation method dissolved large amounts of natural cesium from the sediment and because of large measurement error.

The measured distribution of total molybdenum and molybdenum-100 showed three peaks in concentration at depths of 20.7, 27.5, and 35.4 meters $(68,90$, and 116 feet). The molybdenum data indicated three leak events for molybdenum-bearing waste.

Molybdenum and chromium should have the same geochemical properties; thus, hexavalent molybdenum may be a surrogate for hexavalent chromium. The distributions of both of these elements again suggested three separate leak events with the bulk of the molybdenum slightly retarded with respect to the chromium.

Iodine-129 is considered a very hazardous substance (drinking water standard $=1 \mathrm{pCi} / \mathrm{L}[0.037 \mathrm{~Bq} / \mathrm{L}]$ ) and highly mobile in the natural environment. Very little iodine-129 is expected in tank waste because it was largely partitioned into the vapor phase during operations. However, residual fission-derived iodine disposed to tanks is probably in the tank liquids and available for release during leaks. Stable iodine (iodine-127) should also be present as a reducing agent during chemical processing or as a chemical impurity. Thus, the isotopic ratio of iodine isotopes is likely to vary and can be used as a fingerprint for individual

(b) Evans, J. C., P. E. Dresel, and O. T. Farmer (Pacific Northwest National Laboratory, Richland, Washington), "ICP/MS Isotopic Determination of Nuclear Waste Sources Associated With Hanford Tank Leaks.” Submitted March 27, 2001, to Journal of Environmental Radioactivity. 
waste streams. The distribution of iodine isotopes with depth in samples from borehole C3082 showed that iodine in the sample came from two different leak events.

Several non-isotopic species are known to migrate almost unretarded through the vadose zone. These species include chloride, nitrate, sulfate, and technetium. The distributions of chloride, nitrate, and technetium with depth in borehole C3082 showed two peaks for each constituent.
In conclusion, isotopes of iodine and molybdenum can be used to distinguish different leak events from waste tanks. Cesium isotopes were not successful in discerning different leaks. Ratios of several different unretarded species also can be used to discern different leaks. The separate leaks may be from different tanks or from more than one leak from a single tank. Comparison of isotopic and species ratios of vadose zone sediment can help to determine sources of vadose zone and groundwater contamination.

\subsection{Water Movem ent Through the Vadose Zone as Inferred from Isotopic and Chemical Measurem ents of Borehole Samples}

\section{J. C. Evans, P. E. Dresel, and O. T. Farmer}

To evaluate contaminant transport through the vadose zone to groundwater requires an understanding of how and where water moves in the vadose zone. An isotopic and chemical study of porewater from cores obtained during drilling of RCRA well 299-W22-48, at the S-SX single-shell tank farms in 200-West Area, was done in fiscal year 2001 to investigate this issue. This section summarizes the report of this work, which is found in RPP-7884. ${ }^{\text {(c) }}$

Stable isotopes of hydrogen and oxygen can help indicate the origin of water in the vadose zone near waste sites. A shift in isotope composition to heavier values indicates that the water was partially evaporated before it entered the ground. (Evaporation preferentially removes the lighter isotopes of oxygen and hydrogen so that the remaining water is "heavier.") Heavier porewater can indicate waste is from single-shell tanks or waste disposal cribs.

Well 299-W22-48 was drilled immediately east of Waste Management Area S-SX in 1999 (see Figure 6.2.21). The borehole was drilled in a previously disturbed area in the vicinity of past-practice disposal facilities. Thirty-two samples were collected from the drill core. Porewater was extracted from the samples, and the water content and abundances of the stable isotopes of oxygen and hydrogen were measured at Lawrence Berkeley National Laboratory.

The oxygen and hydrogen isotope composition of groundwater at the Hanford Site suggests that the source for water in the unconfined aquifer is natural precipitation that has not undergone evaporation processes. The composition of the vadose zone porewater, however, indicates that these waters have undergone significant evaporation.

The oxygen isotope composition versus depth for porewater samples is shown in Figure 7.3.5. The oxygen isotope composition of the shallowest sample is much heavier than local precipitation or Hanford Site process water from the Columbia River, two potential sources of surface water. The shift in the isotope composition to heavier values signifies that the waters have been strongly evaporated. This is typical of near-surface soil waters, especially in arid and semiarid environments. At a depth of 2 meters (6.5 feet), the oxygen isotope composition of the porewater reflects that of precipitation and Columbia River water. Beneath 2 meters (6.5 feet), most porewater is shifted to heavier compositions. There are two porewater samples from the deeper part of the core that do not show the effects of evaporation. The deeper sample, from 71.8 meters (236 feet), is from the saturated zone and has the composition of groundwater in the unconfined aquifer. The other sample, at 44.7 meters (147 feet), is from an extremely moist zone. Isotopic analyses for uranium-236 and fission-derived isotopes of molybdenum show no evidence of nuclear production associated with the moist sediment sample.

The pattern of the shallow, 0.5-meter- (1.6-feet-) deep, strongly evaporated sample underlain by the 2 -meter $(6.5$-foot) sample that is the same as

(c) RPP-7884. Draft. "Transport Mechanisms Inferred by Isotope Geochemistry." In Field Investigative Report for Waste Management Area S-SX, Appendix D.6. J. C. Evans, P. E. Dresel, and O. T. Farmer, CH2M HILL Hanford Group, Inc., Richland, Washington. 
unevaporated groundwater, precipitation, or Columbia River water is similar to patterns observed in other studies of shallow, unsaturated soil. The unevaporated sample from 2 meters (6.5 feet) implies that the soil column at well 299-W22-48 experienced anomalously high infiltration that allowed unevaporated water to reach that depth. The oxygen isotopic composition allows the possibility that process water was spilled on the surface at this site; there is anecdotal information suggesting that there once was an infiltration pond for disposing of clean process water in the vicinity.

Data for the water from the moist sediment zone are of great interest in deciphering subsurface water movement. The data show that the water is not from direct, vertical infiltration because the isotopic composition of porewater above and below the moist zone is different than that of the water from the moist zone. The most likely source for the porewater in this zone is the 216-S-3 crib located $\sim 50$ meters ( $\sim 65$ feet) northwest of the borehole, though some contribution from the S-SX tank farms is possible.

In summary, the stable isotopic composition of porewater collected from sediment in Waste Management Area S-SX was used to distinguish water from liquid disposal sources from natural infiltration.

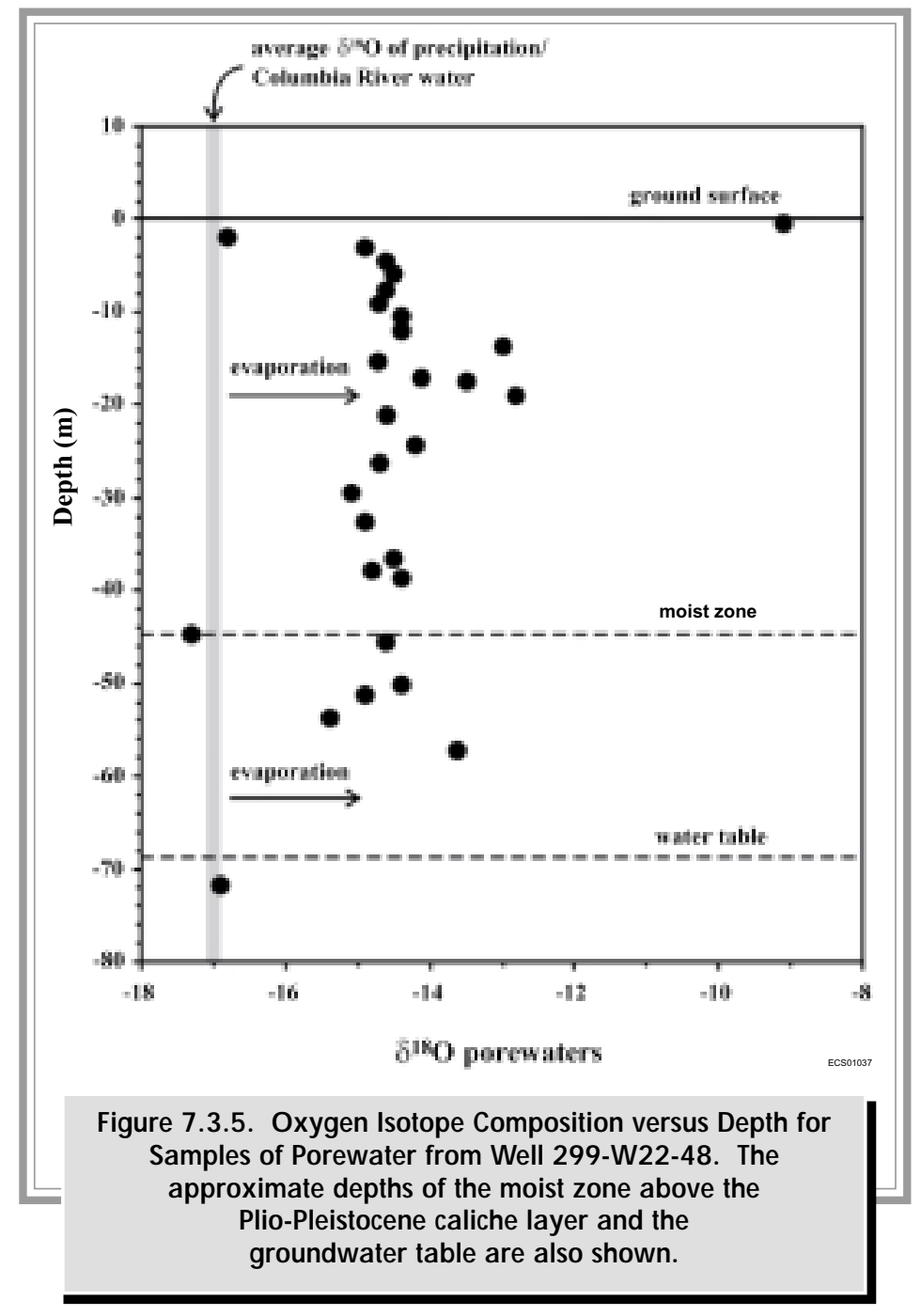

\subsection{Predicting Deep Drainage Using Soil Hydraulic Properties and Soil Texture Data}

\section{G. W. Gee and A. L. Ward}

Movement of contaminants from leaking tanks is accelerated by infiltration of precipitation. Tank farms and other waste sites at Hanford are generally covered with gravel and kept free of vegetation. These factors eased operation of the tanks and prevented uptake of contaminants by plants or animals, but enhanced infiltration of precipitation.

This study used data collected from previous studies to calibrate a simple water balance model that predicts infiltration. The previous studies included Gee et al. 1992, PNNL-13033, Tyler et al. 1999, PNL-6488, PNL-6403, and Gee and Bauder 1986.
Independent drainage data was collected to test the model. The independent data were from a 7 -meter(23-foot-) deep basin lysimeter, a device for measuring infiltration, at the Hanford Site's Solid Waste Landfill where data have been collected since 1996. At each site, texture of the surface soil (grain size distribution) was determined using wet sieving and hydrometer analysis (Gee and Bauder 1986).

Deep infiltration at waste burial sites at the Hanford Site is best analyzed by assessing the complete water balance of the surface soil. Infiltration is an integral component of the water balance and in its simplest form is equal to precipitation minus the sum of storage change plus evapotranspiration plus run-off/run-on. 
Water balance of surface soil is controlled by three main variables: climate, soil, and vegetation. The assessment of net infiltration at the waste sites involved the interaction of these three factors. The Tank Farm Water Balance Model is based on the climate, soil, and vegetation applicable to the tank farms and the fact that most waste sites have highly permeable surfaces and are on relatively level ground (little or no run-off or run-on). The model also assumes that winter precipitation dominates the net infiltration process and that annual water storage changes are negligible.

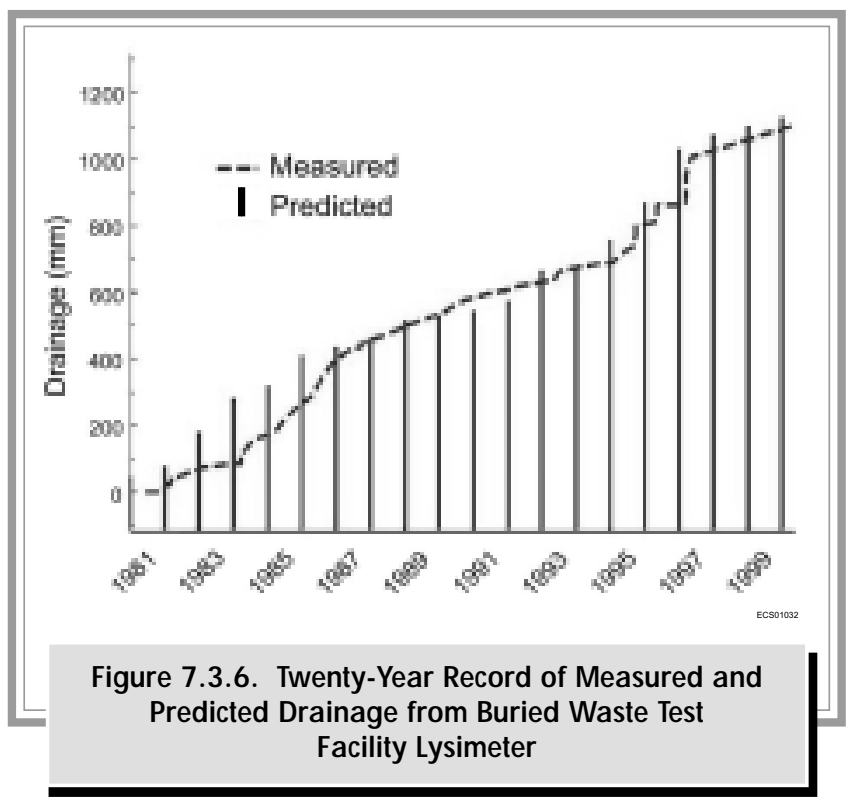

The performance of the water balance model is shown in Figure 7.3.6, where the model is applied to the lysimeter data from the Buried Waste Test Facility. The agreement between modeled and observed infiltration is good. However, the model was not independent of the lysimeter data, because the infiltration for the first 15 years from the lysimeter was used in fitting the evaporation factor in the model. However, the model then was applied to independent data from the Solid Waste Landfill lysimeter (HNF-7173). Table 7.3.1 shows measured annual infiltration compared to that predicted by the water balance model for a 4 -year period. The annual infiltration is predicted within 4 millimeters (0.16 inch) for all 4 years. (The calendar year 1997 winter precipitation exceeds the 1997 annual precipitation because the winter precipitation was calculated from November 1996 to March 1997.)

Uncertainty in the infiltration is dependent on uncertainties in the surface soil texture. Variations in the percentage of fine-grained materials by several percentage points can alter the infiltration estimate by 10 to $20 \mathrm{mil}$ limeters ( 0.4 to 0.8 inch) per year or more. For example, an increase of fine-grained material from $1 \%$ to $7 \%$ reduces the predicted infiltration by a factor of nearly 3 , from 80 to 28 millimeters ( 3.1 to 1.1 inches) per year.

Infiltration predictions were developed for several tank farms, where texture data were available for surface sediment. Table 7.3.2 shows the predicted annual infiltration from the Tank Farm Water Balance Model, based on

\begin{tabular}{|c|c|c|c|c|}
\hline \multirow[b]{2}{*}{ Year } & \multicolumn{4}{|c|}{$\begin{array}{l}\text { Table 7.3.1. Measured Drainage at the Hanford Solid Waste Landfill } \\
\text { Compared to that Predicted by the Tank Farm Water Balance Model }\end{array}$} \\
\hline & $\begin{array}{c}\text { Annual } \\
\text { Precipitation } \\
(\mathbf{m m})^{(\mathrm{a})}\end{array}$ & $\begin{array}{l}\text { Winter } \\
\text { Precipitation } \\
\left(_{(\mathrm{mm})^{(\mathrm{a})}}\right.\end{array}$ & $\begin{array}{c}\text { Measured } \\
\text { Drainage } \\
(\mathrm{mm})^{(\mathrm{a})}\end{array}$ & $\begin{array}{c}\text { Predicted } \\
\text { Drainage } \\
\left(_{(\mathbf{m m})^{(a)}}\right.\end{array}$ \\
\hline 1997 & 162 & 224 & 162 & 158 \\
\hline 1998 & 164 & 107 & 41 & 42 \\
\hline 1999 & 95 & 86 & 22 & 21 \\
\hline 2000 & 205 & 88 & 19 & 23 \\
\hline
\end{tabular}




\begin{tabular}{|c|c|c|c|}
\hline \multicolumn{4}{|c|}{$\begin{array}{l}\text { Table 7.3.2. Predicted Drainage Rates from the Tank Farm Water Balance Model } \\
\text { Related to Percent Fines in Surface Sediment and Percentage of Annual } \\
\text { Precipitation Based on a } 20 \text {-Year Record }\end{array}$} \\
\hline Site/Soil & Percent Fines $^{(a)}$ & Drainage (mm/yr) & Percent Precipitation \\
\hline AP tank farm & 1 & 80 & 43 \\
\hline S tank farm & 3 & 56 & 30 \\
\hline U tank farm & 7 & 28 & 15 \\
\hline Coarse gravel & 0 & 98 & 53 \\
\hline Solid Waste Landfill Site & 3 & 56 & 32 \\
\hline Silt loam & 60 & 0 & 0 \\
\hline
\end{tabular}

surface texture and the past 20-year climate record. Infiltration estimates from the texture data suggest that over a 20 -year period, the average infiltration rate ranged from $15 \%$ to over $50 \%$ of the annual average precipitation (28 to 80 millimeters per year [0.8 to 3.1 inches per year]).

Data available from lysimeter studies at the Hanford Site have shown that winter precipitation and surface textures are the dominant controls to waste site drainage (Gee et al. 1992; PNNL-13033). The calibration data set for the Tank Farm Water Balance Model contains a 20-year precipitation record and infiltration from lysimeters with surfaces ranging from clean gravels to fine silt loams. Combining these data into a water balance model has led to a simple expression for predicting infiltration at tank farms and other waste sites that have bare surfaces. The model does not account for thermal effects on evaporation due to radioisotope heated tank waste, i.e., warmer subsurface temperatures could increase the evaporation rates from tank farms thus decreasing infiltration. For this reason, the values reported here may overestimate the actual infiltration fluxes. There have been no direct measurements of infiltration at Hanford Site tank farms and only one set of measurements for other waste burial grounds (the Solid Waste Landfill), so full verification of the model remains to be completed as additional data are collected. 


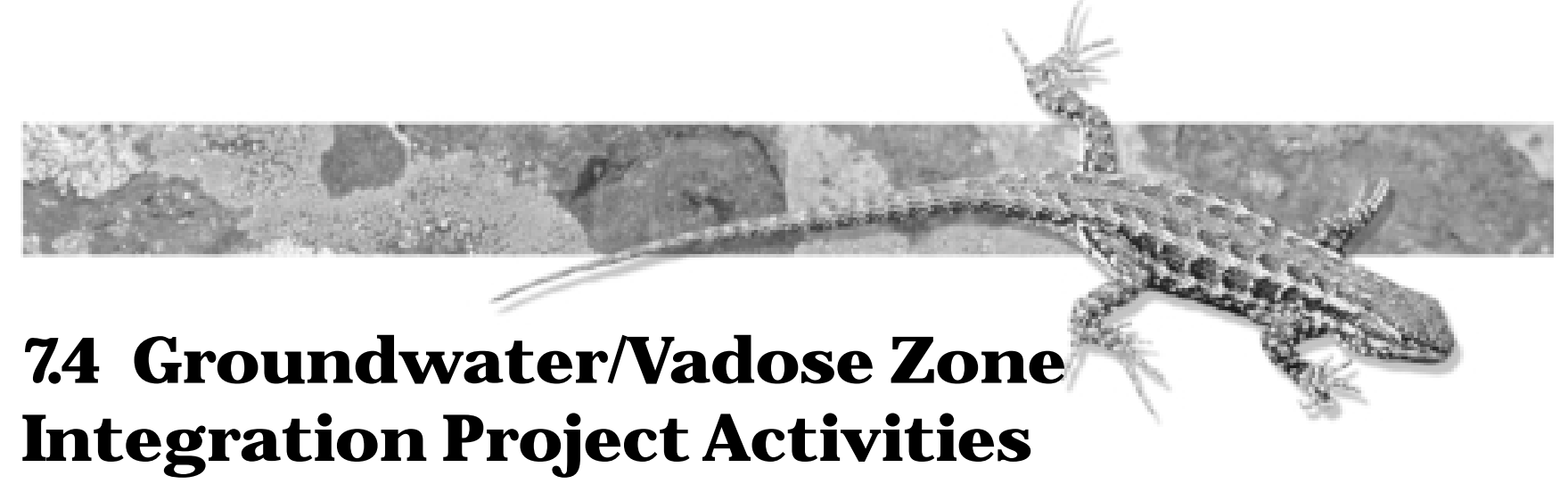

\author{
D. G. H orton
}

Several activities were completed in 2001 to support the Groundwater/Vadose Zone Integration Project's System Assessment Capability modeling efforts. Data were gathered to describe the distribution of subsurface contamination for comparison with the results of numerical models describing contaminant distribution.
Also, activities were completed that describe the features, events, and processes that are important for waste management and remediation efforts at the Hanford Site. This section discusses the activities of the vadose zone module of the System Assessment Capability.

\title{
74.1 Hanford Site Hydrogeologic Databases
}

\section{G. H orton}

The Characterization of Systems Task under the Groundwater/Vadose Zone Integration Project is responsible for establishing a consistent set of data, parameters, and conceptual models to support efforts to estimate the migration and impact of contaminants at the Hanford Site. As part of these efforts, the task assembled a series of catalogs in 2001 that identified the depth and breadth of existing geologic, hydrologic, and geochemical data. These catalogs are the first step in developing a comprehensive, useable, and scientifically defensible database of geologic, hydrologic, and geochemical data.

Fifty-five years of technical data gathering at the Hanford Site have resulted in data scattered among numerous databases, published and unpublished reports, and the technical files of individual contributors. The purpose of the catalogs was to identify these existing data, make an initial cursory assessment of the quality of the data, and gather the sources of the data in one place. Three catalogs were published and a fourth was drafted:

- A C atalog of $G$ eologic Data for the $H$ anford Site (PNNL-13653)

- A C atalog of Vadose Zone H ydraulic Properties for the $\mathrm{H}$ anford Site (PNNL-13672)

- Data C atalog for M odels Simulating Release of C ontaminants from $\mathrm{H}$ anford Site Waste Sources (PNNL-13666)
- $H$ anford $C$ ontaminant $D$ istribution C oefficient D atabase and U sers G uide (PNNL-13895).

The geologic data report (PNNL-13653) includes 2,640 wells and boreholes in the 100 Areas, 200 Areas, and 300 Area from which some kind of geologic data exist. Nearly all of the wells $(2,501)$ have some form of driller's $\log$ or geologist's log. Archived samples are available from 1,740 wells. Particle size distribution data are available from 1,124 of the wells, calcium carbonate content is available from 981 wells, and moisture content data from 423 locations. Most wells have data from numerous samples (e.g., 1.5-meter [5-foot] intervals throughout the well). In addition, some kind of geochemical data (excluding calcium carbonate content data) are available from 587 wells, physical property data (other than particle size distribution and moisture) are available for 269 wells, mineralogic information is available from 52 wells, and geochronology data from 23 wells. The report also contains an annotated bibliography of 158 references that contain the geologic data. This compilation of data sources is the most comprehensive made for the Hanford Site. It is believed that $>90 \%$ of the available geologic data are represented.

The hydraulic property catalog (PNNL-13672) contains data sources from 182 boreholes and surface locations on the Hanford Site. For each sample location, there may be data from multiple depth intervals and many measurements taken at multiple time intervals. Table 7.4.1 shows the types of data available and their locations. 


\begin{tabular}{|c|c|c|c|c|c|c|c|c|c|c|}
\hline $\begin{array}{l}\text { Location } \\
\text { (A rea) }\end{array}$ & Sieve & Density & Moisture & $\begin{array}{l}\text { Unsaturated } \\
\text { Conductivity }\end{array}$ & $\begin{array}{c}\text { Saturated } \\
\text { Conductivity }\end{array}$ & N eutron & Storage & Drainage & $\begin{array}{l}\text { Water } \\
\text { Profile }\end{array}$ & $\begin{array}{c}\text { Air } \\
\text { Permeability }\end{array}$ \\
\hline 100 & 84 & 84 & 84 & 33 & 33 & (a) & .- & .- & .. & .. \\
\hline 200-East & 122 & 125 & 108 & 63 & 46 & 36 & .. & 2 & .. & 1 \\
\hline 200-West & 163 & 124 & 60 & 89 & 29 & .. & 1 & 3 & 1 & 1 \\
\hline 300 & .. & .. & 2 & .. & .- & .. & 1 & 1 & 1 & .. \\
\hline 400 & .- & .. & .. & .. & .. & .. & .. & 1 & 1 & .. \\
\hline 600 & 177 & 168 & 149 & 49 & 46 & .. & 8 & 9 & 8 & .. \\
\hline Total & 468 & 501 & 423 & 234 & 154 & 36 & 10 & 16 & 11 & 2 \\
\hline
\end{tabular}

The report summarizing release models (PNNL13666) used in Hanford Site assessments published over the past 14 years (1987 to 2001)

- provides a summary of descriptions and uses of release models

- describes mathematical formulations that commonly have been used in recent years

- links release models to data on various waste sources found on the Hanford Site (i.e., saltcake, cement, soil-debris, reactor block, glass, and corrosion)

- provides sources of information and data used in the models.

The links allow users to quickly locate the specific release model information and data sources they need to apply the models to future site assessments.
The fourth report (PNNL-13895) contains distribution coefficient data for the sorption of several species on Hanford Site sediments. It is believed that $\sim 90 \%$ of existing distribution coefficients are represented in the database. Table 7.4.2 lists the species for which data are compiled. Included with the distribution coefficients are pertinent experimental data such as the experimental method, equilibration time, initial concentrations in solution, solution/solid ratio, and source reference. In addition to these data, more detailed information about the solution composition and the composition and characteristics of the sediment are given in two appendices of PNNL-13895.

\begin{tabular}{|c|c|c|c|c|c|c|c|}
\hline \multirow[b]{2}{*}{ Species } & \multicolumn{6}{|c|}{ Table 7.4.2. Distribution Coefficients Included in the Geochemical Compilation } & \multirow[b]{2}{*}{$\begin{array}{c}\text { Strontium } \\
\left(\mathbf{S r}^{2+}\right)\end{array}$} \\
\hline & $\underset{\left(\mathrm{Am}^{3+}\right)}{\operatorname{Americium}}$ & $\begin{array}{l}\text { Cobalt } \\
\left(\mathrm{CO}^{2+}\right)\end{array}$ & $\begin{array}{c}\text { Cesium } \\
\left(\mathbf{C s}^{+}\right)\end{array}$ & $\begin{array}{l}\text { Nickel } \\
\left(\mathrm{Ni}^{23+}\right)\end{array}$ & $\begin{array}{l}\text { Lead } \\
\left(\mathrm{Pb}^{2+}\right)\end{array}$ & $\begin{array}{c}\text { Plutonium } \\
\text { (Pu) }\end{array}$ & \\
\hline $\begin{array}{l}\text { Number of } \\
\text { Data }\end{array}$ & 60 & 74 & 126 & 50 & 48 & 87 & 220 \\
\hline Species & $\begin{array}{c}\text { Chromate } \\
\left(\mathrm{CrO}_{4}^{2-)}\right)\end{array}$ & $\begin{array}{l}\text { Iodine } \\
\text { (I) }\end{array}$ & $\begin{array}{l}\text { Nitrate } \\
\left.\text { ( } \mathrm{NO}_{3}^{-}\right)\end{array}$ & $\begin{array}{l}\text { Neptunyl } \\
\text { Ion ( } \mathrm{N} \mathrm{pO}^{2+} \text { ) }\end{array}$ & $\begin{array}{c}\text { Selenite } \\
\text { Ion }\left(\mathrm{SeO}_{4}^{2-}\right)\end{array}$ & $\begin{array}{l}\text { Pertechnetate } \\
\text { Ion }\left(\mathrm{TCO}_{4}^{-}\right)\end{array}$ & $\begin{array}{c}\text { U ranyl } \\
\text { Ion }\left(\mathrm{U} \mathrm{O}_{2}^{2+}\right)\end{array}$ \\
\hline $\begin{array}{l}\text { Number of } \\
\text { Data }\end{array}$ & 20 & 61 & 12 & 84 & 49 & 83 & 76 \\
\hline
\end{tabular}




\subsection{Initial Assessment Using the System Assessment Capability - Prelim inary Vadose Zone Results}

\section{G. H orton and G . V. Last}

An initial assessment is being conducted with the System Assessment Capability that simulates the transport of 10 different radionuclide and chemical contaminants released from 890 wastes sites, over a time frame of about 1100 years from 1944 through 3050. (The System Assessment Capability is the initial set of tools and data to determine the impact of the Hanford Site on the nearby environment.) During 2001, an initial assessment was performed to demonstrate proof-of-principle for the capability. The following discussion focuses on some preliminary results from vadose zone simulations conducted at the end of fiscal year 2001.

Three major efforts were associated with the vadose zone portion of the initial System Assessment Capability assessment: data gathering, history matching, and the initial simulations. This section summarizes each of these efforts.

Data Gathering. Data were compiled to support vadose zone modeling as part of the initial assessment performed using the System Assessment Capability. The data defined the physical and geochemical parameters for the vadose simulations conducted as part of the initial assessment.

Thirteen aggregate areas were defined based on geographically contiguous areas with relatively homogeneous hydrogeologic characteristics. Each of the six 100 Areas were designated as separate aggregate areas; the 200 Areas were divided into six aggregate areas based on differences in hydrogeologic characteristics; and a single aggregate area was defined for the 300 and 400 Areas.

Generalized geologic sequences were defined for each of the 13 aggregate areas. The sequences were based on existing information from driller's logs, geologist's logs, geophysical logs, and published interpretive depths of hydrogeologic units. Estimated average strata thicknesses were used for the generalized columns.

Hydraulic property data were assigned to each layer in each geologic sequence. From these data, residual saturation and effective porosity were estimated. Data were taken from WHC-EP-0883, HNF-4769, RPP-2696, and SAND98-2880.

Six types of waste chemistry were defined for use in the Composite Analysis (PNNL-11800). (The Composite Analysis is a radiological assessment to estimate dose to hypothetical future members of the public from lowlevel waste disposal and all other sources of radioactive contamination at the Hanford Site.) These waste chemistry types describe chemically distinct waste streams that affect the sorption of contaminants.

These same waste chemistry types were adapted for use in the initial assessment of the System Assessment Capability to assign distribution coefficients to each geologic layer in each of the 13 geologic sequences. The distribution coefficients describe the mobility of each specific contaminant in the vadose zone environment.

Finally, recharge rates were estimated for all surface conditions under consideration for the initial assessment of the System Assessment Capability. These conditions include four different barrier designs, degraded barriers, natural conditions, and unique conditions created by human activity.

V adose Zone $\mathbf{H}$ istory Matching. The purpose of the history matching effort was to compare test model predictions with field observations. Eight facilities were selected for System Assessment Capability history matching (Table 7.4.3). These facilities were selected because they represented

- facilities from different aggregate areas

- facilities with a range in discharge from low volume (216-B-46 crib) to high volume (216-A-8 crib)

- facilities that received chemically different waste steams

- facilities that received at least one of the selected constituents of interest (cesium-137, technetium-99, carbon tetrachloride, plutonium-239/240, and tritium)

- facilities for which historical subsurface contaminant distributions through time were available.

Each facility was assigned an array of attributes that included one of the 13 geologic sequences with assigned hydrologic and chemical properties, the volume of waste discharged, and the surface area receiving the discharge.

Four types of data were used to describe the historical distribution of contamination in the vadose zone: borehole spectral gamma-ray logs, laboratory data obtained from soil samples collected during drilling, 


\begin{tabular}{|c|c|c|c|c|}
\hline \multirow[b]{2}{*}{ Facility } & \multicolumn{3}{|c|}{ Table 7.4.3. Test Cases for Vadose Zone History Matching } & \multirow[b]{2}{*}{$\begin{array}{l}\text { Simulation ID } \\
\text { Number }\end{array}$} \\
\hline & Constituent & $\begin{array}{c}\text { Year } \\
\text { Simulated }\end{array}$ & $\begin{array}{l}\text { Facility A rea } \\
\text { Multiplier }\end{array}$ & \\
\hline \multirow{4}{*}{$216-A-8$ crib } & ${ }^{137} \mathrm{Cs}$ & 1995 & $1 \mathrm{x}$ & 1 \\
\hline & & & $2 \mathrm{x}$ & 2 \\
\hline & ${ }^{99} \mathrm{Tc}$ & $1945-2050$ & $1 \mathrm{x}$ & 3 \\
\hline & ${ }^{3} \mathrm{H}$ & $1945-2050$ & $1 \mathrm{x}$ & 4 \\
\hline \multirow[t]{3}{*}{ 216-B-5 reverse well } & ${ }^{137} \mathrm{Cs}$ & 1979 & $1 \mathrm{x}$ & 5 \\
\hline & & & $5 \mathrm{x}$ & 6 \\
\hline & & & $50 \mathrm{x}$ & 7 \\
\hline \multirow[t]{5}{*}{ 216-B-46 crib } & ${ }^{137} \mathrm{Cs}$ & 1991 & $1 \mathrm{x}$ & 8 \\
\hline & & & $0.5 \mathrm{x}$ & 9 \\
\hline & & 1996 & $1 \mathrm{x}$ & 10 \\
\hline & ${ }^{99} \mathrm{Tc}$ & $1945-2050$ & $1 \mathrm{x}$ & 11 \\
\hline & ${ }^{3} \mathrm{H}$ & $1945-2050$ & $1 \mathrm{x}$ & 12 \\
\hline \multirow[t]{2}{*}{ 241-T-106 tank } & ${ }^{137} \mathrm{Cs}$ & 2000 & $1 \mathrm{x}$ & 13 \\
\hline & & & $0.5 \mathrm{x}$ & 14 \\
\hline \multirow[t]{8}{*}{ 216-Z-1A tile field } & ${ }^{239 / 240} \mathrm{Pu}$ & 1998 & $1 \mathrm{x}$ & 15 \\
\hline & & & $2 \mathrm{x}$ & 16 \\
\hline & & 2050 & $1 \mathrm{x}$ & 17 \\
\hline & & & $2 \mathrm{x}$ & 18 \\
\hline & & 3000 & $1 \mathrm{x}$ & 19 \\
\hline & & & $2 \mathrm{x}$ & 20 \\
\hline & Carbon tetrachloride & 1992 & $1 \mathrm{x}$ & 21 \\
\hline & & 2050 & $1 \mathrm{x}$ & 22 \\
\hline \multirow[t]{2}{*}{$216-Z-12$ crib } & ${ }^{239 / 240} \mathrm{Pu}$ & 1998 & $1 \mathrm{x}$ & 23 \\
\hline & & 2050 & $1 \mathrm{x}$ & 24 \\
\hline \multirow[t]{3}{*}{ 216-U-10 pond } & Water & $1940-2045$ & $1 \mathrm{x}$ & 25 \\
\hline & & & $2 x$ & 26 \\
\hline & & & $3 \mathrm{x}$ & 27 \\
\hline \multirow[t]{2}{*}{$216-\mathrm{U}-12 \mathrm{crib}$} & ${ }^{137} \mathrm{Cs}$ & 1991 & $1 \mathrm{x}$ & 28 \\
\hline & & & $2 \mathrm{x}$ & 29 \\
\hline
\end{tabular}

gross gamma-ray logs, and groundwater chemistry data. Three criteria were developed with which to judge the success of the System Assessment Capability simulations. The criteria were

- Does the simulated result place the center of mass of the contaminant distribution within the same hydrogeologic unit as the measured center of mass for the same time period? If yes then,

- Does the simulated center of mass fall within \pm 2 meters ( \pm 6.5 feet) of the measured center of mass for plutonium-239 or within \pm 3 meters ( \pm 10 feet) of the measured center of mass for cesium-137?
- For highly mobile constituents (e.g., carbon tetrachloride, technetium-99, tritium), the success criterion was whether the simulation matched the time of first arrival of a surrogate constituent at the water table within \pm 2 years.

Table 7.4.3 lists the 29 cases tested. Table 7.4.4 shows the results of each history match test. Figure 7.4.1 shows an example history matching result. The figure shows a comparison of two simulated cesium-137 distributions with the measured concentrations for the 216-A-8 crib in the 200-East Area.

The two simulations include (1) a $1 \mathrm{x}$ simulation that used the facility dimensions to define the wetted 


\begin{tabular}{|c|c|c|c|c|c|}
\hline \multirow[b]{2}{*}{ Facility } & \multicolumn{4}{|c|}{ Table 7.4.4. Results of Vadose Zone History Matching(a) } & \multirow[b]{2}{*}{$\begin{array}{l}\text { Simulated } \\
\text { Center of M ass } \\
\text { (depth in m) }\end{array}$} \\
\hline & $\underline{\text { ID }}$ & $\begin{array}{c}\begin{array}{c}\text { Stratigraphic } \\
\text { (or First }\end{array} \\
\text { A rrived) Criteria } \\
\end{array}$ & $\begin{array}{c}\text { Simulated } \\
\text { Stratigraphy (or) } \\
\text { First Arrival) }\end{array}$ & $\begin{array}{l}\text { Center of } \\
\text { Mass Criteria } \\
\text { (depth in } \mathrm{m} \text { ) }\end{array}$ & \\
\hline $216-A-8$ crib & $\begin{array}{l}1 \\
2 \\
3 \\
4\end{array}$ & $\begin{array}{l}\text { Hanford gravel } \\
\text { Not determined } \\
\text { Not determined }\end{array}$ & $\begin{array}{c}H \text { anford sand } \\
\text { Hanford gravel } \\
2017 \\
1956\end{array}$ & 7.8 & $\begin{array}{c}11.2 \\
8.2\end{array}$ \\
\hline 216-B-5 reverse well & $\begin{array}{l}5 \\
6 \\
7\end{array}$ & Ringold Formation & $\begin{array}{l}\text { H anford formation/ } \\
\text { Plio-Pleistocene }\end{array}$ & Not determined & Not determined \\
\hline $216-\mathrm{B}-46 \mathrm{crib}$ & $\begin{array}{c}8 \\
9 \\
10 \\
11 \\
12\end{array}$ & $\begin{array}{l}\text { Hanford gravel } \\
\qquad \begin{array}{c}(1956) \\
(1956)\end{array}\end{array}$ & $\begin{array}{l}\text { Hanford gravel } \\
\qquad \begin{array}{c}(1956) \\
(1956)\end{array}\end{array}$ & $\begin{array}{l}8.3 \\
12.3\end{array}$ & $\begin{array}{l}5.1 \\
5.3 \\
5.1\end{array}$ \\
\hline 241-T-106 tank & $\begin{array}{l}13 \\
14\end{array}$ & Hanford gravel & $\mathrm{H}$ anford gravel & 13.2 & $\begin{array}{l}12.0 \\
12.1\end{array}$ \\
\hline 216-Z-1A tile field & $\begin{array}{l}15 \\
16 \\
17 \\
18 \\
19 \\
20 \\
21 \\
22\end{array}$ & Backfill & $\begin{array}{c}\text { Hanford gravel } \\
\text { NA }{ }^{(b)} \\
\text { NA } \\
\text { NA } \\
\text { NA } \\
\text { CCL4 did not reach }\end{array}$ & 5.2 & $\begin{array}{r}8.2 \\
7.5 \\
\text { NA } \\
\text { NA } \\
\text { NA } \\
\text { NA }\end{array}$ \\
\hline $216-Z-12 \mathrm{crib}$ & $\begin{array}{l}23 \\
24\end{array}$ & Hanford gravel & $\begin{array}{l}\text { Backfill } \\
\text { NA }\end{array}$ & 7.2 & $\begin{array}{r}5.8 \\
\mathrm{NA}\end{array}$ \\
\hline 216-U-10 pond & $\begin{array}{l}25 \\
26 \\
27\end{array}$ & \multicolumn{4}{|c|}{$\begin{array}{l}\text { Simulations for } 216-\mathrm{U}-10 \text { pond were done only to assure that the model worked for a } \\
\text { pond disposal site }\end{array}$} \\
\hline $216-\mathrm{U}-12 \mathrm{crib}$ & $\begin{array}{l}28 \\
29\end{array}$ & Hanford coarse & Hanford coarse & 7.3 & $\begin{array}{l}7.1 \\
6.0\end{array}$ \\
\hline $\begin{array}{l}\text { (a) Criteria in italics } \\
\text { (b) NA = Not appli }\end{array}$ & p & $\begin{array}{l}\text { eptance criteria. } \\
\text { ulations of future con }\end{array}$ & int configurations. & & \\
\hline
\end{tabular}

column area beneath the crib and (2) a $2 x$ simulation that used twice the facility dimensions to define the wetted column area. Adjustments to the wetted areas were an attempt to capture the lateral spreading that normally occurs in the vadose zone.

Comparing the concentrations measured in field data obtained in 1995 with the simulated concentrations for the $1 \mathrm{x}$ case showed that the bulk of contamination as measured in the field was at a depth of 7.8 meters (25.6 feet), whereas the simulated bulk of contamination was at a depth of 11.2 meters ( 37 feet). Also, the bulk of measured contamination was within the Hanford formation gravel sequence, whereas the simulated result was within the Hanford formation sand sequence. Thus, the simulation was outside both acceptance criteria.
Comparing the results for the $2 \mathrm{x}$ case showed that the simulated bulk of contamination was at a depth of 8.2 meters ( 27 feet) and within the Hanford formation gravel sequence. Thus, the $2 \mathrm{x}$ simulation was within the acceptance criteria.

Approximately $30 \%$ of the deterministic test cases initially failed to meet the acceptance criteria. However, modifications to the wetted column areas reduced the failure rate to $<20 \%$. Those test cases that continued to fall outside the acceptance criteria were associated primarily with either plutonium or carbon tetrachloride.

The reasons the plutonium test cases failed were due in part to the assigned generalized stratigraphy and associated hydraulic properties and in part to the 


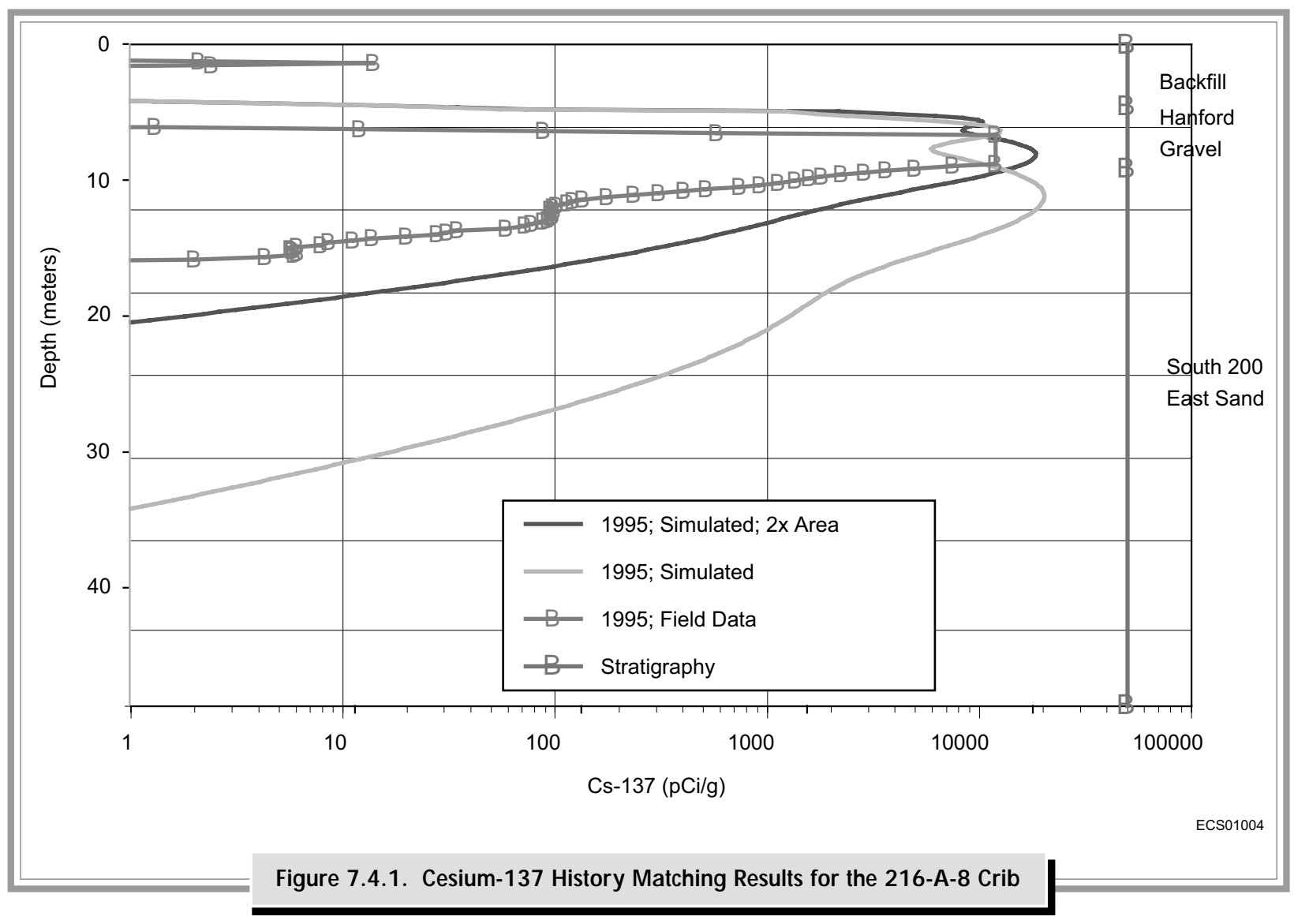

simplified algorithms used to simulate plutonium transport. In reality, plutonium in the effluent stream was probably present as both a plutonium dioxide particulate that was filtered from the effluent by the sediment directly beneath the facilities and as an organometallic complex which transported plutonium deeper in the system (RHO-ST-17), neither of which was accounted for in the simulation.

The carbon tetrachloride simulations failed because they considered only aqueous phase transport and not organic (non-aqueous) phase transport.

The overall results of the history matching exercise indicated that the System Assessment Capability computer codes were ready for the overall history match and initial assessment.

Initial Results of the System A ssessment Capability. The migration of contaminants through the vadose zone was simulated with the Subsurface Transport Over Multiple Phases (STOMP) computer code (PNNL-11217; PNL-8637). The original 890 waste sites were reduced to 719 sites by aggregating nearby solid waste or low volume liquid disposal sites.
Four vadose zone template models were prepared for each of the 13 aggregate areas. These corresponded to sites representing surface liquid disposal, shallow land liquid disposal (cribs and trenches), buried waste tank disposal, and reverse well disposal of contaminants. A total of 67 base templates were prepared. By distributing copies of the base templates, 719 site templates were created, each of which was then modified within the System Assessment Capability model by inserting randomly selected values from the range of possible values for hydrologic and geochemical properties to create the final set of input files for simulation.

Preliminary results from the initial assessment are available for 25 simulations of 9 contaminants at 719 vadose zone release locations, or a total of 161,775 individual simulations. Direct analysis of individual results was impractical, so a way was developed that allowed evaluation of accumulated results in various ways. The results were examined at a variety of levels from individual contaminants at an individual waste disposal site to total releases from the Hanford Site as a whole. The results also indicated where improvements to the initial assessment were needed and provided insight in understanding Hanford Site issues. 
At one level, the total Hanford Site releases from the vadose zone to groundwater were summed over all 719 sites by year, by constituent, and by simulation. An example of this is shown in Figure 7.4.2 that illustrates the total Hanford Site releases by constituent. This figure indicates that nearly all releases from the vadose zone to the groundwater occurred prior to $\sim 1990$, except for carbon tetrachloride and hexavalent chromium, which will continue to be released for some time into the future.

Another analysis determined the mass balance and vadose zone releases to groundwater by disposal facility type and by operational area. For example, Figure 7.4.3 illustrates the releases of tritium from the vadose zone to groundwater from the various types of disposal facilities. The results indicate that nearly all releases are from cribs and that they occurred before $\sim 1995$.

\section{Use of Process Relationship Diagrams to Develop Conceptual Models}

\section{G. V. Last, V. J. Rohay, F. J. Schelling, and L. Soler}

This section reproduces the abstract of the report PNNL-SA-34515 that describes the strengths and limitations of process relation diagrams. The actual master process relationship diagram and two test case diagrams are presented in the original report. They are not reproduced here because of the complexity of the diagrams.

The Characterization of Systems Task under the Groundwater/Vadose Zone Integration Project tested the application of features, events, and processes methodology (Nuclear Energy Agency 2000) for documenting the technical knowledge about the Hanford Site and application of that knowledge for performing impact/risk assessments. As part of that effort, the Characterization of Systems Task is evaluating the use of process relationship diagrams to document the relationships between features, events, and processes and to assist development, communication, and translation of conceptual models (i.e., what is known and not known about a particular environmental problem) into simplified implementation models that can be numerically simulated. A master process relationship diagram was created to describe the most relevant high-level processes and conditions affecting contaminant transport at the Hanford Site.

This diagram graphically represents the logical structure of how the environmental system works and identifies the important processes and their interrelationships. This master diagram was from domainspecific (e.g., vadose zone-specific) diagrams prepared independently for various components (technical

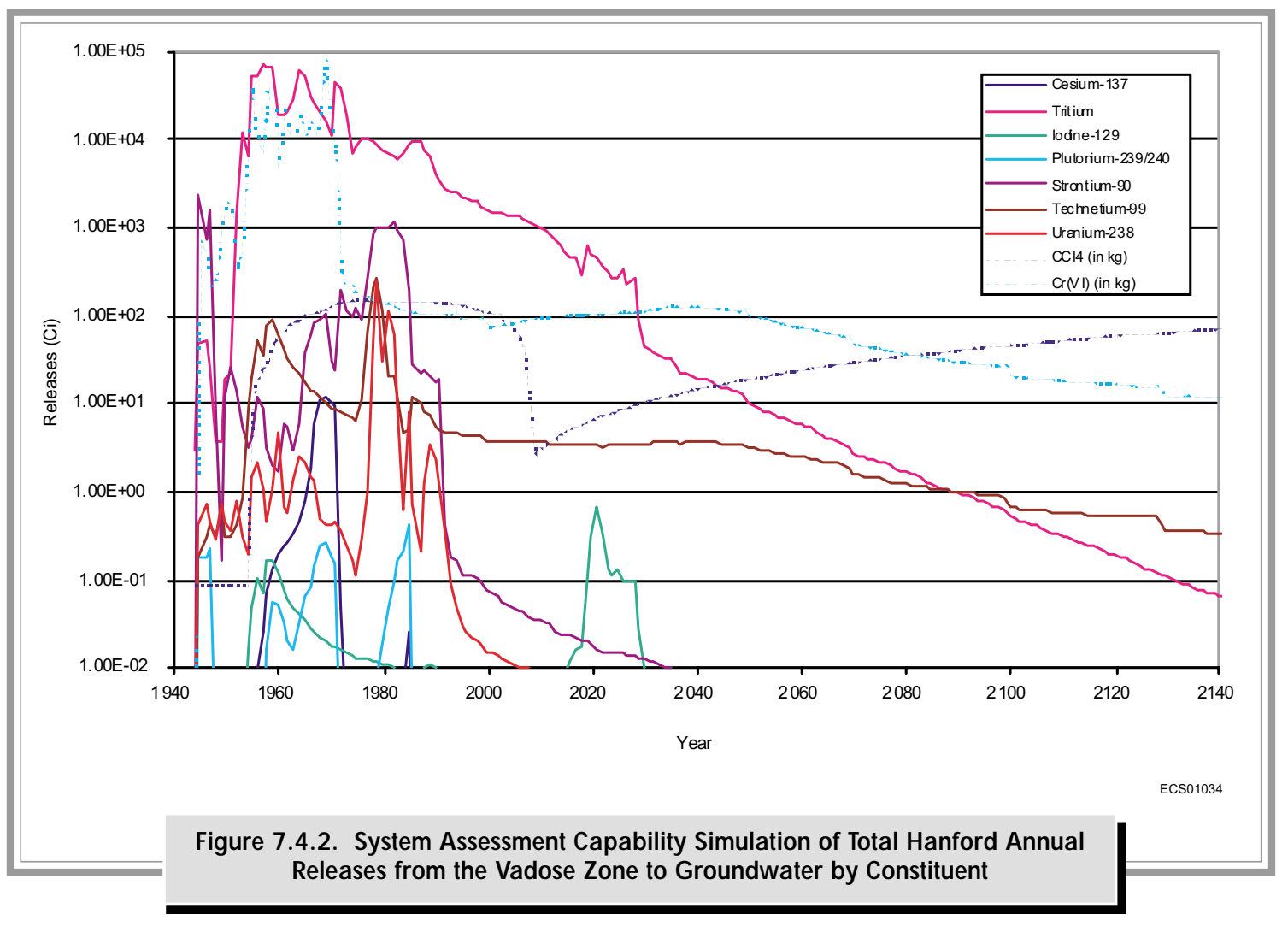




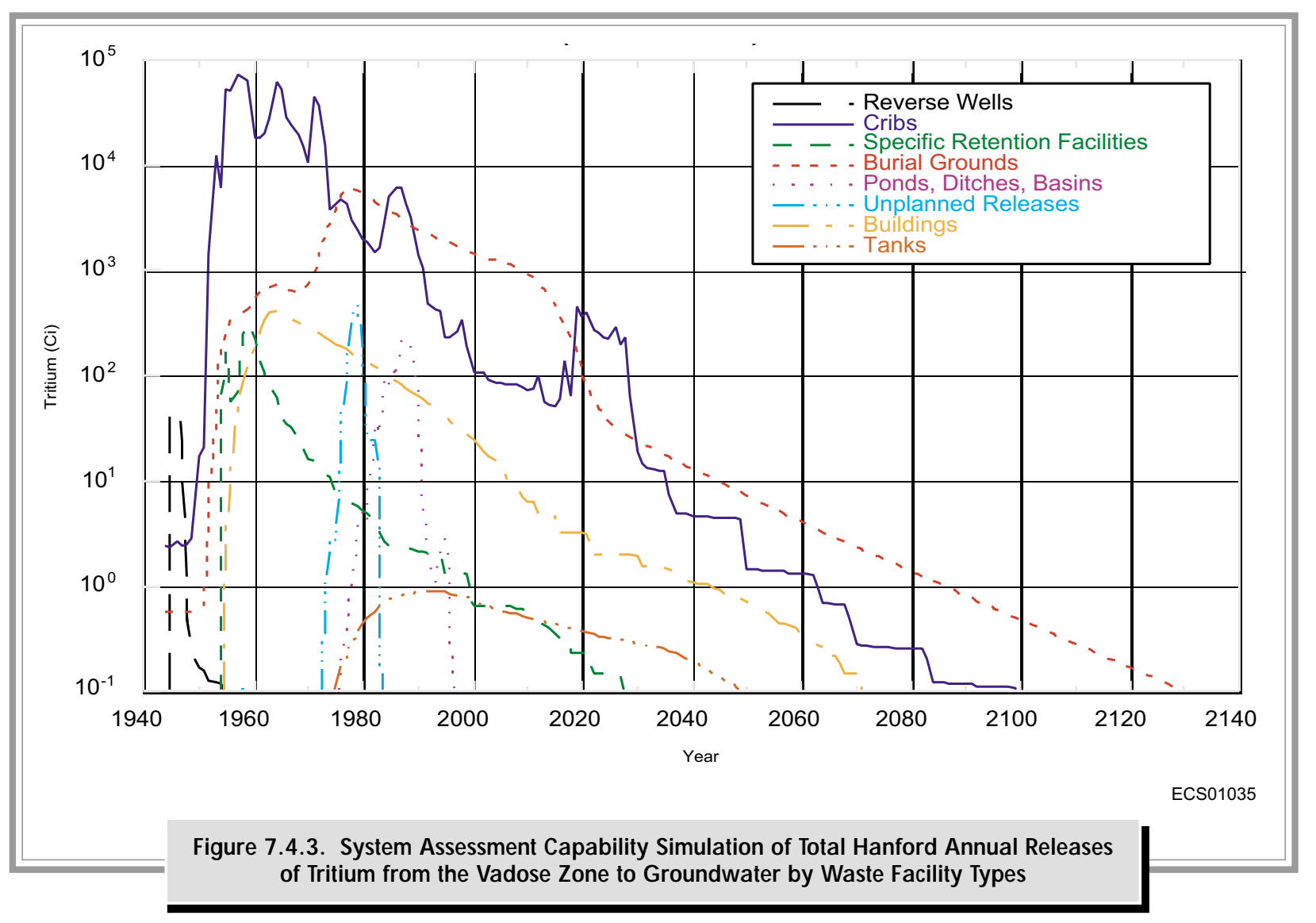

elements) of the system (i.e., inventory, release, vadose zone, groundwater, river, and risk). The diagram was necessarily simplified by focusing on processes, keeping it at a high level, and by not including details of the risk elements. The preparation of this master diagram was intended only as an example or template for the development of problem-specific diagrams.

The master process relationship diagram then was used to analyze two different types of problems from two related operable units. The first problem attempted to identify the dominant, and to some extent the subordinate, processes controlling the fate and transport of all contaminants released from the 200-PW-1 Operable Unit. (The 200-PW-1 Operable Unit is a group of related waste sites in the 200-East and 200-West Areas that received similar uranium-rich process waste.) The second problem attempted to examine different conceptual models for the 200-ZP-1 Operable Unit, a group of related waste sites in the 200-West Area that received carbon tetrachloride wastes, concerning high carbon tetrachloride concentration in groundwater beneath the Plutonium Finishing Plant, and in doing so, to assist site selection and data collection strategies for a proposed borehole that would test these various conceptual models.
These limited efforts suggest that development and application of process relationship diagrams is a useful approach with the flexibility to facilitate the development and documentation of conceptual models for many types of environmental problems. This approach also can provide a consistent framework and method to facilitate the completeness of those conceptual models. One of its greatest values is to facilitate discussion among the principal project scientists.

However, these diagrams can become very complex and can be difficult for audiences to visualize. It is often difficult to show on one diagram all the necessary levels of detail and important features, conditions, and attributes that affect the processes. Thus, several different diagrams at different levels of detail may be needed to represent a given problem. The use of a master process relationship diagram is not intended as a stand-alone tool, but instead should be used in a facilitated process, in combination with other methods (e.g., graphical illustrations, text, influence matrices, calculations), to fully analyze and document the conceptual models. 


\subsection{References}

BHI-00720, Rev. 4. 2000. Performance Evaluation Report for Soil Vapor Extraction Operations at the Carbon Tetrachloride Site, February 1992 - September 1999. V. J. Rohay, Bechtel Hanford, Inc., Richland, Washington.

BHI-01103, Rev. 0. 1999. Clastic Injection Dikes of the Pasco Basin and Vicinity. K. R. Fecht, K. A. Lindsey, B. N. Bjornstad, D. G. Horton, G. V. Last, and S. P. Reidel, Bechtel Hanford, Inc., Richland, Washington.

BHI-01489. 2001. Groundwater Monitoring and Sampling at the Environmental Restoration Disposal Facility, Calendar Year 2000. J. M. Faurote, T. M. Johansen, and C. W. Miller, Bechtel Hanford, Inc., Richland, Washington.

BHI-01541. 2001. 116-H-1 Characterization Borehole Results. J. J. Kious, Bechtel Hanford, Inc., Richland, Washington.

Comprehensive Environmental Response, Compensation, and Liability Act. 1980. Public Law 96-150, as amended, 94 Stat. 2767, 42 USC 9601 et seq.

DOE/RL-88-31. 1990. Remedial Investigation/Feasibility Study Work Plan for the 300-FF-1 Operable Unit, Hanford Site, Richland, Washington. U.S. Department of Energy, Richland Operations Office, Richland, Washington.

DOE/RL-91-32, Draft B. 1991. Expedited Response Action Proposal (EE/CA E EA) for 200 West Area Carbon Tetrachloride Plume, Appendix B. V. J. Rohay and V. G. Johnson for the U.S. Department of Energy, Richland Field Office, Richland, Washington.

Gee, G. W. and J. W. Bauder. 1986. "Particle-Size Analysis." In Methods of Soil Analysis, Part 1. Agronomy Monograph No. 9, A. Klute (ed.), Ch. 15, pp. 383-411, American Society of Agronomy, Madison, Wisconsin.

Gee, G. W., M. J. Fayer, M. L. Rockhold, and M. D. Campbell. 1992. "Variations in Recharge at the Hanford Site." Northwest Science 66(4):237-250.

HNF-4769, Rev. 1. 1999. Far-Field Hydrology Data Package for Immobilized Low-Activity Tank Waste. R. Khaleel, Fluor Daniel Northwest, Inc., Richland, Washington.
HNF-7173, Rev. 0. 2000. Hanford Solid Waste Landfill Closure Plan. DynCorp Tri-Cities Services, Inc., Richland, Washington.

HNF-EP-0182, Rev. 154. 2001. Waste Tank Summary Report for Month Ending January 31, 2001. B. M. Hanlon, CH2M HILL Hanford Group, Inc., Richland, Washington.

MAC-HGLP 1.8.1. 2001. Hanford Tank Farm Vadose Zone Monitoring Project, Baseline Monitoring Plan. U.S. Department of Energy, Grand Junction Office, Grand Junction, Colorado.

Nuclear Energy Agency. 2000. Features, Events and Processes (FEPs) for Geologic Disposal of Radioactive Waste, An International Database. Organisation for Economic Co-Operation and Development (OECD) Publications, France.

PNL-6403. 1987. Recharge at the Hanford Site: Status Report. G. W. Gee, Pacific Northwest Laboratory, Richland, Washington.

PNL-6488. 1988. Characterization of Unsaturated Hydraulic Conductivity at the Hanford Site. M. L. Rockhold, M. J. Fayer, and G. W. Gee, Pacific Northwest Laboratory, Richland, Washington.

PNL-8637. 1993. MSTS-Multiphase Subsurface Transport Simulator User's Guide and Reference. W. E. Nichols and M. D. White, Pacific Northwest Laboratory, Richland, Washington.

PNL-10379. 1995. Geochemical Factors Affecting Radionuclide Transport Through Near and Far Fields at a LowLevel Waste Disposal Site. D. I. Kaplan, R. J. Serne, and M. G. Phipho, Pacific Northwest National Laboratory, Richland, Washington.

PNNL-11217. 1996. STOMP - Subsurface Transport over Multiple Phases: Theory Guide. M. D. White and M. Oostrom, Pacific Northwest National Laboratory, Richland, Washington. 
PNNL-11495. 1998. Chemical Information on Tank Supernatants, Cs Adsorption from Tank Liquids onto Hanford Sediments, and Field Observations of Cs Migration from Past Tank Leaks. R. J. Serne, J. M. Zachara, and D. S. Burke, Pacific Northwest National Laboratory, Richland, Washington.

PNNL-11800. 1998. Composite Analysis for Low-Level Waste Disposal in the 200-Area Platean of the Hanford Site. C. T. Kincaid, M. P. Bergeron, C. R. Cole, M. D. Freshley, N. Hassig, V. G. Johnson, D. I. Kaplan, R. J. Serne, G. P. Steile, D. L. Strenge, P. D. Thorne, L. W. Vail, G. A. Whyatt, and S. K. Wurstner, Pacific Northwest National Laboratory, Richland, Washington.

PNNL-12030. 2000. STOMP, Subsurface Transport Over Multiple Phases. Version 2.0. Theory Guide. M. D. White and M. Oostrom, Pacific Northwest National Laboratory, Richland, Washington.

PNNL-12034. 2000. STOMP, Subsurface Transport Over Multiple Phases. Version 2.0. User's Guide. M. D. White and M. Oostrom, Pacific Northwest National Laboratory, Richland, Washington.

PNNL-12088. 1999. Hanford Site 1998 Environmental Report. R. L. Dirkes, R. W. Hanf, and T. M. Poston (eds.), Pacific Northwest National Laboratory, Richland, Washington.

PNNL-13033. 1999. Recharge Data Package for the Immobilized Low-Activity Waste 2001 Performance Assessment. M. J. Fayer, E. M. Murphy, J. L. Downs, F. O. Khan, C. W. Lindenmeier, and B. N. Bjornstad, Pacific Northwest National Laboratory, Richland, Washington.

PNNL-13080. 1999. Hanford Site Groundwater: Settings, Sources, and Methods. M. J. Hartman (ed.), Pacific Northwest National Laboratory, Richland, Washington.

PNNL-13230. 2000. Hanford Site Environmental Report for Calendar Year 1999. T. M. Poston, R. W. Hanf, and R. L. Dirkes (eds.), Pacific Northwest National Laboratory, Richland, Washington.

PNNL-13404. 2001. Hanford Site Groundwater Monitoring for Fiscal Year 2000. M. J. Hartman, L. F. Morasch, and W. D. Webber (eds.), Pacific Northwest National Laboratory, Richland, Washington.

PNNL-13487. 2001. Hanford Site Environmental Report for Calendar Year 2000. T. M. Poston, R. W. Hanf, R. L. Dirkes, and L. F. Morasch (eds.), Pacific Northwest National Laboratory, Richland, Washington.

PNNL-13653. 2001. A Catalog of Geologic Data for the Hanford Site. D. G. Horton, G. V. Last, T. J Gilmore, and B. N. Bjornstad, Pacific Northwest National Laboratory, Richland, Washington.

PNNL-13656. 2001. Enhanced Site Characterization of the 618-4 Burial Ground. C. J. Murray, G. V. Last, and Y. Chien, Pacific Northwest National Laboratory, Richland, Washington.

PNNL-13666. 2001. Data Catalog for Models Simulating Release of Contaminants from Hanford Site Waste Sources. R. G. Riley and C. A. LoPresti, Pacific Northwest National Laboratory, Richland, Washington.

PNNL-13672. 2001. A Catalog of Vadose Zone Hydraulic Properties for the Hanford Site. E. J. Freeman, R. Khaleel, and P. R. Heller, Pacific Northwest National Laboratory, Richland, Washington.

PNNL-13679. 2001. Vadose Zone Transport Field Study: Status Report. G. W. Gee and A. L. Ward, Pacific Northwest National Laboratory, Richland, Washington.

PNNL-13712. 2001. Installation of a Hydrologic Characterization Network for Vadose Zone Monitoring of a SingleShell Tank Farm at the U.S. Department of Energy Hanford Site. G. W. Gee, A. L. Ward, J. C. Riter, J. B. Sisson, J. M. Hubbel, and H. Sydnor, Pacific Northwest National Laboratory, Richland, Washington.

PNNL-13757-1. 2002. Characterization of Vadose Zone Sediment: Uncontaminated RCRA Borehole Core Samples and Composite Samples. R. J. Serne, H. T. Schaef, B. N. Bjornstad, B. A. Williams, D. C. Lanigan, D. G. Horton, R. E. Clayton, V. L. LeGore, M. J. O'Hara, C. F. Brown, K. E. Parker, I. V. Kutnyakov, J. N. Serne, A. V. Mitroshkov, G. V. Last, S. C. Smith, C. W. Lindenmeier, J. M. Zachara, and D. S. Burke, Pacific Northwest National Laboratory, Richland, Washington.

PNNL-13757-2. 2002. Characterization of Vadose Zone Sediment: Borehole 299-W23-19 (SX-115) in the S-SX Waste Management Area. R. J. Serne, H. T. Schaef, B. N. Bjornstad, D. C. Lanigan, G. W. Gee, C. W. Lindenmeier, R. E. Clayton, V. L. LeGore, M. J. O'Hara, C. F. Brown, R. D. Orr, G. V. Last, I. V. Kutnyakov, D. S. Burke, T. C. Wilson, and B. A. Williams, Pacific Northwest National Laboratory, Richland, Washington.

PNNL-13757-3. 2002. Characterization of Vadose Zone Sediment: Borehole 41-09-39 in the S-SX Waste Management Area. R. J. Serne, G. V. Last, H. T. Schaef, D. C. Lanigan, C. W. Lindenmeier, C. C. Ainsworth, R. E. Clayton, V. L. LeGore, M. J. O'Hara, C. F. Brown, R. D. Orr, I. V. Kutnyakov, T. C. Wilson, K. B. Wagnon, B. A. Williams, and D. S. Burke, Pacific Northwest National Laboratory, Richland, Washington. 
PNNL-13757-4. 2002. Characterization of Vadose Zone Sediment: Slant Borehole SX-108 in theS-SX Waste Management Area. R. J. Serne, G. V. Last, H. T. Schaef, D. C. Lanigan, C. W. Lindenmeier, C. C. Ainsworth, R. E. Clayton, V. L. LeGore, M. J. O'Hara, C. F. Brown, R. D. Orr, I. V. Kutnyakov, T. C. Wilson, K. B. Wagnon, B. A. Williams, and D. S. Burke, Pacific Northwest National Laboratory, Richland, Washington.

PNNL-13895. 2001. Hanford Contaminant Distribution Coefficient Database and Users Guide. K. J. Cantrell, R. J. Serne, and G. V. Last, Pacific Northwest National Laboratory, Richland, Washington.

PNNL-SA-34515. 2001. Use of Process Relationship Diagrams in Development of Conceptual Models. G. V. Last, V. J. Rohay, F. J. Schelling, and L. Soler, Pacific Northwest National Laboratory, Richland, Washington.

Poeter, E. P. and M. C. Hill. 1998. Documentation of UCODE, a Computer Code for Universal Inverse Modeling. U.S. Geological Survey, Water-Resources Investigations Report 98-4080.

Record of Decision (ROD). 1999. DOE Environmental Restoration Disposal Facility, Hanford Site, 200 Area Amended Record of Decision, Decision Summary and Responsiveness Summary. U.S. Environmental Protection Agency, Region 10; Washington State Department of Ecology, and U.S. Department of Energy, Olympia, Washington.

Resource Conservation and Recovery Act. 1976. Public Law 94-580, as amended, 90 Stat. 2795, 42 USC 6901 et seq.

RHO-ST-17. 1979. Distribution of Plutonium and Americium Beneath the 216-A-1A Crib: A Status Report. S. M. Price, R. B. Kasper, M. K. Additon, R. M. Smith, and G. V. Last, Rockwell Hanford Operations, Richland, Washington.

RPP-2696. 2000. Modeling Data Package for S-SX Field Investigation Report (FIR). R. Khaleel, T. E. Jones, A. J. Knepp, F. M. Mann, D. A. Meyers, P. M. Rogers, R. J. Serne, and M. I. Wood, CH2M HILL Hanford Group, Inc., Richland, Washington.
RPP-7921. 2001. BX-102 Borehole Completion Report. K. D. Reynolds, Duratek Federal Services, Inc., Northwest Operations, Richland, Washington.

SAND98-2880. 1999. Stochastic Parameters Development for PORFLOW Simulations of the Hanford AX Tank Farm. C. K. Ho, R. G. Baca, S. H. Conrad, G. A. Smith, L. Shyr, and T. A. Wheeler, Sandia National Laboratories, Albuquerque, New Mexico.

Tyler, S. W., B. R. Scanlon, G. W. Gee, and G. B. Allison. 1999. "Water and Solute Transport in Arid Vadose Zones: Innovations in Measurement and Analysis." In: Vadose Zone Hydrology, M. B. Parlange and J. W. Hopmans (eds.), pp. 334-373, Oxford Press, New York.

WAC 173-160. "Minimum Standards for Construction and Maintenance of Wells." Washington Administrative Code, Olympia, Washington.

WAC 173-200. "Water Quality Standards for Ground Waters of the State of Washington." Washington Administrative Code, Olympia, Washington.

WAC 173-303. "Dangerous Waste Regulations." Washington Administrative Code, Olympia, Washington.

WAC 246-290. "Maximum Contaminant Levels (MCLs)." Washington Administrative Code, Olympia, Washington.

WHC-EP-0883. 1995. Variability and Scaling of Hydraulic Properties for 200 Areas Soils, Hanford Site. R. Khaleel and E. J. Freeman, Westinghouse Hanford Company, Richland, Washington.

WHC-SD-EN-TI-061, Rev. 0. 1992. Geophysical Surveys Performed by the Automatic and Measurement Sciences Department of the Pacific Northwest Laboratory at Hanford Burial Grounds 619-4 and 618-5, Westinghouse Hanford Company, Richland, Washington.

WHC-SD-EN-TI-101. 1993. Carbon Tetrachloride Evaporative Losses and Residual Inventory Beneath 200 West Area at the Hanford Site. Prepared by Ebasco Services for Westinghouse Hanford Company, Richland, Washington. 


\title{
8.0 Other Hanford Site Environmental Programs
}

\author{
R. W. H anf
}

At the Hanford Site, a variety of environmental activities are performed to comply with laws and regulations, to enhance environmental quality, and to monitor the impact of environmental pollutants from site operations.
This section summarizes activities conducted in 2001 to monitor the climatology and meteorology, to assess the status of ecological monitoring and compliance, to monitor and manage cultural resources, and to actively involve the public in environmental surveillance activities. 


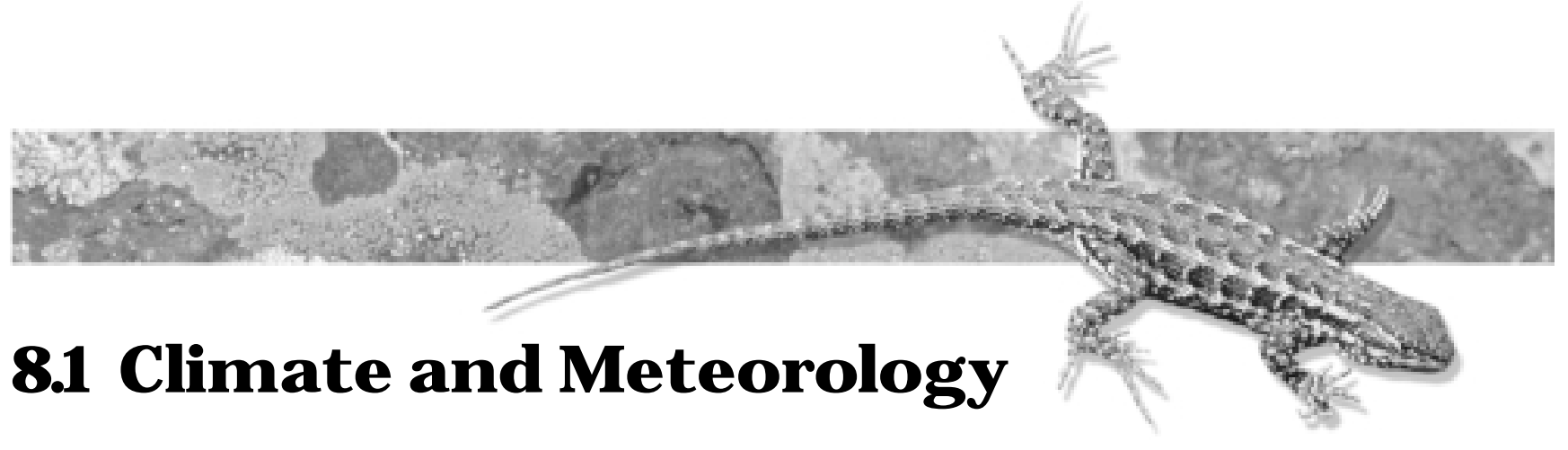

\author{
D. J. H oitink
}

Meteorological measurements are taken to support Hanford Site emergency preparedness and response, operations, and atmospheric dispersion calculations for dose assessments (Appendix E, Tables E.5 and E.7 through E.9). Support is provided through weather forecasting and maintaining and distributing climatological data. Forecasting is provided to help manage weatherdependent operations. Climatological data are provided to help plan weather-dependent activities and are used as a resource to assess the environmental effects of site operations. A summary of requests for meteorological data from facilities and organizations both on and off the Hanford Site in 2001 is provided in Table 8.1.1.

Local data to support the Hanford Meteorology Station operations are provided via the Hanford Meteorological Monitoring Network. This network consists of 30 remote monitoring stations that transmit data to the Hanford Meteorology Station via radio telemetry every 15 minutes. There are twenty-seven 9 -meter (30-foot) towers and three 61-meter (200-foot) towers. Meteorological parameters collected at these stations include wind speed, wind direction, temperature, precipitation, atmospheric pressure, and relative humidity; however, not all parameters are collected at all stations. Figure 8.1.1 shows the 2001 wind roses (i.e., diagrams showing direction and frequencies of wind) measured at a height of 9 meters ( 30 feet) for the 30 meteorological monitoring stations on and around the Hanford Site.

The Cascade Range, beyond Yakima to the west, greatly influences the climate of the Hanford Site because of its rain shadow effect. The regional temperatures, precipitation, and winds are affected also by the

Real-time and historical data from the Hanford Meteorological Station can be obtained at http://etd.pnl.gov:2080/ HMS. Data on this web site include hourly weather observations, 15-minute data from the Hanford Meteorological Monitoring Network, monthly climatological summaries, and historical data. presence of mountain barriers. The Rocky Mountains and ranges in southern British Columbia protect the inland basin from the more severe cold polar air masses moving southward across Canada and winter storms associated with them.

The Hanford Meteorology Station is located on the Central Plateau, where the prevailing wind direction is from the northwest during all months of the year. The secondary wind direction is from the southwest. Summaries of wind direction indicate that winds from the northwestern quadrant occur most often during winter and summer. During spring and fall, the frequency of southwesterly winds increases, with a corresponding decrease in the northwesterly flow. Monthly average wind speeds are lowest during winter months, averaging about 3 meters per second ( 6 to 7 miles per hour), and highest during summer, averaging about 4 meters per second ( 8 to 9 miles per hour). Wind speeds that are well above average are usually associated with southwesterly winds. However, summertime drainage winds are generally northwesterly and frequently exceed 13 meters per second ( 30 miles per hour). These winds are most prevalent over the northern portion of the site.

Atmospheric dispersion is a function of wind speed, wind duration and direction, atmospheric stability, and mixing depth. Dispersion conditions are generally good if winds are moderate to strong, the atmosphere is of neutral or unstable stratification, and there is a deep mixing layer. Good dispersion conditions associated with neutral and unstable stratification exist $\sim 57 \%$ of the time during summer. Less favorable conditions may occur when wind speed is light and the mixing layer is shallow. These conditions are most common during winter, when moderate to extremely stable stratification exists $\sim 66 \%$ of the time. Occasionally, there are extended periods of poor dispersion conditions, primarily during winter, that are associated with stagnant air in stationary high-pressure systems. 
Table 8.1.1. Requests for Meteorological Data from Facilities and Organizations on and off the Hanford Site, 2001

\section{Requestor}

\section{Onsite}

100 Area (other)

101 SY Complex

222S/WSCF Labs

300 Area (other)

B Plant ${ }^{(a, b)}$

BHI/subcontractors

Canister Storage

Construction

Crane and Rigging

DOE-RL

Electrical Disp.

Emerg. Preparedness

Energy Northwest

Evaporator

FDH (other)

FFTF

Fire Dept.

HAMMER Facility

Hanford Patrol

Industrial Hygiene

Pest Control

PFP

Photography

PNNL

Salt Wells

Solid Waste

T Plant

Tank farms

ThermalHanford Inc.

Track/Road Maint.

WBGT

WRAP/ERDF/other

Monthly Total

Number of Requests

\begin{tabular}{|c|c|c|c|c|c|c|c|c|c|c|c|c|}
\hline Jan & Feb & Mar & Apr & May & Jun & Jul & Aug & Sep & Oct & Nov & Dec & Annual Tota \\
\hline 17 & 16 & 10 & 15 & 13 & 19 & 29 & 40 & 29 & 53 & 50 & 63 & 354 \\
\hline 0 & 0 & 0 & 0 & 0 & 0 & 0 & 0 & 0 & 0 & 0 & 0 & 0 \\
\hline 3 & 0 & 2 & 5 & 2 & 1 & 2 & 1 & 0 & 3 & 2 & 1 & 22 \\
\hline 34 & 10 & 13 & 8 & 8 & 24 & 4 & 13 & 16 & 2 & 3 & 5 & 140 \\
\hline 0 & 1 & 0 & 0 & 0 & 0 & 1 & 0 & 0 & 0 & 0 & 0 & 2 \\
\hline 2 & 3 & 0 & 0 & 1 & 0 & 0 & 1 & 0 & 1 & 1 & 1 & 10 \\
\hline 0 & 1 & 0 & 0 & 1 & 0 & 0 & 1 & 1 & 0 & 1 & 1 & 6 \\
\hline 1 & 1 & 3 & 1 & 1 & 2 & 3 & 7 & 2 & 4 & 7 & 8 & 40 \\
\hline 0 & 0 & 0 & 0 & 0 & 13 & 1 & 2 & 1 & 7 & 1 & 0 & 25 \\
\hline 0 & 3 & 8 & 1 & 3 & 2 & 2 & 2 & 2 & 2 & 2 & 1 & 28 \\
\hline 25 & 19 & 27 & 23 & 24 & 18 & 20 & 17 & 22 & 24 & 23 & 26 & 268 \\
\hline 21 & 34 & 17 & 26 & 23 & 24 & 11 & 19 & 21 & 23 & 8 & 12 & 239 \\
\hline 0 & 0 & 2 & 0 & 0 & 2 & 0 & 0 & 0 & 2 & 1 & 0 & 7 \\
\hline 0 & 0 & 0 & 0 & 0 & 0 & 0 & 0 & 0 & 0 & 0 & 0 & 0 \\
\hline 3 & 21 & 10 & 4 & 4 & 2 & 1 & 12 & 1 & 2 & 1 & 2 & 63 \\
\hline 1 & 3 & 2 & 4 & 3 & 2 & 1 & 2 & 0 & 1 & 2 & 1 & 22 \\
\hline 31 & 25 & 32 & 30 & 28 & 64 & 45 & 36 & 36 & 27 & 32 & 36 & 422 \\
\hline 0 & 1 & 1 & 4 & 4 & 4 & 3 & 5 & 3 & 3 & 0 & 0 & 28 \\
\hline 2 & 3 & 1 & 0 & 3 & 2 & 2 & 0 & 1 & 0 & 3 & 6 & 23 \\
\hline 15 & 30 & 26 & 10 & 23 & 14 & 14 & 9 & 19 & 14 & 8 & 9 & 191 \\
\hline 1 & 3 & 4 & 9 & 22 & 9 & 11 & 4 & 30 & 12 & 2 & 5 & 112 \\
\hline 30 & 36 & 42 & 8 & 2 & 2 & 0 & 12 & 1 & 46 & 41 & 33 & 253 \\
\hline 1 & 1 & 0 & 1 & 0 & 0 & 2 & 0 & 0 & 0 & 2 & 0 & 7 \\
\hline 9 & 1 & 6 & 4 & 3 & 4 & 10 & 31 & 4 & 27 & 44 & 15 & 158 \\
\hline 1 & 1 & 0 & 7 & 1 & 8 & 0 & 4 & 0 & 4 & 4 & 4 & 34 \\
\hline 2 & 0 & 1 & 0 & 0 & 0 & 0 & 0 & 0 & 0 & 0 & 1 & 4 \\
\hline 2 & 1 & 0 & 2 & 2 & 3 & 3 & 1 & 1 & 3 & 6 & 4 & 28 \\
\hline 205 & 185 & 265 & 290 & 235 & 239 & 278 & 253 & 255 & 287 & 289 & 286 & 3067 \\
\hline 0 & 0 & 0 & 0 & 0 & 0 & 0 & 0 & 0 & 0 & 0 & 0 & 0 \\
\hline 12 & 7 & 0 & 2 & 0 & 0 & 0 & 0 & 0 & 0 & 12 & 20 & 53 \\
\hline 0 & 0 & 0 & 1 & 17 & 26 & 117 & 139 & 16 & 1 & 0 & 0 & 317 \\
\hline 2 & 1 & 0 & 1 & 0 & 0 & 2 & 1 & 0 & 0 & 1 & 0 & 8 \\
\hline 420 & 407 & 472 & 456 & 423 & 484 & 562 & 612 & 461 & 548 & 546 & 540 & 5,931 \\
\hline
\end{tabular}


Table 8.1.1. (contd)

Requestor

Number of Requests

\section{Offsite}

Benton Co. PUD

City of Richland

DOE LAS

Lamb Weston

NWS

RLD Medical Off.

Tri City Herald

TV/Radio Stns.

US Fish/Wildlife

Monthly Total

\begin{tabular}{ccccc}
\hline Jan & Feb & Mar & Apr & May \\
3 & 0 & 0 & 0 & 0 \\
0 & 0 & 1 & 0 & 0 \\
0 & 0 & 0 & 0 & 0 \\
0 & 0 & 1 & 0 & 0 \\
2 & 0 & 0 & 0 & 0 \\
32 & 28 & 26 & 28 & 30 \\
0 & 0 & 1 & 1 & 1 \\
0 & 0 & 0 & 0 & 0 \\
0 & 0 & 0 & 2 & 5 \\
37 & 28 & 29 & 31 & 36
\end{tabular}

(a) Includes production forecasts.

(b) Production forecasts no longer issued.

BHI $=$ Bechtel Hanford, Inc.

DOE LAS $=$ DOE Las Vegas

DOE-RL = DOE Richland Operations Office.

ERDF = Environmental Restoration Disposal Facility

FDH $=$ Fluor Hanford, Inc.

FFTF $\quad=$ Fast Flux Test Facility.

NWS $\quad=$ National Weather Service.

PFP $\quad=$ Plutonium Finishing Plant

PNNL = Pacific Northwest National Laboratory.

PUD $\quad=$ Public Utility District.

RLD $\quad=$ Richland.

WBGT = Wet bulb globe temperature (heat stress).

WRAP = Waste Receiving and Packaging Facility.

WSCF $\quad=$ Waste Sampling and Characterization Facility. 


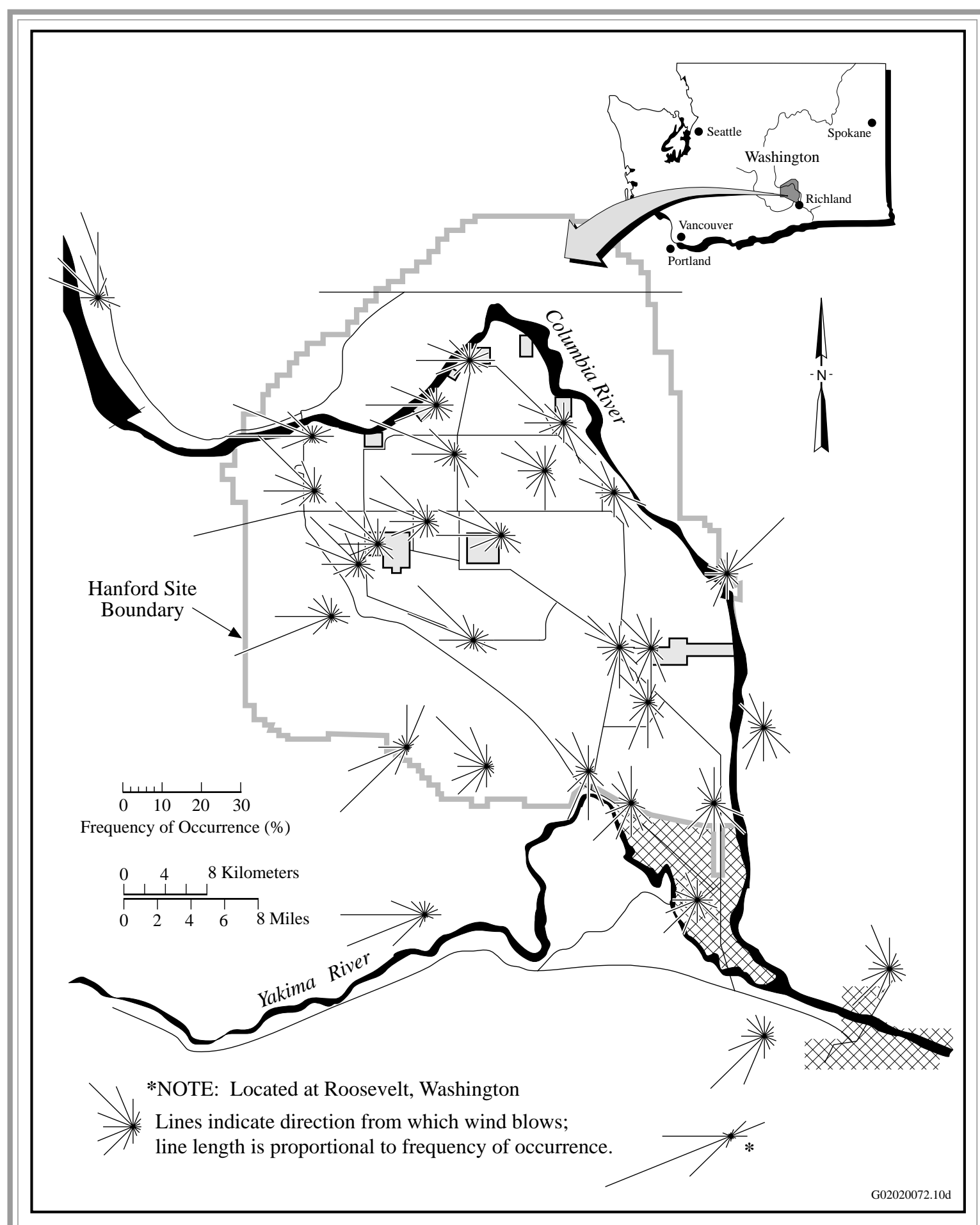

Figure 8.1.1. Hanford Meteorological Monitoring Network Wind Roses, 2001 (measured at a height of 9 meters [30 feet]). Individual lines indicate direction from which wind blows. 


\subsection{Historical Information}

Daily and monthly averages and extremes of temperature, dew point temperature, and relative humidity for 1945 through 2001 are reported in PNNL-13859. From 1945 through 2001, the record maximum temperature was $45^{\circ} \mathrm{C}\left(113^{\circ} \mathrm{F}\right)$ recorded in August 1961, and the record minimum temperature was $-30.6^{\circ} \mathrm{C}\left(-23^{\circ} \mathrm{F}\right)$ in February 1950. Normal monthly average temperatures ranged from a low of $-0.2^{\circ} \mathrm{C}\left(31.7^{\circ} \mathrm{F}\right)$ in December to a high of $24.6^{\circ} \mathrm{C}\left(76.3^{\circ} \mathrm{F}\right)$ in July. During winter, the highest monthly average temperature at the Hanford Meteorology Station was $6.9^{\circ} \mathrm{C}\left(44.5^{\circ} \mathrm{F}\right)$ in February 1991 , and the record lowest was $-11.1^{\circ} \mathrm{C}\left(12.1^{\circ} \mathrm{F}\right)$ in January 1950. During summer, the record maximum monthly average temperature was $27.9^{\circ} \mathrm{C}\left(82.2^{\circ} \mathrm{F}\right)$ in July 1985 , and the record minimum was $17.2^{\circ} \mathrm{C}\left(63.0^{\circ} \mathrm{F}\right)$ in June 1953. The normal annual relative humidity at the Hanford Meteorology Station is 54\%. Humidity is highest during winter, averaging $~ 76 \%$, and lowest during summer, averaging $\sim 36 \%$. Normal annual precipitation at the Hanford Meteorology Station is 17.7 centimeters (6.98 inches). The wettest year on record, 1995, received 31 centimeters ( 12.31 inches) of precipitation; the driest, 1976, received 8 centimeters (2.99 inches). Most precipitation occurs during late autumn and winter, with more than half of the annual amount occurring from November through February. The snowiest winter on record, 1992-1993, received 142.5 centimeters (56.1 inches) of snow.

\subsection{Results of 2001Monitoring}

Calendar year 2001 was slightly warmer than normal and precipitation was below normal.

The average temperature for 2001 was $12.4^{\circ} \mathrm{C}$ $\left(54.3^{\circ} \mathrm{F}\right)$, which was $0.4^{\circ} \mathrm{C}\left(0.7^{\circ} \mathrm{F}\right)$ above normal $\left(12.0^{\circ} \mathrm{C}\right.$ $\left.\left[53.6^{\circ} \mathrm{F}\right]\right)$. Eight months during 2001 were warmer than normal; four months were cooler than normal. December had the greatest positive departure, $1.8^{\circ} \mathrm{C}\left(3.2^{\circ} \mathrm{F}\right)$; and June, at $1.6^{\circ} \mathrm{C}\left(2.8^{\circ} \mathrm{F}\right)$ below normal, had the greatest negative departure.

Precipitation for 2001 totaled 16.9 centimeters (6.66 inches), $95 \%$ of normal (17.7 centimeters [6.98 inches]). Snowfall for 2001 totaled 38.4 centimeters (15.1 inches) (compared to an annual normal snowfall of 39.1 centimeters [15.4 inches]).
The average wind speed for 2001 was 3.4 meters per second ( 7.6 miles per hour), which was normal. The peak gust for the year was 31 meters per second (69 miles per hour) on December 16.

There were eight dust storms recorded at the Hanford Meteorology Station during 2001. There have been an average of five dust storms per year at the Hanford Meteorology Station during the entire period of record (1945-2001).

Table 8.1.2 provides monthly and annual climatological data from the Hanford Meteorology Station for 2001. 
Table 8.1.2. Monthly and Annual Climatological Data from the Hanford Meteorology Station, 2001

Hanford Meteorology Station, 40 kilometers (25 miles) northwest of Richland, Washington, latitude $46^{\circ} 34 ' \mathrm{~N}$, longitude $119^{\circ} 35^{\prime} \mathrm{W}$, elevation 223 meters ( 733 feet)

\begin{tabular}{|c|c|c|c|c|c|c|c|c|c|c|c|c|c|c|c|c|c|c|c|}
\hline \multirow{2}{*}{$\begin{array}{l}\text { f } \\
\text { ¿ } \\
\Sigma\end{array}$} & \multicolumn{8}{|c|}{ Temperatures, ${ }^{\circ} \mathrm{C}$} & \multicolumn{4}{|c|}{ Precipitation (cm) } & \multirow{2}{*}{\multicolumn{2}{|c|}{$\begin{array}{c}\text { Relative } \\
\text { Humidity } \\
\text { (\%) }\end{array}$}} & \multicolumn{5}{|c|}{ 15-m Wind ${ }^{(a)}$} \\
\hline & \multicolumn{4}{|c|}{ Averages } & \multicolumn{4}{|c|}{ Extremes } & $\begin{array}{l}\bar{B} \\
0 \\
\end{array}$ & 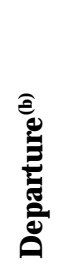 & \multicolumn{2}{|c|}{ Snowfall } & & & 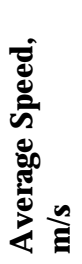 & $\frac{\bar{g}}{\frac{\partial}{d}}$ & \multicolumn{3}{|c|}{ Peak Gusts } \\
\hline $\mathrm{J}$ & 3.7 & -2.1 & 0.8 & +0.9 & 13.3 & $31^{(c)}$ & -6.7 & 15 & 0.7 & -1.5 & 5.8 & -4.8 & 84.8 & +7.5 & 2.4 & -0.4 & 15.6 & SW & 5 \\
\hline F & 6.9 & -2.9 & 2.1 & -1.2 & 12.2 & $24^{(c)}$ & -8.3 & 17 & 1.1 & -0.7 & 10.9 & +4.3 & 72.4 & +1.9 & 2.9 & -0.3 & 14.8 & WNW & 5 \\
\hline M & 15.0 & 1.5 & 8.2 & +0.4 & 21.1 & 24 & -5.0 & 3 & 1.7 & +0.2 & 0 & -1.0 & 59.2 & +2.6 & 3.6 & 0 & 25.0 & W & 13 \\
\hline A & 17.5 & 4.1 & 10.8 & -1.2 & 28.3 & $26^{(c)}$ & -2.2 & $14^{(\mathrm{c})}$ & 2.1 & +1.0 & 0 & $-T^{(\mathrm{d})}$ & 50.8 & +3.5 & 3.8 & -0.1 & 22.4 & WSW & 28 \\
\hline M & 26.2 & 9.1 & 17.6 & +1.1 & 38.3 & 23 & 1.1 & 3 & 0.2 & -1.2 & 0 & 0 & 35.1 & -7.9 & 4.1 & +0.1 & 22.8 & SW & 28 \\
\hline $\mathrm{J}$ & 26.6 & 11.7 & 19.2 & -1.6 & 37.8 & 21 & 6.7 & 2 & 3.2 & +2.2 & 0 & 0 & 42.7 & +3.1 & 3.9 & -0.1 & 19.7 & SSW & 24 \\
\hline $\mathrm{J}$ & 32.7 & 16.3 & 24.4 & -0.2 & 41.1 & 4 & 11.7 & $21^{(\mathrm{c})}$ & 0.1 & -0.6 & 0 & 0 & 34.1 & +0.7 & 3.8 & 0 & 17.9 & WNW & 5 \\
\hline A & 34.1 & 16.7 & 25.4 & +1.3 & 40.6 & 12 & 10.0 & 24 & 0.2 & -0.5 & 0 & 0 & 35.1 & -0.5 & 3.5 & 0 & 18.3 & WNW & 18 \\
\hline $\mathrm{O}$ & 18.6 & 5.3 & 11.9 & +0.3 & 28.3 & 1 & -0.6 & 28 & 0.9 & -0.3 & 0 & -0.3 & 51.9 & -4.5 & 3.6 & +0.7 & 28.2 & WSW & 23 \\
\hline $\mathrm{N}$ & 10.5 & 1.5 & 6.0 & +1.5 & 20.0 & 14 & -3.3 & $29^{(\mathrm{c})}$ & 4.2 & +1.8 & 12.7 & +6.9 & 81.4 & +7.7 & 2.6 & -0.3 & 19.7 & S & 14 \\
\hline $\mathrm{D}$ & 5.3 & -2.1 & 1.6 & +1.8 & 14.4 & 16 & -8.9 & 25 & 2.0 & -0.8 & 8.9 & -5.8 & 78.7 & -1.4 & 3.4 & +0.8 & 30.8 & S & 16 \\
\hline$Y^{(\mathrm{e})}$ & 18.8 & 5.9 & 12.4 & +0.4 & 41.1 & $\begin{array}{r}\mathrm{Jul} \\
4 \\
\end{array}$ & -8.9 & $\begin{array}{r}\text { Dec } \\
25 \\
\end{array}$ & 16.9 & -0.8 & 38.4 & -0.8 & 55.4 & +0.8 & 3.4 & 0 & 30.8 & $\mathrm{~S}$ & $\begin{array}{r}\text { Dec } \\
16 \\
\end{array}$ \\
\hline
\end{tabular}

NOTE: See Appendix A, Table A.2 for unit conversion information.

(a) Measured on a tower 15 meters (50 feet) above the ground.

(b) Departure columns indicate positive or negative departure of meteorological parameters from 30-year (1971-2000) climatological normals.

(c) Latest of several occurrences.

(d) Trace.

(e) Yearly averages, extremes, and totals. 


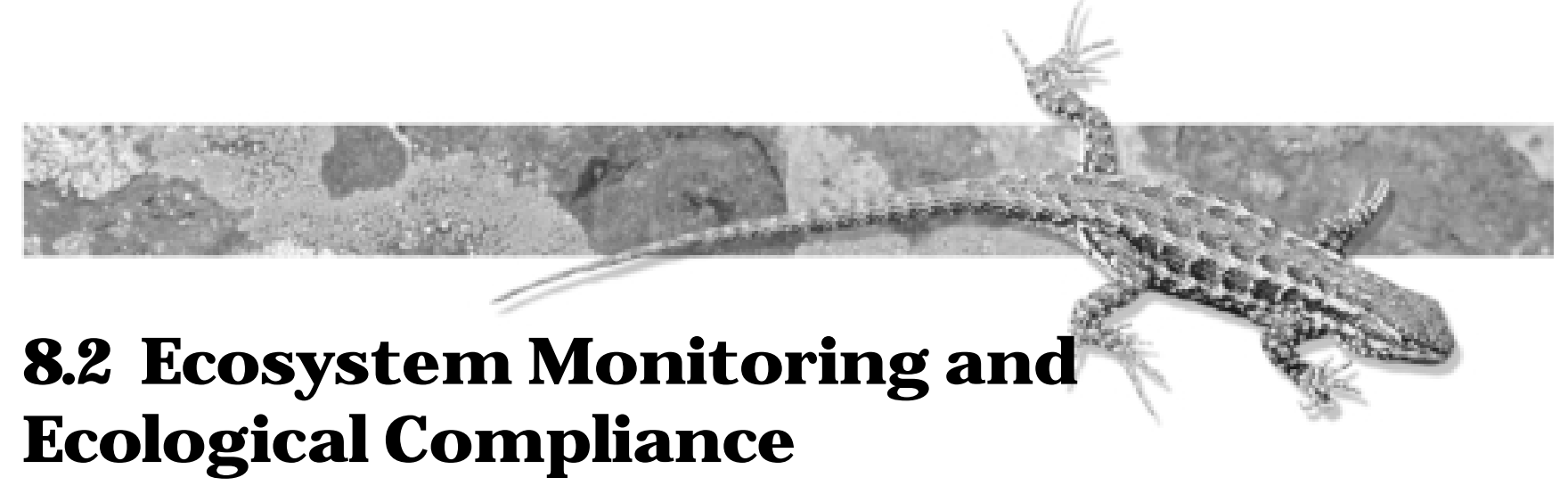

\section{L. C adwell, J. L. D owns, R. P. M ueller, M. R. Sackschewsky, M. A. Simmons, and B. L. T iller}

The Hanford Site is a relatively undisturbed area of shrub-steppe that contains a rich, natural diversity of plant and animal species adapted to the region's semiarid environment. In a summary document based on 5 years of intense study, The Nature Conservancy of Washington (1999) reported that "The Hanford Site Biodiversity Inventory has produced remarkable findings in each of the biological subject areas that were addressed: plant communities, rare plants, noxious weeds, small mammals, insects (aquatic and terrestrial), amphibians and reptiles, and soil mosses and lichens (the microbiotic crust)." In 2000, the biodiversity of Hanford was further recognized as a national asset when portions of the site were designated as the Hanford Reach National Monument (65 FR 114). Ecosystem monitoring and ecological compliance have multiple objectives that support completion of Hanford's waste management and environmental restoration mission:

- assuring Hanford Site operational compliance with laws and regulations including the Endangered
Species A ct of 1973, the B ald and Golden Eagle Protection A ct, and the M igratory Bird Treaty A ct

- providing data for environmental impact and ecological risk assessments

- providing maps and information useful for biological resource impact mitigation during facility expansion

- supporting Hanford Site land-use planning

- protecting natural resources within the DOEoperated portions of the Hanford Site including the DOE-managed portion of the Hanford Reach National Monument

- providing information useful to the tribes, Hanford natural resource stakeholders, and the public on the status of some of Hanford's most highly valued biological resources.

\subsubsection{Chinook Salmon}

Chinook salmon are an important resource in the Pacific Northwest; they are caught commercially and for recreation. Salmon are also of cultural importance to Native American tribes. Today, the most important natural spawning area in the mainstem Columbia River for the fall chinook salmon is found in the free-flowing Hanford Reach. In the early years of the Hanford Site, there were few spawning nests (redds) in the Hanford Reach (Figure 8.2.1). Between 1943 and 1971, a number of dams were constructed on the Columbia River. Their reservoirs eliminated most mainstem spawning areas, resulting in increased numbers of salmon spawning in the Hanford Reach. Fisheries management strategies aimed at maintaining spawning populations in the mainstem Columbia River also have contributed to the increases.

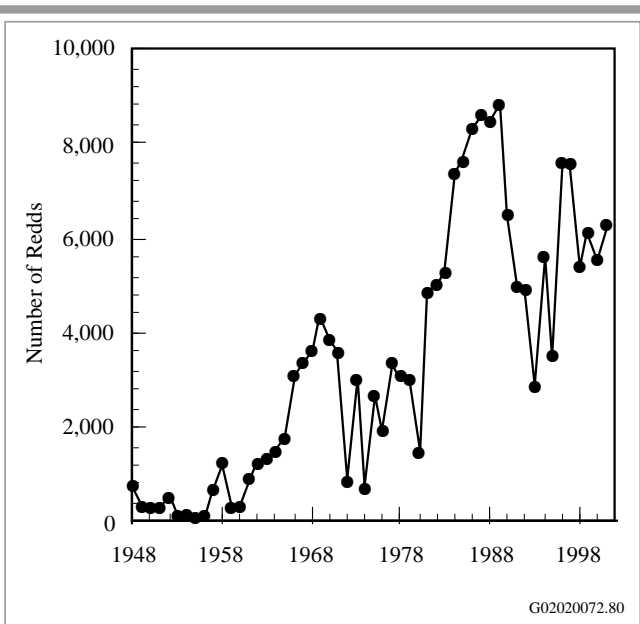

Figure 8.2.1. N umber of Fall Chinook Salmon Spawning Redds in the Hanford Reach, 1948 through 2001 
The number of fall chinook salmon redds counted in the Hanford Reach by aerial surveys increased during the 1960s, 1970s, and 1980s until reaching a high in 1989 of nearly 9,000 (see Figure 8.2.1). In the early 1990s, redd counts declined to approximately one-third of the 1989 peak. The number of redds peaked again in 1996 and 1997 and has once again declined. In 2001, $\sim 6,248$ redds were observed, an increase of 741 from 2000 and $\sim 80 \%$ of the 1996 and 1997 totals. The main use areas were similar to previous years with the majority of redds occurring near Locke Island, the Columbia
River islands between river miles 365-368 (Islands 8 through 10), and Vernita Bar. Aerial surveys do not yield absolute redd counts because visibility varies, depending on water depth and other factors, and because the number of redds in high-density locations cannot be counted with absolute accuracy. However, redd survey data generally agree with adult numbers obtained by counting migrating adult fish at fish ladders on the Columbia River. The Hanford Reach remains the largest spawning area for fall chinook salmon in the mainstem Columbia River.

\subsubsection{Rocky Mountain Elk}

Rocky Mountain elk did not inhabit the Hanford Site when it was established in 1943. Elk were first observed on the Fitzner/Eberhardt Arid Lands Ecology Reserve in the winter of 1972. A few animals stayed and reproduced. The Rattlesnake Hills elk herd now occupies portions of the Hanford Site, the United States Army's Yakima Training Center, and private land along Rattlesnake Ridge. Total herd size was estimated from census data during the 1999 post-calving season at 838 animals and at 747 after the 1999 hunting season (Figure 8.2.2). A roundup conducted by the U.S. Fish and Wildlife Service and Washington Department of Fish and Wildlife in mid-March 2000 resulted in the removal of 171 animals. The fall 2000 hunting season that followed the summer 2000 fire was abnormally successful with the harvest of over 200 animals bringing the post-hunting season herd size to 440 animals. In 2001, calving increased from 32 calves produced per 100 cows in 2000 to an estimated 46 calves per 100 cows. Also in 2001, the total Rattlesnake Hills elk harvest declined to $\sim 75$ animals. The net result for 2001 was a decrease in the post-calving estimate to 561 animals from 660 in 2000. However, the reduced hunting season harvest resulted in an increase in the 2001 post-hunting estimate to 484 animals. Barring additional herd reduction actions by either the Washington Department of Fish and Wildlife or the U.S. Fish and Wildlife Service, continued population growth of the herd is anticipated in the future. The Washington Department of Fish and Wildlife has primary responsibility for management of the elk herd and works cooperatively with the U.S. Fish and Wildlife Service, which has primary land management

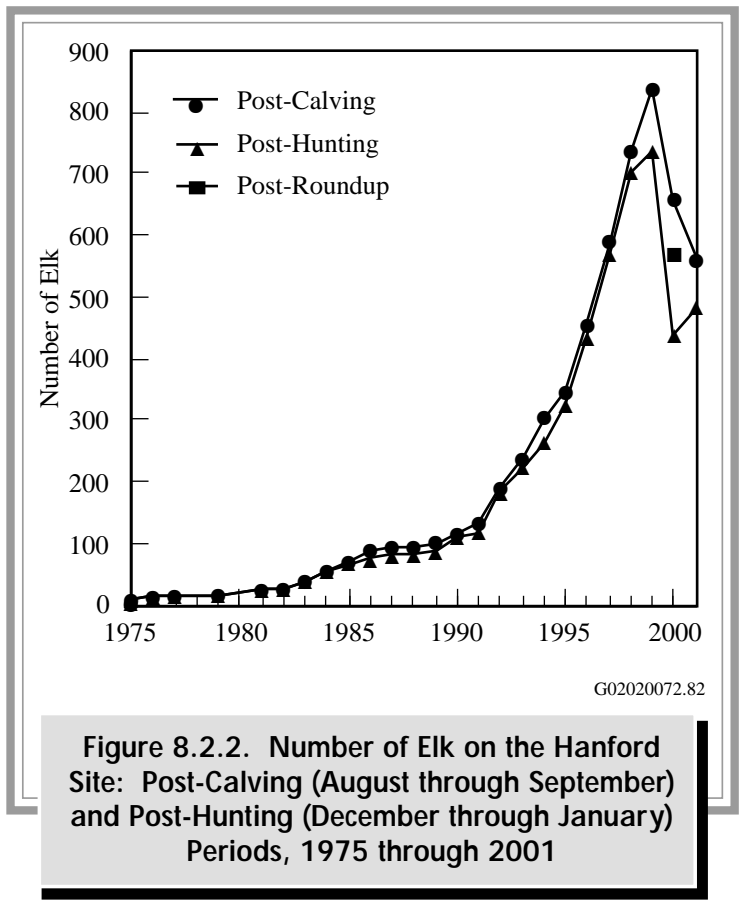

responsibility for the Hanford Reach National Monument land that encompasses much of the Rattlesnake Hills elk herd range.

There were three elk/vehicle collisions in calendar year 2001 (Figure 8.2.3). The collision sites generally corresponded to the location of elk/vehicle collisions from previous years.

\subsection{Mule Deer}

Systematic roadside observations of mule deer have been conducted during the post-hunting (DecemberJanuary) periods since 1993. The surveys are conducted to monitor trends in age and sex ratios of mule deer, to examine trends in the relative abundance of deer on the Hanford Site, and to monitor the frequency of testicular atrophy in mule deer. The survey route is divided into a north and south region just north of the Hanford town site. 
Epidemiological data and microscopic examinations of mule deer ( 0 docoileus hemionus) tissue samples from the Hanford Site in the early 1990s revealed that nearly one quarter of the mule deer (bucks) had undergone some level of testicular atrophy (degeneration of the testicles after maturity). A special study was initiated in 1992 to describe the occurrences on a spatial scale and to examine possible influences of contaminants from the Hanford Site. Although the results of this study (Tiller et al. 1997; PNNL-11518) found no single factor as the primary cause, analyses of the affected and normal animal's contaminant levels, physiology, behaviors, histology of tissues, and other indicators of population health, indicated Hanford-derived contaminants were not likely a causative agent.

Tiller et al. (1997) described a positive relationship between the frequency of the anomaly and the age class distribution within the population. Severely degenerative/ atrophic testes were found to occur only in 5- to 12-year-old bucks. Since hunting is not allowed on Hanford Site, deer survival rates are high and there is a corresponding increase in the number of animals in the older $(5+$ years $)$ age classes, thus magnifying the frequency of this condition in the Hanford Site deer population.

Figure 8.2.4 illustrates trends in the observed frequency of bucks (number of affected males per 100 males) that exhibited signs of testicular atrophy (velvet-covered antlers) and atrophic (shrunken) testicles during the post-hunting roadside surveys from 1994 through 2001. In 1993, an estimated 15\% of the males were affected on the Hanford Site (Tiller et al. 1997). Ten affected animals were euthanized in 1994 and 1995 to obtain a variety of tissue samples for chemical and histological examination. Between 1994 and 1997, the percentage of affected males decreased to around $5 \%$ and remained relatively constant; however, survey results in 1998 and 1999 indicated the frequency of the anomaly returned to 1993 levels (15\%). Also, more animals in the southern region of the site appeared to be affected (see Figure 8.2.4). Survey results obtained in

2001 indicate the frequency of bucks with testicular atrophy continues to decline with only a single affected animal observed this year in the southern region and none in the northern region of the Hanford Site.

The number of fawns surviving the first year after birth is used to estimate the annual rate of young successfully added to the deer herds. Figure 8.2.5 illustrates trends in fawn:doe ratios from 1994 through 2001 in the northern and southern region deer herds. In both regions of the Hanford Site, fawn survival declined substantially from over 20 fawns per 100 does in 1994 to less than 10 fawns per 100 does in 1997. Since 1997, fawn survival has recovered to $\sim 30$ fawns per 100 does in 2001, which is similar to other mule deer populations in a shrub-steppe environment (Tiller et al. 1997). 


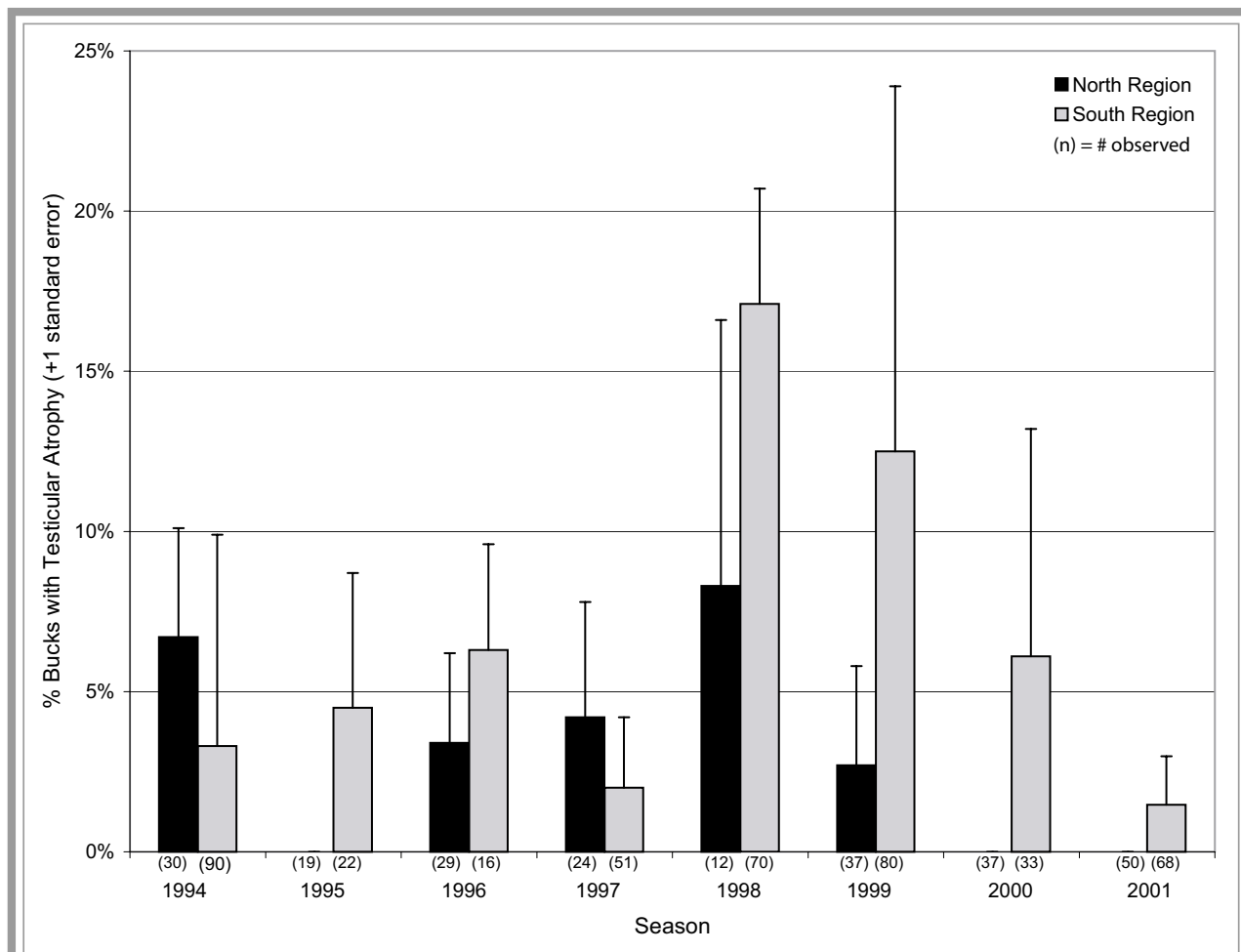

Figure 8.2.4. Percent of Mule Deer Bucks with Testicular Atrophy on the Hanford Site, 1994 through 2001 (see Figure 4.5.1 for region locations)

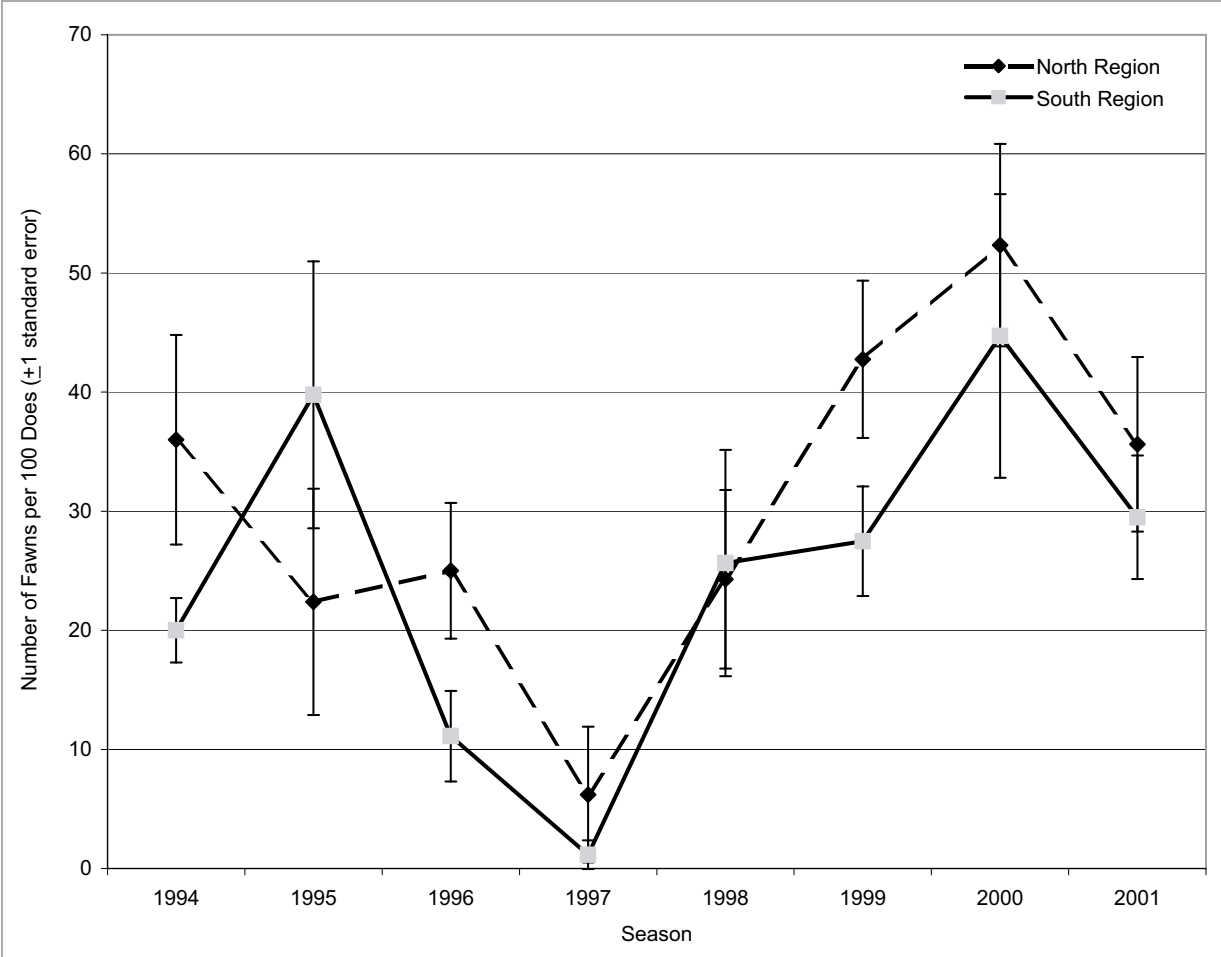

Figure 8.2.5. Roadside Survey Results for Trends in Fawn:Doe Ratios seen per Survey on the Hanford Site, 1994 through 2001 (see Figure 4.5.1 for region locations) 
Continued roadside surveys to monitor both the frequency of testicular atrophy and to document the demographic trends of mule deer on the Hanford Site will allow project scientists to evaluate the health of the deer population and attempt to isolate factors contributing to any observed changes.

\subsubsection{Plant Biodiversity Inventories}

The Hanford Site contains biologically diverse shrub-steppe plant communities that have been protected from disturbance, except for fire, over the past 55 years. This protection has allowed plant species and communities that have been displaced by agriculture and development in other parts of the Columbia Basin to thrive at Hanford. Surveys and mapping efforts have documented the occurrence and extent of rare plant populations and plant community types on the Hanford Site (Nature Conservancy 1999). Populations of rare plants include taxa listed by Washington State as endangered, threatened, or sensitive (see Appendix G) and the locations of species that are listed as review group 1 (i.e., taxa in need of additional field work before status can be determined) (Washington Natural Heritage Program 1997). Data are collected for plant populations and plant communities to develop baseline information and to monitor any changes resulting from Hanford operations. The data provide information that is used for site planning processes and land-use policy development.

More than 100 rare plant populations of 31 different taxa are found at the Hanford Site (Figure 8.2.6). The U.S. Fish and Wildlife Service has designated five of these 31 taxa (including the two new species, Umtanum buckwheat [E riogonum codium] and White Bluffs bladderpod [Lesquerella tuplashensis]) as species of concern in the Columbia River Basin Ecoregion. These two new species are proposed as candidates for federal listing. In addition to the rare plant populations, several areas on the Hanford Site are designated as special habitat types with regard to potential occurrence of plant species of concern listed by Washington State. These are areas that potentially support populations of rare annual forbs that have been documented in adjacent habitat.

Surveys in 2001 continued to indicate increases in the numbers of Piper's daisy (E rigeron piperianus), a species of concern occurring in the 200 Areas. One subpopulation in the 200 Areas was eliminated through inadvertent overspray of herbicides. Populations of another species of concern in the Columbia River Basin Ecoregion, persistent sepal yellowcress (Rorippa columbiae), do not appear to have experienced significant recovery after declining as a result of the high river flow levels from 1995 through 2000. Persistent sepal yellowcress is a rhizomatous perennial found in moist soil along the Columbia River within the Hanford Site. This species is often inundated by river flows, but little is known concerning long-term survival under continuous inundation. Surveys in 2001 continued to show low numbers of stems at a cobble beach adjacent to the 100-F Area on the Hanford Reach and on Island 18 across from the 300 Area (Table 8.2.1), and no stems were observed in flower between 1997 and 1999. Number of stems found in 2001 on Locke Island did increase from previous years with $>25 \%$ of the plants producing flowers. Fluctuating river flow levels appear to influence population fluctuations of this species.

Maps showing the extent and distribution of types of vegetation cover found on the Hanford Site have been updated to include recent work delineating the plant communities in central Hanford (Salstrom and Easterly 1997; Nature Conservancy 1999). The updated maps were merged with existing maps for the Fitzner/ Eberhardt Arid Lands Ecology Reserve Unit, the Wahluke Unit, and the Saddle Mountain Unit of the Hanford Reach National Monument. The plant community map was updated in 2001 to reflect the changes in plant community composition resulting from the wildfire in June 2000 and to incorporate riparian areas mapped by Salstrom and Easterly in 1995. Updated vegetation maps can be viewed on the Ecosystem Monitoring Project web page (www.pnl.gov/ecology/ ecosystem).

\subsubsection{Sagebrush Die-Off}

Big sagebrush (A rtemisia tridentata subspecies wyomingensis) is the most common shrub component of shrub-steppe vegetation on the Hanford Site. Sagebrush stands represent an important resource for wildlife that are dependent on sagebrush habitat to survive and successfully reproduce, such as black-tailed jackrabbits, sage sparrows, sage grouse, and loggerhead shrikes. Since 1993, areas of sagebrush die-off have been documented in stands near the 100-D Area, the cause of which is not known. Shrub die-off is not uncommon in 


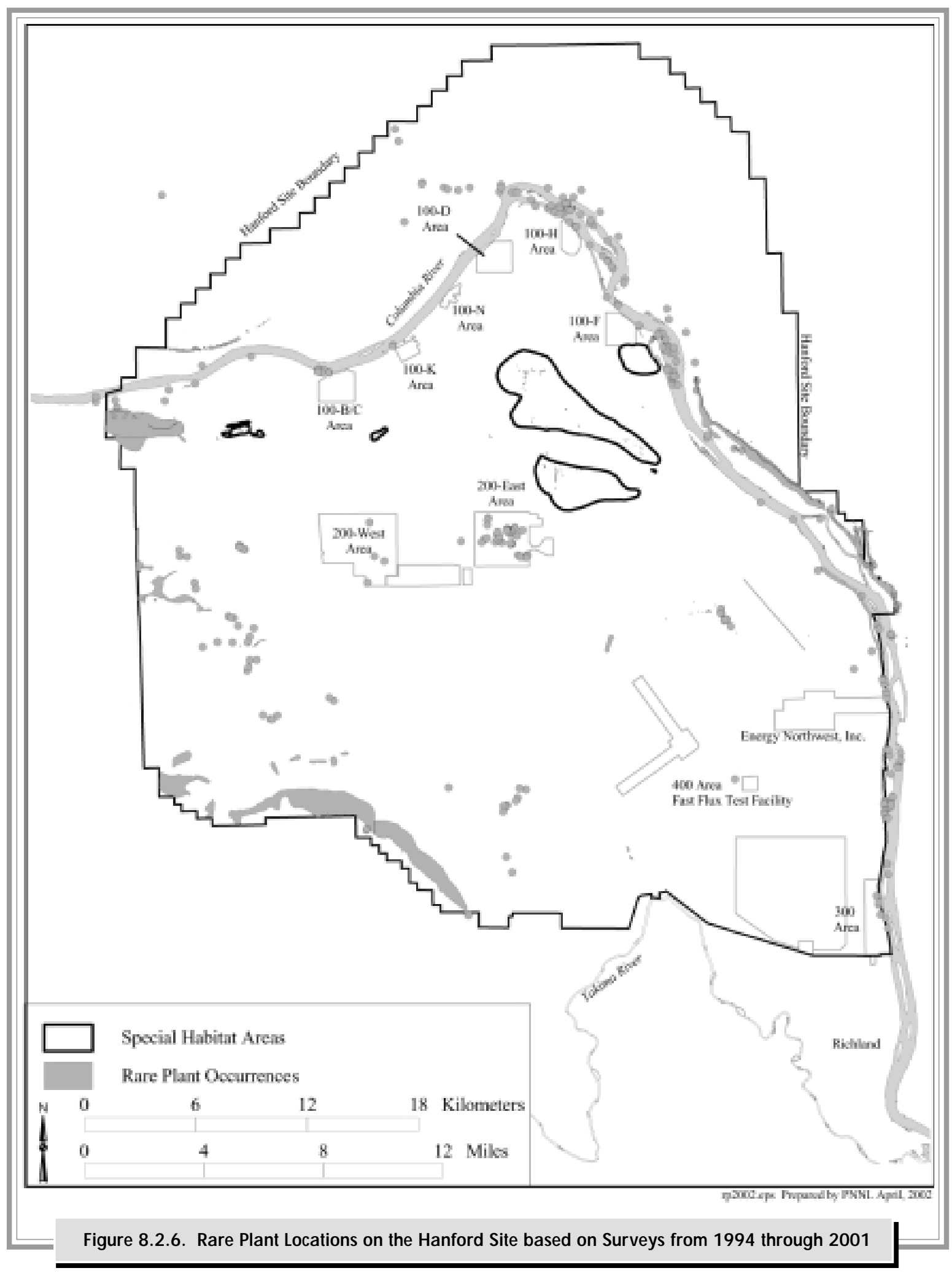


Table 8.2.1. Numbers of Rorippa columbia $e^{(a)}$ Stems Counted along the Hanford Reach of the Columbia River, 1994, 1998, 1999, 2000, and 2001

\begin{tabular}{|c|c|c|c|c|c|}
\hline Survey Location & 1994 Counts & 1998 Counts & 1999 Counts & 2000 Counts & 2001 Counts \\
\hline 100-F beach & $>15,000$ & 70 & 94 & 196 & 17 \\
\hline Locke Island & $>10,000$ & 117 & Not surveyed ${ }^{(\mathrm{b})}$ & 1,038 & 1,793 \\
\hline Island $18^{(\mathrm{c})}$ & $>10,000$ & 0 & Not surveyed & 19 & 0 \\
\hline $\begin{array}{l}\text { (a) Persistent sep } \\
\text { (b) High water le } \\
\text { (c) Located in the }\end{array}$ & $\begin{array}{l}\text { yellowcress. } \\
\text { ls prevented acc } \\
\text { Columbia River }\end{array}$ & $\begin{array}{l}\text { to populations. } \\
\text { he } 300 \text { Area. }\end{array}$ & & & \\
\hline
\end{tabular}

the intermountain west and such episodes have been reported from British Columbia, Idaho, Nevada, Utah, and Wyoming (Dobrowolski and Ewing 1990). Die-off of shrubs has been attributed to severe rootlet mortality, root rot, soil salinity, anaerobiosis, and vascular shoot wilt induced by fungal pathogens (Nelson et al. 1989; Weber et al. 1989). To date, no evidence exists suggesting any relationship between Hanford Site operations and the distribution and extent of the die-off of sagebrush. Big sagebrush is the only vascular plant species that has declined in the areas monitored. Other shrubs, such as hopsage ( $G$ rayia spinosa) and bitterbrush (Purshia tridentata), with similar deep root systems appear unaffected. In the monitored areas, herbaceous plant species, such as native bunchgrasses, also appear to remain relatively healthy and vigorous.

The extent of the die-off on the Hanford Site was mapped and survey data were collected in 1996 and 1997 to establish a baseline for monitoring future expansion of the die-off (PNNL-11700). The resulting report indicated that a total area of 1,776 hectares (4,388 acres) showed evidence of sagebrush decline, with a central portion of 280 hectares (692 acres) where shrub death was estimated to be $\sim 80 \%$ or greater. Observations of shrub vigor (percent canopy defoliation) show continuing declines in shrub health in the die-off areas and along the boundary of the die-off areas.

Annual surveys from 1997 through 2001 of shrubs within the die-off areas indicated significant declines in sagebrush during 1997 through 1999. Shrubs along transects were classified by amount of live canopy in the following manner: dead, less than 50\% live canopy, $50 \%$ to $90 \%$ live canopy, and more than $90 \%$ live canopy. These measurements indicated that though few shrubs actually died along each measured transect, $10 \%$ to $35 \%$ of shrubs measured declined by at least one category between 1997 and 2001. Surveys in 2001 indicated continued decline in sagebrush vigor on transect 6 outside the main die-off area. Two transects were burned in a small wildfire that occurred near the 100 Areas Fire Station and shrubs could no longer be measured (Table 8.2.2). However, the data also indicate a lack of establishment of new shrub seedlings that would be necessary for recovery of the population.

\begin{tabular}{|c|c|c|c|c|c|c|c|c|}
\hline \multirow[b]{2}{*}{$\underline{T \text { ransect }}$} & \multicolumn{8}{|c|}{$\begin{array}{l}\text { Table 8.2.2. Decline of Sagebrush Conditions Measured along Six Transects within and along the } \\
\text { Boundaries of the Sagebrush Die-Off Area on the Hanford Site }\end{array}$} \\
\hline & $\begin{array}{l}\% \text { Dead } \\
1997\end{array}$ & $\begin{array}{l}\% \text { Dead } \\
1999\end{array}$ & $\begin{array}{l}\% \text { Dead } \\
\underline{2000}\end{array}$ & $\begin{array}{l}\% \text { Dead } \\
\underline{2001}\end{array}$ & $\begin{array}{l}\%>90 \% \text { Live } \\
\text { Canopy } 1997\end{array}$ & $\begin{array}{l}\%>90 \% \text { Live } \\
\text { Canopy } 1999\end{array}$ & $\begin{array}{l}\%>90 \% \text { Live } \\
\text { Canopy } 2000\end{array}$ & $\begin{array}{l}\%>90 \% \text { Live } \\
\text { Canopy } 2001\end{array}$ \\
\hline $1(n=27)$ & 95 & 95 & 95 & (a) & 5 & 5 & 5 & (a) \\
\hline $2(n=34)$ & 18 & 18 & 18 & (a) & 41 & 35 & 22 & (a) \\
\hline $3(n=31)$ & 81 & 84 & 84 & 88 & 10 & 0 & 0 & 0 \\
\hline $4(n=50)$ & 48 & 48 & 48 & 50 & 14 & 4 & 6 & 2 \\
\hline $5(n=61)$ & 15 & 16 & 20 & 22 & 43 & 15 & 24 & 0 \\
\hline $6(n=51)$ & 18 & 18 & 18 & 18 & 54 & 27 & 27 & 4 \\
\hline
\end{tabular}




\subsubsection{Ecological Compliance}

Policies of the DOE Richland Operations Office require that all projects having the potential to adversely affect biological resources have an ecological compliance review performed prior to initiation of the project. This review assures that the DOE is in compliance with the Endangered Species A ct and the M igratory Bird T reaty $A$ ct. It also assures that other significant resources such as Washington State listed species of concern, wetlands, and native shrub steppe habitats are adequately considered during the project planning process. Where effects are identified, mitigation action is prescribed. Mitigation actions can include avoidance, minimization, rectification, or compensation.

Since many projects occur during periods of the year when the plants are not growing and plants are difficult to identify or evaluate, each of the operational areas (200-East and 200-West, all of the 100 Areas, and the 300 Area) are surveyed each spring. These baseline surveys provide information about the habitat types, and species inventories and abundance, which can then be used throughout the rest of the year to assess potential project impacts. Examples of the baseline survey maps are available at http://www.pnl.gov/ecology/ ecosystem/Compliance/comp.html.

A total of 109 ecological compliance reviews were performed during 2001 in support of general Hanford Site activities. An additional 60 reviews were performed in support of environmental restoration activities. The total number of reviews prepared in 2001 (169) was similar to the number performed in 2000 (Table 8.2.3).

\begin{tabular}{|c|c|c|c|c|c|}
\hline Calendar Year & 100 A reas & 200 A reas & 300 A rea & Other $^{(a)}$ & $\underline{\text { Total }}$ \\
\hline 1997 & 8 & 79 & 44 & 33 & 164 \\
\hline 1998 & 42 & 91 & 28 & 47 & 208 \\
\hline 1999 & 36 & 72 & 36 & 52 & 196 \\
\hline 2000 & 36 & 52 & 27 & 47 & 161 \\
\hline 2001 & 26 & 64 & 27 & 52 & 169 \\
\hline Totals & 147 & 358 & 162 & 231 & 898 \\
\hline
\end{tabular}




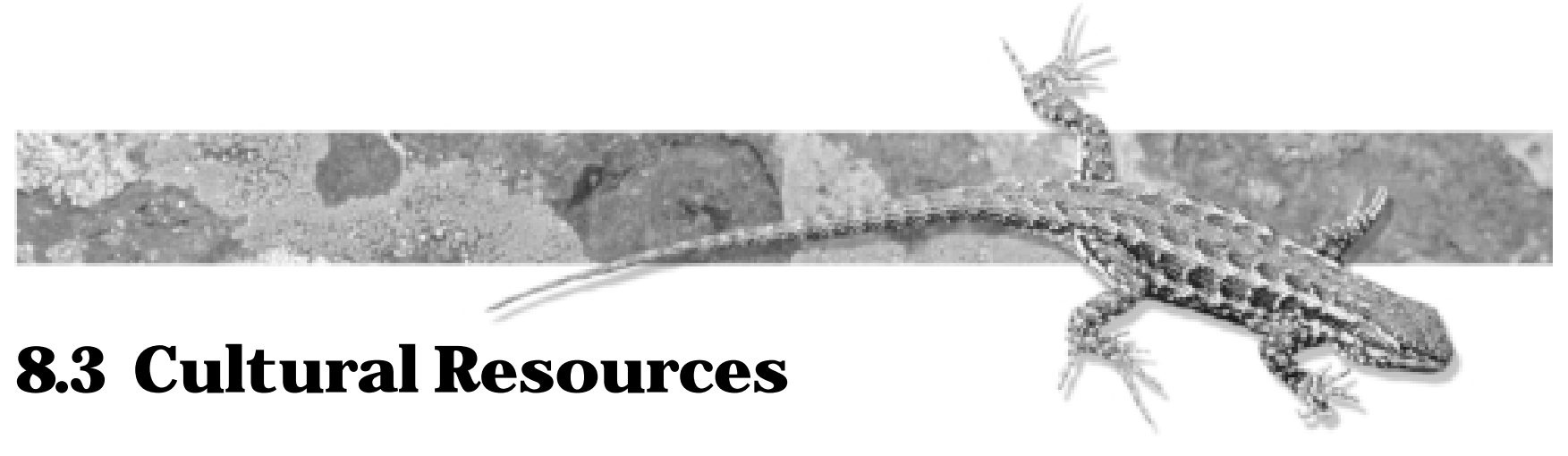

L. L. H ale and D. W . H arvey

The U.S. Department of Energy (DOE), Richland Operations Office, established a cultural resources program in 1987 that is managed by the Hanford Cultural Resources Laboratory as part of the Pacific Northwest National Laboratory (PNL-6942). Pacific Northwest National Laboratory, Bechtel Hanford, Inc., and
CH2M HILL Hanford, Inc. provided support to DOE for the cultural resources program on the Hanford Site throughout 2001. The U.S. Fish and Wildlife Service also has managed cultural resources on the Hanford Site since October 1999.

\subsubsection{Monitoring Cultural Resources}

The DOE Richland Operations Office has the responsibility for determining effective management and protection policies for the Hanford Site's cultural resources. The Hanford Cultural Resources Laboratory has maintained a monitoring program since 1987 to determine the impact of DOE Richland Operations Office policies and to safeguard cultural resources from adverse effects associated with natural processes or unauthorized excavation and collection that violate federal laws.

Monitoring conducted during 2001 focused on four site or place categories: Locke Island's erosion transects, archaeological sites with natural and visitor impacts, historic buildings and structures, and places with Native American burials.

\subsubsection{Locke Island Erosion}

Erosion monitoring at Locke Island has been ongoing since 1994. Locke Island, located on the Columbia River in the Hanford Reach National Monument, contains some of the best-preserved evidence of prehistoric village sites still existing in the Columbia Basin and is included within the Locke Island National Register Archaeological District. The island has sustained loss due to erosion along its eastern shoreline that has affected archaeological materials. Recent studies have shown that this is due to a large landslide on the eastern side of the Columbia River.

In the 1960s and 1970s, intensive irrigation development began to occur east of Locke Island, above the White Bluffs, which form the eastern boundary of the
Columbia River channel in this area. As a result, the White Bluffs began to show geological failures as excess irrigation water seeped out along the bluffs. One of the largest such failures, known as the "Locke Island Landslide," is located just east of Locke Island. By the early 1980s, the extent of this landslide had moved westward into the river channel toward the island and was directing the current at the island's eastern perimeter. Erosion of the eastern bank of the island accelerated, threatening the cultural resources. By the early 1990s, the erosion had exposed cultural features and artifacts along the bank, leading to the beginning of intermittent monitoring of the erosion cutbank. In 1994, DOE initiated more scheduled, systematic monitoring of island erosion to better understand the physical processes involved as well as mitigate ongoing loss of the archaeological record (PNNL-11970).

Erosion monitoring continued at the Locke Island erosion transects during 2001. The greatest loss recorded at any one monitoring transect was 1 meter (3.28 feet), as measured perpendicularly from the Columbia River (Figure 8.3.1). This amount of erosion was much less than the 19.6 meters (64.3 feet) of horizontal cutbank lost to the river at a single transect in 1997 during a period of high water flow (PNNL-11970). Two transects showed a 0.1 meter ( 0.33 foot) gain in 2001, which was caused by measuring discrepancies and bank separation prior to collapse. The overall reduction in erosion observed from 1997 to 2001 was likely attributable to several factors including a slow and steady snowmelt following the 1998-1999 winter season, less dramatic river fluctuations during periods of high water, and a wider channel on the east side of Locke Island (Figure 8.3.2). 

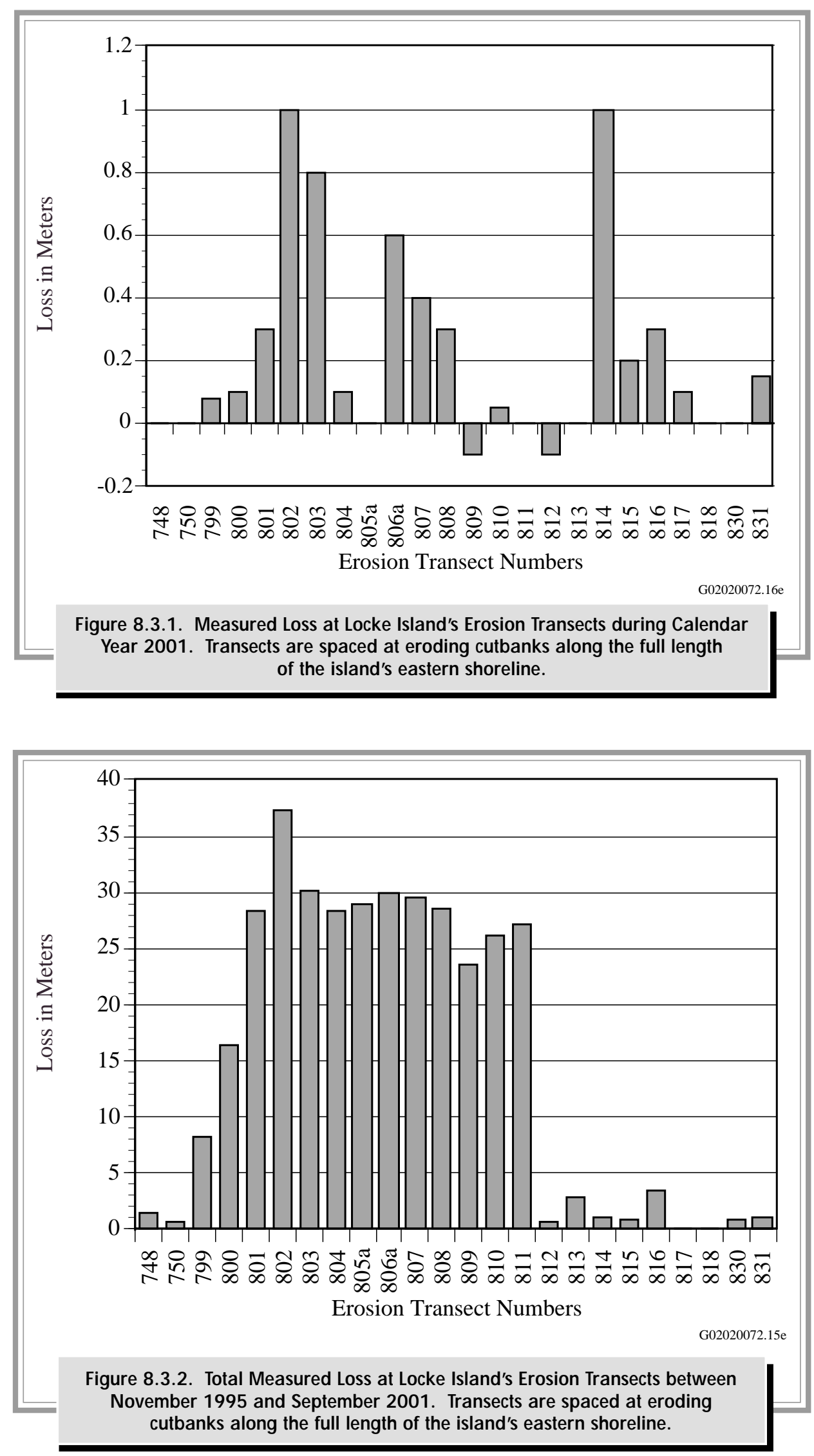


\subsubsection{Archaeological Sites}

Monitoring associated with the second category, archaeological sites with natural and visitor impacts, began in 1998 and continued in 2001. Eighty-six archaeological sites were monitored to gather empirical data about

- the natural characteristics of each site (i.e., landform, stratigraphy)

- the processes adversely affecting the site (such as riverbank erosion, wind erosion, or human visitation)

- the trends in change at the site (e.g., likelihood of increasing erosion or eventual stability).

Monitoring stations established at each archaeological site in this category facilitated the collection of standardized data unique to each site. In 2001, effects observed and measured at these sites were due to recreational use, visitor impact, and/or natural weathering processes. The data collected at these archaeological sites will be used to monitor changes that may impact the site, predict outcomes, and proactively manage other similar archaeological sites across the Hanford Site.

\subsubsection{Historic Buildings}

Monitoring of historic buildings in 2001 focused on Bruggemann's Warehouse, the only cobblestone structure remaining on the Hanford Site, the White Bluffs Bank building, and the Hanford town site high school. The buildings were photographed and locations of structural deterioration were identified. Future monitoring inspections will continue to gather data about any crack widening and structural leaning that may occur.

\subsubsection{Cemeteries}

Places with cemeteries or known human remains include locations that are sacred to the Wanapum People, Yakama Nation, Confederated Tribes of the Umatilla Indian Reservation, and the Nez Perce Tribe. In 2001, all these places were monitored to document baseline conditions, determine whether wind or water erosion had exposed human remains, and assure that violations of Federal laws were not present or ongoing at these important places. Overall, places with human remains were found to be stable in 2001. However, one violation (collector digging) was noted at one cemetery or place with human remains.

In summary, a total of 83 archaeological sites, 3 buildings, and a number of cemetery or burial locations were monitored during 2001. Of the incidents recorded at these monitored places, 64 of 83 were related to natural causes such as animal trailing and digging, wind-caused erosion or aggradations, and water erosion. Seventeen percent of the incidents were determined to be human-related causes such as vehicle traffic where sites were exposed in roads or recreational activities such as fishing or duck hunting. Six percent of the incidents were found to be associated with recent collector digging within archaeological site boundaries and/or surface collection of artifacts. Such digging and collection on federal lands is a violation of federal law.

\subsubsection{Native American Involvement}

Members of the Confederated Tribes of the Umatilla Indian Reservation, Yakama Nation, Nez Perce Tribe, and Wanapum People were actively involved in the cultural resources program during 2001. Each tribe was involved in deciding DOE's cultural resource program work scope, budget, and schedule. Monthly meetings on cultural resource issues provided a venue for the exchange of information between DOE, tribal staff members, and site contractors about projects and work on the Hanford Site. These meetings included discussions of sitewide projects dealing with a wide range of topics: the groundwater/vadose zone, sagebrush mitigation, survey of Hanford's large dune fields, $\mathrm{N}$ ative $\mathrm{A}$ merican $\mathrm{G}$ raves Protection and Repatriation $\mathrm{Act}$ issues, cultural resources management policies on the Hanford Reach National Monument, A rchaeological Resources Protection A ct of 1979 permit for re-licensing of Wanapum and Priest Rapid Dams, A rchaeological Resources Protection of 1979 A ct violations, and updates on a draft archaeological programmatic agreement and the Hanford Cultural Resources Management Plan (PNL-6942). Tribal staff and site contractors worked together during the completion of several field surveys to identify and record cultural features, sites, and landscapes in advance of new construction and archaeological test excavations and to monitor numerous projects requiring excavation during the year.

One member of the Wanapum People assisted with cultural resource surveys, site form preparation, records management, and equipment use in 2001. In addition, interviews were conducted with Wanapum elders concerning traditional cultural properties on the Hanford Site. 


\subsubsection{Public Involvement}

Public involvement is an important component of a cultural resources management program. To accomplish this, DOE developed mechanisms that allow the public access to cultural resources information and the ability to comment and make recommendations concerning the management of cultural resources on the Hanford Site. These mechanisms were woven into draft public involvement procedures that include input provided by the public and Hanford Site staff over the past several years.

Workshops were organized and conducted to seek public comment on a variety of cultural resource initiatives and projects undertaken by DOE. Since 2000, comments have been sought on an updated draft of the Hanford Cultural Resources Management Plan (PNL-6942) and a draft of public involvement procedures. The purpose of public involvement procedures was to determine the process that the Hanford Cultural Resources Program will follow to interact with interested groups. Major interest groups involved in assisting DOE with cultural resource initiatives included the B Reactor Museum Association, White Bluffs-Hanford Pioneer Association, the Washington State Railroad Historical Society, and local historical societies and museums.

One Public Issues Exchange Workshop was held in 2001. At this workshop, there were discussions pertaining to efforts undertaken by the U.S. Fish and Wildlife Service to stabilize the East White Bluffs log cabin, planned exhibits for Black History Month, status of plans for the rehabilitation of the White Bluffs Bank building, and an update on the various initiatives for the preservation of B Reactor, including the preservation of B Reactor artifacts and completion of Historic American Engineering Record documentation of B Reactor.

These workshop discussions indicated continual strong support for the use of B Reactor as a publicly accessible museum. A Save America's Treasures grant proposal, a Federal Historic Preservation Fund grant program to preserve nationally significant structures and sites, was discussed as a means to fund renovation of B Reactor.

Additional discussions at the workshop focused on the ongoing curation of Manhattan Project and Cold War era artifacts into the Hanford collection, and an update on the draft History of the Plutonium Production Facilities at the Hanford Site Historic District, 1943-1990, which was completed and distributed for public review in 1999-2000, and is scheduled to be completed and submitted to DOE Richland Operations Office for publication in 2002.

In 2001, DOE continued to document the oral histories of early residents of areas now part of the Hanford Site as well as Native Americans, former Hanford Site workers, and current site employees. A total of 18 interviews were conducted in 2001. The Oral History Pilot Project identified pre-1943 Euro-American settlement themes that led to an interview of Judge Lloyd Wiehl, former resident of East White Bluffs and the Wiehl Ranch, an area now part of the Hanford Site.

\subsubsection{Section 106 Activities}

Pursuant to Section 106 of the $\mathrm{N}$ ational H istoric Preservation A ct, cultural resources reviews must be conducted before a federally funded, federally assisted, or federally licensed ground disturbance or building alteration/demolition project can take place. Because the Hanford Site is a federal facility, cultural resource reviews are required to identify properties within the proposed project area that may be eligible for, or listed in, the National Register of Historic Places and evaluate the project's potential to affect any such property. The recently modified cultural resource review process includes two review options. The first option allows DOE to consider the review process complete if the proposed projects have no potential to effect historic properties. The second option involves notification of the
State Historic Preservation Officer, tribes, and interested parties if a project has potential to affect a historic property.

During 2001, Hanford Site contractors requested 150 cultural resource reviews (Figure 8.3.3). A majority of the reviews involved areas that had been previously surveyed or were located on previously disturbed ground. Of the areas reviewed, 11 also were monitored during the construction phase, 1 required an archaeological survey, and 86 involved proposed building modifications, demolitions, and Programmatic Agreement for the Built Environment (DOE/RL-96-77) exemptions. Exempt properties are those buildings and structures that are clearly not historic; therefore, they are 


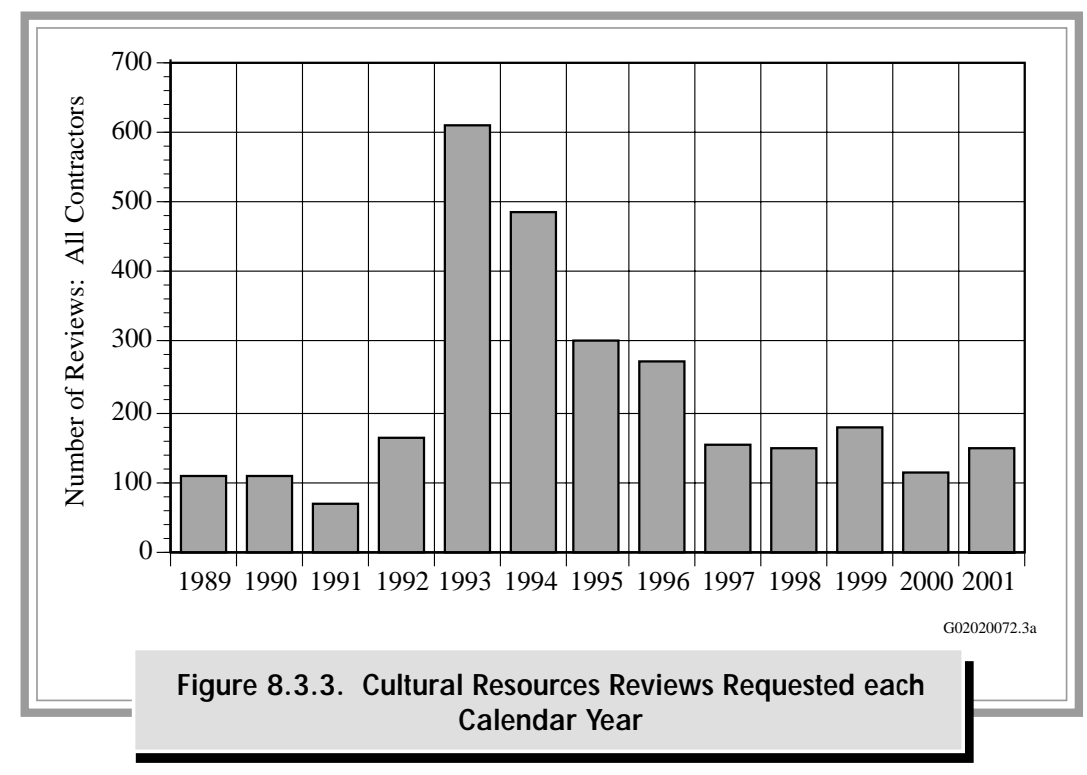

not required to be evaluated for listing in the National Register of Historic Places due to their obvious lack of historic significance. The archaeological survey covered a total of $\sim 32$ hectares ( $~ 80$ acres) and no isolated finds or archaeological sites were recorded.

\subsubsection{Section 110 Activities}

Section 110 of the $\mathrm{N}$ ational $\mathrm{H}$ istoric Preservation A ct requires that federal agencies undertake a program to identify, evaluate, and nominate historic properties and consider the use and reuse of historic buildings or structures. Agencies are further required to maintain and manage historic properties in a way that considers preservation of their value and assures that preservationrelated activities are completed in consultation with other agencies, the tribes, and the general public.

During 2001, DOE was in the process of evaluating the feasibility of retaining various historic structures on the Hanford Site, including the Hanford town site high school and the Coyote Rapids hydroelectric pumping plant, two pre-Manhattan Project era buildings. An assessment of the structural condition of both buildings was completed. The studies detailed existing conditions, interim actions, conservation needs, and immediate stabilization requirements. Both studies developed cost estimates for stabilization. A committee comprised of members of the interested public and staff of DOE, Bechtel Hanford, Inc., and Pacific Northwest National Laboratory continued to explore stabilization and restoration alternatives for the historic White Bluffs Bank building.

In 2001, management activities conducted to fulfill Section 110 requirements included continued implementation of the Programmatic Agreement for the Built
Environment (DOE/RL-96-77) and application of the Hanford Site curation strategy to identify, evaluate, and preserve Manhattan Project and Cold War era artifacts (DOE/RL-97-71). Since Section 110 activities began on the Hanford Site, 531 buildings/structures have been documented on historic property inventory forms and are on file at the Hanford Cultural Resources Laboratory (Figure 8.3.4).

Five surveys comprised the 2001 Section 110 efforts: the 24 Command Wildland Fire Assessment, the Fiscal Year 2001 Site Monitoring Task - Rattlesnake Mountain Survey, the Gable Butte Block Survey, the Fiscal Year 2001 Fire Assessment - 100 Areas Fire Survey, and the Fiscal Year 2001 Low Water River Survey. A total of $\sim 1,068$ hectares (2,641 acres) were surveyed in 2001 for Section 110 compliance.

The 24 Command Wildland Fire Assessment survey was the result of the U.S. Department of Interior's Burn Area Emergency Rehabilitation team's assessment of the effects of the 24 Command Wildland Fire on the site's cultural resources. The 24 Command Wildland Fire was a large wildfire that burned portions of the site and the Hanford Reach National Monument in the summer of 2000 (PNNL-13487). The team recommended that DOE complete an inventory of locations disturbed by fire suppression efforts, and complete a field inventory and evaluation of sites previously recorded 


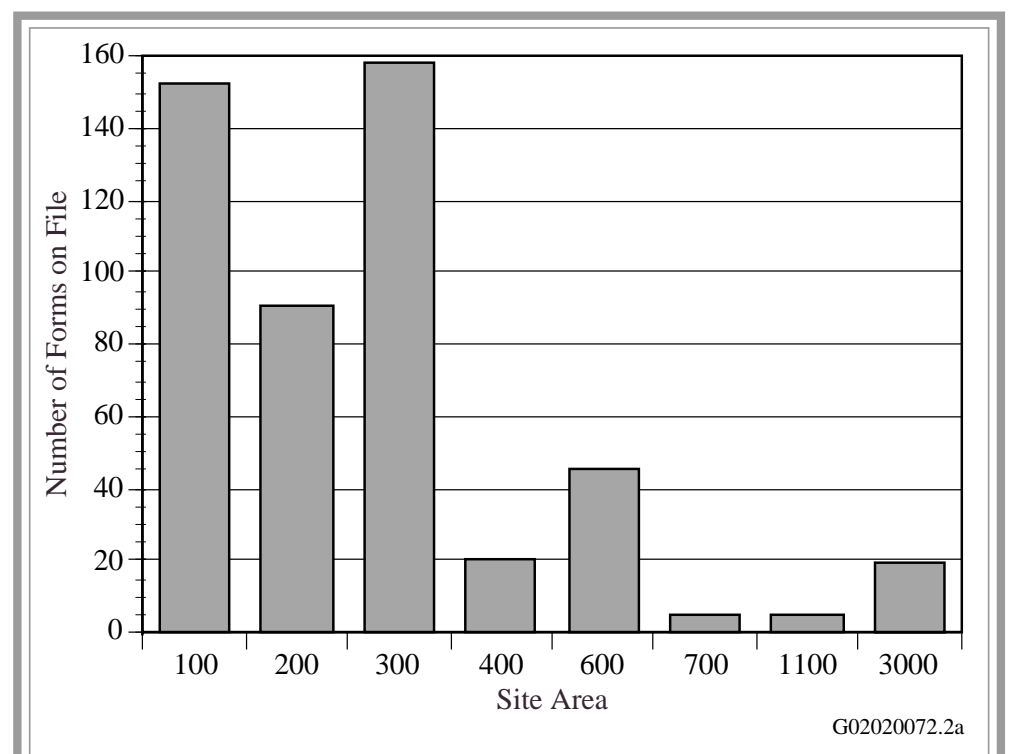

Figure 8.3.4. Former and Current Hanford Buildings and Structures Documented with a Washington State Historic Property Inventory Form. The 1100 and 3000 Areas are former site areas.

area was surveyed because Gable Butte is a geographical extension of Gable Mountain and is likely to be associated with the Gable Mountain Cultural District that was determined eligible for the National Register of Historic Places in 1990. The survey covered $\sim 98$ hectares ( 244 acres). Fourteen archaeological sites and five isolated finds were recorded during the survey. Archaeological features recorded included cairns, talus pits, two hunting sites/game drives, several lithic scatters, and flaked detritus. These prehistoric features were evidence that the area was likely to have been used for spirit quests by local tribes. Historic period artifacts consisted of four isolated finds, including fence posts and cans.

The Fiscal Year 2001 Fire Assessment 100 Areas Fire Survey was conducted by the Hanford Cultural Resources Laboratory with assistance from members of the Confederated Tribes of the Umatilla Indian Reservation. The survey, which covered

within the burn area. The 2001 assessment was conducted by the Hanford Cultural Resources Laboratory with the assistance of the Confederated Tribes of the Umatilla Indian Reservation, the $\mathrm{Nez}$ Perce Tribe, the Yakama Nation, and the Wanapum People. Five newly identified archaeological sites and two newly identified isolated finds were recorded during the assessment. Twenty-four previously recorded sites and four previously recorded isolated finds also were assessed for damage from the fire. Within the burn area, an additional 21 isolated finds and 4 sites could not be relocated during the survey. Although the fire destroyed wooden artifacts and structures, the fire did expose previously heavily vegetated areas around several historic antiaircraft artillery sites in the burn area that resulted in the discovery of concrete foundations and pads, sidewalks and other non-wooden artifacts associated with these sites.

The Fiscal Year 2001 Site Monitoring Task - Rattlesnake Mountain Survey was conducted by the Hanford Cultural Resources Laboratory with assistance from the Nez Perce Tribe. Approximately 36 hectares ( 90 acres) were surveyed on top of Rattlesnake Mountain around the radio towers and the observatory. This survey was undertaken to inventory cultural resources at the summit of the mountain. Three prehistoric archaeological sites consisting of rock cairns were recorded.

The Gable Butte Block Survey was conducted by the Hanford Cultural Resources Laboratory with assistance from members of the Wanapum People and the Confederated Tribes of the Umatilla Indian Reservation. The $\sim 571$ hectares $(\sim 1,413$ acres $)$, was conducted in response to a wildfire started by two lightening strikes in the 100 Areas in June 2001. One archaeological site and two isolated finds were recorded during the survey. The survey also noted that the area suffered minor archaeological impacts from fire suppression activities.

The Fiscal Year 2001 Low Water River Survey was conducted by the Hanford Cultural Resources Laboratory with assistance from members of the Wanapum People, Yakama Nation, and Nez Perce Tribe. The intent of the 190-hectare (470-acre) survey was to examine areas immediately adjacent to the Columbia River that were exposed during low river flows. Two newly identified historic sites were recorded, both linear rock features most likely associated with mining activities in the early 1900s. In addition, two newly identified prehistoric isolates were discovered, a net sinker and a bifacial tool. Many previously recorded sites also were observed during the survey. The survey noted that the archaeological sites exhibited minimal erosion damage.

\subsubsection{Historic District}

During 2001, the building mitigation project continued to implement the Programmatic Agreement for the Built Environment (DOE/RL-96-77) and the sitewide treatment plan (DOE/RL-97-56) at the Hanford Site. The treatment plan is stipulated in the programmatic agreement and directs that a mitigation document be produced that chronicles the history of the Hanford 
Site during the Manhattan Project and Cold War periods. The draft History of the Plutonium Production Facilities at the Hanford Site Historic District, 1943. 1990 was completed and distributed in 1999 for public review, regulatory review, and peer review. Review comments have been received by DOE and included in the final document that is to be published in 2002.

The Hanford Site Manhattan Project and Cold War Era Historic District was established in 1996, and 185 buildings, structures, and complexes were determined eligible for listing in the National Register of Historic Places as contributing properties within the historic district recommended for individual documentation. A contributing property is a building, structure, site, or object that adds to the historic significance of a historic district (Figure 8.3.5). Subsequent public meetings and staff evaluations identified additional properties in the 600, 700, and former 1100 Areas, including the Hanford Site railroad and the Hanford Atmospheric Dispersion Test Facility, as contributing properties within the historic district and recommended for individual documentation, bringing the total to 190 (Figure 8.3.6). All of the buildings, structures, and complexes recommended for individual documentation have been documented according to standards identified in the sitewide treatment plan (DOE/RL-97-56). Six historic properties, including B Reactor, have been documented at the Historic American Engineering Record level, 46 have been documented with Expanded

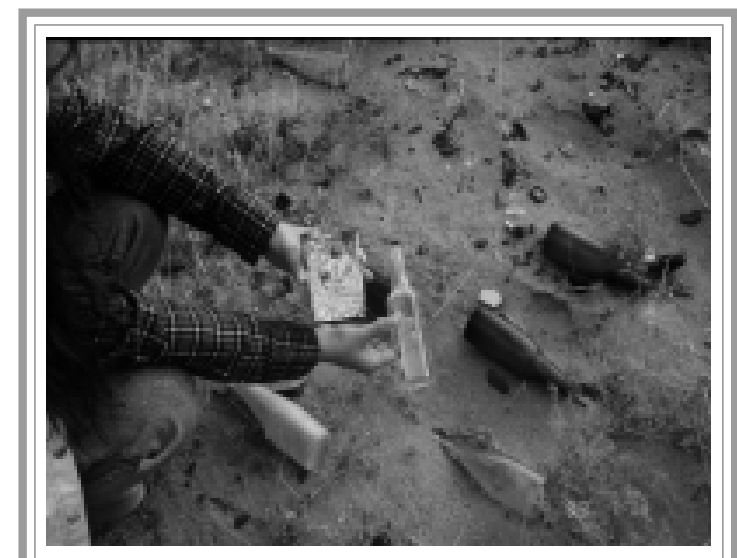

Figure 8.3.5. Historic Sites are Commonly Found during Surveys Conducted at the Hanford Site

Historic Property Inventory Forms, while standard Historic Property Inventory Forms have been prepared for the remaining 138 buildings and structures.

Approximately 900 buildings and structures have been identified as either contributing properties with no individual documentation requirement or as noncontributing/exempt buildings and structures. These buildings will be documented in a database maintained by DOE. According to the Programmatic Agreement for the Built Environment (DOE/RL-96-77), certain

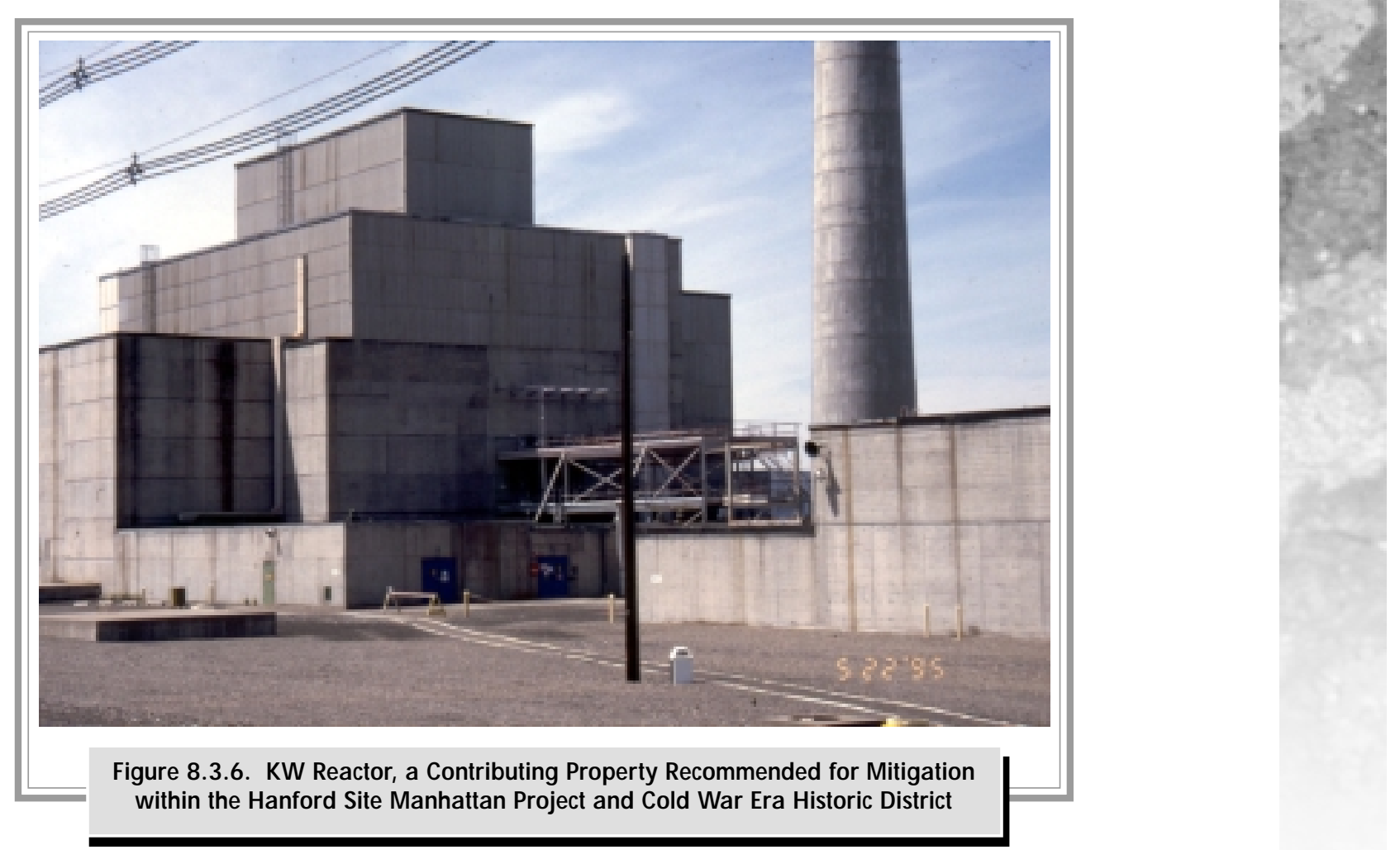


property types such as mobile trailers, modular buildings, storage tanks, towers, wells, and structures with minimal or no visible surface manifestations are exempt from the identification and evaluation requirement.

\subsubsection{Hanford Curation Strategy}

The application of the curation strategy for artifacts and records associated with the Hanford Site Manhattan Project and Cold War Era Historic District continued in 2001. The strategy is stipulated in the Programmatic Agreement for the Built Environment (DOE/RL-96-77), which directs DOE to assess the contents of Hanford's historic buildings and structures prior to the commencement of deactivation, decontamination, or decommissioning activities. The purpose of the assessments is to identify and preserve any artifacts (e.g., control panels, signs, scale models, machinery) that may have interpretive or educational value as exhibits within national, state, or local museums. The assessments are accomplished by conducting walkthroughs of the contributing properties within the historic district by teams of cultural resources specialists, historians, archivists/curators, and facility experts. Twenty-five walkthroughs were conducted in 2001, including 16 in facilities in the 300 Area, 1 in the 600 Area, 7 in the 100 Areas, and 1 in the 200 Areas. Industrial artifacts were tagged and recorded by the Hanford Cultural Resources Laboratory and transferred to the custody of the Columbia River Exhibition of History, Science and Technology museum for curation.

DOE's archaeological collections and associated records continued to be housed in Pacific Northwest National Laboratory's repositories during 2001. A draft management plan that deals specifically with archaeological collections, developed in 1998, was used during 2001 to guide access and use of the collections and to provide guidelines for acquisition and transfer of collections. A pest management and monitoring effort for archaeological collections conducted during 2001 found no indications of pest infestations.

\subsubsection{Education and Research}

Educational activities associated with the cultural resources program in 2001 consisted of lectures on a variety of topics, to groups ranging from public school classrooms to civic groups, colleges, and professional societies. Several symposia were organized throughout the Pacific Northwest region to present DOE's cultural resources management techniques to professional groups and societies. Washington's Archaeology Month provided educational opportunities in the form of lectures and social gatherings for residents of the Tri-Cities' area through the efforts of staff and professionals from Washington State University, the DOE, and the Pacific Northwest National Laboratory.

Several cultural resources newsletters were written by staff of the Pacific Northwest National Laboratory, DOE, and Bechtel Hanford, Inc. that focused on Hanford histories and cultural resources management issues on the Hanford Site, including stabilization plans for the White Bluffs Bank building, establishment of the Hanford Site, documentation of Manhattan Project and Cold War buildings, archaeological excavations and Hanford's prehistory, long-term cultural site monitoring, Hanford's historic farming landscape, early pre-Hanford Site settlements and the White Bluffs landing, and updates on the B Reactor project.

Pacific Northwest National Laboratory participated in the Associated Western Universities, Inc. program by hosting a student intern involved in field and laboratory work with Hanford Cultural Resources Laboratory staff.

Research activities continued as part of compliance work. Research in the field of archaeology and history focused on archaeological site preservation and protection and documentation of the site's built environment from the Manhattan Project and Cold War periods. 


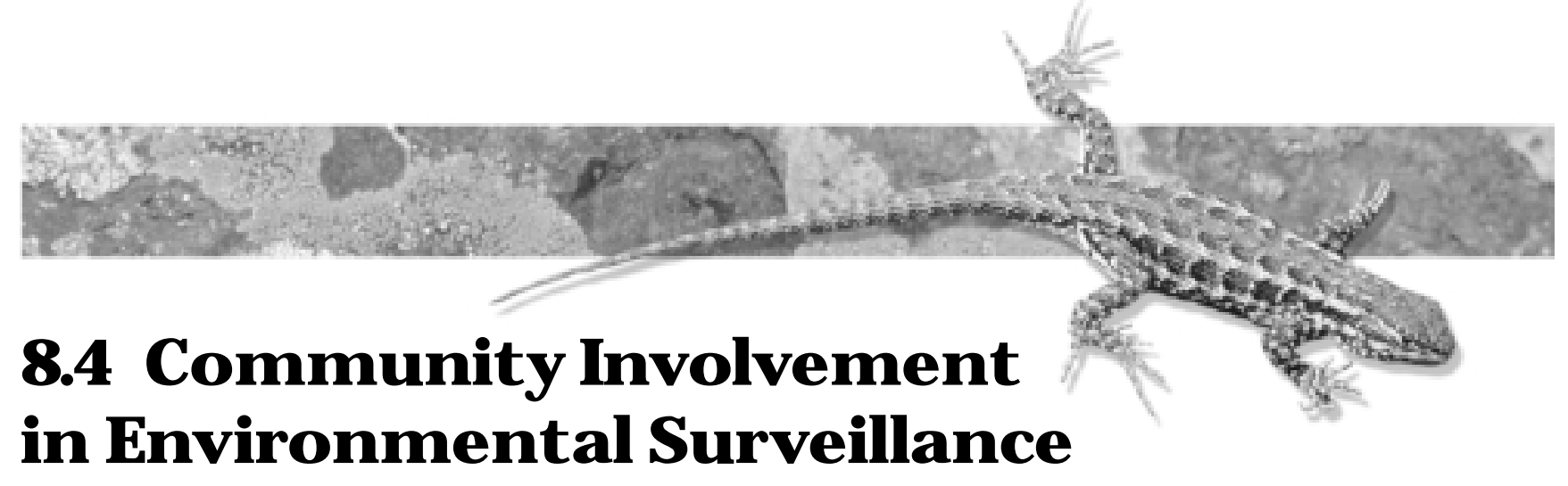

R. W. H anf

Since 1991, citizens living near the Hanford Site have actively participated in site environmental sur veillance activities through the Surface Environmental Surveillance Project. During 2001, local teachers operated nine radiological air-sampling stations at selected locations around the site perimeter. These stations were located in Basin City, Richland, Pasco, Kennewick, north Franklin County, Othello, Mattawa, Toppenish, and Benton City, Washington (see Figure 4.1.1). Each station consisted of equipment to collect air samples and to monitor ambient radiation levels. Four of the nine stations also included large, lighted, informational displays that provided real-time meteorological and radiological information as well as general information on

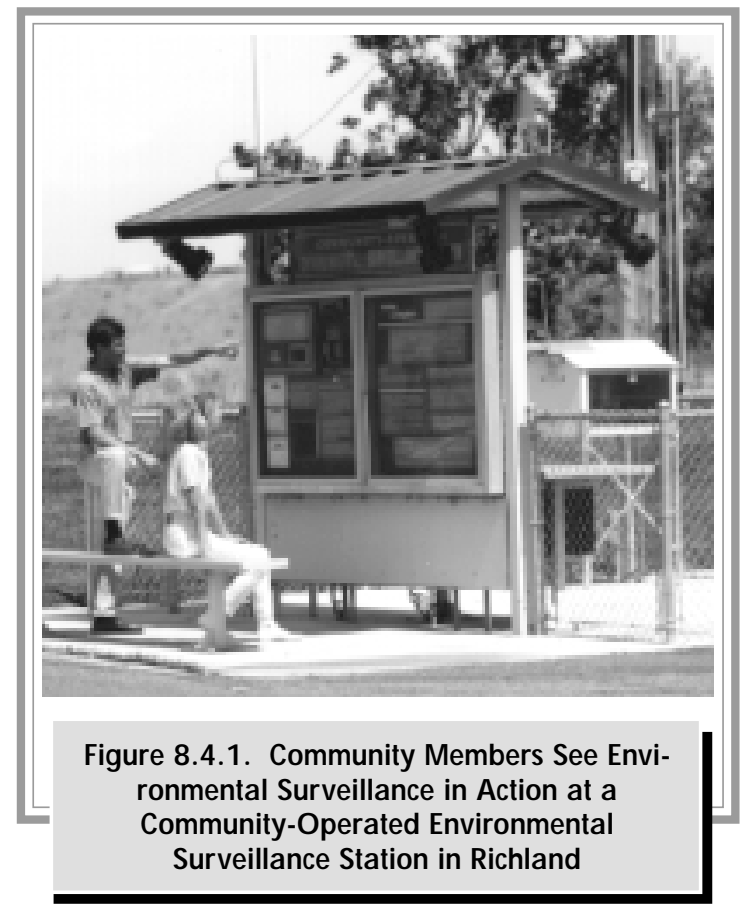

station equipment, sample types, and analyses (Figure 8.4.1). The station managers' names and telephone numbers were provided on the four displays for anyone desiring additional information about the purpose of the station, station equipment, or analytical results.

Two teachers from schools located near the stations were selected to operate each station. The teachers were responsible for collecting a variety of air samples, preparing the samples and collection records for submission to the analytical laboratory, monitoring the performance of station equipment, performing minor station maintenance, and participating in scheduled training. They also served as points of contact for local citizens. Pacific Northwest National Laboratory personnel worked closely with the teachers to provide training, maintain station equipment and displays, and coordinate sampling and analytical efforts with other Hanford Site environmental surveillance. Analytical results for samples collected at these stations in 2001 are discussed in Section 4.1. Results of gamma radiation measurements obtained at selected stations are discussed briefly in Section 4.7.

As a result of a reduced project budget in fiscal year 2002, the number of teacher-operated air-sampling stations was reduced from nine to four at the end of January 2002. The only stations that remained teachermanaged were those with displays and computerized data-collection systems. These stations were located in Basin City, Richland, Toppenish, and at Edwin Markham School in north Franklin County. The stations without displays continued to operate but Pacific Northwest National Laboratory personnel, who operated the stations prior to teacher involvement, resumed sample collection responsibilities. 


\subsection{References}

65 FR 114. June 13, 2000. Presidential Proclamation 7319, "Establishment of the Hanford Reach National Monument." Federal Register.

Archaeological Resources Protection Act of 1979. 1979. Public Law 96-95, as amended, 16 USC 470-470ii.

Bald and Golden Eagle Protection Act. 1992. Public Law 87-884, as amended, 76 Stat. 1246, 16 USC 688 et seq.

Dobrowolski, J. P. and K. Ewing. 1990. "Vegetation Dynamics and Environmental Attributes of a Great Basin Valley Exhibiting Widespread Shrub Dieback." In Symposium on Cheatgrass Invasion, Shrub Die-Off, and Other Aspects of Shrub Biology and Management, Las Vegas, Nevada. U.S. Department of Agriculture, Intermountain Research Station, Provo, Utah, pp. 103-114.

DOE/RL-96-77. 1996. Programmatic Agreement Among the U.S. Department of Energy, Richland Operations Office, the Advisory Council on Historic Preservation, and the Washington State Historic Preservation Office for the Maintenance, Deactivation, Alteration, and Demolition of the Built Environment on the Hanford Site, Washington. U.S. Department of Energy, Richland Operations Office, Richland, Washington.

DOE/RL-97-56, Rev. 1. 1998. Hanford Site Manhattan Project and Cold War Era Historic District Treatment Plan. T. E. Marceau, Bechtel Hanford, Inc. for U.S. Department of Energy, Richland Operations Office, Richland, Washington.

DOE/RL-97-71. 1997. Hanford Curation Strategy: Manhattan Project and Cold War Era Artifacts and Records. U.S. Department of Energy, Richland Operations Office, Richland, Washington.

Endangered Species Act of 1973. 1973. Public Laws 93-205 through 100-707, as amended, 87 Stat. 884, 16 USC 1531 et seq.

Migratory Bird Treaty Act. 1918. Chapter 128, as amended, 40 Stat. 755, 16 USC 703-712.

National Historic Preservation Act. 1966. Public Law 89-665, as amended, 16 USC 470 et seq.
Native American Graves Protection and Repatriation Act. 1990. Public Law 101-601, as amended, 25 USC 3001 et seq.

Nature Conservancy. 1999. Biodiversity Inventory and Analysis of the Hanford Site. Final Report 1994-1999. The Nature Conservancy of Washington, Seattle, Washington.

Nelson, D. L., D. J. Weber, and S. C. Garvin. 1989. "The Possible Role of Plant Disease in the Recent Wildland Shrub Dieoff in Utah." In Symposium on Cheatgrass Invasion, Shrub Die-Off, and Other Aspects of Shrub Biology and Management, Las Vegas, Nevada, pp. 84-90.

PNL-6942. 1989. Hanford Cultural Resources Management Plan. J. C. Chatters (ed.), Pacific Northwest Laboratory, Richland, Washington.

PNNL-11518. 1997. Investigation of Anatomical Anomalies in the Hanford Site Mule Deer. B. L. Tiller, G. E. Dagle, L. L. Cadwell, T. M. Poston, and A. Oganesian, Pacific Northwest National Laboratory, Richland, Washington.

PNNL-11700. 1997. Characterization of a Sagebrush (Artemisia tridentata subsp. Wyomingensis) Die-Off on the Hanford Site. A. Cardenas, J. Lewinsohn, C. Auger, J. L. Downs, L. L. Cadwell, and R. Burrows, Pacific Northwest National Laboratory, Richland, Washington.

PNNL-11970. 1998. Monitoring Bank Erosion at the Locke Island Archaeological National Register District: Summary of 1996/1997 Field Activities. P. R. Nickens (ed.), B. N. Bjornstad, N. A. Cadoret, and M. K. Wright, Pacific Northwest National Laboratory, Richland, Washington.

PNNL-13487. 2001. Hanford Site Environmental Report for Calendar Year 2000. T. M. Poston, R. W. Hanf, R. L. Dirkes, and L. F. Morasch (eds.), Pacific Northwest National Laboratory, Richland, Washington.

PNNL-13859. 2002. Hanford Site Climatological Data Summary 2001 With Historical Data. D. J. Hoitink, K. W. Burk, J. V. Ramsdell, and W. J. Shaw, Pacific Northwest National Laboratory, Richland, Washington. 
Salstrom, D. and R. Easterly. 1997. Central Hanford 1997 Plant Community Inventory. Report to The Nature Conservancy of Washington, Seattle, Washington.

Tiller, B. L., G. E. Dagle, and L. L. Cadwell. 1997. "Testicular Atrophy in a Mule Deer Population." J. Wildl. Manage. 33(3):420-429.
Washington Natural Heritage Program. 1997. Rare Plant Species County List. Washington State Department of Natural Resources, Olympia, Washington (AvailableURL: http://www.wa.gov/dnr/htdocs/fr/nhp/refdesk/fsrefix.html)

Weber, D. J., D. L. Nelson, W. M. Hess, and R. B. Bhat. 1989. "Salinity and Moisture Stress in Relation to Dieoff of Wildland Shrubs." In Symposium on Cheatgrass Invasion, Shrub Die-Off, and Other Aspects of Shrub Biology and Management, Las Vegas, Nevada. U.S. Department of Agriculture, Intermountain Research Station, Provo, Utah. 


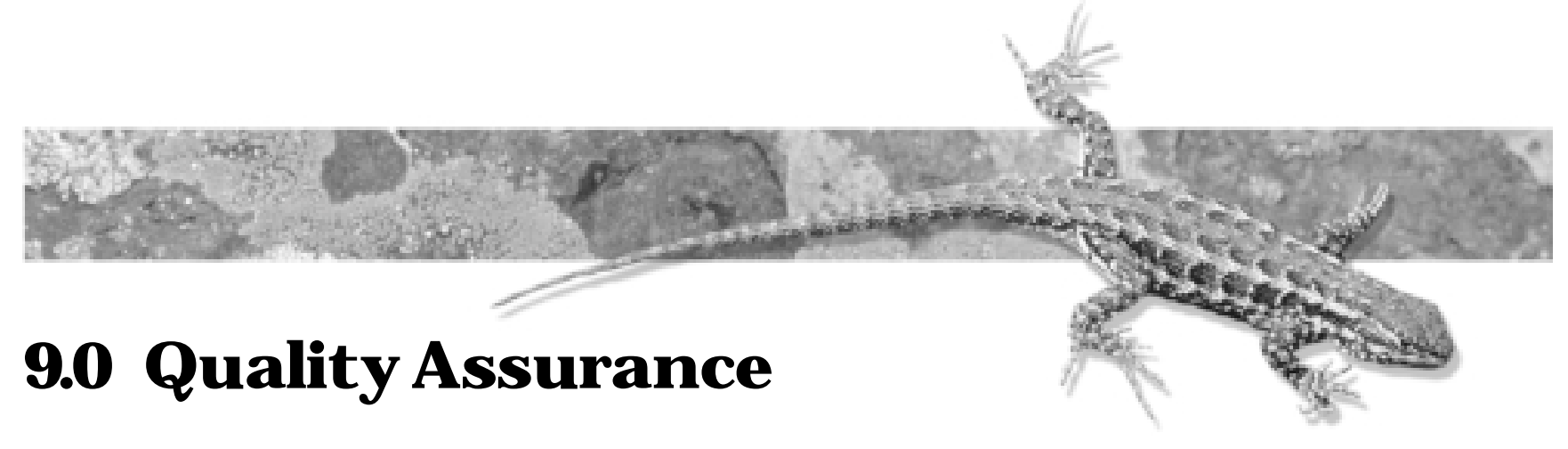

E. A. Lepel, L. P. Diediker, and D. L. Dyekman

Quality assurance and quality control practices are incorporated into all aspects of Hanford Site environmental monitoring and surveillance programs. This section discusses specific measures taken to assure quality in project management, sample collection, and analytical results.

Samples were collected and analyzed according to documented standard analytical procedures. Analytical data quality was verified by a continuing program of internal laboratory quality control, participation in interlaboratory crosschecks, replicate sampling and analysis, submittal of blind standard samples and blanks, and splitting samples with other laboratories.
Quality assurance/quality control for the Hanford Site environmental monitoring and surveillance programs also included procedures and protocols to

- document instrument calibrations

- conduct program-specific activities in the field

- maintain groundwater wells to assure representative samples were collected

- avoid cross-contamination by using dedicated well sampling pumps.

\subsubsection{Environmental Surveillance and Groundw ater Monitoring}

During 2001, comprehensive quality assurance programs, including various quality control practices, were maintained to assure the quality of data collected through the Surface Environmental Surveillance Project and the Hanford Groundwater Monitoring Project. Quality assurance plans were maintained for all program activities and defined the appropriate controls and documentation required by the U.S. Environmental Protection Agency (EPA) and the U.S. Department of Energy (DOE) for the project-specific requirements.

\subsubsection{Project Management Quality Assurance}

Site environmental surveillance, groundwater monitoring, and related programs such as processing of thermoluminescent dosimeters and performing dose calculations were subject to an overall quality assurance program. This program implemented the requirements of DOE Order 414.1A. Quality assurance plans are maintained by the site surveillance and groundwater monitoring projects; these plans describe the specific quality assurance elements that apply to each project.
These plans were approved by a quality assurance organization that conducted surveillances and audits to verify compliance with the plans. Work performed through contracts, such as sample analysis, must meet the same quality assurance requirements. Potential equipment and service suppliers are audited before service contracts or material purchases that could have had a significant impact on quality within the project are approved and awarded.

\subsubsection{Sam ple Collection Quality Assurance/Quality Control}

Surface Environmental Surveillance Project samples were collected by staff trained to conduct sampling according to approved and documented procedures (PNL-MA-580). Continuity of all sampling location identities was maintained through careful documentation. Field replicates were collected for water, soil, and biota samples (Table 9.0.1). Eighty-seven percent of the field replicate results for 2001 were acceptable. The results were acceptable if the relative standard deviation 
Table 9.0.1. Summary of Surface Environmental Surveillance Project Field Replicate Results, 2001

\begin{tabular}{|c|c|c|c|}
\hline Medium & Radionuclides & $\begin{array}{c}\text { Number of } \\
\text { Results Reported } \\
\end{array}$ & $\begin{array}{l}\text { Number V } \\
\text { Control Li }\end{array}$ \\
\hline \multirow[t]{8}{*}{ Water } & Gross alpha & 8 & 7 \\
\hline & Gross beta & 9 & 9 \\
\hline & ${ }^{3} \mathrm{H}$ & 35 & 35 \\
\hline & ${ }^{7} \mathrm{Be},{ }^{40} \mathrm{~K},{ }^{60} \mathrm{Co},{ }^{106} \mathrm{Ru},{ }^{125} \mathrm{Sb},{ }^{134} \mathrm{Cs},{ }^{137} \mathrm{Cs},{ }^{154} \mathrm{Eu},{ }^{155} \mathrm{Eu}$ & 13 & 11 \\
\hline & ${ }^{90} \mathrm{Sr}$ & 0 & 0 \\
\hline & ${ }^{99} \mathrm{Tc}$ & 0 & 0 \\
\hline & ${ }^{234} \mathrm{U},{ }^{235} \mathrm{U},{ }^{238} \mathrm{U}$ & 25 & 24 \\
\hline & ${ }^{238} \mathrm{Pu},{ }^{239 / 240} \mathrm{Pu}$ & 7 & 4 \\
\hline \multirow[t]{8}{*}{ Soil } & Gross alpha & 1 & 0 \\
\hline & Gross beta & 2 & 2 \\
\hline & ${ }^{3} \mathrm{H}$ & 0 & 0 \\
\hline & ${ }^{7} \mathrm{Be},{ }^{40} \mathrm{~K},{ }^{60} \mathrm{Co},{ }^{106} \mathrm{Ru},{ }^{125} \mathrm{Sb},{ }^{134} \mathrm{Cs},{ }^{137} \mathrm{Cs},{ }^{154} \mathrm{Eu},{ }^{155} \mathrm{Eu}$ & 8 & 6 \\
\hline & ${ }^{90} \mathrm{Sr}$ & 4 & 4 \\
\hline & ${ }^{234} \mathrm{U},{ }^{235} \mathrm{U},{ }^{238} \mathrm{U}$ & 27 & 22 \\
\hline & ${ }^{238} \mathrm{Pu},{ }^{239 / 240} \mathrm{Pu}$ & 17 & 13 \\
\hline & ${ }^{228} \mathrm{Th},{ }^{232} \mathrm{Th}$ & 3 & 2 \\
\hline \multirow[t]{8}{*}{ Biota } & Gross alpha & 2 & 0 \\
\hline & Gross beta & 2 & 0 \\
\hline & ${ }^{3} \mathrm{H}$ & 1 & 1 \\
\hline & ${ }^{7} \mathrm{Be},{ }^{40} \mathrm{~K},{ }^{60} \mathrm{Co},{ }^{106} \mathrm{Ru},{ }^{125} \mathrm{Sb},{ }^{134} \mathrm{Cs},{ }^{137} \mathrm{Cs},{ }^{154} \mathrm{Eu},{ }^{155} \mathrm{Eu}$ & 29 & 29 \\
\hline & ${ }^{90} \mathrm{Sr}$ & 9 & 8 \\
\hline & ${ }^{99} \mathrm{Tc}$ & 2 & 2 \\
\hline & ${ }^{234} \mathrm{U},{ }^{235} \mathrm{U},{ }^{238} \mathrm{U}$ & 3 & 2 \\
\hline & ${ }^{238} \mathrm{Pu},{ }^{239 / 240} \mathrm{Pu}$ & 7 & 5 \\
\hline
\end{tabular}

(a) The sample and duplicate results are acceptable if they fall within the control limit of $\pm 30 \%$ for the sample and duplicate results above the detection limit or minimum detectable concentration.

was $>30 \%$ for the sample and duplicate results. However, plutonium-238 and plutonium-239/240 failed in all three media at least twice, uranium-234, $-235,-238$ and gross alpha failed in all three media at least once, and thorium-228 and thorium-232 and strontium-90 failed in one media at least once.

Samples for the Hanford Groundwater Monitoring Project were collected by trained staff according to approved and documented procedures (PNNL-13788, Appendix B). Chain-of-custody procedures were followed (EPA 1986). Samples representing full trip blanks and field replicates were obtained during field operations. Summaries of the 2001 groundwater field quality control sample results are provided in Appendix B of PNNL-13788. The percentage of acceptable field blank and replicate results in fiscal year 2001 were $97 \%$ for field blanks and $98 \%$ for field replicates.

\subsubsection{Analytical Results Quality Assurance/Quality Control}

Routine chemical analyses of water samples were performed under contract primarily by Severn Trent Laboratories, Incorporated, St. Louis, Missouri, for environmental surveillance and groundwater monitoring. Some routine analyses of hazardous and non-hazardous chemicals for the Comprehensive Environmental Response, Compensation, and Liability Act (CERCLA) groundwater program also were performed under contract by Lionville Laboratory, Lionville, Pennsylvania. Each laboratory participated in the EPA Water Pollution and Water Supply Performance Evaluation Studies. Each laboratory maintained an internal quality control program that met the requirements in Test Methods for Evaluating 
Solid Waste: Physical/Chemical Methods, SW-846, Third Edition (EPA 1986); each program was audited and reviewed internally and by Pacific Northwest National Laboratory. Pacific Northwest National Laboratory submitted additional quality control double-blind spiked samples for analysis.

Routine radiochemical analyses of samples for the Surface Environmental Surveillance and Hanford Groundwater Monitoring Projects were performed primarily by Severn Trent Laboratories, Incorporated, Richland, Washington. Severn Trent Laboratory, Richland, participated in DOE's Quality Assessment Program at the Environmental Measurements Laboratory in New York, and the Proficiency Testing Program at Environmental Resource Associates in Arvada, Colorado. The Environmental Resource Associates program replaced the EPA's Laboratory Intercomparison Studies Program, which was discontinued in December 1998. Environmental Resource Associates prepared and distributed proficiency standard samples according to EPA requirements. A quality control blind spiked sample program also was conducted for each project by Pacific Northwest National Laboratory. Each laboratory maintains an internal quality control program, which was audited and reviewed internally and by Pacific Northwest National Laboratory. Additional information on these quality control efforts is provided in the following sections.

\subsubsection{DOE and EPA Comparison Studies}

Standard water samples were distributed blind to participating laboratories as part of the EPA performance evaluation program. These blind samples contained specific organic and inorganic analytes that had concentrations unknown to the analyzing laboratories. After analysis, the results were submitted to Environmental Resource Associates, the EPA performance evaluation program sponsor, for comparison with known values and results from other participating laboratories. Summaries of the results for 2001 are provided in PNNL-13788, Appendix B, for the primary laboratory, Severn Trent Laboratories, Incorporated, St. Louis.

The DOE Quality Assessment Program and Environmental Resource Associates' Proficiency Testing Program provided standard samples of environmental media (e.g., water, air filters, soil, vegetation) that contained specific amounts of one or more radionuclides that were unknown by the participating laboratory. After analysis, the results were forwarded to DOE or Environmental Resource Associates for comparison with known values and results from other laboratories. Both
DOE and Environmental Resource Associates had established criteria for evaluating the accuracy of results (NERL-Ci-0045; EML-611; EML-613). Summaries of the 2001 results are provided in Tables 9.0.2 and 9.0.3. Ninety-five percent of the DOE quality assessment sample results fell within the acceptable control limits. Ninety-three percent of the Environmental Resource Associates samples fell within the acceptable control limit range.

\subsubsection{Pacific Northwest National Laboratory Evaluations}

In addition to DOE and EPA interlaboratory quality control programs, Pacific Northwest National Laboratory maintained a quality control program to evaluate analytical contractor precision and accuracy and to conduct special intercomparisons. This program included the use of blind spiked samples. Blind spiked quality control samples and blanks were prepared and submitted to check the accuracy and precision of analyses at Severn Trent Laboratories, Incorporated, Richland. In 2001, 325 blind spiked samples were submitted for groundwater (PNNL-13788, Appendix B) and for air filters, vegetation, soil, and surface water (Table 9.0.4). For results of all water sample nonradiochemistry blind spiked determinations, the results are discussed in Appendix B of PNNL-13788, and did indicate an acceptable performance by the laboratory.

For all media, 98\% of Severn Trent Laboratories, Incorporated, Richland, radiochemistry blind spiked determinations were within the control limits ( $>30 \%$ of the known value), which indicated acceptable results. The only determination that failed was for cobalt- 60 in soil.

\subsubsection{Quality Assurance Task Force Results}

Pacific Northwest National Laboratory also participated in a Quality Assurance Task Force, a program coordinated by the Washington State Department of Health. Public and private organizations from Idaho, Oregon, Washington, and Georgia participated in analyzing the intercomparison samples in 1999 and 2000. For the 2001 intercomparison sample exchange, samples from a Hanford Site well were collected. Results for uranium-234, -235, and -238 were determined. Pacific Northwest National Laboratory values for uranium-234 and uranium-238 agreed well with the respective grand means. However, the reported values for uranium-235 were $30 \%$ below the grand mean (Table 9.0.5). 
Table 9.0.2. Summary of Laboratory Performance on DOE Q uality Assessment Program Samples, 2001

\begin{tabular}{|c|c|c|c|}
\hline Medium & Radionuclides & $\begin{array}{l}\text { N umber of Results } \\
\text { Reported for Each } \\
\text { Analyte }\end{array}$ & $\begin{array}{c}\text { N umber Within } \\
\text { Acceptable Control } \\
\text { Limits }^{(\mathrm{a})}\end{array}$ \\
\hline \multicolumn{4}{|c|}{ Severn Trent Laboratories, Richland, Washington } \\
\hline \multirow[t]{2}{*}{ Air filter particulate } & $\begin{array}{l}\text { Gross alpha, gross beta, }{ }^{54} \mathrm{Mn},{ }^{60} \mathrm{Co} \text {, } \\
{ }^{90} \mathrm{Sr},{ }^{125} \mathrm{Sb},{ }^{134} \mathrm{Cs},{ }^{137} \mathrm{Cs},{ }^{238} \mathrm{Pu},{ }^{239} \mathrm{Pu} \text {, } \\
{ }^{241} \mathrm{Am} \text { total uranium }\end{array}$ & 2 & 2 \\
\hline & ${ }^{234} \mathrm{U},{ }^{238} \mathrm{U}$ & 1 & 1 \\
\hline \multirow[t]{3}{*}{ Soil } & $\begin{array}{l}{ }^{40} \mathrm{~K},{ }^{137} \mathrm{Cs},{ }^{212} \mathrm{~Pb},{ }^{214} \mathrm{Bi},{ }^{214} \mathrm{~Pb},{ }^{228} \mathrm{Ac} \text {, } \\
{ }^{239} \mathrm{Pu},{ }^{241} \mathrm{Am} \text {, total uranium }\end{array}$ & 2 & 2 \\
\hline & ${ }^{212} \mathrm{Bi},{ }^{234} \mathrm{Th}$ & 2 & 1 \\
\hline & ${ }^{90} \mathrm{Sr},{ }^{234} \mathrm{U},{ }^{238} \mathrm{U}$ & 1 & 1 \\
\hline Vegetation & $\begin{array}{l}{ }^{40} \mathrm{~K},{ }^{60} \mathrm{Co},{ }^{90} \mathrm{Sr},{ }^{137} \mathrm{Cs},{ }^{239} \mathrm{Pu},{ }^{241} \mathrm{Am}, \\
{ }^{444} \mathrm{Cm}\end{array}$ & 2 & 2 \\
\hline \multirow[t]{3}{*}{ Water } & $\begin{array}{l}\text { Gross alpha, gross beta, }{ }^{3} \mathrm{H},{ }^{90} \mathrm{Sr} \text {, } \\
{ }^{238} \mathrm{Pu},{ }^{239} \mathrm{Pu},{ }^{241} \mathrm{Am} \text {, total uranium }\end{array}$ & 2 & 2 \\
\hline & ${ }^{60} \mathrm{Co},{ }^{137} \mathrm{Cs}$ & 2 & 1 \\
\hline & ${ }^{234} \mathrm{U},{ }^{238} \mathrm{U}$ & 1 & 1 \\
\hline
\end{tabular}

Table 9.0.3. Summary of Laboratory Performance on Environmental Resource Associates Proficiency Testing Program, 2001

\begin{tabular}{|c|c|c|c|}
\hline Medium & Radionuclides & $\begin{array}{l}\text { Number of Results } \\
\text { Reported for Each } \\
\text { Analyte }\end{array}$ & $\begin{array}{c}\text { Number } \\
\text { Control Li } \\
\text { Each An }\end{array}$ \\
\hline \multicolumn{4}{|c|}{ Severn Trent Laboratories, Richland, Washington } \\
\hline \multirow[t]{6}{*}{ Water } & Gross alpha & 4 & \\
\hline & Gross beta & 4 & 3 \\
\hline & $\begin{array}{l}{ }^{60} \mathrm{Co},{ }^{90} \mathrm{Sr},{ }^{134} \mathrm{Cs},{ }^{137} \mathrm{Cs},{ }^{226} \mathrm{Ra}, \\
{ }^{228} \mathrm{Ra}\end{array}$ & 4 & \\
\hline & ${ }^{89} \mathrm{Sr}$, total uranium & 4 & \\
\hline & ${ }^{65} \mathrm{Zn},{ }^{133} \mathrm{Ba}$ & 2 & \\
\hline & ${ }^{3} \mathrm{H},{ }^{131} \mathrm{I}$ & 1 & \\
\hline
\end{tabular}

(a) Control limits are from NERL-Ci-0045. 
Table 9.0.4. Summary of Surface Environmental Surveillance Project Blind Spiked Determinations, 2001

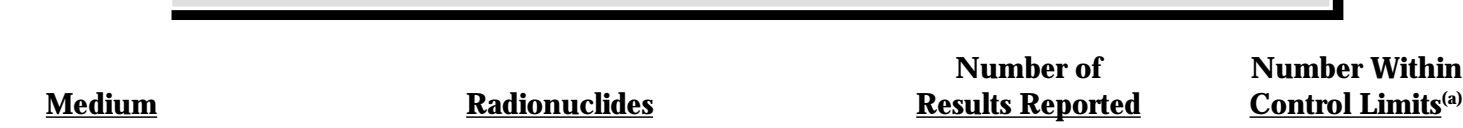

Severn Trent Laboratories, Richland, Washington

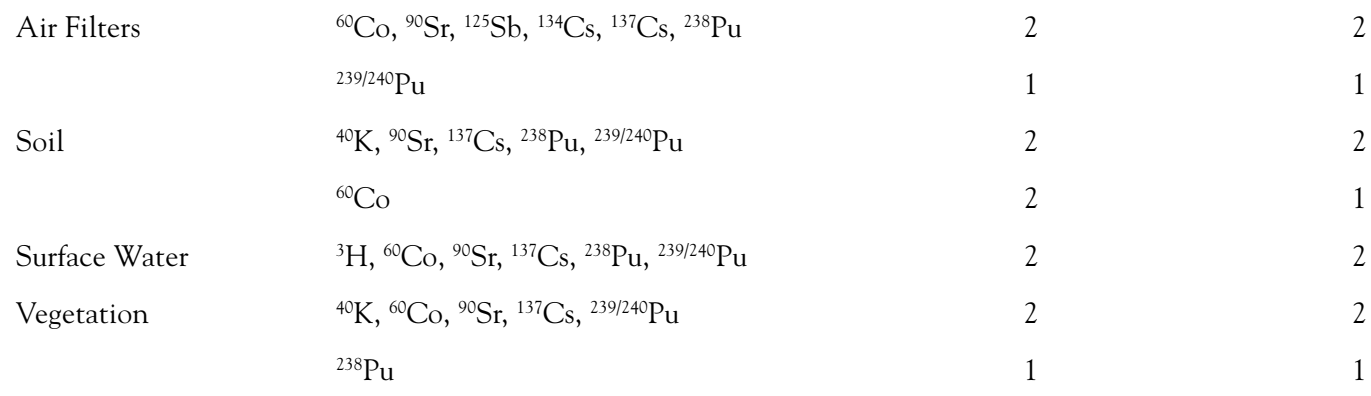

(a) Control limit of $\pm 30 \%$.

\subsubsection{Laboratory Internal Quality Assurance Programs}

The analytical laboratories were required to maintain an internal quality assurance and control program. Periodically, the laboratories were audited internally for compliance to the quality assurance and control programs. At Severn Trent Laboratories, Incorporated, St. Louis, the quality control programs met the quality assurance and control criteria in Test Methods for Evaluating Solid Waste: Physical/ Chemical Methods, SW-846, Third Edition (EPA 1986). The laboratories also were required to maintain a system to review and analyze the results of the quality control samples to detect problems that may have arisen from contamination, inadequate calibrations, calculation errors, or improper procedure performance. Method detection levels were determined at least annually for each analytical method.

The internal quality control program at Severn Trent Laboratories, Incorporated, Richland, involved routine calibrations of counting instruments, yield determinations of radiochemical procedures, frequent radiation check sources and background counts, replicate and spiked sample analyses, matrix and reagent blanks, and maintenance of control charts to indicate analytical deficiencies. Available calibration standards traceable to the National Institute of Standards and Technology were used for radiochemical calibrations. Calculation of minimum detectable concentrations involved the use of factors such as the average counting efficiencies and background for detection instruments, length of time for background and sample counts, sample volumes, radiochemical yields, and a pre-designated uncertainty multiplier (EPA 520/1-80-012).

Periodically, inspections of services were performed that documented conformance with contractual requirements of the analytical facility and provided the 
framework to identify and resolve potential performance problems. Responses to assessment and inspection findings were documented by written communication, and corrective actions were verified by follow-up audits and inspections. In 2001, assessments of Severn Trent Laboratories, Incorporated, Richland, and Severn Trent Laboratories, Incorporated, St. Louis, were conducted February 25 to March 1, 2001 and April 24 to 26, 2001, respectively. Representatives from Bechtel Hanford, Inc. performed the Richland audit, and Hanford Site's Integrated Contractor Assessment Team, consisting of representatives from Bechtel Hanford, Inc. and Pacific Northwest National Laboratory conducted the St. Louis audit. The purpose of the assessments was to evaluate the continued support of analytical services to Hanford Site contractors as specified in the statement of work between Fluor Hanford, Inc. and Severn Trent Laboratories. Additional information may be found in PNNL-13788, Appendix B.

Internal laboratory quality control program data were reported with the analytical results. Scientists at Pacific Northwest National Laboratory summarized the results quarterly. The Surface Environmental Surveillance Project and the Groundwater Monitoring Project indicated an acceptable performance for the internal quality control program at Severn Trent Laboratories, Richland and St. Louis.

\subsubsection{Media Audits and Comparisons}

Additional audits and comparisons were conducted on several specific types of samples. The Washington
State Department of Health routinely co-sampled various environmental media and measured external radiation levels at multiple locations during 2001. Media that were co-sampled and analyzed for radionuclides included groundwater, water from 20 locations along and across the Columbia River, water from 5 riverbank springs, water from 1 onsite drinking water location, sediment from 14 Columbia River sites, and soil from 11 locations throughout the Hanford Site. Also co-sampled and analyzed for radionuclides were upwind and downwind samples of leafy vegetables, alfalfa, fruit, tomatoes, concord grapes, whitefish, geese, rabbits, and wine. The Washington State Department of Health and Pacific Northwest National Laboratory co-sampled data may be found in PNNL-13910, APP. 1.

The U.S. Food and Drug Administration also received co-samples from upwind and downwind sampling locations and analyzed grapes, leafy vegetables (cabbage), potatoes, and alfalfa for radionuclides (Table 9.0.6). There is good agreement between the U.S. Food and Drug Administration and Pacific Northwest National Laboratory data.

Quality control for environmental thermoluminescent dosimeters included the audit exposure of three environmental thermoluminescent dosimeters per quarter to known values of radiation (between 17 and $30 \mathrm{mR}$ ). On average, the thermoluminescent dosimeter measurements were unbiased. For 12 measurements, the lowest ratio of determined/known was 0.94; the highest determined/known ratio was 1.05 , with an average of $1.01 \pm 0.03$ (Table 9.0.7).

\subsubsection{Effluent Monitoring and Near-Facility Environmental Monitoring}

The Effluent Monitoring and Near-Facility Environmental Monitoring Programs were subject to the quality assurance requirements specified in the Hanford Analytical Services Quality Assurance Requirements Document (DOE/RL-96-68). These quality assurance programs complied with DOE Order 414.1A, using standards from the American Society of Mechanical Engineers (ASME NQA-1-1997) as their basis. The program also adhered to the guidelines and objectives in EPA/005/80 and EPA QA/R-5.

The monitoring programs each have a quality assurance plan describing applicable quality assurance elements. These plans were approved by contractor quality assurance groups, who conducted surveillances and audits to verify compliance with the plans. Work such as sample analysis performed through contracts had to meet the requirements of these plans. Suppliers are audited before the contract selection was made for equipment and services that may have significantly affected the quality of a project.

\subsubsection{Sam ple Collection Quality Assurance}

Samples for the Effluent Monitoring and NearFacility Environmental Monitoring Programs were collected by staff trained in accordance with approved procedures. Established sampling locations were 
Table 9.0.6. Comparison of U.S. Food and Drug Administration Co-Sampling, $2001^{\text {(a) }}$

\begin{tabular}{|c|c|c|c|c|c|c|c|}
\hline Medium & $\begin{array}{c}\text { Sampling } \\
\text { Area }\end{array}$ & Organization & $\begin{array}{c}\text { Strontium-90, } \\
\text { pCi/g/(b,c) }\end{array}$ & $\begin{array}{c}\text { Cesium-137, } \\
\text { pCi/g/(b,c) }\end{array}$ & $\begin{array}{l}\text { Ruthenium-106, } \\
\qquad \mathrm{pCi} / \mathrm{g}^{(\mathrm{b}, \mathrm{c})}\end{array}$ & $\begin{array}{l}\text { Iodine-131 } \\
\mathrm{pCi} / \mathbf{g}^{(\mathrm{b}, \mathrm{c})}\end{array}$ & $\begin{array}{l}\text { Tritium } \\
\mathrm{pCi} / \mathrm{g}^{(\mathrm{b}, \mathrm{c})}\end{array}$ \\
\hline \multirow[t]{2}{*}{$\begin{array}{l}\text { Alfalfa } \\
\text { (stem-leaf) }\end{array}$} & Sunnyside & $\begin{array}{l}\mathrm{FDA}^{(\mathrm{d})} \\
\mathrm{FDA} \\
\mathrm{PNNL}^{(\mathrm{e})}\end{array}$ & $\begin{array}{l}0.0085 \pm 0.0019 \\
0.0079 \pm 0.0021 \\
0.0656 \pm 0.042\end{array}$ & $\begin{array}{c}<0.045 \\
<0.045 \\
0.0030 \pm 0.042\end{array}$ & $\begin{array}{c}<0.10 \\
<0.10 \\
-0.08 \pm 0.39\end{array}$ & $\begin{array}{l}<0.045 \\
<0.045 \\
\mathrm{NA}^{(f)}\end{array}$ & $\begin{array}{c}<0.0020 \\
<0.0020 \\
\text { NA }\end{array}$ \\
\hline & Riverview & $\begin{array}{l}\text { FDA } \\
\text { FDA } \\
\text { PNNL }\end{array}$ & $\begin{array}{c}0.0103 \pm 0.0021 \\
0.0097 \pm 0.0021 \\
0.047 \pm 0.038\end{array}$ & $\begin{array}{c}<0.045 \\
<0.045 \\
0.0038 \pm 0.049\end{array}$ & $\begin{array}{c}<0.10 \\
<0.10 \\
-0.080 \pm 0.45\end{array}$ & $\begin{array}{l}<0.045 \\
<0.045 \\
\text { NA }\end{array}$ & $\begin{array}{c}<0.0020 \\
<0.0020 \\
\text { NA }\end{array}$ \\
\hline \multirow[t]{2}{*}{$\begin{array}{l}\text { Leafy vegetables } \\
\text { (stem-leaf) }\end{array}$} & Sunnyside & $\begin{array}{l}\text { FDA } \\
\text { FDA } \\
\text { PNNL }\end{array}$ & $\begin{array}{c}0.0038 \pm 0.0018 \\
<0.002 \\
0.00042 \pm 0.0021\end{array}$ & $\begin{array}{c}<0.045 \\
<0.045 \\
-0.00056 \pm 0.013\end{array}$ & $\begin{array}{c}<0.10 \\
<0.10 \\
0.021 \pm 0.11\end{array}$ & $\begin{array}{l}<0.045 \\
<0.045 \\
\text { NA }\end{array}$ & $\begin{array}{c}<0.0020 \\
<0.0020 \\
\text { NA }\end{array}$ \\
\hline & Riverview & $\begin{array}{l}\text { FDA } \\
\text { FDA } \\
\text { PNNL }\end{array}$ & $\begin{array}{c}<0.002 \\
<0.002 \\
0.0094 \pm 0.0043\end{array}$ & $\begin{array}{c}<0.045 \\
<0.045 \\
-0.0034 \pm 0.011\end{array}$ & $\begin{array}{c}<0.10 \\
<0.10 \\
0.0041 \pm 0.1\end{array}$ & $\begin{array}{c}<0.045 \\
<0.045 \\
\text { NA }\end{array}$ & $\begin{array}{c}<0.0020 \\
<0.0020 \\
\text { NA }\end{array}$ \\
\hline Potato tuber & Sunnyside & $\begin{array}{l}\text { FDA } \\
\text { FDA } \\
\text { PNNL }\end{array}$ & $\begin{array}{c}<0.002 \\
<0.002 \\
0.0022 \pm 0.0042\end{array}$ & $\begin{array}{c}<0.045 \\
<0.045 \\
0.0018 \pm 0.0059\end{array}$ & $\begin{array}{c}<0.10 \\
<0.10 \\
-0.045 \pm 0.051\end{array}$ & $\begin{array}{c}<0.045 \\
<0.045 \\
\text { NA }\end{array}$ & $\begin{array}{c}<0.0020 \\
<0.0020 \\
\text { NA }\end{array}$ \\
\hline $\begin{array}{l}\text { Grapes, } \\
\text { Concord }\end{array}$ & Riverview & $\begin{array}{l}\text { FDA } \\
\text { FDA } \\
\text { PNNL }\end{array}$ & $\begin{array}{c}<0.002 \\
<0.002 \\
0.0072 \pm 0.0037\end{array}$ & $\begin{array}{c}<0.045 \\
<0.045 \\
-0.0043 \pm 0.0051\end{array}$ & $\begin{array}{c}<0.10 \\
<0.10 \\
0.0076 \pm 0.045\end{array}$ & $\begin{array}{c}<0.045 \\
<0.045 \\
\text { NA }\end{array}$ & $\begin{array}{c}<0.0020 \\
<0.0020 \\
\text { NA }\end{array}$ \\
\hline $\begin{array}{l}\text { (a) Sample resu } \\
\text { (b) To convert } \\
\text { (c) Errors repor } \\
\text { (d) FDA = U.S } \\
\text { (e) PNNL = Pa } \\
\text { (f) NA = Not a }\end{array}$ & $\begin{array}{l}\text { s are wet wei } \\
\text { ii/g to Bq/g, } \\
\text { d are } 2 \text { sigma } \\
\text { ood and Dru } \\
\text { fic Northwes } \\
\text { alyzed; not sp }\end{array}$ & $\begin{array}{l}\text { ultiply by } 0.037 \text {. } \\
\text { Less than }(<) \text { va } \\
\text { Administration. } \\
\text { National Laborat } \\
\text { cifically requeste }\end{array}$ & $\begin{array}{l}\text { les are minimum det } \\
\text { ry. } \\
\text { by contract unless } p\end{array}$ & $\begin{array}{l}\text { tectable activities a } \\
\text { present. }\end{array}$ & 3 sigma. & & \\
\hline
\end{tabular}

\begin{tabular}{|c|c|c|c|c|}
\hline Quarter & Exposure Date & Known Exposure, $\mathrm{mR}$ & Determined Exposure, $\mathbf{m R}$ & $\begin{array}{c}\text { Ratio of } \\
\text { Determined/ } \\
\text { Known Exposure }\end{array}$ \\
\hline $1 \mathrm{st}$ & February 23, 2001 & $\begin{array}{l}24.0 \pm 0.4 \\
28.0 \pm 0.5 \\
19.0 \pm 0.3\end{array}$ & $\begin{array}{l}24.9 \pm 0.2 \\
27.6 \pm 0.8 \\
19.2 \pm 0.7\end{array}$ & $\begin{array}{l}1.04 \\
0.98 \\
1.01\end{array}$ \\
\hline 2nd & May 15, 2001 & $\begin{array}{l}29.0 \pm 0.5 \\
18.0 \pm 0.3 \\
23.0 \pm 0.4\end{array}$ & $\begin{array}{l}30.0 \pm 0.3 \\
18.4 \pm 0.1 \\
23.7 \pm 0.6\end{array}$ & $\begin{array}{l}1.03 \\
1.02 \\
1.03\end{array}$ \\
\hline $3 \mathrm{rd}$ & August 20, 2001 & $\begin{array}{l}25.0 \pm 0.4 \\
17.0 \pm 0.3 \\
28.0 \pm 0.5\end{array}$ & $\begin{array}{l}25.3 \pm 0.4 \\
16.1 \pm 0.5 \\
26.3 \pm 1.4\end{array}$ & $\begin{array}{l}1.01 \\
0.95 \\
0.94\end{array}$ \\
\hline 4 th & November 16, 2001 & $\begin{array}{l}30.0 \pm 0.5 \\
21.0 \pm 0.4 \\
27.0 \pm 0.5\end{array}$ & $\begin{array}{l}31.5 \pm 0.4 \\
21.5 \pm 0.5 \\
27.0 \pm 0.4\end{array}$ & $\begin{array}{l}1.05 \\
1.02 \\
1.00\end{array}$ \\
\hline
\end{tabular}


identified and documented to assure continuity of data for those sites and are described in DOE/RL-91-50.

\subsubsection{Analytical Results Quality Assurance}

Samples for the Effluent Monitoring and NearFacility Environmental Monitoring Programs were analyzed by up to three different analytical laboratories. The use of these laboratories is dependent on the Hanford contractor collecting the samples and contract(s) established between the contractor and the analytical laboratory(ies). Table 9.0.8 provides a summary of the Hanford Site's analytical laboratories used for effluent monitoring and near-facility monitoring samples.

The quality of the analytical data was assured by several means. Counting room instruments, for instance, were kept within calibration limits through daily checks, the results of which were stored in computer databases. Radiochemical standards used in analyses were regularly measured and the results were reported and tracked. Formal, written laboratory procedures were used to analyze samples. Analytical procedural control was assured through administrative procedures. Chemical technologists at the laboratory(ies) were qualified to perform analyses by attending formal classroom and on-thejob training.

The participation of the Hanford Site analytical laboratories in EPA and DOE laboratory performance programs also served to assure the quality of the data produced. The Waste Sampling and Characterization Facility performance was evaluated in four different laboratory performance studies for calendar year 2001. In the EPA Water Pollution Studies $\# 73$ and $\# 78$ for inorganic and organic analyses, 311 different analytes and compounds were submitted to the Waste Sampling and Characterization Facility for analysis. Of the 311 analyses performed, 292 results were acceptable while 19 were unacceptable for a total acceptable rate of $95 \%$. In the DOE Mixed Analyte Performance Evaluation Program studies (MAPEP-00-W8 and MAPEP-01-S8), 68 different radionuclides and analytes were submitted to the Waste Sampling and Characterization Facility for analysis. Of the 68 different analyses performed, 66 results were acceptable while 2 were unacceptable for a total acceptable rate of $97 \%$. In the National Institute of Standards and Technology Radiochemistry Program study, eight different radionuclides were submitted to the Waste Sampling Characterization Facility for 40 different analyses. All radionuclide results were acceptable for a total of 100\% acceptable rate. In the DOE Quality Assessment Program, 74 different radionuclides were submitted to the Waste Sampling Characterization Facility for analysis. Of the 74 analyses performed, 70 results were acceptable while 4 were unacceptable for a total acceptable rate of $95 \%$. Performance results for DOE Quality Assessment Program and others are presented in Tables 9.0.9 through 9.0.11.

Table 9.0.8. Hanford Site Laboratories used by Contractor and Sample Type, 2001

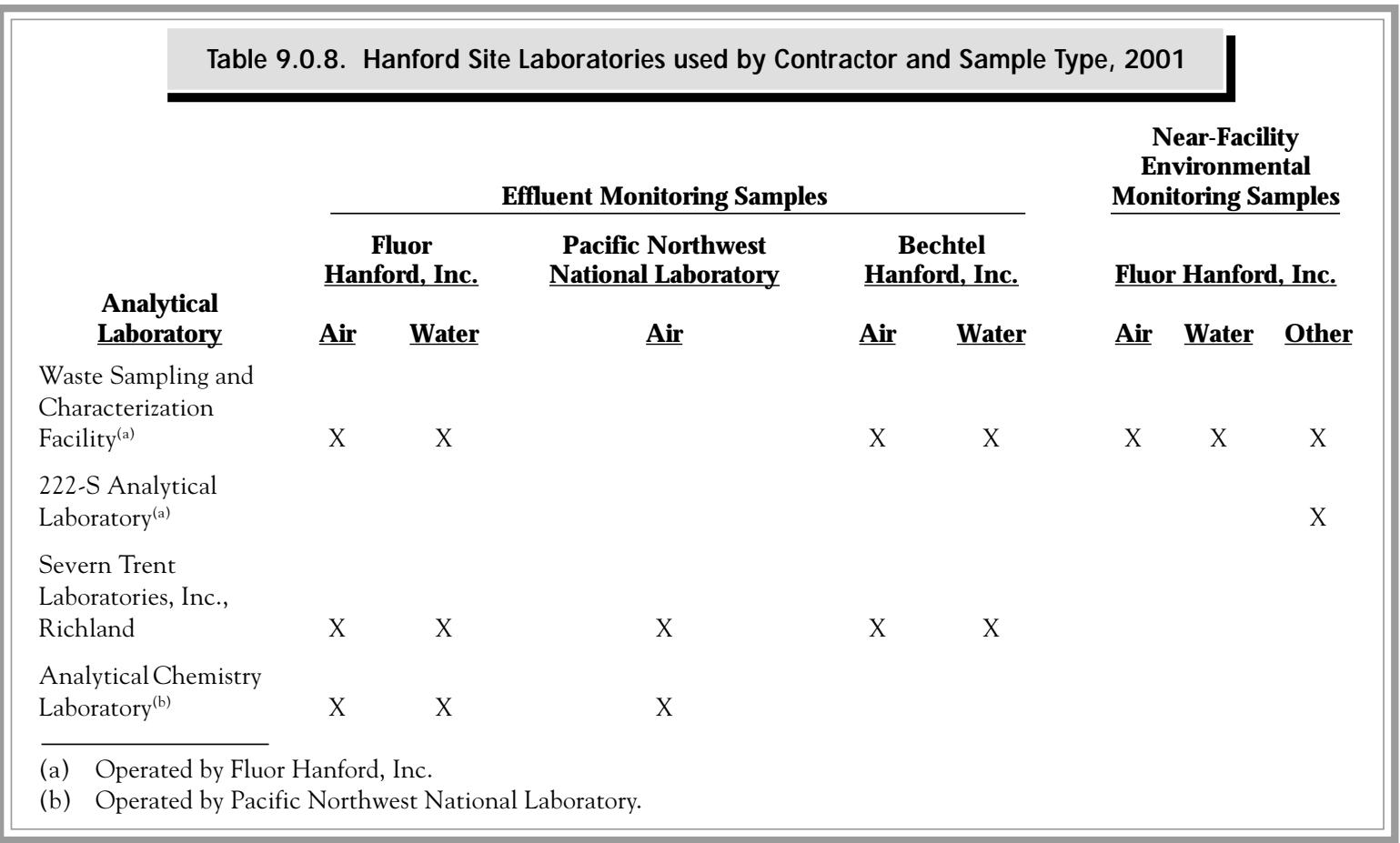


Table 9.0.9. Waste Sampling and Characterization Facility ${ }^{(a)}$ Performance on DOE Q uality Assessment Program Samples, 2001

\begin{tabular}{|c|c|c|c|}
\hline Medium & Radionuclide & $\begin{array}{l}\text { Number } \\
\text { of Results } \\
\text { Reported }\end{array}$ & $\begin{array}{c}\begin{array}{c}\text { Number } \\
\text { Within Control } \\
\text { Limits }\end{array} \\
\end{array}$ \\
\hline Air filters & $\begin{array}{l}{ }^{54} \mathrm{Mn},{ }^{60} \mathrm{Co},{ }^{90} \mathrm{Sr},{ }^{134} \mathrm{Cs},{ }^{137} \mathrm{Cs},{ }^{234} \mathrm{U}, \\
{ }^{238} \mathrm{Pu},{ }^{238} \mathrm{U},{ }^{239} \mathrm{Pu},{ }^{241} \mathrm{Am} \text {, gross } \\
\text { alpha, gross beta }\end{array}$ & 24 & $\begin{array}{c}22 \\
\left({ }^{134} \mathrm{Cs} \text { and }{ }^{54} \mathrm{Mn}\right. \\
\text { failed once })\end{array}$ \\
\hline Soil & $\begin{array}{l}{ }^{40} \mathrm{~K},{ }^{90} \mathrm{Sr},{ }^{137} \mathrm{Cs},{ }^{234} \mathrm{U},{ }^{238} \mathrm{U},{ }^{239} \mathrm{Pu}, \\
{ }^{241} \mathrm{Am}\end{array}$ & 14 & $\begin{array}{l}12 \\
\left({ }^{234} \mathrm{U} \text { and }{ }^{238} \mathrm{U}\right. \\
\text { failed once })\end{array}$ \\
\hline Vegetation & $\begin{array}{l}{ }^{40} \mathrm{~K},{ }^{60} \mathrm{Co},{ }^{90} \mathrm{Sr},{ }^{137} \mathrm{Cs},{ }^{239} \mathrm{Pu},{ }^{241} \mathrm{Am}, \\
{ }^{244} \mathrm{Cm}\end{array}$ & 14 & 14 \\
\hline Water & $\begin{array}{l}{ }^{3} \mathrm{H},{ }^{60} \mathrm{Co},{ }^{90} \mathrm{Sr},{ }^{137} \mathrm{Cs},{ }^{234} \mathrm{U},{ }^{238} \mathrm{Pu},{ }^{238} \mathrm{U}, \\
{ }^{239} \mathrm{Pu},{ }^{241} \mathrm{Am} \text {, gross alpha, gross beta }\end{array}$ & 22 & 22 \\
\hline
\end{tabular}

Table 9.0.10. 222-S Analytical Laboratory(a) Performance on DOE Q uality Assessment Program Samples, 2001

\begin{tabular}{|c|c|c|c|}
\hline Medium & Radionuclide & $\begin{array}{l}\text { Number } \\
\text { of Results } \\
\text { Reported }\end{array}$ & $\begin{array}{c}\text { Number } \\
\text { N umber Within } \\
\text { Acceptable Limits }\end{array}$ \\
\hline Air filters & $\begin{array}{l}{ }^{54} \mathrm{Mn},{ }^{60} \mathrm{Co},{ }^{90} \mathrm{Sr},{ }^{134} \mathrm{Cs},{ }^{137} \mathrm{Cs},{ }^{238} \mathrm{Pu}, \\
{ }^{239} \mathrm{Pu},{ }^{241} \mathrm{Am} \text {, gross alpha, gross beta }\end{array}$ & 18 & 14 \\
\hline Soil & $\begin{array}{l}{ }^{90} \mathrm{Sr},{ }^{137} \mathrm{Cs},{ }^{212} \mathrm{~Pb},{ }^{214} \mathrm{Bi},{ }^{214} \mathrm{~Pb},{ }^{228} \mathrm{Ac}, \\
{ }^{239} \mathrm{Pu} \text {, total uranium }\end{array}$ & 12 & 12 \\
\hline Vegetation & ${ }^{60} \mathrm{Co},{ }^{90} \mathrm{Sr},{ }^{137} \mathrm{Cs},{ }^{239} \mathrm{Pu},{ }^{241} \mathrm{Am},{ }^{244} \mathrm{Cm}$ & 11 & 11 \\
\hline Water & $\begin{array}{l}{ }^{3} \mathrm{H},{ }^{60} \mathrm{Co},{ }^{90} \mathrm{Sr},{ }^{137} \mathrm{Cs},{ }^{238} \mathrm{Pu},{ }^{239} \mathrm{Pu}, \\
{ }^{241} \mathrm{Am} \text {, gross alpha, gross beta, total } \\
\text { uranium }\end{array}$ & 20 & 18 \\
\hline
\end{tabular}

(a) Onsite "high-level" radiological laboratory operated by Fluor Hanford, Inc. (Note: These samples are "low-level" environmental activity samples.)

Table 9.0.11. 222-S Analytical Laboratory (a) Performance on EPA Laboratory Water Pollution Inorganic and Organic Studies, 2001

\section{Water Pollution Study \\ Laboratory \\ (WP-74) A pril 2001 $\%$ Acceptable}

$88^{(\mathrm{b})}$

\section{Water Pollution Study (WP-80) 0 ctober 2001 $\%$ Acceptable}

$92^{(c)}$

(a) Onsite "high-level" radiological laboratory operated by Fluor Hanford, Inc.

(b) Thirty-seven of 42 analytes scored as acceptable.

(c) Eighty-seven of 95 analytes scored as acceptable. 


\subsubsection{References}

ASME-NQA-1-1997. 1997. Quality Assurance Requirements for Nuclear Facility Applications. American Society of Mechanical Engineers, New York.

Comprehensive Environmental Response, Compensation, and Liability Act. 1980. Public Law 96-150, as amended, 94 Stat. 2767, 42 USC 9601 et seq.

DOE Order 414.1A. "Quality Assurance."

DOE/RL-91-50, Rev. 3. 2000. Environmental Monitoring Plan, United States Department of Energy Richland Operations Office. U.S. Department of Energy, Richland Operations Office, Richland, Washington.

DOE/RL-96-68. 1996. Hanford Analytical Services Quality Assurance Requirements Document. U.S. Department of Energy, Richland Operations Office, Richland, Washington.

EML-611. December 2000. Semi-Annual Report of the Department of Energy, Office of Environmental Management, Quality Assessment Program. P. D. Greenlaw and A. Berne, Environmental Measurements Laboratory, U.S. Department of Energy, New York.

EML-613. June 2001. Semi-Annual Report of the Department of Energy, Office of Environmental Management, Quality Assessment Program. P. D. Greenlaw and A. Berne, Environmental Measurements Laboratory, U.S. Department of Energy, New York.

EML-615. December 2001. Semi-Annual Report of the Department of Energy, Office of Environmental Management, Quality Assessment Program. P. D. Greenlaw and A. Berne, Environmental Measurements Laboratory, U.S. Department of Energy, New York.

EPA. 1986. Test Methods for Evaluating Solid Waste: Physical/Chemical Methods, SW-846, Third Edition. Office of Solid Waste and Emergency Response, U.S. Environmental Protection Agency, Washington, D.C.
EPA/005/80. 1980. Interim Guidelines and Specifications for Preparing Quality Assurance Project Plans. U.S. Environmental Protection Agency, Washington, D.C.

EPA 520/1-80-012. 1980. Upgrading Environmental Radiation Data: Health Physics Society Committee Report HPSR-1 (1980). U.S. Environmental Protection Agency, Washington, D.C.

EPA QA/R-5. 1994. Requirements for Quality Assurance Project Plans for Environmental Data Operations. U.S. Environmental Protection Agency, Washington, D.C.

MAPEP-00-W8. 2001. Water Sample MAPEP-00-W8 Participating Laboratory Report. U.S. Department of Energy, Mixed Analyte Performance Evaluation Program, Radiological and Environmental Sciences Laboratory, Idaho Falls, Idaho.

MAPEP-01-S8. 2001. Soil Sample MAPEP-01-S8 Participating Laboratory Report. U.S. Department of Energy, Mixed Analyte Performance Evaluation Program, Radiological and Environmental Sciences Laboratory, Idaho Falls, Idaho.

NERL-Ci-0045. December 30, 1998. National Standards for Water Proficiency Testing Studies, Criteria Document. U.S. Environmental Protection Agency, Washington, D.C.

PNL-MA-580, Rev. 3. 2000. Surface Environmental Surveillance Procedures Manual. R. W. Hanf and T. M. Poston (eds.), Pacific Northwest National Laboratory, Richland, Washington.

PNNL-13910, APP. 1. 2002. Hanford Site Environmental Surveillance Data Report for Calendar Year 2001. L. E. Bisping, Pacific Northwest National Laboratory, Richland, Washington.

PNNL-13788. 2002. Hanford Site Groundwater Monitoring for Fiscal Year 2001. M. J. Hartman, L. F. Morasch, and W. D. Webber (eds.), Pacific Northwest National Laboratory, Richland, Washington. 


\section{Appendix A Helpful Information}

The following information is provided to assist the reader in understanding this report. Definitions of technical terms can be found in Appendix C.

\section{Scientific Notation}

Scientific notation is used in this report to express very large or very small numbers. For example, the number 1 billion could be written as 1,000,000,000 or, by using scientific or "E" notation, written as $1 \times 10^{9}$ or 1.0E+09. Translating from scientific notation to a more traditional number requires moving the decimal point either left or right from its current location. If the value given is $2.0 \times 10^{3}$ (or 2.0E+03), the decimal point should be moved three places to the right so that the number would then read 2,000. If the value given is $2.0 \times 10^{-5}$ (or 2.0E-05), the decimal point should be moved five places to the left so that the result would be 0.00002 .

\section{Units of Measure}

The primary units of measure used in this report are metric. Table A.1 summarizes and defines the terms and corresponding symbols (metric and non-metric). A conversion table is also provided in Table A.2.

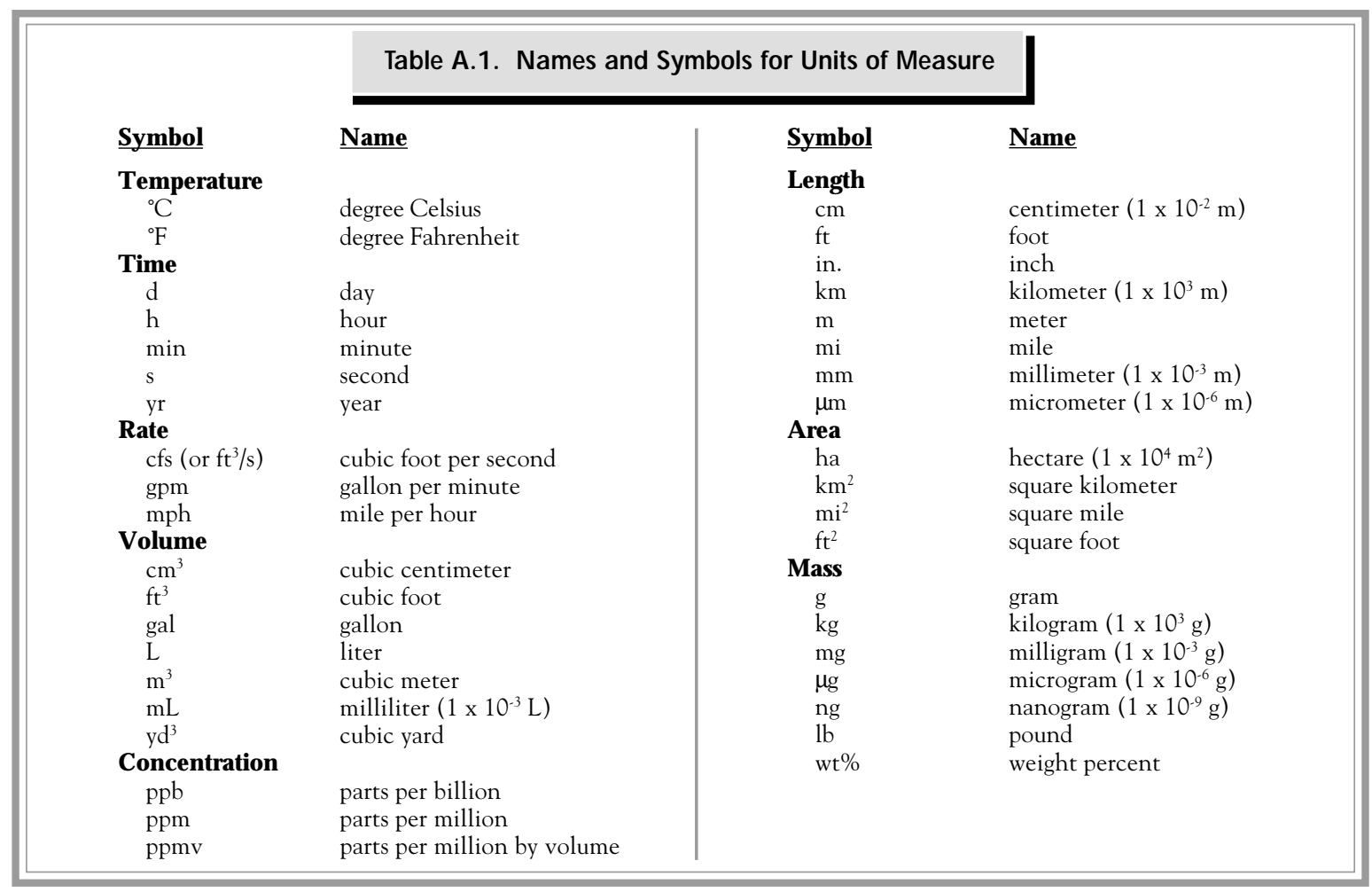




\begin{tabular}{|c|c|c|c|c|c|}
\hline Multiply & By & To O btain & Multiply & By & To O btain \\
\hline in. & 2.54 & $\mathrm{~cm}$ & $\mathrm{~cm}$ & 0.394 & in. \\
\hline $\mathrm{ft}$ & 0.305 & $\mathrm{~m}$ & $\mathrm{~m}$ & 3.28 & $\mathrm{ft}$ \\
\hline $\mathrm{mi}$ & 1.61 & $\mathrm{~km}$ & $\mathrm{~km}$ & 0.621 & $\mathrm{mi}$ \\
\hline $\mathrm{lb}$ & 0.454 & $\mathrm{~kg}$ & $\mathrm{~kg}$ & 2.205 & $\mathrm{lb}$ \\
\hline gal & 3.785 & $\mathrm{~L}$ & $\mathrm{~L}$ & 0.2642 & gal \\
\hline $\mathrm{ft}^{2}$ & 0.093 & $\mathrm{~m}^{2}$ & $\mathrm{~m}^{2}$ & 10.76 & $\mathrm{ft}^{2}$ \\
\hline acre & 0.405 & ha & ha & 2.47 & acres \\
\hline $\mathrm{mi}^{2}$ & 2.59 & $\mathrm{~km}^{2}$ & $\mathrm{~km}^{2}$ & 0.386 & $\mathrm{mi}^{2}$ \\
\hline $\mathrm{ft}^{3}$ & 0.0283 & $\mathrm{~m}^{3}$ & $\mathrm{~m}^{3}$ & 35.31 & $\mathrm{ft}^{3}$ \\
\hline$y d^{3}$ & 0.7646 & $\mathrm{~m}^{3}$ & $\mathrm{~m}^{3}$ & 1.308 & $\mathrm{yd}^{3}$ \\
\hline $\mathrm{nCi}$ & 0.001 & $\mathrm{pCi}$ & $\mathrm{pCi}$ & 1,000 & $\mathrm{nCi}$ \\
\hline $\mathrm{pCi} / \mathrm{L}$ & $10^{-9}$ & $\mu \mathrm{Ci} / \mathrm{mL}$ & $\mu \mathrm{Ci} / \mathrm{mL}$ & $10^{9}$ & $\mathrm{pCi} / \mathrm{L}$ \\
\hline $\mathrm{pCi} / \mathrm{m}^{3}$ & $10^{-12}$ & $\mathrm{Ci} / \mathrm{m}^{3}$ & $\mathrm{Ci} / \mathrm{m}^{3}$ & $10^{12}$ & $\mathrm{pCi} / \mathrm{m}^{3}$ \\
\hline $\mathrm{pCi} / \mathrm{m}^{3}$ & $10^{-15}$ & $\mathrm{mCi} / \mathrm{cm}^{3}$ & $\mathrm{mCi} / \mathrm{cm}^{3}$ & $10^{15}$ & $\mathrm{pCi} / \mathrm{m}^{3}$ \\
\hline $\mathrm{mCi} / \mathrm{km}^{2}$ & 1.0 & $\mathrm{nCi} / \mathrm{m}^{2}$ & $\mathrm{nCi} / \mathrm{m}^{2}$ & 1.0 & $\mathrm{mCi} / \mathrm{km}^{2}$ \\
\hline $\mathrm{Bq}$ & $2.7 \times 10^{-11}$ & $\mathrm{Ci}$ & $\mathrm{Ci}$ & $3.7 \times 10^{10}$ & $\mathrm{~Bq}$ \\
\hline $\mathrm{Bq}$ & 27 & $\mathrm{pCi}$ & $\mathrm{pCi}$ & 0.037 & $\mathrm{~Bq}$ \\
\hline Gy & 100 & $\mathrm{rad}$ & $\mathrm{rad}$ & 0.01 & Gy \\
\hline Sv & 100 & rem & rem & 0.01 & Sv \\
\hline $\mathrm{ppb}$ & 0.001 & ppm & ppm & 1,000 & $\mathrm{ppb}$ \\
\hline${ }^{\circ} \mathrm{F}$ & $\left({ }^{\circ} \mathrm{F}-32\right) \div 9 / 5$ & ${ }^{\circ} \mathrm{C}$ & ${ }^{\circ} \mathrm{C}$ & $\left({ }^{\circ} \mathrm{C} \times 9 / 5\right)+32$ & ${ }^{\circ} \mathrm{F}$ \\
\hline g & 0.035 & $\mathrm{Oz}$ & $\mathrm{Oz}$ & 28.349 & $\mathrm{~g}$ \\
\hline metric ton & 1.1 & ton & ton & 0.9078 & metric ton \\
\hline
\end{tabular}

\section{Radioactivity Units}

Much of this report deals with levels of radioactivity in various environmental media. Radioactivity in this report is usually discussed in units of curies (Ci), with units of becquerels (B q) in parenthesis (Table A.3). The curie is the basic unit used to describe the amount of radioactivity present, and activities are generally expressed in terms of curies per mass or volume (e.g., picocuries per liter). One curie is equivalent to 37 billion disintegrations per second or is a quantity of any radionuclide that decays at the rate of 37 billion disintegrations per second. Conversely, one becquerel is equivalent to one disintegration per second. Nuclear disintegrations produce spontaneous emissions of alpha or beta particles, gamma radiation, or combinations of these. Table A.4 includes selected conversions from curies to becquerels.

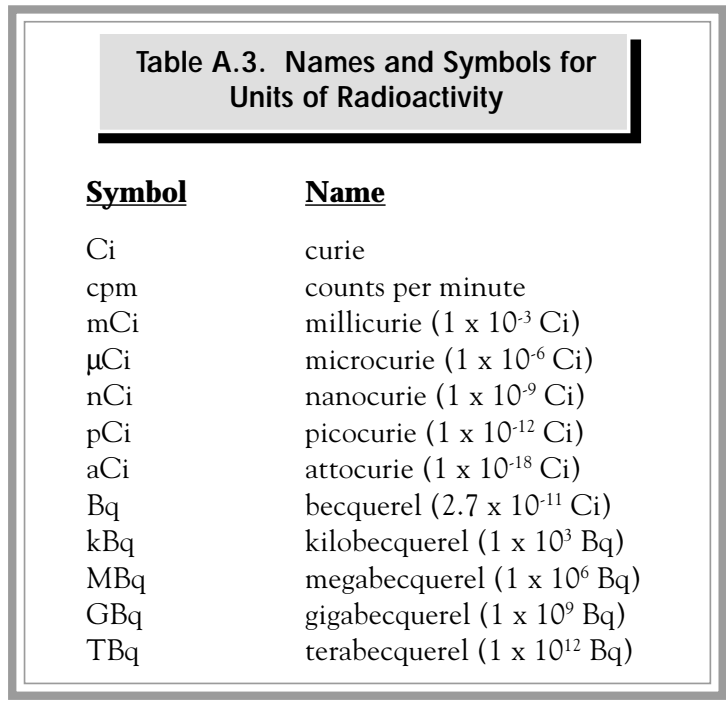

\section{Radiological Dose Units}

The amount of ionizing radiation energy absorbed by a living organism is expressed in terms of radiological dose. Radiological dose in this report is usually written in terms of effective dose equivalent and reported numerically in units of millirems (mrem), with the metric units millisieverts ( $\mathbf{m S v}$ ) following in parenthesis or footnoted (Table A.5). Millirem (millisievert) is a term that relates ionizing radiation and biological effect or risk (to humans). A dose of 0.01 millirem (1 millisievert) has a biological effect similar to 


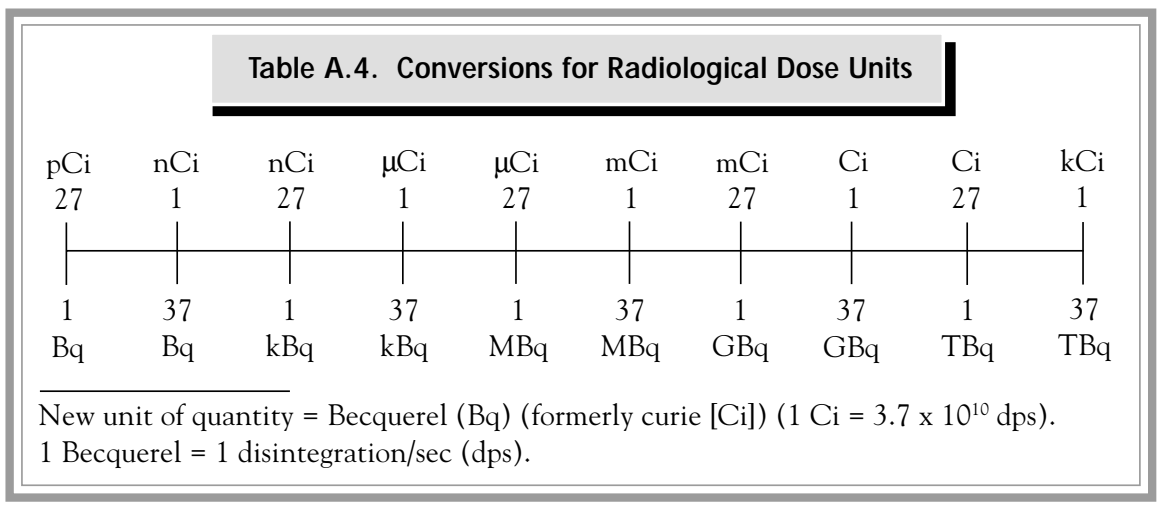

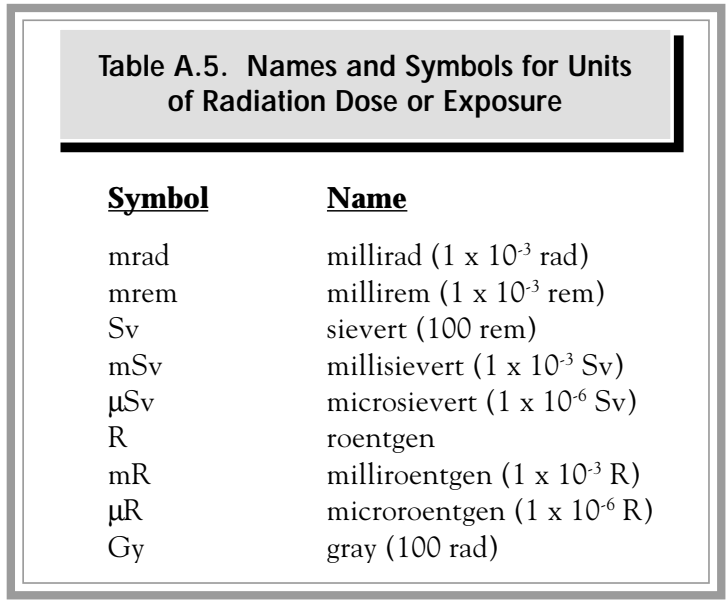

the dose received from an approximate 1-day exposure to natural background radiation. An acute (short-term) dose of 1,000 to 4,000 millirems $(100,000$ to 400,000 millisieverts) can cause radiation sickness in humans. An acute dose of 4,000 to 5,000 millirems (400,000 to 500,000 millisieverts), if left untreated, results in death $\sim 50 \%$ of the time. Exposure to lower amounts of radiation (10 millirems [1,000 millisieverts] or less) produces no immediate observable effects, but long-term (delayed) effects are possible. The average person in the United States receives an annual dose from exposure to naturally produced radiation of $\sim 3$ millirems (300 millisieverts). Medical and dental $\mathrm{x}$-rays and air travel add to this total. (See Section 5.7 for a more in-depth discussion of risk comparisons.) Table A.6 includes selected conversions from rems to sieverts.

Also used in this report is the metric unit rad, with the corresponding unit Gray (Gy) in parenthesis or footnoted. The rad (Gray) is a measure of the energy absorbed by any material, whereas a rem relates to both the amount of radiation energy absorbed by humans and its consequence. The Gray can be converted to rad by multiplying by 100 . The conversions in Table A.6 can also be used to convert Grays to rads.

A roentgen is a measure of radiation exposure with no SI equivalent. In the metric system, it is expressed in terms of energy per unit mass over time (e.g., watts [W] per kilogram). For conversion purposes, one microroentgen per hour $((\mathrm{R} / \mathrm{h})$ is equal to 2.109 picowatts per kilogram $(\mathrm{pW} / \mathrm{kg})$.

Additional information on radiation and dose terminology can be found in Appendix C. A list of the radionuclides discussed in this report, their symbols, and their half-lives are included in Table A.7.

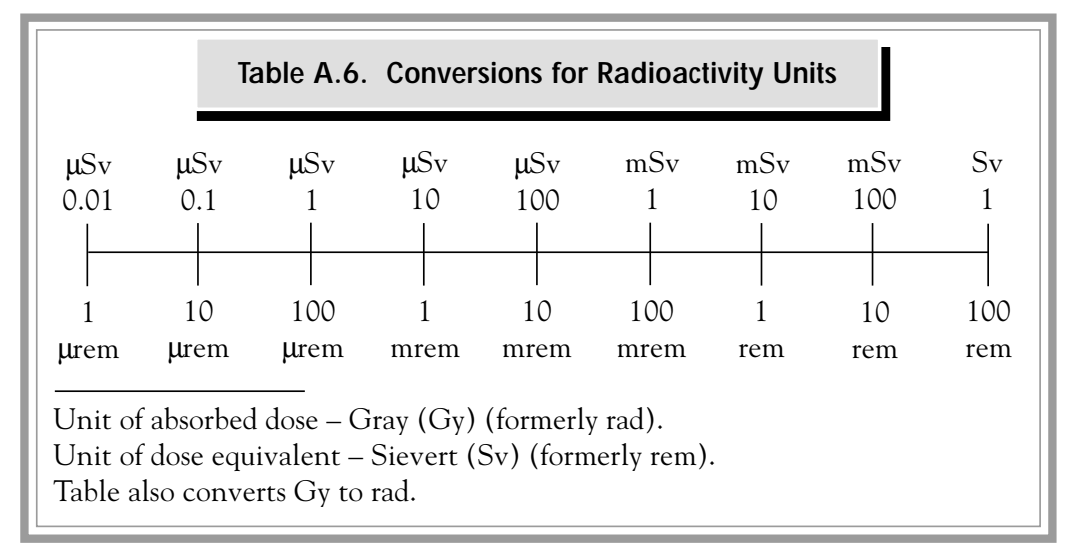




\begin{tabular}{|c|c|c|c|c|c|}
\hline Symbol & Radionuclide & $\underline{H}$ alf-Life & Symbol & Radionuclide & $\underline{\mathrm{H} \text { alf-Life }}$ \\
\hline${ }^{3} \mathrm{H}$ & tritium & $12.35 \mathrm{yr}$ & ${ }^{137 \mathrm{~m}} \mathrm{Ba}$ & barium-137m & $2.552 \mathrm{~min}$ \\
\hline${ }^{7} \mathrm{Be}$ & beryllium-7 & $53.44 \mathrm{~d}$ & ${ }^{152} \mathrm{Eu}$ & europium-152 & $13.3 \mathrm{yr}$ \\
\hline${ }^{14} \mathrm{C}$ & carbon-14 & $5,730 \mathrm{yr}$ & ${ }^{154} \mathrm{Eu}$ & europium-154 & $8.8 \mathrm{yr}$ \\
\hline${ }^{40} \mathrm{~K}$ & potassium-40 & $1.3 \times 10^{8} \mathrm{yr}$ & ${ }^{155} \mathrm{Eu}$ & europium-155 & $5 \mathrm{yr}$ \\
\hline${ }^{51} \mathrm{Cr}$ & chromium-51 & $27.7 \mathrm{~d}$ & ${ }^{212} \mathrm{~Pb}$ & lead-212 & $10.6 \mathrm{~h}$ \\
\hline${ }^{54} \mathrm{Mn}$ & manganese-54 & $312.7 \mathrm{~d}$ & ${ }^{220} \mathrm{Rn}$ & radon- 220 & $56 \mathrm{~s}$ \\
\hline${ }^{55} \mathrm{Fe}$ & iron-55 & $2.7 \mathrm{yr}$ & ${ }^{222} \mathrm{Rn}$ & radon-222 & $3.8 \mathrm{~d}$ \\
\hline${ }^{59} \mathrm{Fe}$ & iron-59 & $44.63 \mathrm{~d}$ & ${ }^{232} \mathrm{Th}$ & thorium-232 & $1.4 \times 10^{10} \mathrm{yr}$ \\
\hline${ }^{59} \mathrm{Ni}$ & nickel-59 & $75,000 \mathrm{yr}$ & $\mathrm{U}$ or uranium ${ }^{(\mathrm{b})}$ & uranium total & . (c) \\
\hline${ }^{60} \mathrm{Co}$ & cobalt -60 & $5.3 \mathrm{yr}$ & ${ }^{233} \mathrm{U}$ & uranium-233 & $1.59 \times 10^{5} \mathrm{yr}$ \\
\hline${ }^{63} \mathrm{Ni}$ & nickel-63 & $100.1 \mathrm{yr}$ & ${ }^{234} \mathrm{U}$ & uranium-234 & $2.4 \times 10^{5} \mathrm{yr}$ \\
\hline${ }^{65} \mathrm{Zn}$ & zinc- 65 & $243.9 \mathrm{~d}$ & ${ }^{235} \mathrm{U}$ & uranium-235 & $7 \times 10^{8} \mathrm{yr}$ \\
\hline${ }^{85} \mathrm{Kr}$ & krypton-85 & $10.7 \mathrm{yr}$ & ${ }^{237} \mathrm{~Np}$ & neptunium-237 & $2.14 \times 10^{6} \mathrm{yr}$ \\
\hline${ }^{90} \mathrm{Sr}$ & strontium-90 & $29.1 \mathrm{yr}$ & ${ }^{238} \mathrm{U}$ & uranium-238 & $4.5 \times 10^{9} \mathrm{yr}$ \\
\hline${ }^{90} \mathrm{Y}$ & yttrium-90 & $64.1 \mathrm{~h}$ & ${ }^{238} \mathrm{Pu}$ & plutonium-238 & $87.7 \mathrm{yr}$ \\
\hline${ }^{95} \mathrm{Zr}$ & zirconium-95 & $63.98 \mathrm{~d}$ & ${ }^{239} \mathrm{Pu}$ & plutonium-239 & $2.4 \times 10^{4} \mathrm{yr}$ \\
\hline${ }^{99} \mathrm{Tc}$ & technetium-99 & $2.1 \times 10^{5} \mathrm{yr}$ & ${ }^{240} \mathrm{Pu}$ & plutonium-240 & $6.5 \times 10^{3} \mathrm{yr}$ \\
\hline${ }^{103} \mathrm{Ru}$ & ruthenium-103 & $39.3 \mathrm{~d}$ & ${ }^{241} \mathrm{Pu}$ & plutonium-241 & $14.4 \mathrm{yr}$ \\
\hline${ }^{106} \mathrm{Ru}$ & ruthenium-106 & $368.2 \mathrm{~d}$ & ${ }^{242} \mathrm{Pu}$ & plutonium-242 & $3.76 \times 10^{5} \mathrm{yr}$ \\
\hline${ }^{113} \mathrm{Sn}$ & $\operatorname{tin}-113$ & $115 \mathrm{~d}$ & ${ }^{241} \mathrm{Am}$ & americium-241 & $432.2 \mathrm{yr}$ \\
\hline${ }^{125} \mathrm{Sb}$ & antimony-125 & $2.8 \mathrm{yr}$ & ${ }^{243} \mathrm{Am}$ & americium-243 & $7,380 \mathrm{yr}$ \\
\hline${ }^{129} \mathrm{I}$ & iodine- 129 & $1.6 \times 10^{7} \mathrm{yr}$ & ${ }^{243} \mathrm{Cm}$ & curium-243 & $28.5 \mathrm{yr}$ \\
\hline${ }^{131} \mathrm{I}$ & iodine-131 & $8 \mathrm{~d}$ & ${ }^{244} \mathrm{Cm}$ & curium-244 & $18.11 \mathrm{yr}$ \\
\hline${ }^{134} \mathrm{Cs}$ & cesium-134 & $2.1 \mathrm{yr}$ & ${ }^{245} \mathrm{Cm}$ & curium-245 & $8,500 \mathrm{yr}$ \\
\hline${ }^{137} \mathrm{Cs}$ & cesium-137 & $30 \mathrm{yr}$ & & & \\
\hline \multicolumn{6}{|c|}{ 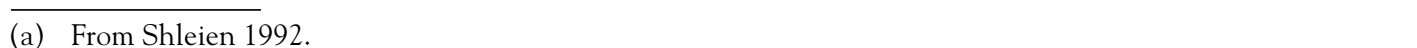 } \\
\hline \multicolumn{6}{|c|}{ (b) Total uranium may also be indicated by U-natural (U-nat) or U-mass. } \\
\hline \multicolumn{6}{|c|}{ (c) Natural uranium is a mixture dominated by ${ }^{238} \mathrm{U}$, thus the half-life is approximately $4.5 \times 10^{9}$ years. } \\
\hline
\end{tabular}

\section{Chemical and Elemental Nomenclature}

The chemical contaminants discussed in this report are listed in Table A.8 along with their chemical (or elemental) names and their corresponding symbols.

\section{Understanding the Data Tables}

Some degree of variability, or uncertainty, is associated with all analytical measurements. This uncertainty is the consequence of a series of minor, often unintentional or unavoidable, inaccuracies related to collecting and analyzing the samples. These inaccuracies could include errors associated with reading or recording the result, handling or processing the sample, calibrating the counting instrument, and numerical rounding. With radionuclides, inaccuracies can also result from the randomness of radioactive decay. In this report, the uncertainties used include standard deviation, total propagated analytical uncertainty, and standard error of the mean. If the reported concentration of a given constituent is smaller than its associated uncertainty (e.g., $40 \pm 200$ ), the sample may not contain that constituent. Such lowconcentration values are considered to be below detection, meaning the concentration of the constituent in the sample is so low that it is undetected by the method and/or instrument.

\section{Standard Deviation}

The standard deviation (SD) of sample data relates to the variation around the mean of a set of individual 
Table A.8. Elemental and Chemical Constituent Nomenclature

\begin{tabular}{|c|c|c|c|}
\hline Symbol & Constituent & Symbol & Constituent \\
\hline $\mathrm{Ag}$ & silver & $\mathrm{Hg}$ & mercury \\
\hline $\mathrm{Al}$ & aluminum & $K^{\circ}$ & potassium \\
\hline As & arsenic & $\mathrm{LiF}$ & lithium fluoride \\
\hline B & boron & $\mathrm{Mg}$ & magnesium \\
\hline $\mathrm{Ba}$ & barium & $\mathrm{Mn}$ & manganese \\
\hline $\mathrm{Be}$ & beryllium & Mo & molybdenum \\
\hline $\mathrm{Br}$ & bromine & $\mathrm{NH}_{3}$ & ammonia \\
\hline $\mathrm{C}$ & carbon & $\mathrm{NH}_{4}^{+}$ & ammonium \\
\hline $\mathrm{Ca}$ & calcium & $\mathrm{N}^{4}$ & nitrogen \\
\hline $\mathrm{CaF}_{2}$ & calcium fluoride & $\mathrm{Na}$ & sodium \\
\hline $\mathrm{CCl}_{4}^{2}$ & carbon tetrachloride & $\mathrm{Ni}$ & nickel \\
\hline $\mathrm{Cd}^{4}$ & cadmium & $\mathrm{NO}_{2}^{-}$ & nitrite \\
\hline $\mathrm{CHCl}_{3}$ & trichloromethane & $\mathrm{NO}_{3}^{-}$ & nitrate \\
\hline $\mathrm{Cl}^{-}$ & chloride & $\mathrm{Pb}$ & lead \\
\hline $\mathrm{CN}^{-}$ & cyanide & $\mathrm{PO}_{4}^{-3}$ & phosphate \\
\hline $\mathrm{Cr}^{+6}$ & chromium (species) & $\mathrm{P}^{4}$ & phosphorus \\
\hline $\mathrm{Cr}$ & chromium (total) & $\mathrm{Sb}$ & antimony \\
\hline $\mathrm{CO}_{3}^{-2}$ & carbonate & Se & selenium \\
\hline Co & cobalt & $\mathrm{Si}$ & silicon \\
\hline $\mathrm{Cu}$ & copper & $\mathrm{Sr}$ & strontium \\
\hline $\mathrm{F}^{-}$ & fluoride & $\mathrm{SO}_{4}^{-2}$ & sulfate \\
\hline $\mathrm{Fe}$ & iron & $\mathrm{Ti}^{4}$ & titanium \\
\hline \multirow{2}{*}{$\mathrm{HCO}_{3}$} & bicarbonate & $\mathrm{Tl}$ & thallium \\
\hline & & V & vanadium \\
\hline
\end{tabular}

sample results. If differences in analytical results occur among samples, then two times the standard deviation (or $\pm 2 \mathrm{SD}$ ) implies that $95 \%$ of the time, a re-count or re-analysis of the same sample would give a value somewhere between the mean result minus the standard deviation and the mean result plus the standard deviation. Analytical results that are close together will have a smaller deviation than the deviation for results that are spread farther apart.

\section{Total Propagated Analytical Uncertainty}

For samples that are prepared or manipulated in the laboratory prior to counting (counting the rate of radioactive emissions from a sample), the total propagated analytical uncertainty includes both the counting uncertainty and the uncertainty associated with sample preparation and chemical separations. For samples that are not manipulated in the laboratory before counting, the total propagated analytical uncertainty only accounts for the uncertainty associated with counting the sample. The uncertainty associated with samples that are analyzed but not counted includes only the analytical process uncertainty. In this situation, the total propagated analytical uncertainty is assumed to be the nominal detection limit.

\section{Standard Error of the Mean}

Just as individual values are accompanied by counting uncertainties, mean values (averages) are accompanied by \pm 2 times the standard error of the calculated mean (or \pm 2 SEM). If the data fluctuate randomly, then two times the standard error of the mean is a measure of the uncertainty in the estimated mean of the data from this randomness. If trends or periodic (e.g., seasonal) fluctuations are present, then two times the standard error of the mean is primarily a measure of the variability in the trends and fluctuations about the mean of the data. As with other uncertainties, two times the standard error of the mean implies that $~ 95 \%$ of the time the next calculated mean will fall somewhere between the reported value minus the standard error and the reported value plus the standard error.

\section{Median, Maximum, and Minimum Values}

Median (or sometimes mean), maximum, and minimum values are reported in some sections of this report. A median value is the middle value when all the values are arranged in order of increasing or decreasing magnitude. For example, the median value in the series of 
numbers $-1,2,3,3,4,5,5,5,6$ is 4 . The maximum value would be 6 and the minimum value would be 1 . Median, maximum, and minimum values are reported when there are too few analytical results to accurately determine the mean with a \pm statistical uncertainty or when the data do not follow a bell-shape (i.e., normal) distribution. Figure A.1 provides a graphical representation of median (or sometimes mean), maximum, and minimum values. The upper line is the maximum value, the center dot is the median (or mean) value, and the lower line is the minimum value.

\section{Negative Concentrations}

There is always a small amount of natural radiation in the environment. The instruments used in the laboratory to measure radioactivity in Hanford Site environmental media are sensitive enough to measure the natural, or background, radiation along with any contaminant radiation in a sample. To obtain a true measure of the contaminant level in a sample, the natural, or background, radiation level must be subtracted from the total amount of radioactivity measured by an instrument. Because of the randomness of radioactive emissions and the very low activities of some contaminants, it is possible to obtain a background measurement that is larger than the actual contaminant measurement. When the larger background measurement is subtracted from the smaller contaminant measurement, a negative result is generated. The negative results are reported because they are essential when conducting statistical evaluations of the data.

\section{Understanding Graphic Information}

Graphs are useful when comparing numbers collected at several locations or at one location over time. Graphs make it easy to visualize differences in data where they exist. However, while graphs may make it easy to evaluate data, they also may lead the reader to incorrect conclusions if they are not interpreted correctly. Careful consideration should be given to the scale (linear or logarithmic), concentration units, and type of uncertainty used.

Some of the data graphed in this report are plotted using logarithmic, or compressed, scales. Logarithmic scales are useful when plotting two or more numbers that differ greatly in size. For example, a sample with a

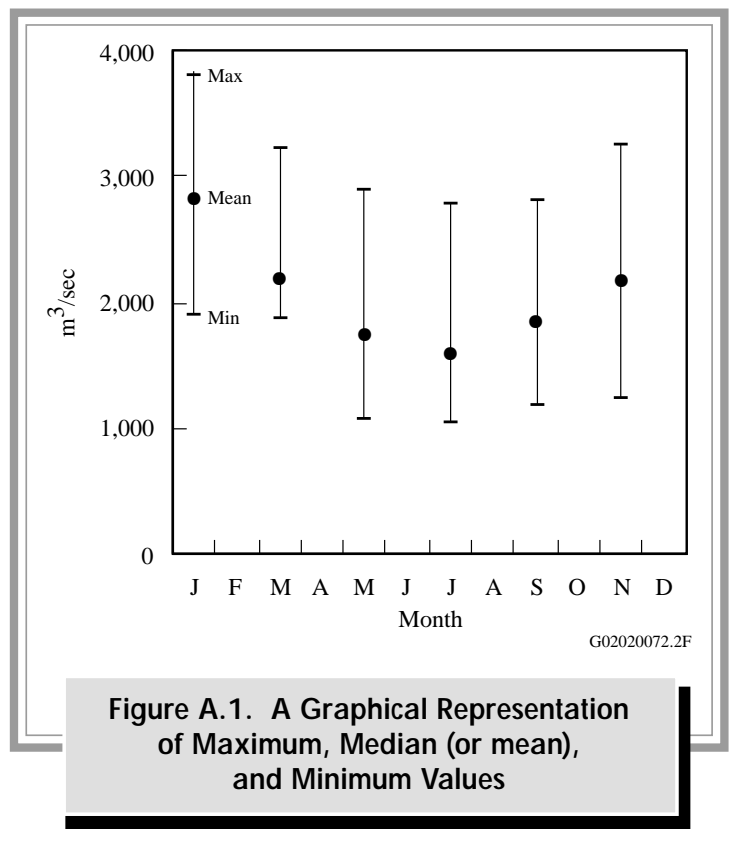

concentration of 5 grams per liter would get lost at the bottom of the graph if plotted on a linear scale with a sample having a concentration of 1,000 grams per liter (Figure A.2). A logarithmic plot of these same two numbers allows the reader to see both data points clearly (Figure A.3).

The mean (average) and median (defined earlier) values graphed in this report have vertical lines extending above and below the data point. When used with a mean value, these lines (called error bars) indicate the amount of uncertainty (standard deviation, total propagated analytical uncertainty, or two standard error of the mean) in the reported result. The error bars in this report represent a $95 \%$ chance that the mean is between the upper and lower ends of the error bar and a 5\% chance that the true mean is either lower or higher than

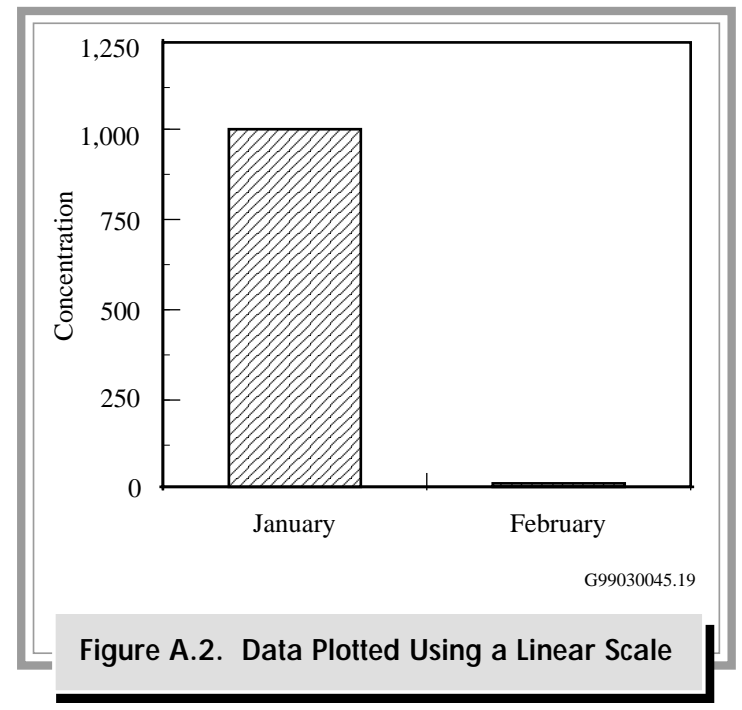




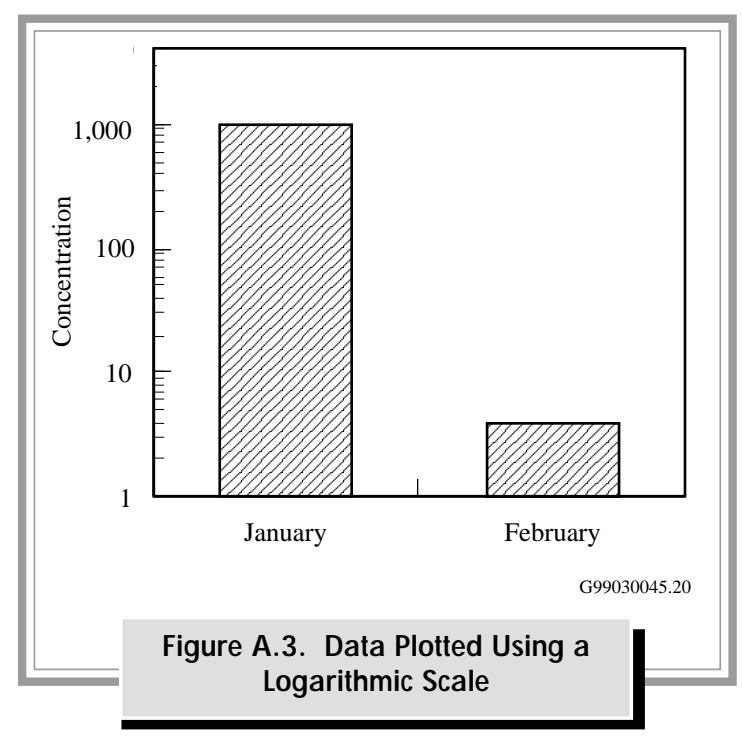

the error bar. ${ }^{(a)}$ For example, in Figure A.4, the first plotted mean is $2.0 \pm 1.1$, so there is a $95 \%$ chance that the true mean is between 0.9 and 3.1 , a $2.5 \%$ chance that it is less than 0.9 , and a $2.5 \%$ chance that it is greater than 3.1. Error bars are computed statistically, employing all of the information used to generate the mean value. These bars provide a quick, visual indication that one mean may be statistically similar to or different from another mean. If the error bars of two or more means overlap, as is the case with means 1 and 3 and

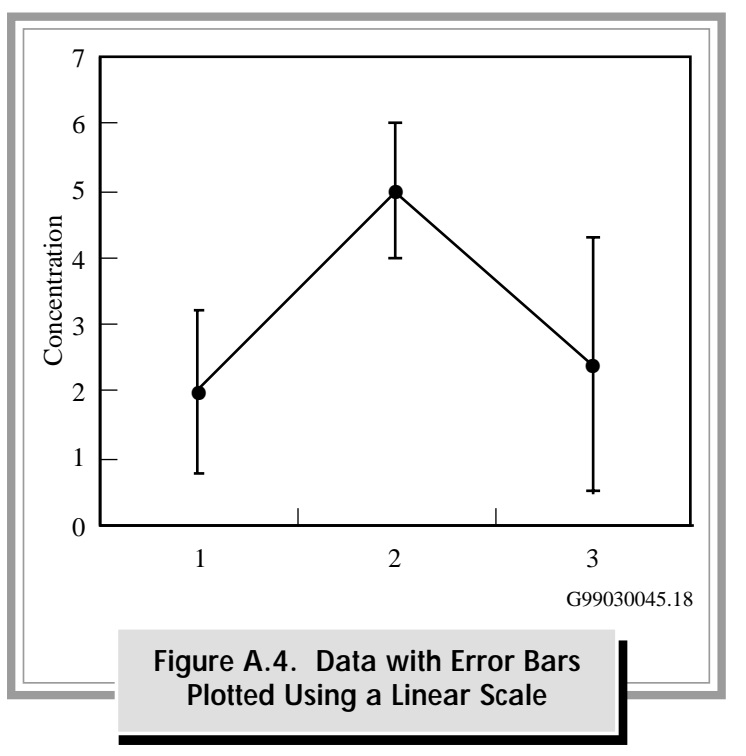

means 2 and 3, the means may be statistically similar. If the error bars do not overlap (means 1 and 2), the means may be statistically different. Means that appear to be very different visually (means 2 and 3 ) may actually be quite similar when compared statistically.

When vertical lines are used with median values, the lower end of each bar represents the minimum concentration measured; the upper end of each bar represents the maximum concentration measured.

\section{Greater Than $(\rightarrow$ or Less Than ( $\Varangle$ Sym bols}

Greater than $(>)$ or less than $(<)$ symbols are used to indicate that the actual value may either be larger than the number given or smaller than the number given. For example, $>0.09$ would indicate that the actual value is greater than 0.09 . An inequality symbol pointed in the opposite direction $(<0.09)$ would indicate that the number is less than the value presented. An inequality symbol used with an underscore $(\leq$ or $\geq)$ indicates that the actual value is less than or equal to or greater than or equal to the number given, respectively.

\section{Reference}

Shleien, B. 1992. The Health Physics and Radiological $\mathrm{H}$ ealth $\mathrm{H}$ andbook, Revised Edition. Scinta, Inc., Silver Spring, Maryland.

(a) Assuming a normal statistical distribution of the data. 


\title{
Appendix B Additional Monitoring Results for 2001
}

\author{
G. W. Patton
}

This appendix contains additional information on 2001 monitoring results, supplementing the data summarized in the main body of the report. More detailed information is available in PNNL-13910, APP. 1. 
Table B.1. Radionudide Concentrations in Columbia River Water at Priest Rapids Dam, 2001 Compared to Previous 5 Years

\section{No. of \\ Samples \\ 2001 Maximum

centration, ${ }^{(b)}$ pCi/L

Radionuclide $^{(\mathrm{a})}$

\section{Composite System}

Tritium

Alpha (gross)

Beta (gross)

Strontium-90

Technetium-99

Iodine-129

Uranium-234

Uranium-235

Uranium-238

Uranium (total)

\section{Continuous System}

Cobalt -60

Cesium-137

Europium-155

Plutonium-239/240

12
12
12
12
12
4
12
12
12
12

\section{$66 \pm 8.8$}

$1.7 \pm 1.1$

$2.1 \pm 1.7^{(\mathrm{f})}$

$0.092 \pm 0.035$

$0.26 \pm 0.27^{(\mathrm{f})}$

$0.000019 \pm 0.0000025$

$0.26 \pm 0.058$

$0.014 \pm 0.011$

$0.22 \pm 0.053$

$0.47 \pm 0.076$

$0.0013 \pm 0.00062^{(\mathrm{f})}$

$0.0040 \pm 0.0028^{(f)}$

$0.0032 \pm 0.0013$

$0.0034 \pm 0.0021^{(\mathrm{f})}$

$0.0012 \pm 0.0016^{(f)}$

$0.0044 \pm 0.0040$

$0.00018 \pm 0.000069$

$0.000055 \pm 0.000072^{(f)}$

$\begin{aligned} 37 & \pm 22 \\ 0.53 & \pm 0.84 \\ 0.47 & \pm 1.8 \\ 0.073 & \pm 0.027 \\ -0.0011 & \pm 0.24 \\ 0.0000064 & \pm 0.000017 \\ 0.24 & \pm 0.038 \\ 0.0070 & \pm 0.0074 \\ 0.18 & \pm 0.056 \\ 0.42 & \pm 0.082\end{aligned}$

$0.00046 \pm 0.0020^{(f)}$

$0.0013 \pm 0.0029^{(1)}$

$0.00086 \pm 0.0017$

$0.00075 \pm 0.0022^{(\mathrm{f})}$

$0.00018 \pm 0.0012^{(f)}$

$0.00099 \pm 0.0030$

$0.000068 \pm 0.00015$

$0.000035 \pm 0.000048$

\begin{tabular}{cc} 
& \multicolumn{1}{c}{$\mathbf{1 9 9 6 - 2 0 0 0}$} \\
\hline $\begin{array}{c}\text { No. of } \\
\text { Samples }\end{array}$ & \multicolumn{1}{c}{ Concentration } \\
& Maximum \\
& \\
58 & $200 \pm 22$ \\
60 & $5.6 \pm 3.1$ \\
60 & $7.7 \pm 2.2$ \\
60 & $0.13 \pm 0.062$ \\
60 & $1.6 \pm 0.69$ \\
20 & $0.000022 \pm 0.0000021$ \\
60 & $0.42 \pm 0.087$ \\
60 & $0.025 \pm 0.016$ \\
60 & $0.38 \pm 0.080$ \\
60 & $0.81 \pm 0.18$
\end{tabular}

$0.0013 \pm 0.0016^{(f)}$

$0.0065 \pm 0.0057$

$0.0031 \pm 0.0016^{(f)}$

$0.24 \pm 5.0^{(f)}$

$0.0032 \pm 0.0044^{(f)}$

$0.012 \pm 0.014^{(\mathrm{f})}$

$0.00028 \pm 0.00010$

$0.000072 \pm 0.000082^{(f)}$
Ambient Surface Water Quality Standard, pCi/L

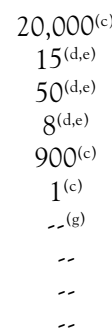

$100^{(c)}$

$200^{(c)}$

$600^{(c)}$

$0.0075 \pm 0.079$

$0.00041 \pm 0.0023$

$0.0014 \pm 0.0082$

$0.000049 \pm 0.00012$

$0.000020 \pm 0.000023$

(a) Radionuclides measured using the continuous system show the particulate (P) and dissolved (D) fractions separately. Other radionuclides are based on unfiltered samples collected by the composite system (see Section 4.2)

(b) Maximum values are \pm total propagated analytical uncertainty ( 2 sigma). Averages are \pm 2 standard deviations of the calculated mean. To convert to international metric system units, multiply $\mathrm{pCi} / \mathrm{L}$ by 0.037 to obtain $\mathrm{Bq} / \mathrm{L}$.

(c) WAC $173-201 \mathrm{~A}-050$ and EPA-570/9-76-003

(d) WAC 246-290

(e) 40 CFR 141

(f) Less than the detection limit.

(g) Dashes indicate no concentration guides available. 
Table B.2. Radionudide Concentrations in Columbia River Water at the Richland Pumphouse, 2001 Compared to Previous 5 Years

\begin{tabular}{ll} 
& \multicolumn{2}{c}{2001} \\
\hline No. of & \multicolumn{1}{c}{ Concentration, ${ }^{(b)}$ pCi/L } \\
\cline { 2 - 2 } Samples & Maximum
\end{tabular}

Radionuclide(a) $^{\text {(a) }}$

\section{Composite System}

Tritium

Alpha (gross)

Beta (gross)

Strontium-90

Technetium-99

Iodine-129

Uranium-234

Uranium-235

Uranium-238

Uranium (total)

Samples

Maximum

Average

$$
\begin{aligned}
130 & \pm 14 \\
1.4 & \pm 1.0 \\
1.9 & \pm 1.7^{(\mathrm{e})} \\
0.094 & \pm 0.039 \\
0.12 & \pm 0.19^{(\mathrm{e})} \\
0.00019 & \pm 0.000021 \\
0.32 & \pm 0.072 \\
0.016 & \pm 0.022^{(\mathrm{e})} \\
0.30 & \pm 0.066 \\
0.63 & \pm 0.095
\end{aligned}
$$

\section{Continuous System}

\section{Cobalt-60}

Cesium-137

Europium-155

Plutonium-239/240

$\mathrm{P}$
$\mathrm{D}$
$\mathrm{P}$
$\mathrm{D}$
$\mathrm{P}$
$\mathrm{D}$
$\mathrm{P}$
$\mathrm{D}$

\begin{abstract}
$0.0015 \pm 0.0008^{(\mathrm{e})}$
$0.0025 \pm 0.0018^{(\mathrm{e})}$

$0.0013 \pm 0.00068^{(\mathrm{e})}$

$0.0022 \pm 0.0019^{(\mathrm{e})}$

$0.0020 \pm 0.0015^{(\mathrm{e})}$

$0.0030 \pm 0.0041^{(\mathrm{e})}$

$0.000073 \pm 0.000043$

$0.00015 \pm 0.000070$
\end{abstract}

$\begin{aligned} 81 & \pm 49 \\ 0.58 & \pm 0.84 \\ 0.68 & \pm 1.6 \\ 0.065 & \pm 0.037 \\ 0.024 & \pm 0.14 \\ 0.00012 & \pm 0.00010 \\ 0.28 & \pm 0.056 \\ 0.0093 & \pm 0.0073 \\ 0.22 & \pm 0.069 \\ 0.52 & \pm 0.060\end{aligned}$
$0.00048 \pm 0.0010^{(\mathrm{e})}$
$0.00079+0.0017^{(\mathrm{e})}$
$0.000048 \pm 0.0022^{(\mathrm{e})}$
$0.00088 \pm 0.0018^{(\mathrm{e})}$
$0.00035 \pm 0.0017^{(0)}$
$0.00093 \pm 0.0030^{(\mathrm{e})}$
$0.000033 \pm 0.000058$
$0.000052 \pm 0.00013$

\begin{tabular}{cc} 
& $\begin{array}{r}\mathbf{1 9 9 6 - 2 0 0 0} \\
\text { No. of } \\
\text { Samples }\end{array}$ \\
\cline { 2 - 2 } & Maximum \\
& \\
58 & $150 \pm 18$ \\
60 & $2.2 \pm 1.1$ \\
60 & $6.6 \pm 2.5$ \\
60 & $0.30 \pm 0.081$ \\
60 & $0.53 \pm 0.52$ \\
19 & $0.00016 \pm 0.000013$ \\
60 & $0.40 \pm 0.075$ \\
60 & $0.024 \pm 0.015$ \\
60 & $0.30 \pm 0.060$ \\
60 & $0.70 \pm 0.14$
\end{tabular}

$\begin{array}{ll}36 & 0.0016 \pm 0.001^{(\mathrm{e})} \\ 36 & 0.0048 \pm 0.0037^{(\mathrm{e})} \\ 36 & 0.0037 \pm 0.0015 \\ 36 & 0.0071 \pm 0.0052^{(\mathrm{e})} \\ 36 & 0.0029 \pm 0.017^{(\mathrm{e})} \\ 36 & 0.0077 \pm 0.013^{(\mathrm{e})} \\ 20 & 0.00017 \pm 0.000087 \\ 20 & 0.00016 \pm 0.000091\end{array}$

Ambient Surface

Water Quality

Standard, pCi/L

$$
\begin{gathered}
20,000^{(c)} \\
15^{(c, d)} \\
50^{(c, d)} \\
8^{(c, d)} \\
900^{(f)} \\
1^{(f)} \\
-.^{(g)} \\
-. \\
-. \\
-\cdot
\end{gathered}
$$

$0.0089 \pm 0.012$

$0.22 \pm 0.075$

$0.49 \pm 0.16$

$\begin{array}{rlr}0.00016 & \pm 0.0010 & 100^{(f)} \\ 0.00067 & \pm 0.0031 & \\ 0.0010 & \pm 0.0017 & 200^{(f)} \\ 0.0012 & \pm 0.0031 & \\ 0.00027 & \pm 0.0026 & 600^{(f)} \\ 0.00076 & \pm 0.0077 & \\ 0.000043 & \pm 0.000088 & - \\ 0.000038 & \pm 0.000080 & \end{array}$

(a) Radionuclides measured using the continuous system show the particulate (P) and dissolved (D) fractions separately. Other radionuclides are based on unfiltered samples collected by the composite system (see Section 4.2).

(b) Maximum values are \pm total propagated analytical uncertainty ( 2 sigma). Averages are \pm 2 standard error of the calculated mean. To convert to international metric system units, multiply $\mathrm{pCi} / \mathrm{L}$ by 0.037 to obtain $\mathrm{Bq} / \mathrm{L}$

(c) 40 CFR 141

(d) WAC 246-290

(e) Less than the detection limit.

(f) WAC 173-201A-050 and EPA-570/9-76-003.

(g) Dashes indicate no concentration guides available. 
Table B.3. Radionuclide Concentrations Measured in Columbia River Water along Transects of the Hanford Reach, 2001

No. of

Transect/Radionuclide

Vernita B ridge (HRM 0.3) (b) $^{(\mathrm{b})}$

Tritium

Strontium-90

Uranium (total)

100-N Area (HRM 9.5)

Tritium

Strontium-90

Uranium (total)

100-F A rea (HRM 19)

Tritium

Strontium-90

Uranium (total)

\section{H anford Town Site}

(HRM 28.7)

Tritium

Strontium-90

Uranium (total)

300 Area (HRM 43.1)

Tritium

Strontium-90

Uranium (total)

Richland Pumphouse

(HRM 46.4)

Tritium

Strontium-90

Uranium (total)

\section{Samples}

16

16

16

\section{7}

7

7

6
6
6

6
$36 \pm 6.8$
$0.076 \pm 0.033$
$0.44 \pm 0.078$
$34 \pm 6.6$
$0.041 \pm 0.028$
$0.37 \pm 0.068$
$23 \pm 5.9$
$0.046 \pm 0.029$
$0.39 \pm 0.069$

$53 \pm 78$

$0.083 \pm 0.076$

$0.44 \pm 0.092$
$39 \pm 40$
$0.071 \pm 0.030$
$0.45 \pm 0.10$

$34 \pm 2.0$

$0.062 \pm 0.022$

$0.41 \pm 0.064$

$\begin{aligned} 820 & \pm 73 \\ 0.069 & \pm 0.032 \\ 0.49 & \pm 0.096\end{aligned}$

$36 \pm 6.7$

$0.040 \pm 0.028$

$0.38 \pm 0.069$

$210 \pm 630$

$0.057 \pm 0.019$

$0.43 \pm 0.094$
$49 \pm 8.2$
$0.074 \pm 0.039$

$30 \pm 6.2$

$0.054 \pm 0.031$

$0.41 \pm 0.072$

$36 \pm 15$

$0.064 \pm 0.0016$

$0.66 \pm 1.1$
$130 \pm 14$
$0.084 \pm 0.035$
$0.91 \pm 0.14$
$23 \pm 5.8$
$0.053 \pm 0.033$
$0.39 \pm 0.087$

(a) Maximum and minimum values are \pm total propagated analytical uncertainty. Mean values are \pm 2 standard error of the mean. To convert to international metric system units, multiply $\mathrm{pCi} / \mathrm{L}$ by 0.037 to obtain $\mathrm{Bq} / \mathrm{L}$.

(b) $\mathrm{HRM}=$ Hanford River Mile (e.g., Vernita Bridge crossing is Mile 0, the Richland Pumphouse is Mile 46.4).

(c) Below detection limit. 
Table B.4. Radionuclide Concentrations Measured in Columbia River Water at Near-Shore Locations in the Hanford Reach, 2001

\section{Near-Shore/Radionuclide \\ Vernita B ridge (HRM 0.3)(b)}

Tritium

Strontium-90

Uranium (total)

\section{0-N A rea (HRM 8.4 to 9.8)}

Tritium

Strontium-90

Uranium (total)

100-F A rea (HRM 18-23)

Tritium

Strontium-90

Uranium (total)

\section{H anford Town Site}

(HRM 26 to 30)

Tritium

Strontium-90

Uranium (total)

300 A rea (HRM 41.5 to 43.1)

Tritium

Strontium-90

Uranium (total)

\section{Richland Pumphouse}

(HRM 43.5 to 46.4)

Tritium

Strontium-90

Uranium (total)
No. of

Samples

4

4

4

6

6

6

3

3

$$
\begin{aligned}
37 & \pm 8.3 \\
0.072 & \pm 0.032 \\
0.48 & \pm 0.082
\end{aligned}
$$

Concentration, ${ }^{(\mathrm{a})} \mathrm{pCi} / \mathrm{L}$

\begin{tabular}{ccc}
\hline Maximum & Minimum & Mean \\
& & \\
$70 \pm 9.3$ & $28 \pm 6.2$ & $41 \pm 39$ \\
$0.11 \pm 0.15^{(c)}$ & $0.055 \pm 0.029$ & $0.074 \pm 0.050$ \\
$0.59 \pm 0.12$ & $0.38 \pm 0.072$ & $0.48 \pm 0.094$
\end{tabular}

$$
\begin{aligned}
& 130 \pm 14 \\
& 0.28 \pm 0.079 \\
& 0.44 \pm 0.079
\end{aligned}
$$
$62 \pm 8.7$
$0.066 \pm 0.032$
$0.32 \pm 0.068$

$\begin{aligned} 99 & \pm 58 \\ 0.15 & \pm 0.16 \\ 0.40 & \pm 0.096\end{aligned}$

$35 \pm 3.2$

$0.064 \pm 0.016$

$0.42 \pm 0.10$

$0.055 \pm 0.031$

$0.37 \pm 0.068$

$$
\begin{aligned}
5,100 & \pm 440 \\
0.077 & \pm 0.033 \\
0.61 & \pm 0.099
\end{aligned}
$$
$40 \pm 7.0$
$0.040 \pm 0.028$
$0.42 \pm 0.075$
$1,500 \pm 4,200$
$0.064 \pm 0.028$
$0.48 \pm 0.16$
$550 \pm 50$
$0.082 \pm 0.037$

$0.66 \pm 0.10$
$43 \pm 7.2$
$0.059 \pm 0.032$
$0.44 \pm 0.074$

$180 \pm 420$

$0.072 \pm 0.017$

$0.49 \pm 0.18$

$\begin{array}{ll}23 & 130 \pm 14 \\ 22 & 0.12 \pm 0.044 \\ 22 & 0.58 \pm 0.098\end{array}$

$\begin{aligned} 28 & \pm 6.4 \\ 0.041 & \pm 0.028 \\ 0.39 & \pm 0.072\end{aligned}$

$66 \pm 52$

$0.071 \pm 0.030$

$0.48 \pm 0.094$

(a) Maximum and minimum values are \pm total propagated analytical uncertainty. Mean values are \pm 2 standard deviations. To convert to international metric system units, multiply $\mathrm{pCi} / \mathrm{L}$ by 0.037 to obtain $\mathrm{Bq} / \mathrm{L}$.

(b) $\mathrm{HRM}=$ Hanford River Mile (e.g., Vernita Bridge crossing is Mile 0, the Richland Pumphouse is Mile 46.4).

(c) Below detection limit. 
Table B.5. Selected U.S. Geological Survey Columbia River Water Quality Data, (a) 2001

\section{Analysis}

Temperature

Dissolved oxygen

Turbidity

$\mathrm{pH}$

Sulfate, dissolved

Dissolved solids,

$180^{\circ} \mathrm{C}\left(356^{\circ} \mathrm{F}\right)$

Specific conductance

Total hardness, as

$\mathrm{CaCO}_{3}$

Alkalinity

Phosphorus, total

Chromium, dissolved

Dissolved organic

carbon

Iron, dissolved

Ammonia, dissolved,

as $\mathrm{N}$

Nitrite + nitrate,

dissolved, as $\mathrm{N}$

(a) Provisional data from U.S. Geological Survey National Stream Quality Accounting Network (NASQAN), subject to revision.

(b) From WAC 173-201A

(c) NTU $=$ Nephelometric turbidity units.

(d) Dashes indicate no standard available.

\section{Gelected U.S. Geological Sumey Columbia River Water Quality Data, 2001}

\begin{tabular}{|c|c|c|c|c|c|c|c|c|c|}
\hline \multirow[b]{2}{*}{ Units } & \multicolumn{4}{|c|}{ Vemita Bridge (upstream) } & \multicolumn{4}{|c|}{$\begin{array}{c}\text { Richland Pumphouse (downstream) } \\
\end{array}$} & \multirow{2}{*}{$\begin{array}{c}\text { Washington Ambient } \\
\text { Surface Water } \\
\text { Quality Standard (b) } \\
\end{array}$} \\
\hline & $\begin{array}{c}\text { No. of } \\
\text { Samples }\end{array}$ & Median & Maximum & Minimum & $\begin{array}{c}\text { No. of } \\
\text { Samples }\end{array}$ & Median & Maximum & Minimum & \\
\hline${ }^{\circ} \mathrm{C}$ & 4 & 11 & 19 & 6.6 & 5 & 8.5 & 19 & 4.5 & 20 (maximum) \\
\hline $\mathrm{mg} / \mathrm{L}$ & 4 & 11 & 13 & 9.4 & 5 & 11 & 12 & 8.9 & 8 (minimum) \\
\hline $\mathrm{NTU}^{(\mathrm{c})}$ & 4 & 2.2 & 3.0 & 1.3 & 4 & 1.8 & 4.1 & 0.90 & $5+$ background \\
\hline $\mathrm{pH}$ units & 4 & 8.1 & 8.5 & 8.0 & 5 & 8.1 & 8.3 & 7.9 & $6.5-8.5$ \\
\hline $\mathrm{mg} / \mathrm{L}$ & 4 & 9.0 & 11 & 8.4 & 5 & 9.3 & 12 & 9.1 & .-(d) \\
\hline $\mathrm{mg} / \mathrm{L}$ & 4 & 85 & 97 & 80 & 5 & 79 & 97 & 75 & .- \\
\hline$\mu \mathrm{S} / \mathrm{cm}$ & 4 & 142 & 158 & 134 & 5 & 143 & 161 & 139 & -. \\
\hline $\mathrm{mg} / \mathrm{L}$ & 4 & 63 & 71 & 59 & 5 & 65 & 74 & 61 & .- \\
\hline $\mathrm{mg} / \mathrm{L}$ & 4 & 57 & 63 & 53 & 5 & 60 & 64 & 52 & \\
\hline $\mathrm{mg} / \mathrm{L}$ & 4 & $<0.06$ & $<0.06$ & $<0.06$ & 5 & $<0.06$ & $<0.06$ & $<0.06$ & -. \\
\hline$\mu \mathrm{g} / \mathrm{L}$ & 4 & $<0.8$ & $<0.8$ & $<0.8$ & 5 & $<0.8$ & $<0.8$ & $<0.8$ & .- \\
\hline $\mathrm{mg} / \mathrm{L}$ & 4 & 1.3 & 2.4 & 1.1 & 4 & 1.4 & 1.7 & 1.1 & -. \\
\hline$\mu \mathrm{g} / \mathrm{L}$ & 4 & $<10$ & $<10$ & $<10$ & 5 & $<10$ & $<10$ & $<10$ & .- \\
\hline $\mathrm{mg} / \mathrm{L}$ & 4 & $<0.40$ & $<0.41$ & $<0.40$ & 5 & $<0.40$ & $<0.41$ & $<0.40$ & .- \\
\hline $\mathrm{mg} / \mathrm{L}$ & 4 & 0.098 & 0.15 & 0.046 & 5 & 0.11 & 0.16 & 0.073 & -. \\
\hline
\end{tabular}




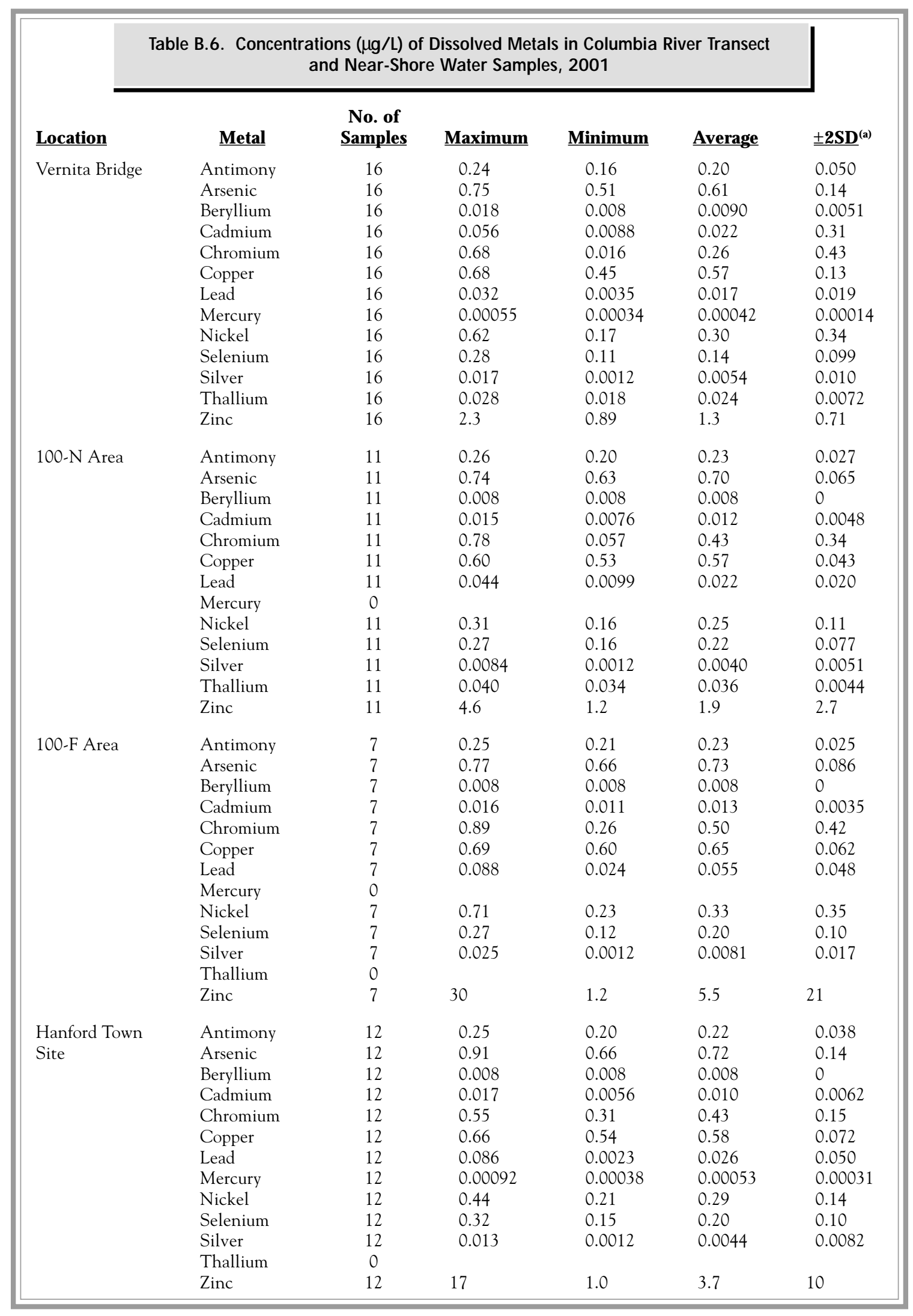




\begin{tabular}{|c|c|c|c|c|c|c|}
\hline \multirow[b]{2}{*}{ Location } & \multirow[b]{2}{*}{ Metal } & \multicolumn{2}{|c|}{ Table B.6. (contd) } & \multirow[b]{2}{*}{ Minimum } & \multirow[b]{2}{*}{ Average } & \multirow[b]{2}{*}{$\pm \underline{2 S D^{(a)}}$} \\
\hline & & $\begin{array}{c}\text { No. of } \\
\text { Samples }\end{array}$ & Maximum & & & \\
\hline \multirow[t]{13}{*}{300 Area } & Antimony & 12 & 0.22 & 0.21 & 0.22 & 0.0087 \\
\hline & Arsenic & 12 & 0.88 & 0.65 & 0.73 & 0.14 \\
\hline & Beryllium & 12 & 0.008 & 0.008 & 0.008 & 0 \\
\hline & Cadmium & 12 & 0.022 & 0.0084 & 0.013 & 0.0077 \\
\hline & Chromium & 12 & 0.48 & 0.21 & 0.34 & 0.15 \\
\hline & Copper & 12 & 0.68 & 0.55 & 0.60 & 0.092 \\
\hline & Lead & 12 & 0.16 & 0.0056 & 0.032 & 0.088 \\
\hline & Mercury & 0 & & & & \\
\hline & Nickel & 12 & 0.29 & 0.18 & 0.24 & 0.060 \\
\hline & Selenium & 12 & 0.80 & 0.16 & 0.29 & 0.47 \\
\hline & Silver & 12 & 0.0012 & 0.0012 & 0.0012 & 0 \\
\hline & Thallium & 0 & & & & \\
\hline & Zinc & 12 & 2.4 & 1.2 & 1.5 & 0.66 \\
\hline Richland & Antimony & 43 & 0.26 & 0.16 & 0.20 & 0.048 \\
\hline \multirow[t]{12}{*}{ Pumphouse } & Arsenic & 43 & 1.1 & 0.49 & 0.63 & 0.23 \\
\hline & Beryllium & 43 & 0.017 & 0.008 & 0.0084 & 0.0033 \\
\hline & Cadmium & 43 & 0.069 & 0.0064 & 0.024 & 0.034 \\
\hline & Chromium & 43 & 0.67 & 0.016 & 0.17 & 0.32 \\
\hline & Copper & 43 & 0.71 & 0.44 & 0.55 & 0.15 \\
\hline & Lead & 43 & 0.83 & 0.0021 & 0.044 & 0.26 \\
\hline & Mercury & 43 & 0.00067 & 0.00022 & 0.00046 & 0.00018 \\
\hline & Nickel & 43 & 3.2 & 0.12 & 0.30 & 0.93 \\
\hline & Selenium & 43 & 0.31 & 0.11 & 0.14 & 0.10 \\
\hline & Silver & 43 & 0.029 & 0.0012 & 0.0050 & 0.010 \\
\hline & Thallium & 43 & 0.028 & 0.017 & 0.022 & 0.0057 \\
\hline & Zinc & 43 & 5.1 & 0.82 & 1.4 & 1.7 \\
\hline
\end{tabular}




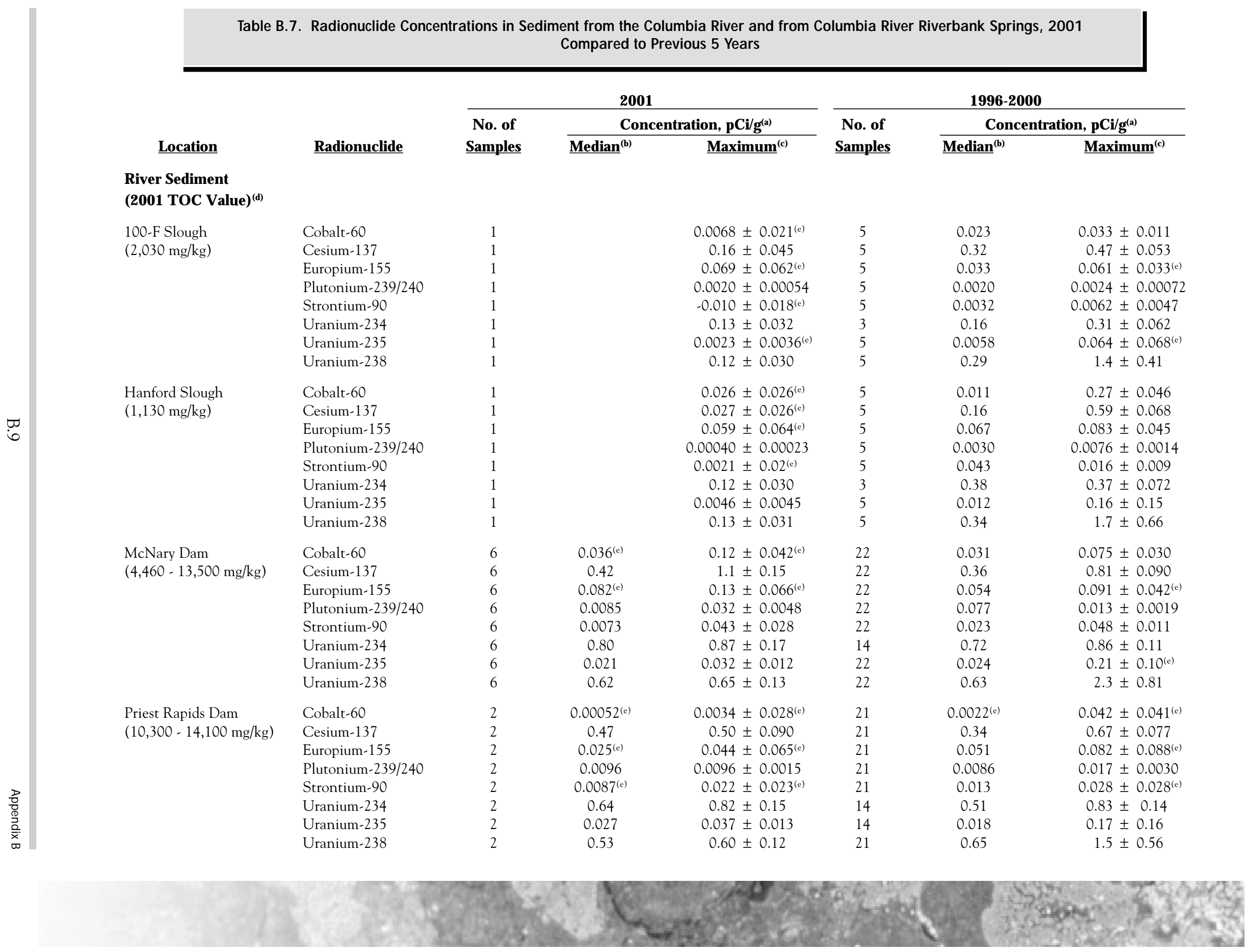


Table B.7. (contd)

\begin{tabular}{ll}
\multicolumn{1}{c}{ Location } & \multicolumn{1}{c}{ Radionuclide } \\
Richland & Cobalt-60 \\
$(4,170 \mathrm{mg} / \mathrm{kg})$ & Cesium-137 \\
& Europium-155 \\
& Plutonium-239/240 \\
& Strontium-90 \\
& Uranium-234 \\
& Uranium-235 \\
& Uranium-238 \\
& Cobalt-60 \\
& Cesium-137 \\
White Bluffs Slough & Europium-155 \\
$(16,500 \mathrm{mg} / \mathrm{kg})$ & Plutonium-239/240 \\
& Strontium-90 \\
& Uranium-234 \\
& Uranium-235 \\
& Uranium-238
\end{tabular}

\begin{tabular}{c}
$\begin{array}{c}\text { No. of } \\
\text { Sample }\end{array}$ \\
\hline 1 \\
1 \\
1 \\
1 \\
1 \\
1 \\
1 \\
1 \\
\\
1 \\
1 \\
1 \\
1 \\
1 \\
1 \\
1 \\
1
\end{tabular}

\section{Riverbank Spring Sediment}

$\begin{array}{ll}\text { 100-B Spring } & \text { Cobalt-60 } \\ & \text { Cesium-137 } \\ & \text { Europium-155 } \\ & \text { Strontium-90 } \\ & \text { Uranium-234 } \\ & \text { Uranium-235 } \\ & \text { Uranium-238 } \\ & \\ & \text { Cobalt-60 } \\ \text { 100-F Spring } & \text { Cesium-137 } \\ & \text { Europium-155 } \\ & \text { Strontium-90 } \\ & \text { Uranium-234 } \\ & \text { Uranium-235 } \\ & \text { Uranium-238 }\end{array}$

2001

Concentration, $\mathbf{p C i} / \mathrm{g}^{\text {(a) }}$

Median $^{(\mathbf{b})}$ Maximum $^{(\mathrm{c})}$

$0.032 \pm 0.023^{(\mathrm{e})}$

$0.24 \pm 0.049$

$0.035 \pm 0.056^{(\mathrm{e})}$

$0.0016 \pm 0.00049$

$-0.0073 \pm 0.023^{(\mathrm{e})}$

$0.16 \pm 0.044$

$0.011 \pm 0.0094$

$0.12 \pm 0.034$

$0.051 \pm 0.031^{(\mathrm{e})}$

$0.58 \pm 0.098$

$0.053 \pm 0.075^{(\mathrm{e})}$

$0.0044 \pm 0.0010$

$-0.014 \pm 0.017$

$0.47 \pm 0.093$

$0.013 \pm 0.0070$

$0.38 \pm 0.075$

$0.022 \pm 0.013^{(\mathrm{e})}$

$0.075 \pm 0.019$

$0.088 \pm 0.036$

$0.0030 \pm 0.025^{(\mathrm{e})}$

$0.48 \pm 0.097$

$0.014 \pm 0.0089$

$0.41 \pm 0.085$

$0.016 \pm 0.011^{(\mathrm{e})}$

$0.14 \pm 0.023$

$0.070 \pm 0.031^{(\mathrm{e})}$

$0.0018 \pm 0.025^{(\mathrm{e})}$

$0.70 \pm 0.14$

$0.060 \pm 0.019$

$0.65 \pm 0.13$
1996-2000

\begin{tabular}{ccc} 
No. of & \multicolumn{2}{c}{ Concentration, $\mathbf{~ P C i} / \mathbf{g}^{\text {(a) }}$} \\
\cline { 2 - 2 } Samples & Median $^{(\mathbf{b})}$ & $\underline{\text { Maximum }^{(\mathbf{c})}}$ \\
5 & 0.020 & $0.039 \pm 0.019$ \\
5 & 0.23 & $0.24 \pm 0.033$ \\
5 & $0.030^{(\mathrm{e})}$ & $0.062 \pm 0.032^{(\mathrm{e})}$ \\
5 & 0.0020 & $0.0034 \pm 0.00073$ \\
5 & 0.0043 & $0.0063 \pm 0.0041$ \\
3 & 0.24 & $0.25 \pm 0.053$ \\
5 & 0.014 & $0.068 \pm 0.13$ \\
5 & 0.24 & $2.1 \pm 0.54$ \\
& & \\
5 & 0.061 & $0.20 \pm 0.031$ \\
5 & 0.53 & $0.60 \pm 0.067$ \\
5 & 0.052 & $0.10 \pm 0.034^{(\mathrm{e})}$ \\
5 & 0.0049 & $0.0058 \pm 0.0011$ \\
5 & 0.0050 & $0.010 \pm 0.0057$ \\
3 & 0.30 & $0.69 \pm 0.13$ \\
5 & 0.0087 & $0.14 \pm 0.14^{(\mathrm{e})}$ \\
5 & 0.59 & $1.9 \pm 0.52$
\end{tabular}

0.010

$0.051 \pm 0.024^{(\mathrm{e})}$

$0.14 \pm 0.026$

$0.11 \pm 0.072^{(\mathrm{e})}$

$0.074^{(e)}$

$0.0020^{(\mathrm{e})}$

0.26

0.029

0.40

$.0041 \pm 0.0083^{(e)}$

$0.49 \pm 0.087$

$0.20 \pm 0.10^{(\mathrm{e})}$

$1.2 \pm 0.38$

0.021

0.14

$0.030^{(\mathrm{e})}$

0.0087

0.43

0.036

0.56

$0.044 \pm 0.024^{(\mathrm{e})}$

$0.32 \pm 0.040$

$0.055 \pm 0.031^{(\mathrm{e})}$

$0.013 \pm 0.032^{(\mathrm{e})}$

$0.69 \pm 0.078$

$0.16 \pm 0.076$

$1.4 \pm 0.54$ 
Table B.7. (contd)

2001

Concentration, $\mathrm{pCi} / \mathrm{g}^{\text {(a) }} \quad$ No. of

No. of

Median $^{(\mathbf{b})}$

\section{Cobalt -60}

Cesium-137

Europium-155

Strontium-90

Uranium-234

Uranium-235

Uranium-238

300 Area Spring

Cobalt -60

Cesium-137

Europium-155

Uranium-234

Uranium-235

Uranium-238

Hanford Spring

\section{Cobalt- 60}

Cesium-137

Europium-155

Uranium-234

Uranium-235

Uranium-238

\section{Samples}

0

0

0

$\begin{array}{rcrl}1 & & 0.00067 & \pm 0.0089^{(\mathrm{e})} \\ 1 & 0.038 & \pm 0.013 \\ 1 & & 0.064 & \pm 0.027^{(\mathrm{e})} \\ 3 & 1.8 & 2.7 & \pm 0.49 \\ 3 & 0.076 & 0.10 \pm 0.026 \\ 3 & 1.8 & 2.4 \pm 0.44\end{array}$

\section{6-2000}

Concentration, $\mathrm{pCi} / \mathrm{g}^{(\mathrm{a})}$

Samples

1
1

6

6

6
6

6
6
4

4
6
6

\begin{tabular}{cc}
\multicolumn{2}{c}{ Concentration, $\mathbf{~ p C i / \mathbf { g } ^ { ( \mathbf { a } ) }}$} \\
\hline Median $^{(\mathbf{b})}$ & \multicolumn{1}{c}{ Maximum $^{(\mathbf{c})}$} \\
& $0.015 \pm 0.021^{(\mathrm{e})}$ \\
& $0.19 \pm 0.046$ \\
& $0.039 \pm 0.047$ \\
& $0.0085 \pm 0.0048$ \\
& \\
& $0.14 \pm 0.065^{(\mathrm{e})}$ \\
& $0.82 \pm 0.24$ \\
& \\
$0.012^{(\mathrm{e})}$ & $0.020 \pm 0.010^{(\mathrm{e})}$ \\
0.11 & $0.27 \pm 0.035$ \\
$0.038^{(\mathrm{e})}$ & $0.086 \pm 0.035^{(\mathrm{e})}$ \\
2.8 & $3.9 \pm 0.60$ \\
0.11 & $0.19 \pm 0.11^{(\mathrm{e})}$ \\
2.1 & $3.7 \pm 0.57$
\end{tabular}

0.054

0.21

$0.067^{(\mathrm{e})}$

0.58

0.018

0.53
$0.067 \pm 0.026$

$0.25 \pm 0.058$

$0.10 \pm 0.053^{(e)}$

$0.75 \pm 0.13$

$1.6 \pm 0.56$
$0.025 \pm 0.077^{(\mathrm{e})}$

(a) To convert to international metric system units, multiply $\mathrm{pCi} / \mathrm{g}$ by 0.037 to obtain $\mathrm{Bq} / \mathrm{g}$.

(b) Median values are not provided when only one sample analyzed.

(c) Values are \pm total propagated analytical uncertainty.

(d) TOC $=$ Total organic content

(e) Below detection limit. 


\begin{tabular}{|c|c|c|c|c|}
\hline \multirow[b]{2}{*}{ Metal } & \multicolumn{4}{|c|}{$\begin{array}{l}\text { Table B.8. Median Metal Concentrations ( } \mathrm{mg} / \mathrm{kg} \text { dry wt.) in } \\
\text { Columbia River Sediment, } 2001\end{array}$} \\
\hline & $\begin{array}{c}(n=2) \\
\text { Priest Rapids } \\
\text { Dam }\end{array}$ & $\begin{array}{c}(n=3) \\
\text { Hanford } \\
\text { Reach }^{(a)}\end{array}$ & $\begin{array}{c}(n=2) \\
\text { McN ary } \\
\text { Dam }\end{array}$ & $\begin{array}{c}(n=6) \\
\text { Riverbank } \\
\text { Springs }\end{array}$ \\
\hline Antimony & 0.63 & 0.55 & 0.83 & 0.58 \\
\hline Arsenic & 5.9 & 4.4 & 8.7 & 4.0 \\
\hline Beryllium & 1.5 & 1.3 & 1.6 & 1.3 \\
\hline Cadmium & 2.6 & 0.60 & 1.9 & 0.57 \\
\hline Chromium & 72 & 59 & 70 & 77 \\
\hline Copper & 26 & 22 & 34 & 16 \\
\hline Lead & 37 & 23 & 57 & 18 \\
\hline Mercury & 0.069 & 0.0045 & 0.060 & 0.00090 \\
\hline Nickel & 29 & 17 & 26 & 18 \\
\hline Selenium & 0.93 & 0.46 & 0.47 & 0.35 \\
\hline Silver & 0.34 & 0.30 & 0.36 & 0.13 \\
\hline Thallium & 0.75 & 0.60 & 0.78 & 0.56 \\
\hline Zinc & 310 & 220 & 300 & 150 \\
\hline $\begin{array}{l}\text { (a) } 100-\mathrm{F} S \\
\text { (b) } 100-\mathrm{B}\end{array}$ & $\begin{array}{l}\text { lough, Hanford Slough, } \\
\text { trea, 100-F Area, and } 30\end{array}$ & $\begin{array}{l}\text { Richland. } \\
\text { ea. }\end{array}$ & & \\
\hline
\end{tabular}


Table B.9. Radionudide Concentrations Measured in Water from Riverbank Springs, 2001 Compared to Previous 5 Years

\begin{tabular}{|c|c|c|c|c|c|c|c|}
\hline \multirow[b]{3}{*}{ Location/Radionuclide } & \multicolumn{3}{|c|}{2001} & \multicolumn{3}{|c|}{$1996-2000$} & \multirow{3}{*}{$\begin{array}{l}\text { Washington S } \\
\text { Ambient Surf } \\
\text { Water Quali } \\
\text { Standard, }{ }^{(b)} \text {. }\end{array}$} \\
\hline & \multirow{2}{*}{$\begin{array}{l}\text { No. of } \\
\text { Samples }\end{array}$} & \multicolumn{2}{|c|}{ Concentation, $^{(\mathrm{a})} \mathbf{p C i / L}$} & \multirow{2}{*}{$\begin{array}{l}\text { No. of } \\
\text { Samples }\end{array}$} & \multicolumn{2}{|c|}{ Concentration, ${ }^{(\mathrm{a})} \mathrm{pCi} / \mathrm{L}$} & \\
\hline & & Maximum & Median & & Maximum & Median & \\
\hline \multicolumn{8}{|l|}{ 100-B Area } \\
\hline Alpha (gross) & 4 & $9.4 \pm 3.8$ & 3.9 & 6 & $2.0 \pm 1.4$ & 1.7 & 15 \\
\hline Beta (gross) & 4 & $24 \pm 4.5$ & 7.2 & 6 & $15 \pm 3.1$ & 7.4 & 50 \\
\hline Strontium-90 & 4 & $0.070 \pm 0.28^{(\mathrm{c})}$ & $0.019^{(c)}$ & 6 & $4.5 \pm 1.0$ & 0.031 & 8 \\
\hline Technetium-99 & 2 & $5.9 \pm 0.50$ & 4.0 & 4 & $18 \pm 2.3$ & 7.9 & $900^{(\mathrm{d})}$ \\
\hline Tritium & 4 & $8,000 \pm 690$ & 6,300 & 6 & $24,000 \pm 1,800$ & 13,000 & 20,000 \\
\hline \multicolumn{8}{|l|}{ 100-D Area } \\
\hline Alpha (gross) & 2 & $1.6 \pm 1.8^{(c)}$ & $0.71^{(c)}$ & 7 & $0.98 \pm 1.4^{(\mathrm{c})}$ & 0.50 & 15 \\
\hline Beta (gross) & 2 & $14 \pm 3.0$ & 8.8 & 7 & $14 \pm 3.6$ & 2.9 & 50 \\
\hline Strontium-90 & 1 & $0.55 \pm 0.17$ & 0.55 & 7 & $5.3 \pm 1.2$ & 1.4 & 8 \\
\hline Tritium & 2 & $9,400 \pm 1,000$ & 7,300 & 7 & $4,800 \pm 450$ & 360 & 20,000 \\
\hline \multicolumn{8}{|l|}{ 100-F Area } \\
\hline Alpha (gross) & 4 & $5.2 \pm 2.9$ & 4.4 & 5 & $41 \pm 18$ & 4.0 & 15 \\
\hline Beta (gross) & 4 & $10 \pm 2.6$ & 8.3 & 5 & $65 \pm 11$ & 7.8 & 50 \\
\hline Strontium-90 & 4 & $0.27 \pm 0.43^{(\mathrm{c})}$ & $-0.023^{(c)}$ & 5 & $0.094 \pm 0.057$ & 0.013 & 8 \\
\hline Tritium & 4 & $1,500 \pm 320$ & 1,400 & 5 & $1,800 \pm 240$ & 1,100 & 20,000 \\
\hline Uranium (total) & 2 & $5.2 \pm 0.70$ & 4.8 & 5 & $9.2 \pm 0.79$ & 4.6 & .-(e) \\
\hline \multicolumn{8}{|l|}{ 100-H Area } \\
\hline Alpha (gross) & 7 & $2.8 \pm 2.2$ & 0.71 & 6 & $10 \pm 3.7$ & 2.0 & 15 \\
\hline Beta (gross) & 7 & $27 \pm 4.7$ & 8.1 & 6 & $72 \pm 8.6$ & 20 & 50 \\
\hline Strontium-90 & 4 & $14 \pm 3.2$ & 1.9 & 5 & $17 \pm 3.1$ & 5.6 & 8 \\
\hline Technetium-99 & 4 & $4.5 \pm 0.41$ & 0.025 & 6 & $77 \pm 8.7$ & 0.77 & 900 \\
\hline Tritium & 7 & $5,500 \pm 470$ & 840 & 6 & $2,300 \pm 270$ & 480 & 20,000 \\
\hline Uranium (total) & 4 & $2.5 \pm 0.33$ & 1.3 & 6 & $9.3 \pm 0.70$ & 1.2 & -. \\
\hline \multicolumn{8}{|l|}{ 100-K Area } \\
\hline Alpha (gross) & 2 & $0.025 \pm 0.71^{(c)}$ & $-0.072^{(\mathrm{c})}$ & 5 & $4.1 \pm 2.1$ & 1.9 & 15 \\
\hline Beta (gross) & 2 & $3.8 \pm 2.0$ & 3.1 & 5 & $6.3 \pm 2.1$ & 5.0 & 50 \\
\hline Strontium-90 & 0 & & & 5 & $2.1 \pm 0.52$ & 0.035 & 8 \\
\hline Technetium-99 & 0 & & & 1 & $0.27 \pm 0.26$ & & $900^{(\mathrm{d})}$ \\
\hline Tritium & 2 & $5,800 \pm 640$ & 2,900 & 5 & $12,000 \pm 970$ & 5,400 & 20,000 \\
\hline
\end{tabular}


Table B.9. (contrd)

\section{Location/Radionuclide}

\section{N Area}

Alpha (gross)

Beta (gross)

Strontium-90

Tritium

\section{Area}

Alpha (gross)

Beta (gross)

Iodine-129

Technetium-99

Tritium

Uranium (total)

\section{Hanford Town Site}

Alpha (gross)

Beta (gross)

lodine-129

Technetium-99

Tritium

Uranium (total)

\section{Richland (HRM 44.4)}

Tritium

Uranium (total)

\section{Vernita Bridge}

Alpha (gross)

Beta (gross)

Strontium-90

Tritium

Uranium (total)
2001

No.
Sam
2
2
2

Concentra

\begin{tabular}{|c|c|c|}
\hline 2 & $2.2 \pm 1.5$ & 1.9 \\
\hline 2 & $5.5 \pm 20$ & 4.6 \\
\hline & $0.039 \pm 0.044^{(c)}$ & $0.026^{(c)}$ \\
\hline & $17,000 \pm 800$ & 12,000 \\
\hline
\end{tabular}

Median

$\begin{array}{rlr}88 & \pm 21 & 76 \\ 33 & \pm 5.4 & 23 \\ & \pm \\ 11 & \pm 0.96 & 10.4 \\ 12,000 & \pm 580 & 6,900 \\ 100 & \pm 13 & 62\end{array}$

$100 \pm 13$

62

\begin{tabular}{|c|c|c|}
\hline 2 & $5.0 \pm 2.5$ & 4.0 \\
\hline 2 & $\begin{array}{c}36 \pm 5.8 \\
\pm\end{array}$ & 34 \\
\hline & $110 \pm 7.5$ & 97 \\
\hline & $110,000 \pm 4,100$ & 100,000 \\
\hline 2 & $3.9 \pm 0.52$ & 3.8 \\
\hline
\end{tabular}

$230 \pm 23$

$1.6 \pm 0.24$

$4.2 \pm 1.8$

$8.4 \pm 1.8$

$0.026 \pm 0.061^{(c)}$

$35 \pm 6.9$

$0.43 \pm 0.075$
1996-2000

\begin{tabular}{lll}
\hline No. of & Concentration, ${ }^{\left({ }^{(a)}\right.} \mathbf{p C i} / \mathbf{L}$ \\
\cline { 3 - 3 } & Mamples &
\end{tabular}

Washington State Ambient Surface

Water Quality

Standard, ${ }^{(b)}$ pCi/L

15
50
8
20,000

$16,000 \pm 1,400$

$9,900 \pm 1,800$

1.1

4.0

$24,000 \pm 1,900$

17,000

20,000

$\begin{array}{rlr}230 & \pm 49 & 69 \\ 49 & \pm 7.9 & 26 \\ 0.0062 & \pm 0.00056 & 0.0050 \\ 16 & \pm 2.0 & 12 \\ 11,000 & \pm 570 & 9,600 \\ 210 & \pm 26 & 58\end{array}$

$$
\begin{gathered}
15 \\
50 \\
1 \\
900^{(d)} \\
20,000
\end{gathered}
$$

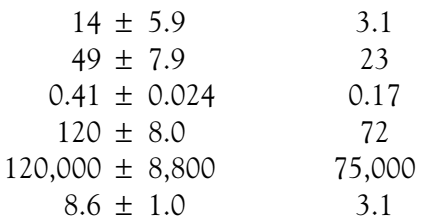

15

50

$900^{(d)}$

20,000

-

20,000

-

-

-

(a) Maximum values are \pm total propagated analytical uncertainty. To convert to international metric system units, multiply $\mathrm{pCi} / \mathrm{L}$ by 0.037 to obtain $\mathrm{Bq} / \mathrm{L}$.

(b) WAC 246-290, 40 CFR 141, and Appendix D, Table D.2.

(c) Value below the detection limit.

(d) WAC 173-201A-050 and EPA-570/9-76-003

(e) Dashes indicate no concentration guides available. 


\begin{tabular}{|c|c|c|c|c|c|}
\hline \multirow[b]{2}{*}{ Location } & \multicolumn{4}{|c|}{$\begin{array}{l}\text { Annual Average Dose Rates Measured on and around the Hanford Sit } \\
\text { in Calendar Year } 2001\end{array}$} & \multirow[b]{2}{*}{$\begin{array}{l}\text { Annual Average } \\
\text { (mrem/yr) }^{(\mathrm{a})}\end{array}$} \\
\hline & $\begin{array}{l}\text { Location } \\
\text { Number }\end{array}$ & $\begin{array}{l}\text { Annual Average } \\
\text { (mrem/yr) }^{(\mathrm{a})}\end{array}$ & Location & $\begin{array}{l}\text { Location } \\
\text { Number }\end{array}$ & \\
\hline \multicolumn{3}{|l|}{ Onsite ${ }^{(b)}$} & \multicolumn{3}{|l|}{ Community ${ }^{(c)}$} \\
\hline $100 \mathrm{~K}$ Area & 1 & $79 \pm 16$ & Mattawa & 12 & $79 \pm 10$ \\
\hline 100 D Area & 2 & $86 \pm 19$ & Othello & 13 & $76 \pm 9$ \\
\hline 100 F Met Tower & 3 & $87 \pm 10$ & Basin City & 14 & $78 \pm 12$ \\
\hline Hanford Townsite & 4 & $80 \pm 6$ & Edwin Markham School & 15 & $76 \pm 5$ \\
\hline $\mathrm{N}$ of $200 \mathrm{E}$ & 5 & $90 \pm 12$ & Leslie Groves - Richlnd ${ }^{(\mathrm{d})}$ & 16 & $91 \pm 0$ \\
\hline B Pond & 6 & $96 \pm 8$ & Pasco & 17 & $86 \pm 5$ \\
\hline$E$ of $200 \mathrm{E}$ & 7 & $90 \pm 12$ & Kennewick - Ely Street & 18 & $76 \pm 9$ \\
\hline 200ESE & 8 & $87 \pm 11$ & Benton City & 19 & $86 \pm 18$ \\
\hline S of $200 \mathrm{E}$ & 9 & $87 \pm 30$ & Distant $\mathbf{t}^{(\mathrm{c})}$ & & \\
\hline 200 Tel. Exchange & 10 & $85 \pm 17$ & $\begin{array}{l}\text { Distant } \\
\text { Yakima }\end{array}$ & 20 & $73 \pm 8$ \\
\hline $\mathrm{SW}$ of B/C Cribs & $\begin{array}{l}11 \\
12\end{array}$ & $\begin{array}{l}88 \pm 17 \\
84+4\end{array}$ & $\begin{array}{l}\text { rakima } \\
\text { Toppenish }\end{array}$ & 21 & $71 \pm 10$ \\
\hline $\begin{array}{l}200 \text { W SE } \\
\text { Army Loop Camp }\end{array}$ & $\begin{array}{l}12 \\
13\end{array}$ & $\begin{array}{l}84 \pm 4 \\
87 \pm 10\end{array}$ & \multicolumn{3}{|l|}{ Columbia River Shoreline ${ }^{(\mathrm{e})}$} \\
\hline 3705 Bldg. 300 Area & 14 & $82 \pm 11$ & S End Vernita Bridge $\mathrm{e}^{(f)}$ & 1 & $74 \pm 9$ \\
\hline 300 Water Intake & 15 & $80 \pm 8$ & Above 100 B Area & 2 & $89 \pm 14$ \\
\hline 300 Southwest Gate & 16 & $80 \pm 12$ & Below 100B Ret Basin & 3 & $97 \pm 15$ \\
\hline 300 South Gate & 17 & $83 \pm 9$ & Above $1 \mathrm{~K}$ Boat Ramp & 4 & $83 \pm 7$ \\
\hline 300 Trench & 18 & $83 \pm 7$ & Below $100 \mathrm{~N}$ Outfall & 5 & $110 \pm 11$ \\
\hline $300 \mathrm{NE}$ & 19 & $87 \pm 8$ & Above Tip 100N Berm & 6 & $93 \pm 5$ \\
\hline $400 \mathrm{E}$ & 20 & $82 \pm 5$ & 100 N Trench Spring & 7 & $129 \pm 6$ \\
\hline $400 \mathrm{~W}$ & 21 & $86 \pm 9$ & Below 100 D Area & 8 & $77 \pm 12$ \\
\hline $400 \mathrm{~S}$ & 22 & $82 \pm 13$ & 100-D Island & 9 & $79 \pm 10$ \\
\hline $400 \mathrm{~N}$ & 23 & $81 \pm 9$ & $100 \mathrm{H}$ Area & 10 & $86 \pm 9$ \\
\hline US Ecology NE Corner & 24 & $88 \pm 10$ & Lo End Locke Isl & 11 & $93 \pm 12$ \\
\hline US Ecology SE Corner & 25 & $88 \pm 7$ & White Bluffs Fy Lnd. & 12 & $87 \pm 9$ \\
\hline US Ecology NW Corner & 26 & $88 \pm 10$ & White Bluffs Slough ${ }^{(\mathrm{g})}$ & 13 & $101 \pm 22$ \\
\hline US Ecology SW Corner & 27 & $94 \pm 7$ & Below $100 \mathrm{~F}$ & 14 & $81 \pm 5$ \\
\hline Wye Barricade & 28 & $88 \pm 14$ & 100 F Flood Plain & 15 & $87 \pm 9$ \\
\hline WPPSS 1 ; $S$ of WNP 2 & 29 & $89 \pm 4$ & Hanford Slough & 16 & $96 \pm 13$ \\
\hline \multirow{2}{*}{\multicolumn{3}{|c|}{ Perimeter $(\mathrm{c})$}} & Hanf Powerline Xing & 17 & $94 \pm 9$ \\
\hline & & & Hanford RR Track & 18 & $96 \pm 9$ \\
\hline Ringold Met Tower & 1 & $94 \pm 7$ & Savage Isl Slough & 19 & $79 \pm 7$ \\
\hline W End of Fir Road & 2 & $93 \pm 8$ & Ringold Island & 20 & $85 \pm 8$ \\
\hline Dogwood Met Tower & 3 & $94 \pm 7$ & Powerline Crossing & 21 & $87 \pm 7$ \\
\hline Byers Landing & 4 & $99 \pm 16$ & S End Wooded Island & 22 & $98 \pm 21$ \\
\hline Battelle Complex & 5 & $80 \pm 10$ & Islnd Above 300 Area & 23 & $92 \pm 11$ \\
\hline WPPSS 4; WPS Warehse & 6 & $82 \pm 12$ & Island Near 300 Area & 24 & $90 \pm 14$ \\
\hline Horn Rapids Substa & 7 & $87 \pm 8$ & Port of Benton-River & 25 & $85 \pm 15$ \\
\hline $\begin{array}{l}\text { Prosser Barricade } \\
\text { Yakima Barricade }\end{array}$ & $\begin{array}{l}8 \\
9\end{array}$ & $\begin{array}{l}92 \pm 9 \\
95 \pm 10\end{array}$ & Isl DS Bateman Isl & 26 & $95 \pm 7$ \\
\hline Rattlesnake Springs & 10 & $94 \pm 13$ & & & \\
\hline Wahluke Slope & 11 & $90 \pm 7$ & & & \\
\hline $\begin{array}{l}\text { (a) } \pm 2 \text { standard deviations o } \\
\text { (b) All locations are shown } \\
\text { (c) All locations are shown } \\
\text { (d) Only one quarter of data } \\
\text { (e) All locations are shown } \\
\text { (f) Moved to Shoreline grou } \\
\text { (g) Only two quarters of dat }\end{array}$ & $\begin{array}{l}\text { f the dose rat } \\
\text { n Figure } 4.7 \\
\text { n Figure } 4.7 \\
\text { Figure } 4.7 \\
\text { ping due to } \\
\text {. }\end{array}$ & indalism. & & & \\
\hline
\end{tabular}




\section{References}

40 CFR 141. U.S. Environmental Protection Agency. "National Primary Drinking Water Regulations; Radionuclides; Proposed Rule." C ode of Federal Regulations.

EPA-570/9-76-003. 1976. N ational Interim Primary D rinking Water Regulations. Office of Water Supply, U.S. Environmental Protection Agency, Washington, D.C.

PNNL-13910, APP. 1. 2002. H anford Site E nvironmental Surveillance Data Report for C alendar Year 2000. L. E. Bisping, Pacific Northwest National Laboratory, Richland, Washington.
WAC 173-201A. "Water Quality Standards for Surface Waters of the State of Washington." Washington Administrative Code, Olympia, Washington.

WAC 246-290. "Group A Public Water Systems." Washington Administrative Code, Olympia, Washington. 


\section{Appendix C Glossary}

Words appearing in italic are defined in this glossary.

absorbed dose - Energy absorbed per unit mass from any kind of ionizing radiation in any kind of matter. Unit: rad.

activation product - Material made radioactive by exposure to radiation from a source such as a nuclear reactor's neutrons.

adsorption - The accumulation of gases, liquids, or solutes on the surface of a solid or liquid.

alpha particle - A positively charged particle ejected spontaneously from the nuclei of some radioactive elements. It has low penetrating power and short range. The most energetic alpha will generally fail to penetrate the skin. Alphas are hazardous when an alpha-emitting isotope is introduced into the body.

anion - A negatively charged ion.

aquifer - Permeable geologic unit that can hold and/or transmit significant quantities of water.

background radiation - Radiation in the natural environment, including cosmic rays from space and radiation from naturally occurring radioactive elements in the air, in the earth, and in our bodies. In the United States, the average person receives approximately 300 millirems of background radiation per year.

bank storage - Hydrologic term that describes river water that flows into and is retained in permeable stream banks during periods of high river stage. Flow is reversed during periods of low river stage.

becquerel (B q) - Unit of radioactivity equal to one nuclear transformation per second $(1 \mathrm{~Bq}=1$ disintegration/s). Another unit of radioactivity, the curie, is related to the becquerel: $1 \mathrm{Ci}=3.7 \times 10^{10} \mathrm{~Bq}$.

beta particle - A charged particle emitted from a nucleus during radioactive decay. Large amounts of beta particles may cause skin burns and are harmful if they enter the body. Beta particles are easily stopped by a thin sheet of metal or plastic. boundary dose rate - Dose rate measured or calculated at publicly accessible locations on or near the Hanford Site boundary.

cation - A positively charged ion.

clean closed - A facility is classified as "clean closed" under RCRA regulations when all dangerous waste has been removed and groundwater monitoring is no longer required.

collective total effective dose equivalent - Sum of the total effective dose equivalents for individuals composing a defined population. The units for this are "personrems" or "person-sieverts."

committed dose equivalent - The dose equivalent to organs or tissues that will be received from an intake of radioactive material by an individual during the 50-year period following intake.

committed effective dose equivalent - The sum of the committed dose equivalent from sources inside the body.

composite sample - Sample formed by mixing discrete samples taken at different times or from different locations.

confined aquifer - An aquifer bounded above and below by less-permeable layers. Groundwater in the confined aquifer is under a pressure greater than atmospheric pressure.

continuous sample - Sample formed by the continuous collection of the medium or contaminants within the medium during the entire sample period.

controlled area - An area to which access is controlled to protect individuals from exposure to radiation or radioactive and/or hazardous materials.

cosmic radiation - High-energy subatomic particles and electromagnetic radiation from outer space that bombard the earth. Cosmic radiation is part of natural background radiation. 
crib - An underground structure designed to receive liquid waste that percolates into the soil directly or percolates into the soil after having traveled through a connected tile field.

curie (Ci) - A unit of radioactivity equal to 37 billion $\left(3.7 \times 10^{10}\right)$ nuclear transformations per second. The curie is related to the becquerel: $1 \mathrm{~Bq}=$ $0.000000000027 \mathrm{Ci}$.

decay - The decrease in the amount of any radioactive material with the passage of time. See radioactivity.

decay product - The atomic nucleus or nuclei that are left after radioactive transformation of a radioactive material. Decay products may be radioactive or nonradioactive (stable). Formerly called "daughter product." See radioactivity.

deep-dose equivalent - The dose equivalent at a tissue depth of 1 centimeter from radiations originating outside of the body.

derived concentration guide (DCG) - Concentrations of radionuclides in air and water that an individual could continuously consume, inhale, or be immersed in at average annual rates, and not receive an effective dose equivalent of greater than 100 millirems per year.

detection level - Minimum amount of a substance that can be measured with a specified or implied confidence that the analytical result is greater than zero.

dispersion - Process whereby effluents are spread or mixed as they are transported by groundwater or air.

dose equivalent - Product of the absorbed dose, the quality factor, and any other modifying factors. The dose equivalent is a quantity for comparing the biological effectiveness of different kinds of radiation on a common scale. The unit of dose equivalent is the rem. A millirem is one one-thousandth of a rem.

dose rate - A quantity indicating how fast or slow radiation dose is accumulated over time. "Dose rate" is generally used to denote absorbed dose rate, dose equivalent rate, etc. Units: rads or millirads per hour $(\mathrm{rad} / \mathrm{h}$ or $\mathrm{mrad} / \mathrm{h}$ ) for absorbed dose rate; rems or millirems per hour $(\mathrm{rem} / \mathrm{h}$ or $\mathrm{mrem} / \mathrm{h})$ for dose equivalent rate.

dosimeter - Portable device for measuring the total accumulated exposure or absorbed dose from ionizing radiation fields.

effective dose - See "effective dose equivalent." effective dose equivalent - The sum of products of dose equivalent to each tissue or organ and the tissue weighting factor for each tissue or organ. The tissue weighting factors put doses to various tissues and organs on an equal basis in terms of health risk.

effluent - Liquid or gaseous waste streams released from a facility.

effluent monitoring - Sampling or measuring specific liquid or gaseous effluent streams for the presence of pollutants.

exposure - The interaction of an organism with a physical agent (e.g., radiation) or a chemical agent (e.g., arsenic) of interest. Also used as a term for quantifying $\mathrm{x}$ and gamma radiation fields. See roentgen.

external radiation - Radiation originating from a source outside the body.

facies - The aspect, appearance, and characteristics of a rock unit, usually reflecting the conditions of its origin (Bates and Jackson 1980).

fallout - Radioactive materials that are released into the earth's atmosphere following a nuclear explosion or atmospheric release and that eventually fall to earth.

fission - The splitting or breaking apart of a nucleus into at least two other nuclei, accompanied with a release of a relatively large amount of energy. For example, when a heavy atom such as uranium is split, large amounts of energy, including radiation and neutrons, are released along with the new nuclei (which are fission products; see below).

fission products - Elements formed from fissioning. Many fission products are radioactive.

gamma radiation - High-energy electromagnetic radiation originating in radioactive decay or nuclear reactions. If needed, shielding can be lead, steel, concrete, earth, or water. The needed thickness of the shield is determined by the intensity and duration of exposure.

grab sample - A short duration sample (e.g., air, water, soil) that is "grabbed" from the collection site.

grand mean - A "means of means" or an "overall mean" where there is some subdivision of the data where means were already provided for each subdivision.

groundwater - Subsurface water that is in the pore spaces of soil and geologic units.

gray (Gy) - Unit of absorbed dose in the International System of Units (SI) equal to 1 joule per kilogram. $1 \mathrm{~Gy}=100 \mathrm{rad}$. 
half-life - Length of time in which a radioactive substance will lose one half of its radioactivity by decay. Half-lives range from a fraction of a second to billions of years, and each radionuclide has a unique half-life.

high-level waste - Highly radioactive waste material resulting from the reprocessing of spent nuclear fuel, including liquid waste produced directly in reprocessing and any solid material derived from such liquid waste that contains fission products and other radioisotopes in sufficient concentrations to require permanent isolation.

internal radiation - Radiation from radioactive material inside the body.

ion exchange - The reversible exchange of one species of ion for a different species of ion within a medium.

irradiation - Exposure to radiation.

isotopes - Nuclides of the same chemical element with differing number of neutrons. Isotopes of the same element (e.g., ${ }^{238} \mathrm{Pu},{ }^{239} \mathrm{Pu},{ }^{240} \mathrm{Pu},{ }^{241} \mathrm{Pu}$ ) have almost identical chemical properties.

legacy waste - Waste that was generated prior to cleanup associated with deactivation and decommissioning.

low-level waste - Radioactive waste that is not highlevel radioactive waste, spent nuclear fuel, transuranic waste, byproduct material, or naturally occurring radioactive material.

lysimeter - An instrument to measure the water percolating through soil and determine the materials dissolved by the water.

maximally exposed individual - A hypothetical member of the public residing near the Hanford Site who, by virtue of location and living habits, could receive the highest possible radiation dose from radionuclides/ radiation originating from Hanford.

mean - Average value of a series of measurements. The mean, $\mathrm{X}$, was computed as:

$$
X=\frac{1}{n} \sum_{i=1}^{n} X_{i}
$$

where $\mathrm{n}$ is the number of measurements and $\mathrm{X}_{\mathrm{i}}$ is the ith measurement.

median - Middle value in a set of results when the data are ranked in increasing or decreasing order.

millirem - A unit of radiation dose equivalent that is equal to one one-thousandth (1/1000) of a rem. According to U.S. Department of Energy standards, an individual member of the public may receive no more than
100 millirems per year from a site's operation. This limit does not include radiation received for medical treatment or the $\sim 300$ millirems that people receive annually from natural background radiation.

\section{minimum detectable amount or concentration -}

Smallest amount or concentration of a chemical or radioactive material that can be reliably detected in a sample.

mitigation - Prevention or reduction of expected risks to workers, the public, or the environment.

mixed waste - A dangerous, extremely hazardous, or acutely hazardous waste that contains both a nonradioactive hazardous component and a radioactive component.

noble gas - Any of a group of chemically and biologically inert gases that includes argon, krypton, and xenon. These gases are not retained in the body following inhalation. The principal exposure pathways for radioactive noble gases are direct external dose from the surrounding air.

nuclide - A particular combination of neutrons and protons. A radionuclide is radioactive.

offsite locations - Sampling and measurement locations outside the Hanford Site boundary.

onsite locations - Sampling and measurement locations within the Hanford Site boundary.

operable unit- A discrete area for which an incremental step can be taken toward comprehensively addressing site problems. The cleanup of a site can be divided into a number of operable units, depending on the complexity of the problems associated with the site.

outfall - End of a drain or pipe that carries wastewater or other effluents into a ditch, pond, or river.

person-rem or person-sievert (person-Sv) - Unit of collective total effective dose equivalent. 1 person-Sv = 100 person-rems.

photon - A particle of high-energy electromagnetic radiation, characterized by energy, frequency, and wave length. Gamma radiation and $\mathrm{x}$ radiation ( $\mathrm{x}$-rays) are both comprised of photons.

plume - The cloud of a pollutant in air, surface water, or groundwater formed after the pollutant is released from a source. 
plutonium - A heavy, radioactive, manmade metallic element consisting of several isotopes. One important isotope is ${ }^{239} \mathrm{Pu}$, which is produced by the irradiation of ${ }^{238} \mathrm{U}$. Routine analysis cannot distinguish between the ${ }^{239} \mathrm{Pu}$ and ${ }^{240} \mathrm{Pu}$ isotopes; hence, the term ${ }^{239 / 240} \mathrm{Pu}$ as used in this report is symbolic of the presence of one or both of these isotopes in the analytical results.

quality assurance - Actions that provide confidence that an item or process meets or exceeds that user's requirements and expectations.

quality control - Comprises all those actions necessary to control and verify the features and characteristics of a material, process, product, or service to specified requirements. Quality control is an element of quality assurance.

rad - The unit of absorbed dose. $1 \mathrm{rad}=0.01 \operatorname{gray}(\mathrm{Gy})$.

radiation - The energy emitted in the form of photons or particles such as those thrown off by transforming (decaying) atoms. For this report, radiation refers to ionizing types of radiation; not radiowaves, microwaves, radiant light, or other types of non-ionizing radiation.

radiation limit - The permissible upper bounds of radiation doses.

radioactivity - Property possessed by some radioisotopes of emitting radiation (such as alpha, beta, or gamma photons) spontaneously in their decay process.

radioisotope - An unstable isotope of an element that decays or disintegrates spontaneously, emitting radiation (Shleien 1992).

radionuclide - A species of atoms having a particular number of protons $(Z)$, a particular number of neutrons (A), and a particular atomic weight $(\mathrm{N}=\mathrm{Z}+\mathrm{A})$ that happens to emit radiation. Carbon-14 is a radionuclide. Carbon-12 is not and is called just a "nuclide."

recruitment - Survival from one life form or stage to the next or from one age class to the next.

rem - A unit of dose equivalent and effective dose equivalent.

remediation - Reduction of known risks to the public and environment to an agreed upon level.

risk - The probability that a detrimental health effect will occur.

roentgen (R) - Unit of $\mathrm{x}$-ray or gamma photon exposure measured in air, historically used to describe external radiation levels. An exposure of 1 roentgen typically causes an effective dose of 1 rem. sievert (Sv) - Unit of dose equivalent and effective dose equivalent in the International System of Units (SI) equal to 100 rems.

special case waste - Waste for which there is an undetermined disposal path because of high levels of radioactivity and difficulties in characterization, classification, and packaging.

specific retention facilities - Historical structures consisting of cribs, ditches, trenches, or holes in the ground that received relatively small volumes of high concentration liquid radioactive waste. The small volume of liquid waste was designed to prevent flushing of the contaminants through the soil column to the groundwater.

spectrometer - A spectroscope with a calibrated scale for measuring the positions of spectral lines.

spectroscopy - The branch of physics concerned with the production, measurement, and interpretation of electromagnetic spectra arising from either emission or absorption of radiant energy by various substances.

spent fuel - Uranium metal or oxide and its metal container that have been used to power a nuclear reactor. It is highly radioactive and typically contains fission products, plutonium, and residual uranium.

standard error of the mean - A measure of the precision of a mean of observed values; that is, an estimate of how close a mean of observed values is expected to be to the true mean. The standard error (SE) of the mean is computed as

$$
S E=\sqrt{\frac{S^{2}}{n}}
$$

where $S^{2}$ is the variance of the measurements, $n$, computed as

$$
S^{2}=\frac{1}{n-1} \sum_{i=1}^{n}\left(X_{i}-X\right)^{2}
$$

$\mathrm{X}$ is the mean of $\mathrm{n}$ measurements.

This estimator, $\mathrm{S}^{2}$, includes the variance among the samples and the counting variance. The estimated $\mathrm{S}^{2}$ may occasionally be less than the average counting variance.

thiourea - An organic chemical soluble in cold water used in photography, photocopying, and thyroid medication. 
transient calibration - The trial-and-error adjustment of aquifer parameters under conditions of changing flow velocity.

transuranic - An element with an atomic number greater than 92 (92 is the atomic number of uranium).

transuranic waste - Waste containing more than 100 nanocuries $\left(10^{-9}\right.$ curies $)$ of alpha-emitting transuranic isotopes (isotopes with atomic numbers greater than uranium) per gram of waste with half-lives greater than 20 years.

thermoluminescent dosimeter - A device containing a material that, after being exposed to beta and/or gamma radiation, emits light when processed and heated. The amount of light emitted is proportional to the absorbed dose to the thermoluminescent dosimeter.

total effective dose equivalent - The sum of committed effective dose equivalent from intakes of radioactive material and deep-dose equivalent from external radiation. Unit: rem or sievert. unconfined aquifer - An aquifer containing groundwater that is not confined above by relatively impermeable rocks. The pressure at the top of the unconfined aquifer is equal to that of the atmosphere. At Hanford, the unconfined aquifer is the uppermost aquifer and is most susceptible to contamination from site operations.

vadose zone - Underground area from the surface to the top of the water table or aquifer.

volatile organic compounds - Lightweight organic compounds that vaporize easily. Used in solvents and degreasing compounds as raw materials, volatile compounds are generally considered to be below the molecular weight of $\mathrm{C}_{10}$ hydrocarbons.

water table - Theoretical surface represented by the elevation of water surfaces in wells penetrating only a short distance into the unconfined aquifer.

wind rose - Star-shaped diagram that shows how often winds of various speeds blow from different directions, usually based on yearly averages.

\section{References}

Bates, R. L. and J. A. Jackson (eds.). 1980. Glossary of Geology. American Geological Institute, Falls Church, Virginia.
Shleien, B. (ed.). 1992. The Health Physics and Radiological Health Handbook, Revised Edition. Scinta, Inc., Silver Spring, Maryland. 


\title{
Appendix D Standards and Permits
}

\author{
R. W. Hanf
}

Operations at the Hanford Site must conform to a variety of government standards and permits designed to assure the biological and physical quality of the environment for public health, ecological, or aesthetic considerations. The primary environmental quality standards and permits applicable to Hanford Site operations in 2001 are listed in the following tables. The state of Washington has water quality standards for the Columbia River, defined in Washington Administrative Code (WAC 173-201A). The Hanford Reach of the Columbia River has been designated as Class A (Excellent). This designation requires that the water be usable for substantially all needs, including drinking water, recreation, and wildlife. Class A water standards are summarized in Table D.1. Table D.2 summarizes drinking water standards from the U.S. Environmental Protection Agency (EPA) in the Code of Federal Regulations (40 CFR 141) and WAC 246-290. Select surface freshwater quality criteria for toxic pollutants are included in Table D.3.

Environmental radiation protection standards are published in U.S. Department of Energy (DOE) Order 5400.5. The order establishes limits for public radiation dose and gives guidance to keep radiation exposures to members of the public as low as reasonably achievable. These standards are based on guidelines recommended by authoritative organizations such as the International Commission on Radiological Protection and the National Council on Radiation Protection and Measurements. DOE initiated a policy to create and implement public radiation protection standards that are generally consistent with the standards used by the U.S. Nuclear Regulatory Commission to regulate and license non-DOE nuclear facilities, such as nuclear power plants. Table D.4 shows the radiation standards from DOE Order 5400.5, 40 CFR 61, and 40 CFR 141. These standards govern allowable public exposures to ionizing radiation from DOE operations.

DOE Order 5400.5 established derived concentration guides that reflect the concentrations of radionuclides in water and air that an individual could continuously consume, inhale, or be immersed in at average annual levels without exceeding an effective dose equivalent of 100 millirems per year. Derived concentration guides are not exposure limits but are simply reference values that are provided to allow for comparisons of radionuclide concentrations in environmental media. Table D. 5 lists selected DOE derived concentration guides for radionuclides of particular interest at the Hanford Site. The guides are useful reference values but do not generally represent concentrations in the environment that assure compliance with either DOE, Clean Air Act, or drinking water dose standards.

Permits required for regulated releases to water and air have been issued by EPA under the National Pollutant Discharge Elimination System of the Clean Water Act and the Prevention of Significant Deterioration requirements of the Clean Air Act. Also, under authority granted by the Clean Air Act, the Washington State Department of Health issued a permit for Hanford Site radioactive air emissions. Permits to collect wildlife for environmental sampling are issued by the Washington Department of Fish and Wildlife and the U.S. Fish and Wildlife Service. Current permits are discussed in Table D.6. 
Table D.1. Washington State Water Q uality Standards for the Hanford Reach of the Columbia River ${ }^{(a)}$

\section{Parameter}

Fecal coliform

Dissolved oxygen

Temperature

$\mathrm{pH}$

Turbidity

Toxic, radioactive, or deleterious materials

Aesthetic value

Radioactive substances

Toxic substances

\section{Permissible Levels}

1) Geometric mean value less than or equal to 100 colonies/100 milliliters

2) Less than or equal to $10 \%$ of samples may exceed 200 colonies $/ 100$ milliliters

Greater than $8 \mathrm{mg} / \mathrm{L}$

1) Less than or equal to $18^{\circ} \mathrm{C}\left(64^{\circ} \mathrm{F}\right)$ as a result of human activities

2) When natural conditions exceed $18^{\circ} \mathrm{C}\left(64^{\circ} \mathrm{F}\right)$, no temperature increases will be allowed that will raise the temperature of the receiving water by more than $0.3^{\circ} \mathrm{C}$

3) Incremental temperature increases resulting from point sources shall not at any time exceed $t=28 /(T+7)$, where $t=$ maximum permissible temperature increase measured at a mixing zone boundary and $\mathrm{T}=$ background temperature. Incremental temperature increases resulting from non-point sources shall not exceed $2.8^{\circ} \mathrm{C}$

1) 6.5 to 8.5 range

2) Less than 0.5 unit induced variation

Turbidity shall be less than or equal to 5 nephelometric turbidity units over background turbidity when the background turbidity is 50 nephelometric units or less, and shall not increase more than $10 \%$ when the background turbidity is $>50$ nephelometric units

Concentrations shall be below those which have the potential either singularly or cumulatively to adversely affect characteristic water uses, cause acute or chronic conditions to the most sensitive biota dependent upon those waters, or adversely affect public health

Shall not be impaired by the presence of materials or their effects, excluding those of natural origin, which offend the senses of sight, smell, touch, or taste

Deleterious concentrations of radioactive materials for all classes shall be as determined by the lowest practicable level attainable and in no case shall exceed $1 / 12.5$ of the values list in WAC 246-221-290 or EPA drinking water regulations for radionuclides, as published in the Federal Register of July 9, 1976 or subsequent revisions thereto (see Table D.2)

Shall not be introduced above natural background levels in waters of the state that have the potential either singularly or cumulatively to adversely affect characteristic water uses, cause acute or chronic toxicity to the most sensitive biota dependent on those waters, or adversely affect public health, as determined by the department (see Table D.3)

(a) WAC 173-201A 
Table D.2. Selected Drinking Water Standards

Radiological Constituent

Gross alpha ${ }^{(b)}$

Radium-226

Beta particle and photon activity

Tritium

Beryllium-7

Cobalt -60

Strontium-90

Technetium-99

Ruthenium-106

Antimony-125

Iodine-129

Iodine- 131

Cesium-134

Cesium-137

Europium-154

Europium-155

Uranium

Fluoride

Nitrate, as $\mathrm{NO}_{3}$

Chromium

Cyanide

Trichlorethene

Tetrachloroethene

Carbon tetrachloride

Chloroform (THM)(k)

cis-1,2-Dichloroethene
Contaminant Leve

$15 \mathrm{pCi} / \mathrm{L}$

$20 \mathrm{pCi} / \mathrm{L}^{(\mathrm{d})}$

$4 \mathrm{mrem} / \mathrm{yr}^{(\mathrm{e})}$

$30 \mu \mathrm{g} / \mathrm{L}^{(\mathrm{h})}$

$4 \mathrm{mg} / \mathrm{L}$

$45 \mathrm{mg} / \mathrm{L}$

$100 \mu \mathrm{g} / \mathrm{L}$

$200 \mu \mathrm{g} / \mathrm{L}$

$5 \mu \mathrm{g} / \mathrm{L}$

$5 \mu \mathrm{g} / \mathrm{L}$

$5 \mu \mathrm{g} / \mathrm{L}$

$100 \mu \mathrm{g} / \mathrm{L}$

$0.07 \mathrm{mg} / \mathrm{L}$
Interim Drinking

Water Standard

$$
\begin{gathered}
3 \mathrm{pCi} / \mathrm{L}^{(c)} \\
20,000^{(f)} \mathrm{pCi} / \mathrm{L} \\
6,000^{(f)} \mathrm{pCi} / \mathrm{L} \\
100^{(f)} \mathrm{pCi} / \mathrm{L} \\
8^{(f)} \mathrm{pCi} / \mathrm{L} \\
900^{(f)} \mathrm{pCi} / \mathrm{L} \\
30^{(f)} \mathrm{pCi} / \mathrm{L} \\
300^{(f)} \mathrm{pCi} / \mathrm{L} \\
1^{(f)} \mathrm{pCi} / \mathrm{L} \\
3^{(f)} \mathrm{pCi} / \mathrm{L} \\
20,000^{(f)} \mathrm{pCi} / \mathrm{L} \\
200^{(f)} \mathrm{pCi} / \mathrm{L} \\
200^{(f)} \mathrm{pCi} / \mathrm{L} \\
600^{(f)} \mathrm{pCi} / \mathrm{L}
\end{gathered}
$$

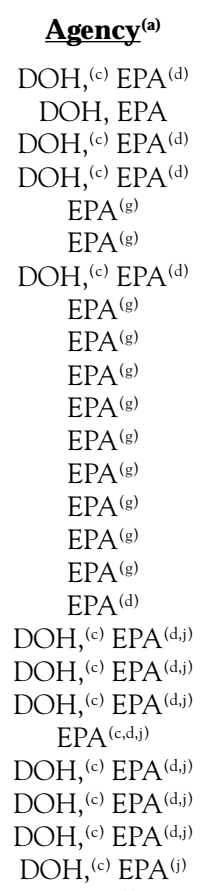

$\mathrm{EPA}^{(\mathrm{j})}$
Status

Final

Final

Final

Interim

Interim

Interim

Interim

Interim

Interim

Interim

Interim

Interim

Interim

Interim

Interim

Interim

Final $^{(\mathrm{i})}$

Final/under review

Final

Final

Final

Final

Final

Final

Final

Final

(a) $\mathrm{DOH}=$ Washington State Department of Health, EPA = U.S. Environmental Protection Agency.

(b) Excluding radium-226, radon, and uranium.

(c) WAC 246-290.

(d) 40 CFR 141.

(e) Beta and photon radioactivity from manmade radionuclides. Annual average activity shall not exceed a $4 \mathrm{mrem} / \mathrm{yr}$ effective dose equivalent.

(f) Activity assumed to yield an annual dose of $4 \mathrm{mrem} / \mathrm{yr}$.

(g) EPA-570/9-76-003.

(h) Equivalent to $27 \mathrm{pCi} / \mathrm{L}$ (assuming typical uranium natural abundance in rock).

(i) Final rule promulgated December 7, 2000 (65 FR 76708).

(j) EPA 822-R-96-001.

(k) Standard is for total trihalomethanes (THM). 


\begin{tabular}{|c|c|c|c|c|}
\hline \multirow{2}{*}{\multicolumn{2}{|c|}{$\begin{array}{r}\text { Compound } \\
\text { Dissolved Metals }\end{array}$}} & $\begin{array}{c}\text { Level that } \\
\text { Yields Acute } \\
\text { Toxicity, } \mu \mathrm{g} / \mathbf{L}^{(\mathrm{a})}\end{array}$ & $\begin{array}{c}\text { Level that } \\
\text { Y ields Chronic } \\
\text { Toxicity, } \mu \mathrm{g} / \mathbf{L}^{\text {(a) }}\end{array}$ & $\begin{array}{c}\text { Level to Protect } \\
\text { H uman H ealth for } \\
\text { the Consumption of } \\
\text { Water and Organisms, } \mu g^{\prime} L^{(b)}\end{array}$ \\
\hline & & & & \\
\hline \multicolumn{2}{|c|}{ Antimony } & -. & -. & 14 \\
\hline \multicolumn{2}{|c|}{ Arsenic } & 360.0 & 190.0 & 0.018 \\
\hline \multicolumn{2}{|c|}{ Cadmium } & $1.6^{(\mathrm{c})}$ & $0.59^{(\mathrm{d})}$ & -. \\
\hline \multicolumn{2}{|c|}{ Chromium(VI) } & 16 & 10 & .- \\
\hline \multicolumn{2}{|c|}{ Copper } & $8.4^{(\mathrm{e})}$ & $6.0^{(f)}$ & -. \\
\hline \multicolumn{2}{|c|}{ Lead } & $28^{(\mathrm{g})}$ & $1.1^{(\mathrm{h})}$ & .. \\
\hline \multicolumn{2}{|c|}{ Nickel } & $750^{(\mathrm{i})}$ & $83^{(\mathrm{j})}$ & 610 \\
\hline \multicolumn{2}{|c|}{ Silver } & $0.94^{(\mathrm{k})}$ & - & - \\
\hline \multicolumn{2}{|c|}{ Thallium } & - & - & 1.7 \\
\hline \multicolumn{2}{|c|}{ Zinc } & $60^{(1)}$ & $55^{(\mathrm{m})}$ & - \\
\hline \multicolumn{5}{|c|}{ Total Recoverable Metals } \\
\hline \multicolumn{2}{|c|}{ Chromium(III $)^{(\mathrm{n})}$} & $300^{(0)}$ & $96^{(\mathrm{p})}$ & -. \\
\hline \multicolumn{2}{|c|}{ Mercury } & 2.1 & 0.012 & 0.14 \\
\hline \multicolumn{2}{|c|}{ Selenium } & 20 & 5.0 & -. \\
\hline \multicolumn{5}{|c|}{ Anions } \\
\hline \multicolumn{2}{|c|}{ Cyanide ${ }^{(q)}$} & 22.0 & 5.2 & 700 \\
\hline \multicolumn{2}{|c|}{ Chloride $^{(\mathrm{r})}$} & 860,000 & 230,000 & -. \\
\hline \multicolumn{5}{|c|}{ Organic Compounds } \\
\hline \multicolumn{2}{|c|}{ Benzene } & -. & -. & 1.2 \\
\hline \multicolumn{2}{|c|}{ Carbon tetrachloride } & .. & .. & 0.25 \\
\hline \multicolumn{2}{|c|}{ Chloroform } & -. & - & 5.7 \\
\hline $1,2-\mathrm{I}$ & Dichloroethane & .- & .. & 0.38 \\
\hline Metl & nylene chloride & - & -. & 4.7 \\
\hline Tolu & ene & -. & .- & 6,800 \\
\hline Tetra & chloroethene & -. & -. & 0.8 \\
\hline $1,1,2$ & -Trichloroethane & -. & -. & 0.60 \\
\hline Trich & loroethene & -. & -. & 2.7 \\
\hline Viny & 1 chloride & -. & -. & 2 \\
\hline $1,4-\mathrm{I}$ & Dichlorobenzene & - & - & 400 \\
\hline & WAC $173-201 \mathrm{~A}$ & hess dependent crite & inimum value of 47 & $\mathrm{CO}_{3} / \mathrm{L}$ for $1992-2000$ water \\
\hline & 40 CFR 131.36. & 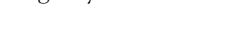 & (a) & \\
\hline (c) & (1.1017 - [ln(har & ) $\exp (1.128[\ln ($ har & 828). Hardness exp & $\mathrm{mg} \mathrm{CaCO}_{3} / \mathrm{L}$ \\
\hline & (1.1017 - $[\ln ($ har & ) $\exp (0.7852[\ln (\mathrm{ha}$ & .490) & \\
\hline & $(0.960) \exp (0.94$ & ]$-1.464)$ & & \\
\hline & $(0.960) \exp (0.85$ & ]$-1.465)$ & & \\
\hline & (1.4620 - [ln (har & $\exp (1.273[\ln ($ hardr & 60). & \\
\hline & $(1.4620-[\ln ($ har & $\exp (1.273[\ln ($ hardr & 05). & \\
\hline & $(0.998) \exp (0.84$ & ]$+3.3612)$ & & \\
\hline & $(0.997) \exp (0.84$ & ]$+1.1645)$ & & \\
\hline & $(0.85) \exp (1.72[$ & $.52)$ & & \\
\hline (1) & $(0.978) \exp (0.84$ & ]$+0.8604)$ & & \\
\hline (m) & $(0.986) \exp (0.84$ & ]$+0.7614)$ & & \\
\hline & $\begin{array}{l}\text { Where methods } \\
\text { chromium. }\end{array}$ & alent chromium are & le, these criteria are & presented by total recoverable \\
\hline & $(0.316) \exp (0.81$ & ]$+3.688)$ & & \\
\hline & $(0.860) \exp (0.81$ & )]+1.561) & & \\
\hline & Criteria based on & ciable method. & & \\
\hline & Dissolved in asso & dium. & & \\
\hline
\end{tabular}


All Pathways (limits from DOE Order 5400.5)

The effective dose equivalent for any member of the public from all routine DOE operations ${ }^{(\mathrm{b})}$ shall not exceed the values given below.

Routine public dose

Potential authorized temporary public dose ${ }^{(\mathrm{d})}$ $\frac{\text { Effective Dose Equivalent }}{(\mathrm{c})}$
$\underline{\mathrm{mrem} / \mathrm{yr}} \underline{\mathrm{mSv} / \mathrm{yr}}$

100

500

5

Dose to N ative A quatic A nimal Organisms from Liquid Discharges (interim limits from DOE Order 5400.5)

Radioactive material in liquid waste discharged to natural waterways shall not cause an absorbed dose ${ }^{(e)}$ to native aquatic animal organisms that exceeds $1 \mathrm{rad} / \mathrm{d}(10 \mathrm{mGy} / \mathrm{d})$.

Drinking Water Pathway O nly (limits from 40 CFR 141 and DOE Order 5400.5)

Radionuclide concentrations in DOE-operated public drinking water supplies shall not cause persons consuming the water to receive an effective dose equivalent greater than $4 \mathrm{mrem} / \mathrm{yr}(0.04 \mathrm{mSv} / \mathrm{yr})$. DOE operations shall not cause private or public drinking water systems downstream of the facility discharge to exceed the radiological drinking water limits in 40 CFR 141 (see Table D.2).

Air Pathways Only (limits from 40 CFR 61)

$$
\begin{aligned}
& \frac{\text { Effective Dose Equivalent }}{(\mathrm{c})} \\
& \underline{\mathrm{mrem} / \mathrm{yr}} \underline{\mathrm{mSv} / \mathrm{yr}}
\end{aligned}
$$

Public dose limit at location of maximum annual air concentration as a consequence of routine DOE operations ${ }^{(b)}$
10

0.1

(a) Radiation doses received from natural background, residual weapons testing and nuclear accident fallout, medical exposures, and consumer products are excluded from the implementation of these dose limits.

(b) "Routine DOE operations" implies normal, planned activities and does not include actual or potential accidental or unplanned releases.

(c) Effective dose equivalent is expressed in rem (or millirem) and sievert (or millisievert).

(d) Authorized temporary annual dose limits may be greater than $100 \mathrm{mrem} / \mathrm{yr}$ (but cannot exceed $500 \mathrm{mrem} / \mathrm{yr}$ ) if unusual circumstances exist that make avoidance of doses greater than $100 \mathrm{mrem} / \mathrm{yr}$ to the public impracticable. DOE Richland Operations Office is required to request and receive specific authorization from DOE Headquarters for an increase from the routine public dose limit to a temporary annual dose limit.

(e) Absorbed dose is expressed in rad (or millirad) with the corresponding value in gray (or milligray) in parentheses. 
Table D.5. Selected Derived Concentration Guides ${ }^{(a, b, c)}$

Radionuclide

Tritium

Carbon-14

Chromium-51

Manganese-54

Cobalt -60

Zinc-65

Krypton-85

Strontium-90

Technetium-99

Ruthenium-103

Ruthenium-106

Antimony-125

Iodine-129

Iodine-131

Cesium-137

Cerium-144

Europium-154

Europium-155

Uranium-234

Uranium-235

Uranium-238

Plutonium-238

Plutonium-239

Plutonium-240

Americium-241
Ingested Water,

pCi/L

$2,000,000$

70,000

$1,000,000$

50,000

5,000

9,000

$\mathrm{NS}^{(\mathrm{d})}$

1,000

100,000

50,000

6,000

60,000

500

3,000

3,000

7,000

20,000

100,000

500

600

600

40

30

30

30
Inhaled Air $\mathrm{pCi} / \mathrm{m}^{3}$

100,000

500,000

60,000

2,000

80

600

$3,000,000^{(\mathrm{e})}$

2,000

2,000

30

1,000

70

400

400

30

50

300

0.09

0.1

0.1

0.03

0.02

0.02

0.02

(a) Concentration of a specific radionuclide in water or air that could be continuously consumed or inhaled at average annual rates and not exceed an effective dose equivalent of $100 \mathrm{mrem} / \mathrm{yr}$.

(b) Values in this table represent the lowest, most-conservative, derived concentration guides considered potentially applicable to Hanford Site operations and may be adjusted upward (larger) if accurate solubility information is available.

(c) From DOE Order 5400.5.

(d) NS = No numerical standard, but the effective dose equivalent cannot exceed $100 \mathrm{mrem} / \mathrm{yr}$.

(e) Air immersion derived concentration guides. 


\section{Clean A ir Act Permits}

Prevention of Significant Deterioration Permit No. PSD-X80-14, issued to DOE Richland Operations Office by EPA Region 10; covers emission of $\mathrm{NO}_{\mathrm{x}}$ to the atmosphere from the Plutonium-Uranium Extraction Plant and the Uranium-TriOxide Plant. No expiration date.

Hanford Site Air Operating Permit 00-05-006 covers operations on the Hanford Site having a potential to emit airborne emissions. Effective July 2, 2001, expires July 1, 2006. The permit is intended to provide a compilation of applicable Clean Air Act requirements both for radioactive and non-radioactive emissions at the Hanford Site. It will be implemented through federal and state programs.

State License FF-01 was incorporated into the Hanford Site air operating permit.

\section{Clean Water Act - National Pollutant D ischarge Elimination System Permits}

Permit WA-002591-7 (governing effluent discharges to the Columbia River) includes the outfall for the 300 Area Treated Effluent Disposal Facility and two outfalls in the 100-K Area.

Permit WAR05A57F, issued May 30, 2001, governs stormwater discharges.

\section{Washington State Department of Ecology - State Wastewater Permits}

Permit ST 4500 allows treated wastewater from the Effluent Treatment Facility to be discharged to the StateApproved Land Disposal Site. Expires August 1, 2005.

Permit ST 4501 allows for the discharge of cooling water and other primarily uncontaminated wastewater from 400 Area facilities to two ponds located north-northeast of the 400 Area perimeter fence. Re-issuance of a new permit is expected in 2002.

Permit ST 4502 allows treated effluent from the 200-East and 200-West Areas to be discharged to the 200 Area Treated Effluent Disposal Facility. Expires May 2005.

Permit ST 4507 allows domestic wastewater to be discharged to the 100-N Area sewage lagoon. Permit expires in May 2002. A renewal application has been submitted.

Permit ST 4508 allows for the discharge of wastewater associated with hydrotesting, maintenance, and construction activities under specific conditions. Expires May 30, 2002. A renewal application has been submitted.

Permit ST 4509 allows for cooling water, condensate discharges, and miscellaneous discharges from pump leaks, valve wastewater, and tank overflows under controlled conditions. Expires May 1, 2003.

Permit ST 4510 covers wastewater discharges associated with industrial stormwater under controlled conditions. Expires April 1, 2004.

\section{Wildlife Sampling Permits}

Scientific Collection Permit 01-040b, issued by Washington Department of Fish and Wildlife to Pacific Northwest National Laboratory for 2001; covered the collection of food fish, shellfish, and wildlife, including game fish, for environmental monitoring purposes. Renewed annually.

Federal Fish and Wildlife Permit No. MB671877-0, issued by the U.S. Fish and Wildlife Service to Pacific Northwest National Laboratory; covers the collection of migratory wildlife. Expires December 31, 2002.

Copies of the regulations concerning these permits may be obtained from the following organizations:

State of Washington

Department of Ecology

P.O. Box 47600

Olympia, WA 92504-7600
U.S. Environmental Protection Agency

Region 10

1200 Sixth Avenue

Seattle, WA 98101
U.S. Department of Energy Richland Operations Office 825 Jadwin Avenue Richland, WA 99352 


\section{References}

40 CFR 61. U.S. Environmental Protection Agency. "National Emission Standards for Hazardous Air Pollutants." Code of Federal Regulations.

40 CFR 131.36. U.S. Environmental Protection Agency. "Toxics Criteria for Those States not Complying with the Clean Water Act Section 303(c)(2)(B)." Code of Federal Regulations.

40 CFR 141. U.S. Environmental Protection Agency. "National Primary Drinking Water Regulations." Code of Federal Regulations.

65 FR 76708. December 7, 2000. U.S. Environmental Protection Agency. "National Primary Drinking Water Regulations; Radionuclides; Final Rule." Federal Register.

Clean Air Act. 1986. Public Law 88-206, as amended, 42 USC 7401 et seq.

Clean Water Act. 1977. Public Law 95-217, as amended, 91 Stat. 1566 and Public Law 96-148, as amended.

DOE Order 5400.5. "Radiation Protection of the Public and the Environment."
EPA-570/9-76-003. 1976. National Interim Primary Drinking Water Regulations. Office of Water Supply, U.S. Environmental Protection Agency, Washington, D.C.

EPA 822-R-96-001. 1996. Drinking Water Regulations and Health Advisories. Office of Water, U.S. Environmental Protection Agency, Washington, D.C.

WAC 173-201A. "Water Quality Standards for Surface Waters of the State of Washington." Washington Administrative Code, Olympia, Washington.

WAC 173-201A-040. "Toxic Substances." Washington Administrative Code, Olympia, Washington.

WAC 246-221-290. "Appendix A - Annual Limits on Intake (ALI) and Derived Air Concentrations (DAC) of Radionuclides for Occupational Exposure; Effluent Concentrations; Concentrations for Release to Sanitary Sewerage." Washington Administrative Code, Olympia, Washington.

WAC246-290. "Group A Public Water Systems.” Washington Administrative Code, Olympia, Washington. 


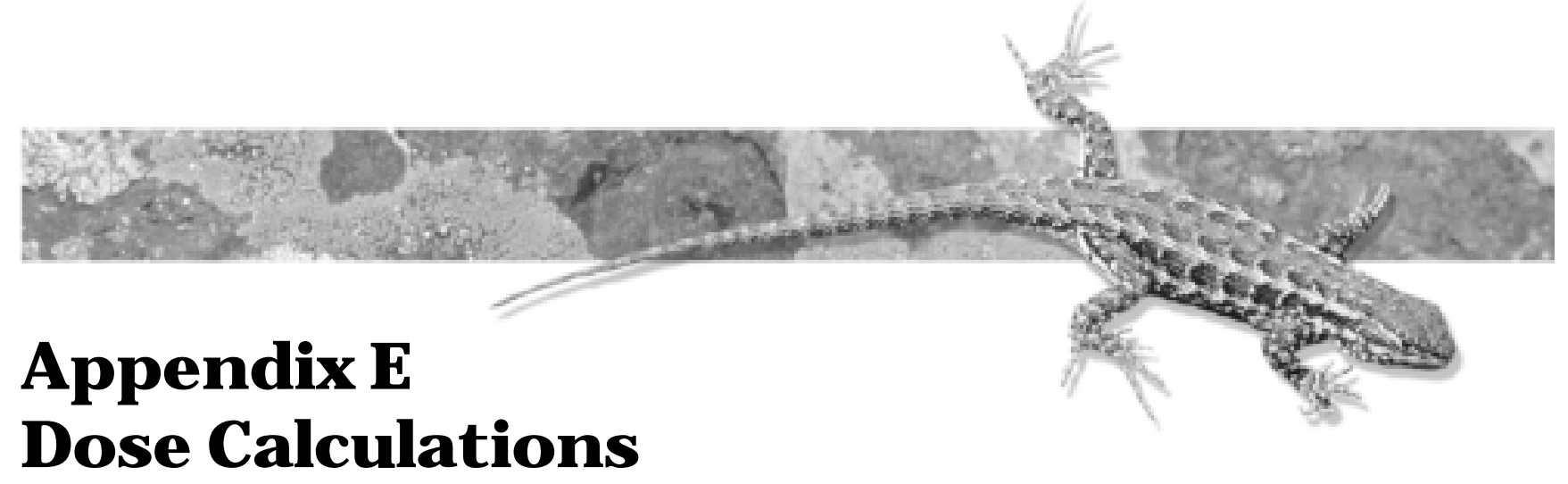

\section{E. J. Antonio}

The radiological dose that the public could have received in 2001 from Hanford Site operations was calculated in terms of the "total effective dose equivalent." The total effective dose equivalent is the sum of the effective dose equivalent from external sources and the committed effective dose equivalent for internal exposure. Effective dose equivalent is a weighted sum of doses to organs and tissues that accounts for the sensitivity of the tissue and the nature of the radiation causing the dose. It is calculated in units of millirem (millisievert $^{(\mathrm{a})}$ for individuals and in units of person-rem for the collective dose received by the total population within an 80-kilometer (50-mile) radius of the site operations areas. This appendix describes how the doses in this report were calculated.

Releases of radionuclides from Hanford Site operations are usually too low to be measured in offsite air, drinking water, and food crops. Therefore, the air dose calculations were based on measurements made at the point of release (stacks and vents). The water pathway dose calculations were based on measurements of releases to the Columbia River (from the 100 Areas) or the difference in detectable radionuclide concentrations measured upstream and downstream of the site. Environmental radionuclide concentrations were estimated from the effluent measurements by environmental transport models.

The transport of radionuclides in the environment to the point of exposure is predicted by empirically derived models of exposure pathways. These models calculate radionuclide levels in air, water, and foods. Radionuclides taken into the body by inhalation or ingestion may be distributed among different organs and retained for various times. In addition, long-lived radionuclides deposited on the ground become possible sources for long-term external exposure and uptake by agricultural products. Dietary and exposure parameters were applied to calculate radionuclide intakes and radiological doses to the public. Standardized computer programs were used to perform the calculations. These programs contain internally consistent mathematical models that use sitespecific dispersion and uptake parameters. These programs are incorporated in a master code, GENII (PNL-6584), which employs the dosimetry methodology described in International Commission on Radiological Protection reports (1979a, 1979b, 1980, 1981a, 1981b, 1982a, 1982b, 1988). The assumptions and data used in these calculations are described below.

The RAD-BCG calculator was used to screen the radionuclide concentrations in environmental media for exceeding conservatively set biota concentration guides. Both internal and external doses to aquatic, riparian, and terrestrial animals as well as to terrestrial plants are included in the screening process. The screening process is described in A Graded Approach for Evaluating Radiation Doses to Aquatic and Terrestrial Biota (DOE 2000). ${ }^{\text {(b) }}$

The computer program, CAP88-PC, was used to calculate dose to a maximally exposed individual as required by the U.S. Environmental Protection Agency (EPA) through the Code of Federal Regulations (40 CFR 61, Subpart H) from airborne radionuclide effluents (other than radon) released at U.S. Department of Energy (DOE) facilities. Technical details of the CAP88-PC calculations are provided in detail in the 2000 air emissions report (DOE/RL-2001-32).

(a) $1 \mathrm{rem}(0.01 \mathrm{~Sv})=1,000 \mathrm{mrem}(10 \mathrm{mSv})$.

(b) Memorandum from Dr. David Michaels (Assistant Secretary for Environmental, Safety, and Health) to Distribution, Availability of DOE Technical Standard, "A Graded Approach for Evaluating Radiation Doses to Aquatic and Terrestrial Biota (Project ENVR0011)," for use in DOE Compliance and Risk Assessment Activities, dated July 19, 2000. 


\section{Types of Dose Calculations Performed}

Calculations of radiological doses to the public from radionuclides released into the environment are performed to demonstrate compliance with applicable standards and regulations.

\section{DOE Order 5400.5 requires:}

- effective dose equivalent to be used in estimating public doses

- biokinetic models and metabolic parameters given by the International Commission on Radiological Protection to be used when estimating doses

- doses to the public to be calculated using facility effluent data when environmental concentrations are too low to measure accurately.

The calculation of the effective dose equivalent takes into account the long-term (50 years) internal exposure from radionuclides taken into the body during the current year. The effective dose equivalent is the sum of individual committed (50 years) organ doses multiplied by weighting factors that represent the proportion of the total health effect risk that each organ would receive from uniform irradiation of the whole body. Internal organs may also be irradiated from external sources of radiation. The external exposure received during the current year is added to the committed internal dose to obtain the total effective dose equivalent. In this report, the effective dose equivalent is expressed in rem (or millirem) with the corresponding value in sievert (or millisievert) in parentheses. The numerous transfer factors used for pathway and dose calculations have been documented in GENII (PNL-6584) and in PNL-3777.

The following types of radiological doses were estimated.

\section{Boundary Dose Rate (mrem/h and mrem/yr).}

The external radiological dose rates during the year in areas accessible by the general public were determined from measurements obtained near operating facilities.

\section{Maximally Exposed Individual Dose (mrem).}

The maximally exposed individual is a hypothetical member of the public who lives at a location and has a lifestyle that makes it unlikely that other members of the public would receive higher doses. All potentially significant exposure pathways to this hypothetical individual were considered, including the following:

- inhalation of airborne radionuclides

- submersion in airborne radionuclides
- ingestion of foodstuffs contaminated by radionuclides deposited on vegetation and the ground by both airborne deposition and irrigation water drawn from the Columbia River downstream of N Reactor

- exposure to ground contaminated by both airborne deposition and irrigation water

- ingestion of fish taken from the Columbia River

- recreation along the Columbia River, including boating, swimming, and shoreline activities.

Determination of the Location of Maximally Exposed Individual. The location of the hypothetical maximally exposed individual can vary from year to year, depending on the relative contributions of the several sources of radioactive effluents released to the air and to the Columbia River from Hanford facilities. Since 1990, three separate locations (see Figure 5.0.1) have been used to assess the dose to the maximally exposed individual: (1) the Ringold area, 26 kilometers (16 miles) east of separations facilities in the 200 Areas; (2) the Sagemoor area, across the Columbia River from the 300 Area; and (3) the Riverview area across the river from Richland. Scientists consider where a person would receive the maximum exposure to radionuclides from both air and water. Although the Ringold area is closer than Riverview to Hanford facilities that historically released airborne effluents, at Riverview the maximally exposed individual receives a higher dose rate from radionuclides in the Columbia River than a Ringold resident. The applicable exposure pathways for Ringold and Sagemoor are described in the following paragraphs. In 1990, the maximally exposed individual was located at Ringold. In 1991, 1992, and again in 2000, the maximally exposed individual resided in the Riverview area. However, from 1996 through 1999, the hypothetical, maximally exposed individual was located across the Columbia River from the 300 Area at Sagemoor (see Figure 5.0.2).

Ringold Maximally Exposed Individual. The Ringold area is situated to maximize air pathway exposures from emissions in the 200 Areas, including direct exposure to a contaminated plume, inhalation, external exposure to radionuclides that deposit on the ground, and ingestion of locally grown food products contaminated by air deposition. In addition, it is assumed that individuals at Ringold irrigate their crops with water taken from the Columbia River downstream of where groundwater enters the river from the 100 and 200-East 
Areas. This results in additional exposures from ingestion of irrigated food products and external irradiation from radionuclides deposited on the ground by irrigation. Recreational use of the Columbia River also is considered for this individual, resulting in direct exposure from water and radionuclides deposited on the shoreline and doses from ingestion of locally caught fish.

Riverview Maximally Exposed Individual. The Riverview area is situated to maximize water pathway exposures to effluents from Hanford facilities. For the calculation, it was assumed that the Riverview maximally exposed individual obtained domestic water from a local water treatment system that pumped from the Columbia River just downstream of the Hanford Site. In addition, it was assumed that individuals at Riverview irrigate their crops with water taken from the Columbia River. This results in additional exposures from ingestion of irrigated food products and external irradiation from radionuclides deposited on the ground by irrigation. Recreational use of the Columbia River was also considered, resulting in direct exposure from water and radionuclides deposited on the shoreline and doses from ingestion of locally caught fish. This individual also receives exposure via the air pathways, including direct exposure to a contaminated plume, inhalation, external exposure to radionuclides that deposit on the ground, and ingestion of locally grown food products contaminated by air deposition.

\section{Sagemoor Maximally Exposed Individual.}

Because of the shift in site operations from nuclear weapons production to the current mission of managing waste products, cleaning up the site, and researching new ideas and technologies for waste disposal and cleanup, the significance of air emissions from production facilities in the 200 Areas has decreased compared to emissions from research facilities in the 300 Area.

An individual at Sagemoor, located 1.5 kilometers ( 1 mile) directly across the Columbia River from the 300 Area, receives the maximum exposure to airborne emissions from the 300 Area, and other exposure pathways as an individual at Ringold. However, domestic water at this location comes from wells rather than from the river, and wells in this region are not directly contaminated by radionuclides of Hanford origin (EPS-87-367A). Because the farms located across from the 300 Area obtain irrigation water from the Columbia River upstream of the Hanford Site, the conservative assumption was made that the diet of an individual from the Sagemoor location consisted totally of foods purchased from the Riverview area, which could contain radionuclides present in both the liquid effluent and air emissions pathways. The added contribution of radionuclides in the Riverview irrigation water maximizes the calculated dose from the air and water pathways combined.

80-kilometer (50-mile) Collective Doses (person-rem). Regulatory limits have not been established for population doses. However, evaluation of the collective population doses to all residents within an 80-kilometer (50-mile) radius of Hanford Site operations is required by DOE Order 5400.5. The radiological dose to the collective population within 80 kilometers (50 miles) of the site operations areas was calculated to demonstrate compliance with environmental regulations, confirm adherence to DOE environmental protection policies, and provide information to the public. The 80-kilometer (50-mile) collective dose is the sum of doses to all individual members of the public within 80 kilometers (50 miles) of the site operations areas.

Pathways similar to those used for the maximally exposed individual were used to calculate doses to the offsite population. In calculating the effective dose, an estimate was made of the fraction of the offsite population expected to be affected by each pathway. The exposure pathways for the population are as follows.

Drinking Water. The cities of Richland and Pasco obtain their municipal water directly and Kennewick indirectly from the Columbia River downstream from the Hanford Site. A total population of 70,000 in the three cities drinks water derived from the Columbia River.

Irrigated Food. Columbia River water is withdrawn for irrigation of small vegetable gardens and farms in the Riverview district of Pasco in Franklin County. Enough food is grown in this district to feed an estimated 2,000 people. Commercial crops are also irrigated by Columbia River water in the Horn Rapids area of Benton County. These crops are widely distributed.

River Recreation. These activities include swimming, boating, and shoreline recreation. Specific pathways include external exposure from radionuclides in the water or on the shoreline and ingestion of river water while swimming. An estimated 125,000 people who reside within 80 kilometers (50 miles) of the Hanford Site operations areas are assumed to be affected by these pathways.

Fish Consumption. Population doses from the consumption of fish obtained locally from the Columbia River were calculated from an estimated total annual catch of 15,000 kilograms (33,075 pounds) per year without reference to a specified human group of consumers. 
The data that are needed to perform dose calculations are based on either measured upstream/downstream differences or measured effluent releases and include information on initial transport through the atmosphere or river, transfer or accumulation in terrestrial and aquatic pathways, and public exposure. By comparison, radiological dose calculations based on measured activities of radionuclides in food require data describing only dietary and recreational activities and exposure times. These data are discussed below.

\section{Population Distribution and Atmospheric Dispersion}

Geographic distributions of the population residing within an 80-kilometer (50-mile) radius of the Hanford Site operating areas are shown in PNNL-13910, APP. 1. These distributions are based on 2000 Bureau of the Census data (U.S. Census Bureau 2001a, 2001b). These data influence the population dose by providing estimates of the number of people exposed to radioactive effluents and their proximity to the points of release.
Atmospheric dispersion data are also shown in PNNL-13910, APP. 1. These data describe the transport and dilution of airborne radioactive material, which influence the amounts of radionuclides being transported through the air to specific locations.

\section{Terrestrial and Aquatic Pathways}

Important parameters affecting the movement of radionuclides within exposure pathways such as irrigation rates, growing periods, and holdup periods are listed in Table E.1. Certain parameters are specific to the lifestyles of either "maximally exposed" or "average" individuals.

\begin{tabular}{|c|c|c|c|c|c|}
\hline \multirow[b]{2}{*}{ Medium } & \multicolumn{2}{|c|}{ Holdup, $\mathrm{d}^{(\mathrm{a})}$} & \multirow[b]{2}{*}{ Growing Period, $d$} & \multirow[b]{2}{*}{$\begin{array}{l}\text { Yield, } \\
\mathrm{kg} / \mathrm{m}^{2}\end{array}$} & \multirow[b]{2}{*}{$\begin{array}{c}\text { Irrigation Rate, } \\
\mathrm{L} / \mathrm{m}^{2} / \mathrm{mo}^{\circ}\end{array}$} \\
\hline & $\begin{array}{l}\text { Maximally Exposed } \\
\text { Individual } \\
\end{array}$ & $\begin{array}{c}\text { A verage } \\
\text { Individual } \\
\end{array}$ & & & \\
\hline Leafy vegetables & 1 & 14 & 90 & 1.5 & 150 \\
\hline Other vegetables & 5 & 14 & 90 & 4 & 170 \\
\hline Fruit & 5 & 14 & 90 & 2 & 150 \\
\hline Cereal & 180 & 180 & 90 & 0.8 & 0 \\
\hline Eggs & 1 & 18 & 90 & 0.8 & 0 \\
\hline Milk & 1 & 4 & -. & -. & -. \\
\hline Hay & $(100)^{(b)}$ & $(100)$ & 45 & 2 & 200 \\
\hline Pasture & (0) & (0) & 30 & 1.5 & 200 \\
\hline Red meat & 15 & 34 & -. & -. & -. \\
\hline Hay & (100) & (100) & 45 & 2 & 200 \\
\hline Grain & $(180)$ & $(180)$ & 90 & 0.8 & 0 \\
\hline Poultry & 1 & 34 & 90 & 0.8 & 0 \\
\hline Fish & 1 & 1 & -. & -. & -. \\
\hline Drinking water & 1 & 1 & -. & -. & -. \\
\hline
\end{tabular}




\section{Public Exposure}

The offsite radiological dose is related to the extent of external exposure to or intake of radionuclides released from Hanford Site operations. Tables E.2 through E.4 give the parameters describing the diet, residency, and river recreation parameters assumed for "maximally exposed" and "average" individuals.

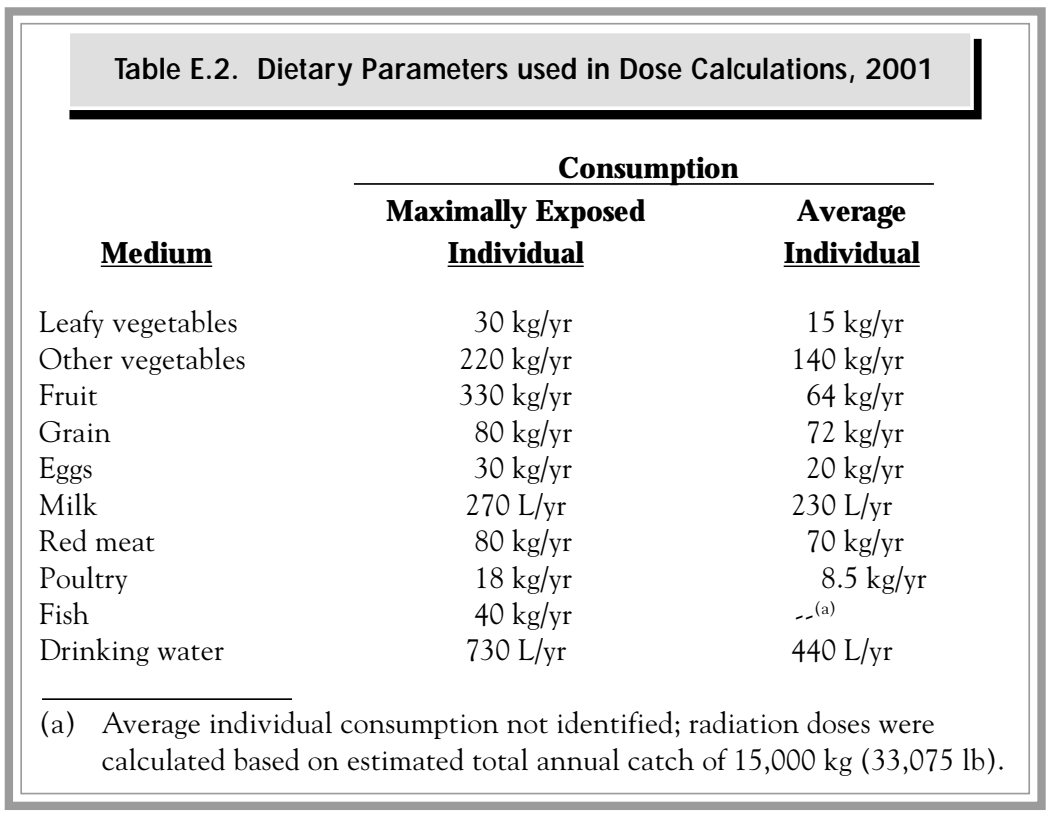

Table E.3. Residency Parameters used in Dose Calculations, 2001

\begin{tabular}{ccc} 
& \multicolumn{2}{c}{ Exposure, $\mathbf{h} / \mathbf{y r}$} \\
\cline { 2 - 3 } Parameter & $\begin{array}{c}\text { Maximally Exposed } \\
\text { Individual }\end{array}$ & $\begin{array}{c}\text { Average } \\
\text { Individua }\end{array}$ \\
aund contamination & 4,383 & 2,920 \\
Air submersion $^{\text {In }}$ & 8,766 & 8,766 \\
halation $^{(a)}$ & 8,766 & 8,766
\end{tabular}

(a) Inhalation rates: adult $270 \mathrm{~cm}^{3} / \mathrm{s}$.

Table E.4. Recreational Parameters used in Dose Calculations, 2001

\begin{tabular}{lcc}
\hline & \multicolumn{2}{c}{ Exposure, $\mathbf{h} / \mathbf{y r} \mathbf{r}^{(\mathbf{a})}$} \\
\cline { 2 - 3 } Parameter & $\begin{array}{c}\text { Maximally Exposed } \\
\text { Individual }\end{array}$ & $\begin{array}{c}\text { A verage } \\
\text { Individual }\end{array}$ \\
$\begin{array}{l}\text { Shoreline } \\
\text { Boating }\end{array}$ & 500 & 17 \\
Swimming & 100 & 5 \\
\hline (a) $\begin{array}{l}\text { Assumed river-water travel times from 100-N Area to the point of aquatic } \\
\text { recreation were 8 hours for the maximally exposed individual and 13 hours } \\
\text { for the average individual. Correspondingly lesser times were used for } \\
\text { other locations. }\end{array}$
\end{tabular}




\section{Dose Calculation Documentation}

DOE established the Hanford Dose Overview Panel to promote consistency and defensibility of environmental dose calculations at Hanford. The panel is responsible for defining standard, documented computer codes and input parameters used for radiological dose calculations for the public in the vicinity of the Hanford Site.
Only those procedures, models, and parameters previously defined by the panel were used to calculate the radiological doses (PNL-3777). The calculations were then reviewed by the panel. Summaries of dose calculation technical details for this report are shown in Tables E.5 through E.9 and in PNNL-13910, APP. 1.

\section{Area Drinking Water}

Drinking water at the Fast Flux Test Facility contained slightly elevated levels of tritium. The potential doses to 400 Area workers consuming this water in 2001 are given in Table E.10.

\section{Air Surveillance Inhalation Doses}

Radionuclide concentrations measured in ambient air at locations on or near the Hanford Site were used to calculate radiological doses from breathing. Inhalation rates were taken from ICRP 66. Occupancy times ranged from $100 \%$ at offsite locations to $33 \%$ for onsite locations.

\begin{tabular}{|c|c|c|}
\hline \multicolumn{2}{|c|}{ Facility name } & 100-K Area \\
\hline \multicolumn{2}{|c|}{ Releases (Ci) } & $\begin{array}{l}{ }^{60} \mathrm{Co}\left(3.0 \times 10^{-8}\right),{ }^{90} \mathrm{Sr}\left(9.0 \times 10^{-6}\right),{ }^{137} \mathrm{Cs}\left(2.5 \times 10^{-5}\right),{ }^{238} \mathrm{Pu}\left(1.5 \times 10^{-7}\right), \\
{ }^{239 / 240} \mathrm{Pu}\left(1.2 \times 10^{-6}\right)(\mathrm{a}),{ }^{241} \mathrm{Pu}\left(1.2 \times 10^{-5}\right),{ }^{241} \mathrm{Am}\left(9.5 \times 10^{-7}\right)\end{array}$ \\
\hline \multicolumn{2}{|c|}{ Meteorological conditions } & $\begin{array}{l}2001 \text { annual average, calculated from data collected at the } \\
100-K \text { Area and the Hanford Meteorology Station from January } \\
\text { through December 2001, using the computer code HANCHI }\end{array}$ \\
\hline \multicolumn{2}{|c|}{$\overline{\mathrm{X}} / \mathrm{Q}^{\prime}$} & $\begin{array}{l}\text { Maximally exposed individual, } 3.8 \times 10^{-9} \mathrm{~s} / \mathrm{m}^{3} \text { at } 41 \mathrm{~km}(26 \mathrm{mi}) \mathrm{SE} \\
80-\mathrm{km}(50-\mathrm{mi}) \text { population, } 1.1 \times 10^{-3} \mathrm{~s} / \mathrm{m}^{3} \text { person-s } / \mathrm{m}^{3}\end{array}$ \\
\hline \multicolumn{2}{|c|}{ Release height } & 89-m (292-ft) effective stack height \\
\hline \multicolumn{2}{|c|}{ Population distribution } & 482,000 (PNNL-13910, APP. 1, Table D-1) \\
\hline \multicolumn{2}{|c|}{ Computer code } & GENII, Version 1.485, December 3, 1990 (PNL-6584) \\
\hline \multicolumn{2}{|c|}{ Doses calculated } & $\begin{array}{l}\text { Chronic, } 1 \text {-yr exposure, } 50 \text {-yr committed internal dose equivalent, } \\
\text { and annual effective dose equivalent to individual and population }\end{array}$ \\
\hline \multicolumn{2}{|c|}{ Pathways considered } & $\begin{array}{l}\text { External exposure to plume and ground deposits } \\
\text { Inhalation } \\
\text { Ingestion of foods produced locally at Riverview }\end{array}$ \\
\hline \multicolumn{2}{|c|}{ Files addressed } & $\begin{array}{l}\text { Radionuclide Library, Rev. 7-1-92 } \\
\text { Food Transfer Library, Rev. 8-29-88 } \\
\text { External Dose Factor Library, Rev. 5-9-88 } \\
\text { Internal Dose Factor Library, Rev. 12-3-90 }\end{array}$ \\
\hline \multicolumn{3}{|c|}{$\begin{array}{l}\text { (a) This value includes gross alpha release data. Gross alpha and unspecified alpha results assumed to be } \\
{ }_{239 / 240} \mathrm{Pu} \text { for dose calculations. }\end{array}$} \\
\hline
\end{tabular}


Table E.6. Technical Details of 100-N Area Liquid Release Dose Calculations, 2001

Facility name

Releases $(\mathrm{Ci})$

Mean river flow

Shore-width factor

Population distribution

Computer code

Doses calculated

Pathways considered

Files addressed
100-N Area

${ }^{3} \mathrm{H}\left(1.1 \times 10^{-1}\right),{ }^{90} \mathrm{Sr}\left(2.1 \times 10^{-1}\right),{ }^{239} \mathrm{Pu}\left(3.9 \times 10^{-5}\right),{ }^{241} \mathrm{Am}\left(1.0 \times 10^{-5}\right)$

$2,143 \mathrm{~m}^{3} / \mathrm{s}\left(75,700 \mathrm{ft}^{3} / \mathrm{s}\right)$

0.2

70,000 for drinking water pathway

125,000 for aquatic recreation

2,000 for consumption of irrigated foodstuffs

$15,000 \mathrm{~kg} / \mathrm{yr}(33,075 \mathrm{lb} / \mathrm{yr})$ total harvest of Columbia River fish

GENII, Version 1.485, December 3, 1990 (PNL-6584)

Chronic, 1-yr exposure, 50-yr committed internal dose equivalent, and annual effective dose equivalent to individual and population

External exposure to irrigated soil, to river water, and to shoreline sediments

Ingestion of aquatic foods and irrigated farm products

Radionuclide Library, Rev. 7-1-92

Food Transfer Library, Rev. 8-29-88

External Dose Factor Library, Rev. 5-9-88

Internal Dose Factor Library, Rev. 12-3-90

Bioaccumulation Factor Library, Rev. 10-26-92 


\begin{tabular}{|c|c|}
\hline Facility name & 200 Areas \\
\hline \multirow[t]{4}{*}{ Releases (Ci) } & 200-East Area \\
\hline & $\begin{array}{l}{ }^{90} \mathrm{Sr}\left(1.2 \times 10^{-4}\right),{ }^{129} \mathrm{I}\left(8.4 \times 10^{-4}\right),{ }^{137} \mathrm{Cs}\left(1.2 \times 10^{-4}\right),{ }^{238} \mathrm{Pu}\left(4.4 \times 10^{-8}\right), \\
{ }^{239 / 240} \mathrm{Pu}\left(2.1 \times 10^{-6}\right),{ }^{241} \mathrm{Pu}\left(3.1 \times 10^{-6}\right),{ }^{241} \mathrm{Am}\left(2.6 \times 10^{-6}\right)\end{array}$ \\
\hline & 200-West Area \\
\hline & $\begin{array}{l}{ }^{90} \mathrm{Sr}\left(1.4 \times 10^{-4}\right),{ }^{137} \mathrm{Cs}\left(5.0 \times 10^{-5}\right),{ }^{238} \mathrm{Pu}\left(4.5 \times 10^{-6}\right),{ }^{239 / 240} \mathrm{Pu}(2.6 \mathrm{x} \\
\left.10^{-4}\right),{ }^{241} \mathrm{Pu}\left(1.4 \times 10^{-4}\right),{ }^{241} \mathrm{Am}\left(4.2 \times 10^{-5}\right)\end{array}$ \\
\hline Meteorological conditions & $\begin{array}{l}2001 \text { annual average, calculated from data collected at the Hanford } \\
\text { Meteorology Station from January through December 2001, using the } \\
\text { computer code HANCHI }\end{array}$ \\
\hline$\overline{\mathrm{X}} / \mathrm{Q}^{\prime}$ & $\begin{array}{l}\text { Maximally exposed individual, } 1.3 \times 10^{-8} \mathrm{~s} / \mathrm{m}^{3} \text { at } 34 \mathrm{~km}(21 \mathrm{mi}) \mathrm{SE} \\
80-\mathrm{km}(50-\mathrm{mi}) \text { population, } 2.0 \times 10^{-3} \text { person-s } / \mathrm{m}^{3}\end{array}$ \\
\hline Release height & 89-m (292-ft) effective stack height \\
\hline Population distribution & 486,000 (PNNL-13910, APP. 1, Table D-2) \\
\hline Computer code & GENII, Version 1.485, December 3, 1990 (PNL-6584) \\
\hline Doses calculated & $\begin{array}{l}\text { Chronic, } 1 \text {-yr exposure, } 50 \text {-yr committed internal dose equivalent, and } \\
\text { annual effective dose equivalent to individual and population }\end{array}$ \\
\hline Pathways considered & $\begin{array}{l}\text { External exposure to plume and ground deposits } \\
\text { Inhalation } \\
\text { Ingestion of foods produced locally at Riverview }\end{array}$ \\
\hline Files addressed & $\begin{array}{l}\text { Radionuclide Library, Rev. 7-1-92 } \\
\text { Food Transfer Library, Rev. 8-29-88 } \\
\text { External Dose Factor Library, Rev. 5-9-88 } \\
\text { Internal Dose Factor Library, Rev. 12-3-90 }\end{array}$ \\
\hline
\end{tabular}


Table E.8. Technical Details of 300 Area Airborne Release Dose Calculations, 2001

Facility name

Releases $(\mathrm{Ci})$

Meteorological conditions

$\overline{\mathrm{X}} / \mathrm{Q}^{\prime}$

Release height

Population distribution

Computer code

Doses calculated

Pathways considered

Files addressed
300 Area

${ }^{3} \mathrm{H}(\text { as HT })^{\text {(a) }}\left(8.9 \times 10^{1}\right),{ }^{3} \mathrm{H}($ as HTO $){ }^{\text {(a) }}\left(2.4 \times 10^{2}\right),{ }^{90} \mathrm{Sr}\left(2.8 \times 10^{-5}\right)$, ${ }^{137} \mathrm{Cs}\left(3.7 \times 10^{-6}\right),{ }^{238} \mathrm{Pu}\left(7.7 \times 10^{-9}\right),{ }^{239 / 240} \mathrm{Pu}\left(1.8 \times 10^{-7}\right)$,

${ }^{241} \mathrm{Am}\left(2.5 \times 10^{-8}\right)$

2001 annual average, calculated from data collected at the 300 Area and the Hanford Meteorology Station from January through December 2001, using the computer code HANCHI

Maximally exposed individual at residence, $5.8 \times 10^{-7} \mathrm{~s} / \mathrm{m}^{3}$ at $1.5 \mathrm{~km}$ (1 $\mathrm{mi}) \mathrm{E} ; 80-\mathrm{km}(50-\mathrm{mi})$ population, $8.7 \times 10^{-3}$ person-s $/ \mathrm{m}^{3}$

$10 \mathrm{~m}(33 \mathrm{ft})$

349,000 (PNNL-13910, APP. 1, Table D-3)

GENII, Version 1.485, December 3, 1990 (PNL-6584)

Chronic, 1-yr exposure, 50-yr committed internal dose equivalent, and annual effective dose equivalent to individual and population

External exposure to plume and ground deposits Inhalation

Ingestion of foods produced locally at Riverview

Radionuclide Library, Rev 7-1-92

Food Transfer Library, Rev. 8-29-88

External Dose Factor Library, Rev. 5-9-88

Internal Dose Factor Library, Rev. 12-3-90

(a) $\mathrm{HT}=$ Elemental tritium; $\mathrm{HTO}=$ Tritiated water vapor. 
Table E.9. Technical Details of 400 Area Airborne Release Dose Calculations, 2001

Facility name

Releases $(\mathrm{Ci})$

Meteorological conditions

$\overline{\mathrm{X}} / \mathrm{Q}^{\prime}$

Release height

Population distribution

Computer code

Doses calculated

Pathways considered

Files addressed
400 Area

$$
{ }^{3} \mathrm{H}(\text { as HTO }) \text { (a) }\left(3.1 \times 10^{-1}\right),{ }^{137} \mathrm{Cs}\left(7.5 \times 10^{-6}\right),{ }^{239 / 240} \mathrm{Pu}\left(6.9 \times 10^{-7}\right)
$$

2001 annual average, calculated from data collected at the 400 Area and the Hanford Meteorology Station from January through December 2001, using the computer code HANCHI

Maximally exposed individual at residence, $7.0 \times 10^{-8} \mathrm{~s} / \mathrm{m}^{3}$ at $11 \mathrm{~km}$ (7 mi) SE; $80-\mathrm{km}(50-\mathrm{mi})$ population, $45.2 \times 10^{-3}$ person-s $/ \mathrm{m}^{3}$

$10 \mathrm{~m}(33 \mathrm{ft})$

354,000 (PNNL-13910, APP. 1, Table D-4)

GENII, Version 1.485, December 3, 1990 (PNL-6584)

Chronic, 1 -yr exposure, 50-yr committed internal dose equivalent, and annual effective dose equivalent to individual and population

External exposure to plume and ground deposits

Inhalation

Ingestion of foods produced locally at Riverview

Radionuclide Library, Rev 7-1-92

Food Transfer Library, Rev. 8-29-88

External Dose Factor Library, Rev. 5-9-88

Internal Dose Factor Library, Rev. 12-3-90

(a) $\mathrm{HTO}=$ Tritiated water vapor.

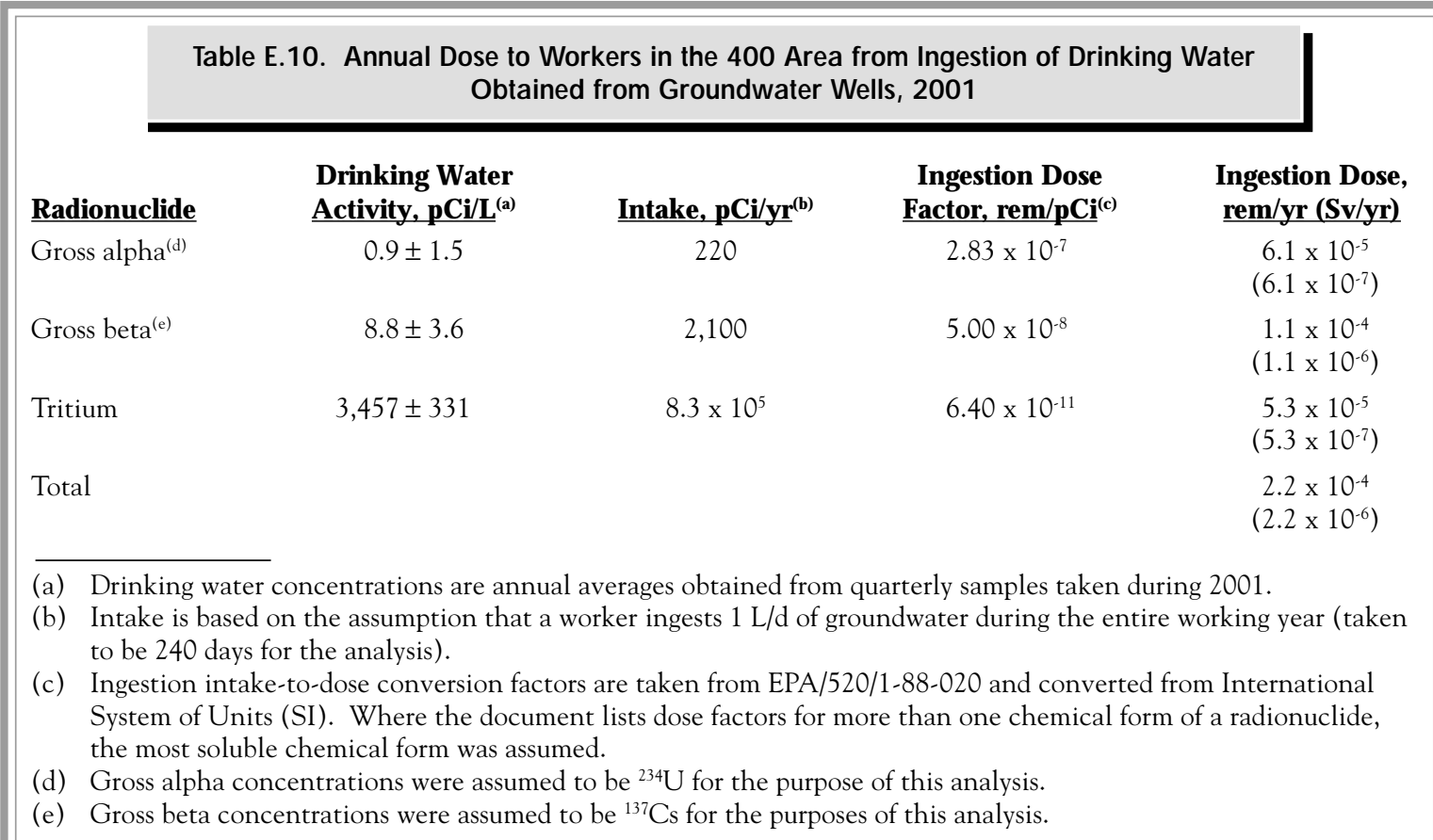




\section{References}

40 CFR 61, Subpart H. U.S. Environmental Protection Agency. "National Emission Standards for Hazardous Air Pollutants." Code of Federal Regulations.

DOE. 2000. A Graded Approach for Evaluating Radiation Doses to Aquatic and Terrestrial Biota. Interim Technical Standard. ENVR-0011. Prepared by U.S. Department of Energy, Office of Environmental Policy and Guidance; Air, Water, and Radiation Division (EH-412), Washington, D.C.

DOE Order 5400.5. "Radiation Protection of the Public and the Environment."

DOE/RL-2001-32. 2001. Radionuclide Air Emissions Report for the Hanford Site, Calendar Year 2000. D. J. Rokkan, K. Rhoads, and L. H. Staven, U.S. Department of Energy, Richland Operations Office, Richland, Washington.

EPA/520/1-88-020. 1988. Limiting Values of Radionuclide Intake and Air Concentration and Dose Conversion Factors for Inhalation, Submersion, and Ingestion. Federal Guidance Report No. 11. K. F. Eckerman, A. B. Wolbarst, and A.C.B. Richardson, Office of Radiation Programs, U.S. Environmental Protection Agency, Washington, D.C.

EPS-87-367A. 1988. Environmental Radiation Program, 26th Annual Report, January Through December 1987. Washington State Department of Health, Olympia, Washington.

International Commission on Radiological Protection. 1979a. "ICRP Publication 30, Part 1, Limits for Intakes of Radionuclides by Workers." Annals of the ICRP 2:3/4, Pergamon Press, Elmsford, New York.

International Commission on Radiological Protection. 1979b. "ICRP Publication 30, Supplement to Part 1, Limits for Intakes of Radionuclides by Workers." Annals of the ICRP 3:1-4, Pergamon Press, Elmsford, New York.

International Commission on Radiological Protection. 1980. "ICRP Publication 30, Part 2, Limits for Intakes of Radionuclides by Workers." Annals of the ICRP 4:3/4, Pergamon Press, Elmsford, New York.

International Commission on Radiological Protection. 1981a. "ICRP Publication 30, Supplement to Part 2, Limits for Intakes of Radionuclides by Workers." Annals of the ICRP 5:1-6, Pergamon Press, Elmsford, New York.
International Commission on Radiological Protection. 1981b. "ICRP Publication 30, Part 3 Including Addendum to Parts 1 and 2, Limits for Intakes of Radionuclides by Workers." Annals of the ICRP 6:2/3, Pergamon Press, Elmsford, New York.

International Commission on Radiological Protection. 1982a. "ICRP Publication 30, Supplement A to Part 3, Limits for Intakes of Radionuclides by Workers." Annals of the ICRP 7:1-3, Pergamon Press, Elmsford, New York.

International Commission on Radiological Protection. 1982b. "ICRP Publication 30, Supplement B to Part 3 Including Addendum to Supplements to Parts 1 and 2, Limits for Intakes of Radionuclides by Workers." Annals of the ICRP 8:1-3, Pergamon Press, Elmsford, New York.

International Commission on Radiological Protection. 1988. "ICRP Publication 30, Part 4, Limits for Intakes of Radionuclides by Workers: an Addendum." Annals of the ICRP 19:4, Pergamon Press, Elmsford, New York.

PNL-3777, Rev. 2. 1993. Recommended Environmental Dose Calculation Methods and Hanford-Specific Parameters. R. G. Schreckhise, K. Rhoads, J. S. Davis, B. A. Napier, and J. V. Ramsdell, Pacific Northwest Laboratory, Richland, Washington.

PNL-6584. 1988. GENII - The Hanford Environmental Radiation Dosimetry Software System, 3 vols. B. A. Napier, R. A. Peloquin, D. L. Strenge, and J. V. Ramsdell, Pacific Northwest Laboratory, Richland, Washington.

PNNL-13487, APP. 1. 2000. Hanford Site Environmental Surveillance Data for Calendar Year 1999. L. E. Bisping, Pacific Northwest National Laboratory, Richland, Washington.

U.S. Census Bureau. 2001a. Census 2000 Redistricting Data (P.L. 94-171) Summary File - Washington. U.S. Bureau of the Census, U.S. Department of Commerce, Washington, D.C. Available URL: http:// www.ofm.wa.gov/census2000/index.htm

U.S. Census Bureau. 2001b. Census 2000 Redistricting Data (P.L. 94-171) Summary File - Oregon. U.S. Bureau of the Census, U.S. Department of Commerce, Washington, D.C. 


\section{Appendix F \\ Radionuclides Detected by Gam ma Spectroscopy (Gam ma Scan)}

One of the several forms of radiation is gamma radiation. Gamma radiation is emitted by many radionuclides. Gamma spectroscopy, sometimes called a gamma scan, is used to detect the presence of the radionuclides shown in Table F.1. These radionuclides may be natural or result from Hanford Site operations. They include activation products formed by the absorption of a neutron by a stable element and fission products that occur following fission (splitting) of nuclear fuel radionuclides such as uranium-235 or plutonium-239. Some of these radionuclides may not be discussed in the main body of this report if they are below detection levels.

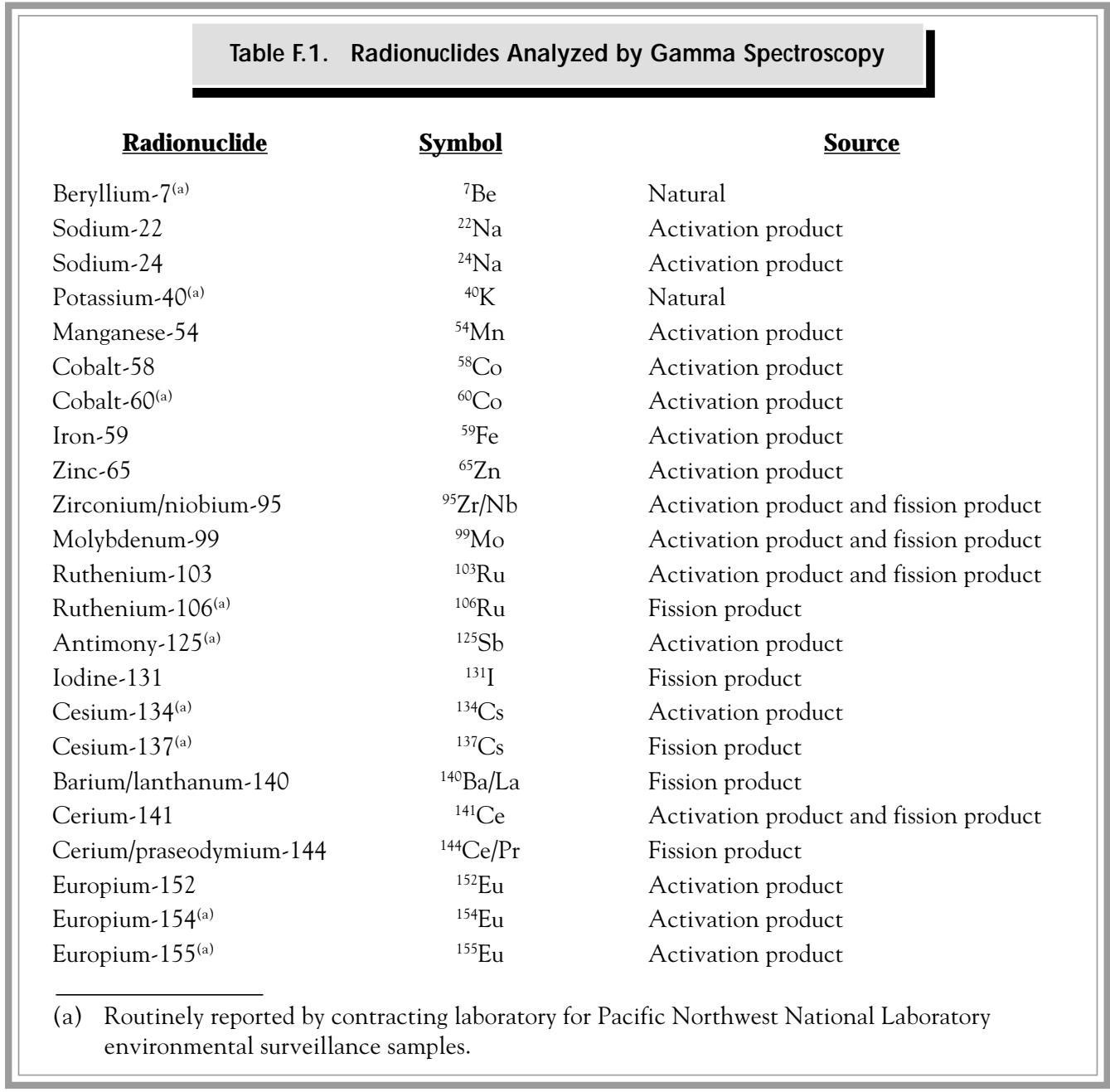




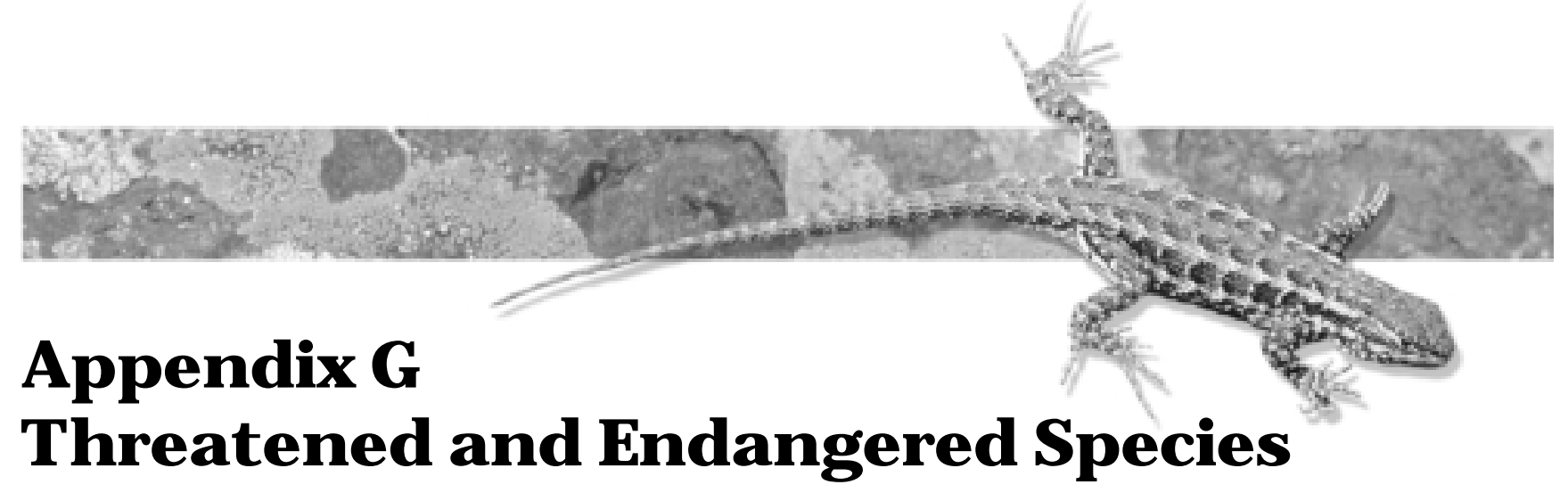

\author{
R. K. Zufelt
}

This appendix discusses the federal and state threatened and endangered species, candidate species, and plant species of concern potentially found on the Hanford Site. Threatened and endangered species are listed by the federal government in Title 50, Code of Federal Regulations, Part 17; Washington Natural Heritage Program (2000); and Washington Department of Fish and Wildlife (2000).

\title{
Threatened or Endangered Species
}

The purposes of the Endangered Species A ct of 1973, as amended, are to (1) provide a means to conserve critical ecosystems, (2) provide a program for the conservation of threatened and endangered species, and (3) assure that appropriate steps are taken to achieve the purposes of the treaties and conventions established in the act. Threatened and endangered species of plants and animals occurring or potentially occurring on the Hanford Site are listed in Table G.1.

Identification of candidate species can assist environmental planning efforts by providing advance notice of potential listing as a threatened or endangered species, allowing resource managers to alleviate threats and thereby possibly remove the need to list species as endangered or threatened. Even if a candidate species is subsequently listed, the early notice could result in fewer restrictions on human activities in the environment by prompting candidate conservation measures to alleviate threats to the species. Washington State candidate species animals occurring or potentially occurring on the Hanford Site are listed in Table G.2. Plant species not listed as threatened or endangered but considered "candidates" for listing are identified by Washington State as "species of concern." Washington State plant species of concern potentially found on the Hanford Site are listed in Table G.3.

\section{Hanford Status}

No plants or mammals on the federal list of endangered and threatened species (50 CFR 17) are known to occur on the Hanford Site. There are, however, one bird species and two fish species on the federal list of threatened and endangered species (see Table G.1). In addition, eight species of plants, and five species of birds have been listed as either threatened or endangered by Washington State. The National Marine Fisheries Service has the responsibility for the federal listing of anadromous fish (i.e., fish which require both saltwater and freshwater to complete a life cycle). Upper-Columbia
River steelhead and upper-Columbia River spring-run chinook salmon were listed as endangered evolutionary significant units by National Marine Fisheries Service (2000) in August 1997 and March 1999, respectively.

Several species of plants and animals are under consideration for formal listing as candidate species by Washington State. There are 15 state-level candidate species of plants and animals (see Table G.2) and 46 plant species of concern (see Table G.3). 


\begin{tabular}{|llc|}
\hline \multicolumn{4}{|c|}{ Table G.1. Federal or Washington State Threatened and Endangered } \\
Species on the Hanford Site
\end{tabular}


Table G.2. Washington State Candidate Animal Species on the Hanford Site

\section{Common Name}

Molluscs

Giant Columbia River spire snail ${ }^{(a)}$

Giant Columbia River limpet

\section{Fish}

Spring-run chinook ${ }^{(\mathrm{b})}$

Steelhead ${ }^{(b)}$

\section{Insects}

Columbia River tiger beetle ${ }^{(c)}$

\section{Birds}

Burrowing owl ${ }^{(\mathrm{a})}$

Common loon

Golden eagle

Loggerhead shrike ${ }^{(a)}$

Merlin

Northern goshawk $\mathrm{k}^{(\mathrm{a}, \mathrm{d})}$

Sage sparrow

Sage thrasher

\section{Reptiles}

Striped whipsnake

\section{Mammals}

Black-tailed jackrabbit

Merriam's shrew

Washington ground squirrel $l^{(\mathrm{d}, \mathrm{e})}$

White-tailed jackrabbit

\section{Scientific Name}

Fluminicola ( = Lithoglyphus) columbiana Fisherola (= Lanx) nuttalli

O ncorhynchus tshawytscha

O ncorhynchus mykiss

C icindela columbica
A thene cunicularia

$G$ avia immer

A quila chrysaetos

Lanius ludovicianus

F alco columbarius

A ccipter gentilis

A mphispiza belli

0 reoscoptes montanus

M asticophis taeniatus

Lepus californicus

Sorex merriami

Spermophilus washingtoni

Lepus townsendii
(a) Federal species of concern.
(b) Federal endangered.
(c) Probable, but not observed, on the Hanford Site.
(d) Reported, but seldom observed, on the Hanford Site.
(e) Federal candidate. 
Table G.3. Washington State Plant Species of Concern on the Hanford Site

\section{Common Name}

Annual paintbrush

Awned halfchaff sedge

Basalt milk-vetch

Bristly combseed

Brittle prickly pear

Canadian St. John's wort

Chaffweed

Columbia River mugwort

Coyote tobacco

Crouching milkvetch

Desert dodder

Desert evening-primrose

False pimpernel

Fuzzytongue penstemon

Geyer's milkvetch

Grand redstem

Gray cryptantha

Great Basin gilia

Hedge hog cactus

Kittitas larkspur

Lowland toothcup

Miner's candle

Piper's daisy

Robinson's onion

Rosy balsamroot

Rosy pussypaws

Scilla onion

Shining flatsedge

Small-flowered evening-primrose

Small-flowered nama

Smooth cliffbrake

Snake River cryptantha

Southern mudwort

Stalked-pod milkvetch

Suksdorf's monkey flower

Winged combseed
Scientific Name

C astilleja exilis

Lipocarpha ( = H emicarpha) aristulata

A stragalus conjunctus var. rickardii

Pectocarya setosa

0 puntia fragilis

$\mathrm{H}$ ypericum majus

$C$ entunculus minimus

A rtemesia lindleyana

$\mathrm{N}$ icotiana attenuata

A stragalus succumbens

C uscuta denticulata

0 enothera caespitosa

L indernia dubia anagallidea

Penstemon eriantherus whitedii

A stragalus geyeri

A mmannia robusta

C ryptantha leucophaea

$G$ ilia leptomeria

Pediocactus simpsonii var. robustior

D elphinium multiplex

Rotala ramosior

C ryptantha scoparia

E rigeron piperianus

A llium robinsonii

Balsamorhiza rosea

Calyptridium roseum

A llium scilloides

C yperus bipartitus (rivularis)

$C$ amissonia ( $=0$ enothera) minor

$\mathrm{N}$ ama densum var. parviflorum

Pellaea glabella simplex

C ryptantha spiculifera ( $=\mathrm{C}$. interrupta)

L imosella acaulis

A stragalus sclerocarpus

$M$ imulus suksdorfii

Pectocarya linearis
State Listing ${ }^{(a)}$

R1

R1

R1

W

R1

$\mathrm{S}$

R1

W

S

W

S

$\mathrm{S}$

R2

R1

$\mathrm{S}$

R1

$\mathrm{S}$

R1

R1

W

R1

R1

$\mathrm{S}$

W

W

S

W

S

R1

R1

W

$\mathrm{S}$

W

W

S

R1

The following species have been reported on the Hanford Site, but the known collections are questionable in terms of location or identification, and have not been recently collected on the Hanford Site.

Beaked spike-rush

Dense sedge

Eleocharis rostellata

C arex densa

Collinsia sparsiflora var. bruciae

E pipactis gigantea

Giant helleborine

Medic milkvetch

Orange balsam

A stragalus speirocarpus

Impatiens aurella

A stragalus arrectus

C irsium brevifolium

C arex hystericina

A renaria franklinii thompsonii

S
S
S
S
W
R2
S
W
S
R2

Porcupine sedge
Thompson's sandwort

(a) $\mathrm{S}=$ Sensitive (i.e., taxa vulnerable or declining) and could become endangered or threatened without active management or removal of threats.

$\mathrm{R} 1$ = Taxa for which there are insufficient data to support listing as threatened, endangered, or sensitive (formerly monitor group 1 ).

$\mathrm{R} 2$ = Taxa with unresolved taxanomic questions (formerly monitor group 2).

$\mathrm{W}=$ Taxa that are more abundant and/or less threatened than previously assumed (formerly monitor group 3). 


\section{References}

50 CFR 17, U.S. Fish and Wildlife Service, Department of the Interior, "Endangered and Threatened Wildlife and Plants." C ode of F ederal Regulations.

Endangered Species A ct. 1973. Public Laws 93-205 through 100-707.

National Marine Fisheries Service. 2000. ESA Status Pages. AvailableURL:http://www.nwr.noaa.gov/1salmon/ salmesa/specprof.htm
Washington Natural Heritage Program. 2000. Rare Plant Species C ounty List. Washington State Department of Natural Resources, Olympia, Washington. Available URL: http://www.wa.gov/dnr/htdocs/fr/nhp/refdesk/ fsrefix.htm

Washington Department of Fish and Wildlife. 2000. Priority $\mathrm{H}$ abitats and Species L ist. Olympia, Washington. Available URL: http://www.wa.gov/wdfw/hab/ phspage.htm 


\section{Index}

T wo typographical conventions are used in thisindex: an italicized $\mathrm{F}$ is used to denote a figure and an italicized $\mathrm{T}$ is used to denote a table.

100 A reas

americium-241, 3.14

carbon-14, 6.18, 6.36

cesium-137, 3.13T, 3.18, 4.16

chromium, $2.45-2.46,4.38,6.41-6.43$

cobalt-60, 3.13T, 3.14-3.15, 4.16

Columbia River studies, 2.5

contamination sources, 3.4, 3.6, 6.3

description, 1.2, 2.57

external radiation, 3.24, 3.26, 3.27F , 4.78, 5.8

gross beta, 4.35

nitrate, 6.39

plutonium, 3.10, 3.14, 4.15

remediation, ix, xii, 2.41, 2.42-2.43

soil, 3.18, 3.19T , 3.20T

strontium-90

air, 3.10, 3.13T , 3.14, 4.15

groundwater, 6.34-6.36

soil, 3.18

vegetation, 3.18

trichloroethene, 6.47

tritium, 4.35, 4.36, 6.16-6.17, 6.18

uranium, 3.10, 3.13, 3.14, 6.30

vegetation, $3.18,3.21,3.24 \mathrm{~T}, 3.25 \mathrm{~T}, 8.13,8.15$

wildlife, 4.60

See also specific facilities and media

$100 \mathrm{~A}$ reas Fire Survey 8.22

100-B A rea 4.35, 4.38

100-B/C A rea

remediation, 2.41, 2.42

soil sampling, 3.18

strontium-90, 3.10, 6.34

tritium, 6.16

uranium, 3.10

100-BC-1 and 100-BC-2 pipelines, 2.12

100-D A rea

chromium, 4.38, 6.41, 6.42F, 6.43F

nitrate, 6.39

sagebrush die-off, 8.13, 8.15

strontium-90, 6.34

100-D/DR A rea, 2.41, 2.43
100-F A rea

chromium, 4.38

external radiation, 3.24

nitrate, 6.39

plutonium, 3.10

remediation, 2.42, 2.43

soil sampling, 3.18

strontium-90, 3.10, 6.34

trichloroethene, 6.47

tritium, 6.16

uranium, 3.10

100-H R-1 O perable U nit, 2.12

100-K A rea

americium-241, 3.14

carbon-14, 6.18, 6.36

chromium, 4.38, 6.41, 6.44F

external radiation, 3.26

plutonium-239/240, 3.14

strontium-90, 3.14, 6.34

trichloroethene, 6.47

tritium, 6.17, 6.18

uranium, 3.14

100-N A rea

cesium-137, 3.18

chromium, 4.38, 6.43

external radiation, $3.26,3.27 \mathrm{~F}, 4.78,5.8$

nitrate, 6.39

soil, 3.18, 3.20T

springs (See riverbank springs)

strontium-90, 3.18, 4.27-4.28, 4.34, 6.34-6.36

tritium, 4.35, 4.36, 6.17

vegetation, 3.21, 3.24T , 3.25T

wildlife, 4.60

See also specific facilities and media

100-N surveillance and maintenance/transition projects, 3.14

100-N R-1 O perable U nit, 2.42

100-N R-1 remedial action site, 3.14, 3.18

105-D interim safe storage projects, 3.10, 3.14

105-DR interim safe storage projects, 3.10

105-F interim safe storage projects, 3.10 
105-H interim safe storage projects, 3.10, 3.14

116- $\mathrm{H}-1$ trench, 7.8-7.9

116-N - 1 T reatment, Storage, and Disposal Facility, 2.42

116-N -3 T reatment, Storage, and Disposal Facility, $2.42,3.15,3.26,6.34$

183-H solar evaporation basins, 6.30

200 A rea Treated Effluent Disposal Facility, 2.40

200 A reas

carbon tetrachloride, 6.45-6.47, 6.56

cesium-137, 3.15, 3.21, 6.36

chlorinated hydrocarbons, $6.46 \mathrm{~F}$

chromium, 6.43

cobalt-60, 6.36

contamination sources, $3.4,6.3$

cyanide, 6.48

description, 1.2

external radiation, $3.26,3.28,4.72$

fluoride, 6.48

groundwater flow, 6.53

iodine-129, 6.25

nitrate, $6.39-6.40$

plutonium-239/240, 3.15, 3.21

remedial investigation/feasibility studies, 2.47-2.48

remediation, ix

soil, 3.18, 3.21T

strontium-90, 3.15, 6.29F, 6.36

technetium-99, 6.28, 6.29F, 6.31F, 6.49

trichloroethene, 6.48

tritium, 6.17, 6.19-6.22F, 6.20-6.22

uranium, 3.15, 6.29F, 6.30-6.32

vadose zone characterization and protection,

7.3-7.7, 7.12-7.13

vegetation, 3.21, 3.25T, 3.30

wildlife, 3.30, 4.60

See also specific facilities and media

200 A reas $V$ adose Zone C haracterization Project, 7.8

200-BP-1 Prototype $\mathrm{H}$ anford Barrier Performance

M onitoring, 2.48

200-C S-1 O perable U nit, 2.47

200-C W - 10 perable U nit, 2.47

200-East A rea

cesium-137, 3.15, 6.36

chromium, 6.43

cobalt-60, 6.36

cyanide, 6.48

description, 1.2

groundwater flow, 6.53

iodine-129, 6.25

nitrate, 6.39

plutonium-239/240, 3.15

strontium-90, 3.15, 6.29F, 6.36

technetium-99, 6.28, 6.29F, 6.49

tritium, 6.17, 6.19-6.22F

uranium, 3.15, 6.29F, 6.30

vadose zone characterization, 7.3-7.5
200-East A rea (contd)

vegetation, 3.30

wildlife, 3.30

See also specific facilities and media

200-LW -1 0 perable U nit, 2.47

200-M W -1 O perable U nit, 2.47-2.48

200-PW -1 O perable U nit, 2.11-2.12, 2.48, 7.42

200-PW -2 0 perable U nit, 2.48

200-T W -1 O perable U nit, 2.48, 7.8

200-T W -2 O perable U nit, 2.48, 7.8

200-U P-1 O perable U nit, 2.46

200-W est A rea

carbon tetrachloride, 6.45-6.47, 6.56

cesium-137, 3.15

chlorinated hydrocarbons, $6.46 \mathrm{~F}$

chromium, 6.43

description, 1.2

fluoride, 6.48

groundwater flow, 6.53

iodine- $129,6.25$

nitrate, $6.39-6.40$

plutonium-239/240, 3.15

strontium-90, 3.15, 6.36

technetium-99, 6.28, 6.31F

trichloroethene, 6.48

tritium, 6.20-6.22

uranium, 3.15, 6.30-6.32

vadose zone, 7.5-7.7, 7.12-7.13

wildlife, 3.30

See also specific facilities and media

200-ZP-1 O perable U nit, 7.42

212-R Railroad Car Disposition A rea, 3.29

216-A -8 crib, 7.38-7.39, 7.40F

216-B-3 pond. See B Pond

216-U -1 crib, 6.30, 6.40

216-U -2 crib, 6.30, 6.40

216-U -10 pond. See U Pond

216-Z-9 trench, 6.40

221-T Plant. See T Plant complex

221-U Facility. See U Plant

222-S laboratory, 2.22, 9.9T

224-T facility, 2.31

233-S Plutonium Concentration Facility, 2.43

242-A evaporator, 2.24, 2.39

242-S evaporator, 7.13

242-T evaporator, 6.25

300 A rea

chromium, 4.38

cis-1,2-dichloroethene, 6.48

Columbia River shoreline, 4.5, 4.42

contamination sources, 3.4, 6.3

description, 1.2

drinking water, 4.46

external radiation, 3.28

gross al pha and beta, 4.35, 4.37F

nitrate, 6.40 
300 A rea (contd)

remediation, ix, 2.31

soil, 3.21T

tritium, 4.13, 4.35, 4.37F, 6.22-6.25

uranium, 3.18, 3.22, 3.26T , 4.35, 4.37F, 6.32, 6.33F

vegetation, 3.21, 3.22

See also specific facilities and media

300 A rea T reated Effluent Disposal Facility, 2.32

300-FF-1 O perable U nit, 2.12, 2.42

300-FF-2 O perable U nit, 2.42

309 Building, 2.34

310 T reated Effluent Disposal Facility, 2.32

316-5 process trench, $6.32,6.48$

324 Building, 2.31

327 Building, 2.31-2.32

337 Building, 2.34

$340 \mathrm{~W}$ aste $\mathrm{H}$ andling Facility, 2.32

400 A rea

contamination sources, 3.4

description, 1.2

drinking water, $4.45,4.46,4.47 \mathrm{~T}, 4.48 \mathrm{~F}$

external radiation, 3.28

soil, 3.18, 3.21T

tritium, 6.25

vegetation, 3.21, 3.22, 3.26T

See also specific facilities and media

600-23 site, 2.41, 2.55

600-104 site, 2.41

600 A rea

cesium-137, 3.21

chromium, 6.45

contamination sources, 3.5

description, 1.2

nitrate, 6.40

plutonium-239/240, 3.21

remediation, 2.41

soil, 3.18, 3.21T

strontium-90, 3.21, 6.36

trichloroethene, 6.47

tritium, 6.17, 6.19F-6.22F

vegetation, 3.21, 3.25T

See also specific facilities and media

616-A crib. See State-A pproved Land Disposal Site

618-4 burial ground, 7.12

618-11 burial ground, $6.24-6.25,7.10-7.11 \mathrm{~F}$

1100 A rea, $1.2,2.5,6.40$

1301-N Liquid W aste Disposal Facility, 3.18, 3.20T, $3.24 \mathrm{~T}, 3.26,6.17,6.43$

1325-N Liquid W aste Disposal Facility, 2.42, 3.15, 3.26, 6.34

A

A ccelerated D eactivation Project, 2.31

A dvanced Reactors T ransition Project, ix- $x, 2.34$

aggregate materials, 2.28 air

community monitoring stations, xiii, 4.7, 4.10, 4.72, 4.78-4.79T, 8.25

non-radionuclides, 3.5-3.6

particulate monitoring, 4.16-4.18F

radiation dose, 4.5, 5.7-5.8, 5.9-5.10

radionuclides, 3.3-3.5, 3.9-3.15, 4.10-4.16, 4.69F

regulatory compliance, 2.21-2.22

sampling and analysis methods, 3.3-3.4, 4.7-4.10,

8.9-8.10, 8.25

See also wind and dust

alfalfa, 4.53-4.54

americium-241, 3.14

ammonia, 3.5

analysis methods

air, 3.3-3.4

hold times, 3.9, 4.7

sediment, 4.22T

surface water, 4.21T , 4.23, 4.31, 4.34, 4.38

wildlife, 4.55

analytical laboratories at $\mathrm{H}$ anford Site, 9.8T

animals. See wildlife

antiaircraft artillery sites, 8.22

aquifers. See groundwater

archaeological sites, 8.19, 8.22

A rmy L oop R oad. See clastic dikes

arsenic, 4.30, 4.38, 7.9

asbestos, 2.21, 2.34

atmospheric dispersion, 8.3

average dose rate calculation, $4.71-4.72$

B

B-C ell, 2.31

B Plant, 2.44

B Pond, 2.12, 4.72, 6.53, 7.8

B R eactor and historic preservation, 8.20

background level measurements, 4.4-4.5

bald eagles, 2.25

baseline survey maps, 8.16

Benton Clean A ir A uthority, 2.21, 4.17

biodiversity, 8.9, 8.13, 8.14F

biota concentration guides, 5.10

birds, 2.25, 3.30, 4.57-4.58, 4.59F, 5.8

boundary of $\mathrm{H}$ anford Site changing at Site closure, 6.56

dose rate, 4.72, 4.74F, 4.76T , 4.77F, 5.8

Bruggemann's W arehouse, 8.19

brush fire, 2.56

See also wildfire

buildings. See facilities

Byers Landing, 4.67, 4.72 
calibration of groundwater model, 6.55

C anada geese, 4.57-4.58, 4.59F, 5.8

Canyon Disposition Initiative, ix, 2.44

CA P-88, 5.7

carbon-14, 6.17, 6.18F, 6.36, 7.9

carbon tetrachloride

air, 3.6

groundwater, 6.45-6.47

modeling, $6.56-6.58 \mathrm{~F}, 7.40$

remediation, $2.46,2.47,6.45,7.17-7.20$

TPA changes, 2.11-2.12

Cascade M ountains, 8.3

catalogs of vadose zone data, 7.35-7.36

categorical exclusions, 2.26

cemeteries, 8.19

C entral Landfill. See Solid W aste Landfill

C entral Plateau, 1.1, 2.48

C entral Plateau Risk Framework G uidance, 2.48

Central W aste Complex, 2.36-2.37, 2.39

CERCLA . See C omprehensive Environmental Response,

Compensation, and Liability A ct cesium-137

air, 3.14-3.15, 4.16

food and farm products, $4.49,4.53-4.54$

groundwater, 6.36

soil, $4.65 \mathrm{~F}$

vadose zone, 7.8, 7.9, 7.29

vegetation, 3.18, 3.21, 4.67

wildlife, 4.55, 4.56, 4.57, 4.58, 5.8

cesium capsules, 2.33

change requests to TPA , 2.11-2.13

chemical pathway and exposure analysis, 4.2

chemicals

drinking water report, 4.43

expanded surveillance, 4.2

groundwater, 6.3, 6.37-6.48

inventories, $2.59,2.60 \mathrm{~T}$

management systems, 2.14

chinook salmon, 2.5, 2.25, 8.9-8.10

chloride and leak study, 7.30

chlorinated hydrocarbons 6.45-6.48

See also specific hydrocarbons

chloroform in groundwater, 6.47

chromium, 2.45-2.46, 4.38, 6.41-6.45, 7.9, 7.41

cis-1,2-dichloroethene and groundwater, 6.48

clastic dikes, 7.25, 7.26-7.29

clastic sill, 7.29

Clean A ir A ct, 2.20-2.22, 5.7-5.8

C lean W ater $A$ ct, $2.22-2.23$

climatology, xiii, 8.3-8.8T

cobalt-60

air, 3.14-3.15, 4.16

groundwater, 6.36

quality control, 9.3 cobalt-60 (contd)

vadose zone, $7.8,7.9$

vegetation, 3.18

Cold C reek V alley, 6.40

Cold Test Facility, 2.53

Cold V acuum Drying Facility, 2.29, 3.26

collective dose, 5.2, 5.4-5.6F

Collodion, 2.20

Columbia River

bank storage, $4.33-4.34$

cultural resources, 2.26, 8.17-8.18T, 8.22

description, 1.2, 4.19, 4.20, 4.23F

external radiation, $4.72,4.76-4.78$

groundwater, 2.50, 6.3, 6.32, 6.49

non-radionuclides, 4.28-4.30, 4.32-4.33

radionuclides, 4.23-4.28, 4.32F, 4.52, 6.20, 6.25

restoration, 1.1

salmon spawning, 8.9-8.10

sampling, 2.45-2.46, 4.20, 4.22-4.23, 4.31, 4.75F

sediment, 4.30-4.31, 4.33

studies and assessments, 2.5, 4.5, 4.42

waste discharges, 3.6, 4.19-4.20

water quality, 4.20, 4.28-4.30

See also drinking water

community air monitoring stations, xiii, 4.7, 4.10, 4.72, $4.78-4.80,8.25$

Community Relation Plan for $\mathrm{H}$ anford Site Tri-Party A greement Public Involvement, 2.4, 2.6

Community Right-to-K now and E mergency Planning A ct, 2.15

Composite A nalysis, 6.56, 7.37

C omprehensive E nvironmental Response, Compensation, and Liability A ct, 2.5, 2.14

computer models

data and accuracy, 7.26, 7.29

fate and transport after closure, 2.48, 2.49, 2.50,

$6.56,7.37-7.42$

groundwater, 6.55-6.58F

release models, 7.36

vadose zone, 7.25

water balance, 7.31-7.33

Concord grapes, 4.53

confined aquifer, 6.1, 6.2, 6.48-6.49, 6.50F

See also groundwater; vadose zone

continuous air monitoring systems, 3.4

contract for mixed waste treatment, 2.38

contributing property, 8.23

corrosion control in tanks, 2.50-2.51

corrosion monitoring system, 2.50-2.51

cottontail rabbits, 4.58-4.60

Coupled Fluid, Energy, and Solute T ransport code, 6.55

cribs

carbon-14, 6.36

chromium, 6.43

cobalt- $60,6.36$ 
cribs ( contd)

cyanide, 6.48

nitrate, $6.39,6.40$

porewater source, 7.31

strontium-90, 6.36

technetium-99, 6.28

trichloroethene, 6.48

tritium, 6.17, 6.22

uranium, 6.30

cultural resource reviews, $8.20-8.21$

cultural resources, xiii, 2.25-2.26, 8.17-8.24

curation strategy for $\mathrm{H}$ anford Site, 8.24

cyanide in groundwater, 6.48

D

dams and Columbia River, 4.19, 4.22, 4.23-4.26, 4.31

dangerous waste, $2.16,2.57$

design of surveillance, 4.2-4.5

detectable value, 4.10

diagrams, process relationship, 7.41-7.42

diffuse sources of airborne radionuclides, 5.7-5.8

distribution coefficient data catalog, 7.36

DOE. See U.S. D epartment of Energy

double salt experiments, 2.51

double-shell tanks. See tanks, underground

drinking water

radiation dose, 5.8-5.9

radionuclides, $4.46-4.48 \mathrm{~F}, 6.14,6.25$

regulations and standards, 2.23, 6.13

sampling, 4.46

systems and supply facilities, 4.43-4.45

See also groundwater

Dual N ozzle Pulsating M ixer Pump, 2.52

dust and wind, 2.56, 4.16-4.18F , 8.3, 8.6F, 8.7

\section{$\mathbf{E}$}

ecological compliance review, 8.16

ecosystem monitoring, 8.9-8.16

Ecosystem M onitoring Project, 8.13

Effluent T reatment Facility, 2.39-2.40, 7.15

electrical conductivity, 7.6-7.7

electrical generating plants and lines, 2.41, 3.5

electrochemical noise-based corrosion monitoring

system, 2.50-2.51

electrolytic en richment technique, 4.51

elk, Rocky M ountain, 8.10, 8.11F

emergency occurrences, 2.55

E mergency Planning and C ommunity Right-to-K now A ct, 2.15

Endangered Species A ct, 2.25

Enhanced Site Characterization System, 7.12

environmental assessments, 2.28

environmental impact statements, 2.27-2.28

Environmental $\mathrm{M}$ anagement Science Program, 2.7 environmental management systems, 2.14

environmental occurrences, vii, 2.55-2.56

Environmental Resource A ssociates, 9.3, 9.4T

Environmental Restoration Disposal Facility external radiation, 3.28

leachate analysis, 7.15

operation, $2.40,2.42$

radionuclides, $3.15,3.18$

Environmental Restoration Project, 2.41-2.44

environmental surveillance, 4.1-4.80

EPA . See U.S. Environmental Protection A gency

Equipment Disposition Project, 2.33

europium in vadose zone, 7.9

evaporators, 2.24, 2.39, 6.25, 7.13

exposure pathway, 4.2-4.4

external radiation

boundary dose, 5.8

measurements, 3.15-3.16, 3.22, 3.24, 3.26-3.29, 4.71- 4.80

quality assurance, 9.6, 9.7T

See also radiation dose

extrusion press, 1.5, 5.7-5.8

F

facilities

2001 overview, vii

deactivation, 2.31, 2.43

meteorological data requests, 8.4T -8.5T

monitoring, 3.3-3.30, 9.6-9.9

TPA changes, 2.13

See also specific facilities (e. g. , B Plant)

Facility Decommissioning Project, 2.43

Fast Flux T est Facility, 2.27, 2.33-2.34, 4.38, 4.40, 5.8-5.9

Federal Insecticide, Fungicide, and Rodenticide A ct, 2.24

ferrocyanide in groundwater, 6.48

field replicates, 9.1-9.2

fish

rainbow trout, 2.50

salmon, 2.5, 2.25, 8.9-8.10

steelhead trout, 2.25

whitefish, 4.56-4.57, 4.58F

Fitzner/Eberhardt A rid Lands Ecology Reserve, 1.2, $2.41,4.61,4.66 \mathrm{~T}, 4.67$

fluidic-based pulse-jet system, 2.52

fluoride in groundwater, 6.48

food and farm products, 4.49-4.54, 6.40, 9.6, 9.7T

fruit and radionuclides, 4.53

fuel storage basins

external radiation, $3.24,3.26$

remediation, 2.29-2.30, 2.43

TPA changes, 2.13

tritium source, 6.17

fugitive sources, 4.4, 5.7-5.8 


\section{G}

Gable Butte Block Survey, 8.22

$\mathrm{G}$ able M ountain Pond, 2.12, 6.36

gamma-emitting radionuclides, 3.15, 4.51, 4.53, 4.78-4.79T

GA SVIT $®, 2.38$

geese, 4.57-4.58, 4.59F

G eiger counters, 4.72, 4.78

See also radiation dose

GEN II computer code, 5.1, 5.2

geologic data catalog, 7.35

geophysical logging, 7.7-7.8

geophysical surveys, 7.12

grapes, 4.53

graveyards, 8.19

$G$ reening the $G$ overnment Through Leadership in Environmental $\mathrm{M}$ anagement, 2.15

gross al pha

air, 4.10, 4.13

field surveys, 3.29

quality assurance, 9.2

surface water, 4.23, 4.24, 4.35, 4.40

gross beta

air, 4.13, 4.14F

field surveys, 3.29

purpose, 4.23

surface water, 4.24, 4.35, 4.38, 4.40

groundwater

background levels, 6.1

flow, 4.34, 6.49, 6.50F-6.54F, 6.55

modeling, 2.50, 6.55-6.58F

monitoring strategy, $6.1-6.2$

non-radionuclides, 6.37-6.48, 6.49

public dose estimates, 4.5

quality assurance, 9.2

radionuclides, 6.13-6.37, 6.49

RCRA facilities and units, 2.17T -2.19T , 6.9F

restoration

2001 activities, xi-xii, xT , 2.45-2.46

non-radionuclides, $6.40,6.41,6.45$

radionuclides, 6.28

sampling and analysis, 6.10-6.12, 6.48

transporting contaminants, 6.2-6.3

See also drinking water

$\mathrm{G}$ roundwater $\mathrm{N}$ adose Zone Integration Project, $\mathrm{xT}$, xi-xii, 2.44-2.50, 7.35-7.42

\section{H}

H anford A dvisory Board, 2.6

$\mathrm{H}$ anford C ultural Resources Laboratory, 8.17

$\mathrm{H}$ anford Facility RCRA Permit, 2.16

$\mathrm{H}$ anford Federal Facility $\mathrm{A}$ greement and $\mathrm{C}$ onsent

Order, 2.3-2.4, 2.9-2.13
$\mathrm{H}$ anford Federal Facility $\mathrm{A}$ greement and $\mathrm{C}$ onsent

O rder A dministrative Record and Public

Information Repository, 2.6

$\mathrm{H}$ anford G eographical Information System, 3.16

$\mathrm{H}$ anford $\mathrm{G}$ roundwater $\mathrm{M}$ on itoring Project, 6.1, 9.1-9.6

$H$ anford $H$ appenings calendar, 2.6

$\mathrm{H}$ anford M eteorology Station, 8.3

$\mathrm{H}$ anford $\mathrm{N}$ atural Resource T rustee $\mathrm{C}$ ouncil, 2.5

$\mathrm{H}$ anford Patrol Training A cademy, 2.23

$\mathrm{H}$ anford Reach $\mathrm{N}$ ational $\mathrm{M}$ onument cultural resources, 2.26, 8.17-8.18T

description, 1.2, 1.4F, 4.19

external radiation on shoreline, 4.72

salmon spawning, 8.9-8.10

See also Columbia River

$H$ anford Site description, 1.2-1.5

$\mathrm{H}$ anford Site $\mathrm{M}$ anhattan Project and $\mathrm{C}$ old $\mathrm{W}$ ar Era H istoric District, 8.22-8.24

$\mathrm{H}$ anford Site $\mathrm{O}$ ccurrence $\mathrm{N}$ otification Center, 2.55

$\mathrm{H}$ anford Site T echnology Coordination G roup, 2.6-2.7

$\mathrm{H}$ anford T ank Farms $\mathrm{V}$ adose Zone M onitoring

Project, 7.21

H anford town site, 4.27, 4.34-4.35, 4.36F, 6.17

$\mathrm{H}$ anford $U$ pdate, 2.6

hardness of C olumbia River, 4.30

hazardous chemicals, 2.60T

hazardous waste shipped offsite, $2.58 \mathrm{~T}$

heal th effects from radiation, 5.11-5.12

heavy equipment, 2.33

helium-3/helium- 4 ratios, $7.10-7.11 \mathrm{~F}$

herbicides, 3.30, 8.13

high-level waste management, 2.57

high-rate logging system, 2.49

historic buildings, 8.19

historic district, 8.22-8.24

historic property inventory forms, 8.21, 8.22F

history matching in vadose zone, 7.37-7.40

$\mathrm{H}$ istory of the Plutonium Production Facilities at the

$\mathrm{H}$ anford Site $\mathrm{H}$ istoric D istrict, 1943-1990, 8.23

history pilot project, 8.20

hydraulic gradients, 6.3

hydraulic property data catalog, 7.35-7.36T

hydrogeologic databases, 7.35-7.36

hydrology of groundwater, 6.2

See also confined aquifer; unconfined aquifer

Ice H arbor Dam, 4.31

immobilized low-activity waste site, proposed, 7.23, 7.25

immobilizing tank waste, 2.36

in situ redox manipulation, 2.46

Indian tribes, 2.4-2.5, 2.26, 8.19, 8.22 
industrial sources of airborne radionuclides and dose, 5.10

See also diffuse sources of airborne radionuclides inhalation dose, 5.9-5.10

See also radiation dose

injection control wells, 2.40-2.41

Insecticide, Fungicide, and Rodenticide A ct, 2.24

integrated monitoring plan, 6.5

Integration of Information Focus A rea, 2.48-2.49

intercommunication and aquifers, 6.49, 6.55

internal quality assurance programs, 9.5-9.6

intrusion prevention and tanks, 2.35

iodine-129

air, 4.7, 4.15

food and farm products, 4.49, 4.51, 4.52F

groundwater, $6.25,6.27 \mathrm{~F}, 6.49$

surface water, $4.26,4.35$

vadose zone, $7.29-7.30$

irrigation water, 4.40-4.41, 4.52

ISO 14001, 2.14

isotopic fingerprinting and tanks, 7.29-7.30

J

J.A . Jones site, 2.41

K

K Basins, 2.13, 2.29-2.30, 3.24, 3.26

KW Reactor, 8.23F

$\mathbf{L}$

land disposal restrictions report, 2.11

land use restrictions, 6.56

Laser Interferometer $\mathrm{G}$ ravitational W ave $\mathrm{O}$ bservatory $1.4-1.5$

laws. See regulations

leachate in trenches, 7.15, 7.16-7.17

lead, 2.15

Liquid Effluent Retention Facility, 2.20, 2.39

liquid effluents

contaminants, 3.3, 3.4T , 3.6-3.7

groundwater recharge, 6.53

permits and sources, 2.22-2.23, 4.20

public dose estimates, 4.5

treatment, xi, 2.32, 2.38-2.41

liquid waste volume generated, v, 2.57, 2.60T

Locke Island, 8.17-8.18T

low-level waste

commercial burial site, 1.4, 2.28, 4.72

management, 2.57

proposed site survey, 3.30

sources, 2.38

TPA change request, 2.11
Low W ater River Survey, 8.22

lysimeters, 7.31, 7.32, 7.33

M

macroencapsulation, 2.38

$\mathrm{M}$ anagement $\mathrm{C}$ ouncil for $\mathrm{H}$ anford Site T echnology Coordination G roup, 2.7

management of $\mathrm{H}$ anford Site, 1.5-1.6

maximally exposed offsite person, 5.2-5.4, 5.7, 5.8, 5.12

maximum boundary dose rate, 5.8

maximum onsite occupational dose, 5.2, 5.7-5.8

See also workers and dose

M cG ee/R iverlands area, 1.2

$\mathrm{M}$ cN ary Dam, 4.31

mercury in vadose zone, 7.9

metal extrusion facility, 1.5, 5.7-5.8

meteorology, xiii, 8.3-8.8T

mice, 3.30

M igratory B ird T reaty A ct, 2.25

milk, 4.51-4.52

miscellan eous streams, 2.40

mission of $\mathrm{H}$ anford Site, 1.1

mixed waste, $v, 2.38$

$M$ ixed W aste T reatment Facility, 2.38

modeling. See computer models

molybdenum and leak study, 7.29, 7.30

monitoring and facilities, 3.1-3.30

mule deer, 8.10-8.13

multi-canister overpacks, 2.29-2.30

$\mathbf{N}$

$\mathrm{N}$ Springs. See riverbank springs

$\mathrm{N}$ ational Environmental Policy $\mathrm{A}$ ct, $2.26-2.28$

$\mathrm{N}$ ational $\mathrm{H}$ istoric Preservation $\mathrm{A} \mathrm{ct}, 8.20-8.24$

$\mathrm{N}$ ational Institute of Standards and T echnology

Radiochemistry Program, 9.8

$\mathrm{N}$ ative A mericans, 2.4-2.5, 2.26, 8.19, 8.22

$\mathrm{N}$ avy reactor compartments, 2.38

near-facility monitoring, 3.9-3.30, 9.6-9.9

nitrate

groundwater, 2.46, 6.37-6.40, 6.49

restoration, 6.40

surface water, 4.29-4.30, 4.38

vadose zone, 7.6, 7.30

nominal detection limit, 4.10

non-dangerous waste, 2.57

$\mathbf{0}$

objectives of surveillance, 4.1-4.2

occupational doses, 4.72, 4.76T , 5.2, 5.7-5.8, 5.9-5.10

occurrences, vii, $2.55-2.56$ 
off-normal occurrences, 2.56

offsite environmental impact statements, 2.27

oil in monitoring well, 2.56

O ral History Pilot Project, 8.20

O regon (state), 2.3

ozone-depleting substances ( refrigerants), 2.21

\section{$\mathbf{P}$}

particulate monitoring. See wind and dust

percolation drains. See injection control wells

perimeter of $\mathrm{H}$ anford Site

changing at Site closure, 6.56

dose rate, $4.72,4.74 \mathrm{~F}, 4.76 \mathrm{~T}, 4.77 \mathrm{~F}, 5.8$

permeability of soil, 7.27

persistent sepal yellowcress, 8.13, 8.15F

pesticides, 2.24

$\mathrm{pH}$ in vadose zone, 7.7

phthalate esters, 7.15

Piper's daisy, 8.13

Pit V iper, 2.51

plants. See food and farm products; vegetation

Plio-Pleistocene U nit, 7.20

plutonium

air, 3.10, 3.14, 3.15, 4.15, 4.69F

Columbia River, 4.26

environmental impact statements, 2.27

groundwater, 6.37

quality assurance, 9.2

soil, 4.63, 4.65F , 4.66F , 4.69F

vadose zone, $7.9,7.39-7.40$

vegetation, 3.18, 3.21, 4.67, 4.69F

wildfire, 4.67

Plutonium Concentration Facility, 2.43

Plutonium Finishing Plant

2001 accomplishments, 2.32-2.33

chloroform, 6.47

environmental impact statements, 2.27

regulatory compliance, $2.13,2.22$

trichloroethene, 6.48

Plutonium Recycle T est Reactor, 2.34

Plutonium-U ranium Extraction Plant, 2.44, 6.17, 6.39

Pollution Prevention A ct, 2.15

Pollution Prevention Program, ix, 2.29

polychlorinated biphenyls, 2.24, 2.55

ponds

dose calculations, 5.10

external radiation, 4.72

radionuclides, 4.38, 4.40, 6.36

TPA changes, 2.12

water-table levels, 6.53, 7.8

precipitation, 6.49, 7.31-7.33, 8.7

pressurized ionization chambers, 4.72

Priest Rapids Dam, 4.22, 4.23-4.26, 4.31

process relation diagrams, 7.41-7.42

Proficiency T esting Program at EPA , 9.3, 9.4T programmatic environmental impact statements, 2.27

project management and quality assurance, 9.1

Prototype $\mathrm{H}$ anford Barrier, 2.48

public

air monitoring stations, xiii, 4.7, 4.10, 4.72, 4.78-4.80, 8.25

external radiation, $4.72,4.74 \mathrm{~F}, 4.76$

involvement, 2.5-2.6, 2.48-2.49, 8.20, 8.24

radiation dose, 5.2-5.6F, 5.7, 5.9-5.10

water supply and tritium, 6.24

Public Involvement Focus A rea, 2.48-2.49

Public Issues Exchange W orkshop, 8.20

pump-and-treat systems

2001 activities, $x T$

locations, xiF

non-radionuclides, $2.45,2.46,6.28,6.40,6.41,6.45$

radionuclides, $2.46,6.28$

Q

qual ity assurance, xiii, 9.1-9.10

Q uality A ssurance T ask Force, 9.3, 9.5T

\section{$\mathbf{R}$}

rabbitbrush, 3.30

rabbits, 4.58-4.60

RA D-BCG Calculator, 5.10-5.11T

Radiation A rea Remedial A ction Program, 2.44

radiation dose

air calculations, 4.5

measurements, 3.15-3.16, 3.22, 3.24, 3.26-3.29, 4.71- 4.80

potential dose, xii, 5.1-5.12

quality assurance, 9.6, 9.7T

Radioactive M ixed W aste Disposal Facility, 2.37, 2.38

radioactive waste generated, $v$

radiological pathway analysis and exposure assessment, 4.2

Radionuclide A ssessment System, 2.36, 7.20, 7.21

radionuclides. See specific radionuclides

radon and groundwater, 7.8

railcars, 2.33, 3.29

rainbow trout, 2.50

Rattlesnake M ountain Survey, 8.22

RCRA. See Resource C onservation and Recovery A ct reactors

cultural resources, 8.20, 8.23F

disposition, ix- $x, 2.27,2.33-2.34,2.38,2.43$

drinking water, 5.8-5.9

surface water, 4.38, 4.40

Reduction-0 xidation Plant, 6.20, 6.48

regulations

compliance, vi, 2.9-2.28, 3.7-3.8T , 5.7-5.8, 8.20-8.24

fresh water sediment 4.33 
release model data catalog, 7.36

remedial investigations and actions, 2.11-2.12, 2.47-2.48

Remote- $\mathrm{H}$ andled Immobilized Low-A ctivity W aste Disposal Facility, 3.30

reportable releases, 3.7-3.8T

Resource $C$ onservation and Recovery A ct, 2.16-2.20, 6.9F , 6.59-6.60T

respiratory irritation in tank farm, 2.56

revegetation, xii, 2.41

Richland N orth A rea, 1.2

Richland Pumphouse, 4.22, 4.23-4.26, 4.46

risk and radiation exposure, 5.11-5.12

River Corridor Project, ix-x, 2.30-2.33

riverbank springs

characterization and risk study, 4.5

dose rates, 3.26, 3.27F , 5.10

groundwater, 6.34

remediation, 2.46

sampling, 3.15

spring water, 3.15, 3.16T , 4.33-4.38, 4.39T

vegetation, 3.18, 3.25T

rivers. See specific rivers

Riverview A rea, 4.40-4.41, 4.52, 4.53

Rocky M ountain elk, 8.10, 8.11F

Rocky M ountains, 8.3

$\mathbf{S}$

Saddle M ountain, 1.2

Safe D rinking W ater A ct, 2.23

Safety Issue Resolution Project, 2.35

safety issues in tanks, 2.35-2.36

sagebrush, 8.13, 8.15

Sagemoor, 4.51-4.52, 5.2, 5.4, 5.7

salmon, 2.5, 2.25, 8.9-8.10

saltcake removal, 2.52

sampling

air, 3.9, 3.10T , 3.11T , 4.7-4.10

drinking water, 4.46

environmental surveillance zones, 4.4, 4.5T

external radiation, 3.22, 3.24, 3.26, 4.71-4.72, $4.73 \mathrm{~F}-4.75 \mathrm{~F}, 4.78$

food and farm products, 4.49, 4.50F , 4.51T

groundwater, 6.1, 6.2

investigative collections, 3.29-3.30

particulate matter, 4.16

qual ity assurance, 9.1-9.2, 9.6, 9.8

sediment, 4.20, 4.22T , 4.31

soil, 4.61

surface water, 4.20F , 4.21T , 4.22-4.23, 4.34, 4.38

vegetation, 4.52, 4.65

wildlife, 4.55, 4.57-4.60

sanitary waste, 2.23

Science and Technology Focus A rea, 2.49-2.50

Section 106 of N H PA , 8.20-8.21
Section 110 of N H PA , 8.21-8.24

sediment in Columbia River, 4.30-4.31, 4.33

seismic characterization, 7.23-7.25

shipments of waste to $\mathrm{H}$ anford, $v$

single-shell tanks. See tanks, underground

Sisson-Lu experimental site, 7.23, 7.25

Site-W ide Fiel dwork Integration Focus A rea, $2.45-2.48$

Snake River, 4.31

sodium in vadose zone, 7.6

soil

quality assurance, 9.1-9.2, 9.5T

radionuclides, 3.15-3.17, 3.17-3.18, 3.19F-3.21T , 4.61-4.65, 4.66F , 4.66T , 4.69F

remediation, $2.42-2.43$

sampling, 3.29, 4.61, 4.62F

surface texture, 7.32-7.33

See also vadose zone

soil gas monitoring, 7.17

soil gas survey for tritium, 7.10-7.11F

Soil Inventory M odel, 2.49

soil-vapor extraction system, xT , xiF , 2.47, 3.6T , 7.17- 7.20

solid waste

environmental impact statements, 2.27-2.28

management, xi, 2.36-2.41, 2.57

offsite transportation, $2.58 \mathrm{~T}$

onsite generation or storage, $v, 2.58 \mathrm{~T}, 2.59 \mathrm{~T}$

Solid W aste Landfill, 7.16-7.17, 7.18F , 7.31, 7.32

speck contamination, 3.16, 3.29

spectral gamma logging, 2.49, 7.7-7.8

Spent N uclear Fuel Project, ix, 2.13, 2.29-2.30

spirit quests, 8.22

sportsman dose, 5.8

springs. See riverbank springs

stabilizing tanks, 2.35

stakeholder involvement, 2.1-2.7, 2.48-2.49

See also public

State-A pproved Land Disposal Site

description, 2.39

non-radioactive effluents, 3.7

radioactive effluents, $2.39,6.14,6.16,6.22$

sources, 3.6

State W astewater Discharge Permit Program, 2.23

steelhead trout, 2.25

stormwater, 2.23

strontium-90

air, 3.10, 3.14, 3.15, 4.15

food and farm products, 4.49, 4.53-4.54

groundwater, 2.46, 6.29F , 6.32, 6.34-6.36

irrigation water, 4.41

quality assurance, 9.2

restoration, 6.36

soil, $4.65 \mathrm{~F}$

surface water, $3.15,4.25,4.27-4.28,4.34$ 
strontium-90 (contd)

vadose zone, $7.5,7.9$

vegetation, 3.18, 3.21, 4.52-4.53, 4.67

wildlife, 4.55, 4.56, 4.57-4.58, 4.58-4.60, 5.8

strontium capsules, 2.33

surface contamination, 3.15-3.16, 3.20T -3.21T, 3.29

Surface Environmental Surveillance Project, 4.1-4.8, 9.1

surface water

characterization and risk study, 4.5

Columbia River description, 1.2

contamination sources, 3.6, 6.20, 6.25

cultural resources, $2.26,8.17-8.18 \mathrm{~T}, 8.22$

dose rates, $3.26,3.27 \mathrm{~F}, 5.10$

external radiation, $4.72,4.76-4.78$

groundwater interface, 2.50, 6.3, 6.34, 6.49

remediation, $1.1,2.46$

salmon spawning, 8.9, 8.10

shoreline study, 4.5

surveillance, $2.45-2.46,3.15,3.16 \mathrm{~T}, 4.19-4.42$, $4.52,4.75 \mathrm{~F}$

TPA changes, 2.12

vegetation, 3.18, 3.25T

Surveillance/M aintenance and T ransition Project, 2.43-2.44

Synthetic A perture Focusing T echnique, 2.52

System A ssessment C apability, 2.48, 2.49, 2.50, 6.56, 7.37- 7.42

System A ssessment C apability Focus A rea, 2.48

\section{$\mathbf{T}$}

T Plant complex, 2.28, 2.37, 6.22, 6.48

T ank Farm W ater Balance M odel, 7.32-7.33

Tank Farms V adose Zone M onitoring Project, 7.21

tanks, underground

2001 overview, $x-x i, 2.34-2.35$

air and regulatory compliance, 2.22

external radiation, 3.28

ion exchange in soil, 7.6

leak studies, 2.49-2.50, 7.29-7.30

liquid added, $v$

remediation, 2.50-2.53 (See also vitrification)

safety issues, 2.35-2.36

supplemental environmental impact statements, 2.27

surface water controls. 7.12-7.13

TPA change requests, $2.12-2.13$

vadose zone, 2.49-2.50, 7.3-7.7, 7.20-7.22,

$7.25-7.26,7.30-7.33$

See also groundwater

T anks Focus A rea, 2.50-2.53

technetium-99

groundwater, 2.46, 6.25, 6.28, 6.29F, 6.30F, 6.31F, 6.49

leak study, 7.29, 7.30 technetium-99 (contd)

rainbow trout, 2.50

restoration, 6.28

surface water, $4.35,4.40$

vadose zone, $7.3,7.5,7.7$

Technical Review Focus A rea, 2.48

temperatures and climate, 8.7

testicular atrophy in mule deer, 8.10-8.11, 8.12T , 8.13

thermoluminescent dosimeters, 3.22, 3.24, 4.71,

$4.73 \mathrm{~F}-4.75 \mathrm{~F}$

See also radiation dose

thorium and quality assurance, 9.2

Topographical M apping System, 2.52

total hardness of C olumbia River, 4.30

T oxic Substances C ontrol A ct, 2.24

transmissivity of groundwater, $6.49,6.52 \mathrm{~F}$

transporting contaminants, 6.2-6.3, 7.25-7.26, 7.30-7.31

transuranic waste management, 2.57

trenches

characterization, 7.8-7.9

contaminant source, $6.32,6.40,6.48$

description and use, 2.37, 2.38

leachate, 7.15, 7.16-7.17

See also Environmental Restoration Disposal Facility

Tri-Party A greement. See $\mathrm{H}$ anford Federal Facility

$A$ greement and $C$ onsent $O$ rder

trichloroethene in groundwater, 6.47-6.48

tritium

air, 4.7, 4.10, 4.13, 4.14F

Columbia River, 4.24-4.25, 4.26-4.27, 4.28F

drinking water, $4.45,4.46,4.47 \mathrm{~T}, 4.48 \mathrm{~F}, 5.8,6.25$

food and farm products, 4.49, 4.51-4.52, 4.53

groundwater, $2.46,6.14-6.25,6.26 \mathrm{~F}-6.27 \mathrm{~F}, 6.49$, $6.50 \mathrm{~F}$

modeling, 7.41, 7.42F

ponds, $4.38,4.40$

spring water, 3.15, 4.34-4.35

State-A pproved Land D isposal Site, 2.39, 6.14, 6.16, 6.22

vadose zone, 7.10-7.11F

trout, $2.25,2.50$

tumbleweeds, 3.30

\section{$\mathbf{U}$}

U Plant, 2.44, 6.28, 6.30, 6.48

U Pond, 6.53

U mtanum buckwheat, 8.13

unconfined aquifer, 6.1, 6.2, 6.14-6.37, 7.30

unsaturated zone. See vadose zone

unusual occurrences, vii, 2.55

upper basalt-confined aquifer. See confined aquifer uranium

air, 3.10, 3.14, 3.15, 4.15-4.16

groundwater, $2.46,6.28-6.32,6.29 \mathrm{~F}, 6.33 \mathrm{~F}$ 
uranium (contd)

quality assurance, 9.2, 9.3, 9.5T

soil, 3.18, 4.63

surface water, 4.25-4.26, 4.28F, 4.35, 4.40

vadose zone, $7.9,7.21$

vegetation, 3.18, 3.22, 4.67

U .S. Department of Energy

derived concentration guide definition, 3.10, 6.13

$M$ ixed A nalyte Performance Evaluation Program, 9.8

O ffice of River Protection, $x-x i, 1.5-1.6$ (See also tanks, underground)

Q uality A ssessment Program, 9.3, 9.4T, 9.8

Richland 0 perations 0 ffice, 1.5, 2.29, 8.17

U.S. Environmental Protection A gency

mission, 2.3, 2.21

quality assurance, 9.3, 9.4T

water pollution studies, 9.8, 9.9T

U.S. Fish and W ildlife Service, 1.2, 1.5

U.S. Food and Drug A dministration, 9.6, 9.7T

U.S. N avy reactors, 2.38

vadose zone

characterization, 2.49-2.50, 7.3-7.13, 7.35-7.36

definition, 7.1

monitoring, 2.36, 7.15-7.22

remediation, $\mathrm{xT}$, xiF , 2.47, 3.6T, 7.17-7.20

studies, $2.47-2.48,7.23-7.33,7.37-7.42$

See also soil

$V$ adose Zone/G roundwater Integration Project, $x T$, xi-xii, 2.44-2.50, 7.35-7.42

valve pit clean out, 2.51

vegetation

dose calculations, 5.10

inventories, 8.13, 8.14F

radionuclides, 3.18, 3.21-3.22, 3.23F-3.24T , 3.30,

$4.67,4.68 \mathrm{~T}-4.69 \mathrm{~F}$

replanting, xii, 2.41

sagebrush die-off, 8.13, 8.15

sampling, 3.16-3.17, 4.62F, 4.63T , 4.65

See also food and farm products

vehicle collisions with elk, 8.10, 8.11F

Virtual Library, 2.48

vitrification

facility, 2.24, 2.35, 2.36, 2.41

proposed storage site, $7.23,7.25$

tanks selected for, $\mathrm{x}-\mathrm{xi}$

technical review, 2.51-2.52

\section{$\mathbf{W}$}

W ahluke $\mathrm{N}$ orth Slope, 2.41

W ahluke $U$ nit, 1.2

W anapum People, 8.19
W ashington State Department of Ecology, 2.21

W ashington State Department of Fish and W ildlife, 1.2

W ashington State Department of $\mathrm{H}$ ealth, 2.3, 2.21, 9.3, 9.6

W ashington State historic property inventory form, $8.22 \mathrm{~F}$

W aste Encapsulation and Storage Facility, 2.33

waste management, 2.57-2.59T

W aste $M$ anagement A rea B-BX-BY, 7.3-7.5, 7.21-7.22

See also tanks, underground

W aste $M$ anagement $A$ rea S-SX, 7.5-7.7, 7.25, 7.30-7.31

See also tanks, underground

W aste Receiving and Processing Facility, 2.37

See also tanks, underground

W aste Sampling and C haracterization Facility, 3.5, 9.8, 9.9T

W aste T ank Safety Program, 2.35

W aste T reatment Plant, 2.24, 2.35, 2.36, 2.41

wastewater, 2.23, 2.32

W atch List, 2.35

water balance model for infiltration, 7.31-7.33

water content and vadose zone, 7.7, 7.9

water levels and springs, 4.33-4.34

water supply systems, 4.43-4.45, 7.13

water-table aquifer. See unconfined aquifer

water-table elevations, 6.49, 6.51F, 6.53-6.54F

wells

injection control, 2.40-2.41

installations in FY 2001, 2.16, 2.20

intercommunication and aquifers, 6.49, 6.55

monitoring network, 6.5-6.10

oil in monitoring well, 2.56

W est Lake, 4.38, 4.40, 4.41F

White Bluffs, 8.17

W hite Bluffs bladderpod, 8.13

whitefish, 4.56-4.57, 4.58F

W iehl, Lloyd, 8.20

wildfire

in $2001,2.56$

cultural resources, 8.21-8.22

dust, $4.16,4.17$

plutonium increase, 4.67

sagebrush, 8.15

wildlife

bald eagles, 2.25

C anada geese, 4.57-4.58, 4.59F

cesium-137, 4.55, 4.56

dose rates, 5.10-5.11T

human consumption, 5.8

mice, 3.30

mule deer, 8.10-8.13

rabbits, 4.58-4.60

rainbow trout, 2.50 
wildlife (contd)

Rocky M ountain elk, 8.10, 8.11F

salmon, 2.5, 2.25, 8.9-8.10

sampling, 3.30, 4.55

steelhead trout, 2.25

strontium-90, 4.55, 4.56

whitefish, 4.56-4.57, 4.58F

wind and dust, 2.56, 4.16-4.18F , 8.3, 8.6F , 8.7

wine, 4.53

workers and dose, 4.72, 4.76T , 5.2, 5.7-5.8, 5.9-5.10
$\mathbf{Y}$

Yakima River, 6.24, 6.49

Z

zone of aeration. See vadose zone 


\section{Distribution List}

N o. of

Copies

OFFSITE

$C D$

M. T. A dams, M S-8A 33

U.S. N uclear Regulatory C ommission

W ashington, DC 20555

P Lynn A lbin

Division of Radiation Protection

W ashington State Department of $\mathrm{H}$ ealth

P.0. Box 47827

Olympia, WA $98504-7827$

CD M argaret A rnett

W estinghouse Savannah River Company

Building 730-2B

Savannah River Site

A iken, SC 29808

CD ATG, Inc.

2025 Battelle Boulevard

Richland, W A 99352

$C D$

M. R. A ult

US Ecology, Inc.

P.O. Box 638

Richland, W A 99352

CD H. Babad

2540 C ordoba C ourt

Richland, W A 99352

CD/S G. Ballew

Economic Development Coordinator

Benton County Commissioners

P.O. Box 190

Prosser, WA 99350
N o. of

Copies

CD John Bargar, M S-69

Stanford Synchrotron Radiology Laboratory

P.O. Box 4349

Stanford, CA 94025

CD/P/S Basin C ity Branch of M id-Columbia Library

50-A N. Canal Boulevard

Basin City, W A 99343

CD/S James Beaver, M ayor

City of Kennewick

2311 S. Benton Place

Kennewick, W A 99336

CD/S N.Bell

$\mathrm{N}$ orthwest Environmental A dvocates/H anford W atch

133 Southwest Second A venue, Suite 302

Portland, OR 97204-3526

CD/S Max Benitz, Jr.

Benton County Commissioner

District 2

P.O. Box 190

Prosser, WA 99350

CD/P/S Benton City Branch of the M id-C olumbia Library

City Hall

Benton C ity, W A 99320

CD Benton C ounty Clean A ir A uthority

$650 \mathrm{G}$ eorge $W$ ashington $W$ ay

Richland, W A 99352

CD/P/S Raymond P. Berube

Deputy A ssistant Secretary for Environment

$O$ ffice of Environment, Safety, and $\mathrm{H}$ ealth

U.S. Department of Energy, EH -4

1000 Independence $A$ venue S.E.

W ashington, DC 20585

$C D=C D-R O M$

$\mathrm{P}=$ Paper Copy

$S$ = Summary Booklet 
2P Carol M. Borgstrom, Director O ffice of N EPA Policy and Compliance U.S. D epartment of Energy, EH -42 1000 Independence $A$ venue S.E. W ashington, DC 20585

$\mathrm{CD} / \mathrm{S}$

L. Bowman

Benton C ounty Commissioner

District 1

P.O. Box 190

Prosser, W A 99350

CD/S Frank Brock

Franklin County Commissioner

District 3

$1016 \mathrm{~N}$. 4th A venue

P.O. Box 1451

Pasco, W A 99301

CD/P/S Burbank Community Library

875 Lake R oad

Burbank, W A 99323

CD Bureau of Land $M$ anagement

Spokane District O ffice

1103 N. Fancher

Spokane, W A 99212-1275

CD/S Gary Burke, Chairman

C onfederated T ribes of the $U$ matilla Indian

Reservation

P.O. Box 638

Pendleton, OR 97801

CD Norm Buske

c/o G overnment A ccountability Project

1402 Third A venue, Suite 1215

Seattle, W A 98101

CD BWXT Pantex

Pantex Plant

Environmental Restoration Department

P.O. Box 30020

A marillo, TX 79120-0020

P/CD Paula Call

U .S. Fish and W ildlife Service

3250 Port of Benton

Richland, W A 99352

$\mathrm{P} / \mathrm{S} \quad$ Senator $\mathrm{M}$ aria $\mathrm{C}$ antwell

$717 \mathrm{H}$ art Senate 0 ffice Building

W ashington, DC 20510
CD Tom E. Carpenter

G ovenment A ccountability Project

W est C oast $O$ ffice, Suite 1215

14023 rd A venue

Seattle, W A 98101

P $\quad$ Nick C eto

U.S. Environmental Protection A gency

Region 10

O ffice of Environmental Cleanup

Director - H anford Project O ffice

12006 th A venue

Seattle, W A 98101

CD/S Representative Bruce $\mathrm{C}$ handler

P.O. Box 40600

M od 1 Building, Room 114

Olympia, W A 98504-0600

CD Paul C harp

A gency for T oxic Substances and Disease

Registry, E-56

1600 Clifton Road

A tlanta, GA 30333

P Steve C hase

U.S. D epartment of Energy

$M$ aterials and Logistics $M$ anagement

Forrestal Building

1000 Independence A venue, S.W .

W ashington, DC 20585

CD/P/S Columbia Basin College Library

2600 N. 20th A venue

Pasco, WA 99301

CD Columbia $N$ ational W ildlife Refuge

U.S. Fish and W ildlife Service

P.O. Box Drawer $F$

Othello, W A 99344-0227

CD/S The Columbian

P.O. Box 180

Vancouver, W A 98666-0180

P A.W. Conklin

Division of Radiation Protection

W ashington State Department of $\mathrm{H}$ ealth

P.O. Box 47827

Olympia, W A 98504-7827 
No. of

Copies

CD/P/S Connell Branch of the M id-C olumbia Library 118 Columbia

Connell, W A 99326

P A.Tom Cooper

Division of Radiation Protection

W ashington State Department of $\mathrm{H}$ ealth

P.O. Box 47827

Olympia, W A $98504-7827$

CD/S N eva Corkrum

Franklin County Commissioner

District 1

1016 N. 4th A venue

P.O. Box 1451

Pasco, W A 99301

CD/P/S CREHST Museum

95 Lee Boulevard

Richland, W A 99352

CD Lori Cunniff

Environmental Services Division

Brookhaven $\mathrm{N}$ ational Laboratory

P.O. Box 5000

U pton, NY 11973-5000

CD/S AI Danielson

W ashington State Department of $\mathrm{H}$ ealth

5508 Englewood A venue

Yakima, W A 98908

CD/S John Darrington

Richland $\mathrm{C}$ ity $\mathrm{M}$ anager

City $\mathrm{H}$ all

P.O. Box 190

Richland, W A 99352

CD G reg deBruler

Columbia River U nited

P.0. Box 912

Bingen, WA 98605

CD Damon Delistraty

W ashington State Department of Ecology

Eastern Regional O ffice

N. 4601 M onroe

Spokane, W A 99205-1295

CD/S Representative Jerome Delvin

436 John L. O 'Brien Building

P.O. Box 40600

Olympia, W A 98504-0600
N o. of

Copies

CD/S Larry DeW itt

COESP M anager

20090 E. 7th A venue

Kennewick, W A 99337

CD/S Tammy Droppo

COESP $M$ anager

3621 W. Sylvester

Pasco, W A 99301

CD Maxine $M$. Dunkelman

Division of Radiation Protection

W ashington State Department of $\mathrm{H}$ ealth

P.O. Box 47827

Olympia, W A 98504-7827

CD Dirk Dunning

$O$ regon 0 ffice of Energy

$625 \mathrm{M}$ arion Street, NE, Suite 1

Salem, OR 97301-3742

P Jerry W. Elwood, Director

Environmental Sciences Division

U .S. Department of Energy, SC -74

GTN Building

19901 Germantown Road

Germantown, M D 20874-1290

CD/P/S Energy N orthwest Library

P.O. Box 968

Richland, W A 99352

CD/P/S Environmental Health Library

$U$ niversity of $W$ ashington

P.O. Box 357234

Seattle, W A 98195-7234

P John L. Erickson

W ashington State Department of $\mathrm{H}$ ealth

Bio-T errorism, M S-7890

P.O. Box 47890

Olympia, W A 98504-7890

P M ichael Farrow

Confederated Tribes of the $U$ matilla Indian Reservation

Department of $\mathrm{N}$ atural Resources

P.O. Box 638

Pendleton, OR 97801

CD Federal Emergency $M$ anagement $A$ gency

Region $X$

130 228th Street S.W .

Bothell, W A 98021-9796 
CD Chuck Findley, A cting Regional A dministrator

U .S. Environmental Protection A gency

Region 10

12006 th A venue

Seattle, W A 98101

CD Charles H. Fink, M S 1042

Sandia $N$ ational Laboratories

P.O. Box 5800

A Ibuquerque, N M 87185-0854

CD Mike Fox

348 Broadmoor Street

Richland, W A 99352

P A deline Fredin

Confederated Tribes of the Colville

Reservation

P.O. Box 150

N espelem, W A 99155

CD/S A.J.K. Fyall

Benton County Planning Department

P.O. Box 910

Prosser, W A 99350

P Larry E. Gadbois

U.S. Environmental Protection A gency

712 Swift Boulevard, Suite 5, M S B5-01

Richland, W A 99352

CD/S Mike Garrison, M ayor

City of Pasco

909 N . 26th

Pasco, W A 99301

P Rick Gay

C onfederated T ribes of the $U$ matilla Indian

Reservation

P.O. Box 638

Pendleton, OR 97801

CD/P/S N.W. Golchert

A rgonne $\mathrm{N}$ ational Laboratory

9700 S. C ass A venue, Building 331

A rgonne, IL 60439

P Larry G oldstein

$\mathrm{H}$ anford $\mathrm{N}$ atural R esources T rustee $\mathrm{C}$ ouncil

$W$ ashington State Department of Ecology

P.O. Box 47600

Olympia, W A 98504
CD Dibakar G oswami

W ashington State Department of Ecology

Ecology $\mathrm{H}$ anford Project O ffice

1315 W . 4th A venue

Kennewick, WA 99337

CD Doug G reffin

Regulatory Compliance

U S Ecology, Inc.

P.O. Box 638

Richland, WA 99352

CD H. Gucinski, Chair

Pacific $\mathrm{N}$ orthwest $\mathrm{N}$ atural A rea $\mathrm{C}$ ommittee

3200 Jefferson $W$ ay

Corvallis, OR 97311

CD/S Senator Patricia S. Hale

303 Legislative Building

P.O. Box 40408

Olympia, W A 98504-0408

P D oug $\mathrm{H}$ al ford, $\mathrm{M}$ anager

INEEL Environmental Surveillance, Education and Research Program

The S.M . Stoller Corporation

1780 First Street

Idaho Falls, ID 83401

CD David M. Hamby

Department of $\mathrm{N}$ uclear Engineering

130 Radiation Center, E120

$O$ regon State U niversity

Corvallis, OR $97331-5902$

P/S Representative Shirley $\mathrm{H}$ ankins

P.O. Box 40600

M od 1 Building - Room 102

Olympia, W A 98504-0600

P/S Congressman Richard (Doc) H astings

2715 St. A ndrews Loop, Suite D

Pasco, W A 99301

CD Senator $\mathrm{H}$ arold $\mathrm{H}$ ockstatter

401-C Legislative Building

P.O. Box 40413

Olympia, W A 98504-0413

CD Representative Janéa $\mathrm{H}$ ol mquist

421 John L. O 'Brien Building

P.O. Box 40600

Olympia, W A 98504-0600 
CD Senator Jim H oneyford 106-B I rving R. N ewhouse Building P.O. Box 40415

Olympia, W A 98504-0415

CD Balwan Hooda

Environmental Services Division

Brookhaven $\mathrm{N}$ ational Laboratory

Building 120

U pton, NY 11973

CD Greg Hughes

U.S. Fish and W ildlife Service

3250 Port of Benton Boulevard

Richland, W A 99352-1670

P Susan Coburn H ughs

$\mathrm{H}$ anford $\mathrm{N}$ atural Resources T rustee $\mathrm{C}$ ouncil

State of $O$ regon Department of Energy

$625 \mathrm{M}$ arion Street $\mathrm{NE}$

Salem, OR 97310

CD M ickey H unacek

Dade, M oeller, and A ssociates

1845 T erminal Drive, Suite 140

Richland, W A 99352

$C D \quad$ Tracy $A$. Iken berry

Dade, M oeller, and A ssociates

1845 T erminal Drive, Suite 140

Richland, W A 99352

CD G.Tim Jannik

Environmental Dosimetry Department

W estinghouse Savannah River Company

Savannah River T echnology Center

Building 773-42A

A iken, SC 29808

CD/P Richard E. Jaquish

W ashington State Department of $\mathrm{H}$ ealth

$1232 \mathrm{~V}$ intage $A$ venue

Richland, W A 99352

CD/P Russell Jim, M anager

Environmental Restoration and $\mathrm{W}$ aste

$M$ anagement Program

The $\mathrm{C}$ onfederated Tribes and $\mathrm{B}$ ands of the Yakama $\mathrm{N}$ ation

P.O. Box 151

Toppenish, W A 98948
CD/S David R. Johns

COESP A Iternate $M$ anager

59406 E. M ain PR, SE

Benton City, W A 99320

$\mathrm{CD} / \mathrm{S}$ Ken Jones

COESP A Iternate $M$ anager

P.O. Box 481

Benton City, W A 99320

CD Betty S. Jonker, M S 1216

Environmental Technical Support Division

Idaho 0 perations 0 ffice

U.S. Department of Energy

785 D O E Place

Idaho Falls, ID 83401-1562

CD Timothy W. Joseph

$O$ ak Ridge $O$ perations $O$ ffice

U.S. Department of Energy

$\mathrm{N}$ uclear Safety Division

200 A dministration Road

O ak Ridge, TN 37831

$\mathrm{CD} / \mathrm{P} / \mathrm{S}$ Kahlotus Branch of the M id-C olumbia Library $255 \mathrm{E}$. W eston

Kahlotus, W A 99335

$C D / P / S$ Kennewick Branch of the M id-C olumbia Library

1620 S. U nion Street

Kennewick, W A 99338

CD W. A. Kiel

Energy N orthwest

P.O. Box 968

Richland, W A 99352

CD Kay Koontz, Executive Director

Southwest W ashington $\mathrm{H}$ ealth District

P.O. Box 1870

Vancouver, W A 98668-1870

CD/P/S Knight Library

Serials D epartment

1299 U niversity of O regon

Eugene, OR 97403-1299

CD Dan Landeen

$\mathrm{H}$ anford $\mathrm{N}$ atural Resources $\mathrm{T}$ rustee $\mathrm{C}$ ouncil

$\mathrm{N}$ ez Perce Tribe

P.O. Box 365

Lapwai, ID 83540 
CD/S Ryan A. Landvoy

COESP M anager

343 A spen Road

Goldendale, W A 98620

CD J. Leighton, G roundwater Specialist

Bureau of $W$ ater W orks

1120 SW 5th A venue, Room 600

Portland, OR 97204

2CD Jerry M. Leitch, OA Q -107

$U$ U.S. Environmental Protection A gency

$O$ ffice of $A$ ir Q uality

1200 6th A venue

Seattle, W A 98101

CD/S Representative Barb Lisk

P.O. Box 40600

M od 1 Building, Room 101

Olympia, W A 98504-0600

P/S Governor Gary Locke

0 ffice of the $\mathrm{G}$ overnor

P.0. Box 40002

Olympia, W A 98504-0002

CD Robert Lorenz, M anager

Environmental Sampling and Reporting

W estinghouse Savannah River Company

Savannah River Site

Building 735-11A

A iken, SC 29808

CD/S Thea K. Lyall

COESP

29249 Road $O$ Southwest

Mattawa, W A 99349

CD Loren $M$ aas

Framatome A N P

2101 H orn Rapids Road

Richland, W A 99352

CD/S Mitch P. Madison

COESP $M$ anager

1715 N. 18th A venue

Pasco, W A 99301

CD A lbert R. M amatey

W estinghouse Savannah River Company

Savannah River Site

Building 735-11A

A iken, SC 29808
P/S Representative Dave M astin

W ashington State $\mathrm{H}$ ouse of R epresentatives P.O. Box 40600

M od 2 Building, R oom 110-C

Olympia, W A 98504-0600

P/CD Debra M CBaugh

Division of Radiation Protection

W ashington State Department of $\mathrm{H}$ ealth

P.O. Box 47890

Olympia, W A $98504-7890$

CD Steven H.M CC racken, Director

Fernald Environmental M anagement Project

7400 W illey Road

Cincinnati, OH 45030

CD John E. M cD onald, Environmental Scientist

Energy N orthwest

P.0. Box 968

Richland, WA 99352

$C D / S \quad K a t h y M C E a c h e n$

COESP A Iternate $M$ anager

160 Basin Drive

Mesa, W A 99343

CD/P/S M errill's C orner Branch of the M id-C olumbia Library

5240 Eltopia W ay

Eltopia, W A 99330

P Caryle B. Miller

Laboratory Infrastructure Division

$M$ anager, Safety and $O$ ccupational $H$ ealth

U.S. Department of Energy, ER-82

19901 G ermantown Road

Germantown, MD 20874-1290

CD/S Sue Miller

Franklin County Commissioner

District 2

$1016 \mathrm{~N}$. 4th A venue

P.O. Box 1451

Pasco, WA 99301

P A aron Miles

$\mathrm{N}$ ez Perce Tribe

P.0. Box 365

Lapwai, ID 83540 
No. of

Copies

CD Mike Mills

Energy Facility Site Evaluation Council

Compliance $M$ anager

P.O. Box 43172

Olympia, W A $98504-3172$

CD/S John Monley

Richland Deputy $C$ ity $M$ anager

A dministrative and Intergovernmental Services

P.O. Box 190

Richland, W A 99352

CD/S Representative Joyce Mulliken

406 John L. O 'Brien Building

P.O. Box 40600

Olympia, W A $98504-0600$

CD John B. Murphy

$\mathrm{O}$ ak Ridge $\mathrm{N}$ ational Laboratory

P.0. Box 2008, M S-6268

0 ak Ridge, TN 37831-6268

P/S Senator Patty M urray

U nited States Senate

173 Russell Senate O ffice Building

W ashington, DC 20510

3P/ Rosario L. N atoli

3CD/ A ir, W ater, and Radiation Division

3S O ffice of Environment, Safety and $\mathrm{H}$ ealth

U .S. Department of Energy, EH -412

1000 Independence A venue S.W .

W ashington, DC 20585

CD The N ews T ribune

1950 S. State Street

Tacoma, W A 98405

CD Ken Niles, A dministrator

$\mathrm{N}$ uclear Safety Division

$O$ regon 0 ffice of Energy

$625 \mathrm{M}$ arion Street, N E, Suite 1

Salem, OR 97301-3742

P Tom O'Brien

$\mathrm{H}$ anford $\mathrm{N}$ atural Resources T rustee $\mathrm{C}$ ouncil

U.S. Fish and W ildlife Service

Portland Eastside Federal Complex

911 NE 11th A venue

Portland, OR 97232-4181
N o. of

Copies

CD/S Janet $O$ ' $N$ eill

COESP A Iternate $M$ anager

P.O. Box 3067

Pasco, W A 99302

$\mathrm{CD} / \mathrm{S}$ Claude Oliver

Benton County Commissioner

District 3

P.O. Box 190

Prosser, W A 99350

CD/S John O ord

COESP $M$ anager

1028 E. O ak

Othello, W A 99344

CD/P/S O thello Branch of the M id-C olumbia Library 101 East $M$ ain

Othello, W A 99344

CD Carroll Palmer

Yakama $\mathrm{N}$ ation

Department of $\mathrm{N}$ atural Resources

P.0. Box 151

Toppenish, W A 98948

CD/P/S Pasco Branch of the M id-C olumbia Library 1320 W. H opkins

Pasco, W A 99301

P A ristides A . Patrinos, A ssociate Director

$O$ ffice of Biological and Environmental Research

U.S. Department of Energy, SC -70

19901 Germantown Road

Germantown, MD 20874-1290

CD O Iney Patt, Jr., C ouncil C hairman

Confederated Tribes of the $\mathrm{W}$ arm Springs Reservation

P.O. Box 1299

W arm Springs, OR 97761

$\mathrm{CD} / \mathrm{S}$ Jerry Peltier

Mayor, C ity of W est Richland

3801 W. V an Giesen

W est Richland, W A 99353

CD G. M. Pollet, Executive Director

$\mathrm{H}$ eart of A merica, $\mathrm{N}$ W

Cobb Building, Suite 208

1305 Fourth $A$ venue

Seattle, W A 98101 
P Glenn Podonsky, Director

$O$ ffice of Independent $O$ versite and

Performance A ssurance

19901 Germantown Road

Germantown, M D 20874-1290

P Patricia A. Pontes

O ffice of Environmental Policy and G uidance

U.S. D epartment of Energy, EH -41

1000 Independence A venue S.E.

W ashington, DC 20585

CD John B. Price

W ashington State Department of Ecology

Ecology $\mathrm{H}$ anford Project $\mathrm{O}$ ffice

$\mathrm{N}$ uclear $\mathrm{W}$ aste Division

1315 W. 4th A venue

Kennewick, W A 99337

P Stan Pynch, Director

W ashington State Senate Committee

Services

P.O. Box 40466

Olympia, W A 98504-0466

CD Johnny W. Reising

U .S. Department of Energy

Fernald Environmental $\mathrm{M}$ anagement Project

740 W illey Road

Cincinnati, OH 45030

CD/P/S Richland Public Library

$955 \mathrm{~N}$ orthgate $\mathrm{D}$ rive

Richland, W A 99352

CD W. Riggsbee

Confederated Tribes and Bands of the Yakama $\mathrm{N}$ ation

1216 W. Kennewick A venue

Kennewick, W A 99336

CD Mike Ritter

U.S. Fish and W ildlife Service

3250 Port of Benton

Richland, W A 99352

3P G. L. Robertson, Director, M S-7827

Division of Radiation Protection

W ashington State Department of $\mathrm{H}$ ealth

P. 0 . Box 47827

Olympia, W A $98504-7827$
P Jay E. Roderick, Director

Richland Office

U.S. D epartment of Energy, EM -43

Cloverleaf Building

19901 G ermantown R oad

Germantown, MD 20874-1290

P Thomas A. Rollow, Director

$O$ ffice of Special Products and Investigations

U.S. D epartment of Energy, EH -21

1000 Independence A venue, S.W .

W ashington, DC 20585

CD C. Sawyer

SA IC

20201 C entury Building, 3rd Floor

Germantown, MD 20874

CD John W. Schmidt

W ashington State Department of $\mathrm{H}$ ealth

2839 W. Kennewick A venue

Kennewick, WA 99336

CD Dr. G ene Schreckhise, A ssociate Dean

$W$ ashington State $U$ niversity $T$ ri-C ities

2710 U niversity Drive

Richland, WA 99352

CD Seattle Post-Intelligencer

P.O. Box 1909

Seattle, WA 98111-1909

CD Seattle Post-Intelligencer N ewsroom

101 Elliott $A$ venue W est

Seattle, W A 98111

$C D \quad$ Seattle Times

P.0. Box 70

Seattle, W A 98111

CD Lenora Seelatsee

W anapum People

P.O. Box 878

Ephrata, W A 98823

CD Patrick Sobotta, Director

ERW M

$\mathrm{N}$ ez Perce Tribe

P.O. Box 365

Lapwai, ID 83540 
CD Spokesman Review

W. 999 Riverside A venue

Spokane, W A 99201

CD M.D. Squeochs

Department of $\mathrm{N}$ atural Resources

Environmental Program

Yakama $\mathrm{N}$ ation

P.O. Box 151

Toppenish, W A 98948

P S. Dave Stadler

O ffice of Deputy A ssistant Secretary for Field $O$ perations Support and Field $A$ nalysis

U.S. Department of Energy

Forrestal Building, EH -2

1000 Independence A venue, S.W .

W ashington, DC 20585

CD Roger Stanley

$\mathrm{N}$ uclear W aste Programs

W ashington State Department of Ecology

P.O. Box 47600

Olympia, W A $98504-7600$

CD Ernest Stensgar, Chairman

Coeur d'A lene Tribal Council

P.0. Box 408

Plummer, ID 83851-9704

CD/S Cliff L. Stevenson

COESP M anager

70 Canal Drive

M esa, W A 99343

2CD Tim Takaro

U niversity of W ashington

School of Public Health

Department of Environmental $\mathrm{H}$ ealth

P.O. Box 357234

Seattle, W A 98195-7234

CD K. Tanaka

Safety and Security Department

Framatome A N P

$2101 \mathrm{H}$ orn Rapids Road

Richland, WA 99352

CD/S Barb Taylor

COESP A Iternate $M$ anager

1013 Sundance Road

Othello, W A 99344
CD/P/S Technical Services

W alla W alla College Library

105 Southwest A dams

College Place, W A 99324-2295

CD James Thomas

Short, C ressman, \& Burgess PLLC

999 Third A venue, Suite 3000

Seattle, W A 98104-4088

CD/S Karen A. Thomas

COESP A Iternate $M$ anager

6521 W. A rgent

Pasco, W A 99301

P Lisa C. Treichel

U.S. Department of Energy, EM -43

Cloverleaf Building

19901 Germantown Road

Germantown, M D 20874-1290

CD/S Tri-C ity H erald

107 N. Cascade

Kennewick, W A 99336

CD U.S. A rmy C orps of Engineers

Rural Route 6, Box 693

Pasco, W A 99301

CD U.S. Fish and W ildlife Service

$\mathrm{M} C \mathrm{~N}$ ary $\mathrm{N}$ ational W ildlife Refuge

P.0. Box 544

Burbank, W A 99323

CD U.S. Fish and W ildlife Service

Mid-C olumbia N W RC

P.O. Box 2527

Pasco, W A 99302-2527

CD U.S. Fish and W ildlife Service

M oses Lake W ildlife A dministrative Site

Eastern W ashington Ecological Services O ffice

32 C Street

Ephrata, W A 98823

CD U.S. Geological Survey

1201 Pacific A venue, Suite 600

Tacoma, WA 98402 


\section{CD/P/S U.S. G eological Survey Library $950 \mathrm{~N}$ ational Center 12201 Sunrise V alley Drive Reston, VA 20192 \\ P Lauri Vigue \\ $\mathrm{H}$ anford $\mathrm{N}$ atural Resources T rustee $\mathrm{C}$ ouncil Department of Fish and W ildlife 600 C apitol W ay N orth \\ Olympia, W A 98501-1091}

\section{CD/S Chuck A. W agner \\ COESP $M$ anager \\ $1528 \mathrm{H}$ unt $\mathrm{A}$ venue \\ Richland, W A 99352}

CD Doug W alker

IN EEL O versight Program

$900 \mathrm{~N}$. Skyline Drive, Suite $C$

Idaho Falls, ID 83402

CD/P/S A ndrew Wallo, III, Director

A ir, W ater, and Radiation Division

$O$ ffice of Environment, Safety and $\mathrm{H}$ ealth

U .S. Department of Energy

1000 Independence A venue S.W .

W ashington, DC 20585

CD/P/S W ashington State Department of $\mathrm{H}$ ealth

Environmental Section Library

Division of Radiation Protection

P.O. Box 47827

Olympia, W A 98504-7827

P Jim W atts

Federal A dvisory Committee

c/o U .S. Fish and W ildlife Service

3250 Port of Benton

Richland, W A 99352

CD/S D ean W eberling

COESP $M$ anager

23745 Boulder Lane

Mattawa, W A 99349

CD James E. Werner

Energy R\&D Division

Building ID-N

Idaho Falls, ID 83405-1838
$\mathrm{CD} / \mathrm{P} / \mathrm{S}$ W est Benton Branch of the M id-C olumbia Library

614 6th Street

Prosser, W A 99350

$\mathrm{CD} / \mathrm{P} / \mathrm{S}$ W est Richland Branch of the M id-C olumbia

Library

$3803 \mathrm{~V}$ an G iesen

W est Richland, W A 99352

CD/S A voneJ. Williamson

COESP $M$ anager

254 Rockwood Drive

Richland, WA 99352

CD/P Raymond W on

U.S. D epartment of Energy, EM -43

Cloverleaf Building

19901 G ermantown R oad

Germantown, MD 20874-1290

CD J. R. W rzeski, H ead N uclear Engineer

$\mathrm{N}$ aval Systems $\mathrm{C}$ ommand

$\mathrm{N}$ uclear Engineering and Planning

Department

Code 2309

1400 Farragut $A$ venue

Bremerton, W A 98314-5001

CD Yakama A gency

Bureau of Indian A ffairs

P.O. Box 632

Toppenish, W A 98948

CD Yakima H erald-Republic

114 N. 14th Street

Yakima, W A 98901

P Jerel W. Yokel

W ashington State Department of Ecology

1315 W . 4th A venue

Kennewick, W A 99337

P Tom Zeilman

$\mathrm{H}$ anford $\mathrm{N}$ atural Resources $T$ rustee $\mathrm{C}$ ouncil

The $C$ onfederated Tribes and Bands of the Yakama $\mathrm{N}$ ation

P.O. Box 151

Toppenish, W A 98948

CD E. A . Zimmerman

15 Shaw R oad

W oodstock V alley, CT 06280-2623 
N o. of

Copies

CD/S Carol Zwiener-Thomas

COESP A Iternate $M$ anager

65006 E. Sunset V iew Pr. S.E.

Benton City, W A 99320

\section{FOREIG N}

P Professor Lubomir $M$ atel

Department of $\mathrm{N}$ uclear $\mathrm{C}$ hemistry

Faculty of Science

Comenius U niversity

M lynska dol. CH-1

84215 Bratislava

SLOVA KIA

\section{ONSITE ()}

R. L. A aberg (CD)

K. M. A irhart (CD)

T. L. A ldridge (CD)

A. R. A nkrum (CD)

E. J. A ntonio (P)

W. J. A pley (CD)

J.G. A pril (CD)

S. G. A rnold (CD)

E. S. A romi (CD)

L. T. A shjian (CD)

J. F. Bagley (2P/4CD)

D. B. Barnett (CD)

J. M. Barnett (CD)

B. M. Barnes (CD)

Robert C. Barr (P)

G. D. Baston (CD)

R. D. Belden (CD)

G. M. Bell (CD)

M. P. Bergeron (CD)

Jim F. Bertsch (2P)

C. P. Beus (CD)

R. L. Biggerstaff (CD)

G. R. Bilyard (CD)

L. E. Bisping (P)

D. G. Black (CD)

E. M. Bowers (CD)

R. C. Bowman (CD)

A. B. Bowser (CD)

V. C. Boyles (CD)

H. C. Boynton (CD)

C. A . Brandt (CD)

R. F. Brich (CD)

C. R. Briggs ( $C D)$

P. K. Brockman (CD)

T. M. Brouns (CD)

R. C. Brunke (CD)
K3-54

K 8-41

$\mathrm{K} 8-50$

$\mathrm{K} 8-60$

K3-54

K9-01

L6-06

T4-04

H 6-63

H 1-51

BW O (K 1-71)

K6-81

P7-68

T 3-28

H 6-60

A 6-38

$\times 3-40$

A $6-52$

K $9-36$

B2-62

K 6-58

E6-35

K3-54

K6-75

H 8-44

A 2-15

A 1-14

G 3-40

R2-11

T 4-52

K6-85

K 8-50

K 8-50

H 1-11

K 9-69

N $1-26$
$\mathrm{N} \mathrm{O}$. of

Copies

R. W . Bryce (CD)

K 6-75

D. C. Bryson (CD)

J. W. Buck (CD)

A. L. Bunn (CD)

L. L. Burger (CD)

D. J. Carrell (CD)

M. A. Casbon (CD)

B. L. Charboneau (CD)

$Y$. Chien (CD)

C.J. Chou (P)

J. R. Christensen (CD)

S. S. Clark (CD)

S. W. Clark (CD)

K. V. Clarke (P)

S. E. Clarke (CD)

S. B. Clifford (CD)

A. J. Colburn (CD)

S. F. Conley (CD)

J. R. Culmer (CD)

G. D. Cummins (CD)

L. R. Curry (CD)

D. D. Dauble (CD)

J. D. Davis (CD)

R. A. Del $M$ ar (CD)

T. A . Demitruk (CD)

L. P. Diediker (2P/13CD)

L. A . Dietz (CD)

R. L. Dirkes (P)

L. M. Dittmer (CD, P)

B. J. Dixon (CD)

William T. Dixon (P)

R. L. Donahoe (CD)

J. J. Dorian (P)

J. L. Downs (CD)

P. E. Dresel (CD)

J. G. Droppo (CD)

J. P. Duncan (CD)

P. F. Dunigan (CD)

D. L. Dyekman (CD)

R. M. Ecker (CD)

D. P. Ellingson (CD)

R. H. Engelmann (2P/11CD)

L. Erickson (CD)

J. C. Evans (CD)

J. D. Fancher (CD)

O. T. Farmer (CD)

W. T. Farris (CD)

L. L. Fassbender (CD)

J. M. Faurote (CD)

M. J. Fayer (CD)

Karl R. Fecht $(P)$

T. W. Ferns $(2 P / 18 C D)$

G. E. Fitzgibbon (CD)
$\mathrm{H} 6-60$

$\mathrm{K} 6-80$

$\mathrm{K} 6-85$

P7-25

R 1-51

$\mathrm{H} 0-17$

A 6-33

K 6-81

K 6-81

P 7-28

A $5-58$

H $9-01$

A 7-75

A 6-33

N $1-25$

A 5-14

K 6-75

A 3-05

A 1-14

$\mathrm{H} 0-09$

K 6-84

$\mathrm{H}$ 8-60

R 3-32

A 3-02

N 1-24

$\mathrm{H} 0-20$

K 6-75

$\mathrm{H} 0-02$

R 3-32

R 1-51

X 5-60

H 1-11

K 6-85

K 6-96

K 6-80

K 6-85

A 5-58

N 1-24

Sequim

T 1-27

N 1-25

H 6-60

K 6-96

$\times 5-60$

P8-50

K 9-78

K 6-05

$\mathrm{H} 9-03$

$\mathrm{K} 9-33$

$\mathrm{H} 0-02$

A 2-15

$\mathrm{H} 0-09$ 
N o. of

Copies

J. J. Fix (CD)

B. L. Foley (CD)

B. H. Ford (CD)

L. A . Fort (CD)

G. R. Frank (CD)

E. J. Freeman (CD)

R. T. French (CD)

$M$. D. Freshley (CD)

B. G. Fritz (P)

J. S. Fruchter (CD)

R. W . Fulton (P)

M. J. Furman (CD)

K. A. Gano (CD)

S. W . G ajewski (CD)

D. A. Gantt (CD)

G. W. Gee (P)

C. J. Geier (CD)

D. R. G eist (CD)

R. E. G ephart (CD)

M ichele S. G erber (CD)

T.J Gilmore (CD)

C. S. Glantz (CD)

W. M. Glines (CD)

J. W. Golden (CD)

$M$ ary L. Goldie (CD/S)

R. W. Goles (CD)

E. M. G reager (CD)

J. M. Grover (CD)

R. F. Guercia (CD)

Richard H. Gurske (P)

D. L. H agel (CD)

L. L. Hale (CD)

J. B. Hall (CD)

J. W. H andy (CD)

R. W. H anf (132P/161CD/708S)

M. J. H artman (CD)

D. W . H arvey (CD)

H. B. H athaway (CD)

W. M. H ayward (CD)

Joel B. H ebdon (CD/P/S)

R. P. H eck II (CD)

C. W. H edel (CD)

C. L. Hellier (CD)

P. L. H endrickson (CD)

P. S. H enry (CD)

P. D. Henwood (CD)

R. D. Hildebrand (CD)

J. R. Hilliard (CD)

D. J. Hoitink (CD)

D. G. H orton (CD)

X.J. H ubert (CD)

L. R. H uesties (2P)

M. A . Hughes (CD)
K 3-55

A 6-38

E6-35

R2-11

$\mathrm{H} 0-17$

$\mathrm{K} 9-36$

G 3-28

K9-33

K 6-75

K6-96

K6-75

A 6-38

H $0-23$

K9-18

N 2-13

K9-33

K6-04

K 6-85

K 8-88

B3-30

K 6-81

K9-30

A 2-15

$\times 5-50$

A 7-75

K 6-24

T 4-05

H $9-02$

A 6-38

H 8-73

N 1-24

K 6-75

A 2-15

R3-14

K6-75

K6-96

K 6-75

A 2-15

$\times 5-50$

A 5-58

B 7-50

H $9-02$

$\times 0-34$

K 6-04

K 6-75

B2-62

A 6-38

T 7-05

K9-30

K6-81

H 5-25

K6-75

H 0-04
N o. of

Copies

I. D. Jacques (CD)

$\mathrm{H} 9-02$

P. H. Jacobsen (CD)

$\times 4-06$

M. T. Jansky (CD)

M. N. Jarayssi (CD)

N $1-25$

E. A . Jenkins (CD)

$D$. B. Jensen (CD)

H $9-03$

E6-35

A. R. Johnson (CD)

N 1-24

H 5-26

H 9-01

$\mathrm{H} 0-04$

K6-96

K6-75

A 5-16

J. D. Kautzky (CD)

S4-21

L. M. Kelly (CD)

D. P. Kimball (CD)

$\times 4-02$

K6-75

$\mathrm{H} 0-17$

J. J. Kious (CD)

D. L. Klages (CD)

L5-66

K. A. Klein (CD/P/S) A 7-50

A.J. Knepp (CD) E6-35

Greg L. Koller (CD/P/S) K1-36

S. E. Kos (CD) B2-62

O. S. Kramer (CD) A 1-14

R. N. Krekel (P) A 2-15

P. W. Kruger (P) K8-50

P. J. Krupin (P)

R. J. Landon (CD)

A strid P. Larsen (P)

G. V. Last (CD)

G. J. LeBaron (CD)

E. A . Lepel (CD)

J. A . Lerch (CD)

R. D. Lichfield (CD)

D. L. Liddell (CD)

J. K. Linville (CD)

R. W. Lober (CD)

S. S. Lowe (CD)

S. P. Luttrell (CD)

F. M. Mann (CD)

Tom E. M arceau (CD)

A 5-15

$\mathrm{H} 0-02$

A 2-15

K6-81

S4-49

P8-08

L6-06

H $0-15$

G 3-51

H 9-01

H 6-60

H 8-44

K6-96

E6-35

B. M. M arkes (CD)

D. A. Marsh (CD)

M arla K. M arvin (CD/P/S)

R. G. M CC ain (CD)

S. M. McKinney (CD)

D. A. M yers (CD)

W. J. M illsap (CD)

D. L. M itchell (CD)

R. M. Mitchell (CD)

G. B. M itchem (CD)

L. F. Morasch (P)

R. D. Morrison (CD)

J. G. Morse (P)

R. B. Morson (CD)
$\mathrm{H} 0-23$

$\mathrm{H} 1-11$

R3-32

A 7-75

B2-62

H 1-11

E6-35

H 5-26

$\times 4-03$

H 1-11

$\mathrm{H} 0-14$

K6-86

A 1-14

A 6-38

H 3-27 
N o. of
Copies

E. M. M urphy (CD)

C. S. M urray (CD)

B. A . N apier (CD)

G. M. N eath (CD)

K. R. N eiderhiser (P)

B. B. N elson-M aki (CD)

I. C. N elson (CD)

D. E. N ester (CD)

D. R. N ewcomer (CD)

R. R. Nielson (CD)

T. W. N oland (CD)

D. F. O benauer (CD)

G.P. O'Connor (CD)

M. K. Oldfield (CD)

Eric Olds (P)

J. F. Ollero $(P)$

K. B. OIsen (CD)

B. E. O pitz (P)

D. J. Ortiz (CD)

W. L. O sborne (CD)

S. M. O'T oole (CD)

T. L. Page (CD)

G. W. Patton (P)

A. W . Pearson (CD)

C. J. Perkins (CD)

S. W. Petersen (CD)

R. E. Peterson (CD)

Lloyd L. Piper (CD/P/S)

J. L. Polehn (P)

T. M. Poston (P)

L. J. Powell (CD)

P. A. Powell (CD)

J. B. Price (CD)

K. R. Price $(P)$

S. M. Price (CD)

A . L. Prignano (CD)

K. M. Probasco (CD)

K. H. Pryor (CD)

E. L. Radford (CD)

J. V. Ramsdell (CD)

D. G. Ranade (CD)

D. E. Rasmussen (CD)

Jim E. Rasmussen (P)

B. A. Rathbone (CD)

S. P. Reidel (CD)

K. Rhoads (P)

J. C. Ritter (CD)

A nnabelle L. Rodriguez (P/S)

J. M. Rodriguez (CD)

F. V. Roeck (CD)

V. J. Rohay (CD)

D. J. Rokkan (P/CD)

R. C. Roos (CD)
K9-76

K6-81

K3-54

H 6-60

K6-90

T5-57

K3-54

T 4-05

$\mathrm{K} 6-96$

$\times 9-08$

$\mathrm{H} 8-67$

$\times 5-60$

K6-86

$\mathrm{H} 6-60$

H 6-60

$\mathrm{H} 0-02$

K6-96

K6-75

A 2-15

T 7-05

S7-65

K9-18

K6-75

B2-62

H 1-11

E6-35

K6-96

A 6-37

H 6-60

K6-75

K1-46

R 1-51

B5-18

K 6-75

H 8-67

N 1-25

K2-31

K 8-34

K6-75

K 9-30

N $1-26$

L1-04

H 6-60

P7-02

K6-81

K3-54

N 2-34

A 5-58

L4-19

H 0-17

E6-35

N 1-24

L4-19
N o. of

Copies

F. A. Ruck (CD)

N $1-26$

R. W. Russell (CD)

S. B. Saslow (CD)

D. G. Saueressig (CD)

Roy J. Schepens (CD/P/S)

A. J. Schmidt (CD)

P. K. Schuette $(2 \mathrm{CD} / 2 \mathrm{P} / 2 \mathrm{~S})$

W. B. Scott (CD)

R. J. Serne (CD)

J. J. Sharpe (CD)

Y.T. Sherman (CD/P/S)

A. R. Sherwood (CD)

F. M. Simmons (CD)

M. A. Simmons (CD)

G. L. Sinton (CD)

J. 0. Skolrud (CD)

R. M. Smith (CD)

R. L. Smithwick (CD)

S. M. Sobczyk (CD)

J. C. Sonnichsen (CD)

Chris Sorensen $(P)$

P. M. Srubek (CD)

P. S. Stansbury (CD)

D. C. Stapp (CD)

W. E. Starkey (CD)

R. D. Stenner (CD)

J. M. Stitt (CD)

C. P. Strand (CD)

D. J. Strom (CD)

M. J. Sula (CD)

L. C. Swanson (CD)

J. M. Swindoll (CD)

H. A . Sydnor (CD)

S. A. Szendre (CD)

D. D. T eel (CD)

A . E. T eimouri (CD)

K. M. Thompson (CD/P)

S. A . Thompson (CD)

P. D. Thorne (CD)

R. R. Tibbatts (CD)

H. T. Tilden II (CD)

B. L. Tiller (CD)

M. E. Todd (CD)

W. E. Toebe (CD)

A. C. Tortoso (P)

G. D. Trump (CD)

D. B. $V$ an Leuven (CD)

J. A. Van Vliet (CD)

A. L. W ard (CD)

D. C. W ard (30P/50CD)

G. J. W arwick (CD)

D. J. W atson (CD)

K. E. W eeks (CD)
H 6-60

P7-75

T 4-04

$\mathrm{H} 6-60$

K 2-12

$\mathrm{K} 1-33$

H 6-60

P8-37

H $9-01$

A 7-75

N $1-26$

S6-81

K 6-85

A 6-38

N 1-24

K 6-96

A $0-20$

B2-62

N 1-25

H 6-60

T 5-09

K3-54

K 6-75

N 2-34

K 3-54

A 2-34

L6- 04

K 3-56

Sequim

E6-35

T1-27

E6-35

N $1-26$

H $0-23$

A 2-15

A 6-38

$\mathrm{N} 1-25$

K $9-33$

A 7-89

K $3-75$

K $6-85$

E6-35

N 1-26

A 6-38

A $0-20$

H $5-20$

H 6-10

K $9-33$

A 2-15

S3-30

$\times 3-79$

T 4-51 
R. S. W eeks (CD)

S. G. W eiss (CD)

R. T. Wilde (CD)

J. W. Wiley $(C D)$

B. A. W illiams (CD)

J. D. W illiams (CD)

B. D. W illiamson (CD)

J. A. W interhalder (CD)

S. H. W isness (CD/P/S)

V. E. W olff (CD)

M. I. W ood (CD)

T. W. Wood (CD)

R. K. W oodruff (CD)
P7-79

H 0-20

E6-35

K $8-50$

K 6-81

L5-66

A 4-52

A 1-14

A 2-15

A $0-23$

H 8-44

K 7-94

P7-68
J. G. W oolard (CD)

$\mathrm{HO} 0-02$

S. K. W urstner (CD)

$\mathrm{K} 9-36$

R. M. Yasek (CD)

$\mathrm{H} 6-60$

D. E. Zaloudek (CD)

N 1-24

Jamie H. Zeisl oft (P)

A 2-15

R. K. Zufelt (CD)

K 6-85

DOE Public Reading Room (2CD/2P/2S)

$\mathrm{H}$ anford Site $\mathrm{A}$ dministrative

Record (2CD/2P/2S)

$\mathrm{H}$ anford T echnical Library (2CD/2P/2S)

Historical File-T. M. Poston (CD/P/S)

LMSI Central Files (CD/P/S)
$\mathrm{H} 2-53$

H 6-08

P8-55

K 6-75

A 3-88 